\title{
UICN
}

\section{Legalidad Forestal en Mesoamérica}

Grethel Aguilar, Alejandro Iza, Mario Peña y Víctor Milla

Editores

\section{$\Delta V$ \\ VAN \\ Ukaid





\section{Legalidad Forestal en Mesoamérica}





\section{Legalidad Forestal en Mesoamérica}

Grethel Aguilar, Alejandro Iza, Víctor Milla y Mario Peña Editores 
La presentación del material en esta publicación y las denominaciones empleadas para las entidades geográficas no implican en absoluto la expresión de una opinión por parte de la UICN, ni del Centro de Derecho Ambiental ni del Departamento para el Desarrollo Internacional del Reino Unido (DFID) del UK-AID, sobre la situación jurídica de un país, territorio o zona, o de sus autoridades, o acerca de la demarcación de sus límites o fronteras.

Los puntos de vista que se expresan en esa publicación no reflejan necesariamente los de la UICN, ni del Centro de Derecho Ambiental ni DFID.

Esta publicación ha sido posible gracias a la generosidad del Departamento para el Desarrollo Internacional del Reino Unido (DFID).

Publicado por: $\quad$ UICN, Oficina Regional para México, América Central y el Caribe (ORMACC) y el Programa de Derecho Ambiental de la UICN, Centro de Derecho Ambiental

Derechos reservados: (c) 2015 Unión Internacional para la Conservación de la Naturaleza y de los Recursos Naturales

Se autoriza la reproducción de esta publicación con fines educativos y otros fines no comerciales sin permiso escrito previo de parte de quien detenta los derechos de autor con tal de que se mencione la fuente.

Se prohíbe reproducir esta publicación para la venta o para otros fines comerciales sin permiso escrito previo de quien detenta los derechos de autor.

Citación: Grethel Aguilar, Mario Peña, Alejandro Iza, Gustavo Alanis Ortega, Alejandra Sobenes G., Jaime Héctor López Escobar, Mario Vallejo Larios, Marianela Rocha Zúñiga y Jessica Young (2014). Legalidad Forestal en Mesoamérica.

San José, Costa Rica: UICN. viii + 630pp.

ISBN: $\quad$ 978-2-8317-1707-4

DOI: 10.2305/IUCN.CH.2008.EPLP.82.es

Fotografía

de la cubierta:

Giancarlo Pucci

Diagramado

e impreso por:

Diseño Editorial S.A.

Disponible en:

UICN (Unión Internacional para la Conservación de la Naturaleza)

San José, Costa Rica

Tel: ++50622838449

Fax: ++50622838472

ormacc@iucn.org

www.iucn.org/ormacc

Programa de Derecho Ambiental de la UICN

Centro de Derecho Ambiental

Godesberger Allee 108-112

53175 Bonn

Alemania

Tel.: ++49.228.2692 231 Fax: ++49.228.2692 250

elcsecretariat@iucn.org

www.iucn.org/law

El texto de este libro fue impreso en papel hecho de fibra de madera proveniente de bosques bien gestionados, certificada según las normas del Consejo de Manejo Forestal (FSC). 


\section{Índice}

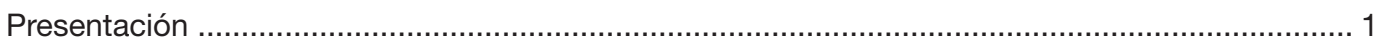

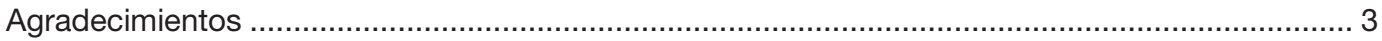

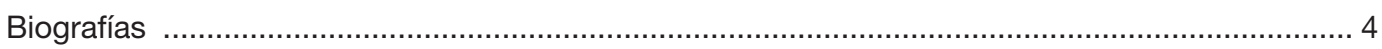

Bosques en Mesoamérica: un enfoque jurídico ................................................................ 7

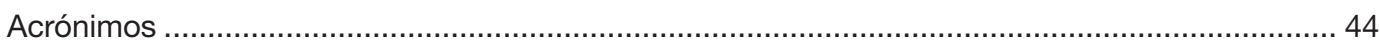

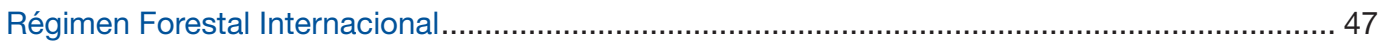

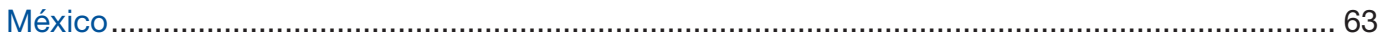

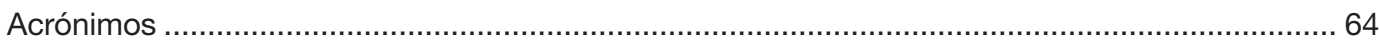

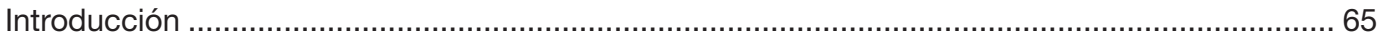

1. Síntesis histórica de la formulación de la Ley Forestal y afines ....................................6 68

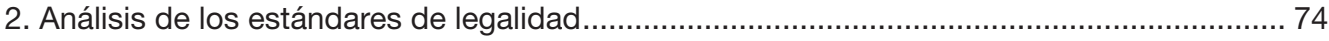

3. Análisis del ámbito de acción de la Administración Forestal ........................................ 79

4. Análisis del sistema de control forestal ...................................................................... 84

5. Análisis de ejecución de procesos judiciales ............................................................. 89

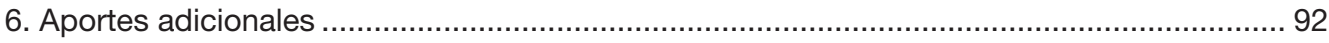

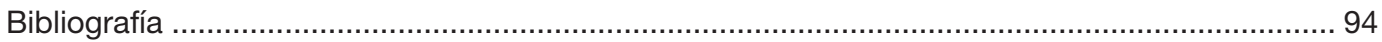

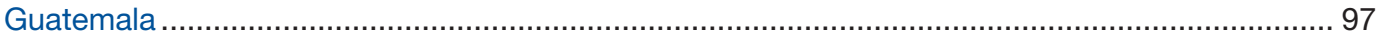

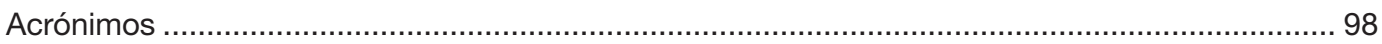

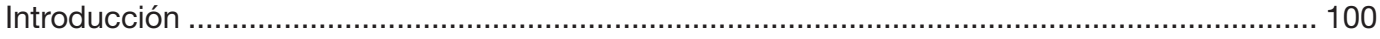

1. Síntesis histórica de la formulación de la Ley Forestal y afines .................................. 103

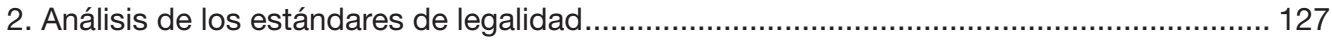

3. Análisis del ámbito de acción de la Administración Forestal ............................................. 133

4. Análisis del sistema de control forestal ...................................................................... 139

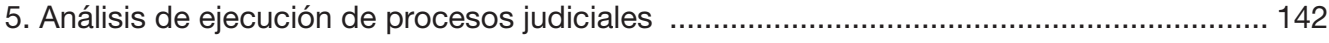

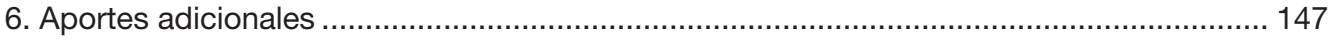

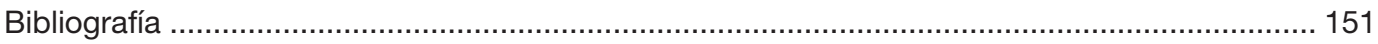




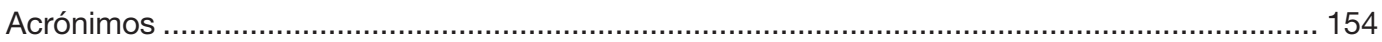

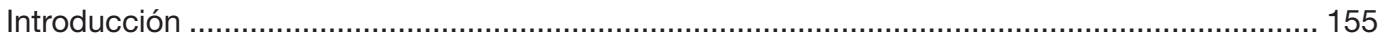

1. Síntesis histórica de la formulación de la Ley Forestal y afines ....................................... 156

2. Análisis de los estándares de legalidad..................................................................... 167

3. Análisis del ámbito de acción de la Administración Forestal ......................................... 176

4. Análisis del sistema de control forestal ....................................................................... 183

5. Análisis de ejecución de procesos judiciales ............................................................. 186

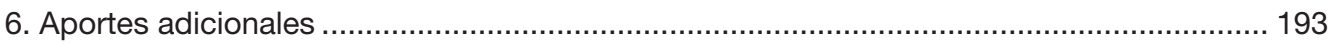

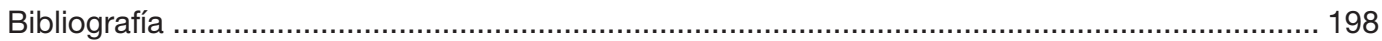

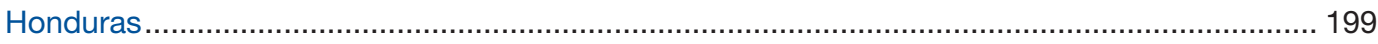

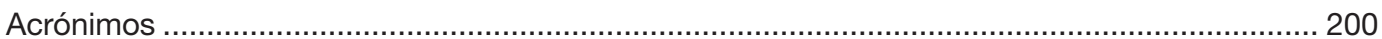

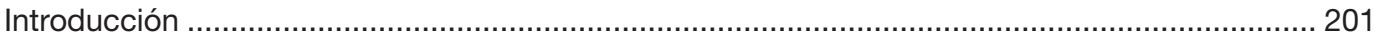

1. Síntesis histórica de la formulación de la Ley Forestal y afines ...................................... 202

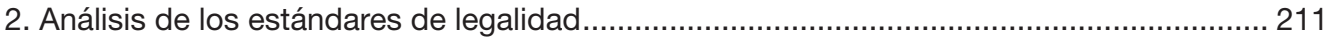

3. Análisis del ámbito de acción de la Administración Forestal ........................................... 218

4. Análisis del sistema de control forestal ....................................................................... 226

5. Análisis de ejecución de procesos judiciales .................................................................. 230

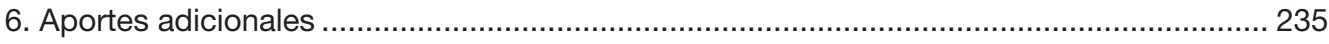

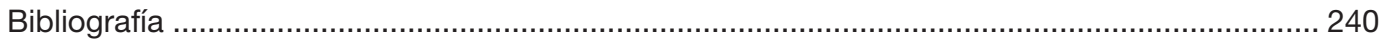

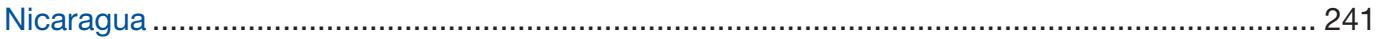

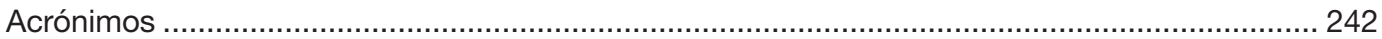

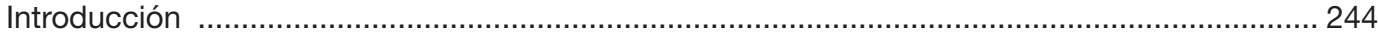

1. Síntesis histórica de la formulación de la Ley Forestal y afines ..........................................245

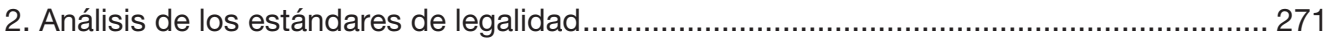

3. Análisis del ámbito de acción de la Administración Forestal .......................................... 273

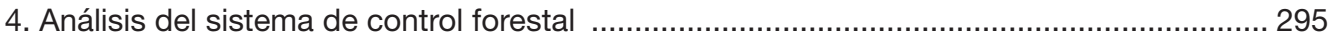

5. Análisis de ejecución de procesos judiciales ................................................................ 304

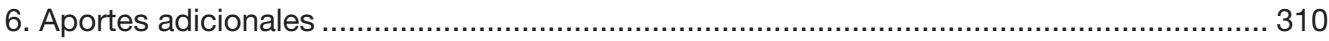

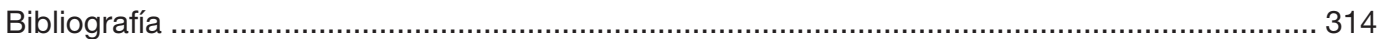


Acrónimos

Introducción

1. Síntesis histórica de la formulación

de la Ley Forestal y afines

2. Análisis de los estándares de legalidad.

3. Análisis del ámbito de acción de la Administración Forestal

4. Análisis de sistema de control forestal 355

5. Análisis de ejecución de procesos judiciales 362

6. Aportes adicionales 370

Bibliografía

Panamá

Acrónimos

Introducción

1. Síntesis histórica de la formulación de la Ley Forestal y afines

2. Análisis de los estándares de legalidad..... 398

3. Análisis del ámbito de acción de la Administración Forestal 408

4. Análisis del sistema de control forestal

5. Análisis de ejecución de procesos judiciales

6. Aportes adicionales

Bibliografía

Anexos

Anexos México

Anexos Guatemala

Anexos El Salvador

Anexos Honduras

Anexos Nicaragua

Anexos Costa Rica

Anexos Panamá 



\section{Presentación}

Las personas en países con bosques tropicales reciben una serie de servicios de estos ecosistemas, como agua limpia, absorción de carbono, productos farmacéuticos, madera, biodiversidad y belleza escénica. Para que podamos seguir gozando estos beneficios, las leyes y políticas deben responder a los retos que enfrentamos en la actualidad. Es por ello que en materia ambiental las regulaciones deben estar siempre a la altura de las necesidades de la conservación y el desarrollo sostenible.

Las naciones ya se comprometieron en el marco del Convenio sobre la Diversidad Biológica y de sus Metas Aichi a reducir como mínimo a la mitad la pérdida de los hábitats naturales, incluidos los bosques para el año 2020; esto implica un gran reto, ya que América Latina y el Caribe enfrentan importantes pérdidas de bosque.

La Comisión Mundial de Derecho Ambiental de la Unión Internacional para la Conservación de la Naturaleza ha sumado esfuerzos con la Oficina Regional para México, América Central y el Caribe, y el Centro de Derecho Ambiental en esta obra, que cuenta con la participación de distinguidos abogados de la región mesoamericana.

La obra que se presenta, "Legalidad Forestal en Mesoamérica”, ilustra las regulaciones y procesos necesarios en cada uno de los países de la región para alcanzar lo que podríamos denominar la legalidad en el aprovechamiento forestal y exportación de madera. Se muestran aquí las fortalezas y retos de los diversos sistemas desde el ángulo jurídico.

Es cada vez más imperioso señalar con claridad las regulaciones necesarias para la conservación, uso sostenible y comercio de productos forestales. Algunas naciones ya están creando mecanismos legales que aseguren la exportación e importación de productos forestales provenientes de fuentes legales. Los acuerdos comerciales entre países tendrán como tarea impulsar regulaciones que favorezcan la gestión sostenible de los bosques de los países tropicales.

Claramente se puede avanzar en el fortalecimiento de un régimen legal que sume a los esfuerzos de conservación reduciendo la tala ilegal del bosque. Respetando el principio de seguridad jurídica, la normativa ambiental que protege los bosques exige innovación para responder a los desafíos actuales; esto irá de la mano con la correcta aplicación de la legislación y sus procesos.

Son esfuerzos como el presentado en esta obra los que con una visión de futuro posibilitan el perfeccionamiento del marco regulatorio y en relación con el presente, conducen a un mayor conocimiento y mejor comprensión de la legislación ambiental existente no solo por la Administración Pública y los actores privados, sino especialmente por los jueces a quienes -en nuestros sistemas constitucionales- les cabe la última palabra. He tenido la oportunidad por medio de una sentencia del Tribunal Superior de Justicia de Brasil de afirmar que: “... En la época actual, ya no hay espacio ni disculpas para que el Poder Judicial omita, dificulte u obstaculice la implementación de la legislación ambiental, sobre todo la forestal. En primer lugar, porque los daños causados y a ser causados son, a menudo, de naturaleza irreversibles y hasta catastróficos (como demuestran las grandes ciudades, llenas de deslizamientos recurrentes, con lamentables pérdidas de vidas humanas e incalculables perjuicios materiales); en segundo lugar, porque el conocimiento acerca del valor de la biodiversidad 
y de su desaparición es copioso e incuestionable; en tercer lugar, porque existen las tecnologías y métodos capaces de conferir una índole sustentable a la explotación de los recursos naturales y finalmente, porque el juez del Siglo XXI es convocado a aplicar no un conjunto de diplomas exóticos, desactualizados, extraños y sin un apoyo en las referencias histórico-culturales del país, sino un microsistema legal coherente, de origen e índole constitucional, que vocaliza -de modo impositivola transición de un Derecho de Daños a un Derecho de Riesgos (sobre los pilares de los principios de la prevención, precaución e in dubio pro natura) y de la propiedad-especulación hacia la propiedadfunción" (Recurso Especial 1.240.122-PR).

En conclusión, no obstante los avances en las últimas décadas y los esfuerzos de las instituciones como la UICN, un régimen legal y eficiente para los bosques nunca ha resultado tan urgente. Desde la Comisión Mundial de Derecho Ambiental esperamos sumar esfuerzos en este camino.

\section{Antonio Herman Benjamin}

Presidente Comisión Mundial de Derecho Ambiental

"Unión Internacional para la Conservación de la Naturaleza

Ministro, Tribunal Superior de Justicia de Brasil (STJ)

Secretario General,

Consejo Consultivo Internacional para la Justicia Ambiental del PNUMA" 


\section{Agradecimientos}

Agradecemos especialmente a los abogados autores de este libro, quienes han dedicado todos sus esfuerzos a presentar desde la perspectiva legal capítulos que recopilan, analizan y contraponen información sobre las fortalezas y principales retos para la conservación y uso sostenible de los recursos forestales de Mesoamérica.

Mucha de la información recopilada por los autores ha sido posible gracias a la buena disposición y apertura de los Ministerios de Ambiente de la región, Oficinas y Comisiones Forestales a nivel del país, y Cortes Supremas de Justicia, entre otras dependencias de gobierno. Se han realizado entrevistas con diversos actores de la sociedad civil y comunidades. A todos ellos nuestro reconocimiento y agradecimiento.

Consideramos necesario resaltar el apoyo brindado por el Departamento para el Desarrollo Internacional (DFID) del Reino Unido, gracias a cuyos aportes hemos logrado financiar una investigación de estas dimensiones.

Reconocemos al Presidente y los miembros de la Comisión Mundial de Derecho Ambiental de la UICN por su apoyo y mensaje contundente y al personal del Centro de Derecho Ambiental y de la Oficina Regional para México, América Central y el Caribe de la UICN por el seguimiento al diseño, diagramación y detalles de esta obra. 


\section{Biografías}

\section{Grethel Aguilar Rojas}

Grethel Aguilar Rojas es abogada especialista en Derecho Internacional, con un Doctorado en Derecho Ambiental de la Universidad de Alicante, España, mención Sobresaliente "cum laude". También ha sido consultora para diversos gobiernos y organizaciones internacionales. En el campo académico ha sido profesora de varios centros de enseñanza, entre ellos la Universidad de Costa Rica, CATIE y Universidad Latina de Costa Rica.

$\mathrm{Ha}$ trabajado con diversas instituciones regionales e internacionales en aspectos relacionados con Derecho Ambiental, agua, gestión ambiental, biodiversidad, recursos genéticos, propiedad intelectual y derechos de comunidades locales y pueblos indígenas.

Cuenta con un importante número de publicaciones, entre las que se encuentran el "Manual de Derecho Ambiental para Centroamérica (2009), "En busca de una distribución equitativa de los beneficios de la Biodiversidad y el Conocimiento Indígena" (2005) y "Gobernanza de Aguas Compartidas" (2009). Desde el 2005 es directora de la Oficina Regional de UICN para la región de México, América Central y el Caribe (ORMACC).

\section{Alejandro Iza}

El Dr. Alejandro Iza es Director del Centro de Derecho Ambiental y Jefe del Programa de Derecho Ambiental de la UICN en Bonn, Alemania.

Abogado, graduado en la Universidad de Buenos Aires, obtuvo su maestría en Derecho Ambiental Internacional en la Universidad de Londres. Tiene un Doctorado en Derecho de la Universidad de Buenos Aires y realizó estudios post-doctorales en La Haya, Bruselas y Hamburgo.

También trabajó para la Comisión Europea, donde se especializó en el tema de demandas relacionadas con legislación ambiental.

Previo a su nombramiento actual, trabajó para el Centro de Derecho Ambiental de la UICN como legal officer desde 1999. Es autor y coautor de varios libros, y trabajos en derecho ambiental con énfasis en temáticas internacionales y ha sido profesor en varias universidades.

\section{Lydia Slobodian}

Lydia Slobodian es un oficial jurídico del Centro de Derecho Ambiental de la UICN. Ella tiene un Juris Doctor del Centro de Leyes de la Universidad de Georgetown, Washington, DC. un BA y un MPhil de la Universidad de Cambridge. Es miembro del Colegio de Abogados del Distrito de Columbia.

Sus trabajos recientes incluyen publicaciones sobre las obligaciones ambientales transgeneracionales e implicaciones legales de comercio virtual de agua. 


\section{Gustavo Alanís Ortega}

Gustavo Alanís Ortega es abogado con una maestría en Derecho Internacional (con especialidad en Derecho Ambiental) en la American University, Washington College of Law, EE.UU. Desde 1993 es Director General del Centro Mexicano de Derecho Ambiental, A.C. (CEMDA).

Ha sido miembro en tres ocasiones del Comité Consultivo Público Conjunto (CCPC) de la Comisión para la Cooperación Ambiental (CCA) del Tratado de Libre Comercio (TLC). Por invitación del Secretario de Medio Ambiente de México, fue miembro del Comité Consultivo de Cambio Climático (2006). Actualmente y desde el 2013, es miembro del Consejo de Cambio Climático.

Desde enero de 2014, fue electo como miembro del Consejo Directivo de la Academia de Derecho Ambiental de la Unión Mundial para la Conservación de la Naturaleza (IUCN). Igualmente, es parte del Consejo Directivo de la Comisión de Derecho Ambiental de la IUCN.

\section{Alejandra Sobenes García}

Alejandra Sobenes García es Máster en Derecho Ambiental y actualmente se desempeña como consultora nacional e internacional.

Sobenes ha sido Presidenta del Consejo Nacional de Áreas Protegidas de Guatemala, Viceministra de Recursos Naturales del Ministerio de Ambiente y Recursos Naturales de Guatemala, docente de derecho ambiental a nivel de especialidad y miembro de la Comisión de Alto Nivel para la elaboración del Informe del Estado del Ambiente en Guatemala, entre otros puestos.

También ha escrito y sido coautora de diversas publicaciones relacionadas principalmente con legislación ambiental, áreas protegidas, biodiversidad y cambio climático.

\section{Jaime Héctor López}

Jaime Héctor López es Licenciado en Ciencias Jurídicas, con una titulación técnica en Legislación y Evaluación Ambiental. Actualmente trabaja como colaborador jurídico en la Corte Suprema de Justicia de El Salvador.

Participó en la consultoría de evaluación y análisis nacional del marco institucional y jurídico del tema bosques y cambio climático, auspiciado por la FAO (2002) y colaboró en la elaboración del Manual de Legislación Ambiental de su país en su segunda edición 2003.

\section{Mario Vallejo Larios}

Mario Vallejo Larios es Doctor en Derecho Ambiental, abogado y bachiller en Ciencias Forestales. Actualmente se desempeña como Gerente de la Consultora Especializada en Legislación y Gestión Ambiental, ECOJURIS.

Recientemente ha trabajado en el diagnóstico del estado actual de REDD+ en Honduras y la evaluación de derechos de carbono, tenencia de la tierra y recursos naturales. Ha sido asesor técnico-legal para la implementación de mecanismos de compensación por servicios ecosistémicos para microcuencas de la Región Trifinio y el análisis sobre causas de deforestación y degradación 
de los bosques en Honduras y el consolidado para Centroamérica y República Dominicana, entre otros. Vallejo Larios es árbitro ambiental por Honduras para el Tratado de Libre Comercio CAFTA-DR y propuesto para el Acuerdo de Asociación UE/Centroamérica.

Ha publicado cerca de 10 libros relacionados con el tema de legislación forestal en Honduras, así como artículos para medios especializados.

\section{Marianela Rocha Zúñiga}

Marianela Rocha Zúñiga es abogada, consultora y docente, con una maestría en Evaluación de Impacto Ambiental del Instituto de Investigaciones Ecológicas de Málaga, España.

De 1997 al 2002 fue Procuradora Ambiental de Nicaragua y es fundadora de la Red de Fiscales y Procuradores Ambientales Centroamericanos. Desde el 2002 es abogada de la firma legal CCA \& Asociados, y desde el año 2010 es abogada de la firma legal regional Officium Lex.

Ha publicado sobre diversos temas ambientales, como la gobernanza de los recursos hídricos y marcos jurídico-institucionales del cambio climático en Centroamérica, México y República Dominicana, entre otros.

\section{Mario Peña Chacón}

Mario Peña Chacón es consultor, investigador y profesor de Derecho Ambiental de la Facultad de Derecho de la Universidad de Costa Rica. También es miembro de la Comisión de Derecho Ambiental de la Unión Internacional para la Conservación de la Naturaleza (UICN).

Ha escrito libros y más de cuarenta ensayos académicos publicados por revistas especializadas de España, Argentina, Brasil, Paraguay, Ecuador, Perú, México, Guatemala, Honduras, Cuba y Costa Rica. Ha sido consultor para diversas instituciones y gobiernos en la región de América Latina. En el 2010, fue galardonado con el Premio Internacional "Claritatis per tutela ambiens" otorgado por (ATINA) por logros académicos destacados en materia ambiental.

\section{Jessica Young}

Jessica Young es Licenciada en Derecho y Ciencias Políticas de la Universidad de Panamá, cuenta con una maestría en Derecho Ambiental de la Universidad del País Vasco y un posgrado en Defensoría Ambiental de la REDEA, Argentina.

Actualmente es consultora para el Banco Mundial como experta evaluadora ambiental, presidenta de la Comisión de Medio Ambiente y Recursos Naturales de la Asociación Panameña de Ejecutivos de Empresa (APEDE), miembro del Consejo Ambiental Consultivo de esta misma asociación, miembro del Consejo de la Sociedad Civil del Banco Interamericano de Desarrollo (BID) y miembro de la Junta Directiva de la Sociedad Audubon de Panamá.

Ha participado en numerosas publicaciones en sus áreas de especialidad, como la Obra Colectiva del Principio de No Regresión en el Derecho Comparado Latinoamericano, publicada por el PNUD (2013). 


\section{Bosques en Mesoamérica: un enfoque jurídico}

Grethel Aguilar Rojas 


\section{Acrónimos}

AACUE: $\quad$ Asociación entre la Unión Europea y sus Estados Miembros

ACB:: $\quad$ Asociación de Colaboración en materia de Bosques

ALIDES: $\quad$ Alianza Centroamericana para el Desarrollo Sostenible

AVAS: $\quad$ Acuerdos Voluntarios de Asociación

CAFTA-DR: Tratado de Libre Comercio entre República Dominicana,

Centroamérica y Estados Unidos

CBD: $\quad$ Convenio sobre la Diversidad Biológica

CCAD: $\quad$ Comisión Centroamericana de Ambiente y Desarrollo

CGIAR: $\quad$ Grupo Consultivo para la Investigación Agrícola Internacional

CIFOR: $\quad$ Centro para la Investigación Forestal Internacional

CITES: $\quad$ Convención sobre el Comercio Internacional de Especies Amenazadas de Fauna y Flora Silvestres

CMDS: $\quad$ Cumbre Mundial sobre el Desarrollo Sostenible del 2002

CMNUCC: Convención Marco de las Naciones Unidas sobre el Cambio Climático

CoC: $\quad$ Certificación de la Cadena de Custodia

COFLAC: Comisión Forestal para América Latina y el Caribe

CONAFOR: Comisión Nacional Forestal

CONEVAL: Consejo Nacional de Evaluación del Desarrollo de la Política Social

ECA-GIRH: Estrategia Centroamericana de Gestión de Recursos Hídricos

EFCA: $\quad$ Estrategia Forestal Centroamericana

EMSA: $\quad$ Estrategia Mesoamericana de Sustentabilidad Ambiental

ERAS: $\quad$ Estrategia Regional Agroambiental y de Salud

ERB: $\quad$ Estrategia Regional para la Conservación y Uso Sostenible de la Biodiversidad

ERCC: $\quad$ Estrategia Regional de Cambio Climático

ER-PIN: $\quad$ Programa de Reducción de Emisiones

EUTR: $\quad$ Reglamento de la Madera de la Unión Europea

FAO: $\quad$ Organización de las Naciones Unidas para la Alimentación

FCPF: $\quad$ Fondo Cooperativo para el Carbono de los Bosques

FIB: $\quad$ Foro Intergubernamental sobre los Bosques

FIP: $\quad$ Programa de Inversión Forestal

FLEGT: $\quad$ Plan de Acción sobre la Aplicación de las Leyes, Gobernanza

y Comercios Forestales

FSC: $\quad$ Consejo de Administración Forestal

OIMT: $\quad$ Organización Internacional de Maderas Tropicales

OMC: $\quad$ Organización Mundial del Comercio

ONU: $\quad$ Organización de las Naciones Unidas 
PAFCA: $\quad$ Plan de Acción Forestal para Centroamérica

PARCA: $\quad$ Plan Ambiental para la Región Centroamericana

PEFC: $\quad$ Asociación para la Certificación Española Forestal

PERCON: Programa Regional de Conectividad

PERFOR: Programa Estratégico Regional para el Manejo de los Ecosistemas Forestales

PROMEBIO: Programa Regional de Monitoreo de la Biodiversidad

RAMSAR: Convención Relativa a los Humedales de Importancia Internacional

SEMARNAT: Secretaría de Medio Ambiente y Recursos Naturales

SG-SICA: Secretaría General del Sistema de Integración Centroamericana

UE: $\quad$ Unión Europea

UICN: $\quad$ Unión Internacional para la Conservación de la Naturaleza

UMF: $\quad$ Unidad de Manejo Forestal

UNFF: $\quad$ Foro de las Naciones Unidas sobre los Bosques

USAID: $\quad$ Agencia de los Estados Unidos para el Desarrollo 


\section{Bosques en Mesoamérica: un enfoque jurídico}

\section{Introducción y contexto}

Ahondar en las implicaciones jurídicas de lo que se ha conocido como la "ilegalidad de los bosques" es una tarea necesaria si buscamos la reducción de la deforestación y degradación de nuestros ecosistemas. Al indicar "ilegalidad de los bosques" hacemos alusión a toda aquella madera que se obtiene o comercializa violando las leyes existentes en un país, incluyendo aquí las obligaciones contenidas en acuerdos y convenios internacionales.

Es importante desde un inicio aclarar que no toda corta del bosque es ilegal. Más bien, las actividades ilegales -es decir, las que no cumplen con el ordenamiento jurídico para el manejo apropiado del bosque- se han convertido en una herramienta de transición que permite en muchos casos un cambio en el uso del suelo, pasando de terrenos forestales a terrenos agrícolas o fincas ganaderas. La tala ilegal y el trasiego ilegal de madera entre países son una causa directa de la degradación ambiental, pero no la principal razón de la deforestación en los países de la región. La consecuencia de la tala ilegal en el área toma un espectro mucho más amplio cuando se entiende que no solo se trata de deforestación del bosque, sino en muchos casos de abrir el paso a la pérdida total del bosque para que la tierra sea utilizada con otros usos ${ }^{1}$.

Es por ello que al abordar el tema de tala ilegal no se puede pensar únicamente en operadores jurídicos o funcionarios de instituciones forestales, sino en un esfuerzo que involucre múltiples sectores, incluyendo entre otros el sector agrícola, hacienda y aduanas, comunidades y el sector privado. No se podría pensar que solo con buenas leyes y políticas el objetivo de detener la tala ilegal se va a cumplir. Esta es más una tarea que debe darse a profundidad de la mano del soporte técnico y aprendizaje acumulado desde diferentes sectores.

El presente documento busca recoger la información referente a los esfuerzos que ha realizado la región mesoamericana por avanzar en fortalecer el marco político y legal para la conservación y manejo sostenible de los bosques. No pretende ser un relato de cada país, ya que esto ha sido tarea de los capítulos nacionales.

Las leyes y políticas forestales han evolucionado lenta, pero positivamente. Hoy podemos afirmar que la utilización de los bosques es regulada no solo porque son proveedores de madera, sino por su basta oferta de bienes y servicios ecosistémicos que benefician a la humanidad, como por ejemplo: agua, recreación, fauna, flora, captación y almacenamiento de carbono, energía renovable y su invaluable relación cultural con pueblos indígenas y comunidades locales. Sin embargo, persiste en algunos países el reclamo desde la perspectiva de los empresarios forestales y comunidades

1. Un estudio reciente de la Unión Europea estima que la mayor deforestación en países tropicales se ha dado por la expansión agrícola. Algunos ejemplos dados son soya, maíz, palma de aceite, arroz, caña de azúcar y ganadería (carne y cuero). Citado por Brack, D., Baily, R. (2013). 'Ending Global Deforestation Policy Options for Consumer Countries', Pág. 3. Chatham House, Forest Trends. Tomado de European Commission (2013). The Impact of EU Consumption on Deforestation: Comprehensive Analysis of the Impact of EU Consumption on Deforestation, Pág. 20. 
manejadoras del bosque asociado a que los marcos regulatorios existentes -en algunos casos por sus complejidades y tiempo de duración en los trámites para permisos forestales- lejos de promover el uso legal de los bosques, incentivan el incremento de la ilegalidad y por consiguiente, aumenta la degradación de los bosques.

En el mundo, entre los años 2000 y el 2010 desaparecieron unas 130 millones de hectáreas de bosques, 40 millones de las cuales eran bosques primarios². México tiene un territorio de 194,3 millones de hectáreas con 64,8 millones de hectáreas en bosques ${ }^{3}$ que representan $33 \%$ del territorio mexicano. En relación con América Latina, México ${ }^{4}$ es uno de los países con mayor cobertura forestal. Por su parte, Centroamérica posee una medida terrestre de 51 millones de hectáreas con una cobertura boscosa de 19,5 millones de hectáreas que representan $38 \%$ de su territorio ${ }^{5}$.

En el informe de la Organización de las Naciones Unidas para la Agricultura y la Alimentación (FAO) del año 2009 se indica que en Centroamérica la pérdida neta de superficie forestal disminuyó entre el 2000 y el 2005 en comparación con la década anterior, y Costa Rica logró un incremento neto de la superficie forestal ${ }^{6}$. No obstante, en términos porcentuales, la región presenta una de las mayores tasas de desaparición forestal del mundo ${ }^{7}$. Centroamérica incrementó su pérdida neta de 54.000 hectáreas anuales en la década de 1990-2000 a 74.000 hectáreas anuales entre el 2000 y el $2010^{8}$. Según las cifras del $2010^{9}$, México y Centroamérica pasaron de una cobertura boscosa de 86,2 millones de hectáreas en el 2005 a 84,3 millones de hectáreas en el 2010.

En México, en el año 1993 se contaba aproximadamente con 69,2 millones de hectáreas de bosques; para el 2005 esto disminuyó a 65,5 millones de hectáreas y en el 2010 la superficie de ecosistemas forestales se estimó en 64,8 millones de hectáreas ${ }^{10}$, todo lo que indica una pérdida importante de bosques en el tiempo ${ }^{11}$. Estos datos se suman a la estimación de que los bosques plantados aumentarán, fomentados por las inversiones y la demanda mundial de madera. Sin embargo, la creciente tasa de plantación no será suficiente para compensar la continua deforestación ${ }^{12}$.

La pérdida de la cobertura forestal es un hecho que ha sido reconocido como uno de los retos de la región que se asocia con las altas tasas de pobreza, los incendios forestales, el avance de la

2. FAO (2010). Datos estadísticos de Evaluación de los Recursos Forestales Mundiales, Roma Italia.

3. FAO define como áreas de bosque tierras que se extienden por más de 0,5 hectáreas dotadas de árboles de una altura mayor a los 5 metros y una cubierta de copas superior a 10\%, o de árboles capaces de alcanzar esta altura in situ. FAO (2008). Directrices para la elaboración de informes nacionales destinados a ERF 2010.

4. FAO (2006). Tendencias y perspectivas del sector forestal en América Latina y el Caribe, Roma, Italia.

5. FAO (2010). Evaluación de los Recursos Forestales Mundiales. Roma, Italia. Datos obtenidos de Anexos Tabla 1. Datos básicos sobre países y áreas, Pág. 228, Tabla 2. Extensión de los bosques y otras tierras boscosas, Págs. 234, 235.

6. FAO (2009). Situación de los Bosques del Mundo. Roma, Italia.

7. América Central presenta una de las mayores tasas de desaparición forestal del mundo en relación con el resto de las subregiones, más de $1 \%$ anual en el período entre el 2000 y el 2005. FAO (2009). Situación de los Bosques del Mundo. Roma, Italia, Pág 37.

8. $\quad$ FAO (2011). Situación de los Bosques del Mundo. Roma, Italia, Pág. 19.

9. FAO (2010). Situación de los Bosques del Mundo. Roma, Italia, Págs. 234, 235.

10. ibid. Pág. 235

11. SEMARNAT (2010). Visión de México sobre REDD+ Hacia un Estrategia Nacional. México, Pág 12.

12. FAO (2009). Situación de los Bosques del Mundo. Roma, Italia, Pág. 43. 
frontera agrícola y eventos naturales como los huracanes. La pobreza tiene un peso importante en la utilización ilegal de la madera, ya que las personas buscan una fuente económica para su subsistencia y a falta muchas veces de opciones, esto se presenta como una solución rápida. En Centroamérica hay 20 millones de personas pobres, lo que representa $46 \%$ de la población ${ }^{13}$ y en México, ${ }^{14}$ los números indican 53,3 millones de personas pobres, un 45,5\% de la totalidad sus habitantes ${ }^{15}$. Además, la desigualdad social y -en algunos casos- la corrupción han dado como resultado el deterioro de los ecosistemas y el aumento de conflictos sociales asociados con los derechos a la tierra y los recursos.

El cambio del uso del suelo es una de las causas más importantes de deforestación de la región. Este cambio es permitido legalmente en algunos países del área y en otros no es permitido, pero se da por medio de la extracción ilegal de madera que prepara el terreno para un cambio de uso. Este cambio da paso en muchos casos al cultivo de productos agrícolas y ganadería, que son a su vez exportados a otros países.

En realidad si aplicáramos la lógica de la trazabilidad en productos agrícolas, algunos podrían ser parte de una cadena de acciones ilegales, en el caso de que el bosque se haya talado ilegalmente para hacer un cambio de uso del suelo. Pero esta es una discusión que parece recién empezar. Desde el ámbito jurídico resulta de vital importancia explorar si estas "mercancías" -mejor conocidas como "commodities"16 - asociadas con actos ilegales de deforestación podrían tener un tratamiento especial en el ámbito nacional o si esto es algo solo relativo a la esfera comercial de las exportaciones.

La idea de considerar la relación entre el sector de producción agrícola y ganadera dentro de lo que se podría considerar actos ilegales de deforestación o manejo no sostenible del bosque por conversión de tierras es un tema delicado y poco abordado. Si incluso esto se liga a las exportaciones, se tendría además que sumar a la ecuación las regulaciones de la Organización Mundial del Comercio. Se podría pensar en regulaciones para mercados de productos certificados que tomen en consideración esta variable, promover el consumo responsable o políticas responsables de compra a nivel de país. De hecho, hay empresas privadas que ya están avanzando implementado prácticas que promuevan la no deforestación ${ }^{17}$. Pero lo cierto del caso es que mientras no existan normas claras y vinculantes que enlacen agricultura, ganadería y bosques seguiremos haciendo invisible un problema que ya está demostrando graves consecuencias. La pérdida del bosque es sin dudas un reto que debe enfrentarse desde diferentes sectores.

13. Programa Estado de la Nación (2013). Pobreza rural en Centroamérica. San José, Costa Rica, Págs. 15, 16.

14. Consejo Nacional de Evaluación del Desarrollo de la Política Social (CONEVAL). 'Resultados de pobreza en México 2012 a nivel nacional y por entidades federativas 2013'. [sitio web]. <http://www.coneval.gob.mx/ Medicion/Paginas/Medici\%C3\%B3n/Pobreza\%202012/Pobreza-2012.aspx> Accedido el 29 de mayo de 2014.

15. ibid. Se debe tomar en consideración que de acuerdo con datos de la CONEVAL, en México en el 2013 la población en pobreza extrema se redujo de 13 millones de personas a 11,5 millones.

16. "Commodity" es cualquier producto destinado a uso comercial. Para el caso de la materia abordada, se trata de productos agrícolas, plantas ornamentales o carne y productos de cuero.

17. Al respecto consultar: Chatham House. 'Energy, Environment and Resources Summary. Deforestationrelated Commodity Supply Chain Controls'. [pdf online], (abril 2013). <http://www.illegallogging.info/sites/ default/files/Deforestation-related_commodity_supply_chains_0.pdf> 


\section{Gobernanza Forestal}

No se podría abordar el tema de la ilegalidad en el sector forestal sin pasar por la "gobernanza forestal o gobernanza de los bosques", sobre lo cual no hay una única definición y tiende a confundirse con la gobernabilidad. La gobernanza es entendida más fácilmente como el proceso de toma de decisiones y cómo estas son tomadas involucrando así a las autoridades estatales y a los ciudadanos.

La "buena gobernanza" sería entonces si se caracteriza por la transparencia, la participación, la gestión eficiente y eficaz, y la distribución justa y equitativa de los beneficios que se obtengan de los bosques. Según un estudio ${ }^{18}$ reciente, la buena gobernanza forestal tiene tres pilares: 1) Marcos políticos, jurídicos, institucionales y reglamentarios, incluidos aquí los de sectores que pudieran afectar el bosque. 2) Procesos de planificación y toma de decisiones, incluida la transparencia y el adecuado funcionamiento de las instituciones. 3) La implementación, aplicación y conformidad de los instrumentos legales que incluye el grado de implementación de los marcos jurídicos su eficacia y eficiencia. Por otro lado, sobre el concepto de "gobernabilidad" tampoco existe una única definición. Para algunos es la posibilidad de un colectivo o grupo para ser gobernado; para otros es sinónimo de gobernanza. En términos generales, podríamos decir que la gobernabilidad hace alusión al estilo o forma de gobierno, a la capacidad de un gobernante de dar respuesta a los retos o concretar sus planes y políticas que presupone una aceptación y legitimidad ${ }^{19}$. Es la posibilidad de poner en ejecución ante un grupo de individuos los acuerdos alcanzados.

Cuando se habla de gobernanza forestal, tendríamos entonces que buscar que la manera, el estilo o el arte de gobernar desde lo local hasta lo nacional y viceversa busque participación y consensos con la sociedad civil, transparencia en la toma de decisiones, respeto, reconocimiento de derechos y una distribución justa y equitativa de los beneficios que se perciben de los bosques. No escapamos aquí de pensar si realmente los países van por el camino acertado o si será necesario fortalecer los instrumentos y hacer reformas legales o políticas para una buena gobernanza forestal que ayude a atacar más de cerca las causas de deforestación y la degradación de los bosques. Es claro que la deforestación está asociada también a problemas ineherentes a los sistemas de gobernanza ineficaces o débiles.

Por ejemplo, uno de los aspectos que se podrían impulsar en camino a esta buena gobernanza forestal es reconocer que los bosques de la región coinciden en muchos casos con áreas protegidas o territorios que son administrados, o donde habitan pueblos indígenas, por lo que una buena gobernanza de los bosques debe incluir una plena participación de las comunidades y pueblos indígenas y el reconocimiento de sus derechos ${ }^{20}$.

18. FAO (2011). Programa sobre los Bosques. Marco para la Evaluación y Seguimiento de la Gobernanza Forestal. Roma, Italia, Págs. 12 y 13.

19. Por gobernanza se entiende: "Arte o manera de gobernar que se propone como objetivo el logro de un desarrollo económico, social e institucional duradero, promoviendo un sano equilibrio entre el Estado, la sociedad civil y el mercado de la economía". La gobernabilidad se define como "cualidad de lo gobernable", es decir, que puede ser gobernado. Diccionario de la Real Academia Española.

20. Al respecto se han dado importantes alcances en Panamá, Honduras y Nicaragua en donde el reconocimiento de algunos territorios indígenas se ha realizado y se está -aunque poco a poco- en un proceso de cómo manejar mejor los bosque existentes en estos territorios. 
También se podría decir que la buena gobernanza forestal conlleva la necesidad de seguridad jurídica para las inversiones, leyes claras que puedan ser seguidas, cumplimiento efectivo, políticas que impidan la deforestación e instituciones fuertes que impulsen un manejo forestal sostenible de la mano de los ciudadanos.

De los análisis de los países se rescata que si bien ha habido desde los años 90 a la fecha importantes avances en el fortalecimiento de las instituciones estatales que realizan una gestión de los bosques, la realidad es que en la mayoría de los países persisten traslapes de competencias, debilidades de índole administrativo y de control. En muchas de esta naciones la responsabilidad de la protección y manejo sostenible de los bosques se divide entre varias instituciones según sea la tarea y esto ocasiona traslapes de funciones entre diversas instituciones ambientales y una dispersión en las acciones nacionales. Podríamos afirmar que ante los retos que enfrenta la región se hace urgente un fortalecimiento institucional en materia ambiental en donde el manejo y conservación de los bosques sea visto como parte del ecosistema y del paisaje natural, siendo un elemento aglutinador de esfuerzos institucionales concertados.

La región tiene la oportunidad de hacer una protección efectiva de sus bosques para beneficio de sus habitantes que viven y dependen de ellos, apoyando el reconocimiento de derechos, la equidad, la legalidad y el fortalecimiento institucional, logrando así una buena gobernanza en el sector forestal.

\section{Una mirada a la situación de la legalidad de los bosques}

Es claro que -a pesar de que los países de la región han realizado importantes esfuerzos por avanzar en la construcción del marco político y legal para la conservación y uso sostenible de los bosquesprevalece la necesidad de hacer con mayor rigurosidad un monitoreo y control de los procesos que llevan a la legalidad en el uso y comercio de la madera. Pareciere al final que no se trata de un asunto de más requisitos, sino de buscar la eficiencia y eficacia de la normativa existente.

El comercio legal de madera que proviene de un uso sostenible de los bosques se ha convertido en una prioridad para alcanzar las metas de conservación de grandes áreas boscosas con las que todavía cuenta México y Centroamérica. Expertos han indicado que “... la tarea está en la verificación de la legalidad de los procesos, más que en la medición de la ilegalidad”21.

Al particular, resulta relevante que los lectores se adentren en los capítulos por país presentados en esta obra que llevará a descubrir que, dependiendo del país, muchas veces la posibilidad de realizar acciones legales va de la mano con las razones de por qué se da la ilegalidad. Por ejemplo, cuando los procesos son complejos, llenos de requisitos, con amplios costos y un sistema preventivo y sancionatorio débil, los usuarios en muchos casos optan por la vía de la ilegalidad. En este sentido, dilucidar las causas de la ilegalidad nos podría llevar a procesos más apegados a las necesidades y realidades actuales. Sería necesario entonces detectar en las leyes, políticas y en la práctica cuáles son los factores que contribuyen a la ilegalidad y con ellos a la deforestación y degradación forestal. Esto implica una tarea que -aunque debe estar liderada por el Estado- tendría que ir de la mano con un diálogo amplio y abierto con el sector forestal privado, las comunidades locales y los pueblos indígenas.

21. Navarro G., Santamaría O. y otros. Análisis del Comercio Internacional de Productos de Madera y su Gobernanza Administrativa. Pág. 4 
Todo apunta a que la simplificación de políticas y leyes que faciliten por un lado conservar los recursos naturales y por el otro, permitir los aprovechamientos forestales sostenibles podría ser una buena herramienta. Sin embargo, esto bajo ningún motivo debería utilizarse para retroceder en la legislación ya avanzada que protege el recurso y mucho menos, eliminarla.

Aquí hacemos un llamado al principio de "no regresión" en materia ambiental que está avanzando para convertirse en uno de los principios del derecho internacional ambiental. Este principio implica que no se deben emitir directrices, reglamentos o leyes que disminuyan los límites ya alcanzados en normas jurídicas anteriores o en la jurisprudencia. Es decir, los logros ya conseguidos deben permanecer y ser vinculantes. La no regresión está expresamente dispuesta en el Tratado de Libre Comercio entre República Dominicana, Centro América y los Estados Unidos de Norteamérica (CAFTA), que indica ${ }^{22}$ “... las Partes reconocen que es inapropiado promover el comercio o la inversión mediante el debilitamiento o reducción de las protecciones contempladas en su legislación ambiental interna. En consecuencia, cada Parte procurará asegurar que no dejará sin efecto o derogará, ni ofrecerá dejar sin efecto o derogar dicha legislación de una manera que debilite o reduzca la protección otorgada por aquella legislación como una forma de incentivar el comercio con otra parte...". También la Unión Europea, en su Resolución del Parlamento Europeo del 29 de septiembre de 2011 sobre la elaboración de una posición común de la UE en la preparación de lo que fue la Conferencia de las Naciones Unidas sobre el Desarrollo Sostenible (Río +20), solicita el reconocimiento del principio de no regresión en el contexto de la protección del medio ambiente y los derechos fundamentales.

No sorprende que -aunque los reportes de país contenidos en esta obra indiquen dificultades para conseguir cifras oficiales sobre el número de denuncias por delitos asociados con el incumplimiento de la legislación forestal- sí se denota de la mayoría de los datos obtenidos que existe un patrón común en el hecho de que en las acciones legales presentadas por delitos de tala ilegal o en general en materia de ambiente el rango de sentencias condenatorias o tan solo de procesos concluidos es sumamente bajo $^{23}$. Una gran mayoría de las causas es desestimada y archivada antes de que llegue a su fase final, alegando obstáculos legales para el desarrollo del proceso. Otra gran parte no es condenatoria entre otras causas por falta de pruebas, inadecuada recolección de las pruebas o presentación incorrecta de la demanda.

Pareciere que -a pesar que las normas jurídicas están en su lugar y pueden ser utilizadas por los ciudadanos como un instrumento que permita denunciar actos ilícitos contra el ambiente, incluida la tala ilegal-sería necesario y urgente hacer un profundo análisis de la eficacia y efectividad de las denuncias. Esto conlleva también a pensar en el costo de estas acciones legales que, en muchos casos, involucran el tiempo y recursos de funcionarios asociados con Ministerios de Ambiente, oficinas forestales, Ministerios de Agricultura y sociedad civil, que se deben sumar al costo del procesamiento de una denuncia en las instancias judiciales. Si se tuviera que hacer una relación

22. CAFTA, Capítulo 17, Artículo 17.2.

23. Por ejemplo, para el año 2012 se presentaron 1.031 denuncias por delitos relacionados con incumplimiento de la Ley Forestal de Costa Rica; de estas, 26 han resultado condenatorias y 56 absolutorias. Fuente: Sección de Estadística, Departamento de Planificación, Poder Judicial de Costa Rica, citado por Mario Peña (2014). Informe para Costa Rica: La Ruta de la Legalidad de la Madera. 
costo-beneficio, es muy probable que nos demos cuenta de que el costo económico y el desgaste humano está siendo mayor que los resultados obtenidos.

A pesar de ello, también debemos reconocer que los jueces de la región han generado a través de los años una importante gama de jurisprudencia ${ }^{24}$ que bien se podría difundir con impactos positivos en la región y en el accionar de los funcionarios de la administración forestal.

Por ejemplo, en materia de reparación del daño ambiental, los tribunales de justicia de Costa Rica han remarcado reiteradamente que: "Quién deteriore el recurso suelo independientemente de la existencia de culpa o dolo o del grado de participación será responsable de indemnizar en la vía judicial que corresponda y de reparar los daños causados al ambiente y a terceros afectados ${ }^{25}$ ". Otro ejemplo, lo da la Corte Suprema de Justicia de Nicaragua en su Sentencia N ${ }^{\circ} 12$ del 27 de febrero de 1997, en el que la Sala Constitucional dice que en el Artículo 181 de la Constitución Política de Nicaragua señala que "... las concesiones y los contratos de explotación racional de los recursos naturales que otorga el Estado en las Regiones Autónomas de la Costa Atlántica, deberán contar con la aprobación del Consejo Regional Autónomo correspondiente...”. Indica la Sala además que las concesiones y contratos de uso de los recursos naturales que no cumplan con esta disposición no serán válidos. Hace así la Corte Suprema un reconocimiento explícito a los derechos de los pueblos indígenas y comunidades étnicas de esta región atlántica para decidir sobre la utilización o no del recurso forestal.

El Principio Precautorio o indubio pro natura ha sido ya aplicado en varios casos en la región y este indica que "cuando haya peligro de daño grave e irreversible, la falta de certeza científica absoluta no deberá utilizarse como razón para postergar la adopción de medidas eficaces en función de los costos para impedir la degradación del medio ambiente"26. Este principio ha tomado especial importancia a la hora de resolver conflictos relacionados con los bosques. Así, por ejemplo, la Corte de Constitucionalidad de la República de Guatemala, en el expediente 2523-2008 de amparo, por la internación en aguas nacionales de una nave remolcada por un buque, con la pretensión de ingreso a un astillero para desguace en playa con el fin de reciclar materiales ferrosos, el juez ordena que no pueden realizar el acto y por lo tanto, se tienen que quedar en la bahía hasta que el Ministerio de Ambiente se pronuncie sobre el caso. La Sala Constitucional de la Corte Suprema de Costa Rica en su voto 6322-2003 ha dicho al respecto “... en el caso de que exista un daño grave o irreversible o una duda al respecto se debe adoptar la medida de precaución e inclusive posponer la actividad de que trate. Lo anterior debido a que en materia ambiental la coacción a posteriori resulta ineficaz, por cuanto de haberse producido ya las consecuencias biológicas y socialmente nocivas, la represión podrá tener una transcendencia moral pero difícilmente compensará los daños ocasionados al ambiente".

Por otro lado, los jueces han recalcado en diversas sentencias la primacía del bien común sobre el particular, el derecho a un medio ambiente sano, adecuado y equilibrado como prioridad para la vida y la salud de la población, la observancia de las obligaciones internacionales adquiridas y lo

24. Al respecto de jurisprudencia regional se puede consultar USAID. Programa de Excelencia Laboral y Ambiental para el CAFTA (2011). Compendio Regional de Jurisprudencia Ambiental.

25. Costa Rica, Tribunal de Casación Penal. Voto 366 del 2003.

26. Principio 15 de la Declaración de Río sobre Medio Ambiente y Desarrollo de 1992. 
establecido en la normativa ordinaria, respecto a la protección y mejoramiento del medio ambiente y los recursos naturales y culturales ${ }^{27}$.

Será necesario también ahondar en el principio de seguridad jurídica, que hace alusión a que se conozca y sé respete lo ya estipulado en la ley y así amparado por el estado de derecho. El cumplimiento de este principio es una garantía que se da al individuo por parte del Estado de que sus derechos basados en la legislación vigente no serán violentados y de así pasar, sería resarcido por el Estado reconociendo el daño causado. La seguridad jurídica está establecida en los países bajo diferentes normas. En general, podríamos decir que se relaciona con el derecho a la información, el hecho de que la ley no pueda ser aplicada retroactivamente, la necesidad de establecer concretamente lo que constituye delitos y sus penas -más conocido como tipificación legal-, la caducidad de las acciones y la prescripción de las acciones legales, las garantías constitucionales y la cosa juzgada. Cuando las reglas cambian según se interpreten o cuando una misma situación es resulta de diferentes formas sin amparo a una ley que les resguarde o cuando se cambia una ley apegada a una situación específica y no en respuesta a la necesidad de llevar la ley al ritmo de los cambios y necesidades sociales, se podría estar también frente a una violación del principio de seguridad jurídica que en algunos casos ha imposibilitado la participación del sector privado y comunidades en acciones de restauración del paisaje forestal, en acciones que eviten la deforestación y la degradación, o limitado las inversiones en el manejo forestal sostenible. Las empresas, comunidades y las personas en general quieren tener certeza, seguridad de que están actuando conforme a un estado de derecho y que esas normas tienen estabilidad, previsibilidad y son cumplidas.

Los bosques, su conservación y manejo han sido objeto de procesos judiciales en todos los países y existe un marco legal que los ampara. Sin embargo, se hace necesario que la región cree espacios para que los funcionarios de la administración judicial compartan sus experiencias, avances y retrocesos en la implementación de las leyes ambientales. Los jueces, fiscales y defensores públicos pueden ser grandes aliados en la tarea de alcanzar la legalidad en el uso sostenible de los bosques. Si bien es cierto hay leyes que pueden y deben actualizarse, lo que en este momento cobra mayor sentido es redoblar esfuerzos en implementar con eficacia lo que se ha alcanzado.

Sin embargo resulta necesario decir que aún teniendo un conjunto de leyes adecuadas e implementadas, un sistema judicial eficaz y funcionarios de la administración del Estado capacitados, esto no será suficiente porque es indispensable que las comunidades y los pueblos indígenas cuenten con sus derechos reconocidos en el tema de tierras, territorios y recursos naturales. De esta forma pueden convertirse en actores empoderados y organizados en la conservación y utilización sostenible de los bosques.

\section{El Derecho Internacional y los bosques}

En la Conferencia de las Naciones Unidas sobre el Medio Ambiente y el Desarrollo de 1992, los países suscribieron una serie de acuerdos que -aunque sin ser vinculantes desde la perspectiva jurídica- los comprometen a establecer una alianza en materia ambiental y de desarrollo sostenible que fomente la cooperación entre los Estados y las sociedades. Durante la Conferencia se aprobó

27. Ejemplo Guatemala, Corte Constitucional Sentencia 1.4.2008 
por parte de los países la Declaración de Río sobre Medio Ambiente y Desarrollo, que fue rubricada junto con otros dos documentos: el Programa 21 y la Declaración de Principios Relativos a los Bosques $^{28}$. Ya en sus Principios 1 y 2 de la Declaración los países dejan claro el derecho soberano de explotar sus recursos forestales en aplicación de su propia política ambiental e indican que el costo de la conservación debe ser compartido equitativamente por los países mediante una mayor cooperación internacional.

También el Programa 21 en su capítulo 11, denominado "Lucha contra la deforestación", indica que existen deficiencias en las políticas que apoyan el desarrollo de los múltiples servicios y funciones de los bosques. En este sentido, plantea varias acciones concretas para su seguimiento, dentro de las que destacan: la necesidad del fortalecimiento de las instituciones nacionales que se encargan de asuntos forestales y el fortalecimiento y aumento de la capacidad para formular e implementar con eficacia políticas, planes, programas, investigaciones y proyectos de ordenación, conservación y desarrollo sostenible de todos los tipos de bosques. Aunque han pasado ya más de 20 años desde que estas acciones se plantearon como prioritarias y se pueden reportar algunos avances, siguen siendo asuntos urgentes de resolver.

En junio del 2012, como fruto de la Conferencia Río+20, los jefes de Estado y de gobierno se pusieron de acuerdo para aprobar el documento llamado "El Futuro que Queremos: una visión común'29", resaltando que los beneficios sociales y económicos de los bosques crean oportunidades para abordar los retos del desarrollo sostenible. Apoyaron las políticas intersectoriales e interinstitucionales que promuevan la ordenación sostenible de los bosques y las medidas para detener y revertir la deforestación y degradación, entre ellas, la promoción del comercio de productos forestales obtenidos lícitamente. Solicitaron que se aumenten los esfuerzos para reforzar los marcos de gobernanza de los bosques y sus medios de aplicación y recalcaron la importancia de iniciativas en curso, como la reducción de las emisiones derivadas de la deforestación y la degradación de los bosques en los países en desarrollo (REDD).

Los países además crearon a través de los años diferentes órganos que han ido evolucionando en el tiempo. El Grupo Intergubernamental Especial sobre los Bosques fue establecido por la decisión 1995/226 del Consejo Económico y Social. A este grupo de trabajo en el seno de Naciones Unidas le siguió el Foro Intergubernamental sobre los Bosques (FIB), establecido por la resolución 1997/65 del mismo Consejo y se reunió anualmente de 1997 al 2000. Para el año 2000 las labores a un más alto nivel son encomendadas al Foro de las Naciones Unidas sobre los Bosques (UNFF), creado por la resolución 2000/35 con el objetivo de "fortalecer el compromiso político con la ordenación, la conservación y el desarrollo sostenible de todos los tipos de bosques".

A nivel regional se creó en 1948 la Comisión Forestal para América Latina y el Caribe (COFLAC), establecida por la Organización de las Naciones Unidas para la Agricultura y la Alimentación (FAO) para proporcionar un foro técnico y político que permita debatir los asuntos forestales. México y

28. La Declaración se autoriza sin fuerza jurídica obligatoria como un instrumento no vinculante que sirve para el consenso mundial relacionado con el ordenamiento, la conservación y el desarrollo sostenible de los bosques.

29. Conferencia de las Naciones Unidas sobre el Desarrollo Sostenible, Río+20. 'El Futuro que Queremos: una visión común'. Río de Janeiro, Brasil, 20-22 de junio de 2012. Anotaciones relacionadas con el Párrafo 193. 
todos los países de Centroamérica son miembros de esta Comisión. En el ámbito centroamericano, la Comisión Centroamericana de Ambiente y Desarrollo (CCAD), como órgano del Sistema de Integración Centroamericano (SICA), cuenta con el Comité Técnico ${ }^{30}$ de Bosques que reúne a las autoridades forestales de la región.

Existe además un número importante de grupos de trabajo a la luz de los principales convenios internacionales que trabajan los temas relacionados con los bosques con la participación de los países de la región. Pareciere entonces que hay espacios para que los países puedan dialogar sobre sus retos y avances con respecto a los bosques. Lo que resulta un reto en la actualidad es hacer más eficientes y efectivas estas participaciones por parte de los Estados, tener menos reuniones de diferentes entidades consolidando en la medida de las posibilidades estos esfuerzos para que sean menos reuniones que se enfoquen en programas concretos y promover el financiamiento de estos espacios para la participación de países en desarrollo.

Aunque existe una importante gama de convenios que tratan temas relacionados con los bosques, hay convenios internacionales que para la región resaltan por su importancia: el Convenio sobre la Diversidad Biológica (CBD), la Convención Marco de las Naciones Unidas sobre Cambio Climático y la Convención sobre el Comercio Internacional de Especies Amenazadas de Fauna y Flora Silvestres (CITES).

A continuación presentamos una tabla que describe, sin incluir convenios regionales, los más importantes instrumentos desde el ámbito internacional, haciendo una relación con su adhesión y ratificación por parte de los países de la región.

30. Los comités técnicos se establecen en atención al Artículo IX del Convenio Constitutivo de la Comisión Centroamericana de Ambiente y Desarrollo (1989). 


\begin{tabular}{|c|c|c|c|c|c|c|c|c|c|c|}
\hline \multirow{2}{*}{$\begin{array}{l}\text { Convenio } \\
\text { Convención }\end{array}$} & \multirow{2}{*}{$\begin{array}{l}\text { Aproba- } \\
\text { ción }\end{array}$} & \multirow{2}{*}{$\begin{array}{l}\text { Entrada } \\
\text { en vigor }\end{array}$} & \multicolumn{8}{|c|}{ Ratificación/adhesión por país ${ }^{31}$} \\
\hline & & & Méx & Bel & ES & Guat & Hon & $\mathrm{Ni}$ & CR & $\mathrm{Pa}$ \\
\hline $\begin{array}{l}\text { Convenio } \\
\text { Internacional } \\
\text { de las Maderas } \\
\text { Tropicales }\end{array}$ & $27 / 01 / 2006$ & 07/12/2011 & $X 2008$ & - & - & X 2011 & 2011 & - & 2013 & $X 2008$ \\
\hline $\begin{array}{l}\text { Convención } \\
\text { Marco de las } \\
\text { Naciones Unidas } \\
\text { sobre el Cambio } \\
\text { Climático }^{32}\end{array}$ & $09 / 05 / 1992^{33}$ & $21 / 03 / 1994$ & 1994 & 1995 & 1996 & 1996 & 1996 & 1996 & 1994 & 1995 \\
\hline $\begin{array}{l}\text { Protocolo de } \\
\text { Kyoto }\end{array}$ & $11 / 12 / 1997$ & $16 / 02 / 2005$ & 2005 & 2005 & 2005 & 2005 & 2005 & 2005 & 2005 & 2005 \\
\hline $\begin{array}{l}\text { Convenio sobre } \\
\text { la Diversidad } \\
\text { Biológica (CBD) }\end{array}$ & 05/06/1992 & 29/12/1993 & 1993 & 1993 & 1994 & 1995 & 1995 & 1995 & 1994 & 1995 \\
\hline $\begin{array}{l}\text { Protocolo de } \\
\text { Nagoya }^{34} \text { (CBD) }\end{array}$ & $29 / 10 / 2010$ & pendiente $^{35}$ & 2012 & - & - & 2014 & 2012 & - & - & 2012 \\
\hline $\begin{array}{l}\text { Convenio } 169 \\
\text { sobre Pueblos } \\
\text { Indígenas y } \\
\text { Tribales en Países } \\
\text { Independientes }\end{array}$ & $27 / 06 / 1989$ & 05/09/1991 & 1990 & - & - & 1996 & 1995 & 2010 & 1993 & - \\
\hline $\begin{array}{l}\text { Convenio de } \\
\text { Viena para la } \\
\text { Protección de la } \\
\text { Capa de Ozono }{ }^{36}\end{array}$ & 22/03/1985 & 22/09/1988 & 1987 & 1997 & 1992 & 1987 & 1993 & 1993 & 1991 & 1989 \\
\hline $\begin{array}{l}\text { Convención sobre } \\
\text { la Protección } \\
\text { del Patrimonio } \\
\text { Mundial, Cultural } \\
\text { y Natural }{ }^{37} \\
\end{array}$ & $16 / 11 / 1972$ & 17/12/1975 & 1984 & 1990 & 1991 & 1979 & 1979 & 1979 & 1977 & 1978 \\
\hline $\begin{array}{l}\text { Convención sobre } \\
\text { el Comercio } \\
\text { Internacional } \\
\text { de Especies } \\
\text { Amenazadas } \\
\end{array}$ & 03/03/1973 & 01/07/1975 & 1991 & 1981 & 1987 & 1980 & 1985 & 1977 & 1975 & 1978 \\
\hline $\begin{array}{l}\text { Convención } \\
\text { Relativa a los } \\
\text { Humedales de } \\
\text { Importancia } \\
\text { Internacional } \\
\text { (Ramsar) }\end{array}$ & 02/02/1971 & 21/12/1975 & 1986 & 1998 & 1999 & 1990 & 1993 & 1997 & 1992 & 1990 \\
\hline
\end{tabular}

Fuente propia ${ }^{31}$

31. Las fechas para la mayoría de los Convenios y Convenciones indican el año de ratificación. Ver notas al pie para mayor detalle por instrumento. 
El Convenio de Cambio Climático claramente desde su concepción consideró los bosques como un tema central para enfrentar los retos asociados con el cambio climático. Los bosques absorben carbono de la atmósfera; contienen $77 \%$ aproximadamente de todo el carbono almacenado en la vegetación y $39 \%$ de todo el carbono almacenado en el suelo ${ }^{32}$. A su vez, la deforestación y la degradación de los bosques representan casi $20 \%$ de las emisiones mundiales de gases de efecto invernadero $(\mathrm{GEI})^{33}$.

El Convenio en su Artículo 4.1 indica la necesidad de “... promover la gestión sostenible y promover y apoyar con su cooperación la conservación y el reforzamiento, según proceda, de los sumideros y depósitos de todos los gases de efecto invernadero no controlados por el Protocolo de Montreal, inclusive la biomasa, los bosques...”. Durante la conferencia de las partes contratantes del Convenio número 13 realizada en Bali en el 2007, en su decisión 1/CP.13-2007 Plan de Acción de Bali y decisión 2/CP13, los países acuerdan abordar "enfoques de política e incentivos positivos sobre temas relacionados con la reducción de emisiones de la deforestación y degradación en países en desarrollo; y el papel de la conservación, gestión sostenible de bosques y mejora de los depósitos forestales de carbono en países en desarrollo", enfoque conocido como REDD+. Sin embargo, no fue sino hasta la Conferencia de las Partes $N^{\circ} 16$ en Cancún, México que REDD+ es reconocido como un mecanismo formal para la mitigación del cambio climático.

El Protocolo de Kyoto es una de las medidas más importantes y pioneras en los esfuerzos por reducir gases de efecto invernadero. Viene a especificar en su Artículo 2.1.a la necesidad de "protección y mejora de los sumideros y depósitos de los gases de efecto invernadero no controlados por el Protocolo de Montreal, teniendo en cuenta sus compromisos en virtud de los acuerdos internacionales pertinentes sobre el medio ambiente; promoción de prácticas sostenibles de gestión forestal, la forestación y la reforestación". Compromete a los países industrializados a estabilizar las emisiones de gases de efecto invernadero, estableciendo metas vinculantes de reducción de emisiones.

El Convenio sobre la Diversidad Biológica en sus Metas Aichi y en particular, la Meta 5 plantea que para el 2020, "se habrá reducido por lo menos a la mitad y, donde resulte factible, se habrá reducido hasta un valor cercano a cero, el ritmo de pérdida de todos los hábitats naturales, incluidos los bosques, y se habrá reducido de manera significativa la degradación y fragmentación”. Esta meta no podrá ser lograda si los bosques siguen siendo objeto de actividades ilegales para su aprovechamiento y comercialización.

Para cumplir con esta meta conviene saber que de acuerdo con la $\mathrm{FAO}^{34} 49 \%$ de la superficie total de la región de América Latina y el Caribe está cubierta por bosques que representan cerca 22\% del área de bosque existente en el mundo. La región posee además $57 \%$ de los bosques primarios del mundo, siendo que $18 \%$ del área total de bosque de la región se encuentra en áreas protegidas.

32. CIFOR, CGIAR. Factsheet, número 10, junio de 2013, Pág 1.

33. Datos tomados del Programa Conjunto de las Naciones Unidas para la Reducción de Emisiones Provenientes de Deforestación y de Degradación de los Bosques y Programa de Naciones para el Medio Ambiente.

34. FAO. 'Bosques'. [sitio web]. <http://www.rlc.fao.org/es/temas/bosques/>. Accedido el 29 de mayo de 2014. 
Centroamérica contaba en el año 2003 con 557 áreas protegidas con una extensión aproximada de 12.986.608 hectáreas. Al 2014 se cuenta con 932 áreas protegidas con una extensión aproximada de 14.514.028 hectáreas. Solo México a la fecha cuenta con 176 áreas protegidas con una extensión de 25.387.972 hectáreas. Adicionalmente, las áreas protegidas privadas en manos de comunidades y organizaciones no gubernamentales pasaron de 191 en el año 2003 a 514 en el $2014^{35}$. Se puede ver cómo la región ha realizado esfuerzos que se reflejan en estos números para cumplir con los compromisos internacionales establecidos en materia de conservación de bosques. Sin embargo, estas vastas áreas siguen siendo vulnerables -entre otros factores- debido a la falta de financiamiento, incendios forestales, cacería ilegal y amenazas de proyectos de desarrollo de gran impacto, entre ellos minería y represas hidroeléctricas.

El Convenio sobre la Diversidad Biológica y su Protocolo de Nagoya sobre Acceso a los Recursos Genéticos y Participación Justa y Equitativa en los Beneficios que se Deriven de su Utilización están estrechamente ligados con los recursos genéticos que provienen de la diversidad biológica, entre ellos lo que provienen de los bosques, así como de la necesidad de reconocer, respetar y valorar el conocimiento tradicional en el ámbito forestal. El Convenio aborda el tema forestal por medio de su programa de trabajo ampliado (anexo a la decisión Vl/22), adoptado en el 2002, que tiene como fin la conservación de la diversidad biológica forestal ${ }^{36}$, la utilización sostenible de sus componentes y el uso justo y equitativo de los beneficios que surgen de la utilización de los recursos genéticos forestales. Las conferencias de las partes han alcanzado a aprobar al menos nueve decisiones ${ }^{37}$ relacionadas con la diversidad biológica forestal.

El Protocolo de Nagoya, con un mayor énfasis en la distribución justa y equitativa de beneficios, establece en sus Artículos 6 y 7 que los países adoptarán medidas, según proceda, con miras a asegurar que se obtenga el consentimiento fundamentado previo o la aprobación y participación de las comunidades indígenas y locales para el acceso a los recursos genéticos cuando estas tengan el derecho establecido a otorgar acceso a dichos recursos y cuando se acceda a los conocimientos tradicionales asociados con recursos genéticos que están en posesión de comunidades indígenas y locales. Estas disposiciones se aplican, entre otros, a los recursos genéticos relacionados con los bosques.

35. Cifras obtenidas de la Unión Internacional para la Naturaleza. Oficina regional para México, Centroamérica y el Caribe. Presentación realiza en el Congreso Mesoamericano de Áreas Protegidas, Costa Rica, 18 de marzo de 2014.

36. Para el Convenio sobre la Diversidad Biológica, la diversidad biológica forestal "es una expresión amplia que refiere a todas las formas de vida que se encuentran en las regiones forestales y a las funciones ecológicas que ellas cumplen. En este sentido, la diversidad biológica forestal no solo concierne a los árboles, sino a una multiplicidad de plantas, animales y microorganismos que viven en las zonas forestales y a la diversidad genética asociada a ellos". Consultar: Convenio sobre la Diversidad Biológica. "¿Qué es la biodiversidad forestal'. [sitio web]. <http://www.cbd.int/forest/what.shtml>.

37. Decisión II/9 Bosques y diversidad biológica, Decisión III/12 Futuro programa de trabajo sobre la diversidad biológica terrestre: diversidad biológica forestal, Decisión IV/7 Diversidad biológica forestal, Decisión V/4 Informe sobre el progreso alcanzado en la aplicación del programa de trabajo sobre la diversidad biológica forestal, Decisión VI/22 Diversidad biológica forestal, Decisión VII/1 Diversidad biológica forestal, Decisión VIII/19 Diversidad biológica forestal: aplicación del programa de trabajo, Decisión IX/5 Diversidad biológica forestal y Decisión X/36 Diversidad biológica forestal. 
La Convención de Lucha Contra la Desertificación tiene como objeto luchar contra la desertización y reducir los efectos de la sequía en los países gravemente afectados por la sequía o la desertización. La Convención cuenta con cinco anexos de aplicación regional, siendo el número tres referente a las medidas en América Latina y el Caribe. En este anexo se indica, entre otros, que en los programas de acción nacionales se tenga en cuenta el "logro de la seguridad alimentaria y desarrollo sostenible de actividades agrícolas, pecuarias, forestales y de fines múltiples"38.

El Convenio Internacional de las Maderas Tropicales (2006) cuenta con versiones anteriores de los años 1983 y 1994, y es el que rige la Organización de Maderas Tropicales (OIMT). En su preámbulo reconoce la importancia de la colaboración para mejorar la aplicación de la legislación forestal y promover el comercio de maderas aprovechadas legalmente. El Convenio describe a sus miembros como gobiernos productores o consumidores y forma un Consejo Internacional de las Maderas Tropicales. Dentro sus objetivos se destaca su función de promover, expandir y diversificar el comercio internacional de maderas tropicales de bosques ordenados de forma sostenible y aprovechados legalmente y promover la ordenación sostenible de los bosques productores de maderas tropicales. Se crea, además, el Fondo de Cooperación de Bali para la ordenación sostenible de los bosques productores.

La Convención sobre el Comercio Internacional de Especies Amenazadas de Fauna y Flora Silvestres -conocido como CITES- ha venido trabajando en establecer una red de cumplimiento y observancia en materia de vida silvestre para combatir el delito transnacional organizado contra la vida silvestre y los bosques. Una de la funciones de CITES es emitir permisos y certificados para especies contenidas en su tres apéndices. En su 14ª reunión (CoP14), La Haya, 2007, la Conferencia de las Partes adoptó las Decisiones 14.60 y 14.61 sobre inspección física de los envíos de madera. Estas decisiones tenían por objeto la creación de un grupo de trabajo para recoger y evaluar el correspondiente material sobre identificación y medición de maderas. También CITES ha creado un grupo de trabajo sobre la caoba ${ }^{39}$.

Los certificados CITES $^{40}$ otorgados por las administraciones del Estado para la exportación e importación de maderas bajo sus listas es por el momento el instrumento que por excelencia se utiliza en caso de exportación de maderas "CITES". Debe tenerse presente que el permiso de exportación CITES se otorga de acuerdo con la legislación nacional del país de exportación, por lo que en todo caso el proceso administrativo y de cumplimiento legal nacional debe implementarse. En este sentido, un permiso CITES va de la mano con la acción que se realiza en las aduanas, las

38. Artículo 4.2, Anexo 3.

39. Para mayor información se puede visitar: Convención sobre el Comercio Internacional de Especies Amenazadas de Fauna y Flora Silvestres. 'Grupo de trabajo sobre la caoba'. [sitio web]. <http://www.cites. org/esp/prog/mwg.php>.

40. CITES regula el comercio de vida silvestre mediante un sistema de permisos y certificados que son emitidos por la autoridad nacional antes de que el espécimen salga del país. El Apéndice I del CITES enlista todas las especies 'amenazadas de extinción' y para las cuales el comercio internacional solo es autorizado excepcionalmente. El Apéndice II incluye especies que pudieran ser amenazadas si no se controla el comercio internacional; para estas, el comercio se rige por estrictas medidas, tanto de exportación como de importación. El Apéndice III incluye especies enlistadas específicamente por un país que necesita cooperación de los otros para controlar la comercialización y prevenir la sobreexplotación dentro de sus límites. 
cuales controlan el tráfico internacional de productos que entran o salen de los países. También participan en el proceso los que dan el permiso en caso de autoridades ambientales o forestales, y la autoridad fitosanitaria en algunas ocasiones. Para especies "no CITES" se cumple con los procedimientos regulares de exportación de madera.

Aquí volvemos a caer en el tema de los costos económicos de estos trámites, pero sobre todo en el tiempo que duran en salir los permisos y la falta de sistemas eficaces y efectivos de verificación, lo que al final puede provocar la ilegalidad en materia de exportaciones. Desde el punto de vista legal se hace necesario hacer una revisión a los procesos de los países que pueden presentar variaciones entre sí y fortalecer de esta manera la implementación de la legislación, prevenir la corrupción y producir beneficios rentables para la población.

A pesar de la estrecha relación ancestral que los pueblos indígenas han tenido con los bosques, las leyes y políticas que reconocen sus derechos al territorio y los recursos han sido lentas y en algunos casos inexistentes. Honduras, Nicaragua y Panamá ${ }^{41}$ han realizado importantes avances reconociendo territorios y avanzando en la tarea del reconocimiento del manejo sostenible de los bosques por pueblos indígenas. También hay que tomar en consideración que muchos pueblos indígenas tienen sus propios sistemas e instituciones encargadas del manejo de sus territorios y recursos. Si bien el Convenio 169 sobre Pueblos Indígenas y Tribales en Países Independientes de la Organización Internacional del Trabajo no aborda directamente el tema de bosques, sí tiene una especial función en servir de instrumento para poder alcanzar medidas que permitan por medio del reconocimiento de derechos la disminución de la ilegalidad en el manejo forestal. En su Artículo 7.4 el Convenio indica: "Los gobiernos deberán tomar medidas, en cooperación con los pueblos interesados, para proteger y preservar el medio ambiente de los territorios que habitan". Es decir, que se impulsa a la coordinación, cooperación y diálogo entre los pueblos indígenas y los gobiernos para alcanzar objetivos de conservación.

La Declaración de las Naciones Unidas sobre los Derechos de los Pueblos Indígenas es esencial para alcanzar la conservación de los recursos naturales. En particular, su Artículo 29.1 avala el principio de que los pueblos indígenas "tienen derecho a la conservación y protección del medio ambiente y a la capacidad productiva de sus tierras, territorios y recursos". Este principio se enlaza con lo establecido en el Convenio 169 de la OIT en el cual se resalta el derecho a consulta a los pueblos indígenas en caso de decisiones administrativas, legislativas o proyectos que puedan afectar sus medios de vida. También su Artículo 15 expresamente indica que los "derechos de los pueblos interesados a los recursos naturales existentes en sus tierras deberán protegerse especialmente. Estos derechos comprenden el derecho de los pueblos indígenas a participar en la utilización, administración y conservación de dichos recursos".

Es sabido que las secretarías de los Convenios Internacionales Ambientales y en particular las conocidas como "Convenciones de Río" han tomado acciones para coordinar sus acciones relativas a bosques y es de esperar que esta cooperación a su vez ayude a los países a poder implementar sus obligaciones asumidas bajo estos instrumentos. Sería pertinente reforzar las tareas dentro de las agendas nacionales ambientales relativas a coordinar el cumplimiento de estas convenciones no

41. Al respecto de los avances en Honduras, Nicaragua y Panamá ver la sección sobre "Bosques Bajo un Enfoque de Derechos" del presente trabajo. 
solo en forma independiente, sino en una manera que se pueda tener un patrón integral que permita su monitoreo en cuanto a impactos y nivel de implementación.

Se tendrá que seguir abonando en la tarea de alcanzar una efectiva coordinación para poder ejecutar mucho de lo que se ha alcanzado. El derecho ambiental tiene un importante puesto en esta construcción y se debería hacer con mayor fuerza análisis de cumplimiento, eficacia y eficiencia de la normativa ambiental que acompaña las acciones necesarias desde el punto de vista jurídico para la "legalidad de los bosques". Juristas de todos los rincones, incluyendo jueces, fiscales, abogados de industrias forestales, especialistas en derecho ambiental, funcionarios de la administración forestal, aduanera y comercio, podrían sin duda hacer un importante aporte a la ruta que busca la legalidad en el uso sostenible de la madera y la conservación de los bosques.

Pareciera que a la fecha no ha habido consenso para contar con un instrumento jurídico internacional que en forma vinculante y coordinada trate el tema de la conservación y uso sostenible de los bosques. Esta es una tarea pendiente que también tendrá que impulsarse con un mayor apoyo político y de la sociedad civil desde todos los rincones del planeta.

\section{Comercio de madera}

En el caso de Centroamérica, según indica un estudio reciente que en el año 2011 las exportaciones de productos de madera a la Unión Europea las realizaron principalmente Guatemala con \$3,6 millones, Costa Rica con $\$ 1,7$ millones y Honduras con $\$ 1,3$ millones; el resto de los países sumó $\$ 1,4$ millones. En relación con exportaciones a Estados Unidos, Honduras, Costa Rica y Guatemala fueron lo que más exportaron con \$53 millones; el resto de la región sumó un total de \$7,5 millones. En términos generales, la región está exportando al resto de Asia, Estados Unidos y China prioritariamente ${ }^{42}$.

Bajo este contexto se hace relevante referirnos a los acuerdos más de índole comercial que sin duda son piezas importantes en lo que a legalidad de las exportaciones de madera y sus productos se refiere. Por ejemplo, son relevantes las negociaciones que la Organización Mundial del Comercio (OMC) realiza en el marco del "Programa de Doha para el Desarrollo", iniciado en el 2001 y sus instrumentos conexos. En la actualidad todo apunta a que la OMC busca apoyar y asegurar el funcionamiento adecuado del libre comercio, teniendo en cuenta al mismo tiempo la protección del medio ambiente. Ha creado desde 1995 un Comité de Comercio y Medio Ambiente dedicado al diálogo entre los gobiernos sobre los efectos de la relación entre las políticas comerciales en el medio ambiente. A partir del año 1995 todos los países de la región centroamericana y México se han adherido como miembros a la OMC.

Además, existen convenios y acuerdos que establecen arreglos comerciales multilaterales o bilaterales que involucran países de la región. A continuación presentamos algunos de los instrumentos más importantes a la fecha.

42. Navarro y otros (2014). Análisis del Comercio Internacional de Productos de Madera y su Gobernanza Administrativa. Región Centroamérica y República Dominicana. Documento UICN-EFI, Earth, Págs. 43 a 45. 


\begin{tabular}{|c|c|c|}
\hline Instrumentos & Fecha y relaciones & Contexto \\
\hline $\begin{array}{l}\text { Tratado de Libre Comercio } \\
\text { República Dominicana- } \\
\text { Centroamérica-Estados Unidos } \\
\text { (CAFTA-DR) }\end{array}$ & $\begin{array}{l}\text { En el año } 2004 \text { se dio la adopción } \\
\text { del texto para todos los países } \\
\text { involucrados, entrando en vigor en } \\
\text { distintas fechas para cada país a } \\
\text { partir del } 2006 .\end{array}$ & $\begin{array}{l}\text { Capítulo } 17 \text { establece mecanismos } \\
\text { voluntarios para el desempeño } \\
\text { ambiental. }\end{array}$ \\
\hline $\begin{array}{l}\text { Acuerdo por el que se establece } \\
\text { una Asociación entre la Unión } \\
\text { Europea y sus Estados Miembros, } \\
\text { por un lado y Centroamérica, por } \\
\text { otro (AACUE) }\end{array}$ & $\begin{array}{l}\text { En mayo del } 2010 \text { finalizaron } \\
\text { negociaciones y fue firmado el } 29 \\
\text { de junio de } 2012 \text { en la Cumbre } \\
\text { del Sistema de Integración } \\
\text { Centroamericana (SICA), realizada } \\
\text { en Tegucigalpa, Honduras. }\end{array}$ & $\begin{array}{l}\text { Trata los temas de comercio } \\
\text { y desarrollo sostenible y en } \\
\text { particular, la materia de comercio } \\
\text { de productos forestales. }\end{array}$ \\
\hline $\begin{array}{l}\text { Lacey Act, United States Of } \\
\text { America }\end{array}$ & $\begin{array}{l}\text { Ley del año } 1900 \text { para prevenir } \\
\text { que cazadores ilegales escaparan } \\
\text { con sus presas cruzando a otro } \\
\text { Estado. En sus enmiendas del año } \\
2008 \text { expandió sus alcances para } \\
\text { combatir el comercio ilegal de la } \\
\text { madera y sus productos. }\end{array}$ & $\begin{array}{l}\text { Da la posibilidad de combatir } \\
\text { crímenes contra la tala ilegal } \\
\text { mediante la exigencia de requisitos } \\
\text { y establecimiento de sanciones. }\end{array}$ \\
\hline $\begin{array}{l}\text { Reglamento (EU) N 995/2010 } \\
\text { del } 20 \text { octubre } 2010 \text { relativo a la } \\
\text { Comercialización de la Madera, } \\
\text { conocido como EUTR, por sus } \\
\text { siglas en inglés }\end{array}$ & $\begin{array}{l}\text { Entró en vigor el } 3 \text { de marzo de } \\
2013 . \\
\text { El Reglamento se complementa } \\
\text { con Reglamento de Ejecución } \\
N^{\circ} \text { (UE) } 607 / 2012 \text { de la Comisión } \\
\text { del } 6 \text { de julio de } 2012 \text { relativo a las } \\
\text { normas detalladas en relación con } \\
\text { el sistema de diligencia debida y el } \\
\text { Reglamento Delegado (UE) } \\
\text { № } 363 / 2012 \text { de la Comisión del } 23 \\
\text { de febrero de } 2012 \text { relativo a las } \\
\text { normas procedimentales para el } \\
\text { reconocimiento y la retirada de las } \\
\text { entidades de supervisión. }\end{array}$ & $\begin{array}{l}\text { Se refiere a medidas para prohibir } \\
\text { el comercio de la madera y } \\
\text { sus productos aprovechados } \\
\text { ilegalmente, en el contexto de } \\
\text { las acciones del Plan de Acción } \\
\text { FLEGT del 2003. Exige a los } \\
\text { agentes que comercialicen en la } \\
\text { UE por primera vez productos } \\
\text { de la madera que ejerzan la } \\
\text { "diligencia debida". }\end{array}$ \\
\hline $\begin{array}{l}\text { Plan de Acción de la Unión } \\
\text { Europea (UE) para la Aplicación } \\
\text { de Leyes, Gobernanza y Comercio } \\
\text { Forestales (FLEGT) }\end{array}$ & $\begin{array}{l}\text { Reglamento CE } 2173 / 2003 \text { del } 12 \\
\text { de diciembre de } 2003 . \\
\text { El Reglamento se complementa } \\
\text { con el Reglamento (CE) N }{ }^{\circ} \\
2173 / 2005 \text { del Consejo, deL } 20 \\
\text { de diciembre de } 2005 \text {, relativo al } \\
\text { establecimiento de un sistema de } \\
\text { licencias FLEGT y el Reglamento } \\
\text { (CE) N } N^{\circ} 1024 / 2008 \text { de la Comisión } \\
\text { deL } 17 \text { de octubre de } 2008 \\
\text { por el que se establecen las } \\
\text { normas adicionales relativas al } \\
\text { establecimiento de un sistema de } \\
\text { licencias FLEGT aplicable a las } \\
\text { importaciones de madera en la } \\
\text { Comunidad Europea. }\end{array}$ & $\begin{array}{l}\text { Impulsa mecanismo para evitar la } \\
\text { ilegalidad en las importaciones de } \\
\text { madera, poniendo responsabilidad } \\
\text { tanto en países consumidores } \\
\text { como suplidores. Fomenta la } \\
\text { gestión sostenible de los bosques } \\
\text { y busca garantizar la legalidad } \\
\text { de la extracción y comercio de } \\
\text { madera y productos derivados. }\end{array}$ \\
\hline
\end{tabular}

Fuente propia

Dos de las negociaciones más importantes que ha impulsado la región han sido el Tratado de Libre Comercio República Dominicana-Centroamérica-Estados Unidos (DR-CAFTA) y el Acuerdo de Asociación entre Centroamérica y la Unión Europea. 
El DR-CAFTA cuenta con un capítulo ambiental (capítulo 17) en donde se establecen mecanismos voluntarios para desempeño ambiental y la aplicación efectiva de las leyes ambientales nacionales. El Tratado indica que cada Parte deberá garantizar que se estimulen en sus leyes altos niveles de protección ambiental, así como asegurar el cumplimiento de la legislación ambiental. Además, crea una Secretaría de Asuntos Ambientales. Esto se liga estrechamente con Lacey Act, que es la ley más antigua de protección de vida silvestre de los Estados Unidos de América, emitida en el año 1900, la cual en sus enmiendas del año 2008 da la posibilidad para combatir los crímenes contra la tala ilegal.

En concreto, la ley prohíbe todo comercio de plantas y sus productos, incluidos muebles, papel y madera que provengan de una fuente ilegal de cualquiera de sus Estados o de un país extranjero; requiere a los importadores declarar el país de origen de producción, el nombre de las especies de todas las plantas y sus productos, y establece sanciones por la violaciones a la ley, incluyendo el decomiso de bienes, embarcaciones, multas y tiempo de prisión ${ }^{43}$.

El Acuerdo de Asociación entre Centroamérica y la Unión Europea trata el tema de comercio y desarrollo sostenible en su Artículo 63, referente a la cooperación y asistencia técnica, siendo que en materia de comercio y medio ambiente indica la necesidad de promover el comercio de los productos derivados de una gestión sostenible de los recursos naturales, incluyendo entre otros la certificación de madera producida legal y sosteniblemente. El Acuerdo presta especial atención a los mecanismos y las iniciativas de comercialización voluntarias y flexibles, dirigidas a promover sistemas productivos ambientalmente sostenibles. Se enfatiza, sin embargo, la necesidad de fortalecer los marcos institucionales para implementar efectivamente los acuerdos internacionales ambientales ratificados por los países, todo siempre reconociendo el derecho de responsabilidad común, pero diferenciada y el derecho de cada Estado a regular sus propias prioridades en materia de desarrollo sostenible.

Más directamente, el Acuerdo en su Artículo 285 indica que cada Parte procurará asegurarse de que su legislación y políticas proporcionen y fomenten altos niveles de protección medioambiental de acuerdo con los convenios internacionales ${ }^{44}$ y procurarán mejorar dicha legislación y políticas en la medida en que estas no sean aplicadas, de manera que constituyan un medio de discriminación arbitrario o injustificado entre las Partes o una restricción encubierta al comercio internacional. Crea, además, diversas instancias, como una Junta de Comercio y Desarrollo Sostenible que está compuesta por autoridades de alto nivel de las administraciones de cada Parte y un Foro Bi-regional de Diálogo de la Sociedad Civil para promover el diálogo entre actores medioambientales, económicos y sociales ${ }^{45}$.

43. World Resources Institute. Fact Sheet: Are you ready for the Lacey Act? 22 de diciembre de 2009.

44. Sobre instrumentos propuestos en materia de comercio de productos forestales véase el Artículo 289 del Acuerdo de Asociación. La lista de acuerdos ambientales multilaterales a los que se refiere el Acuerdo de Asociación se pueden encontrar en el Artículo 287.2.

45. Al respecto se puede consultar los Artículos 294 y 295 del Acuerdo de Asociación. 


\section{UE - Aplicación de Leyes, Gobernanza y Comercio Forestales}

Con un enfoque renovado en torno a mecanismos para evitar la ilegalidad, poniendo responsabilidad no solo en los países productores de madera que deseen exportar madera y sus productos al mercado de la Unión Europea, sino también en los país consumidores, en la Comunicación de la Comisión al Parlamento Europeo y al Consejo del 21 de mayo de 2003, titulada "Aplicación de las leyes, gobernanza y comercio forestales (FLEGT) - Propuesta de plan de acción de la Unión Europea", se propuso una serie de medidas para detener la tala ilegal y promover la gestión forestal sostenible. Esta acción se da de la mano con los compromisos asumidos por los países en la Cumbre Mundial sobre el Desarrollo Sostenible del 2002 (CMDS).

El Plan de Acción FLEGT de la UE combina medidas para facilitar el comercio de madera legal y eliminar el comercio de madera ilegal con la UE. EI Plan reconoce que la UE es un consumidor de maderas tropicales provenientes de países con retos importantes para la aplicación de las leyes y una efectiva gobernanza. Se considera que al exigir legalidad en las importaciones a la UE se crean incentivos para mejorar la gobernanza forestal en los países productores.

En general, además de reducir la ilegalidad en el comercio de madera, lo que este instrumento busca es fortalecer la gobernanza forestal como una de las medidas para combatir la pobreza y mitigar el cambio climático. Este proceso parte de la posibilidad de iniciar diálogos con países en desarrollo exportadores de madera y sus productos, que les permita fortalecer las medidas para prevenir la tala ilegal, un diálogo de países productores de madera a países consumidores bajo el objetivo de alcanzar la legalidad en el comercio forestal, logrando beneficios para el planeta y las personas. Es por ello que dentro de este Plan de Acción la Comisión Europea apoya realizar estudios e investigaciones sobre los niveles y el carácter de la tala ilegal en distintos países, da asistencia técnica y apoya la difusión de dicha información.

Asimismo, para el caso de Centroamérica debemos recordar que el Artículo 289 del Acuerdo de Asociación entre los Estados centroamericanos y la Unión Europea, referente al comercio de productos forestales, indica que con el fin de promover la gestión sostenible de los recursos forestales las Partes se comprometen a trabajar conjuntamente para mejorar la aplicación de la legislación forestal y la gobernanza, así como para promover el comercio lícito y sostenible de productos forestales, a través de instrumentos que pueden incluir, entre otras cosas, el uso efectivo de la CITES con respecto a especies maderables en peligro, esquemas de certificación de productos forestales extraídos de forma sostenible y los acuerdos regionales o bilaterales de asociación voluntaria sobre aplicación de las leyes, gobernanza y comercio forestales.

La Unión Europea ha estado negociando Acuerdos Voluntarios de Asociación FLEGT con países productores de madera que obligan jurídicamente a las partes a poner en práctica un sistema de concesión de licencias y regular el comercio de madera y productos de la madera especificados en los acuerdos FLEGT. Estos acuerdos son conocidos como Acuerdos Voluntarios de Asociación (AVAs) y conllevan el compromiso de los países a garantizar la legalidad de su madera. Se persigue con estos acuerdos lograr un sistema eficiente para asegurar la legalidad que apoyaría a la conservación de los recursos y la calidad de vida. En la región Honduras y Guatemala están haciendo importantes esfuerzos para ser parte de este proceso que sin duda necesitará la revisión del marco legal y políticas existentes, aunado a la participación de pueblos indígenas y comunidades locales. 
Ejemplo de los procedimientos incluidos en un hipotético Acuerdo de Asociación Forestal

\begin{tabular}{|c|l|}
\hline Paso 1: & $\begin{array}{l}\text { El país socio del Plan de Acción Forestal sobre Aplicación de las Leyes, Gobernanza y } \\
\text { Comercio designa el organismo de homologación que estará facultado para aprobar la lista de } \\
\text { los órganos de certificación de la legalidad de los productos de la madera. }\end{array}$ \\
\hline Paso 2: & $\begin{array}{l}\text { El país socio del Plan de Acción Forestal sobre Aplicación de las Leyes, Gobernanza y } \\
\text { Comercio nombra el monitor independiente y crea un mecanismo transparente de resolución de } \\
\text { las diferencias. }\end{array}$ \\
\hline Paso 3: & $\begin{array}{l}\text { La CE confirma que el sistema propuesto para verificar que la madera se ha talado legalmente } \\
\text { es creíble. }\end{array}$ \\
\hline Paso 4: & $\begin{array}{l}\text { Por la madera talada legalmente se emiten certificados con los que las aduanas pueden } \\
\text { autorizar su exportación. La información contenida en los permisos puede también con esa } \\
\text { disposición del público para examen, por ejemplo en una plataforma electrónica. }\end{array}$ \\
\hline Paso 5: & $\begin{array}{l}\text { El permiso de exportación que certifica la tala legal se presenta en el puerto de la comunidad } \\
\text { en el que la madera se presenta para libre práctica y las aduanas del Estado miembro lo } \\
\text { confrontan con la descripción de la partida facilitada en la notificación previa al envío. }\end{array}$ \\
\hline Paso 6: & $\begin{array}{l}\text { Las aduanas solo aceptan declaraciones para libre circulación en la UE si la madera está } \\
\text { acompañada de la licencia de exportación necesaria. }\end{array}$ \\
\hline
\end{tabular}

Fuente: Comunicación de la Comisión al Consejo y al Parlamento Europeo. Aplicación de las Leyes de Gobernanza y Comercio Forestales. Propuesta de Plan de Acción de la UE. Bruselas, 21 de mayo de 2003, Pág. 14.

Para este tipo de acuerdos se han identificado cuatro fases, a saber: 1) preparación donde el país evalúa y se prepara, 2) negociación, las partes se ponen de acuerdo en estándares y alcances para alcanzar la legalidad, 3) desarrollo, las partes desarrollan los sistemas acordados y evalúan su credibilidad y plena implementación cuando todos los sistemas funcionan y se puede exportar la madera a Europa con licencia legal ${ }^{46}$. Se debe tener presente que estos acuerdos son voluntarios y que -una vez firmados- son vinculantes, es decir, obligatorios para ambas partes.

Una licencia FLEGT es aquella expedida por un país productor de madera que cuenta con un Acuerdo Voluntario de Asociación con la Unión Europea. La licencia confirma que la madera es legal ${ }^{47}$. La madera se considera legal cuando siguen las reglas de su país de origen. La licencia además está estrechamente vinculada a la idea de poder identificar el "origen legal de la madera".

Entonces, se debe hacer una distinción entre revelar el origen o procedencia de la madera que estará orientado al país de donde sale el recurso y presenta la posibilidad de rastrear la procedencia en cualquier momento de la cadena de suministro con la legal procedencia origen legal que está relacionado con el hecho de determinar si la madera y sus productos se han obtenido cumpliendo con las leyes nacionales. También en la Lacey Act de Estados Unidos se utiliza el término "fuente legal", haciendo referencia a la prohibición de importar madera proveniente de fuentes no legales, es decir, madera proveniente de actuaciones contra las regulaciones de países extranjeros o Estados Unidos y obliga además a declarar el país de origen de la madera.

46. Al respecto consultar, EFI Informe de Políticas, Número 3. ¿Qué es un acuerdo voluntario de asociación? Enfoque de la Unión Europea.

47. EFI, Ficha Informativa, abril 2013. 
Por su parte, el Reglamento UE N 995 del 2010 European Union Timber Regulation, conocido como EUTR, prohíbe la introducción de madera ilegal o sus productos en el mercado europeo. Este reglamento de reciente aplicación (3 de marzo del año 2013) reconoce como madera legal a la que cumple con la legislación aplicable en el país donde se aproveche. Asimismo, el EUTR regula la entrada de madera en el mercado europeo en colaboración con las empresas de base forestal, las cuales tendrán que desarrollar un sistema de trazabilidad que asegure el origen legal de la materia prima con la que trabajan.

Es así que establece el deber a los operadores de la Unión Europea que introduzcan por primera vez madera o sus productos en el mercado europeo a ejercer un sistema de diligencia debida que asegure la procedencia legal de sus productos. Dentro de los elementos fundamentales del sistema de debida diligencia se encuentran información, análisis del riesgo y mitigación del riesgo. A los comerciantes se les obliga a poder identificar en la cadena de suministro a sus proveedores y clientes, garantizando así su trazabilidad. Esto se aplica a una gran gama de madera y productos de madera, también mobiliario y productos de pasta y papel ${ }^{48}$.

Una pregunta muy frecuente es qué pasa entonces con los certificados CITES. Haciendo un análisis de la legislación de los reglamentos de la Unión Europea ${ }^{49}$, se puede afirmar que los productos maderables que cuentan con una licencia CITES son considerados legales. Pareciere entonces que se debe contar bien con una licencia FLEGT o una licencia CITES que dé cuenta de la legalidad de la madera para poder exportar a Europa. Sin embargo, se hace la aclaración de que el Reglamento de la madera de la UE (EUTR) no prohíbe ni impide el comercio de productos madereros. No obstante, como operadores de la UE, tienen prohibido comercializar madera aprovechada ilegalmente en el mercado de la UE y deben ejercer la diligencia debida ${ }^{50}$ para garantizar que su madera no es ilegal, y solicitar a sus proveedores la información necesaria. Si existe riesgo o duda, se puede solicitar documentación o certificación con una norma de verificación o certificación de terceros ${ }^{51}$ que cumpla la legislación aplicable vigente en el país de aprovechamiento, de acuerdo con las disposiciones del Reglamento de la madera de la UE ${ }^{52}$. Una licencia FLEGT, sin embargo, aseguraría la legalidad y

48. Unión Europea. 'Reglamento de la Unión Europea relativo a la comercialización de la madera'. [pdf online], (2010). <http://ec.europa.eu/environment/forests/pdf/EUTR_Leaflet_ES.pdf>. Accedido el 29 de mayo de 2014.

49. Al respecto, el Reglamento de la UE indica que debe considerarse aprovechada legalmente la madera contenida en los productos de la madera enumerados en los anexos II y III del Reglamento (CE) $N^{\circ} 2173 / 2005$ que procedan de países socios indicados en el anexo I de dicho Reglamento y que cumplan lo dispuesto en el mismo Reglamento. Además, se considerarán aprovechadas legalmente las especies enumeradas en los anexos A, B y C del Reglamento (CE) N 338/97 del Consejo, del 9 de diciembre de 1996, relativo a la protección de especies de la fauna y flora silvestres mediante el control de su comercio, siempre y cuando cumpla lo dispuesto en ese Reglamento y sus disposiciones de aplicación.

50. Para conocer los requisitos de la debida diligencia ver: The European Parliament and The Council of the European Union. 'Regulation (EU) N 995/2010 of the European Parliament and The Council of 20 October 2010'. Official Journal of the European Union [pdf online]. <http://eurlex.europa.eu/LexUriServ/LexUriServ. do?uri=OJ:L:2010:295:0023:0034:EN:PDF>. Accedido el 29 de mayo de 2014.

51. Un ejemplo de esto es la certificación emitida por el Forest Stewardship Council (FSC), establecida en 1993. Esta certificación puede ser aportada en el proceso de verificación de la legalidad, pero no elimina otros procedimientos o requisitos.

52. Información tomada de EFI, Reglamento de la Madera de EU, Preguntas frecuentes, marzo de 2013. 
evitaría estas diligencias. En este sentido, el Reglamento EUTR considera que cumple sus requisitos la madera y los productos de la madera cubiertos por licencias FLEGT o certificados CITES ${ }^{53}$.

A este respecto, el Reglamento ${ }^{54}$ en mención establece las obligaciones de los agentes que comercializan madera y productos de la madera de la Unión Europea, y rescata el hecho de que los bosques prestan servicios medioambientales asociados no solo con la madera, sino con las funciones de los ecosistemas y que la deforestación y degradación de los bosques contribuye en $20 \%$ a las emisiones de CO2 mundiales. Esto lo contrapone con la creciente demanda de madera y sus productos, y la necesidad de reforzar los modelos de gobernanza forestal y eliminar el comercio asociado con la tala ilegal.

El reglamento indica una serie de definiciones dentro de la que cobra especial relevancia el relacionado con "legislación aplicable", indicando que la legislación vigente en el país de aprovechamiento abarca los siguientes aspectos: los derechos de aprovechamiento de madera dentro de los límites publicados oficialmente, los pagos por derechos de aprovechamiento y madera, incluidas las tasas por aprovechamiento, el aprovechamiento incluida la legislación medioambiental y forestal que abarque la gestión forestal y la conservación de la biodiversidad, cuando esté directamente relacionada con el aprovechamiento de la madera, los derechos legales de terceros en relación con el uso y posesión afectados por el aprovechamiento de madera, el comercio y las aduanas en la medida en que afecte al sector forestal.

Dentro del Reglamento de la Unión Europea se plantea que cualquier persona física o jurídica que comercialice madera o productos de la madera debe actuar con la diligencia debida por medio de un sistema de medidas y procedimientos que minimice el riesgo de comercializar en el mercado interior madera aprovechada ilegalmente y productos derivados de esa madera. Ese sistema presenta tres elementos: acceso a la información, evaluación del riesgo y reducción del riesgo detectado. También establece la obligación de trazabilidad, indicando que los comerciantes deben ser capaces hasta por cinco años de identificar en toda la cadena de suministro a los agentes o comerciantes que hayan suministrado la madera y sus productos. Con un mayor nivel de detalle, la UE estipula un Reglamento de Ejecución ${ }^{55}$ de su normativa 995/2010 que amplía la información del sistema de diligencia debida, la frecuencia y naturaleza de los controles sobre las entidades de supervisión, que se complementa con la norma UE 363/2012 relativa a las normas procedimentales para el reconocimiento y la retirada de las entidades de supervisión con un procedimiento transparente, equitativo e independiente.

53. Unión Europea. 'Reglamento de la Unión Europea relativo a la comercialización de la madera'. [pdf online], (2010). <http://www.maderalegal.info/files/documentos/pdfEs20120123011136.pdf>. Accedido el 29 de mayo de 2014.

54. El reglamento $N^{\circ} 995 / 2010$ de la UE entró en vigor 27 días después de su publicación el 12 de noviembre de 2010 y es aplicable a partir del 3 de marzo de 2013.

55. Reglamento de Ejecución (UE) N 607/2012 de la Comisión Europea del 6 de julio de 2012, relativo a las normas detalladas en relación con el sistema de diligencia debida y con la frecuencia y la naturaleza de los controles sobre las entidades de supervisión contempladas en el Reglamento (UE) N 995/2010 del Parlamento Europeo y del Consejo, por el que se establecen las obligaciones de los agentes que comercializan madera y productos de la madera. 
En Estados Unidos de América en la Lacey Act, que fue enmendada en el año 2008 con el fin de prohibir la tenencia y el comercio de madera ilegal, es obligatorio realizar una declaración (PPQ 505) de aduanas, donde se harán notar las especies, la cantidad y el país de producción de la madera y de los productos forestales importados.

Todo apunta a la necesidad de tomar la oportunidad para revisar y hacer más eficiente el marco regulatorio nacional y regional para el aprovechamiento legal de la madera y la conservación de los bosques. Este tipo de regulaciones está creciendo y se esperaría que otros países implementen acciones similares. Así, por ejemplo, en diciembre de 2012, Australia promulgó la Ley de Prohibición de la Tala llegal ${ }^{56}$, prohibiendo la importación de productos de madera procedente de talas ilegales y el procesamiento de madera en bruto producida ilegalmente en Australia. Por ahora con instrumentos como FLEGT y Lacey Act, entre otros, pareciera que hemos entrado ya en una nueva fase de responsabilidades compartidas, al menos en lo que a exportaciones e importaciones se refiere, que podrían traer beneficios concretos para la conservación de los bosques y la mejora de la calidad de vida de las personas. Si todos los países consumidores pusieran este tipo de medidas y los países productores también establecieran sus propias medidas de exportación, en donde se combinen todas las reglas a favor de la "legalidad", se aumentaría la posibilidad de llevar a los consumidores madera y sus productos provenientes de fuentes legales y a favor de la conservación y el desarrollo sostenible.

\section{Certificación forestal}

La certificación forestal voluntaria es otro instrumento que se está utilizando en los esfuerzos por detener la tala ilegal. Se trata de un proceso voluntario mediante el cual el desempeño de operaciones forestales es evaluado y verificado para indicar que cumple con estándares reconocidos y aceptados internacionalmente. Estos sistemas empiezan a aparecer a finales de los años 80 y principios de los 90 como respuesta a la voluntad de los consumidores por contar con productos que aseguren el futuro de los bosques.

Existen en el mundo varios sistemas de certificación forestal desarrollados. Dentro de los que más se conocen están el sistema PEFC (Programme for the Endorsement of Forest Certification) que otorga la Certificación de la Gestión Forestal Sostenible y la Certificación de la Cadena de Custodia y el sistema FSC (Forest Stewardship Council), que cuenta con la Certificación de la Unidad de Manejo Forestal (UMF) y la Certificación de la Cadena de Custodia (CoC). La diferencia entre ambos certificados radica en que el certificado de manejo forestal o gestión forestal abarca aspectos más relacionados con el manejo y planificación del recurso forestal, incluyendo repercusiones económicas y sociales, mientras que el certificado de la cadena de custodia se enfoca más en la trazabilidad de los productos de origen forestal. En la certificación, empresas y comunidades se someten voluntariamente a inspecciones realizadas por terceros bajo la esperanza de encontrar consumidores responsables dentro de la cadena de mercado. Aunque estos sistemas han crecido positivamente, pareciese que no han tenido el gran impacto esperado. Algunos hablan de la necesidad de una evaluación a profundidad.

56. Australian Illegal Logging Prohibition Bill, diciembre de 2012. 
Como se ha podido notar a lo largo de este relato, la suma de esfuerzos entre convenios ambientales internacionales, acuerdos, tratados comerciales y mecanismos voluntarios demuestra el gran interés que las naciones del mundo tienen por conservar y utilizar sosteniblemente los bienes y servicios que los bosques proveen. Sin embargo, es claro que el trabajo en forma más eficaz y menos individualizada sigue siendo una necesidad. Uno de estos esfuerzos, por ejemplo, ha sido el que en el 2001 creó la Asociación de Colaboración en materia de Bosques ${ }^{57}$ (ACB), que es una alianza informal y voluntaria entre catorce secretarías y organizaciones internacionales que llevan a cabo importantes esfuerzos de coordinación para la conservación y desarrollo sostenible de los bosques. Otros esfuerzos entre secretarías de convenciones ambientales se han realizado, pero se tendrán que redoblar esfuerzos en este sentido.

\section{Un marco político centroamericano para los bosques}

La región centroamericana ha sido un área preocupada por sus bosques. Desde 1989, en la Cumbre de Presidentes conocida como "Costa del Sol", los presidentes de la región acordaron crear la Comisión Centroamericana de Ambiente y Desarrollo (CCAD), y en diciembre de ese mismo año, suscribieron el Convenio Centroamericano para la Protección del Ambiente ${ }^{58}$ que da vida jurídica a la Comisión. Este convenio fue ratificado y entró en vigencia el 14 de junio de 1990. Podríamos decir que desde hace ya 24 años los países estaban convencidos de la necesidad de coordinar acciones para enfrentar los retos ambientales, entre ellos la deforestación y degradación de los bosques. Este fue, en su momento, un convenio de gran valor, puesto que en los años anteriores la región había estado sumida en conflictos armados e inestabilidad política.

Tal y como lo expresa el mismo Convenio Centroamericano para la Protección del Ambiente en su apartado de conservación de recursos naturales, la "conservación necesita una acción internacional coordinada, desde el momento en que la destrucción del medio natural no conoce fronteras. Implica la diversidad de todo el mundo natural y la reserva de opciones para una elección futura. Es la responsabilidad colectiva de todos los gobiernos, organizaciones privadas, industrias e individuos".

Es importante anotar que el Sistema de Integración Centroamericana (SICA) fue constituido el 13 de diciembre de 1991 mediante el Protocolo de Tegucigalpa, que entra en vigor hasta 1993, estableciendo la Secretaría General del Sistema de la Integración Centroamericana (SG-SICA) con el objetivo de promover la paz, la democracia y el desarrollo en la región, siendo en la actualidad la Comisión Centroamérica de Ambiente y Desarrollo uno de sus órganos responsables de la agenda ambiental.

Bajo este espíritu, la región emprende una importante tarea de creación legislativa y de planes y programas a nivel regional. En materia de bosques, plantea en el año 1991 el Plan de Acción Forestal para Centroamérica (PAFCA) y en el año 2002 produjo su Estrategia Forestal Centroamericana (EFCA), que impulsa el desarrollo de políticas y programas forestales a nivel de país. En el año 2009

57. Para mayor información consultar: Asociación de Colaboración en Materia de Bosques. [sitio web]. $<$ http://www.cpfweb.org/73947/es/>.

58. Su Convenio Constitutivo fue firmado por los presidentes de Costa Rica, El Salvador, Guatemala, Honduras y Nicaragua en la Cumbre Presidencial realizada en San Isidro de Coronado, Costa Rica, en diciembre de 1989. 
se lanzó el Programa Estratégico Regional para el Manejo de los Ecosistemas Forestales (PERFOR), discutiéndose en este momento (2014) un nuevo ajuste a este programa.

Sin duda, la Cumbre de Río de 1992 también tuvo un trascendental impacto en la región, dando paso al desarrollo de la Alianza Centroamericana para el Desarrollo Sostenible (ALIDES) y en la búsqueda de socios para ella. En la ALIDES, los presidentes le asignan a la CCAD el cumplimiento de los compromisos en materia de medio ambiente y recursos naturales, considerados como la base para la promoción del desarrollo sostenible de la región.

Para este mismo año (1992), los países suscribieron el Convenio para la Conservación de la Biodiversidad y Protección de Áreas Silvestres Prioritarias en América Central (1992), que establece el Consejo Centroamericano de Áreas Protegidas, impulsa la creación de leyes de biodiversidad y enfatiza en dar prioridad a áreas protegidas fronterizas determinadas en las regiones terrestres y costeras.

Pero quizá uno de los principales pasos que marcó un hito en la historia de la construcción de la legalidad de los bosques lo constituyó el Convenio Regional para el Manejo y Conservación de los Ecosistemas Forestales y Desarrollo de Plantaciones Forestales (1993), mejor conocido como Convenio Centroamericano de Bosques, que indica entre otras dentro de sus consideraciones que "la pobreza con la degradación del bosque aumenta pero que el potencial productivo de bienes maderables y no maderables, pueden ser la base sobre la cual los recursos forestales no sólo se conserven, sino que también contribuyan de forma determinante y sustentable a abatir el subdesarrollo en América Central”.

El convenio impulsa la creación de mecanismos financieros, participación pública de los diferentes sectores, pueblos indígenas, sector privado y asociaciones entre otros, en el desarrollo de políticas nacionales en materia forestal. Se centra en el fortalecimiento institucional a nivel nacional y regional creando el Consejo Centroamericano de Bosques, integrado por los Directores de los Servicios Forestales de cada país y los Coordinadores Nacionales de los Planes de Acción Forestal Tropical Nacional o la autoridad que cada Estado designe ${ }^{59}$.

Uno de los aspectos más relevantes del convenio es que propone establecer mecanismos para evitar el tráfico ilegal de especies de flora y fauna, maderas y otros productos, con particular énfasis en el control del comercio ilegal en las regiones fronterizas. Este fue en su momento un convenio visionario y -a pesar de que hoy cumple un poco más de veinte años- muchos de sus enunciados mantienen validez y actualidad, como por ejemplo la necesidad de crear mecanismos que aseguren la reinversión del ingreso generado con base en el recurso forestal o la necesidad de valorar los bienes y servicios del bosque como un mecanismo para el alivio a la pobreza.

Muchos de los Planes Acción Forestal a nivel nacional fueron creados tomando como base este instrumento regional y un importante número de la leyes forestales fueron impulsadas en los países y han sido puestas en práctica en la actualidad, como por ejemplo: la Ley Forestal de Panamá de 1994, la Ley de Forestal de Guatemala de 1996, la Ley Forestal de Costa Rica de 1996, la Ley Forestal de El Salvador del 2002, La Ley de Conservación y Fomento del Sector Forestal de Nicaragua del 2003, reformada el 2004 y la Ley Forestal de Honduras del 2010.

59. Artículo 7 y siguientes del Convenio Centroamericano de Bosques, 1993. 
Para el período 2000-2005 se aprueba el PARCA o Plan de Ambiental para la Región Centroamericana que ayudó al fortalecimiento institucional de los esfuerzos nacionales y regionales, y el impulso para la conservación de los recursos naturales. Con el PARCA II para el período 2005-2010, la región se enfoca en la conservación y uso del patrimonio natural y prevención de la contaminación, y continúa con esfuerzos para el fortalecimiento institucional. En este período, además, se entra en la creación de un número importante de planes y estrategias, entre ellas: el Programa Regional Estratégico de Áreas Protegidas (PERTAP), el Programa Regional de Monitoreo de la Biodiversidad (PROMEBIO), el Programa Regional de Conectividad (PERCON), la Estrategia Regional para la Conservación y Uso Sostenible de la Biodiversidad (ERB), Estrategia Centroamericana para el Manejo del Fuego, Estrategia Mesoamericana de Sustentabilidad Ambiental (EMSA), Estrategia Regional Agroambiental y de Salud (ERAS-2009-2024) y la Estrategia Centroamérica de Gestión de Recursos Hídricos (ECA-GIRH).

En la actualidad se cuenta con un PARCA III (2010-2014) con énfasis en trabajo con otros sectores y dentro de los esfuerzos del plan plurianual del Sistema de Integración Centroamericano (SICA). En este sentido, el PARCA tiene como objetivo la aplicación de los instrumentos de gestión ambiental y promoción de acuerdos y mecanismos de coordinación para la incorporación de la dimensión ambiental en las instancias regionales encargadas de las políticas y estrategias sectoriales. Tiene como prioridades la coordinación interinstitucional y transversalización de la gestión ambiental y dar apoyo a autoridades nacionales para una gestión ambiental que permita enfrentar los retos de calidad ambiental, gestión del patrimonio natural y cambio climático. En el mismo año que se lanza el PARCA III, la región cuenta con una Estrategia Regional de Cambio Climático (ERCC).

No cabe duda de que los esfuerzos regionales han dado sus frutos, sobre todo en el período de los años 90, en el que se dio una gran producción legal y de programas de trabajo, un importante número de los cuales sirvieron de base para lo que luego han sido los esfuerzos nacionales. Mucho se discute sobre la necesidad de buscar en esta nueva década no solo nuevos convenios, políticas y programas, sino realmente un redoblamiento de esfuerzos en el ámbito de implementación de acciones concretas y medibles en el plano nacional que luego en su sumatoria se refleje en el desempeño regional. Aunque dejamos claro que no se trata únicamente de sumar acciones, sino de pensar como región, fortaleciendo la paz y la democracia, reconociendo con respeto las diferencias y sumando las fortalezas como bases sólidas para el desarrollo sostenible.

En una región pequeña en tamaño como lo es Centroamérica, pero grande en riqueza natural, las acciones regionales deben ser cada vez más fuertes, los países tienen que entrelazarse no solo para el comercio y exportación, sino para fortalecer la agenda de desarrollo sostenible. El papel del Sistema de Integración y de la Comisión Centroamericana de Ambiente y Desarrollo es fundamental y representa una posibilidad política viable para empujar la agenda ambiental de la región y no solo impulsar acciones aisladas a nivel nacional. Será necesario hacer una evaluación consciente de los avances y de los retos por venir, sobre todo de cómo fortalecer la aplicación de lo alcanzado hasta el momento. La región ya ha expresado voluntad política a través de los años y es ahora que se deben redoblar los esfuerzos con acciones concretas que motiven a continuar por la vía de la integración de esfuerzos. 


\begin{tabular}{|l|l|}
\hline \multicolumn{1}{|c|}{ Principales convenios regionales } & \multicolumn{1}{c|}{ Año } \\
\hline $\begin{array}{l}\text { Convenio para la Conservación de la Biodiversidad y Protección de } \\
\text { Áreas Silvestres Prioritarias en América Central }\end{array}$ & 5 de junio de 1992 \\
\hline $\begin{array}{l}\text { Acuerdo Regional sobre el Movimiento Transfronterizo de Desechos } \\
\text { Peligrosos }\end{array}$ & 11 de diciembre de 1992 \\
\hline Convenio Regional sobre Cambio Climático & 29 de octubre de 1993 \\
\hline $\begin{array}{l}\text { Convenio para el Manejo y la Conservación de los Ecosistemas } \\
\text { Naturales Forestales y el Desarrollo de Plantaciones Forestales }\end{array}$ & 29 de octubre de 1993 \\
\hline $\begin{array}{l}\text { Convenio de Cooperación para la Protección y el Desarrollo } \\
\text { Sostenible de las Zonas Marinas y Costeras del Pacífico Nordeste y y } \\
\text { su Plan de Acción }\end{array}$ & 18 de febrero de 2002 \\
\hline $\begin{array}{l}\text { Protocolo Regional de Acceso a los Recursos Genéticos } \\
\text { y Bioquímicos y al Conocimiento Tradicional Asociado }\end{array}$ & 2002 \\
\hline
\end{tabular}

Fuente: CCAD, PARCA II

\section{Bosques bajo un enfoque de derechos}

Solo en Centroamérica habitan cerca de 42 millones de personas. La región vivió conflictos armados por décadas, logrando alcanzar la paz a mediados de los años 90 con la firma del último Acuerdo de Paz en 1996 en Guatemala. A pesar de este gran logro, la región enfrenta la exclusión social y la desigualdad. También se apunta que, como producto de la guerra y el narcotráfico, el istmo está frente a un fenómeno de creciente inseguridad. En una reciente publicación de la Revista Science ${ }^{60}$ se indica que una reforma sobre las políticas y leyes de narcotráfico puede aliviar la presión sobre los bosques, dando que muchos de los "hot spots" de bosques coinciden con rutas de narcotráfico.

Los bosques, además, están rodeados de poblaciones con altos índices de pobreza, con conflictos relacionados con derechos de propiedad, retos asociados con la propuesta de construcción de grandes obras de infraestructura, minería y represas, y el impacto del cambio climático. Ante este panorama, la conservación y manejo sostenible de los bosques sigue siendo una prioridad que está en las manos no solo de los gobiernos, sino de las comunidades y pueblos indígenas. La región tendrá que encontrar un balance entre desarrollo económico y la conservación de los recursos naturales.

El concepto de enfoque de derechos a la conservación de la naturaleza tiene como principal objetivo que las actividades de conservación de los recursos naturales reconozcan los derechos de las personas como pilar fundamental del desarrollo sostenible. Incorporar el enfoque de derechos en proyectos, programas, políticas y legislación relacionada con la conservación y utilización de los bosques puede llevar a disminuir la ilegalidad y mejorar la calidad de vida de muchos.

Uno de los puntos medulares para poder avanzar en un enfoque de derechos en la conservación es la necesidad de consolidar los derechos de los grupos campesinos y pueblos indígenas como una de las vías para avanzar en el desarrollo de acciones no solo compatibles con REDD+, sino también con la iniciativa FLEGT.

60. McSweeney K., Nilsen, at all (2014). 'Drug Policy as Conservation Policy: Narco-Deforestation'. Science, volumen 343. 
Esta consolidación de derechos pasa por el reconocimiento de los derechos a la tierra y territorio, pero también por la necesidad de mayor apoyo para pueblos indígenas y comunidades locales, para que puedan continuar con sus prácticas tradicionales positivas de manejo de bosques y sigan siendo guardianes al participar en la tarea de control y verificación de la legalidad desde sus propios territorios.

Las comunidades y pueblos indígenas dependen de los bosques. Es conocido ya en la región que la falta de reconocimientos de derechos, sobre todo aquellos asociados con la tierra, aumenta la deforestación. Para que REDD+ sea efectivo y no se convierta en una amenaza debe impulsar el reconocimiento de estos derechos. También existen discusiones relacionadas con la propiedad de la tierra, los árboles y los derechos del carbono, y la necesidad de mayor participación pública en las discusiones a nivel nacional.

La región tiene casos éxitos de manejo comunitario del bosque en diferentes regiones, como Darién en Panamá, Petén en Guatemala, Bosawás en Nicaragua, y el sur de México, entre otros. Los pueblos indígenas y comunidades no son ajenos al problema de la ilegalidad y de su participación dependerá el éxito de las acciones que los gobiernos emprendan.

El hecho de que en este momento se esté avanzando en procesos como REDD+ y FLEGT lleva a pensar que este podría ser un vehículo para fortalecer el apoyo a procesos de reconocimiento de derechos y fortalecimiento de la gobernanza desde la base de las comunidades. Ya hay muestra en algunos países, como Nicaragua, Panamá y Honduras, de que las acciones políticas en torno al reconocimiento de derechos territoriales que se amarran con procesos de conservación de la naturaleza son posibles y pueden dejar buenos resultados. Por ejemplo, en Nicaragua la Constitución Política en su artículo quinto reconoce la existencia de pueblos indígenas, sus propias formas de organización y establece un régimen de autonomía. Se establecen las Regiones Autónomas del Atlántico Norte y Sur (RAAN/RAAS), basadas en la Constitución Política y un Estatuto de Autonomía. La Constitución Política de Panamá en su Artículo 90 reconoce y respeta la identidad étnica de las comunidades indígenas. El reconocimiento legal del territorio Kuna se concretó mediante la Ley №16 del 19 de febrero de 1953, que organizó la Comarca Kuna Yala. La Ley 22 de 1983 legaliza la Comarca Emberá-Wounaan. En Honduras, los pueblos misquitos lograron obtener los títulos del territorio Katainasta en agosto de 2012 y el correspondiente al territorio Auhya Yari, en mayo de 2013. Estos son ejemplos de importantes avances que han tomado décadas. Pero hay mucho camino por recorrer en la tarea de ligar los derechos de propiedad con los inseparables esfuerzos de conservación y uso sostenible de los bosques realizados por los pueblos indígenas.

Por otra parte, se hace imperante que de la mano de estos reconocimientos se brinde también apoyo para fortalecer las estructuras comunitarias de pueblos indígenas, de manera que se respeten sus prácticas, conocimientos tradicionales innovaciones y derecho consuetudinario. En realidad, el reconocimiento de derechos es un gran avance, pero los impactos serán pocos si no es acompañado de un fortalecimiento de la institucionalidad local.

Los países con diferentes intensidades y voluntades políticas están tratando de involucrar a los actores sociales en estas discusiones. Sin embargo, de los diversos procesos queda claro que es necesario invertir tiempo y recursos para que todos los sectores lleguen a un nivel de entendimiento adecuado. Es decir, es fundamental aumentar el nivel de conocimiento de todas las partes 
involucradas, promover el acceso a la información y la participación en tiempo y forma. Más que consultas, se buscaría la plena participación y más que solo salvaguardas ambientales y sociales que pueden venir desde otras realidades. Se trata de tener procesos internos que respondan también a las realidades locales.

Un enfoque de derechos en la conservación que impulse una mayor interacción, entre conservación de la naturaleza, mantenimiento de los medios de vida y respeto por los derechos de las comunidades locales y pueblos indígenas, es una línea de actuación que no puede ni debe ser vista como un proceso separado de los esfuerzos que se persigan para detener la deforestación y hacer un manejo sostenible de los bosques.

\section{Aspectos legales de REDD+}

Lo primero que abordamos bajo esta temática es la confusión que algunas veces prevalece sobre lo que es conocido como REDD y lo que es REDD+. REDD es un mecanismo voluntario denominado "Reducción de las Emisiones de la Deforestación y la Degradación de los Bosques en los Países en desarrollo", que se ha propuesto para reducir las emisiones de gases de efecto invernadero. En la Conferencia de las Partes realizada en Montreal en el año 2005 durante la COP/11, un grupo de países tropicales denominados Coalición de Naciones del Bosque Lluvioso, encabezados por Papúa Nueva Guinea y Costa Rica, presentó además la idea de la deforestación evitada como contribución a la mitigación del cambio climático.

En el año 2007 en Bali, durante la Conferencia de las Partes del CMNUCC se iniciaron las discusiones para ampliar el concepto y así introducir la conservación de los bosques, el manejo sostenible y la mejora de reservas de bosques, es decir, la restauración o plantación de bosques. En la COP/14 en Poznan en el año 2008, las partes encuentran consenso y reconocen la importancia de la inclusión de los derechos de los pueblos indígenas y nuevas salvaguardas sociales y ambientales, así como la necesidad de introducir conceptos sobre mecanismos financieros y distribución equitativa de beneficios, entre otros. Todo esto para indicar que REDD+ es un mecanismo ampliado que -además de la deforestación y degradación de los bosques- incluye su conservación, manejo y valoración de los almacenes de carbono de los bosques en la reducción de emisiones.

REDD+ fue avanzando a lo largo de las negociaciones de las partes contratantes del CMNUCC. La COP/15 en Copenhague fue el escenario para llegar a lo que se conoce como el Acuerdo de Copenhague, que fue un acuerdo político que da apoyo a REDD+ y busca mecanismos de financiación. Uno de los mayores avances se logró en la COP/16 en Cancún, sobre todo en cuanto a la implementación de REDD+ por etapas ${ }^{61}$ y la posibilidad de establecer salvaguardas ambientales y sociales. En la COP-17 de Durban, se alcanzaron algunos avances en el diálogo relacionado con sistemas de información para salvaguardas y aspectos financieros.

En la reciente COP/18 en Doha (2012), no hubo grandes avances, pero sí mucha discusión, especialmente en asuntos de verificación. Así, llegamos a la COP/19 Varsovia (2013), donde no

61. Etapa 1: Creación de capacidades y básicas y el desarrollo de las Estrategias Nacionales y Planes de Acción; etapa 2: aplicación de las estrategias y acciones de demostración basadas en el resultado; etapa 3: un sistema de medición, reporte y verificación de reducción de emisiones. 
se alcanzaron grandes consensos, pero sí se dieron avances en el calendario para que los países presenten sus objetivos de reducción de emisiones antes de la COP/21 a celebrarse en París, Francia, en el 2015 en miras de lograr un acuerdo universal en este año, que entrará en vigor en el 2020. El acuerdo 2015 debería contener disposiciones específicas para la continuación de REDD+ y su financiación basada en resultados, asegurando el tema de salvaguardas.

También se aprobó una serie de medidas o formas para evitar la deforestación y degradación forestal como una medida efectiva para mitigar emisiones de dióxido de carbono, dando paso a la posibilidad de financiamiento con promesas de $\$ 280$ millones. Aunque este mecanismo lentamente ha ganado apoyo de diferentes sectores y tenido importantes avances, todavía persisten dudas asociadas con el reconocimiento de derechos, formas de implementación y verificación, entre otros aspectos que deberán seguir siendo discutidos y negociados por los países con los insumos de la sociedad civil.

Los países de la región están realizando acciones para desarrollar políticas, estrategias y marcos legales a nivel nacional ${ }^{62}$ que permitan aplicar el mecanismo REDD+. En este camino, los gobiernos y la sociedad civil deberán redoblar sus esfuerzos para detener la deforestación y fortalecer la legalidad de las acciones realizadas en los bosques. La legislación y políticas deberán contener la garantía de procesos inclusivos de participación ciudadana, claridad en los derechos de propiedad y uso de los recursos, distribución justa y equitativa de los beneficios y sistemas prácticos de supervisión, notificación y verificación.

En la actualidad, como puede verse en los estudios de países, existe en menor o mayor grado leyes y políticas asociadas con los bosques. Recientemente en México (2012), Guatemala (2013) y Honduras (2014) se han aprobado además leyes de Cambio Climático ${ }^{63}$. Sin embargo, todavía falta avanzar para poder realmente contar con un marco regulatorio específico que defina -por ejemplo- la propiedad del carbono y la distribución justa y equitativa de beneficios de los recursos económicos provenientes de la venta de créditos de carbono por deforestación evitada. Si bien es cierto se comienza a profundizar en un proceso de formación de derechos sobre el carbono, será necesario establecer la base jurídica para que se puedan dar transacciones claras en el futuro. Existe un importante debate sobre los mercados regulados del carbono y los voluntarios en que sería necesario ahondar estableciendo los papeles del Estado, del sector privado y las comunidades. También es claro que los precios del carbono deben ser más competitivos con mecanismos financieros que permitan que el bosque aumente su valor y sea un incentivo para la conservación y manejo sostenible. La diferencia desde el punto de vista legal entre los derechos en bosques de propiedad estatal, bosques de propiedad privada, concesiones forestales, propiedad colectiva y bosques en territorios indígenas cobran especial importancia en este tipo de regulaciones.

62. Cuéllar, N., Davis, A. (colaboración de Kandel, S). (2013). Tomándole el pulso a REDD+ en Centroamérica. Procesos, actores e implicaciones para la gobernanza territorial. Fundación PRISMA.

63. Guatemala: Ley Marco para Regular la Reducción de la Vulnerabilidad, la Adaptación Obligatoria ante los Efectos del Cambio Climático y la Mitigación de Gases de Efecto Invernadero. Decreto 72.013 del Congreso de la República de Guatemala. Esta Ley fue aprobada el 5 de septiembre de 2013. Honduras: Ley de Cambio Climático, enero de 2014. México: Ley General de Cambio Climático. Texto vigente 10 de octubre de 2012, publicada en el diario oficial de la Federación el 6 de junio de 2012. 
Asimismo y aunque existen importantes avances a la fecha en cuanto al tema de salvaguardas ambientales y sociales, estas siguen siendo débiles en la mayoría de los casos no vinculantes. Dependiendo de la fuente, estas salvaguardas incluyen -entre otros- el consentimiento libre, previo e informado, el derecho a veto, el acceso a la información, el respeto a los derechos humanos, conservación y distribución de beneficios que bien podrían ser parte de reglamentos que se hacen necesarios a nivel regional y nacional. Potenciar este tipo de instrumentos y su aplicación es una tarea que seguimos teniendo por delante.

Por el momento, el mecanismo REDD+ podría convertirse en un aliado en las tareas de mejorar la calidad de vida de muchos si este tipo de salvaguardas son implementadas. Sin embargo, hay que tomar en consideración que en cuanto a la aplicación de los mecanismos REDD+ todavía existen algunos retos. En el caso de los pueblos indígenas, estos han sido cuidadores de sus bosques, por lo que la tasa de deforestación no suele ser alta. Muchos de ellos viven en áreas protegidas y pareciese que el mecanismo REDD+ no los favorece en el cálculo de la compensación de emisiones. Los mecanismos REDD+ han estado enfocados en compensar la reducción de emisiones, evitando la deforestación y degradación ambiental, promoviendo prácticas de manejo forestal sostenible, así como la reforestación y restauración del paisaje. La reducción de emisiones que fomenta o fortalece lo que ya está conservado no ha sido una prioridad. La conservación de reservorios de carbono es un tema que necesita ser discutido con mayor prontitud y respaldo político. Existen esfuerzos en este camino dentro del CMNUCC-REDD+ y el FCPF, pero será necesario prepararse para este proceso. También es sabido que hay diferentes posiciones dentro de los diversos grupos de pueblos indígenas y que se han dado reclamos sobre la necesidad de fortalecer las salvaguardas y avanzar en diálogos más abiertos y participativos.

Los esfuerzos en los últimos años han estado asociados con establecer y comprender las dimensiones sociales y ambientales de REDD+, promoviendo salvaguardas, algunas de las cuales todavía se están desarrollando. El principal paso en el impulso de salvaguardas ha sido el realizado por la Convención Marco de las Naciones Unidas sobre el Cambio Climático (CMNUCC), que en su Conferencia de Partes Contratantes № 16 del año 2010 acuerda una serie de salvaguardas como requisito indispensable para el trabajo en REDD+. Las salvaguardas REDD+ de la CMNUCC ${ }^{64}$ se han convertido en el marco global común de lineamientos a ser aplicados en las actividades REDD+. Estos instrumentos son un requerimiento de desempeño y aunque algunos consideran que son demasiado amplias y flexibles, existiendo el riesgo de una implementación poco efectiva a nivel nacional, lo cierto del caso es que para acceder al futuro mecanismo de CMNUCC-REDD+ los proyectos deben cumplir obligatoriamente con estas salvaguardas. Las Partes Contratantes han seguido profundizando en el tema de salvaguardas y pedido ejemplos a los países de cómo estos instrumentos han sido interpretados y se están aplicando.

Entre los esfuerzos más importantes por establecer salvaguardas están el que ONU-REDD utiliza en sus actividades de preparación, las cuales están fuertemente ligadas al trabajo realizado en este tema en el seno de la CMNUCC. ONU-REDD aplica "Criterios y Principios Sociales y Medio Ambientales" (PCSA), que describen los asuntos que deben tenerse en cuenta durante la preparación

64. Para ver el detalle de las salvaguardas consultar. Pesketta, L., Todd, K. Putting REDD+ Safeguards and Safeguard Information Systems into Practice. UN-REDD Program, Policy Brief 3, Pág. 2. 
e implementación de REDD+. El Banco Mundial usa sus salvaguardas dentro de sus proyectos aplicándolos a su Programa de Inversión Forestal (FIP) y al Fondo Cooperativo para el Carbono de los Bosques (FCPF), que opera desde el 2008 en una alianza mundial para impulsar REDD ${ }^{65}$. Se considera que las salvaguardas ambientales y sociales son un eje central para prevenir, mitigar y reducir los posibles impactos negativos de sus inversiones.

Existen organizaciones de la sociedad civil -entre ellas pueblos indígenas, campesinos, organizaciones no gubernamentales y esfuerzos nacionales- que están trabajando en el desarrollo de salvaguardas y estándares ambientales y sociales. Hay también organizaciones que están adaptando sus propias políticas internas para cumplir con estos estándares. La existencia de un marco legal consensuado por países, pueblos indígenas y organizaciones de la sociedad civil que pudiera promover con eficacia aspectos sociales y ambientales de los programas REDD+ sería algo deseable, principalmente en el ámbito internacional para que luego fuera adoptado por los países en sus propios sistemas regulatorios a nivel nacional.

Para los pueblos indígenas, las salvaguardas son un aliado, pero adicionalmente se podrían promulgar normas jurídicas que determinaran la titularidad de territorios y el manejo comunitario reconociendo prácticas existentes que sean acordes con los objetivos de conservación bajo su cosmovisión. Solo haciendo parte activa a estos pueblos de los procesos existentes es que lograremos resultados buenos y duraderos.

Los mecanismos específicos que garanticen la participación de los pueblos indígenas y comunidades locales deben aparecer en la legislación. Esto implica -entre otros-información adecuada en tiempo, participación en la toma de decisiones que les atañe, derecho a respuesta en tiempo y forma, y consentimiento libre, previo e informado cuando se realicen proyectos en sus territorios o se tomen medidas que los puedan afectar. No se trata solo de hacer una reunión explicativa y poner los nombres de los asistentes en una bitácora.

Este esfuerzo estaría amparado e iría de la mano con la Declaración de las Naciones Unidas sobre los Derechos de los Pueblos Indígenas que avala el principio de que los pueblos indígenas "tienen derecho a la conservación y protección del medio ambiente y a la capacidad productiva de sus tierras, territorios y recursos ${ }^{66 "}$. Además, se enlaza con lo establecido en el Convenio 169 de la OIT, en donde se resalta el derecho a consulta a los pueblos indígenas en caso de decisiones administrativas, legislativas o proyectos que puedan afectar sus medios de vida y con el Convenio sobre la Diversidad Biológica, que hace un llamado a la aplicación del consentimiento libre, previo e informado (CLPI) como un componente fundamental de las actividades que se llevan a cabo o las políticas que se promueven en relación con los pueblos indígenas.

México ha iniciado este camino con la elaboración del documento "Visión de México sobre REDD+"67, el cual identifica como su primera línea estratégica que les permitirá contar con el conocimiento

65. Costa Rica ha suscrito un contrato de pago por reducción de emisiones con el Fondo de Carbono y la mayoría de los países de la región cuenta con un Plan de Preparación para REDD+ dentro del mecanismo proporcionada por el FCPF.

66. Artículo 29.1.

67. En el año 2011 se publicó el documento denominado "Elementos para el Diseño de la Estrategia Nacional REDD+ (ENAREDD+)" en el que se establecen las metas para el 2020. 
y la preparación para elaborar su Estrategia Nacional REDD+ "los arreglos institucionales y políticas públicas". Además, se apega a la necesidad de respetar los derechos de propiedad social salvaguardando el régimen de derechos de ejidos, comunidades y pequeños productores forestales, tanto en lo que se refiere a la propiedad y posesión de sus tierras como en los beneficios que se obtengan del manejo de estas ${ }^{68}$. En la actualidad, dentro de los elementos propuestos por la Estrategia Nacional REDD+ para Consulta Pública (noviembre, 2014) se encuentran las Políticas Públicas y Marco legal; Esquemas de Financiamiento; Arreglos Institucionales y Desarrollo de de Capacidades; Nivel de Referencia; Monitoreo, Reporte y Verificación (MRV); Salvaguardas Sociales y Ambientales; y Comunicación, Participación Social y Transparencia.

Existen además situaciones jurídicas que podrían tornarse complejas, como por ejemplo los temas relacionados con los derechos transferibles del carbono y la prevención de fraude, en donde ya se está hablando en algunos países de inscripción de derechos de propiedad sobre el carbono que garanticen transacciones confiables entre vendedor y comprador o la creación de seguradores de títulos, siendo que si el título del comprador resulta con algún problema, la aseguradora garantizaría los derechos de los compradores. También es posible que se den discusiones legales sobre quién asume el riesgo de la pérdida del carbono por eventos naturales o negligencia humana. Esto podría en algunos casos también regularse vía contractual ${ }^{69}$.

Podríamos concluir que cualquier nuevo instrumento jurídico o adecuación de los ya existentes en materia de conservación de bosques, incentivos económicos, compensaciones, exportación, reforestación, manejo sostenible de bosques, políticas públicas y arreglos institucionales debería hacer un análisis y determinar qué ventajas o retos existen asociados con el mecanismo REDD+. Hacer una revisión de las leyes ya existentes podría traer mayor precisión a lo ya alcanzado y evitar posibles traslapes o superposiciones.

\section{Conclusiones y recomendaciones}

El cambio de uso del suelo para pasar de bosques a terrenos agrícolas y ganaderos es uno de los principales factores de la deforestación y uno de los principales retos que tiene la región. Es urgente y necesario que existan normas claras y vinculantes que enlacen agricultura, ganadería y bosques, haciendo visible el lazo existente entre conservación de bosques, la producción sobre bases legales y sostenibles y el consumo. Esta relación debería, además, sentar responsabilidad no solo para los países que exportan, sino también para los que consumen, de modo que exista un control cruzado y efectivo.

Se reconoce que se realizan esfuerzos iniciales por parte del sector privado para fomentar prácticas que no promuevan la deforestación y que el tema de consumo responsable y de certificación de productos avanza, aunque a paso lento. No obstante, será necesario en forma más contundente tomar medidas vinculantes y obligatorias para todos. No es posible salir de los problemas de tantos años con recetas viejas.

68. Ver Comisión Nacional Forestal (CONAFOR) (2010). Visión de México para REDD. Hacia una Estrategia Nacional. Primera edición.

69. Ver Costenbander, J. (2011). Marcos Jurídicos en Materia de REDD. Bonn, Alemania: UICN. 
Los procesos largos y lentos de tramitación de permisos van en contra de las acciones de conservación y manejo sostenible de los bosques, ya que promueven la ilegalidad. No se trata -sin embargo- de encontrar la solución únicamente en reformas legales, sino en poder implementar con eficacia y eficiencia los procesos que a nivel nacional se proponen para eliminar la ilegalidad.

Una revisión de los procedimientos administrativos y los instrumentos jurídicos que simplifique procesos es necesaria en varios de los países de la región, así como el procesamiento de información confiable.

A nivel del Poder Judicial en todos los países, el trabajo con los jueces, fiscales y defensores públicos a nivel nacional que ayuden a determinar y reforzar el sistema de justicia es una imperante necesidad. La posibilidad de compartir jurisprudencia entre países y buscar soluciones conjuntas a los mismos problemas es una realidad actual. Lamentablemente, es poco el presupuesto que se invierte en esta tarea y donde la cooperación internacional podría hacer efectivo su apoyo.

La madera proveniente de fuentes ilegales no será recibida en los países de la Unión Europea. Se puede afirmar entonces que desde el 2013 es ilícito ingresar al mercado de los países de la Unión Europea madera o sus productos de madera (por ejemplo, muebles o papel ${ }^{70}$ ) que tenga una procedencia ilegal. Los acuerdos FLEGT -aunque sean voluntarios- una vez firmados, son vinculantes y deben respetarse sus obligaciones.

Los países -tanto exportadores como importadores- deberían impulsar políticas que promuevan la utilización de madera proveniente de una fuente legal. FLEGT presenta una oportunidad importante para que las naciones puedan exportar madera a la Unión Europea proveniente de un uso sostenible y legal. La Unión Europea y también DIFD están apoyando a los países de la región para que puedan de manera voluntaria iniciar estos diálogos y fortalecer sus sistemas de verificación y monitoreo de la madera.

Aunque por el momento México y Centroamérica no son grandes exportadores de madera y sus productos a la Unión Europea, la región podría dar buenos ejemplos de cómo implementar el sistema FLEGT. Existe voluntad política y ya en países como Guatemala se ha empezado a socializar el sistema FLEGT. Asimismo, Honduras comenzó a expresar su interés en la posibilidad de negociar un AVA-FLEGT con importantes avances. Será necesario, sin embargo, buscar mecanismos para la implementación efectiva de sus leyes forestales y la normativa que las acompaña.

Los procesos de participación de las comunidades y pueblos indígenas en las discusiones sobre la legalidad de la madera, la tenencia y propiedad de la tierra, propiedad de los árboles y del carbono serán fundamentales para lograr las metas REDD+ y FLEGT. Es muy posible que si no se reconocen y aclaran derechos fundamentales cualquier proceso que se pretenda emprender tomará la ruta más larga en detrimento de los bosques y las comunidades.

70. Para lista de productos bajo este Reglamento ver: The European Parliament and The Council of the European Union. 'Regulation (EU) No 995/2010 of the European Parliament and The Council of 20 October 2010'. Official Journal of the European Union [pdf online]. <http://eurlex.europa.eu/LexUriServ/LexUriServ. do?uri=CELEX:32010R0995:EN:NOT>. 
Es un buen momento para que los países a nivel nacional y de la región valoren los logros alcanzados, identifiquen los retos y redoblen esfuerzos para mejorar la aplicación de las leyes y la gobernanza forestales. Si queremos ser efectivos, esto solo será posible con la participación, la voz y las acciones tangibles de comunidades, pueblos indígenas, empresa privada y autoridades de gobierno.

De los estudios nacionales se desprende que todos los países cuentan con legislación forestal o normativa legal relacionada con los bosques y también que, sin excepción, lo que estas normas legales persiguen es la conservación y el aprovechamiento sostenible de los bosques que reconocen son uno de sus principales bienes. Esto nos lleva a concluir que una mejor implementación de estas leyes de la mano con el poder judicial, el sistema aduanero, el sector privado, las comunidades y pueblos indígenas podría llevarnos a una gobernanza más efectiva de los bosques y a una mayor legalidad.

Es cada vez más claro que las leyes y las políticas en el sector forestal deben hacer mayores esfuerzos para asegurar una distribución justa y equitativa de los beneficios que se generan con los bosques no solo en madera, sino en reducción de emisiones de gases de efecto invernadero y sus negociaciones, beneficios relacionados con el agua y productos no maderables, entre otros. Si esta distribución no se da, es muy probable que la ruta hacia la legalidad sea una tarea inalcanzable.

Los derechos de los pueblos indígenas y las comunidades locales al bosque deben ser respetados, dándoles certeza jurídica sobre sus tierras y territorios, y el acceso a los bosques. Esto posibilitaría un manejo comunitario de los bosques y una mayor posibilidad de ejercer mecanismos de control y vigilancia desde los territorios.

Transparencia y rendimiento de cuentas en manejo forestal son dos tareas en las que la región debe redoblar esfuerzos. Las reformas legislativas en este caso y la simplificación de trámites podrían ser aliadas en este esfuerzo. Sin embargo, será necesario trabajar de la mano con el sector privado y apelar a la responsabilidad social y ambiental de las empresas. El sector privado tiene un papel central a la hora de detener la ilegalidad en la comercialización de la madera y la tala ilegal, y puede ser un aliado en todo el trayecto, que va desde el bosque hasta el mercado o comprador final. En el caso de exportaciones, esta responsabilidad empresarial debería ser por parte de la empresa exportadora, así como de la importadora, con medidas legales en ambos países.

Los gobiernos han alcanzado importantes logros al ratificar CITES. Sin embargo, de los estudios se desprende que en algunos casos esto se ha convertido en un requisito más, no alcanzando el impacto deseado. Sería atinado trabajar para identificar las posibles debilidades del sistema de licencias que regula el comercio de las especies protegidas que se registran en los apéndices del Convenio, ya que estas especies de árboles en peligro son maderas de un gran valor e importancia para la región.

El paso de los cambios legales y políticos ha sido lento, pero ha mostrado avances importantes y positivos en el tiempo. No obstante, las altas tasas de deforestación aunados a los índices de pobreza hacen pensar que se debe actuar con mayor rapidez, reconociendo los atributos ambientales de los bosques, incluidos los productos de la madera utilizada legal y sosteniblemente.

Aunque se acepta que es importante la conservación de los bosques, sería erróneo no admitir la necesidad de una conexión responsable entre el consumo y la producción de madera. Satanizar el 
manejo sostenible de madera en nada ayudaría, puesto que es un hecho real en nuestras sociedades. Sin embargo, la conexión entre aquellos que producen madera y los que la compran puede darse respetando los derechos de las comunidades y pueblos indígenas, así como la legislación nacional e internacional y produciendo beneficios para muchos.

Los países de la región podrían redoblar esfuerzos para fortalecer las instituciones que administran los bosques dotándolas de más presupuesto y posibilidades de capacitación. Esto aplica también para los tribunales supremos de justicia y otras instituciones que participen en la implementación de la legislación forestal y leyes afines, y en la puesta en marcha de un sistema de verificación de la legalidad.

Mesoamérica debe no solo actuar separadamente a nivel nacional, sino fortalecer su agenda regional, en donde los países impulsen la conectividad de sus acciones a favor de los bosques. Los ecosistemas no conocen de fronteras y los países juntos representan uno de los sitios más biodiversos del planeta. El fortalecimiento de la Comisión Centroamérica de Ambiente y Desarrollo como un órgano del Sistema de Integración Centroamericana podría dar mayor viabilidad política a estos esfuerzos regionales de conservación y desarrollo sostenible que en todo caso deberán trabajar de la mano con las organizaciones regionales de sociedad civil y pueblos indígenas.

Los bosques enfrentan en la actualidad una gran presión asociada con la demanda por proyectos mineros, hidroeléctricos, geotermia, agricultura y ganadería a gran escala, así como desarrollos de infraestructura que terminan algunas veces relacionados con talas ilegales. Los mecanismos de toma de decisión con participación pública efectiva y en tiempo para decidir el futuro de los bosques son hoy más que urgentes. Nunca antes la región ha enfrentado tantos retos enfocados en la tarea de determinar qué tipo de desarrollo queremos para los próximos años y para las futuras generaciones.

La implementación de las leyes de manera eficaz y transparente, la prevención de los delitos ambientales, los incentivos a la conservación y manejo sostenible, los pagos por servicios ambientales, las exportaciones basadas en la legalidad de los productos y el control y monitoreo de las medidas tomadas serán factores determinantes en los próximos años. 



\section{Régimen Forestal Internacional}

Alejandro Iza y Lydia Slobodian 


\section{Régimen Forestal Internacional ${ }^{1}$}

\section{Instrumentos e instituciones forestales de carácter global}

Hasta la fecha no hay ningún instrumento jurídicamente vinculante sobre los bosques a nivel global. Sin embargo, puede decirse que existe un arreglo internacional integrado por un conjunto de instrumentos no-vinculantes, organizaciones, iniciativas y procesos que establecen e implementan normas y estándares destinados a la gestión sostenible de los bosques bajo el auspicio del Consejo Económico y Social de las Naciones Unidas. Además de ello, se cuenta con una serie de acuerdos internacionales relativos a maderas tropicales que establecen la Organización Internacional de las Maderas Tropicales, los cuales gestionan las relaciones entre países consumidores y países productores de madera tropical con el objeto de promover el uso y el comercio sostenible de productos forestales.

\section{Acuerdo Internacional sobre los Bosques de las Naciones Unidas}

Los primeros intentos que se dieron por desarrollar un régimen mundial de bosques se remontan al año 1992 durante la Conferencia de las Naciones Unidas sobre el Medio Ambiente y el Desarrollo, realizada en Río de Janeiro, Brasil, en la cual no se pudo alcanzar la adopción de un convenio jurídicamente vinculante, aunque si se adoptó la Declaración Autorizada, sin Fuerza Jurídica Obligatoria, de Principios para un Consenso Mundial respecto de la Ordenación, la Conservación y el Desarrollo Sostenible de Bosques de Todo Tipo, conocidos como los Principios Forestales de la Conferencia de las Naciones Unidas sobre el Medio Ambiente y el Desarrollo (UNCED, por sus siglas en inglés).

Estos principios reconocen la importancia que tienen los bosques para el desarrollo económico, en los procesos ecológicos y para la satisfacción de las necesidades humanas básicas, y hacen un llamado a las políticas e instituciones nacionales e internacionales para que faciliten el uso sostenible de los bosques y el comercio de productos forestales. A pesar de que dichos principios son explícitamente no-vinculantes, representan empero el primer instrumento negociado internacionalmente que reconoce los beneficios y los componentes de una gestión forestal sostenible. Como se afirma en el preámbulo de los Principios Forestales de la UNCED2:

(d) Estos principios reflejan un primer consenso mundial sobre los bosques. Al comprometerse a la pronta aplicación de estos principios, los Estados también deciden mantenerlos bajo evaluación para su adecuación con respecto a la cooperación internacional sobre cuestiones forestales.

Luego de la Conferencia de Río de Janeiro, la Comisión sobre el Desarrollo Sostenible estableció el Panel Intergubernamental sobre Bosques (IPF, por sus siglas en inglés) con el fin de promover la aplicación de los apuntados principios, creando así un foro para la discusión de la política forestal

1. Elaborado por Alejandro Iza y Lydia Slobodian.

2. Declaración Autorizada, sin Fuerza Jurídica Obligatoria, de Principios para un Consenso Mundial respecto de la Ordenación, la Conservación y el Desarrollo Sostenible de los Bosques de Todo Tipo, A/CONF.151/26 (Vol. III), Informe de la Conferencia de las Naciones Unidas sobre el Medio Ambiente y el Desarrollo, Río de Janeiro, 3-14 de junio de 1992, Anexo III. 
internacional e incluyendo el desarrollo de mecanismos legales e institucionales adecuados. El IPF operó de 1995 hasta 1997 y fue sucedido por el Foro Intergubernamental sobre Bosques (IFF, por sus siglas en inglés), que funcionó de 1997 hasta el 2000.

El IFF fue establecido por el Consejo Económico y Social (ECOSOC, por sus siglas en inglés) para resolver asuntos que quedaran pendientes de resolver con el IPF, incluyendo la cuestión relativa a un acuerdo jurídicamente vinculante y el marco institucional para la conservación y el desarrollo sostenible de los bosques. En conjunto, los procesos del IFF/IPF resultaron en 270 propuestas de acción, incluyendo una destinada a establecer un comité intergubernamental de negociación sobre un instrumento jurídicamente vinculante para todos tipos de bosques ${ }^{3}$. Para poner en práctica estas propuestas, el ECOSOC estableció dos instituciones destinadas a servir como marco permanente de un acuerdo internacional en materia de bosques (IAF, por sus siglas en inglés), el Foro de las Naciones Unidas sobre los Bosques y la Asociación de Colaboración en Materia de Bosques

El Foro de las Naciones Unidas sobre Bosques (UNFF, por sus siglas en inglés) ${ }^{5}$ fue establecido como un órgano subsidiario del Consejo Económico y Social con la pertenencia que extiende a todos los Estados miembros de las Naciones Unidas. Su mandato consiste en continuar con el trabajo del IPF/IFF promoviendo la gestión forestal sostenible que incluye la coordinación con instituciones y procesos internacionales, regionales y subregionales.

La Asociación de Colaboración en Materia de Bosques (CPF, por sus siglas en inglés) fue establecida para apoyar el trabajo del UNFF. Constituye una asociación que comprende catorce organismos internacionales, presidida por la FAO y apoyada por la Secretaría de UNFF. Esta asociación facilita la cooperación y el intercambio de información entre sus miembros y la implementación y el apoyo de proyectos que promueven una gestión forestal sostenible.

En el 2006, durante su sexta sesión, el UNFF formuló cuatro objetivos mundiales sobre los bosques, los cuales fueron adoptados por el ECOSOC y continúan sirviendo como directrices para la política forestal internacional ${ }^{6}$. Los objetivos son:

\section{Objetivo global 1}

Revertir la pérdida de cubierta forestal en todo el mundo mediante una ordenación forestal sostenible, incluida la protección, restauración, forestación y reforestación e intensificar los esfuerzos para prevenir la degradación de los bosques.

\section{Objetivo global 2}

Potenciar los beneficios económicos, sociales y ambientales de los bosques, incluyendo el mejoramiento de los medios de vida de las poblaciones dependientes de ellos.

3. Propuestas del GIB / FIB, Propuesta 147 (c), <http://www.un.org/esa/forests/pdf/ipf-iff-proposalsforaction. pdf>. 16 de mayo 2014.

4. Resolución ECOSOC 2000/35.

5. United Nations Forum on Forests. 'About UNFF'. [sitio web]. <http://www.un.org/esa/forests/about.html>. Accedido el 20 de julio de 2014.

6. Resolución del Consejo Económico y Social 2006/49, Resultado de la sexta sesión del Foro de las Naciones Unidas sobre los Bosques, 28 de julio de 2006, Doc. de la ONU. E/2006/INF/2/Add. 1, párr. 3. 


\section{Objetivo global 3}

Aumentar significativamente la superficie de bosques protegidos en todo el mundo y otras áreas de bosques gestionados de manera sostenible, así como la proporción de productos forestales procedentes de bosques gestionados de manera sostenible.

\section{Objetivo global 4}

Revertir la reducción de la cooperación para el desarrollo en materia de gestión sostenible de los bosques y movilizar una cantidad significativamente mayor de nuevos recursos financieros para la implementación de una gestión forestal sostenible.

Al mismo tiempo que se desarrollaban los cuatro objetivos globales apuntados, el UNFF llevaba a cabo negociaciones para un nuevo instrumento internacional sobre los bosques, teniendo en cuenta las propuestas de acción del IPF/IFF. En el 2006 era evidente que este instrumento sería jurídicamente no-vinculante y el ECOSOC solicitó entonces explícitamente al UNFF" "concluir y aprobar, en su séptimo período de sesiones un instrumento jurídicamente no-vinculante para todos los tipos de bosques".

En el 2007, el UNFF finalizó un Instrumento Jurídicamente No-Vinculante sobre Todos los Tipos de Bosques (NLBI, por sus siglas en inglés) que luego fue adoptado por la Asamblea General de la ONU. Para poder alcanzar los cuatro objetivos globales sobre los bosques, el NLBI requiere políticas y programas nacionales de participación y cooperación internacional. También necesita la notificación voluntaria de los Estados miembros, basándose en el mecanismo existente de presentación de informes del UNFF como medio para controlar y evaluar el progreso hacia el logro de estos objetivos ${ }^{9}$.

A pesar de su carácter no-vinculante, al igual que los Principios Forestales de UNCED, el instrumento NLBI es reconocido como una importante herramienta internacional que debe guiar la política nacional e internacional en materia de bosques ${ }^{10}$. Aun siendo jurídicamente no-vinculante, el NLBI representa un acuerdo internacional sobre la definición de una gestión forestal sostenible (SFM, por sus siglas en inglés) y define las acciones necesarias para su aplicación. Ha sido reconocido oficialmente por el Convenio sobre la Diversidad Biológica (CDB), que sí establece un régimen de carácter vinculante. En su novena reunión, la Conferencia de las Partes del CDB decidió que las Partes al convenio deberán cooperar en la aplicación "de las decisiones establecidas por el UNFF, incluyendo el instrumento jurídicamente no-vinculante sobre todos los tipos de bosques"11. Lo anterior otorga al NLBI y al Acuerdo Internacional sobre los Bosques (IAF, por sus siglas en inglés) legitimidad adicional como marco global en materia de gestión forestal.

7. Resolución del Consejo Económico y Social 2006/49, Resultado de la sexta sesión del Foro de las Naciones Unidas sobre los Bosques, 28 de julio de 2006, Doc. de la ONU. E/2006/INF/2/Add. 1, párr. 26.

8. A/RES/62/98, 17 Dic. 2007.

9. ibid. VII. 9.

10. Evaluación Independiente del IAF, Equipo Informe Inicial, febrero de 2014, párr. 45. United Nations Forum on Forests. 'Independent Assessment of the IAF'. [sitio web]. <http://www.un.org/esa/forests/iafassessment.html >. Accedido el 20 de julio de 2014.

11. Decisión CBD COP IX/5, Mayo 2008, párr. 1 (i). 
Los críticos del IAF señalan la carencia de un mecanismo financiero para la implementación de proyectos IAF en materia de gestión forestal sostenible, particularmente en los países en desarrollo que requieren apoyo ${ }^{12}$. El UNFF no tiene control directo sobre el Fondo para el Medio Ambiente Mundial (GEF, por sus siglas en inglés), que sirve como un mecanismo de financiación para otros regímenes ambientales jurídicamente vinculantes, como el CDB, la Convención Marco de las Naciones Unidas sobre Cambio Climático (CMNUCC) y la Convención de las Naciones Unidas de Lucha contra la Desertificación en los Países Afectados por Sequía Grave o Desertificación, en particular en África (UNCCD, por sus siglas en inglés). Sin embargo, la ONU y sus miembros pueden proporcionar orientación e información en las actividades del GEF. Es más, puede decirse que un instrumento jurídicamente vinculante no sería necesario para la creación de un mecanismo de financiación eficaz ${ }^{13}$.

Todavía existe, ello no obstante, la posibilidad de elaborar un instrumento jurídicamente vinculante de carácter global sobre los bosques. En la misma resolución del 2006 en la que ECOSOC solicitara al UNFF la conclusión de un instrumento jurídicamente no-vinculante, ECOSOC decidió que "la eficacia del acuerdo internacional sobre los bosques se revisará en 2015 y sobre esta base se considerará una amplia gama de opciones incluyendo, entre otras cosas, un instrumento jurídicamente vinculante para todo tipo de bosques..." ${ }^{14}$. En su décimo período de sesiones, el UNFF estableció un marco para esta evaluación, incluyendo comunicaciones de los Estados miembros y un proceso de evaluación independiente, que culminarán en una revisión del IAF en el $11^{\circ}$ período de sesiones del UNFF en el 2015.

\section{Organización Internacional de las Maderas Tropicales}

El primer Convenio Internacional de las Maderas Tropicales (CIMT) fue establecido en 1983 bajo los auspicios de la Conferencia de las Naciones Unidas sobre Comercio y Desarrollo (UNCTAD, por sus siglas en inglés) a raíz de un proceso de negociación que data de la cuarta sesión de la UNCTAD en $1976^{15}$.

EI CIMT estableció la Organización Internacional de las Maderas Tropicales (OIMT) para proporcionar un marco de cooperación entre países productores y consumidores para promover la expansión del comercio de la madera y fomentar un uso sostenible y la conservación de bosques tropicales (Art. I).

La versión original del CIMT fue reemplazada en dos ocasiones por otros acuerdos. La versión actual del CIMT fue negociada en el 2006 y entró en vigor en el 2011. Aunque el CIMT del 2006 incluye un mayor enfoque en materia de gestión sostenible, continúa enfatizando la ampliación de la producción y el comercio de maderas tropicales como objetivo clave.

12. Evaluación Independiente del IAF, Equipo Informe Inicial, febrero de 2014, párr. 49.

13. ibid.

14. Resolución del Consejo Económico y Social 2006/49, Resultado de la sexta sesión del Foro de las Naciones Unidas sobre los Bosques, 28 de julio de 2006, Doc. de la ONU. E/2006/INF/2/Add. 1, párr. 32.

15. Resolución de la UNCTAD 93 (IV), 30 de mayo de 1976, dirigida al Secretario General de la UNCTAD que convoque reuniones preparatorias para las negociaciones internacionales sobre productos individuales, incluyendo las maderas tropicales (II y IV. 4). 
La OIMT tiene 68 países miembros de todas las regiones del mundo, divididos en productores de madera (32 países) y consumidores $(36)^{16}$, que en total representan aproximadamente $90 \%$ del comercio mundial de maderas tropicales y $80 \%$ de la cobertura mundial de bosques tropicales ${ }^{17}$. Además de proporcionar un foro para el diálogo entre miembros productores y consumidores, la OIMT formula políticas en materia de ordenación forestal sostenible y comercio, y lleva a cabo proyectos con los países miembros y los organismos de ejecución para promover y aplicar dichas políticas. Los proyectos incluyen formación y desarrollo de capacidades en el sector forestal sostenible, apoyo técnico para el seguimiento y la supervisión de los recursos forestales, y apoyo en el diseño e implementación de los programas de reforestación y prevención de la degradación de los bosques en virtud de las iniciativas REDD+ y el Mecanismo de Desarrollo Limpio del Protocolo de Kyoto ${ }^{18}$. Este trabajo es financiado por dos contribuciones voluntarias establecidas dentro del marco del CIMT: la Cuenta Especial, que apoya los programas temáticos y los proyectos, y el Fondo de Cooperación de Bali especialmente para ayudar a miembros productores a desarrollar una producción forestal sostenible y promover la exportación ${ }^{19}$.

\section{Regímenes globales ambientales, de derechos humanos y comerciales relacionados con los bosques}

Además de los instrumentos globales y las iniciativas específicas relativas a los bosques, existe una serie de regímenes internacionales que cubren otras áreas relevantes para el manejo forestal y el comercio de los recursos forestales. Esta incluye acuerdos multilaterales ambientales, los derechos indígenas y los instrumentos de derechos humanos, así como la Organización Mundial del Comercio (OMC) con sus acuerdos y procesos asociados.

\section{Acuerdos ambientales multilaterales}

Varios acuerdos abordan en forma directa o indirecta el tema de la protección de los recursos forestales. Estos incluyen CDB, CMNUCC, UNCCD, la Convención sobre los Humedales de Importancia Internacional, la Convención del Patrimonio Mundial (WHC, por sus siglas en inglés) y la Convención sobre el Comercio Internacional de Especies Amenazadas (CITES). Por ejemplo, la CMNUCC establece que las Partes deben promover la reducción de las emisiones de gases de efecto invernadero en el sector forestal $[\text { Art. } 4 \text { (c) }]^{20}$ y promover la conservación y mejora de los sumideros de gases de efecto invernadero, incluidos los bosques [Art. 4(d)]. Esto se ha elaborado a través de una serie de decisiones desarrollando mecanismos detallados para la Reducción de Emisiones por Deforestación y Degradación (REDD+, por sus siglas en inglés)²1.

16. Esto incluye los 27 países miembros de la Unión Europea en el momento de entrada en vigor.

17. International Tropical Timber Organization. 'About ITTO'. [sitio web]. <http://www.itto.int/about_itto/>. Accedido el 20 de julio de 2014.

18. International Tropical Timber Organization. 'ITTO at Work'. [sitio web]. <http://www.itto.int/at_work/>. Accedido el 20 de julio de 2014.

19. International Tropical Timber Agreement (2006). Arts. 20-21.

20. Convención Marco de las Naciones Unidas sobre el cambio climático, Nueva York, 1992.

21. Decisión CBD COP X / 2. Plan Estratégico para la Diversidad Biológica 2011-2020. Décima reunión de la Conferencia de las Partes en el Convenio sobre la Diversidad Biológica. Nagoya, Japón. 18 hasta 29 octubre, 2010. Doc. ONU. UNEP/CBD/COP/10/27. 
El régimen del CDB señala los bosques como componentes importantes de los hábitats y de la biodiversidad. En el 2010, las Partes al CDB adoptaron las Metas de Aichi, que incluyen una en particular relativa a reducir como mínimo a la mitad la pérdida de los hábitats naturales, incluidos los bosques hasta el año $2020^{22}$. Estos y otros acuerdos ambientales multilaterales pertinentes a la gestión forestal y el comercio se analizan con más detalle en la siguiente sección.

\section{Derechos humanos y derechos indígenas}

Los instrumentos internacionales sobre derechos humanos y derechos indígenas también resultan de fundamental importancia para la conservación de los bosques. La Declaración sobre los Derechos de los Pueblos Indígenas de las Naciones Unidas (UNDRIP, por sus siglas en inglés) y el Convenio de la Organización Internacional del Trabajo N 169 (Convenio 169 de la OIT) reconocen el derecho de los pueblos indígenas con respecto a la tierra y los recursos naturales en sus territorios, y ambos requieren que los Estados adopten las medidas procesales destinadas a asegurar que estos derechos sean protegidos.

Los instrumentos de derechos humanos, como el Pacto Internacional de Derechos Económicos, Sociales y Culturales (ICESCR, por sus siglas en inglés), también reconocen los derechos de los pueblos indígenas a los recursos naturales en el contexto del derecho a la propiedad, la subsistencia y la cultura. Estos derechos han sido interpretados y elaborados por instancias internacionales de derechos humanos, en particular la Corte Interamericana de Derechos Humanos y la Comisión Africana de Derechos Humanos y de los Pueblos.

La Declaración sobre los Derechos de los Pueblos Indígenas de las Naciones Unidas establece que los pueblos indígenas "tienen derecho a las tierras, territorios y recursos que tradicionalmente han poseído, ocupado o de otra forma utilizado o adquirido" (Art. 26.1) y "al derecho a la conservación y protección del medio ambiente y la capacidad productiva de sus tierras o territorios y recursos" (Art. 29.1). Para hacer realidad estos derechos, los Estados están obligados a reconocer jurídicamente esos derechos sobre tierras y recursos a través de un proceso participativo y transparente, que considera las leyes indígenas, costumbres y sistemas de tenencia de la tierra (Art. 27) y para obtener "consentimiento libre e informado antes de aprobar cualquier proyecto que afecte a sus tierras o territorios y otros recursos, particularmente en relación con el desarrollo, la utilización o la explotación de los recursos minerales, hídricos o de otro tipo" (Art. 32.2). Este principio del consentimiento libre, previo e informado (CLPI), mencionado en la UNDRIP, se ha convertido en un estándar reconocido internacionalmente para la protección de los derechos de los pueblos indígenas en los proyectos que pudieran afectarlos.

El Pacto Internacional de Derechos Económicos, Sociales y Culturales reconoce el derecho de todos los pueblos a "disponer libremente de sus riquezas y recursos naturales" y dispone que "en ningún caso se podrá privar a un pueblo de sus propios medios de subsistencia" (Art. 1.2) ) $^{23}$. El Comité de Derechos Económicos, Sociales y Culturales también ha interpretado el derecho a participar en la vida cultural en virtud del Art. 15 del Pacto que incluye los derechos de los pueblos indígenas a las

22. Decisión CBD COP Decisión X / 2. Plan Estratégico para la Diversidad Biológica 2011-2020. Décima reunión de la Conferencia de las Partes en el Convenio sobre la Diversidad Biológica. Nagoya, Japón. 18 hasta 29 octubre, 2010. Doc. ONU. UNEP/CBD/COP/10/27.

23. Pacto Internacional de Derechos Económicos, Sociales y, GA Res. 2200A/XXI, 16 de diciembre de 1996. 
tierras, territorios y recursos que tradicionalmente han poseído y forman un componente importante de su cultura ${ }^{24}$.

Los tribunales internacionales de derechos humanos han pergeñado los derechos de los pueblos indígenas a los recursos naturales existentes en su territorio, en particular en el contexto de los recursos forestales. En el caso Awas Tingni vs. Nicaragua, la Corte Interamericana de Derechos Humanos $(\mathrm{CIDH})$ determinó que una concesión para la gestión de los bosques en el territorio de la Comunidad Awas Tingni violaba los derechos de propiedad de los miembros de la comunidad en virtud del Art. 21 de la Convención Americana sobre Derechos Humanos ${ }^{25}$. En este caso, la Corte subrayó que una comunidad indígena tiene derecho a una protección especial de sus derechos de propiedad, incluso si carece de título oficial de la tierra que habita. En un caso posterior (Pueblo Saramaka vs. Surinam), la CIDH sostuvo que estos derechos de propiedad implicaban una responsabilidad del Estado a garantizar la participación suficiente en el proceso de toma de decisiones, las evaluaciones de impacto ambiental y social adecuadas, y un beneficio garantizado a la comunidad de los proyectos realizados a cabo en su territorio. En ese caso, el Tribunal consideró que, al otorgar concesiones madereras y de oro sin proporcionar dichas garantías procesales, el Estado violó los derechos de propiedad del pueblo Saramaka.

La Comisión Africana de los Derechos Humanos de los Pueblos citó ambos casos en el asunto Endorois, una violación del derecho de propiedad donde un Estado no logró adoptar las medidas necesarias para proteger los derechos de una comunidad indígena a la tierra y otros recursos dentro de su territorio 26 .

En la práctica, estos derechos indígenas reconocidos internacionalmente exigen a los Estados la aplicación de procedimientos legales especiales en la gestión, el desarrollo y la conservación de los bosques habitados o utilizados por las poblaciones indígenas. Los Estados están obligados a reconocer legalmente los derechos de propiedad de dichas poblaciones aun cuando carezcan de un título formal y proteger estos derechos a través de las garantías procesales, tales como las evaluaciones de impacto ambiental y los procesos de consulta para garantizar la distribución de beneficios y el consentimiento libre, previo e informado de cualquier proyecto que les pueda afectar.

\section{Comercio}

Los acuerdos y los procesos de la Organización Mundial del Comercio (OMC) proporcionan un marco global para la regulación del comercio dirigido principalmente a la eliminación de barreras al libre

24. CESCR Observación General N²1, 21 dic. 2009, Doc. de la ONU. E/C.12/GC/21.

25. Caso de la Comunidad Mayagna (Sumo) Awas Tingni vs. Nicaragua, la Corte Interamericana de Derechos Humanos, Sentencia del 31 de agosto de 2001 (Fondo, Reparaciones y Costas), Serie C № 79. Véase también el Caso del Pueblo Saramaka vs. Surinam, la Corte Interamericana de Derechos Humanos, Sentencia del 28 de noviembre de 2007, Excepciones Preliminares, Fondo, Reparaciones y Costas, Serie C N 172 (encontrando que las concesiones de explotación forestal y de oro otorgadas en el territorio del pueblo Saramaka violaron sus derechos de propiedad debido a la falta de una participación suficiente en el proceso de toma de decisiones y el incumplimiento de las evaluaciones de impacto ambiental y social adecuadas).

26. Comisión Africana de Derechos Humanos y de Pueblos, el Centro de Derechos de las Minorías de Desarrollo (Kenia) y Minority Rights Group (en nombre del Consejo de Bienestar Endorois) v Kenia, №276/03, 25 de noviembre de 2009. 
comercio. Este marco tiene implicaciones para la gestión forestal y el comercio de productos forestales, específicamente en relación con la regulación unilateral de las importaciones y la subvención de madera. La liberalización del comercio entre países productores y países consumidores de madera también podría ocasionar un crecimiento en la industria maderera que, a su vez, podría establecer la necesidad de una regulación adicional.

El Acuerdo General sobre Aranceles Aduaneros y Comercio (GATT, por sus siglas en inglés) y el Acuerdo sobre Obstáculos Técnicos al Comercio (OTC) imponen restricciones a la capacidad de un país para regular sus importaciones. EI GATT sanciona prohibiciones o cuotas a las importaciones (Art. XI) y las tasas o la discriminación normativa de productos importados por una parte contratante y los productos similares importados por otra parte contratante para exportación (Art. I) o productos similares de origen nacional (Art. III). EI OTC aplica las mismas normas antidiscriminatorias con respecto a los reglamentos técnicos, como el etiquetado (Art. OTC. 2.1 y Anexo 1.1). Estas normas podrían interferir potencialmente con la regulación destinada a garantizar el abastecimiento sostenible de los recursos naturales importados. Por ejemplo, en el caso EE.UU.-CamaronesTortugas (Shrimp-Turtle), el Órgano de Apelación de la OMC determinó que la prohibición de los Estados Unidos a la importación de camarones procedentes de países que no requiere el uso de un dispositivo específico para la protección de tortugas marinas durante la pesca de camarón violaba el Art. XI del GATT ${ }^{27}$. De manera significativa, como se muestra en este caso, la expresión "productos similares" se aplica a todos aquellos en relación de competencia, incluso en algunos casos en que los procesos y los métodos de producción sean diferentes. Así, por ejemplo, la madera talada de forma insostenible podría ser considerada como madera sostenible, con el propósito de determinar el impuesto o la discriminación reglamentaria.

El Artículo XX del GATT otorga excepciones a estos requisitos en el caso de medidas "necesarias para proteger la salud humana, animal o vegetal" y medidas "relativas a la conservación de los recursos naturales no renovables". Tales medidas se aplican conjuntamente con restricciones a la producción o al consumo, pero solo si esas medidas "no se aplican de una manera que constituyan un medio de discriminación arbitraria o injustificable" o "una restricción encubierta al comercio internacional" (Art. XX). En el caso previamente mencionado, el Órgano de Apelación constató que la prohibición de las importaciones constituía una discriminación injustificable, ya que tenía la intención de coaccionar a los gobiernos extranjeros a que adoptaran políticas idénticas a la de los Estados Unidos. Por lo tanto, no estaba incluido en la excepción del mencionado Artículo XX. Tras la adopción del informe del Órgano de Apelación, los Estados Unidos revisaron los requisitos de importación de camarones para aumentar la flexibilidad y transparencia, y participó en los intentos de negociación con los países para alcanzar soluciones normativas multilaterales. Posteriormente, el Órgano de Apelación decidió que estos intentos fueron suficientes para eliminar la discriminación injustificable y amparar la prohibición en el Art. XX28.

27. Estados Unidos - Prohibición de las importaciones de determinados camarones y sus derivados, Órgano de Apelación de OMC, 12 de octubre de 1998, Doc. de la OMC. WT/DS58/AB/R.

28. Estados Unidos - Prohibición de las importaciones de determinados camarones y productos del camarón - Recurso al Artículo 21.5 del ESD por Malasia, el Órgano de Apelación de la OMC, 22 de octubre de 2001, Doc. de la OMC. WT/DS58/AB/RW. 
La excepción del Artículo XX no es aplicable a las violaciones al OTC. Sin embargo, en el preámbulo de este acuerdo, se reconoce que "ningún país debe ser impedido de tomar las medidas necesarias... para la protección de personas, los animales o preservación de los vegetales, [o] del medio ambiente... sujeta al requisito que no se apliquen de una forma que constituya un medio de discriminación arbitraria o injustificable... una restricción encubierta al comercio internacional”.

Por la decisión del Órgano de Apelación en el caso EE.UU.-Cigarrillos de clavos de olor (clove), la reglamentación técnica puede ser considerada compatible con el OTC, incluso si tiene un impacto discriminatorio respecto a productos de determinados Estados siempre y cuando dicho impacto esté basado en una distinción reglamentaria legítima ${ }^{29}$. Este puede resultar un estándar difícil de cumplir. En el caso EE.UU.-Atún-Delfines, el Órgano de Apelación declaró que una norma americana de requisitos para las etiquetas "libre de delfines" en los productos del atún violaba el OTC, ya que utilizaba diferentes normas para las prácticas pesqueras en diferentes regiones del mundo, constituyendo así una discriminación en lugar de una distinción reglamentaria legítima ${ }^{30}$.

Estas normas de no-discriminación son importantes para la regulación del comercio de la madera. En efecto, en el marco del GATT la prohibición o la regulación de los recursos forestales de origen no sostenible no debe ser diseñada de manera que no se haga la distinción entre diferentes regiones y no puede estar destinada a obligar a otros países a adoptar idénticas medidas regulatorias. Bajo los esquemas de los OTC, la certificación o el etiquetado de la madera que tiene un impacto de facto sobre un país en particular puede infringir el Artículo 2.1, a menos que se base en una distinción reglamentaria legítima. Por lo tanto, los países importadores deben ser cuidadosos al momento del diseño de regulaciones creadas para promover el comercio de productos forestales sostenibles.

Las normas sobre subvenciones del sistema de la OMC tienen un impacto en países productores de productos forestales. El Acuerdo de la OMC sobre Subvenciones y Medidas Compensatorias (Acuerdo SMC) limita las subvenciones específicas que causen efectos desfavorables en los intereses de otros miembros, incluyendo el caso en que el producto subvencionado tenga una ventaja de precio en un mercado particular. Los países que se han visto afectados negativamente por dichas subvenciones pueden utilizar medidas compensatorias para contrarrestar la ventaja de precio. Los derechos de aprovechamiento de los recursos forestales pueden considerarse como una forma de subsidio. En el caso EE.UU.-Softwood Lumber (madera blanda), el Órgano de Apelación decidió que un programa canadiense que otorgaba la concesión de derechos de aprovechamiento de madera a honorarios relativamente bajos constituía una subvención recurrible en virtud del SMC y por tanto, los Estados Unidos podían aplicar medidas para la aplicación de derechos compensatorios ${ }^{31}$. Este es un caso potencialmente importante para los países exportadores de productos forestales. Si

29. Informe del Grupo Especial: Estados Unidos - Medidas que afectan a la producción y venta de cigarrillos de clavo de olor, el informe del Órgano de Apelación, 4 de abril de 2012, Doc. de la OMC. WT/DS406/AB/R. Objetivos normativos legítimos pueden incluir la protección de la "vida animal o vegetal o la salud" (Art. OTC. 2.2).

30. Informe del Órgano de Apelación, Estados Unidos - Medidas relativas a la importación, comercialización y venta de atún y productos de atún, 16 de mayo de 2012, OMC Doc. WT/DS381/AB/R/R.

31. Estados Unidos - Determinación definitiva con respecto a determinada madera blanda procedente de Canadá, la OMC Órgano de Apelación, WT/DS257/AB/R, 19 de enero de 2004. 
los derechos de recolección y concesiones se otorgan libremente, estos países podrían solicitar derechos compensatorios a otros países productores de madera ${ }^{32}$.

En las últimas dos décadas, la OMC ha comenzado a centrarse en temas relativos a la sostenibilidad. En 1994, se estableció el Comité de Comercio y Medio Ambiente (CCMA) para investigar la relación entre desarrollo sostenible y comercio. La Agenda para el Desarrollo de Doha incluye las negociaciones entre la OMC y los acuerdos multilaterales ambientales, la eliminación de los subsidios y las barreras a los bienes y servicios ambientales perjudiciales para el medio ambiente. También establece que la $\mathrm{OMC}$ aborde en particular el efecto de las medidas ambientales en el comercio y los requisitos del uso del etiquetado ecológico ${ }^{33}$. Estas negociaciones están todavía en curso.

\section{Instrumentos y procesos regionales}

Una serie de acuerdos regionales trata directa o indirectamente la gestión forestal sostenible y el comercio de recursos forestales. El alcance y naturaleza de estos acuerdos varía según la región. Centroamérica es un claro líder en esta área con acuerdos y planes que tratan específicamente la gestión sostenible de los bosques, como se discutirá más adelante. Sin embargo, otras regiones han adoptado instrumentos importantes que abordan cuestiones en el sector forestal, tales como tratados y convenios, procesos ministeriales regionales, criterios e indicadores.

\section{Tratados y convenios regionales}

Además de América Central, es posible que África tenga los regímenes jurídicos internacionales más completos y específicos relacionados con la gestión forestal. La Convención Africana sobre la Conservación de la Naturaleza y los Recursos Naturales revisada en el 2003 establece que los Estados Partes tomarán medidas específicas para proteger la cubierta vegetal, así como la repoblación forestal y el establecimiento de reservas forestales y medidas para controlar incendios, desmonte de tierras y el pastoreo forestal (Art. VIII. 1). Esta convención también contiene disposiciones destinadas a promover la gestión sostenible de las especies vegetales de cosecha y animales (Art. IX), eliminación del comercio ilícito de fauna y flora silvestres (Art. XI), y la creación y gestión sostenible de zonas de conservación, incluyendo las áreas de conservación comunitarias (Art. XII).

África Central y África del Sur tienen sus propios regímenes forestales. El Tratado sobre la Conservación y la Gestión Sustentable de los Ecosistemas Forestales de África Central (2005) obliga a los Estados Partes a dar prioridad a la conservación y la gestión sostenible de los bosques, desarrollar, y poner en marcha los sistemas de certificación, los mecanismos de financiamiento para el desarrollo sostenible de los bosques y la adopción de medidas para detener la tala incontrolada (Art. 1). El Tratado establece formalmente la Comisión de Bosques del África Central (COMIFAC, por sus siglas en francés) y alienta a los gobiernos a poner en práctica el Plan de Convergencia elaborado por la COMIFAC para la creación y gestión de áreas protegidas (Art. 1).

32. Los países productores no maderables no podían imponer un derecho compensatorio, porque no podía argumentar que se vieron afectados negativamente por la subvención.

33. Doha Declaración Ministerial de la OMC, adoptada el 14 de noviembre de 2001, Doc. de la OMC. OMC / MIN (01) / DEC / 1. 
El Protocolo de la Comunidad para el Desarrollo del África del Sur (SADC, por sus siglas en inglés) sobre Silvicultura del $2002^{34}$ se ocupa de la gestión forestal sostenible y el comercio de productos forestales. Este protocolo requiere que los Estados Partes cooperen en la armonización sobre políticas de gestión forestal y la promoción del comercio sostenible y la inversión (Art. 3.2). Disposiciones específicas se refieren a cuestiones de tenencia de la tierra (Art. 5), el monitoreo y evaluación (Art. 8, 9), criterios e indicadores (Art. 8), gestión forestal comunitaria (Art. 12), equidad de género (Art. 13), bosques transfronterizos (Art. 14) y normas comerciales sobre productos forestales (Art. 18). El Protocolo establece que los Estados Partes deberán "adoptar todas las medidas legislativas, administrativas y de ejecución necesarias para hacer frente a las amenazas naturales e inducidas por el hombre a los bosques" (Art. 15).

Aunque no existen acuerdos específicos sobre los bosques en Sudamérica u Oceanía, ambos continentes han adoptado acuerdos ambientales que contemplan temas relacionados con la gestión de los recursos forestales y el comercio.

El Tratado de Cooperación Amazónica (1980) establece un sistema de intercambio de información y de conocimientos técnicos para asegurar la conservación y el uso racional de la flora y la fauna. En 1998, un protocolo al tratado instituyó la Organización del Tratado de Cooperación Amazónica (OTCA, por sus siglas en inglés), la cual implementa varios proyectos en el sector forestal ${ }^{35}$.

En Oceanía, la Convención sobre la Conservación de la Naturaleza en el Pacífico Sur (1976) ${ }^{36}$ no solamente se refiere específicamente a los bosques, sino que fomenta la creación de áreas protegidas y reservas nacionales, incluyendo reservas forestales, que serán protegidas dentro de lo posible de la degradación y la explotación comercial (Art. III-IV).

La Asociación de Naciones del Sudeste Asiático (ASEAN, por sus siglas en inglés) negoció un Acuerdo sobre la Conservación de la Naturaleza y los Recursos Naturales, el cual requiere que las Partes contratantes adopten todas las medidas necesarias para garantizar la conservación de la cubierta forestal a través de reservas forestales y planes de gestión forestal. Sin embargo, desde su firma en 1985, no ha sido aún ratificado por suficientes países para permitir la entrada en vigor. La ASEAN tiene una Red Social Forestal (ASFN, por sus siglas en inglés) que incluye miembros del gobierno, sociedad civil y representantes del sector privado, la cual trabaja conjuntamente para integrar los enfoques sociales de silvicultura en la adaptación al cambio climático y las estrategias de mitigación. Todos los países de la ASEAN son miembros de la ASFN ${ }^{37}$.

\section{Procesos ministeriales y técnicos regionales}

Junto a los regímenes convencionales formales, los procesos regionales e institucionales desempeñan un papel en el establecimiento y la creación de normas para la gestión forestal. Estos incluyen los procesos ministeriales y normas técnicas e indicadores.

34. Entrado en vigor en julio de 2009.

35. Proyectos recientes incluyen un proyecto de registro de monitoreo y uso de la tierra, y un programa sobre el uso sostenible y la conservación de los bosques y la biodiversidad en la región amazónica. Ver: Organización del Tratado de Cooperación Amazónica. [sitio web]. <http://www.otca.info/portal/>. Accedido el 29 de mayo de 2014.

36. Entrado en vigor en junio de 1990.

37. ASFN-ASEAN Social Forestry Network. [sitio web]. <http://www.asfnsec.org>. Accedido el 29 de julio de 2014. 
Los procesos ministeriales regionales para la aplicación de leyes y gobernanza forestales (FLEG, por sus siglas en inglés) están destinados a facilitar la cooperación política y compromisos a nivel regional. A principios de la década del 2000, el Banco Mundial apoyó una serie de conferencias ministeriales a nivel regional sobre FLEG que tuvieron lugar en Asia Oriental y el Pacífico (2001), África (2003), Europa y el norte de Asia (2005) $)^{38}$. Estas conferencias dieron lugar a declaraciones ministeriales afirmando compromisos de colaboración en el fortalecimiento de la gobernanza forestal y el combate de los delitos forestales, incluyendo la Declaración de Bali en Asia Oriental y el Pacífico, la Declaración y Plan de Acción FLEG de África y la Declaración de San Petersburgo en Europa y África del Norte. Europa también tiene una Conferencia Ministerial en curso sobre la Protección de los Bosques en Europa (MCPFE, por sus siglas en inglés) que se ha reunido ya en cinco ocasiones desde 1990, estableciendo periódicamente reuniones de expertos ${ }^{39}$. La MCPFE adoptó una serie de compromisos en materia de gestión sostenible en los bosques en Europa.

La FAO ha promovido varios procesos técnicos regionales para el desarrollo de criterios e indicadores (C\&l) en el manejo forestal sostenible ${ }^{40}$. Estos procesos regionales incluyen el de la Zona Seca de África, el de Lepaterique (América Central), el de los Bosques Secos en Asia, el del Cercano Oriente, la Propuesta de Tarapoto (Región Amazónica), el Proceso Forestal Paneuropeo ${ }^{41}$ y el Proceso de la Organización Africana de la Madera. Igualmente, el Proceso de Montreal desarrolla C\&l para los bosques templados y boreales que se hallan fuera de Europa con 12 países miembros en todo el mundo. En total, la FAO estima que unos 150 países participan en uno o más procesos sobre C\&l.

\section{Mecanismos unilaterales y bilaterales relativos a la cadena de suministro}

En los últimos años, las regiones madereras y los países importadores han comenzado a promover legislaciones destinadas a garantizar la legalidad de la actividad forestal en los países exportadores. A través de regulaciones en la cadena de suministro, los países importadores exigen a los exportadores y vendedores nacionales una prueba de que la madera no ha sido talada ilegalmente. Ejemplos significativos son la Ley Lacey de Estados Unidos (revisada en el 2008), el Reglamento sobre la Madera de la Unión Europa (2010) y la Ley de Prohibición de la Tala llegal de Australia (2012).

\section{Ley Lacey (EE.UU.)}

Una ley de hace 100 años que regula la importación de comercio ilegal de vida silvestre en Estados Unidos fue enmendada en el 2008 para prohibir la importación de una serie de plantas de origen ilegal y productos vegetales, incluyendo todos aquellos derivados de los árboles. Esta ley modificada establece que es ilegal importar cualquier planta o producto vegetal "tomado, poseído, transportado o vendido en violación de cualquier ley o reglamento de cualquier Estado, o cualquier ley extranjera,

38. The World Bank. 'Regional Forest Law Enforcement and Governance (FLEG) Initiatives'. [sitio web], (31 de agosto de 2013). <http://www.worldbank.org/en/topic/forests/brief/fleg-regional-forest-law-enforcementgovernance>. Accedido el 20 de julio de 2014.

39. Forest Europe. [sitio web]. <http://www.foresteurope.org/>. Accedido el 29 de mayo de 2014.

40. FAO. 'Criteria and Indicators - for sustainable forest management'. [sitio web]. <http://www.fao.org/ forestry/ci/>. Accedido el 20 de julio de 2014.

41. En conexión con MCPFE. 
que protege las plantas..."42. Cabe destacar que la ley establece la jurisdicción de los tribunales estadounidenses para interpretar cualquier ley extranjera aplicable para determinar si el producto vegetal importado fue cosechado ilegalmente, aun cuando la ley extranjera no se aplique de forma activa en el país extranjero. La pena por una violación de la Ley Lacey es de hasta cinco años de prisión o una multa de US $\$ 250,000$ para individuos o una multa de US $\$ 500,000$ para corporaciones. La Ley Lacey permite esencialmente a los tribunales estadounidenses hacer valer sus jurisdicciones sobre tala ilegal de madera en los países exportadores, exigiendo a los operadores comerciales privados que demuestren la legalidad de los productos.

\section{FLEGT Unión Europea y el Reglamento de la Madera}

El programa de la Unión Europea para la Aplicación de Leyes, Gobernanza y Comercio (FLEGT, por sus siglas en inglés) creado en el 2005 establece un sistema de Acuerdos Voluntarios de Asociación (VPA, por sus siglas en inglés) entre la Unión Europea y los países exportadores de madera ${ }^{43}$. Estos acuerdos establecen procedimientos jurídicamente vinculantes para garantizar la legalidad de la madera importada a la Unión Europea a través de la concesión de licencias de exportación de madera. A partir del 2014, seis países ${ }^{44}$ han firmado VPAs con la Unión Europea.

En el 2010, la Unión Europea aprobó una nueva legislación, haciendo ilegal la venta de madera o productos derivados de la tala ilegal en el mercado de la Comunidad Europea ${ }^{45}$.

Al igual que la Ley Lacey de Estados Unidos, el Reglamento de la Madera de la Unión Europea 2010 (EUTR, por sus siglas en inglés) obliga a los operadores de la CE a garantizar que los productos de madera que importan o venden no sean derivados de la tala ilegal. Esta regulación abarca los productos que van desde la madera en bruto hasta los muebles, marcos de cuadros y papel (anexo). El Reglamento establece que solo se considerarán legalmente adquiridos aquellos productos acompañados de las licencias FLEGT o permisos CITES (Art. 3). El EUTR estipula que los Estados miembros determinarán las sanciones por violación a la reglamentación y que tales sanciones pueden incluir multas, decomiso de los productos aquellos y la suspensión de la licencia para el comercio (Art. 19).

EI FLEGT y el EUTR establecen un sistema tendiente a promover la legalidad de la tala de madera en los países exportadores a la CE. Los importadores tienden a invertir en países que tengan un VPA y un sistema de licencias FLEGT que pueda proteger a los importadores de una violación del EUTR. Esto crea un incentivo para que los países exportadores de madera puedan negociar VPAs, a fin de seguir promoviendo la inversión y el comercio. Desde el 2010, ocho países han establecido negociaciones en el marco de los VPAs.

42. Ley Lacey 1900, modificada en el 2008, 16 USC $\$ 3371$ et seq. at $\$ 3372(a)(2)(B)$.

43. Reglamento (CE) $N^{\circ} 2173 / 2005$, del 20 de diciembre de 2005 sobre el establecimiento de un sistema de licencias FLEGT aplicable a las importaciones de madera a la Comunidad Europea.

44. Camerún, República Centroafricana, Ghana, Indonesia, Liberia, República del Congo.

45. Reglamento (UE) N 995/2010 del Parlamento Europeo y del Consejo, del 20 de octubre de 2010. Por él se establecen las obligaciones de los agentes que comercializan madera y productos derivados en el mercado. 


\section{Ley para la Prohibición Ilegal de Tala en Australia}

La Ley de Prohibición de la Tala llegal en Australia del $2012^{46}$ determina que la importación de madera talada ilegalmente y los productos de madera sean una ofensa criminal (Art. 8). Los infractores estarán sujetos a multas de hasta $\$ 275,000$ para una corporación o $\$ 55,000$ para un individuo y hasta cinco años de prisión. La Enmienda al Reglamento de Prohibición de Tala llegal del $2013^{47}$, que entrará en vigor en noviembre de 2014, establece los requerimientos adicionales de debida diligencia de los importadores de productos madereros respecto a reunir información suficiente sobre el origen y la legalidad de la tala de madera y los productos, y en la adopción de medidas necesarias para minimizar el riesgo de tala ilegal.

46. Ley № 166 del 2012 en su forma enmendada, 22 de abril de 2013, Ley para Combatir la Tala llegal y para fines relacionados.

47. Tala llegal Prohibición Enmienda Reglamento del 2013, Selecto Instrumento Legislativo № 88, 2013. 



\section{México}

Gustavo Alanis Ortega 


\section{Acrónimos}

CITES: $\quad$ Convención sobre Comercio Internacional de Especies Amenazadas de Flora y Fauna

CONAF: $\quad$ Consejo Nacional Forestal

CONAFOR: Comisión Nacional Forestal

CPF: $\quad$ Código Penal Federal

FLEGT: $\quad$ Plan de acción de la aplicación de leyes, gobernanza y comercio forestales

LCE: $\quad$ Ley Aduanera y la Ley de Comercio Exterior

LDRS: $\quad$ Ley de Desarrollo Rural

LGCC: $\quad$ Ley General de Cambio Climático

LGDFS: Ley General de Desarrollo Forestal Sustentable

LGEEPA: Ley General del Equilibrio Ecológico y la Protección al Ambiente

LFSV: $\quad$ Ley Federal de Sanidad Vegetal

MFC: $\quad$ Manejo Forestal Comunitario

PROFEPA: Procuraduría Federal de la Protección al Ambiente

SAGARPA: Secretaría de Agricultura, Ganadería, Desarrollo Rural, Pesca y Alimentación

SEMARNAT: Secretaría de Medio Ambiente y Recursos Naturales

RAN: $\quad$ Registro Agrario Nacional 


\section{Introducción}

México se caracteriza por tener una superficie forestal en cuyo territorio se encuentra la mayoría de tipos de vegetación terrestre natural conocidos que ocupan una extensión de poco más de 138 millones de hectáreas ( $71 \%$ de la superficie del territorio nacional); de las cuales, $41,2 \%$ corresponde a matorrales xerófilos, $24,2 \%$ a bosques templados, $22,8 \%$ a selvas y $11,8 \%$ a otros tipos de asociaciones de vegetación forestal y pastizales. Estos recursos son de gran importancia para el país desde el punto de vista ambiental, económico y social. Aunado a esto, más del $80 \%$ de los ecosistemas forestales en los que se concentra gran parte de la biodiversidad es de propiedad ejidal y comunal. Los habitantes de estas zonas son los dueños de una importante riqueza biológica. Además, las zonas que ocupan los pueblos indígenas tienen una cubierta de vegetación primaria y secundaria de 18 millones de hectáreas $(75 \%)$. El resto son áreas de pastizales $(11,3 \%)$ y tierras de uso agrícola (11,9\%), en las que se alberga una parte importante de la agro-biodiversidad mesoamericana. Los cuerpos de agua y zonas urbanas cubren el resto de la superficie del país (1,8\%). La superficie con potencial de producción maderable es de 17,8 millones de hectáreas, con dos mil autorizaciones aproximadamente que representan un volumen anual de corta de 8,1 millones de metros cúbicos de madera¹.

Sin embargo, durante el período 2002-2011 la producción forestal maderable ha ido disminuyendo de forma constante, iniciando con 6,7 millones de metros cúbicos rollo $\left(\mathrm{m}^{3} \mathrm{r}\right)$ en el 2002 y finalizando este período con 5,5 millones de $\mathrm{m}^{3} \mathrm{r}$ en el 2011. Desde inicios de esta década, la disminución ha sido continua, con excepción de los años 2003 y 2007, en los cuales la producción alcanzó un volumen alto, como se muestra en la siguiente gráfica²

1. Procuraduría Federal de Protección al Ambiente. 'Informe Anual de PROFEPA 2012'. [pdf online]. <http:// www.profepa.gob.mx/innovaportal/file/5322/1/iap_2012_260813.pdf>. Accedido el 4 de abril de 2014.

2. Anuario Estadístico de la Producción Forestal 2011, CONAFOR. Sistema Nacional de Información Forestal. [sitio web]. <http://www.cnf.gob.mx:8080/snif/portal/economica/anuarios-estadisticos-de-la-produccionforestal>. Accedido el 4 de abril de 2014. 


\section{Producción forestal maderable 2002-2011}

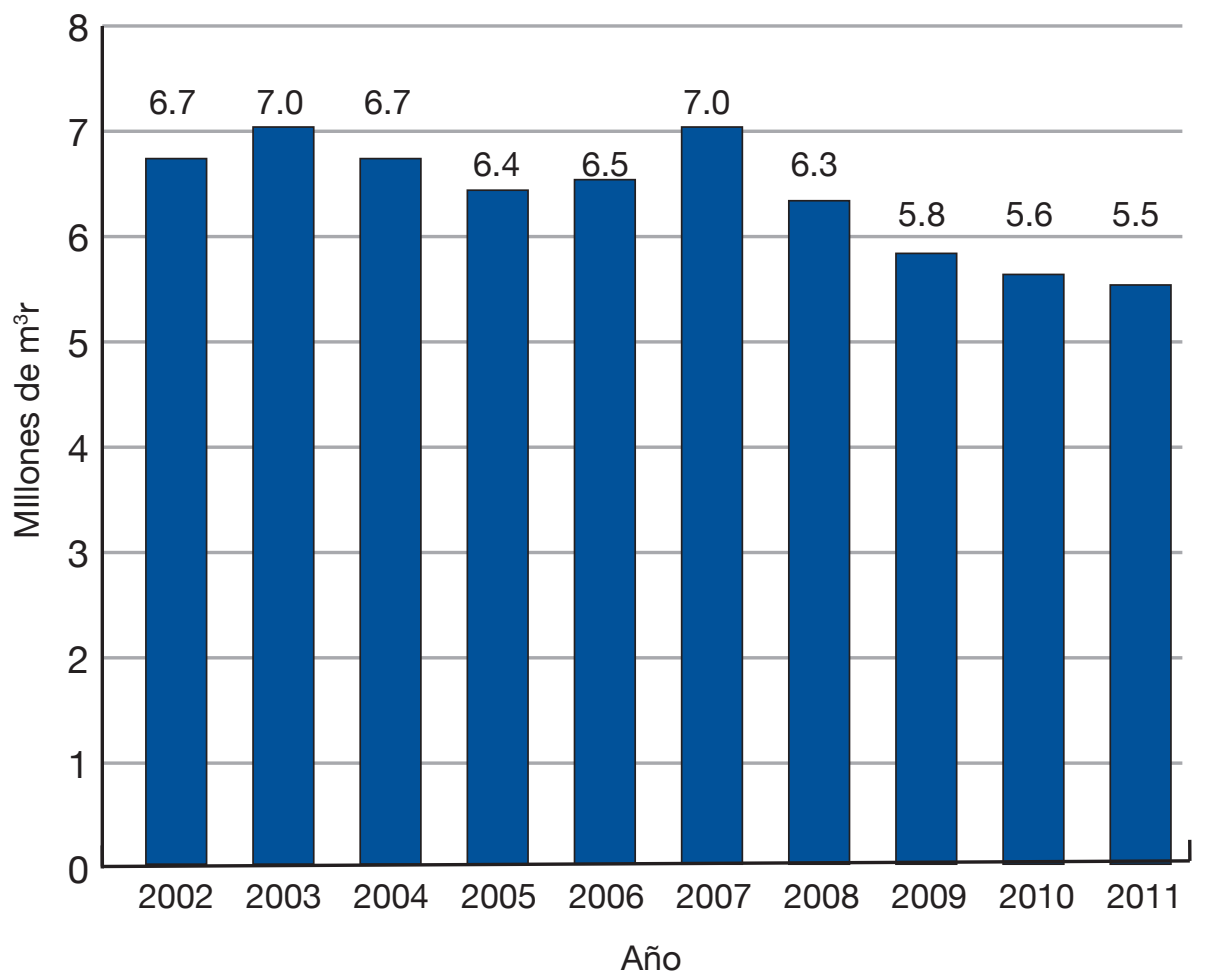

Fuente: Dirección General de Gestión Forestal y de Suelos, SEMARNAT

De la producción forestal nacional maderable por género, las coníferas (pino, oyamel y otras coníferas) contribuyeron con $79,8 \%$, las latifoliadas (encino y otras latifoliadas) con $14,5 \%$ y las tropicales (preciosas y comunes tropicales) con 5,8\% (ver Tabla 1 Anexo).

En cuanto a la balanza comercial forestal del 2007 al 2011, el saldo presenta mínimas variaciones en su déficit durante los últimos 5 años, iniciando el período con un déficit total de US\$5,6 miles de millones y concluyendo con un déficit de US\$5,8 miles de millones. En el 2011, las exportaciones de madera y sus manufacturas incrementó a 299,9 millones (mdd), contra importaciones por un valor de 1,264.4 mdd, siendo el saldo resultante de naturaleza deficitaria equivalente a 964,6 mdd.

Los principales productos exportados fueron los demás de manufacturas de madera, listones y molduras, ventanas, puertas y tableros celulares, junto con cajas y paletas, los cuales en conjunto representaron un valor de $221 \mathrm{mdd}$, equivalente a $73,7 \%$ del valor total de las exportaciones de productos de madera; mientras que los principales productos importados fueron madera aserrada, tableros contrachapados, tableros de fibra y listones, y molduras con un valor global de 961,2 mdd, que equivalen a $76 \%$ del valor total de las importaciones de productos de madera (ver Tabla 2 Anexo). 
En lo que corresponde al volumen de las exportaciones de madera y sus manufacturas durante el 2011, ascendieron a 2.495,1 miles de $\mathrm{m}^{3}$ r, contra importaciones por un volumen de 19.119,7 miles de $\mathrm{m}^{3}$ r, teniendo un déficit equivalente a $16.624,5$ miles de $\mathrm{m}^{3}$ r. Los principales productos exportados fueron chapas de madera, madera aserrada, carbón vegetal y listones y molduras, los cuales en su conjunto representaron un volumen de $2.105,9$ miles de $\mathrm{m}^{3}$ r, equivalente a $84,4 \%$ del volumen total de las exportaciones de productos de madera. Los principales productos importados fueron madera aserrada, chapas de madera, tableros contrachapados, junto con listones y molduras, con un volumen global de $18.177,9$ miles de $\mathrm{m}^{3}$ r, que equivalen a $95,1 \%$ del total de las importaciones de productos de madera (ver Tabla 3 Anexo).

Es importante mencionar que, de las especies maderables exportadas, destacan el pino y el encino, mientras que la caoba, el guayacán y el cedro son las especies que más se comercian bajo el régimen de la Convención sobre Comercio Internacional de Especies Amenazadas de Flora y Fauna (CITES). 


\section{Síntesis histórica de la formulación de la Ley Forestal y afines}

El desarrollo legislativo de la materia forestal en México ha sido constante. La primera Ley Forestal se promulgó en 1926 y en total, se han decretado seis legislaciones forestales más: 1942, 1947, 1960, 1986, 1992 y 2003 (ver Tabla 4 Anexo).

La Ley Forestal de 1926 tuvo como objetivo regularizar la conservación, restauración, propagación y aprovechamiento forestal. Esta ley prohibió a las empresas extranjeras realizar aprovechamientos en tierras que eran de propiedad de comunidades y ejidos. Además, no se permitió a las compañías ser propietarias de los terrenos forestales que tenían en concesión, por lo que el uso de estos terrenos solo lo podían llevar a cabo sus dueños. Una de las principales características de esta ley es que no reglamentaba los aprovechamientos forestales comerciales o de autoconsumo y se enfocaba más al fortalecimiento de la protección y conservación forestal, dejando el aprovechamiento forestal pobremente regulado y debilitado ante otras actividades, por ejemplo, ante el sector agropecuario. La Secretaría de Agricultura y Fomento era la dependencia encargada de ejercer las atribuciones de Poder Ejecutivo Federal y los estados y municipios eran autoridades auxiliares en la materia forestal.

En 1942 se redactó una nueva ley forestal, que fue publicada en 1943. En esta ley se reconoce como objetivo reglamentar, proteger y fomentar la conservación, restauración, propagación y aprovechamiento de la vegetación forestal y de los productos que de ella derivan. Esta ley intentó fomentar el aprovechamiento y la industrialización de los productos forestales a través de la creación de un sistema de "unidades forestales de explotación industrial" con fines de utilidad pública.

Los aprovechamientos comerciales forestales solamente podían ser creados en terrenos de propiedad ejidal o comunal siempre que existiera consenso entre la mayoría de los propietarios ejidatarios o comunero y que tuviera como fin dar un beneficio colectivo a los grupos de población interesados. La autoridad encargada de aplicar esta ley era la Secretaría de Agricultura y Fomento, y como órgano de consulta se creó un Consejo Técnico Forestal que nunca tuvo un funcionamiento efectivo.

La ley de 1943 se derogó con la publicación de una nueva ley forestal en 1947, que tenía como objetivo la protección del bosque contra la erosión y hacia la consideración del bosque como el eje de actividades recreativas, declarando de utilidad pública la conservación de los bosques, así como su función recreativa y productiva. Se considera que esta ley representó un retroceso en la regulación forestal en cuanto a aspectos de manejo que se habían logrado regular muy bien en la ley de 1943.

De esta forma, se perdió detalle en la regulación del aprovechamiento forestal en zonas como terrenos nacionales, los parques nacionales, las zonas vedadas, los terrenos comunales, ejidales y municipales, y los terrenos de propiedad privada. Por otro lado, esta ley permitió que la autoridad enajenara aquellos terrenos que no poseían vegetación maderable para su utilización con fines ganaderos. La ley establecía también que el transporte de los recursos forestales y sus productos debían ser amparados por la documentación forestal respectiva. La Secretaría de Ganadería y Agricultura era la autoridad encargada de aplicar la ley a nivel federal. Se estableció un Consejo Nacional Forestal, el cual determinaba las políticas públicas en la materia y se crearon consejos 
locales en cada uno de los Estados del país presididos por el gobernador respectivo, que tenía la facultad de constituir delegaciones forestales en cada municipio.

La siguiente legislación forestal fue la publicada en 1960 y tuvo como objetivo la conservación, restauración, fomento y aprovechamiento de la vegetación forestal, el transporte y comercio de los productos que se deriven de ella, la administración del servicio forestal, así como el desarrollo e integración de la industria forestal. En la ley se incluyeron algunas reglas vinculadas con el aspecto social del bosque y con la redistribución de la riqueza generada en el sector forestal. A través de esta ley se cancelaron permisos de explotación a empresas extranjeras y solo fueron concedidos a personas y sociedades mexicanas. Además, se terminó el sistema de concesiones forestales, dando paso a la formación de empresas privadas bajo el control de los gobiernos estatales y federal.

La dependencia encargada de aplicar esta ley era la Secretaría de Agricultura y Ganadería a través de la Subsecretaría de Recursos Forestales y de Caza. Con base en la ley se crearon comisiones forestales en cada Estado, presididas por el gobernador respectivo y con representantes de los gobiernos federal y estatal, y de los propietarios de los terrenos forestales. Asimismo, se formaron grupos cívicos forestales, con participación de representantes del gobierno y de iniciativa privada, para realizar tareas de conservación, restauración y propagación de la vegetación forestal.

Mientras se aplicaba esta ley en el sector forestal, en el sector agrario se incentivó la repartición de tierras durante los años 70 y la Comisión Nacional de Desmontes otorgó créditos a los campesinos que eliminaran vegetación de los terrenos para dedicarlo a la agricultura y promovía un Programa Nacional de Ganaderización. Como resultado de estas políticas desarticuladas se creía que los bosques eran terrenos baldíos y zonas carentes de derechos generando deforestación y la ineficacia de los instrumentos de conservación previstos en la legislación forestal, tales como las vedas forestales.

En los años 80 terminó el sistema de concesiones forestales y aumentó la participación de las comunidades sobre sus recursos forestales, así que la ley forestal de 1986 promovió el desarrollo de las empresas forestales comunales y ejidales, siendo los propietarios los que tenían la decisión de aprovechar o no sus recursos. La Secretaría de Agricultura y Recursos Hidráulicos era la autoridad encargada de aplicar esta ley, la cual tenía que garantizar, entre otras cosas, el equilibrio entre la capacidad productiva de los recursos forestales y la capacidad de transformación industrial, el suministro de materias primas forestales y las relaciones justas de intercambio entre los participantes.

En diciembre de 1992 se decretó una nueva ley forestal que trataba de fomentar la actividad industrial y comercial, y garantizar la preservación de los recursos naturales que eran objeto de la actividad. Esta ley limitó la participación del gobierno en la explotación económica de los recursos forestales y creó un Consejo Técnico Consultivo Nacional Forestal como órgano de consulta de la autoridad, así como Consejos Regionales. Esta ley permitió a los ejidos, comunidades, pequeños propietarios, organizaciones de productores y demás personas interesadas elaborar propuestas de políticas de desarrollo, financiamiento y fomento en materia forestal. Cinco años después, en 1997, la ley fue reformada para incluir nuevos elementos: controlar el transporte, almacenamiento y transformación de productos forestales, regular las plantaciones comerciales, reorganizar los servicios técnicos y reducir la tala clandestina. Además, se incluyó un capítulo sobre participación social y derecho a la información. 
Finalmente, en el 2003 se promulgó la Ley General de Desarrollo Forestal Sustentable (LGDFS), la cual es la ley vigente que otorga la propiedad de los recursos forestales a los propietarios de los terrenos en donde éstos se encuentren y creó la Comisión Nacional Forestal (CONAFOR) como un organismo público descentralizado de la Administración Pública Federal, con personalidad jurídica y patrimonio propios, y el objeto de desarrollar, favorecer e impulsar las actividades productivas, de protección, conservación y restauración en materia forestal ${ }^{3}$. Actualmente la LGDFS está en proceso de revisión y reforma intergral.

La ley vigente señala como criterio obligatorio de la política forestal el fomento a la integración de cadenas productivas y comerciales ${ }^{4}$. Por esa razón, los tres ámbitos de gobierno en México tienen atribuciones para facilitar cadenas productivas y promover el mercado internacional, así como para establecer y aplicar la política forestal (ver Tabla 13 Anexo).

Cabe mencionar que, a pesar de que el marco legal mexicano requiere la distribución justa y equitativa de los beneficios relacionados con proyectos y políticas de servicios ambientales forestales, conforme a la LGDFS 5 , la Ley General del Equilibrio Ecológico y la Protección al Ambiente (LGEEPA) y su Reglamento en materia de Áreas Naturales Protegidas ${ }^{6}$ hasta ahora, ninguna ley establece disposiciones que puedan orientar claramente sobre la forma de distribuir los beneficios generados. Lo único que la legislación señala es que los ejidos y las comunidades agrarias tienen derecho a operar de acuerdo con un reglamento interno sin más limitaciones que aquellas actividades que las leyes prohíban ${ }^{7}$. Así, cada comunidad se regirá en esencia por los usos y costumbres del gran mosaico étnico y social que México ofrece, dejando a la organización interna de la comunidad los temas como la distribución de los beneficios para sus integrantes.

En cuanto a la congruencia de la ley forestal con las leyes de comercio internacional, es importante mencionar que México es signatario de diversos instrumentos jurídicos internacionales que se relacionan con el comercio internacional de madera: los Principios Forestales, la Convención sobre Diversidad Biológica, la Convención sobre Comercio Internacional de Especies Amenazadas de Flora y Fauna (CITES), el Convenio Internacional de las Maderas Tropicales, la Convención Marco de las Naciones Unidas sobre Cambio Climático, así como 12 tratados de libre comercio que establecen previsiones y requisitos especiales para el comercio internacional entre los países signatarios, tales como el cumplimiento de las medidas sanitarias y fitosanitarias, así como la comprobación de la legal procedencia de mercancías. El marco legal mexicano guarda consistencia con dichos instrumentos internacionales y aterriza las obligaciones previstas en ellos (ver Tabla 5 Anexo).

La LGDFS vigente, como el marco legal mexicano en general, reconoce la participación social, mas no la define ni la regula detalladamente, lo cual dificulta una participación social efectiva. Si bien existen varios espacios formales en materia de participación, como son los Consejos Consultivos bajo la Ley de Desarrollo Rural (LDRS), la LGEEPA y la LGDFS, ninguno de ellos especifica procedimientos que garanticen el derecho a la participación plena y eficaz, quedando a discreción de los funcionarios

\footnotetext{
3. Art. 17, LGDFS.

4. Art. 32, LGDFS.

5. Art. 134 Bis señala que la distribución de beneficios económicos para los propietarios y legítimos poseedores de terrenos forestales debe realizarse de forma equitativa.

6. Arts. 56 y 81 .

7. Ley Agraria, 27 de febrero de 1992 (última reforma publicada DOF 22-06-2011), Artículo 10.
} 
cómo abordar los aportes/insumos de la opinión pública. En particular, la LGDFS establece en su propio articulado la creación del Consejo Nacional Forestal ${ }^{8}$ (CONAF) como el espacio formal de participación de la sociedad civil. Cabe mencionar que existen otros espacios de participación sui géneris que no están contemplados en la legislación, como es el caso del CTC-REDD+⿳9.

Para lograr efectividad en el tema de participación es necesario subsanar algunos vacíos en el marco legal mexicano, como la falta de reglamentación sobre la consulta o participación en la toma de decisiones Ambientales ${ }^{10}$, reglamentación del derecho al consentimiento, libre, previo e informado contemplado en el Artículo 134 Bis de la LGDFS y difusión de la información culturalmente adecuada para participar, entre otros.

Es importante hacer notar que, si bien la LGDFS es la ley sectorial en el tema forestal, coexiste con gran cantidad de leyes que tienen influencia en la gestión forestal y que se traslapan al tratar de regular las actividades que se desarrollan en una misma unidad territorial. Así, por ejemplo, existen varios conflictos de ley e inconsistencias entre las disposiciones que establecen instrumentos de ordenación y planeación territorial sin una efectiva coordinación entre sí: zonificación forestal ${ }^{11}$, ordenamiento ecológico ${ }^{12}$, planeación rural sustentable y Distritos de Desarrollo Rural ${ }^{13}$, ordenamiento turístico del territorio ${ }^{14}$, ordenamiento territorial de los asentamientos humanos y del desarrollo urbano, y programas municipales de desarrollo urbano $^{15}$.

Las leyes mexicanas regulan la tenencia y producción de bosques y terrenos agrícolas en diversos ordenamientos y con diferentes entendimientos. La LGDFS declara de utilidad pública la conservación, protección y restauración de los ecosistemas forestales y sus elementos, así como las cuencas hidrológico-forestales y la ejecución de obras destinadas a la conservación, protección y/o generación de bienes y servicios ambientales ${ }^{16}$. Mientras tanto, la Ley Agraria (LA) regula la tenencia de tierras agrícolas, las cuales pueden tener terrenos forestales y ganaderas por parte de sociedades mercantiles o civiles, busca la capitalización del campo mexicano por medio de la producción agrícola, donde también contempla un apartado para la producción forestal (ver Tabla 6 Anexo).

8. Art. 155, LGDFS.

9. Para el tema REDD+, la participación social se ha impulsado bajo el marco del Consejo Técnico Consultivo (CTCREDD+), un espacio amplio con participación de instituciones de la sociedad civil, la academia y el gobierno. No obstante, aún existe un importante vacío generado por la mínima participación directa, en este $u$ otros espacios, de ejidos, comunidades y pueblos indígenas, los principales involucrados en la implementación del mecanismo REDD+ en México por ser propietarios de la mayor parte de bosques y selvas del país. Se considera que uno de los problemas comunes en el medio social forestal es la exclusión que enfrentan las mujeres y menores de edad, y los avecindados, al ser excluidos de los procesos de toma de decisiones de los ejidos, por lo cual no tienen participación en la toma de decisiones de este.

10. Como vimos en los hallazgos, el único referente a un procedimiento de consulta está en la LGEEPA y reglamento en material de EIA, que se considera inadecuado.

11. Ídem. Artículo 48.

12. Ley General del Equilibrio Ecológico y Protección al Ambiente. 28 de enero de 1988 (última reforma publicada DOF 30-08-2011), Art. 19.

13. Ley General de Desarrollo Rural Sustentable. 8 de diciembre de 2001 (última reforma publicada DOF 26-05-2011), Artículos 12 y 29.

14. Ley General de Turismo. 18 de junio de 2009 (última reforma publicada DOF 25-05-2011), Artículo 24.

15. Ley General de Asentamientos Humanos. 21 de julio de 1993 (última reforma publicada DOF 30-11-2010), Artículos 11 y 56 .

16. Art. 4, LGDFS. 
La LA deja al ejido, por medio de su reglamento interno, la definición de las reglas para el aprovechamiento de las tierras de uso común, las cuales pueden ser suelos forestales ${ }^{17}$. También indica que las tierras ejidales (parceladas o de uso común) pueden ser objeto de cualquier contrato de asociación o aprovechamiento) y será nula de pleno derecho la asignación de parcelas en bosques o selvas tropicales ${ }^{18}$; es decir, todos los ejidatarios son dueños de las tierras boscosas, pero esto dificulta que puedan reclamar su parte de aprovechamiento. Aún así, la LA no reconoce legalmente la función social y económica de la conservación y los servicios ambientales y de hecho, reputa agrícolas las tierras rústicas no dedicadas a la agricultura, ganadería o aprovechamiento forestal ${ }^{19}$. Esta Ley fomenta la creación de uniones de ejidos, ejidos y comunidades que pueden establecer empresas para el aprovechamiento de sus recursos naturales o de cualquier índole. Las asociaciones rurales de interés colectivo pueden tener como objeto el establecimiento de industrias, aprovechamientos, comercialización y otras actividades económicas, y las sociedades de producción rural, para el aprovechamiento de los recursos naturales, se compondrán de por lo menos dos productores ${ }^{20}$.

Es urgente armonizar el contenido de estas dos leyes para evitar conflictos en los derechos de uso de suelos y en este sentido, la aplicación del mecanismo REDD+ en el país representa un área de oportunidad para lograr dicha armonización toda vez que México REDD+ tiene como objetivo el desarrollo rural sustentable ${ }^{21}$, bajo una lógica de manejo integrado del territorio. El segundo borrador de la Estrategia Nacional REDD+ plantea cinco líneas estratégicas orientadas al diseño final de la ENAREDD+22: arreglos institucionales y políticas públicas, esquemas de financiamiento, nivel de referencia forestal y sistema de medición, reporte y verificación (MRV), desarrollo de capacidades y comunicación, participación social y transparencia.

La Ley General de Cambio Climático (LGCC) ${ }^{23}$ es una referencia obligada para el mecanismo REDD+ en México, toda vez que establece la obligación de CONAFOR para diseñar estrategias políticas, medidas y acciones para transitar a una tasa de $0 \%$ de pérdida de carbono en los ecosistemas originales, para su incorporación en los instrumentos de planeación de la política forestal para el desarrollo sustentable, tomando en consideración el desarrollo sustentable y el manejo forestal comunitario ${ }^{24}$.

El robusto desarrollo legislativo en materia forestal en México contempla varios instrumentos y herramientas que pueden facilitar la implementación del mecanismo REDD+, por ejemplo: el

17. Art. 10, LA.

18. Arts. 45 y 59 , LA.

19. Art. 116, LA.

20. Art. 108 al 11, LA.

21. (Art. 3, fracción XI, LDRS). Desarrollo Rural Sustentable. El mejoramiento integral del bienestar social de la población y las actividades económicas en el territorio comprendido fuera de los núcleos considerados urbanos de acuerdo con las disposiciones aplicables, asegurando la conservación permanente de los recursos naturales, la biodiversidad y los servicios ambientales de dicho territorio.

22. CONAFOR, 2010b. Visión de México sobre REDD+: hacia una estrategia nacional. México, 2010. Pág. 29.

23. Ley General de Cambio Climático. Publicada en el Diario Oficial de la Federación el 6 de junio de 2012. Cámara de Diputados. [sitio web]. <http://www.diputados.gob.mx/LeyesBiblio/pdf/LGCC.pdf >. Accedido el 25 de septiembre de 2013.

24. Artículo Tercero Transitorio, LGCC. 
Inventario Nacional Forestal y de Suelos, los instrumentos económicos, los servicios ambientales y las salvaguardas, disposiciones para sanidad forestal, combate de incendios, restauración, reforestación, autorizaciones y permisos para el aprovechamiento forestal (extractivo y no extractivo, maderable y no maderable), plantaciones forestales comerciales, programas de manejo forestal, prevención y vigilancia, medidas de seguridad y sanciones. En general, la legislación mexicana cuenta con capacidades institucionales en la Secretaría de Medio Ambiente y Recursos Naturales (SEMARNAT) y la CONAFOR (ver Tabla 8 Anexo) que deben ser aprovechados dado que los instrumentos ya existentes -como los Sistemas de Información Forestal ${ }^{25}$, Ambiental ${ }^{26}$, de Desarrollo Rural Sustentable ${ }^{27}$ y el Registro Agrario Nacional ${ }^{28}$ - facilitarán su creación e implementación.

25. Ley General de Desarrollo Forestal Sustentable, 26 de febrero de 2003 (última reforma publicada DOF 24-11-2008), Art. 39.

26. Ley General del Equilibrio Ecológico y Protección al Ambiente. 28 de enero de 1988 (última reforma publicada DOF 30-08-2011), Art. 159 Bis.

27. Ley General de Desarrollo Rural Sustentable. 8 de diciembre de 2001 (última reforma publicada DOF 26-05-2011), Artículos 133.

28. Ley Agraria, 27 de febrero de 1992 (última reforma publicada DOF 22-06-2011), Artículos 152 y 153. 


\section{Análisis de los estándares de legalidad}

Conforme a la Constitución Mexicana, la nación tiene una composición pluricultural sustentada originalmente en sus pueblos indígenas. Los pueblos indígenas son aquellos que descienden de poblaciones que habitaban en el territorio actual del país al iniciarse la colonización y que conservan sus propias instituciones sociales, económicas, culturales y políticas, o parte de ellas, y son comunidades integrantes de un pueblo indígena aquellas que formen una unidad social, económica y cultural, asentadas en un territorio y que reconocen autoridades propias de acuerdo con sus usos y costumbres ${ }^{29}$.

La Constitución Federal reconoce su autonomía para decidir sus formas internas de convivencia y organización social, económica, política y cultural, aplicar sus propios sistemas normativos en la regulación y solución de sus conflictos internos (respetando las garantías individuales, los derechos humanos y de manera relevante, la dignidad e integridad de las mujeres) y elegir de acuerdo con sus normas, procedimientos y prácticas tradicionales las autoridades o representantes (garantizando la participación de las mujeres en condiciones de equidad), entre otros ${ }^{30}$.

Esta disposición es de particular relevancia, dado que aproximadamente $88 \%$ de la riqueza biológica del país es propiedad de ejidos y comunidades. También hay que considerar que, en muchas ocasiones, son las zonas mejor conservadas y con gran potencial de aprovechamiento. Sin embargo, en el ámbito nacional son relativamente pocos los núcleos agrarios con bosques que se dedican a la actividad forestal maderable, a pesar de que casi $25 \%$ de la totalidad de núcleos agrarios en el país cuenta con vegetación forestal. El hecho de que los derechos indígenas (como el respeto a sus formas de organización interna) estén considerados desde la Constitución Mexicana ofrece una muy importante garantía legal para los pueblos ancestrales, pero al mismo tiempo presenta grandes retos para la alineación de leyes y políticas en gran parte del territorio nacional; esto debido a que las constituciones y leyes de las entidades federativas deben establecer las normas para el reconocimiento de las comunidades indígenas como entidades de interés público.

Una gran parte de ejidos y comunidades agrarias e indígenas dependen directamente de los bosques y selvas del país, por lo que se considera un acierto que las leyes ambientales prevean derechos y tratamiento preferencial para los pobladores de las zonas naturales de la nación. De esta forma, el Artículo 45 Bis de la LGEEPA indica que las autoridades deben garantizar garantizarán el otorgamiento de estímulos fiscales y retribuciones económicas a los propietarios, poseedores o titulares de otros derechos sobre tierras, aguas y bosques comprendidos dentro de áreas naturales protegidas.

Por su parte, la LGDFS también indica que la política nacional en materia forestal deberá promover un mejor ingreso y calidad de vida de las personas que participan en la actividad forestal, así como fortalecer las capacidades de decisión, acción y fomento de las comunidades de manera que puedan proteger, conservar y aprovechar los ecosistemas forestales de acuerdo con sus conocimientos,

29. Artículo 2, Constitución Política de los Estados Unidos Mexicanos.

30. Ibíd. 
experiencias y tradiciones ${ }^{31}$. En este sentido, son criterios obligatorios de política forestal de carácter social el respeto al conocimiento de la naturaleza, cultura y tradiciones de los pueblos y comunidades indígenas y su participación directa en la elaboración y ejecución de los programas forestales de las áreas en que habiten, la incorporación efectiva de los propietarios forestales y sus organizaciones en la silvicultura, producción, industria y comercio de los productos forestales, la diversificación o uso múltiple y los bienes y servicios ambientales ${ }^{32}$. La misma legislación forestal señala que la autorización para colecta y uso de recursos biológicos forestales con fines de utilización en investigación y/o biotecnología solo podrá otorgarse si se cuenta con el consentimiento escrito previo, expreso e informado del propietario o legítimo poseedor del predio en el que el recurso biológico forestal se encuentre ${ }^{33}$.

Vale la pena destacar que a partir del 2012 en la LGDFS se establecen salvaguardas sociales para la implementación de proyectos de servicios ambientales en las cuales se establece la obligación de garantizar el consentimiento libre, previo e informado de ejidos, comunidades y pueblos indígenas, la distribución equitativa de beneficios, la certidumbre y respeto a los derechos de propiedad y posesión legítima y acceso a los recursos naturales de los propietarios y legítimos poseedores de la tierra, la inclusión y equidad territorial, cultural, social y de género, la pluralidad y participación social, la transparencia, acceso a la información y rendición de cuentas y el reconocimiento y respeto a las formas de organización interna ${ }^{34}$.

Este tipo de preceptos resultan trascendentales debido a que, en última instancia, la gestión ambiental y el cuidado de los recursos naturales depende de los pobladores rurales, ya sean ejidos, comunidades o pequeños propietarios.

Por otro lado, para poder llevar a cabo el aprovechamiento de recursos maderables en terrenos forestales y preferentemente forestales la persona interesada debe obtener la autorización de la SEMARNAT. Para ello, el trámite comienza con una solicitud de aprovechamiento en la que el interesado debe presentar:

- El nombre, denominación o razón social y domicilio del propietario o poseedor del predio, o de quien tenga el derecho a realizar el aprovechamiento.

- Copia certificada del título que acredite el derecho de propiedad o posesión respecto del terreno o terrenos objeto de la solicitud.

- Tratándose de ejidos y comunidades, deberán presentar acta de asamblea de conformidad con la Ley Agraria en la que se contenga el acuerdo para llevar a cabo el aprovechamiento, así como copia certificada del reglamento interno en el cual se definan las obligaciones y formas de participación en las labores de cultivo, protección y fomento de sus recursos.

- Plano geo-referenciado indicando ubicación, superficie y colindancias del predio.

- El programa de manejo forestal con una proyección que corresponda a un turno.

31. Art. 30, LGDFS.

32. Art. 32, LGDFS.

33. Art. 101.

34. Artículo 134 Bis, LGDFS. 
- Una manifestación, bajo protesta de decir verdad, de la situación legal del predio o predios y en su caso, sobre conflictos agrarios.

- En caso de que el aprovechamiento forestal se quiera realizar en selvas tropicales mayores a 20 hectáreas, en aprovechamientos de especies forestales de difícil regeneración y en áreas naturales protegidas, se requiere integrar al plan de manejo una manifestación de impacto ambiental.

Una vez realizada la solicitud de autorización, la SEMARNAT debe solicitar al Consejo Estatal de que se trate opiniones y observaciones técnicas, previamente a que sean resueltas. El Consejo correspondiente contará con diez días hábiles para emitir su opinión. Transcurrido dicho término, se entenderá que no hay objeción alguna para expedir o negar la autorización ${ }^{35}$.

Las autorizaciones para el aprovechamiento de los recursos forestales tendrán una vigencia correspondiente al ciclo de corta, pudiendo refrendarse cuantas veces sea necesario para lograr los objetivos del programa de manejo respectivo y hasta el término de su vigencia. Sin embargo, estas pueden caducar cuando no se ejerzan durante el término de su vigencia ${ }^{36}$. Dependiendo del tipo de aprovechamiento de que se trate, el pago de derechos como el tiempo de respuesta por parte de la autoridad será diferente (ver Tabla 9 Anexo).

Es importante mencionar que para poder otorgar la autorización de aprovechamiento, así como para determinar las áreas que son susceptibles de aprovechar y/o conservar, la LGDFS establece la zonificación como instrumento en el cual se identifican, agrupan y ordenan los terrenos forestales y preferentemente forestales dentro de las cuencas, subcuencas y microcuencas hidrológicoforestales, por funciones y subfunciones biológicas, ambientales, socioeconómicas, recreativas, protectoras y restauradoras, con fines de manejo ${ }^{37}$. Dicha zonificación se hace con base en los datos del Inventario Nacional Forestal y el ordenamiento ecológico del territorio, y dentro de esta se establecerán tres grandes categorías con distintos tipos (ver Tabla 7 Anexo). Dependiendo del tipo de zona de que se trate, en el programa de manejo del aprovechamiento forestal se establecerán los volúmenes mínimos y máximos cosechados, las áreas mínimas y máximas de impacto del aprovechamiento y si este será restringido o no, entre otras.

Por otro lado, en términos del comercio internacional de madera, son aplicables a la importación y la exportación de madera la Ley Aduanera y la Ley de Comercio Exterior (LCE), las cuales regulan los actos de comercio en sus generalidades, la LGDFS y la Ley Federal de Sanidad Vegetal (LFSV) en cuanto a las previsiones específicas en términos del comercio y la sanidad forestal. De acuerdo con la Ley Aduanera, para poder llevar a cabo la exportación de madera es necesario presentar, entre otros:

- Factura comercial.

- Certificado de origen (documento que estipula mediante cumplimiento de requisitos previos que el producto es originario de México, indica el grado de integración regional de las mercancías).

- Documentos que amparen el cumplimiento de las regulaciones no arancelarias del país de destino: certificado fitosanitario.

35. Artículo 75, LGDFS.

36. Artículo 69, LGDFS.

37. Artículo 48, LGDFS. 
- Certificado CITES en caso de que los productos provengan de alguna de las especies enlistadas en CITES.

- Pedimento de Exportación (documento que avala la salida legal de la mercancía del territorio nacional, que contendrá los datos referentes sobre las cantidades, valor y destino de la mercancía, entre otros.

- Documentos de transporte: es el título de consignación que expide la compañía transportista.

Es muy relevante el tema de los certificados fitosanitarios toda vez que por regla general es la Secretaría de Agricultura, Ganadería, Desarrollo Rural, Pesca y Alimentación (SAGARPA) la autoridad encargada de emitirlo y en temas de sanidad forestal, excepcionalmente lo emite la SEMARNAT, tanto para la importación como para la exportación de materias primas y productos forestales. En ese sentido, la LGDFS y su reglamento establecen los requisitos, plazos y pago de derechos que debe cubrir el interesado para obtener el certificado (ver Tabla 11 Anexo). Cabe señalar que la revisión de materias primas y productos forestales que deban ser certificados se realizará de conformidad con las normas oficiales mexicanas que expida la SEMARNAT (ver Tabla 12 Anexo). Sin este certificado, no es posible llevar a cabo la importación o exportación de madera.

Por lo tanto, la actividad de aprovechamiento y comercio forestal está sujeta -al menos- a dos trámites y a pago de derechos que pueden disminuir el interés en realizar el aprovechamiento forestal a la luz de la legalidad. Al respecto, la Organización de las Naciones Unidas para la Alimentación y la Agricultura (FAO, por sus siglas en inglés) ha señalado que el enfoque empleado para el sector forestal de México plantea la necesidad de recaudar fondos para fortalecer el servicio forestal federal y asegurar un manejo profesional y sostenible de los bosques. Sin embargo, el aumento de los trámites y las cuotas que hay que pagar hacen cada vez más costoso para los dueños de los bosques gestionar un permiso y operar de manera formal y legal. Esto plantea un dilema, pues un aumento en las regulaciones y en los cobros puede desincentivar la formalidad en el sector ${ }^{38}$.

Cabe mencionar que el marco legal nacional está alineado a los requerimientos internacionales aplicables al comercio internacional de madera. Así, por ejemplo, el reglamento de la LGDFS establece que la SEMARNAT expedirá normas que establezcan las medidas de sanidad forestal, sus características y especificaciones para poder llevar a cabo la importación, exportación y reexportación de materias primas y productos forestales, incluyendo los embalajes de madera utilizados en el manejo y protección de bienes ${ }^{39}$.

Con base en este y otros preceptos, se publicó la NOM-144-SEMARNAT-2012, la cual establece las medidas fitosanitarias reconocidas internacionalmente para el embalaje de madera, que se utiliza en el comercio internacional de bienes y mercancías, y cuyo contenido da cumplimiento a la Norma Internacional de Medidas Fitosanitarias (NIMF) para el embalaje de madera denominada "Directrices para Reglamentar el Embalaje de Madera Utilizado en el Comercio Internacional” publicación número 15 y a la Decisión XX/6 de la 20a. Reunión de las Partes del Protocolo de Montreal, de fecha 26 de

38. Programa de Cooperación FAO/Banco Mundial (2012). 'México: Evaluación del impacto del cobro por derechos de aprovechamiento de "madera en pie" y otras tasas (MaPoTs) sobre el manejo forestal'. Estudios de Caso: Volumen IV de VI. [pdf online]. <http://www.fao.org/fileadmin/templates/tci/pdf/ M\%C3\%89XICOCompleteLOW.pdf>. Accedido el 4 de abril de 2014.

39. Artículo 130, Reglamento de la LGDFS. 
mayo de 2009, la cual señala que las partes deben notificar los datos sobre el uso de bromuro de metilo con fines de cuarentena y previos al envío. Ya en el 2004 se había publicado una norma que daba cumplimiento a la NIMF-15; sin embargo, con la modificación del 2009 a la NIMF, México actualizó su marco legal interno de forma tal que la actual norma establece medidas fitosanitarias más estrictas para el uso de madera descortezada para la fabricación del embalaje, incrementar el tiempo de tratamiento con bromuro de metilo a 24 horas de exposición total, así como establecer la obligación de que cualquier madera para estiba debe ser sometida a tratamiento y ostentar la marca reconocida internacionalmente.

De igual forma, el marco legal mexicano contempla instrumentos y mecanismos que dan cumplimiento a la Ley Lacey de Estados Unidos y al Plan de acción de la aplicación de leyes, gobernanza y comercio forestales (FLEGT, por sus siglas en inglés) de la Unión Europea (ver Tabla 10 Anexo) que permiten asegurar que la madera procede de fuentes legales. Así por ejemplo, México es considerado como un país de bajo riesgo para llevar a cabo la importación de madera y productos maderables en España de acuerdo con una de las asociaciones españolas que pretenden ser entidades de supervisión del cumplimiento del FLEGT. De manera específica se considera que el cumplimiento de las leyes es aceptable y necesita mejorarse para garantizar la legalidad y el control sobre las extracciones de madera ${ }^{40}$.

Por lo tanto, es importante destacar que -si bien la legislación mexicana contempla mecanismos e instrumentos que permiten dar cumplimiento a lo establecido porestos ordenamientos internacionalesa nivel interno el seguimiento a las condicionantes de las autorizaciones y la inspección y vigilancia de estas muchas veces no se logra como se analiza en el apartado correspondiente del presente informe, por lo que los vacíos no se encuentran propiamente dentro del marco legal, sino en la etapa de aplicación efectiva de la ley.

40. Asociación Española del Comercio y la Industria de la Madera. 'Fichas de evaluación de riesgo por país'. [sitio web]. <http://www.maderalegal.es/fichas>. Accedido el 4 de abril de 2014. 


\section{Análisis del ámbito de acción de la Administración Forestal}

México es una república representativa, democrática, laica, federal, compuesta por 32 entidades federativas que son libres y soberanas en su régimen interior, pero unidos en una federación establecida según los principios de la Constitución ${ }^{41}$. En este sistema federal existen tres ámbitos de gobierno: Federación, Estados y Municipios. Consecuentemente, existen leyes de competencia federales y de competencia estatal (incluyendo el ámbito municipal); sin embargo, también existen leyes generales en las cuales se establecen las facultades concurrentes para todos los ámbitos de gobierno en determinados temas.

El tema forestal puede ser regulado de manera concurrente, lo cual implica que los tres órdenes de gobierno tienen competencia en la materia; así, la LGDFS establece las facultades de la Federación, las Entidades Federativas y los Municipios que sirven de base de coordinación para la integración y funcionamiento del Servicio Nacional Forestal (ver Tabla 13 Anexo).

Entre las atribuciones que tiene la Federación relacionadas con el comercio de la madera sobresalen aquellas para formular y conducir la política nacional (diseñar y aplicar los instrumentos de política forestal e instrumentos económicos), establecer las bases e instrumentos para promover (mercado de bienes y servicios ambientales, la participación directa de los propietarios y poseedores de los recursos forestales en la comercialización de estos, el Fondo Forestal Mexicano) el manejo forestal sustentable, el desarrollo y fortalecimiento de las organizaciones de productores forestales. La Federación también debe definir y aplicar la regulación (del uso del suelo en terrenos forestales y preferentemente forestales) y expedir autorizaciones y permisos (por excepción, las de cambio de uso del suelo, para el aprovechamiento de los recursos forestales y de las plantaciones forestales comerciales, los certificados y demás documentación fitosanitaria para la exportación e importación de recursos forestales y los permisos previos para el funcionamiento de centros de almacenamiento y transformación de materias primas forestales). Las autoridades federales también regulan la acreditación de la legal procedencia de las materias primas forestales y productos maderables, y coadyuvan con los agentes de las cadenas productivas forestales en la promoción de las exportaciones y el mejoramiento del mercado interno ${ }^{42}$.

Por su parte, las entidades federativas se encuentran facultadas para aplicar los criterios de política forestal y coadyuvar en la adopción y consolidación del Servicio Nacional Forestal, elaborar, coordinar y aplicar los programas relativos al sector forestal de la entidad, promover los bienes y servicios ambientales de los ecosistemas forestales, impulsar la participación directa de los propietarios y poseedores de los recursos forestales en la comercialización de estos. Además deben prestar asesoría y capacitación en prácticas y métodos que conlleven un manejo forestal sustentable, en la elaboración y ejecución de programas de manejo forestal y de plantaciones forestales comerciales, así como en la diversificación de las actividades forestales, en el desarrollo de su organización y en

41. Artículo 42, Constitución Política de los Estados Unidos Mexicanos.

42. Art. 12, LGDFS. 
la creación de empresas sociales forestales, propiciando la integración de cadenas productivas y los sistemas-producto del sector ${ }^{43}$.

Mientras, las autoridades municipales están a cargo de diseñar y aplicar la política forestal del municipio, los criterios de política forestal que no estén expresamente reservados a la Federación o a los Estados e incentivos para promover el desarrollo forestal. También deben apoyar a la Federación y al gobierno de la entidad en la adopción y consolidación del Servicio Nacional Forestal, en los programas integrales de prevención y combate a la extracción ilegal y a la tala clandestina con la Federación y el gobierno de la entidad, así como expedir, previo a su instalación, las licencias o permisos para el establecimiento de centros de almacenamiento o transformación de materias primas forestales en el ámbito de su competencia, considerando los criterios de política forestal establecidos en esta ley y desarrollar y apoyar viveros y programas de producción de plantas ${ }^{44}$.

Hay que resaltar el hecho de que la Federación puede suscribir convenios o acuerdos de coordinación para que los gobiernos de las entidades federativas, con la participación -en su caso- de municipios, asuman una serie de funciones ${ }^{45}$.

En cuanto a las instituciones relacionadas con el aprovechamiento forestal y el comercio internacional, la LGDFS creó la CONAFOR como un organismo público descentralizado de la Administración Pública Federal, con personalidad jurídica y patrimonio propios y el objeto de desarrollar, favorecer e impulsar las actividades productivas, de protección, conservación y restauración en materia forestal ${ }^{46}$.

Mientras que en la Ley Orgánica de la Administración Pública Federal ${ }^{47}$ es donde se establece la competencia de la Secretaria de Medio Ambiente y Recursos Naturales (SEMARNAT) en materia forestal, como promover ante la Secretaría de Economía el establecimiento de medidas de regulación o restricción a la importación/exportación de recursos naturales, en conjunto con sus órganos administrativos desconcentrados (INEEC, PROFEPA) ${ }^{48}$. Conforme a la LGDFS, la SEMARNAT es la autoridad encargada de formular y conducir la política nacional de desarrollo forestal sustentable, diseñar los instrumentos de política forestal y elaborar el Programa Estratégico Forestal Nacional, entre otras. Es decir, es quien regula, controla, autoriza y certifica. La CONAFOR es responsable de aplicar los instrumentos de política ambiental en materia forestal, promover el desarrollo forestal sustentable, ejecutar programas productivos, de restauración, protección, conservación y aprovechamiento sustentable de los ecosistemas forestales y de los suelos en terrenos forestales o preferentemente forestales (ver Tabla 8 Anexo).

Sobre las actividades de comercio en general, la Secretaria de Economía es la autoridad responsable de formular y conducir las políticas generales de comercio exterior e interior, regular, promover y vigilar la comercialización, distribución y consumo de los bienes y servicios y fomentar el comercio

\footnotetext{
43. Art. 12, LGDFS.

44. Art. 15, LGDFS.

45. Art. 24, LGDFS.

46. Art. 17, LGDFS.

47. Ley Orgánica de la Administración Pública Federal. Publicada en el Diario Oficial de la Federación el 29 de diciembre de 1976. Última reforma publicada DOF 02-04-2013. Consultada el 20 de septiembre de 2013.

48. Art. 32 Bis, LOAPF.
} 
exterior del país. También, la Secretaría establece la política de industrialización, distribución y consumo de los productos forestales, determina los aranceles y fija los precios oficiales (escuchando a la Secretaría de Hacienda y Crédito Público), entre otras facultades ${ }^{49}$.

Como ha sido mencionado previamente, en la gestión forestal necesaria para la producción de madera y su comercio, nacional e internacional, existen varias leyes que resultan aplicables y diversas autoridades están involucradas. El Registro Agrario Nacional está obligado a dar parte al Registro Forestal Nacional, el cual debe buscar la coordinación necesaria con los registros públicos de la propiedad establecidos por los gobiernos de los Estados, el Distrito Federal o los Municipios ${ }^{50}$. Además, hay que considerar que, generalmente los usos y aprovechamientos que se den en las tierras ejidales o comunales quedan determinados en los reglamentos y acuerdos de asamblea, los cuales deben inscribirse en el Registro Agrario Nacional (RAN) y hacen de la SAGARPA y la Procuraduría Agraria una autoridad más que tiene injerencia en el tema de comercio de madera.

Otro aspecto importante a considerar dentro de la administración y la gestión forestal es el relacionado con la cantidad de trámites y permisos previstos en la LGDFS. Actualmente hay cuarenta trámites derivados de la aplicación de esta ley, dentro de los cuales se encuentran las autorizaciones de aprovechamiento forestal de maderables y no maderables, emisión de certificados fitosanitarios y la solicitud de reembarque forestal para acreditar la legal procedencia, entre otros (ver Tabla 14 Anexo). Además de estos, existen otros trámites que acompañan el aprovechamiento y comercio forestal, tales como la emisión del certificado CITES o la autorización de impacto ambiental.

Como ya se ha explicado, las autorizaciones para el aprovechamiento forestal las emite la SEMARNAT una vez analizada la solicitud que ingresa el interesado. El siguiente esquema resume los trámites para lograr el manejo integrado de los recursos forestales ante la SEMARNAT, tanto para el aprovechamiento como para la comercialización.

\begin{tabular}{|c|c|c|c|}
\hline Aprovechamiento & Transporte y & omercialización & Informe anual \\
\hline $\begin{array}{l}\text { - Autorización de } \\
\text { Aprovechamiento } \\
\text { Forestal: } 30 \text { días } \\
\text { hábiles } \\
\text { - Autorización de } \\
\text { aprovechamiento } \\
\text { extractivo de } \\
\text { ejemplares, partes y } \\
\text { derivados de la vida } \\
\text { silvestre (para especies } \\
\text { silvestres en riesgo: } \\
\text { CITES o NOM): } 30 \text { días } \\
\text { hábiles } \\
\text { - Manifestación de } \\
\text { impacto ambiental en } \\
\text { los casos señalados } \\
\text { por ley: } 60 \text { días hábiles }\end{array}$ & $\begin{array}{l}\text { - Autorización para } \\
\text { el funcionamiento } \\
\text { de centros de } \\
\text { almacenamiento y } \\
\text { transformación de } \\
\text { materias primas } \\
\text { forestales: } 30 \text { días } \\
\text { hábiles } \\
\text { - Solicitud de } \\
\text { reembarque forestal: } 15 \\
\text { días hábiles }\end{array}$ & $\begin{array}{l}\text { - Solicitud de remisiones } \\
\text { forestales para } \\
\text { acreditar la legal } \\
\text { procedencia de } \\
\text { materias primas } \\
\text { forestales: } 10 \text { días } \\
\text { hábiles } \\
\text { - Certificado fitosanitario } \\
\text { de exportación: } 9 \text { días } \\
\text { hábiles } \\
\text { - Exportación y } \\
\text { reexportación de } \\
\text { ejemplares, partes } \\
\text { y derivados de vida } \\
\text { silvestre (caoba y } \\
\text { cedro): } 10 \text { días hábiles }\end{array}$ & $\begin{array}{l}\text { Informe anual sobre la } \\
\text { ejecución, desarrollo } \\
\text { y cumplimiento } \\
\text { del programa de } \\
\text { aprovechamiento } \\
\text { forestal }\end{array}$ \\
\hline
\end{tabular}

Fuente propia

49. Art. 34, LOAPF.

50. Art. 54, LGDFS. 
De los bienes que proveen los bosques, selvas y matorrales, el más explotado es la madera. Para regular el aprovechamiento de estos recursos, la legislación mexicana prevé que se debe contar con una autorización. Para otorgarla la ley exige, entre otros requisitos, que se mitigue el impacto ambiental, se proteja las especies amenazadas y se tomen medidas preventivas contra incendios y plagas forestales. En el 2008 se otorgaron 1.843 autorizaciones de aprovechamiento forestal, 18,4\% más que el año anterior (ver Tabla 15 Anexo).

Para poder llevar a cabo la exportación de productos de madera, como ya se ha mencionado, además de los requisitos aduaneros, es necesario solicitar un certificado fitosanitario de exportación de materias primas y productos forestales nacionales. Por lo tanto, junto a la solicitud del certificado se debe presentar la documentación del país importador con la que se acredite la necesidad de obtener el certificado fitosanitario de exportación, las medidas fitosanitarias requeridas y las declaraciones fitosanitarias adicionales.

La creciente preocupación sobre el tema de la deforestación ha impulsado la idea sobre la necesidad de establecer criterios de buen manejo forestal a nivel mundial para ayudar a detener la pérdida de bosques y la consecuente pérdida de biodiversidad de flora y fauna. En este sentido, el objetivo de la certificación, procedimiento que implica una evaluación por parte de un certificador independiente, es asegurar que los bosques sean manejados acordes con una serie de principios que incluían aspectos de conservación ambiental, justicia social y sustentabilidad económica. De acuerdo con información de CONAFOR ${ }^{51}$, a junio de 2012 la oferta de padrón de predios y empresas certificadas se encontraba de la siguiente manera:

\begin{tabular}{|l|l|}
\hline \multirow{2}{*}{ Auditorías técnicas preventivas } & $79.595,26$ ha certificadas (22 predios) \\
\cline { 2 - 2 } & $849.704,40$ ha en proceso (146 predios) \\
\hline Certificación Nacional (NMX-AA-143-SCFI-2008) & 7.218 ha certificadas (3 predios) \\
\hline \multirow{4}{*}{ Certificación Internacional (FSC) } & 399.419 ha certificadas \\
\cline { 2 - 2 } & $440.819,95$ ha en proceso \\
\cline { 2 - 2 } & 38 empresas con certificados de cadena de custodia \\
\hline
\end{tabular}

En cuanto al comercio de especies arbóreas que producen maderas comerciales protegidas CITES, este se autoriza otorgando un permiso de exportación (o certificado de reexportación) o un permiso de importación, según sea el caso. Las principales especies comerciadas son el cedro y la caoba, y en términos generales existe una gran dependencia hacia Estados Unidos en las exportaciones (ver Tablas 16 y 17 Anexo). Para realizar la exportación de productos maderables en cumplimiento de la legislación nacional, la Ley Lacey y FLEGT es necesario seguir el siguiente diagrama.

51. CONAFOR. 'Sistema Mexicano de Certificación Forestal y de Cadena de Custodia. [presentación online], (2012). <http://www.conafor.gob.mx:8080/documentos/docs/5/2500Presentaci\%C3\%B3n\%20del\%20 Sistema\%20Nacional\%20de\%20Certificaci\%C3\%B3n\%20Forestal\%20y\%20de\%20Cadena\%20 de\%20Custodia.pdf>. Accedido el 4 de abril de 2014. 


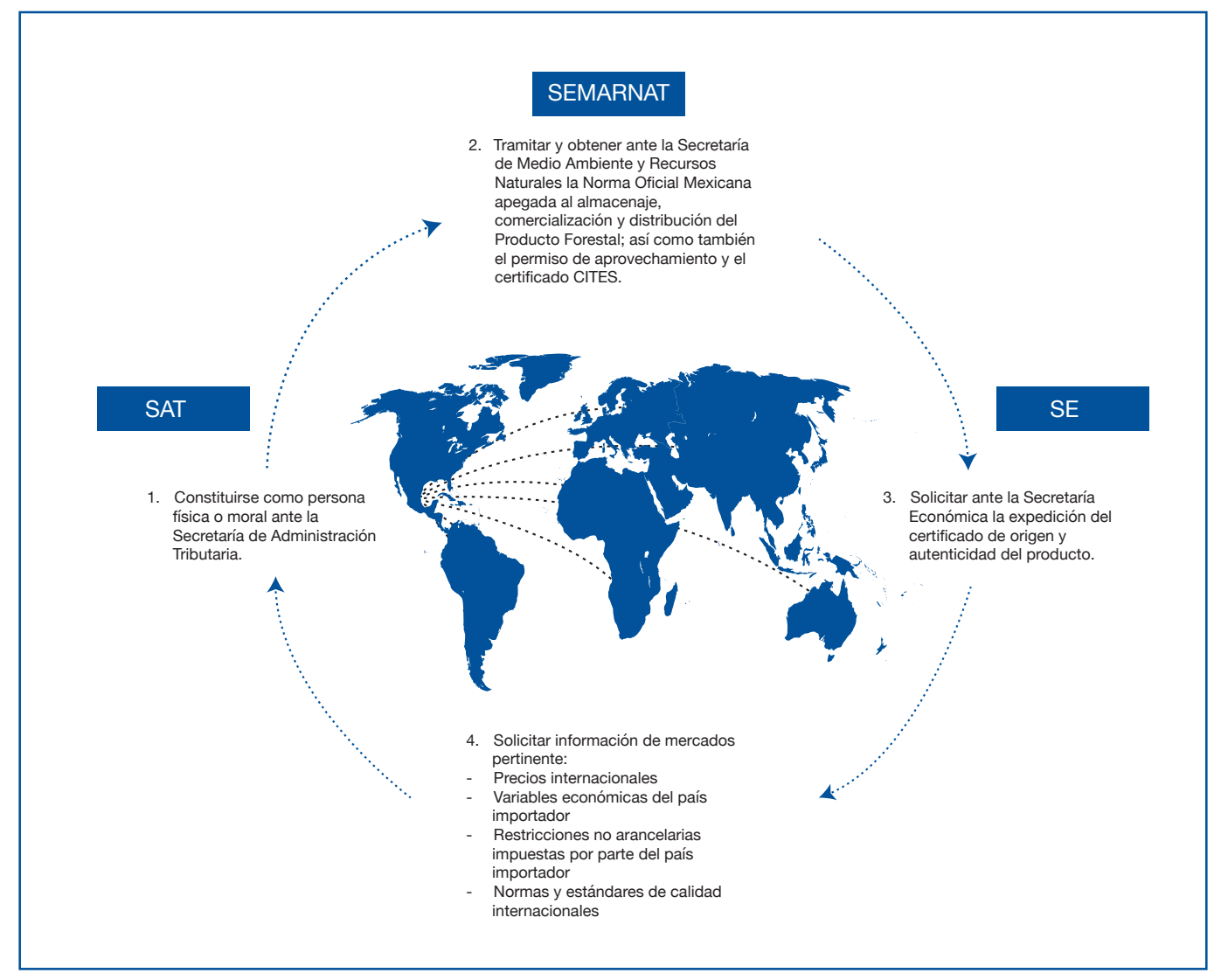

Adaptado de CONAFOR 


\section{Análisis del sistema de control forestal}

Uno de los retos más difíciles para la gestión ambiental es garantizar el cumplimiento de las medidas de control forestal. Hasta ahora, el mercado de madera ilegal en México continúa siendo muy importante gracias a la corrupción o baja aplicación de controles. Asimismo, la presencia de bandas criminales en zonas rurales y las condiciones de pobreza y marginación de comunidades forman una combinación que promueve la tala ilegal, haciéndola un negocio rentable. En México, la autoridad competente de vigilar el cumplimiento de la normatividad ambiental es la Procuraduría Federal de la Protección al Ambiente (PROFEPA), la cual en el sector forestal tiene como función primordial la salvaguarda y patrullaje de los recursos y ecosistemas forestales, así como la prevención de infracciones administrativas del orden forestal ${ }^{52}$.

De manera particular, la PROFEPA tiene como facultades, entre otras ${ }^{53}$ :

- Inspeccionar y vigilar el cumplimiento de las vedas forestales.

- Inspeccionar, verificar y vigilar el cumplimiento de las disposiciones jurídicas aplicables al aprovechamiento de las plantaciones forestales comerciales y a los programas de forestación y reforestación.

- Inspeccionar, verificar y vigilar el cumplimiento de las disposiciones jurídicas que regulan los cambios de uso del suelo en terrenos forestales, los programas de manejo forestal, así como lo relativo al registro y desarrollo de actividades de aprovechamiento de recursos forestales maderables y no maderables, centros de almacenamiento o transformación y el transporte de materias primas forestales, productos y subproductos.

- Inspeccionar y vigilar, dentro del territorio nacional, el cumplimiento de las disposiciones jurídicas aplicables en materia fitosanitaria relacionada con recursos forestales.

- Realizar los actos de inspección, verificación y vigilancia para el cumplimiento de las disposiciones jurídicas aplicables en materia de importación, exportación y reexportación de recursos forestales y su control fitosanitario.

- Supervisar, coordinar, evaluar y realizar la verificación del cumplimiento de las disposiciones relativas al comercio internacional de vida silvestre establecidas en la Convención sobre el Comercio Internacional de Especies Amenazadas de Fauna y Flora Silvestre.

Si bien en la ley están bien delimitadas las atribuciones de la PROFEPA, los problemas en el sistema de control forestal son de índole operativo, como por ejemplo, la incipiente coordinación con otras autoridades vinculadas a los ilícitos como tala clandestina. Asimismo, una de las dificultades en cuanto al comercio internacional forestal es que ni los agentes aduanales ni PROFEPA saben cómo identificar los diversos tipos de madera que tienen regulación específica, por lo que es necesario fortalecer la coordinación interinstitucional Dirección General de Aduanas-PROFEPA y dar mayor

52. Art. 158, LGDFS.

53. Artículos 59 y 60 del Reglamento Interior de la Secretaría de Medio Ambiente y Recursos Naturales. 
detalle y especificidad a los acuerdos que determinan las fracciones arancelarias a fin de facilitar su implementación (ejemplo: detalles que permitan identificar qué tipo de madera es la que se regula).

En cuanto a las medidas de control dentro del territorio nacional, un gran obstáculo ha sido la falta de recursos humanos que puedan dar puntual seguimiento a las actividades de inspección y vigilancia. En este sentido, los acuerdos y convenios que en materia forestal celebre la CONAFOR con personas físicas o morales del sector público, social o privado pueden orientarse a coadyuvar en labores de vigilancia forestal ${ }^{54}$.

En procura de mantener el control, la LGDFS señala que quienes sean titulares de los aprovechamientos forestales y plantaciones forestales, al igual que los centros de almacenamiento y transformación, y quienes realicen el transporte de las materias primas forestales, sus productos y subproductos (con excepción de uso doméstico), deberán acreditar su legal procedencia con la documentación prevista en el reglamento, normas oficiales mexicanas ${ }^{55}$.

Por esta razón, es atribución de la Federación -vía SEMARNAT- regular, expedir y validar la acreditación de la legal procedencia de las materias primas forestales y productos maderables ${ }^{56}$. Asimismo, la legislación forestal considera como infracción carecer de la documentación o los sistemas de control establecidos para acreditar la legal procedencia de materias primas forestales, obtenidas en el aprovechamiento o plantación forestal comercial respectivo, transportar, almacenar, transformar o poseer materias primas forestales sin contar con la documentación o los sistemas de control establecidos para acreditar su legal procedencia, amparar materias primas forestales que no hubieran sido obtenidas de conformidad con las disposiciones de esta ley, su reglamento o de las normas oficiales mexicanas aplicables, a fin de simular su legal procedencia y utilizar más de una vez, alterar o requisitar inadecuadamente la documentación o sistemas de control establecidos para el transporte o comercialización de recursos forestales ${ }^{57}$.

En términos prácticos, el control cruzado de madera implica solicitar al operador del camión los dos documentos que validan la entrada del embarque al aserradero: remisión forestal (original y dos copias) y lista de embarque (de bosque al aserradero). La remisión forestal y el reembarque forestal son expedidos por las delegaciones de la SEMARNAT y son documentos de transporte que acreditan la legal procedencia de las materias primas y subproductos forestales. Además, sirven para llevar un control del volumen de madera en rollo extraído. Así, se puede verificar que el volumen, cantidad y descripción de materia prima coincidan en los dos documentos autorizados por SEMARNAT y verificar que el permiso no haya caducado.

El control cruzado, sin embargo, carece de efectividad toda vez que los permisos y guías emitidos por la autoridad permiten dar seguimiento únicamente al aprovechamiento forestal en el terreno y durante el transporte de la madera, en ocasiones el permiso establece un tiempo suficiente para que el mismo documento sea ilegalmente utilizado en diversas ocasiones. Los centros de almacenamiento, transformación y aserraderos deben registrarse en el Registro Forestal Nacional, pero carpinterías y madererías no, y el contenido de los informes periódicos solicitados por la LGDFS es muy limitado

54. Art. 151, LGDFS.

55. Arts. 62, 115 y 116, LGDFS.

56. Arts. 12, fr. XXV y 16, fr. XXIV.

57. Art. 163, LGDFS. 
y no permite un eficiente control cruzado de información para cotejar cuánta madera entra y cuanta sale, y dar una efectiva custodia a toda la cadena de valor.

Por otro lado, para un efectivo control del aprovechamiento, transformación, transporte y comercialización de la madera una gran ayuda es contar con un efectivo sistema de monitoreo y estadísticas forestales, veraces, confiables y oportunas. En México no hay un sistema como tal, con dichas características. Sin embargo, en el marco legal nacional existe una serie de instrumentos y herramientas que puede ser de gran utilidad, en particular ${ }^{58}$ :

- Sistema Nacional de Información Forestal ${ }^{59}$ : Debe registrar, integrar, organizar, actualizar y difundir la información relacionada con el sector forestal, la cual debe estar disponible para su consulta gratuita y pública. La SEMARNAT regula y la CONAFOR integra.

- Inventario Nacional Forestal y de Suelos ${ }^{60}$ : Es un conjunto de técnicas y procedimientos para obtener información cuantitativa y cualitativa de los recursos forestales, vegetación asociada, componentes y características del territorio forestal. La SEMARNAT regula y la CONAFOR integra. Este inventario debe actualizarse cada cinco años con la superficie y localización de terrenos forestales y preferentemente forestales con que cuenta el país para integrar su información estadística y elaborar su cartografía, los terrenos forestales temporales, los tipos de vegetación forestal y de suelos, las zonas de conservación, protección, restauración y producción forestal, en relación con las cuencas hidrológicas-forestales, las regiones ecológicas, las áreas forestales permanentes y las áreas naturales protegidas, la cuantificación de los recursos forestales, que incluya la valoración de los bienes y servicios ambientales que generen los ecosistemas forestales, así como los impactos que se ocasionen en estos, entre otra información. Estos datos deben ser usados para formular y ejecutar programas (forestales, así como de mitigación y adaptación al cambio climático), integrar la zonificación forestal y evaluar resultados. Se está realizando el levantamiento en campo del segundo ciclo de inventario 2009-2014, lo cual sugiere que los datos más actuales corresponden al año 2008 y la planeación de política ambiental y forestal, por lo tanto, se lleva a cabo con datos y estadísticas retrasadas.

- Registro Forestal Nacional61: Entre la información que en él se debe inscribir se encuentran los programas y autorizaciones de manejo forestal y los programas de manejo de plantaciones forestales comerciales, los decretos de ANP, zonas de restauración y vedas, la transferencia de dominio, uso, usufructo de recursos forestales, programas de manejo forestal, de manejo de plantaciones forestales comerciales y avisos de forestación, las autorizaciones de funcionamiento de centros de almacenamiento y transformación.

- Sistema Nacional de Gestión Forestal62: La SEMARNAT lo integra a partir de los programas de manejo inscritos en el Registro Forestal Nacional para llevar el control, la evaluación y el seguimiento de estos. Cuenta con los grupos de trabajo: Inspección y Vigilancia Forestal, Sistemas de Información, y Comercio y Fomento Económico.

58. Art. 35, LGDFS.

59. Art. 39, LGDFS.

60. Art. 44 al 46 , LGDFS.

61. Art. 51, LGDFS.

62. Art. 56, LGDFS. 
Además de las infracciones administrativas a las que da seguimiento la PROFEPA, existen conductas que pueden ser sancionadas penalmente. Sobre recursos forestales, las conductas sancionables son la tala no autorizada en bosques, selvas, áreas naturales protegidas, transportación no autorizada de productos forestales, almacenamiento, transformación y/o comercialización de recursos forestales, cambios de uso de suelo en selvas, bosques y áreas naturales protegidas y aprovechamiento no autorizado de productos no maderables (tierra procedente de suelos forestales). Asimismo, en materia de ecosistemas se sanciona provocar incendios en bosques, selvas y terrenos forestales. En materia de flora silvestre se penaliza la destrucción, aprovechamiento no autorizado, posesión, transportación, comercialización, exportación e importación ilegal, aprovechamiento o colecta de especies protegidas por la normatividad, aprovechamiento no autorizado de especies sujetas a protección especial, comercio, transporte, almacenamiento o liberación al ambiente de organismos genéticamente modificados, así como las conductas establecidas en el Código Penal Federal (CPF) ${ }^{63}$.

En el 2012, la PROFEPA a nivel nacional, en materia de Recursos Naturales, realizó un total de 25.013 acciones de inspección, vigilancia y operativos, de las cuales, el 33,23\% fue en materia forestal, $15,69 \%$ corresponde a vida silvestre, $33,14 \%$ a recursos marinos, $11,37 \%$ a impacto ambiental y $6,54 \%$ a Zona Federal Marítimo-Terrestre.

Sin embargo, es importante mencionar que no todas estas acciones corresponden a delitos ambientales, sino que pueden ser infracciones administrativas. Asimismo, si bien el sector forestal es el que más infracciones ha acumulado, en los últimos cinco años ha bajado la incidencia de estas (ver 18 Anexo).

Asimismo, la Ley General del Equilibrio Ecológico y Protección al Ambiente establece la figura de la denuncia popular como un mecanismo que permite a la sociedad la posibilidad de denunciar ante la PROFEPA u otras autoridades todo hecho, acto u omisión que produzca o pueda producir desequilibrio ecológico o daños al ambiente o a los recursos naturales, o contravenga las disposiciones legales que regulen materias relacionadas con la protección al ambiente y la preservación y restauración del equilibrio ecológico. La denuncia popular puede presentarse por teléfono, correo electrónico, escrita o de manera personal. Los datos que muestra el siguiente gráfico sobre la materia de las denuncias populares en materia ambiental indican que $43 \%$ de las denuncias ante la Procuraduría Federal de Protección al Ambiente es referente a la materia forestal, siendo esta la más denunciada. Esto indica la existencia de una mayor cantidad de conductas delictivas sobre los recursos forestales con 2.525 denuncias.

63. Procuraduría Federal de Protección al Ambiente. 'Conductas que pueden ser denunciadas penalmente en materia de recursos naturales y Zona Federal Marítimo Terrestre'. [sitio web]. <http://www.profepa.gob.mx/ innovaportal/v/1366/1/mx/conductas_que_pueden_ser_denunciadas_penalmente_en_materia_de_ recursos_naturales_y_zona_federal_maritimo_terrestre.html>. Accedido el 4 de abril de 2014. 


\section{Denuncias recibidas por materia afectada a nivel nacional (2007-2012)}

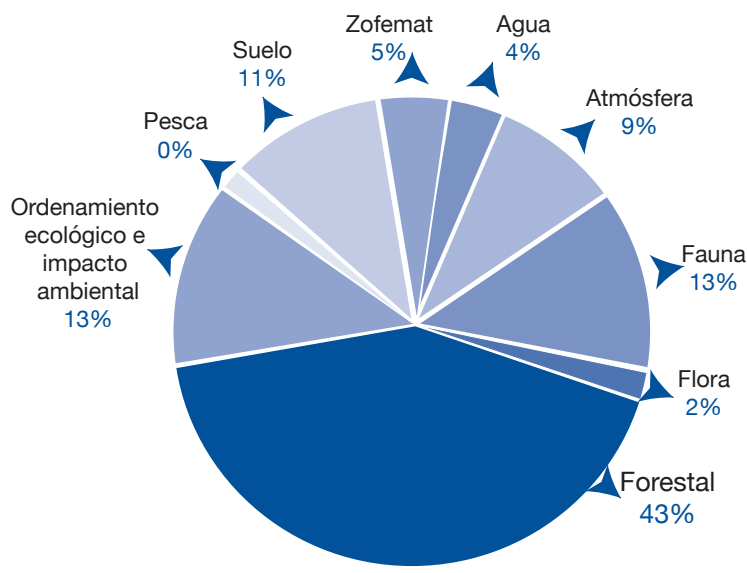

\section{Recurso afectado}

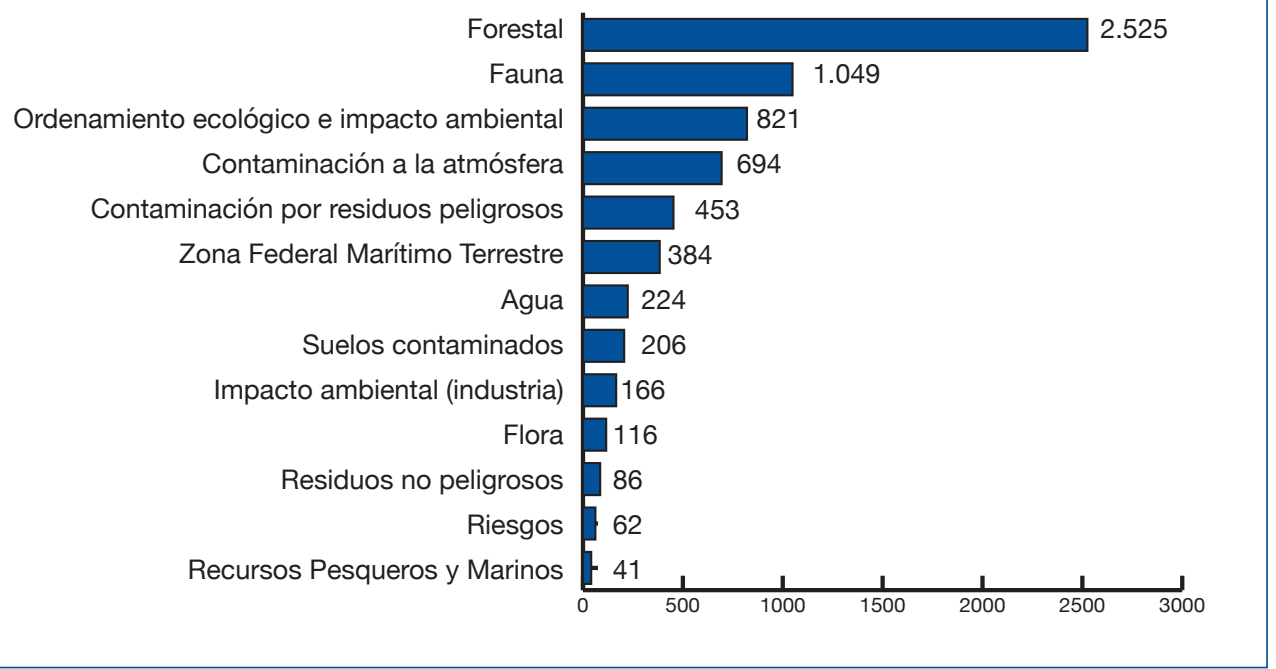

Por otra parte, en el ámbito judicial, los datos sobre denuncias, procesos y sentencias de juzgados federales sobre delitos ambientales por afectación a los recursos forestales señalan las escasas averiguaciones previas y consignaciones por posibles delitos forestales (ver Tabla 19 Anexo). 


\section{Análisis de ejecución de procesos judiciales}

En México no existen tribunales especializados en materia ambiental, aunque la ley de responsabilidad ambiental, de reciente creación prevé su creación. Esto comprende uno de los principales retos que se enfrentan en materia de impartición de justicia, ya que los temas ambientales han adquirido gran importancia. Del conjunto de normas en materia forestal, solo el CPF y la LFSV contemplan tipos o conductas susceptibles de ser sancionadas por medio de un procedimiento judicial, debido a que el CPF ha absorbido los tipos penales que anteriormente estaban contenidos en el resto de las leyes (ver Tabla 20 Anexo).

El resto de los ordenamientos legales solamente comprende faltas, multas, sanciones y cancelaciones, todas ellas de carácter administrativo. Así, por ejemplo, la LGDFS no contempla delitos, únicamente la imposición de medidas de seguridad y sanciones de carácter administrativo por infracciones (cuando no propietarios y poseedores no permitan el acceso de las autoridades a una inspección en materia forestal). En este caso, el procedimiento es administrativo. Sin embargo, esto no exime de la obligación de aplicar el CPF en materia de delitos ambientales por tala clandestina, entre otros.

En relación con los delitos en el comercio internacional, estos están previstos en el Código Fiscal de la Federación, siendo principalmente el delito de contrabando el que más se regula. De esta forma, se considera contrabando cuando se introduzca al país o extraiga de él mercancías sin permiso de autoridad competente, cuando sea necesario este requisito ${ }^{64}$ o se descubran mercancías extranjeras sin la documentación aduanera que acredite que las mercancías se sometieron a los trámites previstos en la Ley Aduanera para su introducción al territorio nacional.

La duración de los procedimientos sobre delitos ambientales varía si se trata de un procedimiento sumario o uno ordinario.

\begin{tabular}{|c|c|c|c|}
\hline Averiguación previa & Preinstrucción & $\begin{array}{l}\text { Cierre de la } \\
\text { instrucción }\end{array}$ & $\begin{array}{c}\text { Ejecución y/o } \\
\text { apelación }\end{array}$ \\
\hline $\begin{array}{l}\text { 1. Hecho delictivo } \\
\text { 2. Aviso al MPF } \\
\text { 3. Investigación } \\
\text { 4. Consignación ante un } \\
\text { juez federal }\end{array}$ & $\begin{array}{l}\text { 1. Presentación del } \\
\text { detenido } \\
\text { 2. El MPF ofrece } \\
\text { pruebas } \\
\text { 3. El juez ratifica la } \\
\text { detención o decreta la } \\
\text { libertad con reservas } \\
\text { de ley } \\
\text { 3. Declaración del } \\
\text { acusado } \\
\text { 4. El juez decreta: } \\
\text { - Formal prisión } \\
\text { - Sujeción a proceso } \\
\text { - }\end{array}$ & $\begin{array}{l}\text { 1. Conclusiones del } \\
\text { MPF } \\
\text { 2. Conclusiones de la } \\
\text { defensa } \\
\text { 3. Sentencia }\end{array}$ & \\
\hline
\end{tabular}

64. Artículo 102, Código Fiscal de la Federación. 


\begin{tabular}{|c|c|c|c|}
\hline $\begin{array}{l}\text { Ministerio Público } \\
\text { Federal (MPF), fiscal }\end{array}$ & \multicolumn{3}{|c|}{ Juez Federal en materia penal } \\
\hline $\begin{array}{l}\text { - } 48 \text { horas con } \\
\text { detenido } \\
\text { - } \quad \text { Sin detenido el } \\
\text { tiempo es indefinido }\end{array}$ & $\begin{array}{ll}\text { - } & 72 \text { horas } \\
\text { - } & 144 \text { si se trata } \\
\text { de delincuencia } \\
\text { organizada }\end{array}$ & $\begin{array}{l}\text { - Cuando la pena } \\
\text { excede } 2 \text { años de } \\
\text { prisión: } 6 \text { meses } \\
\text { - } \quad \text { Cuando la pena no } \\
\text { supera } 2 \text { años de } \\
\text { prisión, es alternativa } \\
\text { o no es sancionada } \\
\text { con prisión: } 2 \text { meses }\end{array}$ & $\begin{array}{l}\text { - } 20 \text { días por cada } \\
\text { conclusión } \\
\text { - } 15 \text { días }\end{array}$ \\
\hline
\end{tabular}

Fuente propia

Es conveniente señalar que a partir del año 2016, el sistema de justicia penal inquisitorio mexicano cambiará por uno de corte adversarial (oral). Dicho sistema ya se realiza en algunos Estados, pero falta su implementación en otros y a nivel federal. Este sistema contempla procesos más rápidos.

Derivado de los procesos judiciales, se han emitido sentencias que han formado jurisprudencia que, aunque escasa, sirve de guía para entender conceptos tales como compensación ambiental y daño ambiental. Destaca en este sentido que ha habido criterios judiciales que señalan que el daño o perjuicio en materia ambiental se debe estudiar desde una perspectiva no solo económica y de manera individual, ya que los daños en materia ambiental (incluido el daño a los recursos forestales) son perjuicios sucesivos al ambiente y su indemnización por el deterioro causado debe incluir la remediación y recuperación del medio ambiente, entendiendo remediación como "el conjunto de actividades tendentes a la recuperación y restablecimiento de las condiciones que propician la evolución y continuidad de los procesos naturales" (ver Tabla 21 Anexo).

Referente a las penas contempladas en los ordenamientos jurídicos en materia de protección al medio ambiente, recursos forestales y comercio, estas prevén diferentes sanciones, desde las de carácter administrativo que se cubren con el pago de una multa con el cumplimiento de alguna cancelación o un decomiso, hasta las de carácter penal, que significan la sanción más fuerte que puede aplicar el Estado por suponer la afectación o puesta en riesgo de estos bienes jurídicos protegidos, como son el medio ambiente y los recursos forestales.

Al año 2011 en México existían 156 agencias ministeriales del fuero federal y 1.207 del fuero común. Este total de agencias recibió por el fuero federal 133.045 denuncias; de las cuales, los delitos contra la salud, portación de arma de fuego, delitos contra instituciones bancarias, por violación a la ley general de población, ataques a las vías generales de comunicación, cometidos por servidores públicos, asociación delictuosa y los delitos fiscales ocupan la gran mayoría de aquellas denuncias; mientras que existe otro rubro mínimo que comprende 54.273 denuncias, en el cual están contemplados el resto de los delitos del fuero federal y donde también se encuentran los delitos al medio ambiente, y consecuentemente, los referentes al comercio ilegal de productos forestales.

Según estadísticas del Poder Judicial de la Federación, los casos que llegan a los juzgados por delitos contra la ecología y el medio ambiente en los últimos cuatro años son de 2.673 detenciones por la probable responsabilidad en la comisión de delitos contra la ecología y el medio ambiente que llegan al Ministerio Público. De esta cantidad de detenciones, en una gran parte de ellas a los 
probables responsables el juez les dejó en libertad por falta de elementos para procesar, manteniendo el expediente en reserva (para cuando haya nuevas pruebas). Desafortunadamente, no existen datos sobre el número de sentencias firmes por estos mismos delitos.

De igual forma, los datos sobre casos que la autoridad consigna y en los que se entabla un proceso penal, concluyendo con una sentencia, son muy pocos comparados con las denuncias y las mismas consignaciones, incluso en el resto de delitos penales (ver Tabla 22 Anexo). Esto es indicador de que el actuar de las autoridades encargadas de vigilar, inspeccionar, proteger y sancionar conductas en materia ambiental debe buscar formas más efectivas para el cuidado y protección del medio ambiente, y en específico de los recursos forestales, ya que los datos arrojados indican un alto índice de conductas delictivas, así como de pérdida de capa forestal y un bajo índice de sanciones, ya sea administrativas o penales.

Además de lo anterior, hay retos que se deben asumir, tales como la falta de especialización en materia ambiental por parte de los jueces, la falta de capacidad de la autoridad protectora, en este caso la PROFEPA, así como la falta de recursos públicos que sean destinados a la protección del medio ambiente y los recursos forestales, el mejor control del comercio, el refuerzo de las políticas públicas que otorguen apoyos a productores y promuevan el aprovechamiento de una manera sustentable.

Uno de los retos de la PROFEPA es resolver los procedimientos tanto de denuncia popular como de inspección y vigilancia a través del cual se sancionan los incumplimientos para que a partir de este el denunciante vea sus pretensiones sobre cuidado y preservación ambiental. Para lograrlo es necesario determinar con oportunidad su procedencia y una coordinación muy estrecha entre las áreas jurídica y de inspección de la PROFEPA. En este sentido, la institución ha elaborado unos lineamientos para la atención de las denuncias que, junto con la creación de comités de denuncia en las delegaciones, puede facilitar una atención racionalizada de estas, con estrategias específicas para cada entidad federativa.

Otro aspecto muy importante es la falta de capacidad, en cuanto a recursos y personal especializado, de la autoridad encargada de la protección y vigilancia del medio ambiente y los recursos forestales (PROFEPA) y por otro, la falta de obligatoriedad y efectividad para hacer cumplir sus resoluciones. Respecto de la falta de recursos en materia ambiental, se debe señalar la diferencia que hay entre el presupuesto asignado a la institución y el monto gastado, observando que con el paso del tiempo los gastos han sido mayores al presupuesto original, lo cual afecta el trabajo de dicha dependencia y el cuidado y protección del medio ambiente y los recursos forestales (ver Tabla 23 Anexo). 


\section{Aportes adicionales}

Derivado de la investigación se puede concluir que el marco legal aplicable al comercio forestal en México es vasto y tiende, en la teoría, al cumplimiento de las obligaciones contenidas en instrumentos internacionales, tales como la Ley Lacey, la NIMF-15 y el Plan europeo FLEGT. No obstante esto, existe una gran amenaza en términos de la eficacia a nivel interno de dicho marco legal al no haber una aplicación efectiva de la ley ni la suficiente inspección y vigilancia por parte de la autoridad competente para disminuir la ilegalidad en el sector.

Si bien existen suficientes instrumentos de política forestal y comercial que pretenden tener un control en la legalidad de las exportaciones, lograr alcanzar el objetivo al $100 \%$ en cuanto a los instrumentos propiamente forestales enfrenta retos como la escasez de presupuesto en el sector forestal, la falta de recursos humanos que puedan dar seguimiento puntual a las autorizaciones, la poca aplicación de la ley en cuanto a delitos ambientales y el aumento de la demanda de productos provenientes de fuentes ilegales en mercados nacionales e internacionales, entre otros.

Aunado a lo anterior, debe considerarse que el marco legal del sector forestal es complejo y a la vez insuficiente al incidir diversos ordenamientos principalmente el ambiental, del agua, de vida silvestre, desarrollo social y desarrollo rural, que provocan confusión, altos costos y dispersión, en ausencia de mecanismos que integren dicho universo. La regulación resulta generalmente excesiva para los productores que optan por actuar dentro del marco de la ley.

Es por lo tanto urgente armonizar el marco legal y regulatorio del sector, principalmente mediante la consolidación de la legislación dispersa en las materias ambiental y de desarrollo rural, procurando en ese proceso la homologación de lenguajes, criterios y conceptos, así como el alineamiento de las disposiciones de cada una de ellas y la supresión de las contradicciones y duplicidad de procedimientos e instancias de autoridad.

Asimismo, es necesario simplificar los procedimientos mediante la fusión de trámites y la asignación de una sola instancia de dictamen, así como el desarrollo y aplicación de mecanismos automáticos de autorización en casos de historial sobresaliente y particularmente con el reconocimiento de procedimientos de certificación.

En relación con la cadena de custodia, actualmente la regulación solo permite establecer una en el transporte de madera y de manera ineficiente (los productos certificados sí tienen una efectiva cadena de custodia de todo el proceso). El enfoque de SEMARNAT/PROFEPA es controlar la oferta de madera ilegal abordando con muy poco personal el problema en campo, pero en un territorio inmenso, lo cual resulta insuficiente y poco costo-efectivo. Por ello, se recomienda cambiar el enfoque para controlar la demanda de madera (en vez de la oferta) de una manera más costoefectiva. También se requiere que toda la información que permita el control cruzado de información sea pública y proactivamente difundida con otras autoridades que controlan el desempeño de comercios, como carpinterías, etc.

Dado el tamaño estimado del mercado de la madera ilegal en México, se requiere impulsar a las comunidades forestales del país para introducir más madera legal y producida sustentablemente al 
mercado, que mantenga un monitoreo preciso de la procedencia. Asimismo, se sugiere establecer esquemas de coadyuvancia social en la vigilancia, coordinados por la PROFEPA e incluir en la acción de regulación y vigilancia a la industria, almacenamiento y comercialización de productos forestales. Se deben generar mecanismos de articulación y coordinación entre las instituciones y las políticas públicas, tomando en cuenta las estructuras y formas de organización local y los instrumentos de gestión forestal comunitaria, así como dar prioridad al Manejo Forestal Comunitario (MFC) para garantizar la integridad de los ecosistemas y los territorios, desarrollar el potencial de generación de beneficios ambientales, favorecer mejores condiciones de vida de los habitantes de los territorios forestales y contribuir a la gobernabilidad de forma tal que se desincentive el aprovechamiento forestal fuera de la ley. 


\section{Bibliografía}

Bray, D.B. et al. (2002). The rise of community forestry in México: history, concepts, and lessons learned from twenty-five years of community timber production, Miami, Flo.: Florida International University. $132 \mathrm{p}$.

Carbonell, M. (2005). El derecho al medio ambiente: legislación básica. México: Porrúa: CNDH, xxxi, $624 \mathrm{p}$.

Cedeño, H. La legislación forestal y su efecto en la restauración en México. Centro de Investigaciones en Ecosistemas, Universidad Nacional Autónoma de México [pdf online] <http://www2.inecc. gob.mx/publicaciones/libros/467/cedenoyperez.html>.

Código Fiscal de la Federación. Publicado en el Diario Oficial de la Federación el 31 de diciembre de 1981. Última reforma publicada DOF 31-12-2012.

Código Penal Federal. Publicado en el Diario Oficial de la Federación el 14 de agosto de 1931. Última reforma publicada DOF 07-06-2013.

Constitución Política de los Estados Unidos Mexicanos. Publicada en el Diario Oficial de la Federación el 5 de febrero de 1917. Última reforma publicada DOF 08-10-2013.

Environmental Law Institute (1998). Aspectos legales del manejo forestal en México / The Institute. Washington, D.C.: ELI, 1998, xvi, 152 p.

Ley Aduanera. Publicada en el Diario Oficial de la Federación el 15 de diciembre de 1995. Última reforma publicada DOF 09-04-2012.

Ley Agraria. Publicada en el Diario Oficial de la Federación el 26 de febrero de 1992. Última reforma publicada DOF 09-04-2012.

Ley de Aguas Nacionales. Publicada en el Diario Oficial de la Federación el $1^{\circ}$ de diciembre de 1992. Última reforma publicada DOF 08-06-2012.

Ley de Desarrollo Rural Sustentable. Publicada en el Diario Oficial de la Federación el 7 de diciembre de 2001. Última reforma publicada DOF 12-01-2012.

Ley Federal de Derechos. Publicada en el Diario Oficial de la Federación el 31 de diciembre de 1981. Última reforma publicada DOF 28-12-2012.

Ley Federal de Sanidad Vegetal. Publicada en el Diario Oficial de la Federación el 5 de enero de 1994. Última reforma publicada DOF 16-11-2011.

Ley General de Cambio Climático. Publicada en DOF el 6 de junio de 2012.

Ley General de Desarrollo Forestal Sustentable. Publicada en el Diario Oficial de la Federación el 25 de febrero de 2003. Última reforma publicada DOF 07-06-2013.

Ley General del Equilibrio Ecológico y Protección al Ambiente. Publicada en el Diario Oficial de la Federación el 28 de enero de 1988. Última reforma publicada DOF 07-06-2013.

Ley General de Vida Silvestre. Publicada en el Diario Oficial de la Federación el 3 de julio de 2000. Última reforma publicada DOF 07-06-2013. 
Paré, L. (1996) Bosques y Plantaciones Forestales / Coord.: Luisa Paré y Sergio Madrid. México, D.F.: Cuadernos Agrarios: Edición Federación Editorial Mexicana, 175 p. gráfs., cuadros (Serie: Cuadernos Agrarios, Año 6, № 14, Nueva Época).

Reglamento de la Ley General de Desarrollo Forestal Sustentable. Publicado en el Diario Oficial de la Federación el 21 de febrero de 2005.

Reglamento de la Ley General del Equilibrio Ecológico y la Protección al Ambiente en Materia de Áreas Naturales Protegidas. Publicado en el Diario Oficial de la Federación el 30 de noviembre de 2000. Última reforma publicada DOF 28-12-2004

United States. Environmental Protection Agency (1955). Deforestation: Technical support document. The Agency. Washington, D.C.: USEPA, 58 p. 



\section{Guatemala}

Alejandra Sobenes G. 


\section{Acrónimos}

ANAM: $\quad$ Asociación Nacional de Municipalidades

AGEXPRONT: Asociación Gremial de Exportadores de Productos No Tradicionales

ASOREMA: Asociación Nacional de Organizaciones No Gubernamentales de los Recursos Naturales, Ecología y Medio Ambiente

CPRG: $\quad$ Constitución Política de la República de Guatemala

CITES: $\quad$ Convención sobre el Comercio Internacional de Especies Amenazadas de Fauna y Flora Silvestre

CONAP: Consejo Nacional de Áreas Protegidas

COFAMA: Comisión de Fabricantes de Madera y Productos Forestales

CPRG: $\quad$ Constitución Política de la República de Guatemala

ENCA: $\quad$ Escuela Nacional Central de Agricultura

ENRD: $\quad$ Estrategia Nacional para Reducir la Deforestación

FAO: $\quad$ Organización de las Naciones Unidas para la Alimentación

IDAEH: Instituto de Antropología e Historia

INAFOR: Instituto Nacional Forestal

INGUAT: Instituto Guatemalteco de Turismo

JD: Junta Directiva

LAP: $\quad$ Ley de Áreas Protegidas

LAIP: $\quad$ Ley de Acceso a la Información Pública

LF: $\quad$ Ley Forestal

LMARN: Ley de Protección y Mejoramiento del Medio Ambiente

LMCC: $\quad$ Ley Marco para Regular la Reducción de la Vulnerabilidad, la Adaptación Obligatoria ante los Efectos del Cambio Climático y la Mitigación de Gases de Efecto Invernadero

MAGA: $\quad$ Ministerio de Agricultura, Ganadería y Alimentación

MARN: $\quad$ Ministerio de Ambiente y Recursos Naturales

MINFIN: $\quad$ Ministerio de Finanzas Públicas

MP: $\quad$ Ministerio Público

PNC: $\quad$ Policía Nacional Civil

PFN: $\quad$ Programa Forestal Nacional

PINFOR: $\quad$ Programa de Incentivos Forestales

PINPEP: $\quad$ Programa Incentivos Forestales para Poseedores de Pequeñas Extensiones de Tierra de Vocación Forestal o Agroforestal

REDD+: $\quad$ Reducción de Emisiones de Gases de Efecto Invernadero por Deforestación Evitada

RLF: $\quad$ Reglamento de la Ley Forestal 
RLAP: $\quad$ Reglamento de la Ley de Áreas Protegidas

SAT: $\quad$ Superintendencia de Administración Tributaria

SEADEX: Servicio Electrónico de Exportaciones

SEINEF Sistema Electrónico de Información de Empresas Forestales

SIFGUA: $\quad$ Sistema de Información Forestal de Guatemala

SIPECIF: $\quad$ Sistema de Prevención y Control de Incendios Forestales

SIGAP: $\quad$ Sistema Guatemalteco de Áreas Protegidas

UE: $\quad$ Unión Europea

UICN: $\quad$ Unión Internacional para la Protección de la Naturaleza

VUPE: $\quad$ Ventanilla Única Para las Exportaciones 


\section{Introducción}

Guatemala tiene una extensión territorial de $108.889 \mathrm{~km}^{2}$. Un poco más de la mitad de su territorio tiene vocación forestal. Según el Mapa de Cobertura Forestal de Guatemala 2010 y Dinámica de la Cobertura Forestal 2006-2010, el país cuenta con una cobertura forestal de 3.722.595 hectáreas, equivalente a $34 \%$ del territorio terrestre nacional ${ }^{1}$. El país ha sido reconocido como megadiverso; esto es, con un alto índice de diversidad de ecosistemas y especies de flora y fauna a nivel mundial. ${ }^{2}$ El país cuenta con 14 ecorregiones, 66 ecosistemas, 14 zonas de vida en un pequeño territorio de 0,5\% de la superficie del planeta. Posee 10.317 especies de flora, 706 especies de aves y otras especies como: 142 anfibios, 244 mamíferos, 245 reptiles y más de 100.000 invertebrados.

Entre las categorías de tipo de bosque, el país tiene bosques primarios/maduros, mayoritariamente constituidos por latifoliadas. El $52 \%$ de la cobertura forestal nacional se ubica dentro del Sistema Nacional de Áreas Protegidas. La tercera parte del territorio nacional corresponde a áreas protegidas, lugares en donde se produce la mayor deforestación.

Al año 2010 Guatemala contaba con una cobertura de bosque equivalente a 3.722 .595 hectáreas, lo que representa $34,2 \%$ del país. Para el período $2006-2010$ se estima que la pérdida anual bruta asciende a 132.137 hectáreas y la ganancia anual bruta a 93.540 hectáreas, lo cual resulta en una pérdida neta de 38.597 hectáreas anuales o 1\% de pérdida anual respecto al bosque existente en el año $2006^{3}$.

Los niveles de deforestación han ido en incremento, poniendo en riesgo la sostenibilidad del recurso. "El balance oferta/demanda global arroja un déficit de 5.725.290 en base seca anuales. Este déficit detectado supone la confirmación de que para ser satisfecho se está avanzando sobre las reservas forestales del país"".

En cuanto a las exportaciones de madera en el año 2012, según datos de SIFGUA, ascendieron a US\$59,793,158 (en relación con los US\$50,465,265 en el 2009).

En Guatemala se han realizado importantes esfuerzos para ir desarrollando el sector forestal. Se ha impulsado y facilitado el cumplimiento de los compromisos de repoblación forestal por el mecanismo de licencias, el establecimiento de nuevas plantaciones, el manejo de rebrotes y regeneración natural, logrando hasta el año 2010 que 161.000 hectáreas de tierras sin cobertura forestal hayan sido reforestadas; de las cuales, 103.400 han sido apoyadas con incentivos a través de los programas PINFOR y PINPEP ${ }^{5}$. Existen varias iniciativas en marcha que refuerzan la gobernanza forestal y están enfocadas en la reducción de emisiones, entre ellas un Programa de Reducción de Emisiones (ER), una Propuesta de ley PROBOSQUES, que busca reforzar los programas de incentivos forestales y un Programa de Apoyo a la Economía Familiar y Campesina (PAFFEC).

1. INAB, CONAP, UVG, URL. Mapa de Cobertura Forestal de Guatemala 2010 y Dinámica de la Cobertura Forestal 2006-2010.

2. CONAP (2008). Guatemala y su Biodiversidad: Un enfoque histórico, cultural, biológico y económico.

3. INAB, CONAP, UVG, URL. Mapa de Cobertura Forestal de Guatemala 2010 y Dinámica de la Cobertura Forestal 2006-2010.

4. INAB, IARNA, FAO (2012). Oferta y demanda de leña en la República de Guatemala. "Woodfuel Integrated Supply/Demand Overview Mapping". Guatemala.

5. INAB (2011). Boletín Manejo Forestal Sostenible. Guatemala. 
El Instituto Nacional de Bosques (INAB) ha desarrollado una Estrategia de Vinculación BosqueIndustria-Mercado ${ }^{6}$ que identificó el estado del arte de la industria forestal en el país, usando el concepto de la cadena de valor; esto es, partiendo del bosque hacia el comercio de los productos con valor agregado e identificó como limitantes las siguientes:

- La cosecha forestal sigue representando un problema al momento de integrar el bosque con la industria. La tecnología utilizada generalmente es baja y se cuenta con muy poca investigación e inversiones sobre este tema.

- El transporte sigue siendo un desafío para Guatemala. A pesar de tener una red vial que ofrece variedad de opciones, se tiene un bajo nivel de mantenimiento de las vías, lo que encarece los costos. También las distancias bosque-industria, en muchos casos, sobrepasan los $100 \mathrm{~km}$, lo cual eleva significativamente el costo de la madera en troza.

- El mercado de productos local se caracteriza por el uso de la madera para construcción. Sin embargo, en general no se exige calidad y el consumidor en la mayoría de los casos no está dispuesto a pagar un mayor precio.

- Las exportaciones, aunque se han incrementado, se centran en productos de escaso valor agregado, como el caso de la madera aserrada y las tarimas (pallets), dirigidas -principalmentea mercados de Estados Unidos y El Salvador. El sector mueble ha sido el más dinámico en la exportación de productos de valor agregado.

- Los costos de la madera en pie y de la energía siguen siendo mayores con respecto a los costos en estos rubros en países desarrollados forestalmente.

- Existe un escaso "desarrollo de productos y mercadeo", incluyendo posibles compradores, competidores, etc. basado en un análisis de las fortalezas y debilidades y ventajas comparativas. Esto, especialmente para las maderas "poco conocidas" (secundarias).

El Programa Forestal Nacional, con apoyo financiero de FAO, IIED, UICN -de la iniciativa Growing Forest Partnerships-, elaboró el Diagnóstico y Marco de Referencia de la Estrategia y Plan de Acción para el Desarrollo Foresto-Industrial de Guatemala, que determinó 7 áreas de resultados, en las cuales la estrategia debe enfocar sus acciones para mejorar el desarrollo de la actividad forestal del país y en particular de la industria forestal, a saber:

- El incremento en la calidad y cantidad de la oferta maderable

- La infraestructura y tecnología para el procesamiento

- El mercadeo y la comercialización

- Las formas y los medios de financiamiento

- Los recursos humanos

- El sistema de organización para el trabajo con enfoque empresarial

- El marco jurídico institucional fiable

6. INAB (2012). Estrategia de Vinculación Bosque-Industria-Mercado de Guatemala. 
La Estrategia desarrolla un planteamiento para cada área de resultado y plantea un horizonte de diez años. Con ella se pretende mejorar el clima de negocios del sector forestal para la integración efectiva del proceso Bosque-Industria-Mercado.

Además de la Estrategia y Plan de Acción para el Desarrollo Foresto-Industrial, en Guatemala también se desarrolla -de forma participativa- una Estrategia Nacional para la Reducción de la Deforestación (ENR). En esta participan diversos actores de gobierno, incluyendo MAGA, MARN, CONAP e INAB, pero también representantes de organizaciones no gubernamentales, academia y sector privado.

En el ámbito del fortalecimiento institucional, el Consejo Nacional de Áreas Protegidas (CONAP), el INAB y el Programa Nacional Forestal han planteado una "Agenda mínima interinstitucional de instrumentos, procedimientos y normas homologadas para la administración forestal, fuera y dentro de Áreas Protegidas" (2011).

Actualmente (2013), el INAB impulsa una nueva Política Nacional de Bosques con una visión más ecosistémica. 


\section{Síntesis histórica de la formulación de la Ley Forestal y afines}

Para el caso puntual de Guatemala, cuando se habla de "las leyes forestales y afines que están vigentes", estas son -básicamente- la Ley Forestal (Decreto 101-96), la Ley de Áreas Protegidas (Decreto 4-89) y la Ley de Protección y Mejoramiento del Medio Ambiente (Decreto 68-86).

La Ley Forestal de 1996 se ubica como la última ley que se emite dentro del proceso histórico del manejo o gestión de lo forestal en el país, bajo la óptica de la productividad de los bosques y la necesidad de someterlos a un manejo racional y sostenido (Decreto 101-96, Art. 1 c).

Entre los años 1945 y 1989 se emitieron importantes leyes relacionadas con el ámbito forestal, como lo son: la declaración del Parque Nacional Tikal, la protección de los conos volcánicos y otros parques nacionales, en los años 50; la regulación constitucional del ambiente y el mandato de la reforestación, a nivel nacional en la Constitución Política de 1985, Art. 97, Medio Ambiente y Equilibrio Ecológico, y Art. 126, Reforestación); la emisión de la Ley de Protección y Mejoramiento del Medio Ambiente (Decreto 68-86) y la Ley de Áreas Protegidas (Decreto 4-89). El avance más relevante contenido en la ley de 1989 fue la introducción de incentivos fiscales (que en posteriores reformas a la ley fueron suprimidos) y la instauración de la independencia administrativa de la institución encargada (INAB).

En lo que corresponde a la historia más reciente y atañe a la institucionalidad de lo forestal, deben mencionarse el Decreto 58-1974 -mediante el cual se crea el Instituto Nacional Forestal (INAFOR)-, la Ley Forestal (Decreto 70-1989) -que crea la Dirección General de Bosques (DIGEBOS)- y la Ley Forestal de 1996 (Decreto 100-1996), mediante la cual se crea el actual Instituto Nacional de Bosques (INAB). En términos generales, la evolución de las instituciones encargadas ha sido hacia la autonomía del manejo del sector forestal. Inicialmente, las instituciones dependían directamente del Ministerio de Agricultura o equivalente, pasando por la figura de la Dirección General de Bosques y Vida Silvestre (DIGEBOS) que, aunque autónoma, tenía una Junta Directiva (JD) dominada por el Gobierno. Actualmente, la Junta Directiva del INAB está conformada de tal manera que la representación del gobierno ya no es mayoritaria.

En el año 1985 se emite una nueva Constitución Política que establece, en su Artículo 126, lo relativo a la reforestación y declara de urgencia nacional y de interés social la reforestación del país y la conservación de los bosques.

Las leyes emitidas en 1986 y 1989 -Ley de Protección del Medio Ambiente (Decreto 68-86) y Ley de Áreas Protegidas (Decreto 4-89)- son de naturaleza novedosa en Guatemala en tanto que introducen el concepto de la "conservación de la diversidad biológica del país" y la necesidad de "establecer áreas protegidas”, muchas de las cuales contienen masa boscosa, con carácter de utilidad pública e interés social.

De esta manera, en el año de 1989, se establece en Guatemala una visión diferenciada del bosque. Por un lado buscando, "maximizar la producción sostenible de los bienes y servicios del bosque" (contenido en uno de los "Considerandos" de la Ley 101-96) y, por el otro, como un medio para 
"asegurar el funcionamiento de los procesos ecológicos esenciales y de los sistemas naturales vitales para el beneficio de todos los guatemaltecos" [Decreto 4-89, Art. 5 a)]. Se establece que, esto último, se debe perseguir en el continente que representan las diferentes áreas protegidas declaradas en el país. La ley (Decreto 4-89) crea, formalmente, el Sistema Guatemalteco de Áreas Protegidas (SIGAP) y se declara un buen número de áreas protegidas, adicionales a algunas ya existentes con anterioridad (como el caso del Parque Nacional Tikal, que data de 1955).

En el año 1996 se emite el Decreto 101-96 que contiene la actual Ley Forestal. La Ley crea el INAB, con carácter de entidad estatal, autónoma, descentralizada, con personalidad jurídica, patrimonio propio e independencia administrativa. Es el órgano de dirección y autoridad competente del Sector Público Agrícola, en materia forestal. Conforma el Patrimonio del INAB y dentro de éste, el Fondo Forestal Privativo. Ordena al Organismo Ejecutivo (Art. 21) aportar anualmente al INAB una asignación presupuestaria no menor del diez por ciento (10\%) del monto global del rubro de Gastos de Administración que se apruebe para el Ministerio de Agricultura, Ganadería y Alimentación, que servirá únicamente de referencia.

La Ley Forestal (Art. 1) declara de urgencia nacional y de interés social la reforestación y la conservación de los bosques, para lo cual se propiciará el desarrollo forestal y su manejo sostenible, mediante el cumplimiento de los siguientes objetivos:

a. Reducir la deforestación de tierras de vocación forestal y el avance de la frontera agrícola, a través del incremento del uso de la tierra de acuerdo con su vocación.

b. Promover la reforestación de áreas forestales actualmente sin bosque.

c. Incrementar la productividad de los bosques existentes, sometiéndolos a manejo racional y sostenido de acuerdo con su potencial biológico y económico.

d. Apoyar, promover e incentivar la inversión pública y privada en actividades forestales para que se incremente la producción, comercialización, diversificación, industrialización y conservación de los recursos forestales.

e. Conservar los ecosistemas forestales del país.

f. Propiciar el mejoramiento del nivel de vida de las comunidades al aumentar la provisión de bienes y servicios provenientes del bosque.

La ley ordena lo relativo a los incentivos forestales (Art. 71) y establece que el Estado otorgará incentivos por medio del INAB, en coordinación con el Ministerio de Finanzas Públicas. La ley crea el Programa de Incentivos Forestales (PINFOR) y ordena que el Estado destine anualmente una partida, en el Presupuesto de Ingresos y Egresos de la Nación, al INAB para otorgar incentivos forestales equivalentes al 1\% del Presupuesto de Ingresos Ordinarios del Estado, a través del Ministerio de Finanzas Públicas. Los incentivos se otorgarán por 20 años a partir de la ley. Establece delitos y faltas en materia forestal, y es considerada como una ley que facilita el manejo forestal, aunque en el ámbito de sanciones tiene algunas debilidades sentidas por quienes administran justicia. 


\section{Cuadro 1. Datos relevantes de las Leyes Forestales de Guatemala} a través de la historia

\begin{tabular}{|c|c|}
\hline Ley & Aspectos relevantes \\
\hline $\begin{array}{l}\text { Decreto } \\
\text { Gubernativo } \\
670\end{array}$ & $\begin{array}{l}\text { Se regula la conservación e incremento de bosques y se da competencia al Ministerio de } \\
\text { Agricultura, año } 1920 .\end{array}$ \\
\hline $\begin{array}{l}\text { Decreto Ley } \\
1.364\end{array}$ & En el año 1925 se emite la primera Ley Forestal. \\
\hline Decreto 170 & $\begin{array}{l}\text { En el año } 1945 \text { se crea la segunda Ley Forestal y se designa la División Forestal del Ministerio } \\
\text { de Agricultura como la entidad competente. }\end{array}$ \\
\hline Decreto 543 & $\begin{array}{l}\text { En el año 1956, esta ley define las "unidades industriales de explotación forestal en bosques } \\
\text { nacionales", introduciendo una definición técnica de "unidad industrial", como "una extensión } \\
\text { de terreno cubierta de bosque con suficiente volumen productivo, capaz de sostener una } \\
\text { corta anual que constituya la base económica para el mantenimiento de una industria } \\
\text { permanente" (FAO, 2002). }\end{array}$ \\
\hline $\begin{array}{l}\text { Decreto } \\
58-74\end{array}$ & $\begin{array}{l}\text { Se forma el Instituto Nacional de Bosques (INAFOR) como ente autónomo y descentralizado, } \\
\text { en } 1974 \text {. Establece un programa de incentivos forestales para personas que realicen gastos } \\
\text { comprobados en plantaciones forestales no menores de } 5 \text { hectáreas, pudiendo deducir } \\
\text { hasta } 50 \% \text { del Impuesto sobre la Renta y del impuesto de circulación de vehículos. Bajo } \\
\text { esa modalidad solo se reforestaron } 20.000 \text { ha durante } 23 \text { años (Escobar, 1996). Mediante } \\
\text { el Decreto } 118-84 \text { se deroga esta Ley y se ratifica lo establecido en materia de incentivos } \\
\text { forestales. }\end{array}$ \\
\hline $\begin{array}{l}\text { Constitución } \\
\text { Política de la } \\
\text { República }\end{array}$ & $\begin{array}{l}\text { En el año } 1985 \text { se emite una nueva Constitución Política la que establece, en su Artículo } 126, \\
\text { lo relativo a la reforestación y declara de urgencia nacional y de interés social la reforestación } \\
\text { del país y la conservación de los bosques, y manda que por ley se determine la forma y } \\
\text { requisitos para la explotación racional de los recursos forestales y su renovación, incluyendo } \\
\text { las resinas, gomas, productos vegetales silvestres no cultivados y demás productos similares, } \\
\text { y fomentará su industrialización. La explotación de todos estos recursos corresponderá } \\
\text { exclusivamente a personas guatemaltecas, individuales o jurídicas. } \\
\text { La norma constitucional regula que los bosques y la vegetación en las riberas de los ríos y } \\
\text { lagos, y en las cercanías de las fuentes de agua, gozarán de especial protección. }\end{array}$ \\
\hline $\begin{array}{l}\text { Decreto } \\
70-89\end{array}$ & $\begin{array}{l}\text { En el año 1989, esta Ley suprime el INAFOR y crea la Dirección General de Bosques } \\
\text { (DIGEBOS) adscrita al Ministerio de Agricultura, Ganadería y Alimentación (MAGA). Promueve } \\
\text { el manejo forestal. Esta ley se refería al aprovechamiento de los bosques y a su protección y } \\
\text { conservación conforme los principios de uso racional y sostenido de los recursos forestales } \\
\text { renovables, al manejo, transporte e industrialización forestal, la forestación y reforestación, } \\
\text { al desarrollo rural e industrias forestales y a delitos y faltas contra recursos forestales. La Ley } \\
\text { establece que no se consideran tierras incultas u ociosas ni serán sujetas de expropiación las } \\
\text { cubiertas de bosques o selvas y las tierras declaradas como protegidas. Clasifica los bosques } \\
\text { como naturales sin manejo, naturales bajo manejo, naturales bajo manejo agroforestal y } \\
\text { artificiales. Establece, además, la necesidad de incentivar la utilización integral del árbol } \\
\text { a través del fomento de sistemas y equipos de industrialización que logren mayor valor } \\
\text { agregado de los productos forestales. }\end{array}$ \\
\hline $\begin{array}{l}\text { Decreto } \\
122-96\end{array}$ & $\begin{array}{l}\text { Se emite la Ley Reguladora del Registro, Autorización y Uso de Motosierras, que establece } \\
\text { normas para el control efectivo del uso y registro de las motosierras, entendiendo éstas como } \\
\text { una herramienta que podría ser letal para los bosques de Guatemala. }\end{array}$ \\
\hline
\end{tabular}




\begin{tabular}{|c|c|}
\hline Ley & Aspectos relevantes \\
\hline $\begin{array}{l}\text { Decreto } \\
4-89\end{array}$ & $\begin{array}{l}\text { Se crea la Ley de Áreas Protegidas, que establece que la diversidad biológica es parte integral } \\
\text { del patrimonio natural de los guatemaltecos y declara de interés nacional su conservación. La } \\
\text { Ley forma el Consejo Nacional de Áreas Protegidas (CONAP) como una entidad dependiente } \\
\text { de la Presidencia de la República, encargada de la aplicación de la Ley de Áreas Protegidas } \\
\text { y con competencia en materia forestal dentro de áreas protegidas. Considera de urgencia } \\
\text { y necesidad nacional el rescate de las especies de flora y fauna en peligro de extinción, de } \\
\text { las amenazadas y la protección de las endémicas. Se refiere a los listados de especies de } \\
\text { fauna y flora silvestre de Guatemala, amenazadas de extinción. Establece que los listados de } \\
\text { especies de flora y fauna de los apéndices I y II del Convenio sobre el Comercio Internacional } \\
\text { de Especies Amenazadas de Flora y Fauna Silvestre (CITES) se consideran oficiales para } \\
\text { Guatemala. Prohíbe la libre exportación y comercialización de las especies silvestres de flora y } \\
\text { fauna amenazadas de extinción extraídas de la naturaleza, y establece delitos. }\end{array}$ \\
\hline $\begin{array}{l}\text { Decreto } \\
101-96\end{array}$ & $\begin{array}{l}\text { En el año } 1996 \text { se emite la actual Ley Forestal, la cual crea el Instituto Nacional de Bosques } \\
\text { (INAB) como un ente autónomo. Declara de urgencia nacional y de interés social la } \\
\text { reforestación y la conservación de los bosques, y establece los procedimientos para el manejo } \\
\text { forestal, diferenciando la competencia dentro y fuera de áreas protegidas. Ordena lo relativo a } \\
\text { los incentivos forestales y establece delitos y faltas. }\end{array}$ \\
\hline $\begin{array}{l}\text { Decreto } \\
51-2010\end{array}$ & $\begin{array}{l}\text { Establece los Incentivos Forestales para Poseedores de Pequeñas Extensiones de Tierra de } \\
\text { Vocación Forestal o Agroforestal (PINPEP) como un alternativa o complemento al PINFOR } \\
\text { (que solo puede entregarse a propietarios con título). }\end{array}$ \\
\hline $\begin{array}{l}\text { Decreto } \\
7-2013\end{array}$ & $\begin{array}{l}\text { La Ley Marco para Regular la Reducción de la Vulnerabilidad, la Adaptación Obligatoria } \\
\text { ante los Efectos del Cambio Climático y la Mitigación de los Gases de Efecto Invernadero } \\
\text { establece un mandato para que el INAB, el CONAP y el MARN ajusten sus planes y proyectos } \\
\text { a las disposiciones de esa ley, promuevan el fomento de servicios ambientales y aumenten } \\
\text { la resiliencia de los ecosistemas forestales ante la variabilidad y el cambio climático para } \\
\text { asegurar el funcionamiento de los procesos ecológicos y los bienes y servicios naturales. } \\
\text { También regula los mercados de carbono y establece un registro de proyectos y regulaciones } \\
\text { para la compensación de emisiones de gases de efecto invernadero. }\end{array}$ \\
\hline
\end{tabular}

\subsection{Formas de participación pública en Guatemala y sus niveles de implementación}

El ordenamiento jurídico relacionado con la participación pública en Guatemala tiene su base principal en la Constitución Política de la República (CPR) de 1985. Es a partir de la Constitución que el concepto se ha derivado a diferentes cuerpos normativos, tales como la Ley de Protección y Mejoramiento del Ambiente (Decreto 68-86), la Ley de los Consejos de Desarrollo Urbano y Rural (Decreto 11-2002), el Código Municipal (Decreto 12-2002 y sus reformas, Decreto 22-2010), la Ley de Acceso a la Información Pública (Decreto 57-2008) y la Ley Marco para Regular la Reducción de la Vulnrabilidad, la Adaptación Obligatoria ante los Efectos del Cambio Climático y la Mitigación de Gases de Efecto Invernadero, Decreto 7-2013.

La participación pública es un derecho que ha tenido que ser luchado para mantenerlo vigente en el país, sobre todo en el tema ambiental. Existen precedentes en la Corte de Constitucionalidad que reafirman que la participación pública fortalece los procesos democráticos que garanticen la paz, la libertad, el respeto y la defensa de los derechos humanos.

La "participación pública" es un derecho que ha tenido que ser luchado para mantenerlo vigente en el país, sobre todo en el tema ambiental. Incluso, existen precedentes en la Corte de Constitucionalidad 
que reafirman que la participación pública fortalece los procesos democráticos que garanticen la paz, la libertad, el respeto y la defensa de los derechos humanos.

El Código Municipal desarrolla ampliamente el tema de la participación ciudadana y contiene un Título y Capítulo destinado a la información y participación ciudadana, que comprende la facilitación de información y participación ciudadana, las facultades de decisión, el derecho a ser informado, la consulta a vecinos y la consulta a comunidades o autoridades indígenas del municipio.

La actual Ley Forestal (Decreto 101-96) fundamenta su creación (tercer "Considerando") en que, para el bienestar nacional, el sector público debe promover y orientar las actividades forestales, buscando maximizar la producción sostenible de bienes y servicios del bosque, propiciando la participación de las comunidades rurales en las actividades y en los beneficios del uso sostenido de los bosques, como fundamento de los programas de desarrollo forestal, mediante el empleo técnico de los bosques de acuerdo con sus características naturales y su entorno social y ecológico, que estimule la actividad privada legal de manejo sostenido, reforestación, artesanía e industria forestal y la participación coordinada del sector privado en todas sus expresiones de desenvolvimiento. Pero ni la ley ni su reglamento regulan ningún tipo de procesos de participación social propiamente dichos.

La Ley Forestal crea el Instituto Nacional Forestal (INAB) ${ }^{7}$, el cual está integrado por una Junta Directiva en la que la representación y participación del sector público es de 2 (MAGA y MINFIN) dentro de un total de 6 representaciones. Las restantes son las de la Asociación Nacional de Municipalidades de Guatemala (ANAM), la de la Escuela Nacional Central de Agricultura de la Universidad de San Carlos de Guatemala (ENCA), la de las gremiales de la Cámara de Industria dedicadas al procesamiento de maderas y otros productos forestales, la de las universidades que imparten estudios forestales y conexos dentro de las profesiones afines y la de la Asociación Nacional de Organizaciones No Gubernamentales de los Recursos Naturales, Ecología y Medio Ambiente (ASOREMA). En términos generales, las atribuciones de la JD del INAB y por ende, de sus integrantes, corresponden al nivel de las decisiones de tipo político, técnico y administrativo de carácter macro concernientes a la jurisdicción temática de la institución (dar seguimiento a las políticas, aprobar los presupuestos, dictar las disposiciones para el funcionamiento de la institución, aprobar los reglamentos internos, autorizar la compra de inmuebles y otros, aprobar las especies de árboles forestales y las regiones de reforestación por incentivos, aprobar los costos de las operaciones de plantación y mantenimiento...).

La Junta Directiva del INAB opera de forma regular y en ella participa activamente el representante de la Asociación de Organizaciones No Gubernamentales de los Recursos Naturales, Ecología y Medio Ambiente (ASOREMA) de Guatemala [entidad que es la representante de la sociedad civil y sus preocupaciones e intereses] y la Gremial Forestal.

La Ley de Áreas Protegidas (LAP) no establece, expresamente, procesos o mecanismos de participación social específicos. Sin embargo, contempla un espacio de participación para una representación de la sociedad civil en la toma de decisiones dentro del Consejo (órgano de dirección del CONAP). Ese Consejo está conformado por representantes de diferentes sectores: el Centro de Estudios Conservacionistas (CECON) de la Universidad de San Carlos de Guatemala, la Asociación Nacional de Municipalidades (ANAM), el sector público (MARN, MAGA, INGUAT, IDAEH) y las 
organizaciones no gubernamentales relacionadas con los recursos naturales y el medio ambiente registradas en CONAP (Art. 10 del Decreto Número 110-96 del Congreso de la República).

En términos generales, las atribuciones del Consejo del CONAP y por ende, de sus integrantes, corresponden al nivel de las decisiones de tipo político de la institución (formular las políticas, aprobar los reglamentos), pero también aprobar la suscripción de concesiones de aprovechamiento y manejo de las áreas protegidas del SIGAP y servir de órgano asesor de la Presidencia de la República y de todas las entidades estatales en materia de conservación, protección y uso de los recursos naturales del país ${ }^{8}$.

La Ley de Áreas Protegidas, así como los Decretos del Congreso de la República que declaran áreas protegidas, permite la administración y manejo de áreas protegidas por organizaciones no gubernamentales. Un ejemplo de ello es la Reserva de Biosfera Sierra de las Minas, administrada por la Fundación Defensores de la Naturaleza y otras entidades que actualmente administran o manejan áreas protegidas.

En materia de "evaluación ambiental", existen espacios para la participación pública contemplados y reconocidos en el Reglamento de Evaluación, Control y Seguimiento Ambiental (Acuerdo Gubernativo 431-2007 y sus reformas, Acuerdo 89-2008).

Las reformas al Reglamento de Evaluación, Control y Seguimiento Ambiental (Acuerdo Gubernativo 89-2008) disponen como "requisito" la participación pública en los procesos de evaluación ambiental desde el diseño de un proyecto y durante toda su vida.

Establece la obligatoriedad del proponente de proyectos y del Ministerio de Ambiente y Recursos Naturales de informar al público que se ha presentado una Evaluación de Impacto Ambiental y da espacio para emitir opinión. Se debe indicar que el propósito es recibir observaciones o incluso la manifestación de oposición, la cual deberá ser fundamentada y entregada a la Dirección de Gestión Ambiental en un plazo de 20 días a partir de la publicación del edicto.

De la misma manera, se especifica que cuando se desarrolle el proyecto, obra, industria o actividad en un sitio donde se utilice un idioma o lengua diferente del español, se debe indicar en los términos de referencia de las Evaluaciones Ambientales y Diagnósticos Ambientales el medio de comunicación y la forma en que se hará conocer entre la población.

La Ley de Protección y Mejoramiento del Medio Ambiente (Decreto 68-86), en su Artículo 30 establece que: "Se concede acción popular para denunciar ante la autoridad todo hecho, acto u omisión que genere contaminación, deterioro o pérdida de recursos naturales o que afecte los niveles de calidad de vida. Si en la localidad no existiera representante del MARN, la Denuncia se podrá hacer ante la autoridad municipal, la que la remitirá para su atención y trámite al mencionado ministerio". El objetivo que se traza este tipo de participación pública, enfocado en la "denuncia", es que una obra, industria o cualquier otra actividad pueda ser cuestionada ante el MARN en su etapa de planeación, construcción o inclusive, de operación.

8. Ley de Áreas Protegidas, Art. 69. 
La Ley de Acceso a la Información Pública (LAIP) [Decreto 57-2008] es de orden público, de interés nacional y utilidad social. Establece las normas y los procedimientos para garantizar a toda persona, natural o jurídica, el acceso a la información o actos de la administración pública (Art. 2).

Adicionalmente a las leyes referidas con anterioridad, debe mencionarse la Ley de los Consejos de Desarrollo Urbano y Rural (Decreto 11-2002) que actualiza el concepto contenido en la Ley de los Consejos de 1987 (Decreto 1041-87) al crear una institucionalidad orientada a que se defina el desarrollo nacional a partir de un modelo de participación ciudadana. Esta ley establece y regula el Sistema Nacional de Consejos de Desarrollo, que comprende cinco niveles, a saber: nacional, regional y departamental (previstos constitucionalmente), municipal -contenido en el Código Municipal (Decreto Legislativo 58-88)- y el comunitario, contemplado en los Acuerdos de Paz. Es un sistema que está estructurado desde la base de la población y tiene como propósito ser el instrumento permanente de participación y representación de la población en el proceso de la definición del desarrollo urbano y rural del país. Sus funciones, entre otras, están orientadas a que sea la población misma la que identifique y priorice sus necesidades e identifique y ejecute programas y proyectos concretos de desarrollo en los niveles regional, departamental, municipal y local.

Respecto a los niveles de implementación de los espacios de participación pública, se debe mencionar que -en cuanto a la participación de la sociedad civil en los órganos de direcciónpareciera ser que la participación pública es efectiva, puesto que la figura contemplada en la ley opera, de manera formal, adecuadamente. No obstante, debe señalarse que la forma en que esa "sociedad civil" es representada en los órganos de dirección debe mejorarse. Al momento, prevalece la fórmula de que los "representantes" sienten que representan a la población y no una fórmula en la cual sea la población la que determine quién los representa.

También debe señalarse la necesidad de fomentar los espacios de diálogo y participación en la construcción de las políticas, los programas y los proyectos forestales a todo nivel y con otros grupos organizados, que no necesariamente son los que están representados en la Junta Directiva del INAB o en el Consejo del CONAP, sobre todo aquellos vinculados con comunidades campesinas $\mathrm{o}$ indígenas.

En el caso del CONAP, el Consejo concentra su actividad en el ámbito de lo que se podría denominar "interno" de la institución (formular las políticas, aprobar los reglamentos, así como aprobar la suscripción de concesiones de aprovechamiento y manejo de las áreas protegidas del SIGAP, entre otras), pero aún tiene serias dificultades en el ámbito de ejercer influencia e incidir positivamente "sirviendo de órgano asesor de la Presidencia de la República y todas las entidades estatales, en materia de conservación, protección y uso de los recursos naturales del país ${ }^{9}$. No obstante, deben adjudicársele importantes batallas libradas exitosamente contra amenazas del sector privado (intento de declarar inconstitucional el Decreto 4-89, Ley de Áreas Protegidas, así como contra autoridades del Organismo Legislativo y Ejecutivo cuando el caso de la prórroga de una concesión petrolera en El Petén). El CONAP cuenta con un registro de organizaciones no gubernamentales de protección y manejo de recursos naturales entre las cuales se elige un representante al Consejo Nacional de Áreas Protegidas.

9. Ley de Áreas Protegidas, Art. 69, h. 
La Ley Marco para Regular la Reducción de la Vulnerabilidad, la Adaptación Obligatoria ante los Efectos del Cambio Climático y la Mitigación de Gases de Efecto Invernadero (Decreto 7-2013), establece como un principio de esa ley la "Participación" e indica que se deberá incluir la participación más amplia de ciudadanos y organizaciones, incluyendo la de los distintos pueblos en el diseño y de planes, programas y acciones en el tema de cambio climático (Art. 6).

Mejorar los niveles de participación pública o social no es un asunto que se pueda resolver o mejorar a nivel normativo (emitiendo leyes). Se trata de un problema que corresponde a tres ámbitos: (a) el uno, que exista o no conciencia en ámbitos suficientemente amplios de la población sobre la necesidad real de llevar a cabo acciones concretas para conservar, proteger y orientar el uso racional de los recursos naturales del país, (b) el otro, que se refiere a la capacidad real que pueda llegar a tener esa población convencida de esas grandes necesidades de obligar -de manera efectiva- a que los partidos y los políticos electos por ellos respondan a esas necesidades al momento de ejercer el poder público (tanto a nivel del Ejecutivo como el Legislativo, el Judicial y el "poder local" -el ámbito municipal-) y por último, (c) el relacionado con la cultura de la organización social y la participación informada, la cual debe seguirse construyendo luego de muchos años de represión derivada de una guerra interna.

Para la efectiva participación en el proceso de evaluación ambiental se requieren dos aspectos fundamentales. El primero va encaminado a que las autoridades cumplan con su función de exigir que las consultas contempladas en la ley se realicen de manera adecuada (realice estrictamente los procedimientos establecidos y se verifique su cumplimiento). Esto implica la necesidad de que se cumpla con el principio constitucional de que el interés común priva sobre el interés particular y el imperativo de reforzar los procedimientos que permitan a las asociaciones de vecinos proceder sin mayores dificultades para hacer valer sus derechos. El segundo aspecto se refiere a que las asociaciones de vecinos lleguen a conocer tanto a saber sus derechos como a conocer y manejar la forma efectiva de reclamarlos.

La participación en el Sistema de Consejos de Desarrollo es un tema complejo que todavía hoy no termina de discutirse. En muchos casos, los espacios de participación se han utilizado para satisfacer intereses particulares y también para la corrupción, y eso ha ocasionado un descrédito al proceso. No obstante, son espacios importantes que se siguen defendiendo por diferentes organizaciones de la sociedad. En algunos casos, han resultado muy beneficiosos para las localidades, en especial para hacer valer sus verdaderos intereses y hacer patentes sus necesidades y sus propuestas desde lo local.

La Política Forestal de Guatemala contempla, entre sus Principios, el de la "Participación equitativa, corresponsabilidad y empresarialidad", orientado a que "la aplicación de las políticas y su retroalimentación ocurra en el marco de un trabajo estrecho entre el Estado y la sociedad civil, así como en el marco de una adecuada asignación de recursos para la producción”. No obstante, la misma política no refleja este principio en su desarrollo y contenido.

Actualmente se está trabajando en la elaboración de una nueva Política de Bosques, que pretende transitar de una política con exclusiva visión forestal a una política de bosques con un fundamento más holístico y ecosistémico. 
Una Política de Bosques que reconozca los derechos de las comunidades a manejar sus recursos es un desafío aún pendiente de alcanzar, así como también lo es el reconocimiento de la participación de las comunidades y los dueños de bosques en la generación de servicios ambientales.

Entre otros temas que aún deben desarrollarse se encuentran el del fortalecimiento a la Gremial Forestal, como una instancia multiplicadora de conocimiento e información y respecto a las funciones del recién creado sistema de extensión agrícola para que pueda asistir con información y apoyo técnico a los comunitarios en los temas agroforestales y en la organización social y formación empresarial.

El país requiere que exista en la población un generalizado conocimiento y conciencia sobre el hecho de que Guatemala es un país de vocación primordialmente forestal. Esto hace imperativo que se promueva el establecimiento de una cultura forestal en el ciudadano, que lo movilice a promover, conservar y reconocer el bosque como el sustento primario del país y fuente principal del bienestar de la sociedad. Esto tendrá, como necesario subproducto, una actitud proactiva en aspectos como la reducción de la vulnerabilidad, la mejora de la capacidad de adaptación a los efectos negativos del fenómeno del cambio climático y la contribución efectiva a la reducción de producción de gases de efecto invernadero (mitigación).

Aunque Guatemala es signataria del Convenio 169 de la OIT sobre pueblos indígenas, aún no ha desarrollado la normativa nacional para su instrumentalización y esto ha causado muchos conflictos en materia de participación pública de pueblos indígenas. La recién creada Ley Marco para Regular la Reducción de la Vulnerabilidad, la Adaptación Obligatoria ante los Efectos del Cambio Climático y la Mitigación de Gases de Efecto Invernadero (Decreto 7-2013) establece el principio de participación de manera transversal para fomentar la participación pública, incluyendo la de los distintos pueblos en el diseño de planes, programas y acciones en el tema de cambio climático, y ordena el cumplimiento de las salvaguardas en el desarrollo de los instrumentos de la ley y los programas y proyectos que se implementen.

En la práctica, la participación pública o participación social sigue siendo un verdadero reto para la sociedad y para el Estado, en general. La información pública, la capacitación, la organización, la legitimación en la representación de grupos y el respeto de las autoridades a la participación social siguen siendo todos temas pendientes de ser tratados y resueltos.

\subsection{Institucionalidad forestal y competencias en torno a aprovechamiento forestal y comercio internacional de productos forestales}

El Instituto Nacional de Bosques (INAB) es el órgano de dirección y autoridad competente del Sector Público Agrícola en materia forestal. Para efectos de dirigir el aprovechamiento y manejo sostenido del bosque, el INAB aprueba las licencias forestales y los denominados "Planes de Manejo" de las diferentes unidades de bosque que ha autorizado. Estos Planes son los instrumentos principales para monitorear el aprovechamiento y las técnicas silvícolas aplicadas a la masa forestal.

EI INAB tiene carácter de entidad estatal, autónoma, descentralizada, con personalidad jurídica y posee patrimonio propio e independencia administrativa. 
El Consejo Nacional de Áreas Protegidas (CONAP) es una entidad con personalidad jurídica que depende directamente de la Presidencia de la República. Es el órgano máximo de dirección y coordinación del Sistema Guatemalteco de Áreas Protegidas (SIGAP), creado por el Decreto 4-89, con jurisdicción en todo el territorio nacional, sus costas marítimas y su espacio aéreo. Tiene autonomía funcional y su presupuesto está integrado por una asignación anual del Estado y el producto de las donaciones específicas de particulares, países amigos, organismos y entidades internacionales (Art. 59 de la Ley de Áreas Protegidas). El CONAP tiene la competencia en materia forestal dentro de áreas protegidas.

Según el Artículo 8 de la Ley Forestal, las Comisiones de Medio Ambiente de las municipalidades con delegación específica del alcalde, son las encargadas de apoyar al Instituto Nacional de Bosques (INAB) en la aplicación de esa ley y su reglamento. Según el Artículo 54 del Reglamento de la Ley Forestal, las municipalidades serán las que otorguen las licencias para la tala de árboles ubicados dentro de sus perímetros urbanos, para volúmenes menores de diez (10) metros cúbicos por licencia, por finca y por año. Para volúmenes mayores de $10 \mathrm{~m}^{3}$, la licencia será otorgada por el INAB. 


\section{Cuadro 2. Marco institucional del aprovechamiento forestal y} el comercio internacional de productos forestales

\begin{tabular}{|c|c|}
\hline Institución & Funciones y atribuciones \\
\hline $\begin{array}{l}\text { Instituto Nacional } \\
\text { de Bosques (INAB), } \\
\text { entidad autónoma }\end{array}$ & $\begin{array}{l}\text { Según el Art. } 6 \text { de la Ley Forestal, son atribuciones del Instituto Nacional de } \\
\text { Bosques las siguientes: } \\
\text { a) Ejecutar las políticas forestales. } \\
\text { b) Promover y fomentar el desarrollo forestal del país mediante el manejo } \\
\text { sostenible de los bosques, la reforestación, la industria y la artesanía forestal, } \\
\text { basada en los recursos forestales y la protección y desarrollo de las cuencas } \\
\text { hidrográficas. } \\
\text { c) Impulsar la investigación para la resolución de problemas de desarrollo } \\
\text { forestal. } \\
\text { d) Coordinar la ejecución de programas de desarrollo forestal a nivel nacional. } \\
\text { e) Otorgar, denegar, supervisar, prorrogar y cancelar el uso de las concesiones } \\
\text { forestales, de las licencias de aprovechamiento de productos forestales, } \\
\text { fuera de las áreas protegidas. } \\
\text { f) Desarrollar programas y proyectos para la conservación de los bosques y } \\
\text { colaborar con las entidades que así lo requieran. } \\
\text { g) Incentivar y fortalecer las carreras técnicas y profesionales en materia } \\
\text { forestal. } \\
\text { h) Elaborar los reglamentos específicos de la institución y de las materias de su } \\
\text { competencia. }\end{array}$ \\
\hline $\begin{array}{l}\text { Consejo Nacional } \\
\text { de Áreas Protegidas } \\
\text { (CONAP), } \\
\text { entidad con } \\
\text { personalidad } \\
\text { jurídica, depende de } \\
\text { la Presidencia de la } \\
\text { República }\end{array}$ & $\begin{array}{l}\text { El Consejo Nacional de Áreas Protegidas es el órgano máximo de dirección } \\
\text { y coordinación del Sistema Guatemalteco de Áreas Protegidas (SIGAP), con } \\
\text { jurisdicción en todo el territorio nacional. EI CONAP es la autoridad nacional } \\
\text { administrativa y científica de la Convención sobre el Comercio Internacional de } \\
\text { Especies Amenazadas de Fauna y Flora Silvestres, CITES. } \\
\text { Según el Art. } 69 \text { de la Ley de Áreas Protegidas, sus atribuciones son: } \\
\text { a) Formular la política y la estrategia de conservación del patrimonio natural de } \\
\text { la nación. } \\
\text { b) Aprobar los reglamentos y las normas de funcionamiento del Sistema } \\
\text { Guatemalteco de Áreas Protegidas (SIGAP). } \\
\text { c) Aprobar los dictámenes de convenios y contratos con entidades o empresas } \\
\text { internacionales. } \\
\text { d) Aprobar su plan estratégico institucional, sus planes y programas anuales de } \\
\text { trabajo y su presupuesto anual. } \\
\text { e) Aprobar la suscripción de concesiones de aprovechamiento y manejo de las } \\
\text { áreas protegidas del SIGAP. } \\
\text { f) Mantener estrecha coordinación e intercomunicación entre las entidades } \\
\text { integrantes del SIGAP, en especial con el MARN. } \\
\text { g) Servir de órgano asesor a la Presidencia de la República y todas las } \\
\text { entidades estatales que requieran sus servicios en materia de conservación y } \\
\text { protección de los recursos naturales del país. } \\
\text { h) Todas aquellas atribuciones que sean necesarias para el buen } \\
\text { funcionamiento del Sistema Guatemalteco de Áreas Protegidas (SIGAP). }\end{array}$ \\
\hline
\end{tabular}




\begin{tabular}{|c|c|}
\hline Institución & Funciones y atribuciones \\
\hline $\begin{array}{l}\text { Ministerio de } \\
\text { Ambiente y } \\
\text { Recursos Naturales } \\
\text { (MARN) }\end{array}$ & 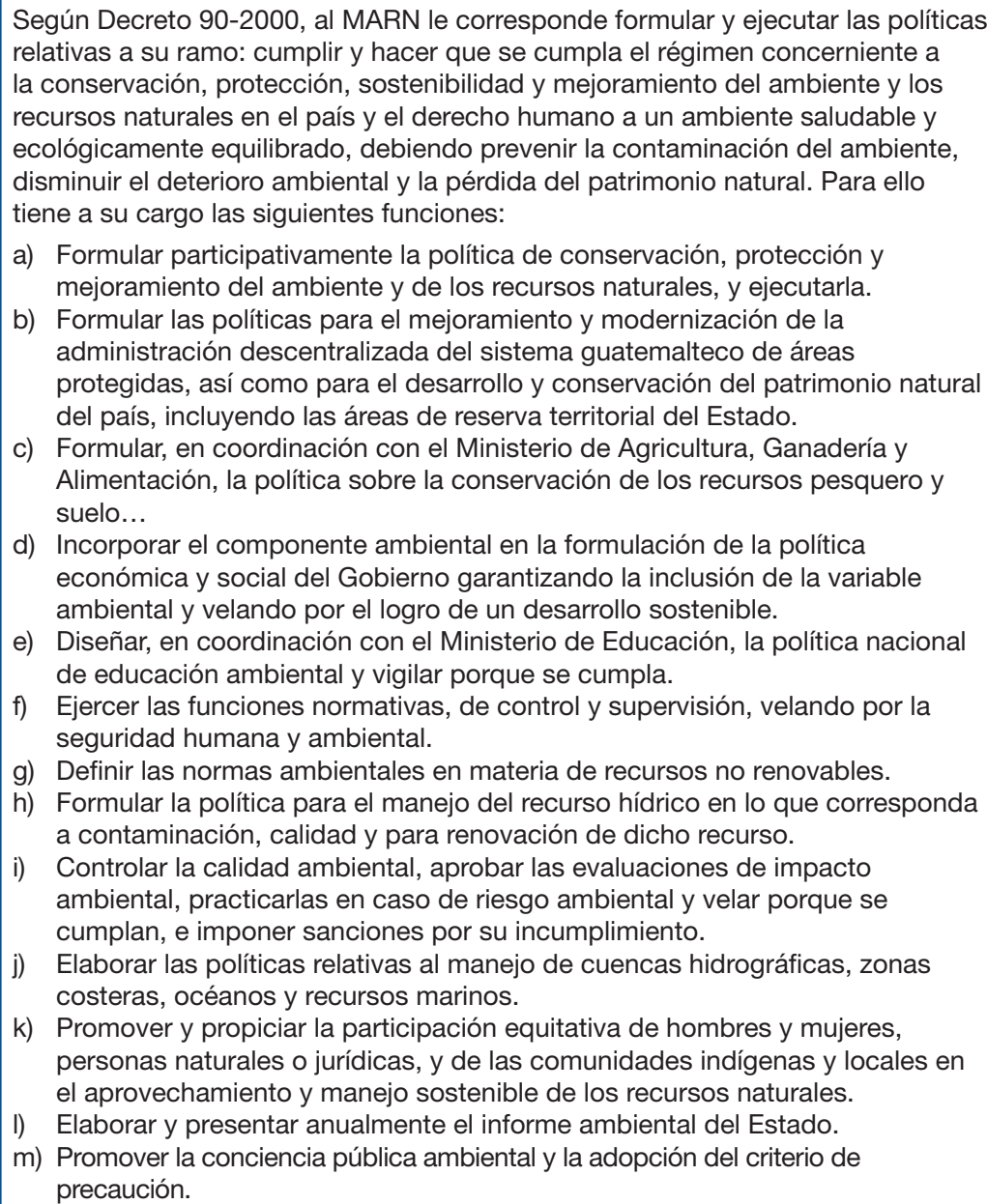 \\
\hline
\end{tabular}




\begin{tabular}{|c|c|}
\hline Institución & Funciones y atribuciones \\
\hline $\begin{array}{l}\text { Ministerio de } \\
\text { Agricultura, } \\
\text { Ganadería y } \\
\text { Alimentación } \\
\text { (MAGA) }\end{array}$ & $\begin{array}{l}\text { El Artículo } 29 \text { de la Ley del Organismo Ejecutivo, reformado por Decreto } \\
\text { 90-2000, establece las funciones del MAGA: } \\
\text {... } \\
\text { b) Proponer y velar por la aplicación de normas claras y estables en materia } \\
\text { de actividades agrícolas, pecuarias y fitozoosanitarias, y de los recursos } \\
\text { hidrobiológicos, estos últimos en lo que le corresponda, buscando la } \\
\text { eficiencia y competitividad en los mercados y teniendo en cuenta la } \\
\text { conservación y protección del medio ambiente. } \\
\text { c) Definir en conjunto con el Ministerio de Ambiente y Recursos Naturales la } \\
\text { política de ordenamiento territorial y de utilización de tierras nacionales y } \\
\text { promover la administración descentralizada en la ejecución de esta política. } \\
\text { d) Formular la política de servicios públicos, agrícolas, pecuarios, } \\
\text { fitozoosanitarios y de los recursos hidrobiológicos, estos últimos en lo que le } \\
\text { ataña y administrar descentralizadamente su ejecución. } \\
\text { e) En coordinación con el Ministerio de Educación, formular la política de } \\
\text { educación agropecuaria ambientalmente compatible, promoviendo la } \\
\text { participación comunitaria. } \\
\text { f) Diseñar, en coordinación con el Ministerio de Economía, las políticas } \\
\text { de comercio exterior de productos agropecuarios y de los recursos } \\
\text { hidrobiológicos, estos últimos en lo que le ataña. } \\
\text { g) Impulsar el desarrollo empresarial de las organizaciones agropecuarias, } \\
\text { pecuarias e hidrobiológicas, estas últimas en lo que le ataña, para fomentar } \\
\text { el desarrollo productivo y competitivo del país. } \\
\text { h)... } \\
\text { i) Ampliar y fortalecer los procedimientos de disponibilidad y acceso a la } \\
\text { información estratégica a productores, comercializadores y consumidores. } \\
\text { j) Ejercer control, supervisión y vigilancia en la calidad y seguridad de la } \\
\text { producción, importación, exportación, transporte, registro, disposición y } \\
\text { uso de productos plaguicidas y fertilizantes, rigiéndose por estándares } \\
\text { internacionalmente aceptados. } \\
\text { Participa como miembro del Consejo del CoNAP, extiende los permisos } \\
\text { fitosanitarios y lleva el registro de empresas autorizadas para emitir certificados } \\
\text { de tratamiento de la NIMF No } 15 \text {. }\end{array}$ \\
\hline
\end{tabular}




\begin{tabular}{|c|c|}
\hline Institución & Funciones y atribuciones \\
\hline $\begin{array}{l}\text { Municipalidades, } \\
\text { entidades } \\
\text { autónomas que } \\
\text { están creando } \\
\text { oficinas forestales } \\
\text { municipales y } \\
\text { cuentan con } \\
\text { una Comisión } \\
\text { de Fomento } \\
\text { Económico, } \\
\text { Turismo, Ambiente y } \\
\text { Recursos Naturales }\end{array}$ & $\begin{array}{l}\text { El Artículo } 35 \text { del Código Municipal, reformado por Decreto 22-2010, establece } \\
\text { las atribuciones generales del Concejo Municipal. Son atribuciones suyas: } \\
\text { c) La convocatoria a los distintos sectores de la sociedad del municipio para } \\
\text { la formulación e institucionalización de las políticas públicas municipales } \\
\text { y de los planes de desarrollo urbano y rural del municipio, identificando y } \\
\text { priorizando las necesidades comunitarias y propuestas de solución a los } \\
\text { problemas locales. } \\
\text { g) La aceptación de la delegación o transferencia de competencias. } \\
\text { h) El planteamiento de conflictos de competencia a otras entidades presentes } \\
\text { en el municipio. } \\
\text { i) La emisión y aprobación de acuerdos, reglamentos y ordenanzas } \\
\text { municipales. } \\
\text { k) Autorizar el proceso de desconcentración del gobierno municipal. } \\
\text { I) La organización de cuerpos técnicos, asesores y consultivos que sean } \\
\text { necesarios al municipio, así como el apoyo que estime necesario a los } \\
\text { consejos asesores indígenas de la alcaldía comunitaria o auxiliar, así como } \\
\text { de los órganos de coordinación de los Consejos Comunitarios de Desarrollo } \\
\text { y de los Consejos Municipales de Desarrollo. } \\
\text { s) La aprobación de los acuerdos o convenios de asociación o cooperación } \\
\text { con otras corporaciones municipales, entidades u organismos públicos o } \\
\text { privados, nacionales e internacionales. } \\
\text { t) La promoción y mantenimiento de relaciones con instituciones públicas } \\
\text { nacionales, regionales, departamentales y municipales. } \\
\text { y) La promoción y protección de los recursos renovables y no renovables del } \\
\text { municipio. } \\
\text { Las Municipalidades cuentan con una Comisión de Fomento económico, } \\
\text { turismo, ambiente y recursos naturales. La comisión presentará al Concejo } \\
\text { Municipal, por intermedio de su presidente, los dictámenes e informes que } \\
\text { les sean requeridos con relación a los asuntos sometidos a su conocimiento y } \\
\text { estudio. } \\
\text { Un representante de la Asociación Nacional de Municipalidades (ANAM) } \\
\text { participa como miembro del Consejo del CONAP. } \\
\text { Existen 164 Oficinas Forestales municipales en el país. }\end{array}$ \\
\hline $\begin{array}{l}\text { Organizaciones no } \\
\text { gubernamentales, } \\
\text { sector privado } \\
\text { y academia }\end{array}$ & $\begin{array}{l}\text { En la Junta Directiva del INAB participa un representante de la Asociación } \\
\text { Nacional de Organizaciones No Gubernamentales de los Recursos Naturales, } \\
\text { Ecología y Medio Ambiente (ASOREMA). En el Consejo Nacional de Áreas } \\
\text { Protegidas participa un delegado de las organizaciones no gubernamentales } \\
\text { relacionadas con los recursos naturales y el medio ambiente registradas en el } \\
\text { CONAP. En ambos cuerpos colegiados participan representantes de la academia } \\
\text { y el sector privado. Como miembros de los órganos de dirección, comparten las } \\
\text { facultades asignadas por ley. }\end{array}$ \\
\hline $\begin{array}{l}\text { Superintendencia } \\
\text { de administración } \\
\text { Tributaria (SAT) }\end{array}$ & Lleva el registro de los importadores y establece los procedimientos a seguir. \\
\hline $\begin{array}{l}\text { Ventanilla Única Para } \\
\text { las Exportaciones } \\
\text { (VUPE) }\end{array}$ & $\begin{array}{l}\text { Según la Ley de Desconcentración de Divisas y el Acuerdo 94-2000, se elimina } \\
\text { la licencia de exportación y se crea el documento de declaración para el } \\
\text { registro y control de exportaciones (DEPEX). De acuerdo con el destino de la } \\
\text { exportación, se utilizará el formulario único centroamericano o el DEPEX. }\end{array}$ \\
\hline OIRSA & Extiende certificados de fumigación en puertos. \\
\hline
\end{tabular}




\begin{tabular}{|l|l|}
\hline \multicolumn{1}{|c|}{ Institución } & \multicolumn{1}{c|}{ Funciones y atribuciones } \\
\hline $\begin{array}{l}\text { Ministerio de la } \\
\text { Defensa y Ministerio } \\
\text { de Gobernación }\end{array}$ & $\begin{array}{l}\text { Tienen competencia para la seguridad en fronteras y la seguridad ciudadana y } \\
\text { realizan operativos de registro para el control de tránsito en el transporte de la } \\
\text { madera. }\end{array}$ \\
\hline $\begin{array}{l}\text { Ministerio de } \\
\text { Economía y } \\
\text { AGEXPORT }\end{array}$ & $\begin{array}{l}\text { El Acuerdo 790-86 crea la Ventanilla Única Para las Exportaciones (VUPE) } \\
\text { bajo la responsabilidad directa del Ministerio de Economía. Este Ministerio, a } \\
\text { través del Acuerdo 575-98, delega a la Asociación Gremial de Exportadores } \\
\text { de Productos No Tradicionales (AGEXPORT) la función de Ventanilla Única } \\
\text { Para las Exportaciones (VUPE), la cual acepta la responsabilidad y a la vez, } \\
\text { se compromete a poner en marcha el Sistema Electrónico de Autorización de } \\
\text { Exportaciones (SEADEX). }\end{array}$ \\
\hline
\end{tabular}

\section{Fuente: Elaboración propia}

En lo que respecta a posibles traslapes entre las competencias y atribuciones del INAB y el CONAP, en principio, estos no se presentan. Los criterios para diferenciar la jurisdicción de cada una son bastante claros. En el caso del CONAP, su jurisdicción se limita a los recursos naturales ubicados dentro de las áreas protegidas legalmente declaradas y para todos los casos de especies protegidas (incluso cuando se encuentren fuera de áreas protegidas). La ley del INAB aplica a todo el territorio nacional, salvo las áreas protegidas y se refiere a los aprovechamientos forestales de madera u otros productos leñosos para los cuales se requiera licencia otorgada por el INAB. Según ese mismo artículo (Decreto 101-96, Art. 49), están exentos de licencia los aprovechamientos de consumo familiar, los de plantaciones voluntarias y sistemas agroforestales plantados voluntariamente.

Las municipalidades, por intermedio de sus Comisiones de Fomento Económico, Turismo, Ambiente y Recursos Naturales, deben jugar un papel en apoyo al INAB (las atribuciones del INAB se encuentran en la LF, Art. 5; las del CONAP en la LAP, Art. 69 y lo referente a las comisiones municipales de medio ambiente, en la LF, Art. 8). Así también, dentro de las municipalidades se han ido creando las oficinas forestales municipales.

En términos de conflictos, lo que se ha presentado son reclamos de particulares con propiedades dentro de áreas protegidas abogando por su derecho a poder manejar y explotar los recursos de su propiedad según la Ley Forestal y su Reglamento, y no a sujetarse a lo estipulado en la Ley de Áreas Protegidas. Pero esto no tiene que ver con "traslapes institucionales". Hasta el momento, las autoridades judiciales, en sus diferentes niveles jerárquicos, han sostenido el principio de la prevalencia del bien común sobre el bien particular cuando se trata de propiedades situadas en jurisdicción de áreas protegidas legalmente declaradas.

En términos de las leyes aplicables, se reclama que el transporte de la madera no está bajo control del INAB y/o del CONAP, sino de un tercero: la Policía Nacional Civil (PNC), que depende del Ministerio de Gobernación.

Las entidades con atribuciones vinculadas al comercio internacional de productos forestales en Guatemala son el INAB y el CONAP. El INAB es el responsable de velar porque no se exporte madera en dimensiones prohibidas ${ }^{10}$ y realizar el control de las exportaciones forestales para garantizar

10. Ley Forestal de Guatemala, Art. 100. 
que sean ilícitas ${ }^{11}$. En la Resolución de Junta Directiva del INAB 4-23-97, se fomenta y regula la exportación de productos forestales (Artículos 59, 65, 88 y 100).

El CONAP, por su parte, es el encargado de velar por la protección de la flora y fauna silvestre, y le corresponde velar porque no se realice la libre exportación y comercialización de las especies silvestres de flora y fauna amenazadas de extinción extraídas de la naturaleza sin llenar los requisitos de ley ${ }^{12}$. Adicionalmente, le compete velar por la aplicación de la Convención sobre el Comercio Internacional de Especies Amenazadas de Fauna y Flora Silvestre (CITES) en Guatemala ${ }^{13}$. Esto incluye estar atento a eventuales cambios en los denominados "Apéndices" de la CITES, pues sucede que -según las circunstancias- una determinada especie puede pasar de una categoría de protección a otra. Resulta importante velar para cuando alguna especie cambie a "Apéndice II". Actualmente en Guatemala están en ese apéndice dos especies de caoba, dos especies de rosul (dalbergia) y el cedro.

Adicionalmente, debe mencionarse la Ventanilla Única Para las Exportaciones (VUPE), creada mediante Acuerdo Gubernativo 790 de 1986 y el Acuerdo 575, de 1998, en el cual se delegan las funciones de la VUPE (originalmente del Ministerio de Economía) a la Asociación Gremial de Exportadores de Productos No Tradicionales (AGEXPRONT). En ella participa un delegado del INAB, especializado en el tema de lo forestal.

La base legal de la Ventanilla Única se encuentra en el Acuerdo 142-2001, en el cual-debido a que la ley de desconcentración de divisas (Acuerdo 94-2000) había eliminado la licencia de exportaciónse crea el documento "Declaración para Registro y Control de Exportaciones" (DEPREX). La Misión del VUPE es centralizar y coordinar las instituciones involucradas en trámites y procedimientos de exportación para facilitar la comercialización externa de los productos guatemaltecos, impulsando el desarrollo de proyectos de comercio exterior para contribuir a mejorar la competitividad del país.

La constante preocupación con respecto a la institucionalidad en el manejo forestal es la carencia de recursos necesarios, derivada de la pobre asignación presupuestaria, así como también la gran movilidad de los funcionarios y la falta de la carrera administrativa, en ausencia de una adecuada Ley de Servicio Civil que promueva la profesionalización en la administración pública.

Se han encontrado "traslapes" o "contradicciones" en el tema de ciertos procedimientos o criterios, como en el caso de la medición de la madera cuando la ocurrencia de ilícitos. En esto se ha venido trabajando por ambas instituciones. Actualmente, el CONAP, el INAB y el Programa Nacional Forestal han planteado una "Agenda mínima interinstitucional de instrumentos, procedimientos y normas homologadas para la administración forestal, fuera y dentro de Áreas Protegidas ${ }^{14}$.

Existe un interesante proyecto interinstitucional que pertenece al sector forestal, desarrollado con el apoyo de la Organización Internacional de Maderas Tropicales (OIMT), denominado "Sistema de Información Forestal de Guatemala" (SIFGUA), que consolida, analiza y difunde información que se genera de las principales actividades forestales del país. Actualmente trabaja con nueve

11. Reglamento de la Ley Forestal, Art. 59.

12. Ley de Áreas Protegidas, Art. 26. Exportación de especies amenazadas.

13. Ibid. Art. 25..

14. INAB, CONAP (2011). Instrumentos, procedimientos y normas homologadas para la administración forestal, fuera y dentro de Áreas Protegidas, una agenda mínima interinstitucional. Guatemala. 
instituciones generadoras de información de primer nivel (INAB, CONAP, OIMT, Banco de Guatemala, Asociación Incidencia Ambiental, Cluster Forestal, AGEXPORT, Gremial Forestal, Instituto Nacional de Estadísticas y el SIPECIF). "El sistema busca centralizar la información y que de esta manera sea divulgada como una sola fuente de información a nivel nacional. Los temas principales son el manejo forestal (dentro y fuera de áreas protegidas), el comercio interno (licencias y exentos de licencias autorizados por los actores responsables del control) y el comercio exterior (importaciones y exportaciones de productos forestales). El siguiente paso del SIFGUA será fortalecer la automatización de procesos, tema importantísimo para un correcto control de las actividades forestales (cadena de custodia de la madera) con lo que llevará al país a reducir los índices de tala ilegal y fomentar el manejo forestal sostenible ${ }^{15}$.

Estos esfuerzos del país resultan relevantes en el marco de los nuevos compromisos comerciales de los tratados de libre comercio. En especial, resultan importantes avances para los compromisos del país que, en un futuro, se pudieran derivar de Lacey Act y FLEGT.

\subsection{Consistencia entre la Ley Forestal, la Ley de Áreas Protegidas y la Ley de Protección y Mejoramiento del Medio Ambiente y otras normas referidas al comercio internacional de productos de madera}

Algunos entrevistados para la elaboración de este trabajo indican que la Ley Forestal del país es una ley de fomento y no restrictiva. En el caso de la Ley de Áreas Protegidas, manifestaron que el espíritu de la ley no es malo, aunque tiene la limitante de que ubica al CONAP como una dependencia de la Presidencia de la República y el Secretario Ejecutivo es nombrado por el Presidente. Por esta razón, en muchos casos la institución ha respondido a la voluntad del Presidente y no al dictado del Consejo, en un escenario de franca disparidad de criterios e intereses. Los entrevistados manifestaron que gran cantidad de la ilegalidad en el aprovechamiento forestal se da en áreas protegidas.

Algunas de las inconsistencias que se pueden identificar entre la Ley Forestal y la Ley de Áreas Protegidas se encuentran en la tipificación de figuras delictivas en términos de que se contradicen. Otro aspecto mencionado es el que se refiere a la integración de los órganos de dirección cuando no incluyen a actores institucionales clave. Este es el caso de la Junta Directiva del INAB, en donde la Ley Forestal no consideró la inclusión del MARN.

Recientemente fue emitida la Ley Marco para Regular la Reducción de la Vulnerabilidad, la Adaptación Obligatoria ante los Efectos del Cambio Climático y la Mitigación de Gases de Efecto Invernadero (Decreto 7-2013), Ilamada de forma abreviada "Ley Marco del Cambio Climático" (LMCC). Aquí se da el caso de que en el órgano de dirección que crea esa ley (el "Consejo Nacional de Cambio Climático") no se incluyó a entidades tan relevantes en el tema como el INAB, el CONAP ni a otras instancias clave, como el Instituto de Vulcanología, Meteorología e Hidrología (INSIVUMEH). Se considera que es una debilidad no haberlos incorporado en la instancia concebida para la toma de decisiones en un tema de tanta relevancia para el país. En el 2014, el Consejo Nacional de Cambio Climático resolvió incorporar al INAB y al CONAP como Asesores permanentes de ese Consejo.

15. Sistema de Información Forestal de Guatemala. [sitio web], (2008-2013). <http://www.sifgua.org.gt>. Accedido el 31 de marzo de 2014. 
La Convención sobre el Comercio Internacional de Especies Amenazadas de Fauna y Flora Silvestre (CITES) fue aprobada mediante Decreto 63-79 del Congreso de la República en febrero de 2000. A través de la Resolución N ALC/043-99 de la Secretaría Ejecutiva, se publicó el Listado Oficial de especies CITES para Guatemala y quedó prohibida la libre exportación y comercialización de las especies silvestres amenazadas de extinción. Dada estas regulaciones, el CONAP y el INAB implementan acciones en materia forestal.

En cuanto a eventuales contradicciones legales, más bien lo que se encuentra son grandes debilidades institucionales para hacer valer la normativa. Las capacidades de control y vigilancia del adecuado manejo forestal son reducidas, con la ausencia de presupuestos institucionales suficientes, adecuados y oportunos para los procesos de vigilancia y seguimiento. Adicionalmente, no se cuenta con recursos para las acciones de prevención, como el caso de combate a incendios forestales, además de que ni el CONAP ni el INAB tienen bajo su control este tema, el cual ha sido asignado a la Coordinadora Nacional para la Reducción de Desastres (CONRED), entidad que no ha fortalecido el Sistema Nacional de Prevención y Prevención de Incendios Forestales (SIPECIF).

La falta de aplicación de políticas de protección del ambiente o la aplicación de políticas gubernamentales contradictorias al adecuado manejo forestal también son temas que afectan sensiblemente el desempeño ambiental. Un ejemplo lo constituye el caso de la política energética, que no considera el consumo ilícito de la leña y no genera planes, programas o proyectos y acciones en atención al aumento de la deforestación en el país.

\subsection{Mecanismos legales y marcos jurídicos que se encuentran dentro de las Estrategias REDD+ Nacionales, referidas al aprovechamiento forestal y al comercio internacional de productos forestales}

Guatemala aprobó (Decreto 15-95 del Congreso de la República) y ratificó la Convención Marco de las Naciones Unidas sobre el Cambio Climático y el Protocolo de Kioto (Decreto 23-99 del Congreso de la República). También aprobó (Decreto 30-95 del Congreso de la República) y ratificó un Convenio Centroamericano de Cambios Climáticos.

Para ordenar el abordaje nacional en materia de cambio climático, el gobierno de Guatemala en el año 2009 aprobó una Política Nacional de Cambio Climático (Acuerdo Gubernativo 329-2009) que, por primera vez, hace referencia a los mercados de carbono y establece que "se investiguen y promocionen los diferentes mercados de carbono identificando y valorando los bienes y servicios naturales que Guatemala, con base en sus recursos forestales y energéticos, así como otros componentes, puedan contribuir a la reducción de emisiones de gases de efecto invernadero".

Desde el año 2010, las autoridades del MARN, MAGA, INAB y CONAP iniciaron una estrecha coordinación de alto nivel más para impulsar, en conjunto y dar seguimiento a distintas iniciativas y acciones en relación con los recursos naturales de Guatemala, con énfasis en los recursos forestales. Una de sus prioridades es impulsar el diseño participativo y la implementación de una Estrategia Nacional para Reducir la Deforestación (ENRD), dentro de la cual la Reducción de Emisiones de Gases de Efecto Invernadero por Deforestación Evitada (REDD+) es considerada un mecanismo que aporta a la ENRD. 
Actualmente, el país cuenta con una Ley Marco para Regular la Reducción de la Vulnerabilidad, la Adaptación Obligatoria ante los Efectos del Cambio Climático y la Mitigación de Gases de Efecto Invernadero (Decreto 7-2013) que establece los lineamientos para los mercados de carbono y el desarrollo de una batería de acciones complementarias vinculadas a la reducción de emisiones (mitigación), de la vulnerabilidad y la adaptación.

\section{Nueva Ley Marco para el Cambio Climático y REDD+}

La Ley Marco para Regular la Reducción de la Vulnerabilidad, la Adaptación Obligatoria ante los Efectos del Cambio Climático y la Mitigación de Gases de Efecto Invernadero establece que el INAB, el CONAP y el MAGA, en coordinación con el MARN, ajustarán y diseñarán las políticas, estrategias, planes, programas y proyectos para el desarrollo y aprovechamiento sostenible y la gestión de los recursos forestales, incluyendo la promoción de los servicios ambientales que reduzcan la emisión de gases de efecto invernadero y la conservación de los ecosistemas forestales (Art. 20). También regula lo relativo a proyectos de mercado de carbono para reducción de emisiones de gases de efecto invernadero, en especial lo relacionado con los derechos, tenencia y negociación de unidades de reducción de emisiones de gases de efecto invernadero (Art. 20).

\section{Fuente propia}

La nueva LMCC ordena la elaboración de la normativa necesaria para la creación y funcionamiento del Registro de Proyectos de Remoción o Reducción de Emisiones de Gases de Efecto Invernadero, así como para los procedimientos de divulgación, promoción, registro, validación, monitoreo y verificación de proyectos. Adicionalmente, establece el Fondo Nacional de Cambio Climático (FONCC), a cargo del MARN, con el objetivo de financiar planes, programas y proyectos de gestión de riesgo para la reducción de la vulnerabilidad, para la adaptación forzosa y la mitigación obligada, así como para el mejoramiento de las capacidades nacionales en cambio climático, el pago por servicios naturales de fijación de carbono, la producción y protección de agua, y la protección de ecosistemas, belleza escénicas y otros.

Uno de los temas de mayor preocupación respecto a la gobernanza es lo que respecta al ámbito institucional y se considera relevante aclarar en ese sentido que la ley NO crea una nueva institucionalidad, con excepción de la creación de Consejo Nacional de Cambio Climático-constituido por entidades ya existentes- como una instancia de coordinación que no tiene personalidad ni personería jurídica.

En el tema de la gobernanza de la REDD+, la LMCC establece claramente en su parte considerativa que para enfrentar el cambio climático es necesario tomar medidas urgentes, apropiadas y sostenidas a nivel nacional, y se refiere a la participación de todas las instituciones públicas "partiendo de la competencia y la rectoría sectorial que le corresponde a cada una". La LMCC confirma la rectoría sectorial y reconoce la competencia de cada institución que se involucra en las acciones para enfrentar los efectos negativos del cambio climático (a partir de las competencias que les fueron asignadas en su ley específica). De manera especial, confirma las competencias de instancias como MARN, CONAP, INAB, MAGA y otras, con lo cual clarifica el papel que le corresponde asumir a estas en cada uno de los temas que aborda la LMCC.

Para el diseño y puesta en acción de una Estrategia de Reducción de la Deforestación existe todo un marco normativo que parte de los tratados internacionales ratificados por Guatemala, así como un amplio marco jurídico nacional robusto integrado por leyes como la Ley de Protección y 
Mejoramiento del Ambiente, la Ley Forestal, la Ley de Áreas Protegidas, el Código Municipal, la Ley de Consejos de Desarrollo Urbano y Rural, y otras, así como un marco institucional al que se hace referencia en este trabajo.

Será un desafío la reglamentación de la LMCC, sobre todo, en lo que respecta a los mercados de carbono; en especial, porque ni la propia Convención Marco de Naciones Unidas sobre Cambio Climático lo ha regulado aún.

Es relevante mencionar que el tema de la REDD+ es complejo en cuanto se refiere a los derechos a la tenencia y negociación de créditos y a los beneficios derivados de tal negociación. Uno de los aspectos más controversiales de la citada Ley Marco de Cambio Climático se refiere, precisamente, a esa materia. El problema que surge del artículo anterior es que en Guatemala existen diversos tipos de tenencia de la tierra que no solo es propiedad privada o posesión, por lo que la norma ha despertado gran inconformidad en aquellos grupos que pudieran tener la posibilidad de desarrollar este tipo de proyectos, pero no se enmarcan dentro de lo establecido.

EI MARN, con la participación del CONAP, INAB, MAGA e instituciones de la sociedad civil, impulsó la elaboración de la Readiness Preparation Proposal (R-PP), a través de la cual se obtuvieron recursos del Forest Carbon Partnership Fund (FCPF) para la construcción participativa de una estrategia ENRD. Actualmente, la R-PP fue aprobada.

Se requiere tener una gran claridad con respecto al concepto y naturaleza de la REDD+, especialmente en cuanto a que la relevancia de este mecanismo no radica en la propiedad de la tierra en donde se desarrolla el mecanismo, sino más bien en el desarrollo de actividades de reducción de emisiones de gases de efecto invernadero por deforestación evitada y que estas tengan legitimación para desarrollarse. Se considera que esta situación no está totalmente clara en el desarrollo del marco normativo.

\subsection{Conflictos que se dan entre los derechos de uso de la tierra y el uso forestal}

La Ley del Fondo Nacional de Tierras (LFNT) [Decreto 24-99], que crea el Fondo de Tierras (FONTIERRAS) para facilitar el acceso a la tierra, establece que FONTIERRAS tendrá disponibilidad sobre las fincas rústicas con vocación agropecuaria, forestal e hidrobiológica inscritas en el Registro de la Propiedad a favor del Estado, que no estén destinadas a proyectos comprobados de educación, investigación, servicio u otros fines de beneficio social. Se exceptúan de este tipo de disponibilidad las zonas declaradas como áreas protegidas y las de reserva nacional (Art. 8).

La LFNT establece que no procederá la adjudicación de tierras por FONTIERRAS en el caso de tierras en posesión privada, de comunidades indígenas, áreas protegidas y reservas territoriales. Las áreas protegidas están sujetas a su propio régimen. En ningún caso podrá tenerse disponibilidad en zonas núcleo y sus zonas de uso múltiple designadas por la Ley de Áreas Protegidas (Art. 45).

La Ley Forestal establece que, antes de la adjudicación de tierras por el Fondo Nacional de Tierras para uso agrícola, deberá contarse con el dictamen del INAB, en el que conste que la tierra a ser adjudicada no es de vocación forestal. El funcionario que incumpla esta disposición incurre en delito ${ }^{16}$.

16. Ley Forestal de Guatemala, Art. 144. 
En la práctica, existen diversos conflictos en donde se desconocen las normas para la protección de áreas protegidas o con vocación forestal en expedientes de adjudicación de tierras por el FONTIERRA. De hecho, en los instrumentos jurídicos para la adjudicación no se incorporan cláusulas de reserva en ese sentido.

Para toda área cubierta con bosque de una extensión mayor a una hectárea, cuya cobertura se propone cambiar por otra no forestal, el interesado deberá presentar al INAB un estudio que asegure que la tierra con bosque no es de vocación forestal. Podrá autorizarse el cambio de cobertura en tierras de vocación forestal si se presenta un Plan de Manejo Agrícola que asegure que la tierra con cobertura forestal es apta para una producción agrícola económica sostenida. Los productos forestales de cualquier naturaleza que resultaren de la operación del cambio autorizado de uso de la tierra podrán ser utilizados y comercializados por el usuario. En este caso, el interesado podrá escoger entre pagar al Fondo Forestal Privativo o reforestar un área igual a la transformada ${ }^{17}$.

En casos de proyectos con el beneficio de incentivos forestales, un propietario privado no puede cambiar unilateralmente el uso de la tierra de su propiedad cubierta de bosque (Decreto 101-96, Art. 98). Dicho de otra manera, si se trata de tierra en áreas cubiertas de bosque que están registradas como beneficiarias del incentivo forestal, el cambio de uso del suelo a un uso distinto al forestal debe ser autorizado. En este caso, debe presentar al INAB un estudio para su conocimiento y aprobación (Decreto 101-96, Art. 46, Cambio de Cobertura).

También tiene que tomarse en cuenta que una propiedad privada, según la ley, puede ser restringida en su uso debido a diferentes criterios, tales como su ubicación con respecto a áreas protegidas legalmente declaradas (adentro o afuera y en qué tipo de zona), las pendientes presentes en la propiedad (por ejemplo, para el propietario en un cono volcánico), las zonas de recarga hídrica en las que puedan localizarse o contener (por ejemplo, su situación con respecto a un cauce o un lago), si se trata de una propiedad rústica o urbana, etc.

En el marco de los Acuerdos de Paz Firme y Duradera (APFD), el Acuerdo sobre Aspectos SocioEconómicos y Situación Agraria (AASESA), año 1996, establece que "dentro de la problemática del desarrollo rural, la tierra tiene un carácter central. Desde la conquista hasta nuestros días, los acontecimientos históricos, a menudo trágicos, han dejado secuelas profundas en las relaciones étnicas, sociales y económicas alrededor de la propiedad y de la explotación del recurso tierra. Han llevado a una situación de concentración de recursos que contrasta con la pobreza de la mayoría, lo cual obstaculiza el desarrollo del país en su conjunto. Es indispensable subsanar y superar este legado, promover un agro más eficiente y más equitativo, fortaleciendo el potencial de todos sus actores, no solamente en el ámbito de las capacidades productivas, sino también en la profundización de las culturas y los sistemas de valores que conviven e intercambian en el campo guatemalteco".

El citado acuerdo (AASESA) establece que "estos cambios permitirán que el país aproveche efectivamente las capacidades de sus habitantes $\mathrm{y}$, en particular, la riqueza de las tradiciones $\mathrm{y}$ culturas de sus pueblos indígenas. Que aproveche asimismo el alto potencial de desarrollo rural que debe a su riqueza en recursos naturales (agrícolas, forestales, biogenéticos e hídricos), y al potencial económico de la explotación agrícola, industrial, comercial y turística de dichos recursos naturales".

17. Ley Forestal de Guatemala, Art. 46. 
En dicho acuerdo se estableció que para el año 1999 debían haberse otorgado a pequeños y medianos campesinos legalmente organizados, 100.000 hectáreas en concesiones de manejo de recursos naturales, para fines de manejo forestal sostenible, administración de áreas protegidas, ecoturismo, protección de fuentes de agua y otras actividades compatibles con el uso potencial sostenible de los recursos naturales de dichas áreas. Es así como surgen las concesiones forestales, de turismo y de manejo de recursos naturales en la Reserva de Biosfera Maya en el Departamento de El Petén. La mayoría de esas concesiones se encuentra aún vigente y en la mayoría de los casos, su desempeño ha sido ejemplar.

El Acuerdo sobre Aspectos Socio-Económicos y Situación Agraria establece que se deberá apoyar la participación del sector privado y las organizaciones comunitarias de base en proyectos de manejo y conservación de recursos naturales renovables a través de incentivos, subsidios directos focalizados o mecanismos de financiamiento en condiciones blandas, en consideración de los beneficios no monetarios que dichos proyectos aportan a la colectividad nacional. En consideración del beneficio que constituye para la comunidad internacional el manejo sostenible y la conservación del patrimonio forestal y biogenético del país, el Gobierno promoverá activamente la cooperación internacional con este empeño".

En el pasado se dieron muchos conflictos en la declaratoria de áreas protegidas que contenía fincas privadas o de comunidades indígenas, sobre todo por un débil proceso de consulta y participación en el proceso de la declaratoria.

Actualmente existen comunidades muy antiguas y tradicionales que manejan sus recursos naturales, en particular los bosques, de conformidad con su conocimiento ancestral y han demostrado un manejo ejemplar. En este sentido, la Constitución Política de la República establece que las comunidades indígenas y otras que tengan tierras que históricamente les pertenecen y tradicionalmente han administrado en forma especial mantendrán ese sistema (Art. 67). Sin embargo, existe también un porcentaje muy alto de poblaciones que no manejan adecuadamente el recurso, además de existir condiciones de pobreza y pobreza extrema que han llevado a utilizar el recurso forestal como un recurso energético -principalmente para el cocimiento de alimentos-. Se estima que $60 \%$ de la población del país consume leña, lo que genera un problema de deforestación, socio-económico y ambiental de grandes dimensiones.

Por otro lado, la recién emitida LMCC ha creado un conflicto derivado de establecer regulaciones sobre derechos, tenencia y negociaciones de reducción de emisiones de carbono u otros gases de efecto invernadero y vincularlas a la propiedad o posesión de la tierra y al definir qué se entiende por dueños de ese tipo de proyectos. El problema surge, esencialmente, al dejar fuera del marco regulatorio a otro tipo de tenencia de la tierra, lo que ha despertado gran inconformidad en aquellos grupos que pudieran tener la posibilidad de desarrollar este tipo de proyectos, pero no se enmarcan dentro de lo establecido.

En el caso de tierras indígenas, existen muchos obstáculos para su reconocimiento y la reinvidicación a su propiedad histórica ${ }^{18}$. Dentro de las tierras que deberían, según la Constitución Política de la

18. Se refiere así a la propiedad original sobre las tierras de las que fueron despojados los indígenas por efecto de la conquista española o por despojos posteriores. José Mario Castillo González. 
República, gozar de protección especial, se encuentran las de las cooperativas, las comunidades indígenas o cualesquiera otra formas de tenencia comunal o colectiva de propiedad agraria así como el patrimonio familiar y vivienda popular, que garanticen su posesión y desarrollo. La Constitución de la República (Art. 67), establece que las comunidades indígenas y otras que tienen tierras que históricamente les pertenecen y que tradicionalmente han administrado en forma especial, mantendrán ese sistema. Lamentablemente, la Constitución Política manda que una ley regulará lo relativo a esa materia sin embargo, a la fecha esa ley aún no ha sido emitida.

Guatemala aprobó el Convenio 169 de la OIT (Decreto 9-96 del Congreso de la República ) sobre Derechos de los Pueblos Indígenas y Tribales. Ese Convenio establece en su Artículo 14.1: "que deberá reconocerse a los pueblos interesados el derecho de propiedad y de posesión sobre las tierras que tradicionalmente ocupan..". lamentablemente aún persisten gran conflictividad respecto al reconocimiento de ese derecho. En ese sentido cabe citar el informe del Relator Especial de Derecho Humanos José Martínez Cobo ${ }^{19}$, quien indica que: "No se encuentra debidamente garantizado ni realmente vigente el derecho de las poblaciones indígenas a las tierras que ellas y sus antepasados han explotado inmemorialmente, ni a las formas de tenencia de la tierra y explotación de los recursos generados históricamente, ni a los recursos que esas tierras contienen. En algunos países, el despojo de las tierras se realiza por medio de instrumentos jurídicos dados por los Estados, en los que los terratenientes tienen todavía una injerencia significativa".

\subsection{Normativa para promover la distribución justa y equitativa de los beneficios de un aprovechamiento sostenible de la madera}

Constitucionalmente, la reforestación y conservación de los bosques es "de urgencia nacional y de interés social". Por su parte, la Ley Forestal establece como atribuciones del INAB promover y fomentar el desarrollo del país mediante el manejo sostenible de los bosques, la reforestación, la industria y la artesanía forestal, basada en los recursos forestales y la protección de las cuencas hidrográficas.

La actual Política Nacional de Diversidad Biológica (Acuerdo Gubernativo 220-2011) establece como un principio la distribución justa y equitativa de beneficios e indica que "los beneficios derivados de los componentes de la diversidad biológica y sus servicios ecosistémicos deben ser distribuidos de manera justa y equitativa en forma concertada con las comunidades locales, basados en consensos y en el ejercicio de ciudadanía de todos los hombres y mujeres que cohabitan el país".

Mediante Decreto 5-95 del Congreso de la República, Guatemala aprobó el Convenio de Diversidad Biológica cuyos objetivos son "la conservación de diversidad biológica, la utilización de sus componentes y la participación justa y equitativa de los beneficios que se deriven de la utilización de los recursos genéticos". No existe una norma de carácter de ley orgánica, además del decreto en mención, que establezca de manera categórica la promoción de la distribución justa y equitativa de los beneficios de un aprovechamiento sostenible de la madera.

19. Relator Especial de la Subcomisión de Prevención de Discriminaciones y Protección a las Minorías. Estudio del Problema de la Discriminación contra las Poblaciones Indígenas. 
Existen esfuerzos por poner en práctica este principio, un caso que vale la pena mencionar es el la distribución de incentivos forestales en donde a través de una Ley de PIMPEP se incluye como beneficiarios a comunidades que, sin tener título de propiedad, puedan acreditar su posesión sobre la tierra y, de esa manera, recibir beneficios de los incentivos en el manejo y conservación de bosques, algo que les estuvo vedado por varios años dado que los incentivos forestales, anteriormente, solo se otorgaban a quienes podría demostrar la propiedad de la tierra. No obstante, se considera que se requiere reforzar las acciones para garantizar el cumplimientos de este principio en el país, sobre todo, en lo que corresponde a las comunidades indígenas y en cumplimiento del Convenio 169 de la OIT y los convenios antes citados. 


\section{Análisis de los estándares de legalidad}

\subsection{Vacíos y conflictos en la aplicación de la legislación forestal y afines}

Tal y como lo reconoce la Constitución Política de la República, Guatemala está formada por diversos grupos étnicos entre los que figuran los grupos indígenas de ascendencia maya. El Estado reconoce, respeta y promueve sus formas de vida, costumbres, tradiciones, formas de organización social, el uso del traje indígena en hombres y mujeres, sus idiomas y sus dialectos (Art. 66). Gozan protección especial del Estado cualesquiera de las formas de tenencia comunal o colectiva de propiedad agraria, así como el patrimonio familiar y vivienda popular.

Las comunidades indígenas reclaman el cumplimiento del Convenio 169 de la Organización Internacional del Trabajo (OIT), aprobado y ratificado por Guatemala, con respecto a los proyectos que se desarrollan en sus territorios, especialmente en lo referente a la consulta previa e informada, así como el manejo de los recursos naturales. Es un tema controversial, sobre todo porque no se ha desarrollado en la legislación ordinaria ni en las leyes de ambiente, forestal y de áreas protegidas. Las comunidades han recurrido a hacer consultas de buena fe entre sus integrantes y llevar los resultados de esas consultas a las autoridades que toman las decisiones. En la mayoría de los casos, estos no son tomados en cuenta por parte de las autoridades que toman las decisiones finales y por ende, genera gran inconformidad y conflictividad.

En relación con los vacíos legales que se encuentran en la Ley Forestal, la Ley de Áreas Protegidas y la Ley de Protección y Mejoramiento del Medio Ambiente, respecto al aprovechamiento forestal y al comercio internacional de productos forestales, muchos entrevistados coinciden en indicar que los problemas no se dan en las leyes, sino en el "desarrollo" o "aplicación" de estas en aspectos que deberían reglamentarse, en la coordinación que se debe dar entre las instituciones, en la armonización de procedimientos y criterios. En particular, el problema se da a nivel institucional por la débil administración pública y los escasos recursos de los cuales disponen.

Conflictos permanentes existen en materia de propiedad y tenencia de las tierras y los derechos derivados. Mucha de la legislación no reconoce otros derechos que los de propiedad y posesión legal, desconociendo todas las otras formas tradicionales o consuetudinarias de manejo de la tierra y los recursos naturales.

En donde siempre existe un permanente conflicto es en la aplicación de las disposiciones del Convenio 169 de la OIT sobre Pueblos Indígenas y Tribales, dado que -aunque Guatemala lo ha ratificado- aún no hay un marco nacional que lo ponga en operación, lo que obliga a la aplicación de una legislación que no considera ni desarrolla los derechos como han sido establecidos en ese Convenio; por ende, se genera discusión. 


\subsection{Requisitos legales que deben satisfacerse en Guatemala para obtener los permisos de aprovechamiento forestal y comercio internacional de productos forestales}

Cualquier aprovechamiento forestal de madera u otros productos leñosos excepto los de consumo familiar y los de plantaciones voluntarias y sistemas agroforestales plantados voluntariamente podrá hacerse solamente con licencia del INAB ${ }^{20}$. La licencia es la autorización para implementar el Plan de Manejo.

La solicitud de aprovechamiento forestal no será admitida si no va acompañada del Plan de Manejo²1.

Cuadro 3. Requisitos para elaborar un Plan de Manejo en áreas no protegidas

\begin{tabular}{|c|c|}
\hline Requisitos técnicos & Requisitos legales \\
\hline $\begin{array}{ll}\text { - } & \text { Descripción biofísica de la propiedad } \\
\text { - } & \text { Superficie con bosque } \\
\text { - } & \text { Tipo y clase de bosque } \\
\text { - } & \text { Área a intervenir } \\
\text { - } & \text { Áreas de protección } \\
\text { - } & \text { Volumen a extraer } \\
\text { - } & \text { Sistema de corte } \\
\text { - } & \text { Crecimiento anual del bosque y su posibilidad de } \\
& \text { corte } \\
\text { - } & \text { Recuperación de la masa forestal } \\
\text { - } & \text { Medidas de prevención contra incendios } \\
& \text { forestales } \\
\text { - } & \text { Tiempo de ejecución }\end{array}$ & $\begin{array}{l}\text { - Solicitud que contenga como mínimo las } \\
\text { generales del propietario del terreno, lugar para } \\
\text { recibir notificaciones, la solicitud en términos } \\
\text { concretos y la firma debidamente autenticada. } \\
\text { - Certificación del Registro de la Propiedad } \\
\text { Inmueble que acredite la propiedad del bien, } \\
\text { indicando anotaciones y gravámenes que } \\
\text { contiene. En caso de que la propiedad no esté } \\
\text { inscrita en el Registro, se podrá aceptar otro } \\
\text { documento que acredite la propiedad. } \\
\text { - Plan de Manejo Forestal. }\end{array}$ \\
\hline
\end{tabular}

Fuente: Adaptado de Ley Forestal

20. Ley Forestal de Guatemala, Art. 49.

21. Ibid. Art. 50 . 


\section{Cuadro 4. Requisitos para elaborar un plan de manejo en áreas protegidas}

\section{Requisitos técnicos}

- Solicitud de autorización con base en el formato que aplique según los objetivos comerciales del proyecto o plan de manejo forestal, el cual deberá ser elaborado por un regente forestal debidamente inscrito en el Registro Nacional de Regentes Forestales del CONAP.

Solicitud de autorización de planes de manejo en sistemas agroforestales establecidos. Previo a la declaratoria del área protegida, deberá presentarse un Plan de Manejo del Sistema Agroforestal. El usuario deberá presentar sus respectivos planes operativos anuales, así como el Instrumento de Evaluación Ambiental.

- Para dar operatividad a los Planes de Manejo Forestal aprobados, previo a la emisión de la licencia forestal correspondiente, el usuario deberá presentar el Plan Operativo Anual. Los Planes de Manejo Forestal para bosque natural deberán presentarse en función del tipo de bosque a manejar y la extensión territorial que se sujetará al manejo, cumpliendo los siguientes lineamientos:

Bosques latifoliados con superficies menores o iguales a 100 hectáreas y mayores a 100 hectáreas requieren un plan de manejo forestal.

Bosques de coníferas o mixtos, con superficies menores o iguales a 5 hectáreas, de 5 a 15 hectáreas y mayores a 15 hectáreas, requieren un plan de manejo forestal realizado con base en el formato específico.

Todo proyecto o plan de manejo forestal deberá ser respaldado por un acta de declaración jurada en la que se manifieste que toda la información consignada en dicho proyecto o plan es verídica.

- Toda solicitud de manejo forestal comercia en áreas protegidas debe presentarse con una fotocopia del expediente completo y una copia electrónica que contenga la siguiente información: a) plan de manejo forestal, b) datos de campo y cálculos del inventario forestal, c) coordenadas que delimitan la poligonal de la finca, los rodales, caminos existentes, caminos por construir, patios de acopio (bacadillas) y recursos hídricos de la finca y d) instrumento de evaluación ambiental correspondiente.

\section{Requisitos legales}

a) Solicitud en la que se detalle claramente el(los) objetivo(s) de la actividad a desarrollar, indicando los datos personales.

b) Fotocopia legalizada del documento personal de identificación del solicitante o representante legal y copia legalizada del documento que acredite la representación debidamente registrada.

c) Certificación del registro de la propiedad del inmueble objeto de la solicitud con su respectivo plano.

En el caso de que el inmueble carezca de inscripción en el registro de la propiedad, el solicitante deberá presentar: i) Certificación extendida por la autoridad municipal competente que acredite la posesión del bien inmueble y en su caso, testimonio de escritura pública donde conste la posesión o ii) Fotocopia legalizada del testimonio del contrato de arredramiento del inmueble objeto de solicitud de manejo forestal.

d) Fotocopia legalizada de la constancia de inscripción en el Registro Nacional de Regentes Forestales del CONAP de la persona responsable de asistir técnicamente en la elaboración de la propuesta e implementación del plan de manejo. Fotocopia legalizada del documento de identificación personal del regente forestal.

Para las solicitudes de autorización de planes de manejo de fuentes semilleras presentar fotocopia legalizada del registro de inscripción del regente que lo acredite como Certificador de Fuentes Semilleras.

Para las solicitudes de autorización de planes de extracción y recuperación por cambio de uso de la tierra, presentar fotocopia legalizada del registro de inscripción del regente que lo acredite como Elaborador de Estudios de Capacidad de Uso de la Tierra.

Para las solicitudes de autorización de planes de manejo de plantaciones forestales o sistemas agroforestales menores a 5 hectáreas no se requerirá un regente forestal.

e) Para las solicitudes de autorización de planes de manejo o aprovechamiento en sistemas agroforestales mayores a 5 hectáreas, se requerirá un regente especializado en sistemas agroforestales.

f) Para las solicitudes de autorización de planes de aprovechamiento forestal en sistemas agroforestales y planes de manejo de plantaciones forestal voluntarias ya establecidas, presentar el certificado, original o copia legalizada de inscripción ante el Registro Nacional Forestal del INAB del sistema agroforestal o plantación voluntaria propuesta a aprovechamiento o manejo.

g) Para las solicitudes de autorización de planes de manejo de fuentes semilleras, presentar fotocopia legalizada del certificado de inscripción de la fuente semillera con la categoría respectiva asignada por el BANSEFOR.

En el contrato de cumplimiento del plan de manejo forestal deberán comparecer el solicitante y el regente que implementará el plan de manejo. 
El INAB, en un término de 60 días contados a partir de la admisión administrativa de la solicitud de licencia, deberá resolver el Plan de Manejo presentado. Después de admitir la solicitud de licencia, tendrá un término máximo de 60 días para aprobarla o improbarla. La vigencia de la licencia será establecida por el INAB.

Al ser conferida la licencia y por tanto, aprobado el Plan de Manejo Forestal, el INAB extenderá al interesado un certificado de licencia. El CONAP emitirá una "Licencia de Aprovechamiento" o "Licencia de Colecta" y cobrará al usuario, según un Cuadro Tarifario aprobado por el Consejo (SC $N^{\circ} 15-2007$ ), la suma de $Q 25.00$. Adicionalmente a ello, le cobrará $10 \%$ sobre el valor del volumen en pie de la madera que se le está autorizando aprovechar.

Cada "Guía de Transporte" que emite el CONAP cuesta Q 30.00. Cada "Permiso Certificado CITES" vale $Q 125.00$.

En el caso de la Ley Forestal, el Artículo 87 establece lo relativo al monto de la licencia para aprovechamiento forestal de la siguiente manera:

"Toda persona, a la que se le conceda licencia para aprovechamiento forestal, pagará un monto equivalente al $10 \%$ del valor de la madera en pie, que debe hacerse efectivo al momento de ser autorizada la licencia. El 50\% del monto recaudado será transferido a las municipalidades donde estén ubicados los bosques aprovechados; este monto será específicamente destinado para el control y vigilancia forestal, y el cincuenta por ciento restante será destinado al Fondo Forestal Privativo. Se exceptúan de este pago los productos forestales provenientes de:

a. Plantaciones registradas en el INAB, que no hubieren sido establecidas por obligaciones de reforestación y los sistemas agroforestales y

b. Bosques que hayan sido manejados según el Plan de Manejo aprobado por INAB y que hayan cumplido con todos los compromisos establecidos en la licencia.

El INAB publicará anualmente el valor de la madera en pie, en el diario oficial y entrará en vigencia a partir del uno de septiembre de cada año".

Licencias emitidas por las municipalidades: Las municipalidades otorgan las licencias para la tala de árboles ubicados dentro de sus perímetros urbanos para volúmenes menores de diez (10) metros cúbicos por licencia por finca y por año. Para volúmenes mayores la licencia será otorgada por el INAB $^{22}$.

Extracción de productos y subproductos forestales: Los productos y subproductos forestales que sean dañados o tumbados por causas naturales podrán ser aprovechados por el propietario del bosque sin mayor requisito que la autorización correspondiente otorgada por el INAB ${ }^{23}$.

22. Ley Forestal de Guatemala, Art. 54.

23. Ibid. Art. 60 
Cuadro 5. Regulaciones para transporte, industrialización y comercialización de madera

\begin{tabular}{|c|c|c|}
\hline Transporte de madera & $\begin{array}{l}\text { Industrializaciones de la } \\
\text { materia prima forestal }\end{array}$ & $\begin{array}{l}\text { Comercialización de } \\
\text { madera a nivel nacional }\end{array}$ \\
\hline $\begin{array}{l}\text { Se establece la "Nota de Envío" } \\
\text { para el transporte y verificación } \\
\text { de procedencia de los productos } \\
\text { forestales. Se divide en: } \\
\text { a) Nota de Envío de Bosque: } \\
\text { Ampara los productos } \\
\text { forestales que provienen del } \\
\text { lugar de aprovechamiento } \\
\text { forestal. Es emitida por el } \\
\text { INAB. Se clasifica en: } \\
\text { a) } 1 \text { Nota de Envío de Licencia o } \\
\text { Concesión Forestal. } \\
\text { a) } 2 \text { Nota de Envío de Exentos de } \\
\text { Licencia Forestal. } \\
\text { Se emite en triplicado. El original } \\
\text { es el único documento que } \\
\text { ampara la procedencia de los } \\
\text { productos forestales autorizados } \\
\text { por el INAB durante el transporte } \\
\text { y en el lugar de destino, el cual } \\
\text { deberá acompañar en todo } \\
\text { momento el producto forestal. } \\
\text { b) Nota de Envío de Empresa: } \\
\text { Ampara los productos } \\
\text { forestales que provienen del } \\
\text { lugar de transformación y/o } \\
\text { comercialización de productos } \\
\text { forestales. Es emitida por las } \\
\text { empresas. } \\
\text { Dentro de áreas protegidas se } \\
\text { deberá portar para cada envío una } \\
\text { "guía de transporte" expedida por } \\
\text { el CONAP. } \\
\text { La guía acredita el origen legal de } \\
\text { especímenes, partes o derivados } \\
\text { de la vida silvestre. Se extiende } \\
\text { en papel de seguridad e indica el } \\
\text { plazo, que no podrá ser menos de } \\
3 \text { ni mayor de } 10 \text { días. Contiene } \\
\text { la documentación legal del origen } \\
\text { del producto, las cantidades } \\
\text { y volúmenes autorizados, el } \\
\text { nombre científico del espécimen, } \\
\text { la procedencia legal y destino, y } \\
\text { la deben acompañar durante la } \\
\text { circulación. }\end{array}$ & $\begin{array}{l}\text { Para establecer un negocio o } \\
\text { industria se requiere su inscripción } \\
\text { en el registro Nacional Forestal del } \\
\text { INAB. } \\
\text { También están obligadas a: } \\
\text { - } \quad \text { Contar con un informe técnico } \\
\text { practicado por la Dirección } \\
\text { Regional o Subregional del } \\
\text { INAB. } \\
\text { - Rendir informes trimestrales } \\
\text { acerca del tipo y cantidad } \\
\text { de materia prima procesada } \\
\text { durante el trimestre anterior } \\
\text { y la cantidad de productos } \\
\text { elaborados y comercializados. } \\
\text { Anotar en sus registros y } \\
\text { reportar la procedencia, } \\
\text { cantidad y tipo de producto } \\
\text { recibido. } \\
\text { Anotar en sus registros } \\
\text { las existencias de materia, } \\
\text { prima, producto en proceso y } \\
\text { producto terminado. } \\
\text { Deberán llevar la contabilidad } \\
\text { sobre el volumen de trozas } \\
\text { compradas o taladas y el volumen } \\
\text { de madera aserrada. El volumen } \\
\text { total de madera a vender debe } \\
\text { ser equivalente al volumen de } \\
\text { trozas autorizadas, menos los } \\
\text { desperdicios causados por el } \\
\text { proceso. } \\
\text { También deben cumplir con } \\
\text { presentar un instrumento de } \\
\text { evaluación ambiental, previas } \\
\text { operaciones y el permiso } \\
\text { municipal. }\end{array}$ & $\begin{array}{l}\text { La empresa debe estar inscrita } \\
\text { en el Registro Mercantil y contar } \\
\text { con patente de comercio. Estar } \\
\text { inscrita como comerciante, } \\
\text { empresa individual o empresa } \\
\text { mercantil y sociedad. Así también } \\
\text { debe contar con su registro } \\
\text { en la Superintendencia de } \\
\text { Administración Tributaria y contar } \\
\text { con el Registro Tributario Unificado } \\
\text { (RTU). } \\
\text { También debe tener el instrumento } \\
\text { de evaluación ambiental, con la } \\
\text { licencia municipal respectiva. }\end{array}$ \\
\hline
\end{tabular}

Fuente: Adaptación de contenidos Ley Forestal y Ley de Áreas Protegidas y su Reglamento, y de Guía del Empresario Responsable de la Madera, AGEXPORT, COFAMA 


\subsection{Estándares para el uso de los recursos forestales}

EI CONAP debe elaborar anualmente los listados de especies silvestres amenazadas de extinción, así como de las endémicas y aquellas que requieren autorización para su aprovechamiento y comercialización. Se prohíbe el corte, exportación, comercialización, recolecta, transporte de especies de flora amenazada de extinción o contenidas en los listados nacionales o internacionales oficiales sin previa autorización del CONAP. Es prohibido autorizar permisos o licencias de aprovechamiento forestal en zona núcleo de áreas protegidas ${ }^{24}$.

También están sujetos a restricciones los árboles que constituyan genotipos superiores identificados por el INAB. Se exceptúan de esta prohibición aquellos provenientes de bosques plantados y registrados en el INAB (Art. 34).

La protección, conservación y restauración del mangle ha sido declarado de interés nacional y está sujeto a regulaciones especiales.

Está prohibido la eliminación del bosque en las partes altas de las cuencas hidrográficas cubiertas de bosque, en particular las que están ubicadas en la zona de recarga hídrica que abastece fuentes de agua, las cuales gozan de protección especial ${ }^{25}$.

La exportación de productos maderables está sujeta a regulaciones fitosanitarias internacionales y la entrega de un certificado CITES para los casos de especies en peligro o amenazadas de extinción.

La explotación de los recursos forestales corresponde exclusivamente a personas guatemaltecas, individuales o jurídicas. Los bosques y la vegetación en las riberas de ríos y lagos, y en las cercanías de las fuentes de agua gozan de protección especial ${ }^{26}$.

24. Reglamento de Ley de Áreas Protegidas, Arts. 24, 25, 26, 27 y 28.

25. Ley Forestal de Guatemala, Art. 47

26. Constitución Política de la República, Art. 126. 


\section{Análisis del ámbito de acción de la Administración Forestal}

\subsection{Competencias legales para el manejo de los recursos forestales}

Las competencias para el manejo de los recursos forestales están dadas, principalmente, por dos leyes ordinarias: Ley Forestal y Ley de Áreas Protegidas (véase cuadro 3). A continuación se presenta un breve análisis sobre el grado de descentralización y el nivel de efectividad de la institucionalidad forestal en el país, la cual tiene asignadas funciones de regulación, coordinación, control y supervisión de actividades de protección, manejo, transformación y comercialización forestal.

\section{Cuadro 6. Apuntes sobre grado de descentralización y nivel de efectividad de competencias instituciones en materia forestal}

\begin{tabular}{|l|l|l|}
\hline \multicolumn{1}{|c|}{ Competencia } & Grado de descentralización & \multicolumn{1}{|c|}{ Nivel de efectividad } \\
\hline $\begin{array}{l}\text { Coordinar y ejecutar políticas de } \\
\text { protección y aprovechamiento } \\
\text { sustentable de los recursos } \\
\text { forestales }\end{array}$ & $\begin{array}{l}\text { El CONAP e INAB cuentan con } \\
\text { delegaciones en toda la República. } \\
\text { Además, en varias municipalidades } \\
\text { existen oficinas forestales, así } \\
\text { como también mecanismos de } \\
\text { coordinación interinstitucional } \\
\text { que promueven el fortalecimiento } \\
\text { de la descentralización y la } \\
\text { desconcentración administrativa. } \\
\text { Actualmente se construye una } \\
\text { nueva política de bosques. }\end{array}$ & $\begin{array}{l}\text { En la práctica, en los } \\
\text { territorios no siempre se da la } \\
\text { efectiva descentralización o } \\
\text { pública. Se han hecho esfuerzos, } \\
\text { aunque no existe un seguimiento } \\
\text { en este sentido. }\end{array}$ \\
\hline $\begin{array}{l}\text { Supervisión y evaluación } \\
\text { del cumplimiento de } \\
\text { aprovechamientos forestales }\end{array}$ & $\begin{array}{l}\text { Actualmente más que } \\
\text { descentralización de las entidades } \\
\text { competentes se lleva a la práctica } \\
\text { procesos de desconcentración. }\end{array}$ & $\begin{array}{l}\text { Este es uno de los problemas más } \\
\text { sentidos, debido a los escasos } \\
\text { recursos con que cuentan las } \\
\text { instituciones competentes. }\end{array}$ \\
\hline $\begin{array}{l}\text { Aprobar o denegar planes } \\
\text { operativos }\end{array}$ & $\begin{array}{l}\text { No hay descentralización. } \\
\text { implementación y operación de }\end{array}$ & $\begin{array}{l}\text { Es efectivo, aunque la debilidad } \\
\text { siempre es la verificación en el } \\
\text { campo. }\end{array}$ \\
\hline incentivos forestales & $\begin{array}{l}\text { No hay descentralización. Las } \\
\text { funciones las maneja directamente } \\
\text { el INAB. }\end{array}$ & $\begin{array}{l}\text { El PIMPEP y el PINFOR han sido } \\
\text { programa muy exitosos, aunque } \\
\text { siempre su mayor debilidad está } \\
\text { en el control y verificación del } \\
\text { cumplimiento. }\end{array}$ \\
\hline $\begin{array}{l}\text { Diseñar e implementar estrategias } \\
\text { sobre el control de la deforestación }\end{array}$ & $\begin{array}{l}\text { Se hacen esfuerzos de } \\
\text { coordinación interinstitucional. }\end{array}$ & $\begin{array}{l}\text { Se ha creado un Grupo de } \\
\text { Coordinación Interinstitucional } \\
\text { de (GCI) en ese sentido, en dos } \\
\text { niveles: uno político y uno técnico, } \\
\text { yestá funcionando, empujando la } \\
\text { Estrategia Nacional de Reducción } \\
\text { de Deforestación (ENRD). }\end{array}$ \\
\hline
\end{tabular}




\begin{tabular}{|c|c|c|}
\hline Competencia & Grado de descentralización & Nivel de efectividad \\
\hline $\begin{array}{l}\text { Combate a la impunidad y } \\
\text { administración de sanciones }\end{array}$ & $\begin{array}{l}\text { No hay descentralización. } \\
\text { Cada institución opera bajo sus } \\
\text { competencias y en los niveles de } \\
\text { desconcentración internos. }\end{array}$ & $\begin{array}{l}\text { No ha sido muy efectiva por varias } \\
\text { razones, en su mayoría vinculadas } \\
\text { a recursos insuficientes, pero } \\
\text { también a la falta de políticas } \\
\text { y estrategias institucionales } \\
\text { para abordar el problema de } \\
\text { la impunidad. Actualmente } \\
\text { se desarrolla una Estrategia } \\
\text { Interinstitucional de Combate a } \\
\text { la Impunidad con varios actores, } \\
\text { entre los cuales está CONAP, } \\
\text { INAB, Ministerio Público, etc. }\end{array}$ \\
\hline Operación de registros forestales & $\begin{array}{l}\text { No hay descentralización, sino } \\
\text { mecanismos de desconcentración } \\
\text { hacia lo interno de las } \\
\text { instituciones. }\end{array}$ & $\begin{array}{l}\text { Es relativamente efectivo. Los } \\
\text { problemas son más bien en el } \\
\text { control y seguimiento. }\end{array}$ \\
\hline $\begin{array}{l}\text { Control de incendios, plagas y } \\
\text { enfermedades }\end{array}$ & $\begin{array}{l}\text { Se creó un Sistema de Prevención } \\
\text { y Control de Incendios (SIPECIF) } \\
\text { y se ha adscrito a la Coordinadora } \\
\text { Nacional para la Reducción de } \\
\text { Desastres. }\end{array}$ & $\begin{array}{l}\text { No es efectiva. No se asignan } \\
\text { recursos suficientes y el tema ha } \\
\text { quedado relegado dentro de los } \\
\text { temas de atención a desastres y } \\
\text { no a temas de prevención. }\end{array}$ \\
\hline $\begin{array}{l}\text { Políticas, iniciativas de ley, } \\
\text { reglamentación }\end{array}$ & $\begin{array}{l}\text { No hay descentralización, excepto } \\
\text { en el caso de la competencia } \\
\text { municipal que poco ha } \\
\text { desarrollado este aspecto. }\end{array}$ & $\begin{array}{l}\text { Es efectivo. El INAB como ente } \\
\text { autónomo y el CONAP, aunque no } \\
\text { es autónomo, tienen facultades } \\
\text { para desarrollar políticas y } \\
\text { regulaciones. Ambas instituciones } \\
\text { han establecido políticas y } \\
\text { regulaciones en su competencia. }\end{array}$ \\
\hline $\begin{array}{l}\text { Promover, ejecutar y supervisar el } \\
\text { sistema de valoración de bienes y } \\
\text { servicios ambientales del bosque }\end{array}$ & No se ha descentralizado. & $\begin{array}{l}\text { No ha sido muy efectivo, pues no } \\
\text { se han desarrollado los sistemas } \\
\text { de reconocimiento y pago por } \\
\text { servicios ambientales. Aún es } \\
\text { incipiente en el país, aunque hay } \\
\text { proyectos que se impulsan al } \\
\text { respecto con algunas ONGs. }\end{array}$ \\
\hline $\begin{array}{l}\text { Establecimiento de sistemas de } \\
\text { información forestal }\end{array}$ & $\begin{array}{l}\text { No se ha descentralizado } \\
\text { totalmente; sin embargo, se } \\
\text { hacen esfuerzos en el Sistema } \\
\text { Nacional de Información Forestal } \\
\text { y se construyen mecanismos } \\
\text { interinstitucionales para el manejo } \\
\text { de la información. }\end{array}$ & $\begin{array}{l}\text { Actualmente se fortalece el } \\
\text { Sistema de Información Forestal } \\
\text { de Guatemala, que es una } \\
\text { iniciativa interinstitucional. La } \\
\text { LMCC ordena la puesta en marcha } \\
\text { de un Sistema de Información } \\
\text { Nacional en Cambio Climático que } \\
\text { requerirá la eficiente operación de } \\
\text { sistemas de información forestal. }\end{array}$ \\
\hline
\end{tabular}

Fuente: Elaboración propia

En términos generales, la gran debilidad se manifiesta en la pobre asignación de recursos a la institucionalidad forestal del país y la falta de control y seguimiento, con fuertes mecanismos de transparencia y participación en el combate a la impunidad, también en la asignación insuficiente en la promoción e implementación de incentivos forestales y, por último, en la falta de visión sistémica de las relaciones entre lo forestal y el desarrollo sostenible del país. 


\subsection{Tipo de permisos forestales en el ámbito de acción de la Ley Forestal y afines}

El aprovechamiento sostenible de los recursos forestales, incluyendo la madera, semillas, resinas, gomas y otros productos no maderables, es otorgado por concesión si se trata de bosques en terrenos nacionales o municipales, o de entidades autónomas o descentralizadas y por licencia, si se trata de terrenos privados cubiertos de bosque. Las concesiones y licencias de aprovechamiento forestal en áreas protegidas las otorga el CONAP27.

\section{Cuadro 7. Diversos tipos de licencias o permisos para actividades forestales}

\begin{tabular}{|l|}
\hline Para manejo forestal \\
\hline Para saneamiento forestal \\
\hline Para el salvamento forestal \\
\hline Para fines científicos \\
\hline Uso y registro de motosierras \\
\hline Aprovechamientos familiares \\
\hline Para cambio de uso de la tierra \\
\hline Autorización de una industria forestal \\
\hline Autorización para instalación de depósito o venta de madera \\
\hline Notas de envío y guías para el transporte de madera \\
\hline Transferencia de licencia a otro propietario \\
\hline Actualización de los planes de manejo \\
\hline Licencias a colectividades pequeñas y medianas \\
\hline Modificación de planes de manejo \\
\hline Planes de manejo de fuentes semilleras \\
\hline Aprovechamientos de árboles con alto potencial de causar daño a viviendas e infraestructura \\
\hline Aprovechamientos por el mantenimiento de rutas viales y sistemas de transmisión eléctrica o de comunicación \\
\hline
\end{tabular}

Fuente: Adaptación propia con información de Ley Forestal y su Reglamento, y Ley de Áreas Protegidas y su Reglamento

27. Ley Forestal de Guatemala, Art. 3. 


\subsection{Diagrama legal-administrativo para que productos de madera accedan a los mercados de Estados Unidos y la Unión Europea}

Guatemala ha suscrito varios acuerdos y tratados comerciales con diferentes países y bloques estratégicos, como el caso del Tratado de Libre Comercio entre Estados Unidos, Centroamérica y República Dominicana (DR-CAFTA), así como tratados comerciales bilaterales con diferentes países. No hay un procedimiento nacional específico para que los productos ingresen a esos mercados. Aplican los procedimientos bajo la legislación vigente.

El gobierno tampoco ha ratificado FLEGT con la UE y parece ser que aún no se está de acuerdo en suscribir un Acuerdo Voluntario de Asociación (AVA). En marzo de 2013, FLEGT entró en vigencia para los europeos; eso es que ningún país europeo puede comprar madera que no demuestre que su compra es lícita. Suscribir un AVA lleva su tiempo. Es un proceso de discusión y socialización. Guatemala va en una segunda etapa, dentro de un proceso interno de mejoramiento de los sistemas de control y seguimiento.

Además, entiende que este proceso es un asunto de país, no es un plan para Lacey Act o el plan de acción FLEGT (UE). Se conformó una Comisión para responder a FLEGT, aunque las acciones se desarrollan por institución para hacerlo a nivel nacional y no a una iniciativa puntual. Se quieren establecer controles no orientados solo a la exportación, sino al mercado nacional. En el INAB ya se venía trabajando en una Estrategia del Combate a la llegalidad. Se diseñó un Plan de Acción interinstitucional y se conformó una Mesa Interinstitucional para la Prevención de la Tala llegal (CONAP, INAB, SAT). El convenio se firmó por 6 años. El plan y la sistematización o información en tiempo real exige la actualización de la norma. El convenio termina en el 2016 y la Vicepresidencia dirige el proceso para actualizarlo. No ha habido reuniones de alto nivel, pero sí a nivel administrativo y técnico del INAB. Dentro del plan está la línea de acción del marco del combate a la ilegalidad. En la actualidad se están elaborando nuevas normas. Ahora existirá un reglamento para fiscalizar empresas.

En Guatemala ha habido 2 reuniones con la Unión Europea con respecto a la transición de FLEG y no han sido tajantes para que inicie inmediatamente. Se espera una transición, por lo que están lanzando iniciativas a países que tengan la intención de suscribir un AVA con ellos, como es el caso de Honduras.

Este tema es complejo. Desde hace 2 años se está promoviendo en Guatemala. El INAB tiene un financiamiento con FAO para socializar FLEG. El INAB y el CONAP deben ver que están en un punto donde involucran al Ministerio de Relaciones Exteriores (MINEX) para que se conozca, primero como sector y luego por las autoridades. No hay iniciativa de alguna ley específica en el Congreso de la República. Guatemala no tiene una hoja de ruta y lleva un proceso de socialización de FLEG hacia arriba.

El país está avanzando en normas y sistemas para definir qué es madera legal, cómo se garantiza y cómo responde a las exigencias que pudiera tener FLEG y Lacey Act. Además, viene implementando procedimientos de Ventanilla Única Para las Exportaciones para la eficientización y agilización de procesos que ya venían desarrollándose hace un tiempo. Se realiza la verificación de todos los documentos. La VUPA no emite licencia de exportación si no se llena los requisitos. 
Los requisitos ${ }^{28}$ para la exportación son:

1. Poseer un Código de Exportador proporcionado por la Ventanilla Única Para las Exportaciones (VUPE).

2. Inscribirse como exportador de productos forestales ante el Registro Nacional Forestal del INAB.

3. Llenar el formulario de Ventanilla Única con los datos del exportador, del producto a exportar y su destino.

4. Contar con factura de venta.

5. Tener el listado de productos a exportar (dimensiones, volumen, clasificación de calidad).

6. Documentos que amparan el origen lícito de los productos (no puede exceder 6 meses de haber sido autorizados).

Los trámites se pueden hacer mediante el Servicio Electrónico de Exportaciones (SEADEX) según Acuerdo Gubernativo 575-98 del Ministerio de Economía, que permite obtener los documentos de exportación vía web con alta disponibilidad de transmisión, 24/7, los 365 días del año. El SEADEX es un sistema gratuito disponible en el portal VUPE.

Una vez cumplido los requisitos anteriores, el INAB extenderá el certificado para exportaciones de productos de madera.

Está prohibida la exportación de manera en troza rolliza o labrada y de madera aserrada de dimensiones mayores de doce centímetros de ancho, excepto:

- Postes, pilotes, durmientes y bloques impregnados a presión

- Productos de plantaciones voluntarias registradas en el INAB

- Partes de muebles y piezas de madera con valor agregado

La importación de especies, partes o derivados de la vida silvestre requieren contar con autorización del CONAP (Art. 73).

28. Fuente: Instituto Nacional de Bosques. [sitio web], (1996-2012). <http://www.inab.gob.gt/>. Accedido el 31 de marzo de 2014. 


\section{Esquema de los trámites que debe seguir un exportador de madera}

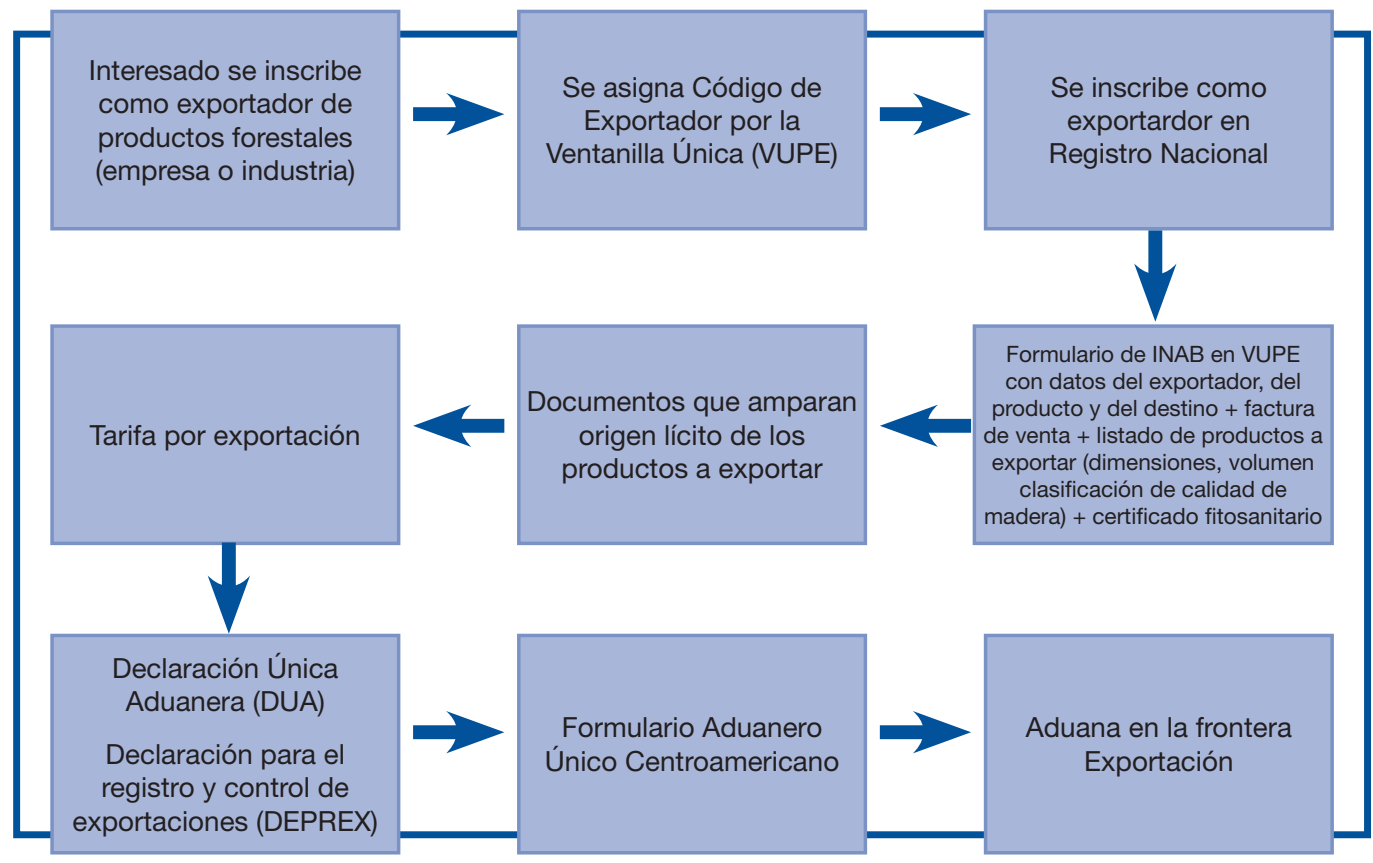

Fuente: Construcción propia con base en requisitos para la exportación de madera, Ley Forestal y su Reglamento, Ley de Áreas Protegidas y su Reglamento, Acuerdo Gubernativo 790-86, Acuerdo Gubernativo 575-98, Resolución Junta Directiva INAB 4-23-97, Acuerdo de Gerencia INAB 52-2001 


\section{Análisis del sistema de control forestal}

Al otorgarse una concesión, el INAB debe realizar controles periódicos que, como mínimo, serán de una vez al año, así como una evaluación quinquenal ${ }^{29}$.

La Ley Forestal establece que "las municipalidades ejecutarán los sistemas de vigilancia que se requieran para evitar los aprovechamientos ilegales de productos forestales a nivel de cada municipio, con el apoyo del INAB y apoyarán las actividades de éste, en el control del aprovechamiento autorizado de productos forestales; el INAB enviará copias de las licencias y planes de manejo a las municipalidades respectivas"30.

El INAB fiscaliza los aserraderos y aduanas del país con el fin de cuantificar, cualificar y verificar la procedencia lícita de los productos forestales ${ }^{31}$.

Con respecto al control estadístico, la Ley Forestal (Art. 88) establece que: "Con el propósito de censar las tierras cubiertas de bosques y de vocación forestal, así como de ejercer un control estadístico de las actividades técnicas y económicas sobre la materia, se crea a cargo del INAB el Registro Nacional Forestal, en el que se inscribirán de oficio o a petición de parte, según sea el caso:

a. Todos los bosques y tierras de vocación forestal, cualquiera que sea su régimen de propiedad, con expresión detallada de los bosques existentes y los datos de registro de la propiedad de las tierras y de la matrícula fiscal.

b. Los aserraderos urbanos y rurales, manuales o mecánicos, destiladores de resina, impregnadoras, procesadoras de celulosa y papel, carpinterías, fábricas de productos semielaborados o totalmente elaborados y demás industrias similares.

c. Las personas que se dediquen a repoblación forestal.

d. Las personas que realicen actividades de exportación o importación de productos forestales, cualesquiera sea su estado.

e. Las personas que se dediquen a la producción de resinas, látex y otros productos del bosque.

f. Los viveros forestales de todo el país.

g. Los productores y exportadores de semillas forestales.

h. Los profesionales y técnicos que actúen como Regentes Forestales indicados en el Artículo 50 de esta ley.

i. Las instituciones, organizaciones y asociaciones relacionadas con la investigación, extensión y capacitación en el área forestal y/o agroforestal".

En relación con el Control de Ingresos y Egresos de las Empresas Forestales ${ }^{32}$, la Ley Forestal establece que toda empresa está obligada a llevar el debido control de ingreso y egreso de productos

29. Ley Forestal de Guatemala, Art. 30..

30. ibid. Art. 58

31. ibid. Art. 63.

32. ibid. Arts. 13 y 64. 
forestales, por medio de notas de envío, libros u hojas móviles autorizados por el INAB, los que deberán ponerse a la vista de las autoridades competentes al momento de serles requeridos. Estos libros deberán llevarse tanto en la sede central de la entidad como en sus sucursales en el caso de que existan.

El control de los aprovechamientos forestales en áreas no protegidas corresponde al INAB y dentro de áreas protegidas al CONAP. El control del transporte en carreteras corresponde al Ministerio de Gobernación.

El control y vigilancia de las áreas protegidas, así como el control de recursos de vida silvestre dentro y fuera de áreas protegidas está a cargo del CONAP y de los guarda-recursos reconocidos por el CONAP. En este último caso, tienen carácter de autoridades y plena potestad para efectuar decomisos, presentar partes, detener, conducir y consignar a los tribunales a los infractores ${ }^{33}$. El CONAP también posee amplias facultades para la inspección, supervisión y control de las concesiones. Además, realiza el control de embarques de especímenes partes y derivados de la vida silvestre (Art. 74).

Para el control de las actividades de aprovechamiento de la vida silvestre, el CONAP lleva registro de las áreas protegidas, de la flora de especies protegidas o amenazadas de extinción comprendidas en el Convenio CITES y el listado nacional, así como un registro de personas que gozan de incentivos forestales y uno de fauna silvestre exótica ${ }^{34}$.

En la legislación forestal y de áreas protegidas no se identifican traslapes o conflictos de competencias. Es en la práctica y sobre todo, en las debilidades institucionales en lo que respecta a control y procedimientos en donde se encuentran algunas dificultades que se han venido identificando por las propias instituciones. En gran medida esas debilidades se deben a la carencia de recursos, pero también a la debilidad en las estrategias interinstitucionales para el efecto. Actualmente se tienen iniciativas para fortalecer la coordinación interinstitucional.

\subsection{Estadísticas forestales}

Tanto el INAB como el CONAP Ilevan estadísticas forestales. Se ha creado un Sistema Nacional de Información Forestal (SIFGUA), donde se pretende reflejar y transparentar toda la información en el manejo forestal en el país ${ }^{35}$.

Se ha definido como objetivo específico del sistema "la formulación, desarrollo e implementación del sistema nacional estadístico forestal, que permita la captura, procesamiento y difusión de información concerniente a la reforestación, deforestación, manejo forestal, aprovechamiento forestal, industrialización y elaboración de la madera, régimen ocupacional y comercialización de productos forestales en mercados internos y externos". En el Sistema participan diez organizaciones: INAB, CONAP, la Organización Internacional de las Maderas Tropicales, OIMT, Banco de Guatemala, Incidencia Ambiental, Cluster Forestal, AGEXPORT, Gremial Forestal, Instituto Nacional de Estadísticas y el SIPECIF.

33. Reglamento de la Ley de Áreas Protegidas, Art. 21.

34. Ley de Áreas Protegidas, Arts. 93-96.

35. Sistema de Información Forestal de Guatemala. [sitio web], (2008-2013). <http://www.sifgua.org.gt>. Accedido el 31 de marzo de 2014. 


\subsection{Control cruzado de certificados de comercio de productos de madera}

Actualmente se cuenta con el Sistema de Información Forestal Guatemalteco (SIFGUA), que trata de transparentar la información forestal del país. El sistema busca centralizar la información y que -de esta manera- se cuente con una sola fuente. Así se contará con una misma información sobre el manejo forestal dentro y fuera de áreas protegidas, comercio interno, comercio exterior y otra información relevante. Se trabaja en fortalecer la automatización de procesos que contemple toda la cadena de custodia de la madera. De esta forma el SIFGUA aportará al adecuado control forestal la transparencia y difusión de datos oportuna y accesible. Un ejemplo del manejo de información cruzada en el SIFGUA lo constituyen los datos de importación y exportación de madera, en donde para construir la estadística se ha tomado como fuente el Sistema Arancelario Centroamericano (SAC), la Ventanilla Única Para las Exportaciones (VUPE) instalada en la Asociación de Guatemalteca de Exportadores (AGEXPORT), el Banco de Guatemala y la Superintendencia de Administración Tributaria (SAT).

\subsection{Denuncias presentada por las autoridades del Estado por el delito de actividades forestales ilegales}

El ente encargado de la persecución penal en Guatemala es el Ministerio Público (MP), que actúa de oficio o a petición de parte. Usualmente son las entidades administrativas con competencia en materia forestal -esto es, CONAP, INAB, MARN y del Ministerio de Gobernación (Policía Nacional Civil)- quienes remiten las denuncias penales al MP para que sean investigadas.

No todas las instituciones públicas cuentan con un registro estadístico de denuncias presentadas. Incluso el mismo Ministerio Público lleva uno incompleto en donde sí es posible identificar las denuncias en materia forestal, pero no si ésta se da dentro de un área protegida. En este último caso, las denuncias pasan a formar parte de una estadística no diferenciada de delitos contra el ambiente; es por ello que se hace complejo presentar un cuadro estadístico que refleje con claridad y precisión la situación en materia de denuncias "forestales".

Una importante debilidad de la institucionalidad ambiental lo constituye el hecho de que no se llevan los adecuados registros y no exista un mecanismo cruzado que permita confirmar los datos generados por el conglomerado de entidades públicas que tienen que ver con la denuncia, su registro y seguimiento. En este sentido, se considera un importante asunto que resolver dentro de las acciones del combate a la impunidad. 


\section{Análisis de ejecución de procesos judiciales}

\subsection{Legislación forestal y afines con relación a los procesos judiciales aplicables al aprovechamiento forestal y comercio internacional de productos forestales}

Según el Instituto de Derecho Ambiental y Desarrollo Sustentable (IDEADS), las instancias con competencia en materia de los ilícitos forestales están organizadas de la forma siguiente: i) la administración pública (INAB, MARN, CONAP y municipalidades, entre otros) que debe poner en conocimiento del MP la ocurrencia de ilícitos forestales, ii) la administración de justicia en cuanto a la aplicación de la justicia y la sanción de los delitos forestales, iii) la producción de la normativa a través del organismo legislativo, que es el único que puede tipificar los delitos y las faltas forestales, iv) la Contraloría General de la Nación, el ente fiscalizador de la administración pública y v) los tribunales de honor de los colegios profesionales.

En el caso específico del Ministerio Público, se creó la Fiscalía de Delitos contra el Ambiente como una instancia especializada. Lamentablemente, a pesar de que dicha fiscalía tiene a su cargo la investigación y persecución de delitos forestales en todo el país, no cuenta con recursos suficientes para tener incidencia nacional. No existen procedimientos que garanticen que la fiscalía especializada tenga control de los casos forestales que llevan otras fiscalías.

Por su parte, se presenta una gran debilidad en las entidades encargadas de impartir justicia. El organismo judicial no cuenta con jueces especializados en materia ambiental. El actual Código Procesal Penal ordena la creación de tribunales ambientales, pero estos no se han creado.

Actualmente existe la carrera judicial y la Escuela de Estudios Judiciales exige que los aspirantes a jueces aprueben un curso de Derecho Ambiental.

El gran reto de la justicia ambiental es el combate a la impunidad ambiental. Es claro que los niveles de deforestación en el país muestran, claramente, que los órganos jurisdiccionales no atienden la mayoría de estos ilícitos, en parte por la falta de denuncias por parte de la ciudadanía; en parte, porque la administración pública no hace su trabajo de control y seguimiento, porque el órgano de investigación y persecución penal no cuenta con suficiente capacidad para atender los casos a nivel nacional y no se han implementado los mecanismos para el adecuado seguimiento y coordinación intra e interinstitucional.

En el año 2004, la Junta Directiva del INAB aprobó la Estrategia para el Combate a la llegalidad en la Actividad Forestal y en el año 2009 se desarrolló el Proyecto de Apoyo para la Implementación de la Estrategia para el Combate a la llegalidad en la Actividad Forestal con financiamiento del Banco Mundial (BM) en ejecución con el INAB y el apoyo de CATIE y el IARNA de la Universidad Rafael Landívar. El informe del proyecto indica que los niveles de impunidad en el país son elevados y que se requiere acciones en lo político, lo técnico, lo financiero y lo educativo para poder combatirla. 
El Lic. Alexander Douglas Villeda, Fiscal de Sección de la Fiscalía de Delitos contra el Ambiente, considera que -en promedio- los procesos judiciales duran entre 3 y 6 meses, pero que existen casos en los que pueden demorar hasta años. En realidad, puede ser muy variable y a ello contribuyen muchas circunstancias. Una de las causas más comunes es que en los juzgados se suspenden las audiencias. Muchas veces estas suspensiones se dan con el propósito de atrasar los procesos. Otro elemento que afecta bastante es el que los propios juzgados le dan prioridad a otro tipo de ilícitos. Por ejemplo, cuando se plantea decidir entre atender un caso por un delito en el que se encuentra detenida una persona y un caso ambiental en el cual la persona está libre, pues está gozando de una medida sustitutiva.

\subsection{Jurisprudencia relevante en relación con la compensación por daño ambiental por delitos de aprovechamiento ilegal de productos forestales}

No existe jurisprudencia en materia forestal en Guatemala (cinco fallos en el mismo sentido emitidos en Casación por la Corte Suprema de Justicia ó tres fallos por la Corte de Constitucionalidad). Lo que hay son precedentes judiciales.

En muchos casos, la Fiscalía de Delitos contra el Ambiente ha aplicado una política que consiste en buscar la desjudicialización, siempre que los sindicados estén dispuestos a comprometerse a reparar los daños causados y acepten que un técnico del INAB sea el que determine los términos en que esa reparación debe darse. Con ello se evita que al sindicado se le conmute su pena de prisión por una multa que -en la mayoría de los casos- no está en proporción con el daño causado y porque el sindicado, muchas veces, para evitar máculas en sus antecedentes penales accede a repararlo. Como principio, la desjudicialización no se aplica en casos de reincidencia.

Para determinar el daño la Ley Forestal (Art. 90) establece que se determinará con base en:

a. El valor del material dañado, explotado o exportado ilícitamente o dejado de reforestar.

b. Si el daño fue cometido en tierras nacionales o privadas.

c. La capacidad de producción y explotación forestal.

d. La gravedad del delito cometido.

e. Las lesiones económicas provocadas a la sociedad por la inversión de recursos en la lucha para mantener los recursos naturales.

f. Otras circunstancias que a juicio del juez sirvan para determinar el daño.

\subsection{Tipos de sanción existentes en la legislación guatemalteca vinculadas con la ilegalidad en el comercio de la madera}

A continuación se presenta un cuadro con los delitos y faltas establecidos tanto en la Ley Forestal como en la Ley de Áreas Protegidas vinculados con el comercio ilegal de madera. 


\section{Cuadro 8. Sanciones en la legislación guatemalteca}

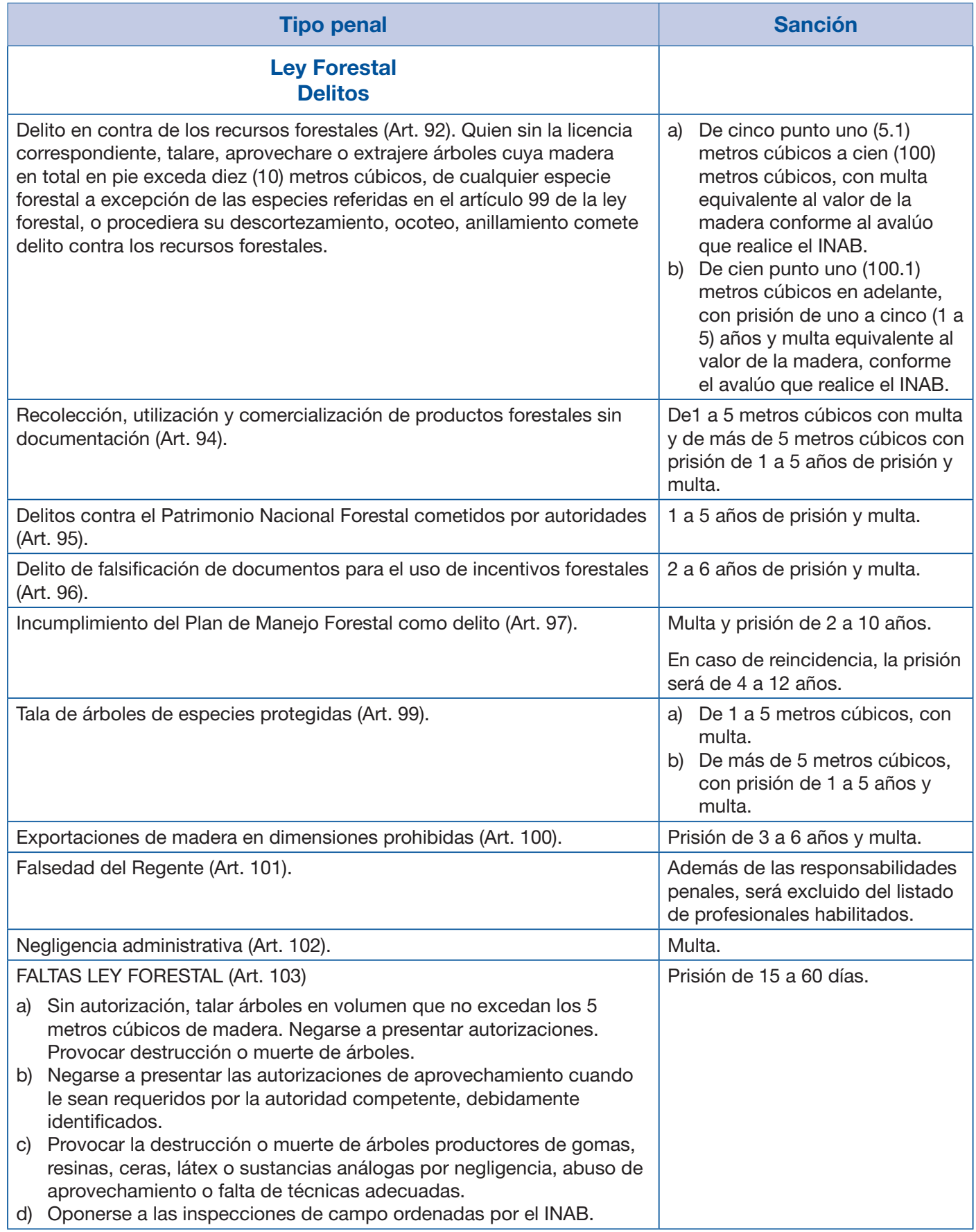




\begin{tabular}{|c|c|}
\hline Tipo penal & Sanción \\
\hline $\begin{array}{l}\text { LEY DE ÁREAS PROTEGIDAS. DELITOS: } \\
\text { Atentado contra el Patrimonio Natural y Cultural de la Nación. Quien } \\
\text { sin contar con licencia corta, recolectar, transportar, intercambiar } \\
\text { o comercializar ejemplares vivos o muertos, partes o derivados de } \\
\text { especies de flora y fauna silvestre no autorizados en la licencia o permiso } \\
\text { (Art. } 81 \text { bis). Incurren también en delito quienes contando con licencia se } \\
\text { extralimitaren o abusaren de los límites permitidos. }\end{array}$ & 5 a 10 años prisión y multa. \\
\hline $\begin{array}{l}\text { Tráfico ilegal de flora y fauna (Art. 82). "Quien ilegalmente transporte, } \\
\text { intercambie, comercialice o exporte ejemplares vivos o muertos, } \\
\text { partes oderivados de productos de flora y fauna silvestre amenazadas } \\
\text { de extinción, así como de las endémicas y de aquellas especies } \\
\text { consideradas dentro de los listados de especies amenazadas en peligro } \\
\text { de extinción publicados por el CONAP". }\end{array}$ & 5 a 10 años prisión y multa. \\
\hline $\begin{array}{l}\text { LEY DE ÁREAS PROTEGIDAS. FALTAS: } \\
\text { Negarse a devolver licencia a CONAP, ya prescrita sin justificar retención } \\
\text { (Art. 81). }\end{array}$ & Multa. \\
\hline Oponerse a inspecciones solicitadas o de oficio por CONAP (Art. 81). & \\
\hline
\end{tabular}

Fuente: Elaboración propia, según lo establecido en la Ley Forestal y Ley de Áreas Protegidas

"Las áreas de vocación forestal con bosque, en las que éste sea destruido o eliminado, sin la licencia correspondiente, sólo podrán destinarse a uso forestal. Al propietario o poseedor por cualquier título, además de imponérsele las sanciones que esta ley estipule, deberá repoblar el terreno bajo cualesquiera de los sistemas de repoblación forestal estipulados en esta ley, en un tiempo no mayor de dos años"36.

La Ley de Áreas Protegidas (Art. 83) estipula que: "Cuando las infracciones establecidas en este capítulo fuesen cometidas por alguna empresa autorizada para operar con productos de flora y fauna silvestre, ésta será sancionada con el doble de la multa, la primera vez, y si reincide, con el cierre de la empresa".

Con respecto al registro de las denuncias, se lleva uno, pero se debe constatar que los números que aparecen solamente brindan información muy general. Un primer asunto es el que se relaciona con el hecho de que el Ministerio Público está organizado en agencias de una manera un tanto especial. Una de ellas es la agencia relacionada con los delitos forestales afuera de las áreas protegidas; otra es la agencia de áreas protegidas. Las estadísticas se van formando con las cifras que reportan las agencias y estas no necesariamente contribuyen a identificar el tipo de delito al que se refieren. Por ejemplo, la cifra que aparece correspondiente al delito de "tráfico ilegal" no indica si se refiere al tráfico de un vegetal o un animal. Se hace imposible distinguir si fue madera. No obstante, sí se pueden reportar algunos números.

Como referencia se presenta un cuadro con información estadística del MP desde el año 2008. Para el caso de los delitos contra el ambiente, se cuenta con dos tipos de tabla. En una se consignan "todos los delitos contra el ambiente" y en la otra "solamente los delitos forestales" que se dieron fuera de áreas protegidas, pero sin especificar qué tipo de delito en particular.

36. Ley Forestal de Guatemala, Art. 43. 
A continuación se muestra un resumen de lo que se consigna en las tablas correspondientes a delitos solamente de tipo forestal ocurridos fuera de áreas protegidas:

Cuadro 9. Denuncias forestales en áreas no protegidas en el período 2008-2013

\begin{tabular}{|l|c|c|c|c|c|c|}
\hline \multicolumn{1}{|c|}{ Año } & 2008 & 2009 & 2010 & 2011 & 2012 & $\begin{array}{c}\text { A sep. } \\
2013\end{array}$ \\
\hline Total de denuncias & 299 & 246 & 252 & 190 & 209 & 177 \\
\hline $\begin{array}{l}\text { Total de sentencias } \\
\text { procedimiento común }\end{array}$ & 5 & 3 & 3 & 3 & 3 & 4 \\
\hline $\begin{array}{l}\text { Total sentencias procedimiento } \\
\text { abreviado }\end{array}$ & 6 & 4 & 4 & 6 & 3 & 13 \\
\hline Total de debates realizados & 6 & & 8 & 3 & 4 & 4 \\
\hline
\end{tabular}

Fuente: Elaboración propia

En términos generales, las leyes existentes son satisfactorias y los aspectos que llevan a problemas podrían ser resueltos vía el establecimiento de la normativa derivada de esas leyes y que aclare algunas dudas. Dicha normativa (reglamentos y disposiciones varias) debería homologarse y armonizarse.

También existen algunas debilidades normativas que bien se podrían resolver cuando las autoridades o las instituciones se pongan de acuerdo entre sí y dispongan cómo deben entenderse para efectos operativos. Algunos ejemplos son los siguientes: en una misma ley se habla de "madera en pie" y luego, de "metros cúbicos", lo que no le da seguridad sobre cómo proceder a los funcionarios que están en el campo. Otro caso se presenta porque las autoridades no se han puesto de acuerdo con respecto a qué entienden por "en" y por "fuera" de áreas protegidas. También se señala que el INAB "no quiere reconocer el listado de especies amenazadas". Como se puede ver, se trata de asuntos que -en buena medida- se podrían resolver si los altos mandos de las diferentes instituciones llegaran a un consenso y coordinaran entre sí.

Se ha planteado la cuestión de si sería adecuado aumentar las penas o no. Aún existen diferentes opiniones. Unos dicen que al aumentar las penas se estaría castigando más severamente a los que son consignados a los tribunales (que son los trabajadores en rango bajo y no los que son auténticamente responsables). Otros opinan que lo que hay que mejorar es la capacidad institucional para que se haga cumplir la ley.

Otro elemento que podría contribuir a mejorar la situación actual es por medio de la creación de juzgados especializados únicamente en el tema ambiental. Con ello se contaría con juzgadores con conocimiento del tema, así como con la certeza de que el juzgado va a conocer los casos ambientales sin relegarlos a un segundo plano o prioridad (como ocurre en la actualidad, cuando el juez da atención prioritaria a un caso en el que se encuentra una persona detenida por sobre aquel en que el sindicado está libre por gozar de una medida sustitutiva). 


\section{Aportes adicionales}

\subsection{Análisis de la situación legal-administrativa para el aprovechamiento de la madera y comercio internacional de productos forestales}

Las personas encuestadas coinciden en que el marco legal administrativo es aceptable y hasta bueno, aunque hay aspectos que sí deberían resolverse como, por ejemplo, el asunto de si es adecuado o no que en Guatemala coexistan dos servicios forestales (el del INAB y el del CONAP).

Otro asunto que se refiere con frecuencia es que, al estar el transporte en jurisdicción de la Policía Nacional Civil (PNC), tanto el INAB como el CONAP quedan al margen y se abren posibilidades de corrupción que inducen a que los madereros ya no confíen en estar en la "legalidad", pues esto resulta ser -en la práctica- un esfuerzo que no tiene sentido, ya que al final los problemas se resuelven con "mordidas" en la carretera o los caminos.

En lo que se refiere a la exportación, se reporta que los mayores problemas se dan en el transporte y las aduanas. Con frecuencia, la PNC, que vigila el transporte, detiene vehículos y les rompe el marchamo para verificar la mercadería que transportan sin seguir ningún protocolo. Lo hacen porque desconfían de que lo que realmente se transporte coincida con lo apuntado en la licencia. Pero esto ocasiona problemas en la frontera/aduanas y finalmente, al destinatario.

En lo que corresponde a las aduanas, las mejores están en los puertos marítimos. Aquí se revisa el contenido de los vehículos o contenedores a partir de un "sistema selectivo" (al azar) y se cumple estrictamente con un protocolo establecido y reconocido previamente. El procedimiento es aceptado y le da seguridad tanto a los exportadores como al INAB, pues se realiza en la presencia de representantes del exportador, de la Superintendencia de Administración Tributaria (SAT) y de un perito. Lamentablemente, en las aduanas terrestres no hay nada de esto. Existe gran corrupción, lo que da lugar a que los transportes pasen solamente con una "nota de envío de empresa" y no como debería ser- con "licencia de exportación" (extendida en la VUPE). Incluso, parece que existen aduanas en las cuales no se ejerce ningún control.

\subsection{Retos y oportunidades jurídicas, y estrategias de fortalecimiento en el corto y largo plazo para el aprovechamiento de la madera y comercio internacional de productos forestales}

El tenor general entre los encuestados es que para arreglar la situación no se debe pensar en "mejorar" la normativa, sino en buscar vías para que se solucione o garantice su correcta aplicación. De manera concreta, se necesita que la SAT agilice su control en las aduanas terrestres (adoptando los protocolos que ya se aplican en las aduanas marítimas y el sistema de "semáforos" ya tan difundido) y que la PNC proceda adecuadamente. 
Varios entrevistados coinciden en que un gran paso sería lograr que las autoridades se vinculen entre sí y coordinen sus acciones. También se apunta a que se debe dar especial atención a una adecuada y permanente capacitación del personal de la PNC y de la SAT en temas relacionados específicamente con la madera y condiciones que deben ser satisfechas para su legal exportación, así como lo relacionado con las especies amenazadas y el convenio CITES.

Un elemento de especial importancia es el relacionado con los denominados "puntos ciegos"; esto es, puntos en los cuales se da el trasiego internacional de productos y no son aduanas formales. Son puntos para el contrabando. Por eso se recomienda hacer los esfuerzos necesarios para detectarlos y controlarlos adecuadamente para que no funcionen.

La dependencia de la selva ha proporcionado beneficios de conservación para los pobladores que dependen de ella. La mayoría de las concesiones forestales comunitarias está por finalizar en 8 años (2021), por lo que es importante hacer una seria consideración para la extensión de esos beneficios en el caso de aquellas concesiones que han demostrado responsabilidad y cumplimiento en el manejo de los recursos naturales, en especial los forestales.

Se debe reformar los Artículos 81 y 83 de la Ley Forestal para que el INAB aumente la inversión del total de incentivos para la reforestación y mantenimiento de bosques naturales. El Programa de Incentivos Forestales (PINFOR) está por terminar en el año 2016, por lo tanto deberán apoyarse los esfuerzos por establecer un sustituto (se propone PROBOSQUES) para el establecimiento de plantaciones, su mantenimiento y el manejo de bosques naturales.

Un mecanismo de certificación que envuelve a la industria es lo que se conoce como Cadena de Custodia, que constituye uno de los elementos en términos de su gestión administrativa y los procedimientos para el seguimiento (tracking) de los productos, desde la fuente hasta los consumidores finales. Con respecto a esto existen pocas industrias en Guatemala con dicho certificado y la mayoría está asociada a los productos provenientes de las concesiones forestales ${ }^{37}$. Los principales problemas con la Cadena de Custodia se dan en el manejo administrativo de estos mecanismos, que es incipiente en Guatemala. Adicionalmente, la falta de estándares nacionales $\mathrm{u}$ oficialmente aprobados por Forest Stewardship Council (FSC) provoca que las evaluaciones se realicen sobre la base de los estándares internacionales.

Es fundamental promover los servicios ambientales generados o relacionados con el bosque, o la reducción de la deforestación y promover mecanismos de pago o reconocimiento por esos servicios, así como apoyar la constitución de incentivos para la conservación de la biodiversidad y las áreas protegidas. También deberá mantenerse actualizado el inventario forestal y mejorar los sistemas de control.

37. WWF-PROARCA, 2005. 


\subsection{Sugerencias a futuro para fortalecer la legalidad del proceso de aprovechamiento de la madera y comercio internacional de productos forestales y con ellos la conservación y aprovechamiento sostenible de los bosques}

Combatir la impunidad y el comercio ilícito de madera es un gran reto para el país. Se requiere la asignación de suficientes recursos para las instituciones responsables y la disposición de personal altamente capacitado para dar cumplimiento a los temas de seguimiento y control, así como en el fortalecimiento al sistema de justicia; en especial, crear tribunales especializados y en los lugares en donde no es posible, capacitar a los jueces y dar seguimiento a la resolución de los casos ambientales, sobre todo sentando precedentes judiciales exitosos y ejemplares. Se debe ampliar la capacidad de la Fiscalía de Delitos contra el Medio Ambiente a fin de que tenga cobertura a nivel nacional. También se necesita fortalecer el desarrollo e implementación de estrategias de combate a la impunidad forestal en Guatemala, lo que incluye la implementación de mecanismos de gobernanza más sofisticados que impliquen gran coordinación nacional e internacional. Así mismo, tiene que darse el adecuado manejo de los registros y estadísticas de denuncias y procesos judiciales que permitan mejorar los niveles de transparencia y seguimiento a las causas forestales.

Es relevante armonizar los procedimientos e instrumentos operativos para el manejo forestal fuera y dentro de las áreas protegidas, fortalecer el Sistema Nacional de Información Forestal (SIFGUA) y fomentar el control cruzado y la transparencia de la información. En ese sentido, debe reforzarse la "Agenda mínima interinstitucional de instrumentos, procedimientos y normas homologadas para la administración forestal, fuera y dentro de Áreas Protegidas" y dar prioridad a la puesta en marcha de las Estrategias de Reducción de la Deforestación, del Combate a la Impunidad Forestal y de la Estrategia Nacional de Producción Sostenible y Uso Eficiente de la Leña. Todas estas acciones tendrán impacto en la implementación de los tratados internacionales que suscriba el país y para el funcionamiento de mecanismos como Lacey Act y FLEGT.

Se requiere un abordaje del problema forestal desde un enfoque sistémico, que permita visibilizar la incidencia de las políticas económicas, sociales, energéticas y de desarrollo en el tema ambiental y forestal. Un claro ejemplo se encuentra en las políticas y planes nacionales de energía que deberán incidir en la reducción del consumo ilícito de madera, como un tema social, económico, ambiental y de adaptación y mitigación de cambio climático. Se recomienda que una nueva "Política de Bosques" recoja ese enfoque sistémico.

Para promover el comercio lícito se requiere mejorar la capacidad competitiva, específicamente en los temas de mercadeo y comercialización, formas y medios de financiamiento, sistemas de organización para el trabajo con enfoque empresarial, acompañado de la infraestructura y la tecnología adecuada. También es fundamental incrementar las capacidades para la cosecha forestal, integrando el bosque con la industria y resolver los temas de transporte y reducción de distancias bosque-industria. En las exportaciones se necesita dar mayor valor agregado al producto. Lo anterior demanda fortalecer la "Estrategia y Plan de Acción para el Desarrollo Foresto-Industrial".

La efectiva y pronta implementación de los incentivos forestales (PIMPEP, PROBOSQUES) es primordial como mecanismo para reducir el uso ilegal de la madera y la pérdida del bosque natural, 
reconociendo un adecuado valor al buen manejo y la conservación de los bosques como medidas estratégicas que reducen la vulnerabilidad, mejoran la adaptación, permiten la adaptación al cambio climático y aumentan la calidad de vida de las poblaciones.

Deberán desarrollarse herramientas que promuevan la descentralización y desconcentraciones de funciones en la implementación de los procedimientos administrativos y en los temas de seguimiento y control forestal. En un país de vocación forestal como Guatemala se requiere construir la "cultura forestal" en los ciudadanos y mejorar los procesos de participación pública informada.

Ante la enorme vulnerabilidad de la nación frente a los efectos adversos del cambio climático, de los cuales tendrá que soportar una carga anormal y desproporcionada, y a las condiciones del deterioro del suelo del territorio nacional y de la calidad y cantidad de agua, el manejo y conservación forestal es un asunto de sobrevivencia y de viabilidad de país. La situación demanda medidas urgentes.

Nota:

Después de la finalización de la presente investigación), 'la Junta Directiva del INAB aprueba el "Reglamento para la Fiscalización de Empresas Forestales" con el que se hace necesario el uso del Sistema Electrónico de Información de Empresas Forestales (SEINEF), el cual entró en vigencia el 18 de febrero de 2014. Este tiene por objetivo mejorar la eficiencia en la gestión forestal mediante los siguientes beneficios:

- Garantiza el origen lícito de los productos forestales al consumidor.

- Reduce la competencia desleal generada por el comercio ilegal de los productos forestales.

- Ahorra tiempo en las gestiones ante el INAB, permitiendo el acceso al Sistema en cualquier momento.

- Proporciona acceso electrónico a información sobre las posibilidades de mercado de bienes y servicios forestales, ya que el empresario puede promocionar sus productos.

- Facilita el comercio nacional e internacional al disponer de una base de información confiable y de ágil acceso sobre los inventarios de productos forestales.

Con el uso del SEINEF se garantiza el origen lícito de los productos forestales provenientes de las empresas registradas del sector'38.

"El 28 de abril de 2014 entró en vigencia el Reglamento para el Transportes de Productos Forestales y su Procedencia Lícita, el cual establece una vigencia de 24 horas para la notas de envío de bosque. Así también, el 28 de abril de 2014 entró en vigencia el Reglamento para la Fiscalización de Empresas Forestales"39.

38. Sistema Electrónico de Información de Empresas Forestales (SEINEF). [sitio web]. <http://186.151.231.165/ industrias/Importante.aspx>. Accedido el 31 de marzo de 2014.

39. ibid. 


\section{Bibliografía}

AGEXORT, COFAMA (2012). Guía de Empresario Responsable de la Madera. Guatemala.

CONAP (2008). Guatemala y su Biodiversidad: Un enfoque histórico, cultural, biológico y económico.

De Camino, R, Breitling, J. (2007). El Cambio es posible: 20 años de Experiencias Innovadoras en los Recursos Naturales de Guatemala. Departamento de Ambiente, Paz y Seguridad de la Universidad para la Paz, Costa Rica/COSUDE.

FAO, UE (enero 2002). Estado de la Información Forestal en Guatemala. Chile.

FAO, UICN, INAB. Growing Forest Partnership, Programa Nacional Forestal de Guatemala, The National Forest Programme Facility.

IARNA (2012). Perfil Ambiental de Guatemala 2010-2012. Vulnerabilidad Local y Creciente Construcción de Riesgo. Guatemala

IDEADS (2007). Manual de Legislación Ambiental. Guatemala.

INAB, CONAP, UVG, URL. Mapa de Cobertura Forestal de Guatemala 2010 y Dinámica de la Cobertura Forestal 2006-2010.

INAB (2011). Boletín Manejo Forestal Sostenible. Guatemala.

INAB (2012). Estrategia de Vinculación Bosque - Industria - Mercado de Guatemala.

INAB (2012). Propuesta de Política Nacional de Bosques.

INAB. Propuesta de Estrategia Nacional de Producción Sostenible y Uso Eficiente de Leña 20132024.

INAB (2006). Reglamento de la Ley Forestal. Resolución 01.43.2005.

INAB, CONAP (2011). Instrumentos, procedimientos y normas homologadas para la administración forestal, fuera y dentro de Áreas Protegidas, una agenda mínima interinstitucional. Guatemala.

INAB, IARNA, FAO (2012). Oferta y demanda de leña en la República de Guatemala. "Woodfuel Integrated Supply/Demand Overview Mapping". Guatemala.

Ley de Áreas Protegidas (1989). Decreto 4-89 del Congreso de la República.

Ley Forestal de Guatemala (1996). Decreto 101-96 del Congreso de la República.

Ley Marco de para Regular la Reducción de la Vulnerabilidad, la Adaptación Obligatoria ante los Efectos del Cambio Climático y la Mitigación de Gases de Efecto Invernadero, Decreto 7-2013 del Congreso de la República.

MAGA-PAFG. Plan de Acción Forestal para Guatemala (2003). Apoyo al seguimiento de la Agenda Forestal de Guatemala (2002-2012). Documento base. Proyecto GCP/GUA/OO8/NET. Guatemala.

MAGA, PAFG, INAB, CONAP (1999). Política Forestal de Guatemala.

Política de Diversidad Biológica de Guatemala. Acuerdo Gubernativo 220-2011 
Política Nacional de Cambio Climático. Acuerdo Gubernativo Acuerdo 329-2009

Reglamento de Transporte de Productos Forestales.

Zamora, R, Barrera Hofman, I (2010). Diagnóstico y Marco de Referencia de la Estrategia y Plan de Acción para el Desarrollo Foresto-Industrial de Guatemala. Guatemala. 


\section{El Salvador}

Jaime Héctor López Escobar 


\section{Acrónimos}

ANP:

ARF:

CAFTA-DR:

CF:

CIEX El Salvador:

CITES:

DGFCR:

DGSVA:

FGR:

LANP:

LCVS:

LF:

LMA:

MAG:

MARN:

PNC:

REDD+:

RLF:
Áreas Naturales Protegidas

Área de Recursos Forestales

Tratado de Libre Comercio entre Centroamérica, República Dominicana y los Estados Unidos

Comisión Forestal

Centro de Trámites de Importaciones y Exportaciones

Convención sobre el Comercio Internacional de Especies Amenazadas de Fauna y Flora Silvestres

Dirección General de Ordenamiento Forestal, Cuencas y Riego

Dirección General de Sanidad Vegetal y Animal

Fiscalía General de la República

Ley de Áreas Naturales Protegidas

Ley de Conservación de Vida Silvestre

Ley Forestal

Ley de Medio Ambiente

Ministerio de Agricultura y Ganadería

Ministerio de Medio Ambiente y Recursos Naturales

Policía Nacional Civil

Reducción de Emisiones de Gases de Efecto Invernadero por Deforestación Evitada

Reglamento de la Ley Forestal 


\section{Introducción}

El Salvador tiene una extensión territorial de $21.041 \mathrm{~km} 2$ y es considerado el país más deforestado de Centroamérica. Según el Informe sobre Desarrollo Humano (IDH) de 2013, presentado por el Programa de Naciones Unidas para el Desarrollo (PNUD), la cobertura forestal en el año 2010 era de $13,9 \%$ del territorio. No obstante, dos años antes fue de 14,3\%. Se estima que entre 1990 y 2010 , la reducción fue de aproximadamente $24 \%$. Estos datos reflejan una realidad y tendencia preocupante.

Según el documento titulado Cobertura Forestal de la República de El Salvador, C.A. Año 2010, del MAG, los factores de la reducción del área boscosa han sido ocasionados por los ciclos históricos de producción agrícola (añil, café y algodón). Además, la alta presión poblacional que sobrepasa los 300 habitantes por kilómetro cuadrado ocasiona la demanda de leña para cocinar y tierra para fines agrícolas. Conforme con el citado documento, para dicho año la superficie ocupada según el tipo de cobertura forestal fue la siguiente: árboles frutales: 4.315,59; bosque caducifolio: 40.747,57; bosque de galería: 15.394,69; bosque de mangle: 35.816,26; bosque siempre verde: 43.028,35; bosque de coníferas: 44.600,88; bosque mixto: 16.934,49; bosque mixto semicaducifolio: 66.193,75; café: 211.845,28; plantaciones de bosque monoespecífico: $2.955,85$ y sistemas agroforestales 439,57 (cantidades en hectáreas).

En el tema del comercio internacional, solo en el año 2013, las exportaciones de productos de madera, carbón vegetal y manufacturas de madera fueron de $\$ 8,635,492.98$, mientras que las importaciones en el mismo año ascendieron a $\$ 31,303,100$.

En este sentido, el estudio que ahora se presenta contiene información recabada de entrevistas hechas a los actores clave relacionados con la temática del aprovechamiento y comercio de madera en El Salvador, así como de la revisión bibliográfica, legal e informática y tiene como finalidad contribuir a los importantes esfuerzos que realiza la UICN dentro de la región. 


\section{Síntesis histórica de la formulación de la Ley Forestal y afines}

La primera referencia expresa aparece en la Ley Agraria del 11 de abril de 1907. El tema de bosques fue incluido bajo el título "Silvicultura" y entre otros aspectos regulaba la tala mediante el permiso correspondiente, que todo propietario de un terreno de más de cuarenta y cinco hectáreas estaba obligado a garantizar la formación de un bosque o a complementar el que ya existiera, en la proporción de una hectárea de bosque por cada cincuenta hectáreas de terreno, así como multas por su incumplimiento. Esta ley fue objeto de constantes reformas hasta que fue sustituida por otra de igual nombre, el 28 de agosto de 1941'. La nueva ley trajo consigo cambios en diferentes aspectos; empero en lo relativo a la silvicultura, el capítulo respectivo permaneció prácticamente invariable. El único cambio sustancial fue que el permiso para la tala debía pedirse al Alcalde Municipal y no al Gobernador Departamental como se preceptuaba en la primera ley.

Varios años después, el 7 de abril de 1949, se emitió el Decreto $N^{\circ} 115^{2}$, destinado a la protección de los bosques salados, vista la desconsiderada explotación de la cual estaba siendo objeto. El citado decreto regulaba, por tanto, la concesión de licencias para su explotación ${ }^{3}$. Este decreto también imponía la obligación gubernamental de crear un reglamento al respecto, lo cual se llevó a cabo en 1969 y se denominó Reglamento para la Explotación de Bosques Salados ${ }^{4}$. La importancia del referido reglamento estriba en que no se limitó únicamente al tema de las licencias, sino que también desarrolló disposiciones orientadas a la protección de los bosques, al uso de la madera salada y a las sanciones correspondientes.

Sin embargo, a pesar de estos instrumentos normativos, se estimó la necesidad de crear una ley con un enfoque diferente, por lo que en 1972 -después de presentado a la Asamblea Legislativa el primer proyecto de Ley Forestal- el Gobierno de El Salvador solicitó al Programa de las Naciones Unidas para la Agricultura y Alimentación que lo asistiera en un proyecto destinado a diseñar y demostrar prácticas modernas de conservación de áreas forestales. En un informe preliminar se identificó la necesidad de realizar una adecuada reforestación gradual y progresiva, con intensificación y reforzamiento de las medidas preventivas contra incendios y plagas forestales, así como la creación de parques nacionales, establecimiento de industrias forestales y mejoramiento de las condiciones de vida de la población campesina vinculada con el bosque.

Pero este informe también incorporaba una especie de diagnóstico legal e institucional relacionado con el sector forestal que prácticamente denunciaba la necesidad de una ley forestal básica para el ordenamiento de la riqueza forestal pública y privada. Señalaba además la insuficiencia del servicio

1. Decreto Legislativo $\mathrm{N}^{\circ} 60$ del veintidós de agosto de 1941, publicado en el Diario Oficial $\mathrm{N}^{\circ} 66$, Tomo 132 , de fecha 21 de marzo de 1942.

2. Decreto Ejecutivo dado en la Casa de Gobierno Revolucionario y publicado en el Diario Oficial $\mathrm{N}^{\circ} 82$, Tomo 146, de fecha 8 de abril de 1949.

3. La aplicación del Decreto $\mathrm{N}^{\circ} 115$ fue ampliada por medio del Decreto $\mathrm{N}^{\circ} 161$ del 11 de junio de 1949 , publicado en el Diario Oficial $\mathrm{N}^{\circ} 131$, de fecha 16 de junio del mismo año.

4. Decreto $\mathrm{N}^{\circ}$ 53, del 28 de mayo de 1969, publicado en el Diario Oficial $\mathrm{N}^{\circ} 105$, Tomo 223 , de fecha 10 de junio de 1969. 
forestal, dado su carácter incipiente en cuanto a medios y organización. Incluso, el informe incluyó comentarios sobre el proyecto de Ley Forestal que estaba pendiente de discusión y aprobación, evidenciando la necesidad de mejorarlo. El resultado fue un nuevo proyecto de Ley Forestal que armonizó criterios técnicos, superó defectos y precisó terminología jurídica, entre otras innovaciones. La ley fue aprobada en 1973 y publicada en el Diario Oficial № 50 del 13 de marzo del mismo año.

En el año 2002, a casi treinta años de la vigencia de la Ley Forestal, se consideró que esta ya no respondía a los objetivos de la política del Estado, en el sentido de estimular la participación del sector privado en el incremento de la cobertura arbórea con fines productivos, así como establecer reglas claras para el libre aprovechamiento de plantaciones forestales y de bosques por regeneración inducida que llevaran a contribuir a solventar las necesidades económicas, ambientales y sociales de las actuales y futuras generaciones. En consecuencia, se promulgó una nueva Ley Forestal vigente a esta fecha ${ }^{5}$. La nueva Ley Forestal, además de procurar el incremento, manejo y aprovechamiento en forma sostenible de los recursos forestales y el desarrollo de la industria maderera, también se ocupó de declarar de "interés económico" el desarrollo forestal del país. Dos años más tarde de su promulgación, se emitió su Reglamento ${ }^{6}$ para su eficaz aplicación, puesto que desarrolla con más detalles las principales figuras jurídicas contenidas en la ley. Obsérvese que para la Ley Forestal de 1973 no se emitió ningún reglamento.

Además de la Ley Forestal (LF) y su reglamento, también existen otros instrumentos que tienen incidencia en el tema forestal, por ejemplo, la Ley del Medio Ambiente (LMA) y su Reglamento General, Ley de Conservación de Vida Silvestre (LCVS), Ley de Áreas Naturales Protegidas (LANP), Código Municipal, Código Penal y la Convención sobre el Comercio Internacional de Especies Amenazadas de Fauna y Flora Silvestres, (CITES), entre otras.

\section{Cuadro 1. Aspectos relevantes de las leyes forestales promulgadas}

\begin{tabular}{|l|l|}
\hline \multicolumn{1}{|c|}{ Legislación } & \multicolumn{1}{c|}{ Aspectos relevantes } \\
\hline Ley Agraria, 1907 & $\begin{array}{l}\text { Permitiría la tala de bosques mediante el permiso correspondiente otorgado por el } \\
\text { Gobernador Departamental pertinente. }\end{array}$ \\
\hline Ley Agraria, 1941 & $\begin{array}{l}\text { El permiso para la tala debía pedirse al Alcalde Municipal y no al Gobernador } \\
\text { Departamental. }\end{array}$ \\
\hline Decreto 115, 1949 & $\begin{array}{l}\text { Destinado a la protección de los bosques salados. Regulaba la concesión de licencias } \\
\text { para su explotación. Ordenó la creación de un reglamento. }\end{array}$ \\
\hline $\begin{array}{l}\text { Reglamento para } \\
\text { la Explotación de } \\
\text { Bosques Salados, } \\
1969\end{array}$ & $\begin{array}{l}\text { Su importancia fue que no se limitó únicamente al tema de las licencias, sino que } \\
\text { también desarrolló disposiciones orientadas a la protección de los bosques, al uso de } \\
\text { la madera salada y las sanciones pertinentes. }\end{array}$ \\
\hline
\end{tabular}

5. Decreto Legislativo $N^{\circ} 852$ del 22 de mayo de 2002, publicado en el Diario Oficial $N^{\circ} 110$, Tomo 355, de fecha 17 de junio de 2002.

6. Decreto $N^{\circ} 53$ del 14 de mayo de 2004, publicado en el Diario Oficial $N^{\circ} 158$, Tomo 364, de fecha 27 de agosto de 2004. 


\begin{tabular}{|l|l|}
\hline \multicolumn{1}{|c|}{ Legislación } & \multicolumn{1}{|c|}{ Aspectos relevantes } \\
\hline Ley Forestal, 1973 & $\begin{array}{l}\text { Fue la primera que reguló propiamente lo relativo a la materia forestal, } \\
\text { conservación, fomento y desarrollo de los recursos naturales renovables. Ordenó el } \\
\text { aprovechamiento forestal, ya sea del patrimonio nacional o privado y estableció las } \\
\text { medidas tendientes a incrementar la masa boscosa del país, así como las actividades } \\
\text { que representen el mejor método para conseguir una silvicultura avanzada y eficaz. }\end{array}$ \\
\hline Ley Forestal, 2002 & $\begin{array}{l}\text { Declara de interés económico el desarrollo forestal del país, desde el establecimiento } \\
\text { de la plantación hasta el aprovechamiento final y todas sus formas de valor agregado. } \\
\text { Crea la Comisión Forestal. Busca estimular la participación del sector privado en el } \\
\text { incremento de la cobertura arbórea con fines productivos, así como establecer reglas } \\
\text { claras para el libre aprovechamiento de plantaciones forestales y de bosques. }\end{array}$ \\
\hline $\begin{array}{l}\text { Reglamento de la } \\
\text { Ley Forestal, 2004 }\end{array}$ & $\begin{array}{l}\text { Desarrolla con más profundidad las principales disposiciones de la ley, como los } \\
\text { planes de manejo forestal, guías de transporte, registro forestal, inventario y sistema } \\
\text { de información forestal, infracciones y sanciones. }\end{array}$ \\
\hline
\end{tabular}

Fuente: Elaboración personal

\subsection{Formas de participación pública contenidas en políticas, leyes forestales y afines, nivel de implementación y los procesos necesarios para su efectividad}

La participación pública es elemental en toda sociedad democrática. En El Salvador, su importancia deviene de la misma Constitución de la República ${ }^{7}$ y se recoge en diferentes instrumentos jurídicos como parte de la democracia participativa.

La Ley Forestal y afines reconocen espacios para la referida participación. No obstante, es de hacer notar que la recién aprobada Ley de Acceso a la Información Pública ${ }^{8}$ puntualmente señala en su considerando IV que la transparencia y el acceso a la información pública son condiciones básicas para una efectiva participación ciudadana, lo cual contribuye al fortalecimiento de las instituciones públicas, al mejoramiento de la calidad de la democracia y a la plena vigencia del Estado de derecho. En este sentido, para la aprobación misma de cada instrumento normativo, ya sea por parte de la Asamblea Legislativa o del Órgano Ejecutivo, se abren espacios de consulta a diferentes sectores de la población, donde se escuchan sus opiniones conforme a los intereses que representan y por consiguiente, estos espacios pueden considerarse efectivos.

Ahora bien, la Ley Forestal (LF) y afines tienen sus propios mecanismos de participación ciudadana para abordar los temas relacionados con el ambiente y particularmente el forestal. En el caso de la LF, el espacio creado para tal efecto es la Comisión Forestal, conformada por representantes del sector forestal y el gobierno. Está encargada de velar por el desarrollo tecnológico e industrial de los recursos forestales, incentivos y demás actividades que tiendan a la recuperación y aprovechamiento sostenible de la cobertura arbórea en el territorio nacional. Sin embargo, este mecanismo -que en principio era la principal instancia participativa- todavía debe alcanzar más protagonismo,

7. Decreto $N^{\circ} 38$ del 15 de diciembre de 1983, publicado en el Diario Oficial $N^{\circ} 234$, Tomo 281, de fecha 16 de diciembre de 1983.

8. Decreto Legislativo $N^{\circ} 534$ del 2 de diciembre de 2010, publicado en el Diario Oficial $N^{\circ} 70$, de fecha 8 de abril de 2011. 
puesto que aglutina a importantes organizaciones del sector productivo y hoy también incorpora a representantes de los pueblos indígenas. En este sentido, para alcanzar un grado de efectividad óptimo se requiere más apoyo institucional, puesto que dicha Comisión lleva poco más de diez años de existir.

Lo que sí ha resultado muy efectivo, en términos de participación pública, ha sido la realización de la Política Forestal para El Salvador $2011-2030^{\circ}$, ya que para su elaboración participaron diferentes sectores de la población mediante un proceso concertado y democrático. Fue impulsada por el Ministerio de Agricultura y Ganadería (MAG), por medio de la Dirección General de Ordenamiento Forestal, Cuencas y Riego (DGFCR). Según dicha política, uno de sus principios es la gestión participativa, en virtud de la cual habrá una intervención conjunta entre la sociedad y el gobierno para compartir decisiones, responsabilidades, costos y beneficios en la ejecución de la política forestal consensuada. No obstante, esta política forestal -a pesar de que ha sido suficientemente consultada- todavía no ha logrado su correspondiente aprobación. Pero cuando esto ocurra, motivaría importantes cambios en el tema de la gestión forestal y puntualmente al de la participación social.

En lo que respecta a las leyes afines, como la $L M A^{10}$, LANP ${ }^{11}$ y LCVS ${ }^{12}$, es el Ministerio de Medio Ambiente y Recursos Naturales (MARN) la autoridad administrativa encargada de ejecutar los mecanismos de participación contenidos en estas. Es importante destacar que la LMA considera la participación de la población como un instrumento de la política del medio ambiente. En este sentido, la consulta pública realizada por dicho Ministerio resulta ser eficaz por cuanto está reconocida como un derecho en la LMA y un requisito elemental conforme a la citada ley para la toma de decisiones en todo lo relacionado con políticas, planes, programas, concesiones para la explotación de recursos naturales, así como de otras obras o proyectos (ver Arts. 8,9, 11 (d) y 25 de la LMA).

Por su parte, la LANP tiene como principal mecanismo de consulta y debate el Consejo Nacional de Áreas Naturales Protegidas, el cual también puede estimarse efectivo si se toma en consideración la amplia participación de diferentes sectores de la población que la integran, es decir, desde el sector gubernamental hasta universidades y toda organización no gubernamental legalmente establecida.

El Código Municipal ${ }^{13}$ es otro importante cuerpo normativo en tanto que tiene por objeto desarrollar los principios constitucionales referentes a la organización, funcionamiento y ejercicio de las facultades autónomas de los municipios. En este sentido, siendo el Municipio ${ }^{14}$ la Unidad Política Administrativa primaria dentro de la organización estatal, su relación con la realidad local es de relevante importancia por la participación pública local que se deriva de él. Entre los mecanismos

9. Se encuentra en espera de ser aprobada.

10. Decreto Legislativo № 233 del 2 de marzo de 1998, publicado en el Diario Oficial $N^{\circ} 79$, Tomo $N^{\circ} 339$, de fecha 4 de mayo de 1998.

11. Decreto Legislativo $N^{\circ} 579$ del 13 de enero de 2005, publicado en el Diario Oficial $N^{\circ} 32$, Tomo $N^{\circ} 366$, de fecha 15 de febrero de 2005.

12. Decreto Legislativo $N^{\circ} 844$ del 14 de abril de 1994, publicado en el Diario Oficial $N^{\circ} 96$, Tomo $\mathrm{N}^{\circ} 323$, de fecha 25 de mayo de 1994.

13. Decreto Legislativo $N^{\circ} 274$ del 31 de enero de 1986, publicado en el Diario Oficial $N^{\circ} 23$, Tomo $N^{\circ} 290$, de fecha 5 de febrero de 1986.

14. Administrativamente El Salvador se compone de doscientos sesenta y dos (262) municipios repartidos en catorce Departamentos. 
de participación ciudadana están el cabildo abierto, consulta popular, consulta vecinal y sectorial y comités de desarrollo local, entre otros. Sin embargo, conforme al Art. 125-F, cada Municipio regulará lo relativo a dicha participación mediante la correspondiente ordenanza municipal ${ }^{15}$; pero en el tema forestal no tiene mayor aplicación práctica.

\subsection{Análisis de la institucionalidad forestal y competencias en torno al aprovechamiento forestal y comercio internacional de productos forestales}

EI MAG es una Secretaría de Estado que conforme a la Ley Forestal es responsable de la aplicación de esta normativa y la autoridad competente para conocer de la actividad forestal productiva. Forma parte de la estructura organizativa del Órgano Ejecutivo y la representa un Ministro nombrado por el Presidente de la República. Sin embargo, la labor estrictamente forestal, en cuanto al tema del aprovechamiento, está encomendada al Área de Recursos Forestales (ARF), que es una dependencia de la División de Recursos Forestales y Cuencas Hidrográficas, y esta a su vez, está subordinada a la Dirección General de Ordenamiento Forestal, Cuencas y Riego del MAG. A dicho Ministerio también pertenece la Dirección General de Sanidad Vegetal y Animal (encargada de la actividad fitosanitaria, según las normas internacionales aplicables) y la Comisión Forestal (CF), que funge como un ente asesor de la institución. Asimismo, el MAG -conforme al Reglamento Especial Para Regular el Comercio Internacional de Especies Amenazadas de Fauna y Flora Silvestres, según la Convención sobre el Comercio Internacional de Especies Amenazadas de Fauna y Flora Silvestres (CITES)- es la autoridad administrativa para este efecto, así como en todo lo referente a los permisos, certificados y procedimientos para los casos de exportación e importación, según los respectivos apéndices de la Convención.

El Organismo Internacional Regional de Sanidad Agropecuaria (OIRSA) asimismo tiene participación institucional, emitiendo -cuando sea el caso- el certificado OIRSA según la Norma Internacional para Medidas Fitosanitarias (NIMF-15).

El Ministerio de Economía (MINEC), que también es una Secretaría de Estado, se encarga de todo lo relacionado con la promoción del comercio interno, regional e internacional, así como la apertura o expansión de mercados para los productos nacionales, procura el desarrollo económico y social, mediante el incremento de la producción, la productividad y la racional utilización de los recursos económicos del país. De igual manera, debe garantizar precios justos a los productores, comerciantes y consumidores, y controla la adecuada aplicación del sistema de pesas y medidas, entre otras funciones.

En el tema de exportaciones, la principal oficina creada para tal fin es el Centro de Trámites de Importaciones y Exportaciones (CIEX El Salvador), una dependencia del Banco Central de Reserva de El Salvador (BCR), cuyo objetivo es precisamente centralizar, agilizar y simplificar los trámites de exportación de las instituciones involucradas en la actividad exportadora y de la que se ampliará en información en el apartado correspondiente.

15. Las ordenanzas son normas de aplicación general dentro del municipio sobre asuntos de interés local, Art. 32 del Código Municipal. 
Consecuentemente, si se examinan las competencias de las instituciones involucradas en el tema de aprovechamiento y comercio forestal, puede inferirse que estas se encuentran claramente distribuidas y estructuradas, y que incluso existe una oficina que todavía facilita la coordinación entre ellas en lo que al comercio se refiere, por lo que no se advierten conflictos ni traslapes de relevancia entre todas (véase el Cuadro 2 para ampliar más al respecto).

\section{Cuadro 2. Funciones de la institucionalidad en relación con el aprovechamiento del comercio internacional de productos forestales}

\begin{tabular}{|c|c|}
\hline $\begin{array}{l}\text { Institución } \\
\text { pública }\end{array}$ & Competencias \\
\hline $\begin{array}{l}\text { Ministerio de } \\
\text { Agricultura y } \\
\text { Ganadería (MAG) }\end{array}$ & 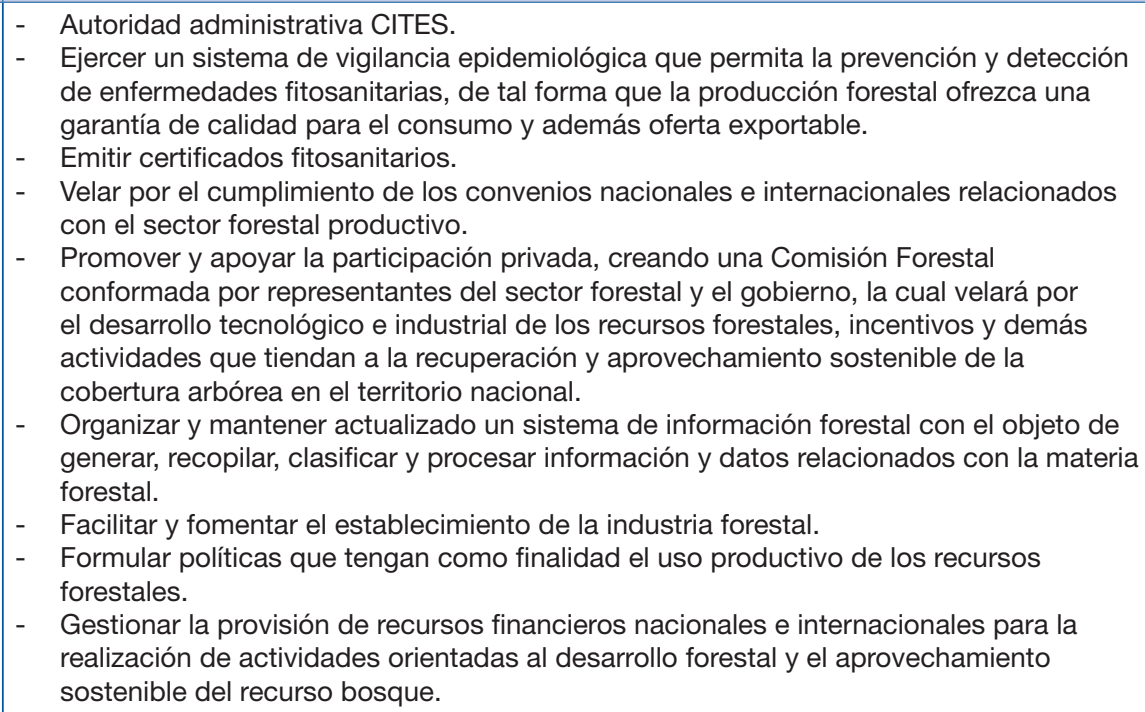 \\
\hline $\begin{array}{l}\text { Área de } \\
\text { Recursos } \\
\text { Forestales (ARF) }\end{array}$ & $\begin{array}{ll}\text { - } & \text { Establecer políticas y estrategias de desarrollo del recurso forestal. } \\
\text { - } & \text { Impulsar acciones y mecanismos que permitan el manejo sostenible de los recursos } \\
\text { - } & \text { Evaluar, aprobar y dar seguimiento a los planes de manejo forestal. } \\
\text { - } & \text { Promover y apoyar la participación privada en el desarrollo forestal. } \\
\text { - } & \text { Planificar y ejecutar proyectos de investigación, capacitación, educación, protección e } \\
\text { industrialización de los recursos forestales. } \\
\text { - } \quad \text { Formular y proponer a la Dirección instrumentos técnicos normativos que tengan } \\
\text { - } \quad \text { Elabo finalidad el uso productivo de los recursos forestales. } \\
\text { - Economía y la Comisión Forestal. } \\
\text { - Promover el incremento, manejo y aprovechamiento en forma sostenible de los } \\
\text { - } \quad \text { Realizar y el desarrollo industrial forestal. } \\
\text { internacionales relacionados compromisos derivados de los convenios nacionales e } \\
\end{array}$ \\
\hline \begin{tabular}{|l|} 
Comisión \\
Forestal (CF)
\end{tabular} & $\begin{array}{ll}\text { - } & \text { Colaborar con el Ministerio de Agricultura y Ganadería en la elaboración del programa } \\
& \text { de incentivos forestales. } \\
\text { - } & \text { Impulsar el desarrollo tecnológico e industrial del sector forestal. } \\
\text { - } & \text { Colaborar en la formulación de políticas forestales. } \\
\text { - } & \text { Apoyar la asociatividad productiva del sector forestal. }\end{array}$ \\
\hline
\end{tabular}




\begin{tabular}{|c|c|}
\hline $\begin{array}{l}\text { Institución } \\
\text { pública }\end{array}$ & Competencias \\
\hline $\begin{array}{l}\text { Ministerio de } \\
\text { Economía } \\
\text { (MINEC) }\end{array}$ & 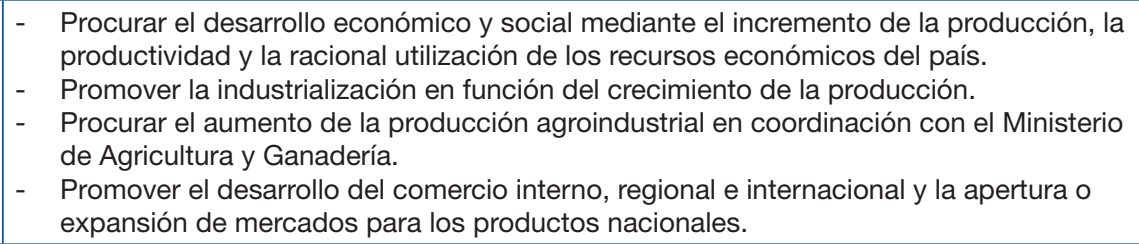 \\
\hline $\begin{array}{l}\text { CIEX, El } \\
\text { Salvador (antes } \\
\text { CENTREX) }\end{array}$ & $\begin{array}{l}\text { - Centralizar, agilizar y simplificar los trámites de exportación de las instituciones } \\
\text { involucradas en la actividad exportadora. }\end{array}$ \\
\hline $\begin{array}{l}\text { Ministerio de } \\
\text { Medio Ambiente } \\
\text { y Recursos } \\
\text { Naturales } \\
\text { (MARN) }\end{array}$ & $\begin{array}{ll}\text { - } & \text { Autoridad científica de CITES. } \\
\text { - } & \text { Formular, planificar y ejecutar las políticas de medio ambiente y recursos naturales. } \\
\text { - } & \text { Ejercer la dirección, control, fiscalización, promoción y desarrollo en materia de medio } \\
& \text { ambiente y recursos naturales. } \\
\text { - } & \text { Realizar la gestión y aprovechamiento sostenible de los bosques. Incluso deja } \\
& \text { claramente establecido que esa gestión se realizará en coordinación con el MAG. }\end{array}$ \\
\hline $\begin{array}{l}\text { Dirección } \\
\text { General de } \\
\text { Aduanas, } \\
\text { Ministerio de } \\
\text { Hacienda }\end{array}$ & $\begin{array}{ll}\text { - } & \text { Aplicar la normativa aduanera y verificar su exacto cumplimiento. } \\
\text { - } & \text { Facilitar y controlar el comercio internacional en lo que le corresponda. } \\
\text { - } & \text { Tasar los derechos e impuestos a que estén afectos, el ingreso o la salida de } \\
& \text { mercancías de acuerdo con los distintos regímenes que se establezcan. } \\
\text { - } & \text { Fiscalización de las obligaciones aduaneras. } \\
\text { - } & \text { Prevención y represión de las infracciones aduaneras cuando le corresponda. } \\
\text { - } & \text { Autoridad CITES con competencia para la observancia. }\end{array}$ \\
\hline Academia & $\begin{array}{l}\text { La Universidad de El Salvador (UES) participa en la Comisión Forestal. Asimismo, las } \\
\text { universidades que tengan la carrera de Ingeniería Agronómica o Biología son parte } \\
\text { del Consejo Nacional de Áreas Naturales Protegidas, que funge como principal foro } \\
\text { consultivo respecto al Sistema de Áreas Naturales Protegidas. }\end{array}$ \\
\hline
\end{tabular}

\subsection{Análisis de la consistencia entre la Ley Forestal y afines con otras legislaciones referidas al comercio internacional de productos de madera}

La Ley Forestal y afines son consistentes entre sí, así como con respecto al tema del comercio internacional. De hecho, la primera atribución que la citada ley y su reglamento confieren al Ministerio de Agricultura y Ganadería es velar por el cumplimiento de los convenios nacionales e internacionales relacionados con el sector forestal productivo.

La Ley de Conservación de Vida Silvestre, en su Artículo 42, le impone al MAG el deber de velar por el cumplimiento y aplicación de los convenios vinculados con el comercio internacional de especies amenazadas de fauna y flora silvestre. Mientras, en el Artículo 6 (letra k) estipula que le corresponde al MARN velar por el cumplimiento de los convenios internacionales ratificados por El Salvador en materia de conservación de la vida silvestre. Adviértase que cada Secretaría de Estado tiene su propia competencia en relación con la vida silvestre.

En este sentido, El Salvador es parte de la Convención sobre el Comercio Internacional de Especies Amenazadas de Fauna y Flora Silvestres. Incluso, mediante el Decreto Ejecutivo $N^{\circ} 45$, se ha 
desarrollado un Reglamento Especial en virtud del cual se exigen certificados especiales CITES para el comercio conforme a los apéndices correspondientes.

La Ley de Sanidad Vegetal y Animal ${ }^{16}$ también se refiere al tema. El Considerando III del Decreto $N^{\circ} 524$ que la contiene menciona como justificación de la ley que los procesos de reactivación económica e integración regional demandan la modernización del Estado en su organización y estructura fitosanitaria y zoosanitaria para atender las exigencias de la apertura del comercio internacional agropecuario y en ese sentido se desarrolla la ley.

En cumplimiento de lo dicho, la Dirección General de Sanidad Vegetal y Animal emite los certificados fitosanitarios de acuerdo con las normas internacionales para medidas fitosanitarias reguladas para tal fin (NIMF-12), mientras que el certificado OIRSA se emite respetándose la NIMF-15.

Pero también tienen incidencia directa los tratados y acuerdos comerciales que El Salvador ha suscrito con diferentes países del mundo ${ }^{17}$, por ejemplo, el Tratado de Libre Comercio CAFTA-DR, en virtud del cual se cumple con la Lacey Act y pese a que El Salvador no es parte de la iniciativa FLEGT, se cumplen con los requisitos que para tal efecto se regulan, según acuerdos comerciales y exigencias de los países de destino. Sin embargo, habrá algunos compromisos todavía pendientes en los que el país puede mejorar, tales como su adhesión al Convenio Internacional de Maderas Tropicales, del cual aún no es parte.

En resumen y al margen de que las condiciones pueden seguirse fortaleciendo, puede concluirse que no existe contradicción alguna entre la Ley Forestal y afines, y que, además, existe una adecuada consistencia entre estas y los demás instrumentos internacionales que se refieren al comercio internacional.

\subsection{Análisis de los mecanismos legales y marcos jurídicos dentro de las estrategias REDD+ nacionales, respecto al aprovechamiento forestal y comercio internacional de productos forestales}

En El Salvador el papel clave en el tema REDD+ lo tiene el MARN. Actualmente se prepara la propuesta de estrategia nacional al respecto, la cual busca contribuir a las grandes metas de la Política Nacional del Medio Ambiente, que son revertir la degradación ambiental y reducir la vulnerabilidad frente al cambio climático. Como parte de su proceso de construcción, la estrategia nacional REDD+ se encuentra en una segunda fase, que incluye un proceso de consulta con todos los actores relevantes, así como la realización de una evaluación ambiental, social y estratégica (SESA, por sus siglas en inglés), la que se realiza con el propósito de garantizar su sostenibilidad. Dentro del MARN se creó el Comité de Cambio Climático del Sistema Nacional de Gestión del Medio Ambiente, destinado a trabajar en las políticas, planes y programas relacionados con la adaptación al cambio climático ${ }^{18}$. También se ha trabajado en una Estrategia Ambiental de Adaptación y Mitigación

16. Decreto Legislativo $\mathrm{N}^{\circ} 524$ del 12 de diciembre de 1995, publicado en el Diario Oficial $\mathrm{N}^{\circ} 234$, Tomo $\mathrm{N}^{\circ} 329$, de fecha 30 de noviembre de 1995.

17. Ver: Sistema Integrado de Comercio Exterior (SICEX). 'Tratados Comerciales'. [sitio web]. <http://www.centrex.gob.sv/scx_html/Tratados_comerciales.html>.

18. A la fecha, se encuentra conformado por los Ministerios de Hacienda, Obras Públicas, Transporte, Vivienda y Desarrollo Urbano, Agricultura y Ganadería, así como de Medio Ambiente y Recursos Naturales. 
al Cambio Climático del Sector Agropecuario, Forestal y Acuícola, como en un Programa Nacional de Restauración de Ecosistemas y Paisajes en virtud del cual se pretende, entre otros objetivos, la restauración y conservación de ecosistemas críticos bajo nuevos regímenes de gobernanza en áreas de manglares, bosques y humedales.

En lo que al marco jurídico internacional y nacional respecta, El Salvador es suscriptor de la Convención Marco de las Naciones Unidas sobre el Cambio Climático (CMNUCC), el Protocolo de Kyoto, el Convenio de Viena para la Protección de la Capa de Ozono, la Convención de las Naciones Unidas de Lucha contra la Desertificación en Países Afectados por la Sequía o Desertificación, así como del Convenio sobre la Diversidad Biológica. En cuanto a la normativa nacional, hay que aclarar que El Salvador todavía no cuenta con una ley especial sobre cambio climático, pero se relacionan con REDD+ especialmente la Constitución de la República, la Ley del Medio Ambiente, la Ley Forestal, la Ley de Áreas Naturales Protegidas, la Ley de Conservación de Vida Silvestre, el Reglamento Especial sobre el Control de las Sustancias Agotadoras de la Capa de Ozono, el Reglamento Especial de Normas Técnicas de Calidad Ambiental y secundariamente, leyes como la Ley de Minería, Ley de Transporte Terrestre, Tránsito y Seguridad Vial, y la Ley de Ordenamiento y Desarrollo Territorial, entre otras.

De estos instrumentos y a favor de REDD+ se derivan importantes mecanismos como los planes de manejo tanto en la parte forestal como en las áreas naturales protegidas, las disposiciones destinadas a la protección del suelo por su capacidad de uso, así como para la erradicación de incendios forestales, los incentivos forestales, el inventario forestal, las concesiones conforme al Artículo 233 de la Constitución de la República y vedas forestales, entre otros. Por consiguiente, es de colegir que no se requiere mayores cambios normativos para la efectiva aplicación y puesta en práctica de REDD+. Sin embargo, sí resulta indispensable la creación de una ley especial sobre la materia que lo facilite, sobre todo porque los mecanismos que aplican a REDD+ se desprenden de un sinfín de normas. Por tanto, no se trata de crear más leyes -a excepción de la anteriormente citada-, sino de adecuar las que sí lo ameriten y poner en práctica las demás en lo que fuere aplicable, de tal manera que se logre contribuir con ello al tema del aprovechamiento forestal y también indirectamente al comercio nacional e internacional.

\subsection{Análisis de conflictos existentes entre derechos de uso de la tierra y los bosques}

Se debe señalar que según información del MARN, 91\% de las tierras de El Salvador se utiliza inapropiadamente, de modo que se emplean sin tomar en consideración la vocación del suelo, lo que genera según sea el caso poco provecho o deterioro de este. Se estima que $45 \%$ muestra un alto conflicto con el uso, otro $45 \%$, bajo conflicto y que solo $9 \%$ se utiliza adecuadamente. Incluso, el Artículo 12 de la Ley Forestal prohíbe el cambio de uso de los suelos clase VI, VII Y VIII que estén cubiertos de árboles, pero aclara que podrán ser aprovechados sosteniblemente, pero manteniendo el mismo uso. La LANP hace referencia expresa a los asentamientos humanos en las áreas protegidas. Esta ley es tajante al prescribir que no se permitirá el establecimiento de nuevos asentamientos humanos ni el crecimiento de infraestructura en los ya existentes. Además busca armonizar la interacción entre la naturaleza y las actividades humanas. 
El aprovechamiento forestal legal por parte de los poseedores de bosques sí es posible siempre que estos comprueben que su tenencia ha sido de buena fe y en legal forma (contratos de arrendamientos y comodatos). En este sentido, no debería influir en el aumento de aprovechamientos ilegales si se realizan conforme a la ley.

Los traslapes entre tierras indígenas, áreas protegidas y zonas de turismo no ocurre en El Salvador. Sin embargo, se han dado conflictos en los bosques salados o manglares. Estos fueron declarados como nacionales por la Ley Forestal de 1973 y esta declaratoria la confirma la LANP, la cual en su Artículo 9 los consideró como bienes nacionales que forman parte del patrimonio natural del Estado. Tanto la Ley Forestal de 1973 como la LANP consideraron que para garantizar la integridad territorial de los bosques salados había que realizar el deslinde y amojonamiento, lo cual no se realizó en la forma adecuada; es decir, no se cumplió con el procedimiento jurídico estipulado por dichas leyes. Esta falta de delimitación jurídica ha propiciado que los propietarios particulares de los inmuebles colindantes al bosque extendieran los límites de sus propiedades. Son contados los casos en que ha intervenido la Fiscalía General de la República y a esto hay que sumarle que el Centro Nacional de Registros (CNR) ha inscrito parcelas de inmuebles rodeados de bosques salados a favor de particulares, perjudicándolos en su extensión y su estado.

Se trata de una falta de respeto de los particulares a los recursos naturales y al medio ambiente, pero también es responsabilidad de las autoridades que legalmente tienen la competencia de proteger y conservar dichos bosques. En efecto, esto ha dado como resultado que exista actualmente ocupaciones ilegales de los terrenos nacionales, los cuales terminan destinándose para la agricultura y por ende, legalizados como propiedades particulares. Incluso, se han presentado ante las autoridades correspondientes alegando la prescripción adquisitiva ${ }^{19}$. Sin embargo, al margen de ello, permanecen en estas condiciones en los terrenos nacionales con el grave riesgo de que puedan ampliar la extensión de dichas parcelas y destruir el bosque salado colindante.

Estos conflictos se tienen con la misma connotación en los bosques naturales que se encuentran en las Áreas Naturales Protegidas (ANP), debido a que muchos de estos inmuebles provienen del proceso de reforma agraria ${ }^{20}$ y cuando el Instituto Salvadoreño de Transformación Agraria los transfiere al Estado para que sean declarados como ANP, estos inmuebles ya tienen a grupos cooperativos viviendo y cultivando, los que en un momento determinado reclaman derechos adquiridos ante la nueva autoridad (MARN).

\subsection{Análisis del marco jurídico para promover la distribución justa y equitativa de los beneficios de un aprovechamiento sostenible de la madera}

La Constitución de la República de El Salvador ha elevado a rango constitucional el deber del Estado de proteger los recursos naturales, así como del medio ambiente, todo a fin de garantizar un desarrollo sostenible. Para reafirmar lo anterior, el inciso segundo de su Artículo 117 declara de interés social la protección, conservación, aprovechamiento racional, restauración o sustitución

19. En Derecho Civil, forma de adquirir el dominio.

20. Tuvo lugar en la década de 1980. 
de los recursos naturales en los términos que establezca la ley. Este deber se ve reflejado en las principales leyes que regulan todo lo referente a los recursos naturales y particularmente en la Ley Forestal.

En este sentido, el Estado de El Salvador asume un gran compromiso en lo que al aprovechamiento sostenible respecta. El objetivo mismo de la Ley Forestal hace referencia expresa al incremento, manejo y aprovechamiento en forma sostenible de los recursos forestales y por ello, este principio del derecho forestal y del derecho ambiental se ve proyectado en todo su desarrollo normativo. Solo en la parte conceptual, el Artículo 2 de la ley define varios conceptos que giran en torno al tema de la sostenibilidad (véase a manera ilustrativa, los conceptos de aprovechamiento forestal, conservación, incentivos forestales, Plan de Manejo Forestal, protección forestal y uso sostenible del bosque).

No obstante, en la legislación forestal todavía hay que trabajar con respecto a mecanismos que promuevan una distribución justa y equitativa de los beneficios de un aprovechamiento sostenible de la madera -como sí ocurre en otras legislaciones que tienen apartados especiales para la implementación de un Sistema Social Forestal del cual puedan derivarse concesiones comunitarias u otros mecanismos de la misma índole-, no solo disposiciones que hacen referencia a la sostenibilidad de los recursos forestales, a pesar de que el país es firmante de importantes instrumentos internacionales que lo reconocen. Lo que sí está reconocido es que conforme a la Constitución de la República (Art. 233) se puedan conceder, pero en términos generales, contratos de usufructo, comodato o arrendamiento a entidades de utilidad pública.

Por otra parte, en lo que se refiere a la cadena de producción forestal, es de advertir que intervienen en ella -además del MAG como autoridad administrativa en la materia- diferentes actores, puesto que dicha cadena comprende desde la generación del material genético hasta la comercialización de los productos resultantes.

El reto de la ley recae precisamente en estimular la producción. Esta idea aparece incluso como justificación de la actual Ley Forestal, específicamente en su considerando III, denunciando que la anterior Ley Forestal de 1973 ya no respondía a los objetivos de la política del Estado en el sentido de estimular la participación del sector privado en el incremento de la cobertura arbórea con fines productivos. En este sentido, la actual Ley Forestal crea en su articulado condiciones para ello, como la participación pública, así como los incentivos que garantizan las inversiones forestales y los beneficios de los bosques. 


\section{Análisis de los estándares de legalidad}

\subsection{Análisis de vacíos y conflictos en la aplicabilidad de la Ley Forestal y afines, poniendo especial atención en las posibilidades y retos a la luz de los sistemas existentes de derecho consuetudinario indígena y derecho positivo de los pueblos y territorios indígenas en los países}

EI Salvador, a diferencia de otras naciones, tiene pendiente (SE ELIMINA PIE DE PAGINA 21) suscribir el Convenio N $N^{\circ} 169$ de la Organización Internacional del Trabajo (OIT) sobre Pueblos Indígenas y Tribales en Países Independientes. Sin embargo, el país recientemente ratificó constitucionalmente que reconoce los pueblos indígenas ${ }^{21}$.

En efecto, como se advierte en el Informe Situacional sobre los Derechos de los Pueblos Indígenas en El Salvador, de la Procuraduría para la Defensa de los Derechos Humanos, correspondiente al año 2012, la Ley del Medio Ambiente -por ejemplo- debería incorporar en su articulado métodos tradicionales indígenas de protección y conservación de la biodiversidad, entre otras características propias del conocimiento indígena. Por ello, El Salvador podría hacer esfuerzos para adecuar también la Ley Forestal y afines, acelerando los cambios estructurales que arriba se han citado y crear una adecuada normativa indígena interna. Debe regularse también el tema del territorio, puesto que a finales del siglo XIX (1882) los pueblos indígenas fueron despojados de sus tierras ancestrales, por lo que actualmente no existe reconocimiento legal al respecto ${ }^{22}$.

Además, como apunta el Director de la Dirección Nacional de Pueblos Indígenas y Diversidad Cultural $^{23}$, es importante que se trabaje en legislación que propicie la consulta libre, previa e informada, de tal manera que se garantice la participación de los pueblos indígenas en la toma de decisiones. Lo anterior significa que deben fortalecerse los espacios de participación existentes y en relación con el tema forestal, uno de ellos es la Comisión Forestal (CF). A la fecha de creación de dicha CF, no figuró en la nómina de sus miembros ninguna organización indígena; pero actualmente, explica el Director de la DGFCR, ya se cuenta con la participación de representantes de los pueblos indígenas.

21. Asamblea Legislativa. Decreto $N^{\circ} 707$ de fecha 12 de junio de 2014. Diario Oficial $N^{\circ} 112$, Tomo $N^{\circ}$ 403. Fecha de publicación: 19 de junio de 2014) y participó en la adopción de la Declaración de las Naciones Unidas sobre los Derechos de los Pueblos Indígenas, por lo que estas acciones podrían ser el referente para la creación y adecuación de la normativa forestal y ambiental correspondiente.

22. El tema de las tierras es el más álgido al hablar de una ratificación del Convenio 169 de la OIT, como de una reforma constitucional, según lo advierte el CCNIS.

23. Esta Dirección es una dependencia de la Secretaría de Cultura de la Presidencia de la República. Se trata de una institución que no tiene autoridad para ordenar, pero funge como promotora, facilitadora y acompañante. 
En resumen, El Salvador tiene como reto en relación con el derecho de los pueblos indígenas la ratificación del referido Convenio de la OIT y adecuar su legislación interna, ya sea reformando la existente o creando leyes especiales al respecto, principalmente para regular el tema del territorio, tomando especial consideración en que ha adoptado la Declaración de las Naciones Unidas sobre los Derechos de los Pueblos Indígenas. En palabras del Consejo Coordinador Nacional Indígena Salvadoreño (CCNIS) ${ }^{24}$, se requiere la creación de todo un marco jurídico al respecto.

\subsection{Análisis de los vacíos legales existentes en la Ley Forestal y afines, respecto al aprovechamiento forestal y comercio internacional de productos forestales}

El Salvador tiene pendiente la aprobación de la Política Forestal (2011-2030) que se ha trabajado bajo una amplia consulta. La importancia de la existencia de esta política es que con ella se tratará de lograr un mejor aprovechamiento de los bosques y demás plantaciones, los cuales empujen al sector a la competitividad dentro de un marco de sostenibilidad, garantizando así que las actividades forestales se integren en el desarrollo local y nacional -entre otras apuestas- estimulando una mayor participación social.

Su ausencia ha implicado que la gestión forestal se venga realizando de manera aislada del desarrollo nacional, es decir, sin integrarse con otros sectores relacionados con el tema. En el documento de trabajo para la propuesta estratégica nacional para REDD+ en El Salvador ${ }^{25}$ se advierte que esta situación ha provocado que el modelo de desarrollo forestal del país durante las últimas décadas haya tenido un carácter extractivista; en otras palabras, dirigido prácticamente de manera exclusiva a la producción de madera y no se ha respondido a las necesidades de fomento que tiene el sector.

En lo que concierne a la Ley Forestal -que dicho sea de paso data del 2002- esta ordenó la creación de la ya explicada Comisión Forestal (CF). Dicha creación se concretizó un año después, en el 2003. Sin embargo, a pesar de que ya han transcurrido más de diez años de esto, la referida CF necesita un instructivo o reglamento de operatividad para que regule su funcionamiento respecto a la forma de integrarse, al desarrollo de sus sesiones y periodicidad de estas, lo cual es prioritario si se considera que desempeña un papel asesor y está compuesta por diferentes actores claves vinculados con el tema forestal.

En términos generales, es necesario crear algunos reglamentos que vendrían a dar reglas claras y compromisos institucionales. Además de un reglamento o instructivo para la Comisión Forestal, es preciso reglamentar también la parte de los incentivos forestales a que alude el Artículo 20 de la Ley Forestal que ordena al MAG, así como al Ministerio de Economía (MINEC), la creación de programas de incentivos que propicien el desarrollo forestal, estimulando de esta manera la inversión privada. También es fundamental un reglamento, instructivo o manual de procedimientos dentro del ARF del MAG en el que se especifiquen los pasos a seguir en todo trámite relacionado con el aprovechamiento y comercio forestal. Actualmente se cuenta con formularios para facilitar las

24. Es una organización con reconocimiento oficial a nivel nacional e internacional que lucha por la defensa de los derechos indígenas y el fortalecimiento de la identidad cultural y autoestima indígena. Reúne aproximadamente a veintitrés organizaciones indígenas a nivel nacional.

25. Lo trabaja el MARN en amplia consulta pública. 
solicitudes que se le dirigen al Jefe del ARF, pero sería oportuno un instrumento que sistematice y ordene cada procedimiento a seguir para que unifiquen criterios a nivel nacional. El Reglamento de la ley tiene regulaciones al respecto, pero no en el sentido que aquí se cita. Asimismo, debe decretarse el Reglamento de la LANP. En efecto, la LANP data del 2005 y muchas de sus disposiciones remiten expresamente a un reglamento para su desarrollo, por lo que cumplirlo haría avanzar al país en el tema de las áreas naturales protegidas.

Igualmente hay que referirse a un conflicto de aplicación relacionado con el tema forestal. El Artículo 258 del Código Penal regula el delito de "Depredación de bosques". El problema está en que este artículo hace referencia expresa a lo "legalmente protegido", lo que significa que, si se causa el mismo tipo de daño en un bosque $u$ otras formaciones vegetales naturales o cultivadas que no estuvieren legalmente protegidas, no habrá sanción, porque simplemente no hay tipificación penal. Otro problema que no necesariamente recae en el factor legal -pero que sí incide en el tema del aprovechamiento y comercio forestal- es la dificultad de poder aplicar plenamente la legislación correspondiente, particularmente la Ley Forestal y su Reglamento, por la falta de recursos materiales y humanos. Hace falta reforzar presupuestariamente al MAG y al MARN para que logren sus objetivos institucionales.

En relación con los compromisos de carácter internacional, El Salvador ha procurado acompañar esfuerzos al respecto y aunque todavía no es parte del Convenio Internacional de Maderas Tropicales, como de otros instrumentos, su legislación secundaria responde adecuadamente a las exigencias de los instrumentos y normas internacionales aplicables al país, como el Tratado de Libre Comercio CAFTA-DR, las Normas Internacionales de Medidas Fitosanitarias, la Convención CITES, la Convención Marco de las Naciones Unidas sobre el Cambio Climático, el Protocolo de Kyoto y el Convenio de Viena para la Protección de la Capa de Ozono, entre otros, que también han dado lugar a la promulgación de reglamentos especiales. Sin embargo, la falta de una apropiada tipicidad penal respecto a los delitos relacionados con los recursos naturales sí genera conflictos, puesto que -por más esfuerzo que se haga por erradicar el aprovechamiento y comercio forestal de tipo ilegalhay conductas que no se encuentran tipificadas en el Código Penal. Por otra parte, es de advertir que para implementar plenamente estos instrumentos se requiere mayores aportes en términos de recursos materiales y humanos.

\subsection{Requisitos legales para los permisos de aprovechamiento forestal y comercio internacional de productos forestales, indicando los actores ligados al proceso, plazos, y costos}

Conforme al Artículo 8 de la LF, todo aprovechamiento de los bosques naturales de propiedad privada estará regulado por un plan de manejo forestal que deberá ser elaborado bajo la responsabilidad del propietario o poseedor del terreno y aprobado por el MAG. El Artículo 17 del Reglamento de la LF establece que el referido plan será aprobado por medio de resolución dictada por el MAG. Se debe aclarar que -si bien es cierto la normativa legal hace referencia al MAG- la oficina ligada a este proceso es el Área de Recursos Forestales (ARF) y el plan es la base del aprovechamiento sostenible. 
Asimismo, la Ley Forestal obliga a los propietarios o poseedores a solicitar autorización del MAG para el aprovechamiento de los productos y subproductos forestales provenientes de árboles dañados o derribados por causas naturales dentro de bosques naturales. Todo lo anterior implica que en El Salvador no puede haber aprovechamiento legal en bosques naturales, si no es conforme a la ley y solamente podrá iniciarse hasta que el respectivo plan de manejo haya sido aprobado por el MAG. Para ello, el interesado presenta una solicitud.

Después de recibida la petición y completada la documentación, el MAG -según el Artículo 15 del RLF- tendrá un término de 30 días hábiles para resolver sobre la aprobación o no del plan de manejo forestal. El Artículo 8 de la LF y 15 de su Reglamento refieren que -en caso de haber transcurrido los 30 días sin que el MAG resuelva lo correspondiente- se tendrá esta por aprobada; es decir, hay silencio administrativo con efecto positivo. Sin embargo, en el ARF aclaran que las solicitudes siempre se han resuelto a tiempo. Si a la solicitud no se le hacen observaciones, se le concede el visto bueno o autorización. En caso contrario, se le regresa al interesado para que supere las deficiencias.

El ARF cuenta con cuatro sedes para estos trámites distribuidos por regiones: región 1, zona occidental, que comprende los Departamentos de Santa Ana (sede regional), Ahuachapán y Sonsonate; región 2, zona central, Departamentos de San Salvador (sede regional), Chalatenango, La Liberad y Cuscatlán; región 3, zona paracentral, Departamentos de San Vicente (sede regional), Cabañas y La Paz, y región 4, zona oriental, Departamentos de San Miguel (sede regional), Morazán, Usulután y La Unión. Toda región tiene sus agencias forestales para atender el territorio que a cada una le corresponde.

Para los requisitos técnicos y legales se presenta el siguiente cuadro. Los requisitos legales se desprenden de la LF y su Reglamento. Con respecto a los requisitos técnicos, hay que señalar que el Articulo 14 del RLF establece que los planes de manejo forestal deberán ser elaborados conforme a las normas técnicas que para tal efecto dictará el MAG por medio de Acuerdo Ejecutivo. 


\section{Cuadro 3. Requisitos para elaborar un plan de manejo forestal}

Requisitos técnicos

- Portada. Debe contener información acerca del área de manejo, el propietario y el profesional forestal encargado de realizar el plan de manejo.

- Resumen del plan de manejo forestal. Deberá contener información acerca de la propiedad, localización geográfica, área total por manejar (área de protección y área de producción), volumen y especies por aprovechar, estrategia de manejo (sistema silvicultural, intensidad de aprovechamiento, principales productos, ciclo de corta, aspectos sociales, ecológicos y ambientales).

- Objetivos conforme a la capacidad productiva del bosque y capacidad del usuario.

- Información básica sobre el estado legal de la propiedad o derechos adquiridos, localización y accesibilidad de la propiedad, superficie por manejar y uso actual del suelo, características biofísicas de la unidad de manejo, descripción de la vegetación y de la fauna.

- Características actuales de producción y manejo forestal (duración, diagnóstico del potencial productivo del bosque, sistema de manejo forestal y planificación del aprovechamiento).

- Actividades de aprovechamiento (actividades de post-aprovechamiento y protección del bosque).

- Cronograma de actividades.

- Mapas.
Requisitos legales

Presentar una solicitud por escrito al MAG en la que se deberá consignar las generales y la ubicación y área del bosque en el que se ejecutará el plan de manejo.

- Presentar fotocopia certificada por notario del documento por medio del cual se acredita la propiedad o la posesión legal del inmueble en que se ejecutará el plan de manejo.

- Cancelar los derechos correspondientes.

- Presentar el documento que contenga el plan de manejo forestal.

- Que el plan de manejo haya sido elaborado por profesionales en ciencias forestales o áreas afines.

Visto bueno o resolución dictada por el MAG. Inscripción en el registro de planes de manejo forestal aprobados.

Fuente: Elaboración personal con base en el RLF y guía de elaboración simplificada

Por otra parte, la LF regula también que habrá aprovechamientos forestales en los que no se requerirá autorización, sino que bastará con una constancia que extenderá el MAG para los casos de las plantaciones forestales privadas (Arts. 16 y 17) y que se exceptúan de todo requerimiento los aprovechamientos que a continuación se detallan:

La tala, poda y raleo con fines de protección y saneamiento en los bosques naturales (Art. 10).

La regulación sobre siembra, poda y tala de árboles en zonas urbanas por ser competencia exclusiva de la municipalidad respectiva (Art. 15).

- El mantenimiento, raleo o aprovechamiento final en plantaciones forestales en propiedades de particulares (Art.16).

- El corte, tala y poda de los árboles de sombra de cafetales y otros de diferentes especies que se encuentren dentro de la plantación de café siempre que la actividad busque la conservación y mejoramiento de esta, y que los árboles no se encuentren incluidos en los listados de especies amenazadas o en peligro de extinción o que se trate de árboles históricos (Art. 17, letra "a").

- El corte, tala y poda de frutales, así como otros cultivos agrícolas permanentes y la tala y poda de árboles aislados ubicados en suelos con vocación agrícola o ganadera siempre que no se trate 
de árboles históricos y no se encuentren entre las especies amenazadas o en peligro de extinción (Art. 17, letra "b").

- La tala de árboles con capacidad de rebrote sin llegar a su eliminación total (Art. 17 letra "c").

En lo relativo a la comercialización, deberá cumplirse con la normativa forestal con respecto a la acreditación de la legal procedencia de la madera, así como con la demás normativa aplicable -la legislación comercial, tributaria, sanidad vegetal y la relacionada con el tema de exportación, entre ellas, los acuerdos comerciales suscritos por El Salvador (véase el tema correspondiente)-.

En cuanto a los costos económicos, el MAG tiene cuadros tarifarios según el tipo de servicios ${ }^{26}$. En este sentido, en los planes de manejo forestal de más de 2 hasta 7 hectáreas, se cobra dos dólares con cincuenta centavos (\$2.50) por hectárea de bosque productivo; de más de 7 hasta 15 hectáreas, dos dólares (\$2) por hectárea de bosque productivo; de más de 15 hasta 65 hectáreas, un dólar (\$1) por hectárea de bosque productivo y para los planes de manejo forestal de más de 65 hectáreas, sesenta y cinco dólares (\$65) como cobro por el plan de manejo. Esto significa que para los casos de menos de 2 hectáreas no habrá costo alguno y para los casos de más de 65 hectáreas, ya no se cobra por hectárea de bosque productivo, sino por el plan de manejo.

El precio de la guía de transporte es de dos dólares (\$2), independientemente de la cantidad que se transporte. Existen dos modelos: Clase A y Clase B. Si solo se necesita un árbol, dos o tres y que no impliquen plan de manejo, se da la Clase B. Pero cuando hay plan, se da la Clase A. Sirven para leña, madera, carbón y otros.

El permiso certificado CITES, que también lo extiende el MAG por medio de su oficina CITES, tiene un valor de quince dólares (\$15) y el certificado NO CITES cuesta seis dólares con cuarenta y cinco centavos (\$6.45). El certificado fitosanitario vale seis dólares con cuarenta y cinco centavos (\$6.45) por cada 10.000 kilogramos o fracción y lo emite la Dirección General de Sanidad Vegetal y Animal del MAG. También se cumplen con las Normas Internacionales de Medidas Fitosanitarias, particularmente la (NIMF-15).

Regulaciones más específicas sobre transporte, industrialización y comercialización se pueden ver en el cuadro que se presenta a continuación.

26. Se publican en el Diario Oficial. 
Cuadro 4. Regulaciones para transporte, industrialización y comercialización de madera

\begin{tabular}{|c|c|c|}
\hline Transporte de madera & Industrialización & Comercialización \\
\hline $\begin{array}{l}\text { Conforme al Artículo } 21 \text { del RLF, } \\
\text { toda persona natural o jurídica que } \\
\text { transporte, almacene, comercialice } \\
\text { o industrialice productos forestales } \\
\text { maderables y no maderables } \\
\text { está en la obligación de probar la } \\
\text { procedencia legal de estos, así: } \\
\text { - } \quad \text { Guías de transporte emitidas } \\
\text { por el propietario. Diseñadas } \\
\text { para el transporte de productos } \\
\text { y subproductos provenientes } \\
\text { de bosques naturales que } \\
\text { posean planes de manejo } \\
\text { forestal aprobados o de } \\
\text { plantaciones forestales. } \\
\text { Guías de transporte emitidas } \\
\text { por el MAG. Diseñadas para el } \\
\text { transporte de aprovechamiento } \\
\text { de productos y subproductos } \\
\text { forestales que no posean plan } \\
\text { de manejo. } \\
\text { Póliza de importación. Para } \\
\text { el transporte de productos } \\
\text { y subproductos forestales } \\
\text { importados. } \\
\text { Factura, comprobante } \\
\text { de crédito fiscal o } \\
\text { guía de transporte. } \\
\text { Para almacenamiento, } \\
\text { industrialización y } \\
\text { comercialización de productos } \\
\text { y subproductos forestales. }\end{array}$ & $\begin{array}{l}\text { El MAG llevará un Registro } \\
\text { Forestal de los establecimientos } \\
\text { de madera, aserraderos y } \\
\text { procesadores de productos } \\
\text { forestales. En este sentido, según } \\
\text { la Ley Forestal y su reglamento, } \\
\text { para el establecimiento de una } \\
\text { industria se requiere: } \\
\text { - } \quad \text { Número correlativo. } \\
\text { - } \quad \text { Generales del propietario. } \\
\text { - } \quad \text { Nombre de la empresa y } \\
\text { ubicación de sus oficinas, } \\
\text { sucursales, agencias y } \\
\text { distribuidoras. } \\
\text { - Volúmenes estimados de } \\
\text { productos y subproductos } \\
\text { procesados y comercializados } \\
\text { en forma mensual. } \\
\text { - Origen y especie de los } \\
\text { productos y subproductos } \\
\text { forestales que comercializa. }\end{array}$ & $\begin{array}{l}\text { Toda persona natural o jurídica, } \\
\text { que opere como comerciante, } \\
\text { debe conforme al Código de } \\
\text { Comercio: } \\
\text { - } \quad \text { Obtener matrícula personal. } \\
\text { - } \quad \text { Matricular la empresa } \\
\text { mercantil. } \\
\text { - } \quad \text { Llevar la contabilidad y la } \\
\text { correspondencia en la forma } \\
\text { prescrita por el Código de } \\
\text { Comercio. } \\
\text { - Inscribir en el Registro de } \\
\text { Comercio los documentos } \\
\text { relativos a su negocio que } \\
\text { estén sujetos a esta formalidad } \\
\text { y cumplir los demás requisitos } \\
\text { de publicidad mercantil que la } \\
\text { ley establece. } \\
\text { Mantener su actividad } \\
\text { dentro de los límites legales } \\
\text { y abstenerse de toda } \\
\text { competencia desleal. }\end{array}$ \\
\hline
\end{tabular}

\subsection{Indicar los estándares que regulan el uso de los recursos forestales y sus tipos de permisos, a la luz de la legislación existente sobre aprovechamiento forestal y el comercio internacional de productos forestales}

El Artículo 117 de la Constitución de la República declara de interés social la protección, restauración, desarrollo y aprovechamiento de los recursos naturales y agrega que dicha protección, conservación y mejoramiento de los recursos naturales y del medio serán objeto de leyes especiales.

La Ley Forestal es tajante al declarar de interés económico el desarrollo forestal del país desde el establecimiento de la plantación hasta el aprovechamiento final y todas sus formas de valor agregado, así como establecer las condiciones para estimular la participación del sector privado en la reforestación del territorio nacional con fines productivos. Sin embargo, también es categórica 
al exceptuar de su regulación las áreas naturales protegidas y los bosques salados. Lo anterior se encuentra normado en el Artículo 1 e implica que no puede haber aprovechamiento ni comercio forestal al respecto. Esta excepción la confirma la Ley de Áreas Naturales Protegidas. Su Artículo 3 declara de interés social el establecimiento, manejo y desarrollo de las Áreas Naturales Protegidas que forman parte del Patrimonio Natural del país. Por su parte, el Artículo 9, en su inciso tercero, preceptúa que los bosques salados son bienes nacionales y forman parte del patrimonio natural del Estado. De modo que es esta ley especial la que establece el régimen legal aplicable, tanto en el aspecto de la administración, manejo e incremento de estas.

Dentro de las potestades del MARN, por medio del Sistema de Áreas Naturales Protegidas, está la de declarar vedas para la conservación de los recursos contenidos en las áreas naturales protegidas. Siempre dentro del marco de la LANP, el MARN autorizará las zonas de amortiguamiento y en las regiones de influencia de propiedad privada el desarrollo de actividades que sean compatibles con los objetivos de las Áreas Naturales Protegidas. La LANP también establece que en estas Áreas Naturales no se permitirá el establecimiento de nuevos asentamientos humanos ni el crecimiento de infraestructura en los ya existentes.

Conforme a la Ley de Conservación de Vida Silvestre, el MARN es la autoridad responsable de elaborar y mantener actualizados los listados oficiales de especies amenazadas y en peligro de extinción, procurando su protección y restauración ${ }^{27}$. Esta Ley regula también en su Artículo 11 que en caso de que las poblaciones de vida silvestre requieran protección especial para la recuperación o estabilidad de sus poblaciones, el MARN -a través de su jefatura- podrá establecer vedas parciales o totales de uso en tiempo, lugar y espacio. El MAG en coordinación con el MARN emitió veda temporal para el aprovechamiento de los recursos naturales en la zona denominada Zanjón del Chino, Bahía de Jiquilisco, Departamento de Usulután. Esta veda ha dado resultados positivos en la conservación de los recursos naturales en la zona, especialmente en la parte forestal y su biodiversidad (moluscos). Con esta medida los más beneficiados han sido los pobladores de las comunidades aledañas, ya que se han protegido y conservado los recursos naturales por tiempo determinado y son aprovechados posteriormente en épocas específicas por el acuerdo de declaratoria de veda en la zona.

La Ley Forestal también declara áreas de uso restringido de modo que sus propietarios tendrán la obligación de manejar de manera sostenible la vegetación existente. Estos casos son puntualmente los siguientes:

- Los terrenos que bordeen los nacimientos de agua o manantiales, en un área que tenga como radio por lo menos veinticinco metros, o lo que determine el estudio técnico respectivo, medidos horizontalmente a partir de su máxima crecida.

- Los terrenos riberanos de ríos y quebradas en una extensión equivalente al doble de la mayor profundidad del cauce, medida en forma horizontal a partir del nivel más alto alcanzado por las aguas en ambas riberas, en un período de retorno de cincuenta años.

- Los terrenos en una zona de cincuenta metros medida horizontalmente a partir de su más alta crecida en tiempo normal de los lagos y lagunas naturales, y de las riberas de los embalses

27. La última actualización data del 2009 y debe revisarse cada cinco años. 
artificiales construidos por el Estado o por particulares, la cual deberá estar permanentemente arbolada.

- Los terrenos de las partes altas de las cuencas hidrográficas, en especial las que están en zonas de recarga hídrica.

- Las áreas que por su potencial de deslizamiento debido a fuertes pendientes constituyen un peligro para las poblaciones.

- Los suelos clase VIII.

La Ley Forestal, de igual forma que la LANP y la LCVS, tiene regulada la facultad de establecer vedas forestales temporales. Estas podrán ser declaradas de manera parcial o total en bosques naturales. No obstante, el personal del ARF expresa que durante los últimos 5 años no se ha decretado ninguna veda forestal por parte del MAG, pero aclara que actualmente se está trabajando en la elaboración de una para la protección de una especie que no se encuentra en el listado de especies de vida silvestre amenazada o en peligro de extinción, conforme al acuerdo respectivo emitido por el MARN ${ }^{28}$. Se trata de las especies Dalbergia, particularmente la Retusa y Tucurensis, que se están aprovechando sin consideración alguna. EI MAG pretende que se introduzcan estas especies al referido listado que debe actualizarse precisamente este año. Sin embargo, mientras tanto, se está tratando también de impulsar una veda forestal para su protección. El personal del ARF señala que algunos países ya la prohibieron.

28. Acuerdo número 36 de fecha 11 de mayo de 2009, publicado en el Diario Oficial $N^{\circ} 103$, Tomo $N^{\circ} 383$, de fecha 5 de junio de 2009. 


\section{Análisis del ámbito de acción de la Administración Forestal}

\subsection{Definición de competencias para el manejo de los recursos forestales, grado de descentralización y su nivel de efectividad en el ámbito de acción de la Ley Forestal y afines}

En El Salvador, las competencias para el manejo de los recursos forestales se encuentran establecidas principalmente en la Ley Forestal y su Reglamento, pero también se advierten en otros instrumentos normativos de carácter interno de la institución.

Conforme a la Ley Forestal, el MAG es el responsable de la aplicación de la normativa forestal y la autoridad para conocer de la actividad forestal productiva. No obstante, como ya se ha señalado antes, organizativamente existe la Dirección General de Ordenamiento Forestal, Cuencas y Riego, dentro de la cual está la División de Recursos Forestales y Cuencas Hidrográficas, y como parte de esta, el Área de Recursos Forestales (véase para efecto ilustrativo el Cuadro 5).

Cuadro 5. Competencias, grado de descentralización y nivel de efectividad, en el manejo de los recursos forestales

\begin{tabular}{|l|l|l|}
\hline \multicolumn{1}{|c|}{ Competencias } & Grado de descentralización & \multicolumn{1}{|c|}{ Nivel de efectividad } \\
\hline $\begin{array}{l}\text { Evaluar, aprobar o denegar los } \\
\text { planes de manejo forestal. }\end{array}$ & No hay descentralización. & Es efectivo. \\
\hline $\begin{array}{l}\text { Dar seguimiento a los planes de } \\
\text { manejo forestal. }\end{array}$ & No hay descentralización. & $\begin{array}{l}\text { No siempre ha sido posible darles } \\
\text { seguimiento. }\end{array}$ \\
\hline $\begin{array}{l}\text { Apoyar la formulación de planes de } \\
\text { desarrollo forestal para pequeños } \\
\text { reforestadores y productores de } \\
\text { laderas de escasos recursos. }\end{array}$ & No hay descentralización. & $\begin{array}{l}\text { Es efectivo e incluso se cuenta con } \\
\text { formatos diseñados para tal fin. }\end{array}$ \\
\hline $\begin{array}{l}\text { Promover y apoyar la participación } \\
\text { privada en el desarrollo forestal. }\end{array}$ & No hay descentralización. & $\begin{array}{l}\text { El espacio creado para ello es la } \\
\text { Comisión Forestal. Sin embargo, } \\
\text { es importante que sus sesiones } \\
\text { tengan lugar con más regularidad. }\end{array}$ \\
\hline $\begin{array}{l}\text { Organizar y mantener actualizado } \\
\text { un sistema de información forestal } \\
\text { con el objeto de generar, recopilar, } \\
\text { clasificar y procesar información y } \\
\text { datos relacionados con la materia } \\
\text { forestal. }\end{array}$ & No hay descentralización. & $\begin{array}{l}\text { Debe mejorarse. El Sistema } \\
\text { de Información Forestal no se } \\
\text { encuentra actualizado. }\end{array}$ \\
\hline $\begin{array}{l}\text { Facilitar y fomentar el } \\
\text { establecimiento de la industria } \\
\text { forestal. }\end{array}$ & $\begin{array}{l}\text { No hay descentralización, pero } \\
\text { debe trabajarse en coordinación } \\
\text { con otras instituciones. }\end{array}$ & $\begin{array}{l}\text { Es efectivo. Las reglas para su } \\
\text { establecimiento son claras. }\end{array}$ \\
\hline
\end{tabular}




\begin{tabular}{|l|l|l|}
\hline \multicolumn{1}{|c|}{ Competencias } & \multicolumn{1}{|c|}{ Grado de descentralización } & \multicolumn{1}{c|}{ Nivel de efectividad } \\
\hline $\begin{array}{l}\text { Formular políticas que tengan } \\
\text { como finalidad el uso productivo } \\
\text { de los recursos forestales. }\end{array}$ & $\begin{array}{l}\text { No hay descentralización, pero } \\
\text { debe realizarse en amplia consulta } \\
\text { con diferentes sectores de la } \\
\text { población. }\end{array}$ & $\begin{array}{l}\text { Actualmente existe una política al } \\
\text { respecto que está a la espera de } \\
\text { su aprobación. }\end{array}$ \\
\hline $\begin{array}{l}\text { Elaborar programas de incentivos } \\
\text { forestales en coordinación con } \\
\text { el Ministerio de Economía y la } \\
\text { Comisión Forestal. }\end{array}$ & No hay descentralización. & Debe trabajarse. \\
\hline $\begin{array}{l}\text { Decretar vedas forestales cuando } \\
\text { las condiciones ecológicas de una } \\
\text { zona lo ameriten. }\end{array}$ & No hay descentralización. & $\begin{array}{l}\text { A la fecha no se ha decretado } \\
\text { ninguna. No obstante, se está } \\
\text { trabajando en un proyecto al } \\
\text { respecto. }\end{array}$ \\
\hline $\begin{array}{l}\text { Llevar un Registro Forestal de } \\
\text { los planes de manejo forestal } \\
\text { aprobados, plantaciones } \\
\text { forestales, ventas de madera y } \\
\text { otros. }\end{array}$ & No hay descentralización. & Debe actualizarse. \\
\hline $\begin{array}{l}\text { Elaborar un inventario forestal } \\
\text { sobre área de bosques naturales } \\
\text { y plantaciones forestales a nivel } \\
\text { nacional y la cuantificación y } \\
\text { calificación de los recursos } \\
\text { forestales. }\end{array}$ & No hay descentralización. & Debe trabajarse. \\
\hline $\begin{array}{l}\text { Establecer y mantener actualizado } \\
\text { un Sistema de Información } \\
\text { Forestal. }\end{array}$ & No hay descentralización. & Debe actualizarse. \\
\hline $\begin{array}{l}\text { Conocer de las infracciones a } \\
\text { la ley e imponer las sanciones } \\
\text { respectivas. }\end{array}$ & No hay descentralización. & Es efectivo. \\
\hline
\end{tabular}

Fuente: Elaboración personal con base en la LFy entrevistas a personal del MAG

Adviértase que estas atribuciones están concentradas en la autoridad del MAG y que según el organigrama de la institución y dentro del nivel operativo centralizado, le corresponde cumplirlas al ARF, que cuenta con 4 regiones para dar cobertura a nivel nacional y que cada región tiene sus propias oficinas forestales. Esto significa que lo que existe principalmente es desconcentración de funciones. Por otra parte, en lo que al nivel de efectividad se refiere, influye también y quizá principalmente- la limitada asignación presupuestaria con la que se trabaja, reflejada en la falta de recursos materiales y humanos.

\subsection{Definición de los tipos de permisos forestales en el ámbito de acción de la Ley Forestal y afines}

La Ley Forestal y su Reglamento, así como las demás leyes afines, regulan lo concerniente a los diferentes tipos de permisos relacionados con la temática del aprovechamiento y comercio forestal. La LF hace distinciones al respecto, así: a) Si se trata de bosques naturales en propiedades privadas, su aprovechamiento solo puede ser por medio de los planes de manejo forestal debidamente aprobados por el MAG, es decir, mediante una autorización (Art. 8). b) Tratándose de terrenos del 
Estado, tal aprovechamiento puede hacerse mediante concesión, pero respetándose el Artículo 233 de la Constitución de la República y el respectivo plan de manejo (Art. 22). c) Se exceptúa de toda autorización al respecto -salvo para su transporte, comercialización e industrialización- las plantaciones forestales privadas (Art. 16).

En este sentido, el plan de manejo forestal es el documento que contiene la planeación técnica que regula el uso y aprovechamiento sostenible del bosque; mientras que para el transporte y comercialización, los documentos para probar la legítima procedencia de los productos y subproductos forestales son las guías de transporte o facturas. En cuanto a la importación, se requiere una póliza de importación (véase el tema de exportación en el apartado correspondiente).

Sin embargo, si bien es cierto que el plan de manejo forestal faculta para el uso y aprovechamiento, existen otras actividades forestales que ameritan permisos y registros especiales que se detallan en el cuadro que a continuación se presenta.

\section{Cuadro 6. Permisos, autorizaciones y registros para la actividad forestal}

\begin{tabular}{|c|}
\hline Actividad forestal \\
\hline - Autorización del Plan de Manejo Forestal \\
\hline $\begin{array}{l}\text { - Permiso para aprovechamiento de los productos y subproductos forestales provenientes de árboles } \\
\text { dañados o derribados por causas naturales dentro de bosques naturales }\end{array}$ \\
\hline $\begin{array}{l}\text { - Permiso para desarrollar proyectos de investigación orientados a la producción, manejo, industrialización y } \\
\text { comercialización, en inmuebles propiedad del Estado }\end{array}$ \\
\hline - Registro de Planes de Manejo Forestal \\
\hline - Registro y acreditación de formuladores de los Planes de Manejo Forestal \\
\hline - Registro de plantaciones forestales, rodales semilleros y viveros \\
\hline - Renovación de Registro quinquenal para formuladores de Planes de Manejo Forestal \\
\hline $\begin{array}{l}\text { - Autorización de quema prescrita para la prevención de incendios forestales o de inducción para el control } \\
\text { de plagas y enfermedades, como para favorecer la regeneración natural }\end{array}$ \\
\hline - Registro de ventas de madera \\
\hline - Registro de aserraderos y procesadores de productos forestales \\
\hline - Permiso para el transporte de productos forestales maderables y no maderables \\
\hline
\end{tabular}

\subsection{Definición de un diagrama legal-administrativo para acceder a los permisos de aprovechamiento forestal y comercio internacional de madera}

El Salvador cuenta con el Centro de Trámites de Importaciones y Exportaciones (CIEX El Salvador) ${ }^{29}$. Originalmente llamado Centro de Trámites de Exportación (CENTREX) y creado en 1987, pasó a llamarse CIEX El Salvador desde el día 6 de abril de 2011. Forma parte de la estructura orgánica del

29. Decreto Ejecutivo número 599, de fecha 20 de enero de 2011, publicado en el Diario Oficial $\mathrm{N}^{\circ} 390$, de fecha 31 de enero de 2011. 
Banco Central de Reserva de El Salvador y tiene como objetivos centralizar, agilizar y simplificar los trámites de exportación de las instituciones involucradas en la actividad exportadora. Para facilitar los trámites se cuenta con un sistema electrónico llamado Sistema Integrado de Comercio Exterior (SICEX), que interconecta a los exportadores, instituciones del Estado vinculadas al comercio exterior y a CIEX El Salvador. No tiene costo y es rápido.

En este sentido, los requisitos para la exportación se encuentran disponibles en la página electrónica de CIEX EI Salvador y pueden verse en el diagrama que para tal efecto se presenta en este apartado. Sin embargo, en detalle primero es hay que tomar en cuenta que -conforme al Sistema Arancelariola madera se encuentra ubicada dentro de la categoría de madera, carbón vegetal y manufacturas de madera. El exportador debe inscribirse en CIEX EI Salvador para la realización de los respectivos trámites, el cual emitirá el Formulario Aduanero Único Centroamericano (FAUCA) o la Declaración de Mercancías (DM). El primero para las exportaciones hacia Centroamérica y la segunda para fuera de ella. En todo caso, deben considerarse requisitos especiales, como los siguientes:

Certificado Fitosanitario: La DGSVA certifica que al momento de la exportación los productos han sido inspeccionados de acuerdo con los procedimientos adecuados y que se consideran aptos para la exportación. Se emite conforme a la (NIMF-12).

Certificado OIRSA: Se emite en cumplimiento de normas para el embalaje de la madera. Se verifica conforme a la Norma Internacional para Medidas Fitosanitarias (NIMF-15) para evitar riesgos a la salud y el medio ambiente.

Certificado de Origen: Si el país de destino lo requiere. Se emplea para acreditar documentalmente que una mercancía califica como originaria.

Certificado CITES y NO CITES: Para los casos en que tenga lugar, según la Convención y el Reglamento respectivo. Particularmente, el reglamento preceptúa lo que la persona interesada en obtener el respectivo permiso deberá presentar a la Autoridad Administrativa (véase el Cuadro siguiente).

\section{Cuadro 7. Trámite para la obtención de permisos y certificados, Oficina CITES}

\section{Reglamento CITES}

Solicitud que contiene información de acuerdo con lo establecido en el Art. 38 del Reglamento.

Permiso de Importación del país de destino.

Documento mediante el cual se comprueba que el espécimen fue obtenido legalmente.

Dictamen de la autoridad científica que manifieste que la exportación no perjudicará la supervivencia de dicha especie.

Resolución.

Fuente: Elaboración personal, conforme al Reglamento CITES 
Diagrama del trámite a seguir para exportación

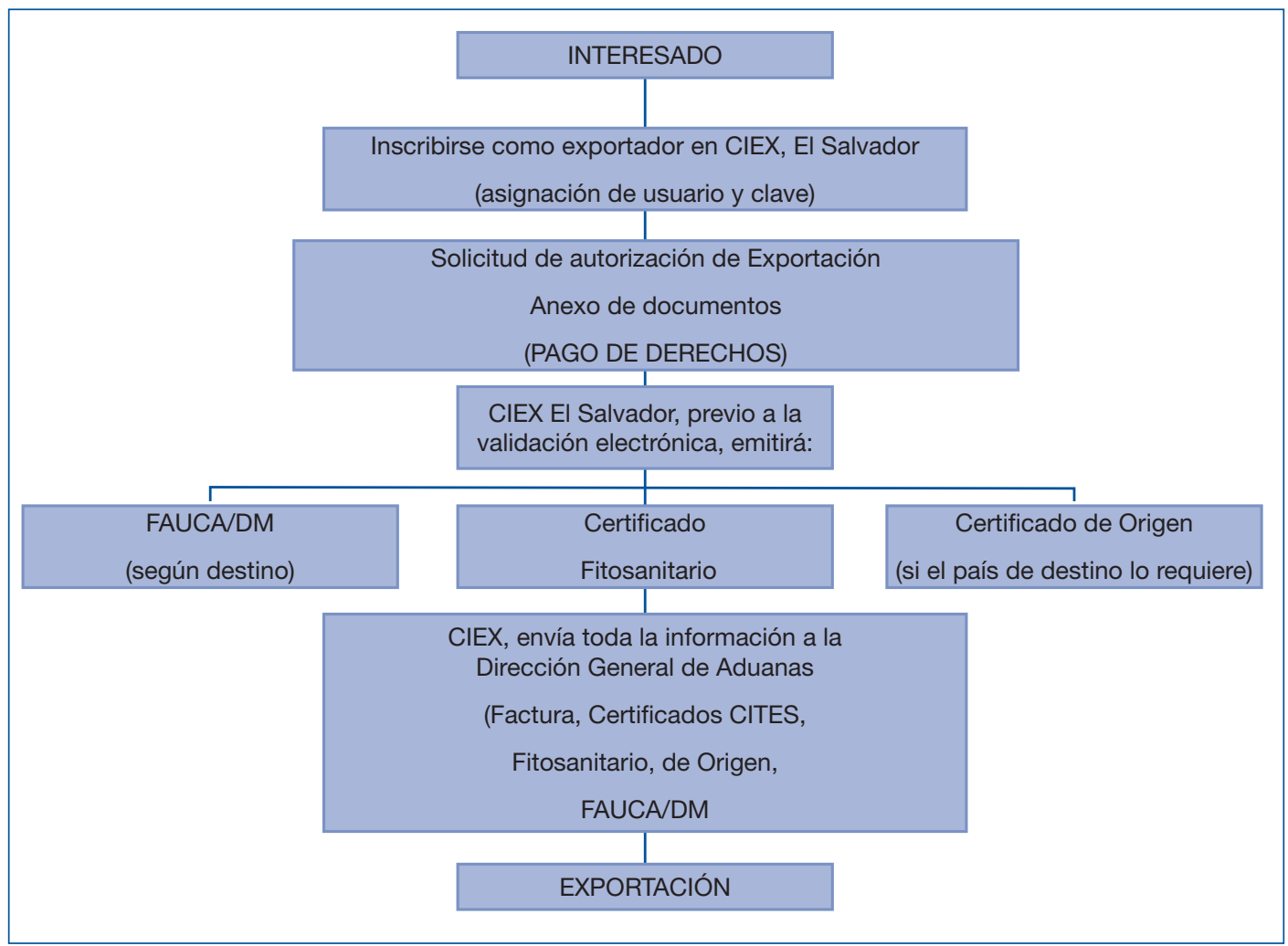

Fuente: CENTREX. 'Guía de Trámites de Exportación'. [sitio web]. <http://www.gob.sv/scx_html/guia_tramites. $h t m l$.

\subsection{Definición de un diagrama legal-administrativo para que productos de madera de la región accedan los mercados de Estados Unidos de América y la Unión Europea, en el marco jurídico de la Lacey Act (EE.UU.) y el plan de acción FLEGT (UE)}

En relación con el marco jurídico de la Lacey Act (EE.UU) y el Plan de Acción FLEGT (UE) para que productos de madera de El Salvador accedan a los mercados de Estados Unidos de América y la Unión Europea, es de señalar que en El Salvador no hay diagramado un procedimiento al respecto. Sin embargo, al ser el país suscriptor del CAFTA DR, debe imperativamente cumplirse con las exigencias de este en todo sentido y particularmente en lo referente a la parte ambiental. De modo que es por vía de este acuerdo comercial que tiene viabilidad la Lacey Act.

En lo que concierne a la iniciativa FLEGT, El Salvador aún no es parte de ella. No obstante, para las exportaciones deberá cumplirse con las exigencias que para tal efecto se regulan según acuerdos comerciales y exigencias de los países de destino, puesto que lo anterior no significa que se estén obviando esfuerzos por garantizar la legalidad al respecto. Por ejemplo, El Salvador cumple con la 
Convención sobre el Comercio Internacional de Especies Amenazadas de Fauna y Flora Silvestres (CITES), en virtud de la cual exige el certificado CITES, entre otros.

\subsection{Análisis de las estadísticas en los últimos 5 años provenientes de la administración forestal, fitosanitaria y aduanal (p. ej. planes de manejo, facturas comerciales, declaraciones de productos comerciados, certificados de origen, certificados fitosanitarios, comercialización de especies, CITES)}

La Ley Forestal, conforme a los Artículos 31, 32 y 33, prescribe que el MAG está en obligación -primero- de llevar un Registro Forestal específicamente para planes de manejo forestal aprobados, plantaciones forestales, rodales semilleros, viveros forestales y ventas de madera, aserraderos y procesadores de productos forestales; segundo, un inventario forestal que comprenda información sobre el área de bosques naturales y plantaciones forestales a nivel nacional, y la cuantificación y calificación de los recursos forestales; tercero, un Sistema de Información Forestal.

Sin embargo, a pesar de que la misma ley estatuye el deber de mantener esta información actualizada, la realidad es diferente. El problema de la limitada asignación de recursos financieros afecta su cumplimiento, por lo que no toda esta información está disponible y la que sí lo está tampoco se encuentra actualizada.

Conforme a estos archivos, el MAG tiene registrados ciento quince planes de manejo aprobados. No obstante, la institución -por medio del Área de Recursos Forestales- informa que de este dato solamente se encuentran dieciocho vigentes a la fecha ${ }^{30}$; los demás ya están caducados.

Es importante destacar que del número total de planes de manejo que tiene registrado el MAG, solamente uno es latifoliado, mientras que todos los demás corresponden a coníferas. Esto ha implicado que los formatos que ha ido desarrollando el MAG están diseñados en función de coníferas; de tal manera que si se presentara otro latifoliado, deberá trabajarse empleando el único formato existente, pero adecuándose a sus propias características que la identifiquen.

El ARF también informa, a manera estadística, que de las 4 oficinas regionales con que opera, la mayor demanda de trámites forestales como planes de manejo y guías de transporte se tiene en la región dos, es decir, la que corresponde a la zona central del país, pero particularmente del Departamento de Chalatenango y dentro de este, concretamente de los Municipios de La Palma, San Ignacio y San Fernando.

En lo relativo a la demás información, resulta difícil para el ARF recopilarla, puesto que -además de que la base de datos del MAG no está actualizada, existe otra dificultad al respecto. Como se ha explicado en los apartados precedentes, el ARF tiene agencias forestales en todo el país, distribuidas por regiones y cada una está encargada del manejo forestal de su zona ${ }^{31}$. Sin embargo, no todas las oficinas cuentan con un sistema o base de datos que favorezca llevar los registros pertinentes de manera eficiente y oportuna.

30. La vigencia es de cinco años.

31. Otro problema es que no en todas las agencias forestales hay colecturías para pagar las guías de transporte. 
En todo caso, el ARF estima que emite aproximadamente diez mil guías de transporte por año. El mismo problema ocurre con las resoluciones sobre aprovechamiento forestal, ya que cada agente forestal está investido de autoridad para emitirlas. Solo en el Departamento de Santa Ana se calcula que se dictaron aproximadamente quinientas resoluciones y a nivel nacional quizá se hayan dado unas dos mil autorizaciones.

En resumen, hay un fuerte compromiso por parte del MAG de actualizar sus registros y modernizar todo lo relativo a la actividad forestal para que logre cumplir con los objetivos institucionales. En cuanto al comercio internacional, la autoridad que los registra es el Banco Central de Reserva de El Salvador.

Sin embargo, en la información proporcionada no puede apreciarse el movimiento comercial por especie, pero el ARF detalla que se ha observado un aumento en las exportaciones del género Dalbergia, particularmente de las especies Retusa y Tucurensis, que se están exportando a China y Taiwán.

Con base en la información proporcionada por el BCR, se presenta a continuación el siguiente cuadro estadístico sobre las exportaciones de productos forestales durante el período comprendido entre los años 2008 a 2013. Se presenta en valores y peso.

\section{Cuadro 8. Valores y kilogramos exportados}

\begin{tabular}{|c|c|c|c|c|c|}
\hline 2008 & 2009 & 2010 & 2011 & 2012 & 2013 \\
\hline Valores & Valores & Valores & Valores & Valores & Valores \\
$5,682,102.86$ & $5,274,442.66$ & $5,479,292.55$ & $8,620,816.86$ & $7,760,056.61$ & $8,635,492.98$ \\
\hline Kilogramos & Kilogramos & Kilogramos & Kilogramos & Kilogramos & Kilogramos \\
$28.588 .455,68$ & $26.866 .329,84$ & $27.651 .199,44$ & $41.217 .965,82$ & $30.535 .356,18$ & $28.608 .512,29$ \\
\hline
\end{tabular}

Fuente: Elaboración personal con datos proporcionados por el BCR. 


\section{Análisis del sistema de control forestal}

\subsection{Análisis de la existencia de conflicto de competencia entre los responsables de la administración y ejecución de los sistemas de control forestal}

El MAG es la principal autoridad en lo que respecta a la actividad forestal. Sin embargo, en lo concerniente al control forestal, también intervienen otros entes que, al igual que el MAG, tienen sus propias competencias, pero que por sus objetivos institucionales coinciden y deben coordinar esfuerzos. Entre estas instituciones están MARN, Policía Nacional Civil (PNC), Fiscalía General de la República (FGR) -por medio de su Unidad de Medio Ambiente-, Dirección General de Aduanas y las dependencias del mismo MAG, como la Dirección General de Sanidad Vegetal y Animal, y el Área de Recursos Forestales de la DGFCR.

Si bien es cierto que conforme a la Ley Forestal y afines no se advierten conflictos de competencia muy significativos al respecto, algunas veces se dan diferencias entre instituciones como el MARN y la Dirección General de Aduanas en el sentido de que existe poca coordinación entre ellas y falta capacitación para los técnicos que revisan y controlan en las aduanas del país, ya que -debido a esa falta de conocimiento- a veces se tiene poca certeza en la identificación de especies forestales que están en los listados de especies amenazadas o en peligro de extinción.

No obstante, en términos generales, las instituciones relacionadas con el control forestal funcionan correctamente y a pesar de que muchas veces los problemas de coordinación entre estas responden a limitaciones presupuestarias, sus competencias están claramente delimitadas.

\subsection{Detalle de requerimientos de control forestal explícitos en la Ley Forestal y afines}

La Ley Forestal y su reglamento regulan sus propios mecanismos de control forestal con la finalidad de garantizar la legalidad y sostenibilidad del aprovechamiento forestal y que pueden advertirse en diferentes secciones de su articulado. Obsérvese que la implementación de diferentes registros (para planes de manejo, plantaciones forestales, formuladores de planes de manejo, ventas de madera, aserraderos y procesadores de productos forestales) tiene por objetivo precisamente ejercer un control forestal al respecto, en el sentido de que se requiere su inscripción. De hecho, su regulación en la LF se encuentra dentro de su Título Quinto, denominado "Organismos de Financiamiento y Control Forestal”. Es más, dentro de ese apartado yace también la obligación de llevar un inventario y un sistema de información forestal.

Asimismo están diseñadas las disposiciones referidas al transporte, almacenamiento, comercialización e industrialización de productos forestales cuando dicha normativa exige documentos especiales para ello, a fin de probar el origen legal de la madera, como guías de transporte, facturas o pólizas de importación. 
Otros controles explícitos contenidos en dicha normativa pueden constatarse en la facultad que se le encomienda a la PNC para interceptar cargamentos de productos y subproductos forestales a efecto de comprobar su legal procedencia, así como en el RLF, que contiene un capítulo para la actuación de la PNC, destinada a la forma de obrar en decomisos que tengan lugar como resultado de aprovechamiento y comercio forestal de tipo ilegal.

La PNC cuenta con agentes dedicados a este tipo de controles en las carreteras, principalmente en zonas estratégicas y a estos esfuerzos se suman entes como la Dirección General de Aduanas, que debe verificar la documentación legal para la importación y exportación de productos forestales y la Dirección General de Sanidad Vegetal y Animal, la cual tiene que certificar que los referidos productos cumplan con las medidas fitosanitarias, entre otras que ya se han enunciado en este estudio, como CITES, certificados de origen y OIRSA.

Consecuentemente, el control en lo relativo al aprovechamiento forestal lo ejerce el MAG por medio de sus propios mecanismos; mientras que lo tocante a las demás facetas, como su transporte, comercialización o exportación, lo ejercen diferentes instituciones, pero de manera conjunta con el MAG.

\subsection{Determinar la existencia de un sistema de monitoreo de estadísticas forestales y su impacto en la ilegalidad del aprovechamiento forestal}

El Salvador todavía no cuenta con un Sistema de Monitoreo de Estadísticas Forestales. No obstante, conforme al Artículo 33 de la Ley Forestal y 35 de su Reglamento, debe existir un Sistema de Información Forestal. Dentro de la estructura organizativa del ARF figura la oficina denominada Registro, Estadística e Información Forestal. Sin embargo, a pesar de que la ley y el reglamento señalan que deberá mantenerse actualizado y estará a disposición del público, lo cierto es que se requiere más apoyo presupuestario para su cumplimiento.

Como se advirtió en el tema 3.5 (Análisis de las estadísticas...), la falta de asignación presupuestaria suficiente imposibilita contar con los recursos materiales y humanos para cumplir con esta obligación; de modo que no solo no se recaba su totalidad, sino que incluso la que sí existe tampoco se encuentra actualizada.

En consecuencia, uno de los retos del MAG es implementar un sistema de monitoreo, así como modernizar y actualizar sus registros en todo lo relativo a la actividad forestal, ya sea bajo recursos propios o por medio de alianzas estratégicas, para que logre cumplir con este objetivo institucional. En este sentido, mientras esto no ocurra, no es posible determinar su impacto en la ilegalidad del aprovechamiento forestal. No obstante, resulta evidente que su implementación permitiría tener una idea cierta de la situación forestal en el país y tomar decisiones e impulsar programas o estrategias más acordes con la realidad nacional. 


\subsection{Análisis del control cruzado de certificados de comercio de productos de madera}

En el control cruzado de certificados de comercio de productos de madera que se ejerce en El Salvador intervienen diferentes instituciones que se involucran de acuerdo con sus competencias (MAG, MARN, Dirección General de Sanidad Vegetal y Animal, Dirección General de Aduanas, Oficina CITES, OIRSA y CIEX EI Salvador, entre otros), emitiendo la documentación legal respectiva (certificados, facturas y otros).

CIEX El Salvador facilita este control cruzado de certificados e incluso por medio del Sistema Integrado de Comercio Exterior (SICEX), que interconecta a los exportadores, instituciones del Estado vinculadas al comercio exterior y a CIEX El Salvador, dicho control se realiza electrónicamente, por lo que resulta eficiente y efectivo para estos efectos, ya que toda la documentación pertinente es validada previo a su envío a la Dirección General de Aduanas.

Sin embargo, como se apuntó en el tema 4.1 (Análisis de la existencia de conflicto de competencia...), la falta de capacitación técnica para el personal destacado en las aduanas del país, en lo que a la identificación y verificación de las especies respecta, provoca que algunas veces se pueda estar comercializando especies que se encuentren amenazadas o en peligro de extinción. Se pretende que al fortalecer estos controles el aprovechamiento y la comercialización de productos forestales se enmarque conforme a la ley.

\subsection{Número de las denuncias presentadas por las autoridades del Estado por el delito de actividades forestales ilegales}

Conforme a la Ley Forestal y su reglamento, le corresponde al MAG conocer de las infracciones a la ley e imponer las sanciones respectivas; lo anterior sin perjuicio de la acción judicial correspondiente. Esto significa que -en caso de que la infracción forestal diere origen a un hecho tipificado como delito en el Código Penal- la autoridad forestal lo hará del conocimiento de la Fiscalía General de la República (FGR) una vez se haya concluido el procedimiento administrativo correspondiente; es decir, que la institución facultada para promover la acción penal es el Ministerio Público por medio de la Fiscalía General de la República.

Como ya se ha explicado, se cuenta con cuatro regiones para la administración forestal, según las zonas en que se divide el país (occidental, central, paracentral y oriental) y cada región lleva sus propios registros de los procedimientos sustanciados y de los casos remitidos a la FGR.

En este sentido, la información proporcionada corresponde a los registros que la oficina jurídica de la DGFCR lleva al respecto, pero de las regiones 2 y 3 (zona central y paracentral) y conforme a estos datos, se advierte que los casos remitidos a la FGR por actividades forestales ilegales son aproximadamente 5 por año; es decir, que la mayoría de casos sustanciados concluyen con la respectiva sanción económica y solo un reducido porcentaje termina remitiéndose a la FGR a efecto de que sea dicha oficina la que califique si son o no constitutivos de delito. La referida oficina jurídica de la DGFCR explica que lo que más remiten a la FGR son expedientes para cumplimiento de multa, frente a un reducido número de posibles delitos. 


\section{Análisis de ejecución de procesos judiciales}

\subsection{Análisis de la Ley Forestal y regulaciones afines a la luz de los procesos judiciales existentes en materia de aprovechamiento forestal y comercio internacional de productos forestales}

Primeramente, debe aclararse que conforme a la Ley Forestal y regulaciones afines existen procedimientos administrativos y judiciales. Los administrativos están destinados para las infracciones que no constituyan delito. Las autoridades administrativas que impone las sanciones correspondientes, según sea el caso, son el MAG y el MARN. Mientras que toda actividad de aprovechamiento forestal y comercio ilegal que sea constitutivo de delito compete su conocimiento al órgano judicial por medio de los tribunales correspondientes, es decir, a los tribunales con competencia en materia penal. La acción penal la ejerce el Ministerio Público por medio de la Fiscalía General de la República, institución que cuenta con una Unidad Fiscal de Delitos de Medio Ambiente y que a la fecha ha sido fortalecida con más recurso humano.

En este sentido, los procesos judiciales propiamente dichos son promovidos por la FGR ante los tribunales con competencia en materia penal conforme a los delitos tipificados en el Código Penal y se sigue el proceso que para tal efecto está previsto en el Código Procesal Penal. Empero, los jueces de la materia también se apoyan en la normativa administrativa -como lo es la misma Ley Forestal y su Reglamento- para los aspectos conceptuales y en las demás leyes afines, como la LMA, LCVS, LANP e incluso en el Código Procesal Civil y Mercantil y el Código de Comercio, entre otras. En el ámbito del comercio internacional tiene aplicación lo dispuesto en el Tratado de Libre Comercio entre Estados Unidos, Centroamérica y República Dominicana, CAFTA-DR y demás instrumentos internacionales.

Sin embargo, si bien es cierto que la Unidad Fiscal ha sido reforzada, la Ley Forestal solo regula faltas administrativas, no delitos, puesto que su tipificación está destinada al Código Penal y conforme a este instrumento normativo algunas actividades relacionadas con el aprovechamiento forestal ilegal están fuera del alcance penal, por lo que muchas conductas de este tipo terminan siendo castigadas únicamente con sanciones económicas por medio de la Ley Forestal, lo que conlleva a impunidad.

\subsection{Duración de los procesos judiciales relacionados con el aprovechamiento forestal y comercio internacional de productos forestales}

Como se aclaró en el apartado 5.1 (Análisis de la Ley Forestal y regulaciones afines), los procesos o procedimientos con respecto al tema forestal son de tipo administrativo y judicial. Judicialmente, el proceso por aprovechamiento y comercio forestal ilícito se desarrolla en tres fases, así: una audiencia inicial ante un Juez de Paz, una audiencia preliminar ante un Juez de Instrucción y la vista pública 
ante un Tribunal de Sentencia, que conforme lo preceptúa el Artículo 53 del Código Procesal Penal ${ }^{32}$ está integrado por tres jueces.

La etapa de instrucción es la que absorbe más tiempo; dura como máximo seis meses y tiene por objeto la preparación de la vista pública mediante la recolección de todos los elementos que permitan fundar la acusación del fiscal o del querellante y preparar la defensa del imputado. En la vista pública tiene lugar la producción de la prueba (por ejemplo: pericial, testimonial, documental, inspecciones, valoración de daños y valoración económica) y es donde se pronuncia la sentencia. Sin embargo, no necesariamente se debe llegar hasta esta fase, puesto que puede haber lugar a otra forma de terminación del proceso o salida alterna, o incluso que se haya seguido un procedimiento especial, como podría ser el procedimiento abreviado regulado en los Artículos 417 y 418 del Código Procesal Penal.

Los procesos penales están sujetos a diferentes situaciones incidentales que vuelven complejo poder establecer un tiempo de duración predeterminado. Su duración dependerá de cómo se desenvuelve cada juicio en particular, pero respetándose las garantías del debido proceso y los plazos legales y judiciales al respecto. No obstante, el Jefe de la Unidad de Medio Ambiente de la FGR estima que la duración de los procesos relativos a delitos de esta índole es aproximadamente de siete meses a un año.

\section{Cuadro 9. Secuencia del proceso judicial}

\begin{tabular}{|c|c|}
\hline & Etapas \\
\hline - Requerimiento Fiscal (Art. 294) & \\
\hline - Audiencia Inicial (Art. 297) & \\
\hline - Instrucción Formal (Art. 301) & \\
\hline - Audiencia Preliminar (Art. 355) & \\
\hline - Auto de Apertura a Juicio (Art. 364) & \\
\hline - Remisión a Tribunal de Sentencia & \\
\hline - Vista Pública & \\
\hline
\end{tabular}

Fuente: Elaboración personal con base en el Código Procesal Penal

En lo que respecta a la parte administrativa, La Ley Forestal establece en su Artículo 34 que corresponde al MAG conocer de las infracciones a dicha ley e imponer las sanciones respectivas sin perjuicio de la acción judicial correspondiente.

A partir del Artículo 37 de la misma ley, se encuentra normado el procedimiento a seguir. Puede iniciar de oficio o por denuncia, levantándose acta dentro de los ocho días siguientes después de cometida la infracción. EI MAG cita por una sola vez al presunto infractor para que comparezca

32. Decreto Legislativo $\mathrm{N}^{\circ} 733$ del 22 de octubre de 2008, publicado en el Diario Oficial $\mathrm{N}^{\circ} 20$, Tomo $\mathrm{N}^{\circ} 382$, de fecha 30 de enero de 2009. 
dentro de los ocho días hábiles siguientes de la citación. Si la persona citada no comparece dentro del referido plazo, se le declara rebelde; pero si comparece y hace oposición, se abrirá a pruebas por el término de cuatro días hábiles. Concluido el término probatorio, se pronunciará resolución definitiva dentro del tercer día hábil. Esta última admite recurso de revisión. En resumen y conforme a la ley, el procedimiento administrativo tiene una duración aproximadamente de un mes y medio a dos meses. No obstante, por la falta de personal y las peculiaridades propias de los procedimientos, no siempre es posible sustanciarlos en dicho período.

En forma secuencial, el procedimiento sería así:

\section{Cuadro 10. Procedimiento Administrativo, LF}

\section{Etapas}

- Infracción

- Acta (OCHO días)

- Citación (OCHO días)

- Comparecencia o rebeldía

- Apertura a pruebas (CUATRO días)

- Resolución definitiva (TRES días)

- Recurso de revisión (TRES días)

- Resolución definitiva (DIEZ días)

\subsection{Jurisprudencia relevante en relación con compensación por daño ambiental por el delito de aprovechamiento ilegal de productos forestales}

En El Salvador, la jurisprudencia o doctrina legal viene dada por la Sala de lo Penal de la honorable Corte Suprema de Justicia. Empero, en el tema de la compensación por daño ambiental por el delito de aprovechamiento ilegal de productos forestales no hay formación ni publicación alguna de esta. Es decir, sí existen sentencias referidas a los delitos relacionados con el aprovechamiento forestal de tipo ilegal, pero no puntualmente al tema que aquí ocupa. Tampoco fue posible ubicar en el Centro de Documentación Judicial jurisprudencia en la que se desarrolle la compensación ambiental.

Al margen de lo expresado, es importante citar que la Ley Forestal no regula nada respecto al daño ambiental, sino que lo hace la LMA. En su parte conceptual, en su Artículo 5, define daño ambiental como toda pérdida, disminución, deterioro o perjuicio que se ocasione al ambiente o a uno o más de sus componentes, en contravención a las normas legales. Agrega que el daño podrá ser grave cuando ponga en peligro la salud de grupos humanos, ecosistemas o especies de flora y fauna, e irreversible cuando los efectos que produzca sean irreparables y definitivos. Mientras, en 
el Artículo 96 se hace referencia al valúo de daños al medio ambiente. Incluso, de la LMA se deriva un reglamento especial denominado Reglamento Especial para la Compensación Ambiental ${ }^{33}$, cuyo objeto es precisamente dictar normas que reconozcan formas directas de compensación ambiental.

\subsection{Tipos de penas existentes en la legislación y su vinculación con la ilegalidad en el comercio de madera (p. ej. penalidades según ámbito administrativo y judicial)}

En lo relacionado con el área judicial, el Código Penal solamente regula dos delitos que se refieren explícitamente al tema forestal, pero ninguno puntualmente al comercio ilegal de productos forestales. En este sentido, dentro del Libro Segundo de dicho Código se ubica el Título X que trata de los delitos relativos a la ordenación del territorio, la protección de los recursos naturales y al medio ambiente. Dentro de este se encuentra el Capítulo II sobre los delitos en relación con la naturaleza y el medio ambiente que comprende, entre otros delitos, los que a continuación se detallan:

\section{Depredación de Bosques (Art. 258)}

El que destruyere, quemare, talare o dañare, en todo o en parte, bosques u otras formaciones vegetales naturales o cultivadas que estuvieren legalmente protegidas será sancionado con prisión de tres a seis años. Se exceptúan de cualquier pena los agricultores que realicen labores agrícolas estrictamente culturales.

\section{Depredación de Flora Protegida (Art. 259)}

El que cortare, talare, quemare, arrancare, recolectare, comerciare o efectuare tráfico ilegal de alguna especie o subespecie de flora protegida o destruyere o alterare gravemente su medio natural será sancionado con prisión de uno a tres años. En la misma pena incurrirá quien en espacio natural protegido dañare gravemente alguno de los elementos que hubieren servido para calificarlo como tal.

Como se podrá apreciar, no está tipificado ningún delito sobre comercio ilegal o transporte ilegal de productos forestales. Si bien es cierto que el delito de depredación de flora protegida toca el punto de la comercialización, esta alude exclusivamente a la flora protegida. Sin embargo, el Código Penal cuenta con una disposición en el Título VIII que trata de los delitos relativos al Patrimonio, en su Capítulo II, sobre los delitos del robo, la extorsión y la receptación, que literalmente dice:

\section{Conducción de mercaderías de dudosa procedencia (Art. 214-b)}

El que en vehículo automotor de carga condujere mercadería sin la debida documentación que ampare la legítima propiedad o procedencia de la misma, sin importar la cantidad, será sancionado con una pena de dos a cuatro años de prisión.

Es decir que, aunque no se encuentre ubicado dentro del capítulo de los delitos contra la naturaleza, en la práctica es bajo esta figura en la que se ubica toda conducta ilícita en virtud de la cual se pretenda comercializar sin la documentación respectiva. También existen otros delitos que no se ubican en el capítulo de la naturaleza y el medio ambiente, pero que en determinadas circunstancias

33. Decreto Ejecutivo $N^{\circ} 50$ del 4 de mayo de 2004, publicado en el Diario Oficial $N^{\circ} 93$, Tomo $N^{\circ} 363$, de fecha 21 de mayo de 2004. 
se relacionan con el tema, como el de la falsedad de documentos, hurto y hurto agravado. Incluso puede haber lugar al concurso de delitos. Además, es importante señalar que las tipificaciones existentes y de las cuales se han hecho referencia en este apartado no pueden ser vistas aisladamente, sino que para su aplicación es necesario que el operador de justicia complemente el tipo penal con las disposiciones que para tal efecto se encuentran desarrolladas en la Ley Forestal y afines.

Respecto a la sede administrativa, la Ley Forestal y su reglamento disponen claramente diferentes supuestos de infracción a la ley con sus respectivas sanciones (véase el Cuadro 11).

\section{Cuadro 11. Infracciones y sanciones, LF}

\begin{tabular}{|c|c|}
\hline Infracción & Sanción \\
\hline $\begin{array}{l}\text { - Talar sin la autorización correspondiente árboles en } \\
\text { los bosques naturales. }\end{array}$ & 2 a 5 salarios mínimos por cada árbol talado. \\
\hline $\begin{array}{l}\text { - Comercializar las guías de transporte para } \\
\text { productos forestales. }\end{array}$ & 2 a 5 salarios mínimos por cada guía. \\
\hline $\begin{array}{l}\text { - Transportar productos o subproductos forestales } \\
\text { sin la documentación que acredite su legítima } \\
\text { procedencia o presentarla con falsificaciones o } \\
\text { alteraciones. }\end{array}$ & 5 a 8 salarios mínimos. \\
\hline $\begin{array}{l}\text { - No cumplir con los lineamientos o condiciones } \\
\text { establecidas en las autorizaciones otorgadas por } \\
\text { el MAG. }\end{array}$ & 20 a 25 salarios mínimos. \\
\hline $\begin{array}{l}\text { - Aprovechar por cualquier medio bienes del } \\
\text { patrimonio forestal del Estado a que se refiere esta } \\
\text { ley sin la autorización correspondiente. }\end{array}$ & 10 a 12 salarios mínimos. \\
\hline
\end{tabular}

Fuente: Elaboración personal basada en la LF

En cuanto a la efectividad del esquema de sanciones forestales, en lo judicial la FGR hace un buen trabajo. Sin embargo, resulta inefectiva la tipificación existente en el Código Penal, por cuanto deja por fuera toda conducta ilícita relacionada con la depredación de bosque y flora que no se encuentre legalmente protegida, de modo que los jueces en estos casos terminan dictando sobreseimientos y como lo ha confirmado el jefe de la referida Unidad Ambiental, un alto porcentaje de los casos que son judicializados terminan con sobreseimiento precisamente por esta razón. De igual forma, la compensación del daño causado solo logrará efectividad en la medida que sean creados los Tribunales Ambientales.

En lo administrativo la realidad es diferente. La tipificación de infracciones con sus correspondientes sanciones es más amplia. No obstante, en contraste con la FGR, la oficina jurídica de la DGFCR requiere más personal para lograr cumplir con los plazos legales en la sustanciación de los procedimientos. En este sentido, puede inferirse que la tipificación es aceptable, pero para alcanzar un nivel de efectividad óptimo se hace preciso dotarle de mayor recuso humano. 


\subsection{Número de casos presentados y casos desestimados o con sentencia condenatoria para el período 2008-2013}

La Fiscalía General de la República, como parte del Ministerio Público, tiene por mandato constitucional la dirección de la investigación del delito con la colaboración de la Policía Nacional Civil, así como promover la acción penal de oficio o a petición de parte. Dispone de su propia Ley Orgánica que desarrolla ampliamente su estructura y atribuciones. En lo que al tema forestal respecta, cuenta con la Unidad Fiscal de Delitos de Medio Ambiente. Esta Unidad cuenta con oficinas en los Departamentos de San Salvador, Santa Ana, San Vicente y San Miguel, y de conformidad con el área de influencia territorial en que ejercen su trabajo, cada una lleva sus propios registros de los casos presentados por delitos relacionados con el aprovechamiento y comercio ilegal de tipo forestal, pero no la disponen en un registro único.

En este sentido, la información pertinente a este apartado, no obstante haberse requerido por escrito a las oficinas centrales de la FGR, a la fecha de entrega de este informe final solamente habían sido proporcionados los datos correspondientes a la sede central ubicada en San Salvador. Al respecto, la información suministrada por la FGR es la siguiente:

\section{Cuadro 12. Delito depredación de bosques}

\begin{tabular}{|l|l|l|}
\hline \multicolumn{1}{|c|}{ Referencia } & \multicolumn{1}{|c|}{ Resultado } & \multicolumn{1}{c|}{ Estado actual } \\
\hline 58-UDMA-2008 & Instrucción con medidas & Archivo \\
\hline 91-UDMA-2009 & Suspensión condicional del procedimiento & Archivo \\
\hline 07-UDMA-2010 & Sobreseimiento definitivo & Archivo \\
\hline 51-UDMA-2010 & Condenatorio & Archivo \\
\hline 83-UDMA-2010 & Condenatorio & Archivo \\
\hline 84-UDMA-2010 & Condenatorio & Archivo \\
\hline 55-UDMA-2011 & Condenatorio & Archivo \\
\hline 01-UDMA-2012 & Sobreseimiento definitivo & Archivo \\
\hline 59-UDMA-2012 & Sobreseimiento definitivo & Archivo \\
\hline 85-UDMA-2012 & Suspensión condicional del procedimiento & Archivo \\
\hline 20-UDMA-2013 & Condenatorio & Archivo \\
\hline 44-UDMA-2013 & Sobreseimiento definitivo & Archivo \\
\hline
\end{tabular}

Fuente: Elaboración personal con base en datos proporcionados por la FGR 


\subsection{Análisis de retos en el ámbito judicial en materia de aprovechamiento forestal y comercio internacional de productos forestales}

Uno de los principales retos en el ámbito judicial es poner en funcionamiento plenamente los Tribunales Ambientales. ${ }^{34}$ Dicho mandato data desde 1998 y actualmente solamente hay un tribunal en funcionamiento.

Respecto a los aspectos administrativos, la normativa es bastante completa y el procedimiento cuyo conocimiento corresponde al MAG- está claramente definido con sus respectivas tipificaciones y sanciones. No obstante, el MARN también sigue procedimientos relativos a sus competencias derivados principalmente de la LMA, LANP y LCVS. Algunas infracciones reguladas en ellas tienen relación con la temática forestal. En este sentido, se podrían realizar esfuerzos por unificarlos.

Sin embargo, en cuanto a la tipificación penal, también debe trabajarse. Como se especificó anteriormente, en la temática forestal solo existen dos delitos expresamente tipificados en el Código Penal y se refieren concreta y principalmente a la depredación. Se hace necesaria una tipificación más amplia que aborde conductas relacionadas con la comercialización ilegal de productos y subproductos forestales.

Sobre la tipificación de los delitos de depredación de bosques y flora protegida, su regulación resulta insuficiente en términos prácticos, puesto que la exigencia en ambos presupuestos legales de encontrarse el bosque o la flora "legalmente protegida" deja por fuera un sinnúmero de casos en los que tiene lugar la depredación de bosque o flora como tal, pero que quedan impunes por no encontrarse legalmente protegidas como dispone la norma. Lo que ocurre es que los jueces verifican si existe o no calificación alguna que establezca que se encuentre legalmente protegido y si no lo está, simplemente se trata de un caso atípico y el juicio termina en sobreseimiento. Por lo tanto, como está actualmente la regulación, debe demostrársele al juez -en caso de que así sea- que una determinada especie se encuentra protegida conforme a la ley.

Según expresa el Jefe de la Unidad de Medio Ambiente de la FGR, la mayoría de casos que son sometidos a los tribunales terminan impunes por estas circunstancias. Por ello, es menester que trabajen conjuntamente FGR, MAG y MARN, así como otros actores relacionados con el tema-como los mismos jueces- para que se coordinen esfuerzos por lograr cambios normativos al respecto.

34. Asamblea Legislativa. Decreto $N^{\circ} 684$ de fecha 22 de mayo de 2014. Diario Oficial $N^{\circ} 105$, Tomo $N^{\circ} 403$. Fecha de publicación: 9 de junio de 2014). 


\section{Aportes adicionales}

\subsection{Análisis de la situación legal-administrativa para el aprovechamiento de la madera y comercio internacional de productos forestales}

La actual LF sustituyó a la de 1973 para potenciar el desarrollo forestal del país e incluso lo declaró de interés económico. Dicha ley, la LMA, LANP y la LCVS son coherentes entre sí y si bien es cierto pueden mejorarse decretándose algunos reglamentos para optimizar y hacer eficiente su aplicación, los mecanismos de participación pública, la institucionalidad, competencias y atribuciones contenidas en estas se encuentran claramente determinadas, de modo que pueden considerarse aceptables. En lo que respecta a la legislación relacionada con el comercio internacional, El Salvador todavía tiene algunos compromisos pendientes, como adherirse al Convenio Internacional de Maderas Tropicales, entre otros. Sin embargo, hay un esfuerzo notable en el tema, puesto que sí es parte de otros instrumentos fundamentales y cumple con requerimientos internacionales, como las normas fitosanitarias (NIMF).

En aspectos puntuales como REDD+, ya se están haciendo esfuerzos en ello. Todavía no hay una ley especial, pero se está trabajando por una estrategia nacional que dará viabilidad a su aplicación. En cuanto a conflictos entre derechos de uso de la tierra y los bosques, no se advierten traslapes al respecto y con respecto a la distribución justa y equitativa de los beneficios de un aprovechamiento sostenible de la madera, la legislación regula ampliamente su sostenibilidad, pero debe trabajarse por desarrollar mecanismos para su promoción.

Sobre los estándares de legalidad, acerca de los derechos de los pueblos indígenas, se ha reformado la Constitución y se ha adoptado la Declaración de las Naciones Unidas sobre los Derechos de los Pueblos Indígenas que -por hoy- debe ser el referente para la adecuación de la normativa interna, ya que sigue pendiente la ratificación del Convenio $\mathrm{N}^{\circ} 169$ de la OIT. En cuanto a los aspectos legales relacionados con los permisos de aprovechamiento forestal, la LF es bastante precisa y tiene reglas claras para su trámite, porque hace distinciones interesantes entre bosques naturales y plantaciones forestales, regulando también diferentes tipos de aprovechamientos e impulsando el plan de manejo forestal como el principal instrumento para ello. Empero, en cuanto al cuadro tarifario, llama la atención que las guías de transporte cuesten lo mismo independientemente de las cantidades de productos que se transporten, en contraste con el aprovechamiento, que es por hectáreas de bosque productivo. Esto podría regularse mejor.

Las competencias de la administración forestal se encuentran bien delimitadas; corresponden al MAG, pero se delegan en el ARF, ente subordinado a la DGFCR y en términos generales, puede establecerse que estas son efectivas con excepción de algunas funciones que deben trabajarse más, como la parte de registros, estadísticas, inventarios e información forestal. Sin embargo, se insiste en que para que la administración forestal logre objetivos institucionales se le provea de mayores recursos económicos. 
En lo referente al comercio y exportación, hay avances significativos que lo facilitan y que incluso puede hacerse en línea. Se trata de CIEX El Salvador, el cual reúne en sí a las principales oficinas vinculadas al comercio internacional. Los requisitos para exportar permiten asegurar la legalidad al respecto, cumpliendo con los compromisos internacionales. Los Certificados Fitosanitarios, CITES, de Origen, OIRSA (NIMF-15) contribuyen a ello. Los costos son aceptables; algunos trámites no tienen costo, unos tienen precio fijo y otros son variables en proporción a cantidad, lo cual es razonable. También se respetan los acuerdos internacionales y requisitos exigidos conforme a los países de destino.

En relación con el control forestal, no se advierten conflictos de competencia entre las instituciones involucradas (MAG, MARN, PNC, FGR, Dirección General de Aduanas, Dirección General de Sanidad Vegetal y Animal, Oficina CITES, OIRSA y CIEX El Salvador, entre otros). No obstante, sería recomendable que permanentemente se capacite técnicamente al personal de aduanas, así como a los agentes de la PNC que están facultados para revisar productos forestales, a fin de que puedan identificar y corroborar que los productos que se detallan en los documentos con los que se ampara su procedencia efectivamente correspondan a ellos.

Sobre los requerimientos de control forestal, la LF regula diferentes mecanismos, desde la idea misma del plan de manejo forestal hasta los diferentes registros que debe llevar el MAG, así como el inventario y el sistema de información forestal del cual ya se ha hablado, pero que necesita mejorarse. Para el transporte también se regulan controles forestales, como la exigencia de guías de transporte, facturas o pólizas de importación, según sea el caso y para el comercio internacional, con diferentes documentos y certificados. Sin embargo, uno de los temas en que la administración forestal debe trabajar más, referido al control forestal, es la implementación de un sistema de monitoreo de estadísticas forestales que venga a modernizar la forma de llevar la información dentro de la administración forestal. El control cruzado es efectivo, más aún con la participación de CIEX El Salvador.

La actividad procesal sancionatoria tiene sus peculiaridades, principalmente la judicial. La administrativa tiene una tipificación de infracciones bastante completa que abarca diferentes aspectos, pero no todos son constitutivos de delito. La mayoría se queda con sanciones de tipo económicas. En lo judicial, el problema principal radica en la limitada tipificación de delitos y su redacción.

\subsection{Retos y oportunidades jurídicas, y estrategias de fortalecimiento en el corto y largo plazo para el aprovechamiento de la madera y comercio internacional de productos forestales}

El Salvador tiene entre sus retos y oportunidades jurídicas la puesta en marcha de una política forestal nacional que marque el rumbo que se debe seguir para mejorar la competitividad, sin perder de vista la sostenibilidad. Ya está elaborada, aunque falta su aprobación.

También se deben decretar los instrumentos normativos pendientes y que se encuentran ordenados por disposición de la ley, como es el caso del reglamento para la LANP, entre otros que facilitarían la aplicación de las leyes y el mejoramiento del trabajo institucional. En el tema de los derechos de 
los pueblos indígenas, es importante un reconocimiento constitucional, la ratificación del Convenio 169 de la OIT y crear legislación interna indígena como adecuación de la existente. Debe procurarse la adhesión del país a otros instrumentos internacionales de los cuales aún no es parte y que han sido señalados acá.

No obstante, hay que enfatizar que no solo se trata de leyes, sino de mejorar el trabajo institucional y para ello resulta impostergable trabajar en una estrategia forestal al respecto, que involucre a las diferentes instituciones relacionadas, como representantes de los sectores productivos del país, dándole principalmente énfasis a la sostenibilidad de los recursos forestales.

La idea es trabajar desde incentivar la producción, bajo condiciones de sostenibilidad, hasta su aprovechamiento final y su comercialización, de tal manera que las instituciones correspondientes actúen bajo un mismo lineamiento y esfuerzo. Para lograrlo deben asignarse más recursos económicos para un mejor funcionamiento e invertir en talleres de capacitación y trabajo conjunto con el personal de las diferentes instituciones relacionadas con el tema. Por ejemplo, en el seguimiento que debe darse a todo plan de manejo autorizado por el ARF, la realidad es que esto no siempre ha sido posible por falta de recursos, pero el personal del ARF reconoce su importancia y está procurando hacerlo con los planes de manejo que actualmente están vigentes.

Por otra parte, debe trabajarse a corto plazo para actualizar la información e inventario forestal a que aluden los Artículos 32 y 33 de la LF, por cuanto eso permitiría tener una idea cierta de la situación forestal en el país, tomar decisiones e implementar programas o estrategias más acordes con la realidad nacional. Incluso, el tema es tan prioritario que se ha considerado como parte de la propuesta de estrategia REDD+ que actualmente sigue elaborándose.

Es importante modernizar no solo la propia sede del ARF, sino todas las Agencias Forestales que se encuentran diseminadas en el territorio de la República, por lo menos con el equipo tecnológico suficiente para que puedan operar de manera más eficiente y llevar registros de sus actuaciones por medio de un sistema computarizado que facilite llevar información actualizada de toda la actividad forestal a nivel nacional y crear un programa de capacitación permanente para su personal.

Además, consecuentemente con lo dicho en el tema 6.1 (Análisis de la situación legaladministrativa), la PNC debe estar más atenta a la verificación de la legalidad con el transporte. En el mismo sentido, pero referido al tema de la comercialización, si bien es cierto existen facilidades y eficiencia en lo que a la exportación se refiere, los requisitos de legalidad-principalmente en el transporte y paso por fronteras- tiene que fortalecerse, puesto que de la información recabada vía entrevistas se advierten algunas debilidades en los controles al respecto y esto solo podría superarse asignando personal capacitado y creando mejores alianzas de trabajo con la Policía Nacional Civil para evitar ilegalidades y corrupción, principalmente con aquellas especies que se encuentran amenazadas o en peligro de extinción. 


\subsection{Sugerencias a futuro para fortalecer la legalidad del proceso de aprovechamiento de la madera y comercio internacional de productos forestales, y con ello la conservación y aprovechamiento sostenible de los bosques}

Lo primero que debe hacerse es reforzarse la institucionalidad involucrada en el tema forestal, así como la creación de alianzas estratégicas para la erradicación de la ilegalidad, la impunidad y la corrupción en el aprovechamiento y comercio de la madera. Una institución fuerte, con recursos y herramientas apropiadas, podrá ejercer mejor su trabajo y tener presencia e incidencia en todo el territorio nacional. Esto implicaría crear un programa de capacitación permanente para el personal forestal.

Los mecanismos de participación pública, si bien es cierto en términos generales pueden considerarse aceptables, en el tema propiamente forestal debe mejorarse, principalmente la Comisión Forestal como ente asesor relacionado. Tiene que conferírsele más protagonismo. Con la propuesta de la Política Forestal, también se pretende mejorar la participación de las municipalidades.

En lo que a la conservación y aprovechamiento sostenible concierne, debe trabajarse en alianza con los sectores productivos del país, creando políticas, programas e incentivos que contribuyan a generar confianza y estimulen la inversión y consecuentemente, la producción competitiva. Mientras, en el tema de comercialización, debería establecerse una unidad especializada en ello en el MAG, que trabaje de cerca con los productores e interesados en comercializar y exportar sus productos forestales.

Asimismo, para fortalecer la legalidad en el aprovechamiento y comercio de madera es importante que el ARF facilite algunos trámites, por ejemplo, con respecto a las guías de transporte, ya que -al no haber colecturías en todas las agencias forestales- algunos usuarios deben trasladarse a grandes distancias para pagarlas y se dice, según han observado, que algunos optan por mejor obviar el trámite y proceder de manera clandestina e ilegal. En este sentido, es preciso dotar de colecturías a todas las agencias para hacer menos burocrático el trámite.

Uno de los puntos más importantes que tiene que desarrollarse es con respecto al sistema de información forestal. Son varios los aspectos a tomar en cuenta, entre ellos, dotación de equipo adecuado a todas las agencias forestales, personal especializado para sistematizar estadísticas y alianzas institucionales para la recopilación de información.

La PNC podría mantener controles permanentes, principalmente en las zonas con mayor actividad forestal del país. El personal de las aduanas tiene que estar debidamente capacitado, tanto en la revisión de la documentación legal como en reconocer las especies de madera que se estén transportando, puesto que se sabe que algunas especies se transportan con otros nombres. Todas las agencias forestales podrían darle seguimiento a los planes de manejo y monitorear permanente y constantemente los proyectos que se encuentren dentro del área territorial de trabajo, y principalmente, se fomentaría una cultura de respeto y apego a la ley.

En lo que respecta al sistema judicial, es elemental que también se trabaje en su fortalecimiento, particularmente en el pleno funcionamiento de los Tribunales Ambientales a que se refiere el Artículo 99 de la Ley del Medio Ambiente. Es un deber del Estado establecer la jurisdicción ambiental. 
Es importante que se mejore la tipificación penal. Los Artículos 258 y 259 del Código Penal, que regulan la depredación de bosque y flora, deben ser reformados, porque dichas normas hacen referencia expresa a bosques y flora legalmente protegidas, de modo que si se produce esa misma depredación en un bosque o flora que no estuviere legalmente protegida, no habrá sanción que no hay tipificación penal. Según expresó el Jefe de la Unidad de Medio Ambiente de la FGR, esto ocurre en la práctica. Como están actualmente redactados se favorece la impunidad y propicia el aprovechamiento ilegal.

En resumen, para lograr muchos de los retos y sugerencias que aquí se han citado se requiere apoyo presupuestario, pero sobretodo, voluntad política. Y por ahora, como lo advierten algunos de los entrevistados, la importancia del tema forestal no se ha logrado dimensionar como corresponde, por lo que hay un fuerte compromiso de volverlo una prioridad en la agenda política nacional. 


\section{Bibliografía}

Álvarez Cáceres, G.A. (1979). Consideraciones Generales sobre la Ley Forestal. San Salvador, El Salvador.

Código Penal y Código Procesal Penal. El Salvador.

Convención sobre el Comercio Internacional de Especies Amenazadas de Fauna y Flora Silvestres.

Ley de Áreas Naturales Protegidas El Salvador.

Ley de Conservación de Vida Silvestre. El Salvador.

Ley Forestal. El Salvador.

Ley de Medio Ambiente. El Salvador.

Ministerio de Agricultura y Ganadería. Cobertura Forestal de la República de El Salvador, C.A. Año 2010.

Ministerio de Agricultura y Ganadería. Guía para la elaboración simplificada de planes generales de manejo forestal (PGMF). El Salvador.

Ministerio de Agricultura y Ganadería. Memoria Anual de Labores 2012-2013.

Ministerio de Agricultura y Ganadería. Política Forestal para El Salvador, 2011-2030.

Ministerio de Medio Ambiente y Recursos Naturales. Propuesta de Preparación para REDD + (RPP) Para el país: EL SALVADOR.

Organización Internacional del Trabajo (OIT). Convenio N 169 sobre Pueblos Indígenas y Tribales en Países Independientes.

Procuraduría para la Defensa de los Derechos Humanos [PDDH] (2012). Informe Situacional sobre los Derechos de los Pueblos Indígenas en El Salvador.

Programa de las Naciones Unidas para el Desarrollo [PNUD] (2013). Informe sobre Desarrollo Humano.

Reglamento de la Ley Forestal. El Salvador.

Reglamento de la Organización Interna del MAG. El Salvador.

Reglamento General de la Ley del Medio Ambiente. El Salvador. 


\section{Honduras}

Mario Vallejo Larios 


\section{Acrónimos}

AFE: $\quad$ Administración Forestal del Estado

AFH: $\quad$ Agenda Forestal Hondureña

CAFTA-DR: Tratado de Libre Comercio entre Centroamérica, República Dominicana y los Estados Unidos

CENTREX: Centro de Trámites de Exportaciones

CIPF: $\quad$ Centro de Información y Patrimonio Forestal

COHDEFOR: Corporación Hondureña de Desarrollo Forestal

CONADEH: Comisionado Nacional de Derechos Humanos

DEl: $\quad$ Dirección Ejecutiva de Ingresos

FEMA: $\quad$ Fiscalía Especial del Medio Ambiente

ICF: Instituto Nacional de Desarrollo Forestal, Áreas Protegidas y Vida Silvestre

IHT: Instituto Hondureño de Turismo

LFAPVS: $\quad$ Ley Forestal, Áreas Protegidas y Vida Silvestre

MFI: $\quad$ Monitoreo Forestal Independiente

NIFM-15: Norma Internacional de Medidas Fitosanitarias

OIRSA: $\quad$ Organismo Internacional Regional de Sanidad Agropecuaria

SAG: $\quad$ Secretaría de Agricultura y Ganadería

SEFIN: $\quad$ Secretaría de Finanzas

SERNA: Secretaría de Recursos Naturales y Ambiente

SIC: $\quad$ Secretaría de Industria y Comercio

SINFOR: $\quad$ Sistema Nacional de Investigación Forestal

UGFE: $\quad$ Unidad de Gobernanza Forestal y Economía

UICN: $\quad$ Unión Internacional para la Conservación

UNAH: Universidad Nacional Autónoma de Honduras 


\section{Introducción}

El presente documento fue elaborado mediante examen de documentos, técnicos, legales e institucionales, entrevistas con expertos y funcionarios relacionados con el tema de gobernanza en el sector forestal y con la propia experiencia del investigador, en su doble condición de profesional forestal y de las ciencias jurídicas.

Como punto de partida, a continuación se señala los datos sobre la situación actual del Sector Forestal, presentados en el documento contentivo de las metas institucionales del Instituto Nacional de Desarrollo Forestal, Áreas Protegidas y Vida Silvestre (ICF) 2010-2014.

\section{Descripción de la situación actual del sector forestal en Honduras}

\begin{tabular}{|l|r|}
\hline Superficie con bosques (millones de ha) & 6,59 \\
\hline Superficie de áreas protegidas (millones de ha) & 3,32 \\
\hline Producción anual de madera (m³) & 880.000 \\
\hline Industrias forestales primarias y secundarias & 632 \\
\hline Tasa de deforestación anual (ha/año) & 62.000 \\
\hline Grupos beneficiarios del Sistema Social Forestal & 65.000 \\
\hline Área afectada por incendios forestales (ha/año) & 70.000 \\
\hline Número de empleos directos & 173.000 \\
\hline Número de empleos indirectos & 248,2 \\
\hline Exportaciones forestales (millones de US\$) & \\
\hline
\end{tabular}

Fuente: Elaboración propia con datos del Anuario Estadístico Forestal y otros documentos. 


\section{Síntesis histórica de la formulación de la Ley Forestal y afines}

\subsection{Síntesis histórico y formas de participación pública en políticas y leyes forestales}

A mediados del siglo XX fue emitida la primera Ley Forestal propiamente dicha mediante Decreto 184 de 1955, ya que antes se reguló este sector con base en disposiciones vinculadas a otros campos, en especial el de recursos naturales, que tenía una clara tendencia agrícola/ganadera. En 1961, con el Decreto 117 se derogó la de 1955 y esta a su vez fue derogada en 1971 con el Decreto Número 85, que tuvo vigencia hasta que fue aprobada la Ley Forestal, Áreas Protegidas y Vida Silvestre (LFAPVS), mediante Decreto 98-2007 del 13 de septiembre de 2007. En el ínterin se emitió el Decreto Ley 103 el 10 de enero de 1974 que reformaba varios artículos de la Ley Forestal de 1971 y la Ley para la Modernización Agrícola (Decreto 31-92 del 5 de marzo de 1992) que modificaba el Decreto 103.

La primera política forestal propiamente dicha se emitió recién en 1995 cuando el Plan de Acción Forestal se convirtió en el documento base de la Política Forestal de Honduras para el período 19962015, que fue concertado en un foro nacional donde hubo participación de representantes de todos los sectores de la sociedad hondureña. Posteriormente, se creó la Política Forestal, Áreas Protegidas y Vida Silvestre en una primera versión en el 2001 que tuvo como marco de referencia la propuesta de Ley Forestal, Áreas Protegidas y Vida Silvestre y una segunda versión aprobada en el 2010 para ajustarlas a las políticas nacionales contenidas en la ley que dio vida a la "Visión de País-Plan de Nación" que plantea los objetivos y metas de la administración pública con un horizonte de 28 años.

Hasta la aprobación de la Ley Forestal vigente, las leyes se aprobaron por el Congreso Nacional a solicitud del Poder Ejecutivo, que las formuló con base en los aportes de sus cuadros técnicos con muy poca participación de otros sectores de la sociedad. Sin embargo, las políticas desde 1995 han sido ampliamente discutidas por todos los sectores, primero bajo la coordinación directa de la Administración Forestal del Estado (AFE) y luego, en el marco de la Agenda Forestal Hondureña (AFH), una organización privada que desde el 2000 se convirtió en un foro de concertación de los actores del Sector Forestal donde se discuten las políticas, normas legales y otras iniciativas en torno a este.

En la LFAPVS de 2007 fueron creados a nivel nacional, regional, departamental y local los consejos consultivos forestales, áreas protegidas y vida silvestre como las instancias de participación ciudadana, consulta y apoyo a la Administración Forestal del Estado (léase el Anexo 1 de este informe para conocer las funciones de estos consejos en sus respectivos niveles).

Además de los representantes de las instituciones públicas vinculadas al Sector Forestal, estos consejos aglutinan a organizaciones representativas del sector privado y sector social de la economía, incluyendo los pueblos indígenas y afro-hondureños. Este colectivo puede hacer recomendaciones y proponer iniciativas sobre políticas y acciones en torno a la gestión forestal del país. 
El nivel de implementación de los procesos de formulación de las políticas y leyes forestales en el marco de la Agenda Forestal Hondureña (AFH) se puede considerar efectivo y eficaz por la credibilidad que este foro de concertación ha logrado entre la sociedad al discutir temas relacionados con el Sector Nacional. En la AFH converge una diversidad de actores, como los antes mencionados, incluso la Comisión de Ambiente y Recursos Naturales del Congreso Nacional, y hasta representantes del Poder Judicial cuando se discutió el capítulo de los delitos forestales de la nueva ley.

\section{Cuadro 1. Datos relevantes en las leyes forestales de Honduras} a través de la historia

\begin{tabular}{|c|c|}
\hline Ley & Aspectos relevantes \\
\hline $\begin{array}{l}\text { Ley Forestal, } \\
\text { Decreto } 184\end{array}$ & $\begin{array}{l}\text { Se crea el Departamento Forestal de la Dirección General de Recursos Naturales, en el } \\
\text { Ministerio de Agricultura y la Policía Forestal. }\end{array}$ \\
\hline $\begin{array}{l}\text { Ley Forestal, } \\
\text { Decreto } 117\end{array}$ & $\begin{array}{l}\text { Se crea la Guardería Forestal del Estado y las primeras áreas forestales protegidas. } \\
\text { La actividad forestal se adscribe a la Dirección General de Recursos Forestales y Caza } \\
\text { dentro del que pasa a denominarse Ministerio de Recursos Naturales. }\end{array}$ \\
\hline & $\begin{array}{l}\text { El Secretario de Estado en el Despacho de Recursos Naturales es el encargado de aplicar } \\
\text { las disposiciones forestales. } \\
\text { Las funciones forestales se adscriben a la Dirección General de Recursos Forestales y } \\
\text { Caza. } \\
\text { Se aprueba el Fondo Forestal Nacional para promover programas y proyectos de } \\
\text { recuperación, protección y ordenación de las áreas forestales. } \\
\text { Se crean seis áreas forestales protegidas y dos zonas de interés forestal, así como } \\
\text { el Catálogo del Patrimonio Público Forestal Inalienable para inscribir todas las áreas } \\
\text { protegidas y las zonas de interés forestal que se declaran catalogables. }\end{array}$ \\
\hline $\begin{array}{l}\text { Decreto } \\
\text { Ley } 103\end{array}$ & $\begin{array}{l}\text { Se nacionaliza el vuelo forestal. Los bosques, independientemente de la naturaleza jurídica } \\
\text { de las tierras donde estos se encuentran, pasan a ser propiedad del Estado, el cual asume } \\
\text { todas las funciones forestales que en anteriores leyes desempeñaba el sector privado } \\
\text { (aprovechamiento, transporte y comercialización). } \\
\text { Se crea el Sistema Social Forestal para dar participación de los beneficios del } \\
\text { aprovechamiento forestal a los campesinos que viven dentro o en los alrededores de las } \\
\text { áreas forestales. } \\
\text { Se establece la Corporación Hondureña de Desarrollo Forestal (COHDEFOR), entidad } \\
\text { descentralizada dotada de autonomía y con patrimonio propio, que asume las funciones } \\
\text { representativas de la Administración Forestal del Estado. }\end{array}$ \\
\hline $\begin{array}{l}\text { Ley para la } \\
\text { Modernización } \\
\text { Agrícola, } \\
\text { Decreto } 31-92\end{array}$ & $\begin{array}{l}\text { Se devuelve el vuelo forestal al titular de dominio de la tierra. } \\
\text { Se formaliza el plan de manejo forestal como un instrumento técnico-legal obligatorio para } \\
\text { asegurar la sostenibilidad del recurso arbóreo. } \\
\text { El Sistema Social Forestal queda limitado a las áreas forestales nacionales y en las ejidales } \\
\text { con autorización de la municipalidad. } \\
\text { El Estado solo puede realizar actividades normativas, mientras que el sector privado las de } \\
\text { aprovechamiento, transporte y comercialización de productos forestales. }\end{array}$ \\
\hline
\end{tabular}




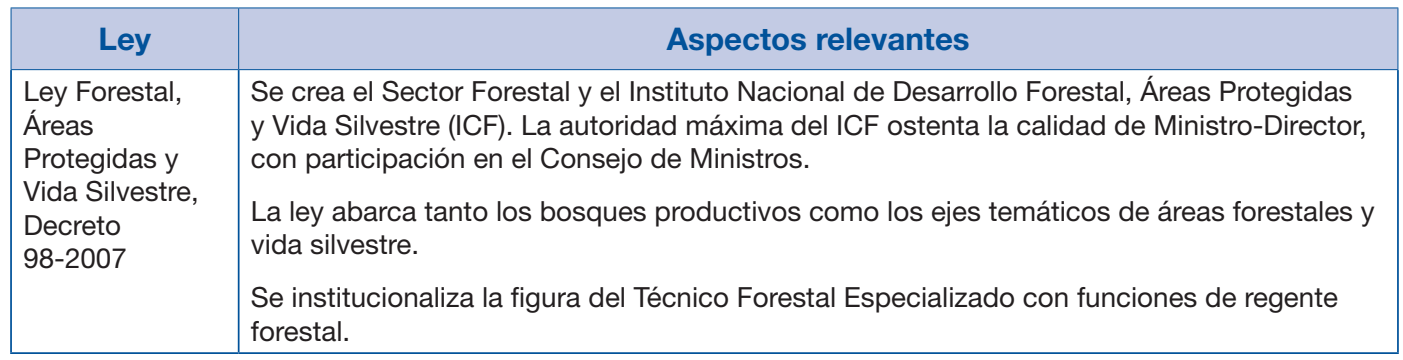

Fuente: Elaboración propia con recursos del Centro de Información del Consultor

\subsection{Institucionalidad forestal y competencias en torno al aprovechamiento forestal y comercio internacional de productos forestales}

El Instituto Nacional de Conservación y Desarrollo Forestal, Áreas Protegidas y Vida Silvestre (ICF) es un ente desconcentrado dependiente de la Presidencia de la República que tiene la condición de Autoridad Forestal Nacional, siendo en consecuencia representativo de la Administración Forestal del Estado. En el ejercicio de su competencia administra el recurso forestal público para garantizar su manejo racional y sostenible, y regula y controla el recurso natural privado para garantizar la sostenibilidad ambiental de los aprovechamientos. Está dotado de capacidad jurídica para emitir actos administrativos de su competencia, celebrar contratos y comparecer ante los Tribunales de la República.

A la Secretaría de Industria y Comercio (SIC) le compete la formulación, coordinación ejecución y evaluación de las políticas relacionadas con el fomento y el desarrollo del comercio internacional de bienes y servicios, y la promoción de las exportaciones. También realiza el control de pesas y medidas de las actividades comerciales e industriales, en coordinación con las municipalidades. Es el punto focal nacional de los tratados de libre comercio.

Igual que a las otras secretarías de Estado (Agricultura y Ganadería [SAG] y Recursos Naturales y Ambiente [SERNA]), que tienen relación con las actividades de aprovechamiento forestal y comercio internacional de productos forestales, la SIC es responsable de conducir los asuntos de su respectivo ramo, observando las políticas e instrucciones que imparte el Presidente de la República. En tal sentido, se convierte en la autoridad nacional en la materia que conduce.

Las municipalidades también están relacionadas con la temática bajo estudio y tienen doble condición: a) son la máxima autoridad dentro del término municipal y por lo tanto, responsables de aplicar la legislación en su ámbito territorial y b) son propietarias de áreas forestales y bosques.

Las principales funciones de las instituciones vinculadas con el aprovechamiento forestal y el comercio internacional de productos forestales están señaladas en el Cuadro 2. Después de analizar dichas funciones, no se encuentran traslapes o conflictos entre ellas, lo cual no significa que no existan problemas originados, en parte, por la falta de desempeño en las responsabilidades que cada una de estas entidades tiene para que las funciones se cumplan. 


\section{Cuadro 2. Funciones de la institucionalidad hondureña aprovechamiento forestal y comercio internacional de productos forestales}

\begin{tabular}{|c|c|}
\hline $\begin{array}{l}\text { Institució } \\
\text { pública }\end{array}$ & Funciones en el comercio internacional de madera \\
\hline \begin{tabular}{|l|} 
Instituto \\
Nacional de \\
Conservación \\
y Desarrollo \\
Forestal, Áreas \\
Protegidas y \\
Vida Silvestre \\
(ICF)
\end{tabular} & $\begin{array}{l}\text { Velar por el cumplimiento de la normativa relacionada con la conservación de la } \\
\text { biodiversidad. } \\
\text { Promover el desarrollo del sector forestal en todos sus componentes sociales, } \\
\text { económicos, culturales y ambientales en un marco de sostenibilidad. } \\
\text { Coordinar y articular las actividades de las entidades que conforman el sector forestal, } \\
\text { promoviendo la gestión participativa y descentralizada. } \\
\text { Aprobar o denegar los planes de manejo. } \\
\text { Cancelar las resoluciones o permisos que autorizan el aprovechamiento previsto en los } \\
\text { planes de manejo. } \\
\text { Conocer en única instancia los reclamos administrativos que presenten los afectados por } \\
\text { las resoluciones que emita. } \\
\text { Determinar los precios base para las subastas públicas de madera conforme a la } \\
\text { metodología establecida. } \\
\text { Diseñar e implementar la estrategia nacional para el control de la tala y el transporte ilegal } \\
\text { de los productos forestales. } \\
\text { Autoridad administrativa CITES. }\end{array}$ \\
\hline $\begin{array}{l}\text { Secretaría de } \\
\text { Industria y } \\
\text { Comercio (SIC) }\end{array}$ & $\begin{array}{l}\text { Formular, coordinar, ejecutar y evaluar las políticas relacionadas con comercio nacional e } \\
\text { internacional de bienes y servicios y la promoción de las exportaciones. } \\
\text { Ser el punto focal nacional para los tratados de libre comercio. } \\
\text { Conducir las negociaciones de tratados comerciales que Honduras realice con otros } \\
\text { países. } \\
\text { Coordinar la formulación de estrategias para negociar los tratados comerciales. } \\
\text { Conducir estudios de impacto económico como resultado de la negociación de } \\
\text { los tratados. }\end{array}$ \\
\hline $\begin{array}{l}\text { Secretaría de } \\
\text { Agricultura y } \\
\text { Ganadería (SAG) }\end{array}$ & $\begin{array}{l}\text { Realizar diagnóstico y vigilancia epidemiológica de las plagas y enfermedades en } \\
\text { vegetales y animales, evaluando su incidencia y prevalencia. } \\
\text { Pre-certificar los productos de origen vegetal, así como los establecimientos que los } \\
\text { elaboran. } \\
\text { Realizar control cuarentenario de las exportaciones y tránsito de productos y } \\
\text { subproductos de origen vegetal y medios de transporte. } \\
\text { Adoptar normas y aplicar las medidas fitozoosanitarias para el comercio nacional, regional } \\
\text { e internacional de vegetales, sus productos e insumos agropecuarios. } \\
\text { Emitir certificados fitosanitarios de exportación internacional. } \\
\text { Autoridad administrativa para la Convención CITES. } \\
\text { Autoridad fitozoosanitaria a través del Servicio Nacional de Sanidad Agropecuaria. }\end{array}$ \\
\hline
\end{tabular}




\begin{tabular}{|c|c|}
\hline $\begin{array}{l}\text { Institución } \\
\text { pública }\end{array}$ & Funciones en el comercio internacional de madera \\
\hline $\begin{array}{l}\text { Secretaría } \\
\text { de Recursos } \\
\text { Naturales y } \\
\text { Ambiente } \\
\text { (SERNA) }\end{array}$ & $\begin{array}{l}\text { Organizar y manejar el Sistema Nacional de Evaluación de Impacto Ambiental a través de } \\
\text { la Dirección General de Evaluación y Control Ambiental (DECA). } \\
\text { Expedir y controlar las licencias ambientales y practicar auditorías ambientales. } \\
\text { Servir como punto de contacto para recibir las consultas sobre la aplicación de la } \\
\text { legislación ambiental que afecta al comercio en los TLC. } \\
\text { Autoridad científica de CITES a través de la Dirección de Biodiversidad. }\end{array}$ \\
\hline Munic & $\begin{array}{l}\text { Crear, reformar y derogar los instrumentos normativos locales de conformidad con esta } \\
\text { ley. } \\
\text { Celebrar asambleas de carácter consultivo en cabildo abierto con representantes de } \\
\text { organizaciones en temas que afectan a la comunidad (ecológicos y otros). } \\
\text { Convocar a plebiscito a los ciudadanos vecinos del municipio para tomar decisiones } \\
\text { sobre asuntos de suma importancia, a juicio de la Corporación (ecológicos y otros). El } \\
\text { resultado del plebiscito será de obligatorio cumplimiento y deberá ser publicado. } \\
\text { Proteger la ecología, el medio ambiente y promover la reforestación. } \\
\text { Emitir permisos de operación para las actividades forestales que se realicen en el } \\
\text { municipio. } \\
\text { Expedir licencias ambientales y ejercer controles en caso de tener licenciamiento } \\
\text { ambiental delegado. } \\
\text { Suscribir convenios en el Gobierno Central y con otras entidades descentralizadas con } \\
\text { las cuales concurra en la explotación de los recursos, en los que figuren las áreas de } \\
\text { explotación, sistemas de reforestación, protección del medio ambiente y pagos que les } \\
\text { correspondan. }\end{array}$ \\
\hline \begin{tabular}{|l|} 
Secretaría de \\
Finanzas (SEFIN)
\end{tabular} & $\begin{array}{l}\text { Ejercer control fiscal de las operaciones de importación o exportación de bienes, o de } \\
\text { cualquiera otra actividad relacionada que se realicen en los puertos marítimos o terrestres } \\
\text { y en los aeropuertos por medio del servicio de aduanas. } \\
\text { Tener control fiscal de las operaciones que se lleven a cabo en zonas libres u otras zonas } \\
\text { francas, en los almacenes generales de depósito. } \\
\text { Autoridad aduanera, dependencia de la Dirección Ejecutiva de Ingresos (DEI). }\end{array}$ \\
\hline Academia & $\begin{array}{l}\text { La Universidad Nacional Autónoma de Honduras (UNAH), a través del Departamento de } \\
\text { Biología, Escuela Nacional de Ciencias Forestales y la Escuela Agrícola Panamericana, se } \\
\text { reconoce como autoridad científica para la Convención CITES }\end{array}$ \\
\hline
\end{tabular}

Fuente: Leyes que regulan cada una de las instituciones mencionadas y el Reglamento de organización, funcionamiento y competencias del Poder Ejecutivo

\subsection{Consistencia entre la Ley Forestal y afines con otras legislaciones referidas al comercio internacional de productos de madera}

Al ser de aprobación reciente y haber considerado para su elaboración la legislación vigente que directa o indirectamente impacta en el Sector Forestal, la LFAPVS es consistente en aspectos vinculados al comercio internacional, tanto con la legislación nacional como internacional. 
Sobre la temática bajo estudio, en el articulado de la ley mencionada destaca que el ICF determina los precios base para las subastas públicas de madera tomando en cuenta el precio internacional de los productos. Las disposiciones de esta ley son congruentes con las políticas relacionadas con el fomento del comercio internacional y de las exportaciones que impulsa la Secretaría de Industria y Comercio, y las que se relacionan con la administración de los servicios de sanidad vegetal, que compete a la Secretaría de Agricultura y Ganadería, y con el cumplimiento de las disposiciones ambientales emanadas de la Ley General del Ambiente.

En la legislación nacional, lo relativo al Pago por Servicios Ambientales y su eventual vínculo al comercio internacional de bonos de carbono, aunque no se refiere expresamente a la madera, como bien derivado del bosque es atendido en la LFAPVS y también lo contiene la Ley General de Aguas, ambas leyes de vigencia reciente. La consistencia entre estas leyes no es clara y pueden existir aristas que ameritarían una armonización mediante discusiones y acuerdos interinstitucionales.

Por otra parte, la legislación manda que el ICF, en su condición de administrador de las áreas forestales, lo haga de acuerdo con las disposiciones de la LFAPVS y los convenios internacionales aprobados y ratificados por el Estado. Las maderas procesadas y demás productos forestales aprovechados legalmente pueden ser comercializados por sus propietarios, tanto en el mercado nacional como en el internacional, sujetándose a la aplicación de las disposiciones vigentes en materia forestal, aduanera, tributaria, cambiaria, de sanidad vegetal y los convenios internacionales que regulen su comercio.

La estipulación descrita es válida tanto para el TLC CAFTA-DR como para el Acuerdo de Asociación de la Unión Europea con Centroamérica, que ya son ley vigente en el país; pero asimismo, la LFAPVS dispone que en la negociación de los convenios de integración y libre comercio que suscriba el Gobierno de la República deben incluirse disposiciones que favorezcan el acceso de los productos forestales nacionales a los mercados internacionales. El capítulo 17 del CAFTA-DR sirve de marco para el respeto de la Lacey Act cuando se importe productos forestales hacia el mercado estadounidense.

Lo anterior incluye el Convenio Internacional de Maderas Tropicales, aprobado por el Congreso Nacional de Honduras mediante Decreto Legislativo 54-2011 del 18 de mayo de 2011 y la Norma Internacional de Medidas Fitosanitarias (NIFM-15), cuya aplicación corresponde a la Secretaría de Agricultura y Ganadería a través del Servicio Nacional de Seguridad Agropecuaria. También se entiende que incluirá al mecanismo FLEGT cuando sea aprobado oficialmente por el país, ya que todavía está en proceso de negociación.

\subsection{Mecanismos legales y marcos jurídicos dentro de las Estrategia REDD+ respecto al aprovechamiento y comercio internacional de productos forestales}

La investigación en la legislación hondureña permite identificar que en 18 leyes nacionales de diferente jerarquía, empezando por la Constitución de la República y cinco tratados, convenios o convenciones internacionales, hay disposiciones que aplican a la temática de REDD+. A ella hay que sumar los reglamentos que se derivan de las leyes. A continuación se menciona el nombre de 
los tratados y leyes aplicables, las cuales tienen sus respectivos datos de ubicación por número de decreto y fecha de publicación en la sección de documentación revisada1.

Los tratados internacionales identificados son: Convención Marco de las Naciones Unidas sobre el Cambio Climático, Convención de las Naciones Unidas de Lucha Contra la Desertificación en Países Afectados por la Sequía o Desertificación, Convenio 169 sobre Pueblos Indígenas y Tribales en Países Independientes, Convenio sobre la Diversidad Biológica y Convención para la Protección de la Capa de Ozono.

Pese a que no hay una ley nacional de cambio climático, un proyecto de ley está en proceso de aprobación en el Congreso Nacional. Dicho proyecto se basa en la Estrategia Nacional de Cambio Climático aprobada en el 2010, que abarca la temática de REDD+ en el país.

En la legislación nacional secundaria son ordenamiento legal referente para REDD+ la Ley Forestal, Áreas Protegidas y Vida Silvestre, y la Ley General del Ambiente, pero también son importantes las leyes sectoriales: Ley para la Modernización y el Desarrollo del Sector Agrícola, Ley para la Protección de la Actividad Caficultora y Ley de Reforma Agraria, así como las normas generales: Ley Visión de País y un Plan de Nación para Honduras, Ley de Propiedad, Ley de Ordenamiento Territorial, Ley General de Aguas, Ley General de Minería, Ley de Municipalidades y Ley de Expropiación Forzosa, que tienen incidencia directa en la temática de REDD+ sin perjuicio de otras leyes que tienen incidencia indirecta.

Con relación a REDD+, en la legislación nacional se identifican como mecanismos para el aprovechamiento forestal y comercio internacional de productos forestales los planes de manejo forestal, los fondos para la inversión y conservación forestal, y los certificados de plantaciones; también las modalidades contractuales siguientes: contrato de actividades forestales, contrato de aprovechamiento, contrato de manejo forestal comunitario y contrato de usufructo, todos ellos derivados de la Ley Forestal, Áreas Protegidas y Vida Silvestre. Las figuras mencionadas son válidas tanto para el comercio nacional como internacional.

Una conclusión permitida sobre el régimen legal REDD+ en Honduras es que es amplio y disperso y para lograr la gobernabilidad en ese tema resulta necesario recurrir a una gran cantidad de leyes que -aunque se supone que deben ser complementarias- al tratar de aplicarlas al caso concreto se encuentran algunos problemas, entre los cuales los más comunes son los vacíos y duplicidades, y la antigüedad de algunas leyes, al extremo de estar obsoletas en varias de sus partes. Por otro lado, los mecanismos legales para el aprovechamiento forestal no son exclusivos para el comercio internacional, pero se pueden utilizar con este propósito mediante el cumplimiento de la normativa que se exige para las exportaciones de productos forestales, que pueden estar en los propios tratados de libre comercio, así como en las disposiciones ambientales, sanitarias, aduaneras, cambiarias y tributarias vigentes.

\subsection{Conflictos entre derechos de uso de la tierra y los bosques}

El Artículo 7 de la LFAPVS dispone que en ningún caso las áreas forestales se han de considerar tierras incultas $u$ ociosas y no podrán ser objeto de afectación con fines de Reforma Agraria ni tampoco de titulación, pero al menos cuatro leyes permiten la afectación y titulación en casos

1. El marco legal REDD fue ajustado de: GIZ-CCAD-SERNA-ICF (2012). Diagnóstico legal REDD+ en Honduras. 
especiales señalados en ellas ${ }^{2}$. La tierra forestal particular todavía es afectada para proyectos agrícolas y ganaderos aunque sea expresamente prohibido en la ley y en las áreas forestales públicas la gobernabilidad es baja, lo que propicia la tala ilegal con severos efectos en la comercialización de productos forestales, en especial la madera.

A lo anterior hay que agregar que las leyes que permiten las concesiones mineras, para proyectos de energía renovable o algunas actividades agroindustriales, como la palma africana y el café, se superponen con los derechos que tienen los usufructuarios o asentados en áreas forestales públicas y eventualmente, hasta en las de tenencia privada.

También existen conflictos de uso entre las zonas indígenas, áreas protegidas y zonas de turismo. En las zonas indígenas hay un proceso de regularización que involucra la participación de los pueblos autóctonos en procura de eliminar los conflictos, mientras que en las áreas protegidas y las zonas de turismo se busca eliminar los problemas mediante la implementación de una estrategia nacional de ecoturismo, basada en las disposiciones de la LFAPVS y concertada entre las instituciones que tienen responsabilidad de gerenciar ambos sectores.

El aprovechamiento forestal legal por parte de los poseedores de bosques nacionales es posible cuando la actividad es permitida en el respectivo plan de manejo y cuentan con el contrato de usufructo que le autoriza a gozar los beneficios del bosque con cargo del compromiso de conservar su forma y restituirla al Estado. Tal situación, cuando se maneja adecuadamente, se concibe como un mecanismo que ayuda a disminuir la tala ilegal, aunque el derecho de acceso al uso de los recursos es solo uno de los elementos que influyen para que la cadena del aprovechamiento forestal no tenga los indicadores de legalidad correctos.

Otro aspecto a considerar en esta sección es el traslape entre tierras indígenas con las áreas protegidas y estas con las zonas de turismo, o éstas con las tierras indígenas para el aprovechamiento ilegal de productos forestales. A pesar de que tales traslapes existen en la práctica, los problemas por esta causa no tienen consecuencias significativas respecto a la legalidad, porque de hecho el corte de madera en estas zonas -además de prohibido- no es una alternativa en el contexto de los pueblos indígenas, los co-manejadores de áreas protegidas u operadores de turismo. Sin embargo, vale señalar que tanto en las áreas protegidas como en las tierras indígenas se han identificado notables focos de deforestación causados por ilegales que se vinculan a agricultores, ganaderos y comerciantes de madera, igualmente infractores forestales.

\subsection{Marco jurídico para promover la distribución justa y equitativa de los beneficios de un aprovechamiento sostenible de la madera}

Según el Art. 340 de la Constitución de la República, el aprovechamiento forestal se considera de utilidad y necesidad pública, y el Estado debe reglamentarlo de acuerdo con el interés social, fijando las condiciones de su otorgamiento a los particulares. El mismo sentido se enuncia en la Ley General del Ambiente cuando en el Artículo 45 dispone que: "El recurso forestal deberá ser manejado y

2. Ley de Municipalidades, Ley de Ordenamiento Territorial, Ley de Propiedad y Ley de Protección a la Caficultura. 
utilizado bajo el principio de protección de la biodiversidad, rendimiento sostenible y el concepto de uso múltiple del recurso, atendiendo sus funciones económicas, ecológicas y sociales".

La LFAPVS reafirma este principio al disponer que el acceso y la participación de la población en el manejo sostenible de los recursos forestales públicos, propiciando la generación de mayores beneficios económicos, sociales y ambientales, deben hacerse bajo principios de equidad (Art. 2). El manejo de los recursos forestales -manda el Artículo 68- se hará utilizando eficiencia y productividad bajo criterios técnicos administrativos de máximo rendimiento, uso múltiple y equidad social, de forma que asegure la sostenibilidad de los ecosistemas y su capacidad productora, protectora y ambiental.

En el título dedicado al Sistema Social Forestal de la LFAPVS se dispone que el ICF debe promover y fortalecer este sistema como medio para incorporar a las comunidades que habitan en o alrededor de áreas nacionales de vocación forestal en las actividades de protección, manejo, forestación y aprovechamiento integral del bosque, incluyendo la transformación, industrialización y comercialización de sus productos (Art. 126). Las comunidades organizadas, acreditadas ante el ICF, tendrán derecho preferencial para suscribir contratos de manejo forestal sobre dichos bosques (Art. 128).

Respecto a la cadena de producción de madera, la ley ordena que los aprovechamientos forestales que tengan fines comerciales estarán sujetos a un plan de manejo, elaborado bajo la responsabilidad del titular de la tierra (Arts. 90 y 91), mientras que la transformación y la incorporación de mayor valor agregado en los procesos industriales deben ser fomentados por el sector social y privado a efecto de generar empleo y una mayor eficiencia en la utilización de los recursos forestales (Art. 96). Las maderas procesadas pueden ser comercializadas por sus propietarios, tanto en el mercado nacional como en el internacional, sujetándose a la aplicación de las disposiciones vigentes en materia forestal, aduanera, tributaria, cambiaria, de sanidad vegetal y los Convenios Internacionales que regulen su comercio (Art. 102).

Además del Sistema Social Forestal y los contratos de manejo forestal ya mencionados, que pueden ser considerados como mecanismos legales para la distribución justa y equitativa de los beneficios del bosque, también caen en esta categoría los contratos de usufructo y las concesiones forestales dadas en condiciones favorables a favor de las comunidades asentadas en tierras forestales, según se dispone en la Ley Forestal, Áreas Protegidas y Vida Silvestre, tanto en el título dedicado al Sistema Social como en otras disposiciones diseminadas en otras partes del texto legal. 


\section{Análisis de los estándares de legalidad}

\subsection{Vacíos y conflictos en la aplicación de la legislación forestal y afines}

La LFAPVS fue aprobada recientemente después de una amplia discusión por los distintos sectores de la sociedad hondureña involucrados en la gestión forestal; por ello debería tener muy pocos vacíos, al menos en los actuales momentos. No obstante, en el tema de áreas protegidas no se percibe claridad en relación con cuál es el espacio sujeto a protección especial, ya que muchos sectores consideran que las restricciones de aprovechamiento de recursos que tiene la zona núcleo son iguales para la zona de amortiguamiento. También falta la definición de algunas categorías de áreas protegidas que fueron declaradas con una visión administrativa y no técnica-científica.

Asimismo, se observa que faltan algunos reglamentos o normas técnicas en campos donde convergen con otras instituciones, en especial con el Instituto Hondureño de Turismo (IHT), para la gestión de diversos aspectos relacionados con el turismo en las áreas protegidas que también se observa respecto al manejo compartido de estos espacios con otros actores que coadyuvan con el ICF. Lo mismo sucede con la Guardería Forestal del Estado que, pese a que la LFAPVS la adscribe al ICF, en otro decreto se delegó a las Fuerzas Armadas.

Sobre vacíos legales respecto al aprovechamiento forestal y comercio internacional de productos forestales, se puede decir que no son evidentes en la legislación secundaria vigente, ya que tanto la LFAPVS como la legislación en otras materias han sido ajustadas a las exigencias de los tratados de libre comercio sin que -al menos con el CAFTA-DR, que ya tiene siete años de vigencia- haya habido problemas de aplicación.

Sin embargo, en forma general y a lo interno, se observan conflictos de aplicación de la legislación forestal en varios escenarios: a) el ICF, en su condición de institución representativa de la Administración Forestal del Estado, está muy debilitada en recursos humanos y financieros; b) existen muchas tierras cuyo régimen de propiedad no está claro, siendo notoria la ocupación de áreas forestales públicas por personas que aducen tener la propiedad plena; c) el Instituto Nacional Agrario (INA) eventualmente titula tierras nacionales de vocación forestal que legalmente está prohibido; d) un alto porcentaje de las infracciones forestales fueron tipificadas como delitos, que deben ser conocidos por juzgados y tribunales saturados de casos de delitos comunes y sin la capacitación necesaria para juzgar los delitos especiales que serían los forestales; e) se ha dado competencias técnicas a otras instituciones que no tienen la pericia para ello (Fuerzas Armadas en labores de protección forestal y reforestación) ${ }^{3}$.

Por otra parte, las comunidades locales afiliadas al Sistema Social Forestal tienen derechos legales de usufructo y regularización en las áreas forestales que no pueden ser debidamente atendidas por la debilidad del ICF. Sobre los pueblos indígenas y afrohondureños en conflicto se puede reconocer

3. Síntesis de las conclusiones de GIZ-CCAD-SERNA-ICF (2011). Identificación preliminar de las causas de deforestación y degradación forestal en Honduras. 
que falta la titulación de algunos territorios, pero este proceso-que corresponde al INA e ICF en forma coordinada y participativa con los representativos autóctonos- ya cuenta con varias comunidades favorecidas con títulos plenos de naturaleza comunal y colectiva ${ }^{4}$.

Por último, vale referirse en esta sección a los vacíos y conflictos en la aplicación tanto de la Ley Forestal y normas legales afines, en especial la Ley de Propiedad. Pese a que estas leyes tienen disposiciones teóricamente armónicas con el Convenio sobre Pueblos Indígenas y Tribales, de parte de los pueblos autóctonos ha habido reclamos, aunque estos poco tienen que ver con el aprovechamiento forestal dentro de sus territorios.

\subsection{Requisitos legales para los permisos de aprovechamiento forestal y comercio internacional de productos forestales}

Todo aprovechamiento de los bosques en propiedad pública o privada estará regulado por un plan de manejo forestal que debe ser preparado por el titular de dominio de la tierra con base en un procedimiento establecido en el Reglamento de la LFAPVS. Este es el instrumento más importante para el aprovechamiento forestal sostenible y su elaboración, aprobación y monitoreo requieren una serie de requisitos técnico-legales que se detallan en el Cuadro 3.

El procedimiento inicia con la solicitud de un dictamen de no objeción (visto bueno, técnico-legal) que hace el propietario al ICF para que lo autorice a elaborar el plan de manejo. En representación del propietario, un Técnico Forestal Calificado prepara dicho plan, después de lo cual se presenta una petición para su aprobación por el ICF, que resuelve dentro de 30 días hábiles para bosques de coníferas y 60 días hábiles para latifoliados. Los planes operativos anuales que se desprenden de un plan de manejo aprobado y vigente serán resueltos por el ICF en un plazo no mayor de 20 días hábiles desde su presentación (Artículo 169).

Después de aprobado el plan de manejo, su titular debe presentar la copia certificada de la resolución del ICF ante la corporación municipal, en cuyo término se ejecutará este para su inscripción en el Registro Municipal. De acuerdo con sus intereses económicos, el propietario puede hacer el aprovechamiento forestal por sí mismo o a través de terceras personas, que usualmente son los empresarios de la madera, quienes incluso proveen la asistencia técnica (de ser requerida por los dueños).

Previo a la aprobación de los planes operativos anuales, se establece una garantía bancaria o depositaria para el cumplimiento de las Normas Técnicas y Reglamentarias, cuyos valores son con base en el volumen, así: diámetro menor a 30 centímetros = volumen x L. $100^{5} \times 15 \%$; diámetro mayor a 30 centímetros = volumen $\times$ L. $190 \times 15 \%$.

Las mismas normas disponen que el ICF puede establecer una Garantía de Cumplimiento de Regeneración en coníferas que se calcula: L. 2,500 por hectárea (esta tasa no aplica en el caso de raleo). El pago de la tasa de servicios administrativos se cobra de la siguiente manera: diámetro de 10 a 23,9 centímetros = $12 \mathrm{~L} . / \mathrm{m}^{3}$; diámetro de 24-29,9 centímetros $=24 \mathrm{~L} . / \mathrm{m}^{3}$; diámetro de más de 30 centímetros $=40 \mathrm{~L} . / \mathrm{m}^{3}$.

4. INA. Informe de logros del Instituto Nacional Agrario 2010-2013.

5. 1 dólar equivale a L. 20,54 al cambio del día. 
El precio de productos forestales en bosque nacional de coníferas se cobra de acuerdo con la subasta correspondiente y el cobro por servicios técnicos operativos forestales en bosque privado y ejidal es de L. $40 / \mathrm{m}^{3}$ para postes de luz y madera en pie para aserrío. El valor de productos forestales en bosque nacional de latifoliados se cobra por especie, con un valor que varía por categoría desde la caoba, el cedro y las especies en peligro de extinción cuando han abandonado este estatus o provienen de plantaciones, que se valora en L. $1,500 / \mathrm{m}^{3}$, hasta los que tienen menor valor comercial, que se paga a L. $180 / \mathrm{m}^{3}$. En el primer caso, el cobro por servicios técnicos operativos forestales en bosque privado y ejidal es de L. $140 / \mathrm{m}^{3}$ y L. $30 / \mathrm{m}^{3}$ en el segundo 6 .

\section{Cuadro 3. Requisitos para elaborar un plan de manejo}

\begin{tabular}{|c|c|}
\hline cos & Requisitos \\
\hline $\begin{array}{l}\text { 1. Portada (generales del sitio, propietario y técnico firmados y } \\
\text { sellados) } \\
\text { 2. Memorandos internos de remisión y dictámenes técnicos de } \\
\text { visitas de comprobación al campo } \\
\text { 3. Constancia de recibo del documento del PM } \\
\text { 4. Trámites } \\
\text { 5. Revisión del Plan de Manejo } \\
\text { 6. Base de datos } \\
\text { 7. Resumen del Plan } \\
\text { 8. Descripción del terreno } \\
\text { 9. Diseño del inventario forestal, cuadro de ordenación, tablas } \\
\text { de rodal } \\
\text { 10. Plan de Protección Forestal } \\
\text { 11. Red vial } \\
\text { 12. Actividades silviculturales planificadas por año } \\
\text { 13. Regulaciones de acuerdo con Manual de Norma Técnica } \\
\text { 14. Descripción de mapas: a) ubicación, b) uso actual y caminos } \\
\text { y senderos, c) pendientes, d) actividades por año, e) suelos, } \\
\text { f)compartimientos, g) protección e hídricos } \\
\text { 15. Coordenadas utm/ups de puntos relevantes } \\
\text { 16. Cálculo del premuestreo } \\
\text { 17. Cálculo del error de muestreo } \\
\text { 18. Incremento medio anual } \\
\text { 19. Descripción corta anual permisible (de no ser calculado con } \\
\text { base en el incremento medio anual) } \\
\text { 20. Tablas de rodal y existencias por estrato } \\
\text { 21. Cálculo de la necesidad de raleo (en caso de bosque joven) } \\
\text { 22. Hojas de campo (originales) } \\
\text { 23. Plan de protección } \\
\text { 24. CD del proyecto con los mapas impresos en Arc-View e } \\
\text { información general del documento } \\
\text { 25. Si es readecuación, dar cumplimiento a circular sobre } \\
\text { normas técnicas de readecuación de planes de manejo } \\
\text { 26. Historial del Plan de Manejo }\end{array}$ & $\begin{array}{l}\text { 1. Solicitud de aprobación que incluya } \\
\text { poder de representación } \\
\text { 2. Carta poder (autenticada) } \\
\text { 3. Constancia de nombramiento del } \\
\text { profesional forestal por el propietario } \\
\text { para elaborar el PMF } \\
\text { 4. Constancia de aceptación por el } \\
\text { técnico que elaboró el PMF } \\
\text { 5. Copia de Resolución de No Objeción } \\
\text { para elaborar el Plan de Manejo } \\
\text { 6. Solvencia vigente del técnico al } \\
\text { momento de presentar el documento } \\
\text { 7. Punto acta de la corporación } \\
\text { nombrando al Alcalde para que los } \\
\text { represente ante las autoridades de la } \\
\text { AFE-ICF (Ejidal) } \\
\text { 8. Autorización a la AFE para monitorear } \\
\text { el PMF (autenticada) } \\
\text { 9. Libertad de gravamen con fecha de } \\
\text { expedición no mayor de dos meses } \\
\text { (original) } \\
\text { 10. Copia de la escritura pública } \\
\text { (autenticada) } \\
\text { 11. Certificación de asiento del Registro } \\
\text { de Propiedad (original o copia } \\
\text { autenticada) } \\
\text { 12. Autorización de la entidad que tiene } \\
\text { gravada la escritura } \\
\text { 13. Autenticación de las firmas del } \\
\text { propietario en todo lo firmado } \\
\text { 14. Nota de responsabilidad legal y técnica } \\
\text { por parte del propietario y el técnico } \\
\text { 15. Contrato de derecho y obligaciones } \\
\text { entre el técnico y el propietario } \\
\text { (Art. 163) }\end{array}$ \\
\hline
\end{tabular}

Fuente: Requisitos técnicos y legales para elaborar planes de manejo

6. ICF (2009). Requisitos técnicos y legales para elaborar planes de manejo y planes operativos anuales. 
En la Administración Forestal del Estado se manejan requisitos para otras actividades que tienen relación con el aprovechamiento forestal; las más relevantes son: para participar en las subastas de lotes de madera en pie, para el registro e instalación de depósito o venta local de madera, para la autorización, instalación e inscripción de una industria forestal primaria y secundaria, y para elaborar un plan operativo ${ }^{7}$.

Los demás permisos se detallan en la sección que nominalmente se refiere al diagrama legaladministrativo para que los productos de madera accedan a los mercados de Estados Unidos de América y la Unión Europea.

En el Título V del Reglamento General de la Ley Forestal, Áreas Protegidas y Vida Silvestre se regula lo relativo a la industrialización, comercialización y transporte de madera y otros productos forestales, tal como se detalla en el Cuadro 4.

7. Ing. Lindersay Eguigurems, Jefe de Manejo Forestal, ICF. [comunicación personal]. 


\section{Cuadro 4. Regulaciones para transporte, industrialización} y comercialización de madera en Honduras

\begin{tabular}{|c|c|c|}
\hline Transporte de madera & $\begin{array}{l}\text { Industrialización de la } \\
\text { materia prima forestal }\end{array}$ & $\begin{array}{l}\text { Comercialización de } \\
\text { madera a nivel nacional }\end{array}$ \\
\hline $\begin{array}{l}\text { El elemento esencial es la guía } \\
\text { de movilización o "factura" } \\
\text { codificada, que es elaborada } \\
\text { según indicaciones del ICF. } \\
\text { Dicha guía debe indicar, entre } \\
\text { otras formalidades, fecha, clase, } \\
\text { cantidad, procedencia y destino de } \\
\text { los productos transportados. } \\
\text { Las guías de movilización de cada } \\
\text { talonario son selladas y firmadas } \\
\text { por la correspondiente Oficina } \\
\text { Forestal del ICF y entregadas } \\
\text { a los titulares del bosque, de } \\
\text { los aprovechamientos o de las } \\
\text { industrias autorizadas, de acuerdo } \\
\text { con la producción estimada. Se } \\
\text { usan sellos de seguridad. } \\
\text { La entrega de los talonarios, con } \\
\text { indicación del número de guías } \\
\text { o facturas y sus respectivos } \\
\text { números correlativos, se registra } \\
\text { en el libro que para tal efecto lleva } \\
\text { la Región de Conservación del ICF. } \\
\text { Cada guía o factura consta de un } \\
\text { original y cuatro copias. El original } \\
\text { es la guía propiamente dicha, } \\
\text { debiendo acompañar siempre los } \\
\text { productos transportados durante } \\
\text { su circulación, desde el punto de } \\
\text { origen hasta el lugar de destino. }\end{array}$ & $\begin{array}{l}\text { Los interesados deben solicitar } \\
\text { licencia de operación al ICF } \\
\text { acompañando: } \\
\text { 1) Memoria técnica (descripción } \\
\text { del procesamiento de los } \\
\text { productos, materia prima } \\
\text { a emplear, fuentes de } \\
\text { abastecimiento, productos a } \\
\text { elaborar, instalaciones, equipo } \\
\text { y maquinaria y localización, } \\
\text { mapa de ubicación del } \\
\text { sitio, diagrama de flujo de } \\
\text { producción. } \\
\text { 2) Licencia ambiental expedida } \\
\text { por la autoridad competente. } \\
\text { 3) Certificación íntegra del asiento } \\
\text { del inmueble donde se instalará } \\
\text { o contrato de arrendamiento u } \\
\text { otro documento que acredite la } \\
\text { disponibilidad. } \\
\text { 4) Registro Tributario Nacional del } \\
\text { titular. } \\
\text { 5) Permiso municipal de } \\
\text { operación. } \\
\text { La Licencia de Operación debe } \\
\text { estar en lugar visible al público } \\
\text { dentro del plantel, así como las } \\
\text { facturas de adquisición de la } \\
\text { madera disponibles in situ para su } \\
\text { verificación por la autoridad. } \\
\text { Los titulares de las industrias } \\
\text { tienen que elaborar y presentar } \\
\text { informes mensuales al ICF. } \\
\text { Todo cambio de los locales o } \\
\text { planteles deberá notificarse al ICF } \\
\text { con treinta días de antelación, lo } \\
\text { mismo que el cambio de equipos } \\
\text { o maquinaria, o la introducción } \\
\text { de nuevas tecnologías en los } \\
\text { procesos industriales. }\end{array}$ & $\begin{array}{l}\text { El ICF autoriza las "ventas de } \\
\text { madera" que deben presentar } \\
\text { informes mensuales al ICF. Para su } \\
\text { inscripción en el registro del ICF el } \\
\text { solicitante debe acompañar: } \\
\text { 1) Original y copia de la escritura } \\
\text { de constitución de comerciante } \\
\text { debidamente inscrita y } \\
\text { registrada, cuya original } \\
\text { cotejada se devolverá al } \\
\text { interesado. } \\
\text { 2) Fotocopia del Permiso de } \\
\text { Operación vigente de la } \\
\text { Alcaldía Municipal. } \\
\text { 3) Titulo del inmueble a favor } \\
\text { del solicitante y en su caso, } \\
\text { contrato de arrendamiento } \\
\text { respectivo del lugar en donde } \\
\text { se instalará el depósito. } \\
\text { 4) En el caso de terrenos y } \\
\text { edificios donde está ubicada la } \\
\text { venta de productos forestales, } \\
\text { mostrar su ubicación en una } \\
\text { hoja cartográfica y geo- } \\
\text { referenciado en duro y digital. }\end{array}$ \\
\hline
\end{tabular}

Fuente: Elaboración propia con base en el Reglamento General de la Ley Forestal, Áreas Protegidas y Vida Silvestre

De acuerdo con el Reglamento de la LFAPVS, la madera en rollo o escuadrada proveniente de los aprovechamientos forestales autorizados, así como la madera aserrada o de otra manera procesada, puede ser comercializada por sus legítimos propietarios, sujetándose a las reglas siguientes:

1. La madera no procesada solo puede ser comercializada en el mercado nacional.

2. La madera procesada puede ser comercializada en el mercado nacional o internacional. 
3. La madera proveniente de plantaciones puede comercializarse libremente en el mercado nacional o internacional previo Certificado de Plantación extendido por el ICF.

4. Los productos de la industria secundaria podrán ser comercializados en el mercado nacional o internacional.

5. Otros productos forestales procesados podrán ser comercializados en el mercado nacional e internacional.

Lo anterior se entiende sin perjuicio de lo que dispongan los tratados internacionales aplicables.

En todos los casos se requerirá acreditar la procedencia de los productos. Su origen necesariamente debe ser un aprovechamiento autorizado y ejecutado conforme al plan de manejo forestal aprobado por el ICF o una industria que cuente con su respectiva licencia de operación y cumpla con los demás requisitos legales o reglamentarios.

La comercialización -además de cumplir con la legislación forestal vigente- también deberá cumplir con la legislación tributaria y de sanidad vegetal, y en el caso de operaciones de exportación, la legislación aduanera, cambiaria y los convenios internacionales que regulen su comercio.

\subsection{Estándares para el uso de los recursos forestales}

Los estándares de utilización son: altura del tocón: $30 \mathrm{~cm}$ desde el suelo, diámetro de aprovechamiento industrial: $30 \mathrm{~cm}$ a la altura del pecho (DAP) y diámetro en la punta del árbol: $10 \mathrm{~cm}$. El volumen máximo está señalado en la corta anual permisible que se aprueba para cada plan de manejo.

En las zonas de protección, según el Artículo 109 de la LFAPVS, en ningún caso se puede otorgar permisos o licencias para el aprovechamiento de los recursos en las zonas núcleos de las áreas protegidas y de vida silvestre; en las zonas de amortiguamiento solo es posible realizar las actividades económicas que sean acordadas con los planes de manejo o los planes operativos que hayan sido debidamente aprobados por el ICF.

De acuerdo con el Art. 409 del Reglamento LFAPVS, la declaratoria de especies amenazadas o en peligro de extinción, así como la declaratoria de vedas forestales y otras medidas pertinentes, las hace el ICF amparado en estudios técnicos, tomando en consideración lo dispuesto en los tratados y convenios internacionales en la materia, en especial la Convención CITES. Por lo tanto, el grupo de especies forestales permitidas para su aprovechamiento estará acorde con lo que para el país se enliste en los Apéndices II y III de la CITES.

En el marco del Sistema Social Forestal, que es el mecanismo de desarrollo socioeconómico de las comunidades y grupos organizados, cuyos miembros viven dentro o alrededor de las áreas forestales públicas, se incorporan estos al manejo forestal como sector prioritario, mediante el uso sostenible y diversificado de los recursos forestales y con plena participación en las actividades de protección o de conservación y en los beneficios en que se deriven del aprovechamiento de sus productos y subproductos. Mediante contrato de manejo forestal comunitario, el ICF otorga el aprovechamiento a los grupos organizados a cualquier asociación legalmente reconocida por el Estado que reúna los requisitos establecidos por la AFE.

8. Ing. Carlos Mejía Sandress, Técnico Forestal Calificado. [comunicación personal]. 
Algunas restricciones en el transporte de madera son impuestas en el Reglamento de la Ley Forestal, Áreas Protegidas y Vida Silvestre. Solamente se permite el transporte de madera proveniente de aprovechamientos o de la industria primaria en el horario de cinco de la mañana a nueve de la noche. La madera en rollo, escuadrada o labrada deberá transportarse de manera visible.

La falta de presentación de la guía de movilización cuando sea requerida por autoridad competente faculta para proceder a un decomiso provisional de los productos forestales transportados, debiendo levantar acta y comunicar al Ministerio Público para la investigación oportuna, deduciendo la responsabilidad que corresponda. La sanción por transportar productos forestales sin autorización implica penas de entre cuatro y siete años de reclusión más multa que oscila entre 20 a 60 días de salarios mínimos en su categoría más alta.

El ordenamiento jurídico forestal dispone que solo se pueda realizar actividades forestales con la opinión favorable de los grupos étnicos cuando se afecten territorios indígenas o de afro-hondureños utilizando la consulta previa, libre e informada. En todo caso, es obligatorio que se respete sus prácticas tradicionales y culturales, dando oportunidad para que estos colectivos participen en el diseño, desarrollo y distribución de los beneficios de los proyectos o actividades realizadas en sus territorios.

En otras leyes, como la Ley para la Protección del Patrimonio Cultural de la Nación (Decreto 22097), Ley para la Modernización y Desarrollo del Sector Agrícola (Decreto 31-92), Ley de Reforma Agraria (Decreto 170-74) y Ley de Pesca (Decreto 154-1959), se imponen restricciones de corta y aprovechamiento.

La exportación de productos maderables-incluido los embalajes de madera-está sujeta a regulaciones fitosanitarias internacionales y la entrega de un Certificado CITES por parte de la Secretaría de Agricultura y Ganadería (SAG). Para la importación de madera se aplica las disposiciones contenidas en la Resolución 010-2001 emitida por SAG/SENASA (Servicio Nacional de Sanidad Agropecuaria).

Por disposición en el Artículo 102 de la LFAPVS, se prohíbe la exportación de maderas de especies de hoja ancha que provengan de bosques naturales. Este producto solamente se puede exportar si ha sido transformado o procesado. La madera en rollo o escuadrada, sin ulterior valor agregado, únicamente puede ser comercializada en el mercado interno.

Una dificultad al aplicar las medidas fitosanitarias en Honduras es la falta de articulación y coordinación de las instituciones responsables y la debilidad de estas para garantizar el estatus sanitario uniforme que debe guiar sus acciones. Es probable que la fuente de la confusión surja con la emisión de las leyes que regulan la materia y la yuxtaposición de leyes nuevas que no derogan regulaciones previas ${ }^{9}$.

9. SAG/SENASA, 2011. Política en medidas sanitarias y fitosanitarias en Honduras, Daniel Meza Palma, consultor. 


\section{Análisis del ámbito de acción de la Administración Forestal}

\subsection{Competencias legales para manejo de los recursos forestales}

Las competencias para el manejo de los recursos forestales están dadas exclusivamente en la Ley Forestal, Áreas Protegidas y Vida Silvestre (LFAPVS) sin perjuicio de otras que aparecen en su reglamento. En una forma general, al sector público -representado por el ICF- le competen las funciones normativas, reguladoras, coordinadoras, supervisoras y facilitadoras de las actividades de protección, manejo, transformación y comercialización forestal, y al sector privado y sector social de la economía las funciones de protección, producción, manejo, transformación y comercialización (Art. 9).

Las competencias específicas, contenidas en el Artículo 18 de la Ley y en otras disposiciones de esta ley y su reglamento -identificadas por el consultor- se incluyen en el cuadro siguiente, con su grado de descentralización y nivel de efectividad según la percepción del consultor.

\section{Cuadro 5. Competencias legales para el manejo}

\section{de recursos forestales en Honduras}

\begin{tabular}{|l|l|l|}
\hline \multicolumn{1}{|c|}{ Competencia } & Grado de descentralización & \multicolumn{1}{|c|}{ Nivel de efectividad } \\
\hline $\begin{array}{l}\text { Coordinar y ejecutar políticas de } \\
\text { protección, aprovechamiento, } \\
\text { fomento y uso sostenible de los } \\
\text { recursos forestales. }\end{array}$ & $\begin{array}{l}\text { Se descentraliza en los consejos } \\
\text { consultivos forestales. La Agenda } \\
\text { Forestal Hondureña (AFH) facilita la la } \\
\text { formulación de estas políticas. }\end{array}$ & $\begin{array}{l}\text { La coordinación de la formulación } \\
\text { de las políticas funcionó bien en } \\
\text { el ámbito de la AFH, fue efectiva. } \\
\text { La ejecución con apoyo de los } \\
\text { consejos consultivos no ha sido } \\
\text { implementada totalmente. }\end{array}$ \\
\hline $\begin{array}{l}\text { Supervisar y evaluar el } \\
\text { cumplimiento de los planes de } \\
\text { manejo. }\end{array}$ & $\begin{array}{l}\text { Se puede descentralizar en los } \\
\text { técnicos forestales calificados. }\end{array}$ & $\begin{array}{l}\text { No es tan efectivo por escasez de } \\
\text { recursos en el ICF. }\end{array}$ \\
\hline $\begin{array}{l}\text { Aprobar o denegar planes } \\
\text { operativos, autorizar prórrogas o } \\
\text { cancelar planes aprobados. }\end{array}$ & No hay descentralización. & Es efectiva. \\
\hline $\begin{array}{l}\text { Suspender la ejecución de los } \\
\text { planes operativos por daño } \\
\text { ambiental imprevisto. }\end{array}$ & No hay descentralización. & $\begin{array}{l}\text { Es efectiva en la medida en que } \\
\text { haya conocimiento del daño. }\end{array}$ \\
\hline $\begin{array}{l}\text { Realizar supervisiones y auditorías } \\
\text { técnicas y socio-ambientales. }\end{array}$ & $\begin{array}{l}\text { Se puede descentralizar en los } \\
\text { técnicos forestales calificados. }\end{array}$ & $\begin{array}{l}\text { No es tan efectivo por escasez de } \\
\text { recursos en el ICF. }\end{array}$ \\
\hline $\begin{array}{l}\text { Administrar contratos de manejo } \\
\text { forestal sobre áreas deforestadas } \\
\text { o degradadas a fin de proceder a } \\
\text { su reforestación. }\end{array}$ & $\begin{array}{l}\text { Se trabaja a través del Fondo } \\
\text { de Reinversión Forestal y un } \\
\text { porcentaje es absorbido por las } \\
\text { Fuerzas Armadas. }\end{array}$ & $\begin{array}{l}\text { No es efectivo, porque no hay } \\
\text { control de calidad ni mecanismos } \\
\text { expeditos para acceder a los } \\
\text { fondos. }\end{array}$ \\
\hline
\end{tabular}




\begin{tabular}{|c|c|c|}
\hline Competencia & Grado de descentralización & Nivel de efectividad \\
\hline $\begin{array}{l}\text { Diseñar e implementar una } \\
\text { estrategia nacional para el control } \\
\text { de la tala y el transporte ilegal de } \\
\text { los productos forestales. }\end{array}$ & $\begin{array}{l}\text { Es coordinada por el ICF con } \\
\text { apoyo de los actores que } \\
\text { intervienen en la cadena de } \\
\text { custodia desde que se corta el } \\
\text { árbol hasta su procesamiento y } \\
\text { comercialización. }\end{array}$ & $\begin{array}{l}\text { La iniciativa es reciente y no se } \\
\text { puede evaluar resultados directos } \\
\text { que impacten en la reducción de la } \\
\text { tala y el transporte ilegal. }\end{array}$ \\
\hline $\begin{array}{l}\text { Calificar las infracciones e imponer } \\
\text { las sanciones administrativas. }\end{array}$ & No hay descentralización. & $\begin{array}{l}\text { No es tan efectivo por escasez de } \\
\text { recursos en el ICF. }\end{array}$ \\
\hline $\begin{array}{l}\text { Mantener el registro de industrias } \\
\text { forestales, planteles de ventas de } \\
\text { productos forestales y propietarios } \\
\text { de motosierras. }\end{array}$ & No hay descentralización. & Es efectivo. \\
\hline $\begin{array}{l}\text { Suscribir o cancelar contratos } \\
\text { de usufructo en áreas forestales } \\
\text { públicas de acuerdo con la ley. }\end{array}$ & No hay descentralización. & Es efectivo. \\
\hline $\begin{array}{l}\text { Mantener registro e identificación } \\
\text { del personal de la industria forestal } \\
\text { y subcontratistas de ejecución de } \\
\text { planes de manejo. }\end{array}$ & No hay descentralización. & Es efectivo. \\
\hline $\begin{array}{l}\text { Ejecutar actividades de control de } \\
\text { incendios, plagas y enfermedades } \\
\text { forestales. }\end{array}$ & $\begin{array}{l}\text { El control de incendios se ha } \\
\text { delegado en las Fuerzas Armadas, } \\
\text { el Cuerpo de Bomberos y los } \\
\text { municipios. }\end{array}$ & $\begin{array}{l}\text { No es tan efectivo, porque no se } \\
\text { observa reducción de la incidencia } \\
\text { anual de incendios forestales. }\end{array}$ \\
\hline $\begin{array}{l}\text { Proponer políticas, iniciativas de } \\
\text { ley y reglamentarias para el buen } \\
\text { manejo forestal. }\end{array}$ & No hay descentralización. & $\begin{array}{l}\text { Es efectivo por el acceso del } \\
\text { sector forestal al Consejo de } \\
\text { Ministros. }\end{array}$ \\
\hline $\begin{array}{l}\text { Promover, ejecutar y supervisar el } \\
\text { sistema de valoración por bienes y } \\
\text { servicios ambientales del bosque. }\end{array}$ & $\begin{array}{l}\text { Se ha descentralizado en el } \\
\text { Sistema Nacional de Investigación } \\
\text { Forestal (SINFOR). }\end{array}$ & $\begin{array}{l}\text { No es tan efectivo. Hay pocos } \\
\text { avances en esta materia. }\end{array}$ \\
\hline $\begin{array}{l}\text { Promover el desarrollo de la } \\
\text { industria secundaria de productos } \\
\text { forestales. }\end{array}$ & $\begin{array}{l}\text { Se coordina con otras entidades, } \\
\text { en especial del sector privado. }\end{array}$ & $\begin{array}{l}\text { Se ha desarrollado un poco la } \\
\text { industria secundaria, pero sin } \\
\text { incidir de manera significativa en la } \\
\text { producción general. }\end{array}$ \\
\hline
\end{tabular}

Fuente: Elaboración propia con base en la Ley Forestal, Áreas Protegidas y Vida Silvestre

Una regla general en este ítem es que las funciones legales están concentradas en el ICF, que tiene el mandato de promover la gestión participativa y descentralizada. La descentralización funciona a medias, salvo la que por disposición de leyes especiales se delega en las Fuerzas Armadas, quienes realizan actividades de protección forestal y reforestación absorbiendo el presupuesto que debería ser para la entidad representativa de la autoridad forestal, con el lógico debilitamiento de esta. La debilidad del ICF se manifiesta con escasez de recursos y poca credibilidad ante la sociedad que incide para que las competencias sean cumplidas de manera eficaz y efectiva.

\subsection{Tipos de permisos forestales en el ámbito de acción de la Ley Forestal y afines}

Con el cumplimiento del plan de manejo forestal correspondiente, debidamente aprobado por la autoridad forestal (ICF), se tiene acceso a los diferentes permisos que implica el aprovechamiento 
forestal. En el plan de manejo se cumple con el requisito de hacer una evaluación de impacto ambiental e incluye los planes operativos anuales por quinquenio. El plan de manejo faculta el corte -por medio de la cuota permisible aprobada en el plan operativo anual-, el transporte y comercialización, por las guías de movilización o facturas.

Para activar una industria forestal, primaria o secundaria, se requiere una autorización de instalación y operación.

Desde el punto de vista forestal, a nivel nacional e internacional, el plan de manejo cumple como requisito de permiso forestal general. Sin embargo, la autoridad impone una serie de permisos específicos para determinadas actividades relacionadas con el corte, aprovechamiento, adquisición, procesamiento, industrialización, transporte, exportación e importación, quemas, etc. En el cuadro siguiente se señalan los permisos o registros exigidos por el ICF, mientras que los requisitos para la comercialización internacional se detallan en el Cuadro 7 de la Sección D-4.

\section{Cuadro 6. Permisos para la realización de actividades forestales vinculadas al comercio de madera en Honduras}

\begin{tabular}{|l|}
\hline Autorización de realizar plan de manejo forestal \\
\hline Permiso para aprovechamiento de madera afectada por plagas \\
\hline Finiquito para finalización de contratos de aprovechamiento \\
\hline Autorización para la instalación e inscripción de una industria forestal \\
\hline Permiso para instalación de depósito o venta local de madera \\
\hline Autorización para cambio de nombre de una industria forestal o una venta local de madera \\
\hline Notificación sobre cambio de propietario de una industria forestal o una venta local de madera \\
\hline Registro de equipo forestal utilizado en la industria y del personal calificado \\
\hline Registro de cambio de equipos o maquinaria, o introducción de nuevas tecnologías en la industria \\
\hline Registro de firmas y entrega de guías de movilización selladas por las oficinas forestales del ICF \\
\hline Registro de Técnicos Forestales Calificados \\
\hline Registro de contratos de diferente tipo de actividades forestales suscritos por el ICF \\
\hline
\end{tabular}

Fuente: Portal electrónico del ICF y análisis de la Ley y Reglamento Forestal, Áreas Protegidas y Vida Silvestre

\subsection{Diagrama legal-administrativo para que productos de madera accedan los mercados de Estados Unidos y la Unión Europea}

En este último escenario no hay un procedimiento ni diagrama específico para que los productos de madera puedan ingresar al mercado norteamericano y de la Unión Europea, salvo cumplir con la legislación nacional, ambiental y sectorial respectiva. Cabe señalar que la iniciativa FLEGT ha sido aprobada a nivel del Poder Ejecutivo, pero falta la aprobación del Congreso Nacional para que sea obligatoria. En el ámbito del CAFTA-DR, que tiene seis años de vigencia ${ }^{10}$, la exigencia es cumplir

10. En contraste con el Acuerdo de Asociación con la Unión Europea, que entró en vigencia en agosto de 2013. 
con el capítulo ambiental, dentro de lo cual se ubica la legislación forestal y ello vale eventualmente para cumplir la Lacey Act.

No obstante, hay una serie de requisitos generales para que los productos puedan entrar al mercado extranjero y en la Figura 1 se detalla el conjunto de trámites que debe seguir un exportador de madera en Honduras. Después de realizar las acciones que legalizan el producto que se va a exportar, el punto de partida es identificar la clasificación arancelaria dentro de la cual se ubica este. De acuerdo con el Sistema Arancelario Centroamericano (SAC), la madera se clasifica dentro del capítulo que corresponde a: "Madera, carbón vegetal y manufacturas de madera", donde se detallan los distintos rubros de madera.

El exportador hondureño debe realizar una serie de trámites previos a la exportación de sus productos. El Centro de Trámites de Exportaciones (CENTREX) de la Secretaría de Industria y Comercio (SIC) facilita al exportador la realización de dichos trámites juntando una serie de instituciones en una ventanilla única de exportaciones ${ }^{11}$.

Las instituciones que participan en CENTREX son: a) Secretaría de Agricultura y Ganadería (Sanidad Animal y Sanidad Vegetal), b) Banco Central de Honduras (Departamento Internacional), c) Secretaría de Industria y Comercio (Dirección General de Sectores Productivos), d) Dirección Ejecutiva de Ingresos (DEI) y e) Organismo Internacional Regional de Sanidad Agropecuaria (OIRSA).

Cuando es del caso, previo a ingresar al CENTREX se debe contar con el respectivo permiso CITES o el certificado de tratamiento cuarentenario que exige el Organismo Regional de Sanidad Agropecuaria (OIRSA).

Los requisitos específicos para el ingreso de manufacturas de madera al mercado de la UE son:

- Certificado fitosanitario.

- Cumplimiento de las disposiciones del reglamento de la UE basado en la Convención sobre el Comercio Internacional de Especies Amenazadas de Fauna y Flora Silvestres (CITES).

- Cumplimiento de las normas de empaque, que tienen como objetivo proteger el medio ambiente, así como prevenir cualquier riesgo a la salud de los consumidores.

- Cumplimiento de las normas técnicas para los productos de construcción (si aplica).

11. GTZ, ANDI, CCIT, COHEP, FIDE (2010). Manufacturas de madera: Ficha 25/UE. 
Con relación a la CITES, el procedimiento para la obtención de permisos y certificados por parte de la autoridad competente (Secretaría de Agricultura y Ganadería [SAG]), puede verse en el cuadro siguiente.

\section{Cuadro 7. Procedimiento para la obtención de permisos y certificados CITES}

1. Solicitud (Apoderado legal)

2. Si la solicitud es para especies de Apéndice I (cría en cautiverio), se debe tener una solicitud de importación del país de destino

3. Permisos zoo y fitosanitarios

4. Inscrito en el registro de la SAG

5. Remitir para dictamen (a Departamento de Vida Silvestre del ICF o la Dirección General de Pesca y Acuicultura de la SAG)

6. Emisión de Certificado (Ministro de Agricultura y Ganadería [SAG])

Fuente: Reglamento de procedimientos para la aplicación de la Convención CITES en Honduras, (Acuerdo 966-03) 
En la siguiente figura se detalla los pasos que deben seguir los interesados en exportar madera desde Honduras.

Figura 1. Esquema de los trámites que debe seguir un exportador de madera en Honduras

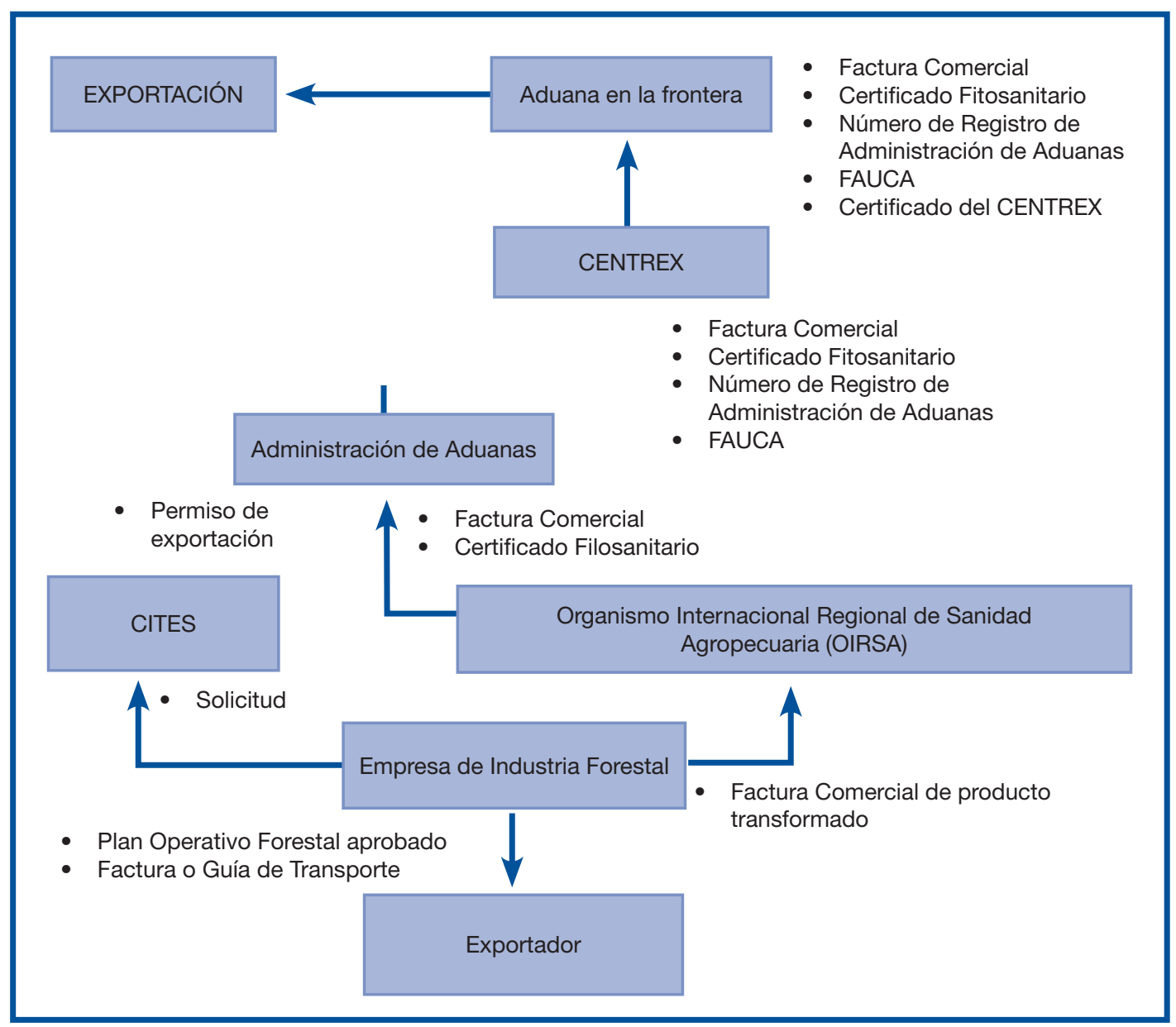

Fuente: Análisis del comercio transfronterizo de productos forestales en Centroamérica 


\subsection{Estadísticas sobre aprovechamiento forestal y comercio internacional de madera}

El último Anuario Estadístico Forestal es del 2012, que corresponde a la información del 2011. Ese año se aprobaron 55 planes de manejo en terrenos nacionales, ejidales y privados, con un área bajo manejo de 5.245,01 hectáreas (ha) y una corta anual permitida de 48.831,39 $\mathrm{m}^{3}$. Ese mismo año se readecuaron 48 planes de manejo con un área bajo manejo de 18.575,98 ha y una corta anual permitida de $37.462,61 \mathrm{~m}^{3}$.

Estaban vigentes antes del 2011691 planes de manejo con un área bajo manejo de 532.372,87 ha y una corta anual permitida de 855.905,01 $\mathrm{m}^{3}$.

Otras estadísticas forestales, extraídas de los Anuarios Estadísticos Forestales, elaborado por la Unidad de Estadísticas y Centro de Información y Patrimonio Forestal del ICF, se presentan en los cuadros siguientes.

\section{Cuadro 8. Aprovechamiento de madera y de producción anual} de madera aserrada de pino 2007-2011

\begin{tabular}{|c|c|c|c|c|}
\hline \multirow{2}{*}{ Año } & \multicolumn{2}{|c|}{ Madera aprovechada (miles de $\mathbf{m}^{3}$ ) } & \multirow{2}{*}{$\begin{array}{c}\text { Madera } \\
\text { aserrada* } \\
\text { (miles de pt) }\end{array}$} \\
\cline { 2 - 4 } & Coníferas & Latifoliadas & Total & $159.204,8$ \\
\hline 2007 & 800,9 & 21 & 821,9 & $142.751,0$ \\
\hline 2008 & 645,9 & 15,6 & 661,5 & $113.250,5$ \\
\hline 2009 & 499,4 & 24,5 & 523,9 & $98.180,2$ \\
\hline 2010 & 448,6 & 15,6 & 464,2 & \\
\hline
\end{tabular}

* Diferentes productos: madera aserrada, plywood, palillos, nasas, pallets y otros

Cuadro 9. Exportación de madera de coníferas 2007-2011

\begin{tabular}{|c|c|c|}
\hline Año & Mil US\$ & Mil pies tablares (pt) \\
\hline 2007 & $31,747.13$ & $58.254,52$ \\
\hline 2008 & $27,933.90$ & $48.842,28$ \\
\hline 2009 & $15,859.24$ & $28.993,23$ \\
\hline 2010 & $12,781.36$ & $19.846,77$ \\
\hline 2011 & $12,493.76$ & $16.944,90$ \\
\hline
\end{tabular}

Fuente: Estadísticas forestales del ICF combinadas con datos del Banco Central de Honduras 
Cuadro 10. Exportación de madera latifoliada 2007-2011

\begin{tabular}{|c|c|c|}
\hline Año & Mil US\$ & Mil kilogramos (kg) \\
\hline 2007 & $6,880.97$ & $7.788,64$ \\
\hline 2008 & $3,006.81$ & $2.999,82$ \\
\hline 2009 & 889.93 & 869,27 \\
\hline 2010 & 186.81 & 208,97 \\
\hline 2011 & 60.41 & 45,65 \\
\hline
\end{tabular}

Fuente: Estadísticas forestales del ICF combinadas con datos del Banco Central de Honduras

Los datos de los cuadros 8, 9 y 10 denotan una disminución de la actividad forestal maderera, tanto en el aprovechamiento de madera en general como en la exportación de madera, que es el principal producto forestal exportable.

Los datos incluidos en los cuadros 9 y 10 indican una notable disminución en la exportación de madera hondureña, tanto en la de coníferas que disminuyó de US\$31,747 en el 2007 hasta US $\$ 12,494$ por madera exportada de pino en el 2011 , lo que significa una caída significativa de $39,4 \%$ por ingresos en ese rubro en cinco años. Por otra parte, la caída fue más estrepitosa en la exportación de madera de hoja ancha, que disminuyó de US\$6,881 percibidos en el 2007 hasta US $\$ 60.41$ en el 2011. Esto es significativo si se considera que este tipo de madera es la que se exporta en el marco de la Convención CITES.

Además de la crisis política del 2009, que indudablemente impactó en las exportaciones nacionales de madera, también se percibe un decrecimiento sistemático en los cinco años analizados, ya que la curva se ha mantenido descendente, lo cual puede ser un indicador de que el mercado internacional de madera tiene menos vigor o que el país ha perdido competitividad en este rubro. 


\section{Análisis del sistema de control forestal}

\subsection{Conflictos de competencias entre los responsables de la administración y ejecución de los sistemas de control forestal}

En la legislación forestal no se detectan conflictos en el sistema de control forestal. La LFAPVS reconoce que el ICF tiene las funciones de administrar el recurso forestal público, así como la regulación y control del recurso natural privado en un marco de desarrollo sostenible. Como coadyuvantes, en los sistemas de control el ICF tiene apoyo de las Fuerzas Armadas, la Policía Nacional, la Fiscalía y Procuraduría del Ambiente e incluso, del sistema judicial en casos de decomiso que resulten de un delito forestal.

No obstante, con la creación de la unidad especializada en materia de ecosistema y ambiente (conocida como Unidad Especializada de Soldados Forestales) bajo la égida de las Fuerzas Armadas, se generó un conflicto real de competencias con el ICF, que tiene como mandato de la LFAPVS crear una Unidad de Guardias Forestales. Ambas instancias tienen funciones similares, pero no se logra integrar las funciones técnico-legales que tiene el ICF con las policiales, que son inherentes a la Policía Nacional y no a las Fuerzas Armadas ${ }^{12}$.

\subsection{Requerimientos de control forestal en la Ley Forestal y normas legales afines}

La ilegalidad en las actividades forestales ha sido reconocida ampliamente en Honduras, con grandes pérdidas para el país por reducción de ingresos y deterioro de los ecosistemas forestales ${ }^{13}$, a lo que se suma las pérdidas ocasionadas por los incendios, plagas y enfermedades forestales. Lo anterior motivó a que en la LFAPVS se ordenara que el ICF implementara varias acciones para frenar esta ilegalidad. Entre estas:

- Diseño e implementación de una estrategia nacional para el control de la tala y el transporte ilegal de los productos forestales.

- Creación de mecanismos de control para el transporte de productos y subproductos forestales en coordinación con la Policía Nacional, el Ministerio Público y otras dependencias del Estado.

- Preparación del Plan Nacional de Protección Contra Incendios Forestales y el Plan Nacional de Control de Plagas y Enfermedades Forestales.

- Creación de la Unidad de Guardias Forestales como una unidad especializada en la supervisión y monitoreo de las actividades forestales.

12. COLPROFORH. (2013). Petición al Consejo de Ministros para reconsiderar acto administrativo que entrega bosques a las Fuerzas Armadas.

13. FEHCAFOR, REMBLAH, ODI-DFID, Banco Mundial, ACDI (2012). La producción forestal no controlada en Honduras. Elaborado por Filippo del Gatto. 
A lo anterior hay que sumar al Monitoreo Forestal Independiente (MFI), un programa adscrito al Comisionado Nacional de Derechos Humanos (CONADEH), que trata los temas de gobernanza, transparencia y aplicación de la legislación en el sector forestal.

El MFI se centra en investigaciones sobre el terreno con el objetivo de proporcionar evidencia fiable sobre el manejo forestal y denunciar actividades ilegales. Mediante inspecciones in situ se ha logrado documentar irregularidades como talas fuera de límites autorizados, autorización ilegal de aprovechamientos forestales, usurpación de tierras, transporte y comercialización de productos forestales e industrialización ilegal de productos forestales ${ }^{14}$.

\subsection{Estadísticas forestales y su impacto en la ilegalidad del aprovechamiento forestal}

En el ICF funciona la sección de Estadísticas Forestales, adscrita al Centro de Información y Patrimonio Forestal (CIPF), que es responsable de recabar las estadísticas que se generan en el sector, en el área de silvicultura, protección forestal, producción forestal, sistema social forestal, áreas protegidas y comercio internacional, entre otra información que se recopila en el documento denominado Anuario Estadístico Forestal.

Mediante convenio interinstitucional, el Instituto Nacional de Conservación y Desarrollo Forestal, Áreas Protegidas y Vida Silvestre (ICF) coordina con el Banco Central de Honduras (BCH) y el Instituto Nacional de Estadísticas (INE) a fin de establecer los puntos vinculantes en materia de estadística forestal. Los elementos de coordinación corresponden a la definición de productos prioritarios, los vínculos con Aduanas, el aporte de los productos forestales al PIB, la diferenciación entre el PIB de la Actividad Silvicultural y el PIB del Sector Forestal ${ }^{15}$.

Por falta de un programa de monitoreo, no es posible determinar el impacto de las estadísticas en la ilegalidad del aprovechamiento forestal. De hecho, la percepción particular es que mientras no haya mecanismos efectivos de control, solo será eso, "estadísticas".

\subsection{Control cruzado de certificados de comercio de productos de madera}

El cuadro siguiente ilustra el control de certificados de comercio, que es válido para los productos de madera que buscan ingresar al mercado internacional.

14. Ing. Fausto Mejía, Director Monitoreo Forestal Independiente. [comunicación personal].

15. Ing. Alma Duarte, Directora del Centro de Información y Patrimonio Forestal. [comunicación personal]. 


\section{Cuadro 11. Documentos requeridos para exportar madera y sus productos}

\begin{tabular}{|l|l|l|l|}
\hline \multicolumn{1}{|c|}{ Documento } & \multicolumn{1}{c|}{ Institución } & \multicolumn{1}{c|}{ Descripción } & \multicolumn{1}{c|}{ Costo } \\
\hline $\begin{array}{l}\text { Certificado fitosanitario } \\
\text { internacional de } \\
\text { exportación }\end{array}$ & $\begin{array}{l}\text { Secretaría de Agricultura } \\
\text { y Ganadería (SAG), } \\
\text { ventanilla CENTREX }\end{array}$ & $\begin{array}{l}\text { Para la exportación de } \\
\text { plantas vivas, productos } \\
\text { y subproductos de origen } \\
\text { vegetal }\end{array}$ & $\begin{array}{l}\text { L. } 350 \\
\text { Más: a) timbre de cinco } \\
\text { (5) lempiras del Colegio } \\
\text { de Agrónomos de } \\
\text { Honduras y timbre fiscal } \\
\text { de un (1) lempira }\end{array}$ \\
\hline $\begin{array}{l}\text { Declaración de } \\
\text { exportación }\end{array}$ & $\begin{array}{l}\text { Banco Central de } \\
\text { Honduras, ventanilla } \\
\text { CENTREX }\end{array}$ & $\begin{array}{l}\text { Para la exportación de } \\
\text { cualquier producto }\end{array}$ & No hay \\
\hline $\begin{array}{l}\text { Declaración de ingreso } \\
\text { de divisas. }\end{array}$ & $\begin{array}{l}\text { Institución bancaria } \\
\text { con la que se hizo la } \\
\text { operación. }\end{array}$ & $\begin{array}{l}\text { En caso de que las } \\
\text { exportaciones de } \\
\text { cualquier producto } \\
\text { sean realizadas en } \\
\text { forma de Anticipo o } \\
\text { con Endeudamiento } \\
\text { Externo (Incisos 1 } \\
\text { y 2 del apartado G } \\
\text { de la Declaración de } \\
\text { Exportación). }\end{array}$ & No hay. \\
\hline $\begin{array}{l}\text { Certificado de Origen } \\
\text { (Forma A) }\end{array}$ & $\begin{array}{l}\text { Asociación Nacional de } \\
\text { Industriales (ANDI). }\end{array}$ & $\begin{array}{l}\text { Para las exportaciones de } \\
\text { productos amparados en } \\
\text { el Sistema Generalizado } \\
\text { de Preferencias (SGP+). }\end{array}$ & $\begin{array}{l}\text { US\$5 o su equivalente } \\
\text { en Lempiras a la tasa de } \\
\text { cambio vigente. }\end{array}$ \\
\hline
\end{tabular}

Fuente: sic.gob.hn 
Un análisis preliminar sobre el control cruzado de certificados de comercio de productos de madera que, además de las que se mencionan en el Cuadro 11, involucra otras tres instituciones públicas (ICF en el origen de los productos, Secretaría de Industria y Comercio -promotora del comercio exterior- y la Secretaría de Finanzas, a través de la Dirección de Aduanas, encargada de los trámites aduaneros) y dos entidades privadas hace pensar en la necesidad de un adecuado procedimiento de coordinación que se consigue con el funcionamiento de una ventanilla única que, según informes, ha funcionado bien.

No obstante, un estudio sobre el comercio de madera en Centroamérica señala que el hecho de que se cumpla con los requisitos administrativos hace que la madera sea oficialmente "legal", pero "puede perfectamente ocurrir que la madera sea aprovechada ilegalmente y subsecuentemente exportada legalmente. El problema entonces no es la presencia o menos de documentos que amparan una carga de madera, sino el valor de estos documentos"16. Según el estudio, es prioritario buscar mecanismos de verificación que aumenten la credibilidad de la documentación legal.

\subsection{Denuncias presentadas por las autoridades del Estado por el delito de actividades forestales ilegales}

El ente responsable de presentar denuncias ante el Ministerio Público o la Procuraduría de Ambiente y Recursos Naturales es el ICF, pero no es posible acceder a las estadísticas sobre este tema, ya que los archivos se perdieron en un incendio de las oficinas de ese instituto el presente año ${ }^{17}$.

16. Navarro, Sánchez, Del Gatto. (2013). Análisis del comercio transfronterizo de productos forestales en Centroamérica.

17. Abog. Orlando Núñez, Asesor Legal ICF. [comunicación personal]. 


\section{Análisis de ejecución de procesos judiciales}

\subsection{Legislación forestal y afines, con relación a los procesos judiciales aplicables al aprovechamiento forestal y comercio internacional de productos forestales}

En el proceso judicial donde se ventilan asuntos relacionados con el aprovechamiento y comercialización de productos forestales, los jueces imparten justicia con base en las disposiciones que sobre estas materias están contenidas tanto en la legislación forestal como en materias afines (ambientales, laborales y para el comercio internacional, las reglas que sirvan para la aplicación del CAFTA-DR). En forma subsidiaria se recurre al Código Procesal Civil cuando son asuntos mercantiles, así como también al Código Penal u otra norma aplicable según la jurisdicción de que se trate.

La representación de la sociedad o del Estado, según el caso, corresponde a los fiscales del Ministerio Público o los procuradores de la República, sin que haya una atención especial a este tipo de causas que -igual que otras- se distribuyen entre los órganos jurisdiccionales competentes de acuerdo con el orden de llegada, pero que en la práctica suelen ser relegadas por casos de mayor relevancia social.

En el procedimiento se cumple con los plazos establecidos en la ley que sirve de fundamento a la causa, pero si esta no tiene plazos, el juez o tribunal los señala. En el ámbito administrativo el procedimiento aplicable a las causas forestales está contenido en la Ley de Procedimientos Administrativos. En torno al aprovechamiento, la legislación forestal tipifica como delito el corte, aprovechamiento o transporte y comercialización ilegal de productos y subproductos forestales ${ }^{18}$. La legislación forestal no tipifica delitos o faltas administrativas por el comercio internacional de madera, por lo que cabe entender que aplica este mismo procedimiento.

En el Cuadro 12 se observa la duración del proceso administrativo relacionada con las actividades ilegales mencionadas en el párrafo anterior, en las cuales el juez o tribunal se ajustaría a los plazos y requisitos de la Ley de Procedimiento Administrativo, aunque en los pocos casos sometidos lo normal es que la duración sea mayor.

18. Ley Forestal, Áreas Protegidas y Vida Silvestre, Arts. 172-174. 
Cuadro 12. Trámite por delitos relacionados con el aprovechamiento ilegal de productos forestales

Trámite de causas forestales según Ley de Procedimiento Administrativo

- Presentación y completación de requisitos: tres (3) días

- Apertura a prueba: entre 10-20 días

- Aceptación de peritos propuestos: cinco (5) días

- Emisión de informes o dictámenes técnicos: Máximo 15 días

- Vista de pruebas y actuaciones a las partes: 20 días

- Resolución cuando se resuelve de plano el fondo del asunto: 10 días después de la última actuación

- Resolución si no se resuelve de plano el asunto (se debe evacuar actuaciones intermedias): 60 días de notificarse la primera providencia

\section{Fuente propia}

El silencio en la jurisdicción administrativa es positivo, aplicable mediante la interposición de la figura de la afirmativa ficta, que se define como "la decisión normativa de carácter administrativo por la cual todas las peticiones por escrito de los ciudadanos, usuarios, empresas o entidades que se hagan a la autoridad pública, si no se contestan en el plazo que marca la Ley o las disposiciones administrativas, se consideran aceptadas"19.

\subsection{Jurisprudencia relevante en relación con compensación por daño ambiental por el delito de aprovechamiento ilegal de productos forestales}

La jurisprudencia en Honduras corresponde a tres sentencias de la Corte Suprema de Justicia con el mismo pronunciamiento sobre un mismo tema. Pero aunque existe jurisprudencia en diversas materias (agrario, civil, constitucional, laboral, inquilinato, penal) y pese a que existen recursos de casación y de amparo pendientes de resolver por la Corte Suprema de Justicia sobre cuestiones de ambiente, no se pudo conocer ninguna jurisprudencia en materia forestal ${ }^{20}$.

\subsection{Tipos de penas en la legislación vinculadas con la ilegalidad en el comercio de madera}

Las infracciones por incumplimiento a la legislación forestal están tipificadas en la Ley Forestal, Áreas Protegidas y Vida Silvestre, clasificándolas en delitos e infracciones. Con relación al comercio de madera, esta ley solo contempla delitos, ya que las infracciones que se tipifican no son aplicables al comercio de productos forestales. Tampoco hay infracciones en el Reglamento General de la LFAPVS, porque se decidió elaborar un reglamento especial, que aun está en proyecto.

19. Ley de Simplificación Administrativa, Decreto 255-2002, Art. 29.

20. Esto se deduce al revisar el portal electrónico del Poder Judicial de Honduras que, en su página correspondiente a la Jurisprudencia, no acredita ningún caso directamente relacionado con el ambiente. 


\section{Cuadro 13. Sanciones por incumplimiento a las disposiciones en la LFAPVS vinculadas al comercio de madera}

\begin{tabular}{|l|l|}
\hline \multicolumn{1}{|c|}{ Delito } & \multicolumn{1}{c|}{ Sanción } \\
\hline $\begin{array}{l}\text { Corte o aprovechamiento ilegal de productos o } \\
\text { subproductos forestales }\end{array}$ & $\begin{array}{l}\text { 9 a } 12 \text { años de reclusión, más siembra de plántulas } \\
\text { del doble de lo apropiado ilegalmente }\end{array}$ \\
\hline $\begin{array}{l}\text { Transporte ilegal de productos o subproductos } \\
\text { forestales }\end{array}$ & $\begin{array}{l}4 \text { a } 7 \text { años de reclusión, más multa equivalente entre } \\
20 \text { y } 60 \text { días de salarios mínimos }\end{array}$ \\
\hline $\begin{array}{l}\text { Comercialización ilegal de productos o subproductos } \\
\text { forestales }\end{array}$ & 6 a 9 años de reclusión \\
\hline $\begin{array}{l}\text { Industrialización ilegal de productos o subproductos } \\
\text { forestales }\end{array}$ & 9 a 12 años de reclusión \\
\hline Tráfico ilegal de productos o subproductos forestales & 12 a 15 años de reclusión \\
\hline
\end{tabular}

Fuente: Ley Forestal, Áreas Protegidas y Vida Silvestre

En la legislación nacional tampoco se contemplan delitos o infracciones administrativas específicas respecto al comercio internacional de especies CITES. Correspondería tipificar estas infracciones en la Ley General del Ambiente, la Ley Forestal, Áreas Protegidas y Vida Silvestre, la Ley Fitozoosanitaria o la Ley de Pesca, pero en ninguna de ellas fue posible identificar un delito o falta específica con relación a CITES.

Como oportunidad para tipificar infracciones específicas en el marco de la Convención CITES como faltas administrativas se puede identificar el proyecto de reglamento de sanciones por incumplimiento a la legislación forestal, que actualmente está en proceso de elaboración por parte del ICF, teniendo pendiente una socialización para someterlo a la opinión de la Procuraduría General de la República y posteriormente, a la aprobación del Presidente de la República en Consejo de Ministros.

\subsection{Casos presentados, desestimados o con sentencia en el período 2008-2013}

En la Fiscalía Especial del Medio Ambiente (FEMA) del Ministerio Público se obtuvo estadísticas de las denuncias presentadas en el período comprendido entre el 2007 y el 2011. Los dos últimos años ya hay datos sobre el decomiso de madera y de especies de flora y fauna. Cada año se observa un incremento en el número de denuncias recibidas respecto al año anterior, lo que seguramente indica una mayor atención a las causas forestales.

Al consultar los órganos responsables de impartir justicia por casos forestales, en especial la Fiscalía Especial del Medio Ambiente (FEMA) ${ }^{21}$, no se consiguió datos sobre sentencias ni causas desestimadas debido a que son globales para todo el sector ambiente y en el ICF, que mantenía las estadísticas del sector forestal, la información se perdió por causa de un incendio que afectó todas las oficinas centrales en Tegucigalpa.

21. No fue posible conseguir información en la procuraduría del Ambiente que representa al Estado cuando se afecta bienes o intereses del Estado, aunque es conocido que los casos que allí se llevan coinciden en su trámite con la FEMA. 
Cuadro 14. Denuncias recibidas en el Ministerio Público por casos forestales 2007-2011

\begin{tabular}{|c|c|c|c|c|}
\hline \multirow{2}{*}{ Año } & \multirow{2}{*}{$\begin{array}{c}\text { Denuncias } \\
\text { presentadas }\end{array}$} & Madera $(\mathrm{pt})$ & Fauna (c/u) & $\begin{array}{c}\text { Valor en } \\
\text { lempiras }\end{array}$ \\
\cline { 4 - 5 } & 36 & $\mathrm{n} / \mathrm{a}$ & $\mathrm{n} / \mathrm{a}$ & $\mathrm{n} / \mathrm{a}$ \\
\hline 2007 & 38 & $\mathrm{n} / \mathrm{a}$ & $\mathrm{n} / \mathrm{a}$ & $\mathrm{n} / \mathrm{a}$ \\
\hline 2008 & 66 & $\mathrm{n} / \mathrm{a}$ & $\mathrm{n} / \mathrm{a}$ & $\mathrm{n} / \mathrm{a}$ \\
\hline 2009 & 124 & 31.642 & 12 & $653.628,79$ \\
\hline 2010 & 281 & $32.549,87$ & 13 & $689.538,79$ \\
\hline 2011 & & & & \\
\hline
\end{tabular}

Fuente: Memorias del Ministerio Público del 2007 al 2011

El análisis sobre el sistema de aplicación de la justicia en casos forestales no deja duda de que no es efectivo. En el ámbito administrativo se reciben denuncias que si son presunciones de delitos se turnan a las instancias responsables de incoar la acción penal pública (Ministerio Público y Procuraduría del Ambiente), quienes se encargan de hacer el requerimiento judicial correspondiente, optando por ejercer el criterio de oportunidad en la mayoría de los casos por razones de simplificación procesal. Pero no hay evidencia de que estas medidas repercutan a reparar el mal causado al bosque (para referirlo a la materia de estudio).

Para ejemplo, de 222 denuncias recibidas en un año en la Fiscalía del Ambiente del Ministerio Público, 127 fueron sometidas a investigación por la Dirección de Investigación Criminal. En lugar de judicializar las causas, 36 recibieron criterio de oportunidad por razones de simplificación procesal y las demás fueron desestimadas ${ }^{22}$.

Por otra parte, la atención a las infracciones forestales tipificadas como faltas en la legislación forestal corresponde al ICF, que carece de recurso humano y logística suficiente para resolverlas. De hecho, se logró confirmar que, desde que se aprobó la nueva ley forestal en el 2007, la autoridad administrativa forestal no conoce estas denuncias, aduciendo que no tiene el respectivo reglamento de sanciones por incumplimiento de la legislación forestal.

\subsection{Retos en el ámbito judicial para el aprovechamiento forestal y comercio internacional de productos forestales}

El reto en el ámbito judicial no es exclusivo para el aprovechamiento forestal o el comercio internacional, sino que abarca todas las áreas vinculadas a la materia forestal y del ambiente en general. En el 2011, los actores vinculados a la aplicación de la justicia ambiental identificaron como retos los siguientes:

22. Chinchilla Guerra, M. (2006). Memoria anual de abogados ambientalistas. México, D.F. 
- Creación de tribunales especializados en ambiente, con capacitación especial en la materia forestal por ser esta la que mayores denuncias recibe por parte de la población.

- Acceso a bases de datos de otras instituciones como: Dirección Ejecutiva de Ingresos (DEI), Registro Nacional de las Personas y Registro de la Propiedad, entre otras, para facilitar la investigación al ahorrar tiempo en las diligencias propias de cada denuncia interpuesta.

- Creación de un laboratorio forense ambiental que permita, de forma expedita, contar con la prueba científica para la sustentación de los casos, pues en muchas ocasiones el delito no se puede probar por la falta de pruebas de laboratorio.

- Aplicación efectiva del Reglamento de Consultas, Denuncias y Quejas Ambientales, que involucra todas las instituciones con competencias administrativas o judiciales, mediante un proceso interactivo, aprovechando la tecnología de última generación.

\section{Cuadro 15. Lineamientos y estado actual del Reglamento de consultas, denuncias y quejas ambientales}

Este Reglamento tiene como objetivo general propiciar un mejor servicio y funcionamiento del dispositivo administrativo de atención a la ciudadanía que desea hacer consultas, presentar denuncias o quejas relacionadas con el universo de las actividades ambientales, entre las cuales tienen un nivel especial las forestales, en atención a que la mayoría de denuncias por presuntas infracciones ambientales pertenece al sector forestal.

Con la aplicación del Reglamento se pretende:

- Sistematizar y automatizar el manejo de la información pública relacionada con las consultas, denuncias y quejas ambientales para asegurar el acceso constante y actualizado por parte de la ciudadanía.

- Aplicar el procedimiento para que estos puedan presentar denuncias o sus quejas por infracciones contra la legislación ambiental, por parte de los funcionarios públicos y de la ciudadanía en general.

- Institucionalizar un sistema y un órgano especializado para atender a la ciudadanía en el proceso de recepción y atención a las Consultas, Denuncias y Quejas en materia ambiental.

- Resolver a satisfacción y de conformidad con la ley las consultas, denuncias y quejas ambientales presentadas al Sistema.

- Todo lo anterior, con base en un sistema integrando todas las instituciones vinculadas a la gestión ambiental por medio de tecnologías informáticas.

Con relación al tema de estudio, la aplicación de este reglamento aseguraría la atención pronta y efectiva a las denuncias presentadas por la ciudadanía por presuntas infracciones forestales. La utilización de herramientas informáticas significa un ahorro de tiempo y garantiza la prontitud y transparencia en el proceso.

Este proyecto de reglamento está en proceso de aprobación desde el año 2010 y funcionarios de la Secretaría de Recursos Naturales y Ambiente dieron la información de que este fue aprobado en el 2012. Sin embargo, no se pudo acceder a la publicación en La Gaceta, que es la etapa final para que una norma legal entre en vigencia.

Fuente: Propuesta en proceso de aprobación del Reglamento de consultas, denuncias y quejas ambientales. Proyecto USAID / MIRA. [sitio web]. <http://www. mirahonduras.org>. 


\section{Aportes adicionales}

\subsection{Antecedentes y situación actual de la legislación forestal}

En los últimos 50 años, la legislación forestal hondureña ha pasado por diversas etapas, desde un período de organización de la Administración Forestal del Estado y sus instituciones técnicoadministrativas al Estado empresario y posterior devolución del vuelo forestal a los titulares de dominio de la tierra entre 1974-1992. Con la actual Ley Forestal, Áreas Protegidas y Vida Silvestre se procura insertar el sector forestal dentro de la moderna legislación de este recurso. Esta ley es muy armónica con el resto de la legislación afín a la materia forestal, cuenta con interesantes mecanismos de participación ciudadana e incorpora conceptos ambientales relacionados con el ambiente, la sociedad y el mercado de productos forestales.

La institucionalidad forestal se dinamiza elevando a nivel de sector a lo que antaño apenas era un apéndice del Ministerio de Agricultura. También crece de categoría el ICF. Como el órgano de dirección superior forestal tiene categoría de ministro, con acceso directo al Consejo de Ministros. En aplicación de la ley se adopta la iniciativa REDD+ y FLEGT, y se busca estructurar el procedimiento adecuado para incursionar en el mercado del carbono forestal.

Sin embargo, la situación real del sector forestal, en especial del ICF, parece lejos de tener el músculo suficiente para cumplir con los numerosos y difíciles retos que le plantea la legislación. A los pocos recursos asignados vía presupuesto hay que sumar que tiene que lidiar con la herencia de los altos índices de ilegalidad que laceran todavía más las posibilidades de salir adelante en la difícil tarea de administrar el recurso forestal en un país que ampliamente tiene esta vocación, con una conflictiva situación respecto a la tenencia, uso y acceso a la tierra forestal pública que limita la distribución equitativa de los beneficios del bosque (sus productos, bienes y servicios) y con los conflictos de competencia con otras instituciones que, como las Fuerzas Armadas, invaden su esfera jurisdiccional y erosionan los recursos escasos.

\subsection{Estándares para el uso de productos forestales}

Los patrones de legalidad respecto al aprovechamiento forestal en el país se pueden considerar bastante estrictos, aunque se observan vacíos sobre este tema en las áreas protegidas que suponen un aprovechamiento de recursos en la zona de amortiguamiento. En relación con el aprovechamiento forestal y comercio internacional de productos forestales, se puede decir que no se observan vacíos evidentes. No obstante, el hecho de que un alto porcentaje de las infracciones forestales haya sido tipificado como delitos dificulta su conocimiento por juzgados y tribunales que están saturados de casos de delitos comunes y sin la capacitación necesaria para juzgar los delitos especiales donde se ubica los forestales y con un aparato administrativo débil para atender las pocas infracciones tipificadas como faltas forestales.

Igual sucede con las comunidades locales afiliadas al Sistema Social Forestal que, pese a tener derechos legales de usufructo y regularización en las áreas forestales, no pueden ser debidamente 
atendidas por la debilidad del ICF. Pero hay avances en torno al reconocimiento y legalización de los derechos de los pueblos indígenas y afrohondureños, a quienes se les ha extendido títulos plenos comunales en un proceso donde participan las representaciones étnicas y las instituciones públicas involucradas.

Con respecto a los requisitos legales para los permisos de aprovechamiento forestal y comercio internacional de productos forestales, desde el ámbito administrativo, estos se basan en el cumplimiento de un plan de manejo elaborado por el propietario y aprobado por el ICF. Sin embargo, este instrumento se percibe como muy complejo y costoso, para lo cual basta recordar que en el estudio fueron identificados 26 requisitos técnicos y 15 de tipo legal, lo que incluye el cumplimiento de garantías y pagos.

Lo anterior provoca que, pese a que hay un plazo legal para aprobar el plan de manejo, este difícilmente se cumple, además de que después se debe cumplir con toda la normativa legal para ejecutar la actividad forestal que corresponda y con los requisitos legales para acceder al mercado internacional que supone el trámite en diferentes instituciones, aunque esto se simplifica por tener una ventanilla única.

Por otra parte, los estándares para el uso de los recursos forestales -a pesar de que se rigen por normas diferenciadas en cuanto al tipo de bosque donde se hace el aprovechamiento (zona de protección o de producción), tipo de especie o producto a exportar, situación social del beneficiario del bosque y atención a tratados internacionales y normas legales nacionales (ambientales y fitosanitarias, entre otras)- pueden ser de aplicación complicada sin la adecuada información y seguimiento. Al contrario, los estándares legales no parecen muy difíciles de cumplir si se cuenta con una normativa clara y conocida por los interesados, tanto beneficiarios como la misma autoridad. En cualquiera de los casos, la falta de aplicación se convierte en un factor adicional de ilegalidad.

\subsection{Análisis del ámbito de acción de la Administración Forestal}

La Administración Forestal del Estado, representada por el ICF, tiene el reto de descentralizar poderes que históricamente han estado concentrados en la entidad pública forestal a nivel central. Según la ley, al ICF le competen las funciones normativas, reguladoras, coordinadoras, supervisoras y facilitadoras de las actividades de protección, manejo, transformación y comercialización forestal, mientras que al sector privado y sector social de la economía las funciones de protección, producción, manejo, transformación y comercialización de productos y subproductos del bosque, todo ello en el marco de una política nacional que exige la delegación de funciones.

No obstante, las numerosas funciones que -por ley o motu proprio- el ICF delega en las direcciones regionales o en otros actores de la sociedad en muchos casos no tienen los mínimos niveles de efectividad que se podrían considerar adecuados en una administración forestal eficiente y eficaz. Los recursos escasos del ICF y la propia tendencia a mantener centralizadas las funciones impiden la descentralización forestal efectiva. También hay que agregar que determinadas decisiones, como la delegación de funciones eminentemente técnicas en las Fuerzas Armadas, erosionan el raquítico presupuesto del ICF y le restan credibilidad a esta institución ante la sociedad hondureña. 
La exigencia de permisos para diferentes actividades que se derivan de la legislación forestal y otras normas legales afines, como la ambiental, de salud, aduanal, etc. -aunque son numerosos- en la mayoría de los casos se puede considerar pertinente y necesaria, pero con la advertencia de que en varios de estos permisos, sobre todo los que debe aprobar el ICF, se imponen requisitos innecesarios que hace más complicado darles la atención debida con los recursos de la institución, vuelve más oneroso el trámite y puede propiciar la recurrencia a canales ilegales que al final redundan en falta de competitividad de los productos forestales hondureños en el mercado internacional.

Por último, en el análisis del ámbito de acción de la administración forestal es menester referir que las estadísticas forestales de producción y exportación no reflejan el potencial del recurso forestal hondureño. Claramente se observa una curva descendente en los últimos cinco años, pero que puede llevarse más atrás en el tiempo. En cualquier caso, la situación amerita un análisis especial, ya que responsabilizar la baja producción y exportación de madera y otros productos a la crisis política del 2009 y a la baja en el mercado internacional de madera serían excusas demasiado simples.

\subsection{Análisis del sistema de control forestal}

En la legislación forestal no se detectan conflictos en el sistema de control forestal. El ICF tiene las funciones de administrar el recurso forestal público y la regulación y control del recurso natural privado en un marco de desarrollo sostenible. Como coadyuvantes, en los sistemas de control el ICF tiene apoyo de las Fuerzas Armadas, la Policía Nacional y la Fiscalía y Procuraduría del Ambiente e incluso, del sistema judicial en casos de decomiso que resulten de un delito forestal. No obstante, con la creación de la Unidad especializada en materia de ecosistema y ambiente bajo la égida de las Fuerzas Armadas se generó un conflicto real de competencias con el ICF cuando esta unidad tergiversa el mandato de la LFAPVS al crear una Unidad de Guardias Forestales.

El accionar integrado de la institucionalidad hondureña para frenar la ilegalidad en las actividades forestales se debe considerar un imperativo categórico; pero más que dar competencias a entidades fuera de su ámbito, debería ser mediante la creación o funcionamiento de mecanismos efectivos de coordinación entre todos los actores con funciones de autoridad, prevención y control de las actividades forestales.

El monitoreo de las estadísticas forestales es algo que funciona bien. No obstante, no es posible determinar el impacto que estas tienen en el aprovechamiento forestal y el comercio de madera, salvo las de seguir las tendencias históricas en cada caso. La experiencia de muchos años repercute en una sistematización que cubre la mayoría de los indicadores de interés para el Sector Forestal y para el aprovechamiento y comercio en particular. Sin embargo, de acuerdo con lo investigado, queda pendiente de incorporar los indicadores de aplicación de la justicia, ya que no fue posible obtener datos que indicaran el número de denuncias, casos resueltos por la vía administrativa o remitidos a los juzgados. Esto se mantenía en expedientes físicos en el ICF, pero se quemaron en el incendio ocurrido en dichas instalaciones.

En relación con los certificados de madera, lo estudiado permite concluir que existe un control cruzado de certificados de comercio de productos de madera hacia el mercado internacional. En la ventanilla CENTREX convergen las facturas comerciales, certificaciones aduanales, fitosanitarias, 
etc. emitidas por diferentes instituciones públicas y privadas que tienen competencias o interés en la comercialización de los productos forestales. Sin embargo, se advierte que el hecho de que se cumpla con los requisitos administrativos no necesariamente significa que la madera sea aprovechada legalmente. Por lo tanto, se hace necesario buscar mecanismos de verificación que aumenten la credibilidad de la documentación legal.

\subsection{Análisis de ejecución de procesos judiciales}

La legislación nacional que aplica a los procesos judiciales en el aprovechamiento forestal y comercio internacional de productos forestales tiene su base en la Ley Forestal, Áreas Protegidas y Vida Silvestre en la parte técnico-administrativa forestal, para lo cual también aplica la Ley General del Ambiente. Ambas son importantes para el comercio internacional, en especial el que ya se genera en el ámbito del CAFTA-DR y el que puede resultar del Acuerdo de Asociación con la Unión Europea o para la iniciativa FLEGT.

Las entidades que representan a la sociedad o al Estado en procesos judiciales (fiscales del Ministerio Público o los procuradores de la República) no tienen mucho éxito al concurrir a los tribunales, porque los delitos forestales reciben poca atención, siendo relegados por las causas de delitos comunes. Ello obliga a pensar en la opción de reforzar el sistema administrativo, donde el ICF -en coordinación con las municipalidades- conozca las faltas y resuelva en los plazos establecidos, asegurando que las sanciones se cumplan.

La situación actual, en la que la mayoría de infracciones se tipifica como delitos que no son atendidos en el sistema judicial, solo genera impunidad, por lo que se podría plantear la iniciativa de replantear las infracciones forestales, dejando como delitos solo aquellas que significan una grave afectación a los ecosistemas o la sociedad. Dentro del sistema administrativo fortalecido, donde el ICF imponga multas que sean cobradas por las municipalidades, habría un escenario para que las resoluciones se cumplan por las mayores posibilidades de las municipalidades para realizar los cobros, evitando así que las infracciones queden impunes.

\subsection{Retos en el ámbito judicial para el aprovechamiento forestal y comercio internacional de productos forestales}

El reto en el ámbito judicial no es exclusivo para el aprovechamiento forestal o el comercio internacional, sino que abarca todas las áreas vinculadas a la materia forestal y del ambiente en general. Los desafíos identificados en el contenido del documento tienen una lógica y sencillez que hace pensar que la solución a la problemática forestal probablemente no sea tan compleja.

No obstante, la implementación de las medidas mencionadas en la sección 5.5 requiere un compromiso político con un sector forestal que históricamente ha sido relegado e incomprendido, lo cual en la legislación parece estar superado, pero en la práctica impera la misma situación, posiblemente agravada. Por otra parte, se necesita la inversión de recursos humanos y financieros, que son escasos en el país. La colaboración internacional podría ser más efectiva si se destina a encontrar solución al problema global sin perder esfuerzos en situaciones puntuales que pueden resolver problemas menores sin influir en la solución general. 


\section{POST SCRITUM}

Con la Ley para optimizar la Administración Pública, mejorar los servicios a la ciudadanía y fortalecimiento de la transparencia en el Gobierno (Decreto 266-2013, publicado el 23 de enero de 2014) diversos contenidos de esta publicación serán objeto de modificación, agregados o suprimidos.

La atribución que en este decreto se da al Presidente de la República para crear, modificar o suspender secretarías de Estado o de los organismos o entidades desconcentrados, en Consejo de Ministros, augura una modificación significativa a la actual estructura administrativa del Estado, que deberá tomarse en consideración para la lectura de la presente obra.

Lo anterior es válido para algunas instituciones públicas que se mencionan en este documento, tal como los casos del Instituto de Conservación y Desarrollo Forestal (ICF), que de una entidad desconcentrada, adscrita a la Presidencia de la República, pasa a ser una Dirección General de la Secretaría de Energía, Recursos Naturales y Ambiente y de la Secretaría de Industria y Comercio (SIC) que se modificó a Secretaría de Desarrollo Económico. 


\section{Bibliografía}

Anuario Estadístico Forestal (2007-2010, 2011).

Chinchilla Guerra, M. (2006). Memoria anual de abogados ambientalistas. México, D.F.

COLPROFORH (2013). Petición al Consejo de Ministros para reconsiderar acto administrativo que entrega bosques a las Fuerzas Armadas.

Departamento de Auditoría Técnica (2011). Metodología para el control de transporte de productos y subproductos forestales.

FAO, Banco Mundial (2012). Evaluación del impacto del cobro por derechos de aprovechamiento de "madera en pie" y otras tasas sobre el manejo forestal.

FEHCAFOR, REMBLAH, ODI-DFID, Banco Mundial, ACDI (2012). La producción forestal no controlada en Honduras. Elaborado por Filippo del Gatto.

GIZ, CCAD, SERNA, ICF (2012). Diagnóstico legal REDD+ en Honduras 2012.

GIZ, CCAD, SERNA, ICF (2011). Identificación preliminar de las causas de deforestación y degradación forestal en Honduras.

GTZ, ANDI, CCIT, COHEP, FIDE (2010). Manufacturas de madera: Ficha 25/UE.

ICF. (2009). Requisitos técnicos y legales para elaborar planes de manejo y planes operativos anuales.

INA. Informe de logros del Instituto Nacional Agrario 2010-2013.

Navarro, Sánchez, Del Gatto (2013). Análisis del comercio transfronterizo de productos forestales en Centroamérica.

Normas técnicas y reglamentarias para la elaboración de Planes de Manejo 2010.

OIRSA/SENASA (2011). Política en medidas sanitarias y fitosanitarias de Honduras.

SAG/SERNA/ICF (2011). Aplicación de la Convención CITES en Honduras. 


\section{Nicaragua}

Marianela Rocha Zúniga 


\section{Acrónimos}

AMUNIC: $\quad$ Asociación de Municipios de Nicaragua

BECO: $\quad$ Batallón Ecológico del Ejército de Nicaragua

CAS: $\quad$ Cooperativas Agrícolas Sandinistas

CEJUDHCAN: Centro por la Justicia y los Derechos Humanos de la Costa Atlántica de Nicaragua

CETREX: Centro de Trámites de Exportaciones

CIDH: $\quad$ Corte Interamericana de Derechos Humanos

CIERA: $\quad$ Centro de Investigación y Estudio de la Reforma Agraria

CITES: $\quad$ Convención sobre Comercio Internacional de Especies Amenazadas de Flora y Fauna Silvestre

CONAFOR: Comisión Nacional Forestal

CGR: $\quad$ Contraloría General de la República

CSJ: $\quad$ Corte Suprema de Justicia

DGA: Dirección General de Aduana

DGI: $\quad$ Dirección General de Ingresos

EIA: $\quad$ Estudio de Impacto Ambiental

ENDE: $\quad$ Estrategia Nacional de Deforestación Evitada

EPA: $\quad$ Environmental Protection Agency

ERA: Estrategia Agroalimentaria

FONADEFO: Fondo Nacional de Desarrollo Forestal

GIZ: $\quad$ Agencia Alemana para el Desarrollo Sostenible

GOFOs: Comités de Gobernanza Forestal

GPC: $\quad$ Gabinetes de Participación Ciudadana

GRAAN: Gobierno de la Región Autónoma del Atlántico Norte

GRAAS: Gobierno de la Región Autónoma del Atlántico Sur

INAFOR: Instituto Nacional Forestal

INTUR: Instituto Nicaragüense de Turismo

MAG: $\quad$ Ministerio Agropecuario.

MARENA: Ministerio del Ambiente y los Recursos Naturales

MIFIC: $\quad$ Ministerio de Fomento, Industria y Comercio

MINEM: $\quad$ Ministerio de Energía y Minas

NHLA: National Hardwood Lumber Association

OAIP: $\quad$ Oficina de Acceso a la Información Pública-MARENA

PAF-NIC: $\quad$ Plan de Acción Forestal de Nicaragua

PDFN: $\quad$ Plan de Desarrollo Forestal de la República de Nicaragua

PERFOR: Programa Estratégico Regional para el Manejo de los Ecosistemas Forestales

PMF: $\quad$ Plan General de Manejo Forestal

POA: $\quad$ Plan Operativo Anual 
PNF: $\quad$ Programa Nacional Forestal

REDD: $\quad$ Reducción de Emisiones Vía Deforestación y Degradación de Bosques

RPP/ENDE: Fase preparatoria de REDD+ bajo los esfuerzos nacionales para reducir la Deforestación y Degradación Forestal

RUC: $\quad$ Registro Único de Contribuyente

SINAP: $\quad$ Sistema Nacional de Áreas Protegidas

SNAF: $\quad$ Sistema Nacional de Administración Forestal

SINAPRED: Sistema Nacional de Prevención, Mitigación y Atención de Desastres

UNAG: Unión Nacional de Agricultores y Ganaderos 


\section{Introducción}

Nicaragua cuenta con un gran potencial forestal considerando las más de 8 millones de hectáreas con vocación forestal que posee, lo que significa más de $65 \%$ del territorio nacional. La cubierta boscosa actual es de aproximadamente 5,5 millones de hectáreas, que no se ha podido maximizar por la falta de un plan estratégico articulado a nivel nacional que promueva un desarrollo forestal sustentable. Los bosques no se aprovechan, sino que están siendo explotados irracionalmente ya sea con fines industriales o energéticos, o de conversión de uso del suelo, lo que eleva la tasa anual de deforestación hasta las 100.000 hectáreas 1 .

El aprovechamiento forestal por parte de las empresas forestales y dueños de bosques se acompaña a su vez de la dependencia que tienen las clases sociales más necesitadas de Nicaragua, quienes de ahí obtienen en primer lugar la fuente energética para la cocción de los alimentos², madera para la construcción de sus viviendas, así como para siembra de alimentos. Esta situación contribuye a la constante deforestación en el territorio, decreciendo la superficie de bosques.

Para algunos dueños de bosque este recurso continúa siendo un obstáculo en sus planes de expansión agrícola; de tal forma que la principal amenaza para el recurso forestal sigue siendo la deforestación motivada para siembra de cultivos agrícolas y la ganadería.

Actualmente existe un programa impulsado por el Gobierno denominado "Cruzada Nacional de Reforestación", en el que participa la empresa privada y Organismos No Gubernamentales interesados en la recuperación de las áreas degradadas, debido al avance de la frontera agrícola y las altas tasas de deforestación. Durante el período 2007-2011 el Estado reforestó 82.559,54 hectáreas ${ }^{3}$.

En el presente análisis encontraremos información sobre la situación forestal en Nicaragua, cómo se está manejando y desarrollando, basado en las normas y conceptos jurídicos establecidos para el desarrollo y manejo de la actividad forestal sostenible, procedimientos y requisitos para su aprovechamiento, mecanismos de participación ciudadana, así como los principales retos que desde la perspectiva legal existen para reducir la ilegalidad en el aprovechamiento forestal, promoviendo además un clima de negocios eficaz y eficiente que favorezca a las comunidades y la conservación de los recursos naturales.

El trabajo también se fundamenta en el intercambio con diversos interlocutores sectoriales privados, gobiernos y datos estadísticos.

1. Ministerio Agropecuario Forestal (MAGFOR), Proyecto Forestal de Nicaragua (PROFOR), Banco Mundial (BM) (2005). Propuesta de Estrategia de Fomento Forestal. $1^{\text {a }}$ edición, Managua, Nicaragua, Pág. 1. El Censo Forestal 2005-2008 señala que la cobertura forestal de Nicaragua supera los 7 millones de hectáreas.

2. "En $60 \%$ de hogares nicas cocinan con leña". En el país, a nivel del casco urbano y rural, unas 800.000 familias utilizan el recurso, es decir, unos 3,2 millones de personas, explicó el Director Ejecutivo del Instituto Nacional Forestal, William Schwartz. Vidaurre, A. y EFE. 'En 60\% de hogares nicas cocinan con leña'. El Nuevo Diario.com.ni [periódico online], (30 de agosto de 2013). <http://www.elnuevodiario.com.ni/ nacionales/295576-60-de-hogares-nicas-cocinan-lena>. Accedido el 31 de marzo de 2014.

3. Instituto Nacional Forestal. [sitio web]. <http://www.inafor.gob.ni>. Accedido el 31 de marzo de 2014. 


\section{Síntesis histórica de la formulación de la Ley Forestal y afines ${ }^{4}$}

Los antecedentes de la legislación forestal en Nicaragua podemos situarlos en el año 1905, año en que se dictó la Ley sobre Conservación de Bosques, la cual establecía disposiciones para "impedir la tala irregular o exagerada de los bosques y de la vegetación que protege la fertilidad del suelo, pues es un hecho comprobado que una de las causas determinantes de la desecación de las fuentes, de la falta de lluvias y de la aridez consiguiente de los campos y de las vías públicas, es el descuajamiento de los montes, que es preciso evitar"'.

A la norma anteriormente citada le siguieron:

- Ley Agraria que establece disposiciones para el corte y aprovechamiento de madera (1917).

- Decreto que establece requisitos para el comercio de la madera de construcción (1929).

- Decreto 314-A, Compensación por Resiembra, por medio del cual se le cobraba el valor de la reposición del recurso forestal a las empresas que fueron beneficiadas por Concesiones Madereras, que no podían o no querían hacer ordenación del bosque o reforestación de predios. El Estado se dispuso a realizar el trabajo de reforestación y por tal motivo, cobraba este incentivo (1937).

- Decreto 105 que establece las tasas de aprovechamiento e impuestos por exportación de madera, así como sanciones por su corte ilegal (1948).

- Ley 235, Ley de Emergencia sobre Aprovechamiento Racional de los Bosques, donde el Estado define de interés público el aprovechamiento racional y conservación de los recursos forestales. Esta ley contenía regulaciones restrictivas y prohibitivas que no podían ponerse en práctica, ya que, por otra parte, el Estado fomentaba por otras vías la conversión de los bosques en tierras agrícolas (1976).

- Decreto 1381, Ley de Conservación, Protección y Desarrollo de las Riquezas Forestales del País (1976).

En la década de los años ochenta hubo modificaciones en la política forestal. Se nacionalizaron las empresas madereras, pero los conflictos armados en las zonas forestales frenaron las actividades madereras. En 1992 se formuló el Plan de Acción Forestal de Nicaragua (PAF-NIC), que recogió las recomendaciones del Plan de Desarrollo Forestal de la República de Nicaragua (PDFN) de 1983, oficializado por el Acuerdo Presidencial 246-92, Apoyo a la Estrategia de Conservación para el Desarrollo Sostenible, Ordenamiento Ambiental del Territorio y Plan de Acción Forestal.

4. Los antecedes legales e institucionales de la administración forestal en Nicaragua fueron tomados de Ortega Blando, V.M. (1966). 'Legislación Forestal en Nicaragua. Críticas y Sugerencias'. Tesis. Managua: Escuela Nacional de Agricultura y Ganadería, y del Resumen del Estado Actual del Manejo y Ordenación Forestal en Nicaragua. FAO. 'Estado y tendencias de la ordenación forestal en 17 países de América Latina'. [sitio web]. <http://www.fao.org/docrep/008/j2628s/j2628s14.htm>. Accedido el 31 de marzo de 2014.

5. Parte considerativa de la Ley sobre Conservación de Bosques, 21 de junio de 1905. 
En el año 1993 se dictó el Decreto 45-93, Reglamento Forestal que fue sustituido en el año 2003 por la Ley 462, Ley de Conservación, Fomento y Desarrollo Sostenible del Sector Forestal6.

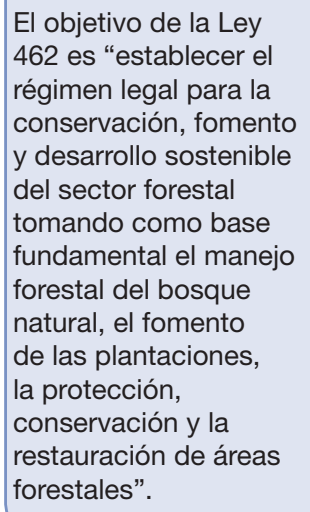

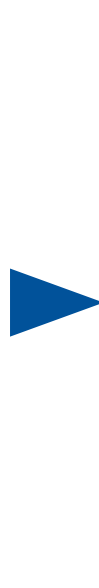

Crea el Sistema

Nacional de

Administración

Forestal (SNAF), el cual estará integrado por las entidades del sector público y por personas naturales o jurídicas involucradas en la actividad forestal. Estas personas deberán ser acreditadas y registradas por el INAFOR (Art. 3).

\section{Fuente propia}

La Ley 462 se debe articular, principalmente, con las siguientes normas jurídicas: Ley 864, Ley de Reforma a la Ley 290, Ley de Organización, Competencia y Procedimientos del Poder Ejecutivo, Ley 217, Ley General del Medio Ambiente y Recursos Naturales, reformada por la Ley 647 del 2008 y sus Reglamentos, de la Ley 40 y 261, Reformas e Incorporaciones a la Ley 40, Ley de Municipios y sus reformas, de la Ley 28, Estatuto de Autonomía de las Regiones de la Costa Atlántica, de la Ley 445, Ley del Régimen de Propiedad Comunal de los Pueblos Indígenas y Comunidades Étnicas de las Regiones Autónomas de la Costa Atlántica de Nicaragua y de los ríos Bocay, Coco, Indio y Maíz y otras normas de nuestro ordenamiento jurídico que se detallan en el anexo 1 del presente informe.

\subsection{Formas de participación pública contenidas en políticas, leyes forestales y afines, nivel de implementación y procesos necesarios para su efectividad}

El Inventario Forestal 2007-2008 señala que las áreas fuera de bosque (con árboles) representan una mayor superficie que las áreas de bosque, lo que en alguna medida refleja el cambio de uso del suelo, respecto a su potencial y al proceso de degradación del bosque en el país, ya que las tierras forestales han sido sustituidas por otros usos de la tierra?

6. Por medio de la Ley 462 se derogan las siguientes leyes: Ley de Conservación de Bosques, del 21 de junio de 1905; Ley de Emergencia sobre Aprovechamiento Racional de los Bosques, del 3 de marzo de 1976; Ley de Conservación, Protección y Desarrollo de las Riquezas Forestales del País, Decreto Número 1381, del 27 de septiembre de 1976; Ley № 222 Ley de Suspensión de la Tramitación de Solicitudes de Otorgamiento de Concesiones y Contratos de Exploración y Explotación de los Recursos Naturales, del 11 de junio de 1996 y cualquier otra disposición legal que de manera tácita o expresa se le oponga.

7. La información que se presenta sobre estas superficies fue estimada tomando como base una superficie continental del país de $130.000 \mathrm{~km}^{2}$. 
Superficie con presencia de árboles, en bosques y fuera del bosque ${ }^{8}$

\begin{tabular}{|l|r|c|}
\hline \multicolumn{1}{|c|}{ Tipo de superficie } & \multicolumn{1}{c|}{ Área en ha } & \multicolumn{1}{c|}{ Porcentaje (\%) } \\
\hline Bosque & 3.254 .145 & \multicolumn{1}{c|}{43} \\
\hline Bosque natural & 3.180 .466 & \\
\hline Plantaciones & 73.679 & \\
\hline Áreas fuera de bosques (con árboles) & 4.318 .344 & \multicolumn{1}{|c|}{57} \\
\hline Tierra con árboles o arbustos naturales & 2.219 .217 & \\
\hline Otras tierras agroforestales & 2.099 .127 & \\
\hline Total & 7.572 .489 & 100 \\
\hline
\end{tabular}

Este hallazgo resalta el interés de fortalecer los espacios de participación ciudadana en la gestión y conservación de las 7.572 .489 hectáreas de los recursos forestales del país. Nicaragua cuenta con leyes que permiten dicha participación de una manera activa en la toma de decisiones. Existen instrumentos de gestión ambiental que -implementados por ciudadanos- contribuyen a la conservación y aprovechamiento de los recursos naturales, como el manejo sostenible, las plantaciones forestales y las Reservas Silvestres Privadas.

La Constitución Política de la República en su artículo 7 establece que "Nicaragua es una República democrática, participativa y representativa..." y en su artículo 50 señala que "Los ciudadanos tienen derecho de participar en igualdad de condiciones en los asuntos públicos y en la gestión estatal. Por medio de la ley se garantizará, nacional y localmente, la participación efectiva del pueblo".

Antes de comentar la ley que garantiza la participación efectiva de los ciudadanos, como señala la Constitución, es importante destacar una aproximación a lo que entendemos por democracia participativa. De acuerdo con el Dr. Joan Vintró Castell, la democracia participativa es aquel conjunto de prácticas democráticas que permiten a los ciudadanos, individualmente o a través de asociaciones, intervenir, de manera estable y autónoma, en los procedimientos de actuación de las instituciones públicas con capacidad de iniciativa y de presencia activa en la preparación y adopción de la decisión final y en el seguimiento de la ejecución de esta9.

Según el ámbito conceptual que destaca el Dr. Vintró, en el año 2003 se aprobó la Ley 475, Ley de Participación Ciudadana ${ }^{10}$, la cual tiene por objeto promover el ejercicio pleno de la ciudadanía en el ámbito político, social, económico y cultural, mediante la creación y operación de mecanismos institucionales que permitan una interacción fluida entre el Estado y la sociedad nicaragüense, contribuyendo con ello al fortalecimiento de la libertad y la democracia participativa y representativa establecido en la Constitución Política de la República.

8 Inventario Forestal 2007-2008, Pág. 58.

9. Democracia participativa y renovación democrática. Cátedra Xavier Gorrostiaga, SJ. UCA. Nicaragua, 2012.

10. Publicada en La Gaceta № 241 del 19 de diciembre de 2003. 
Este conjunto de regulaciones se fundamentan en los Artículos 7 y 50 de la Constitución Política de la República, como expresión del reconocimiento de la democracia participativa y representativa, así como el derecho de participar en igualdad de condiciones en los asuntos de la gestión pública del Estado y en los instrumentos internacionales en materia de derechos humanos suscritos y ratificados por Nicaragua, aplicando los principios generales del derecho aceptados universalmente sobre esta materia.

Los instrumentos de participación ciudadana establecidos en el Artículo 2 de la Ley 475 son:

1. La iniciativa ciudadana en general, para el caso de las normas de ámbito nacional, regional autónomo y local.

2. La consulta ciudadana de normas en la fase del dictamen, en el ámbito nacional, regional autónomo, departamental y local.

3. Las instancias consultivas para la formulación, seguimiento y evaluación de las políticas públicas en el ámbito nacional, regional autónomo, departamental y local.

4. Las asociaciones de pobladores y las organizaciones gremiales, sectoriales, sociales, organizaciones de mujeres y jóvenes en el ámbito local.

5. La consulta ciudadana en el ámbito local.

El Artículo 50 de la Ley 475 establece que de conformidad con lo establecido en el Artículo 28, numeral 7 de la Ley 40 y 261 Ley de Municipios, en cada municipio deberá integrarse un Comité de Desarrollo Municipal (CDM) para cooperar en la gestión y planificación del desarrollo económico y social de su respectivo territorio.

A estos instrumentos de participación ciudadana se les puede agregar los derechos de petición y denuncia ciudadana. En particular la Ley 217, Ley General del Ambiente y los Recursos Naturales, que establece en su Artículo 2 que toda persona podrá tener participación ciudadana para promover el inicio de acciones administrativas, civiles o penales en contra de los que infrinjan la presente ley. Es decir, todo ciudadano tiene legitimidad procesal para iniciar acciones por delitos o infracciones contra el ambiente y los recursos naturales.

De manera particular, en el tema forestal el Decreto 69-2008, Política Nacional de Desarrollo Sostenible del Sector Forestal de Nicaragua ${ }^{11}$, propone con un alto nivel de participación ciudadana contribuir a mejorar la calidad de vida de las generaciones actuales y futuras de la población nicaragüense, priorizando las familias de pequeños y medianos productores agropecuarios y forestales, campesinos, trabajadores del campo, pueblos indígenas, afrodescendientes y comunidades étnicas.

Entre los Principios Rectores de la Política Nacional de Desarrollo Sostenible del Sector Forestal de Nicaragua se encuentra la participación ciudadana como eje transversal que promueve la integración e incidencia de los nicaragüenses en los procesos de formulación, implementación, armonización y evaluación de los marcos de políticas, jurídicos, programas y proyectos agropecuarios y forestales, articulando los mecanismos de concertación de los consejos comunitarios y otras instancias de participación social del sector.

11. Publicado en La Gaceta, Diario Oficial N ${ }^{\circ} 3$ del 7 de enero de 2009. 
Por su parte, la Ley 462 en sus considerandos determina que el sector forestal en Nicaragua debe constituirse en un eje del desarrollo económico y social del país con la participación de todos los involucrados en la ejecución de la actividad forestal y que el fomento forestal se realizará en coordinación con otras entidades del sector público relacionadas y con la participación del sector privado.

El Reglamento de la Ley 462 estipula que la Comisión Nacional Forestal (CONAFOR) tendrá -entre otras funciones- impulsar el desarrollo de foros nacionales, regionales o locales para plantear las problemáticas forestales que se sucedan en los territorios y en el país, y conocer sobre el planteamiento de posibles soluciones desde las localidades o de la sociedad civil.

Cabe mencionar que en el año 2007 se dictó el Decreto 112-2007 de Creación de los Consejos y Gabinete del Poder Ciudadano (CPC) ${ }^{12}$. Los Consejos del Poder Ciudadano son organizaciones comunitarias creadas por el gobierno con el propósito de incentivar y profundizar la participación ciudadana en la toma de decisiones en sus comunidades. Los ciudadanos participan en la elaboración de propuestas en los programas del gobierno. Estos Consejos tienen cobertura en áreas urbanas y rurales del país; de esta manera, todos los ciudadanos ejercen el derecho de participar e involucrarse en temas de su interés, relacionados con los derechos de las mujeres, niños, adultos mayores, educación, medio ambiente y salud, entre otros. En cada comunidad se nombra un coordinador general y un coordinador de área temática ${ }^{13}$.

Este decreto crea el Gabinete Nacional del Poder Ciudadano, integrado por los Consejos de Poder Ciudadano a través de un representante de cada uno de los dieciséis sectores establecidos en el artículo anterior de cada uno de los quince departamentos y dos Regiones Autónomas existentes en el país; es decir, este Gabinete Nacional compuesto por 272 personas estará integrado por dieciséis personas de cada uno de los quinces departamentos y las dos Regiones Autónomas del país, en representación de cada uno de los dieciséis sectores, más el Presidente de la República - que lo presidirá- y la Coordinadora de la Secretaría de Comunicación y Ciudadanía del Gobierno de la República, los Ministros de Estado, Presidentes de entes autónomos y gubernamentales, autoridades de la Policía Nacional, la Junta de Directores del CONPES ${ }^{14}$ y demás funcionarios gubernamentales que determine el Presidente de la República. También podrán formar parte de este Gabinete representantes de los distintos sectores económicos y sociales del país que soliciten su participación y esta sea aprobada.

12. Publicado en la Gaceta, Diario Oficial № 230 del 29 noviembre de 2007.

13. Los Consejos y Gabinetes del Poder Ciudadano tienen presencia en las comunidades, comarcas, barrios, distritos, municipios, departamentos, regiones autónomas y a nivel nacional, debiendo existir en cada una de ellos: Coordinadores de Promoción de Derechos de Ciudadanía (capacitación), Comunicación y Propaganda, Seguridad Ciudadana, Intercambios Comunitarios y Solidaridad, Derechos de la Mujer, Derechos de Jóvenes y Niños, Derechos de Adultos Mayores, Salud, Educación, Medio Ambiente, Transporte e Infraestructura, Desarrollo Rural, Cultura, Deporte, de Propuestas hacia los Gobiernos Locales, de Programas y Proyectos de Promoción de Empleo, Auto-Empleo y Trabajo Comunitario, Coordinador General y todos aquellos otros que ellos mismos decidan.

14. El Artículo 150 inciso 13 de la Constitución Política de Nicaragua, entre otras atribuciones presidenciales, establece que el Presidente de la República creará un Consejo Nacional de Planificación Económica Social (CONPES) que le sirva de apoyo para dirigir la política económica y social del país. En el Consejo estarán representadas las organizaciones empresariales, laborales, cooperativas, comunitarias y otras que determine el Presidente de la República. Este consejo funcionó hasta el año 2007, año en que asumió Daniel Ortega como Presidente de la República. 
Aunque la Constitución por medio de la creación del CONPES, de la Ley 475 y de otros principios constitucionales propone un modelo de participación acorde con el concepto de democracia participativa que permite a los ciudadanos, individualmente o a través de asociaciones, intervenir de manera estable y autónoma, en la práctica ha sido sustituido por los nuevos conceptos de participación que ha implantado el gobierno actual por medio del Decreto 112-2007, convirtiéndose estos en los únicos interlocutores con los actores gubernamentales.

Por lo pronto, se debe destacar que los CPC, hoy convertidos en Gabinetes de Familia, Comunidad y Vida, tienen una labor gubernamental en el tema forestal ${ }^{15}$. INAFOR, en representación de la Política Administrativa para el uso de los Recursos Naturales y Manejo Forestal, dice que luego de recibida la solicitud del permiso debe comunicarse por escrito al alcalde $\mathrm{o}$ alcaldesa, o a quienes ellos deleguen, Ejército de Nicaragua, Policía Nacional, MARENA, representante del Gabinete de la Familia Comunidad y Vida, y a las Autoridades Autónomas Regionales de la Costa Caribe.

El municipalista Silvio Prado considera que el diseño de los CPC no facilita un mecanismo plural de participación ciudadana en libertad ${ }^{16}$.

\subsection{Institucionalidad forestal y competencias en torno al aprovechamiento forestal y comercio internacional de productos forestales}

La Ley 462 crea el Sistema Nacional de Administración Forestal (SNAF), el cual está integrado por las entidades del sector público y personas naturales o jurídicas involucradas en la actividad forestal. Estas personas deberán ser acreditadas y registradas por el Instituto Nacional Forestal (INAFOR).

Las entidades del sector público que conforman el Sistema Nacional de Administración Forestal serán las que por competencias y funciones lo tengan establecido en la Ley 290, Ley de Organización, Competencia y Procedimientos del Poder Ejecutivo y sus reformas, en la Ley 28, Estatuto de la Autonomía de las Regiones de la Costa Atlántica de Nicaragua y la Ley 40 y 261, Reformas e Incorporaciones a la Ley $N^{\circ} 40$ Ley de Municipios y sus reformas.

\section{Competencias por institución}

\section{Instituto Nacional Forestal (INAFOR)}

La Ley 864, Ley de Reforma a la Ley N²90, Ley de Organización, Competencias y Procedimientos del Poder Ejecutivo ${ }^{17}$ establece en su Artículo 14 que el Instituto Nacional Forestal (INAFOR) es un ente descentralizado que estará bajo la Rectoría Sectorial de la Presidencia de la República.

La Administración Forestal en todo el territorio nacional es la que ejecutará a través del instituto Nacional Forestal INAFOR ${ }^{18}$. La Ley 864 le transfiere al Instituto Nacional Forestal (INAFOR) las

15. INAFOR (2013). Ruta de Operativización de la Política Administrativa para el Uso de los Recursos Naturales y Manejo Forestal.

16. Prado, S. (2008). Entre los CDM y los CPC. Centro de Estudios y Análisis Político. Managua.

17. Publicada en La Gaceta, Diario Oficial $N^{\circ} 91$ del 20 de mayo de 2014.

18. La Ley 864 en su artículo 58 establece la siguiente reorganización de competencias: En el ámbito de 
facultades, competencias y recursos otorgados de la administración forestal estatal (AdForest) del Ministerio Agropecuario.

Al INAFOR le corresponden las funciones siguientes ${ }^{19}$ :

a. Vigilar el aprovechamiento sostenible de los recursos forestales de la nación, ejerciendo facultades de inspección, disponiendo las medidas, correcciones y sanciones pertinentes de conformidad con esta Ley y su Reglamento.

b. Ejecutar en lo que le corresponda la política de desarrollo forestal de Nicaragua.

c. Aprobar los Permisos de Aprovechamiento y conocer, evaluar y fiscalizar los planes de manejo forestal.

d. Proponer las normas técnicas obligatorias para el manejo forestal diversificado, para su debida aprobación de conformidad con la ley de la materia.

e. Suscribir convenios con los gobiernos municipales u organismos públicos o privados delegando funciones de vigilancia y control o fomento trasladando los recursos necesarios en el caso de que el convenio se establezca con un gobierno municipal.

f. Coadyuvar con las instancias sanitarias la realización de todas las acciones necesarias para la prevención y combate de plagas y enfermedades, y vigilar el cumplimiento de las normas sanitarias relativas a las especies forestales.

g. Ejecutar las medidas necesarias para prevenir, mitigar y combatir incendios forestales.

h. Establecer las coordinaciones con el MARENA para el establecimiento o levantamiento, en su caso, de vedas forestales y ejercer su control.

i. Generar información estadística del sector forestal.

j. Administrar el Registro Nacional Forestal y llevar el inventario nacional de los recursos forestales.

k. Expedir el aval correspondiente para el goce de los incentivos establecidos en la presente ley.

I. Facilitar la certificación forestal nacional e internacional.

m. Promover y ejecutar con los gobiernos locales y la sociedad civil programas de fomento forestal y especialmente aquellos encaminados a la reforestación de zonas degradadas.

n. Disponer la realización de auditorías forestales externas, conocer sus resultados y resolver lo que corresponda.

o. Conocer de los recursos que correspondan dentro del procedimiento administrativo.

p. Acreditar a los Regentes y Técnicos Forestales Municipales.

competencia de la Presidencia de la República: 1. Le corresponde a la Presidencia de la República, la administración Forestal en todo el territorio nacional, la que ejecutara a través del instituto Nacional Forestal INAFOR en calidad de ente de gobierno descentralizado, con autonomía funcional técnica y administrativa, patrimonio propio y con capacidad en materia de su competencia. El INAFOR estará bajo la rectoría sectorial de la Presidencia de la República, el Director y Sub director del Instituto Nacional Forestal, serán nombrados por el Presidente de la República.

19. Artículo 7 de la Ley 462. 
También le corresponde, según nuestra interpretación del Artículo 58 de la Ley 864, formular la política y normas forestales, supervisar los programas de fomento forestal, informar sobre el sector forestal y definir los precios de referencia del sector ${ }^{20}$.

EI INAFOR desarrolla sus actividades a través de distritos forestales desconcentrados, de los cuales deberán al menos participar representantes de las siguientes instituciones: Alcaldías, Consejos Regionales, Universidades donde existan, Policía Nacional, Ejército Nacional, Ministerio de Educación, MARENA y Representantes de Asociaciones Forestales. Todas las actividades mencionadas en los incisos anteriores deberán ser coordinadas con las autoridades municipales.

Para ejercer estas funciones a nivel nacional, INAFOR se estructuró en diez distritos forestales. El Distrito Forestal es una instancia organizativa-funcional y técnico-operativa, que permite una efectiva gestión del INAFOR en el territorio, en el cual se trasladan responsabilidades y capacidades para la implementación del proceso de desconcentración, procurando la optimización de los recursos humanos, financieros y materiales, así como la participación activa de los actores locales y dar cumplimiento al mandato y prioridades institucionales. Es el responsable de la aplicación de las normas técnicas, de la política forestal y de la coordinación interinstitucional. También se delegará en él el adecuado y oportuno control de la actividad forestal, así como la toma de decisiones y acciones fundamentales para la orientación de prioridades en el desarrollo del sector forestal ${ }^{21}$.

El seguimiento, vigilancia y control de las actividades forestales estará a cargo del INAFOR, quien podrá ejercerla a través de los Regentes Forestales ${ }^{22}$, Auditores Forestales ${ }^{23}$ y Técnicos Forestales Municipales debidamente acreditados ${ }^{24}$.

\section{Ministerio de Ambiente y Recursos Naturales (MARENA)}

EI MARENA es la autoridad nacional competente en materia de regulación, normación, monitoreo control de la calidad ambiental, del uso sostenible de los recursos naturales renovables y el manejo ambiental de los no renovables, conforme lo dispuesto en la Ley 217, Ley General del Medio Ambiente y los Recursos Naturales, y demás leyes vigentes. El MARENA es además la institución competente para sancionar administrativamente por el incumplimiento de las normas ambientales. Estas atribuciones las ejercerá en coordinación con otros organismos estatales y las autoridades regionales y municipales pertinentes ${ }^{25}$.

20 La Ley 462 en su Artículo 6 le otorgaba esta función al Ministerio Agropecuario y Forestal.

21. INAFOR. [sitio web]. <http://www.inafor.gob.ni/index.php?option=com_content\&view=article\&id=15\&lte mid=59>. Accedido el 31 de marzo de 2014.

22. Regente Forestal: El Profesional o Técnico Forestal acreditado por el INAFOR para que -de conformidad con las leyes y reglamentos- garantice la ejecución del Plan de Manejo Forestal aprobado por la autoridad correspondiente en una unidad de producción. El Regente Forestal es contratado directamente por la persona o empresa responsable de los manejos.

23. Auditor Forestal: El Profesional o Técnico Forestal o la empresa especializada, independiente, acreditado por el INAFOR para evaluar la ejecución de los Planes de Manejo Forestal y permisos de aprovechamiento.

24. Artículos 14 y 9 de la Ley 462.

25. Artículo 3 del Decreto 9-96, Reglamento de la Ley 217, Ley General del Medio Ambiente y de los Recursos Naturales. Publicado en La Gaceta, Diario Oficial № 163 del 29 de agosto de 1996. 
En materia de recursos naturales ejerce las siguientes funciones ${ }^{26}$ :

a. Formular, proponer y dirigir la normación y regulación del uso sostenible de los recursos naturales y el monitoreo, control de calidad y uso adecuado de estos.

b. Coordinar con el Ministerio Agropecuario la planificación sectorial y las políticas de uso sostenible de los suelos agrícolas, ganaderos y forestales en todo el territorio nacional.

EI MARENA administra el sistema de áreas protegidas del país, con sus respectivas zonas de amortiguamiento. El Artículo 7 de la Ley $647^{27}$ que reforma el Art. 17 de la Ley $N^{\circ} 217$ establece que la protección de los recursos naturales del país es objeto de seguridad nacional, así como de la más elevada responsabilidad y prioridad del Estado. Dentro de ese espíritu, en las áreas protegidas se establece veda para el recurso forestal total y permanente.

En las zonas de amortiguamiento de la Reserva de la Biósfera de Bosawás, las Áreas Protegidas del Sureste y la Reserva Natural Cerro Wawashang, así como en las futuras que se acuerden, se establece un área perimetral externa de diez kilómetros medidos a partir del límite del área protegida que la constituye, en el que únicamente se permitirá el aprovechamiento forestal con fines domésticos no comerciales y para uso exclusivo en el área ${ }^{28}$.

La conservación, restauración y aprovechamiento sostenible de bosques de manglares es responsabilidad del MARENA de conformidad con lo establecido en la Ley 217 y el Artículo 20 de la Ley 462. Este ministerio es la autoridad encargada de designar la Autoridad Administrativa y las Autoridades Científicas de CITES de acuerdo con los requisitos y procedimientos que establezcan las disposiciones de la Convención CITES y la ley especial de la materia ${ }^{29}$.

\section{Ministerio Agropecuario (MAG)}

Al Ministerio Agropecuario le corresponden las funciones siguientes ${ }^{30}$ :

a) Formular políticas, planes y estrategias de desarrollo agropecuario.

b) Identificar y priorizar la demanda de crédito y asistencia tecnológica de las actividades agropecuarias.

c) Formular y proponer la política de distribución, propiedad y uso de las tierras rurales del Estado.

d) Formular propuestas y coordinar con el Ministerio del Ambiente y de los Recursos Naturales y la Autoridad Nacional del Agua, los programas de protección del sistema ecológico, con énfasis en la conservación de suelos y aguas.

e) Formular y proponer la Delimitación de las zonas, áreas y límites de desarrollo agropecuario.

26. Artículo 28 incisos d y e de la Ley 290, Ley de Organización, Competencia y Procedimiento del Poder Ejecutivo.

27. Ley 647, Ley de reformas y adiciones a la Ley 217, Ley General del Medio ambiente y los Recursos Naturales. Publicada en La Gaceta, Diario Oficial № 62 del 3 de abril de 2008.

28. Artículo 24, Ley 647.

29. Artículo 7 del Decreto 8-98, Normas y Procedimientos para la Exportación e Importación de Especies de Flora y Fauna Silvestres de Nicaragua. 


\section{Instituto de Protección y Sanidad Agropecuaria}

Es la institución encargada de emitir los permisos sanitarios y fitosanitarios que sean necesarios para cumplir con las obligaciones contraídas en base a la Ley o en virtud de compromisos adquiridos a nivel internacional ${ }^{31}$.

\section{Gobiernos Municipales}

Los Gobiernos Municipales tienen competencia en todas las materias que incidan en el desarrollo socioeconómico y la conservación del ambiente y los recursos naturales de su circunscripción territorial ${ }^{32}$. En el tema de recursos naturales, el municipio controla el uso racional y contribuye a su monitoreo, vigilancia y control en coordinación con los entes nacionales correspondientes.

Los gobiernos municipales, previa aprobación de sus respectivos Consejos, podrán celebrar Convenios de Delegación de Atribuciones Forestales con el INAFOR para el otorgamiento de permisos de aprovechamiento comercial, seguimiento, vigilancia y control, mediante mecanismos que serán definidos en el Reglamento de la ley33.

\section{Regiones Autónomas de la Costa Atlántica de Nicaragua}

Las Regiones Autónomas son Personas Jurídicas de Derecho Público que siguen en lo que corresponde políticas, planes y orientaciones nacionales. Tienen a través de sus órganos administrativos la atribución de promover el racional uso, goce y disfrute de las aguas, bosques, tierras comunales y la defensa de su sistema ecológico ${ }^{34}$, tomando en consideración los criterios de las comunidades de la Costa Atlántica de Nicaragua y las normas que al respecto establezcan los organismos competentes ${ }^{35}$.

\section{Dirección General de Aduana (DGA)}

Tiene a su cargo la administración de los servicios aduaneros para el control y facilitación del comercio exterior por medio del desarrollo y mejoramiento constante de la técnica aduanera y de los tributos establecidos a favor del Estado que gravan el tráfico internacional de mercancías y las relaciones derivadas de ellos ${ }^{36}$.

\section{Centro de Trámites de Exportaciones (CETREX)}

Es una entidad pública que brinda servicio al sector exportador. Fue creado mediante el Decreto Presidencial 30-94, del 28 de junio de 1994. Se estableció con el objeto de centralizar la ejecución de las funciones específicas de las entidades públicas que atienden los trámites requeridos por exportadores. Está adscrito a la Comisión Nacional de Promoción de Exportaciones.

31. Ley 862, Ley Creadora del Instituto de Protección y Sanidad Agropecuaria. Publicada en La Gaceta, Diario Oficial № 91 del 20 de mayo de 2014.

32. Artículo 6 de la Ley 40 y 261, Reformas e Incorporaciones a la Ley $N^{\circ} 40$ Ley de Municipios y sus reformas.

33. Artículo 10 de la Ley 462.

34. Artículo 8, inciso 4 de la Ley 28, Estatuto de Autonomía de las Regiones de la Costa Atlántica de Nicaragua.

35. Artículos 18 y 19 del Decreto A.N. 3584, Reglamento de la Ley 28.

36. Artículo 4 de la Ley 339, Ley creadora de la Dirección General de Servicios Aduaneros y de Reforma de la Ley creadora de la Dirección General de Ingresos. 


\section{Procuraduría para la Defensa del Ambiente y los Recursos Naturales ${ }^{37}$}

La Procuraduría Ambiental tiene a su cargo la representación del Estado en todas las acciones administrativas, civiles y penales relacionadas con la protección y defensa del medio ambiente y los recursos naturales, todo de conformidad con la Ley General del Medio Ambiente y los Recursos Naturales, su reglamento y demás leyes de la materia.

\section{Unidad Especializada contra los Delitos Ambientales, Ministerio Público ${ }^{38}$}

Es la unidad especializada del Ministerio Público que se encarga de investigar y promover acciones por los Delitos contra el Medio Ambiente y los Recursos Naturales.

\section{Policía Nacional}

Es responsable de la prevención y persecución del delito, y la preservación del orden público. Vela por el respeto y preservación de los bienes propiedad del Estado y de los particulares, y brinda el auxilio necesario al Poder Judicial y a otras autoridades que lo requieran conforme a la ley para el cumplimiento de sus funciones ${ }^{39}$.

\section{Ejército de Nicaragua}

Coadyuva en la conservación y renovación de los recursos naturales, en mejorar el medio ambiente y el equilibrio ecológico y demás planes estratégicos que establezca el Presidente de la República ${ }^{40}$. El Ejército de Nicaragua vigila y controla la zona de restricción de quince kilómetros desde los límites fronterizos hacia el interior del país, donde se prohíbe el aprovechamiento forestal para todas las especies, a excepción del aprovechamiento domiciliar y de plantaciones, establecido en la normativa especial de la materia. El Ejército actúa en coordinación con el Ministerio del Ambiente y de los Recursos Naturales, el Instituto Nacional Forestal (INAFOR) y demás instituciones competentes ${ }^{41}$.

\section{Poder Judicial}

Tiene la facultad de juzgar y ejecutar lo juzgado, así como conocer todos aquellos procedimientos no contenciosos. La función jurisdiccional es única y se ejerce por los juzgados y tribunales previstos en la Ley 260, Ley Orgánica del Poder Judicial.

El Poder Judicial nicaragüense no tiene una jurisdicción especializada para temas ambientales a pesar de que la Fiscalía y la Procuraduría tienen funcionarios especializados en estos temas. Los casos ambientales son conocidos en su mayoría por la jurisdicción constitucional y los juzgados penales.

37. Artículos 23 y 24 del Decreto 24-2002, Reglamento de la Ley Orgánica de la Procuraduría General de la República.

38. Ley 346, Ley Orgánica del Ministerio Público.

39. Ley 228 Ley de la Policía Nacional.

40. Ley 181, Código de Organización, Jurisdicción y Previsión Social Militar.

41. Ley 647, Artículo 18, adiciones al Artículo 100 de la Ley № 217 y Artículo 22 de la Ley 749, Ley de Régimen Jurídico de Fronteras, publicada en La Gaceta, Diario Oficial № 244 del 22 de diciembre de 2010. 


\section{Instancias de coordinación interinstitucional del sector forestal ${ }^{42}$}

\begin{tabular}{|c|c|c|}
\hline Instancia & Integrantes & Competencia \\
\hline $\begin{array}{l}\text { Comisión Nacional } \\
\text { Forestal } \\
\text { (CONAFOR) }\end{array}$ & $\begin{array}{l}\text { - } \text { - Mirector del INAFOR (Secretario Ejecutivo de la Comisión) } \\
\text { - Ministro del MAG } \\
\text { - Ministro del MIFIC } \\
\text { - Ministro de Educación, Cultura y Deportes Representante de } \\
\text { - } \text { Reada uno de los Consejos Regionales Autónomos } \\
\text { - Representante de las empresas forestales } \\
\text { - Representante de las organizaciones de dueños de bosques } \\
\text { - } \text { ambientalistas } \\
\text { - Representante de la Asociación de Municipios. } \\
\text { - Representante de las Asociaciones de Profesionales Forestales } \\
\text { - Representante de INTUR } \\
\text { - } \text { Represente de la Policía Nacional } \\
\text { - Re del Ejército Nacional }\end{array}$ & $\begin{array}{l}\text { Instancia del más alto } \\
\text { nivel y foro para la } \\
\text { concertación social del } \\
\text { sector forestal, la cual } \\
\text { tendrá participación en la } \\
\text { formulación, seguimiento, } \\
\text { control y aprobación de } \\
\text { la política, la estrategia } \\
\text { y demás normativas que } \\
\text { se aprueben en materia } \\
\text { forestal (Artículo 5, Ley } \\
\text { 462). }\end{array}$ \\
\hline $\begin{array}{l}\text { Comisiones } \\
\text { Forestales } \\
\text { Regionales, } \\
\text { Departamentales y } \\
\text { Municipales }\end{array}$ & $\begin{array}{l}\text { 1. Delegado del MAG } \\
\text { 2. Delegado del MARENA } \\
\text { 3. Delgado del MIFIC } \\
\text { 4. Delegado del Ministerio de Educación, Cultura y Deportes } \\
\text { 5. Miembro del Consejo Municipal } \\
\text { 6. Miembro del Consejo Regional, en su caso } \\
\text { 7. Representante de ONG ambientalista } \\
\text { 8. Representante de las asociaciones de forestales } \\
\text { 9. Representante de la Policía Nacional } \\
\text { 10. Representante del Ejército Nacional } \\
\text { 11. Representante de INTUR }\end{array}$ & $\begin{array}{l}\text { Coordinar con la } \\
\text { CONAFOR la ejecución, } \\
\text { seguimiento y control } \\
\text { de las actividades de } \\
\text { conservación, fomento } \\
\text { y desarrollo en sus } \\
\text { respectivos territorios } \\
\text { (Artículo 5, Ley 462). }\end{array}$ \\
\hline
\end{tabular}

EI INAFOR ha logrado institucionalizar las instancias de diálogo y coordinación a nivel nacional y territorial. La Comisión Nacional Forestal es la máxima instancia de concertación del sector y tiene su expresión territorial en las COMUFOR (Comisiones Municipales Forestales). En ambas instancias hay un diálogo permanente buscando el consenso sobre los temas de interés para el desarrollo del sector forestal ${ }^{43}$.

42. Artículo 5 de la Ley 462.

43. Informe Anual MAGFOR, 2011, Pág. VI. 


\subsection{Ley forestal y su consistencia con otras legislaciones referidas al comercio internacional de productos de madera}

El comercio internacional de madera en Nicaragua está regido por las normas nacionales e internacionales que establecen los requisitos para la exportación de madera. En Nicaragua, toda persona natural o jurídica que se dedique a este tipo de exportación debe estar inscrita como exportador en el Centro de Trámite de Exportaciones (CETREX) ${ }^{44}$.

Cabe destacar que la Ley 462 en el Artículo 8, inciso c refiere únicamente al registro de empresas e industrias forestales, pero según la información brindada por el CETREX toda persona natural o jurídica puede ser exportadora ${ }^{45}$.

Entre los diversos requisitos que solicita el CETREX para exportar madera está el Permiso CITES para las maderas protegidas por este convenio o el Certificado de origen CITES para las maderas que no están reguladas por este convenio en Nicaragua, pero sí por otros países parte del convenio, un Recibo Fiscal y/o Constancia de Retención emitida por el aserrío de los impuestos de madera, la Constancia de Certificación Fitosanitaria y/o Certificado de Fumigación, si el país destino lo requiere y la Constancia de Inspección de INAFOR. INAFOR debe acreditar la legalidad del origen de la madera.

44. De conformidad con su Decreto creador, 30-94, el CETREX tendrá las siguientes funciones:

a) Unificar las actividades correspondientes de las dependencias involucradas en el trámite de exportación.

b) Simplificar el proceso exportador, disminuyendo sus costos financieros y humanos para el sector privado.

c) Controlar en general el sistema y generar las estadísticas internas requeridas.

d) Atender solicitudes de información y asesoría relacionadas con el trámite de exportación.

e) Realizar el trámite documentario en forma ágil y oportuna.

f) Establecer oficinas de CETREX en puestos fronterizos o donde el sistema lo requiera, de forma tal que agilice, organice y verifique los procedimientos de exportación en la salida de los productos del país.

g) Verificar y controlar los precios declarados en las exportaciones (Sub-Facturación y SobreFacturación), posterior al proceso de exportación e informar de ello a la Comisión Nacional de Exportaciones y a la Dirección General de Aduanas.

45. Centro de Trámites de las Exportaciones. 'Requisitos de inscripción'. [sitio web]. <http://www.cetrex.gob. ni/website/servicios/inscripcion.jsp>. Accedido el 31 de marzo de 2014. 
De acuerdo con la Resolución Ministerial $004-2007^{46}$ de MARENA que establece "las regulaciones para la exportación de las especies: Caoba, Cedro Real, Pochote y Ceibo en su segunda transformación", los exportadores deben: "Estar registrados como exportador ante la Dirección General de Comercio y Medio Ambiente de MARENA, conforme a las disposiciones contenidas en la Convención CITES y el Decreto 8-98, Normas y Procedimientos para la Exportación e Importación de Especies de Flora y Fauna Silvestre de Nicaragua ${ }^{47}$ y ante el Registro Nacional Forestal de conformidad al Art. 8, inciso c) de la Ley de Conservación, Fomento y Desarrollo Sostenible del Sector Forestal (Ley 462)".

Con el objetivo de fortalecer los mecanismos e instrumentos de control para el otorgamiento de permisos para el comercio de especies incluidas en los apéndices de CITES, el MARENA dictó la Resolución Ministerial 13-04-13: "Establecer el procedimiento administrativo para la obtención del permiso para el comercio internacional de las especies forestales de competencia de MARENA". Esta Resolución aplica para las especies forestales competencia de MARENA, es decir, las incluidas en los apéndices CITES y aquellas que por problemas de similitud de características morfológicas con las especies CITES para las que sea necesaria su regulación.

46. Artículo 5, Requisitos para obtener el permiso de exportación de MARENA. Todo solicitante deberá:

a. Estar registrado como exportador ante la Dirección General de Comercio y Medio Ambiente de MARENA (hoy ante la Dirección General de Patrimonio Natural o Autoridad Administrativa CITES), conforme con las disposiciones contenidas en la Convención CITES y el Decreto 8-98.

b. Presentar una solicitud por escrito ante la Dirección General de Comercio y Medio Ambiente del MARENA, la cual deberá contener:

b.1 Cantidad de volumen a exportar, expresada en metros cúbicos.

b.2 Presentar Constancia de Inspección Técnica para la Exportación de Madera del Instituto Nacional Forestal (INAFOR), que indique claramente la procedencia legal de la madera, señalando que no fue adquirida en contravención con la legislación nacional forestal vigente y que está soportada en un Plan de Manejo respectivo, debiendo anexar la lista de empaque pertinente y las guías forestales (página celeste y su respectiva copia).

b.3 Presentar en original y copia para su debido cotejo de Factura de Venta para Exportación debidamente numerada, orden de trabajo, en su caso y con pie de imprenta fiscal de venta con los requisitos legales pertinentes. No se aceptarán facturas de venta para exportación que no coincidan con el volumen consignado en la Constancia de Inspección Técnica para la Exportación de Madera emitida por INAFOR.

b.4 País destino.

b.5 Puerto de salida en Nicaragua.

b.6 Puerto de entrada del país destino.

47. El Decreto 8-98 ha sido actualizado con el objetivo de incorporar las decisiones tomadas en el marco del Convenio CITES con posterioridad al año en que fue dictado. Incluye la reexportación y actualiza los formatos para el otorgamiento de permisos. El decreto actualizado aún no ha sido aprobado por la Presidencia de la República. 
En el Artículo 3 de esta Resolución se establecen los tipos de maderas reguladas.

\section{Se entenderá para la aplicación efectiva de la presente Resolución} las siguientes especies forestales

\begin{tabular}{|c|c|}
\hline Nombre común & Nombre científico \\
\hline La Caoba & Swietenia macrophylla \\
\hline Cedro Real & Cedrela odorata \\
\hline Granadillo & Dalbergia tucurensis \\
\hline Nambar & Dalbergia retusa \\
\hline Almendro de Montaña & Dipterix panamensis \\
\hline Guayacán & Guaiacum spp \\
\hline Coyote & Platymiscium pinnatum \\
\hline
\end{tabular}

El Artículo 4 de la Resolución 13-04-1348 establece los requisitos para obtener un permiso de exportación CITES. El trámite dura 8 días, salvo que los documentos solicitados no estén completos, para lo cual se dará un plazo de 3 días para completarlos.

Posterior a la publicación de la Resolución 13-04-13, la Resolución Ministerial 004-2007 de MARENA que establece las regulaciones para la exportación de las especies: Caoba, Cedro Real, Pochote y Ceibo fue parcialmente derogada para la caoba y cedro real, y quedaría vigente para el pochote y ceibo. Sin embargo, la experiencia de MARENA en este punto es que -al no estar el pochote y el ceibo en los anexos CITES- no les es requerido a los exportadores el permiso que regula la Resolución 004-2007.

En mayo de 2013 mediante la Resolución 33-2013 de INAFOR, se creó el Sistema de Trazabilidad Forestal en Nicaragua, el cual es una herramienta de control, seguimiento y registro de los productos que se extraen de las áreas de producción forestal hacia su punto de destino. El objetivo de este sistema es contar con un mejor seguimiento de la madera que se extrae de las áreas de producción para disminuir la tala ilegal de árboles.

En cuanto a la protección fitosanitaria, el Instituto de Protección y Sanidad Agropecuaria es el encargado de emitir el certificado fitosanitario, el cual señala el tipo de tratamiento de desinfección realizado, la descripción del envío, nombre y dirección del exportador, nombre y dirección del consignatario, nombre del producto y cantidad declarada, nombre botánico, numero y descripción del envío, marcas de distinción, lugar de origen, puerto de trasporte declarado, puesto de salida, fecha, nombre del funcionario que autoriza, firma y sello.

\subsection{Mecanismos legales y marco jurídico dentro de la estrategia REDD+ nacional}

La ENDE-REDD+ en Nicaragua es una estrategia de país que integra acciones en los niveles nacional, subnacional y local orientadas a revertir las principales causas de la deforestación y degradación de los bosques, considerando la restitución de derechos de los pueblos originarios y del pueblo nicaragüense en general al goce, uso y disfrute de los ecosistemas forestales de forma racional

48. Publicada en La Gaceta, Diario Oficial Nº 236 del 12 diciembre de 2013. 
y sostenida. El objetivo de la propuesta de estrategia ENDE es reducir la tasa de deforestación y degradación forestal, mejorando el valor económico de los bosques y de sus co-beneficios (servicios ecosistémicos) en los ámbitos del Programa Nacional Forestal (PNF), biodiversidad y conservación, de ganadería y agricultura sostenible y de REDD+.

La propuesta ENDE-REDD+ surge en el año 2007 como continuidad de los procesos participativos de gobernanza forestal basados en la política y legislación sectorial como mecanismo para enfrentar de forma efectiva la deforestación y degradación forestal como causa directa del cambio climático ${ }^{49}$. El marco jurídico para la implementación de ENDE-REED+ se enmarca en los artículos constitucionales 60 -que garantiza el derecho al ambiente sano de los nicaragüenses-, 102 (que establece que los recursos naturales son patrimonio nacional, la preservación del ambiente y la conservación, desarrollo y explotación racional de los recursos naturales corresponden al Estado y que este tiene el deber de resguardarlos), 63 -que establece el derecho de los nicaragüenses estar protegidos contra el hambre- y los artículos 5, 89, 90, 180 y 181 relativos a la protección de los pueblos indígenas.

En complemento con los artículos constitucionales descritos, las políticas y legislación ambiental, forestal y de seguridad alimentaria y normas vigentes en el país son la base legal e institucional de la ENDE-REED+. Asimismo, es base fundamental de esta Estrategia el Plan Nacional de Adaptación al Cambio Climático.

49. MARENA, GIZ, CCAD (marzo 2013). Informe sobre sistematización temprana de la experiencia ENDE$R E D D+$ en Nicaragua. Estrategia Nacional para reducir la deforestación y degradación forestal, ENDE$R E D D+$. Facilitador: Dámaso Barquero Gaitán, con la colaboración de Dennis Mairena Arauz. Managua. 


\section{Enfoque Nacional de REED+ ${ }^{50}$}

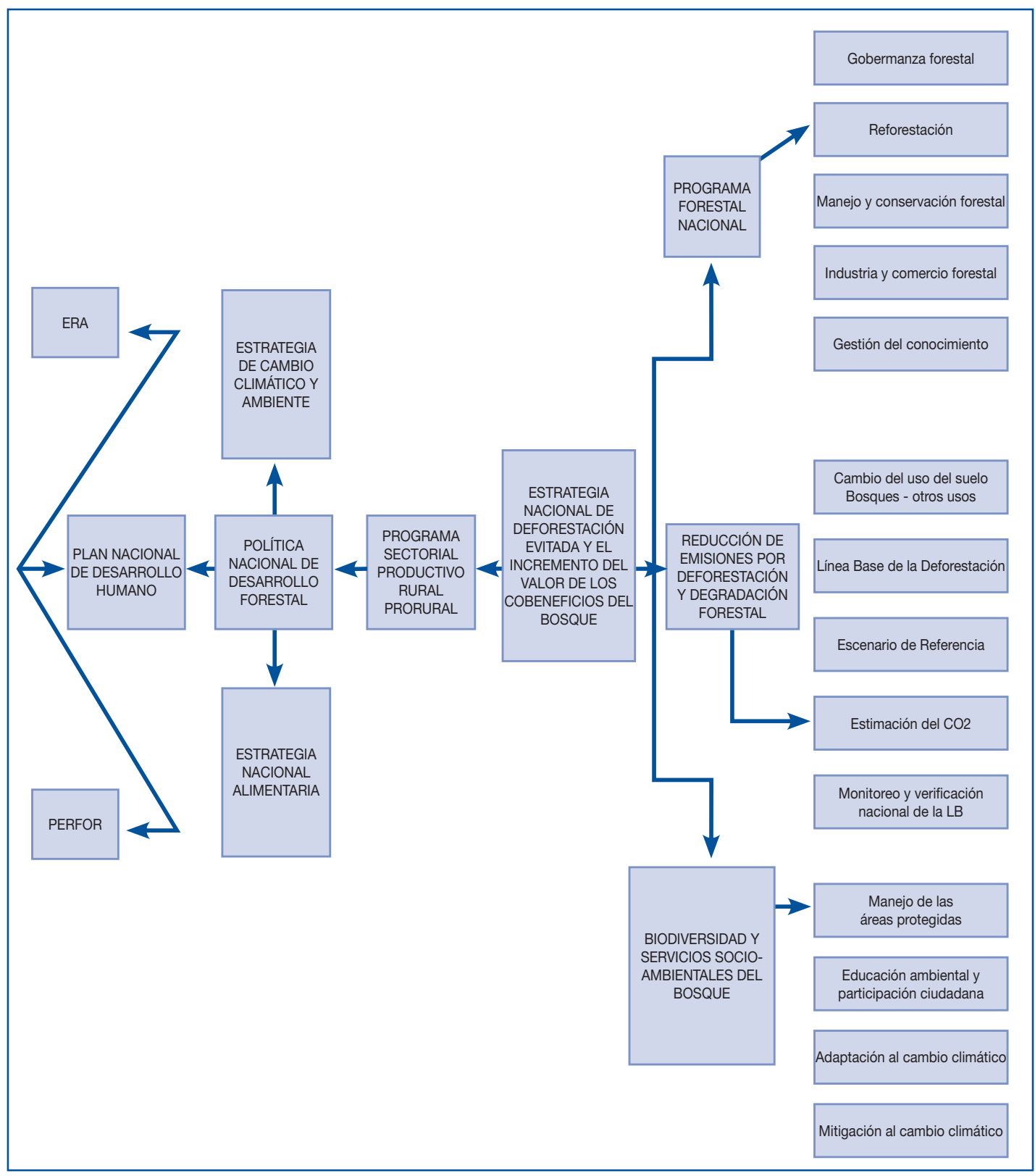

Fuente: Gutierrez J. Taller REDD-CCA-GIZ.

50. Gutiérrez, J. (2011). Taller REDD-CCA-GIZ. Guatemala: MARENA, MAGFOR, INAFOR. 


\section{Descripción de las instancias que conforman los niveles de decisión, participación y concertación de la plataforma ENDE Nicaragua ${ }^{51}$}

\begin{tabular}{|l|l|l|}
\hline Niveles & \multicolumn{1}{|c|}{ Instancias } & \multicolumn{1}{c|}{ Descripción } \\
\hline 1 & $\begin{array}{l}\text { MARENA, INAFOR, INETER, } \\
\text { MAGFOR, GRAAN, GRAAS, } \\
\text { MINEM, SE-SINAPRED, } \\
\text { AMUNIC, representantes de } \\
\text { dueños de bosques, ONG y de } \\
\text { sociedad civil. }\end{array}$ & $\begin{array}{l}\text { Es la instancia de toma de decisión de ENDE/R-PP. } \\
\text { MARENA tiene el punto focal en el proceso END-REDD y } \\
\text { en conjunto con el INAFOR, GRAAN Y GRAAS, los demás } \\
\text { actores tomarán decisiones pertinentes para facilitar el } \\
\text { proceso. }\end{array}$ \\
\hline 2 & $\begin{array}{l}\text { Plataforma institucional } \\
\text { ENDE-REDD+ conformada } \\
\text { por técnicos del MARENA, } \\
\text { INAFOR, MAGFOR, Gobiernos } \\
\text { Regionales y organizaciones de } \\
\text { cooperación técnica relevantes } \\
\text { en el tema, como GTZ, FAO, } \\
\text { PNUD, CATIE. }\end{array}$ & $\begin{array}{l}\text { Esta plataforma será el órgano técnico especializado en el } \\
\text { tema REDD, la cual deberá preparar Términos de Referencia, } \\
\text { revisar y dictaminar técnicamente el ENDE-RPP, dar } \\
\text { seguimiento en el proceso de la estrategia ENDE-REDD+ y } \\
\text { proveer las recomendaciones pertinentes al nivel 1. }\end{array}$ \\
\hline $\begin{array}{l}\text { Comisión Nacional Forestal } \\
\text { (CONAFOR) y Comités de } \\
\text { Gobernanza Forestal (GOFOs), } \\
\text { incluyendo los Gabinetes de } \\
\text { Participación Ciudadana (GPC), } \\
\text { comunidades indígenas y } \\
\text { propietarios de bosques. }\end{array}$ & $\begin{array}{l}\text { CONAFOR será la instancia de consulta y concertación de } \\
\text { la Estrategia Nacional de Reducción de la Deforestación y } \\
\text { Degradación Forestal. Para este efecto se contará con el } \\
\text { apoyo de su órgano técnico a nivel territorial y nacional en } \\
\text { los GOFOs, en los cuales están representados, entre otros, } \\
\text { los Gabinetes del Poder Ciudadano (GPC), comunidades } \\
\text { indígenas y propietarios de bosques. }\end{array}$ \\
\hline
\end{tabular}

De manera preliminar se identifican las siguientes preocupaciones e impactos ambientales dentro del marco de referencias de la estrategia ENDE-REED+ ${ }^{52}$. Cabe destacar que coinciden con lo que en el país se describe como problemas generales del sector forestal y que son descritos en diversos apartados de este informe.

51. Gutiérrez, J. (2011). Taller REDD-CCA-GIZ. Guatemala: MARENA, MAGFOR, INAFOR.

52. Readiness Preparation Proposal (R-PP) for Country: Nicaragua. Date of submission or revision: $1^{\circ}$ de junio de 2012. Formal Versión 7, Págs. 256 y 257. 


\section{Preocupaciones ambientales y sociales preliminares en el Contexto ENDE-REDD+}

1. Deforestación y pérdida de ecosistemas naturales protegidos causados por:

Extracción de árboles maderables para la comercialización ilegal en los mercados locales

Extracción de madera para producción de carbón y leña, entre otros.

2. La promoción de patrones de crecimiento agrícola de monocultivo altamente dependiente de insumos externos y la ganadería extensiva.

La agricultura migratoria a pequeña y mediana escala y las quemas agrícolas incontroladas para incrementar la productividad de los suelos.

3. Alto riesgo por fenómenos naturales.

4. La legalidad de la tierra y la definición de los derechos de propiedad de las comunidades indígenas.

Falta de identificación de los diferentes derechos (tanto jurídicos como consuetudinarios) y sus derechos a tierras, territorios y recursos, y la necesidad de una reforma y armonización del marco jurídico.

5. La migración interna y el crecimiento poblacional.

6. La baja capacidad institucional para ordenar y controlar la actividad forestal, además de garantizar la participación de todos los actores.

7. El impulso de políticas y programas oficiales agroexportadores que favorecen la deforestación.

8. El desconocimiento y débil mercado para productos y servicios forestales.

9. La falta de educación e información en la población.

\section{Impactos}

- Limitada capacidad de los bosques para regenerar los bienes y servicios ambientales.

- Pérdida de biodiversidad genética, nativa y endémica.

- Acelerada degradación de los ecosistemas.

- Disminución de los recursos hídricos.

- Incremento de gases de efecto invernadero.

- Áreas de bosques reducidas.

- Mayor degradación de los recursos naturales por el cambio de uso de los suelos de vocación forestal para la agricultura y ganadería.

- Mayor degradación de los suelos por el uso de prácticas agrícolas inadecuadas.

- Pérdida de plantas medicinales, forestales y maderables, fauna y otros organismos vivos terrestres y acuáticos que garantizan la fertilidad del suelo y la reproducción de las plantas y animales.

- Mayor erosión del suelo y el aumento de zonas secas.

- Mayor frecuencia de eventos naturales como: inundaciones, sequías, deslaves y huracanes.

- Un aumento de las áreas de desertificación y sequía.

- Aumento de temperatura.

- Mayor vulnerabilidad en las poblaciones indígenas y comunidades campesinas.

- No se reconoce ni respeta los derechos legales y consuetudinarios de los pueblos indígenas y comunidades locales que tradicionalmente han poseído, ocupado o de otra forma utilizado las tierras, territorios y recursos.

- Aumento de los conflictos relacionados con tierras, territorios y recursos.

- Aumento de las prácticas de la deforestación y la quema de manera extensiva.

- La existencia de un sistema de monitoreo deficiente.

- Limitada participación de los actores.

- No se reconocen, mejoran y fortalecen los conocimientos tradicionales de pueblos indígenas en relación con su ecosistema y medioambiente.

- La disminución de la calidad de vida de la población que depende de los ecosistemas forestales.

- Débiles mecanismos participativos, poco eficaces y eficientes que permitan establecer una distribución equitativa de los beneficios del programa entre los grupos de titulares de derechos y actores pertinentes, teniendo en cuenta los costos, beneficios y riesgos asociados. 


\begin{tabular}{|l|l|}
\hline $\begin{array}{c}\text { Preocupaciones ambientales y } \\
\text { sociales preliminares en el Contexto } \\
\text { ENDE-REDD+ }\end{array}$ & Impactos \\
\hline $\begin{array}{l}\text { 10. La poca participación de las mujeres en } \\
\text { las asambleas comunales. }\end{array}$ & $\begin{array}{l}\text { - La limitada participación de las mujeres en los procesos de } \\
\text { - } \begin{array}{l}\text { Ponsulta y participación. } \\
\text { indígenas. }\end{array}\end{array}$ \\
\hline $\begin{array}{l}\text { 11. Desarraigo cultural de los pueblos } \\
\text { indígenas con el bosque. }\end{array}$ & $\begin{array}{l}\text { - Cambios en la dinámica de sus medios de vida sostenible. } \\
\text { - Aumento de la vulnerabilidad social y económica si no se } \\
\text { están preparando para la reconversión tecnológica. }\end{array}$ \\
\hline
\end{tabular}

\subsection{Conflictos existentes entre derechos de uso de la tierra y los bosques}

En los años 70 la estructura de tenencia de la tierra en Nicaragua mostraba que alrededor de 52,4\% de la tierra agrícola estaba en manos del $4 \%$ de familias. Cerca de $34 \%$ de la población rural estaba conformada por campesinos sin tierra. Con la instauración del gobierno sandinista en julio de 1979 se realizó la reforma agraria, entregándole a cientos de nicaragüenses tierras obtenidas por diversos medios $^{53}$.

Las confiscaciones de propiedades en Nicaragua se iniciaron en 1979 y la aplicación masiva de la Ley de Reforma Agraria se inició en el período 1982/83. Las entregas de tierras en este período estaban condicionadas a que los beneficiarios aceptaran organizarse en Cooperativas Agrícolas Sandinistas (CAS) y siguieran el plan de producción impuesto por las CAS. Según cifras del Centro de Investigación y Estudio de la Reforma Agraria (CIERA), entre 1979 y 1984 el sector reformado afectó tres millones de manzanas de un total de 8.073.000 manzanas de tierras rurales de Nicaragua, es decir, $37,2 \%$ del total de tierras en uso agrícola a nivel nacional. Las empresas estatales agrícolas (APP) comprendían 50,5\% del área reformada y el restante en cooperativas y otras formas asociativas de producción. Todo esto se hizo prácticamente sin emisión de títulos de propiedad ${ }^{54}$.

La titulación de las tierras asignadas se inició en 1990 con el gobierno de Violeta Chamorro. Este gobierno entregó tierras, no necesariamente titulada, sino asignada, a nuevos propietarios para cumplir sus obligaciones de pacificación. Los gobiernos subsiguientes han seguido titulando, indemnizando a confiscados y en algunos casos, devolviendo el bien a sus dueños originales.

Estos antecedentes permiten comprender mejor el gran problema actual de la tenencia de la tierra en Nicaragua, donde la información que se pueda extraer de los Registros de la Propiedad acerca de la titularidad del bien no da garantía alguna de ser la situación real de la propiedad investigada.

Con todo ello, hay que mencionar que los aspectos más descuidados en el tema de la tenencia de la tierra han sido las tierras nacionales y municipales. Estas siempre se han considerado como tierra de nadie, en donde cualquier persona se establece, demarca con carriles un área y después de un determinado período, obtiene el dominio y posesión total de la tierra mediante un título supletorio. De esa manera, el Estado perdió gran parte de su patrimonio ${ }^{55}$.

53. Corral, L. (1999). Reforma y Tenencia de la Tierra en Nicaragua.

54. ibid.

55. Informe del Ambiente, Nicaragua, 2001, Pág. 23. 
A pesar de la alta inseguridad en la tenencia de la tierra en Nicaragua, la actividad de los mercados de tierra ha sido dinámica. En una encuesta realizada en $1995^{56}$ se encontró una alta participación de los encuestados en el mercado de tierras. Más de $21 \%$ de los entrevistados compró tierras entre 1990-95. Un 33\% de las transacciones había involucrado títulos de la reforma agraria sin estar registrados en los registros públicos.

Mención aparte merecen las tierras que son propiedad de las comunidades indígenas de Nicaragua. Aquí debemos diferenciar los derechos que tienen las comunidades del Pacífico y centro de Nicaragua con las que tienen las comunidades del Caribe. El artículo 5 de la Constitución Política de Nicaragua establece que el Estado reconoce la existencia de los pueblos indígenas, que gozan de los derechos, deberes y garantías consignados en la Constitución y en especial los de mantener y desarrollar su identidad y cultura, tener sus propias formas de organización social y administrar sus asuntos locales, así como mantener las formas comunales de propiedad de sus tierras y el goce, uso y disfrute de estas, todo de conformidad con la ley. Para las Comunidades de la Costa Atlántica se establece el régimen de autonomía en la presente Constitución.

Este artículo constitucional a su vez determina que las diferentes formas de propiedad: pública, privada, asociativa, cooperativa y comunitaria deberán ser garantizadas y estimuladas sin discriminación para producir riquezas y todas ellas dentro de su libre funcionamiento deberán cumplir una función social.

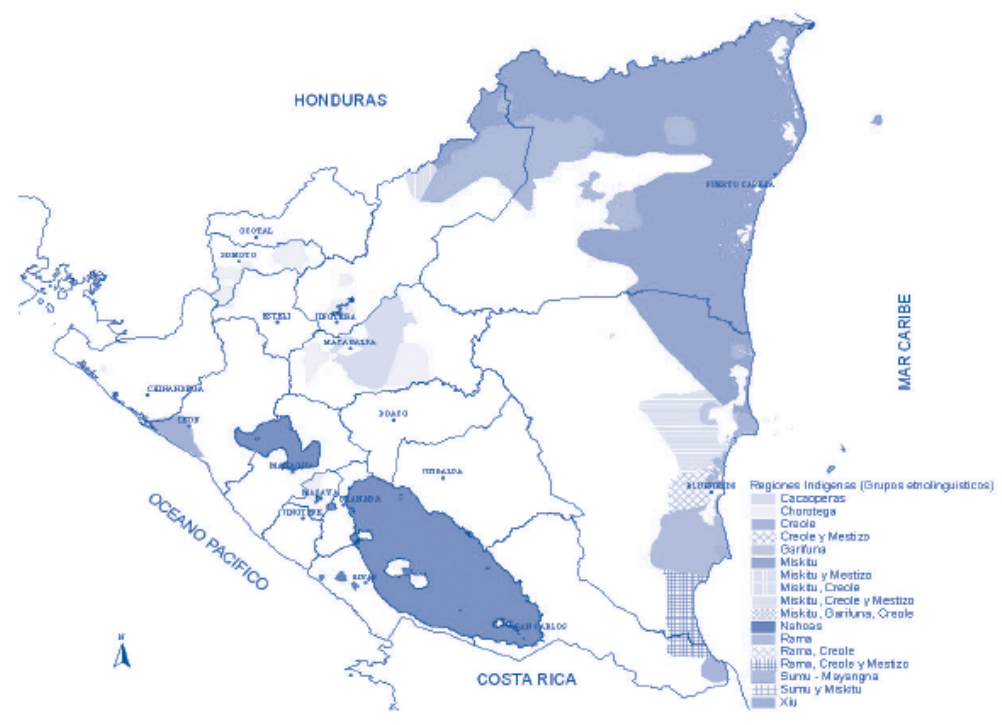

Fuente: CADRI. 'Marco jurídico de los derechos territoriales de los pueblos indígenas en Nicaragua'. [presentación online]. <http://www.cadri.org/wp-content/uploads/2008/07/marco-juridico-de-los-derechos-territoriales-de-lospueblos-indigenasnic.ppt>.

56. Estudio de NITLAPAN citado por Davis, B. Los Hogares Agropecuarios en Nicaragua: Un Análisis de Tipología. Proyecto GCP/RLA/115/ITA, FAO, 1997. 


\section{Regiones indígenas (grupos etnolingüísticos)}

\begin{tabular}{|c|c|}
\hline \multicolumn{2}{|c|}{ Población indígena en Nicaragua } \\
\hline Pueblo indígena & Población \\
\hline Miskito & 150.000 \\
\hline Mayangna-Sumu & 13.500 \\
\hline Rama & 1.350 \\
\hline Garífuna & 2.000 \\
\hline Creole & 43.000 \\
\hline Chorotega & 166.000 \\
\hline Nahoas & 20.000 \\
\hline Sutiaba-Okan Xiu & 49.000 \\
\hline Matagalpa & 98.000 \\
\hline Chontales & 14.000 \\
\hline TOTAL & 556.850 \\
\hline
\end{tabular}

Fuente: CADRI. 'Marco jurídico de los derechos territoriales de los pueblos indígenas en Nicaragua'. [presentación online]. <http://www.cadri.org/wp-content/uploads/2008/07/marco-juridico-de-los-derechos-territoriales-de-lospueblos-indigenasnic.ppt>.

Los pueblos indígenas del Pacífico y centro de Nicaragua no cuentan con una regulación especial sobre la tenencia de su tierra. Existe en la Asamblea Nacional una Iniciativa de Ley General de Pueblos Indígenas que pretende regular la naturaleza jurídica, la jurisdicción, la competencia y la coordinación y complementariedad de los gobiernos de los pueblos indígenas con el conjunto de la administración pública del Estado de Nicaragua.

Sin embargo, para las Comunidades de la Costa Atlántica la Constitución Política reconoce el derecho que tienen de vivir y desarrollarse bajo las formas de organización social que corresponden a sus tradiciones históricas y culturales. El Estado debe garantizar a estas comunidades el disfrute de sus recursos naturales, la efectividad de sus formas de propiedad comunal y la libre elección de sus autoridades y representantes. Asimismo, garantiza la preservación de sus culturas y lenguas, religiones y costumbres (Art. 180 Constitucional).

La Constitución de la República establece en su Artículo 181 que el Estado organizará, por medio de una ley, el régimen de autonomía para los pueblos indígenas y las Comunidades étnicas de la Costa Atlántica, la que deberá contener entre otras normas: las atribuciones de sus órganos de gobierno, su relación con el Poder Ejecutivo y Legislativo, y con los municipios y el ejercicio de sus derechos. Dicha ley, para su aprobación y reforma, requerirá la mayoría establecida para la reforma a las leyes constitucionales. Señala este artículo que las concesiones y los contratos de explotación racional de los recursos naturales que otorga el Estado en las Regiones Autónomas de la Costa Atlántica deberán contar con la aprobación del Consejo Regional Autónomo correspondiente. Para este fin se dictó la Ley 28, Estatuto de Autonomía de las Regiones de la Costa Atlántica de 1987, su reglamento, Decreto 3584 y la Ley 445, Ley del Régimen de Propiedad Comunal de los Pueblos 
Indígenas y Comunidades Étnicas de las Regiones Autónomas de la Costa Atlántica de Nicaragua y de los Ríos Bocay, Coco, Indio y Maíz, estos dos últimos en el año 2003.

La Ley 445 establece el régimen de autoridades indígenas, régimen de propiedad, legalización de tierras y la potestad sobre sus riquezas naturales. Si bien los derechos de propiedad de las comunidades del Caribe nicaragüense, zona donde se encuentra la mayor cantidad de bosque tropical de Nicaragua, están resguardados en la Constitución, Ley 28 y Ley 445, en la práctica la falta de limitación y titulación ha llevado a diversos conflictos ${ }^{57}$ y a no permitir el desarrollo de un adecuado aprovechamiento forestal. Ejemplo de ello es la comunidad de Awas Tingni de la Región Autónoma del Atlántico Norte, que sigue siendo un referente en la lucha de los territorios indígenas del país, ya que por primera vez el Estado de Nicaragua fue llevado ante la Corte Interamericana de Derechos Humanos (CIDH) por violentar sus derechos a la propiedad comunitaria. Diez años han transcurrido y a pesar de que se logró la aprobación de una legislación que protegiera los derechos de la tierra indígena, aún queda pendiente el saneamiento de sus territorios ${ }^{58}$.

En declaraciones al Diario La Prensa ${ }^{59}$, la jurista Lottie Cuningham, Directora del Centro por la Justicia y los Derechos Humanos de la Costa Atlántica de Nicaragua (CEJUDHCAN), dijo que la demanda de Awas Tingni responsabiliza al Gobierno de Nicaragua a crear mecanismos de titulación y saneamiento, como la Ley 445, ya que las comunidades indígenas del Caribe enfrentan el problema de la invasión de sus tierras y por ende, la destrucción de sus recursos naturales. Según Cuningham, en el 2003, cuando Awas Tingni hizo su demanda, en el territorio indígena vivían 49

57. Ejemplo de ello es la Sentencia CSJ No 123 de la 1:30 p.m. del 13 de junio del año 2000 . En esta sentencia se admite un Recurso de Amparo interpuesto por la Comunidad Indígena de Rama Cay en contra del Delegado Regional del Instituto Nicaragüense de Reforma Agraria, a quien se denuncia por haber ordenado y promovido la invasión de tierras de la Comunidad a un grupo de personas desmovilizadas de la Resistencia Nicaragüense que entraban armadas, saqueaban y pretendían apoderarse sobre un área de 500 manzanas. La Corte acogió el Recurso fundamentando su Resolución en los Arts. 5, 89 y 180 de la Constitución que protegen los derechos indígenas y en el Art. 36 de la Ley de Autonomía que asegura el carácter inalienable, inembargable e imprescriptible de las tierras comunales.

58. Invasión en tierras indígenas, La Prensa, miércoles 30 de octubre de 2013. Esta nota se refiere a la Sentencia CIDH del 31 de agosto de 2001 en denuncia promovida por la Comunidad Indígena SumoMayagna de Awas Tingni en contra del Gobierno de Nicaragua, que declaró que el Estado violó el derecho a la protección judicial consagrado en el Artículo 25 de la Convención Americana sobre Derechos Humanos, en perjuicio de los miembros de la Comunidad Mayagna (Sumo) Awas Tingni, en conexión con los Artículos 1.1 y 2 de la Convención, de conformidad con lo expuesto en el párrafo 139 de la presente sentencia. Declara que el Estado violó el derecho a la propiedad consagrado en el Artículo 21 de la Convención Americana sobre Derechos Humanos, en perjuicio de los miembros de la Comunidad Mayagna (Sumo) Awas Tingni, en conexión con los Artículos 1.1 y 2 de la Convención, de conformidad con lo expuesto en el párrafo 155 de la presente sentencia. Decide, por equidad, que el Estado debe invertir, por concepto de reparación del DAÑO INMATERIAL, en el plazo de 12 meses, la suma total de US\$50,000 (cincuenta mil dólares de los Estados Unidos de América) en obras o servicios de interés colectivo en beneficio de la Comunidad Mayagna (Sumo) Awas Tingni, de común acuerdo con esta y bajo la supervisión de la CIDH de conformidad con lo expuesto en el párrafo 167 de la presente sentencia. Decide, por equidad, que el Estado debe pagar a los miembros de la Comunidad Mayagna (Sumo) Awas Tingni, por conducto de la $\mathrm{CIDH}$, la suma total de US $\$ 30,000$ (treinta mil dólares de los Estados Unidos de América) por concepto de gastos y costas en que incurrieron los miembros de dicha Comunidad y sus representantes, ambos causados en los procesos internos y en el proceso internacional ante el Sistema Interamericano de Protección, de conformidad con lo expuesto en el párrafo 169 de la presente sentencia.

59. 'Invasión en tierras indígenas'. La Prensa del 30 de octubre de 2013. 
familias invasoras. Diez años más tarde, según el último diagnóstico que se realizó, se comprobó que hay más de 400 familias invasoras.

De acuerdo con el Informe Ejecutivo de la CONADETI y las CIDTs, al 30 de junio del año 2013, el estado de avance de demarcación y titulación de los territorios de la RAAN, RAAS y la Zona del Régimen Especial desde el año 2005 al año 2013 es el siguiente: 16 territorios en la Región Autónoma del Atlántico Norte, 3 territorios en la Región Autónoma del Atlántico Sur y 2 en la Zona de Régimen Especial (Departamento de Jinotega). Los 21 territorios titulados suman 28,14\% del territorio nacional.

La titulación de las tierras en la zona del Caribe y centro de Nicaragua tiene enorme relevancia por dos razones; la primera es que la mayoría de los bosques tropicales están situados en el Caribe y segundo, porque la titulación de la tierra es un eje indispensable para la implementación de los programas ENDE-REED+.

Un caso emblemático en el Caribe es la Reserva de Biosfera Bosawas poblada por diversias etnias que exigen titulación de sus tierras. Bosawas es un territorio similar al El Salvador. En su seno habitan 270 especies de plantas, más de 200 especies de animales (el 13\% de las especies tropicales conocidas) y unas 200 mil especies de insectos. Pero la gran selva centroamericana cae al paso apresurado de las motosierras y la invasión humana. Un informe publicado en agosto de 2012 y preparado por la Agencia Alemana para el Desarrollo Sostenible (GIZ) y por la Unión Nacional de Agricultores y Ganaderos (UNAG) muestra que la reserva languidece a un ritmo de 42 mil hectáreas de bosque arrasadas al año, y que desde 1987 hasta 2010, Bosawas ha perdido más de 564 mil hectáreas (unos 5,640 kilómetros cuadrados, aproximadamente). El estudio, coordinado por el investigador Marcial López, demuestra exhaustivamente cómo el bosque ha perdido terreno en Bosawas, pasando de más de un millón 604 mil hectáreas en 1987 a un millón 039 mil en 2010. En cuanto al bosque virgen de la reserva, éste pasó de un millón 170 mil hectáreas en 1987, a 832,237 en 2010. Es decir que hasta esa fecha se había perdido un total de 3,379 kilómetros cuadrados de bosque virgen ${ }^{60}$.

\subsection{Marco jurídico para promover la distribución justa y equitativa de los beneficios de un aprovechamiento sostenible de madera}

En la Cruzada Nacional de Reforestación se ha logrado reforestar en el período 2007-2010 $65.342,54$ ha. La tasa de sobrevivencia es de $80 \%$ y se establecieron 473 viveros con un potencial de reforestación de 11.000 ha ${ }^{61}$. Además, se está asimilando el tema del aprovechamiento forestal sostenible como una actividad viable para incrementar los ingresos económicos de diversas familias del área rural nicaragüenses dedicadas tradicionalmente a la agricultura.

60. Salinas, C. y otros. 'El ocaso de BOSAWAS'. Confidencial [revista electrónica], 28 de abril de 2014. $<$ http://www.confidencial.com.ni/bosawas/>.

61. Informe Anual MAGFOR, 2011, Pág. VI. 
EI MAGFOR presentó como un importante logro la forestería comunitaria, a través de la cual las empresas conformadas en la costa caribe y el occidente del país han podido aprovechar la madera caída, en especial del Huracán Félix y transformarlas con el apoyo del INAFOR, obteniendo mayores ingresos y mejorando sus conocimientos sobre sus recursos ${ }^{62}$.

Las leyes forestales permiten el aprovechamiento forestal, salvo las especies en veda; sin embargo, en el tema de aprovechamiento de madera por parte de los propietarios un factor a considerar son los costos de los dueños y/o empresarios del sector forestal para acceder a los permisos de aprovechamiento. Se deben trasladar más de una vez hasta el sitio donde está la delegación de INAFOR y/o Municipalidad. Además de los costos que deben asumir por la tramitación del permiso, plan de manejo regente forestal y labores de aprovechamiento, deben también asumir costos propios del Estado al tener que trasladar a los funcionarios de INAFOR para la realización de inspecciones y en ocasiones, asumir sus viáticos de hospedaje y alimentación. Por estas razones, entre otras, algunos dueños de bosques venden sus árboles en pie a precios inferiores, evitándose así la gestión de los permisos de traslados de madera y exportación. Un ejemplo de ello es recogido en la investigación "Emergencia en el bosque"63: En el caso de la Caoba del Atlántico, la especie forestal de mayor valor comercial internacional, los hermanos Ubeda Rivera -por ejemplo- colocan el metro cúbico de la madera aserrada, de mayor calidad (FAST-Select) y con certificación FSC, a un precio promedio de US\$1,500.00. No obstante, pagan a US\$30.00 el árbol de madera preciosa (roja) a las comunidades indígenas, de donde extraen los árboles".

Otro ejemplo relevante es el precio de la madera conocida como cocobolo o granadillo (Dalbergia). Según un exportador entrevistado, el precio del pie tablar de madera varía según el puerto de embarque.

\begin{tabular}{|c|c|}
\hline Puerto Corinto & U\$8.50 pie tablar \\
\hline Puerto El Rama & U\$5.00 pie tablar \\
\hline Ciudad de Blufields & U\$3.00 pie tablar \\
\hline
\end{tabular}

\section{Fuente propia}

El precio en que este exportador nicaragüense vende en China esta madera es de U\$35 pie tablar.

El granadillo representó el 22 por ciento del total de madera exportada y ocupó el tercer lugar en cuanto a permisos autorizados por el INAFOR durante el primer semestre de 2012. El Director Ejecutivo del INAFOR, William Schwartz, señala que en los últimos tres años "ha venido una gran cantidad de ciudadanos chinos que están comprando granadillo para exportarlo a Hong Kong, incluso Taiwán, pero fundamentalmente a China Continental. El granadillo ha venido subiendo de precio". El granadillo representó $22 \%$ del total de madera exportada y ocupó el tercer lugar en cuanto a permisos autorizados por el INAFOR durante el primer semestre del $2012^{64}$.

62. Informe Anual MAGFOR, 2011, Pág. VI.

63. Fonseca R. y De Castro C. (enero, 2007). Emergencia en el Bosque. Centro de Investigación de la Comunicación (CINCO), en asociación con el Centro para las Políticas Internacionales (CIP), con sede en Washington D.C., Pág. 18.

64. Enríquez O. 'La "Mafia" del Granadillo'. Confidencial [revista electrónica], (10 de diciembre de 2012). <http://www.confidencial.com.ni/articulo/9380/>. Accedido el 31 de marzo de 2014. 
Sin embargo, las ganancias por la explotación de esta madera se ven diluidas por la dificultad del dueño del bosque en ser él mismo el exportador y por la legalidad imperante en el sector. La mayoría de exportadores compra la madera, no la produce y paga precios mínimos al dueño del bosque con la excusa de los costos de traslado y exportación.

Existen algunos proyectos como los impulsados por la Red Mesoamericana y del Caribe de Comercio Forestal, Jagwood, donde diez empresas nicaragüenses del sector madera y mueble están listas para abrirse mercado en la Unión Europea (UE) en el marco del Acuerdo de Asociación que entró en vigencia el pasado primero de agosto de 2013. Esas empresas cuentan con certificados medioambientales, uno de los requisitos que pide la UE para comprar productos de madera ${ }^{65}$. No obstante, muy pocos dueños de bosque tienen los mecanismos e instrumentos de manera autónoma para ser los propios productores y comercializadores de madera o bien, no tienen títulos sobre sus propiedades, lo que los hace incurrir en ilegalidad, logrando precios de venta aún más bajos.

65. Vidaurre, A. 'Sector madera y mueble listo para el AdA'. El Nuevo Diario.com.ni [periódico online], (30 de agosto de 2013). <http://www.elnuevodiario.com.ni/economia/295541-sector-madera-mueble-listo-ada>. Accedido el 31 de marzo de 2014. 


\section{Análisis de los estándares de legalidad}

\subsection{Vacíos y conflictos en la aplicabilidad de la Ley Forestal y afines, poniendo especial atención en las posibilidades y retos a la luz de los sistemas existentes de derecho consuetudinario indígena y derecho positivo de los pueblos y territorios indígenas en los países}

En Nicaragua, los pueblos indígenas y afrodescendientes, comunidades étnicas y locales tienen derechos constitucionales orientados a proteger sus sistemas de vida tradicionales basados en la diversidad biológica, siendo preciso respetar, mantener y promover sus conocimientos, innovaciones y prácticas tradicionales que coadyuven a la conservación y utilización sostenible de la diversidad biológica, así como fomentar su participación y la distribución equitativa de los beneficios que se deriven de la utilización de la diversidad biológica, disposiciones que se fortalecen del Convenio sobre Pueblos Indígenas y Tribales en Países Independientes de $1989^{66}$.

Ya se comentó que con el objetivo de materializar estos derechos se dictó la Ley 28, Estatuto de Autonomía de las Regiones de la Costa Atlántica de 1987, su reglamento, Decreto 3584 y la Ley 445, Ley del Régimen de Propiedad Comunal de los Pueblos Indígenas y Comunidades Étnicas de las Regiones Autónomas de la Costa Atlántica de Nicaragua y de los Ríos Bocay, Coco, Indio y Maíz, estos dos últimos en el año 2003.

Sin embargo, a pesar de contar con este respaldo legal, reconocido incluso internacionalmente con la sentencia del caso impulsado por Comunidad Indígena Sumo-Mayangna de Awas Tingni ante la $\mathrm{CIDH}$, la inseguridad en la tenencia de la tierra por falta de titulación sigue siendo el principal obstáculo para el desarrollo de la actividad forestal en las Comunidades indígenas de la Costa Atlántica de Nicaragua, provocando incluso graves hechos de violencia ${ }^{67}$. La inseguridad en la tenencia de la tierra -sumada a las dificultades económicas para la tramitación de los planes y permisos de aprovechamiento, aserrado y traslado de la madera- ocasiona que la mayor ganancia financiera no quede en manos de los dueños del bosque.

66. Ratificado por la Asamblea Nacional mediante Decreto A.N. № 5934 el 6 de mayo de 2010 publicado en La Gaceta, Diario Oficial N 105 del 4 de junio de 2010 y ratificado por el Presidente de la República por Decreto № 30-2010 del 21 de junio de 2010 y publicado en La Gaceta, Diario Oficial № 121 del 28 de junio de 2010.

67. La Presidenta del Centro por la Justicia y los Derechos Humanos de la Costa Atlántica de Nicaragua (CEJUDHCAN) declaró que la avalancha de colonos sobre los territorios de las comunidades indígenas de las Regiones Autónomas del Caribe nicaragüense y en la Zona Wanki-Bocay (en Jinotega) es la causa de los 60 crímenes que han estremecido esa extensa región del territorio nacional en los últimos cinco años. Señaló que, en igual período, más de 1.000 colonos llegados de 12 departamentos del país han invadido 59.515,30 kilómetros cuadrados de tierras indígenas. Por esta razón, urgió a las autoridades estatales la aplicación de la Ley 445 o Ley de Régimen de Propiedad Comunal de los Pueblos Indígenas, principalmente en lo que refiere a la llamada fase de saneamiento. García, E. '60 crímenes en 5 años en tierras indígenas'. El Nuevo Diario.com.ni [periódico online], (28 de noviembre de 2013). <http://www.elnuevodiario.com.ni/ nacionales/303383-60-crimenes-5-anos-tierras-indigenas $>$. Accedido el 31 de marzo de 2014. 


\subsection{Vacíos legales existentes en la Ley Forestal y afines, respecto al aprovechamiento forestal y comercio internacional de productos forestales}

En entrevista realizada a la Licenciada Sandra Tijerino, ex Directora del Instituto Nacional Forestal ${ }^{68}$, señala que las restricciones legales y la frágil institución forestal están deteriorando el sector forestal del país. Las causas que identifica para esta situación son las siguientes:

- Inadecuado uso y manejo de la información forestal nacional en los procesos de planificación, regulación, control y fomento forestal.

- Conflictos de competencia entre la Entidad Forestal Nacional y otros entes involucrados que originan incertidumbre en las inversiones nacionales.

- Restricciones institucionales que han potenciado la ilegalidad y la destrucción del recurso natural.

- Priorización gubernamental hacia otros sectores productivos que compiten con el manejo sostenible forestal/bosques con mucho respaldo político y recursos.

- La pobreza como problemática nacional generalizada. Las áreas de bosque son las tierras que con relativa facilidad pueden ser ocupadas por la migración de grupos provenientes del resto del país y la ineficiencia productiva que conlleva su colonización.

- Falta de institucionalidad forestal.

- Reducción de las inversiones públicas provenientes de proyectos y préstamos.

68. La Licenciada Tijerino fue también Autoridad Administrativa de CITES-Nicaragua. 


\section{Análisis del ámbito de acción de la Administración Forestal}

\subsection{Tipos de permisos forestales en el ámbito de acción de la Ley Forestal y afines}

La administración forestal a nivel central está a cargo del INAFOR -que otorga y regula lo relativo al aprovechamiento en tierras privadas y en el otorgamiento de concesiones en tierras propiedad del Estado- y el MARENA, que regula lo relativo a la actividad forestal en áreas protegidas y bosques de manglar.

Las atribuciones en materia forestal del INAFOR pueden ser delegadas a los Gobiernos Municipales de conformidad con los Artículos 10 y 11 de la Ley 462 y Artículo 32 del Decreto 73-2003, Reglamento de la Ley Forestal.

\section{Acceso a los recursos forestales}

La Ley 462 en sus Artículos del 41 a 47 establece las disposiciones que regulan las concesiones forestales. A su vez, el Decreto 106-2005, desarrollando lo dispuesto en estos artículos, dicta las "Disposiciones que Regulan las Concesiones Forestales".

Concesiones Forestales: Podrá solicitar y obtener concesiones forestales cualquier persona natural o jurídica siempre que el área esté disponible y cumpla con los requisitos establecidos en esta ley y su Reglamento, salvo aquellas personas que la Constitución Política señala como inhibidas para tal fin. EI INAFOR es la institución del Estado encargada de la administración de las tierras forestales nacionales, que estarán sujetas a concesiones o contratos de explotación racional de conformidad con los Artículos 102 y 181 de la Constitución Política. Se consideran tierras forestales nacionales las que no tienen dueño.

Aprovechamiento de bosques naturales: Esta actividad requiere un permiso de aprovechamiento emitido por el INAFOR, que tendrá como condición previa la aprobación de un Plan de Manejo Forestal, cuya presentación y ejecución estará bajo la responsabilidad de los propietarios o de quien ejerza los derechos sobre este. La forma, requisitos y procedimientos para la aprobación de un plan de manejo forestal y la emisión de un permiso de aprovechamiento está determinada en el Decreto 73-2003, Reglamento Forestal.

EI INAFOR otorga permisos de aprovechamiento forestal de una(s) determinada(s) clase(s) de madera, por un volumen determinado y en área determinada. Será otorgado por un año y prorrogable por un lapso no mayor de un año previa inspección técnica ${ }^{69}$. Cuando se trate de aprovechamientos comerciales en áreas menores de 10 hectáreas, el permiso se podrá extender en un solo trámite y con requisitos simplificados.

69. Artículo 38 del Decreto 73-2003, Reglamento de la Ley 462. 
El Artículo 47 del Reglamento de la Ley 462 establece que para la obtención de un permiso de aprovechamiento forestal el solicitante deberá presentar ante la delegación correspondiente del INAFOR lo siguiente:

1. Para el aprovechamiento forestal en fincas con áreas boscosas menores de 10 ha:

a. Plan de reposición forestal (guía metodológica del INAFOR)

b. Designación del regente

c. Título de dominio de la propiedad o documento posesorio

d. Cesión de derecho en original o copia autenticada por Notario Público en el caso de ceder los derechos de aprovechamiento

e. Autorización de la Dirección General de Áreas Protegidas del MARENA cuando la propiedad se encuentre dentro de estas

2. Para el aprovechamiento forestal en fincas con áreas boscosas mayores de 10 ha:

a. Plan mínimo de manejo forestal (guía metodológica del INAFOR)

b. Designación del regente

c. Título de dominio de la propiedad o documento posesorio

d. Cesión de derecho en original o copia autenticada en el caso de ceder los derechos de aprovechamiento

e. Cuando la propiedad se encuentra en un área protegida, autorización de la Dirección General Áreas Protegidas del MARENA

3. Para el manejo forestal en bosques naturales (áreas de bosque no fragmentado):

a. Solicitud por escrito de aprobación del permiso de aprovechamiento

b. Plan general de manejo forestal con sus respectivos planes operativos anuales (guía metodológica del INAFOR)

c. Designación del regente

d. Título de dominio de la propiedad o documento posesorio

e. Cesión de derecho en original o copia autenticada en el caso de ceder los derechos de aprovechamiento

f. Autorización de la Dirección General de Áreas Protegidas del MARENA cuando la propiedad se encuentre dentro de ellas

Los permisos de aprovechamiento forestal serán otorgados, una vez cumplidos los requisitos establecidos en el artículo anterior, en los siguientes períodos:

1. Para el aprovechamiento forestal en fincas con áreas boscosas menores de 10 ha: 1 día hábil

2. Para el aprovechamiento forestal en fincas con áreas boscosas mayores de 10 ha: 15 días hábiles

3. Para el manejo forestal en bosques naturales (no fragmentado): 30 días hábiles 


\subsection{Diagrama legal-administrativo para acceder a los permisos de aprovechamiento forestal y comercio internacional de madera}

De acuerdo con lo establecido en la Ley 462, las actividades de manejo y aprovechamiento forestal en bosques naturales, en áreas mayores a quinientas (500) hectáreas, previo a la autorización correspondiente, requerirá la elaboración de un Estudio de Impacto Ambiental (EIA) para obtener el Permiso Ambiental otorgado por MARENA. Este será parte integrante del Plan de Manejo ${ }^{70}$.

Se prohíbe el corte, extracción o destrucción de árboles de aquellas especies protegidas y en vías de extinción que se encuentren registradas en listados nacionales y convenios internacionales ratificados por el país. Se exceptúan los árboles provenientes de plantaciones debidamente registradas en el Registro Nacional Forestal ${ }^{71}$.

De conformidad con los Artículos del 43 a 47 del Decreto 73-2003, el manejo forestal en bosques naturales se realizará obligatoriamente preparando un plan de manejo forestal. El contenido de los planes de manejo forestal se establecerá en la correspondiente guía metodológica autorizada por el INAFOR.

El aprovechamiento forestal en fincas con sistemas productivos agrosilvopastoriles, respecto a áreas de bosques naturales que excedan 10 hectáreas, se realizará atendiendo la correspondiente guía metodológica autorizada por el INAFOR. El aprovechamiento forestal en fincas con sistemas productivos agrosilvopastoriles, respecto a áreas de bosques naturales que sean menores de 10 hectáreas, se hará atendiendo la correspondiente guía metodológica autorizada por el INAFOR.

El aprovechamiento en bosques se realizará a través de la elaboración de un plan general de manejo forestal de acuerdo con la guía metodológica autorizada por el INAFOR.

Para el aprovechamiento forestal en bosques naturales se establecen los siguientes instrumentos:

- Plan General de Manejo Forestal (PGMF)

- Planes Operativos Anuales (POA)

- Plan de saneamiento forestal para afectaciones de plagas, enfermedades y cortas sanitarias

- Plan de saneamiento forestal y reposición del recurso para la madera caída ocasionada por fenómenos naturales

70. Artículo 17 de la Ley 462 y Decreto 76-2006. Evaluación Ambiental, Artículo 17. Impactos Ambientales Altos. Las obras, proyectos, industrias y actividades considerados Categoría Ambiental II que pueden causar impactos ambientales potenciales altos están sujetos a un Estudio de Impacto Ambiental. Clasifican en esta categoría los siguientes tipos de proyectos: Categoría II inciso 7, Manejo y aprovechamiento forestal en bosques naturales 0 en plantaciones forestales en superficies mayores a quinientas hectáreas (500 ha) y Artículo 39 del Decreto 73-2003, Reglamento de la Ley 462.

71. Artículo 19 de la Ley 462. 
Pasos para obtener un permiso de aprovechamiento (área menor a 5.000 ha) ${ }^{72}$

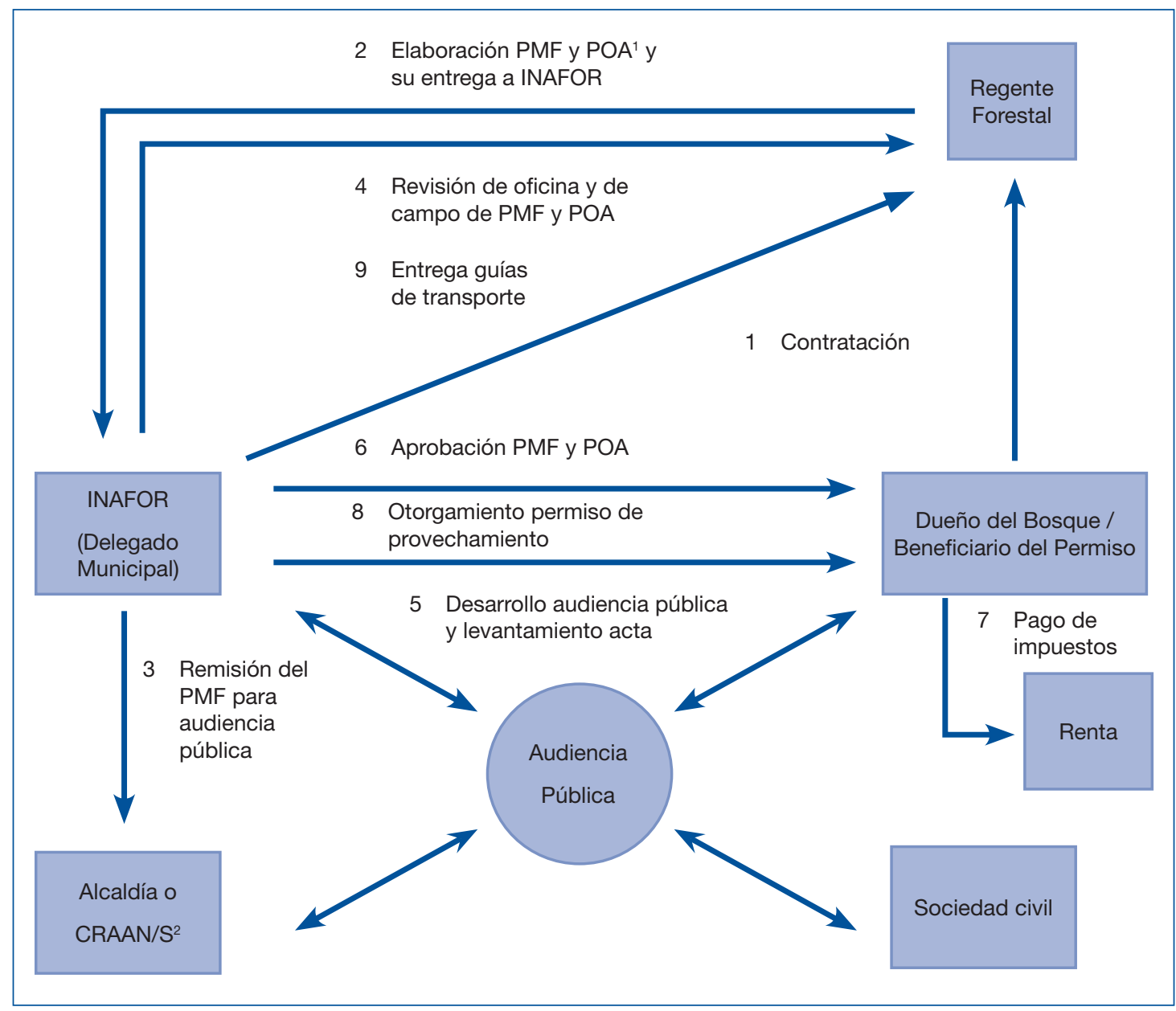

1. Respectivamente plan de manejo forestal y plan operativo anual.

2. Consejo de la Región Autónoma Atlántico Norte y Consejo de la Región Autónoma Atlántico Sur

El INAFOR, en el documento Ruta de Operativización de la Política Administrativa para el Uso de los Recursos Naturales y Manejo Forestal, detalla los siguientes tipos de permisos:

- Plan de Manejo Forestal y su respectivo Plan Operativo Anual

- Planes de Saneamientos

- Permisos no comerciales para uso de la finca

- Permisos Especiales para proyecto de beneficio social

72. Diagrama elaborado por Del Gatto F., Navarro G., Faurby O., Argüello A. Verificación de la Legalidad en el Sector Forestal Nicaragüense. UICN, GTZ, VERIFOR, UE, CATIE, SNV. Rainforest Alliance, Pág. 13. 
- Permisos de Leña

- Permiso Agrosilvopastoriles

- Permiso de Podas

El procedimiento para su obtención, según este documento, es el siguiente:

- Solicitar por escrito el aprovechamiento al INAFOR.

- Comunicar por escrito al alcalde o alcaldesa, o a quienes ellos deleguen, Ejército de Nicaragua, Policía Nacional, MARENA, representante del Gabinete de la Familia Comunidad y Vida, y a las Autoridades Autónomas Regionales de la Costa Caribe.

- EI INAFOR convocará a los miembros de la Comisión Interinstitucional para la revisión del permiso solicitado en el Gabinete.

- El INAFOR convocará a los miembros de la Comisión Interinstitucional para la inspección de campo de cada solicitud de Permiso de Aprovechamiento.

- La Comisión Interinstitucional dictaminará la propuesta de aprobación o denegación, que deberá ser ratificada o denegada por el Concejo Municipal.

- Para emitir el permiso de aprovechamiento el INAFOR deberá contar con el Aval de la Alcaldía Municipal y del Consejo Regional, en el caso de las Regiones Autónomas.

- En el caso de los Planes Generales de Manejo Forestal, se convocará a los miembros de la Comisión Interinstitucional a la Audiencia Pública que manda la ley para su aprobación o denegación. En las Regiones Autónomas el Plan de Manejo deberá ser aprobado por el pleno del Consejo Regional.

- EI INAFOR convocará a los miembros de la Comisión Interinstitucional para la Inspección de Post-aprovechamiento.

- En caso de denuncias, actuará esta misma Comisión para determinar si se abre o no procesos administrativos.

- La Comisión Interinstitucional inspeccionará la documentación que debe llevar cada medio de transporte forestal.

- Los medios de transporte serán inspeccionados en los puestos de control establecidos en la ruta obligatoria en el nuevo Sistema de Trazabilidad Forestal.

- Mensualmente se enviarán informes con los permisos emitidos a la Contraloría General de la República para su Control y Fiscalización.

\section{Pagos por aprovechamiento forestal}

Se establece un pago único por derecho de aprovechamiento por metro cúbico extraído de madera en rollo de los bosques naturales, que se fija en seis por ciento (6\%) del precio de este, el cual será establecido periódicamente por el Ministerio Agropecuario y Forestal ${ }^{73}$. El Reglamento de la presente

73. Acuerdo Ministerial 31-2009. De los precios de referencia para la aplicación del pago único por derecho de aprovechamiento del recurso forestal. 
ley deberá establecer la metodología para el cálculo de los precios de referencia. La industria forestal en toda su cadena estará sujeta al pago del Impuesto sobre la Renta (IR) como las demás industrias del país, salvo los incentivos establecidos en esta ley ${ }^{74}$. La industria forestal en toda su cadena estará sujeta al pago del impuesto sobre la renta (IR).

El monto de las recaudaciones que el Estado reciba en concepto de pagos por derecho de aprovechamiento, multas, derechos de vigencia, subastas por decomiso, conforme a lo establecido en la presente ley y su Reglamento deberán enterarse en una cuenta especial que para tal efecto llevará la Tesorería General de la República, la que a su vez distribuirá lo recaudado en un plazo no mayor de treinta días de la siguiente forma ${ }^{75}$ :

\section{En las Regiones Autónomas}

Según lo dispuesto en la Ley № 445, Ley del Régimen de Propiedad Comunal de los Pueblos Indígenas y Comunidades Étnicas de las Regiones Autónomas de la Costa Atlántica de Nicaragua y de los Ríos Bocay, Coco, Indio Maíz, se establece:

a. $25 \%$ para la comunidad o comunidades indígenas donde se encuentre el recurso a aprovechar

b. $25 \%$ para el municipio en donde se encuentra la comunidad indígena

c. $25 \%$ para el Consejo Regional y Gobierno Regional correspondiente

d. $25 \%$ para el Tesoro Nacional

2. En el resto del país

a. $35 \%$ directamente a las alcaldías donde se origine el aprovechamiento

b. $50 \%$ al Fondo Nacional de Desarrollo Forestal (FONADEFO)

c. $15 \%$ de remanente al Tesoro Nacional

Para fines de establecer los valores el INAFOR considerará los siguientes elementos básicos:

Se definirán categorías en las cuales se agruparán las especies forestales para facilitar la aplicación del 6\%. El INAFOR establecerá precios razonables de mercado de las diferentes categorías de especies forestales para la aplicación del $6 \%$ en un plazo no mayor de 30 días. Dicha metodología se

74. Artículo 284 de la Ley 822. Esta ley en su Artículo 296, inciso 4, deroga el Artículo 48 de la Ley 462.

75. Aunque así lo señala la ley, en la práctica los Gobiernos Municipales y otros actores se quejan de la falta de control y transparencia en la distribución de estos ingresos. Vemos, por ejemplo, lo que recoge el artículo de la Revista Encuentro 2007, Año XXXIX, № 77, 9-28. Dilemas de los Funcionarios Punta de Lanza en la Gestión Ambiental en Río San Juan Nicaragua, que cita: "De los ingresos que percibió el gobierno central del aprovechamiento forestal para el 2004 -sin incluir el porcentaje que le corresponde al gobierno local-, el 99\% provinieron de pagos de permisos de aprovechamiento (cantidad y tipo de madera, marqueo e inspecciones) y menos del $1 \%$ de los ingresos se derivaron del control (multas y subastas). Contrastados con los frecuentes y abiertos comentarios sobre aprovechamiento y prácticas ilegales en el campo, estos datos parecen indicar que por el bajo nivel de control, el Estado pierde muchos recursos además del beneficio de tener un sector forestal debidamente regulado. Con la aplicación de la Ley Forestal, la Alcaldía debe de recibir del MHCP un $35 \%$ de las recaudaciones por el aprovechamiento forestal en su municipio. Sin embargo, la Alcaldía ha tenido problemas por no tener un control y conocimiento de las cantidades que deberían de recibir del MHCP por la madera que es extraída del municipio. Además, reciben las transferencias con retrasos y algunas veces incompletas. De acuerdo al dato de la transferencia para el 2004, la Alcaldía Municipal ha recibido aproximadamente un $22 \%$ y no el $35 \%$ establecido por ley. Es decir, que según estos datos, hace falta la tercera parte de la transferencia a la Alcaldía", Págs. 16 y 17. 
revisará y consultará cada año con la CONAFOR en los meses de septiembre y octubre para definir los precios del siguiente año calendario. El precio de referencia será únicamente utilizado para el establecimiento de los derechos de aprovechamiento.

La publicación de los precios o valores de referencia, mencionados en el Artículo 48 de la Ley, se hará una vez al año por el INAFOR durante el mes de septiembre y octubre, entrando en vigencia a partir del $1^{\circ}$ de noviembre del año en curso. En caso de no publicarse nuevos valores en la fecha establecida, continuarán en vigencia los del período anterior para el siguiente año.

\section{Transporte de productos forestales}

El Artículo 30 de la Ley 462 establece que para efectos del transporte por cualquier medio todos los productos forestales procedentes del aprovechamiento de bosque natural o plantaciones forestales deben contar con el certificado de origen que acredite su legalidad, el cual será emitido por el INAFOR y sin costo alguno. En el caso de que provenga de las Áreas Protegidas, la emisión del certificado le corresponderá al MARENA ${ }^{76}$.

Se prohíbe la circulación de vehículos que transportan madera en rollo y aserrada entre las 6 de la tarde y las 5 de la mañana ${ }^{77}$.

Los requisitos para el trasporte de recursos forestales son los siguientes:

\section{Transporte de madera en rollo}

- Guía forestal original de madera en rollo

- Certificado de origen

- Permiso de transporte

- Fotocopia de permiso forestal

\section{Transporte de madera procesada}

- Guía forestal original de madera procesada

- Fotocopia de guías de madera en rollo

- Certificado de origen

- Factura de aserrado o venta de madera

- Permiso de trasporte

- Lista de empaque o inventario detallado de las piezas

El transportista deberá tramitar un permiso para el transporte de la madera conforme la guía autorizada; esto deberá hacerlo ante las oficinas del INAFOR del respectivo Municipio. Las especies

76. La Ley 647, que reforma a la Ley 217, Ley General del Medio Ambiente y los Recursos Naturales, en su Artículo 7 que reforma el Artículo 17 de la Ley N²17, establece: "Art. 17... La protección de los recursos naturales del país es objeto de seguridad nacional, así como, de la más elevada responsabilidad y prioridad del Estado, dentro de ese espíritu en las áreas protegidas se establece veda para el recurso forestal total y permanente".

77. Artículo 115 de la Ley 431, Ley para el Régimen de Circulación Vehicular e Infracciones de Tránsito. 
no afectadas por la veda no podrán ser transportadas de 6 p.m. a 5 a.m. los días sábados, domingos y feriados. La madera que es transportada debe ir debidamente marcada con lo siguiente: № Guía Forestal, $\mathrm{N}^{\circ}$ Permiso de Aprovechamiento, $\mathrm{N}^{\circ}$ de Troza y Marca del beneficiario.

De acuerdo con disposiciones administrativas del INAFOR, las personas naturales y jurídicas que se dediquen al transporte de recursos forestales deberán reportar las guías de transporte en todas las Delegaciones Distritales, Municipales y Puestos de Control Forestal del INAFOR en todo el trayecto de la ruta y destino final del recurso forestal. En caso de no existir Delegación o Puesto de Control Forestal del INAFOR en la ruta, el transportista deberá reportarse y presentar las guías en la Unidad Militar del Ejército de Nicaragua o en su defecto, en la Estación Policial. El control se verificará colocando en la guía forestal el sello de la institución que corresponda, el nombre de la persona que controla y su cargo. Si las guías de transporte no reflejan estos controles, serán retenidas junto a la madera y los medios de transporte hasta que el transportista subsane la omisión.

\subsection{Diagrama legal-administrativo para que productos de madera de la región accedan a los mercados de los Estados Unidos y Unión Europea en el marco jurídico de la Lacey Act y el Plan de Acción FLEGT}

En Nicaragua, para poder exportar toda persona natural o jurídica debe estar inscrita como exportador en el Centro de Trámite de Exportaciones (CETREX). Los requisitos para inscribirse como exportador varían para persona natural y persona jurídica.

\section{Persona natural}

- Fotocopia del Registro Único de Contribuyentes (RUC)

- Constancia de contribuyente de la Dirección General de Ingresos (DGI)

- Registro de firmas

- Identificación de exportador y sus representantes, si los tiene

- Poder especial ante CETREX notariado para las agencias aduaneras

- Llenar hoja de solicitud de inscripción autenticada por un abogado

- Certificado CITES

- Constancia de certificación fitosanitaria y/o certificado de fumigación, si el país destino lo requiere

\section{Persona jurídica}

- Fotocopia del Registro Único de Contribuyentes (RUC)

- Constancia de contribuyente de la Dirección General de Ingresos (DGI)

- Registro de firmas

- Escritura de constitución original y fotocopia debidamente inscrita en el Registro Mercantil

- Poder general de administración debidamente inscrito en el Registro Mercantil 
- Las cooperativas deben presentar La Gaceta donde se les confiere la persona jurídica y documento del MITRAB que certifique la vigencia de la cooperativa

- Carta del presidente o gerente general autorizando firmas o personas encargadas de la empresa para realizar trámites cuando no envían agentes aduaneros

- Llenar hoja de solicitud de inscripción autenticada por un abogado

- Formulario Declaración de Mercancías de Exportación

- Factura de Exportación

- Certificado CITES

- Constancia de inspección del INAFOR

- Recibo fiscal y/o constancia de retención emitida por el aserrío de los impuestos de madera

- Constancia de certificación fitosanitaria y/o certificado de fumigación, si el país destino lo requiere

Para la exportación de Productos Forestales se debe presentar en el Centro de Trámites para las Exportaciones (CETREX) la siguiente documentación que, a su vez, es verificada por la Dirección General de Aduanas ubicadas en los puertos y puestos fronterizos del país:

- Formulario Declaración de Mercancías de Exportación

- Factura de exportación

- Permiso/Certificado CITES ${ }^{78}$

78. La Resolución Ministerial de MARENA 13-04-13 que, según nuestro entender, deroga tácita y no expresamente la Resolución Ministerial de MARENA 004-2007 establece que para obtener el permiso de exportación todo solicitante deberá:

- Estar registrado como exportador en el Departamento de CITES de MARENA conforme con las disposiciones contenidas en la Convención CITES y el Decreto 8-98, Normas y Procedimientos para la Exportación e Importación de Especies de Flora y Fauna Silvestre de Nicaragua.

- Presentar una solicitud por escrito ante la Oficina de Acceso a la Información Pública (OAIP) de MARENA, la cual deberá contener:

- $\quad$ Nombre y dirección del exportador

- $\quad$ Nombre y dirección del importador

- País importador

- $\quad$ Puerto de Salida en Nicaragua

- $\quad$ Puerto de Entrada del País de importador

- $\quad$ Nombre común y científico de la especie a exportar

- $\quad$ Cantidad de volumen a exportar expresada en metros cúbicos

- Dirección electrónica de contacto

- Teléfonos de contacto

Se deberán presentar los siguientes documentos en original y copia para conformar el debido expediente administrativo.

- $\quad$ Constancia de Inspección Técnica para la Exportación de madera del Instituto Nacional Forestal (INAFOR).

- $\quad$ Permiso de aprovechamiento forestal debidamente aprobado por INAFOR firmado y sellado.

- $\quad$ Las guías forestales autorizadas por INAFOR para el transporte de madera.

- $\quad$ Factura de venta para la exportación debidamente numerada con pie de imprenta fiscal.

- $\quad$ Según sea el caso, escritura pública de cesión de derecho de extracción de madera.

- $\quad$ Minuta de pago original y copia del permiso de exportación.

Recepcionada la solicitud, la Autoridad Administrativa CITES-NI verificará el cumplimiento de los requisitos señalados y demás obligaciones consignadas en la Convención CITES y el Decreto 8-98. 
- Constancia de inspección de INAFOR

- Recibo fiscal y/o constancia de retención emitida por el aserrío de los impuestos de madera

- Constancia de certificación fitosanitaria y/o certificado de fumigación, si el país destino lo requiere

\section{Proceso de exportación de madera en Nicaragua}

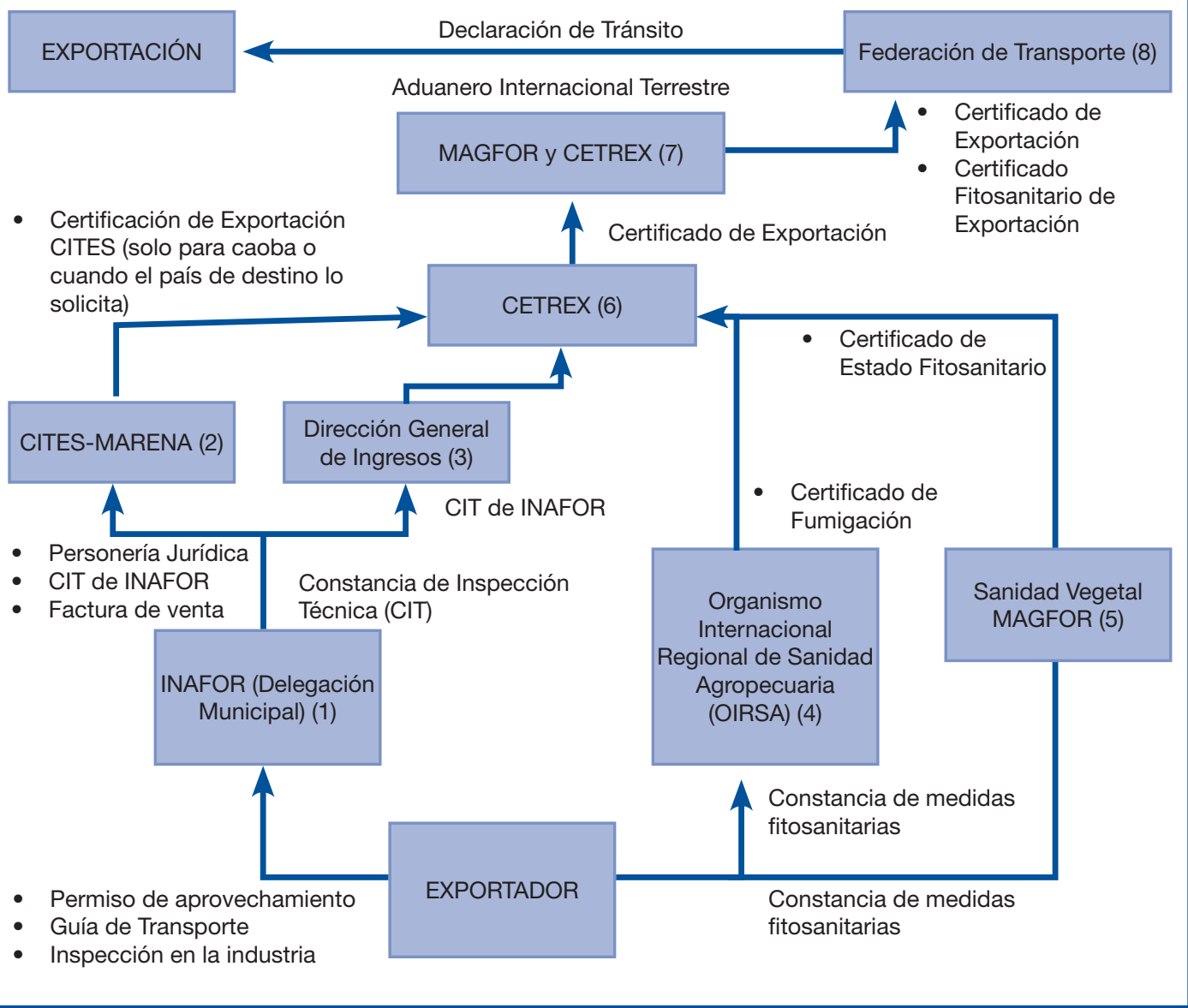

Fuente: GIZ. CEI. MASRENACE (2011)

En caso de incumplimiento de los requisitos establecidos, se concederá un plazo de tres días hábiles para que el interesado los complemente y aclare alguna observación realizada sobre la documentación presentada. Entregada la solicitud en debida forma y llenados los requisitos correspondientes, la Autoridad Administrativa CITES-NI otorgará el Permiso de Exportación en un plazo no mayor a ocho días laborales, previo pago del Permiso de Exportación, el cual deberá ser depositado en la cuenta que para tales efectos ha dispuesto la Tesorería General de la República, debiendo presentar copia para su debido cotejo de la minuta de depósito respectiva. En caso de que el permiso sea denegado, el interesado podrá interponer los recursos administrativos de conformidad con la Ley 290, Ley de Organización, Competencias y Procedimientos del Poder Ejecutivo.

79. GIZ, CEI, MASRENACE (2011). Fomento de la exportación de madera aserrada certifica a: Layasiksa y Las 
La Cooperación Alemana en Nicaragua (GTZ) y el Centro de Exportaciones e Inversiones (CEI) realizó un estudio de mercado para madera aserrada certificada en las comunidades indígenas de Layasiksa y Las Crucetas de la Región Autónoma del Atlántico Norte (RAAN) de Nicaragua, con el fin de mejorar la competitividad de los productores y prepararlos para el proceso de exportación e internacionalización de sus productos. Veamos a continuación los elementos relevantes del estudio y en particular las estadísticas de demanda interna y los requisitos para la exportación a países como Costa Rica, Estados Unidos e Italia.

El Estudio establece que el potencial comercial del sector en Nicaragua es de $120.000 .097 \mathrm{~m}^{3}$. Las exportaciones de madera aserrada en el año 2009 fueron de 4.869 .369 kg, equivalente a aproximadamente $10.820 \mathrm{~m}^{3}$. El potencial de exportación no utilizado fue de $119.989 .276 \mathrm{~m}^{3}$.

A nivel nacional, el área certificada FSC "pura" es de 10.579 ha y de madera controlada FSC (CW, por sus siglas en inglés) es de $80.173,88$ ha $^{80}$.

La demanda a nivel nacional de madera identificada por el estudio del CEI-GTZ es la siguiente.

El comportamiento del año 2009 en las exportaciones de madera fue asíi1:

- El producto de madera más exportado por Nicaragua es la madera aserrada (32\%).

- Las especies de madera aserrada más exportadas son nancitón (49\%) y cedro macho (47\%).

- Los principales mercados destino son, en orden de importancia: República Dominicana (29\%), Estados Unidos (17\%) y Honduras (16\%).

Crucetas. Managua. Pág. 32.

80. El Forest Stewardship Council o Consejo de Administración Forestal es una organización no gubernamental internacional con sede en Bonn, Alemania. Fue creada en 1993 con el objetivo de promover una gestión forestal ambientalmente responsable, socialmente beneficiosa y económicamente viable en los bosques de todo el mundo. A través de procesos consultivos, la FSC desarrolla estándares y políticas para el manejo sostenible de los bosques, además de acreditar entidades certificadoras para evaluar a los candidatos a la certificación forestal. El FSC (Consejo Administrativo Forestal) establece dos tipos de certificaciones: a) FSC Chain of Custody (CoC) y b) FSC Controlled Wood (CW). El Primero (FSC CoC), rastrea el producto certificado a través de todo el proceso de producción, desde el bosque hasta el consumidor final, incluyendo todas las etapas sucesivas del proceso, la transformación, la fabricación y la distribución. La segunda certificación (FSC CW) permite a los productores combinar madera certificada con madera no certificada, la cual debe cumplir los requerimientos de Madera Controlada del FSC, entre ellas, no provenir de las siguientes fuentes: 1) madera cosechada ilegalmente, 2) madera cosechada en violación a los derechos tradicionales y civiles, 3) madera cosechada en bosques en los que sus altos valores de conservación (áreas protegidas) se vean amenazados con las actividades de manejo, etc. La madera controlada (FSC CW) debe ser verificada independientemente antes de ser mezclada con la madera certificada para convertirse en parte de un mismo producto que se pueda vender llevando la etiqueta o sello del FSC. Fomento de la exportación de madera aserrada certificada Layasiksa y Las Crucetas. GIZ, CEI, MASRENACE, Managua, 2011, Pág. 6.

81. GIZ, CEI, MASRENACE (2011). Fomento de la exportación de madera aserrada certificada: Layasiksa y Las Crucetas. Managua, Pág. 13 y 20. 
El estudio señala las importaciones centroamericanas de madera aserrada, relación valor-volumen.

Importaciones centroamericanas de madera aserrada, relación valor-volumen ${ }^{82}$

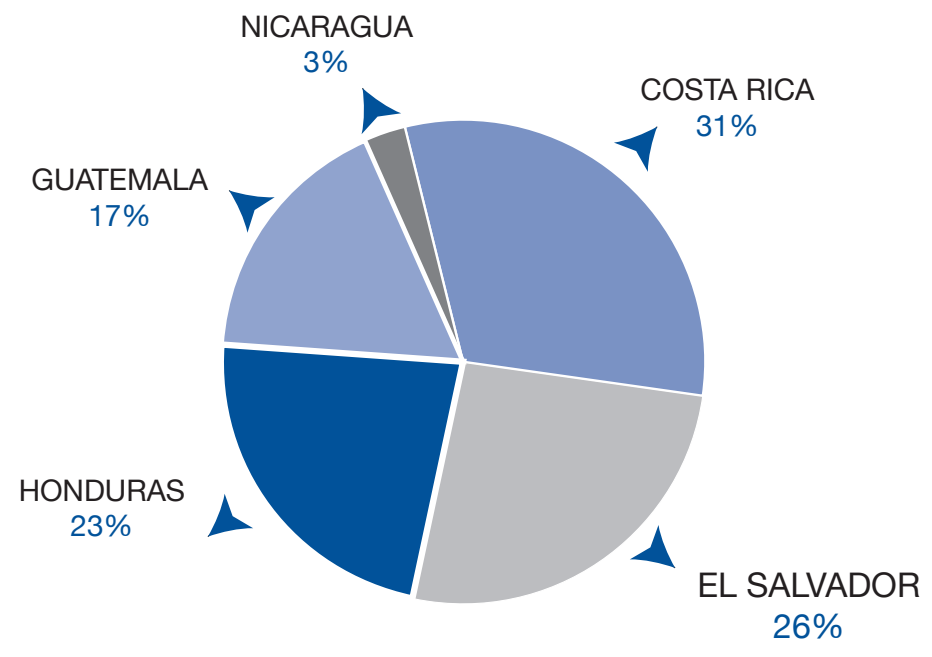

Importaciones centroamericanas de madera aserrada:

US 32,481

Fuente: GIZ. CEI. MASRENACE. 2011

\begin{tabular}{|l|c|c|c|}
\hline \multicolumn{1}{|c|}{ País importador } & $\begin{array}{c}\text { Valor 2009 } \\
\text { miles USD }\end{array}$ & Cantidad 2009 Tons. & (USD/unidad) \\
\hline Centroamérica & $\mathbf{3 2 . 4 8 1}$ & $\mathbf{6 7 . 7 3 2}$ & $\mathbf{4 8 0}$ \\
\hline Costa Rica & 10.154 & 15.745 & 645 \\
\hline El Salvador & 8.319 & 23.026 & 361 \\
\hline Honduras & 7.566 & 16.611 & 455 \\
\hline Guatemala & 5.357 & 9.757 & 549 \\
\hline Nicaragua & 1.085 & 2.593 & 418 \\
\hline
\end{tabular}

82. GIZ, CEI, MASRENACE (2011). Fomento de la exportación de madera aserrada certificada: Layasiksa y Las Crucetas. Managua, Pág. 21. Fuente: Trademap. 
De acuerdo a este estudio los requisitos para exportar madera a los siguientes países son los siguientes.

\section{Requisitos para exportación a Costa Rica}

Según el estudio, este país paga el mejor precio de madera aserrada en Centroamérica. Los requisitos de acceso son los siguientes:

- Arancel: 0\% por el Tratado de Integración Centroamericana

- Requisitos no Arancelarios

Los documentos a presentar para exportar madera a nivel interregional en Centroamérica, con base en el Acuerdo de Integración Centroamericana y la Unión Aduanera Centroamericana, son:

- Formulario Aduanero Único Centroamericano (FAUCA)

- Constancia de certificación fitosanitaria y/o fumigación

- Factura de exportación

- Certificado CITES (Caoba)

- Constancia de inspección técnica para la exportación de INAFOR, el cual verifica el producto en los aserríos

- Recibo fiscal y/o constancia de retención emitida por el aserrío de los impuestos de madera

\section{Requisitos para exportación a Estados Unidos}

Para exportar a Estados Unidos Nicaragua goza de un arancel de $0 \%$ por el CAFTA. Es requisito no arancelario el Certificado Convención sobre el Comercio Internacional de Especies Amenazadas de Fauna y Flora Silvestres (CITES).

Es requisito fitosanitario que la madera sea tratada con calor $\left(56{ }^{\circ} \mathrm{C} \times 30 \mathrm{~min}\right.$.) o productos químicos (bromuro metílico). El tratamiento químico es el método más usado para los productos de madera. Si se usan conservantes, estos deben ser aprobados por la Agencia de Protección Ambiental de EE.UU. (Environmental Protection Agency [EPA]).

El requisito de importación de Material de Empaque de Madera tiene que llevar el logo visible (WPM, por sus siglas en inglés). El importador de Estados Unidos debe contar con un permiso de importación (permiso PPQ forma 585), así como cumplir con los estándares de calidad establecidos por la Asociación Nacional de Madera Aserrada (National Hardwood Lumber Association (NHLA), que vela por el cumplimiento de las normas de calidad en la madera aserrada. La norma de la NHLA establece las categorías de clasificación para la madera aserrada ${ }^{83}$.

83. GIZ, CEI, MASRENACE. 'Fomento de la exportación de madera aserrada certificada: Layasiksa y Las Crucetas'. [presentación online], (marzo de 2011). <http://www.nhla.com/pdf/NHLA\%20Spanish\%20 Rule\%20Book.pdf>. Accedido el 31 de marzo de 2014. 
La documentación comúnmente requerida para las importaciones a Estados Unidos es la siguiente:

- Conocimiento de embarque: Describe las condiciones bajo las cuales el transportador acepta las mercancías y detalla la naturaleza y cantidad de las mercancías, el nombre del vehículo de transporte, marcas y números de identificación y el destino.

- Especificaciones de embalaje: Cantidad y tipo de artículos transportados.

- Certificado fitosanitario.

- Factura: Deberá mencionar las direcciones del sitio de origen y del destino final, producto transportado, cantidad, valor monetario y razón de embarque.

\section{Requisitos para exportación a Italia}

Italia es el país, de acuerdo con el estudio, principal importador de madera aserrada de la Unión Europea $^{84}$. Los requisitos de acceso son los siguientes:

El arancel establecido es de 0\% (SGP). Ya en el país es aplicable el Impuesto de valor agregado (20\%) para el ingreso de madera al mercado de Italia.

Los requisitos no arancelarios que establece el Comité Europeo de Normalización (CEN), a través de la Directiva 89/106/EEC (The Construction Product Directive) que establece los requerimientos esenciales, son:

- Resistencia Mecánica

- Seguridad en caso de incendio

- Higiene, salud y protección ambiental

- Seguridad en su uso

- Protección contra el ruido

- Ahorro de energía

- Retención de calor

En lo relativo a sustancias tóxicas, se debe cumplir la Directiva 76/769/EEC y la Directiva 2001/90/ EC ${ }^{85}$ y en lo relativo a certificación fitosanitaria, la Directiva 2000/29/CE ${ }^{86}$.

84. A través del Sistema Generalizado de Preferencias (en adelante SGP) que la UE aplica a la madera de las especies en estudio (pino, cedro macho y nancitón) provenientes de Nicaragua, el arancel de importación es de $0 \%$. Cada uno de los países de la Unión Europea tiene sus requisitos adicionales.

85. Consejo de las Comunidades Europeas. 'Directiva del Consejo de 27 de julio de 1976 relativa a la aproximación de las disposiciones legales, reglamentarias y administrativas de los Estados miembros que limitan la comercialización y el uso de determinadas sustancias y preparados peligrosos'. [pdf online]. <http://eurlex.europa.eu/LexUriServ/LexUriServ.do?uri=CONSLEG:1976L0769:20081211:ES:PDF>. Accedido el 31 de marzo de 2014.

86. Consejo de la Unión Europea. 'Directiva 2000/29/CE del Consejo de 8 de mayo de 2000 relativa a las medidas de protección contra la introducción en la Comunidad de organismos nocivos para los vegetales o productos vegetales y contra su propagación en el interior de la Comunidad'. [pdf online]. <http://eur-lex. europa.eu/LexUriServ/LexUriServ.do?uri=OJ:L:2000:169:0001:0112:ES:PDF>. Accedido el 31 de marzo de 2014. 
El ente Nazionale Italiano di Unificazione otorga los estándares generales de acuerdo con el producto. Los compradores esperan siempre materiales (madera) de excelente calidad, lo que incluye un buen sistema de secado al horno, libre de parásitos, agrietados, partidos y de árboles ya maduros de bosques manejados ecológicamente y con sostenibilidad. Se establece de previo el tratamiento que deberá tener la madera al ingresar a la Unión Europea.

Otras certificaciones: Leyes Forestales, Gobernanza y Exportación (Forest Law Enforcement Governance and Trade [FLEGT]), una iniciativa de la Unión Europea establecida en el año 2003 y que inició su desarrollo en el año 2005, dirigida a todos los países que exportan madera a la UE. El propósito de la implementación de dicho sistema es responder al problema de la tala ilegal en los bosques de todo el planeta. A través de los Acuerdos Voluntarios de Asociación (AVA) los países firman acuerdos bilaterales con los países de la Unión Europea. Para el mercado italiano es necesario tener en cuenta la certificación ICMQ, que respalda que la madera y sus productos son recomendables para utilizarse en la industria de la construcción en dicho mercado.

\subsection{Análisis de estadísticas de los últimos cinco años provenientes de la Administración Forestal, Fitosanitaria y Aduanal}

A partir de la entrada en vigencia de la Ley 585, Ley de Veda para el Corte, Aprovechamiento y Comercialización del Recurso Forestal, se prohíbe la exportación de madera en: rollo, timber, aserrada de cualquier especie forestal que provenga de bosques naturales.

De acuerdo con las estadísticas proporcionadas por INAFOR de los años 2008-2012, se otorgaron los siguientes permisos de aprovechamiento forestal ${ }^{87}$.

\begin{tabular}{|c|c|c|c|}
\hline Año & Permisos & $\mathbf{N}^{\circ}$ de árboles & $\mathbf{m}^{3}$ autorizados \\
\hline 2008 & 1.395 & 375.465 & 747.901 .330 \\
\hline 2009 & 1.082 & 236.493 & $203.619,26$ \\
\hline 2010 & 1.101 & 333.160 & $262.725,12$ \\
\hline 2011 & 1.268 & 236.333 & $257.773,86$ \\
\hline 2012 & 1.250 & 272.596 & $168.080,73$ \\
\hline
\end{tabular}

\section{Fuente propia}

Se debe mencionar que cada una de las instituciones con competencias en el sector forestal lleva sus registros estadísticos. Sin embargo, no podemos decir que existe un registro único relacionado con los permisos de corte, transporte y exportación de madera. Esta falta de control cruzado se subsana, según los funcionarios entrevistados, con la coordinación que existe entre los diversos actores institucionales.

87. Datos consolidados de los informes anuales proporcionados por INAFOR. 
Veamos a continuación las estadísticas que presentan el Centro de Trámites de las Exportaciones (CETREX) para los años 2008 a septiembre de 2013, la Dirección General de Aduanas para el año 2010 y la Autoridad Administrativa de CITES del Ministerio del Ambiente y los Recursos Naturales sobre las exportaciones para los años 2007 a 2011.

\begin{tabular}{|c|c|c|c|c|c|c|c|c|c|c|c|}
\hline \multicolumn{12}{|c|}{$\begin{array}{l}\text { Centro de Trámites de las Exportaciones (CETREX) } \\
\text { Exportaciones autorizadas de los } 20 \text { principales productos }\end{array}$} \\
\hline \multicolumn{12}{|c|}{ PERÍODO: ENERO-DICIEMBRE 2008-200988 } \\
\hline \multirow[b]{2}{*}{ 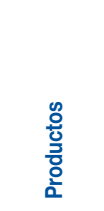 } & \multicolumn{2}{|c|}{ Enero-Diciembre 2008} & \multicolumn{2}{|c|}{ Enero-Diciembre 2009} & \multicolumn{4}{|c|}{ Variación 2008-2009 } & \multicolumn{2}{|c|}{$\begin{array}{l}\text { Precio Prom } \\
\text { (\$/KG) }\end{array}$} & $\begin{array}{l}\% \\
\text { Variación } \\
\text { Precio }\end{array}$ \\
\hline & $\begin{array}{l}\text { Peso } \\
\text { Bruto } \\
\text { (KG) }\end{array}$ & $\begin{array}{l}\text { Valor } \\
\text { Fob } \\
\text { (US\$) }\end{array}$ & $\begin{array}{l}\text { Peso } \\
\text { Bruto } \\
\text { (KG) }\end{array}$ & $\begin{array}{l}\text { Valor Fob } \\
\text { (US\$) }\end{array}$ & $\begin{array}{l}\text { Peso } \\
\text { Bruto } \\
\text { (KG) }\end{array}$ & $\%$ & $\begin{array}{l}\text { Valor } \\
\text { Fob } \\
\text { (US\$) }\end{array}$ & $\%$ & 2008 & 2009 & $\begin{array}{l}2008- \\
2009\end{array}$ \\
\hline $\begin{array}{l}\text { Madera } \\
\text { aserrada }\end{array}$ & $984.952,75$ & $633,259.22$ & $3.024 .947,54$ & $961,267.54$ & $2.039 .994,79$ & 2,07 & $328,008.32$ & 0,52 & 0,64 & 0,32 & $-50,57$ \\
\hline $\begin{array}{l}\text { Madera en } \\
\text { bruto }\end{array}$ & 0,00 & 0.00 & $37.536,01$ & $8,300.00$ & $37.536,01$ & & $8,300.00$ & & & 0,22 & \\
\hline $\begin{array}{l}\text { Madera } \\
\text { procesada }\end{array}$ & $4.160 .516,55$ & $1,390,590.34$ & $3.907 .029,90$ & $1,347,418.21$ & $-253.486,65$ & $-0,06$ & $-43.172,13$ & $-0,03$ & 0,33 & 0,34 & 3,18 \\
\hline $\begin{array}{l}\text { Productos } \\
\text { de madera }\end{array}$ & $3.418 .262,10$ & $2,928,529.51$ & $3.454 .896,14$ & $2,490,709.24$ & $36.634,04$ & 0,01 & -437.820 .27 & $-0,15$ & 0,86 & 0,72 & $-15,85$ \\
\hline
\end{tabular}

\section{Centro de Trámites de las Exportaciones (CETREX) Exportaciones autorizadas de productos}

\begin{tabular}{|c|c|c|c|c|c|c|c|c|c|c|c|}
\hline \multicolumn{12}{|c|}{ PERÍODO: ENERO-DICIEMBRE 2009-201089 } \\
\hline \multirow[b]{2}{*}{ 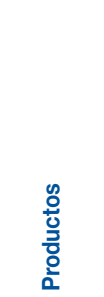 } & \multicolumn{2}{|c|}{ Enero-Diciembre 2009} & \multicolumn{2}{|c|}{ Enero-Diciembre 2010} & \multicolumn{4}{|c|}{ Variación 2009-2010 } & \multicolumn{2}{|c|}{$\begin{array}{l}\text { Precio Prom } \\
\text { (\$/KG) }\end{array}$} & \multirow{2}{*}{$\begin{array}{l}\% \\
\begin{array}{l}\text { Varia- } \\
\text { ción } \\
\text { Pre- } \\
\text { cio }\end{array} \\
2009- \\
2010\end{array}$} \\
\hline & $\begin{array}{l}\text { Peso } \\
\text { Bruto } \\
\text { (KG) }\end{array}$ & $\begin{array}{l}\text { Valor Fob } \\
\text { (US\$) }\end{array}$ & $\begin{array}{l}\text { Peso Bruto } \\
\text { (KG) }\end{array}$ & $\begin{array}{l}\text { Valor Fob } \\
\text { (US\$) }\end{array}$ & $\begin{array}{l}\text { Peso } \\
\text { Bruto } \\
\text { (KG) }\end{array}$ & $\%$ & $\begin{array}{l}\text { Valor Fob } \\
\text { (US\$) }\end{array}$ & $\%$ & 2009 & 2010 & \\
\hline $\begin{array}{l}\text { Madera } \\
\text { aserrada }\end{array}$ & $3.024 .947,54$ & $961,267.54$ & $7.444 .854,60$ & $3,037,272.04$ & $4.419 .907,06$ & 1,46 & $2,076,004.50$ & 2,16 & 0,32 & 0,41 & 28,38 \\
\hline $\begin{array}{l}\text { Madera en } \\
\text { bruto }\end{array}$ & $37.536,01$ & $8,300.00$ & 0,00 & 0.00 & $-37.536,01$ & $-1,00$ & $-8,300.00$ & $-1,00$ & 0,22 & & $-100,00$ \\
\hline $\begin{array}{l}\text { Madera } \\
\text { procesada }\end{array}$ & $3.907 .029,90$ & $1,347,418.21$ & $11.192 .716,70$ & $3,847,431.94$ & $7.285 .686,80$ & 1,86 & $2,500,013.73$ & 1,86 & 0,34 & 0,34 & $-0,33$ \\
\hline $\begin{array}{l}\text { Productos } \\
\text { de madera }\end{array}$ & $3.434 .395,15$ & $2,481,969.24$ & $5.337 .034,94$ & $4,447,529.99$ & $1.902 .639,79$ & 0,55 & $1,965,560.75$ & 0.79 & 0,72 & 0,83 & 15,31 \\
\hline
\end{tabular}

88. Centro de Trámites de las Exportaciones (CETREX). 'Exportaciones autorizadas de los 20 principales productos. Período enero-diciembre 2008-2009'. [tabla]. <http://www.cetrex.gob.ni/website/servicios/ tproduc09.jsp>. Accedido el 31 de marzo de 2014.

89. Centro de Trámites de las Exportaciones (CETREX). 'Exportaciones autorizadas de productos. Período enero-diciembre 2009-2010'. [tabla]. <http://www.cetrex.gob.ni/website/servicios/tproduc10.jsp>. Accedido el 31 de marzo de 2014. 


\section{Centro de Trámites de las Exportaciones (CETREX) Exportaciones autorizadas de productos}

\begin{tabular}{|c|c|c|c|c|c|c|c|c|c|c|c|}
\hline \multicolumn{12}{|c|}{ PERIODO: ENERO-DICIEMBRE 2010-201190 } \\
\hline \multirow{2}{*}{ 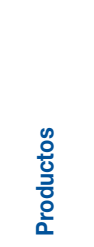 } & \multicolumn{2}{|c|}{ Enero-Diciembre 2010} & \multicolumn{2}{|c|}{ Enero-Diciembre 2011} & \multicolumn{4}{|c|}{ Variación 2010-2011 } & \multicolumn{2}{|c|}{$\begin{array}{l}\text { Precio Prom } \\
\text { (\$/KG) }\end{array}$} & \multirow{2}{*}{$\begin{array}{l}\% \\
\begin{array}{l}\text { Varia- } \\
\text { ción } \\
\text { Precio }\end{array} \\
2010- \\
2011\end{array}$} \\
\hline & $\begin{array}{l}\text { Peso } \\
\text { Bruto } \\
\text { (KG) }\end{array}$ & $\begin{array}{l}\text { Valor } \\
\text { Fob(US\$) }\end{array}$ & $\begin{array}{l}\text { Peso } \\
\text { Bruto } \\
\text { (KG) }\end{array}$ & $\begin{array}{l}\text { Valor } \\
\text { Fob } \\
\text { (US\$) }\end{array}$ & $\begin{array}{l}\text { Peso } \\
\text { Bruto } \\
\text { (KG) }\end{array}$ & $\%$ & $\begin{array}{l}\text { Valor } \\
\text { Fob } \\
\text { (US\$) }\end{array}$ & $\%$ & 2010 & 2011 & \\
\hline $\begin{array}{l}\text { Madera } \\
\text { aserrada }\end{array}$ & $7.444 .854,60$ & $3,037,272.04$ & $13.927 .796,09$ & $6,415,045.81$ & $6.482 .941,49$ & 0,87 & $3,377,773.77$ & 1,11 & 0,41 & 0,46 & 12,90 \\
\hline $\begin{array}{l}\text { Madera en } \\
\text { bruto }\end{array}$ & & & $68.275,50$ & $35,304.46$ & $68.275,50$ & & $35,304.46$ & & & 0,52 & \\
\hline $\begin{array}{l}\text { Madera } \\
\text { procesada }\end{array}$ & $11.192 .716,70$ & $3,847,431.94$ & $14.786 .282,42$ & $5,214,250.69$ & $3.593 .565,72$ & 0,32 & $1,366,818.75$ & 0,36 & 0,34 & 0,35 & 2,59 \\
\hline $\begin{array}{l}\text { Productos } \\
\text { de madera }\end{array}$ & $5.336 .404,94$ & $4,447,169.99$ & $6.371 .926,66$ & $4,512,822.60$ & $1.035 .521,72$ & 0,19 & $65,652.61$ & 0,01 & 0,83 & 0,71 & $-15,01$ \\
\hline
\end{tabular}

\section{Centro de Trámites de las Exportaciones (CETREX) Exportaciones autorizadas de productos}

\section{PERIODO: ENERO-DICIEMBRE 2011-201291}

\begin{tabular}{|c|c|c|c|c|c|c|c|c|c|c|c|}
\hline \multirow{2}{*}{ 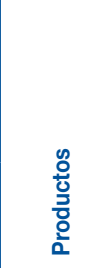 } & \multicolumn{2}{|c|}{ Enero-Diciembre 2011} & \multicolumn{2}{|c|}{$\begin{array}{l}\text { Enero-Diciembre } \\
2012\end{array}$} & \multicolumn{4}{|c|}{ Variación 2011-2012 } & \multicolumn{2}{|c|}{$\begin{array}{l}\text { Precio } \\
\text { Prom }(\$ / K G)\end{array}$} & \multirow{2}{*}{$\begin{array}{l}\% \\
\begin{array}{l}\text { Varia- } \\
\text { ción } \\
\text { Pre- } \\
\text { cio }\end{array} \\
2011- \\
2012\end{array}$} \\
\hline & $\begin{array}{l}\text { Peso } \\
\text { Bruto } \\
\text { (KG) }\end{array}$ & $\begin{array}{l}\text { Valor Fob } \\
\text { (US\$) }\end{array}$ & $\begin{array}{l}\text { Peso } \\
\text { Bruto } \\
\text { (KG) }\end{array}$ & $\begin{array}{l}\text { Valor Fob } \\
\text { (US\$) }\end{array}$ & $\begin{array}{l}\text { Peso } \\
\text { Bruto } \\
\text { (KG) }\end{array}$ & $\%$ & $\begin{array}{l}\text { Valor } \\
\text { Fob } \\
\text { (US\$) }\end{array}$ & $\%$ & $2,011.00$ & $2,012.00$ & \\
\hline $\begin{array}{l}\text { Madera } \\
\text { aserrada }\end{array}$ & $7.524 .697,06$ & $3,740,666.94$ & $4.750 .276,41$ & $2,921,293.87$ & $-2.774 .420,65$ & $-0,37$ & $-819,373.07$ & $-0,22$ & 0,50 & 0,61 & 23,71 \\
\hline $\begin{array}{l}\text { Madera en } \\
\text { bruto }\end{array}$ & $68.275,50$ & $35,304.46$ & $25.436,25$ & $20,316.00$ & $-42.839,25$ & $-0,63$ & $-14,988.46$ & $-0,42$ & 0,52 & 0,80 & 54,46 \\
\hline $\begin{array}{l}\text { Madera } \\
\text { procesada }\end{array}$ & 21.171.199,04 & $7,884,805.11$ & $16.049 .576,84$ & $7,369,255.10$ & $-5.121 .622,20$ & $-0,24$ & $-515,550.01$ & $-0,07$ & 0,37 & 0,46 & 23,29 \\
\hline $\begin{array}{l}\text { Productos } \\
\text { de madera }\end{array}$ & $6.368 .327,29$ & $4,495,133.08$ & $3.241 .748,76$ & $5,859,440.11$ & $-3.126 .578,53$ & $-0,49$ & $1,364,307.03$ & 0,30 & 0,71 & 1,81 & 156,07 \\
\hline
\end{tabular}

90. Centro de Trámites de las Exportaciones (CETREX). 'Exportaciones autorizadas de productos. Período enero-diciembre 2010-2011'. [tabla]. http://www.cetrex.gob.ni/website/servicios/tproduc11.jsp

91. Centro de Trámites de las Exportaciones (CETREX). 'Exportaciones autorizadas de productos. Período enero-diciembre 2011-2012'. [tabla]. <http://www.cetrex.gob.ni/website/servicios/tproduc12.html>. Accedido el 31 de marzo de 2014. 


\begin{tabular}{|c|c|c|c|c|c|c|c|c|c|c|c|}
\hline \multicolumn{12}{|c|}{$\begin{array}{c}\text { Centro de Trámites de las Exportaciones (CETREX) } \\
\text { Exportaciones autorizadas por productos }\end{array}$} \\
\hline \multicolumn{12}{|c|}{ PERIODO: ENERO-DICIEMBRE 2012-201392 } \\
\hline \multirow[b]{2}{*}{$\begin{array}{l}\stackrel{0}{0} \\
\frac{0}{0} \\
\text { 옴 }\end{array}$} & \multicolumn{2}{|c|}{$\begin{array}{l}\text { Enero-Diciembre } \\
2012\end{array}$} & \multicolumn{2}{|c|}{$\begin{array}{l}\text { Enero-Diciembre } \\
2013\end{array}$} & \multicolumn{4}{|c|}{$\begin{array}{l}\text { Variación } \\
2012-2013\end{array}$} & \multicolumn{2}{|c|}{ 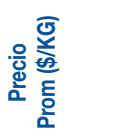 } & \multirow{2}{*}{ 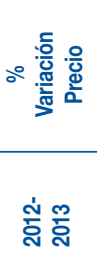 } \\
\hline & $\begin{array}{l}\text { Peso Bruto } \\
\text { (KG) }\end{array}$ & $\begin{array}{l}\text { Valor } \\
\text { Fob } \\
\text { (US\$) }\end{array}$ & $\begin{array}{l}\text { Peso Bruto } \\
\text { (KG) }\end{array}$ & $\begin{array}{l}\text { Valor Fob } \\
\text { (US\$) }\end{array}$ & $\begin{array}{l}\text { Peso Bruto } \\
\text { (KG) }\end{array}$ & $\%$ & $\begin{array}{l}\text { Valor Fob } \\
\text { (US\$) }\end{array}$ & $\%$ & $\begin{array}{l}8 \\
\text { N̦ } \\
\text { N }\end{array}$ & $\begin{array}{l}8 \\
\text { j. } \\
\text { o }\end{array}$ & \\
\hline $\begin{array}{l}\text { Madera } \\
\text { aserrada }\end{array}$ & $4.750 .276,41$ & $2,921,293.87$ & $3.496 .707,72$ & $2,249,398.46$ & $-1.253 .568,69$ & $-0,26$ & $-671,895.41$ & $-0,23$ & 0,61 & 0,64 & 4,60 \\
\hline $\begin{array}{l}\text { Madera en } \\
\text { bruto }\end{array}$ & $25.436,25$ & $20,316.00$ & $34.619,83$ & $5,195.27$ & $9.183,58$ & 0,36 & $-15,120.73$ & $-0,74$ & 0,80 & 0,15 & $-81,21$ \\
\hline $\begin{array}{l}\text { Madera } \\
\text { procesada }\end{array}$ & $16.049 .576,84$ & $7,369,255.10$ & $10.649 .546,41$ & $8,707,617.18$ & $-5.400 .030,43$ & $-0,34$ & $1,338,362.08$ & 0,18 & 0,46 & 0,82 & 78,08 \\
\hline $\begin{array}{l}\text { Productos } \\
\text { de madera }\end{array}$ & $3.218 .493,76$ & $5,856,780.11$ & $4.728 .114,22$ & $7,351,760.03$ & $1.509 .620,46$ & 0.47 & $1,494,979.92$ & 0,26 & 1,82 & 1,55 & $-14,55$ \\
\hline
\end{tabular}

\section{Dirección General de Aduanas}

Exportaciones de productos de madera del año $2010^{93}$

\begin{tabular}{|l|c|c|}
\hline \multicolumn{1}{|c|}{ PRODUCTO } & MILES KG & VALOR FOB MILES U\$ \\
\hline Carbón & 605.2 & 127.9 \\
\hline Pino sin aserrar & 324.7 & 121.2 \\
\hline Pino aserrado & 317.9 & 79.2 \\
\hline Caoba & 40.3 & 19.1 \\
\hline Aserradas, otras & $15,305.1$ & $7,418.3$ \\
\hline Madera procesada y & $8,676.5$ & $5,833.60$ \\
Prod. de madera, no muebles & & 731.6 \\
\hline Muebles de madera & 315.8 & \\
\hline
\end{tabular}

Fuente: CEl con datos de la Dirección General de Aduanas (DGA).

92. Centro de Trámites de las Exportaciones (CETREX). 'Exportaciones autorizadas de productos. Período enero-diciembre 2012-2013'. [tabla]. <http://www.cetrex.gob.ni/website/servicios/tproduc13.html>. Accedido el 31 de marzo de 2014.

93. GIZ, CEI, MASRENACE (2011). Fomento de la exportación de madera aserrada certificada: Layasiksa y Las Crucetas. Managua, Pág. 17. 


\section{Oficina de CITES, MARENA}

\section{Consolidados de exportaciones realizadas del año 2007-2011}

\begin{tabular}{|c|c|c|c|c|c|c|c|}
\hline \multirow{2}{*}{ CONCEPTO } & \multicolumn{5}{|c|}{ Año } & \multirow{2}{*}{ Total } & \multirow{2}{*}{ Observaciones } \\
\hline & 2007 & 2008 & 2009 & 2010 & 2011 & & \\
\hline Caoba $\left(\mathrm{m}^{3}\right)$ & $1.388,71$ & $1.359,37$ & 799,49 & 710,74 & 219,1 & $4.477,41$ & $\begin{array}{l}\text { Exportación de madera en } \\
\text { segunda transformación y } \\
\text { proveniente de planes de } \\
\text { manejo del Huracán Félix }\end{array}$ \\
\hline Nambaro $\left(\mathrm{m}^{3}\right)$ & - & & - & 48,43 & 66,1 & 114,5 & \\
\hline \multirow[t]{2}{*}{ Bambú } & - & - & - & 10.000 & - & 10.000 & Plantas \\
\hline & - & - & - & 40 & - & 40 & $\mathrm{~m}^{3}$ \\
\hline Cactos & - & - & - & 25 & - & 25 & $\mathrm{~kg}$ de hojas \\
\hline
\end{tabular}

\subsection{Incentivos y facilitación a la actividad forestal}

Serán beneficiarios de los incentivos las personas naturales o jurídicas que realicen inversiones en bosques naturales y plantaciones forestales, por sí mismos o por terceros, en predios propios o ajenos y que cumplan con los requisitos de registro que se establecen en el reglamento correspondiente ${ }^{94}$.

Los siguientes beneficios fiscales ${ }^{95}$ para la actividad forestal se extienden hasta el 31 de diciembre del año 2023:

1. Gozarán de la exoneración del pago del cincuenta por ciento (50\%) del Impuesto Municipal sobre Ventas y del cincuenta por ciento (50\%) sobre las utilidades derivadas del aprovechamiento aquellas plantaciones registradas ante la entidad reguladora.

2. Se exonera del pago de Impuesto de Bienes Inmuebles a las áreas de las propiedades en donde se establezcan plantaciones forestales y las áreas donde se realice manejo forestal a través de un Plan de Manejo Forestal.

3. Las empresas de cualquier giro de negocios que inviertan en plantaciones forestales podrán deducir como gasto $50 \%$ del monto invertido para fines del IR.

4. Se exonera del pago de derechos e impuesto a la importación a las empresas de Segunda Transformación y Tercera Transformación que importen maquinaria, equipos y accesorios que mejore su nivel tecnológico en el procesamiento de la madera, excluyendo los aserríos.

5. Todas las instituciones del Estado deberán priorizar en sus contrataciones la adquisición de bienes elaborados con madera que tienen el debido certificado forestal del Instituto Nacional Forestal,

94. Artículo 296, inciso 4 de la Ley 822, Ley de Concertación Tributaria derogó el Artículo 38 de la Ley 462, Ley de Conservación, Fomento y Desarrollo Sostenible del Sector Forestal.

95. El Artículo 314 de la Ley 822 establece una vigencia temporal de los incentivos forestales. Las inversiones forestales aprobadas conforme la Ley $N^{\circ} 462$, Ley de Conservación, Fomento y Desarrollo Sostenible del Sector Forestal, publicada en La Gaceta, Diario Oficial № 168 del 4 de septiembre del año 2003, continuarán siendo beneficiadas con los incentivos fiscales hasta la fecha en que se acojan los nuevos incentivos fiscales establecidos en el Artículo 283 de esta Ley. 
pudiendo reconocer hasta $5 \%$ en la diferencia de precios dentro de la licitación o concurso de compras.

6. Todas las personas naturales y jurídicas podrán deducirse hasta $100 \%$ del pago de IR cuando este sea destinado a la promoción de reforestación o creación de plantaciones forestales. A efectos de esta deducción, de previo el contribuyente deberá presentar su iniciativa forestal ante el Instituto Nacional Forestal ${ }^{96}$.

En el año 2008 el MAGFOR publicó el Manual de Incentivos para el Desarrollo de Inversiones Forestales Sostenibles, el cual explica el marco de ley, procedimientos administrativos y las rutas críticas que las personas naturales o jurídicas que realicen o realizarán inversiones en el sector forestal deben cumplir ${ }^{97}$.

Otros mecanismos estatales identificados en el tema de incentivos son los implementados por el MAGFOR a través del mandato de la Ley 765, el Fondo Forestal creado en la Ley 462 y el Banco Produzcamos creado en la Ley 640.

\section{a. Ley $\quad N^{\circ} 765$, Ley de Fomento a la Producción Agroecológica u Orgánica}

Este ley tiene como objetivo proteger y restaurar la integridad de los ecosistemas, la diversidad biológica y los procesos naturales que sustenten la vida y lograr el Bien Común de la Madre Tierra y de la Humanidad. Esta ley le otorga al Ministerio Agropecuario y Forestal la competencia de formular políticas y programas enfocados al fomento y promoción de la producción agroecológica y/o orgánica, y coordinar con las instancias correspondientes la promoción de la capacitación y formación a todos los niveles en materia de producción agroecológica y/o orgánica, entre otras.

\section{b. Fondo Nacional de Desarrollo Forestal (FONADEFO) ${ }^{98}$}

El FONADEFO es un ente descentralizado adscrito al INAFOR, creado por la Ley 462, Ley de Conservación, Fomento y Desarrollo Sostenible del Sector Forestal. Representa uno de los componentes forestales del Programa Sectorial de Desarrollo Rural Productivo (PRORURAL) y es manejado por un Comité que ocupa la posición más alta en su organigrama, compuesto por un funcionario de las siguientes entidades: Ministro Agropecuario y Forestal (MAGFOR), Ministro de Hacienda y Crédito Público (MHCP), Ministro del Ambiente y los Recursos Naturales (MARENA), Director Ejecutivo Instituto Nacional Forestal (INAFOR), que funciona como Secretario Ejecutivo del

96. El pasado mes de octubre de 2013 dos diputados del Partido Liberal Constitucionalista presentaron el Proyecto de Ley creadora del Bono de Incentivo para el Aprovechamiento Forestal. El objeto de esta ley es exonerar del pago de tributos nacionales y municipales, y por una sola vez, a quienes de forma privada, individual y/o colectivamente se dediquen a la plantación de árboles con miras a la utilidad económica mediante su comercialización y/o industrialización bajo las siguientes condiciones: a) que las áreas para la plantación de árboles no sean inferior a 30 hectáreas ni mayor a 500, b) que previo al corte de cada árbol siembre al menos un árbol para la reforestación continua y al menos $1 / 3$ de tiempo antes de dicho corte, c) utilice mano de obra local o sea, del municipio en donde se encuentre ubicada la plantación, especialmente para la creación de viveros, siembra, cuido y corte de árboles, d) que las especies de árboles sean aptas para su comercialización y/o industrialización, ya sean especies originarias de Nicaragua o especies introducidas, pero debidamente certificadas. Actualmente se está discutiendo en la Comisión de Producción, Economía y Presupuesto.

97. MAGFOR (2008). Manual de inventivos para el desarrollo de inversiones forestales sostenibles, Pág. 5.

98. Fuente: FONADEFO. [sitio web]. <http://www.fonadefo.org/fonadefo.php>. Accedido el 31 de marzo de 2014. 
Comité y un miembro de la Junta Directiva de los Consejos Regionales Autónomos de la Costa Atlántica: RAAN y RAAS.

Su objetivo general es promover un proceso de participación de pequeños y medianos productores, vinculados al desarrollo forestal basado en la transferencia de tecnología forestal, la adaptabilidad, replicabilidad y sostenibilidad.

EI FONADEFO realiza las siguientes funciones:

- Financia programas y proyectos del sector forestal.

- Promueve las plantaciones forestales.

- Promueve los sistemas agroforestales y silvopastoriles.

- Promueve la innovación tecnológica en la cadena productiva.

- Promueve el buen manejo del sector forestal.

En relación con los fondos de financiamiento de FONADEFO, a la fecha han sido aprovechados por grandes empresas de madera y las pequeñas se han quedado rezagadas en sus solicitudes.

De acuerdo con la información obtenida, en la Región Autónoma del Atlántico Norte han sido beneficiadas varias comunidades con proyectos financiados por FONADEFO, entre ellos:

- Reforestación de la microcuenca del Río Ully, en el Municipio de Siuna.

- Reforestación de la microcuenca del Río Concha en el Municipio de Bonanza.

- Siembra de árboles maderables y frutales en las comunidades de Santa Rosa de Paraska y Sislao en Mulukuku.

- Reforestación de la parte alta del Río Brakia en la comunidad de Tuapi en el Municipio de Puerto Cabezas.

- Recuperación de la cobertura vegetal en la microcuenca Ulwastara y Trintara de la comunidad indígena de Waspán con montos entre 300 y 734.7 miles de córdobas ${ }^{99}$.

Actualmente, el Fondo facilita recursos financieros entre $\mathrm{C} \$ 50,000$ a $\mathrm{C} \$ 500,000$.

Los recursos que se facilita a las Empresas Forestales pueden ser:

1. Reembolsables y no reembolsables con tratamientos diferenciados para

- Plantaciones forestales y agroforestales.

- Manejo sostenible y empresarial de bosque natural.

- Pago por servicios ambientales.

- Acciones forestales en zonas de frontera agrícola.

2. Recursos reembolsables para infraestructura productiva para el sector forestal.

3. Cofinanciamiento para innovación tecnológica en la cadena forestal.

4. Asistencia técnica privada en forma competitiva.

99. Fuente: FONADEFO. [sitio web]. <http://www.fonadefo.org/fonadefo.php>. Accedido el 31 de marzo de 2014. 
5. Fortalecimiento de capacidades en toda la cadena productiva forestal, gremios y organizaciones forestales.

Los proyectos pueden ser presentados por las Alcaldías, cooperativas, comunidades indígenas, asociaciones gremiales, PYMES, ONGs, artesanos y universidades. Los participantes deben presentar planes de negocios para proyectos reembolsables y planes de inversión municipal para proyectos no reembolsables. Los criterios de elegibilidad son:

Para proyectos reembolsables

- rentabilidad

- especies productivas

- mejora de los procesos de producción

- tierras regularizadas

- captura de carbono y áreas de conservación

- innovación tecnológica

\section{Para proyectos no reembolsables}

- especies productivas

- mejora de los procesos de producción

- cuencas hidrográficas

- cultivos agroforestales

- captura de carbono

- innovación tecnológica

- conservación del suelo

- sistemas silvopastoriles

\section{c. Banco Produzcamos ${ }^{100}$}

Es un banco estatal creado mediante Ley 640, Ley creadora del Banco de Fomento de la Producción (Produzcamos) ${ }^{101}$ que fomenta las actividades productivas y está dirigido a micros, pequeños y medianos productores del sector agropecuario e industrial.

Las tasas de interés activas del Banco se supone que son más competitivas que las de la banca privada y estas son establecidas por el Consejo Directivo, incluyendo las tarifas por servicios y cualquier otra carga financiera a favor del Banco, teniendo en cuenta su rentabilidad económica y su función de fomento. El Banco PRODUZCAMOS se encuentra en siete sitios a nivel nacional, en los Departamentos de Chinandega, Estelí, Juigalpa, Matagalpa, RAAS, San Carlos y Rivas.

100. GIZ, CEI, MASRENACE (2011). Fomento de la exportación de madera aserrada certificada: Layasiksa y Las Crucetas. Managua. FONADEFO, Perfil Institucional 2008 Fondo Nacional de Desarrollo Forestal, con el apoyo de GIZ (antes GTZ), octubre de 2008, Managua, Nicaragua.

101. Publicada en La Gaceta, Diario Oficial № 223 del martes 20 de noviembre de 2007. 


\section{Análisis del sistema de control forestal}

\subsection{Conflictos de competencia entre responsables de la administración y ejecución de los sistemas de control forestal}

En este punto el tema de gobernanza e institucionalidad es de gran relevancia, dado que aún persisten algunos conflictos de competencia entre algunas autoridades. Por ejemplo, el MARENA ha señalado que se han presentado casos en los que el INAFOR ha estado en proceso de otorgar permisos para extracción de madera en sitios RAMSAR, áreas donde le compete al MARENA extender -o denegarlos permisos de aprovechamiento forestal. La prohibición por el MARENA de algo permitido por el INAFOR crea rechazo entre los pobladores ante los funcionarios del MARENA ${ }^{102}$.

Según el informe presentado por el Teniente Coronel Marvin Paniagua, jefe del Batallón Ecológico en la VIII Región Militar, este año han desarrollado 3.291 operativos de acompañamiento forestal, para los cuales han hecho uso de unos 10.911 elementos armados ${ }^{103}$. Se debe destacar que en algunos de estos operativos incluso se han presentado conflictos con autoridades de INAFOR, ya que chocan las competencias de ambas instituciones en la vigilancia y control.

La misma situación sucede con algunos permisos que otorgan municipalidades, síndicos en comunidades indígenas y Gobiernos Regionales Autónomos bajo la figura de aprovechamiento mínimo y de subsistencia; esto sucede ante la falta de presencia de INAFOR y de MARENA según corresponda.

Según el documento "Ruta de Operativización de la Política Administrativa para el Uso de los Recursos Naturales y Manejo Forestal" del año 2013, cada vez que INAFOR reciba una solicitud de aprovechamiento debe comunicar por escrito al alcalde o alcaldesa, o a quienes ellos deleguen, Ejército de Nicaragua, Policía Nacional, MARENA, representante del Gabinete de la Familia Comunidad y Vida y a las Autoridades Autónomas Regionales de la Costa Caribe. INAFOR convocará a los miembros de la Comisión Interinstitucional para la revisión del permiso solicitado en el Gabinete y para la inspección de Campo de cada solicitud de Permiso de Aprovechamiento. La Comisión Interinstitucional dictaminará la propuesta de aprobación o denegación, que deberá ser ratificada o denegada por el Concejo Municipal.

102. Revista Encuentro 2007, Año XXXIX, № 77, 9-28, Pág. 23.

103. Artola, G.A. 'C $\$ 10$ millones en madera ocupada'. El Nuevo Diario.com.ni [periódico online], (27 de agosto de 2013). <http://www.elnuevodiario.com.ni/nacionales/295308-c10-millones-madera-ocupada>. Accedido el 31 de marzo de 2014. 


\subsection{Requerimientos de control forestal explícitos en la Ley Forestal y afines}

El Artículo 12 de la Ley 462 dicta que el INAFOR será responsable de supervisar, monitorear, fiscalizar y controlar la ejecución de las normas técnicas forestales y Planes de Manejo Forestales en todo el territorio nacional estableciendo las debidas coordinaciones con las Comisiones Forestales respectivas.

Sin perjuicio de lo establecido en el Artículo 12 de esta ley, el seguimiento, vigilancia y control de las actividades forestales estará a cargo del INAFOR, quien podrá ejercerla a través de los Regentes Forestales, Auditores Forestales y Técnicos Forestales Municipales debidamente acreditados.

Los mecanismos de seguimiento, vigilancia, monitoreo y control a que se refiere el Art. 14 de la ley serán entre otros: inspecciones, auditorías sobre planes de manejo y aprovechamiento forestal, el registro y revisión de inventarios de productos forestales y la revisión del transporte de dichos productos.

Para una mayor efectividad en el ejercicio del seguimiento, vigilancia y control forestal, el INAFOR puede solicitar la colaboración de las autoridades del orden público, que prestarán el apoyo requerido en el marco de la ley ${ }^{104}$.

\subsection{Sistema de monitoreo de estadísticas forestales y su impacto en la ilegalidad del aprovechamiento forestal}

No existe un sistema unificado de estadísticas de aprovechamiento forestal ni de la exportación en Nicaragua. Cada una de las instituciones tiene sus propias estadísticas y formatos, y se comparte información si es requerida entre una y otra institución. En la presente investigación los entrevistados no hicieron énfasis en problemas de ilegalidad.

\section{Autoridad administrativa de CITES}

En cuanto al tema de control, la Autoridad CITES refiere que algunos países le han consultado sobre la legalidad de algunos permisos CITES emitidos en Nicaragua y que en los años estudiados todos han sido verificados y son legales. Por su parte, la Aduana refiere que se limita a revisar la documentación de exportación, pero que sus funcionarios no están capacitados para la verificación del tipo de madera que según los documentos es la que se está exportando.

104. En entrevista realizada a la Licda. Sandra Tijerino, expresaba sobre el tema del control lo siguiente: "En los últimos años, se ha presumido sin sustento efectivo que la tasa de actividad informal es elevadísima y suponen que es realizada por muchos pequeños madereros sobre los cuales no existe capacidad gubernamental para ejercer control y consecuentemente que este segmento es el responsable de la alta tasa de deforestación del país. Para mitigar estas acciones ilícitas, la respuesta del gobierno ha sido el incremento de medidas coercitivas, restrictivas y policíacas, comprobadamente inefectivas, que repercuten de forma negativa en el sector formal y legal, el cual debería ser incentivado y protegido por su aporte productivo a la economía nacional y por el compromiso que sostiene con el manejo adecuado de los bosques". 


\section{INAFOR}

Esta institución tramita los casos de incumplimiento de las normas forestales por la vía administrativa, imponiendo multas u otro tipo de sanciones como la reparación del daño. En el Registro Forestal Nacional de INAFOR no se contemplan los casos por infracción o delitos forestales. En los informes anuales proporcionados por INAFOR se destaca lo siguiente:

En el año 2011 la Dirección de Asesoría Legal de INAFOR dictó un total de 78 Resoluciones Administrativas emitidas en virtud de Recursos de Apelación que fueron resueltas de la forma siguiente:

- Trece (13) resueltas a favor del recurrente.

- Diecinueve (19) Resoluciones Administrativas confirmaron el decomiso de recursos forestales de las especies siguientes: Granadillo $112.083 \mathrm{~m}^{3}$, Cedro Real $42.832 \mathrm{~m}^{3}$, Caoba 12,08 $\mathrm{m}^{3}$, Guapinol $2.063 \mathrm{~m}^{3}$, coyote, pochote, laurel, genízaro, $5.173 \mathrm{~m}^{3}$, Teca 0,042 $\mathrm{m}^{3}$, Almendro 0,047. Se decomisaron 3.239.067 pt de leña de las especies quebracho, laurel y pino.

- Veinticuatro (24) Resoluciones Administrativas que confirmaron las multas impuestas para un total de $U \$ 36,500$.

- Catorce (14) Resoluciones confirmando el decomiso de catorce medios de transporte.

- Cuatro (4) Resoluciones Administrativas declarando nulos los procesos administrativos iniciados por los delegados municipales.

- Una (1) Resolución Administrativa confirmando la suspensión de un regente forestal.

- Dos (2) Resoluciones decomisando dos motosierras.

- Una (1) Resolución Administrativa de amonestación.

En el año 2012 la Dirección de Asesoría Legal de INAFOR dictó un total 94 Resoluciones:

- Diecinueve (19) Resoluciones Administrativas fueron resueltas con sanción de amonestación por escrito.

- Seis (6) Resoluciones Administrativas fueron resueltas a favor del usuario, resolviendo el recurso de apelación con un ha lugar.

- Seis (6) Resoluciones Administrativas declarando la suspensión de regentes y nulidad del proceso administrativo iniciado por el Delegado Municipal.

- Veintitrés (23) Resoluciones Administrativas confirmaron la sanción de multa impuesta por el Delegado Municipal para un total de ochenta y seis mil quinientos $(U \$ 86,500)$ y sesenta mil córdobas netos.

- Veintisiete (27) Resoluciones Administrativas confirmaron el decomiso de recursos forestales de las especies siguientes: Granadillo $585.405 \mathrm{~m}^{3}$, Cedro Real $30.477 \mathrm{~m}^{3}$, Guapinol $3.817 \mathrm{~m}^{3}$, Coyote 23,43 $\mathrm{m}^{3}$, Teca 2,40 $\mathrm{m}^{3}$, Falso Roble 0,802 $\mathrm{m}^{3}$, Nacascolo $4.365 \mathrm{~m}^{3}$, Cedro Macho 0,65 $\mathrm{m}^{3}$, Guanacaste Negro 16,95 $\mathrm{m}^{3}$, Guanacaste Oreja 63,72 $\mathrm{m}^{3}$, Cortés $18.035 \mathrm{~m}^{3}$, Níspero $11.354 \mathrm{~m}^{3}$, Guácimo $0,87 \mathrm{~m}^{3}$ para un total de $653.561,82 \mathrm{~m}^{3}$ de recursos forestales. Además, se confirmó el decomiso de once toneladas métricas $\left(11 \mathrm{tm}^{3}\right)$ de leña de diferentes especies. 
Trece (13) Resoluciones confirmaron el decomiso de medios de transporte; de ellos, cinco (5) cabezales, cuatro (4) camiones, dos (2) camionetas, un (1) microbús y un (1) container.

Como un mecanismo para fortalecer el control y vigilancia de los recursos forestales, en el año 2012 el INAFOR realizó las siguientes actividades:

a. Fortalecimiento de la coordinación interinstitucional entre el INAFOR y el Ejército con todo lo relacionado con el control de transporte de recursos forestales.

b. Capacitación realizada a los Delegados Distritales, Municipales, Inspectores y Técnicos Forestales sobre Manejo y Aplicación del Manual Práctico de Procedimiento Administrativo aplicado al Sector Forestal.

c. Capacitación realizada a Jueces y Magistrados del Departamento de Chontales sobre legislación forestal y manual práctico de procedimientos administrativos.

\section{Ejército de Nicaragua}

Otra institución vinculada a la vigilancia en el sector forestal es el Ejército de Nicaragua, el cual, recientemente, ha hecho declaraciones sobre la ilegalidad en el sector forestal.

El Teniente Coronel Marvin Paniagua es el jefe del Batallón Ecológico (BECO) del Ejército, ubicado en Las Minas a 318 kilómetros al noroeste de Managua. Entre el 2005 y 2010, se perdieron al menos 436 mil hectáreas de bosque. La culpa es del avance de la frontera agrícola, la invasión de colonos y el negocio de tráfico ilegal de la madera. A mediados de enero de 2012, militares se esparcieron en la Región Autónoma del Atlántico Sur. Durante tres días, en la reserva de Waswashang, el Ejército encontró más de 112 mil pies tablares de granadillo, un cargamento abandonado en la selva que costaba al menos US\$1,35 millones. Nadie reclamó la madera que había sido apilada cuidadosamente en esta región distante, lejos de cualquier escrutinio ${ }^{105}$.

El jefe del BECO señala que la retención de madera ilegal en el año 2012 fue de 570.432,78 pies tablares de cedro real, cedro macho, caoba y granadillo. Fundamentalmente esa es la madera que se trafica de manera ilegal. Los métodos que más se usa para evadir la ley son guías forestales falsificadas o utilizadas hasta dos o tres veces. Según este reportaje, la madera está saliendo de importantes áreas protegidas como Bosawás, de Nueva Guinea en la reserva Indio Maíz y de otros lugares de Nicaragua.

Los empresarios y exportadores entrevistados lamentan la falta de legalidad en el sector y esto a pesar de que se cuenta con diversos tipos penales en el Código Penal y la Ley 735, Ley de Prevención, Investigación y Persecución del Crimen Organizado y de la Administración de los Bienes Incautados, Decomisados y Abandonados ${ }^{106}$ que señala: “... a efectos de esta Ley se consideran delitos de crimen organizado los delitos graves, que revistan en su comisión las conductas típicas de esos delitos, siendo estos los siguientes: ... 25) Corte, aprovechamiento y veda forestal, tipificado en el párrafo cuarto del artículo 384 del Código Penal”.

105. Enríquez O. 'La "Mafia" del Granadillo'. Confidencial [revista electrónica], (10 de diciembre de 2012). <http://www.confidencial.com.ni/articulo/9380/>. Accedido el 31 de marzo de 2014.

106. Publicada en Las Gacetas № 199 y 200 del 19 y 20 de octubre de 2010. 


\subsection{Control cruzado de certificados de comercio de productos de madera}

No existe un control cruzado de certificados de comercio de productos de madera, pero sí es requisito para exportar la presentación de los documentos establecidos por las leyes forestales para el aprovechamiento y trasporte de madera, el permiso CITES o Certificado de Origen según corresponda.

\subsection{Denuncias presentadas por las autoridades del Estado por delito de actividades forestales ilegales}

La tala ilegal de bosques es una de las causas importantes de la deforestación y degradación de los bosques. Los datos al respecto son imprecisos. No obstante, estudios realizados en el 2000 y 2003 indican que el volumen extraído por la tala ilegal es equivalente a $60 \%$ de los volúmenes de corte autorizados y registrados por el INAFOR. Según el Informe Anual del INAFOR 2009, en el año 2000 autorizó la corta de $56.100 \mathrm{~m}^{3}$ de madera en rollo, pero las exportaciones fueron de $70.392 \mathrm{~m}^{3}$ de madera aserrada. Estudios realizados por el Banco Mundial indican que el corte ilegal de madera oscila alrededor de los 30.000-35.000 $\mathrm{m}^{3}$ en maderas latifoliadas y entre 110.000 y $135.000 \mathrm{~m}^{3}$ en maderas de coníferas. El mismo estudio estima que las pérdidas fiscales producto de la tala ilegal cuestan al gobierno de Nicaragua entre US\$4 y US\$8 millones al año. Evaluado en términos de valor actual neto (VAN), estas pérdidas se estiman entre los US\$30 y US\$60 millones ${ }^{107}$.

En entrevista realizada con el Fiscal Nacional Ambiental del Ministerio Público, esta institución no lleva las estadísticas por tipo de delito; tampoco tiene las estadísticas a nivel nacional, sino solo del Departamento de Managua y estas tampoco están completas para los años que interesan a esta investigación. Vemos por ejemplo en el año 2011, el cual nos fue proporcionado que ingresaron 134 causas, 12 se desestimaron, 114 pasaron ese año en investigación y solo en 8 casos se presentó acusación. No se recogen los resultados de los juicios tramitados a partir de las 8 acusaciones.

El Artículo 5 de la Ley 647 modifica el Artículo 9 de la Ley $N^{\circ} 217$, que se lee así: "Se crea la Procuraduría para la Defensa del Ambiente y de los Recursos Naturales ${ }^{108}$, como rama especializada de la Procuraduría General de la República. Esta ejercerá la representación y defensa de los intereses del Estado y la sociedad en los juicios que se promuevan en materia ambiental, sean de índole administrativa, civil o penal, además, se le deberá reconocer la condición de víctima en lo referido a los delitos contra el Medio Ambiente y los Recursos Naturales". En el ámbito administrativo la Procuraduría actúa directamente ante la autoridad competente presentando la denuncia, solicitando la sanción administrativa correspondiente y la reparación del daño.

En la vía penal, para los delitos graves, la procuraduría como representante de la víctima, entiéndase el Estado, debe esperar el pronunciamiento del Ministerio Público; sin embargo, para el ejercicio de la acción penal por la víctima en delitos menos graves, sin perjuicio de la potestad del Ministerio

107. Readiness Preparation Proposal (R-PP) for Country: Nicaragua. Date of submission or revision: $1^{\circ}$ de junio de 2012. Formal Versión 7, Pág. 74.

108. No se pudo realizar entrevista a los funcionarios de la Procuraduría Ambiental ni acceder a las estadísticas de los casos por delitos forestales que ha tramitado en los años estudiados en la presente investigación. 
Público de ejercer de oficio la acción penal de conformidad con lo establecido en el Código Procesal Penal, en los delitos menos graves, la víctima podrá ejercerla directamente ante el juzgado competente sin necesidad de agotar la vía administrativa. Cuando hubiere detenido, la acción se podrá ejercer dentro de las cuarenta y ocho horas desde el inicio de la detención. En este caso, la Policía Nacional y el Ministerio Público brindarán facilidades a la víctima o a su representante para formular la acusación. Admitida la acusación, el juez remitirá copia de esta al Ministerio Público, que podrá intervenir en cualquier momento del proceso para coadyuvar en la acción ejercida por la víctima de los delitos menos graves de acción pública ${ }^{109}$.

A partir de la aprobación de esta disposición del Código Penal, la Policía Nacional se ha visto bajo el dilema jurídico de determinar quién es la autoridad competente -Procuraduría o Fiscalía- para valorar, a partir de su investigación y acusar, si fuese el caso, en los delitos ambientales menos graves. También las instituciones se podrían ver en el dilema de quién es la autoridad competente para interponer una denuncia por delitos forestales ${ }^{110}$.

Sin embargo, al ser dos entidades relevantes del Estado, deberían establecer protocolos de funcionamiento para el tratamiento de delitos ambientales, tanto graves como menos graves y para buscar el resarcimiento de los daños ambientales donde juega un importante papel la Procuraduría.

En un punto que sí coinciden ambas instituciones es en la aplicación de los principios de oportunidad para los casos de delitos ambientales, los cuales han sido además aceptados por los jueces del Poder Judicial.

El Artículo 55 del Código Procesal Penal establece que son manifestaciones del principio de oportunidad la mediación ${ }^{111}$, la prescindencia de la acción ${ }^{112}$, el acuerdo ${ }^{113}$ y la suspensión

109 Código Penal, Art. 564.

110. No se pudo realizar entrevista a los funcionarios de la Procuraduría Ambiental ni acceder a las estadísticas de los casos por delitos forestales que ha tramitado en los años estudiados en la presente investigación.

111. El Código Procesal Penal de Nicaragua establece en su Artículo 56 la figura de la mediación, la cual procede en los siguientes supuestos: Las faltas, los delitos imprudentes o culposos, los delitos patrimoniales cometidos entre particulares sin mediar violencia o intimidación y los delitos sancionados con penas menos graves.

112. El Ministerio Público deberá ejercer la acción penal pública en todos los casos en que sea procedente, con arreglo a las disposiciones de la ley. No obstante, el representante del Ministerio Público podrá prescindir total o parcialmente de la persecución penal, limitarla a alguna o algunas infracciones o personas que participaron en el hecho cuando (artículo 59 del Código Procesal Penal):

1. La participación en el delito objeto del principio de oportunidad sea menor que aquella cuya persecución facilita o el delito conexo que se deja de perseguir sea más leve que aquel cuya persecución facilita o cuya continuación o perpetración evita y el acusado colabore eficazmente con la investigación, brinde información esencial para evitar que continúe el delito o se perpetren otros, ayude a esclarecer el hecho investigado $u$ otros conexos.

2. El acusado haya sufrido, a consecuencia del hecho, daño físico o moral grave que torne desproporcionada la aplicación de una pena, o cuando concurran los presupuestos bajo los cuales el tribunal está autorizado para prescindir de la pena.

3. La pena o medida de seguridad que pueda imponerse por el hecho o la infracción de cuya persecución se prescinde carezca de importancia en consideración a la pena o medida de seguridad ya impuesta o a la que se debe esperar por los restantes hechos o infracciones, o la que se le impuso o se le impondría en un proceso tramitado en el extranjero. En estos últimos casos podrá prescindirse de la extradición activa y concederse la pasiva.

113. Iniciado el proceso, siempre que el acusado admita su responsabilidad en los hechos que se le imputan, 
condicional de la persecución ${ }^{14}$. Y dice a continuación: "No se aplicará el principio de oportunidad cuando se trate de delitos contra el Estado o cometidos con ocasión del ejercicio de sus funciones por funcionarios nombrados por el Presidente de la República o la Asamblea Nacional, o por los que hayan sido electos popularmente o sean funcionarios de confianza".

De acuerdo con el Artículo 102 de la Constitución, los recursos naturales son patrimonio nacional. La preservación del ambiente y la conservación, desarrollo y explotación racional de los recursos naturales corresponden al Estado. Este podrá celebrar contratos de explotación racional de estos recursos cuando el interés nacional lo requiera.

La Sala Constitucional de la Corte Suprema de Justicia en Sentencia $N^{\circ} 101$ del 6 de septiembre de 1989, interpretando el alcance del Artículo 102 Constitucional, definió Patrimonio del Estado como "el conjunto de bienes y derechos, recursos e inversiones que como elementos constitutivos de su estructura social o como resultado de su actividad norma ha acumulado el Estado y posee a título de dueño o propietario, para destinarlos o afectados en forma permanente, a la prestación directa o indirecta de los servicios públicos a su cuidado o a la realización de sus propios objetivos o finalidades de su política social y económica... El Estado tiene una potestad soberana sobre su territorio, un derecho real institucional".

En el año 2002, mediante la Sentencia $N^{\circ} 31$ del 23 de mayo, señala también en referencia al Artículo 102 Constitucional: "al ser los recursos naturales patrimonio de la nacional, quien los tutela es el Estado... En consecuencia, los recursos naturales constituyen patrimonio nacional, de dominio público, que pertenece al Estado".

Según la interpretación que la Sala Constitucional nicaragüense ha hecho, en al menos dos sentencias sobre el tema de los recursos naturales como patrimonio nacional y del Artículo 5 de la Ley 647 que le reconoce la condición de "víctima" a la Procuraduría, representante del Estado, en los delitos contra el ambiente y los recursos naturales no parece correcta la aplicación de los principios de oportunidad, ya que el Código Procesal Penal señala expresamente que "no se aplicará el principio de oportunidad cuando se trate de delitos contra el Estado".

Debido a la falta de estadísticas de la Procuraduría y Fiscalía, no se puede externar una conclusión sobre la eficacia que han tenido las normas penales. Un poco más de información sobre este tema se obtuvo de la Dirección de Asesoría Legal de INAFOR.

En el informe Anual de la Dirección de Asesoría Legal de INAFOR del año 2011 se evidencia que se elaboraron y presentaron ante la Corte Suprema de Justicia un total de 7 personamientos e informes de Recursos de Amparos Administrativos. En este mismo año fueron notificados de treinta y nueve

en su beneficio y por economía procesal, el Ministerio Público y la defensa, previa autorización expresa del acusado, pueden entablar conversaciones en búsqueda de un acuerdo que anticipadamente pueda ponerle fin al proceso. Mediante el acuerdo se podrá prescindir parcialmente de la persecución penal o limitarla a alguna o algunas infracciones o personas participantes en el hecho y disminuir el grado de participación y la sanción penal. Estas conversaciones pueden tomar lugar en cualquier etapa del proceso hasta antes de la sentencia o del veredicto, en su caso... (Artículo 61 del Código Procesal Penal).

114. Por una sola vez, en delitos imprudentes o menos graves, si el acusado sin condena previa por sentencia firme manifiesta conformidad con los términos de la acusación antes de la convocatoria a Juicio y admite la veracidad de los hechos que se le imputan, el fiscal podrá proponer al juez la suspensión condicional de la persecución penal (Artículo 63 del Código Procesal Penal). 
(39) sentencias emitidas por la Sala Constitucional de la Corte Suprema de Justicia, resolviendo de la manera siguiente: diez (10) sentencias confirmaron el decomiso de medios de transporte, diez (10) sentencias confirmaron las multas impuestas por un total de cuarenta y seis mil dólares netos (U\$46,000), cinco (5) sentencias confirmaron el decomiso de recursos forestales, un total de once (11) sentencias fueron resueltas con ha lugar al recurso de amparo promovido por los recurrentes, una (1) sentencia resolvió declarar desierto el recurso y se confirmó el Aval Forestal $N^{\circ} 00001$ emitido por el INAFOR, una (1) sentencia de la Corte Suprema de Justicia confirmó la veda del almendro.

En el Informe Anual del año 2012, se señala que en materia penal la Dirección de Asesoría Legal atendió (2) juicios penales, uno en la ciudad de Boaco y otro en el Municipio de Nindirí. Asimismo, se tramitaron los casos siempre en la jurisdicción penal contra la Empresa SAROSA por el delito de fraude en contra del Estado, falsificación ideológica en perjuicio de INAFOR San Fernando-Nueva Segovia y por peculado realizado en perjuicio del FONADEFO ${ }^{115}$.

\section{Análisis de ejecución de procesos judiciales}

En Nicaragua no existe justicia especializada para casos ambientales; es por ello que en la jurisdicción civil no encontramos casos ambientales. Sí hallamos casos en la jurisdicción penal y la constitucional. En Nicaragua el proceso penal tiene una duración de hasta dos meses si no hay reo detenido y un mes si hay reo detenido para obtener una sentencia de primera instancia si el competente es un juez local. La apelación de esta sentencia debe interponerse al tercer día de notificada y su resolución, independientemente del plazo que da el Código Procesal Penal, puede durar hasta un año ${ }^{116}$. El proceso penal en un juzgado de distrito tiene una duración de seis meses si el reo no está detenido y tres meses si el reo está detenido. La apelación de la sentencia dictada por el juez debe interponerse al sexto de la de notificación de esta.

115. No se logró obtener las sentencias que concluyeron con la tramitación de estos casos.

116. Información obtenida en entrevista a Fiscal Ambiental de Nicaragua Rubén Gutiérrez. 


\section{Flujograma del proceso penal nicaragüense en los casos en que el competente es un juzgado de distrito ${ }^{117}$}

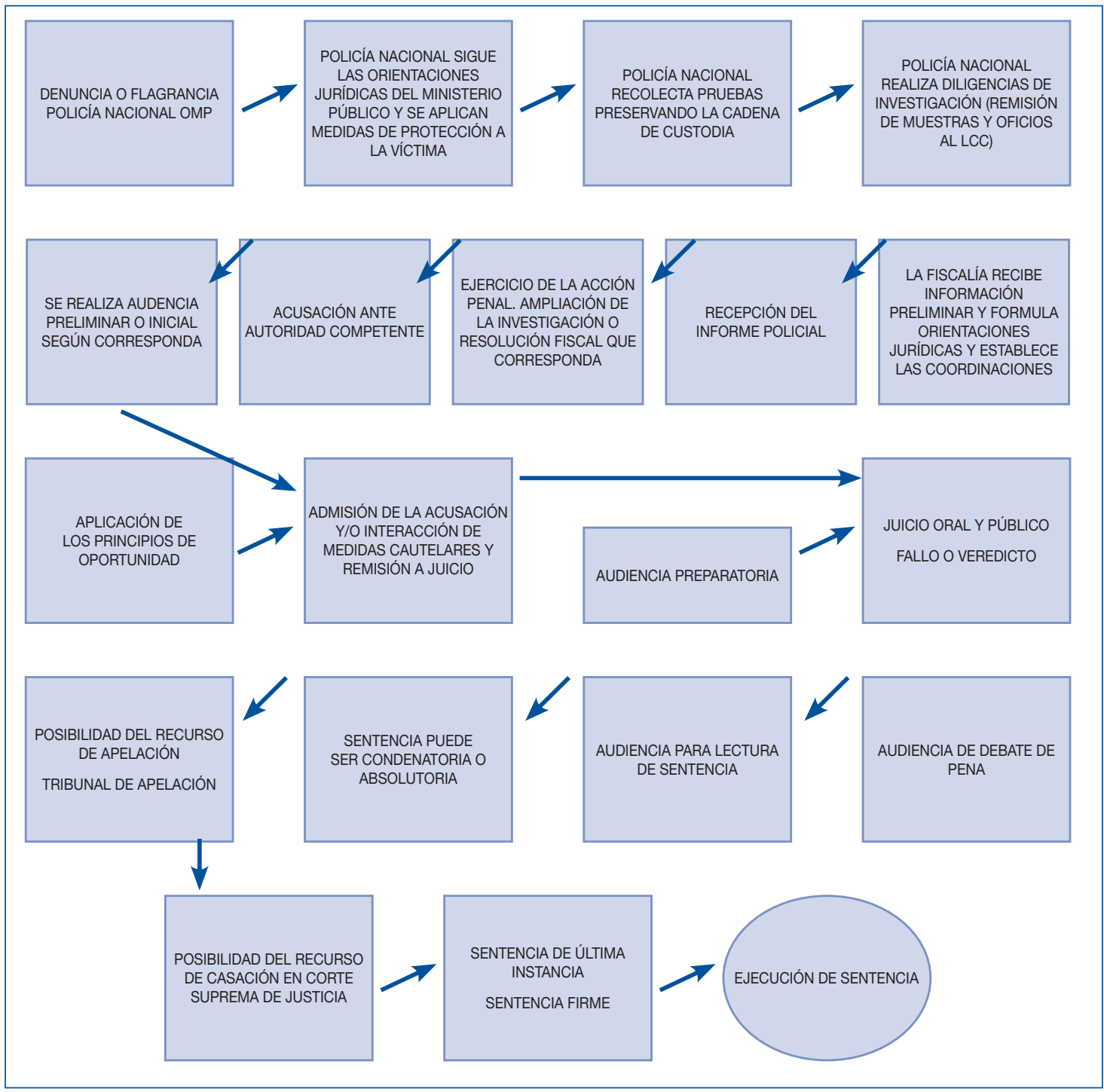

117. Méndez, M. (2009). Diagramas de procedimiento en el juicio por delitos de conformidad al Código Procesal Penal. 


\section{Análisis de ejecución de procesos judiciales}

En Nicaragua no se le ha dado tratamiento judicial a la figura del daño ambiental. Los mecanismos de reparación de estos daños causados son tramitados vía administrativa y generalmente se establecen medidas de reparación como complemento de una sanción principal. En la vía penal, utilizando la figura de los principios de oportunidad se establecen mecanismos de reparación del daño.

Se presenta en el anexo 2 una recopilación de sentencias de la Sala Constitucional relacionadas con actividades forestales. En general, son sentencias que tienen su origen en procesos administrativos tramitados ante INAFOR. Aunque en el país existe una ley que regula la materia contenciosoadministrativa, no es la vía más utilizada por los ciudadanos que se sienten agraviados por las actuaciones de la administración pública.

\subsection{Tipos de penas existentes en la legislación y su vinculación con la ilegalidad en el comercio de madera}

El incumplimiento de las disposiciones legales y de los mandatos de los órganos de gestión ambiental lleva aparejado en el ordenamiento jurídico nicaragüense la imposición de sanciones civiles, penales y administrativas. Las sanciones administrativas pueden consistir en multas, suspensión de actividades o clausura definitiva. Las penales pueden ser sanciones pecuniarias o de privación de libertad y las civiles generalmente están vinculadas a la reparación ambiental de los daños ocasionados y en algunos sistemas jurídicos, a las indemnizaciones por daño ambiental.

\section{Infracciones administrativas}

Las infracciones a la presente ley serán sancionadas administrativamente por el INAFOR o la autoridad a quien este expresamente delegue de la siguiente manera ${ }^{118}$ :

\section{Se considerará como infracción leve las siguientes:}

a) No permitir el acceso a plantaciones forestales, viveros y a cualquier área de bosque natural, estatal o privada a las autoridades responsables de las inspecciones o auditorías técnicas.

b) No portar los documentos que acrediten legalmente la procedencia, transporte, almacenamiento, transformación o posesión de materia prima forestal que se obtengan del aprovechamiento.

c) No dar aviso ni presentar informes, establecidos en la presente ley y su Reglamento.

d) Provocar por imprudencia incendios en terrenos forestales.

La reincidencia de una infracción leve será considerada como infracción grave.

118. Artículos del 53 al 58 de la Ley 462. 


\section{Se considerarán como infracciones graves las siguientes:}

a) Cortar más de cinco árboles que no hayan sido marcados en la ejecución de un plan operativo anual.

b) Realizar aprovechamiento de los recursos forestales sin contar con un Permiso de Aprovechamiento.

La reincidencia de una infracción grave será considerada como infracción muy grave.

\section{Se considerarán como infracciones muy graves las siguientes:}

a) Negarse a contribuir y a participar en la prevención, combate y control de plagas, enfermedades e incendios forestales en terrenos propios.

b) Provocar intencionalmente incendios que afecten los recursos forestales.

c) Realizar actividades de corte, extracción, transporte, transformación o comercialización de recursos forestales de forma ilegal o sin su certificado de origen.

d) Realizar en terrenos forestales actividades distintas a lo estipulado en el Plan de Manejo.

La reincidencia de una infracción muy grave ocasionará la suspensión temporal del permiso de aprovechamiento, concesión o el cierre temporal de la industria o empresa comercializadora de productos forestales.

La infracción leve será sancionada con una amonestación por escrito la primera vez y si reincide, se considerará como una infracción grave, procediendo la multa correspondiente. La infracción grave será sancionada con multa de US\$500 hasta US\$5,000 (o su equivalente en moneda nacional), la primera vez y si reincide se considerará como una infracción muy grave, procediendo la sanción que corresponda. Toda infracción muy grave será sancionada con el decomiso del ilícito para subasta, cuando sea aplicable, no pudiendo el infractor participar en esta. Cuando no proceda el decomiso, deberá pagar el doble del máximo establecido para una infracción grave.

En el caso de realizar actividades de corte, extracción, transporte, transformación o comercialización de recursos forestales de forma ilegal o sin su certificado de origen, la autoridad procederá al decomiso y subasta del medio de transporte utilizado para la comisión del ilícito. El producto de la subasta será enterado en las cuentas especiales especificadas para tal fin por la Tesorería General de la República.

La Ley 462 establece que son áreas forestales de protección municipal las ubicadas a 200 metros de las costas, lagos, embalses naturales, embalses artificiales, fuentes de agua, a 50 metros de cada lado de los cauces y ríos, en pendientes mayores de $75 \%$.

En estas áreas se prohíbe el corte de árboles en cualquiera de sus modalidades y el aprovechamiento forestal de la tala rasa, el uso de plaguicidas y la remoción total de la vegetación herbácea.

Por otra parte, la Ley 585, Ley de Veda para el Corte, Aprovechamiento y Comercialización del Recurso Forestal ${ }^{119}$ ha establecido que son especies en veda la caoba, el cedro real, el pochote,

119. Publicada en La Gaceta, Diario Oficial N²20 del 21 de junio de 2006. 
el pino, el mangle y el ceibo ${ }^{120}$. Mediante Resolución de MARENA Nº2-01-2013 está vedado indefinidamente el almendro (Dipterix panamensis).

La Procuraduría para la Defensa del Medio Ambiente y los Recursos Naturales deberá ser parte en los recursos administrativos originados por violación de artículos de la presente ley y sus reglamentos.

De la resolución que aplica las sanciones establecidas en este capítulo caben los recursos establecidos en la Ley de Organización, Competencia y Procedimientos del Poder Ejecutivo, Ley 290. Con la Resolución de tales recursos se agota la vía administrativa ${ }^{121}$.

El monto de las multas establecidas en este capítulo deberá enterarse a la cuenta especial de la Tesorería General de la República en un plazo no mayor de siete días hábiles a partir de la notificación de esta. Las infracciones y sanciones establecidas en la presente Ley Forestal son sin perjuicio de las responsabilidades penales y civiles que se contemplen en las leyes respectivas.

\section{Delitos Forestales}

El Código Penal de Nicaragua contempla diversos tipos penales que sancionan las conductas lesivas al medio ambiente. En la tramitación de los casos penales intervienen diversos actores: la Policía Nacional en su papel investigativo, el fiscal en representación de la sociedad víctima del delito, el Procurador Ambiental como representante del Estado, el juez penal como órgano jurisdiccional y los funcionarios del Estado como peritos expertos. Asimismo, puede participar en el proceso cualquier particular como víctima del delito o perito. Se destacan en el cuadro a continuación las disposiciones penales que están vinculadas al tema forestal.

120. A pesar de la prohibición del aprovechamiento de estas especies, la Comisión Interinstitucional Forestal, reunida en fecha del 17 de diciembre del año 2007, en referencia a los permisos de aprovechamiento no comercial luego del análisis del Art. 1 de la Ley de Veda, acordó por unanimidad de votos permitirle al Instituto Nacional Forestal otorgar permisos de aprovechamiento forestal no comercial en áreas protegidas, relacionadas directamente con la implementación del Programa Productivo Alimentario (PPA), del Bono Productivo (BP), ampliamente conocido como Programa Hambre Cero. Mediante Circular DE-WSC-493-12-07 emitida por el Director Ejecutivo del INAFOR se orientó que el otorgamiento de los permisos de aprovechamiento no comercial a los beneficiarios del Programa Productivo Alimentario será otorgado en armonía con lo establecido en los Arts. 52, 53 y 54 del Reglamento de la Ley No 462, Decreto (73-2003) siempre y cuando se encuentren verificados ante el Ministerio Agropecuario y Forestal (MAGFOR) la inclusión de dicho beneficiario en el bono productivo. De igual forma, deberá contarse con el aval del Ministerio del Ambiente y los Recursos Naturales (MARENA) cuando la madera provenga de áreas protegidas.

121. En Nicaragua no existe una Ley de Procedimiento Administrativo, por lo cual cada una de las leyes sectoriales establece un procedimiento para sancionar las infracciones. Solamente el tema de los recursos administrativos que se tramitan ante el Poder Ejecutivo está regulado por una sola norma, la Ley 290, Ley de Organización, Competencias y Procedimientos del Poder Ejecutivo publicada en La Gaceta, Diario Oficial $N^{\circ} 102$, del 3 de junio de 1998. 


\section{Ley N 641 Código Penal}

Publicada en La Gaceta, Diario Oficial N 83, 84, 85, 86 y 87 del 5, 6, 7, 8 y 9 de mayo de $2008^{122}$

\section{Delitos y faltas contra \\ los recursos naturales}

\section{Art. 373 Aprovechamiento ilegal de recursos naturales}

El que, sin autorización de la autoridad competente o excediéndose de lo autorizado, aproveche, oculte, comercie, explote, transporte, trafique o se beneficie de los especímenes, productos o partes de los recursos de la fauna, de los recursos forestales, florísticos, hidrobiológicos, genéticos y sustancias minerales.

\section{Art. $\mathbf{3 8 3}$ Incendios forestales}

El que provoque un incendio forestal o incite a otros a la realización de un incendio forestal.

Quien estando autorizado por autoridad competente y a causa de su imprudencia realice quemas agrícolas que causen daños fuera de las áreas destinadas para realizar dicha quema.

Quien sin autorización de autoridad competente realice quemas agrícolas y cause daños en zonas de bosque.

No constituirán delito las quemas controladas y autorizadas por la autoridad competente ni los daños producidos como consecuencia de una situación fortuita o inesperada.

\section{Art. 384 Corte, aprovechamiento y veda forestal}

Quien sin la autorización correspondiente destruya, remueva total o parcialmente árboles o plantas en terrenos estatales, baldíos, comunales, propiedad particular y vías públicas.

Quien sin la autorización correspondiente tale de forma rasante árboles en tierras definidas como forestales o de vocación forestal.

El que autorice la tala rasante en áreas definidas como forestal o de vocación forestal para cambiar la vocación del uso del suelo.

Si las actividades descritas en los párrafos anteriores se realizan en áreas protegidas.

El que realice cortes de especies en veda.

\section{Art. 385 Talas en vertientes y pendientes}

Quien, aunque fuese el propietario, deforeste, tale o destruya árboles o arbustos en áreas destinadas a la protección de vertientes o manantiales naturales o pendientes determinadas por la ley de la materia.

\section{Art. 386 Corte, transporte y comercialización ilegal de madera}

El que corte, transporte o comercialice recursos forestales sin el respectivo permiso de la autoridad competente.

\section{Art. 387 Corte o poda de árboles en casco urbano}

El que corte o pode destructivamente uno o más árboles a orillas de las carreteras, avenidas, calles o bulevares, servidumbres de tendido eléctrico o telecomunicaciones.

\section{Sanción}

Sancionado con prisión de 6 meses a 2 años de prisión y de 100 a 300 días multa.

Sancionado con pena de 2 a 4 años de prisión y multa de 500 a 1.000 días.

Sancionado con 50 a 200 días multa.

Sancionado con pena de 2 a 4 años de prisión y multa de 500 a 1.000 días, cuyos extremos mayores y menor serán aumentados al doble.

Sancionado con pena de 6 meses a 2 años de prisión y de 200 a 500 días multa.

Sancionado con pena de 2 a 5 años de prisión y de 200 a 500 días multa.

Sancionado con pena de 3 a 7 años de prisión e inhabilitación especial por el mismo período para ejercer empleo o cargo público.

Pena será de 4 a 10 años de prisión y de 500 a mil 1.000 multa.

Sancionado con prisión de 3 a 7 años.

Pena de 2 a 5 años de prisión y de 500 a 1.000 días multa.

Sancionado con pena de 2 a 4 años de prisión y de 500 a 800 días multa.

Sancionado con pena de 6 meses a 4 años de prisión.

122. Fuente: Elaboración propia de contenido de Código Penal Nicaragüense. 


\section{Art. 388 Incumplimiento de Estudio de Impacto Ambiental}

El que deforeste, tale o destruya, remueva total o parcialmente la vegetación herbácea o árboles sin cumplir, cuando corresponda, con los Estudios de Impacto Ambiental (EIA) y las normativas técnicas y ambientales establecidas por la autoridad competente.

Art. 389 Restitución, reparación y compensación de daño ambiental

En el caso de los delitos contemplados en este Título, el juez deberá ordenar a costa del autor o autores del hecho y de acuerdo con el principio de proporcionalidad alguna de las siguientes medidas en orden de prelación.

- La restitución al Estado previo a la producción del hecho punible.

- La reparación del daño ambiental causado.

- La compensación total del daño ambiental producido.

Si los delitos fueren realizados por intermedio de una persona jurídica, se le aplicarán además las consecuencias accesorias que recaen sobre la persona jurídica previstas en este Código.

\section{FALTAS}

Art. 554 Maltrato de árboles o arbustos

Quien fije en árboles o arbustos ubicados en lugares públicos rótulos, carteles, papeletas o les aplique pintura o cualquier sustancia que no tenga por finalidad su preservación u ornato o de cualquier otra forma los maltrate.

Art. 555 Corte o poda de árboles en propiedad privada

Quien corte o pode árboles de forma destructiva en propiedad privada.
Sancionado con prisión de 2 a 4 años y de 200 a 500 días multa.
Sancionado con 10 a 30 días multa o trabajo en beneficio de la comunidad de 10 a 30 jornadas de 2 horas diarias.

\subsection{Número de casos presentados y número de casos desestimados o con sentencia condenatoria para el período 2008-2013}

Los órganos competentes en este tema -fiscalía, Poder Judicial e INAFOR- no tienen estadísticas específicas sobre este punto. Sí se recoge en algunos casos la cantidad de procesos, pero no sus resultados, salvo las sentencias recopiladas en el anexo 2 de este trabajo. No pudimos acceder a las estadísticas que lleva la Procuraduría para la Defensa del Ambiente y los Recursos Naturales.

\subsection{Retos en el ámbito judicial en materia de aprovechamiento forestal y comercio internacional de productos forestales}

Los conflictos ambientales y sus consecuencias generan nuevos retos para el ejercicio del derecho y para el Poder Judicial. Es tarea fundamental de todo sistema legal ambiental la aplicación e interpretación de este derecho.

Los juicios ambientales presentan características y desafíos que los hacen diferentes de otros tipos de casos que son típicamente conocidos por el Poder Judicial. Estos jueces deben auxiliarse no solo 
de las normas jurídicas, sino de opiniones de peritos, expertos ambientales y funcionarios de Estado competentes en materia ambiental. Asimismo, demanda la necesidad de jueces que tengan criterios propios para comprender los conceptos técnicos de la materia ${ }^{123}$.

Nicaragua cuenta con Fiscales y Procuradores Ambientales con una amplia institucionalidad ambiental y con abundantes recursos naturales. Las leyes ambientales establecen diversos tipos de infracciones administrativas que -una vez tramitadas por la vía administrativa- se elevan en bastante porcentaje a la jurisdicción constitucional. También se cuenta con diversos tipos penales relacionados con los recursos forestales que son conocidos por la fiscalía, policía y procuraduría en su etapa de investigación y por los jueces en su etapa de juzgamiento.

Para que los actores estén más articulados y mejorar la aplicación del derecho ambiental en el ámbito judicial se recomienda construir un área especializada dentro del Poder Judicial, como existe para la niñez, familia y propiedad, entre otras, debido a la relevancia del bien jurídico protegido.

123. Instituto de Investigaciones Jurídicas de la UNAM. 'Experiencias y mejores prácticas en la aplicación judicial del Derecho Ambiental'. [pdf online]. <http://biblio.juridicas.unam.mx/libros/6/2954/5.pdf>. Accedido el 31 de marzo de 2014. 


\section{Aportes adicionales}

\subsection{Análisis de la situación legal-administrativa para el aprovechamiento de la madera y comercio internacional de productos forestales}

De acuerdo con el documento "Valoración Forestal Nicaragua 2000", en 1950 Nicaragua contaba con un área efectiva de bosques de 52\% (bosques cerrados), lo que correspondía ese año a 6.257 .656 ha. En el año 2000, han desaparecido 386.648 ha según el mapa forestal' ${ }^{124}$.

El MAGFOR ha señalado que 71,9\% del territorio nacional corresponde a tierras de vocación forestal, incluyendo bosques de producción, de protección y de conservación. Dentro de ese $71,9 \%$ de tierras de vocación forestal va incluido $26,2 \%$ que puede tener uso silvopastoril y uso agrosilvopastoril. De manera general se señala el siguiente potencial de las tierras del país ${ }^{125}$.

La cobertura forestal de Nicaragua ha disminuido drásticamente. Las causas de la pérdida de la cobertura boscosa son varias: el concepto de "mejoras" que apoyaba la destrucción del bosque en aras de cultivos tradicionales productivos, café, algodón, ganadería, el avance de la frontera agrícola producto de la reforma agraria y de la demanda lógica de producción, el uso generalizado de leña, la pobreza extrema, falta de manufactura, inseguridad en la tenencia de la tierra, la costumbre de cultivar la tierra previa limpieza con quemas, la tala ilegal, los efectos naturales como huracanes, plagas, etc. y otros de ámbito más institucional como es la falta de presupuesto y por ende, de vigilancia y control de las instituciones que administran la actividad forestal en el país.

De acuerdo con la Investigación "Emergencia en el Bosque", estudios del Banco Mundial estiman que el corte ilegal de madera alcanza los 170.000 metros cúbicos anuales de maderas latifoliadas y coníferas $^{126}$.

A partir del año 2000, con el fin de detener la destrucción de los bosques y el tráfico ilegal de madera, se han dictado vedas forestales, distintas normativas y planes forestales que no han tenido la eficacia esperada. Una drástica medida fue tomada el 3 de mayo de 2006, en sesión plena de Consejo de Ministros, por el Presidente de la República, Ing. Enrique Bolaños, al emitir el Decreto 32-2006, Estado de Emergencia Económica, en vista de que -a pesar de las medidas adoptadas por diversas instituciones para "controlar el despale y la extracción ilegal de los recursos forestales en diversas zonas del país"- se hace necesario recurrir a medidas más eficientes de control. En consecuencia, decreta el estado de emergencia económica en la Región Autónoma del Atlántico Norte (RAAN), Región Autónoma del Atlántico Sur (RAAS) y en los Departamentos de Nueva Segovia y Río San Juan "por la tala, transporte, manejo, procesamiento, almacenamiento, posesión,

124. MAGFOR, INAFOR (2005). Valoración forestal Nicaragua 2000. Proyecto de Innovación y Aprendizaje en Forestería Sostenible (PROFOR). Banco Mundial, Pág. 11.

125. ibid.

126. Fonseca R. y De Castro C. (enero, 2007). Emergencia en el Bosque. Centro de Investigación de la Comunicación (CINCO), en asociación con el Centro para las Políticas Internacionales (CIP), con sede en Washington D.C. 
exportación y comercialización ilegales de los recursos forestales" por un período de 80 días, a partir del 7 de mayo de $2006^{127}$.

Si nos situamos en el año 2013, a pesar de un amplio y reciente marco legal forestal, derivado a raíz de la Ley 462 del 2003, donde se establece -además de mecanismos de control y vigilanciamedidas de fomento, incentivos, simplificación de trámites, convenios de delegación a los gobiernos municipales, regentes y auditores forestales, la situación de depredación e ilegalidad dentro del sector forestal sigue siendo grave.

Como señala el estudio Verificación de la Legalidad en el Sector Forestal Nicaragüense: 'La debilidad institucional del INAFOR es a menudo mencionada como la causa principal de la falta de aplicación del marco legal vigente. Para decirlo con las palabras de Kräuter et al (2003), "[el] INAFOR no dispone de los recursos humanos, medios e insumos necesarios para poder ejercer su función como institución rectora del aprovechamiento sostenible de los recursos forestales. Esta situación afecta no solamente una adecuada revisión técnica de los planes de manejo... sino también el monitoreo in situ de su adecuada implementación". La incapacidad de cumplir sus responsabilidades por la falta de recursos es abiertamente reconocida por las mismas autoridades del INAFOR (CINCO y CIP, 2006) $)^{128}$.

Pero a la debilidad reconocida del INAFOR se le debe sumar la política general del Estado que, sin renunciar a la protección del recurso forestal, promueve en zonas de reconocida vocación forestal actividades como la minería, ganadería y agricultura. También debe destacarse que destinar parte de una finca agropecuaria a protección forestal sigue sin ser rentable. El trámite para que el propietario de la finca pueda acceder a los beneficios fiscales por la plantación es altamente burocrático. Otra causa es la poca información y acceso a los mercados de carbono por plantaciones forestales ${ }^{129}$. Otro factor a considerar son los costos de los dueños y/o empresarios del sector forestal para acceder a los permisos de aprovechamiento, traslados de madera y exportación, ya abordados anteriormente.

En general, INAFOR monitorea con más efectividad a empresas formales, pero sigue habiendo un gran sector informal e ilegal que ocasiona un desequilibrio en el sector y competencia desleal empresarial.

Debe tomarse en cuenta en este punto el papel de los Regentes Forestales, que son contratados directamente por el titular o empresa autorizada para la realización del aprovechamiento forestal como garante de la ejecución del Plan de Manejo aprobado. Sin embargo, algunos sectores cuestionan

127. Fonseca R. y De Castro C. (enero, 2007). Emergencia en el Bosque. Centro de Investigación de la Comunicación (CINCO), en asociación con el Centro para las Políticas Internacionales (CIP), con sede en Washington D.C., Pág. 21.

128. Del Gatto F., Navarro G., Faurby O., Argüello A. Verificación de la Legalidad en el Sector Forestal Nicaragüense. UICN, GTZ, VERIFOR, UE, CATIE, SNV. Rainforest Alliance, Pág. 22.

129. En entrevista realizada a la Directora de Paso Pacífico de Nicaragua, ONG que impulsa el Proyecto Retorno al Bosque en el Istmo de Rivas, expresó que trabajan con los propietarios privados de la zona para reforestar 1.000 hectáreas de bosques tropicales secos y húmedos con árboles nativos y uno de sus objetivos es recibir créditos de carbono a cambio. El proyecto de reforestación en pequeña escala ha proporcionado asistencia técnica y asesoramiento a los propietarios individuales, cooperativas y comunidades que estén interesados en la reforestación de sus propiedades. Sin embargo, por aspectos de variabilidad del mercado de carbono, los bonos ofrecidos por el proyecto no fueron rentables. 
esta figura, ya que argumentan que el hecho de que sea el dueño del Plan de Manejo quien le pague su salario le resta autonomía a este profesional. Veamos por ejemplo las consideraciones del ex Procurador Ambiental Lisandro D’León: “Según mi criterio, los regentes forestales vinieron a convertirse en una medicina peor que la enfermedad. Se supone que están obligados a llenar la guía de aprovechamiento en el terreno, señalando además qué árboles se van a cortar y de qué forma hacerlo, respetando las normas técnicas. Sin embargo, nosotros hemos quitado (incautado) guías en blanco a madereros, que nos han manifestado que el regente así se las entrega, para evadir la responsabilidad de ir al campo"130.

Reconociendo esta problemática desde el año 2008, INAFOR impulsa el Programa Forestal Nacional del Poder Ciudadano (PFN), compuesto por cinco sub-programas: Gobernanza e Institucionalidad, Reforestación y Restauración Forestal, Manejo y Conservación Forestal, Desarrollo de la Industria y Comercio Forestal, Generación y Gestión del Conocimiento.

\subsection{Retos, oportunidades jurídicas y estrategias para el fortalecimiento en el corto y largo plazo para el aprovechamiento de madera y comercio internacional de productos forestales}

- Se debe implementar el instrumento de gestión denominado "Auditoría Forestal". A la fecha no se han acreditado los auditores y persiste un cierto clima de impunidad por parte de la población. Se cree que los Regentes Forestales no están cumpliendo bien su papel debido a que son personas que dependen salarialmente del dueño del Plan de Manejo.

- Es necesario agilizar los procesos de demarcación, titulación y saneamiento de tierras indígenas en la Costa Caribe a fin de evitar conflictos entre comunidades y colonos, y a la vez fomentar las Empresas Forestales Comunitarias.

- Tiene que fortalecerse presupuestariamente el Instituto Nacional Forestal y las demás instancias que regulan e incentivan el sector forestal, sobre todo a partir de la reciente reforma de la Ley 290 donde esta institución sale de la esfera del antiguo Ministerio Agropecuario y Forestal (MAGFOR), ahora MAG.

- Se deben simplificar los trámites para el aprovechamiento forestal y la exportación de este producto.

- Se debe potencializar las capacidades actuales que brinda el sector forestal para la creación de empleo y obtención de recursos. Véase a continuación el cuadro elaborado por la Licda. Sandra Tijerino sobre las capacidades actuales y empleo.

130. Fonseca R. y De Castro C. (enero, 2007). Emergencia en el Bosque. Centro de Investigación de la Comunicación (CINCO), en asociación con el Centro para las Políticas Internacionales (CIP), con sede en Washington D.C., Pág. 13. 


\begin{tabular}{|l|l|l|l|}
\hline \multicolumn{1}{|c|}{ 1er. Eslabón } & \multicolumn{1}{|c|}{ 2do. Eslabón } & 3er. Eslabón & \multicolumn{1}{c|}{ 4to. Eslabón } \\
\hline $\begin{array}{l}\text { Manejo y Extracción } \\
\text { del Bosque y de } \\
\text { Plantaciones }\end{array}$ & Primera Transformación & Segunda Transformación & $\begin{array}{l}\text { Comercialización de } \\
\text { Productos Finales }\end{array}$ \\
\hline
\end{tabular}

- Es primordial establecer una coordinación efectiva y fluida entre el Poder Judicial, Ministerio Público, Procuraduría Ambiental, INAFOR, Ministerio del Ambiente y los Recursos Naturales (MARENA) Gobiernos Regionales y Alcaldías para la efectiva aplicación de los delitos ambientales.

- Tiene que incrementar el ejercicio de acciones administrativas en los casos que correspondan, mediante asesoría legal de INAFOR, Procuraduría Ambiental y Ministerio Público, en los plazos y términos establecidos en las leyes.

\subsection{Sugerencias a futuro para fortalecer la legalidad del proceso de aprovechamiento de la madera y comercio internacional de productos forestales, y con ellos la conservación y aprovechamiento de los bosques}

El estudio de mercado para madera aserrada certificada en las comunidades indígenas de Layasiksa y Las Crucetas de la RAAN realizado por la Cooperación Alemana en Nicaragua (GIZ) y el Centro de Exportaciones e Inversiones (CEI) establece una serie de recomendaciones que retomamos en este trabajo, a las cuales le hacemos algunas adiciones de índole institucional que consideramos válidas para todas las zonas del país donde se realiza aprovechamiento, comercialización, transporte y exportación de productos forestales.

Para el sector forestal se recomienda:

- Capacitar a los dueños de bosque, al personal de los aserríos y comercializadores sobre la legislación nacional que brinda beneficios al sector forestal.

- Reducir el tiempo de pago de los compradores de madera a los proveedores.

- Identificar y utilizar fuentes de financiamiento adecuadas a las necesidades del sector.

- Promover la autonomía económica empresarial de los dueños de bosque y de aserríos a través de capacitaciones sobre organización empresarial.

- Identificar y utilizar nuevas fuentes de servicios disponibles que puedan ofrecer a las empresas comunitarias mejor equipamiento para extracción y transporte a precios más accesibles.

- Fortalecer la investigación y la recopilación de los conocimientos tradicionales sobre otros beneficios de los productos forestales ${ }^{131}$.

- Implementar, con ayuda de los actores pertinentes, una campaña nacional de concientización sobre los beneficios ambientales, sociales y económicos de consumir/comercializar madera certificada.

131. El Sr. Hoover Castaño de la Empresa MADEXPORT expresó que su empresa cuenta con un plan de manejo en Prinzapolka, Región Autónoma del Atlántico Norte y además de las actividades propias de aprovechamiento forestal, él realiza investigación sobre las propiedades de las 25 especies existentes en su plan de manejo. Mayor información en Dalbergia Retusa. [sitio web]. <http://www.dalbergiaretusa.com>. 


\section{Bibliografía}

Del Gatto F., Navarro G., Faurby O., Argüello A. Verificación de la Legalidad en el Sector Forestal Nicaragüense. UICN, GTZ, VERIFOR, UE, CATIE, SNV. Rainforest Alliance.

'Dilemas de los Funcionarios Punta de Lanza en la Gestión Ambiental en Río San Juan Nicaragua'. Revista Encuentro 2007, Año XXXIX, № 77, 9-28.

Enríquez. O. 'La “Mafia” del Granadillo'. Confidencial [revista electrónica]. <http://www.confidencial. com.ni/articulo/9380/>.

FAO. 'Resumen del estado actual del manejo y ordenación forestal en Nicaragua'. [pdf online]. <http://www.fao.org/docrep/008/j2628s/j2628s14.htm>.

Fonseca R. y De Castro C. (enero, 2007). Emergencia en el bosque. Centro de Investigación de la Comunicación (CINCO), en asociación con el Centro para las Políticas Internacionales (CIP), con sede en Washington D.C.

García, E. '60 crímenes en 5 años en tierras indígenas'. El Nuevo Diario.com.ni [periódico online], (28 de noviembre de 2013). http://www.elnuevodiario.com.ni/nacionales/303383-60-crimenes-5anos-tierras-indigenas>.

GIZ, CEI, MASRENACE (2011). Fomento de la exportación de madera aserrada certificada: Layasiksa y Las Crucetas. Managua.

Gutiérrez, J. (2011). Taller REDD-CCA-GIZ. Guatemala: MARENA, MAGFOR, INAFOR.

Instituto de Investigaciones Jurídicas de la UNAM. 'Experiencias y mejores prácticas en la aplicación judicial del Derecho Ambiental'. [pdf online]. <http://biblio.juridicas.unam.mx/libros/6/2954/5.pdf>

Instituto Nacional Forestal (2011). Informe Anual. Dirección de Asesoría Legal. INAFOR.

Instituto Nacional Forestal (2012). Informe Anual. Dirección de Asesoría Legal INAFOR.

Instituto Nacional Forestal (2008). Programa Forestal Nacional del Poder Ciudadano (PFN).

Instituto Nacional Forestal (2009). Resultados del Inventario Nacional Forestal: Nicaragua 2007-2008. 1. ed. Managua: INAFOR.

Instituto Nacional Forestal. [sitio web]. <http://www.inafor.gob.ni/index.php?option=com_content\&v iew $=$ article\&id=15\&ltemid $=59$ > .

INAFOR/GTZ (2011). Manual práctico de procedimiento administrativo aplicado al sector forestal. Managua.

INAFOR, PGR, Ministerio Público, MARENA, GTZ (2010). Consultas Jurídicas en Materia Forestal. Respuestas y Comentarios, 2007-2009. Managua.

López M. (2012). 'Análisis de las causas de deforestación y avances de la Frontera Agrícola en las zonas de amortiguamiento y Zona Núcleo de la Reserva de Biosfera de BOSAWAS-RAAN'. Nicaragua. Unión Europea. UNAG-Nicaragua. GIZ. OXFAM. [pdf online]. <http://masrenace. wikispaces.com/file/view/Informe_final_RBB_12.07.12.pdf>.

MAGFOR (2008). Compendio Jurídico Forestal de Nicaragua. 
MAGFOR (2008). Manual de inventivos para el desarrollo de inversiones forestales sostenibles.

MAGFOR, INAFOR (2005). Valoración forestal Nicaragua 2000. Proyecto de Innovación y Aprendizaje en Forestería Sostenible (PROFOR). Banco Mundial.

MARENA, GIZ, CCAD (marzo 2013). Informe sobre sistematización temprana de la experiencia ENDE-REDD+ en Nicaragua. Estrategia Nacional para reducir la deforestación y degradación forestal, ENDE-REDD+. Facilitador: Dámaso Barquero Gaitán, con la colaboración de Dennis Mairena Arauz. Managua.

Ortega Blandón, V.M. (1966). 'Legislación Forestal en Nicaragua. Críticas y Sugerencias'. Tesis. Managua: Escuela Nacional de Agricultura y Ganadería.

Prado, S. (2008). Entre los CDM y los CPC. Centro de Estudios y Análisis Político. Managua.

Readiness Preparation Proposal (R-PP) for Country: Nicaragua. Fecha de presentación o revisión: $1^{\circ}$ de junio de 2012. Formal Versión 7.

Rivas Leclair, M.A. (2010). Nicaragua en Compendio Regional de Jurisprudencia Ambiental. DR-CAFTA. USAID.

Rocha Zúñiga, M. (2006). Diagnóstico legal sobre el funcionamiento de las Secretarías de las Reservas de Biosfera de Bosawas y el Sureste de Nicaragua. MASRENACE-GTZ. Managua.

Salinas, C. y otros. 'El ocaso de BOSAWAS'. Confidencial [revista electrónica], 28 de abril de 2014. $<$ http://www.confidencial.com.ni/bosawas/>.

Vidaurre, A. y EFE. 'En 60\% de hogares nicas cocinan con leña'. El Nuevo Diario.com.ni [periódico online], (30 de agosto de 2013). <http://www.elnuevodiario.com.ni/nacionales/295576-60-dehogares-nicas-cocinan-lena>.

Vintró Castell, J. (2012). Democracia participativa y renovación democrática. Cátedra Xavier Gorrostiaga, SJ. UCA. Nicaragua.

\section{Personas que proporcionaron información a través de entrevistas}

\begin{tabular}{|c|c|}
\hline Sandra Tijerino & Consultora en temas forestales \\
\hline Hoover Castaño & MADERAS DE EXPORTACION( MADEXPORT) S.A. \\
\hline Liza Gonzalez & PASO PACIFICO. Proyecto Retorno al Bosque \\
\hline Gladys Cruz & Asesora Legal del MAGFOR \\
\hline Dora Pantoja & Asesora Legal de INAFOR \\
\hline Orlando Corrales & Sub-Director de Asesoría Legal de INAFOR \\
\hline Anielka Reyes & Funcionaria del Registro Forestal Nacional INAFOR \\
\hline Alvaro Duarte & Fiscal Ambiental Nacional \\
\hline Rubén Gutierrez & Regente Forestal \\
\hline Alvaro Centeno & Autoridad Administrativa de CITES-Nicaragua \\
\hline René Castellón & Directora de la Unidad de Asesoría Legal de MARENA \\
\hline María Elsa Jarquín & Periodista \\
\hline Indira Ugarte & \\
\hline
\end{tabular}





\section{Costa Rica}

Mario Peña Chacón 


\section{Acrónimos}

ACNUDH: $\quad$ Alto Comisionado de las Naciones Unidas para los Derechos Humanos

ADI: $\quad$ Asociación de Desarrollo Integral

ADII: $\quad$ Asociación de Desarrollo Integral Indígena

AFE: $\quad$ Autoridad del Estado

ARESEP: $\quad$ Autoridad Reguladora de los Servicios Públicos

AVA: $\quad$ Acuerdo voluntario de Asociación

BCCR: Banco Central de Costa Rica

BID: $\quad$ Banco Interamericano de Desarrollo

BIRF: $\quad$ Banco Internacional de Reconstrucción y Fomento

CAF: $\quad$ Certificado de Abono Forestal

CAFTA-DR: Tratado de Libre Comercio entre los Estados Unidos, Centro América y República Dominicana

CATIE: $\quad$ Centro Agronómico Tropical de Investigación y Enseñanza

CCF: Cámara Costarricense Forestal

CCT: $\quad$ Centro Científico Tropical

CEDARENA: Centro de Derecho Ambiental y Recursos Naturales

CEPAL: $\quad$ Comisión Económica para América Latina y el Caribe

CGR: $\quad$ Contraloría General de la República

CIAgro: $\quad$ Colegio de Ingenieros Agrónomos

CICAFOC: Coordinadora Indígena Campesina de Agroforestería Comunitaria Centroamericana

CIFOR: $\quad$ Centro Internacional de Investigación Forestal

CIMT: $\quad$ Convenio Internacional de las Maderas Tropicales

CITES: $\quad$ Convención sobre el Comercio Internacional de Flora y Fauna Silvestre

CNSF: $\quad$ Comisión Nacional de Sostenibilidad Forestal

COLAC: $\quad$ Consejos Locales de Área de Conservación

COMEX: Ministerio de Comercio Exterior

CONAC: $\quad$ Consejo Nacional de Áreas de Conservación

CONAGEBIO: Comisión Nacional de Gestión de la Biodiversidad

CORAC: Consejo Regional de Áreas de Conservación

COVIRENA: Comités de Vigilancia de los Recursos Naturales

CRA: $\quad$ Consejo Regional Ambiental

CSA: Certificado de Servicios Ambientales

DAP: Diámetro altura de pecho

DGA: Dirección General de Aduanas

DGTD: $\quad$ Dirección General de Tributación Directa

DHR: Defensoría de los Habitantes de la República

DUA: Declaración Única Aduanera 
EARTH: $\quad$ Escuela de Agricultura de la Región Tropical Húmeda

ECTI: $\quad$ Estrategia para el Control de la Tala llegal

EIA: $\quad$ Evaluación de Impacto Ambiental

ENCC: $\quad$ Estrategia Nacional de Cambio Climático

EsIA: $\quad$ Estudio de Impacto Ambiental

FAO: $\quad$ Organización de las Naciones Unidas para la Alimentación y la Agricultura

FLEGT: $\quad$ Aplicación de Leyes, Gobernanza y Comercio Forestales de la Unión Europea (por sus siglas en inglés, Forest Law, Enforcement, Governance and Trade)

FONAFIFO: Fondo Nacional de Financiamiento Forestal

FSC: $\quad$ Consejo de Administración Forestal (por sus siglas en inglés, Forest Stewardship Council)

GEF: $\quad$ Fondo Mundial Ambiental (por sus siglas en inglés, Global Environmental Facility)

GEl: $\quad$ Gas efecto invernadero

HT: $\quad$ Empresa privada de tratamiento térmico

IMN: Instituto Meteorológico Nacional

INDER: Instituto de Desarrollo Rural

INVU: Instituto Nacional de Vivienda y Urbanismo

ITCR: Instituto Tecnológico de Costa Rica

JUNAFORCA: Junta Forestal Campesina

LA: $\quad$ Ley de Aguas

LB: $\quad$ Ley de Biodiversidad

LCVS: $\quad$ Ley de Conservación de la Vida Silvestre

LF: Ley Forestal

LGAP: $\quad$ Ley General de Administración Pública

LGS: $\quad$ Ley General de Salud

LOA: Ley Orgánica del Ambiente

LUMCS: $\quad$ Ley de Uso, Manejo y Conservación de Suelos

LZMT: $\quad$ Ley de la Zona Marítima Terrestre

MAG: $\quad$ Ministerio de Agricultura y Ganadería

MDL: $\quad$ Mecanismo Desarrollo Limpio

MDVCCR: Mercado Doméstico Voluntario de Carbono de Costa Rica

MEIC: $\quad$ Ministerio de Economía Industria y Comercio

$\mathrm{MH}: \quad$ Ministerio de Hacienda

MIE: $\quad$ Manejo Integrado de Ecosistemas

MINAE: $\quad$ Ministerio de Ambiente y Energía

MP: $\quad$ Ministerio Público

MS: $\quad$ Ministerio de Salud

NIMF-15: Norma Internacional sobre Medidas Fitosanitarias, directrices para Reglamentar Embalaje de Madera 
OIMT: $\quad$ Organización Internacional de las Maderas Tropicales

OIRSA: $\quad$ Organismo Internacional Regional de Sanidad Agropecuaria

OIT: $\quad$ Organización Internacional del Trabajo

ONGs: $\quad$ Organizaciones No Gubernamentales

ONF: Oficina Nacional Forestal

ONU: $\quad$ Organización de Naciones Unidas

PERFOR: $\quad$ Plan Estratégico para el Manejo de los Ecosistemas Forestales

PGR: $\quad$ Procuraduría General de la República

PNDR: $\quad$ Plan Nacional de Desarrollo Forestal

PNE: $\quad$ Patrimonio Natural del Estado

PNUD: $\quad$ Programa de Naciones Unidas para el Desarrollo

PNUMA: $\quad$ Programa de Naciones Unidas para el Medio Ambiente

PROCOMER: Promotora Comercio Exterior

PSA: $\quad$ Pago por Servicios Ambientales

RLZMT: $\quad$ Reglamento Ley Zona Marítimo-Terrestre

SETENA: Secretaría Técnica Nacional Ambiental

SFE: $\quad$ Servicio Fitosanitario del Estado

SIA: $\quad$ Sistema de Información Aduanera

SINAC: $\quad$ Sistema Nacional de Áreas de Conservación

SIREFOR: $\quad$ Sistema de Información de los Recursos Forestales

TAA: $\quad$ Tribunal Ambiental Administrativo

TICA: $\quad$ Tecnología de Información para el Control Aduanero

UCC: $\quad$ Unidades de Compensación Costarricense

UCR: $\quad$ Universidad de Costa Rica

UNA: $\quad$ Universidad Nacional

UICN: $\quad$ Unión Internacional para la Conservación de la Naturaleza

UN-REDD: Programa de Naciones Unidas para la Reducción de Emisiones Provenientes de Deforestación y Degradación de Suelos en Países en Desarrollo

VCS: Verified Carbon Standard

VUCE: Ventanilla Única de Comercio Exterior 


\section{Introducción}

Costa Rica, siendo un país tropical con gran diversidad de suelos y climas, estaba originalmente cubierto casi en su totalidad por bosques naturales, exceptuando los páramos de la Cordillera de Talamanca, sabanas naturales ubicadas principalmente en el Valle de El General y en la provincia de Guanacaste, y varios humedales distribuidos en todo el país. Estos bosques fueron alterados desde el tiempo precolombino por los indígenas que ocupaban el territorio nacional y su alteración se incrementó con la llegada de los europeos ${ }^{1}$.

Como consecuencia de la explosión demográfica a partir de los tiempos coloniales y hasta la década de los años 60 del siglo anterior, se deforestó casi $40 \%$ del territorio costarricense. Es precisamente a partir de los años 60 que se inició una serie de cambios en la estructura económica y las políticas agrarias nacionales que tuvo como consecuencia un proceso acelerado de deforestación, el cual alcanzó su máximo impacto a mediados de los años 80 cuando se llegó a la cifra más baja de $41 \%$ del territorio nacional con cobertura forestal. A finales de la década de los 80 se presentaron de nuevo cambios notorios en la estructura económica y las políticas del país que desincentivaron la deforestación y se vieron reforzados con algunas acciones del Estado en materia de desarrollo económico y conservación, iniciándose así un proceso de restauración de cobertura forestal que llegó para el año 1997 a 42\%, en el 2000 a 47\%, el 2005 a 51,4\% y finalmente, 52,3\% en el $2010^{2}$.

A partir de los datos que muestra el XVIII Informe del Estado de la Nación en Desarrollo Humano Sostenible del año 2012, es posible afirmar que el país ha consolidado la recuperación de su cobertura boscosa, lo cual no necesariamente indica que los bosques están desplazando actividades productivas, sino que se han recuperado áreas abandonadas y otras que han sido incluidas en programas de reforestación. El citado informe establece que debe tenerse presente que es poco probable a futuro el aumento de la cobertura boscosa en grandes áreas, debido a la existencia de zonas de suma importancia que están siendo dedicadas a la producción agropecuaria. También aclara que aún existe deforestación, se sigue perdiendo bosque, aunque el balance se torna positivo por la recuperación de cobertura.

Pese a lo anterior, los bosques enfrentan una serie de amenazas, entre ellas los constantes incendios forestales. Según estadísticas del Programa Nacional de Incendios Forestales del Sistema Nacional de Áreas de Conservación (SINAC), en el 2010 se quemaron 18.683 hectáreas de bosque y en el 2011 9.500 hectáreas $^{3}$. Asimismo, en el 2011 el Tribunal Ambiental Administrativo recibió 55 denuncias

1. Calvo, J. 'Bosques, Cobertura y Recursos Naturales', ponencia para el Décimo Quinto Informe del Estado de la Nación en Desarrollo Humano Sostenible del año 2009. [pdf online]. <http://www.estadonacion.or.cr/ bibliotecavirtual/costa-rica/estado-de-la-nacion/ponencias/490-informe-xv-bosque>. Accedido el 4 de abril de 2014.

2. Información estadística extraída del XVIII Informe del Estado de la Nación en Desarrollo Humano Sostenible. [sitio web]. <http://www.estadonacion.or.cr>. Accedido el 4 de abril de 2014.

3. Sistema de Información de los Recursos Forestales de Costa Rica. 'Estudio de Cobertura Forestal del 2005'. [pdf online]. <http://www.sirefor.go.cr/index.php?option=comcontent\&view=article\&id=20\&lte mid=31>. Accedido el 4 de abril de 2014. 
por tala ilegal de árboles y en las oficinas de las distintas áreas de conservación se atendieron, para este mismo período, 2.165 quejas sobre asuntos forestales ${ }^{4}$.

Según datos extraídos del Censo Nacional de la Industria Forestal Primaria en Costa Rica elaborado por el SINAC en el año 2011, el país tiene varios años de mostrar una tendencia de alto uso de madera proveniente de plantaciones forestales -lo cual ha reducido la presión sobre los bosques-, la industria del aserrío primario trabaja fundamentalmente con madera de plantaciones forestales en $68 \%$ y que cerca de $24 \%$ proviene de potreros o sistemas agroforestales. El Censo menciona 46 especies como las más importantes en la industria, con una presencia mayoritaria de la melina, el laurel y la teca, que suman $49 \%$ del total.

4. Cabrera Medaglia, J. 'Marco Legal Ambiental, capacidades regulatorias y conflictos ambientales relevantes', ponencia para el XVIII Informe del Estado de la Nación. [pdf online]. <http://www.estadonacion. or.cr/bibliotecavirtual/costa-rica/estado-de-la-nacion/informe-actual/informe-por-capitulo/armonia>. Accedido el 4 de abril de 2014. 


\section{Síntesis histórica de la formulación de la Ley Forestal y afines}

Durante los tiempos coloniales y por la importancia de su uso, España y Portugal establecieron normas jurídicas aplicables a sus colonias a través de leyes, ordenanzas y cédulas reales que contenían regulaciones sobre árboles, bosques y montes. Las "Ordenanzas de Nueva España y Leyes de India" disponían que los montes estuvieran al alcance de toda la comunidad (peninsulares y nativos), estableciendo prohibiciones para cortar árboles nuevos y obligaciones de plantar y replantar arboledas.

Luego de la independencia se dictaron las primeras leyes forestales de América Latina: Chile (1872), Ecuador (1875), República Dominicana (1884), México (1894) y Perú (1898) mientras que Costa Rica promulgó su primera Ley Forestal hasta el año $1969^{5}$.

A continuación se detallan los aspectos más relevantes de las distintas leyes forestales promulgadas en Costa Rica ${ }^{6}$.

\section{Ley Forestal № 4475 (1969)}

Establece que las tierras forestales consideradas prioritarias por la Administración Forestal pueden ser expropiadas y deben someterse obligatoriamente al régimen forestal.

Permite cambiar los bosques a otros usos del suelo en proyectos de asentamiento o en cualquier proyecto privado agrícola o ganadero cuyos planes impliquen eliminar el bosque.

Se asignaron funciones excesivas a la Dirección General Forestal. Posibilita rebajar los costos de reforestación de los impuestos sobre la renta.

Protege la industria forestal a través de ventajas para concesiones en reservas forestales, exenciones tributarias, prohibición de exportar madera rolliza y restricciones en las importaciones de productos forestales.

\section{Ley de Reforestación $N^{\circ} 6184$ (1977)}

Establece la obligación del Estado costarricense de reforestar el territorio nacional, para lo cual se debía destinar una suma no menor a $2 \%$ del total de recursos destinados a créditos de la actividad agropecuaria por parte de los bancos comerciales del Estado. Para esos créditos, el interés no debía de ser mayor a $8 \%$, las garantías estarían constituidas por los árboles.

5. Chen Piu Deza, H. 'Análisis del Marco Legal para el Aprovechamiento Sostenible y Comercio de Madera en la región de Mesoamérica'. Ponencia para el VIII Congreso Derecho Forestal, Costa Rica 2011. [pdf online]. <http://web.catie.ac.cr/congresoforestal/imagexpositores/HUGOCHEPIU.pdf>. Accedido el 4 de abril de 2014.

6. Sobre el tema puede consultarse el documento denominado: FONAFIFO: Más de una década de acción. (2005), Infoterra Editores. [pdf online]. <http://www.fonafifo.com/paginasespanol/noticias/FBS/ UnadecadadeAccion.pdf>. 


\section{Ley Forestal $N^{\circ} 7032$ (1986) Y Ley Forestal $N^{\circ} 7174$ (1990)}

Autoriza al Ejecutivo para que incluya las explotaciones forestales que considere necesarias dentro de las áreas protegidas o que las someta a manejo forestal.

Amplía el área de zonas protegidas.

Permite una fuerte intervención de la Administración Forestal en el uso de los recursos forestales.

El permiso especial para cortar árboles requiere aprobación municipal. Establece un impuesto sobre el valor de la madera en pie y una garantía de reposición de $20 \%$ del valor por cada metro cúbico autorizado. Establece el Certificado de Abono Forestal (CAF) como incentivo directo para la reforestación. Mantiene la protección de la industria forestal.

\section{Ley Forestal $N^{\circ} 7575$ (1996)}

Prohíbe cambios en el uso de áreas boscosas.

Introduce restricciones a la explotación de especies forestales.

Prohíbe la exportación de madera escuadrada y rolliza.

Crea el Fondo Nacional de Financiamiento Forestal (FONAFIFO) y establece el Programa de Pago de

Servicios Ambientales que presta el bosque.

\subsection{Formas de participación pública contenidas en políticas, leyes forestales y afines, nivel de implementación y procesos necesarios para su efectividad}

La participación ciudadana en Costa Rica está contemplada en la Constitución Política como un principio rector establecido en el Artículo 9, el cual dispone que "el Gobierno de la República es popular, representativo, participativo, alternativo y responsable”. En materia estrictamente ambiental, la Constitución Política reconoce de manera expresa en su numeral 50 el derecho fundamental a un ambiente sano y ecológicamente equilibrado, artículo que ha servido de fundamento para el desarrollo jurisprudencial del componente de participación pública ambiental.

El sistema costarricense de participación pública ambiental puede calificarse como democrático a partir de una interpretación de diversos artículos constitucionales, específicamente 1, 9, 46 y 50. Al respecto, la Sala Constitucional, mediante la sentencia 2007-449, señaló: “... Como mínimo, el principio democrático importa respeto de los principios de participación y representación política, base de nuestro sistema. Por ello, estima la mayoría de esta Sala que cualquier integración de órganos colectivos, debe encontrar en la representatividad su instrumento pragmático de realización".

Ante ausencia de una ley general de participación pública, ha sido la Sala Constitucional -a través de sus sentencias- la que ha logrado dotar de contenido el concepto de participación ciudadana con base en sus tres dimensiones básicas: el derecho de acceso a la información, el derecho a la participación per se y el derecho de acceso a la justicia en materia ambiental, dimensiones que se deben cumplir de manera obligatoria en los procesos administrativos y judiciales propios de la justicia ambiental. 
Dentro de la normativa ambiental costarricense es posible identificar diversos espacios de participación ciudadana, tales como:

- Consejos Regionales Ambientales (CRA) ${ }^{7}$

- Consejos Regionales de Áreas de Conservación (CORAC) y Consejos Locales de Áreas de Conservación (COLAC) dentro del Sistema Nacional de Áreas de Conservación (SINAC) ${ }^{8}$

- Comités por Áreas de Manejo, Conservación y Recuperación de Suelos ${ }^{9}$

- Comisión Mixta Asesora de la Secretaría Técnica Nacional Ambiental (SETENA) ${ }^{10}$

- Comisiones de Ambiente dentro de las Municipalidades ${ }^{11}$

- Comisión Nacional para la Gestión de la Biodiversidad (CONAGEBIO)12

- Comités de Vigilancia de los Recursos Naturales (COVIRENAS) ${ }^{13}$

- Consejos Locales de Corredores Biológicos ${ }^{14}$

- Oficina Nacional Forestal (ONF) ${ }^{15}$

- Comisión Nacional de Sostenibilidad Forestal ${ }^{16}$

Específicamente en materia forestal, el marco normativo incorpora varias instancias de participación pública. La Ley Orgánica del Ambiente crea los Consejos Regionales Ambientales (CRA), adscritos al MINAE, como máxima instancia regional desconcentrada, con participación de la sociedad civil mediante organizaciones ecológicas y gobiernos estudiantiles de centros de enseñanza secundaria ubicados en la región, para el análisis, la discusión, la denuncia y el control de las actividades, los programas y los proyectos en materia ambiental.

Según la Ley Forestal, los CRA ostentan funciones relacionadas con la protección y aprovechamiento forestal, tales como: conocer y analizar los problemas forestales de la región donde están constituidos y coadyuvar al control y la protección forestal, participar activamente en la concepción y formulación de las políticas regionales de incentivo a la reforestación, prevenir y combatir plagas, enfermedades e incendios forestales en los terrenos del patrimonio natural del Estado y además, colaborar en la prevención de plagas, enfermedades e incendios forestales en plantaciones y bosques privados, dar seguimiento al avance y cumplimiento de las políticas regionales de desarrollo forestal y pronunciarse

7. Ley N ${ }^{\circ}$ 7575: Ley Forestal, La Gaceta 72, 1996, Artículo 9.

8. Ley N $N^{\circ} 7788$ : Ley de Biodiversidad, La Gaceta 101, 1998, Artículo 29.

9. Ley N ${ }^{\circ}$ 7779: Ley de Uso, Manejo y Conservación de Suelos, La Gaceta, 1998, Artículos 34, 35, 36, 37, 39 y 40 .

10. Decreto 32631-MINAE del 2 de mayo de 2005, reformado mediante Decreto 37181-MINAET del 23 de abril de 2012.

11. Ley $\mathrm{N}^{\circ} 77894$ del 30 de abril de 1998.

12. Ley $N^{\circ}$ 7788: Ley de Biodiversidad, La Gaceta 101, 1998, Artículo 29.

13. Decreto $N^{\circ}$ 26923: Reglamento a la Ley de Uso, Manejo y Conservación de Suelos.

14. Decreto №33106: Programa Nacional de Corredores Biológicos de Costa Rica, La Gaceta 130, 2006.

15. La Oficina Forestal Nacional (ONF) es un ente participativo para la definición de políticas e incluye varios actores del sector forestal privado y de organizaciones ecológicas.

16. Adscrita al Ministerio de Ingenieros Agrónomos. Comisión Nacional de Sostenibilidad. [documento online]. <http://www.ing-agronomos.or.cr/comisiones/102-comision-nacional-de-sostenibilidad-forestal.html>. Accedido el 28 de marzo de 2014. 
sobre ellos, recomendar a la Administración Forestal del Estado el orden de prioridad de las áreas por incentivar y autorizar la corta de árboles.

Si bien corresponde al MINAE velar por la protección y conservación de los bosques y terrenos forestales, la ciudadanía puede colaborar en el cumplimiento de esta función por medio de inspectores de recursos naturales ad honórem y de comités de vigilancia de bosques. Los Comités de Vigilancia de los Recursos Naturales (COVIRENA) constituyen un cuerpo de bien social auspiciado por el MINAE, creado para coadyuvar en la aplicación de la legislación ambiental. Este cuerpo se encuentra conformado por ciudadanos que prestan sus servicios de manera honoraria, motivados por el único interés de ayudar en la conservación y vigilancia de los recursos naturales. Los COVIRENA están integrados por inspectores y vigilantes que cumplen funciones de vigilancia, control y denuncia.

Por su parte, la Ley de Biodiversidad de 1998, en un intento por promover la gestión local del Sistema Nacional de Áreas de Conservación (SINAC), creó los Consejos Regionales de Áreas de Conservación (CORAC) que integran la participación pública dentro de su seno, con funciones relacionadas con la gestión forestal, tales como: recomendar al Consejo Nacional de Áreas de Conservación (CONAC) la creación, modificación o cambio de categoría de las áreas silvestres protegidas, participar en el combate de plagas e incendios forestales, recomendar las áreas que deben recibir incentivos forestales, autorizar la corta de árboles en potrero y emitir los certificados de origen para la madera extraída en las plantaciones forestales.

En la Ley de Uso, Manejo y Conservación de Suelos se aborda la importancia de la participación activa de las comunidades e incluso se insta a la conformación de sectores de producción de las zonas en las que se pongan en funcionamiento los Comités de Conservación de Suelos.

Por su parte, las Comisiones Ambientales Municipales, creadas en el Código Municipal de 1998, se han constituido en instancias facilitadoras de la participación directa en el quehacer municipal. Estas comisiones, nombradas por el Concejo Municipal y conformadas por regidores y síndicos, abren un espacio de participación a personas u organizaciones no gubernamentales en calidad de asesores.

La participación pública ambiental en materia forestal se da también a través de organizaciones sociales que tramitan y se benefician del Programa Nacional de Pago de Servicios Ambientales que lidera el Fondo Nacional de Financiamiento Forestal (FONAFIFO).

A la vez, existen varias organizaciones regionales vinculadas con actividades forestales, dentro de las que destacan: Asociación Indígena y Campesina de Agroforestería Comunitaria, Asociación de Pequeños Productores de Talamanca, Unión Nacional Agroforestal, Centro Agrícola Cantonal de Hojancha, Central Agrícola Cantonal de Mora, Coopesilencio, Corredor Biológico Talamanca Caribe, Asociación para el Desarrollo Sostenible de la Región Atlántica y la Comisión de Desarrollo Forestal de San Carlos.

En general, el diseño y funcionamiento de las instancias de participación ambiental relacionadas con la protección y el aprovechamiento forestal es poco claro, y en algunos casos, existen duplicidades de funciones, lo cual ha dificultado su eficaz funcionamiento, siendo el principal reto en esta materia lograr cumplir a cabalidad con los lineamientos del principio 10 de la Declaración de Río 92 y del Convenio de Aarhus ${ }^{17}$ o sea, que la participación ciudadana se dé a partir de las etapas

17. La Convención sobre Acceso a la Información, Participación Pública en la Toma de Decisiones y Acceso a la Justicia en Temas Medioambientales de la UNECE, conocida normalmente como el Convenio de Aarhus, 
más tempranas de la planificación de la decisión ambiental, con el fin de que su voluntad se vea reflejada bajo un aporte de mejoramiento y perfeccionamiento de los aspectos sociales, ambientales e incluso económicos.

\subsection{Institucionalidad forestal y competencias en torno al aprovechamiento forestal y comercio internacional de productos forestales}

La institucionalidad forestal costarricense se encuentra conformada por el Sistema Nacional de Áreas de Conservación (SINAC), el Fondo Nacional de Financiamiento Forestal (FONAFIFO), la Oficina Nacional Forestal (ONF), el Ministerio de Agricultura y Ganadería (MAG), el Ministerio de Hacienda -por medio de la Dirección General de Aduanas (DGA)-, el Servicio Fitosanitario del Estado (SFE), el Colegio de Ingenieros Agrónomos (CIAgro) y las municipalidades.

Ligadas a estas instituciones es posible encontrar otros actores satélite, tales como Junta Nacional Forestal Campesina (JUNAFORCA), Cámara Costarricense Forestal (CCF), Asociación Coordinadora Indígena y Campesina de Agroforestería Comunitaria Centroamericana (ACICAFOC), Organización de las Naciones Unidas para la Agricultura y la Alimentación (FAO), Centro Agronómico Tropical de Investigación y Enseñanza (CATIE), Escuela de Agricultura de la Región Tropical Húmeda (EARTH) y Unión Mundial para la Conservación (UICN), así como instituciones de educación superior como la Universidad de Costa Rica (UCR), el Instituto Tecnológico de Costa Rica (ITCR) y la Universidad Nacional (UNA).

La Autoridad Forestal del Estado (AFE) es responsable de dirigir el manejo forestal del país y está conformada por el Sistema Nacional de Áreas de Conservación (SINAC) y el Fondo Nacional de Financiamiento Forestal (FONAFIFO), ambos órganos desconcentrados del Ministerio de Ambiente y Energía.

EI SINAC fue creado por la Ley de Biodiversidad de 1998 como un sistema participativo de coordinación y manejo, organizado en once áreas de conservación, siendo su naturaleza jurídica la de un órgano con desconcentración máxima ${ }^{18}$ del MINAE con personalidad jurídica instrumental para la administración de sus propios recursos. Cada área de conservación tiene un centro administrativo regional, donde se toman las decisiones operativas y financieras con un relativo nivel de autonomía. El contacto con los ciudadanos se da en las 32 oficinas locales del SINAC, las cuales manejan las acciones de promoción y control forestal.

Dentro de sus principales competencias forestales es posible citar: conservar los recursos forestales del país, aprobar los planes de manejo forestal, dictar los lineamientos de los planes de manejo forestal y velar para que se ejecuten efectivamente, establecer vedas de las especies forestales en vías o en peligro de extinción, prevenir y controlar que no existan aprovechamientos forestales ilegales, denunciar ante la Procuraduría Ambiental y de la Zona Marítimo-Terrestre, Contraloría Ambiental, Tribunal Ambiental Administrativo, así como ante el Ministerio Público, cualquier irregularidad en la aplicación de la Ley Forestal.

fue firmada el 25 de junio de 1998 en la ciudad danesa de Aarhus. Entró en vigor el 30 de octubre de 2001.

18. El término desconcentración implica la atribución exclusiva e independiente de competencia en el desempeño de sus funciones; es, por tanto, una excepción al principio de jerarquía. 
Por su parte, el Fondo Nacional de Financiamiento Forestal (FONAFIFO) es el órgano de desconcentración máxima con personería jurídica instrumental dentro de la estructura organizativa de la AFE que promueve el Programa Nacional de Pago por Servicios Ambientales; además, es quien capta recursos y administra el financiamiento de los servicios ambientales. Su objetivo es financiar para beneficio de pequeños y medianos productores -mediante créditos $u$ otros mecanismos de fomento del manejo del bosque, intervenido o no- los procesos de forestación, reforestación, viveros forestales, sistemas agroforestales, recuperación de áreas desnudadas y los cambios tecnológicos en aprovechamiento e industrialización de los recursos forestales.

El Programa de Pago por Servicios Ambientales está a cargo del Ministerio de Ambiente y Energía (MINAE) mediante el SINAC y el FONAFIFO. Al primero le corresponde la definición, planificación, ejecución y evaluación de políticas de conservación del país, así como de los criterios de priorización para definir las áreas de inversión del programa; además, el monitoreo y seguimiento estratégico de los proyectos respectivos. El segundo es el encargado de captar y colocar los recursos financieros en los proyectos y también de las labores operativas relacionadas con el control y el monitoreo de estos. Corresponde al Fondo Nacional de Financiamiento Forestal la gestión, comercialización y captación de recursos financieros para el pago de servicios ambientales, tanto a nivel nacional e internacional, por parte de entidades privadas o públicas de carácter nacional o internacional.

La Ley Forestal crea la Oficina Nacional Forestal (ONF) como un ente público no estatal con personalidad jurídica propia, conformado por una junta directiva integrada por dos representantes de las organizaciones de pequeños productores, dos representantes de otras organizaciones de productores forestales, dos representantes de los industrializadores de la madera, un representante de las organizaciones comerciantes de madera, un representante de artesanos y productores de madera, y un representante de los grupos ecologistas del país.

Como principales funciones de la ONF pueden citarse proponer al MINAE las políticas y estrategias forestales, ejecutar y apoyar programas de capacitación tecnológica, estudios e investigaciones, impulsar programas de prevención y fomento de las inversiones en el sector, divulgar información sobre mercados, costos y otros para la comercialización de la madera, promover la constitución y el fortalecimiento de asociaciones y grupos organizados para el desarrollo del sector forestal, asesorar a los Consejos Regionales Ambientales y coordinar con las municipalidades.

La Ley Forestal asigna a las municipalidades expresamente la obligación de coordinar con el MINAE las labores de control forestal y fiscal, así como de prevención de incendios forestales.

Por su parte, el Colegio de Ingenieros Agrónomos de Costa Rica (CIAgro) realiza la función de vigilancia, fiscalización y sanción de los regentes forestales en cuanto al ejercicio liberal de la profesión, sin detrimento de la supervisión que pueda recibir también por parte de la Administración Forestal del Estado, como consecuencia de las amplias facultades que la Ley Forestal le otorga.

Corresponde a la Dirección General de Aduanas del Ministerio de Hacienda, de conformidad con la Ley General de Aduanas, realizar inspecciones y controles de mercancías sujetas a control aduanero, incluyendo las exportaciones e importaciones de madera y productos forestales, y el cobro de los impuestos respectivos. Tratándose de exportación e importación de maderas y sus productos incluidos en los apéndices CITES (Convención sobre el Comercio Internacional de Especies Amenazadas de Fauna y Flora Silvestre), la autoridad aduanal está en la obligación de 
exigir los respectivos permisos CITES emitidos por la Autoridad Administrativa CITES nacional o del país de origen. En Costa Rica la autoridad CITES es el MINAE.

Por último, corresponde al Servicio Fitosanitario del Estado lo concerniente a la regulación del embalaje de madera utilizado en el comercio internacional siguiendo los lineamientos de la norma NIMF-15 oficializada a través del Decreto Ejecutivo 32622-MAG, con el fin de reducir el riesgo de introducción y/o dispersión de plagas cuarentenarias relacionadas con el embalaje de madera (incluida la madera de estiba), fabricado de madera en bruto de coníferas y no coníferas, utilizado en el comercio internacional.

En el Informe de Fiscalización de la Contraloría General de la República (DFOE-PGAA-7-2008 Informe sobre la evaluación de la aplicación de políticas y normativa en materia de recursos forestales por el Ministerio de Ambiente y Energía), la CGR le llama la atención al SINAC con respecto a sus debilidades a nivel de toma de decisiones y control operativo que le impiden llevar a cabo una gestión eficiente en materia de control de aprovechamiento sostenible del recurso forestal y le hace señalamientos y recomendaciones específicas orientadas a mejorar la planificación, gestión y control en aspectos relevantes.

En cuanto al Programa de Pago de Servicios Ambientales, en el Informe de Fiscalización DFOE-IF-08-2011 ("Acerca de los efectos del Programa de Pago por Servicios Ambientales implementado por el Estado costarricense"), la CGR determinó que FONAFIFO ha actuado como un ente facilitador del desarrollo forestal y sus demandas al habilitar procedimientos que agilizan la admisión, registro y control de las fincas de los beneficiarios, mientras que el SINAC ha omitido acciones propias de su papel rector en materia de conservación y la gestión del programa. Todo lo anterior ha generado que se haya tendido a fortalecer el desarrollo forestal, más que en apego a la concepción de los servicios ambientales.

En cuanto a la gestión del CIAgro, el capítulo ambiental del XVI Informe del Estado de la Nación recomienda fortalecer su función fiscalizadora por medio del aumento de sus ingresos, lo cual se podría lograr por medio de la estrategia REDD+, de donde podrían salir los fondos para dotarlo de recurso humano temporal para atender el rezago de inspecciones de rutina y poner al día la atención, tramitología y seguimiento de denuncias, así como también de recursos logísticos como transporte, hardware y software, y un sistema de documentación que genere información y toma de decisiones debidamente enlazado con otras iniciativas ${ }^{19}$.

En esta materia, el principal reto consiste en mejorar el nivel de coordinación entre las distintas instituciones que conforman la Administración Forestal del Estado costarricense, lo cual propiciaría con mayor facilidad el cumplimiento de las regulaciones previstas para el aprovechamiento y control forestal.

19. Al respecto se recomienda la ponencia de German Obando para el XVI Informe del Estado de la Nación. 'Bosque, cobertura y recursos forestales, 2009'. [pdf online], <http://www.estadonacion.or.cr/files/ biblioteca_virtual/016/german_obando.pdf>. 


\subsection{Ley Forestal y su consistencia con otras legislaciones referidas al comercio internacional de productos de madera}

La Ley Forestal, luego de diecisiete años de su puesta en vigencia, debido a las escasas modificaciones de que ha sido objeto, presenta una serie de debilidades que han tratado de ser enmendadas principalmente mediante la promulgación de nuevas leyes, decretos y reglamentos, así como por jurisprudencia constitucional, civil, penal y administrativa emanada de las distintas Salas de la Corte Suprema de Justicia.

Normas ambientales posteriores a su promulgación, tales como la Ley de Biodiversidad, Ley de Uso, Manejo y Conservación de Suelos, y en especial su propio reglamento general, así como los reglamentos de las citadas leyes, cumplieron un papel integrador y armonizador que favorece su aplicación.

En materia de comercio internacional, la Ley Forestal en su Artículo 26 prohíbe la exportación de madera en trozas y escuadrada proveniente de bosques, prohibición que se enmarca dentro de una política de recuperación y uso sostenible donde Costa Rica ha alcanzado importantes avances en las últimas décadas.

Resulta interesante que, a pesar de que la Ley de Conservación de Vida Silvestre excluye los árboles forestales como parte de la flora silvestre, para efectos de la exportación sí incluyó los productos y subproductos de los árboles maderables que se encuentren en peligro de extinción o incluidos en los apéndices de la convención CITES, razón por la cual todo el esquema de prohibiciones y sanciones se encuentra regulado por este cuerpo normativo ${ }^{20}$.

Por lo anterior, es la Ley de Conservación de Vida Silvestre y no la Ley Forestal la que regula y a la vez, sanciona la importación y la exportación de los productos y subproductos de los árboles maderables declarados en peligro de extinción, con poblaciones reducidas o que se encuentran en los apéndices de la Convención CITES. Al efecto fue emitido el Decreto Ejecutivo 27654-MINAE denominado "Procedimiento para el Trámite de Permisos de Importación y Exportación de Especies de Flora y Fauna Silvestres".

La Ley General de Aduanas dispone que se pueden realizar inspecciones y controles de mercancías sujetas a control aduanero, incluyendo las exportaciones. En el caso de que se autorice la exportación de madera o productos de madera, se requiere la presentación de información relativa al tipo, volumen y peso del producto. En materia fitosanitaria, el Decreto Ejecutivo 32622 regula el embalaje de madera utilizado en el comercio internacional oficializando la norma NIMF-15.

Por su parte, el derecho internacional ambiental -especialmente el Convenio de Diversidad Biológica, Convenio de las Naciones Unidas para la Lucha contra la Desertificación, Convenio Marco sobre Cambio Marco de las Naciones Unidas sobre Cambio Climático, las Convenciones CITES y Ramsar, Convenio Internacional de Maderas Tropicales, Convenio Centroamericano de Biodiversidad, Convenio Centroamericano de Manejo y Conservación de los Ecosistemas Naturales Forestales y el Desarrollo de Plantaciones Forestales, entre otros- funge como norte y parámetros de interpretación

20. La LCVS regula los requisitos y permisos para realizar importación y exportación de vida silvestre en el Capítulo IX, en los Artículos del 70 al 81 y en el Reglamento, del Artículo 34 al 41. 
de la normativa forestal interna en la medida en que dichos instrumentos internacionales gozan de la prerrogativa de ser de obligado acatamiento y plenamente ejecutables según lo ha interpretado en reiteradas ocasiones la jurisprudencia emanada de la Sala Constitucional21.

Costa Rica ha venido realizando una serie de esfuerzos, entre ellos la reforestación de especies nativas, el manejo sostenible del bosque y la implementación del Pago por Servicios Ambientales (PSA), para adherirse al Convenio Internacional de Maderas Tropicales, trabajo que culminó el pasado 20 de agosto de 2013 cuando la Asamblea Legislativa lo aprobó en segundo debate, quedando aún pendiente todo lo relativo a su implementación y adaptación de la normativa interna.

Mientras tanto, en la Convención sobre el Comercio Internacional de Especies Amenazadas de Fauna y Flora Silvestres (CITES) ${ }^{22}$ no se hace la diferencia que contiene la legislación costarricense entre árbol forestal y el resto de la flora silvestre, tal y como se definen en las respectivas leyes, por lo que en cualquiera de los apéndices de CITES pueden encontrarse especies de árboles junto con especies de los otros tipos de flora silvestre. Por ello, vale resaltar que el legislador haya incluido en el Artículo 91 de la Ley de Conservación de Vida Silvestre una protección para la exportación de árboles maderables en peligro de extinción o incluidos en los apéndices de CITES, agravando incluso la sanción para esos casos.

Siempre en el tema de comercio internacional de madera, en el año 2008 el Congreso de Estados Unidos aprobó una nueva regulación denominada Lacey Act que declaró ilegal la importación, exportación, transporte, venta, recepción, adquisición o compra interestatal o internacional de cualquier planta extraída u objeto de comercio en contra de las leyes estadounidenses, de un Estado de Estados Unidos o de las leyes extranjeras pertinentes.

Además, el Parlamento Europeo también aprobó una normativa que entró en vigor en marzo de 2013, la cual exige que todos los agentes que comercialicen productos madereros en el mercado por primera vez deben llevar a cabo la diligencia debida. Además, establece que es un delito comerciar con productos de madera ilegal en el mercado de la Unión Europea. Este reglamento es parte de una iniciativa del 2003: el Plan de Acción de la Aplicación de Leyes, Gobernanza y Comercio Forestales (FLEGT, por sus siglas en inglés) de la Unión Europea. El Plan de Acción de FLEGT reconoce el papel que desempeñan tanto productores como consumidores para frenar y detener la cosecha y el comercio de madera ilegal.

La Lacey Act se basa en hechos, no en documentos. Esto significa que no existe el requisito de disponer de una certificación o verificación del origen legal, pero también implica que no se aceptan documentos, sellos, licencias o marcados como prueba definitiva de la legalidad. Cada comprador estadounidense es libre de determinar la mejor manera de actuar con la debida precaución y evitar comerciar con madera ilegal según su propio perfil de riesgo y nivel de comodidad con sus proveedores. Por su parte, dentro del Plan de Acción FLEGT solo se aceptan como pruebas de legalidad las licencias FLEGT y los permisos CITES. Las licencias FLEGT abarcan la madera procedente de un país que tenga un Acuerdo Voluntario de Asociación (AVA) con la UE y cuyo sistema de garantía de la legalidad de la madera haya sido declarado funcional. La Convención sobre

21. Al respecto es posible citar la sentencia constitucional 6240-93 de las catorce horas del 26 de noviembre de 1993.

22. CITES fue firmada en Washington el 3 de marzo de 1973 y enmendada en Bonn el 22 de junio de 1979. 
el Comercio Internacional de Especies Amenazadas de Fauna y Flora Silvestres (CITES) abarca los permisos para la exportación de madera incluida en los Anexos A, B o C del Reglamento CITES.

Si bien, la Ley Forestal es omisa por sí misma respecto a múltiples aspectos propios del comercio internacional de madera, lo cierto del caso es que la normativa, tanto anterior como posterior a su promulgación, subsana y logra llenar parcialmente tales vacíos, quedando aún pendiente tanto la suscripción de un AVA entre Costa Rica y la Unión Europea, así como la operativización interna del Convenio Internacional de Maderas Tropicales.

\subsection{Mecanismos legales y marcos jurídicos dentro de las Estrategias REDD+ respecto al aprovechamiento forestal y comercio internacional de productos forestales ${ }^{23}$}

Las principales iniciativas, políticas y normas que dan sustento a la implementación de la Estrategia REDD+ de Costa Rica son las siguientes:

\section{a. Estrategia para el Control de la Tala llegal (ECTI)}

Implementada durante el período del 2002 y el 2007 con resultados importantes, y que a falta de recursos se redujo su accionar. Dentro de las acciones correctivas para prevenir y disminuir la tala ilegal se encuentran: acciones correctivas estructurales, ajustar la política forestal, simplificar requisitos y facilitar el acceso al recurso, exigir reposición del recurso para los inventarios forestales, reformar la Ley 7575, reestructurar el SINAC y acciones correctivas para mejorar el proceso de fiscalización y brigadas regionales de control de la tala ilegal.

\section{b. Inventario Forestal Nacional}

Su principal objetivo es la elaboración de un diagnóstico nacional sobre el estado de los recursos forestales y del suelo, y establecer un Sistema de Monitoreo de los Recursos Forestales y del Suelo (áreas prioritarias para la conservación de la biodiversidad y de bosques potenciales como fuentes y sumideros de carbono).

\section{c. Programa de Pagos por Servicios Ambientales (PSA)}

Este programa reconoce que los bosques producen servicios ambientales que tienen un valor y estos deben ser compensados por sus usuarios. Dándole un verdadero valor al recurso, sus titulares se convierten en verdaderos defensores de los bosques y con esto se reducen los riesgos de deforestación, que representan la segunda fuente de producción de gases de efecto invernadero en el mundo. Su financiamiento depende de que exista un reconocimiento o retribución económica por parte de aquellos que se benefician de los servicios ambientales.

23. Para mayores detalles referirse a la Propuesta para la Preparación de Readiness R-PP Costa Rica, abril 2011. FUNDECOR. [sitio web]. <http://www.fundecor.org/es/propuesta-para-la-preparacion-de-readinessr-pp-costa-rica-presentado-forest-carbon-partnership>. 


\section{d. Estrategia Nacional de Cambio Climático (ENCC)}

Prioriza en mitigación, adaptación, métrica, tecnología, educación y financiamiento, todo con el objetivo común de la integración de la política de cambio climático de acuerdo con la competitividad a largo plazo del país y la estrategia de desarrollo sostenible.

El concepto de "Carbono Neutralidad", al que Costa Rica se ha comprometido, se refiere a la práctica de balancear los equivalentes de emisiones de dióxido de carbono (CO2), incluyendo no solamente emisiones directas de $\mathrm{CO} 2$, sino también emisiones de los otros gases de efecto invernadero (GEI), tales como óxido nitroso, metano y fluoruros de carbono, medidos en términos de sus equivalentes de dióxido de carbono, a nivel de país. Se pretende compensar las emisiones de carbono que libera el país con dosis equivalentes de oxígeno para el año 2021.

\section{e. Proyecto Reducción de Emisiones REDD (ER-PIN)}

Un proyecto de Reducción de Emisiones REDD (ER-PIN) para Costa Rica ha sido incluido en el Fondo de Carbono en marzo de 2013, con el objetivo de firmar un acuerdo de compra de reducción de emisiones. Para ello, el país desarrollará un Sistema de Monitoreo, Reporte y Verificación de Emisiones y Remociones de GEl para los diferentes sectores (energía, desechos, uso del suelo y cambio de uso del suelo).

\section{f. Mercado Doméstico Voluntario de Carbono de Costa Rica}

Es la norma nacional de carbono neutralidad INTE 12-01-06:2011 la que define las condiciones bajo las cuales una empresa o institución puede ser certificada por el país como carbono neutral.

La normativa se basa en la necesidad de reducción de las emisiones a niveles significativos que podrán ser complementadas por unidades de compensación, las cuales pueden provenir de tres fuentes: el Mecanismo de Desarrollo Limpio (MDL), el uso de créditos de carbono provenientes de Verified Carbon Standard (VCS) y las Unidades de Compensación Costarricense (UCC).

Para viabilizar la generación de UCC, el MINAE creó el Mercado Doméstico Voluntario de Carbono de Costa Rica (MDVCCR), con el apoyo del Programa de las Naciones Unidas para el Desarrollo (PNUD) e inició el proceso de diseño e implementación del MDVCCR con el desarrollo de una hoja de ruta para el establecimiento de este mercado.

\section{g. Plan Nacional de Desarrollo Forestal 2011-2020}

Tiene como objetivo asegurar la implementación y consolidación de la política forestal del país que contribuya al desarrollo sostenible en su dimensión social, económica y ambiental. Su alcance son los ecosistemas y tierras forestales ubicadas dentro y fuera del Patrimonio Natural del Estado (PNE) y busca que el sector forestal costarricense sea reconocido, rentable, sustentable (económica, social, ambiental y culturalmente), competitivo, imprescindible y estratégico para la calidad de vida de los habitantes del país.

\section{h. Proyecto de Ley de Cambio Climático}

Su objeto es establecer un marco operativo para el desarrollo de políticas públicas de mitigación y adaptación al cambio climático. Este marco operativo regula la planificación, ejecución y control 
de las actividades para la gestión integrada de la mitigación y adaptación al cambio climático en el territorio nacional.

De lo anteriormente expuesto es posible concluir que Costa Rica, mediante acciones anteriores a la formulación de la estrategia REDD+, ya había implementado políticas y normativas que tenían como finalidad la reducción de los gases de efecto invernadero de la atmósfera, por medio de la ratificación del Convenio Marco de Cambio Climático y su Protocolo de Kioto, prohibición establecida en la Ley Forestal de 1996 de cambio de uso de suelo forestal, la puesta en práctica del Programa de Pago por Servicios Ambientales (Ley Forestal y Ley de Biodiversidad), así como la implementación de políticas que tienen como fin la detención de la deforestación y el control de la tala ilegal.

Acciones posteriores como la promulgación de la Estrategia Nacional de Cambio Climático, el Plan Nacional de Desarrollo Forestal, el establecimiento de la meta país de la carbono neutralidad 2021, la creación y regulación jurídica de un mercado doméstico voluntario de carbono, así como la iniciativa de proyecto de ley de cambio climático, refuerzan ese marco político-jurídico-institucional que busca cumplir con los compromisos y metas asumidos por el país en materia de cambio climático, específicamente respecto a la reducción de emisiones de la deforestación y degradación de bosques, y el papel de la conservación, manejo sostenible de bosques y el aumento de las reservas de carbono.

\subsection{Conflictos existentes entre derechos de uso de la tierra y los bosques}

Los principales conflictos por derechos de uso de tierra y bosque ocurren tanto entre propietarios y poseedores de bosques, entre los mismos poseedores de terrenos boscosos y especialmente entre poseedores ilegales (invasores) y comunidades indígenas.

En relación con la tenencia de la tierra, la normativa agraria y ambiental les otorga a los usuarios del bosque varias formas de demostrar su posesión lícita o derechos de propiedad que les permita el acceso legal a los recursos del bosque. Tratándose de controversias entre propietarios y poseedores de bosques, y entre estos últimos, la jurisprudencia emanada tanto de los Tribunales Agrarios como de la Sala Primera de la Corte Suprema de Justicia ha desarrollado de manera reiterada el instituto real de la posesión ambiental y dentro de esta, la posesión forestal, diferenciándola claramente de otros tipos de posesión, como la civil y la agraria.

A pesar de la protección otorgada vía jurisprudencial, actualmente le es imposible al poseedor de bosque el aprovechamiento forestal, salvo aquellos que cuenten con sentencia firme de información posesoria y los que posean contratos, como el de arrendamiento, que les otorga el derecho de corta ${ }^{24}$.

Si bien al poseedor de bosque le está vedado su aprovechamiento, sí le está facultado participar como beneficiario del Programa de Pago de Servicios Ambientales del Fondo Nacional de Financiamiento Forestal para la modalidad de pago por reforestación y protección de bosques.

Por otra parte y tratándose de conflictos de derechos de uso y bosques en territorio indígena, es importante tomar en cuenta que a pesar que la titularidad de los territorios descansa, de forma

24. Reglamento de la Ley Forestal, Art. 89. 
colectiva, en la comunidad misma y que las tierras no se pueden vender, alquilar, arrendar o traspasar por su carácter imprescriptible e inalienable ${ }^{25}$, en la práctica se continúan realizando traspasos ilegales sin que la declaración de nulidad sea la constante.

No obstante el carácter inalienable, imprescriptible e intransferible de los 24 territorios del país, la tenencia de la tierra de los pueblos indígenas se encuentra en situación de inseguridad jurídica debido a las invasiones y ventas de sus territorios por personas no indígenas. Frente a las invasiones, el Estado no ha logrado dar una respuesta eficaz para desalojar o reubicar a los invasores ${ }^{26}$.

La riqueza en biodiversidad y recursos naturales (incluyendo recurso forestal) de los territorios indígenas aumenta la inseguridad territorial por el interés de empresas privadas y públicas en la explotación de sus recursos. Los proyectos de desarrollo económico son aprobados y concesionados, en ocasiones sin consultar a los pueblos que se verían afectados por dichos proyectos; lo anterior aunque se trata de una obligación jurídica establecida por el Convenio 169 de la Organización Internacional del Trabajo y reconocida ampliamente a través de la jurisprudencia constitucional.

El despojo de los territorios indígenas y la explotación de los recursos forestales dentro de sus tierras ha sido objeto de denuncias nacionales e internacionales que instan al país a respetar los derechos colectivos e individuales de esos pueblos.

Como conclusión, es posible afirmar que a pesar de la protección que le brinda tanto la normativa como la jurisprudencia al propietario forestal como al poseedor forestal en cuanto a seguridad jurídica en la tenencia de la tierra, lo cierto del caso es que el segundo sigue siendo la parte más desprotegida de la relación jurídica, impidiéndosele el aprovechamiento forestal al carecer de título registral que demuestre su titularidad, lo que puede tener como consecuencia indirecta la tala ilegal de bosques y terrenos con aptitud forestal.

Situación similar sucede con los bosques ubicados en territorios indígenas, los cuales corren peligro, aunque su aprovechamiento está supeditado exclusivamente a los pueblos indígenas que los poseen y cuya titularidad recae en las distintas Asociaciones de Desarrollo Integral, debido a problemas catastrales de traslapes, aunado a la invasión ilegal de no indígenas, así como problemas internos de gobernanza. Mientras el Estado costarricense no resuelva y dé seguridad jurídica y catastral a los pueblos indígenas, sus recursos naturales corren peligro de ser aprovechados y explotados de manera no sostenible.

\subsection{Marco jurídico para promover la distribución justa y equitativa de los beneficios de un aprovechamiento sostenible de la madera}

A partir del voto constitucional 2013-10540 del 7 de agosto de 2013, el cual desarrolla por primera vez el principio de desarrollo sostenible democrático, se convierte en una obligación del Estado garantizar la distribución justa y equitativa de los costos y beneficios derivados del aprovechamiento sostenible de los recursos naturales, que incluye -por supuesto- los recursos forestales, de modo

25. Así lo dispone expresamente el artículo 3 de la Ley Indígena número 6172 del 29 de noviembre de 1977.

26. Informe de Diagnóstico de la situación de los derechos humanos de los pueblos indígenas de América Central realizado por ACNUDH, 2013. 
que alcance y beneficie al mayor número posible de personas y permita el progreso solidario de las familias que componen el sector social y productivo forestal.

Ahora bien, de conformidad con el Informe de Costos de Acceso a la Legalidad, Cadenas y Actores de Mercado de la Madera Legal e llegal en Costa Rica $^{27}$ respecto a la distribución de riqueza entre los actores y actividades principales de las cadenas de mercado forestal, el estatus de legalidad fomenta la equidad en la distribución de la riqueza proveniente del bosque entre los distintos actores. Por el contrario, el estatus de ilegalidad favorece la concentración de esta en los últimos eslabones de las cadenas de mercado.

Según el citado informe, el propietario resulta protegido (recibe mejores precios) con el madereo en troza y las operaciones legales. El madereo hormiga obliga al propietario a asumir la ineficiencia del aserrío en finca, por cuanto solo se le paga el volumen que sale y lo pone en gran desventaja económica. Claro está que si el madereo hormiga lo realiza el mismo propietario de la madera, el panorama cambiaría radicalmente a su favor.

En las restantes cadenas de mercado, el propietario de la madera enfrenta la desventaja de precios de venta más bajos debido al estatus de ilegalidad en las operaciones posteriores. El actor más beneficiado en la mayoría de las cadenas modeladas parece ser el depósito, con excepción del caso del madereo hormiga legal, donde resulta serlo el intermediario. Los ingresos promedio del depósito resultan al menos $9 \%$ superiores a los de los otros actores. Bajo los supuestos asumidos en el citado estudio, el intermediario definitivamente es el motor de las cadenas de mercado estudiadas y es quien asume las mayores cuotas de riesgo.

Por su parte, el informe denominado Madera Legal, Verificación y Gobernanza del Sector Foresta/28 llega a la conclusión de que los pobres en particular enfrentan considerables barreras para el cumplimiento legal, aun cuando posean derechos de uso de los bosques. Esto refleja la complejidad de las regulaciones y los altos costos de transacción para obtener permisos. En Costa Rica, el cumplimiento de los criterios e indicadores obligatorios de manejo forestal sostenible dejan pérdidas por US\$200 por hectárea, que deben compensarse con pagos por servicios ambientales.

Dentro de los mecanismos jurídicos que buscan favorecer la distribución justa y equitativa de los beneficios derivados del aprovechamiento forestal es posible encontrar el impuesto forestal de 3\% sobre la transferencia de la madera en trozas, el cual debe ser determinado por la Administración Forestal del Estado. El hecho generador del impuesto está constituido por la industrialización primaria de la madera o en el caso de la madera importada ${ }^{29}$.

27. CEDARENA, 2006.

28. Brown D. (2010). $1^{\text {a }}$ edición. Turrialba, Costa Rica: CATIE.

29 Son contribuyentes del Impuesto a las Ventas y el Impuesto General Forestal todas aquellas personas físicas o jurídicas que realicen el hecho generador que se describe así: Ventas habituales de madera en troza por parte de propietario o propietaria de centros de industrialización primaria de madera. Se mantienen por habituales las ventas constantes como actividad principal y predominantes de la empresa que se ejecutan en forma pública. Asimismo, serán contribuyentes de dichos impuestos los importadores de maderas conforme con lo dispuesto por la Ley $N^{\circ} 6826$ vigente. El Impuesto General Forestal en la industria deberá ser cobrado para todos los casos diez días después de la publicación del presente reglamento en el Diario Oficial La Gaceta, Artículo 98, Reglamento Ley Forestal. 
Por su parte, el fondo forestal creado por la Ley Forestal se usa para pagar a los propietarios de bosques por los servicios ambientales que su bosque natural, plantación forestal o sistema agroforestal ofrece a la sociedad.

Otro de los mecanismos de distribución de los beneficios derivados de la actividad forestal es el Programa de Pago por Servicios Ambientales del FONAFIFO, el cual compensa a los titulares por los servicios ambientales que sus bosques, plantaciones forestales y sistemas agroforestales brindan al país.

La Ley Forestal en su Artículo 6 prevé un mecanismo de distribución a favor del Ministerio de Educación Pública a través de la obligación que recae en la Administración Forestal del Estado de donarle la madera decomisada y aquella producto de desastres naturales o ampliación de carreteras para que construya mobiliario, repare infraestructura en escuelas y colegios públicos o utilice en las asignaturas de ebanistería, torno, carpintería y otras.

Además, el sistema jurídico costarricense reconoce varios tipos de tenencia de la tierra y da prioridad para el pago de servicios ambientales a las organizaciones de pequeños propietarios y regiones donde las comunidades tienen bajos índices de desarrollo.

De igual modo, los recursos naturales que se encuentran en territorios indígenas son de su propiedad administrados por la Asociación de Desarrollo Integral Indígena. En el caso de los beneficios que se derivan de la disposición o explotación racional de los recursos naturales (explotaciones forestales, pago por servicios ambientales $u$ otro tipo), estos deben ser concebidos como patrimonio de la comunidad y será a través del mecanismo que defina la estructura jurídica correspondiente -o sea, la ADII- que tales ingresos se distribuyan o inviertan, ya sea repartiéndolos proporcionalmente entre los miembros de la comunidad indígena, levantando obras comunales o en cualquier acción que implique un beneficio colectivo. 


\section{Análisis de los estándares de legalidad}

\subsection{Vacíos y conflictos en la aplicabilidad de la Ley Forestal y afines, tomando especial atención en las posibilidades y retos a la luz de los sistemas existentes de derecho consuetudinario indígena y derecho positivo de los pueblos y territorios indígenas en los países}

El Derecho Internacional de los Derechos Humanos ha sido profuso en el reconocimiento de los derechos de las poblaciones indígenas, destacando en ese sentido lo establecido en los siguientes instrumentos: Declaración Universal de los Derechos Humanos (Artículos 1, 2.1, 7, 17.1 y 27), Pacto Internacional de Derechos Civiles y Políticos (Art. 27), Pacto Internacional de Derechos Económicos, Sociales y Culturales (Artículos 1.1 y 2), Declaración Americana de los Derechos y Deberes del Hombre (2, 13 y 23), Convención Americana sobre Derechos Humanos (Artículos 24 y 26).

En forma concreta, ha sido la Organización Internacional del Trabajo (OIT) la que ha generado la regulación más específica respecto de los derechos de los pueblos indígenas. En ese sentido, los Convenios números 107 y 169 contienen una detallada enumeración de derechos reconocidos a estos pueblos, de donde resulta especialmente importante lo atinente a las tierras indígenas. También es posible citar los esfuerzos realizados por el Grupo de Trabajo de Pueblos Indígenas en el marco de la Convención de Diversidad Biológica.

Entre los derechos que se ha reconocido a las comunidades indígenas está el que -a fin de que defiendan el entorno natural de sus tierras- se les consulte en los procedimientos relativos a ellas o que de alguna forma puedan afectar su derecho a desenvolverse con garantía de su calidad de vida, pues de lo contrario se quebranta el debido proceso con respecto a los derechos fundamentales de los pueblos indígenas interesados ${ }^{30}$. En ese orden de ideas, cualquier aprovechamiento de recursos naturales en territorios indígenas debe contar con el consentimiento libre, previo e informado de los pueblos indígenas e informárseles sobre cualquier solicitud de aprovechamiento, aun cuando se trate de recursos naturales en propiedad privada.

El reconocimiento de los derechos de los pueblos indígenas sobre los recursos naturales está íntimamente relacionado con los derechos sobre sus tierras y los territorios. En consecuencia, el artículo 15.1 del Convenio 169 OIT establece como principio básico que los pueblos indígenas tienen derecho a los recursos naturales renovables y no renovables pertenecientes a sus tierras, así como a participar en la utilización, administración y conservación de tales recursos. 
Aunado a lo anterior, el Convenio 169 OIT reconoce los siguientes derechos:

\section{Derechos reconocidos en el Convenio 169 OIT}

Ser consultados antes de emprender la prospección o explotación de los recursos naturales existentes en sus tierras.

Conocer los impactos que tendrán las tareas de prospección y explotación.

Beneficiarse de las ganancias que reporten la explotación y el uso de los recursos naturales.

Tener parte en los beneficios que reporten la prospección o explotación de los recursos naturales de sus tierras.

Recibir una indemnización por los daños causados por la prospección y explotación de los recursos naturales.

A nivel del derecho interno y en virtud de que la Ley Forestal fue omisa en desarrollar lineamientos específicos al respecto, el aprovechamiento forestal en territorios indígenas se rige por el Decreto Ejecutivo 27800-MINAE del 16 de marzo de 1999 que desarrolla la disposición contenida en el Artículo 6 de la Ley Indígena, el cual indica que solamente los indígenas están facultados para construir casas, talar árboles, explotar los recursos maderables o plantar cultivos para su provecho dentro de los límites de sus territorios.

El Decreto 27800 restringe el aprovechamiento del recurso forestal en los casos de permisos para la eliminación o aprovechamiento de árboles en terrenos sin cobertura boscosa y con fines domésticos en beneficio de sus habitantes. La labor de aprovechamiento está a cargo de la Asociación de Desarrollo Integral Indígena (ADII) como una medida para salvaguardar algunos de sus más arraigados principios y costumbres.

Las disposiciones contenidas en el Decreto Ejecutivo 27800 sobre aprovechamiento forestal son anteriores a la entrada en vigencia del Convenio 169 OIT y de la promulgación por parte de la Asamblea General de las Naciones Unidas de la Declaración sobre Pueblos Indígenas, razón por la cual dicho decreto debe ser interpretado en la actualidad de manera sistémica, sistemática y evolutiva, a la luz de ambos instrumentos de derecho internacional.

Esta tarea interpretativa y armonizadora ha recaído en la Sala Constitucional, la cual -mediante múltiples votos- reconoció el carácter vinculante, superior y plenamente exigible de las obligaciones y derechos contenidos en el Convenio 169 de la OIT.

En definitiva, dentro de las tareas pendientes se encuentra la promulgación de una nueva ley que sustituya a la desfasada Ley Indígena de 1979 y que se encuentre en armonía tanto con el Convenio 169 OIT como con la Declaración de las Naciones Unidas sobre Pueblos Indígenas.

\subsection{Vacíos legales existentes en la Ley Forestal y afines, respecto al aprovechamiento forestal y comercio internacional de productos forestales}

Los principales vacíos de la Ley Forestal respecto al aprovechamiento forestal y su comercio internacional están relacionados con el desfase que muestra frente a instrumentos internacionales de posterior ratificación, entre ellos el Convenio Internacional de Maderas Tropicales y el Convenio 169 de la Organización Internacional del Trabajo. 
Aunado a lo anterior, también es posible citar como parte de sus debilidades la ausencia de la integración dentro de su articulado de los enfoques ecosistémico, gestión integrada, cambio climático, derechos humanos y género.

Otra inconsistencia que presenta la Ley Forestal es su definición de bosque ${ }^{31}$, la cual es insuficiente, ya que ampara en forma deficitaria este bien jurídico tutelado, con el agravante de que es a partir de esta que se generan las demás definiciones de los tipos de terrenos que son objeto de corta, en algunos casos reguladamente y en otras, hasta en forma irrestricta. Vale resaltar que mediante el voto 2007-3923 la Sala Constitucional le ordenó a la Asamblea Legislativa, por medio de la reforma a la Ley Forestal, modificar la definición de bosque con el fin de que cumpla con los preceptos mencionados.

Es importante destacar que el sistema de certificación forestal contenido en el Artículo 26 de la ley -además de que no operó en la práctica- fue declarado inconstitucional mediante el voto 6312-03 en relación con el sistema de aprobación de planes de manejo y la eximente realización de Evaluación de Impacto Ambiental, sin que a la fecha la Asamblea Legislativa haya modificado su regulación para ajustarlo a los lineamientos esbozados por la Sala Constitucional en el citado voto.

Por último, en materia de sanciones la conducta de eliminación de árboles, como socavar raíces, taladrar para eliminar la savia o envenenar suelo en lugar del árbol, no encuadran en el tipo penal del Artículo 63, inciso b de la Ley Forestal, por lo que se encuentra sin sanción penal. De igual forma, la conducta de exportar madera en trozas y escuadrada proveniente de bosques del Artículo 26 no tiene sanción, salvo que se trate de especies CITES, en la que se aplican las sanciones previstas por la Ley de Conservación de Vida Silvestre.

A pesar de los vacíos antes citados, es fundamental señalar que muchos de ellos pueden ser subsanados acudiendo en algunos casos a la jurisprudencia y en otros a criterios de interpretación sistemáticos y evolutivos.

\subsection{Estándares que regulan los recursos forestales a la luz de la legislación existente sobre aprovechamiento forestal y comercio internacional de productos forestales}

Las limitaciones y estándares de la Ley Forestal están claramente vinculados al concepto de bosque, donde el carácter determinante es básicamente la superficie de terreno que este debe ocupar, de más de 2 hectáreas para ser considerado como tal. A contrario sensu y en la forma descrita, no existe bosque en aquellos terrenos con una superficie inferior a las dos hectáreas ni por aquellos árboles que no sean autóctonos.

La legislación forestal costarricense establece una serie de limitaciones y estándares para el aprovechamiento forestal tanto en terrenos de dominio público como en bosques privados, los

31. "Ecosistema nativo o autóctono, intervenido o no, regenerado por sucesión natural u otras técnicas forestales, que ocupa una superficie de dos o más hectáreas, caracterizada por la presencia de árboles maduros de diferentes edades, especies y porte variado, con uno o más doseles que cubran más del setenta por ciento (70\%) de esa superficie y donde existan más de sesenta árboles por hectárea de quince o más centímetros de diámetro medido a la altura del pecho (DAP)", Artículo 2, inciso d), Ley Forestal. 
cuales encuentran sustento constitucional en el Artículo 45 como limitaciones de interés social. Estas restricciones, limitaciones y estándares forestales son los siguientes:

\section{Limitaciones y estándares al aprovechamiento forestal}

Prohibición de aprovechamiento forestal en terrenos del Patrimonio Forestal del Estado.

Prohibición de aprovechamiento de especies vedadas.

Prohibición de cambio de uso de suelo y establecimiento de plantaciones forestales en terrenos privados cubiertos de bosque.

Corta y aprovechamiento del bosque privado, para los cuales se requiere un plan de manejo forestal y ajustarse a los Estándares de Sostenibilidad para Manejo Forestal Sostenible y el Código de Buenas Prácticas Forestales.

Prohibición de exportación de madera en trozas y escuadrada proveniente de bosques.

La persona física o jurídica que posea madera en troza, escuadrada o aserrada, para realizar sus actividades, deberá comprobar que el producto forestal posee el respectivo permiso de aprovechamiento o demostrar su procedencia.

No se podrá movilizar madera en trozas, escuadrada ni aserrada proveniente de bosque ni de plantación si no se cuenta con la documentación respectiva.

Horarios de transporte de madera en troza y block escuadrada y aserrada: lunes a viernes de 5 a.m. a 9 p.m. y los sábados de 5 a.m. a 5 p.m. (se exceptúa las plantaciones forestales y depósitos de madera).

Criterios y estándares de manejo forestal sostenible limitan la cantidad de árboles que pueden ser aprovechados, la forma de aprovechamiento y el equipo a ser utilizado DE-30763 y DE-27998.

Limitaciones de aprovechamiento dentro de reservas indígenas.

Comercio internacional de madera debe ajustarse a las obligaciones impuestas en la Ley General de Aduanas, norma fitosanitaria de embalaje NIMF-15 y las obligaciones contenidas en el Convenio CITES. 


\section{Análisis del ámbito de acción de la Administración Forestal}

\subsection{Definición de competencias para el manejo de los recursos forestales, grado de descentralización y su nivel de efectividad en el ámbito de acción de la Ley Forestal y afines}

Si bien es la Administración Forestal del Estado -por medio del Sistema Nacional de Áreas de Conservación- la entidad encargada del otorgamiento de permisos de aprovechamiento forestal, el bloque de legalidad ambiental le otorga, bajo ciertas circunstancias específicas y limitadas, dicha potestad a otras instancias descentralizadas, tales como municipalidades, Consejos Regionales Ambientales (CRA) y Asociaciones de Desarrollo Integral Indígena (ADII).

Los Consejos Regionales Ambientales, de conformidad con el Artículo 27 de la Ley Forestal, disponen de facultades para otorgar permisos de tala supeditados a terrenos de uso agropecuario y sin bosques siempre y cuando la corta o aprovechamiento sea inferior a diez árboles, tomando en cuenta que la misma norma limita el aprovechamiento hasta un máximo de tres árboles por hectárea anualmente.

Tratándose de aprovechamiento forestal o tala de árboles en terrenos sin bosque y que por sus características no son un sistema agroforestal, el Artículo 90 del Reglamento de la Ley Forestal establece que las personas podrán decidir si solicitan la autorización ante el Consejo Regional Ambiental o en la municipalidad donde se encuentre el inmueble si no superan un total de veinte árboles por año.

Con respecto a los permisos de aprovechamiento dentro de territorios indígenas, el Decreto Ejecutivo 27800-MINAE le otorga potestades a las Asociaciones de Desarrollo Integral Indígena (ADII) para autorizar la corta y aprovechamiento forestal, siendo que el MINAE -a través del SINAC- presta la colaboración y participación en actividades de capacitación, entrenamiento y asistencia técnica.

A pesar de la existencia de estas tres instancias de descentralización (municipalidades, Consejos Regionales Ambientales y Asociaciones de Desarrollo Integral Indígena), en la práctica la gestión forestal sigue estando concentrada en cada una de las Áreas de Conservación del SINAC, siendo la regla que la solicitud de permisos se tramita ante esta instancia desconcentrada del Ministerio de Ambiente y Energía, y la excepción es la gestión forestal fuera del SINAC. 


\subsection{Tipos de permiso forestales en el ámbito de acción de la Ley Forestal y afines ${ }^{32}$}

Básicamente es posible clasificar los permisos forestales en los siguientes:

\section{Permisos de aprovechamiento en Patrimonio Natural del Estado}

De conformidad con el Artículo 18 de la Ley Forestal, en terrenos del PNE el Estado podrá realizar o autorizar únicamente labores de investigación, capacitación y ecoturismo una vez aprobadas por el Ministerio de Ambiente y Energía, quien define -cuando corresponde- la realización de evaluaciones de impacto ambiental.

\section{Permisos de aprovechamiento en bosques privados}

En terrenos considerados bosque, según el Artículo 3 de la Ley Forestal, el SINAC puede autorizar determinado tipo de actividades, como por ejemplo proyectos de infraestructura, de naturaleza estatal o privada y de conveniencia nacional, construcción de casas, oficinas, establos, corrales, viveros, caminos, puentes y otras instalaciones dedicadas a la recreación, ecoturismo y otros afines en terrenos y fincas de dominio privado, cortar árboles por razones de seguridad humana o de interés científico, prevenir incendios forestales, desastres naturales u otras causas análogas, así como para el aprovechamiento.

Estos bosques solo pueden ser aprovechados si sus titulares legítimos cuentan con un Plan de Manejo debidamente aprobado por el SINAC siempre y cuando se analice previamente el impacto que este pueda ocasionar. Para ello, la persona legitimada puede someterse al Plan de Manejo y al Sistema de Certificación Forestal ${ }^{33}$ a través de la participación de un Certificador Forestal debidamente acreditado por la Administración Forestal del Estado o presentar una solicitud ante la oficina subregional para la respectiva aprobación del Plan de Manejo. En el primer caso, será un Certificador Forestal debidamente acreditado por la AFE quien deberá garantizar previamente que el plan de manejo cumple con los requisitos legales y técnicos para luego continuar el procedimiento de autorización. En el segundo, la solicitud que inicia el trámite debe ir firmada por un profesional forestal, el cual será responsable por la información que suscriba.

Asimismo, de acuerdo con el Artículo 21 de la Ley Forestal debe existir un regente forestal, que estará a cargo de la ejecución del plan de manejo y será responsable de que este se cumpla, con las responsabilidades penales y civiles que derivan de su cargo.

\section{Permiso de aprovechamiento forestal en terrenos privados de uso agropecuario sin bosque}

Según el Artículo 27 de Ley Forestal solo podrá cortarse hasta un máximo de 3 árboles por hectárea anualmente en terrenos de uso agropecuario y sin bosque después de obtener la autorización del Consejo Regional Ambiental. Si la corta sobrepasare los 10 árboles por inmueble, se requerirá la autorización de la Administración Forestal del Estado. De modo que esta norma autoriza la tala de árboles en terrenos de uso agropecuario y sin bosque, los cuales según el Artículo 2 del Reglamento

32. Referirse a la sección de Anexos.

33. En la práctica el sistema de aprovechamiento por medio de Certificación Forestal no se encuentra en operación debido a la declaratoria de inconstitucionalidad. 
a la Ley Forestal son aquellas fincas privadas con la presencia de árboles no establecidos bajo un sistema agroforestal o fincas que tienen áreas con cobertura boscosa menores a dos hectáreas o aquellos árboles ubicados en áreas urbanas.

\section{Permiso de aprovechamiento forestal en terrenos privados no agropecuarios sin bosque}

Con respecto al aprovechamiento forestal o tala de árboles en terrenos sin bosque y que por sus características no son un sistema agroforestal, el Artículo 90 del Reglamento de la Ley Forestal dispone que las personas podrán decidir si solicitan la autorización ante el Consejo Regional Ambiental o en la municipalidad donde se encuentre el inmueble siempre y cuando no superen un total de veinte árboles por año ${ }^{34}$. La solicitud debe ser presentada por el propietario o poseedor del inmueble según los requisitos que para cada caso establezcan tanto los Consejos Regionales como las respectivas municipalidades. En un plazo de 10 días los Consejos Regionales Ambientales deben resolver y extender los permisos de corta y transporte. Dichos Consejos y las municipalidades están obligados a remitir copia de la documentación a la Administración Forestal del Estado.

\section{Permiso de movilización de madera}

Los permisos de movilización de madera proveniente de bosques y sistemas agroforestales los expide el SINAC, mientras que en plantaciones forestales son otorgados directamente por el regente forestal.

Los requisitos para el transporte de madera se establecen en el Decreto Ejecutivo 30494-MINAESP-MOPT. El transporte de madera en troza y block escuadrada y aserrada solo es posible de lunes a viernes de 5 a.m. a 9 p.m. y los sábados de 5 a.m. a 5 p.m. Se exceptúa las plantaciones y depósitos de madera. Queda prohibido el transporte fuera del horario mencionado.

Los siguientes son los documentos necesarios para el transporte de la madera por vías públicas terrestres en el territorio nacional.

34. Aprovechamientos mayores a veinte árboles requieren la supervisión de un Regente Forestal. 


\section{Documentos necesarios para el transporte de la madera}

\begin{tabular}{|l|l|l|}
\hline \multicolumn{1}{|c|}{ Origen } & \multicolumn{1}{|c|}{ Tipo } & \multicolumn{1}{c|}{ Documentación necesaria } \\
\hline Bosque natural & Madera en troza & Guía de transporte y una placa en cada una de las trozas. \\
\hline Plantaciones forestales & $\begin{array}{l}\text { Madera en troza, } \\
\text { escuadrada o aserrada }\end{array}$ & $\begin{array}{l}\text { Certificado de origen o la respectiva Guía de Transporte } \\
\text { de madera emitida por el regente forestal (distintivos de } \\
\text { los medios de transporte se aplicarán de acuerdo con el } \\
\text { Artículo 9 de este decreto). }\end{array}$ \\
\hline $\begin{array}{l}\text { Sistemas } \\
\text { agroforestales }\end{array}$ & Madera en troza & $\begin{array}{l}\text { Guía de transporte y una placa color anaranjada en cada } \\
\text { una de las trozas. }\end{array}$ \\
\hline $\begin{array}{l}\text { Terrenos de uso } \\
\text { agropecuario y sin } \\
\text { bosque }\end{array}$ & Madera en troza & $\begin{array}{l}\text { Guía de transporte y una placa color amarillo en cada una } \\
\text { de las trozas. }\end{array}$ \\
\hline $\begin{array}{l}\text { Centro de } \\
\text { industrialización } \\
\text { primaria, aserraderos } \\
\text { portátiles; no aplica } \\
\text { para la industria de } \\
\text { plantaciones }\end{array}$ & $\begin{array}{l}\text { Madera en troza } \\
\text { escuadrada o aserrada }\end{array}$ & $\begin{array}{l}\text { Factura de compraventa o del servicio de aserrío } \\
\text { debidamente autorizada por la Dirección General de } \\
\text { Tributación Directa y con el detalle del Impuesto de } \\
\text { Ventas. La factura deberá identificar claramente al } \\
\text { comprador y al vendedor de la madera. } \\
\text { Si se trata de madera aserrada "in situ", deberá aportar la } \\
\text { guía de transporte para madera aserrada más la factura } \\
\text { de aserrío, salvo que se trate del propietario de la finca, en } \\
\text { cuyo caso debe portar la guía de transporte emitida por } \\
\text { la AFE. }\end{array}$ \\
\hline
\end{tabular}

\section{Permisos para la adquisición y procesamiento de la madera}

De conformidad con el Artículo 72 del Reglamento de la Ley Forestal, toda persona física o jurídica que industrialice materia prima procedente del bosque, de árboles en terrenos de uso agropecuario no plantados o árboles caídos, ya sean industrias estacionarias o de manera ambulante, deberá estar inscrita ante la AFE. Por su parte, el numeral 77 del citado reglamente dispone que la documentación para el transporte de madera será entregada y depositada en la industria donde se transformará. Esta deberá adjuntarse a la factura que formalice la transacción del bien y le servirá como respaldo. El incumplimiento a lo anterior aplicará la sanción establecida en el Artículo 63 de la Ley Forestal y la correspondiente en la Ley Tributaria.

\section{Permiso para la realización de quemas}

El Reglamento de la Ley Forestal en su Artículo 34 establece que para otorgar un permiso de quema el funcionario competente de la Administración Forestal del Estado deberá visitar de previo el lugar donde se pretende quemar, para verificar en el acto la capacidad de uso del suelo y la existencia de los requisitos mínimos de prevención, que serán determinados por cada Área de Conservación. Si se han tomado las medidas indicadas, el funcionario otorgará en el mismo acto el permiso, señalando -si fuera procedente- las medidas adicionales que deberán tomarse al momento de realizar la quema.

\section{Permisos para el tráfico internacional de maderas}

- Madera procedente de plantación forestal: Se encuentra exenta de los permisos de exportación del Ministerio de Ambiente y Energía (MINAE), pero deben presentarse documentos que certifiquen que es proveniente de plantación en el puerto de salida, los cuales tienen que ser emitidos por el MINAE o un regente forestal debidamente acreditado por el Colegio de Ingenieros Agrónomos. 
- Madera de especies no amenazadas de extinción procedente del bosque: Solamente se autoriza su salida siempre y cuando proceda de un Plan de Manejo de Bosque Natural previamente autorizado y Certificado de Origen, extendidos ambos por el MINAE. La exportación de madera rolliza está prohibida, excepto la procedente de plantaciones que no sean especies nacionales.

- Maderas incluidas en los apéndices CITES (Convención sobre el Comercio Internacional de Especies Amenazadas de Fauna y Flora Silvestre) para la Exportación: Para su exportación se requiere el permiso CITES en el puerto de salida, el cual es emitido por la Autoridad Administrativa CITES, siendo que se requiere necesariamente que se trate de producto elaborado y que la madera proceda de un plan de manejo previamente aprobado por el MINAE. Para su importación se debe contar con el permiso de exportación de la Autoridad Administrativa CITES del País de Origen y el permiso de importación de la Autoridad Administrativa CITES de Costa Rica en el puerto de entrada. Las especies maderables en peligro de extinción que se encuentran en CITES son: Caoba (Suletennia humilis), Caoba (Suletennia macrophylla), Cristóbal (Platymiscium pleiostackyum), Guayacán Real (Guaiacum sanctum), Ajo (Caryocar costarricenses). Todas estas especies requieren permiso CITES, tanto de entrada como de salida. Otras especies que requieren dicho permiso para el Tráfico Internacional, aunque algunas de estas no son nativas, también deben portar dichos permisos, tales como toda la familia de orquidacea y cactaceae (Cycas revoluta, Cycas circinales, todas las euforbias suculentas, Zamia Skinnerii y Zamia furfuracea) ${ }^{35}$.

La importación de madera necesita la autorización fitosanitaria expedida por el Servicio Fitosanitario del Estado (SFE), institución a la que le corresponde además la Regulación del Embalaje de Madera utilizado en el Comercio Internacional siguiendo los lineamientos de la norma NIMF-15 oficializada a través del Decreto Ejecutivo 32622-MAG.

\subsection{Diagrama legal-administrativo para acceder a los permisos de aprovechamiento forestal y comercio internacional de madera}

El documento denominado "Análisis del Comercio Internacional de Productos de Madera y su Gobernanza en la Región de América Central y la República Dominicana”, elaborado por EFI/EARTH/ IUCN en el 2013, ofrece los siguientes diagramas de flujo de los procedimientos para el comercio internacional de la madera, donde también destacan los costos de acceso al comercio legal, siendo en el caso de la exportación de 2 a 14 días, 13 documentos y entre \$231 y \$404 por contenedor; mientras que tratándose de importaciones los costos son de 3 a 6 días, 12 documentos y entre $\$ 299$ y $\$ 429$ por contenedor.

35. Decreto Ejecutivo 27654 Procedimiento para el trámite de permisos de importación y exportación de especies de flora y fauna silvestres. 


\section{Cantidad de pasos, instituciones y documentos requeridos para realizar una exportación de productos de madera en Costa Rica en el 2012}

\section{EXPORTACIÓN}

\section{Recinto Aduanero (DGA) en} frontera o puerto (4)
- Autorización de la DGA para levante (verde) o revisión física de mercadería (rojo)

- Todos los documentos sellados por la DGA
- Permiso CITES o No CITES del MINAE de exportación (3)

Oficina central CITES-MINAE (1)

\section{- Formulario de solicitud (2)}

- Copia de factura de procedencia de la madera con guías de transporte o el permiso forestal (1)
- Factura comercial de exportación (6)

- Documento de transporte: Carta de Porte o Bill of Landing (13)

- Certificado fitosanitario del MAG (10)

- $\quad$ faUCA o DUA (9)

- Si aplica, certificado de origen (11), permiso CITES (3) y certificado de fumigación o tratamiento HT (5)

- Si aplica, certificado de procedencia de la madera para plantación y permiso forestal para bosque (12)

\section{VUCE (3)}

- Factura comercial de exportación (6)

- Solicitud del certificado fitosanitario (7) y si aplica, certificado de origen (8)

- $\quad$ Si aplica, copia permiso CITES-MINAE (3)

- Certificado de fumigación o tratamiento HT (5)

- Formulario de solicitud al OIRSA (4)

- O tratamiento térmico $(\mathrm{HT})$ a una empresa privada

\section{Exportador}

Costos de acceso al comercio legal: 2-14 días, 13 documentos y entre $\$ 231$ y $\$ 404 /$ contenedor

Fuente: Navarro, G., (2013). Santamaría O., Vargas, (2013). L., Milla, V. (2013). Información obtenida durante el trabajo de campo en Costa Rica. 


\section{Cantidad de pasos, instituciones y documentos requeridos para realizar una importación de madera en Costa Rica en el 2012}

- Mensaje de la DGA de recepción de declaración (DUA)

- Autorización de la DGA para levante (verde) o revisión física de mercadería (rojo)

- Aspersión de la unidad de carga

\section{IMPORTACIÓN}

Recinto Aduanero (DGA) en frontera o puerto (3.2)

- Comprobante de pago de impuestos y aranceles (10)

- Declaración en línea por TICA (9)

- Constancia de inspección (12)

- Si aplica, fumigación

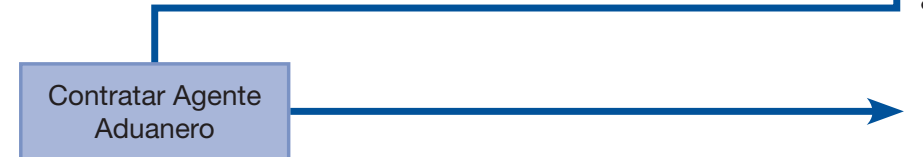

Oficina Aduana MAG-OIRSA
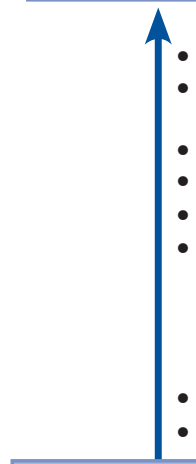

Factura del país de origen (2)

- Si aplica, solicitud de

- Documento de transporte: fumigación (11)

Carta de Porte o Bill of Landing (3)

- Certificado de origen (5)

- FAUCA o póliza de exportación (6)

- Certificado fitosanitario del país de origen (5)

- Si aplica, permiso CITES de exportación del país de origen (8) y permiso fitosanitario de importación SFE-MAG (12)

- Permiso fitosanitario de importación SFE-MAG (4)

- Requisitos fitosanitarios del producto

\section{Oficina Central del} SFE-MAG

- Solicitud de permiso previo fitosanitario FAD (1)

- Factura o proforma del exportador del país de origen (2)

- Documento de transporte: Carta de Porte o BL (3)

Importador

Costos de acceso al comercio legal: 3-6 días, 12 documentos y entre $\$ 299$ y $\$ 429 /$ contenedor

Fuente: Navarro, G., (2013). Santamaría O., Vargas, (2013). L., Milla, V. (2013). Información obtenida durante el trabajo de campo en Costa Rica. 


\subsection{Análisis de estadísticas de los últimos cinco años provenientes de la Administración Forestal, Fitosanitaria y Aduanal}

El XVIII Informe del Estado de la Nación expone que el país tiene varios años de mostrar una tendencia de alto uso de madera proveniente de plantaciones, lo cual ha reducido la presión sobre los bosques. No obstante, se mantienen las prácticas de tala ilegal y modalidades de manejo de bosques que generan críticas de las organizaciones ambientalistas. Para conocer con mayor detalle el comportamiento de este sector, por primera vez el país cuenta con una fuente de información de alcance nacional: el "Censo Nacional de la Industria Forestal Primaria en Costa Rica", elaborado por el Sistema Nacional de Áreas de Conservación (SINAC) en el 2011. Gracias a este trabajo se han reunido estadísticas sobre la producción y el uso de los recursos forestales, y otros datos de esta industria que anteriormente no estaban disponibles.

El Censo reportó un consumo anual nacional de madera en troza de 267,1 millones de pulgadas de madera tica (PMT), lo que equivale a 738.103 metros cúbicos. El uso diario se estima en $45 \%$ de la capacidad instalada de procesamiento en aserraderos y bloqueadoras, y de $32 \%$ para las motosierras con marco.

Los resultados del Censo sugieren que la industria del aserrío primario trabaja fundamentalmente con madera de plantaciones forestales (68\%) y que cerca de $24 \%$ proviene de potreros o sistemas agroforestales. Se mencionaron 46 especies como las más importantes en la industria, con una presencia mayoritaria de melina, laurel y teca, que suman $49 \%$ del total. En el mercado los precios más elevados de las especies finas, decorativas y duras corresponden a teca y almendro, usadas por lo general en la construcción, además de las empleadas en la fabricación de muebles de finos acabados, como el cenízaro, el cedro amargo y el guanacaste. Los menores precios son los de la caobilla, el pochote y el laurel. Esta nueva información complementa los resultados de la evaluación del Plan Nacional de Desarrollo Forestal (2001-2010), realizada en el 2010 por la comisión interinstitucional encargada de esa labor. 


\begin{tabular}{|c|c|c|}
\hline \multicolumn{3}{|c|}{$\begin{array}{l}\text { Algunos datos del Censo Nacional de la Industria Forestal Primaria según tipo de } \\
\text { instalación, } 2011\end{array}$} \\
\hline \multicolumn{3}{|c|}{ Consumo anual de madera en troza } \\
\hline & Millones de PMTa/ & Metros cúbicos \\
\hline Aserraderos y bloqueadoras & 252,3 & 697.089 \\
\hline Motosierras con marco & 14,8 & 41.014 \\
\hline Consumo total anual & 267,1 & 738.103 \\
\hline \multicolumn{3}{|c|}{ Capacidad instalada y consumo diario (PMTa/ por día) } \\
\hline & $\begin{array}{l}\text { Capacidad instalada de } \\
\text { procesamiento promedio }\end{array}$ & $\begin{array}{l}\text { Consumo diario } \\
\text { promedio de madera en troza }\end{array}$ \\
\hline Aserraderos y bloqueadoras & 4.222 & 1.983 \\
\hline Motosierras con marco & 733 & 236 \\
\hline Origen de la madera & Porcentaje & \\
\hline Plantaciones forestales & 68 & \\
\hline Potreros & 15 & \\
\hline $\begin{array}{l}\text { Plantaciones o sistemas } \\
\text { agroforestales }\end{array}$ & 9 & \\
\hline Potreros o bosques & 7 & \\
\hline Bosques & 1 & \\
\hline
\end{tabular}

\section{a/ PMT: Pulgadas de madera tica}

Fuente: SINAC-MINAET, 2011

Por su parte, de la información estadística recopilada para el año 2012 por la Oficina Nacional Forestal con respecto a la balanza comercial y principales tendencias de las exportaciones e importaciones de madera y muebles de madera en Costa Rica resaltan los siguiente datos relevantes:

1. El déficit comercial retomó su crecimiento acelerado. La brecha entre las exportaciones e importaciones de productos de madera y muebles aumentó significativamente, ubicándose en $\mathbf{- \$ 1 7 , 0 5}$ millones; lo anterior debido al aumento significativo de muebles de madera y las importaciones de madera aserrada, y en menor medida otros productos como tableros de partículas, de fibra de madera y la madera contrachapada.

2. Los principales productos exportados fueron madera en bruto y aserrada, paletas, cajones, cajas y similares, sumado a obras de carpintería. Los destinos más comunes de las exportaciones fueron Estados Unidos, Singapur, India, Vietnam y China.

3. Chile, China, Estados Unidos, Guatemala y España destacan como los más importantes países de procedencia de las importaciones de productos primarios de madera.

4. Los destinos de nuestros muebles fueron -primordialmente- Estados Unidos, Panamá y Nicaragua, mientras que las importaciones de muebles de madera provienen de China, Estados Unidos y Brasil.

En materia de balanza comercial, los datos que presenta el Ministerio de Comercio Exterior (COMEX) para el año 2012 reflejan la siguiente situación comercial. 


\section{Costa Rica: comercio exterior del sector maderero}

\section{Millones de USD}

Costa Rica: balanza comercial sector maderero, 2008-2012

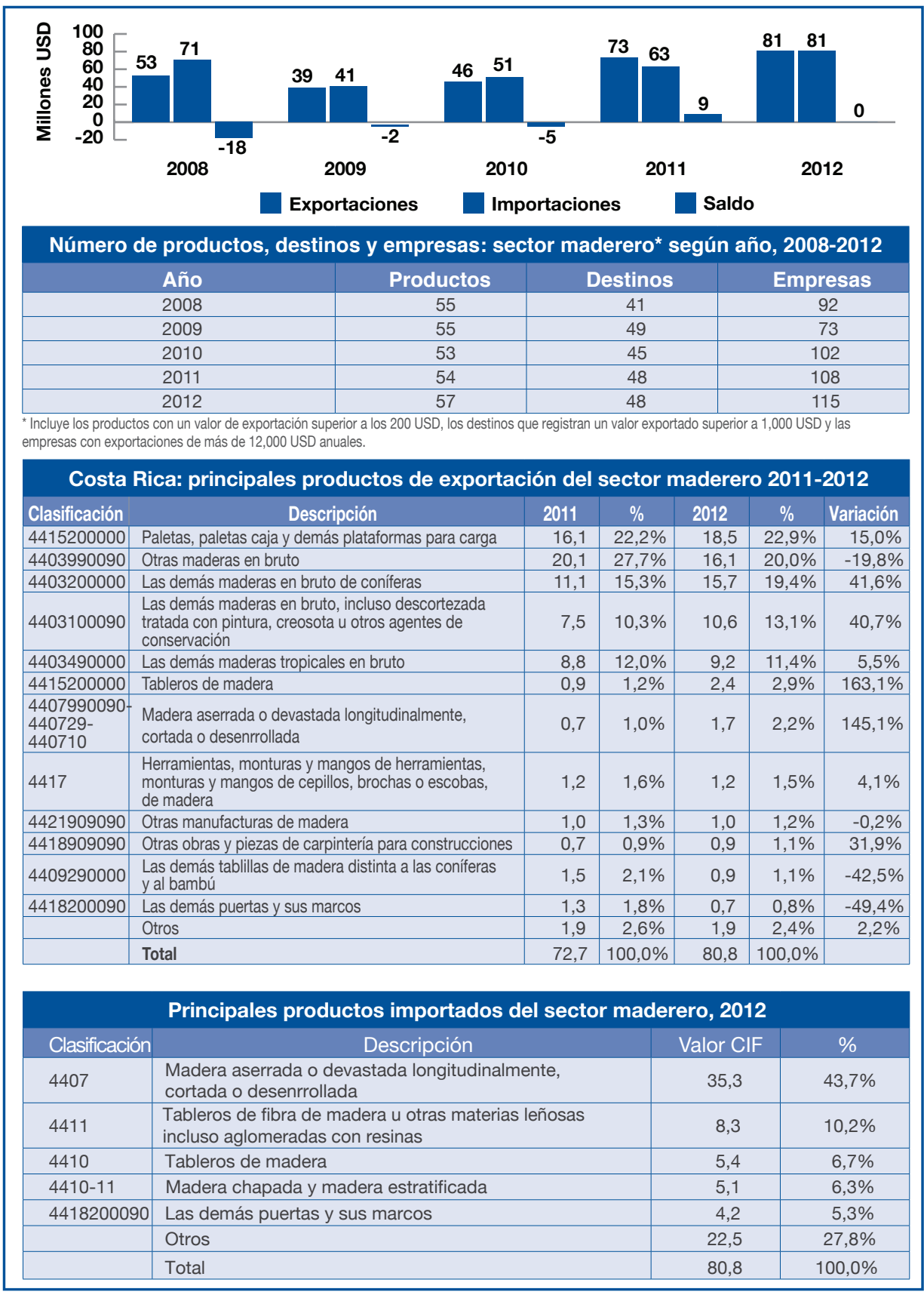


Costa Rica: exportaciones del sector maderero según región, 2012

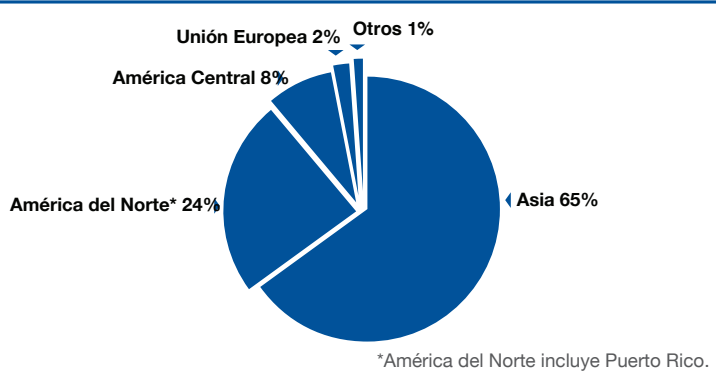

Principales destinos de exportación del sector maderero, 2011-2012

\begin{tabular}{|l|r|r|r|r|}
\hline País & $\mathbf{2 0 1 1}$ & \multicolumn{1}{c|}{$\boldsymbol{\%}$} & \multicolumn{1}{c|}{$\mathbf{2 0 1 2}$} & \multicolumn{1}{c|}{$\%$} \\
\hline Estados Unidos* & 16,2 & $22,3 \%$ & 19,2 & $23,8 \%$ \\
\hline Singapur & 8,8 & $12,1 \%$ & 18,8 & $23,2 \%$ \\
\hline India & 15,1 & $20,7 \%$ & 16,2 & $20,0 \%$ \\
\hline Vietnam & 15,6 & $21,5 \%$ & 10,6 & $13,1 \%$ \\
\hline China & 4,9 & $6,7 \%$ & 3,9 & $4,8 \%$ \\
\hline Otros & 12,2 & $16,8 \%$ & 12,2 & $15,1 \%$ \\
\hline Total & 72,7 & $100,0 \%$ & 80,8 & $100,0 \%$ \\
\hline
\end{tabular}

*Incluye Puerto Rico.

Principales empresas exportadoras del sector maderero, 2012

Exportador

Posición

Multiservicios La Sabana S.A.

Panamerican Woods (Plantations) S.A.

Outspan Costa Rica S.A.

Maderas Preciosas Costa Rica S.A.

Fortune Global Trading - FGT S.A.

Vcn Packaging Costa Rica S.A.

Green West Pvt S.A.

Fruticolor S.A.

Durpanel S.A.

Panamerican Exim Inc. S.A.

Flor y Fauna Dos S.A.

Maderas Matroase S.A.

Repremar Shipping Services S.A.

Brais Quirós Karina

Kimber de Centro América S.A.

\begin{tabular}{|c|}
\hline 1 \\
\hline 2 \\
\hline 3 \\
\hline 5 \\
\hline 6 \\
\hline 7 \\
\hline 8 \\
\hline 9 \\
\hline 10 \\
\hline 11 \\
\hline 12 \\
\hline 13 \\
\hline 14 \\
\hline 15 \\
\hline
\end{tabular}

Fuente: COMEX 2013 
Costa Rica: exportaciones del sector maderero según región, 2012

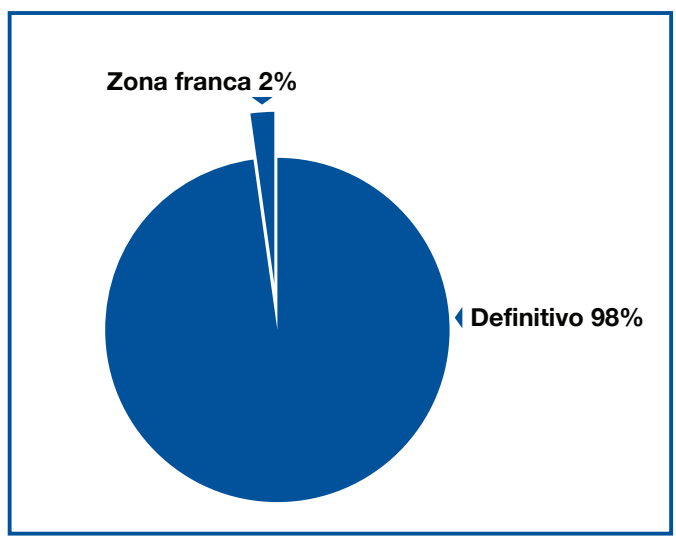

Fuente: COMEX 2013

Por último, específicamente en materia de comercio internacional de especies CITES, el anexo país Costa Rica del estudio "Análisis del comercio internacional de productos de madera y su gobernanza administrativa en la región de América Central y la República Dominicana" ${ }^{36}$ muestra las siguientes estadísticas.

Costa Rica: Importaciones de especies CITES en volumen $\left(\mathrm{m}^{3}\right)$ y peso $(\mathrm{kg})$ para Costa Rica del 2006 al 2011

\begin{tabular}{|c|c|c|c|c|c|c|c|c|c|c|c|c|c|}
\hline \multicolumn{2}{|c|}{ Nombre } & \multicolumn{2}{|c|}{2006} & \multicolumn{2}{|c|}{2007} & \multicolumn{2}{|c|}{2008} & \multicolumn{2}{|c|}{2009} & \multicolumn{2}{|c|}{$\begin{array}{c}2010- \\
2011\end{array}$} & \multicolumn{2}{|c|}{ Totales } \\
\hline Común & Científico & 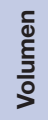 & $\begin{array}{l}\stackrel{0}{\$} \\
0 \\
0\end{array}$ & $\begin{array}{l}\frac{c}{\Phi} \\
\frac{\xi}{3} \\
\end{array}$ & $\begin{array}{l}\text { o } \\
\text { \& }\end{array}$ & $\begin{array}{l}\frac{}{\Phi} \\
\frac{\xi}{3}\end{array}$ & \& & 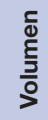 & $\begin{array}{l}8 \\
\$ 0 \\
0\end{array}$ & $\begin{array}{l}\frac{5}{\Phi} \\
\text { छे } \\
0\end{array}$ & \& & $\begin{array}{l}\frac{\bar{\Phi}}{\Phi} \\
\frac{\Xi}{\equiv} \\
\end{array}$ & $\begin{array}{l}0 \\
0 \\
0 \\
0\end{array}$ \\
\hline $\begin{array}{l}\text { Caoba } \\
\text { (registrada } \\
\text { en } \mathrm{m}^{3} \text { ) }\end{array}$ & $\begin{array}{l}\text { Swetenia } \\
\text { macrophylla }\end{array}$ & 33 & 23.114 & & & 272 & 190.400 & & & & & 305 & 213.514 \\
\hline $\begin{array}{l}\text { Caoba } \\
\text { (registrada } \\
\text { en kg) }\end{array}$ & $\begin{array}{l}\text { Swetenia } \\
\text { macrophylla }\end{array}$ & 1,9 & 1.300 & 0,1 & 50 & 130 & 91.000 & & & & & 132 & 92.300 \\
\hline $\begin{array}{l}\text { Almendro } \\
\text { (registrado } \\
\text { en } \mathrm{m}^{3} \text { ) }\end{array}$ & \begin{tabular}{|l} 
Dypteris \\
panamensis
\end{tabular} & & & & & & & 498 & 348.600 & & & 498 & 348.600 \\
\hline \multicolumn{2}{|c|}{ Totales } & 35 & 24.414 & 0,1 & 50 & 402 & 281.400 & 498 & 348.600 & 0 & 0 & 935 & 654.414 \\
\hline
\end{tabular}

Fuente: EFI/EARTHIIUCN, 2013

36. EFI/EARTH/IUCN 2013. 


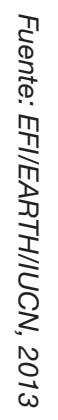

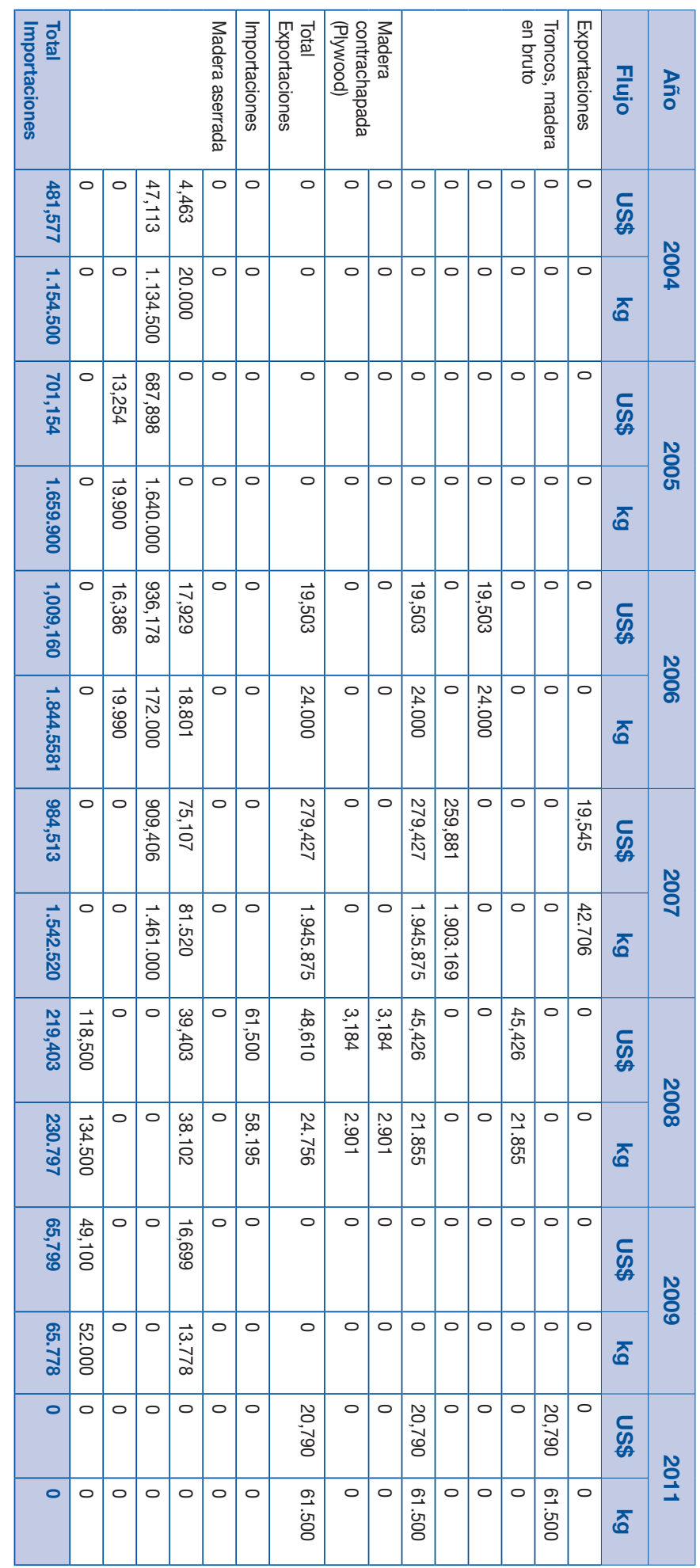

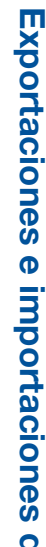

으

8
응
$\frac{1}{2}$
$\frac{1}{0}$
$\frac{1}{7}$

c

$<$

\&

증

ชั

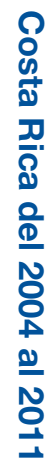




\section{Análisis de sistema de control forestal}

La Administración Forestal del Estado abarca una mezcla de agentes estatales, privados e independientes comprometidos con el control y verificación del aprovechamiento forestal. Según la Ley Forestal, el MINAE ostenta un papel de administrador y a la vez, ejecutor del sistema de control forestal. Las funciones de administrador y fiscalizador las ejerce por medio de la AFE, en manos del SINAC, según el reglamento de la Ley Forestal.

El rol fiscalizador lo ejerce conjuntamente la AFE con las municipalidades, Consejos Regionales Ambientales y con figuras como regentes forestales, inspectores de recursos naturales ad honórem mediante los Comités de Vigilancia de los Recursos Naturales (COVIRENAS) y en menor medida, la Contraloría Ambiental. La labor sancionadora la ejercen el SINAC, el Tribunal Ambiental Administrativo y el Poder Judicial por medio del impulso del Ministerio Público, mientras que la fiscalización y sanción de los regentes forestales lo realiza el Colegio de Ingenieros Agrónomos (CIAgro).

Los funcionarios de la AFE gozan de carácter de autoridad de policía, debiendo denunciar ante las autoridades competentes las infracciones a la Ley Forestal y afines.

Por su parte, los inspectores ad honórem, regulados por el Decreto Ejecutivo DE-26923, están divididos en dos categorías: inspectores de recursos naturales y vigilantes de recursos naturales. Ambos coadyuvan con la aplicación de la legislación ambiental-forestal y carecen de autoridad de policía, pero poseen funciones de vigilancia, control, denuncia y testimonio.

Los regentes forestales, profesionales en ciencias forestales incorporados al colegio profesional, son los encargados de elaborar los planes de manejo forestal. La ejecución del plan está a cargo del regente, quien posee fe pública y es el responsable de su cumplimiento, respondiendo por sus actuaciones en la vía penal y solidariamente en la civil.

La AFE -a través de las Oficinas Subregionales del SINAC- es la responsable de llevar a cabo el auditoraje de los planes de manejo. Para ello está facultada a ingresar al inmueble donde se ejecuta las veces que considere conveniente. El auditoraje puede hacerlo directamente o por contrato de servicios de auditoraje, con profesionales forestales o personas jurídicas dedicadas a esta actividad, que en ningún caso podrán ser las mismas que hayan participado en el plan de manejo.

Por su parte, el Contralor Ambiental en el desempeño de sus competencias en materia forestal está facultado para hacer toda clase de visitas o inspecciones, investigar y presentar las denuncias que considere necesarias. No obstante, su actuación siempre será hacia lo interno de la AFE.

El Colegio de Ingenieros Agrónomos de Costa Rica (ClAgro) ejerce la función de vigilancia, fiscalización y sanción de los regentes forestales, en cuanto al ejercicio liberal de la profesión, sin detrimento de la supervisión que pueda recibir también por parte de la Administración Forestal del Estado, como consecuencia de las amplias facultades que la Ley Forestal le otorga.

A continuación se detalla el diagrama de flujo del procedimiento de control forestal. 


\section{Flujo de procedimientos de control en el sistema de control forestal de Costa Rica}

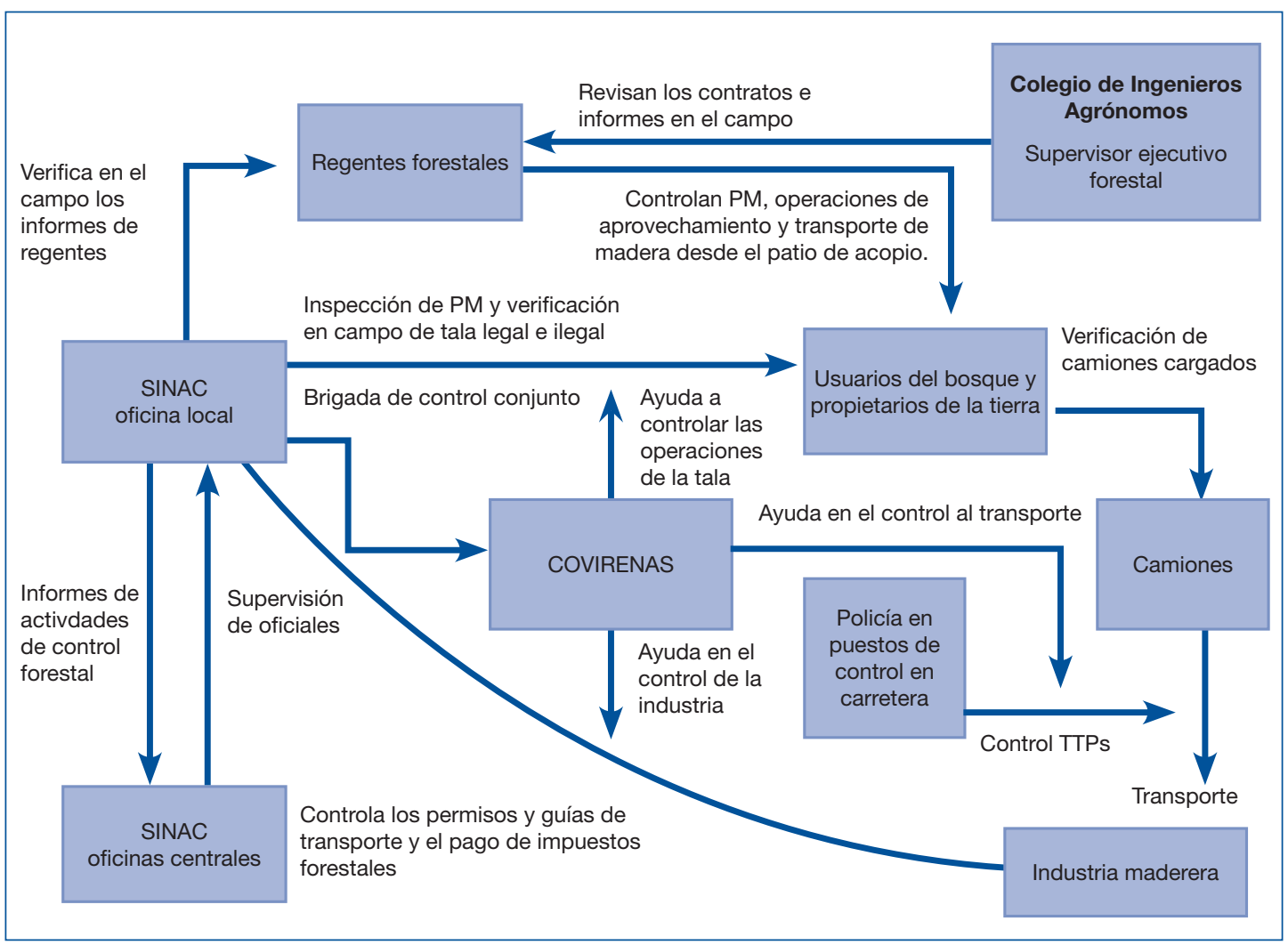

Fuente: Brown D. (2010). Madera Legal, Verificación y Gobernanza en el Sector Forestal. $1^{a}$ edición. Turrialba, Costa Rica: CATIE.

Las oficinas locales del SINAC llevan a cabo inspecciones de campo antes de autorizar la corta de madera. Los regentes forestales son responsables de monitorear la ejecución del aprovechamiento y registrar sus contratos ante el CIAgro para que el Supervisor Forestal Ejecutivo supervise su trabajo. EI SINAC extiende el permiso de transporte solo después de recibir un informe de regencia positivo, el cual debe verificarse en el campo. Los permisos de transporte se pueden usar para el control de la cadena de custodia, así el usuario del bosque y la industria pueden verificar la cantidad y tipo de productos transportados desde la fuente original hasta el destino final. Estos permisos son revisados a lo largo de la ruta por la policía, a menudo en colaboración con brigadas del SINAC y COVIRENAS. El personal local del SINAC inspecciona los aserraderos para asegurarse de que las trozas apiladas y la madera procesada hayan sido legalmente obtenidas; para ello revisan los permisos de transporte y las etiquetas. Además, recogen todas las guías de transporte usadas y se aseguran de que se han pagado los impuestos forestales por el período y los volúmenes correctos ${ }^{37}$.

37. Información extraída de: Brown D. (2010). Madera Legal, Verificación y Gobernanza en el Sector Forestal. $1^{\text {a }}$ edición. Turrialba, Costa Rica: CATIE. 


\subsection{Conflictos de competencia entre responsables de la administración y ejecución de los sistemas de control forestal}

El sistema de control forestal costarricense comprende una amplia variedad de actores que ejecutan diversas funciones, lo cual permite realizar controles cruzados entre actores. Sin embargo, el actor central (SINAC) es el que lleva la principal carga de competencias y funciones.

La falta de coordinación dentro del sistema de control crea dificultades para las unidades de control policial, quienes constituyen un ente aislado en la cadena de control forestal y que, por lo general, carecen de la información necesaria sobre las actividades que deben controlar. Tampoco tienen la capacidad para verificar especies forestales, calcular volúmenes ni corroborar el origen de la madera transportada contra la guía de transporte.

CIAgro es responsable de la administración, supervisión y sanción a sus miembros, los regentes forestales, sin otros controles externos. En consecuencia, SINAC carece de competencia para fiscalizar el trabajo de los regentes. Además, la dependencia económica del regente forestal a manos del maderero eventualmente podría convertirse en una amenaza a su independencia funcional.

Por último, el XVIII Informe del Estado de la Nación señaló que los gobiernos locales no juegan un papel activo en la administración y control de los recursos forestales en sus territorios a pesar de que las políticas nacionales y las leyes forestales están orientadas hacia la descentralización y desconcentración de la administración de los recursos forestales. Este cambio de responsabilidades tiene un costo que pocas veces se tiene en cuenta: los fondos requeridos para crear capacidades en los organismos locales y regionales, de manera que logren efectivamente adueñarse de la administración y control de sus recursos forestales.

\subsection{Requerimientos de control forestal explícitos en la Ley Forestal y afines}

Los instrumentos de control forestal previstos en la Ley Forestal, su reglamento general y normativa relacionada son los siguientes.

\section{Plan de Manejo Forestal}

Según el Artículo 20 de Ley Forestal, los bosques solo podrán aprovecharse si cuentan con un plan de manejo que contenga el impacto que puede ocasionar sobre el ambiente. La AFE lo aprobará según los criterios de sostenibilidad certificados de previo, conforme a los principios de fiscalización y los procedimientos que se establezcan en el reglamento de la presente ley para ese fin.

Al aprobarse el plan, se tendrá por autorizada su ejecución durante el período contemplado en él sin que sea necesario obtener periódicamente nuevas autorizaciones de aprovechamiento. El plan se elabora por un profesional en ciencias forestales y se ejecuta por un regente forestal que ostenta fe pública y es responsable de que se cumpla. Ambos funcionarios responden por sus actuaciones en la vía penal y solidariamente en la civil. Los principios, criterios e indicadores se encuentran regulados por el DE-34559 referido a bosques primarios y DE-27998-MINAE para el manejo forestal sostenible de bosques secundarios y certificación forestal. 


\section{Planes Certificados}

De acuerdo con DE-30310, se reconoce como sistema de certificación forestal el Consejo de Manejo Forestal (FSC) y por tanto, se reconocen los certificadores acreditados ante él y los otorgados en el país (Art. 2).

Cualquier empresa, organización o propietario que cuente con la certificación forestal otorgada por una entidad debidamente acreditada ante un sistema de certificación forestal, reconocido por AFE, gozará para todos los efectos legales de una certificación nacional y tendrá los mismos derechos y las mismas obligaciones establecidas en la legislación nacional. Debido a una acción de inconstitucionalidad resuelta en contra de varias de estas disposiciones, el sistema no operó (el Voto 6312-2003 declaró inconstitucional este sistema de aprobación de los planes y la circunstancia eximente de la EIA).

\section{Inventarios Forestales}

En el caso de los permisos de corta de árboles en terrenos de uso agropecuario y sin bosque, tiene que presentarse un inventario forestal elaborado por un profesional en ciencias forestales, así como elaborarse un croquis de la finca en el que se indique la ubicación aproximada de los árboles a $\operatorname{cortar}^{38}$. La solicitud debe contener constancia del profesional responsable en la cual se establezca que el área no corresponde a bosque o parte de un bosque según su definición y cumplir con requisitos del Artículo 85 del Reglamento Ley Forestal. Estos permisos pueden ser otorgados por el Consejo Regional Ambiental si se trata de un máximo de 3 árboles por hectárea; si es mayor, se requiere autorización del $\mathrm{SINAC}^{39}$.

\section{Certificado de Origen}

El Artículo 28 de la Ley Forestal excluye de la aplicación de la mayoría de las regulaciones las plantaciones forestales, incluidos los sistemas agroforestales y los árboles plantados individualmente y sus productos, los que no requieren permiso de corta. El transporte puede realizarse con certificado de origen emitido por el regente forestal en el cual conste que se trata de madera proveniente de plantaciones forestales o sistemas agroforestales.

\section{Guías de Transporte}

- Bosque natural: Madera en troza, guía amarilla de transporte y una placa en cada una de las trozas.

- Plantaciones forestales: Madera en troza, escuadrada o aserrada, Certificado de Origen o guía de transporte de madera emitida por regente forestal.

- Sistemas agroforestales: Madera en troza, guía de transporte y una placa anaranjada en cada troza.

- Terrenos de uso agropecuario y sin bosque, madera en troza, guía de transporte y una placa color amarillo en cada una de las trozas.

38. Reglamento de la Ley Forestal, Art. 91.

39. Ley Forestal, Art. 27. 
- Centros de industrialización primaria, aserraderos portátiles (no aplica a industrias de plantaciones forestales): Madera en troza, factura de compraventa o del servicio de aserrío debidamente autorizada por la Dirección General de Tributación Directa y con el detalle del impuesto de venta. La factura debe indicar claramente el comprador y vendedor de la madera. Si se trata de madera aserrada in situ, tendrá aportar guía de transporte para madera aserrada más la factura de aserrío, salvo que se trate del propietario de la finca, en cuyo caso debe portar la guía de transporte.

\subsection{Sistema de monitoreo de estadísticas forestales y su impacto en la ilegalidad del aprovechamiento forestal}

Desde el 2011, el SINAC cuenta con una plataforma tecnológica conocida como Sistema de Información para el Control del Aprovechamiento Forestal (SICAF). Durante el trabajo de campo que se realiza como parte de la tramitación de los permisos de aprovechamiento forestal o de corta, los funcionarios anotan la geo-referencia (posición de GPS) de los árboles de la finca y así saben la ubicación de cada uno de ellos. Esa información se incluye en el expediente digital que tiene cada finca en el SICAF y con solo tener acceso a Internet, pueden revisar todo lo concerniente a ese permiso forestal.

A la vez, se cuenta con el Sistema de Información de los Recursos Forestales de Costa Rica (SIREFOR), promulgado mediante el Decreto Ejecutivo $N^{\circ} 33826-M I N A E$. Su objetivo es convertirse en un sistema integrado para el manejo de la información de los recursos forestales, brindando información en varias temáticas en el ámbito de bosques, reforestación, aprovechamiento forestal, manejo del fuego e industria y comercio, entre otros.

Específicamente en materia de control forestal, a partir del 2013 SIREFOR se encuentra implementando dos plataformas tecnológicas con el fin de lograr un mejor control de la madera para con ello asegurar su legalidad. La combinación de dos sistemas de información permitirá a los encargados del control forestal verificar la legalidad de la madera que transita por las carreteras del país.

A la vez, en el 2013 el SINAC empezó a implementar otro sistema de control, enfocado en el manejo de guías de transporte y placas de madera. Cada guía y cada placa poseen un número único que es ingresado en el sistema. A la hora de otorgar el permiso, el sistema asigna automáticamente una cantidad de guías de transporte y placas según lo autorizado.

\subsection{Control cruzado de certificados de comercio de productos de madera}

El sistema de control forestal costarricense incorpora controles cruzados y balances. Existe un control cruzado entre el personal del SINAC, COVIRENAS y la policía. La madera ilegalmente aprovechada es objeto de decomiso y eventualmente, de sanciones judiciales y/o administrativas. Si el acusado es encontrado culpable, el Poder Judicial remata la madera y deposita el dinero obtenido en una cuenta. $50 \%$ va a la municipalidad y el otro $50 \%$ a un fondo forestal.

El sistema de denuncia de irregularidades cometidas por regentes forestales es abierto; tanto el SINAC, la policía y COVIRENAS, como cualquier persona se encuentran legitimados para interponer queja o denuncia ante el CIAgro o el Poder Judicial. 
También es importante considerar que las oficinas centrales del SINAC realizan auditorías internas y controles periódicos a sus oficinas locales.

Con ayuda de plataformas tecnológicas se pretende mejorar los controles cruzados entre la policía, COVIRENAS, regentes forestales y el SINAC. El Sistema de Información de Recursos Forestales (SIREFOR) pretende ejercer un mejor control de la madera para así asegurar su legalidad y la tecnología ayudaría a combatir los casos de corrupción que se podrían presentar en el proceso de asignación de las placas y guías, así como en los operativos de carretera.

\section{Controles cruzados y sanciones en los procedimientos administrativos y de verificación en Costa Rica}

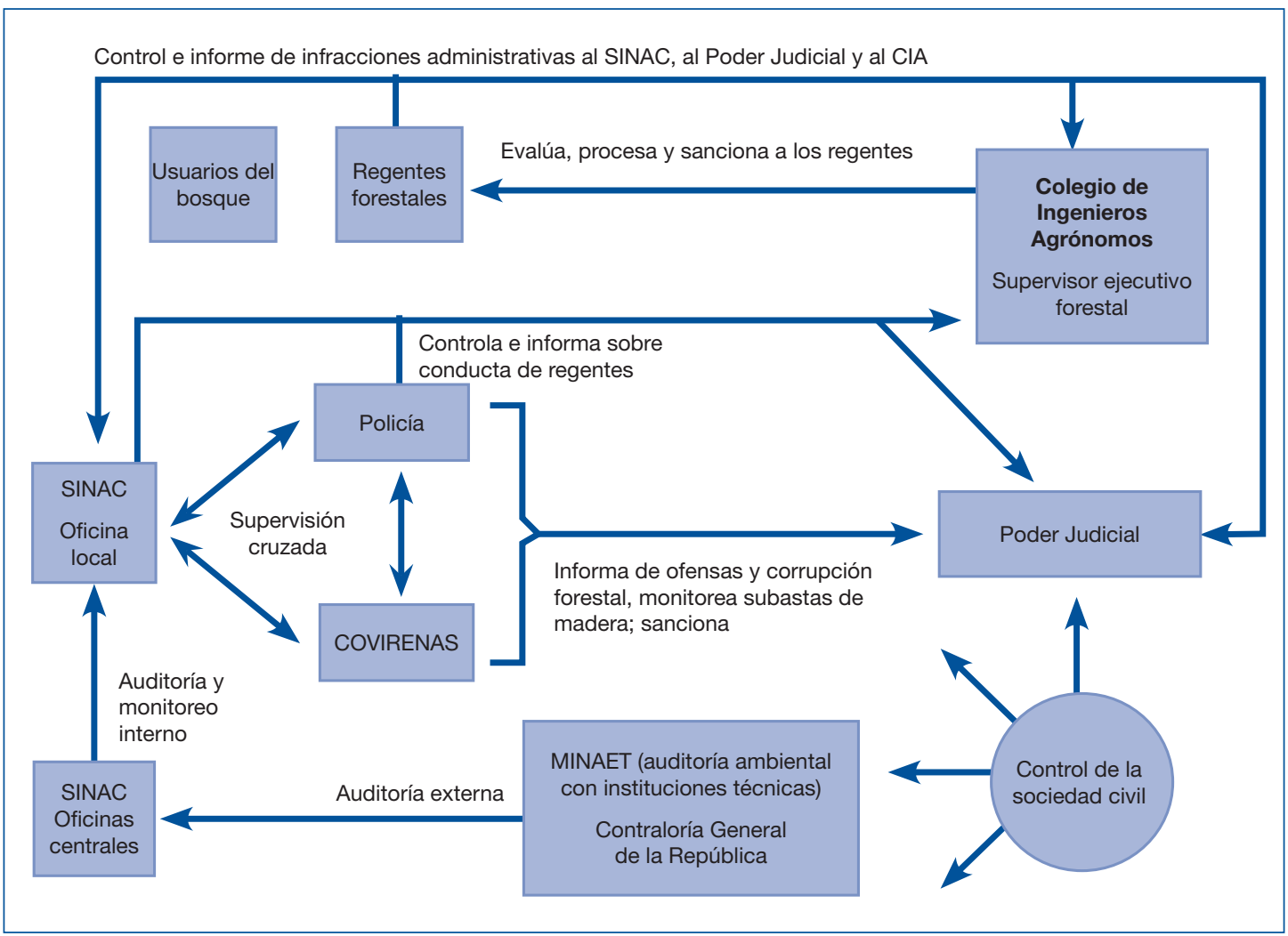

Fuente: Brown D. (2010). Madera Legal, Verificación y Gobernanza en el Sector Forestal. $1^{\text {a }}$ edición. Turrialba, Costa Rica: CATIE. 


\subsection{Denuncias presentadas por las autoridades del Estado por delito de actividades forestales ilegales}

Los datos suministrados por el Tribunal Ambiental y procesados en el siguiente cuadro reflejan un crecimiento sostenido anual en el número de denuncias presentadas ante esta instancia por parte de otras autoridades administrativas.

\begin{tabular}{|c|c|c|c|c|c|}
\hline \multicolumn{6}{|c|}{ Denuncias por infracción a la Ley Forestal ante el TAA } \\
\hline \multirow{2}{*}{ Instituciones } & \multicolumn{5}{|c|}{ Año } \\
\hline & 2009 & 2010 & 2011 & 2012 & 2013 \\
\hline SINAC & 3 & 89 & 94 & 165 & 86 \\
\hline DGM, MINAE & 1 & 1 & & & \\
\hline Municipalidades & 8 & 17 & 33 & 18 & 26 \\
\hline SETENA & 1 & 6 & & 1 & 1 \\
\hline DA, MINAE & & 4 & 16 & 11 & \\
\hline SNG & & & 1 & 1 & 1 \\
\hline MINSA & & & 1 & 1 & 1 \\
\hline Contraloría Ambiental & & & & 1 & 1 \\
\hline INVU & & & & 1 & 1 \\
\hline Fiscalía Ambiental & & & 1 & & \\
\hline DIGECA, MINAE & & & 1 & & \\
\hline AyA & & 1 & & & \\
\hline MINAE CENTRAL & & 2 & & & \\
\hline TOTAL & 13 & 120 & 147 & 199 & 117 \\
\hline
\end{tabular}

Fuente: Creación propia con datos suministrados por el TAA. Los datos incluyen información actualizada al mes de julio de 2013.

Lastimosamente, la Sección de Estadística del Poder Judicial no cuenta con el desglose de denuncias presentadas por actor. 


\section{Análisis de ejecución de procesos judiciales}

\subsection{Ley Forestal y regulaciones afines a la luz de los procesos judiciales existentes en materia de aprovechamiento forestal y comercio internacional de productos forestal}

La aplicación del régimen de prevención, sanción y restauración previsto en la Ley Forestal es de conocimiento en la vía judicial a través de la jurisdicción penal y en la vía administrativa por parte del Tribunal Ambiental Administrativo.

De acuerdo con el principio de intervención mínima, idealmente solo las conductas absolutamente gravosas para el ambiente merecen una sanción de índole penal en la respectiva jurisdicción especializada. De otra forma, cuando la conducta no llega a ese rango de peligrosidad, sería el Derecho Administrativo sancionador el encargado de imponer las respectivas penas por medio del Tribunal Ambiental Administrativo.

En reiteradas ocasiones, la Sala Constitucional ha reconocido el papel independiente y autónomo de la jurisdicción penal respecto al régimen administrativo sancionador propio del Tribunal Ambiental Administrativo, así como la potestad sancionatoria de ambas instancias de impartición de justicia ambiental; al efecto, es posible citar los Votos 12044-2001, 13535-2004 y 14076-2004 9690-2008.

Es importante recalcar que -tanto en la vía penal como la administrativa- ante el Tribunal Ambiental Administrativo existe la obligación del juzgador de ordenar y asegurarse de la recomposición de los ecosistemas forestales degradados, idealmente al estado anterior a la afectación (reparación in natura).

\subsection{Jurisprudencia relevante en relación con compensación por daño ambiental por el delito de aprovechamiento ilegal de productos forestales}

Las reglas de la restauración ambiental han sido objeto de análisis jurisprudencial por parte tanto de la Sala Constitucional como de la Sala Primera de la Corte Suprema de Justicia ${ }^{40}$. Ahora bien, específicamente en materia de restauración forestal, es posible citar los siguientes fallos provenientes del Tribunal de Casación Penal.

40. El voto más relevante en el tema es el 675-2007 de la Sala Primera de la Corte Suprema de Justicia. 


\section{Jurisprudencia relevante en materia de reparación, restauración y compensación forestal}

\begin{tabular}{|c|c|c|}
\hline Tema & Dato & Extracto \\
\hline $\begin{array}{l}\text { Prevalencia de } \\
\text { la reparación in } \\
\text { natura; delito } \\
\text { cambio uso } \\
\text { de suelo, Ley } \\
\text { Forestal }\end{array}$ & $\begin{array}{l}\text { Voto } N^{\circ} 366-2003 \text { de } \\
\text { las } 11: 54 \text { horas del } \\
\text { 05/05/2003, Tribunal } \\
\text { de Casación Penal }\end{array}$ & $\begin{array}{l}\text { "En el presente caso, en que el daño es el cambio del uso del } \\
\text { suelo del bosque para dedicarlo a agricultura, la reacción estatal } \\
\text { tiene su límite en la reparación del daño, que de todas formas } \\
\text { no se completará en los tres años de ejecución condicional de } \\
\text { la pena, puesto que el bosque es producto de años y años de } \\
\text { nacimiento, desarrollo y muerte de muchos seres vegetales y } \\
\text { animales; sin embargo, la exclusión de los cultivos y de todo } \\
\text { elemento con que se ha sustituido el bosque, así como el } \\
\text { restablecimiento de especies vegetales en la medida adecuada } \\
\text { para regenerar lo destruido, son un principio para la reparación } \\
\text { que en algunos años se alcanzará". }\end{array}$ \\
\hline $\begin{array}{l}\text { Obligación de } \\
\text { restauración de } \\
\text { suelos forestales }\end{array}$ & $\begin{array}{l}\text { Voto } N^{\circ} 366-2003 \text { de } \\
\text { las 11:54 horas del } \\
\text { 05/05/2003, Tribunal } \\
\text { de Casación Penal }\end{array}$ & $\begin{array}{l}\text { "Debe quedar claro que la protección del suelo de los bosques } \\
\text { consagrada en los artículos } 2,6,10 . c, 19 \text { y } 38 . f \text { de la Ley } \\
\text { Forestal, } 52 \text { de la Ley de Uso, Manejo y Conservación de Suelos, } \\
53,54 \text { y } 55 \text { de la Ley Orgánica del Ambiente, } 53 \text { y } 54 \text { de la Ley } \\
\text { de Biodiversidad, no termina o se suspende cuando por actos de } \\
\text { seres humanos (incendios provocados, talas ilegales, etc.) o por } \\
\text { hechos de la naturaleza (inundaciones, terremotos, incendios, } \\
\text { etc.) el bosque viene a menos; antes por el contrario, ante } \\
\text { esas situaciones se impone al Estado mayor agresividad en la } \\
\text { recuperación y conservación del bosque. Pensar que el deber } \\
\text { de protección del suelo forestal y de otros elementos del bosque } \\
\text { termina por cualquiera de los hechos indicados, se traduciria en } \\
\text { la promoción de actividades ilícitas lesivas del medio ambiente, } \\
\text { para sustituir la ecología por explotaciones agrícolas o de otra } \\
\text { naturaleza, con lo que no habría protección verdadera; es decir, } \\
\text { el espacio ocupado por los bosques es irreductible por esas vías } \\
\text { (principio de irreductibilidad del bosque)". }\end{array}$ \\
\hline $\begin{array}{l}\text { Obligación de } \\
\text { restauración }\end{array}$ & $\begin{array}{l}\text { Voto } N^{\circ} 366-2003 \text { de } \\
\text { las 11:54 horas del } \\
\text { 05/05/2003, Tribunal } \\
\text { de Casación Penal }\end{array}$ & $\begin{array}{l}\text { ‘Esto es, en el caso de autos deben desaparecer la actividad } \\
\text { agrícola del lugar donde corresponde regenerar el bosque, ya sea } \\
\text { que lo haga el condenado en cumplimiento de la cláusula por la } \\
\text { que se le otorga casi como incentivo el beneficio de ejecución } \\
\text { condicional de la pena, ya sea por la acción del Estado; los } \\
\text { funcionarios responsables de la ejecución verán por la eficacia } \\
\text { del fallo de mérito. No hay desproporción o abuso en la condición } \\
\text { impuesta por el juzgador. Esta forma de resolver por parte del } \\
\text { juez de juicio, reafirma el valor normativo de la Const. Pol., que } \\
\text { en sus artículos } 50 \text { y } 74 \text { garantizan a la humanidad entera, con } \\
\text { carácter de irrenunciable, el derecho a un ambiente sano y } \\
\text { ecológicamente equilibrado. Amén de lo anterior, la disposición } \\
\text { judicial en este caso guarda identidad con la disposición } \\
\text { legislativa adoptada en el artículo } 52 \text { de la Ley de Uso, Manejo } \\
\text { y Conservación de Suelos, } N \text { }{ }^{\circ} 7779 \text { de } 30 \text { de abril de } 1998, \text { que } \\
\text { dispone ad litteram: “... Quien contamine o deteriore el recurso } \\
\text { suelo, independientemente de la existencia de culpa o dolo o del } \\
\text { grado de participación, será responsable de indemnizar, en la } \\
\text { vía judicial que corresponda, y de reparar los daños causados al } \\
\text { ambiente y a terceros afectados...”.'. }\end{array}$ \\
\hline
\end{tabular}




\begin{tabular}{|l|l|l|}
\hline \multicolumn{1}{|c|}{ Tema } & \multicolumn{1}{|c|}{ Dato } & \multicolumn{1}{c|}{ Extracto } \\
\hline $\begin{array}{l}\text { Principio de } \\
\text { irreductibilidad } \\
\text { de los bosques }\end{array}$ & $\begin{array}{l}\text { Voto N }{ }^{\circ} 366-2003 \text { de } \\
\text { las 11:54 horas del } \\
\text { 05/05/2003, Tribunal } \\
\text { de Casación Penal }\end{array}$ & $\begin{array}{l}\text { "De este modo, cualquiera que lesione el bosque con tala o } \\
\text { incendios con el propósito de cambiar el destino del terreno, o } \\
\text { cualquiera que pretenda obtener provecho de desastres naturales } \\
\text { que dañen el suelo fore stal, debe comprender que no hay forma } \\
\text { posible de cambiar el destino del suelo, y que el Estado hará } \\
\text { cuanto sea para recuperar el bosque". }\end{array}$ \\
\hline $\begin{array}{l}\text { Obligación de } \\
\text { restauración en } \\
\text { vía penal a pesar } \\
\text { de inexistencia } \\
\text { de acción civil } \\
\text { resarcitorio }\end{array}$ & $\begin{array}{l}\text { Voto No } 366-2003 \text { de } \\
\text { las 11:54 horas del } \\
\text { 05/05/2003, Tribunal } \\
\text { de Casación Penal }\end{array}$ & $\begin{array}{l}\text { "Si bien en el presente asunto lo resuelto por el juzgador no } \\
\text { corresponde a la existencia de una acción civil resarcitoria, } \\
\text { es lo cierto que no sobrepasa la voluntad de la ley, que exige } \\
\text { la reparación de los daños cuando se cometa delito, con } \\
\text { independencia del dolo o de la culpa". }\end{array}$ \\
\hline $\begin{array}{l}\text { Reparación del } \\
\text { daño ambiental, } \\
\text { control y } \\
\text { fiscalización, } \\
\text { vigilancia del } \\
\text { cumplimiento } \\
\text { plan reparador } \\
\text { en materia penal } \\
\text { ambiental }\end{array}$ & $\begin{array}{l}\text { Voto No 425-2011 } \\
\text { de las 9:50 horas del } \\
\text { 30/09/2011, Tribunal } \\
\text { de Casación Penal } \\
\text { del Tercer Circuito } \\
\text { Judicial de Alajuela }\end{array}$ & $\begin{array}{l}\text { "Los reclamos no pueden prosperar: no es al juzgador a quien } \\
\text { le corresponde la tarea de vigilar el cumplimiento del plan } \\
\text { reparador acordado por las partes al admitir la suspensión del } \\
\text { proceso a prueba, sino que ello es tarea exclusiva de una oficina } \\
\text { especializada adscrita a la Dirección General de Adaptación } \\
\text { Social, a la cual incluso le corresponde remitir informes } \\
\text { constantes al juzgador. Si bien existe obligación del Estado } \\
\text { de velar por la protección del medio ambiente, lo mismo que } \\
\text { asegurar su restauración, recuperación y rehabilitación cuando } \\
\text { se ha suscitado un daño ambiental, tal labor no le compete al } \\
\text { juzgador en este caso, sino que para ello existen otras instancias } \\
\text { estatales a las que se les ha encomendado esta función". }\end{array}$ \\
\hline
\end{tabular}

Fuente propia

\subsection{Tipos de penas existentes en la legislación y su vinculación con la ilegalidad en el comercio de madera (p. ej. penalidades según ámbito administrativo y judicial)}

El Artículo 57 de la Ley Forestal dispone que las infracciones previstas en dicha norma constituyen delitos. En el caso de los actos ilícitos comprendidos en esta ley, cuando se trate de personas jurídicas, la responsabilidad civil se extenderá a sus representantes legales. Asimismo, tanto las personas físicas como jurídicas son responsables -civilmente- por el daño ecológico causado de acuerdo con lo que establece el Artículo 1045 del Código Civil. Las autoridades, regentes forestales y certificadores a quienes les competa hacer cumplir la ley Forestal y su reglamento deben ser juzgados como cómplices y sancionados con las mismas penas -según sea el delito- cuando se les compruebe que, a pesar de tener conocimiento de sus violaciones, por negligencia o complacencia no procuren el castigo de los culpables y permitan la infracción de esta ley y su reglamento.

El numeral 64 de la Ley Forestal establece la pena de inhabilitación por infracciones a la normativa forestal por un período de doce meses tanto del(os) infractor(es) como de la finca donde se cometió la infracción.

En el Artículo 65 de la Ley Forestal se regula el decomiso y remate de madera y productos forestales, siendo que la autoridad -previo avalúo realizado por la Administración Forestal del Estado- los rematará en subasta pública dentro de un plazo no mayor de un mes contado a partir de la fecha en que se interpuso la denuncia. 
En cuanto a los criterios de fijación de las penas en delitos forestales, el numeral 66 de la Ley Forestal expone que en sentencia motivada el Juez fijará la duración de la pena, que deberá imponerse de acuerdo con los límites indicados para los delitos que en esta ley se señalan; para ello atenderá a la gravedad del hecho y la personalidad del partícipe, circunstancias que deberá apreciar según el Artículo 71 del Código Penal.

Tratándose de funcionarios públicos que resulten culpables de cualquiera de los delitos tipificados en la Ley Forestal, en sus distintas formas de participación se les aplica la sanción respectiva aumentada en un tercio, tal y como lo prevé el numeral 67 de Ley Forestal.

\section{Conductas y sanciones relacionadas con aprovechamiento ilegal del recurso forestal}

\begin{tabular}{|c|c|c|}
\hline Conducta & Sanción & Observaciones \\
\hline $\begin{array}{l}\text { Cambiar uso de suelo o establecer } \\
\text { plantaciones forestales en terrenos } \\
\text { cubiertos de bosques (Artículo } 19 \text { Ley } \\
\text { Forestal) }\end{array}$ & $\begin{array}{l}\text { Prisión de un mes a tres años } \\
\text { (Artículo } 61 \text { Ley Forestal) }\end{array}$ & $\begin{array}{l}\text { Prohibido salvo que se cuente } \\
\text { con permiso de la AFE para: } \\
\text { construir, llevar a cabo proyectos } \\
\text { de infraestructura de conveniencia } \\
\text { nacional, cortar árboles por } \\
\text { razones de seguridad humana } \\
\text { o de interés científico y prevenir } \\
\text { incendios forestales, desastres } \\
\text { naturales u otras causas análogas. } \\
\text { Debe haberse llenado previamente } \\
\text { un cuestionario de preselección } \\
\text { ante la AFE para determinar la } \\
\text { posibilidad de exigir una ElA } \\
\text { (Artículo } 19 \text { Ley Forestal) } \\
\text { Derribo y decomiso }\end{array}$ \\
\hline $\begin{array}{l}\text { Aprovechamiento de uno o varios } \\
\text { productos forestales en propiedad } \\
\text { privada sin el respectivo permiso de } \\
\text { AFE o a quien cuente con permiso que } \\
\text { no se ajuste al autorizado (Artículo } 61 \\
\text { inciso a) Ley Forestal) }\end{array}$ & Prisión de un mes a tres años & Decomiso \\
\hline $\begin{array}{l}\text { Irrespetar vedas forestales declaradas } \\
\text { (Artículo } 58 \text { inciso c) Ley Forestal) }\end{array}$ & $\begin{array}{l}\text { Prisión de tres meses a tres } \\
\text { años y decomiso }\end{array}$ & Decomiso \\
\hline $\begin{array}{l}\text { Invadir área de conservación o } \\
\text { protección, cualquiera que sea su } \\
\text { categoría de manejo, u otras áreas } \\
\text { boscosas o terrenos sometidos a } \\
\text { régimen forestal, cualquiera que sea } \\
\text { el área ocupada, independientemente } \\
\text { de que se trate de terrenos del PNE o } \\
\text { terrenos de dominio privado (Artículo } \\
58 \text { inciso a Ley Forestal) }\end{array}$ & $\begin{array}{l}\text { Prisión de tres meses a tres } \\
\text { años (Artículo } 58 \text { inciso a) Ley } \\
\text { Forestal) }\end{array}$ & Derribo de infraestructura \\
\hline $\begin{array}{l}\text { Aprovechar recursos forestales en } \\
\text { terrenos del PNE y áreas de protección } \\
\text { para fines distintos de los establecidos } \\
\text { por ley (Artículo } 58 \text { inciso b Ley } \\
\text { Forestal) }\end{array}$ & Tres meses a tres años & Decomiso \\
\hline $\begin{array}{l}\text { Adquirir o procesar productos } \\
\text { forestales sin cumplir con los } \\
\text { requisitos establecidos en la ley } \\
\text { (Artículo } 61 \text { inciso b Ley Forestal) }\end{array}$ & Prisión de un mes a tres años & Decomiso \\
\hline
\end{tabular}




\begin{tabular}{|c|c|c|}
\hline Conducta & Sanción & Observaciones \\
\hline $\begin{array}{l}\text { Sustraer productos forestales de } \\
\text { propiedad privada o del Estado, o } \\
\text { transporte de productos forestales } \\
\text { obtenidos de la misma forma (Artículo } \\
61 \text { inciso e) Ley Forestal) }\end{array}$ & Prisión de un mes a tres años & Decomiso \\
\hline $\begin{array}{l}\text { Construir caminos o trochas en } \\
\text { terrenos con bosque o emplear equipo } \\
\text { o maquinaria de corta, extracción y } \\
\text { transporte en contra de lo dispuesto } \\
\text { en el plan de manejo aprobado por la } \\
\text { AFE (Artículo } 62 \text { Ley Forestal) }\end{array}$ & Prisión de uno a tres años & Decomiso de equipo \\
\hline $\begin{array}{l}\text { Movilización ilegal de madera (Artículo } \\
56 \text { Ley Forestal) }\end{array}$ & $\begin{array}{l}\text { Prisión de un mes a un año } \\
\text { (Artículo } 63 \text { inciso a) Ley } \\
\text { Forestal) }\end{array}$ & \\
\hline $\begin{array}{l}\text { Envenenar o anillar árboles sin permiso } \\
\text { previo de la AFE (Artículo } 63 \text { inciso b) } \\
\text { Ley Forestal) }\end{array}$ & $\begin{array}{l}\text { Prisión de un mes a un año } \\
\text { Inhabilitación del infractor y } \\
\text { de la finca donde se cometió } \\
\text { delito y durante este los } \\
\text { infractores no podrán ser } \\
\text { sujetos de permisos (Artículo } \\
64 \text { Ley Forestal) }\end{array}$ & \\
\hline $\begin{array}{l}\text { Destrucción en bosques nacionales } \\
\text { de árboles que estén situados en } \\
\text { pendientes, orillas de las carreteras y } \\
\text { demás vías de comunicación (Artículo } \\
165 \text { Ley de Aguas) }\end{array}$ & $\begin{array}{l}\text { Multa de doscientos a } \\
\text { quinientos colones }\end{array}$ & $\begin{array}{l}\text { En caso de reincidencia o cuando } \\
\text { el número de árboles exceda de } \\
\text { cinco, la pena será de arresto } \\
\text { inconmutable de dos a seis meses } \\
\text { y obligación de reponer los árboles } \\
\text { destruidos } \\
\text { Expropiación de las fajas de } \\
\text { terrenos en los anchos descritos } \\
\text { en esta acción a uno y otro lado } \\
\text { del curso del río o arroyo en toda } \\
\text { su extensión (Artículo } 151 \text { Ley de } \\
\text { Aguas) }\end{array}$ \\
\hline $\begin{array}{l}\text { Destrucción de árboles que pueden } \\
\text { explotarse sin necesidad de cortarlos } \\
\text { (Artículo } 165 \text { Ley de Aguas) }\end{array}$ & $\begin{array}{l}\text { Multa de doscientos a } \\
\text { quinientos colones }\end{array}$ & $\begin{array}{l}\text { En caso de reincidencia o cuando } \\
\text { el número de árboles exceda de } \\
\text { cinco, la pena será de arresto } \\
\text { inconmutable de dos a seis meses } \\
\text { y obligación de reponer los árboles } \\
\text { destruidos } \\
\text { Expropiación de las fajas de } \\
\text { terrenos en los anchos descritos } \\
\text { en esta acción a uno y otro lado } \\
\text { del curso del río o arroyo en toda } \\
\text { su extensión (Artículo } 151 \text { Ley de } \\
\text { Aguas) }\end{array}$ \\
\hline Causar con dolo incendio forestal & $\begin{array}{l}\text { Prisión de uno a tres años } \\
\text { (Artículo 59 Ley Forestal) }\end{array}$ & \\
\hline Causar con culpa incendio forestal & $\begin{array}{l}\text { Prisión de tres meses a dos } \\
\text { años (Artículo } 60 \text { Ley Forestal }\end{array}$ & \\
\hline
\end{tabular}




\begin{tabular}{|l|l|l|}
\hline \multicolumn{1}{|c|}{ Conducta } & \multicolumn{1}{|c|}{ Sanción } & \multicolumn{1}{c|}{ Observaciones } \\
\hline $\begin{array}{l}\text { Comerciar, negociar, traficar o trasegar } \\
\text { con la flora silvestre, sus productos } \\
\text { o subproductos sin el permiso } \\
\text { respectivo del Sistema Nacional de }\end{array}$ & $\begin{array}{l}\text { Sanción de multa de cinco a } \\
\text { diez salarios base o prisión de } \\
\text { tres a seis meses }\end{array}$ & $\begin{array}{l}\text { Comiso de las piezas que } \\
\text { constituyan el producto de la } \\
\text { infracción }\end{array}$ \\
$\begin{array}{l}\text { trate de planservación cuando se declaradas en peligro } \\
\text { de extinción por el Poder Ejecutivo o } \\
\text { convenciones internacionales }\end{array}$ & & \\
\hline
\end{tabular}

A continuación se detallan las sanciones previstas para conductas relacionadas con el comercio ilegal de madera y productos forestales.

\begin{tabular}{|l|l|l|}
\hline \multicolumn{1}{|c|}{ Conducta } & \multicolumn{1}{|c|}{ Sanción } & \multicolumn{1}{c|}{ Observaciones } \\
\hline $\begin{array}{l}\text { Exportación de madera en trozas y } \\
\text { escuadrada proveniente de bosques } \\
\text { (Artículo 26 Ley Forestal) }\end{array}$ & $\begin{array}{l}\text { No prevista en Ley } \\
\text { Forestal }\end{array}$ & $\begin{array}{l}\text { En caso de que la madera sea producto de } \\
\text { una importación, exportación o reexportación } \\
\text { que violente las disposiciones contempladas } \\
\text { en el Artículo 56 de la Ley Forestal y para } \\
\text { las especies incluidas en los apéndices de } \\
\text { la Convención ClTES, deberá analizarse la } \\
\text { posible comisión del delito de importación o } \\
\text { exportación de madera previsto y sancionado } \\
\text { en el Artículo 91 inciso b) de la Ley de } \\
\text { Conservación de la Vida Silvestre }\end{array}$ \\
\hline $\begin{array}{l}\text { Importar o exportar sin autorización } \\
\text { del Sistema Nacional de Áreas de } \\
\text { Conservación productos o subproductos } \\
\text { de árboles maderables declarados en } \\
\text { peligro de extinción o con poblaciones } \\
\text { reducidas e incluidos en los apéndices de } \\
\text { la CITES }\end{array}$ & $\begin{array}{l}\text { Multa de cinco a quince } \\
\text { salarios base o pena } \\
\text { de prisión de tres a seis }\end{array}$ & $\begin{array}{l}\text { Comiso (Artículo 91 Ley de Conservación de } \\
\text { Vida Silvestre) }\end{array}$ \\
\hline $\begin{array}{l}\text { Importar sin autorización del Sistema } \\
\text { Nacional de Áreas de Conservación flora } \\
\text { silvestre exótica }\end{array}$ & $\begin{array}{l}\text { Multa de 25\% hasta 50\% } \\
\text { de un salario base }\end{array}$ & $\begin{array}{l}\text { Comiso de las piezas que constituyan el } \\
\text { producto de la infracción (Artículo 105 Ley de } \\
\text { Conservación de Vida Silvestre) }\end{array}$ \\
\hline
\end{tabular}

\subsection{Número de casos presentados y número de casos desestimados o con sentencia condenatoria para el período 2008-2013}

Total de denuncias presentadas por delitos ambientales ante el

Tribunal Ambiental Administrativo y el Ministerio Público

\begin{tabular}{|c|c|c|c|}
\hline Año & $\begin{array}{c}\text { Resoluciones } \\
\text { de homologación }\end{array}$ & $\begin{array}{c}\text { Resoluciones } \\
\text { de desestimación }\end{array}$ & $\begin{array}{c}\text { Resoluciones } \\
\text { finales }\end{array}$ \\
\hline 2008 & 7 & 69 & 11 \\
\hline 2009 & 3 & 97 & 4 \\
\hline 2010 & 3 & 83 & 13 \\
\hline 2011 & 2 & 45 & 18 \\
\hline 2012 & 4 & 31 & 10 \\
\hline
\end{tabular}


De los datos expuestos por el XVIII Informe del Estado de la Nación se deduce que el número de denuncias ambientales interpuestas varía año con año, no reflejándose un crecimiento sostenido de estas, siendo el año 2009 el de mayor recepción y el 2012 el de menor número de denuncias presentadas.

\begin{tabular}{|l|r|r|r|r|r|r|}
\hline \multicolumn{7}{|c|}{ Número de denuncias ambientales interpuestas } \\
\hline \multirow{2}{*}{\begin{tabular}{l} 
Instituciones \\
\cline { 2 - 8 }
\end{tabular}} & \multicolumn{7}{|c|}{ Año } \\
\cline { 2 - 7 } & 2007 & \multicolumn{1}{|c|}{2008} & 2009 & 2010 & 2011 & 2012 \\
\hline TAA & 303 & 451 & 462 & 549 & 469 & 439 \\
\hline Ministerio Público & 2.266 & 2.479 & 2.501 & 2.396 & 2.078 & 1.763 \\
\hline Total & 2.569 & 2.930 & 2.963 & 2.945 & 2.547 & 2.202 \\
\hline
\end{tabular}

Fuente: XVIII Informe del Estado de la Nación, información estadística del Tribunal Ambiental Administrativo

\section{Información del Poder Judicial}

\begin{tabular}{|c|c|c|c|c|c|c|}
\hline \multicolumn{7}{|c|}{ Número de denuncias presentadas por delitos forestales } \\
\hline & \multicolumn{7}{|c|}{ Año } \\
\cline { 2 - 7 } & 2007 & 2008 & 2009 & 2010 & 2011 & 2012 \\
\hline Infracción Ley Forestal & 1.708 & 1.769 & 1.585 & 1.525 & 1.249 & 1.031 \\
\hline
\end{tabular}

Fuente: Sección de Estadística, Departamento de Planificación, Poder Judicial

\begin{tabular}{|c|c|c|}
\hline \multicolumn{3}{|c|}{$\begin{array}{l}\text { Personas sentenciadas por los tribunales penales } \\
\text { según delito y tipo de resolución durante el } 2012\end{array}$} \\
\hline \multirow{3}{*}{ Delito Infracción Ley Forestal } & \multicolumn{2}{|c|}{ Tipo de sentencia } \\
\hline & Condenatoria & Absolutoria \\
\hline & 26 & 56 \\
\hline
\end{tabular}

Fuente: Sección de Estadística, Departamento de Planificación, Poder Judicial

\begin{tabular}{|c|c|c|c|c|c|c|c|c|c|c|c|c|c|c|c|c|c|c|c|c|}
\hline \multicolumn{21}{|c|}{ Personas condenadas por los tribunales penales según tipo de delito y pena durante el 2012} \\
\hline$\stackrel{?}{\frac{3}{0}}$ & 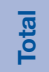 & \multicolumn{19}{|c|}{ Pena } \\
\hline \multirow[t]{2}{*}{ 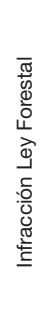 } & & 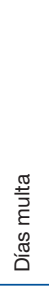 & 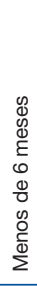 & 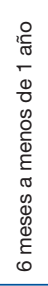 & 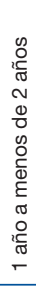 & 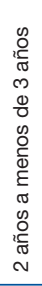 & 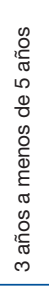 & 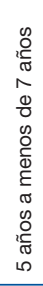 & 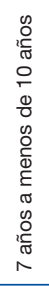 & 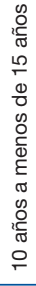 & 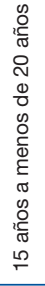 & 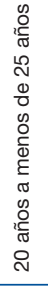 & 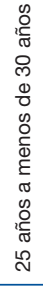 & 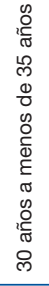 & 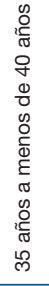 & 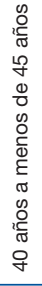 & 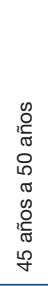 & 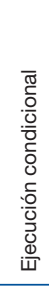 & 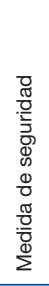 & 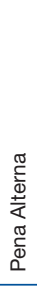 \\
\hline & 26 & 0 & 3 & 0 & 2 & 0 & 0 & 0 & 0 & 0 & 0 & 0 & 0 & 0 & 0 & 0 & 0 & 21 & 0 & 0 \\
\hline
\end{tabular}


Los datos estadísticos aquí recopilados muestran problemas en la aplicación efectiva del esquema sancionatorio por parte tanto del sistema judicial como de la justicia administrativa.

\subsection{Retos en el ámbito judicial en materia de aprovechamiento forestal y comercio internacional de productos forestales}

El principal reto en materia de aprovechamiento forestal y comercio internacional de productos forestales lo constituye la aplicación sostenida y recurrente de la propia legislación forestal, obligación a la que se sometió el país al suscribir el Tratado de Libre Comercio con Estados Unidos, Centroamérica y República Dominicana.

Para cumplir con lo anterior, se hace necesario el reforzamiento de los mecanismos de comando y control o sea, lo concerniente a la fiscalización, supervisión y monitoreo, pero en especial la prevención, sanción y restauración de los ecosistemas forestales degradados.

Un primer paso en ese sentido fue la promulgación de la Política de Persecución Penal de los Delitos Ambientales del Ministerio Público, útil herramienta para la labor de los fiscales, jueces, investigadores del Organismo de Investigación Judicial, policía administrativa, inspectores del MINAET y organizaciones ambientales, entre otras. Estas políticas han optimizado la investigación y juzgamiento de los delitos ambientales, y dentro de estos, los delitos e ilícitos forestales administrativos. Se trata de un instrumento de carácter vinculante para los fiscales de todo el país, que busca lograr la aplicación eficiente de la legislación ambiental-forestal y ha sido también adoptada como documento de referencia por otras instituciones de gobierno, tales como el Ministerio de Ambiente y Energía, Ministerio de Salud y el Tribunal Ambiental Administrativo.

Las políticas de persecución de los delitos ambientales definen las prioridades en la respuesta penal del sistema judicial ante ciertos delitos gravemente lesivos para el medio ambiente y que requieren por su especialidad una clasificación para conocer el catálogo de ilícitos contenidos en el ordenamiento jurídico.

Asimismo, se enfocan en la interpretación de los elementos normativos, sus aspectos probatorios y procedimentales. Van acompañados de protocolos de actuación con otras instituciones como el Ministerio de Ambiente y Energía (Tribunal Ambiental Administrativo, Sistema Nacional de Áreas de Conservación), Procuraduría General de la República y Organismo de Investigación Judicial, entre otros. Con su correcta implementación se busca una mayor eficacia en la formulación de las denuncias y consecuentemente, en la investigación y juzgamiento de los delitos ambientales. 


\section{Aportes adicionales}

\subsection{Análisis de la situación legal-administrativa para el aprovechamiento de la madera y comercio internacional de productos forestales}

La situación legal y administrativa para el aprovechamiento de la madera y comercio internacional de productos forestales se ve caracterizada por:

- El diseño y funcionamiento de algunas de las instancias de participación ambiental relacionadas con la protección y el aprovechamiento forestal son poco claros y en ocasiones, existe duplicidad de funciones, lo cual dificulta su eficaz funcionamiento.

- Las confusas competencias legales asignadas a las distintas instituciones del sector forestal complican la gestión eficiente en materia de control del aprovechamiento sostenible del recurso forestal.

- A pesar de la existencia de tres diferentes instancias de descentralización (municipal, Consejos Regionales Ambientales y Asociaciones de Desarrollo Integral Indígena), en la práctica la gestión forestal sigue estando concentrada en cada una de las Áreas de Conservación del SINAC, sobrecargando sus funciones y obstaculizando su eficaz misión.

- La Ley Forestal, luego de diecisiete años de su puesta en vigencia, presenta una serie de vacíos que han sido enmendados principalmente mediante la promulgación de nuevas leyes, decretos y reglamentos, así como por jurisprudencia constitucional, civil, penal y administrativa emanada de las distintas Salas de la Corte Suprema de Justicia. Queda aún pendiente tanto la suscripción de un AVA con la Unión Europea como la operativización interna del Convenio Internacional de Maderas Tropicales recientemente ratificado.

- Costa Rica cuenta con múltiples políticas y normativa que le permite cumplir con los compromisos que implica la Estrategia REDD+.

- Aunque la normativa y la jurisprudencia le brindan al poseedor forestal la protección en cuanto a la seguridad jurídica en la tenencia de la tierra, se le impide el aprovechamiento forestal por carecer de título registral, lo que tiene como efecto no deseado el incremento en los aprovechamientos irregulares.

- La tenencia de la tierra de los pueblos indígenas se encuentra en situación de inseguridad jurídica debido a las invasiones y ventas de sus territorios por personas no indígenas. Problemas catastrales de traslapes, aunados a la invasión ilegal de no indígenas, ponen en peligro los bosques ubicados dentro de sus territorios.

- Según el informe Madera Legal, Verificación y Gobernanza del Sector Forestal los pobres enfrentan considerables barreras para el cumplimiento legal del aprovechamiento forestal; esto debido a la complejidad de las regulaciones y los altos costos de transacción para obtener permisos. 
- El Programa de Pago por Servicios Ambientales se posiciona como el principal mecanismo de distribución de los beneficios derivados de la actividad.

- La legislación forestal costarricense establece una serie de limitaciones y estándares para el aprovechamiento forestal tanto en terrenos de dominio público como en bosques privados, los cuales encuentran sustento constitucional en el Artículo 45 como limitaciones de interés social.

- El sistema de control forestal comprende una amplia variedad de actores que ejecutan diversas funciones, lo que permite realizar controles cruzados entre actores. Sin embargo, el actor central (SINAC) es el que lleva la principal carga de competencias y funciones. La incorporación de regencias ambientales que -en principio- coadyuvan a la prevención de daños ambientales no ha tenido los efectos deseados.

- El comercio de productos de madera presenta en la actualidad grandes retos en cuanto a su sistema de reporte y verificación de estadísticas, el cual puede llevar a la Administración Forestal del Estado a ser un blanco fácil de fraude.

- El país cuenta con suficiente legislación que castiga el aprovechamiento y comercio ilegal de recursos forestales, así como con reiterada jurisprudencia que obliga al infractor de la legislación forestal a restaurar el ecosistema degradado -en la medida de lo posible- a su estado anterior al hecho dañoso.

- Los datos estadísticos recopilados demuestran problemas en la aplicación efectiva del esquema sancionatorio por parte del sistema judicial y administrativo.

\subsection{Retos y oportunidades jurídicas, y estrategia de fortalecimiento en el corto y largo plazo para el aprovechamiento de la madera y comercio internacional de productos forestales}

El país cuenta con un bloque de legalidad en materia forestal que es posible calificar de disperso y fragmentado. A pesar de lo anterior, también es posible afirmar-salvo algunas excepciones- que los elementos jurídicos esenciales para lograr aprovechamiento racional del recurso forestal y comercio internacional se encuentran presentes dentro del propio sistema; de ahí que el reto primordial sea la aplicación sostenida y recurrente de la legislación forestal, obligación que se contrajo expresamente al suscribir el CAFTA-DR en el año 2007.

Los principales vacíos existentes en la legislación forestal costarricense son la ausencia o insuficiencia de integración del enfoque ecosistémico, gestión integrada, variable cambio climático y equidad de género. En especial, la definición jurídica de bosque contenida en la Ley Forestal es insuficiente y tutela en forma deficitaria estos ecosistemas. A todas luces, se hace urgente y necesario modificar vía legislativa la definición jurídica de bosque, cumpliendo de paso con lo ya ordenado por la Sala Constitucional en el Voto 2007-3923.

En materia procesal se hace necesaria la correcta y eficaz implementación de la Política de Persecución Penal de los Delitos Ambientales del Ministerio Público.

Respecto a la participación pública ambiental, el principal reto es mejorar y posicionar los mecanismos existentes que permitan la participación ciudadana a partir de las etapas más tempranas de la 
planificación ambiental, con el fin que la voluntad de la sociedad civil se vea reflejada bajo un aporte de mejoramiento y perfeccionamiento de los aspectos sociales, ambientales e incluso económicos.

En relación con la institucionalidad, es imprescindible fortalecer a todos los actores responsables de la actividad forestal y mejorar la coordinación inter e intrainstitucional. Con respecto al control forestal, el financiamiento adecuado es crucial para lograr el buen desempeño de cualquier instrumento de verificación. El desafío consiste en lograr una mejora recaudatoria del impuesto forestal creado en la Ley Forestal, lo cual daría mayores recursos a las instituciones encargadas del control y la fiscalización forestal.

Los gobiernos locales aún no juegan un papel activo en la administración y control de los recursos forestales en sus territorios a pesar de que las políticas nacionales y las leyes forestales están orientadas hacia la descentralización y desconcentración de la administración de los recursos forestales. El reto y la oportunidad están en la implementación de mecanismos que logren hacer operativa y eficaz la gestión forestal desconcentrada del SINAC a través de los Consejos Regionales Ambientales, las Municipalidades y las Asociaciones de Desarrollo Integral Indígena.

La independencia financiera de los diferentes componentes del sistema de control es fundamental. La dependencia presupuestaria del regente forestal a manos del maderero podría amenazar su independencia. El desafío consistiría en lograr la autonomía económica de cada uno de los componentes del sistema de control y fiscalización mediante el replanteamiento de la normativa que regula el tema, especialmente el Reglamento de Regencias Forestales.

La recolección y sistematización de la información forestal debe acompañarse de controles; por ello, el reto consiste en lograr que la policía, COVIRENAS, regentes forestales y SINAC cuenten con un sistema de información eficaz para aplicar controles cruzados entre la información que recuperan y los permisos de aprovechamiento.

En materia de comercio internacional de recursos forestales, el principal reto consiste en lograr interpretar y aplicar de manera sistémica, sistemática y evolutiva las normas que regulan el comercio. De igual forma, se hace necesario cumplir en un futuro cercano con los requerimientos exigidos por Lacey Act y FLEGT; en este último caso se requiere la suscripción de un AVA con la Unión Europea.

Implementar sistemas de control eficaces para fortalecer los sistemas de verificación de la legalidad de la madera comercializada internacionalmente es uno de los retos más ambiciosos que se presenta para la institucionalidad forestal tanto nacional como global. Se hace necesario sistematizar y armonizar las estrategias de verificación, monitoreo y reporte de la legalidad del comercio internacional forestal, no solo en el plano fiscal, comercial internacional (CAFTA), forestal (nacional, certificación, CITES), sino también ambiental (CITES, Carbono), para que se pueda cumplir de forma efectiva y creíble con los requerimientos que exige la normativa.

En materia de los conflictos que surgen por la tenencia de la tierra y su aprovechamiento forestal entre particulares, y entre estos y el Estado, el reto primordial consiste en crear instrumentos jurídicos que le permitan al poseedor forestal sin título de propiedad aprovechar de manera racional y sostenible (mediante planes de manejo forestal) el recurso forestal ubicado en el fundo que detenta.

Tratándose de bosques en territorios indígenas, el reto está en lograr que el Estado resuelva y dé seguridad jurídica y catastral a los pueblos indígenas, ya que sus recursos naturales corren peligro de ser aprovechados y explotados de manera no sostenible por terceros no indígenas. 
En cuanto a la recomposición por daño ambiental relacionada con el aprovechamiento ilegal de recursos forestales, el desafío -y a la vez oportunidad-consiste en la unificación de criterios entre los distintos aplicadores del derecho, tanto en vía jurisdiccional como administrativa, en relación con las reglas, lineamientos y criterios a utilizar para reponer el ecosistema forestal a su estado anterior a la afectación y su valoración económica.

\subsection{Sugerencias a futuro para fortalecer la legalidad del proceso de aprovechamiento de la madera y comercio internacional de productos forestales, y con ellos la conservación y aprovechamiento de los bosques}

Para fortalecer la legalidad del proceso de aprovechamiento de la madera y el comercio internacional de productos forestales es necesario y primordial la aplicación sistemática de la normativa que regula la materia, incluyendo tanto el derecho interno como la normativa internacional, y en especial, la jurisprudencia desarrollada por las distintas Salas de Casación de la Corte Suprema de Justicia.

El bloque de legalidad ambiental/forestal debe ser modificado con el fin de incorporar expresamente el enfoque ecosistémico y de gestión integrada de los recursos naturales, la variable cambio climático y la equidad de género. La promulgación de leyes generales sobre cambio climático, pago por servicios ambientales y ley de autonomía indígena sería un paso que acercaría al país a esta meta.

Específicamente con respecto a la Ley Forestal, es urgente, necesario e indispensable la modificación de la definición jurídica del concepto bosque para que incorpore las especies no autóctonas y aquellos ecosistemas forestales con una cabida menor a dos hectáreas. La orden ya está dada por la Sala Constitucional desde el 2007; sin embargo, la Asamblea Legislativa aún no cumple con dicho mandato.

En materia procesal/procedimental relacionada con aprovechamiento forestal ilícito, se recomienda la correcta y eficaz implementación y ejecución de la Política de Persecución Penal de los Delitos Ambientales actualizada en el año 2010, instrumento que da los lineamientos necesarios -tanto de fondo como procesales- para una eficaz aplicación de la legislación forestal en materia de prevención, sanción y compensación ambiental.

Tratándose de políticas forestales, se recomienda la implementación eficaz del Plan Nacional de Desarrollo Forestal, así como la puesta en aplicación de su correspondiente Plan de Acción, incluyendo mecanismos eficientes que permitan medir su avance, así como aprobar las estrategias, reglamentos y manuales necesarios para controlar de forma más efectiva el aprovechamiento sostenible de los recursos forestales del país. A lo anterior debe sumarse la urgencia en la mejora del nivel de coordinación entre las distintas instituciones que conforman la Administración Forestal del Estado, función que debe recaer en el Ministerio de Ambiente y Energía como ente rector del sector forestal.

En relación con la Estrategia REDD+, se recomienda la aprobación de una Ley General del Cambio Climático que sirva de ley sombrilla que le dé integralidad y carácter de sistema no solo a otras normas ya existentes, sino también a la normativa que debe promulgarse, la cual guardan estrecha relación con la temática, como la Ley de Pago por Servicios Ambientales y Ley de Autonomía Indígena. 
En materia de los conflictos que surgen por la tenencia de la tierra y su aprovechamiento forestal entre particulares, se recomienda modificar la normativa actual o bien, la implementación de mecanismos que logren el aprovechamiento forestal por medio de planes de manejo a los poseedores de bosques sin título de propiedad. Con respecto a los conflictos por la tenencia de tierras dentro de territorios indígenas y el aprovechamiento ilegal de sus bosques, el Estado debe resolver y dar seguridad jurídica y catastral a los pueblos indígenas delimitando sus territorios y apoyando a las Asociaciones de Desarrollo Integral Indígena, por medio de la Procuraduría General de la República en los procesos judiciales tendientes a la recuperación de sus territorios actualmente en manos de terceros no indígenas, muchos de ellos poseedores de mala fe sin derecho a indemnización alguna.

Siempre dentro de la temática indígena, urge la modernización de la normativa actual a la luz de los más recientes convenios internacionales y declaraciones de las Naciones Unidas que rigen la materia; para ello se recomienda la aprobación de una nueva Ley de Desarrollo Autónomo de los Pueblos Indígenas que reconozca plenamente la autonomía indígena y su derecho al aprovechamiento sostenible de sus recursos naturales, incluyendo naturalmente sus bosques.

En materia de control forestal, se requiere la modernización del reglamento vigente que regula las actuaciones de los regentes forestales. Es claro que el esquema actual de dependencia presupuestaria del regente forestal a manos del maderero amenaza su independencia de acción. El nuevo reglamento debe claramente distinguir entre manejo forestal y actividades reguladoras. El hecho de que el regente forestal combine actividades de manejo (preparación de planes de manejo) y reguladoras (inspección y certificación de la correcta implementación del plan de manejo) inevitablemente lleva a conflictos de intereses. También se recomienda darle el debido seguimiento y evaluación de resultados al Sistema de Información de Recursos Forestales (SIREFOR).

En materia de descentralización y desconcentración de la función forestal, se recomienda la implementación de mecanismos que permitan hacer operativa y eficaz la gestión forestal desconcentrada del SINAC, lo cual es posible llevar a cabo por medio de directrices por parte del ente rector en la materia.

Por último, en relación con el comercio internacional de recursos forestales, se sugiere la capacitación a los aplicadores del derecho y entidades encargadas de la importación e importación de madera y productos forestales con respecto a los lineamientos que exige el derecho internacional en la materia, en especial la Convención CITES y el recientemente aprobado Convenio Internacional de Maderas Tropicales. 


\section{Bibliografía}

ACNUDH (2013). Informe de Diagnóstico de la Situación de los Derechos Humanos de los Pueblos Indígenas de América Central.

Aguilar, A., Cruz, M. y Jiménez M.S. (2001). Manual de Regulaciones Jurídicas para la Gestión del Recurso Hídrico en Costa Rica. CEDARENA.

Aguilar, A. y Wo Ching, E. (2001). Manual de Competencias Ambientales Municipales. CEDARENA.

Aguilar, G., Iza A. (2009). Derecho Ambiental en Centroamérica. UICN.

Aguilar Rojas, G. (2005). En busca de una distribución equitativa de los beneficios de la biodiversidad y el conocimiento indígena. UICN/MESOAMÉRICA.

Cabrera Medaglia, J. (2006). Manual de Legislación Ambiental Costarricense. San José: Editorial Jurídica Continental.

Cabrera Medaglia, J. 'Marco Legal Ambiental, capacidades regulatorias y conflictos ambientales relevantes', ponencia para el XVIII Informe del Estado de la Nación. [pdf online]. <http://www. estadonacion.or.cr/biblioteca-virtual/costa-rica/estado-de-la-nacion/informe-actual/informepor-capitulo/armonia>.

Cabrera Medaglia, J. (2010). Temas de Biodiversidad, Propiedad Intelectual y Biotecnología. Editorial Jurídica Continental.

Calvo, J. 'Bosques, Cobertura y Recursos Naturales', ponencia para el Décimo Quinto Informe del Estado de la Nación en Desarrollo Humano Sostenible. [pdf online]. <http://www.estadonacion. or.cr/biblioteca-virtual/costa-rica/estado-de-la-nacion/ponencias/490-informe-xv-bosque>.

CATIE/CIFOR (2010). Madera Legal, Verificación y Gobernanza en el Sector Forestal.

CEDARENA (2006). Costo de Acceso a la Legalidad, Cadenas y Actores de Mercado de la Madera Legal e llegal en Costa Rica.

Chacón Castro, R. y Guevara Berger, M. (1992). Territorios indios en Costa Rica: orígenes, situación actual y perspectivas. San José: García Hermanos S.A.

Chacón Castro, R. (2012). Disposiciones Jurídicas, lista de normas jurídicas que tutelan los derechos de los pueblos indígenas en Costa Rica. ISOLMA.

Chen Piu Deza, H. 'Análisis del Marco Legal para el Aprovechamiento Sostenible y Comercio de Madera en la región de Mesoamérica' Ponencia para el VIII Congreso Derecho Forestal, Costa Rica. [pdf online]. <http://web.catie.ac.cr/congresoforestal/imagexpositores/HUGOCHEPIU.pdf>.

Sistema de Información de los Recursos Forestales de Costa Rica. 'Estudio de Cobertura Forestal del 2005'. [pdf online]. <http://www.sirefor.go.cr/index.php?option=comcontent\&view=article\&i $d=20 \&$ Itemid $=31>$.

Ferroukhi, L. (2006). La Gestión Forestal Municipal en América Latina. CIFOR.

FONAFIFO: Más de una década de acción. (2005), Infoterra Editores. [pdf online]. <http://www. fonafifo.com/paginasespanol/noticias/FBS/UnadecadadeAccion.pdf>. 
FPDF. Propuesta para la preparación de Readiness R-PP Costa Rica.

García de Enterría, E. (1995). Curso de Derecho Administrativo. Madrid: Editorial Civitas.

González Ballar, R. (2007). Verdades incómodas sobre la justicia y la gobernabilidad ambiental en Costa Rica. San José: Editorial Jurídica Continental.

Mateos Rodríguez-Arias, A. (1992). Derecho Penal y Protección del Medio Ambiente. Editorial Colex.

MINAE. Estrategia para el Control de la Tala llegal 2002-2007.

MINAE. Plan Nacional de Desarrollo Forestal 2011-2020.

MINAE (2009). Estrategia Nacional de Cambio Climático.

Ministerio Público (2010). Política de Persecución Penal de los Delitos Ambientales del Ministerio Público.

Navarro, G., Santamaría, O., Vargas L. y Milla, V. (2013). Análisis del Comercio Internacional de Productos de Madera y su Gobernanza en la Región de América Central y la República Dominicana. EFI/EARTH/IUCN.

Obando Vargas, G. (2009). 'Bosque, cobertura y recursos forestales'. Ponencia para el XVI Informe del Estado de la Nación en Desarrollo Humano Sostenible.

Peña Chacón, M. 'El rol del derecho penal en la protección del ambiente'. Revista Jurídica Lex Difusión y Análisis, año VIII, N 99, (setiembre 2003), México.

Peña Chacón, M. 'La condena de ejecución condicional de la pena en los delitos ambientales'. Revista Jurídica Lex Difusión y Análisis, año VIII, N 101, (noviembre 2003), México; Dial.com [biblioteca jurídica online], Suplemento Derecho Ambiental, año IX, (martes 11 de abril de 2006), Argentina. <http://www.eldial.com/suplementos/ambiental/ambiental.asp>; Ciberjure [portal jurídico peruano], (16 de agosto de 2006), Perú. <http://www.ciberjure.com.pe>; Revista Criminogénesis, $N^{\circ} 5$, (octubre 2009), México.

Peña Chacón, M. (2003). Régimen Municipal y Medio Ambiente. El Municipio en Iberoamérica, México: Editora Laguna, primera edición; Dial.com [biblioteca jurídica online], Suplemento Derecho Ambiental, año IX, (martes 16 de mayo de 2006), Argentina. <http://www.eldial.com/ suplementos/ambiental/ambiental.asp>; Ciberjure [portal jurídico peruano], (17 de agosto de 2006), Perú. <http://www.ciberjure.com.pe>; Régimen Jurídico Municipal en Iberoamérica, (2009), México: Universidad Nacional Autónoma de México.

Peña Chacón, M. ‘El régimen económico y jurídico de los servicios ambientales'. Revista Lex Difusión y Análisis, año VIII, número especial por mes cien, (octubre 2003), México; Revista Electrónica de Derecho Ambiental "Medio Ambiente \& Derecho", № 10, (enero 2004), España: Universidad de Sevilla. <http://www.cica.es/aliens/gimadus/>; Dial.com [biblioteca jurídica online], Suplemento Derecho Ambiental, año IX, (martes 21 de mayo de 2006), Argentina. <http://www.eldial.com/ suplementos/ambiental/ambiental.asp>; Revista Derecho Ambiental y Ecología, N 44, (agostosetiembre 2011), México. <http://www.ceja.org.mx/IMG/Articulo2daPartepdf.pdf>. 
Peña Chacón, M. 'Reparación y valoración económica de la daños causados al medio ambiente'. Revista Electrónica de Derecho Ambiental "Medio Ambiente \& Derecho", N 12-13, (diciembre 2005), España: Universidad de Sevilla. <http://www.cica.es/aliens/gimadus/>; Dial.com [biblioteca jurídica online], Suplemento Derecho Ambiental, año IX, (lunes 18 de abril de 2006), Argentina. <http://www.eldial.com/suplementos/ambiental/ambiental.asp>.

Peña Chacón, M. 'El carácter democrático del desarrollo sostenible'. Revista Iberoamericana de Derecho Ambiental y Recursos Naturales, N 9, (agosto 2013). <http://www.ijeditores.com.ar/ abm_news_publicacion.php?idpublicacion=19\&idedicion $=270>$.

Peña Chacón, M. 'Daño, Responsabilidad y Reparación Ambiental en la Jurisprudencia Costarricense'. Centro Ecuatoriano de Derecho Ambiental [biblioteca virtual]. <http://www. ceda.org.ec/biblioteca_virtual2.php?menu=18\&submenu1=49\&buscador\&codigo_categ\&b uscar $=$ da $\% F 10 \% 2 \mathrm{C}+$ responsabilidad $+y+$ reparacion+ambiental+en+la+jurisprudencia $+c o s$ tarricense\&opcion>; Dial.com [biblioteca jurídica online], Suplemento de Derecho Ambiental, año XIV, (marzo 2012), Argentina. <http://www.eldial.com/suplementos/ambiental/ambiental. asp>; Revista Iberoamericana de Derecho Ambiental y Recursos Naturales, No 3, (febrero 2012), Argentina. <http://www.ijeditores.com.ar/index.php?ididioma=1\&idcontenido=2\&idpublicacion $=19 \&$ view $=1>$.

Oficina Nacional Forestal. 'Balanza comercial y principales tendencias de las exportaciones e importaciones de madera y muebles de madera en Costa Rica, Estadísticas 2012'. [pdf online]. <http://onfcr.org/media/uploads/documents/balanza_comercial_y_tendencias_de_ exportaciones_e_importaciones_2012.pdf>.

Poleri, A. y Meli, Y. 'La legitimación activa en el Derecho Penal Ambiental'. [pdf online]. $<$ http://indubioprojuris.freeservers.com/ambiental.htm>.

PROCOMER (mayo 2013). Estadísticas de Comercio Exterior 2012.

Programa Estado de la Nación. 'XVIII Informe del Estado de la Nación en Desarrollo Humano Sostenible'. [pdf online]. <http://www.estadonacion.or.cr>.

Saborío Valverde, R. (2003). Eficacia e Invalidez del Acto Administrativo. Editorial Juricentro, tercera edición.

Salazar, R. y Carazo, M. (2003). Sanciones en el Derecho Ambiental: una guía. Editorial Fundación Ambio.

SINAC/SIREFOR (2011). Reporte Estadístico Forestal.

USAID/EFI/ (2013). Todo lo que debe saber sobre Lacey Act, el reglamento de madera de la UE y la Ley Australiana de 2012 para la prohibición de la tala ilegal. 



\section{Panamá}

Jessica Young 


\section{Acrónimos}

$\begin{array}{ll}\text { ANA: } & \text { Autoridad Nacional de Aduanas } \\ \text { ANAM: } & \text { Autoridad Nacional del Ambiente } \\ \text { ANATI: } & \text { Autoridad Nacional de Tierras } \\ \text { AVA: } & \text { Acuerdo Voluntario de Asociación } \\ \text { CITES: } & \text { Convención sobre el Comercio Internacional de Especies Amenazadas de Fauna y } \\ & \text { Flora Silvestres } \\ \text { FAO: } & \text { Organización de Naciones Unidas para la Agricultura y la Alimentación } \\ \text { FONDEFOR: } & \text { Fondo de Desarrollo Forestal } \\ \text { IPPC: } & \text { Convención Internacional de Protección Fitosanitaria } \\ \text { MICl: } & \text { Ministerio de Comercio e Industrias } \\ \text { MIDA: } & \text { Ministerio de Desarrollo Agropecuario } \\ \text { MFS: } & \text { Modelo Forestal Sostenible } \\ \text { OIT: } & \text { Organización Internacional del Trabajo } \\ \text { PIB: } & \text { Producto Interno Bruto } \\ \text { REED+: } & \text { Reducción de Emisiones Provenientes de la Deforestación y Degradación de } \\ \text { SENAFRONT: } & \text { Servicio Nacional de Fronteras } \\ \text { SIA: } & \text { Sistema Interinstitucional del Ambiente } \\ \text { SICA: } & \text { Sistema de Integración Centroamericana } \\ \text { SICE: } & \text { Sistema Integrado de Comercio Exterior } \\ \text { UICN: } & \text { Unión Internacional para la Conservación de la Naturaleza } \\ \text { VICOMEX: } & \text { Viceministerio de Comercio Exterior } \\ & \end{array}$




\section{Introducción}

El presente trabajo recoge una síntesis de las políticas y normativas existentes en Panamá sobre el manejo y aprovechamiento forestal sostenible, su nivel de implementación y efectividad, y los retos que enfrenta el país para conservar la cobertura boscosa que actualmente mantiene, beneficiando a su vez a las comunidades locales.

Datos recientes reportados por la Organización de Naciones Unidas para la Agricultura y la Alimentación (FAO), en su informe FRA 2010¹, cifraron para el 2005 que Panamá disminuyó la cobertura forestal llegando a 3,31 millones de hectáreas y en el 2010 a un total estimado de 3,25 millones de hectáreas.

De acuerdo con la Autoridad Nacional del Ambiente (ANAM), la cobertura boscosa del país para el año 2000 fue de 3.364 .591 hectáreas, es decir, 45\% de la superficie total del país.

El aporte de los recursos forestales al Producto Interno Bruto (PIB) calculado al año 2004 es de solo $0,3 \%$ y en los siguientes años no supera el $1 \%$. No se dispone de información con datos cuantitativos sobre los impactos en el PIB de la deforestación y los cambios de uso de suelo en relación con la disposición de agua, por ejemplo, alimentos y biodiversidad².

Las cifras que registra la ANAM en sus compendios estadísticos dan cuenta de que desde el 2004 a junio de 2013 se han otorgado 87.276 permisos de aprovechamiento forestal y entre el 2009 y junio de 2013 el volumen por $\mathrm{m}^{3}$ otorgado asciende a 433.276,37 $\mathrm{m}^{3}$.

Los datos de exportación de productos o subproductos forestales no ingresan en el ranking de los 10 productos más exportados, por lo que no se encuentra información disponible que detalle estos valores ${ }^{3}$.

En Panamá, a pesar de que la normativa existente reconoce que los suelos son eminentemente de aptitud forestal, el aprovechamiento de los bosques no ha sido sostenible.

La primera Ley Forestal en Panamá data de 1966, derogada en el año 1994 por la Ley 1 de 1994. Ya desde 1966 se estableció la obligatoriedad en todo el territorio nacional de proteger, conservar, mejorar y acrecentar los recursos forestales, y declaró de interés público el aprovechamiento y manejo racional de los bosques y tierras forestales de la Nación ${ }^{4}$. La Ley 1 de 1994 mantiene los mismos objetivos además de educar, investigar, manejar y aprovechar racionalmente los recursos forestales ${ }^{5}$.

1. $\quad$ FAO (2010). Evaluación de los recursos forestales mundiales 2010. Informe principal, Págs. 233 y 238.

2. ANAM (2004). Informe Ambiental Panamá, Pág. 40.

3. Contraloría General de la República (2013). 'Principales indicadores económicos mensuales'. [pdf online]. <http://www.contraloria.gob.pa/inec/archivos/A301b_export_fob2013.pdf>. Accedido el 4 de diciembre de 2013.

4. Comisión Legislativa Permanente (1966). Decreto Ley N 39 del 29 de septiembre de 1966, por la cual se expide la Legislación Forestal de la República de Panamá. Gaceta Oficial 15.733 del 26 de octubre de 1966.

5. Asamblea Legislativa (1994). Ley № 1 del 3 de febrero de 1994, por la cual se establece la Legislación Forestal en la República de Panamá y se dictan otras disposiciones. Gaceta Oficial 22.470 del 7 de febrero de 1994. 
El patrimonio forestal del Estado está conformado por todos los recursos forestales que se encuentran en el territorio nacional, estén en tierras estatales, comarcas indígenas, propiedad privada, tierras patrimoniales (pertenecientes a un ente jurídico gubernamental), sea en territorio insular o peninsular y pueden ser bosques de producción, protección y especiales (ver Cuadro $N^{\circ} 1$ ).

Los controles que establecen las normas en la práctica no muestran niveles de cumplimiento apropiados que definan estándares normativos, presentándose una oportunidad para Panamá de fortalecer estos aspectos de la gobernanza forestal. 


\section{Síntesis histórica de la formulación de la Ley Forestal y afines}

El Régimen de Aprovechamiento establecido en el Decreto Ley 39 de 1966 contenía disposiciones a priori interesantes, como la compensación de particulares en cuyas propiedades se hubieran declarado bosques de protección, por la disminución de las rentas a consecuencia directa e inmediata de la declaración (Art. 39).

Los bosques declarados como especiales solamente podían servir a los fines para los cuales fueron creados o declarados; esto es, se regían por la norma que los creaba. En el caso de los bosques de producción, previo al aprovechamiento se debía realizar un inventario y presentar un plan de trabajo que debía ser aprobado por la autoridad.

La Ley 1 de 1994, norma vigente que regula el Régimen Forestal, basa el aprovechamiento forestal en un sistema de permisos y concesiones para sitios específicos por períodos de tiempo definidos, que pueden otorgarse en todos los bosques de la República de Panamá siempre y cuando los solicitantes cumplan con una serie de requisitos indispensables como el inventario forestal, el plan de manejo forestal, estudio de impacto ambiental y registro forestal, entre otros que se detallan a lo largo de este informe. Uno de los permisos con mayor demanda son los permisos comunitarios y de subsistencia, que contrasta con la decreciente demanda por los demás tipos que exigen más controles, situación que no ha variado en el $2013^{6}$.

La Ley 1 de 1994 es clara al definir que el aprovechamiento forestal sostenible como la "extracción de productos del bosque, con fines económicos, en forma ordenada, aplicando las mejores técnicas silviculturales" (Art. 5.10) y la reglamentación a esta Ley mediante Resolución JD 005-19987 en su Artículo 1.2 define el aprovechamiento forestal "como la extracción y utilización de productos y subproductos forestales, maderables y no maderables (...)".

Desde 1966 el marco normativo reconoce que no todas las tierras tienen características aptas para la agricultura o la ganadería y que estas zonas "inapropiadas" para estas actividades debían mantener la vegetación para cumplir otras funciones importantes, como evitar y controlar la erosión de los suelos, regular y proteger cursos de agua, servir como protección y defensa de vías de

6. La Comisión de Población, Ambiente y Desarrollo de la Asamblea Nacional abrió la discusión para aprobar en primer debate el proyecto de ley 585, que modifica un artículo de la Ley 1 de 1994 sobre el uso doméstico e interés social, con fecha 8 de abril de 2013. La exposición de motivos expresa que el proyecto busca mejorar el status de vida de las personas en áreas rurales y apartadas que necesitan aprovechar sosteniblemente los recursos forestales, pero que no cuentan con recursos para pagar los trámites correspondientes o la tasa por tal (ANAM y el Municipio). El Artículo 27 de la Ley 1 de 1994, en caso de modificarse, expresaría que los permisos de subsistencia no generarán pago o contribución alguno y los beneficiarios compensarán únicamente sembrando el doble de árboles talados. La norma refiere a los artículos del Código Penal sobre venta o traspaso del permiso a terceras personas. Es fundamental verificar si el proyecto de ley prohibiría el traspaso, dado que la ANAM lo autoriza siempre y cuando medie contrato por escrito con el contenido mínimo que exige la norma vigente.

7. La Resolución JD 005-1998 del 22 de enero de 1998, Gaceta Oficial № 23.495 del 22 enero de 1999. 
comunicación, sembradíos (probablemente esta función se asemejaría hoy a la de una zona de amortiguamiento). También se reconocía su función de hábitat clave para especies de fauna y flora. Y aunado a esto había un reconocimiento explícito de que los bosques y tierras forestales podían aportar beneficios obtenidos de "la materia prima forestal", promoviendo y mejorando la industria forestal "racionalmente concebidas".

La norma prohibió la destrucción de los bosques y las tierras forestales, así como el uso irracional de los productos forestales (Art. 15). Cualquier persona que quería dedicarse a la actividad forestal, en cualquiera de sus fases, debía solicitar autorización al Servicio Forestal (Art. 16). Para la explotación se requería la presentación de un plan de trabajo.

Una de las innovaciones de la Ley Forestal de 1966 fue la introducción de las guías forestales, las cuales debían ser expedidas por el Servicio Forestal para autorizar el transporte y comercio de las maderas y cualquier otro producto forestal. Estas guías debían contener información de cantidades, especies, peso o volumen, procedencia y destino del producto transportado (Art. 18). Con esto se establecía un mecanismo de trazabilidad del aprovechamiento forestal. Junto con esto, se creó el registro forestal, en el cual tenía que inscribirse toda persona -física o jurídica- que se dedicara a la explotación, transporte, industrialización o comercio de productos forestales, incluyendo las actividades de recolección y venta de semillas y plantas forestales, o la repoblación.

A pesar de todas las previsiones legales, se estima que entre los años 1970 y 1990 el uso agropecuario aumentó de $28 \%$ a $39 \%$ del territorio (casi un millón de hectáreas). El Informe Ambiental de Panamá de 1999 fue enfático al señalar que "siempre ha faltado la decisión política para formular un programa de ordenamiento territorial. Las tierras nacionales boscosas son consideradas por la ciudadanía como bienes libres y sujetos a ocupación inmediata". Esta aseveración dista mucho de lo establecido en las normas jurídicas vigentes desde el año 1962, por lo que la evolución de las normas ha sido transversalmente opuesta a la capacidad institucional para garantizar su efectiva implementación?

La pérdida de cobertura boscosa fue in crescendo como muestran las gráficas de los Informes del Estado del Ambiente de Panamá de 1999, 2004 y 2009, y de acuerdo con datos de FAO "en el quinquenio comprendido entre los años 1945-1950, aproximadamente el 70\% de la superficie del territorio nacional estaba cubierta de bosques (5.3 millones de hectáreas) y para 1970, esa cobertura se redujo al $50 \%$ (3.8 millones de hectáreas)" ${ }^{10}$ (ver Cuadro №2).

8. ANAM (1999). Informe Ambiental de Panamá, Pág. 16.

9. Este mismo informe señaló categóricamente que "(...) el Código Agrario establece la eliminación del bosque como condición previa para disponer del derecho posesorio o título de propiedad". Esta afirmación no refleja lo establecido en las disposiciones del Código Agrario, siendo probablemente una de las razones por las cuales a lo largo de los años se ha promulgado una cantidad importante de normas, entendiendo que el problema está[ba] en las normas, cuando en realidad uno de los grandes retos para el aprovechamiento forestal sostenible es el cumplimiento de las normas.

10. FAO (2002). Estado de la información forestal en Panamá. Monografía de países. Volumen 13. Santiago de Chile. [pdf online]. <ftp://ftp.fao.org/docrep/fao/006/AD395S/AD395S00.pdf >. Accedido el 4 de diciembre de 2013. FAO. 'VII. Estado actual de la información sobre productos forestales'. [documento online]. <http://www.fao.org/docrep/006/ad395s/ad395s09.htm>. Accedido el 4 de diciembre de 2013. 
En el año 1983, se introdujo en la Constitución Política de 1972 el Régimen Ecológico ${ }^{11}$, que establece que el Estado debe garantizar que la población viva en un ambiente sano y libre de contaminación, donde se satisfagan los requerimientos mínimos para un desarrollo humano adecuado.

En 1992 se aprobó la Ley $24^{12}$ que establecía incentivos y reglamentaba la actividad de la reforestación en Panamá. Los incentivos fueron principalmente fiscales, exonerando del pago de impuestos por las utilidades obtenidas con la comercialización de los productos de las plantaciones forestales y también incluía incentivos migratorios. En las discusiones se plantearon motivaciones de prevención de tala ilegal ${ }^{13} \mathrm{y}$ libre aprovechamiento de lo que una persona "siembre". Esta ley fue modificada y derogada sustancialmente por la Ley 6 de $2005^{14}$ (ver Anexo $N^{\circ} 6$ ). Se evidencia que las normas per se no garantizan un aprovechamiento forestal racional, sostenible ni previenen por sí solas la tala ilegal (ver Gráfica $\left.N^{\circ} 1\right)$.

\subsection{Formas de participación pública, nivel de implementación, procesos para su efectividad}

La Ley 1 de 1994 establece entre sus objetivos fundamentales fomentar el establecimiento de bosques comunales (reforestados por una comunidad) y la creación de organización y empresas de producción, transformación y comercialización de productos forestales (Arts. 3.6 y 3.7) como mecanismos de participación y acceso a los beneficios que generan los bosques y recursos forestales.

En cuanto a participación pública, otro de los objetivos de la Ley Forestal en Panamá es "educar, capacitar, divulgar y crear conciencia sobre la importancia de los recursos forestales en todos los niveles de la población" (Art. 3.10).

La norma establece la obligación de denunciar o poner en conocimiento de las autoridades competentes incendios forestales, plagas o enfermedades forestales en su Artículo 16, siendo esta una forma de participación pública. Las personas que denuncien "formalmente" tala, transporte, procesamiento o posesión ilegal de productos o subproductos forestales, que impliquen decomiso, serán recompensadas. La ANAM debe reglamentar los porcentajes (Art. 97 Resolución 05 de 1998).

11. Acto Constitucional de 1983, Artículos 118 al 121. Cualquier desarrollo debe prevenir la contaminación del ambiente, mantener el equilibrio ecológico y evitar la destrucción de ecosistemas. Se hace énfasis en el uso y aprovechamiento racional de los bosques, tierras y aguas de forma "que se evite su depredación y se asegure su preservación, renovación y permanencia” (Art. 120). El aprovechamiento de los recursos naturales no renovables no debe causar perjuicios ni ambientales ni económicos ni sociales.

12. Ley 24 de 1992, del 23 de noviembre, Gaceta Oficial 22.172 del 27 de noviembre de 1992.

13. "El objetivo principal del proyecto de Ley $N^{\circ} 27$ consiste en crear conciencia de que los daños ecológicos que está sufriendo el país se debe principalmente a causa de la deforestación indiscriminada, y estos daños son tan grandes que solamente la reforestación masiva, en gran escala e inmediata, podrá salvarnos de un desastre ecológico que compromete el desarrollo de toda clase de vida en la tierra". Informe de Primer Debate de la Comisión de Ambiente y Desarrollo sobre el Proyecto de Ley № 27 "por la cual se establecen incentivos y se reglamenta la actividad de reforestación en la República de Panamá", fechado 13 de octubre de 1992, Pág. 1. En las discusiones, además de los legisladores, participaron la Asociación Nacional de Reforestadores, representantes del INRENARE, de la Comisión de Ambiente del Ministerio de Planificación y Política Económica, y del Colegio Nacional de Ingenieros Forestales. No se tiene constancia de participación de comunidades campesinas, afrodescendientes o indígenas ni de asociaciones ecologistas.

14. Ley 6 del 2005, del 2 de febrero, Gaceta Oficial 25.232 del 3 de febrero de 2005. 
En caso de ocurrir un incendio forestal, de acuerdo con el Artículo 19, las autoridades de policía y la ANAM están facultadas para convocar a todos los habitantes para que participen activamente en la extinción del incendio forestal.

Quien solicite autorización para aprovechamiento forestal hasta 5.000 hectáreas está en la obligación de publicar por tres (3) días consecutivos en un periódico de circulación nacional y una vez en la Gaceta Oficial el edicto, emitido por la ANAM, que anuncia la concesión solicitada y su ubicación. Se abre un plazo de veinte (20) días hábiles, que se cuentan a partir de la última publicación, para que cualquier persona pueda presentar oposición pública (Art. 29).

En cuanto a la participación pública en los procesos de exportación e importación de productos forestales y con el fin de proteger los bosques naturales, las autoridades competentes como la ANAM y el Ministerio de Comercio e Industrias (MICl) podrán reglamentar estas actividades previa consulta con los industriales de la madera (Art. 56). También la industria forestal nacional debe ser consultada sobre normas de calidad, tecnologías y sistemas de medidas, entre otros, por la ANAM (Art. 67).

La ANAM tiene la facultad de otorgar primas y premios de estímulo a las actividades forestales científicas, de fomento e industrialización de nuevos productos forestales (Art. 66).

Del articulado de la Ley Forestal se desprende que los mecanismos de participación pública se limitan a la consulta previa al sector de la industria de la madera para normativas forestales y a la figura de oposición pública que se contempla para que cualquier persona pueda oponerse al otorgamiento de un permiso de aprovechamiento forestal.

La Ley General de Ambiente de 1998 también contempla disposiciones sobre la participación pública en la gestión ambiental, que incluye el manejo forestal. Por ejemplo, dentro del proceso de evaluación ambiental se establece la obligatoriedad de realizar consultas e inclusive foros públicos dependiendo de la categoría del estudio de impacto ambiental. El promotor tiene la obligación de involucrar a la ciudadanía en la etapa de planificación y el proceso de evaluación de impacto ambiental del estudio de impacto ambiental (Art. 28 del Decreto Ejecutivo 123 de 2009) ${ }^{15}$. La norma establece los mecanismos de participación aplicables (Art. 29).

La ANAM tiene entre sus atribuciones promover la participación ciudadana, convocar a consulta pública temas o problemas ambientales (Art. 7.11). También está obligada a publicar y dar acceso al público a los estudios de impacto ambiental que se presentan, previo a su aprobación, para que en el plazo estipulado cualquier persona pueda incidir con aportes y/o comentarios.

En el caso de las comarcas o pueblos indígenas, la Ley General de Ambiente obliga a que se les dé participación cuando el aprovechamiento se quiera realizar en sus tierras (Art. 105).

La Ley de Cuencas Hidrográficas, Ley 44 del 2002, establece la conformación de un Comité de Cuencas Hidrográficas, el cual asigna una posición con voz y voto a un representante de la sociedad civil (Art. 8) ${ }^{16}$ (ver Cuadro $\mathrm{N}^{\circ} 3$ ).

15. Decreto Ejecutivo 123 del 2009, del 14 de agosto de 2009, Gaceta Oficial N²5,625 publicada el 6 de septiembre del 2006, que reglamenta el proceso de evaluación de impacto ambiental.

16. Ley 44 del 2002, del 5 de agosto de 2002, Gaceta Oficial № 24613 publicada el 8 de agosto de 2002. El Comité está conformado por el(los) administrador(es) regional(es) de la ANAM, el(los) Director(es) 
Otras normas concordantes establecen mecanismos de participación pública a través de diferentes figuras, como las comisiones consultivas ambientales (ver Anexo 4), espacios de consulta para el ordenamiento ambiental territorial ${ }^{17}$, donde se reconoce que la participación ciudadana es un derecho y un deber ciudadano.

\subsection{Institucionalidad - Competencias}

La Autoridad Nacional del Ambiente (ANAM) es la entidad competente para desarrollar políticas públicas para el aprovechamiento racional de los recursos naturales. Además es la encargada de velar para que en la gestión ambiental se promocione la participación ciudadana para la formulación y ejecución de las políticas, las estrategias y los programas ambientales. También es la máxima autoridad para controlar el acceso a los recursos y desarrollar funciones de control y vigilancia, así como imponer sanciones administrativas que pueden ser amonestaciones verbales, escritas, multas, suspensión provisional o cierre definitivo, además de compensación por daños ${ }^{18}$. Es esta autoridad la que evalúa y aprueba o no los estudios de impacto ambiental, los planes de manejo forestales y los planes de ordenamiento ambiental territorial.

La ANAM concentra las competencias más relevantes en materia de gestión del patrimonio forestal en todos los aspectos relativos a la extracción de madera, aprovechamiento forestal, manejo forestal sostenible, transporte, comercio, posesión de productos forestales y subproductos. Es la autoridad primaria, puesto que sin cumplir sus protocolos y contar previamente con las autorizaciones respectivas que emanan de esta, las instituciones relacionadas con la sanidad vegetal, comercio exterior, importación o exportación no pueden proceder y por ende, autorizar el movimiento de los recursos forestales. Asimismo, mantiene administraciones regionales en cada provincia y agencias, que básicamente replican la estructura central.

El Departamento de Desarrollo y Manejo Forestal debe definir e implementar políticas e instrumentos de regulación y evaluación para el uso racional y sostenible de los recursos hídricos, forestales y suelos, así como procurar programas de investigación. Tiene que (i) velar por la restauración, utilización y mejoramiento del patrimonio forestal del país y (ii) definir, implementar y evaluar la aplicación de políticas, normas e instrumentos que tengan como objetivo la conservación de los recursos forestales.

Los Administradores Regionales poseen delegadas facultades que son vitales para la implementación de las políticas y normas forestales. Por ejemplo, están habilitados para que reciban, evalúen y tramiten las solicitudes de inscripción en el Registro Forestal ${ }^{19}$ e igualmente están facultados para otorgar permisos especiales de aprovechamiento forestal con carácter doméstico o de subsistencia ${ }^{20}$.

Regional(es) del MIDA, MINSA, MICI, AMP, IDAAN, MIVIOT, alcaldes de los municipios ubicados dentro de la cuenca, un representante de la ONG local, ambiental, hasta 2 representantes de usuarios, un representante de corregimiento (se elige anual y es un puesto rotativo entre todos los representantes de corregimiento).

17. Art. 83 del Decreto Ejecutivo 283 del 2006, del 21 de noviembre, Gaceta Oficial 25.690 publicada el 13 de diciembre de 2006.

18. Creada por Ley 41 de 1998. Ver nota al pie número 7. Artículos 3, 7, 21, 48, 62-64 y 71.

19. Resolución 1-98, del 10 de marzo de 1998, Gaceta Oficial 24.709 publicada el 30 de diciembre de 2002.

20. Resolución 568 del 2002, del 27 de noviembre, Gaceta Oficial 24.697 publicada el 11 de diciembre de 2002. 
Según la Resolución 224 del 2003, del 3 de junio, Gaceta Oficial № 24.818 publicada el 12 de junio, otra facultad de los administradores regionales es ordenar el decomiso, retención y venta directa de productos forestales.

En el ámbito municipal, un artículo importante a tomar en cuenta en el contexto del aprovechamiento forestal sostenible es el 246 de la Constitución Nacional que establece entre las fuentes de ingreso municipal "los derechos sobre extracción de madera, explotación y tala de bosques"21. El Régimen Municipal desarrollado en la Ley 106 de 1973 establece en su Artículo 3 que los Municipios deben cumplir y hacer cumplir la Constitución, las leyes y demás normas vigentes. En su Artículo 18.1 se estipula que el Consejo Municipal tiene entre sus funciones defender y fomentar la riqueza forestal. Esto implica que podrían apoyar a la ANAM en las funciones de control, fiscalización y supervisión; lo cual no ocurre en la práctica, pues únicamente se limitan al cobro de la tasa municipal.

Otras disposiciones facultan a los municipios, a través de los alcaldes o los consejos municipales, para aprobar planes de ordenamiento ambiental territorial en sus respectivas jurisdicciones, así como los planes de desarrollo urbano del municipio e incluso, la Ley General de Ambiente reconoce que los municipios pueden crear áreas protegidas, lo cual les permitiría influir en cierta medida en la ordenación de los bosques en su respectivo distrito. Sin embargo, la gestión o manejo forestal sostenible como tal no es una función que esté descentralizada hacia las localidades, permaneciendo como responsabilidad de la ANAM.

El Ministerio de Desarrollo Agropecuario (MIDA) tiene competencias en materia forestal solamente para los trámites de exportación, ya que debe expedir un certificado fitosanitario a través de la Dirección de Sanidad Vegetal que refrenda el estado fitosanitario del material, diseñado de acuerdo con el modelo de certificado de la Convención Internacional de Protección Fitosanitaria (IPPC), así como verificar, cumplir y hacer cumplir las normas NIMF-15 sobre embalaje de madera para la exportación y la importación, y los tratamientos que se le dé a la madera en establecimientos ubicados en Panamá.

El peso de la responsabilidad por la conservación, manejo y aprovechamiento sostenible de los bosques y los recursos forestales recae principalmente en la ANAM, que tiene la última palabra o el puesto más alto en jerarquía para la gestión forestal en el país. De forma simple, si la ANAM no da los permisos, no certifica y no prepara los informes técnicos, ninguna otra entidad puede hacerlo, porque no está facultada legalmente. Además, para el comercio exterior, si algún funcionario de aduanas omite algún paso, trámite o certificación que le corresponda a la ANAM, estaría incurriendo en una falta administrativa y posiblemente en un delito contra el ambiente. Cualquier actividad de tala, socuela, desbroce, transporte, procesamiento y comercialización de la madera en Panamá debe estar aprobada por la ANAM; de lo contrario, sería ilegal (ver Cuadro $\left.N^{\circ} 4\right)$.

21. Es evidente que los Municipios deben garantizar el cumplimiento de la Constitución y las leyes, lo que se desprende de la Constitución Nacional en su Artículo 119 cuando señala que todos tenemos el deber de propiciar un desarrollo social y económico que prevenga la contaminación del ambiente, mantenga el equilibrio ecológico y evite la destrucción de los ecosistemas. En concordancia con la Ley 41 de 1998, que en su Artículo 117 reconoce que los municipios pueden interponer acciones judiciales cuyo objeto sea la defensa del derecho a un ambiente sano. 


\subsection{Comercio internacional de madera}

El Ministerio de Economía y Finanzas de la República de Panamá ha desarrollado e implantado el sistema informático denominado Sistema Integrado de Comercio Exterior (SICE) con el fin de mejorar y facilitar sistemas para el comercio exterior. El país también cuenta con la Autoridad Nacional de Aduanas (ANA), concebida "como un sistema facilitador del intercambio comercial, flexible en sus controles y con énfasis en el desarrollo de las importaciones y exportaciones"22.

Se exige la declaración de exportación, documento que debe indicar información sobre la mercancía en cuanto a naturaleza, origen, cantidad, estado, calidad, valor y partida arancelaria. Con base en esta declaración se aplican los regímenes aduaneros correspondientes y los derechos e impuestos que correspondan.

Para el caso de la exportación de madera o productos provenientes del aprovechamiento forestal de bosques naturales, se requiere presentar ante Aduanas la "licencia previa", es decir, todos aquellos documentos que la autoridad competente (órgano anuente) extienda para certificar que el producto o mercancía es legal y cumple con las disposiciones normativas sectoriales del régimen forestal vigente en Panamá. La ANAM emite una guía de exportación. La madera está considerada como producto que requiere trámite especial, con base en el Decreto Ejecutivo 83 del 2008², en el Convenio Internacional de Maderas Tropicales ratificado por Panamá por Ley 58 del $2007^{24}$ y en la Ley 23 de 1997 del Acuerdo de Marrakech ${ }^{25}$ sobre piezas de madera que se obtienen con diferentes métodos industriales del bosque.

Para el comercio internacional de madera de bosques naturales solo podrán exportarse piezas de madera provenientes de bosque natural cuando se trate de producto terminado de madera, sea por transformación y procesado de forma que esté listo para ser usado y no requiera otra transformación.

De acuerdo con el Artículo 6 del Decreto Ejecutivo 83 del 2008, queda prohibida la exportación de madera en trozas, tucas, rollos, bloques, aserrado o simplemente cepillada de cualquier especie procedente de los bosques naturales que no cumplan con las características que especifica el decreto.

22. Decreto Ley 1 del 2008, del 13 de febrero, Gaceta Oficial № 25.984 publicada el 22 de febrero de 2008, por el cual se crea la Autoridad Nacional de Aduanas y se dictan disposiciones sobre el Régimen Aduanero en la República de Panamá.

23. Decreto Ejecutivo 83 del 2008 , del 10 de julio de 2008, Gaceta Oficial $N^{\circ} 26.099$ publicada el 6 de agosto de 2008, que regula la exportación de madera proveniente de bosque natural o extraída de embalses.

24. Ley 58 del 2007, del 21 de diciembre de 2007, Gaceta Oficial № 25,948 publicada el 27 de diciembre de 2007, que aprueba el Convenio Internacional de las Maderas Tropicales del 2006, adoptado en Ginebra, Suiza. Entre los objetivos principales del Convenio están "proporcionar un marco eficaz para la cooperación y consultas" entre países "productores" y "consumidores", en relación con la expansión y diversificación del comercio mundial, "fomentar la investigación", "mejorar la ordenación forestal" y la "utilización de madera" y resaltamos el objetivo de "fomentar el desarrollo de políticas nacionales encaminadas a la utilización sostenible y la conservación de los bosques tropicales y sus recursos genéticos y al mantenimiento del equilibrio ecológico de las regiones interesadas".

25. Ley 23 de 1997, del 15 de julio de 1997, Gaceta Oficial № 23.340 publicada el 26 de julio de 1997, por la cual se aprueba el Acuerdo de Marrakech, constitutivo de la Organización Mundial del Comercio, el Protocolo de Adhesión de Panamá a dicho Acuerdo junto con sus anexos y lista de compromisos y se adecua la legislación interna. 
La guía de exportación que emite la ANAM es indispensable para que cualesquiera otras autoridades competentes en la hoja de ruta para el comercio internacional, como Aduanas, pueda proceder con el trámite de exportación. La ANAM es la entidad responsable de verificar el cumplimiento normativo antes de emitir la "licencia previa" (órgano anuente), que sería la guía de exportación. Estos datos se incorporan al documento de declaración registrada y deben ser verificados documental y físicamente. La ANAM de forma coordinada con la ANA tiene entre sus competencias fiscalizar y dar seguimiento al producto descrito en las guías de transporte forestal otorgadas por la exportación de productos y subproductos forestales ${ }^{26}$.

Otra norma importante que debe ser tomada en cuenta para el comercio internacional de madera es la relacionada con el comercio de especies amenazadas o en vías de extinción. Panamá ratificó la Convención sobre el Comercio Internacional de Especies Amenazadas de Fauna y Flora Silvestres (CITES) mediante Ley 14 de $1977^{27}$, por lo que todas las especies de árboles incluidos en alguno de los apéndices (I, II y III) de CITES para exportarse deben contar con un permiso de exportación expedido por la ANAM, que tiene que incluir el nombre común, científico, cantidad, nombre y dirección completa del destinatario y del país de origen (en este caso, Panamá) ${ }^{28}$.

Es clave para los exportadores conocer que si alguna especie forestal que está siendo exportada como producto o subproducto está incluida en alguno de los apéndices del CITES, además del permiso de exportación CITES que otorga la ANAM, también requiere un sello oficial con la firma respectiva de la oficina de la ANAM ubicada en los controles de salida. Este sello oficial es requerido por las agencias de aduanas en el país de destino ${ }^{29}$ (ver Gráfica Nㅜㄱ).

La Ley Forestal, a través de su Reglamento (Resolución 05 de 1998), también establece que "los permisos, contratos o autorizaciones de aprovechamiento forestal no otorgan a los beneficiarios derechos de aprovechamiento de especies declaradas en vías de extinción, con poblaciones muy reducidas o pertenecientes a ecosistemas exclusivos". La ANAM debe ajustarse a los convenios internacionales de especies en peligro y por ende, los permisos, contratos o autorizaciones deberán contener las restricciones respectivas, incluyendo las especies a las que se les fije un volumen máximo de corta anual (Art. 31).

26. Decreto Ejecutivo 83 del 2008, Art. 10.

27. Ley 14 de 1977, del 28 de octubre de 1977, Gaceta Oficial № 18.506 publicada el 27 de enero de 1978, por la cual se aprueba la Convención sobre el Comercio Internacional de Especies Amenazadas de Fauna y Flora Silvestre. Entró a regir en Panamá el 19 de noviembre de 1978.

28. La Autoridad Nacional del Ambiente, mediante Resolución 0051-2008 del 2008, del 22 de enero de 2008, Gaceta Oficial № 26.013 del 7 de abril de 2008, estableció el Listado de Especies Amenazadas de Panamá, las cuales requieren medidas específicas de protección. Adicionalmente en su Artículo 4 determina que Panamá acoge los criterios utilizados por la Unión Internacional para la Conservación de la Naturaleza (UICN) y por la Convención para clasificar las especies, subespecies o poblaciones. En concordancia con el cumplimiento del Convenio sobre la Diversidad Biológica, adoptado en la Conferencia Mundial sobre Medio Ambiente y Desarrollo, Río de Janeiro, Brasil, 1992, ratificada por Panamá mediante Ley 2 de 1995, del 12 de enero de 1995, Gaceta Oficial N²2.704 publicada el 17 de enero de 1995.

29. El Manual Operativo Binacional para el Control del Comercio y Tráfico de Fauna y Flora Silvestres entre las Repúblicas de Panamá y Costa Rica detalla cómo opera el procedimiento para las especies de la vida silvestre que, aunque no aplica para las especies forestales (árboles maderables), sirven de referencia. [pdf online]. <http://www.ucipfg.com/Repositorio/ELAP/cites_s/recursos/crpa.pdf >. Accedido el 4 de diciembre de 2013. 
Inclusive, tratándose de permisos de subsistencia o domésticos, la ANAM antes de emitir el permiso de tala inspecciona el árbol que se solicita para aprovechar, con lo cual hay en la normativa vigente herramientas de control previo y control posterior para verificar que se hayan cumplido todos los requisitos y herramientas para el aprovechamiento forestal sostenible, incluyendo la especie, el volumen y el lugar exacto donde se realizará la tala y adónde se transportará y a qué fin se destinará, lo cual permite controlar el aprovechamiento de especies con algún nivel de protección a nivel nacional o incluida en algún apéndice del CITES.

EI MIDA por su parte debe emitir la licencia o certificado fitosanitario para productos manufacturados de origen agropecuario principalmente si lo exige el país de destino. Esta certificación la emite el funcionario del MIDA (Cuarentena) que trabaja en la Ventanilla Única.

Otro aspecto importante a considerar en el comercio internacional de madera es el cumplimiento de las normas internacionales para medidas fitosanitarias relacionadas con el embalaje. Panamá aprobó la Convención Internacional de Protección Fitosanitaria (CIPF) con la Ley 9 de 1992 y la Ley 46 del $2006^{30}$. El MIDA es la entidad competente para establecer las medidas fitosanitarias de prevención a través de la Dirección Nacional de Sanidad Vegetal. Se debe aplicar la normativa NIMF-15 relacionada con el tratamiento de los embalajes de madera, lo que implica que para el comercio internacional de madera el MIDA tiene también que certificar que el embalaje de madera cumple con las disposiciones; es decir, es otra "licencia previa" que se verifica para iniciar los trámites en Aduanas. El Resuelto N DAL-006-ADM-2005 ${ }^{31}$ del MIDA incorpora las directrices que reglamentan el embalaje de madera utilizado en el comercio internacional para minimizar los riegos de introducción y diseminación de plagas asociadas con el embalaje fabricado de madera en bruto de coníferas y no coníferas.

Las medidas son de obligatorio cumplimiento con el fin de minimizar las amenazas para los árboles vivos por riesgos de plagas. La norma aplica para exportación e importación y su incumplimiento acarrea sanciones y medidas contra los productos o subproductos relacionados.

La Ley Forestal de Panamá y normas concordantes, como la Ley General de Ambiente, en relación con el comercio internacional de madera, frente a las exigencias de mercados importantes como Estados Unidos que aplica su Lacey Act desde el 2008 a productos y subproductos forestales, y frente a la Unión Europea y su Plan de Acción sobre aplicación de leyes, gobernanza y comercio forestales (conocido por sus siglas FLEGT ${ }^{32}$, que entró en vigor en marzo del presente año), ya contiene disposiciones que son fundamentales, como la exigencia de identificar y delimitar los bosques existentes en el país, inventariar las especies, exigir para cada trámite de aprovechamiento forestal un inventario forestal, un marcado de árboles para localizar la ubicación exacta, un plan de manejo forestal y para proyectos de más de 50 hectáreas, un estudio de impacto ambiental,

30. Ley 9 de 1992, del 8 de junio de 1992, Gaceta Oficial $N^{\circ} 22.057$ publicada el 16 de junio de 1992. Ley 46 del 2006, del 27 de noviembre de 2006, Gaceta Oficial 25,684 publicada el 4 de diciembre de 2006.

31. Resuelto $N^{\circ}$ DAL-006-ADM-05, de 17 de enero de 2005, Gaceta Oficial № 25.239 publicada el 17 de febrero de 2005, reglamentación sobre NIMF-15. La Convención Internacional de Protección Fitosanitaria (CIPF) aprobó en el año 2002 la nueva norma internacional para materiales de madera para empaque "Directrices para reglamentar el embalaje de madera utilizado en el comercio internacional".

32. FLEGT, Unión Europea, norma completa. [documento online]. <http://eur-lex.europa.eu/LexUriServ/ LexUriServ.do?uri=CELEX:32010R0995:EN:NOT>. Accedido el 4 de diciembre de 2013. 
además de una marquilla o marca para cada pieza extraída o "cosechada" y guía de transporte, entre otras, que facilitan -siempre y cuando se cumplan a cabalidad- conocer el origen de un producto o subproducto forestal y por lo tanto, si es legal o ilegal. Las piezas legales para un sistema de control, supervisión y fiscalización están, pero se requiere voluntad política para conectarlas y hacerlas funcionar armónica y eficazmente.

Frente al Lacey Act, las normas vigentes son suficientes para la trazabilidad siempre que se cumplan en su totalidad ${ }^{33}$. Con relación al FLEGT de la Unión Europea, se recomienda que Panamá negocie un acuerdo voluntario y cumplir con las exigencias establecidas para obtener una licencia específica que, básicamente, verifica que el marco normativo, institucional y de políticas garantiza el aprovechamiento forestal sostenible y reduce las posibilidades de ilegalidad"34. "Solo se considera legal la madera con licencia FLEGT procedente de un país que tenga un Acuerdo Voluntario de Asociación (AVA) con la UE y cuyo sistema de garantía de la legalidad de la madera haya sido declarado funcional. La CITES permite que la exportación de madera incluida en los anexos A, B o C del Reglamento CITES sea aceptada como prueba de legalidad"35.

33. Panamá ha sufrido restricciones en mercados internacionales para la exportación de recursos naturales, caso de los camarones en el año 2004 por detectarse que no se cumplía en el país con la debida implementación de la medida de conservación conocida como dispositivo excluidor de tortugas (DET) que deben portar y utilizar los barcos camaroneros. Berrocal, R. 'EU restringe importaciones de camarones panameños'. La Prensa [periódico online], (24 de diciembre de 2004). <http://mensual.prensa.com/ mensual/contenido/2004/12/24/hoy/portada/94789.html>. Accedido el 4 de diciembre de 2013.

34. Panamá ha sufrido restricciones al comercio exterior con productos de la pesca al ser investigada e incluida en la lista de terceros países no cooperantes contra la pesca ilegal, no declarada y no reglamentada (INDNR) con base en el Reglamento 1005/2008 de la Comisión Europea, por lo que en el 2010 no se pudieron exportar productos pesqueros a la Unión Europea. El proceso se ha mantenido hasta el presente año cuando nuevamente se propuso que Panamá se incluyera en la lista de terceros países no cooperantes contra la pesca INDNR (o pesca IUU, por sus siglas en inglés). Panamá debe asegurar que cuenta y cumple con las políticas y normativas internas de conservación de espacios marinos y prevención, reducción de la pesca ilegal. Cuando no cumple, la Unión Europea puede restringir no solo el comercio como exportación de una especie en particular, sino todas las pesquerías e inclusive, otros bienes que considere, con el fin de castigar ejemplarmente la pesca IUU. Igual es el escenario con Estados Unidos en materia de pesca IUU. European Commission. 'Commission Decision of 15 November 2012 on notifying the third countries that the Commission considers as possible of being identified as non-cooperating third countries pursuant to Council Regulation (EC) № 1005/2008 establishing a Community system to prevent, deter and eliminate illegal, unreported and unregulated fishing'. [pdf online]. <http://eur-lex.europa.eu/ LexUriServ/LexUriServ.do?uri=OJ:C:2012:354:0001:0047:EN:PDF>. Accedido el 4 de diciembre de 2013.

35. FLEGT, Unión Europea. Preguntas frecuentes para due dilligence. [documento online]. <http://www. euflegt.efi.int/files/attachments/euflegt/publications_2013/eutr_faqs_due_diligence_es_1303_v3_rcv.pdf>. Accedido el 4 de diciembre de 2013. 


\subsection{Aprovechamiento forestal sostenible - Estrategia Nacional de Reducción de Emisiones por Deforestación y Degradación de Bosques (REDD+) / Mecanismos legales}

La ANAM, en junio de 2009, estableció su estrategia de Reducción de Emisiones Provenientes de la Deforestación y Degradación de Bosques (REDD+, por sus siglas en inglés), siendo el primer país a nivel mundial con una estrategia REDD+ aprobada por el Banco Mundial y las Naciones Unidas ${ }^{36}$.

REDD+ actualmente se desarrolla en instrumentos de políticas públicas no en la forma de normativas o regulaciones expresamente creadas para ella, sino a través de la creación de una mesa nacional REDD+, conformada por submesas para identificar y desarrollar -de forma concertada y multisectorial- acciones tempranas y proyectos pilotos, aspectos sociales, económicos relevantes, medición, reporte y verificación, comunicación y capacitación, y aspectos legales y arreglos institucionales, lo que denominan salvaguardas para promover el mecanismo REDD+ con el fin de reducir emisiones de forma sostenible.

Como mecanismos legales, REDD+ debe conjugarse con los criterios jurídicos existentes sobre propiedad de la tierra, siendo en Panamá reconocidos los territorios indígenas en comarcas y propiedad colectiva, territorios en régimen de propiedad privada (existiendo inclusive la figura de reservas naturales privadas en la Ley 41 de 1998, Artículo 67) y tierras del Estado en régimen de áreas protegidas (es clave tomar en consideración la situación tenencial dentro de áreas protegidas).

Desde el punto de vista legal, Panamá requiere introducir innovaciones en el marco normativo para desarrollar y regular todo lo relacionado con los sumideros de carbono y captura, entre otros, así como establecer el procedimiento para aplicar a REDD+ cuando se trate de un área protegida o una propiedad privada, y los protocolos de coordinación previa con las comarcas indígenas y tierras colectivas, aunque en relación con las comarcas indígenas ya la normativa que les es aplicable por razón de sus comarcas y jurisdicción sobre las tierras colectivas (tierras pobladas por indígenas, pero que quedaron fuera de las comarcas) les da la prerrogativa o reconoce su derecho de dar consentimiento previo, libre e informado ${ }^{37}$.

Panamá es signataria de la Convención Marco de las Naciones Unidas sobre el Cambio Climático, Ley 10 de $1995^{38}$ y ratificó el Protocolo de Kioto en el año 1998, a través de la Ley $88^{39}$. La ANAM ha trabajado en los últimos años en mecanismos de reducción de emisiones a través de los créditos de

36. ANAM (2009). Estrategia de Reducción de Emisiones Provenientes de la Deforestación y Degradación de Bosques de la República de Panamá aprobada por el Banco Mundial y Naciones Unidas. [documento online]. <http://www.anam.gob.pa/images/stories/documentos_pdf/Estrategia_de_REDD-Panama.pdf>. Accedido el 4 de diciembre de 2013.

37. A nivel de jurisprudencia existe un precedente importante, Fallo Hidroeléctrica Tabasará II por la Corte Suprema de Justicia, Sala Tercera, que "suspendió provisionalmente los efectos de la Resolución $\mathrm{N}^{\circ}$ 1A-04-80-2000 de 1 de febrero de 2000, dictada por la ANAM con la finalidad de evitar que el Ente Regulador autorizará la Concesión y se iniciarán los trabajos despojando a los indígenas de sus tierras e inundando las mismas, sin mediar el consentimiento de ellos". Puede accederse a la decisión de suspensión ingresando el nombre Tabasará en el siguiente enlace: Centro de Documentación Judicial. [sitio web]. $<$ http://bd.organojudicial.gob.pa/registro.html>.

38. Ley 10 de 1995, del 12 de abril de 1995, Gaceta Oficial № 22.763 publicada el 17 de abril de 1995.

39. Ley 88 de 1998, del 30 de noviembre de 1998, Gaceta Oficial №23.703 publicada el 31 de diciembre de 1998. 
carbono. En el año 2007 se aprobó la Política Nacional de Cambio Climático por Decreto Ejecutivo 35 del 2007 y en el año 2011 se estableció el procedimiento de aprobación nacional de proyectos de reducción de emisiones de gases de efecto invernadero que optan al mecanismo de desarrollo limpio (Resolución 155 del 2011) ${ }^{40}$.

Para los proyectos forestales relacionados con mecanismos de desarrollo limpio se debe presentar siempre copia de la resolución que aprueba el plan de reforestación y el plan de manejo forestal, así como copia de la resolución que aprobó el estudio de impacto ambiental -proyectos de más de 50 hectáreas- (Art. 3.e y 3.f de la Resolución 155 del 2011).

Adicionalmente, la figura del regente forestal recientemente aprobada mediante Resolución 05 del 2013 establece que este profesional idóneo será responsable de firmar los informes de monitoreo y cumplimiento no solo de los planes de manejo, sino de la reducción de la deforestación y la degradación de los bosques, así como informes del aumento de reservas de carbono en los bosques y en las plantaciones, siendo una de las primeras normas que de alguna forma se vincula con REDD+.

\subsection{Análisis de conflictos usos de la tierra vs. bosques}

Los análisis de la ANAM, todos publicados en los distintos informes oficiales sobre el estado del ambiente en Panamá 1999, 2004, 2009, así como incluidos en documentos como la Estrategia Nacional de Ambiente, entre otros, han concluido que desde "décadas pasadas" los programas de desarrollo estuvieron dirigidos a "conquistar" los bosques.

En el año 2009 se mantenían las mismas conclusiones, aunque se reconocía un leve incremento de la cobertura boscosa debido a la reforestación y la recuperación de bosques secundarios. Sin embargo, se ponía el foco de atención al conflicto de usos de la tierra y deforestación de masas boscosas generado por la política de titulación masiva del gobierno, ejecutada por la Autoridad Nacional de Tierras (ANATI) [ver títulos de propiedad generados por provincia desde 1999 a 2004] (tomado de Informe del Estado del Medio Ambiente de Panamá 2004, cuadro 47) [ver Cuadro N 5].

No obstante lo anterior, el análisis de las normas arroja como resultado que las disposiciones jurídicas fueron claras en establecer un sistema integrado de manejo de suelos con base en sus características y aptitudes para distintas actividades humanas.

La ANATI fue creada mediante Ley 59 del 2010, del 8 de septiembre de 2010, Gaceta Oficial $\mathrm{N}^{\circ}$ 26.638-A publicada el 8 de octubre de 2010. La ley incorpora elementos de mayor eficiencia en el uso del suelo, tales como asegurar cumplimiento del marco jurídico en materia ambiental, la Comisión Nacional de Límites para delimitar áreas de acuerdo con el uso del suelo más eficiente y apoyo para delimitar áreas protegidas, comarcas indígenas y procesos de ordenamiento territorial.

Se crea el Consejo Nacional de Tierras con la responsabilidad de aportar información básica para investigar, planificar y ejecutar. Otro elemento importante que dispone esta ley es el inventario de

40. Decreto Ejecutivo 35 del 2007, del 26 de febrero de 2007, Gaceta Oficial N²5.764 publicada el 4 de abril de 2007, Política Nacional de Cambio Climático. Resolución 155 del 2011, del 5 de abril de 2011, Gaceta Oficial No26.773-B publicada el 27 de abril de 2011. 
derechos posesorios que hayan sido reconocidos por las autoridades locales o nacionales con anterioridad, así como el Sistema de Información Geográfica y de la Información Catastral.

Para la titulación debe darse una previa declaración de área o zona objeto del programa de titulación. La reglamentación de la Ley 24 del 2006, a través del Decreto Ejecutivo 228 del 2006, del 27 de septiembre de 2006, Gaceta Oficial № 25.641 publicada el 28 de septiembre de 2006, estableció en su Artículo 7 que dentro de las "áreas protegidas o donde existan reductos boscosos, tierras de aptitud preferentemente forestal (...) definida previamente por la autoridad competente" se adjudicará con el concepto favorable de la ANAM que, además, puede establecer condiciones propias al caso concreto. Esto se encuentra en concordancia con la Ley 41 de 1998, General de Ambiente, que en su Artículo 74 establece expresamente que "la tala rasa o deforestación de bosques naturales no se considerará como elemento probatorio por la autoridad competente, para solicitar el reconocimiento del derecho de posesión o titulación de tierras". Igualmente, la Resolución 05-1998 de 1998 que reglamenta la Ley Forestal en su Artículo 14 reafirma que la deforestación no constituye elemento probatorio para adquirir derechos posesorios o títulos de propiedad. La Ley 1 de 1994, Artículo 31, establece que la ANAM debe hacer un avalúo y dar su opinión favorable previo a ninguna adjudicación. El Artículo 5.9 de la Ley 59 del 2010, que crea la ANATI, también es claro al definir la función social de la tierra como la "utilización de tierras para usos ambientales", entre otros.

El Código Agrario, por su parte, estipuló cuáles tierras estatales están sujetas a los fines de la Reforma Agraria (Art. 26) y cuáles no, como por ejemplo las zonas de reserva forestal (Art. 27.3). Reconoce que "todas las personas (...) que tuvieran tierras en propiedad tienen derecho a su uso, goce y disposición plena, con las limitaciones que impone la función social de la tierra (...)”. Esta norma debe ser estudiada e implementada en concordancia con las normas citadas de la ANATI, Ley Forestal, Ley General de Ambiente y con el propio Código que consideró las reservas forestales fuera del alcance de la Reforma Agraria, siendo estas reservas de interés social y de utilidad pública para la conservación, mejoramiento y repoblación de todos los bosques existentes en Panamá, porque controlan la erosión de los suelos (función social), conservan e incrementan la riqueza forestal (función social), evitan el uso irracional y protegen las fuentes de agua (función social).

Adicional a lo anterior, el Código Agrario clasificó la conservación forestal (i) protectora de agua o de cuencas hidrográficas y señala que "la propiedad dedicada a estos fines se considerará para los efectos fiscales como terrenos cultivados" (Arts. 444.1 y 445), es decir, se les consideraba para aplicar a incentivos; (ii) área forestal para prevenir la erosión; (iii) área forestal de recreo, vida silvestre y belleza escénica; (iv) área forestal de explotación forestal permanente para producir madera y permitir la renovación de los recursos forestales, es decir, implica un aprovechamiento forestal sostenible; (v) área forestal desmontable para expansión agrícola y ganadera, que sean "zonas mejor adaptadas" para actividades agrícolas y ganaderas; (vi) áreas reforestadas. Reiteramos que el Artículo 5.9 de la Ley 59 del 2010, que crea la ANATI, definió la función social de la tierra como la "utilización de tierras para usos ambientales", entre otros.

Anterior a esta norma del 2010, la primera Ley Forestal del año 1966 establecía la obligatoriedad para el Estado de clasificar las tierras y los suelos, dependiendo de su vocación o aptitud. De esta forma, ya desde entonces las tierras forestales podían ser clasificadas como no convenientes para la agricultura o ganadería. La Reforma Agraria precisamente incluyó entre sus objetivos la conservación de los recursos naturales y el uso racional. 
Esto demuestra de forma objetiva que los conflictos de usos de la tierra en detrimento de los bosques no es una causa directa por la no existencia de políticas o a la formulación de políticas que estimulaban el cambio de uso de suelo de forma drástica y descontrolada, sino a la no aplicación eficiente y efectiva del marco de políticas y normas existentes para la conservación y aprovechamiento sostenible de los bosques y los suelos. Las normas forestales o relacionadas con el sector forestal han ido propagándose sin mecanismos para su cumplimiento eficaz ${ }^{41}$, sin fortalecer las capacidades para la aplicación y cumplimiento. Por el contrario, se ha reforzado a lo largo de los años la poca credibilidad de los requisitos ambientales en el marco del aprovechamiento forestal sostenible. También se ha fallado en la puesta en acción de mecanismos para empujar que los actores prefieran cumplir las normas antes que infringirlas.

\subsection{Análisis del marco jurídico para promover la distribución justa y equitativa de los beneficios del aprovechamiento forestal sostenible (cadena de custodia productos forestales)}

Panamá ratificó el Convenio Regional para el Manejo y Conservación de los Ecosistemas Naturales, Forestales y el Desarrollo de Plantaciones Forestales mediante la Ley 14 de $1995^{42}$ en el marco del Sistema de Integración Centroamericana (SICA).

La Ley 1 de 1994 establece que las poblaciones indígenas que generen ingresos con el aprovechamiento forestal sostenible, previo permiso otorgado por la ANAM, como autoridad competente, con la autorización previa también de las autoridades máximas de los indígenas según sea el caso-, deben utilizar estos ingresos de forma exclusiva para atender las necesidades de la comunidad. La comunidad indígena es la responsable de ejecutar todas las actividades de aprovechamiento y manejo forestal.

La norma no hace referencia en estos términos a otros grupos étnicos como poblaciones afro o campesinas, aunque sí establece un permiso especial para aprovechamiento forestal sostenible para grupos organizados. Este permiso no está desarrollado para beneficio total de las propias comunidades no indígenas que habitan las zonas boscosas en la Provincia de Darién.

Panamá no ha ratificado el Convenio 169 de la Organización Internacional del Trabajo (OIT) ${ }^{43}$.

41. Entendiendo el cumplimiento eficaz como la implementación total de los requisitos y el logro de los cambios deseados.

42. Ley 14 de 1995, del 21 de abril de 1995. Gaceta Oficial N²2.769 publicada el 25 de abril de 1995. El Convenio fue firmado en Guatemala el 29 de octubre de 1993.

43. Se adoptó en el año 1989 el Convenio 169 sobre Pueblos Indígenas y Tribales en Países Independientes, y entró en vigor en 1991. Es el acuerdo internacional de derecho indígena más conocido en el mundo. Se reconoce este convenio como vinculante para los países firmantes y que lo han ratificado. Panamá no ha firmado este tratado. 
El Plan Nacional de Desarrollo Forestal, que establece un Modelo Forestal Sostenible (MFS) ${ }^{44}$, promociona la generación de beneficios para la población y busca asegurar "la equidad en el acceso a los beneficios generados por los bienes y servicios ambientales", con el fin de "mejorar la calidad de vida de las comunidades rurales" 45 .

El MFS incluye a los grupos indígenas y campesinos como beneficiarios de las capacitaciones técnicas y gerenciales para el manejo del bosque, recolectar semillas, fibras, plantas medicinales y establecer viveros. También incorpora la importancia de generar incentivos para los propietarios que de esta forma deben ser considerados también beneficiarios.

44. ANAM (2008). Plan Nacional de Desarrollo Forestal: Modelo Forestal Sostenible, Pág. 8. El Plan, que fue aprobado por Decreto Ejecutivo 37 del 2009, del 3 de junio de 2009, Gaceta Oficial No 23.302 del 12 de junio de 2009, valida la Política Nacional Forestal, sus principios, objetivos y líneas de acción, la cual se basa en antecedentes, principios, objetivos y líneas de acción para una gestión integrada de los recursos forestales, que propicia un aprovechamiento sostenible, compatibilizando los diferentes usos y la conservación para el desarrollo sostenible del país. Los principios de la Política son: (i) Principio de Valoración, que reconoce el recurso forestal como un bien económico para lo que se requiere un "comportamiento ecológicamente responsable en el uso racional" de estos, (ii) Principio de Manejo Sostenible, (iii) Principio de Multifuncionalidad para la seguridad ambiental, alimentaria, (iv) Principio de Competitividad, (v) Principio de Compensación Ecológica, (vi) Principio de Integración: dentro de la estrategia nacional de desarrollo, promoviendo la participación ciudadana, equidad de género y favoreciendo las zonas rurales, (vii) Principio de Sustentabilidad Ambiental, (viii) Principio de Acceso a la Información, (ix) Principio de Sensibilización, (x) Principio de Participación, (xi) Principio de Coherencia, correlación de políticas, (xii) Principio de Equidad (en concordancia con el Régimen Ecológico de la Constitución Nacional), (xiii) Principio de Coordinación.

45. ibid. Pág. 9. 


\section{Análisis de los estándares de legalidad}

La legislación forestal vigente, Ley 1 de 1994, incorporó el uso de marquillas para marcar los árboles aprovechados con permisos de acuerdo con los procedimientos legales. Ya desde 1966 la norma exigía las guías forestales para todo aquel que se dedicara al transporte y comercio de las maderas y otros productos forestales. De igual forma, se creó desde entonces la obligatoriedad de registrarse para cualquier persona que se dedicara a la explotación, transporte, industrialización o comercio de productos forestales.

La Resolución 244 del $2011^{46}$, en cumplimiento del mandato de la Ley 1 de 1994 y de la Resolución 05 de 1998, regula la inscripción de la marquilla con la que todos los beneficiarios de permisos, concesiones forestales u otras autorizaciones forestales deben marcar la madera que extraen "antes de su movilización". Según la Ley Forestal, "toda madera que no esté marcada será retenida y se aplicará una multa", además de otras sanciones que puedan corresponder. Esto no se aplica en la práctica.

La ANAM debe aplicar los códigos y procedimientos para registrar las marquillas para el marcado de la madera procedente de bosques naturales, previo a su movilización. La información que debe contener la marquilla tiene que ser dada por la ANAM. La vigencia de esta es igual a la del permiso de aprovechamiento forestal otorgado. El costo de la marquilla debe ser financiado por el usuario, quien es responsable de su uso.

Las marquillas podrán ser placas de metal, pintura de aceite o atomizador resistente al agua, marcadores de madera, mazo o ferrete. Todos los que obtengan permiso comunitario, concesión forestal, permiso a grupo organizado, permisos especiales, permiso en finca privada, permiso de regeneración natural manejada, permiso de tala necesaria, permiso para proyecto de desarrollo, permiso de madera deberán contar con su respectiva marquilla. El tamaño y la nomenclatura de las marquillas dependiendo del tipo de permiso están definidos en la norma ${ }^{47}$. El uso indebido de la marquilla puede ser sancionado con multa, retenciones y la anulación del permiso de aprovechamiento forestal.

La marquilla, las guías de transporte forestal y el registro forestal son clave para la cadena de custodia y un sistema de trazabilidad de la madera. Esta norma no se cumple en la práctica ${ }^{48}$.

46. Resolución 244 del 2011, del 21 de abril de 2011, Gaceta Oficial № 26.774-B publicada el 28 de abril de 2011, que permite el registro de una marquilla para la madera procedente de bosques naturales que va a ser movilizada o transportada en el territorio nacional ante la ANAM. Entró a regir el 5 de julio de 2011.

47. ibid. Arts. 1, 2, 3, 4.

48. "En el Darién la ANAM no exige que los beneficiarios de permisos forestales registren su marquilla forestal, que señalen con su marquilla las tucas o bloques que provengan de su territorio y tampoco exige que todo transporte en el interior del Darién esté sustentado en guías forestales de movilización. Con esto se permite que cualquier sitio o puerto sean patios de carga y descarga de madera, así como el libre tránsito de madera por todo el Darién sin marquilla forestal y sin guías de transporte". Pág. 3 de Estrategia institucional para la prevención y control de la tala ilegal en los bosques de Darién en Panamá, citado en nota al pie № 65. 


\subsection{Análisis de vacíos y conflictos de aplicabilidad de la legislación forestal. Caso de comarcas indígenas}

Desde la Constitución Nacional se reconoce en Panamá las comarcas indígenas, en su Artículo 5, cuando señala que Panamá podrá crear otras divisiones políticas; en su Artículo 147 cuando las incorpora al régimen legislativo en el cual deben elegir la cantidad de diputados y al tomarlas en cuenta en caso de hacerse una asamblea constituyente (Artículo 314).

Adicionalmente, el Artículo 90 de la Constitución establece que el Estado panameño reconoce y respeta la identidad étnica de las comunidades indígenas nacionales, y promoverá su desarrollo integral. En el Régimen Agrario reconoce que el Estado dará especial atención a las comunidades indígenas para promover su participación económica, social y política en la vida nacional (Art. 124). En el Artículo 127 se ordena al Estado garantizar a las comunidades indígenas la reserva de las tierras necesarias y la propiedad colectiva de estas para el logro de su bienestar económico y social, y prohíbe la apropiación privada dentro de las tierras asignadas o reconocidas a los grupos indígenas. La ley regulará los procedimientos para lograrlo.

La Ley General de Ambiente, Ley 41 de 1998, incluyó un título completo al tema de los recursos naturales y las comunidades indígenas. El Artículo 97 establece que el Estado respetará, preservará y mantendrá los conocimientos, las innovaciones y las prácticas de las comunidades indígenas y locales relacionados con la conservación y uso sostenible de la diversidad biológica, y promoverá no solo su aplicación, sino la participación de las comunidades indígenas y fomentará que los beneficios derivados se compartan con estas equitativamente.

Los Artículos 99 y 100 de la Ley General de Ambiente establecen que de ninguna forma las actividades de aprovechamiento de los recursos naturales en comarcas o pueblos indígenas pueden causar daño o menoscabo a su integridad cultural, social, económica y de valores espirituales.

En relación con los procedimientos de consulta con comunidades indígenas para realizar actividades, obras o proyectos en su territorio, dichos procedimientos deben estar orientados a establecer acuerdos sobre derechos, costumbres y beneficios compensatorios (Art. 103). Aunado a esto, la ley ordena dar prioridad a los proyectos de aprovechamiento de recursos naturales presentados por los propios indígenas "siempre y cuando cumplan con los requisitos y procedimientos exigidos por la autoridad competente" (Art. 104)

Las comunidades indígenas tienen derecho a una participación de los beneficios económicos que puedan derivarse de actividades de aprovechamiento de recursos naturales dentro de comarcas indígenas siempre que "dichos beneficios no estén contemplados en leyes vigentes" (Art. 105).

En la Ley General de Ambiente también se crearon las Comisiones Consultivas Ambientales Comarcales. Cada una de las comarcas creadas en la República de Panamá cuenta con su propia

49. Si no cumplen con los requisitos o se presume de ilegalidades contra el marco normativo ambiental de la República de Panamá, la autoridad competente -en este caso la ANAM- puede suspender y cancelar los permisos que haya otorgado. Un ejemplo es la Resolución 119 del 2002, del $1^{\circ}$ de marzo de 2002, Gaceta Oficial $N^{\circ} 24.581$ publicada el 25 de junio de 2002, que suspendió el otorgamiento de permisos especiales de aprovechamiento de subsistencia para la especie de madera denominada "bálsamo" en comunidades indígenas Emberá en la Provincia de Darién por haberse detectado tala ilegal. 
norma de creación ${ }^{50}$ y en general estas se han desarrollado basándose en la cosmovisión de identidad indígena, respetando el mandato constitucional de reconocer y establecer mediante ley el derecho a conservar sus costumbres, instituciones propias, compatibles con los derechos fundamentales del marco jurídico nacional y en el contexto jurídico internacional sobre derechos humanos y acceso a los recursos naturales ${ }^{51}$.

La Ley Forestal $\mathrm{N}^{\circ} 1$ de 1994 no desarrolla extensas disposiciones sobre el derecho de las comunidades indígenas en relación con los recursos forestales y su aprovechamiento. En su Artículo 44 establece que en las áreas de comarcas o reservas indígenas y comunidades indígenas la ANAM podrá autorizar permisos y concesiones de aprovechamiento forestal si conjuntamente media autorización por parte de los congresos indígenas respectivos siempre y cuando se cumpla con la presentación de un plan de manejo científico. En general, todos los requisitos y prohibiciones establecidos en la ley son de obligatorio cumplimiento para cualquier persona natural o jurídica, sin distinción y es la autoridad competente (la ANAM) la que aprueba o no un aprovechamiento forestal en todo el territorio de la República de Panamá.

\subsection{Análisis de vacíos sobre aprovechamiento forestal y comercio internacional}

Las actuaciones de la ANAM se orientan principalmente hacia la conservación de las áreas del Sistema Nacional de Áreas Protegidas (SINAP) y el cuidado del ambiente. Ni la actividad forestal ni el fomento del sector forestal están entre las prioridades más urgentes; esto se evidencia en su estructura organizativa y el presupuesto asignado.

Otro de los vacíos en la legislación forestal es que en la actualidad no se cuenta con un programa de extensión ni de investigación forestal en ejecución, a pesar de que las leyes lo contemplan. Tampoco se ha cumplido con implementar la demarcación del patrimonio forestal. Igualmente, el Fondo para el Desarrollo Forestal (FONDEFOR) está creado en la ley, pero se encuentra en suspenso en la práctica. Tampoco hay efectivo cumplimiento de las normas de supervisión y control del manejo sostenible de los bosques que están siendo aprovechados mediante permisos o autorizaciones.

50. La Ley 16 de 1953, del 19 de febrero de 1953, Gaceta Oficial N 12.042 publicada el 7 de abril de 1953 , creó la Comarca de Guna Yala (originalmente denominada Comarca de San Blas). La Ley 22 de 1983, del 8 de noviembre de 1983, Gaceta Oficial N 19.976 publicada el 17 de enero de 1984, creó la Comarca Emberá Wounaan. La Ley 24 de 1996, del 12 de enero, Gaceta Oficial №22.951 publicada el 15 de enero de 1996, creó la Comarca de Madugandí. La Ley 10 de 1997, del 7 de marzo, Gaceta Oficial N²3.242 publicada el 11 de marzo de 1997, creó la Comarca Ngöbe Buglé. La Ley 34 del 2000, del 25 de julio de 2000, Gaceta Oficial № 24.106 publicada el 28 de julio de 2000, creó la Comarca de Wargandí.

51. Instrumentos internacionales, como la Agenda 21, Capítulo 26, reconocen el derecho de las poblaciones y comunidades indígenas de disfrutar a plenitud los derechos humanos y las libertades fundamentales, así como su derecho a proteger sus tierras de actividades que consideran inapropiadas. La Declaración de Principios sobre la Ordenación, Conservación y Desarrollo Sostenible de los Bosques establece entre sus principios que la política de cada país debe reconocer y apoyar la cultura, los intereses y derechos de las poblaciones indígenas; igualmente sucede con otros acuerdos multilaterales de medio ambiente, como el Convenio sobre la Diversidad Biológica (CBD) y el Convenio Marco de Naciones Unidas sobre Cambio Climático, entre otros. 
A pesar de lo anterior, encontramos que en Panamá hay proliferación de normas que regulan en detalle los elementos fundamentales en la cadena de producción forestal con el fin de garantizar sostenibilidad, así como herramientas o instrumentos para la conservación y el manejo ambiental que no cuentan con recursos para su aplicación.

Ha sido difícil hallar algún aspecto del aprovechamiento forestal que no esté regulado o para lo cual no exista un procedimiento. Por el contrario, muchas de las disposiciones jurídicas simplemente no se cumplen.

En el sector forestal la contradicción más grande en el marco jurídico es que la ANAM tiene un doble papel antagónico como juez y parte en defensa de los bosques de forma natural sin aprovechamiento forestal (como lo expresan las normas que crean más del $80 \%$ de las áreas protegidas creadas en el país: se prohíbe talar, se prohíbe extraer recursos naturales).

En cuanto al comercio internacional, es pertinente revisar las adecuaciones para rápidamente vincularse con las iniciativas de REDD+ y FLEGT, entre otras, para lograr dinamizar el comercio de madera justo hacia el exterior, cumpliendo con las disposiciones de buena gobernanza forestal; es decir, revisar si se pueden simplificar los trámites, contando con controles más eficientes y asegurar un cumplimiento mínimo de instrumentos técnicos legales como la marquilla (o código de barras), geo-referencia de los árboles que se talan, la forma, el tiempo y las condiciones para la cubicación de la madera.

\subsection{Requisitos - Actores, costos y plazos}

Entre los requisitos que la Ley 1 de 1994 exige están inventarios forestales o censos ${ }^{52}$, planes de reforestación para determinar la masa boscosa producto de la reforestación, incluyendo su uso y aprovechamiento, y planes de manejo forestales, que son el instrumento mediante el cual se regula el uso y el aprovechamiento racional de los bosques naturales en un área determinada, con el fin de obtener el máximo de beneficio, pero asegurando al mismo tiempo la conservación, mejoramiento y acrecentamiento de los recursos naturales (Artículo 5.9). Los planes y los inventarios tienen que ser elaborados por profesionales idóneos en ciencias forestales que deben contar con idoneidad (Arts. 9 y 11). Toda persona que quiera dedicarse a actividades de aprovechamiento forestal o desee realizar estudios técnicos forestales debe inscribirse en el Libro de Registro Forestal de la ANAM (Art. 9), en la Dirección de Gestión Integrada de Cuencas Hidrográficas.

El Libro de Registro Forestal se llevará en orden secuencial de acuerdo con la fecha de inscripción.

El número de registro forestal se identificará con las siglas de la administración regional respectiva, número de secuencia y año de emisión.

52. La Resolución 05-98 de 1998, que reglamenta la Ley Forestal, define el inventario forestal como la evaluación técnica que se aplica a los bosques naturales o plantados para determinar sus características y su capacidad para aprovechamiento y manejo forestal sostenible. Esta evaluación se realiza en una unidad territorial definida, mediante la aplicación de criterios estadísticos. El inventario forestal nacional es aquel estudio que se realiza para compilar información básica de los bosques, existencia de la madera y demás recursos forestales en bosques naturales y plantados, incluyendo las tierras de aptitud forestal. 
Los requisitos para inscribirse en el Libro de Registro Forestal son: solicitud por escrito describiendo la actividad forestal a la que se dedica, así como sus generales, formulario de inscripción disponible en la ANAM, constancia de persona natural o jurídica (copia de cédula o del certificado del Registro Público), paz y salvo de la ANAM y del Municipio, descripción de quipos, herramientas, maquinaria y transporte que va a utilizar para el aprovechamiento y recibo de pago a la ANAM.

Los que se dediquen a la industrialización, transformación y/o comercialización deben además presentar copia autenticada de permiso de operaciones, tipo de actividad, volumen o cantidad de producto comercializado, descripción de la superficie de producción, instalaciones físicas bajo techo, patios de acopio, depósitos y fuentes de agua, descripción de la actividad, volumen, materia prima requerida, equipo utilizado en el proceso de industrialización, tecnología empleada, método de preservación, secado, tipo de producto elaborado, volumen o cantidad, descripción del personal, nivel de especialización ${ }^{53}$.

Recientemente se ha incorporado la figura del regente forestal ${ }^{54}$, que es el profesional idóneo en ciencias forestales que puede acreditarse en el Registro Forestal de los Profesionales Idóneos en Ciencias Forestales para actuar ante la ANAM una vez cumpla con los requisitos establecidos en la norma y quede habilitado para firmar documentos e instrumentos técnicos forestales.

El Artículo 7 de la Ley Forestal vigente establece la exigencia de un estudio de impacto ambiental siempre que las obras o actividades puedan afectar o deteriorar el medio natural, el cual deberá ser aprobado por la ANAM. Con la Ley 41 de 1998, se legisló sobre el proceso de evaluación ambiental y vía reglamentación, se estableció que solo requieran el Estudio de Impacto Ambiental aquellos proyectos de extracción forestal de bosques nativos en superficies de más de 50 hectáreas (Art. 16) ${ }^{55}$.

La ANAM puede expedir permisos especiales de aprovechamiento forestal, que pueden ser (i) de carácter doméstico o (ii) de subsistencia, "previa comprobación de carencia de recursos económicos" (Art. 27.1). Para los permisos especiales de aprovechamiento forestal la reglamentación de la Resolución 05 de 1998 establece que tiene que presentarse para árboles individuales (i) una solicitud por escrito que debe contener la especie y ubicación del árbol que se quiere talar, el sitio donde se plantará como compensación o el lugar donde se realizará el manejo de la regeneración natural (Art. 41), a razón de 10 por 1 árbol talado o plantones con un mínimo de $70 \%$ de rendimiento, o la regeneración natural de acuerdo con lo que establezca la ANAM. El escrito debe llevar (ii) paz y salvo (que tiene un costo de US\$3) y (iii) copia de la cédula del solicitante. Quien solicita también debe entregar (iv) una declaración escrita donde indique que no tiene recursos económicos. La ANAM tiene la potestad de evaluar el caso y además, debe seguir los parámetros de pobreza que establezcan las autoridades competentes como el Ministerio de Economía y Finanzas. Este tipo de permisos tiene una vigencia de 30 días, prorrogables por la ANAM por 30 días más.

53. La Resolución 444 del 2011, del 8 de julio de 2011, Gaceta Oficial N 26.845 publicada el 8 de agosto de 2011, establece requisitos de inscripción en el Libro de Registro Forestal para las actividades de aprovechamiento forestal que establece la Ley 1 de 1994, en su Artículo 8.

54. La Resolución 05 del 2013, del 8 de enero de 2013, Gaceta Oficial 27,264 publicada el 11 de abril de 2013 , aprueba el Reglamento para la Acreditación del Regente Forestal ante la ANAM.

55. El Decreto Ejecutivo 123 del 2009, del 14 de agosto de 2009, Gaceta Oficial N²6.352-A del 24 de agosto de 2009, reglamenta el Capítulo II del Título IV de la Ley 41 de 1998, General de Ambiente. 
En cuanto a los permisos de aprovechamiento forestal de subsistencia, cuando quien se beneficia desea hacerlo vendiendo el recurso forestal ("venta del producto adquirido"), además de cumplir con lo ya señalado, debe presentar ante la Administración Regional de la ANAM que corresponda copia del contrato de compra-venta forestal, el cual tiene que indicar las generales del comprador y su domicilio, número de permiso de aprovechamiento, volumen, especie y forma en la que recibe el producto. El comprador debe mantener consigo una copia del referido contrato, pues la ANAM se reserva el derecho de solicitárselo en cualquier momento ${ }^{56}$.

En su Artículo 27. 2 la Ley Forestal 1 de 1994, considera otro modelo de negocios, que es que la ANAM otorgue una concesión de aprovechamiento forestal. Los aprovechamientos forestales en tierras nacionales solo podrán realizarse con base en un plan de manejo que garantice la sostenibilidad del bosque.

En todos los casos se debe estar paz y salvo con el Estado, tener capacidad técnica operativa y financiera de capital, identificar los posibles mercados para la comercialización y contar con personal técnico, profesional idóneo en ciencias forestales que será el responsable de hacer el aprovechamiento forestal sostenible.

El aprovechamiento forestal en tierras estatales o áreas boscosas sin título de propiedad se tramita vía concesión. El interesado debe presentar la solicitud y el inventario forestal, plan de manejo y el estudio de impacto ambiental si se trata de más de 50 hectáreas. Dicho estudio tiene que ser aprobado a su vez por la ANAM para que se otorgue la autorización vía concesión.

Los planes de manejo forestales deben contar así mismo con Planes Operativos Anuales (POA) que también deben ser aprobados por la ANAM. Estos POA son de obligatorio cumplimiento (Art. 7 de la reglamentación de la Ley 1 de 1994). La descripción de los equipos y maquinarias que se van a utilizar en el proceso de corta, extracción, transporte y transformación primaria también debe estar en el plan de manejo y de incumplir con lo descrito, se estará frente a causal de suspensión.

La Ley Forestal establece que para transportar madera se requiere una guía de transporte forestal previo al cumplimiento de ciertos requisitos. La Resolución 695 del $2012^{57}$ prohíbe transportar madera en tucas, bloques, aserradas, semiaserradas en horario de 6 p.m. a 8 a.m.; los domingos y feriados durante las 24 horas. Establece que los sábados únicamente se puede transportar de 8 a.m. a 6 p.m. de plantaciones y bosques naturales del Darién y Panamá Este. Las prohibiciones aplican en todo el territorio nacional.

Panamá igualmente cuenta con una norma que determina los criterios y parámetros técnicos básicos para elaborar planes de manejo forestal, destinados a sustentar aprovechamiento forestal no intensivo ${ }^{58}$.

56. Resolución 681 del 2012, del 3 de diciembre de 2012. Gaceta Oficial № 27.182 del 12 de diciembre de 2012.

57. La Resolución 695 del 2012, del 7 de diciembre de 2012. Gaceta Oficial № 27.182 del 12 de diciembre de 2012, regula el transporte de madera en tucas, bloques, serradas o semiserradas en todo el territorio nacional.

58. Resolución 200 del 2004, del 7 de junio, Gaceta Oficial № 25.085 publicada el 2 de julio de 2004. 


\subsection{Estándares para el aprovechamiento forestal}

La Ley Forestal en Panamá establece como objetivos proteger, conservar e incrementar los recursos forestales y promover su manejo y aprovechamiento racional y sostenible, prevenir y controlar la erosión de los suelos, proteger y manejar las cuencas hidrográficas, y estabilizar los suelos. Adicionalmente estipula que la ANAM debe establecer, proteger y regular áreas con atributos excepcionales para salvaguardar la flora, fauna, vida marina, fluvial y el ambiente. Se pueden establecer bosques de protección para salvaguardar cuencas hidrográficas, regular el régimen de aguas y también bosques especiales que se designan para preservar áreas de interés científico, histórico, cultural, educacional, turístico, recreacional, de interés social y utilidad pública. Estos bosques se regirán por los instrumentos normativos que los crean; por lo tanto, no están sujetos a las regulaciones que establece la Ley Forestal para el aprovechamiento forestal que le será complementaria. Esto implica que el instrumento jurídico que crea alguno de estos bosques como área protegida establecerá los criterios, parámetros, condiciones, zonificación y procedimiento para prohibir o autorizar el aprovechamiento forestal sostenible dentro de sus límites. El Artículo 25 señala que solo podrán ser sometidos a actividades que sean compatibles con la naturaleza y objetivos de su creación, basado en efecto en el plan de manejo y las normas aplicables a las áreas protegidas. La reglamentación a través de la Resolución 05 de 1998 establece que se podrán aprovechar racional y sostenidamente siempre y cuando no se atente contra los objetivos de su categoría de manejo, previo estudio y que "no se afecte sensiblemente el ecosistema". Por su parte, el Artículo 69 reitera que no se pueden contravenir los objetivos de creación del área protegida. $Y$ en caso de darse autorización porque se cumplen todos estos requisitos o precondiciones, deberán utilizarse métodos de bajo impacto para la flora y la fauna.

El aprovechamiento forestal sostenible que pueda dañar o destruir árboles o arbustos en zonas circundantes al nacimiento de cualquier cauce natural de agua, áreas adyacentes a lagos, lagunas, ríos y quebradas está prohibido.

Se establecen márgenes o servidumbres de $200 \mathrm{~m}$ si se trata de nacimientos de agua en cerros y de $100 \mathrm{~m}$ si es en terrenos planos. En los ríos y quebradas debe dejarse a cada lado una franja de bosque igual o mayor al ancho del cauce, nunca menor de $10 \mathrm{~m}$ (inclusive si se trata de "bosques artificiales"). Para la ribera de lagos y embalses naturales debe mantenerse una zona de bosque de hasta $100 \mathrm{~m}$ (Art. 23 Ley 1 de 1994).

Tampoco se puede hacer aprovechamiento forestal en las áreas de recarga acuífera de ojos de agua que sean para consumo social. La ley también incluye prohibiciones en cabeceras de ríos, a lo largo de las corrientes de agua y embalses naturales o artificiales. Incluso, aunque se trate de "bosques artificiales", no se puede hacer aprovechamiento forestal ni dañar ni destruir en distancias mínimas de $100 \mathrm{~m}$ en cerros y $50 \mathrm{~m}$ en terreno plano.

En Panamá las maderas se clasifican por su valor comercial en el mercado59. La ANAM reclasificó las maderas comerciales y potencialmente comerciales basándose en el valor comercial de mercado

59. Resolución 66 del 2007, del 8 de febrero de 2007, Gaceta Oficial № 27.740 publicada el $1^{\circ}$ de marzo de 2007. 
para fijar los cobros por servicios que preste la entidad para aprovechamiento del bosque natural (ver Anexos 8 y 9). A través de esta clasificación se han precisado las especies con interés comercial, con el fin de contribuir al aprovechamiento forestal sostenible de los bosques naturales de producción.

En este mismo plano de estándares para el aprovechamiento forestal, basado en el Artículo 62 de la Ley 41 de 1998, General de Ambiente, se establece que "las normas sobre recursos naturales (...) tienen el objetivo de incorporar el concepto de sostenibilidad y racionalidad en el aprovechamiento de los recursos naturales, así como asegurar que la protección del ambiente sea un componente permanente en la política y administración de tales recursos". La ANAM debe velar porque estos mandatos se cumplan y para ello puede emitir normas técnicas y procedimientos administrativos.

En Panamá, los árboles con diámetros de gran magnitud son considerados por la autoridad competente (la ANAM) como de alto valor ecológico, histórico, genético y escénico, por lo que ordena que deben ser preservados para que brinden "servicios ambientales y contribuyan a preservar la diversidad biológica". La Resolución 438 del 200960 establece el diámetro máximo de tala o corta de las especies de gran magnitud (ver Cuadro $\mathrm{N}^{\circ} 6$ ).

Asimismo, la Resolución 05 de 1998, Artículo 6, reguló el cálculo del volumen para árboles en pie en bosques naturales basándose en la tabla de volumen para bosques tropicales de la FAO hasta tanto la ANAM elabore una tabla de volumen ajustada a los bosques naturales del país.

En concordancia con lo anterior, la ANAM aprobó la Resolución 0168 del 200761, que reglamenta la cubicación de madera y fija el margen de tolerancia para los volúmenes de tala que se autoricen mediante permisos, concesiones u otras autorizaciones de aprovechamiento forestal y resuelve que el cálculo del volumen de los árboles en pie (parados) medirá el diámetro a 1,30 m de altura desde el suelo y la altura comercial del tronco (esto servirá para asignar el valor del servicio técnico que la ANAM cobrará).

La norma también incluyó niveles de eficiencia de proceso para controlar los volúmenes autorizados para talar con respecto a los que se movilicen, incluyendo los volúmenes en los establecimientos industriales (Art. 7). Adicionalmente determinó criterios para ajustar la cubicación en los volúmenes dependiendo de la calidad y características de la pieza a cubicar.

El ciclo de corta también es un estándar de la Ley Forestal, que lo define como el período transcurrido entre dos (2) aprovechamientos forestales consecutivos de árboles comerciales en una misma área, donde en el segundo aprovechamiento los árboles remanentes deben haber alcanzado los diámetros comerciales. El diámetro comercial es el diámetro mínimo permitido para el aprovechamiento forestal, bajo criterios de verticalización y eficiencia económica.

En relación con los volúmenes y especies totales y anuales a otorgar, el tamaño de las unidades de manejo forestal, períodos de vigencia de los permisos, contratos y autorizaciones de aprovechamiento

60. La Resolución 438 del 2009, del 18 de junio de 2009, Gaceta Oficial № 26.334 publicada el 29 de julio de 2009, establece medidas para la protección de árboles con diámetros de gran magnitud en Panamá.

61. La Resolución 0168 del 2007, del 2 de abril de 2007, Gaceta Oficial № 25.784 publicada el 4 de mayo de 2007, reglamenta la cubicación de madera y fija el margen de tolerancia para los volúmenes de tala que se autoricen mediante permisos, concesiones u otras autorizaciones de aprovechamiento forestal. 
forestal se basarán en criterios técnicos tales como posibilidad anual del bosque, diámetros mínimos de corta permisible, masa forestal remanente, ciclo de corta y condiciones ecológicas del área ${ }^{62}$.

Se exige a los beneficiarios que implementen métodos silviculturales, según las características y condiciones del área y del bosque, con base en lo que establezca el propio plan de manejo aprobado por la ANAM. "Bajo ningún punto de vista podrán afectar sensiblemente la estructura y composición del bosque"63.

El Artículo 29 de la Resolución 05-98 de 1998 establece que la ANAM, a través del Departamento Forestal, "mantendrá actualizadas las normas y criterios para el manejo forestal sostenido que se deriven de las investigaciones forestales y del avance de la tecnología".

Los beneficiarios deben ajustarse al volumen de corta anual permisible, respetando los márgenes de tolerancia en los límites de los volúmenes anuales de aprovechamientos forestales.

El Artículo 34 de la reglamentación de la Ley Forestal establece que los beneficiarios de un permiso, concesión o autorización de aprovechamiento forestal deben coadyuvar en la protección del área donde se les autorizó a hacer el aprovechamiento contra la caza ilegal, incendios, talas ilegales y colonización, entre otras acciones dañinas o riesgosas para el ambiente.

En el Régimen Forestal de la República de Panamá también se han incluido mediante disposición jurídica medidas específicas para la protección, conservación y uso sostenible de los recursos forestales, a través de la Resolución 281 del 200564. Se ordena (i) identificar, demarcar e inscribir a nombre de la ANAM en el Catastro nacional las áreas de bosques de protección y bosques de producción (la ANAM debe ser apoyada para esto por la ANATI); (ii) oficializar el listado y categoría de especies maderables amenazadas en Panamá; (iii) establecer áreas para la producción de semillas forestales y selección adecuada de árboles semilleros y recolección y comercialización de estas semillas por las propias comunidades; (iv) impulsar la forestería comunitaria como alternativa para la conservación de los bosques naturales remanentes y la biodiversidad a través del manejo forestal sostenible; (v) identificar y aplicar mecanismos financieros necesarios para la implementación a nivel nacional de un sistema de pago y cobro por servicios ambientales e impulsar el sector forestal como estrategia para el desarrollo sostenible.

En Panamá también existe una Ley de Cuencas Hidrográficas. El país está dividido en 52 cuencas, las cuales ocupan todo el territorio nacional de punta a punta. La Ley 44 del $2002^{65}$ establece que cada cuenca debe contar con un plan de manejo, desarrollo, protección y conservación, así como un plan de ordenamiento ambiental territorial de la cuenca hidrográfica, en el que tiene que basarse aquel. El plan de ordenamiento ambiental territorial identifica y programa actividades humanas compatibles

62. Resolución 05-98 de 1998, Art. 28.

63. ibid. Art. 27.

64. Con la Resolución 281 del 2005, del 18 de mayo de 2005, Gaceta Oficial № 25.313 publicada el 3 de junio de 2005, se establecen medidas regulatorias para la protección, conservación y uso sostenible de los recursos forestales en la República de Panamá.

65. La Ley 44 del 2002, del 5 de agosto de 2002, Gaceta Oficial N² 24.613 publicada el 8 de agosto de 2002 , establece el régimen administrativo especial para el manejo, protección y conservación de las cuencas hidrográficas de la República de Panamá. 
con el uso y manejo de los recursos naturales del territorio de la cuenca hidrográfica, respetando la capacidad de carga del entorno natural. En su Artículo 6 la Ley de Cuencas Hidrográficas establece que las concesiones o permisos otorgados por la autoridad competente para explotación y usufructo de recursos naturales, como los recursos forestales, deben cumplir con ambos planes.

La Ley 1 de 1994 faculta a la ANAM para que suspenda -por el término que considere necesariola autorización de permisos o concesiones de aprovechamiento en cualquier parte del territorio nacional por razones sociales, ecológicas, de protección de especies o de seguridad (Art. 38). 


\section{Análisis del ámbito de acción de la Administración Forestal}

\subsection{Competencias, descentralización - Efectividad}

La descentralización es uno de los componentes de la Política Forestal que establece como prioridad la implementación de un proceso de desconcentración hacia las administraciones regionales y descentralización a los gobiernos locales, con el fin de que participen en el manejo y aprovechamiento forestal en bosques naturales y plantaciones, y cualquier otra actividad vinculada con el sector forestal. La descentralización también considera el papel clave de las comunidades, la empresa privada y la sociedad civil.

La Ley General de Ambiente establece en su Artículo 83 que la ANAM debe promover programas de manejo descentralizado de las cuencas por las autoridades locales y los usuarios en relación con sus recursos hídricos.

"La ANAM está organizada para asegurar una gestión descentralizada a través de sus Administraciones Regionales, procurando la participación de los sectores públicos y privados en la gestión ambiental del país, a través del Sistema Interinstitucional del Ambiente y las Comisiones Consultivas Ambientales"66.

La Ley Forestal a través de su reglamentación, Resolución 05-98 de 1998, estipula que los procedimientos y reglamentaciones para aplicar la ley podrán determinarse por el Administrador General de la ANAM o ser delegadas en los Directores y Administradores Regionales (Art. 107).

En la práctica, a pesar de que se han delegado varias funciones en las administraciones regionales, para la comercialización y exportación se realizan muchos trámites en la oficina de Panamá. Entre los empresarios existe la percepción de que la concentración en las oficinas centrales es muy compleja y que hay multiplicidad de funciones entre varios departamentos o direcciones, donde en todos hay que pagar por cada trámite específico sin que haya coordinación interna.

\subsection{Tipos de permisos forestales}

Los permisos forestales pueden ser:

- Concesión en finca privada.

- Concesión en tierras del Estado por licitación pública (en la práctica no se están dando).

- Permiso de subsistencia, doméstico (individual). El permiso especial de aprovechamiento forestal para fines domésticos se otorga para fines de construcción o reparación de viviendas, botes o instrumentos de trabajo, construcciones rurales o de estructuras. Este tipo de permiso

66. ANAM (2004). Informe del Estado del Ambiente de Panamá, Pág. 115. 
es de uso exclusivo del solicitante. Para indígenas también se puede otorgar permiso de aprovechamiento para uso doméstico "en casos debidamente justificados"67.

- Permiso comunitario (grupos debidamente organizados). Solo podrán otorgarse estos permisos siguiendo criterios técnicos de producción y manejo sostenido que debe realizar el propio grupo, cumpliendo lo establecido en el permiso correspondiente ${ }^{68}$.

- Permisos comunitarios en áreas indígenas. Se otorgan conforme las condiciones socioeconómicas de las comunidades. La superficie máxima para aprovechamiento con este tipo de permisos es de 1.000 hectáreas. Las autoridades comarcales tienen que certificar la existencia de la comunidad. También se debe contar con el aval de la Dirección de Política Indigenista del Ministerio de Gobierno. Los ingresos que generen estos permisos deben utilizarse exclusivamente para atender las necesidades de la comunidad. La comunidad indígena es la responsable de ejecutar todas las actividades de aprovechamiento y manejo forestal. Tiene que ser asistida por un profesional idóneo en ciencias forestales. Los responsables y representantes de la comunidad ante la ANAM son la autoridad máxima reconocida.

- Permisos para aprovechar árboles o bosques establecidos mediante una plantación o reforestación en áreas indígenas. Solo deben registrarse en la ANAM y notificar previamente.

En atención a los permisos especiales de aprovechamiento forestal con carácter de subsistencia, estos no pueden ser vendidos ni traspasados bajo ningún título sin autorización legal de la ANAM (el Código Penal vigente sanciona tanto a quien traspase como a quien se favorezca con días multa y penas de prisión [Arts. 403 y 404]). Únicamente la ANAM podrá autorizarlo si media contrato por escrito donde se refleje la venta del producto forestal. El contrato debe contener toda la información de la especie, volumen, forma en que va a ser entregada, datos generales de las partes, incluyendo domicilio y la información precisa del permiso de subsistencia. El trámite tiene que realizarlo personalmente en las dependencias de la ANAM el titular del permiso de subsistencia, presentando un original del contrato. Quien se favorezca del traspaso debe mantener una copia en su poder de este, dado que la ANAM se reserva el derecho de solicitárselo en cualquier momento; inclusive, mantiene la potestad de inspeccionar el producto objeto del contrato ${ }^{69}$ (ver sección de Requisitos Actores, costos y plazos).

La Ley Forestal establece que para transportar madera se requiere una guía de transporte forestal previo el cumplimiento de ciertos requisitos, así como los días y horas en los que se puede transitar con madera transportada desde bosques naturales o plantaciones (ver Cuadro $\mathrm{N}^{\circ} 7$ ).

67. Art. 49 de la Resolución 05 de 1998.

68. ibid. Art. 44.

69. Arts. 1, 2, 3 de la Resolución 681 del 2012. 


\subsection{Proceso legal-administrativo para acceder a los permisos de importación y exportación de madera y sus subproductos (CITES y no CITES)}

En Panamá se cuenta con el Sistema Integrado de Comercio Exterior (SICE) que permite iniciar los trámites de forma virtual ${ }^{70}$ a través de un corredor de aduanas. Este Sistema incluye una fase de verificación que solicita electrónicamente la Licencia Previa al Órgano Anuente (en este caso, es la ANAM) para que la emita o no. En el caso de la madera para exportar, esta licencia previa es la que verifica que se obtenga la Guía de Exportación. Como se ve a continuación, el Sistema tiene dos formas de acceder al trámite si el órgano anuente está inscrito o no en el SICE.

El permiso CITES también sería considerado un requerimiento de Licencia Previa con la que se debe contar para poder proseguir. Es decir, se verifica con el órgano anuente, que puede otorgarlo o no otorgarlo.

Si más adelante se aprueban requisitos específicos para cumplir con FLEGT, también entraría a requerir Licencia Previa para culminar el trámite y lograr la exportación.

En el caso de la importación funciona igual, por ejemplo, si se tratara de madera incluida en CITES para importar a Panamá, se debería reflejar en el Sistema como que se necesita una Licencia Previa (ver Gráfica N4).

\subsection{Análisis de estadísticas de importación y exportación CITES y no CITES de los últimos años}

Se cuenta con información dispersa y a la vez escasa de datos de exportación de madera. FAO tiene algunas cifras del 2009. La Contraloría mantiene en su base de datos ciertas cifras por estadísticas ambientales, pero no está por años para facilitar el análisis.

En cuanto a las estadísticas de importación y exportación CITES, los datos no están disponibles, no son de acceso público en Panamá ni están organizados en la institución como para acceder a ellos. En la web de CITES se pueden verificar los permisos de exportación desde Panamá tramitados en el marco de la Convención ${ }^{71}$. En los años 2011-2012 no se refleja exportación de especies de madera. La ANAM se encontraba organizando la información en la Dirección de Áreas Protegidas y Vida Silvestre, que es la que la tramita. Sin embargo, podemos adelantar que en los últimos informes económicos de exportación de Panamá, los productos o subproductos forestales no aparecen en la lista de los primeros quince en relación con el volumen de exportación ${ }^{72}$.

Las estadísticas de importación y exportación de madera, CITES o no CITES, se deben sistematizar y hacer de acceso público. Las normas vigentes disponen entrega y colecta de información precisa

70. Sistema Integrado de Comercio Exterior. [sitio web]. <http://www.aduanas.gob.pa/index.htm>.

71. CITES. 'CITES Trade: A Snapshot'. [pdf online]. <http://www.unep-wcmc-apps.org/citestrade/report.cfm>. Accedido el 4 de diciembre de 2013.

72. Durán Lima, J.E. y otros (2008). CEPAL. Naciones Unidas. Indicadores de Comercio Exterior y Política Comercial: mediciones de posición y dinamismo comercial. 43 páginas. [pdf online]. <http://www.eclac. org/comercio/publicaciones/xml/9/36069/Mediciones_de_Posicion_y_Dinamismo_Comercial_W_217. pdf $>$. Accedido el 4 de diciembre de 2013. 
en términos de volumen, especies, cantidad, áreas, períodos de corta, plazos, tipo de madera (tuca, trozo, bloque, serrada y semiserrada, entre otros), maquinaria, lugares de industrialización o procesamiento de madera, guías de transporte con información de origen y destino, guías de exportación con información básica de origen, destino, volumen y especies. La información no se procesa de forma eficaz y seguramente no está siendo tomada en cuenta para la toma de decisiones. 


\section{Análisis del sistema de control forestal}

\subsection{Análisis de la existencia de conflictos de competencias entre los responsables de la administración y ejecución de los sistemas de control forestal}

Si leemos todas las leyes y regulaciones en materia forestal y de reforma agraria desde la década de 1960 a la fecha, tanto derogadas como vigentes y luego revisamos los informes oficiales generados por la Autoridad Nacional del Ambiente sobre el estado del ambiente 1999, 2004 y 2009 sobre la biodiversidad, indicadores ambientales y atlas ambiental, entre otros, es fácil deducir que los niveles de cumplimiento legal son muy bajos. Prácticamente las normas no se han cumplido. Las causas probables pueden ser falta de: capacidad para hacer cumplir los requisitos forestales y ambientales, recurso humano calificado, tecnología, así como requisitos poco claros, ambiguos, imprecisos, contradictorios (ejemplo de la norma que regula el aprovechamiento de la especie de cocobolo en Panamá) $)^{73}$.

La Fiscalía Ambiental asegura que los delitos contra el ambiente en Panamá van en aumento, en especial la tala de árboles, además del tráfico de animales exóticos y la contaminación ambiental ${ }^{74}$.

Para contrarrestar la tala ilegal, la ANAM aprobó un programa de monitoreo y vigilancia de controles en Panamá Este y Darién, donde se dan más incidencias, con el fin de reducir al mínimo la tala y el transporte ilegal de madera. De acuerdo con una publicación de la autoridad, el programa cuenta con apoyo de la Policía Nacional, el Servicio Nacional de Fronteras (SENAFRONT), los corregidores de policía (autoridades locales), alcaldes y el gobernador (se entiende de las provincias de Panamá y Darién), así como las fiscalías. El equipo de trabajo por parte de la ANAM lo conforman tres funcionarios de apoyo, ingenieros forestales o agrónomos (no determina número) y el Administrador

73. Protestas de madereros en la Provincia de Darién en septiembre de 2013. Defensoría del Pueblo. 'Defensoría del Pueblo media en cierre de calle por parte de maderero'. [sitio web], (19 de septiembre de 2013). <http:// www.defensoriadelpueblo.gob.pa/index.php?option=com_k2\&view=item\&id=4865:defensoria-delpueblomedia-en-cierre-de-calle-por-parte-de-maderero >. Accedido el 4 de diciembre de 2013. O ver: Arcia, O. 'ANAM suspende extracción de cocobolo en todo Darién'. La Prensa [periódico online], (11 de abril de 2012). <http:// www.prensa.com/impreso/panorama/anam-suspende-extraccion-de-cocobolo-en-todo-darien/83412>. Accedido el 4 de diciembre de 2013.

74. Cobertura de las ilegalidades en los medios de comunicación del 2012. Rivera, S. 'Reforzarán área fronteriza'. La Prensa [periódico online], (10 de agosto de 2013). <http://www.prensa.com/impreso/nacionales/ reforzaran-area-fronteriza/197721>. Accedido el 4 de diciembre de 2013.

'Los nombres tras el negocio del cocobolo'. La Estrella Online [periódico online]. <http://www.laestrella.com. pa/online/impreso/2012/04/13/los-nombres-tras-el-negocio-del-cocobolo.asp $>$. Accedido el 4 de diciembre de 2013.

Soto, G. 'Aumenta el comercio ilegal de madera en Panamá Este'. Panamá América [periódico online], (16 de agosto de 2012). <http://www.panamaamerica.com.pa/notas/1201424-aumenta-el-comercio-ilegal-demadera-en-panamaeste>. Accedido el 4 de diciembre de 2013.

Autoridad Nacional del Ambiente. [sitio web]. <http://www.anam.gob.pa/index.php?option=com_content\&vi ew=article\&id=3182\%3Amonitoreo-contra-tala-ilegal-trafico-de-madera-e-incendios-forestales-en-darieny-panama-este\&catid=102\%3Aprensa\&ltemid=50\&lang=es $>$. Accedido el 4 de diciembre de 2013. 
Regional de la ANAM. La metodología incluye la determinación del área a vigilar, los recorridos para control y vigilancia, y patrullaje.

Adicionalmente, la Ley General de Ambiente establece como uno de los instrumentos de gestión ambiental la supervisión, control y fiscalización (Art. 40) de las actividades en relación con el cumplimiento de otros instrumentos de gestión ambiental, como el estudio de impacto ambiental, el plan de manejo forestal y el inventario forestal, entre otros, y del cumplimiento de las normas ambientales. La supervisión, control y fiscalización son funciones inherentes a la ANAM. Las inspecciones pueden ser programadas o aleatorias y se establece que la autoridad coordinará con otras entidades con competencias sectoriales relacionadas, a través del Sistema Interinstitucional del Ambiente $(\mathrm{SIA})^{75}$.

Los principios de la Política Nacional de Supervisión, Control y Fiscalización son: (i) coercitividad so pena de sanciones administrativas, penales y/o civiles, (ii) responsabilidad ambiental compartida entre todos los actores -quién debe cumplir, quién debe hacer cumplir y quién debe denunciar-, (iii) principio de responsabilidad ambiental: cualquier acción que degrade debe asociar otra acción que compense, mitigue, repare y restaure, (iv) armonización de intereses: mecanismos de mediación, arbitraje, conciliación y audiencias públicas ${ }^{76}$.

Al momento de exportar, la ANAM mantiene inspectores que vigilan los contenedores al momento del embarque. EI MIDA, en sus controles fitosanitarios, también asigna un inspector previo cumplimiento de un trámite en esta entidad. Si la madera no ha sido tratada, debe ser fumigada a través de un trámite con otra entidad, que es OIRSA y el trámite de liquidación de tasas e impuestos se hace en el MICl. Luego, los trámites aduaneros se realizan con la ANA. Todos llevan un costo establecido por la entidad respectiva. Finalmente, la ANAM debe emitir una guía de exportación.

75. El Sistema Interinstitucional del Ambiente (SIA) fue creado en la Ley 41 de 1998, General de Ambiente, Artículo 16, conformado por las instituciones públicas sectoriales con competencias ambientales. Estas instituciones están obligadas a establecer mecanismos de coordinación, consulta y ejecución entre sí. La ANAM establecerá los parámetros del Sistema. El objetivo es armonizar las políticas, evitar conflictos o vacíos de competencia, generar respuestas eficientes, coherentes, con base en los lineamientos de la política nacional del ambiente. También se ordena a la ANAM crear y coordinar una red de unidades ambientales sectoriales como órgano de consulta, análisis y coordinación para la evaluación de impacto ambiental (Artículo 17). Esta última es la que ha estado funcionando en alguna medida en la práctica.

76. ANAM (2008). Estrategia Nacional del Ambiente 2008-2012, Págs. 52-53. La Estrategia reconoce que para lograr que la política de supervisión, control y fiscalización se ejecute eficazmente y en definitiva, apuntar al cumplimiento de las normas ambientales, deben fortalecerse las capacidades institucionales (gobernabilidad), involucrar a las comunidades, hacer una mejor y más eficaz divulgación de las normas ("certeza jurídica"), crear y desarrollar incentivos para el cumplimiento normativo, fortalecer los procedimientos o protocolos de actuación, "promover la constante y permanente retroalimentación de la política" para adaptarla. Esto último se traduciría en establecer indicadores de cumplimiento normativo para de forma continua hacer evaluaciones de cumplimiento y efectividad. 


\subsection{Detalle de requerimientos de control forestal explícitos en la Ley Forestal y afines}

La ANAM es la autoridad competente para reglamentar y fiscalizar el manejo, aprovechamiento, transporte, transformación, tenencia y comercialización de los productos forestales provenientes de bosques naturales (Art. 46 de la Ley 1 de 1994).

Además de la exigencia de un previo marcado de árboles, inventario forestal, plan de manejo forestal y estudio de impacto ambiental, es fundamental la guía de transporte, dado que sin ella no se puede transportar producto o subproducto forestal en el territorio nacional.

Los inspectores, guardaparques y guardabosques de la ANAM "ejercerán funciones de protección, y fiscalización para la conservación, manejo, aprovechamiento y transporte de los recursos naturales. La norma establece que se debe coordinar con la fuerza pública, la cual brindará todo el apoyo que sea necesario para cumplir las normativas".

Las industrias o empresas de transformación y utilización de productos y subproductos forestales están obligadas a suministrar anualmente a las entidades del Estado la información y estadísticas industriales que sean solicitadas, con carácter confidencial. La información podrá en cualquier momento ser verificada por los funcionarios de la ANAM.

Los inspectores de la ANAM pueden inspeccionar en cualquier momento productos y subproductos forestales en posesión de las industrias o empresas transformadoras.

Los propietarios de industrias o empresas transformadoras solo pueden extraer, adquirir y recibir productos forestales cuya extracción y guías de transporte hayan sido autorizadas por la ANAM que, además, podrá decomisarlos.

La ANAM podrá a su vez contratar servicios temporales para la detección, prevención, decomiso, vigilancia y aprovechamiento de productos forestales extraídos ilegalmente, y la evaluación de daños y perjuicios ecológicos.

Panamá ratificó el Convenio Regional para el Manejo y Conservación de los Ecosistemas Naturales, Forestales y el Desarrollo de Plantaciones Forestales mediante Ley 14 de 199577, en el marco del Sistema de Integración Centroamericana (SICA). Esta obligatoriedad fue incluida como requisito previo al otorgamiento de permisos o autorizaciones de aprovechamiento forestal en la Ley 1 de 1994, y posteriormente desarrollada a través de la Ley 41 de 1998, específicamente en las reglamentaciones en relación con el proceso de evaluación ambiental, quedando establecido en el año 2009 a través del Decreto Ejecutivo №123, que exige la presentación para aprobación de un estudio de impacto ambiental para proyectos de aprovechamiento forestal en superficies de más de 50 hectáreas.

Otro mecanismo de control son las autorizaciones de aprovechamiento forestal por unidad de manejo que otorga la ANAM, basadas en el plan de manejo, una vez al año, previo al cumplimiento del permiso o concesión, o autorización de aprovechamiento forestal que se haya dado. Los planes operativos anuales describen detalladamente las actividades forestales que se ejecutarán en un

77. Ley 14 de 1995, del 21 de abril de 1995, Gaceta Oficial № 22.769 publicada el 25 de abril de 1995 . El Convenio fue firmado en Guatemala el 29 de octubre de 1993. 
determinado año y también deben ser previamente aprobadas por la ANAM. El incumplimiento del plan de manejo impedirá el otorgamiento de la siguiente autorización anual de aprovechamiento hasta tanto se subsane la situación y este se cumpla a satisfacción [de la ANAM].

Para los trámites de exportación e importación -dependiendo del destino- tiene que tramitarse el certificado de origen a través de la ventanilla única. Por lo general se hace con el corredor de aduanas de acuerdo con la Regla de Origen. El certificado requiere información sobre generales del importador y exportador, descripción de las mercancías, clasificación arancelaria, criterio preferencial, valor contenido regional, factura y país de origen. Asimismo, se firma como una declaración jurada donde la persona interesada declara que la información es verdadera y exacta, posee los documentos de respaldo, el origen territorial es el que se afirma y se cumple con los requisitos de origen. La autoridad que firma, fecha y sella el certificado de origen es otorgada por el Viceministerio de Comercio Exterior $\left(\operatorname{VICOMEX}{ }^{78}\right)$.

El control para exportar-importar productos o subproductos forestales recae en la ANAM, incluyendo los requerimientos cuando se trata de especies incluidas en alguno de los apéndices del CITES, pues se trata de un producto que requiere un trámite especial, que es la Guía de Exportación que emite la ANAM.

\subsection{Determinar la existencia de un sistema de monitoreo de estadísticas forestales y su impacto en la ilegalidad del aprovechamiento forestal}

Las industrias o empresas de transformación y utilización de productos y subproductos forestales están obligadas a suministrar anualmente a las entidades estatales información y estadísticas industriales.

Un concesionario de aprovechamiento forestal sostenible en bosque natural tiene la obligación de informar cuatrimestralmente a la ANAM sobre todas las operaciones forestales, incluyendo medidas de protección, cantidad de viveros, reforestación realizada, volumen total extraído por especie y si ha construido caminos, entre otros. La norma establece el Libro de Registro Forestal, que es obligatorio para todo aquel que se dedique al aprovechamiento, industrialización, comercialización, reforestación, recolección y venta de semillas, o cualquiera otra de estas actividades o bien, que realice estudios técnicos. De acuerdo con el Artículo 8 de la Ley 1 de 1994, el Libro tiene "la finalidad de mantener actualizada las estadísticas".

Sí existe un sistema creado en la ley que en la práctica no se aplica de forma correcta y no es, por lo tanto, eficiente (cámaras de vídeo para monitorear los puestos de control, por ejemplo). Además, hay denuncias por "blanqueo de madera ilegal" a través de los permisos de subsistencia.

78. El Decreto Ley 6 del 2006, del 15 de febrero de 2006, Gaceta Oficial N² 25.491 publicada el 22 de febrero de 2006, reorganiza el Ministerio de Comercio e Industrias y le crea el Viceministerio de Comercio Exterior (VICOMEX). Los Certificados de Origen están destinados exclusivamente a probar el origen de las mercancías, con vistas a satisfacer las exigencias aduaneras o comerciales. Esta acreditación del origen resulta imprescindible para determinar el arancel aplicable a la importación y los regímenes preferenciales derivados de acuerdos bilaterales o multilaterales entre países. 
En la práctica no se ha instalado y puesto a operar un sistema de recolección, procesamiento, validación, análisis y publicación de datos estadísticos. La información está dispersa en consultorías y proyectos concretos, a nivel privado y público.

Cada oficina provincial de la ANAM desarrolla de forma mensual un informe que consolida la información de todas las actividades forestales, incluyendo la movilización de la madera. Estos informes se envían a la central.

La ANAM se encontraba realizando esfuerzos para manejar las estadísticas y la información de una forma integrada, con apoyo de tecnología y con base en un sistema creado para este fin desde hace algunos años (ver Gráfica $N^{\circ} 5$ ).

\subsection{Análisis del control cruzado de certificados de comercio de productos de madera}

El control que existe es que ni la ANA ni el VICOMEX tramitan documentos de exportación de madera si no cuentan con el requisito previo o licenciamiento previo que recae exclusivamente en la ANAM cuando tramita y expide la guía de transporte, la guía de exportación y el permiso o autorización CITES en el caso de especies amenazadas. Los funcionarios en los puestos de control verifican que se cuente con la documentación (hacen reconocimiento de documentos, sellos, firmas) y si detectan algún faltante o inconsistencia, dan aviso a la ANAM y no proceden.

Los inspectores forestales de la ANAM verifican los embarques in situ, siendo ellos los que están habilitados y cualificados para cotejar la documentación con la mercancía y que todo coincida en volúmenes, especies y fechas, entre otros.

En el mercado local, la forma de control ocurre durante el transporte de la madera. Los controles para verificar la procedencia, así como si la cantidad es la que estaba permitida de acuerdo con los permisos/instrumentos aprobados, son relativamente laxos, pues el control y las mediciones son manuales, sin apoyo de tecnología y no se cumple con el uso de la marquilla como ordena la ley.

La Resolución Nª AG-0244-2011 del 21 de abril de 2011 permite el registro de una marquilla ante la ANAM de la madera procedente de bosques naturales que va a ser movilizada o transportada en el territorio nacional.

Reiteramos que todos los instrumentos que la Ley Forestal prevé deben cotejarse y los datos tienen que coincidir. Uno de los aspectos clave es la participación y nivel de los técnicos de la ANAM para elaborar la guía de transporte, pues esta se elabora con base en la medición que se haga (cubicación) de la madera. Como hemos visto, la norma regula las fórmulas de cubicación para madera en tuca, trozas, árboles en pie, semiprocesada, procesada y especialmente porque la ANAM basa los cobros que hace para las guías y demás permisos en el volumen $\left(\mathrm{m}^{3}\right)$ que se obtiene. Además, la cubicación aplica para todos los permisos, concesiones y autorizaciones de aprovechamiento forestal, incluso el permiso de subsistencia aunque no requiera guía de transporte.

La Ley Forestal y la Ley General de Ambiente facultan a la ANAM para que contrate a terceros como inspectores. Esto apoyaría al recurso humano forestal de la ANAM e inclusive -dependiendo de la forma de contratación y las condiciones- podría añadir elementos más rigurosos de control, aprovechando las ventajas que da la norma en cuanto a contar con herramientas técnicas jurídicas que solo deben cumplirse a cabalidad y se avanzaría mucho en el control de la tala ilegal. 


\subsection{Número de las denuncias presentadas por las autoridades del Estado por el delito de actividades forestales ilegales}

Si bien existen registros de acceso público sobre las estadísticas ambientales, estas son insuficientemente detalladas, por lo que no se conoce cuáles denuncias han sido iniciadas por las autoridades, que se conocerían entonces de oficio ${ }^{79}$. Las denuncias ambientales de las cuales se tiene información son de la jurisdicción administrativa (ver Cuadro $N^{\circ} 8$ ).

En la información disponible en los informes de estadísticas ambientales de la ANAM y como puede evidenciarse en la Gráfica N 6, la tala ocupa el primer lugar, incluso en la información de juzgado ejecutor. Una vez que la ANAM sanciona y ordena el pago de una multa, y el obligado a pagar no la cancela en el término establecido, pasa a cobro coactivo automáticamente, donde se inicia un proceso ejecutivo de cobro. Esta información está disponible y como veremos en la Gráfica 7, el tipo de infracción en el juzgado ejecutor más perseguido es la tala -con 39 casos-, seguido de los Estudios de Impacto Ambiental (EsIA), con 37.

En la jurisdicción penal no se encuentran registros oficiales que estén accesibles.

La Fiscalía Ambiental Quinta de Primer Circuito Judicial proporcionó la información del Cuadro N 9 en la que hasta septiembre se investigaban en este despacho, 15 presuntos delitos de tala ilegal, sin contar que pudiera haber delitos de tramitación y cumplimiento (directa o indirectamente a través de incumplimiento del EsIA) también vinculados al aprovechamiento forestal.

Evidentemente la tala ilegal es uno de los retos en justicia ambiental en Panamá, especialmente en el área este (Darién y las Comarcas), donde WWF ha hecho un análisis de por qué el incremento de la tala y comercio ilegal (ver Gráfica $N^{\circ} 8$ ).

79. Algunas notas periodísticas han registrado casos en los que la ANAM ha puesto en conocimiento de una presunta infracción, es decir, ha hecho la denuncia pública, lo cual puede entenderse como una acción de oficio y no por denuncia de un tercero. Ver: Periódico El Siglo Digital Panamá. [sitio web].

<http://www.elsiglo.com/mensual/2013/10/11/contenido/705564.asp>.

'Viceministro denuncia tala "nocturna" de árboles'. La Prensa [periódico online], (26 de abril de 2012). $<$ http://www.prensa.com/uhora/locales/viceministro-denuncia-tala-\%E2\%80\%98nocturna\%E2\%80\%99de-arboles/87683>.

TVN-2.com. [sitio web]. <http://tvn-2.com/noticias/noticias_detalle.asp?id=104229>. 


\section{Análisis de ejecución de procesos judiciales}

\subsection{Análisis de la Ley Forestal y regulaciones afines a la luz de los procesos judiciales existentes en materia de aprovechamiento forestal y comercio internacional de productos forestales}

La Ley Forestal y normas concordantes como la Ley General de Ambiente y la relacionada con la exportación y evaluación ambiental, entre otras, se toman en su sentido literal en los casos que hemos podido evidenciar en la Corte Suprema de Justicia. Tal y como establece el Código Civil, la ley se entenderá en su sentido literal y no hay lugar a interpretaciones.

Panamá cuenta con una extensa cantidad de disposiciones legales que en resumen protegen el patrimonio forestal del Estado, regulan el ordenamiento de las actividades humanas en función de las aptitudes y características de los suelos, reconociendo la aptitud forestal. El procedimiento para otorgar o no otorgar permiso, autorización o concesión de aprovechamiento forestal está claramente establecido, al igual que las competencias institucionales.

Cualquier persona puede acceder a los recursos forestales que la autoridad competente autorice en función de una serie de criterios de sostenibilidad y salud del bosque siempre y cuando cumpla con el marco legal. Así lo han entendido los magistrados y la procuraduría de la administración al fallar a favor de la legalidad, apegados a lo establecido en las normas.

Si no se cuenta con guía forestal, plan de manejo forestal o permisos de subsistencia que cuente con las características y contenido de información que establecen las normas, se está ante una presunta ilegalidad que amerita sanciones.

La Corte solo no ha fallado por omisión de funciones al incumplirse de forma sistemática todo el ordenamiento jurídico que regula el aprovechamiento forestal sostenible. Un resumen de los fallos se presenta en el Anexo 11.

\subsection{Duración de los procesos judiciales relacionados con el aprovechamiento forestal y comercio internacional de productos forestales}

El término legal en la vía penal es de cuatro (4) meses ${ }^{80}$ para la instrucción sumaria de los procesos penales de delitos contra el ambiente. Luego de culminado ese término, el fiscal tiene derecho a solicitar prórroga al tribunal, el cual a veces la concede y señala el término adicional, que podría ser de un mes o hasta que se agote la investigación. También puede ocurrir que se niegue la prórroga.

Es posible que se dé el caso de que se remita en el término de cuatro (4) meses y en el tribunal se demore la notificación, fijación de fecha de audiencia y resolución de este -siendo esto otros cuatro meses-, lo que da un aproximado de ocho (8) meses de duración en total de procesos judiciales en la vía penal.

80. Artículo 2033 del Código Judicial de Panamá. 
En la vía administrativa, la duración de los procesos por medio de denuncia dura aproximadamente treinta (30) días, que es el plazo que se deduce del proceso administrativo según el Decreto Ejecutivo 57 del $2000^{81}$ y el que establece la Ley 38 del $2000^{82}$, de Procedimiento Administrativo que es supletoria en casos de denuncia y principal en investigaciones de oficio (sin denuncia por tercera persona).

La Asesoría Legal de la ANAM cuenta con cinco (5) días hábiles desde que recibe la denuncia para notificar al denunciado que es objeto de una investigación formal por parte de esta entidad. Si la denuncia no procede, tiene cinco (5) días hábiles para notificar al denunciante, con la explicación de por qué no procede. El presunto infractor tendrá un plazo no mayor de diez (10) días hábiles para presentar sus alegatos y pruebas de descargo.

Concluido el plazo para los alegatos, la Administración Regional de la ANAM adoptará una decisión. Contra la resolución de la Administración Regional de la ANAM pueden interponerse recurso de reconsideración, que agota la vía gubernativa, es decir, la contestación que la ANAM dé a este recurso es su posición final y ya solo podría recurrirse ante la Corte Suprema de Justicia (ver Gráfica N²).

\subsection{Jurisprudencia relevante en relación con la compensación por daño ambiental por el delito de aprovechamiento ilegal de productos forestales}

La Ley General de Ambiente, Ley 41 de 1998, establece que la ANAM puede ordenar al infractor de la normativa ambiental el pago del costo de limpieza, mitigación y compensación del daño ambiental sin detrimento de las demás sanciones que puedan imponerse. No se encontraron casos específicos de compensación por daño ambiental por delitos forestales. Sí hay jurisprudencia por tala ilegal e incumplimiento de la legislación forestal vigente.

En la decisión de la Corte, Expediente 660-01, del 9 de marzo de 2005 (Farallón Development Resorts Inc. contra la ANAM), dentro de la demanda contencioso-administrativa de plena jurisdicción, con el fin de que la Sala Tercera de la Corte Suprema de Justicia declarara nula -por ilegal- la Resolución № AG-0011-2001 del 16 de enero de 2001, dictada por el Administrador Nacional del Ambiente, donde la ANAM multaba a la empresa demandante y ordenaba la compensación por la tala de 1,2 hectáreas de mangle y 6 hectáreas de rastrojos, la Corte falló a favor de la ANAM, la cual-además de la multa- ordenó la compensación a través de la reforestación de 10 hectáreas que debía contar con su respectivo plan de reforestación. La infracción se dio por talar sin los permisos correspondientes que exige la normativa forestal. La empresa era reincidente.

Otra jurisprudencia que reconoce la facultad que tiene la ANAM de ordenar la compensación por daño ambiental es la del 26 de noviembre de 2008 (Desarrollos del Golf, S.A. contra la ANAM), dentro del proceso contencioso-administrativo en la Sala Tercera de la Corte Suprema de Justicia (Expediente

81. El Decreto Ejecutivo 57 del 2000, del 16 de marzo de 2000, Gaceta Oficial N²4.014 publicada el 21 de marzo de 2003, reglamenta la conformación y funcionamiento de las Comisiones Consultivas Ambientales, Título V de las denuncias por infracciones administrativas a la ley, Arts. 51 al 66.

82. La Ley 38 del 2000, del 31 de julio de 2000, Gaceta Oficial N²4.109 publicada el 2 de agosto de 2000 , regula el procedimiento administrativo general y crea la Procuraduría de la Administración, Art. 40.1. 
410-06) para que se declare nula por ilegal la Resolución N ADMR-PM-046-2005 dictada por la Administración Regional de la ANAM Metropolitana. La Resolución demandada de ilegal sancionaba a la empresa demandante con una multa por la infracción de cinco mil dólares $(\$ 5,000)$ y un monto en concepto de indemnización ecológica por la suma de cuarenta mil seiscientos dólares $(\$ 40,600)$ "por la remoción de 4,64 hectáreas de bosque secundario con bosque intermedio y 53,36 hectáreas de remoción de gramíneas para el desarrollo del proyecto Villas del Golf II”. En este caso se sienta el precedente de que la ANAM tiene facultad legal para imponer sanciones por infracción a las normas legales e indemnización ecológica.

La responsabilidad objetiva, de igual forma, está definida como la "obligación del que cause daño o contamine, directa o indirectamente, a las personas, al medio natural, o a las cosas, de resarcir el daño y perjuicios causados" (Art. 2) y todas las personas tenemos el deber, estamos obligadas a prevenir el daño ambiental y controlar la contaminación ambiental (Art. 106).

Panamá cuenta con las herramientas legales para que la autoridad competente en la jurisdicción administrativa, así como los operadores de justicia en el ámbito judicial, puedan exigir la reparación del daño causado por aprovechamiento forestal ilegal.

\subsection{Tipos de penas existentes en la legislación y su vinculación con la ilegalidad en el comercio de madera (penalidades en el ámbito administrativo y judicial)}

De acuerdo con la Ley General de Ambiente, Ley 41 de 1998, la Autoridad Nacional del Ambiente tiene la facultad de imponer sanciones que pueden ser pecuniarias (multas), amonestaciones (verbales o escritas), suspensión provisional de la obra, proyecto o actividad, incluso el cierre definitivo (Art. 7.19), conforme lo que establece la propia ley y las demás normas concordantes. De igual forma, la ANAM puede interponer sanciones $u$ ordenar la suspensión de obras, proyectos o actividades cuando hay incumplimientos en el proceso de evaluación ambiental (Art. 30). Esta autoridad tiene la facultad de sancionar cualquier actividad, pública o privada, "que provoque o pueda provocar degradación severa de los suelos", además de ordenar que se tomen acciones para la recuperación o mitigación de los suelos (Art. 76). La actividad forestal requiere -a partir de 50 hectáreas- la presentación de un estudio de impacto ambiental y la actividad de aprovechamiento forestal que por su naturaleza puede provocar afectación a los suelos.

La Ley General de Ambiente desarrolló un sistema de triple responsabilidad y responsabilidad objetiva para enfrentar los riesgos y daños contra el ambiente. En cuanto a la responsabilidad objetiva, la ley claramente determinó que se trata de la obligación para cualquier persona que causa daño o contamine, directa o indirectamente, a personas, medio natural, bienes materiales o cosas, de resarcir el daño y los perjuicios causados (Art. 2). Esto implica que la propia ley reconoce que hay obligación de reparar, compensar e indemnizar por daños o riesgos al ambiente ${ }^{83}$.

83. El ambiente es definido en la Ley General de Ambiente de la República de Panamá como el "conjunto o sistema de elementos naturales y artificiales de naturaleza física, química, biológica o sociocultural, en constante interacción y en permanente modificación por la acción humana o natural, que rige y condiciona la existencia y desarrollo de la vida en sus múltiples manifestaciones", Art. 2. 
La responsabilidad ambiental está desarrollada en el Título VIII de la Ley General de Ambiente y en armonía con preceptos constitucionales del Régimen Ecológico, establece que todas las personas en la República de Panamá tienen el deber de prevenir daños y controlar la contaminación ambiental (Art. 106). Este tipo de responsabilidad es triple, por cuanto se reconoce que puede ser civil, penal o administrativa según sea el caso (Art. 107). "La responsabilidad administrativa es independiente de la responsabilidad civil por daños al ambiente, así como de la penal” (Art. 111).

Se considera legitimado para accionar por cualquiera de las tres vías, administrativa, civil o penal, cualquier individuo o grupo de personas u organizaciones, con base en los intereses difusos o colectivos (Art. 111).

La violación a la Ley General de Ambiente es considerada una infracción administrativa a priori, lo que la ANAM puede sancionar con multas de hasta un millón de dólares $(\$ 1,000,000)$ y el Consejo Nacional del Ambiente hasta por diez millones de dólares $(\$ 10,000,000)$. El cálculo de la multa se formula dependiendo de la gravedad de la infracción, si hay reincidencia, entre otros que establezcan disposiciones concordantes.

Además de la sanción pecuniaria, la ANAM puede ordenar el pago del costo de limpieza, las acciones de mitigación y compensación del daño ambiental (tiene que haberse comprobado un resultado). Esta facultad es independiente de la responsabilidad civil y penal que correspondan (Art. 114).

La Ley General de Ambiente establece la obligatoriedad del proceso de evaluación de impacto ambiental para toda actividad, obra, proyecto que "por su naturaleza, características, efectos, ubicación o recursos pueden generar riesgo ambiental". El estudio de impacto ambiental debe presentarse previo a cualquier acción (Art. 23, reglamentado por el Decreto Ejecutivo 123 del 2009). Si se incumple el proceso de evaluación o con el estudio de impacto ambiental aprobado por la ANAM y se produce contaminación, se genera responsabilidad civil, administrativa o penal (Art. 107).

En cuanto a reparar el daño al ambiente (o a la salud) causado por uso o aprovechamiento de un recurso natural, hay obligación de quien resulte responsable de causar el daño de repararlo mediante medidas de mitigación y prevención. Todos los costos deben ser asumidos por esta persona, sea natural o jurídica.

La Ley General de Ambiente estipula que la Ley Forestal, Ley 1 de 1994, es concordante con ella. En relación con las sanciones, la Ley Forestal determina que se infringe la legislación que regula el aprovechamiento forestal en los siguientes casos:

- Aprovechamiento forestal sin autorización (Art. 94.1).

- Incumplimiento de las obligaciones legales que surgen de los permisos, concesiones, autorizaciones y los planes de manejo forestal (Art. 94.2).

- Tala, allanamiento, envenenamiento sin permiso de la ANAM (Art. 94.3).

- Incumplimiento de normas sobre incendios y plagas (Art. 94.4).

- Destrucción o alteración de linderos y señales que haya establecido la ANAM (Art. 94.5), los cuales deberá pagar en 100\%.

- Adquirir, transportar, transformar y comercializar productos y subproductos forestales sin los permisos respectivos expedidos por la autoridad competente (Art. 94.6). 
- Negarse a entregar a la autoridad competente información sobre el origen, aprovechamiento, transformación, comercialización y transporte, y/o impedir las inspecciones a estos productos (Art. 94.7).

- Talar a orillas de ojos de agua, lagos, lagunas, ríos, quebradas (Art. 94.8).

- Cualquier otro incumplimiento a la Ley Forestal (Art. 94.9).

Si ocurre que el infractor es reincidente, la ANAM tiene la potestad legal de imponer el doble de la sanción de la anterior y podrá inhabilitarlo para ser sujeto de permisos o concesiones de aprovechamiento forestal ni negociar con la autoridad por un término no inferior a 5 años ni mayor a 20 (Art. 96).

Una vez la ANAM comprueba la ilegalidad en materia forestal, puede ordenar la retención y decomiso de los productos aprovechados de forma ilegal (Art. 97). Los productos decomisados pueden ser utilizados por la ANAM o vendidos mediante subasta de acuerdo con el procedimiento legal existente.

Con la Ley Forestal también se faculta a la ANAM para sancionar cuando se declare menos madera o productos o subproductos forestales. La multa puede ser por el doble del valor que no se declaró, además de exigirse el pago de los impuestos omitidos.

La multa por infracciones a la Ley Forestal en zonas de humedales, ecosistemas frágiles o exclusivos, áreas de investigación, de árboles semilleros o manejadas con fines especiales, o bosques de protección especial o con pendientes superiores al 100\% de declividad puede ser el doble de los montos indicados. La sanción impuesta va a depender de si hay o no otras leyes especiales que establezcan otras sanciones u otros montos.

Los productos o subproductos que no lleven la marquilla correspondiente para su movilización acarrearán multa por un monto no inferior a veinte dólares (\$20) por metro cúbico en rollo o de treinta y cinco dólares (\$35) por metro cúbico procesado o por tonelada.

La Ley Forestal faculta a la ANAM para sancionar por falta de guía de transporte con la retención y una multa no menor a veinte dólares (\$20) por metro cúbico en rollo o de treinta y cinco dólares (\$35) por metro cúbico en bloque procesado o por tonelada. En este caso de infracción por incumplimiento de la guía forestal, los productos o subproductos forestales se devuelven siempre y cuando estos sean de procedencia legal.

Dar información falsa a la ANAM o negarse a brindar aquella que involucre tala, transporte, venta o el procesamiento de productos y subproductos forestales puede conducir a multa de mínimo treinta dólares (\$35) por metro cúbico en rollo o de cincuenta dólares (\$50) por metro cúbico procesado, semiprocesado o por tonelada.

Otra infracción administrativa por violaciones a la Ley Forestal es la transferencia de los derechos de los permisos, contratos o autorizaciones de aprovechamiento forestal, que conllevará a la anulación de estos documentos más multa de mínimo veinte dólares (\$20) por metro cúbico en rollo o treinta dólares (\$30) por metro cúbico si está procesada o semiprocesada, o por tonelada métrica aplicable a todos los volúmenes talados en estas condiciones de ilegalidad.

Violar los límites de los perímetros de las áreas para el aprovechamiento forestal autorizado o de las unidades de manejo genera multas a razón de cien dólares $(\$ 100)$ por kilómetro cuadrado no 
delimitado. De igual manera, se sanciona al que se exceda del margen de tolerancia de volúmenes anuales de aprovechamiento si estos fueron establecidos con anterioridad. En estos casos se paga un recargo calculado sobre el precio del producto. Si el exceso es superior al $100 \%$, además la sanción implica el decomiso de la madera (se entiende el excedente ilegal).

La ANAM también podrá sancionar el aprovechamiento forestal de una unidad de manejo forestal, aprobada en un plan de manejo, sin la debida autorización (se da para cada unidad de manejo, individualizado). El incumplimiento del plan de reforestación también puede ser sancionado con multa, al igual que el incumplimiento del manejo de la regeneración.

La reincidencia puede suponer la exclusión del Libro de Registro Forestal por un período de entre 5 y 20 años, dependiendo de la sumatoria de las multas que acumule. Para los pequeños taladores implica la exclusión del Registro Forestal a razón de 1 año por cada mil dólares $(\$ 1,000)$ de multa impuesta o si cometió dos o más infracciones en menos de un año.

El Estado podrá cobrar al infractor, cuyo incumplimiento de las normas y regulaciones implique plagas, enfermedades e incendio, $25 \%$ del costo en el que incurra para controlar y combatir estos, sin afectación del derecho a exigir indemnización al infractor.

El Código Penal de la República de Panamá ${ }^{84}$ incorpora tipos penales directamente relacionados con la tala ilegal y el aprovechamiento forestal ilegal (ver Anexo 10). El régimen aduanero y el de sanidad vegetal también contemplan sanciones administrativas y penales por incumplimiento a sus respectivas normativas.

Las violaciones al CITES pueden ser investigadas y procesadas por la ANAM en la jurisdicción administrativa aplicando las sanciones descritas anteriormente. En la jurisdicción penal, todos los tipos penales descritos incluyen como agravante que la especie esté listada como protegida, aumentándose la pena de un tercio a la mitad. Las especies protegidas serán las contenidas en los apéndices CITES, en la lista de especies protegidas establecida por la ANAM y en la Lista Roja de la Unión Internacional para la Conservación de la Naturaleza (UICN), a criterio del juzgador, que tendrá que remitirse a las normas existentes dado que los tipos penales son parcialmente en blanco y por ende, de reenvío.

\subsection{Número de casos presentados y número de casos desestimados o con sentencia condenatoria para el período 2008-2013}

De acuerdo con los datos de la Contraloría General de la República, Instituto de Estadísticas y Censo, los casos registrados como "delitos ecológicos" en el período 2007-2009 fueron de un total de 419 en el 2007, 384 en el 2008 y 314 en el 2009, siendo el Distrito Judicial I el de mayor incidencia de casos. Panamá tuvo 86 casos en el 2009, 146 en el 2008 y 113 en el 2009. La provincia de Darién (que es una de las provincias donde más masa forestal o bosques se encuentran en la República de Panamá, provincia en la que se encuentra además la Comarca Emberá-Wounaan) contó por su parte

84. Adoptado por la Ley 14 del 2007, con las modificaciones y adiciones introducidas por la Ley 26 del 2008 , Ley 5 del 2009, la Ley 68 del 2009 y la Ley 14 del 2010, publicada en Gaceta Oficial N² 26.519 del 26 de abril de 2010. 
con un registro de 41 casos en el 2007, 58 en el 2008 y 31 en el $2009^{85}$. En el año 2010 la cifra total de "delitos ecológicos" registrados fue de 181. Darién con 27 casos y Panamá con $54^{86}$.

Otra cifra que se maneja de forma pública en relación con los delitos contra la vida silvestre, específicamente contra la vida ecológica, es 101 para el año 2009 y 143 para el año 2010, de acuerdo con los registros del Informe de Criminalidad del $2010^{87}$.

La organización de la sociedad civil Alianza Ciudadana Pro Justicia, en su análisis de auditoría ciudadana sobre la justicia penal en Panamá, reportó que las denuncias registradas por supuestos delitos contra el ambiente en el año 2008 fue de 73, de 47 en el 2009 y de 66 en el año 2010. Basado en esto, se genera una gran interrogante de por qué las cifras no coinciden. Si tomamos los datos del Informe de Criminalidad del 2010, podríamos inferir que en el 2009 sí hubo 47 casos de denuncia; 54 fueron de oficio. $Y$ en el 2010 serían entonces 77 casos de oficio, tomando en cuenta que las denuncias presentadas fueron 66, según la Alianza. En realidad, esto es un ejercicio meramente especulativo, porque al no haber información suficiente es muy difícil determinar si las denuncias generaron una investigación y si esta derivó en un encausamiento.

En ninguna de estas publicaciones se desglosa en función de los delitos, por lo que no está a disposición pública el número de delitos investigados, sobreseídos o condenados por tala ilegal. Aunque se afirma que estos han incrementado, por ejemplo del 2007 al 2009, “(...) conductas lesivas al ambiente, las cuales según las estadísticas reflejan un incremento en relación a los años 2007, 2008 y lo que resta (...) de 2009, sobre todo en los delitos Contra los Recursos Naturales"88.

Con relación a las estadísticas de números de casos y casos desestimados o con sentencia del 2008 al 2013 por tala ilegal y aprovechamiento forestal ilegal, el Ministerio Público reportó a través de la Fiscalía Quinta Ambiental del Primer Circuito Judicial de Panamá que está trabajando en ello y no hay acceso público a esta información desglosada en los recursos digitales disponibles.

85. Contraloría General de la República de Panamá (2005-2009). Instituto Nacional de Estadística y Censo. Boletín de Estadísticas Ambientales período 2005-09, cuadros 109 y 110. [pdf online].

<http://www.contraloria.gob.pa/inec/Publicaciones/Publicaciones.aspx?ID_SUBCATEGORIA=49\&ID_ PUBLICACION=354\&ID_IDIOMA=1\&ID_CATEGORIA=16>. Accedido el 4 de diciembre de 2013.

86. Contraloría General de la República de Panamá (2010). Instituto Nacional de Estadística y Censo. Boletín de Estadísticas Ambientales período 2006-10, cuadro 112. [pdf online]. <http://www.contraloria.gob.pa/ inec/archivos/P5161112.pdf>. Accedido el 4 de diciembre de 2013.

87. Ministerio de Seguridad Pública (2010). Sistema Nacional Integrado de Estadísticas Criminales (SIEC), Pág. 12.

88. Ruth Morcillo, Fiscal Quinta de Circuito, Primer Circuito Judicial de Panamá. Morcillo, R.M. (2009). 'La investigación del delito ecológico en Panamá'. Pág. 32. [pdf online]. <http://www.pnuma.org/deramb/ actividades/jornadaderecho/presentaciones/la_investigacion_del_delito_ecologico_en_panama.pdf>. Accedido el 4 de diciembre de 2013. 


\subsection{Análisis de retos en el ámbito judicial en materia de aprovechamiento forestal y comercio internacional de productos forestales}

La Ley General de Ambiente, en su Artículo $122^{89}$, crea la Fiscalía Superior del Ambiente con sede en la provincia de Panamá, así como cinco fiscalías superiores: (i) Colón y Guna Yala (comarca), (ii) Panamá, (iii) provincias centrales, (iv) Chiriquí y Bocas del Toro, y (v) Darién, con el objetivo de que investiguen los delitos contra el ambiente. Estas fiscalías no han sido designadas ni puestas en operación.

El Ministerio Público ha asignado la investigación de los delitos contra el ambiente a algunas fiscalías ya existentes, como la quinta, la undécima y la duodécima, así como las de Chiriquí y Bocas del Toro, mediante Resolución № 8 del 25 de agosto de 2000 y la Resolución N 25 del 15 de julio de 2010. Estas fiscalías no solo atienden los delitos contra el ambiente, sino casos de robo, hurtos y corrupción, entre otros.

Algunos retos señalados por funcionarios del Ministerio Público son la dificultad de probar el daño ambiental y la de encontrar peritos que no le cuesten tantos recursos al Estado, para lo cual han establecido convenios con la ANAM, la Universidad Tecnológica, el Instituto Smithsonian de Investigaciones Tropicales y organizaciones no gubernamentales, con el fin de consolidar y fortalecer un banco de datos de peritos.

Un gran problema es la falta de fiscalías especializadas, donde no solo el fiscal esté entrenado en el derecho ambiental, sino todo el personal que -de una forma u otra- se encuentre vinculado con la investigación de los delitos contra el ambiente. Las fiscalías no cuentan con personal especializado y al no manejar el tema de forma exclusiva, deben diluirse y compartir las habilidades investigando otros tipos de delitos que no están relacionados con la materia ambiental.

Es fundamental que el personal del Ministerio Público se capacite constantemente de forma sistemática en ambiente y recursos naturales para una mejor aplicación de la ley y mayor desempeño en sus funciones. Se debe invertir en herramientas tecnológicas que faciliten su labor de investigación ${ }^{90}$. De igual forma, es importante que los funcionarios de la ANAM, tanto de las oficinas centrales como las regionales, reciban capacitación sobre derecho ambiental, derecho

89. Un antecedente de los delitos contra el ambiente y las fiscalías de instrucción citado por el Ministerio Público es la Resolución N 43/I2I de 1990 dictada dentro del marco del VIII Congreso sobre la Prevención del Delito y el Tratamiento del Delincuente de la Organización de las Naciones Unidas.

90. En materia ambiental se elaboró en Panamá por parte de una ONG de conservación de ambiente una Guía de Análisis de Delitos contra el Ambiente para facilitar la búsqueda de normas administrativas al analizar los tipos penales parcialmente en blanco que remiten a estas. MARVIVA. 'Manual de Acceso a la Información y Participación Ciudadana en Temas Ambientales'. [pdf online], (2012). <http://www.marviva.net/index. php/es/nuestro-trabajo/publicaciones/doc_download/63-guia-de-analisis-de-los-delitos-contra-elambiente>. Accedido el 4 de diciembre de 2013. Panamá pertenece también a la Red de Fiscales Ambientales, lo cual le permite trabajar con sus homólogos en el intercambio de experiencias y colaboración en materia ambiental. Red de Fiscales Ambientales de Centroamérica, Panamá y Procurador Ambiental de República Dominicana. 'Estatutos de la Red de Fiscales Ambientales de Centroamérica, Panamá y Procurador Ambiental de República Dominicana'. [pdf online].

$<$ http://consejodeministeriospublicoscentroamericano.com/PDFS/CONVENCIONES_N/RED_DE_ FISCALES_AMBIENTALES_DE_CENTROAMERICA.pdf $>$. Accedido el 4 de diciembre de 2013. 
penal ambiental y específicamente en material forestal, especialmente los funcionarios de otros departamentos que tienen injerencia como asesoría legal.

En cuanto a los retos en el ámbito judicial para perseguir delitos forestales, estarían en primer plano la cubicación y/o cuantificación de la madera para poder verificar su procedencia ilícita, cruzando la información con los permisos, las guías forestales y las marquillas. Se deben crear y/o fortalecer protocolos de actuación para descartar falsas o fraudulentas inspecciones, guías de transportes adulterados y permisos que no corresponden. Otros de los aspectos a considerar son la falta de control administrativo eficiente, la puesta en funcionamiento de las cámaras de vídeo que transmitían 24/7 desde puestos de control clave, el uso de este tipo de tecnología que monitoree de forma permanente los controles, así como dispositivos que den señal por satélite de la ubicación exacta de las personas con autorización, permiso o concesión y de los transportes utilizados. También se debe incorporar la tecnología en las marquillas, introduciendo -por ejemplo- códigos de barras (scanning bar codes) que puedan verificarse por escáner en tiempo real. Una mayor tecnología, mejores sistemas de información y accesibilidad facilitarán la verificación.

La gobernanza forestal debe generar herramientas eficientes para enfrentar las prácticas irregulares, como el incumplimiento sistemático de las normas, prácticas corruptas, abuso de poder, comercio ilegal y detener o minimizar "la conversión ilegal de los bosques y la explotación irracional"1".

Existen iniciativas para el comercio internacional, las cuales buscan "desarrollar un sistema de licencias madereras" que garantice el comercio internacional solo de madera autorizada que haya sido extraída, procesada, transportada y exportada de forma legal. Los mercados internacionales se pondrán cada vez más estrictos, por lo que entre los retos está verificar paso a paso la cadena de custodia y un sistema de trazabilidad de la madera que sea operativo y eficiente en la práctica (Plan de Acción para Acuerdos de Asociación Voluntaria con la Unión Europea, por ejemplo) ${ }^{92}$.

91. FAO y OIMT (2010). La observancia de la legislación forestal y la gobernanza de los bosques en los países tropicales. Una evaluación región por región del estado de la observancia de la legislación forestal y la gobernanza de los bosques en los países tropicales, y mejoras recomendadas, Págs. 4-28.

92. ibid. Pág. 6. 


\section{Aportes adicionales}

\subsection{Análisis de la situación legal-administrativa para el aprovechamiento de la madera y comercio internacional de productos forestales}

En Panamá, la ANAM es la entidad autónoma encargada de manejar, gestionar, regular, ordenar, inventariar y proteger los recursos forestales del país. Tiene funciones en distintos niveles de intervención: político, legal, técnico y de extensionista forestal, porque debe promover el aprovechamiento forestal como una actividad productiva; además tiene el papel de supervisorfiscalizador, sancionador y educador.

Su ámbito de acción es en todo el territorio nacional, pero su alcance es internacional, ya que no puede salir ni entrar madera de Panamá sin los controles de la ANAM. Para exportar es requisito sine qua non contar con una guía de exportación que -para obtenerla- debe contar con la verificación de la mercancía en el puesto de salida por parte del inspector forestal de la ANAM. Sin su firma y sello, el trámite no pasa por aduanas. Tampoco lo hace si no se realizan los pagos respectivos dependiendo del cubicaje de la madera.

En el caso del comercio exterior de especies amenazadas listadas en CITES, la ANAM también es la entidad que debe otorgar el permiso de acuerdo con los procedimientos que establece la propia Convención.

Asimismo, tiene como función certificar, avalar y asegurar de forma oficial y con apego a las normas qué producto forestal o subproducto cumple con las normativas nacionales, porque cuenta con todos los requisitos que la ley establece; esto frente a los requerimientos en Estados Unidos (Lacey Act) o la Unión Europea (FLEGT).

El Ministerio de Desarrollo Agropecuario (MIDA) tiene una participación muy puntual sobre normas de sanidad basadas también en convenios internacionales para no propagar plagas ni enfermedades. No obstante, sigue siendo la ANAM la que debe hacer constar que la madera no es producto de tala o aprovechamiento ilegal.

Probablemente, la cantidad importante de normas existentes relacionadas con el sector forestal ha sobrepasado la capacidad institucional y toma sentido la propuesta desde un subsector forestal (reforestadores) de que las funciones sean compartidas entre la ANAM y otra institución o crear una nueva entidad.

Hasta que haya cambios en la legislación nuevamente, hay más de veinte normas que cumplir. La ANAM requiere dar nuevo impulso a la coordinación interinstitucional para poder apoyarse en otras entidades no solo para perseguir infractores, sino para incentivar buenas prácticas de manejo forestal y cumplimiento normativo (incentivos). 


\subsection{Retos y oportunidades jurídicas, y estrategias de fortalecimiento en el corto y largo plazo para el aprovechamiento de la madera y comercio internacional de productos forestales}

Si Panamá toma la decisión de priorizar la Unión Europea como un destino para exportar madera importante para el sector, es el momento de revisar objetivamente cuáles son las trabas para cumplir con las normas. Ya ha habido experiencia en el país sobre perder acceso a mercados porque solo se cuenta con un listado de normas que no se cumplen. FLEGT es una oportunidad de redireccionar recursos para mejorar la manera en que se hacen cumplir las normas más elementales -como el ordenamiento territorial en función de los bosques y las especies de interés comercial, considerando las distintas jurisdicciones (tierras comarcales, privadas y áreas protegidas, entre otras)- e introducir tecnologías para todos los procedimientos, tanto trámites como control posterior. Se requiere más recurso humano capacitado a nivel institucional (no solamente en la ANAM) y en las comunidades, especialmente si estas van a incursionar en el manejo forestal sostenible o aprovechamiento forestal sostenible dentro de la Estrategia REDD+.

Es fundamental revisar de forma exhaustiva todos los trámites para simplificar donde se pueda, así como los costos. En este momento es más económico y más simple aprovechar el bosque con permisos de subsistencia, que son comercializados con un procedimiento normado por la propia ANAM que seguir todo el procedimiento legal para formalizar una actividad. Esta área gris debe ser eliminada legalmente.

Para ayudar al estudio de las normas, Panamá podría en el corto plazo crear un listado/código de revisión o algún tipo de formato más amigable que ayude a compilar todas las normas existentes en materia forestal, las cuales están disgregadas en resoluciones administrativas y que para su conocimiento y estudio deben conocerse las reglas de hermenéutica legal.

En el tema de información y estadísticas también tiene que ordenarse el sistema y nombrar dentro de la institución un grupo técnico que se dedique a tiempo completo a esta labor de modo que pueda depurar la información hasta la fecha.

CITES merece un manual para su propio procedimiento y que la información esté disponible no solo para el público, sino para facilitar la toma de decisiones.

En el corto plazo es primordial verificar todo el diagrama de flujo para medir la madera en cualquiera de sus formas, porque esta información es fundamental para garantizar un manejo sostenible de los bosques.

Los bosques de producción deben estar plenamente identificados y geo-referenciados, así como los árboles tienen que pasar de ser punteados a mano en un mapa a ser geo-referenciados.

Aplicando la normativa existente y haciendo una valoración de los avances y las trabas se podrá generar un sistema de indicadores que ayude a la autoridad competente a gestionar con amplitud de maniobra y menos reacción.

El sector forestal debe considerar seriamente que las normas no necesitan otras normas para aplicarse, sino herramientas -ya sea en recursos humanos, voluntad política, disposición a cumplir y tecnología- como elementos clave, sin detrimento de que existan otros. La normativa que se 
requiera fluirá cuando se necesite. No es que no se requiera normar, pero sí tener cuidado de no generar una pluralidad que dificulte precisamente su aplicación.

\subsection{Sugerencias a futuro para fortalecer la legalidad del proceso de aprovechamiento de la madera y comercio internacional de productos forestales, y con ellos la conservación y aprovechamiento sostenible de los bosques}

Las prácticas de aprovechamiento forestal se alejan un tanto de la sostenibilidad. La institucionalidad debe ser fortalecida, y la ANAM tiene que esforzarse para implementar las políticas y el marco normativo vigente. Las comunidades indígenas, afro y campesinas deben ser capacitadas para el manejo forestal y el monitoreo. Asimismo, es fundamental conseguir una cadena de valor plenamente funcional, conectando todos los eslabones e impulsarse la voluntad de armarla, logrando la agregación de actores. En las comarcas hay más de 250.000 hectáreas con potencial para aprovechamiento forestal sostenible que requiere personal que maneje técnicamente los aprovechamientos forestales y tenga preparación en manejo silvicultural. Los inventarios forestales y el aprovechamiento sostenible están muy bien planteados en el papel aunque en la práctica están muy distantes; estas distancias deben recortarse.

Los bosques tienen que ser entendidos primero como patrimonio clave que debe ser protegido por sus facultades como hábitat, banco de biodiversidad y sumidero o captador de $\mathrm{CO} 2$, también como fuente de riqueza forestal que redunda en beneficios económicos cuando el aprovechamiento puede ser bien manejado, siempre que el bosque permita la producción sostenible.

A lo largo de los años, Panamá ha desestimado la vocación natural de los suelos y no ha sido muy estricto en el cumplimiento de estándares legales, dejando las malas prácticas forestales impunes de cualquier sanción que hubiera fortalecido el ánimo de colaboración y cumplimiento normativo que permitiera el aprovechamiento forestal sostenible. Esta es una oportunidad para el país, porque a priori pudieran verse cambios sustanciales tan solo con el cumplimiento de las normas más relevantes.

Se requiere una política forestal integrada y en armonía con las demás políticas de desarrollo, también más voluntad de acción de los actores políticos para lograr superar los retos y generar casos de éxito en el aprovechamiento forestal sostenible en Panamá.

Una opción que plantean algunos especialistas es recuperar suelos degradados con reforestación de especies nativas es una alternativa económica que ayudaría al aprovechamiento forestal sostenible de bosques naturales, ya que baja la presión sobre estos y genera riquezas.

Para que el aprovechamiento forestal de un bosque natural sea sostenible se ha estudiado que deben aprovecharse (extraer) por hectárea un máximo de 6 árboles, dependiendo de las características del área, la especie y las condiciones para la extracción, el inventario que ha determinado la condición de la especie -específicamente determinando cuáles no tienen que tocarse, porque son semilleros-, entre otras. Esto debe aplicarse de forma que el retorno de la inversión no se realice sacrificando el patrimonio forestal. Además, exige buenas prácticas y respetar los ciclos de corta. 
En Panamá existe por lo general un marco regulatorio adecuado para el aprovechamiento forestal sostenible que necesita esfuerzos y procedimientos para su correcta aplicación y el Estado debe invertir en mecanismos de control de subjetividades por parte de los servidores públicos relacionados con los procedimientos.

Existe una oportunidad de identificar fondos de inversión que acepten menor ganancia y mayor riesgo, pero que a su vez quieran como resultado la protección del bosque (Impact Investors o multilaterales o mixtos).

En el fondo, es un problema sistémico: cómo lograr alinear un sistema político que crea un marco económico que requiere altas ganancias con un sistema natural y social que permite ciertas ganancias o bajas ganancias si se maneja sosteniblemente.

Funcionaría si hay fondos disponibles que paguen por el valor intangible de los bosques, como está ocurriendo en otros países -por ejemplo en la Unión Europea- donde se reconoce lo que se denomina "Green Infrastructure" o infraestructura verde, en la que el Estado paga por la infraestructura que necesita para funcionar (carreteras, puentes, desagües, sistemas de agua y de saneamiento, entre otros, es decir, toda la infraestructura básica de un país) y además empieza a reconocer que son básicos y esenciales el aire, la biodiversidad y la capacidad de la tierra de proveer agua. Entonces se paga también por esta infraestructura, como bosques y ríos. Otros países tienen ya medidas ambientales en esta línea (es el caso de Alemania). Los bosques en las selvas del Darién, por ejemplo, son infraestructura verde y se debe lograr compensar, estimular e impulsar buenas prácticas de manejo forestal sostenible.

Es muy importante cuantificar cuánto vale realmente el bosque para que el Estado pueda incluirlo en sus cuentas ambientales, macro y micro, y generar mecanismos basados en esto para incentivar y apoyar actividades de aprovechamiento forestal sostenible, además de otras actividades alternas como una opción económica para las comunidades rurales y las comarcas indígenas y/o tierras colectivas que puedan hacer un uso sostenible de recursos disponibles sin la presión de una tasa de rentabilidad que atente contra el patrimonio forestal.

La distorsión que hay en las cuentas nacionales también debe corregirse, en el sentido de que la tabla de compensación por afectación de un bosque no se ajusta al concepto de infraestructura verde de un país. Esta tabla tiene que basarse en el valor real de los activos de las empresas... sí, de las empresas extractoras que deberán pagar el costo real por destrucción de la selva, de forma indirecta, a través del abuso de los permisos de subsistencia y permisos comunitarios.

El bosque natural tiene diferentes capacidades de producción en espacios y en accesos. Por lo tanto, resulta importante acompañar estos procesos de análisis participativos y divulgación sobre las actividades que no son sostenibles y se consideran mal negocio, porque sencillamente las condiciones y la aptitud de los suelos no funcionan con actividades incompatibles y producen pérdidas para todos, ya que no mantienen intactos los servicios ambientales que dan los bosques, como suelos no degradados y agua.

Producir valores a los humanos y a la población, y a la vez valores ambientales es fundamental; esta sería la meta. 


\section{Bibliografía}

ANAM (1999). Informe Ambiental de Panamá.

ANAM (2000). Inventario forestal de la República de Panamá de 1947 al año 2000.

ANAM (2004). Informe Ambiental de Panamá.

ANAM (2008). Estrategia Nacional del Ambiente 2008-2012.

ANAM (2008). Plan Nacional de Desarrollo Forestal: Modelo Forestal Sostenible.

ANAM (2009). Compendio estadístico ambiental.

ANAM (2009). Estrategia de Reducción de Emisiones Provenientes de la Deforestación y Degradación de Bosques de la República de Panamá aprobada por el Banco Mundial y Naciones Unidas.

ANAM (2009). Informe Ambiental de Panamá.

ANAM (2010). Cuarto Informe Nacional de Panamá ante el Convenio sobre la Diversidad Biológica.

ANAM (2011). Compendio estadístico año 2011.

ANAM (2011). Indicadores ambientales de la República de Panamá.

ANAM, CATIE, WWF, FORMIN FINLAND-FI (2011). Aprendizajes en manejo forestal comunitario. Comarca Emberá-Wounaan, Darién, Panamá.

ANAM, WWF, Congreso General Emberá-Wounaan (2010). Estrategia institucional para la prevención y control de la tala ilegal en los bosques de Darién en Panamá.

Arauz, C.A., Pizzurno, P. Nacionalismo y radicalismo (1956-1968). Un gobierno difícil, en una época de recesión económica. El desgaste del modelo oligárquico y los Proyectos de Tratados RoblesJohnson. El Gobierno de Torrijos (1968-1981) para el Diario Crítica, Editora Panamá América.

Asamblea Nacional (1966). Actas de discusión de segundo y tercer debate para la aprobación de la Ley Forestal de 1966.

Asamblea Nacional (1992). Informe de Primer Debate de la Comisión de Ambiente y Desarrollo sobre el Proyecto de Ley $N^{\circ} 27$ "por la cual se establecen incentivos y se reglamenta la actividad de reforestación en la República de Panamá”, fechado 13 de octubre de 1992.

Asamblea Nacional (1992). Actas de discusión de segundo y tercer debate para la aprobación de la Ley Forestal de 1994.

CATIE (2012). Producción de madera en sistemas agroforestales en América Central.

CCAD, ANAM, MINAE (2007). Manual Operativo Binacional Transfronterizo (MOB) para el Control del Comercio y Tráfico de Fauna y Flora Silvestres entre las Repúblicas de Panamá y Costa Rica.

Contraloría General de la República de Panamá. Instituto Nacional de Estadística y Censo (20052009). Boletín de Estadísticas Ambientales período 2005-09. Cuadros 109 y 110.

Contraloría General de la República de Panamá. Instituto Nacional de Estadística y Censo (2010). Boletín de Estadísticas Ambientales período 2006-10. Cuadro 112.

Contraloría General de la República de Panamá (2013). Principales indicadores económicos mensuales. 
Coordinadora Nacional de los Pueblos Indígenas de Panamá (2009). Informe final: elaboración de un marco de referencia sobre la participación de los pueblos indígenas de la República de Panamá dentro del contexto de la propuesta de UN-REDD Panamá.

Díaz, I., Pineda, E. y otros (2012). Incentivos y desincentivos a la actividad forestal en Panamá. CATIE y Ministerio de Asuntos Exteriores de Finlandia.

Durán Lima, J.E. y otros. (2008). CEPAL. Naciones Unidas. Indicadores de Comercio Exterior y Política Comercial: mediciones de posición y dinamismo comercial. 43 páginas.

FAO (2002). Estado de la información forestal en Panamá. Monografía de países. Volumen 13. Santiago de Chile.

FAO (2010). Evaluación de los recursos forestales mundiales 2010. Informe principal.

FAO, OIMT (2010). La observancia de la legislación forestal y la gobernanza de los bosques en los países tropicales. Una evaluación región por región del estado de la observancia de la legislación forestal y la gobernanza de los bosques en los países tropicales, y mejoras recomendadas.

Hewitt, D. (2012). Fortalecimiento de la Gobernanza Forestal. Programa EU-FAO-FLEGT.

Huertas, H. (2012). Querella penal contra autoridades de gobierno por delitos contra el derecho internacional de los derechos humanos, delitos contra el ambiente, la salud, entre otros por presunto aprovechamiento ilegal de madera.

INEC (2010). Comercio Exterior de Productos de Madera en la República de Panamá 2006-10.

INEC (2010). Indicadores de la industria de la madera en la República de Panamá 2006-10.

Jaén N., Eustorgio (2013). Abordajes de Salvaguardas en el Marco de la Estrategia REDD en Panamá. ANAM. Programa ONU-REDD.

Leonardi, A. y otros (2012). Cómo combinar el comercio justo con la certificación de manejo forestal. Proyecto Madera Justa en Acción co-financiado por la Unión Europea.

MarViva (2011). Guía de Análisis de Delitos contra el Ambiente [en la República de Panamá].

Ministerio de Seguridad Pública (2010). Sistema Nacional Integrado de Estadísticas Criminales (SIEC).

Morcillo Saavedra, R.M. (2009). La investigación del delito ecológico en Panamá. Jornadas de Derecho con el PNUMA.

NeDrüa (2012). Resumen público sobre sus actividades de aprovechamiento forestal sostenible en la Comarca Emberá-Wounaan.

ONU-REDD Panamá (2013). Informe de evaluación de medio término.

Sistema Integrado de Comercio Exterior (SICE) (2013). Manual de Declaración Aduanera. Panamá.

Unión Europea (2013). Preguntas frecuentes para due dilligence sobre FLEGT.

USAID y otros (2012). Todo lo que debe saber sobre la Lacey Act de EE.UU., el Reglamento de la madera de la UE y la Ley Australiana de 2012 para la prohibición de la tala ilegal.

Valiente, A. (2002). Compilación. Derechos de los pueblos indígenas de Panamá. 
Anexos 


\section{Anexos México}

Tabla 1. Producción forestal maderable por género y/o grupo $\left(\mathrm{m}^{3} \mathrm{r}\right)$

\begin{tabular}{|l|r|r|r|}
\hline \multicolumn{1}{|c|}{ Producto } & \multicolumn{2}{c|}{2011} & \multicolumn{1}{c|}{ Participación \% } \\
\hline Pino & 4.240 .954 & 4.195 .403 & 76,3 \\
\hline Oyamel & 201.270 & 168.947 & 3,1 \\
\hline Otras coníferas & 46.305 & 24.391 & 0,4 \\
\hline Encino & 547.752 & 523.335 & 9,5 \\
\hline Otras latifoliadas & 247.325 & 271.949 & 4,9 \\
\hline Preciosas & 51.460 & 16.969 & 0,3 \\
\hline Comunes tropicales & 292.023 & 299.992 & 5,5 \\
\hline Total & 5.627 .088 & 5.201 .085 & 100 \\
\hline
\end{tabular}

Fuente: Dirección General de Gestión Forestal y de Suelos, SEMARNAT

Tabla 2. Balanza Comercial Forestal 2011 (valor en miles de dólares)

\begin{tabular}{|l|r|r|r|}
\hline \multicolumn{1}{|c|}{ Lescripción } & Exportación & Importación & \multicolumn{1}{c|}{ Saldo } \\
\hline \multicolumn{1}{|c|}{ Leña } & 1,909 & 861 & 1,048 \\
\hline Carbón vegetal & 19,188 & 190 & 18,998 \\
\hline Madera en rollo, postes & 4,693 & 8,190 & $-3,496$ \\
\hline Flejes de madera & 5 & 1,876 & $-1,872$ \\
\hline Lana y harina de madera & 5 & 2,771 & $-2,766$ \\
\hline Durmientes & 4,496 & 18,661 & $-14,165$ \\
\hline Madera aserrada & 12,960 & 430,975 & $-418,016$ \\
\hline Chapas de madera & 2,234 & 57,568 & $-55,334$ \\
\hline Listones y molduras & 49,603 & 70,491 & $-20,889$ \\
\hline Tableros aglomerados & 13,269 & 44,818 & $-31,549$ \\
\hline Tableros de fibra & 1,331 & 176,183 & $-174,852$ \\
\hline Tableros contrachapados & 2,034 & 283,552 & $-281,518$ \\
\hline Madera densificada & 151 & 3,968 & $-3,818$ \\
\hline Marcos para cuadros & 10,306 & 4,331 & 5,975 \\
\hline Cajas y paletas & 1,086 & 38,086 & $-7,199$ \\
\hline Barriles, cubas, duelas & 46,541 & 3,471 & $-3,274$ \\
\hline Herramientas, mangos p/escobas & $30,83,47188$ & 52,083 & $-13,069$ \\
\hline Ventanas, puertas, tableros celulares & 14,155 & $-5,542$ \\
\hline Artículo de mesa y cocina & & & $-3,660$ \\
\hline
\end{tabular}




\begin{tabular}{|l|r|r|r|}
\hline \multicolumn{1}{|c|}{ Descripción } & Exportación & Importación & \multicolumn{1}{c|}{ Saldo } \\
\hline Marquetería y taracea & 4,050 & 11,610 & $-7,559$ \\
\hline Los demás de manufacturas de madera & 93,959 & 35,981 & 57,978 \\
\hline Subtotal de productos de madera & 299,864 & $1,264,443$ & $-964,579$ \\
\hline Celulosa y fibras secundarias & 79,432 & $1,258,705$ & $-1,079,273$ \\
\hline Productos de papel & $1,184,310$ & $4,932,046$ & $-3,747,736$ \\
\hline Subtotal de celulosa y papel & $1,263,742$ & $6,090,752$ & $-4,827,009$ \\
\hline Total & $1,563,606$ & $7,355,194$ & $-5,791,588$ \\
\hline
\end{tabular}

Fuente: Dirección General de Gestión Forestal y de Suelos con información de la Secretaría de Economía

Tabla 3.

Importaciones y exportaciones de productos forestales 2011 (volumen en $\mathrm{m}^{3} \mathrm{r}$ )

\begin{tabular}{|c|c|c|c|}
\hline Descripción & Exportación & Importación & Saldo \\
\hline Leña & 28.101 & 4.116 & 23.986 \\
\hline Carbón vegetal & 366.914 & 1.182 & 365.732 \\
\hline Madera en rollo, postes & 33.116 & 90.273 & -57.157 \\
\hline Flejes de madera & 30 & 25.940 & -25.910 \\
\hline Lana y harina de madera & 12 & 14.542 & -14.530 \\
\hline Durmientes & 22.394 & 82.300 & -59.906 \\
\hline Madera aserrada & 559.262 & 16.973 .634 & -16.314 .472 \\
\hline Chapas de madera & 980.154 & 705.362 & 274.792 \\
\hline Listones y molduras & 199.534 & 269.035 & -69.502 \\
\hline Tableros aglomerados & 31.780 & 114.023 & -82.243 \\
\hline Tableros de fibra & 1.351 & 245.297 & -243.946 \\
\hline Tableros contrachapados & 1.781 & 329.847 & -328.065 \\
\hline Madera densificada & 24 & 863 & -839 \\
\hline Marcos para cuadros & 9.269 & 2.516 & 6.753 \\
\hline Cajas y paletas & 156.089 & 204.448 & -48.359 \\
\hline Barriles, cubas, duelas & 136 & 3.864 & -3.728 \\
\hline Herramientas, mangos p/escobas & 1.082 & 15.377 & -14.295 \\
\hline Ventanas, puertas, tableros celulares & 41.575 & 97.118 & -55.543 \\
\hline Artículo de mesa y cocina & 637 & 3.405 & -2.768 \\
\hline Marquetería y taracea & 2.725 & 4.369 & -1.644 \\
\hline Los demás de manufacturas de madera & 59.181 & 32.162 & 27.018 \\
\hline Subtotal de productos de madera & 2.495 .147 & 19.119 .672 & -16.624 .525 \\
\hline Celulosa y fibras secundarias & 760.372 & 6.388 .142 & -5.627 .770 \\
\hline Productos de papel & 2.163 .437 & 12.850 .853 & -10.687 .416 \\
\hline Total de celulosa y papel & 2.923 .809 & 19.238.995 & -16.315 .186 \\
\hline Total & 5.418 .956 & 38.358 .667 & -32.939 .711 \\
\hline
\end{tabular}

Fuente: Dirección General de Gestión Forestal y de Suelos con información de la Secretaría de Economía 
Tabla 4. Evolución de la legislación forestal en México

\begin{tabular}{|c|c|c|}
\hline Ley & Reglamento & \\
\hline $\begin{array}{c}\text { Fecha de } \\
\text { publicación }\end{array}$ & $\begin{array}{c}\text { Fecha de } \\
\text { publicación }\end{array}$ & Institución responsable \\
\hline 24 de abril de 1926 & 15 de octubre de 1927 & Secretaría de Agricultura y Fomento \\
\hline 17 de marzo de 1943 & 28 de junio de 1944 & Secretaría de Agricultura y Fomento \\
\hline 10 de enero de 1948 & 15 de septiembre de 1950 & Secretaría de Agricultura y Ganadería \\
\hline 16 de enero de 1960 & 23 de enero de 1961 & Secretaría de Agricultura y Ganadería \\
\hline 30 de mayo de 1986 & 13 de julio de 1988 & Secretaría de Agricultura y Recursos Hidráulicos \\
\hline 22 de diciembre de 1992 & 21 de febrero de 1994 & Secretaría de Agricultura y Recursos Hidráulicos \\
\hline 20 de mayo de $1997^{\star}$ & 25 de septiembre de 1998 & $\begin{array}{l}\text { Secretaría de Medio Ambiente, } \\
\text { Recursos Naturales y Pesca }\end{array}$ \\
\hline 25 de febrero de 2003 & 21 de febrero de 2005 & Secretaría de Medio Ambiente y Recursos Naturales \\
\hline
\end{tabular}

* Esta no fue una nueva ley, sino una importante reforma de la ley de 1992 para hacerla congruente con las reformas hechas a LGEEPA en 1996. 
Tabla 5. Consistencia entre tratados internacionales y legislación nacional

\begin{tabular}{|c|c|c|c|c|c|c|}
\hline \multirow{2}{*}{$\begin{array}{l}\text { Tratado o convención } \\
\text { internacional }\end{array}$} & \multicolumn{6}{|c|}{ Legislación nacional aplicable } \\
\hline & LGCC & LGEEPA & LGDFS & LGVS & LDRS & LA \\
\hline $\begin{array}{l}\text { Principios Forestales: Reafirman } \\
\text { el derecho soberano de los países } \\
\text { sobre los recursos forestales, así } \\
\text { como la necesidad de apoyo a } \\
\text { las comunidades forestales y la } \\
\text { contribución de los ecosistemas } \\
\text { forestales a la economía rural y estilos } \\
\text { de vida. }\end{array}$ & & $\mathbf{x}$ & $\mathbf{x}$ & $\mathbf{x}$ & & $\mathbf{x}$ \\
\hline $\begin{array}{l}\text { Convención sobre Diversidad } \\
\text { Biológica: Exige que cada país } \\
\text { formule planes de manejo y } \\
\text { estrategias nacionales para la } \\
\text { conservación de la biodiversidad, } \\
\text { así como integrarla en la política } \\
\text { nacional. }\end{array}$ & $x$ & $x$ & & $\mathbf{x}$ & & \\
\hline $\begin{array}{l}\text { Convención sobre Comercio } \\
\text { Internacional de Especies } \\
\text { Amenazadas de Flora y Fauna } \\
\text { Silvestre: Establece categorías de } \\
\text { riesgo y regula el comercio de estas } \\
\text { especies atendiendo a la clasificación } \\
\text { de cada una de ellas. }\end{array}$ & & $\mathbf{x}$ & $x$ & $x$ & & \\
\hline $\begin{array}{l}\text { Convenio Internacional de las } \\
\text { Maderas Tropicales: México es } \\
\text { miembro de la Organización } \\
\text { Internacional de las Maderas } \\
\text { Tropicales, organización } \\
\text { intergubernamental que promueve } \\
\text { la conservación y la ordenación, la } \\
\text { utilización y el comercio sostenible } \\
\text { de los recursos de los bosques } \\
\text { tropicales bajo el auspicio de las } \\
\text { Naciones Unidas. }\end{array}$ & & $\mathbf{x}$ & $\mathbf{x}$ & $\mathbf{x}$ & & \\
\hline $\begin{array}{l}\text { Convención Marco de las Naciones } \\
\text { Unidas sobre Cambio Climático } \\
\text { (REDD+): A partir de su } 11^{\circ} \\
\text { Conferencia de las Partes, en } \\
\text { Montreal, } 2007 \text {, ha desarrollado el } \\
\text { tema forestal resultando en lo que } \\
\text { hoy se conoce como el mecanismo } \\
\text { REDD+. }\end{array}$ & $x$ & $\mathbf{x}$ & $\mathbf{x}$ & $x$ & $\mathbf{x}$ & $x$ \\
\hline
\end{tabular}




\section{Tabla 6. Conflictos entre derecho de uso de la tierra y de uso de los bosques}

\begin{tabular}{l} 
Conflicto \\
\multicolumn{1}{c}{ DERECHO DE USO DE LA TIERRA } \\
(Ley Agraria)
\end{tabular}

Deja al ejido, por medio de su reglamento interno, la definición de las reglas para el aprovechamiento de las tierras de uso común. Estas pueden ser suelos forestales. (Art. 10 LA).

Establece que el destino (uso) de las tierras ejidales es decisión de la asamblea, la cual podrá realizar contratos, convenios, delimitación, asignación y definir el destino de tierras de uso común así como su régimen de explotación, conversión del régimen ejidal al comunal, instauración, modificación y cancelación del régimen de explotación colectiva (Art. 23 LA).

Las tierras ejidales (parceladas o de uso común) podrán ser objeto de cualquier contrato de asociación o aprovechamiento (Art. 45)

La posesión de tierras ejidales (excepto bosques o selvas) de manera pacífica y pública durante 5 años (buena fe) o 10 (mala fe) adquirirá los mismos derechos que cualquier ejidatario (Art. 48).

El artículo 59 manifiesta que será nula de pleno derecho la asignación de parcelas en bosques o selvas tropicales, así busca asegurar y dar protección a estos.

Las tierras de uso común constituyen el sustento económico del ejido y pueden ser aportadas a sociedades mercantiles o civiles en las que participe el ejido o los ejidatarios (para cualquier tipo de producción).

Tierras parceladas (art. 76 LA): derecho de aprovechamiento, uso y usufructo. Son enajenables.

Las uniones de ejidos, ejidos y comunidades pueden establecer empresas para el aprovechamiento de sus recursos naturales o de cualquier índole (Art. 108).

Las asociaciones rurales de interés colectivo pueden tener como objeto el establecimiento de industrias, aprovechamientos, comercialización y otras actividades económicas (Art. 110).
DERECHOS DE USO DE LOS BOSQUES (LGDFS)

Declara de utilidad pública la conservación, protección y restauración de los ecosistemas forestales y sus elementos, así como de las cuencas hidrológicoforestales, y la ejecución de obras destinadas a la conservación, protección y/o generación de bienes y servicios ambientales

Esta ley tiene por objeto regular y fomentar la conservación, protección, restauración, producción, ordenación, el cultivo, manejo y aprovechamiento de los ecosistemas forestales del país y sus recursos.

\section{Objetivos generales:}

I. Contribuir al desarrollo social, económico, ecológico y ambiental del país, mediante el manejo integral sustentable de los recursos forestales, así como de las cuencas y ecosistemas hidrológico-forestales, sin perjuicio de lo previsto en otros ordenamientos;

II. Impulsar la silvicultura y el aprovechamiento de los recursos forestales, para que contribuyan con bienes y servicios que aseguren el mejoramiento del nivel de vida de los mexicanos, especialmente el de los propietarios y pobladores forestales;

III. Desarrollar los bienes y servicios ambientales y proteger, mantener y aumentar la biodiversidad que brindan los recursos forestales;

(...)

\section{También son objetivos:}

V. Fortalecer y ampliar la participación de la producción forestal en el crecimiento económico nacional;

VI. Promover una efectiva incorporación de la actividad forestal en el desarrollo rural;

VIII. Recuperar y desarrollar bosques en terrenos preferentemente forestales, para que cumplan con la función de conservar suelos y aguas, además de dinamizar el desarrollo rural;

XI. Promover y consolidar las áreas forestales permanentes, impulsando su delimitación y manejo sostenible, evitando que el cambio de uso de suelo con fines agropecuarios o de cualquier otra índole afecte su permanencia y potencialidad;

XII. Compatibilizar las actividades de pastoreo y agrícolas en terrenos forestales y preferentemente forestales; 


\section{Conflictos entre:}

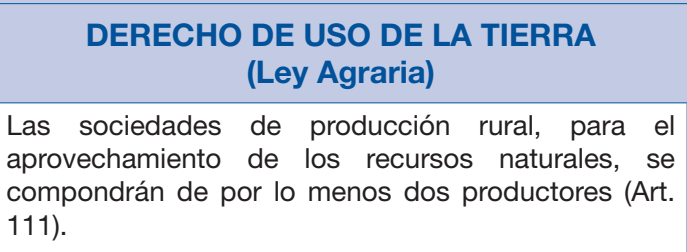

Las sociedades civiles o mercantiles pueden propietarias de tierras agrícolas, y estas pueden ser enajenables una vez que están parceladas.

La Pequeña propiedad agrícola es de 150 has para algodón; 300 has para el cultivo de plátano, caña de azúcar, café, henequén, hule, palma, vid, olivo, quina, vainilla, cacao, agave nopal y árboles frutales; y 100 has para cultivos vegetales.

Mientras que la Pequeña propiedad forestal que comprende bosques y selvas de cualquier clase es de hasta 800 has (Art. 116), lo cual permite a cualquier productos, incluso de manera individual, de ser titular de una gran cantidad de propiedad forestal.

Finalmente, contempla disposiciones que fomentan el uso de suelo forestal y que permite a las sociedades civiles o mercantiles ser propietarias de tierras forestales, las cuales podrán:

- Tener en propiedad de tierras forestales hasta de 25 veces los límites de la propiedad individual.

- Deberán participar en la sociedad, por lo menos, tantos individuos como veces la sociedad rebase los límites de la pequeña propiedad.

Su objeto social deberá limitarse a: producción, transformación o comercialización de productos forestales, y demás actos accesorios.

\section{DERECHOS DE USO DE LOS BOSQUES} (LGDFS)

XVI. Promover y regular las forestaciones con propósito comercial;

XIX. Propiciar la productividad en toda la cadena forestal;

XXIII. Contribuir al desarrollo socioeconómico de los pueblos y comunidades indígenas, así como de ejidatarios, comuneros, cooperativas, pequeños propietarios y demás poseedores de recursos forestales;

XXX. Promover instrumentos económicos para fomentar el desarrollo forestal;

XXXI. Impulsar el desarrollo de la empresa social forestal y comunal en los pueblos y comunidades indígenas, y

Esta ley regula lo referente a la protección y aprovechamiento de los bosques en México mediante la implementación de programas de fomento y manejo, apoyos a la producción forestal, reforestación, empresas con producción forestal y define competencias entre autoridades (Federales, estatales y municipales).

La Semarnat, apoyado de la Conafor, como órgano conductos de la política nacional y desarrollo forestal sustentable, y entre otras, tiene facultades para:

- Expedir autorizaciones de cambio de uso de suelo de los terrenos forestales.

- Expedir permisos, autorizaciones, certificados y licencias para el aprovechamiento de recursos forestales.

- Expedir certificados y demás documentación para la exportación e importación de productos y materias primas forestales.

Define los principios rectores de la política forestal nacional, como área prioritaria del desarrollo nacional, la promoción del fomento forestal sustentable mediante capacitación, atención a usuarios y propietarios, el establecimiento de mercados y de mecanismos de mercado, y la consolidación de una cultura forestal para su protección, preservación y aprovechamiento sustentable de los recursos forestales y bienes y servicios ambientales. 


\begin{tabular}{|c|c|}
\hline Categoría & Tipos \\
\hline $\begin{array}{l}\text { Zonas de conservación } \\
\text { y aprovechamiento } \\
\text { restringido o prohibido }\end{array}$ & 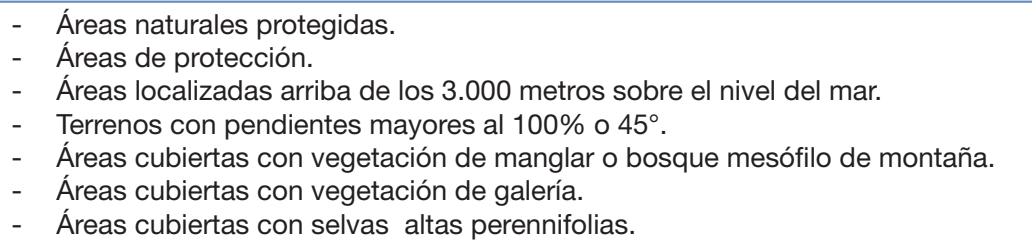 \\
\hline Zonas de producción & $\begin{array}{l}\text { - Terrenos forestales de productividad alta, caracterizados por tener una } \\
\text { cobertura de copa de más de } 50 \% \text { o una altura promedio de los árboles } \\
\text { dominantes igual o mayor a } 16 \mathrm{~m} \text {. } \\
\text { - } \quad \text { Terrenos forestales de productividad media, caracterizados por tener una } \\
\text { cobertura de copa de entre } 20 \%-50 \% \text { o una altura promedio de los árboles } \\
\text { dominantes menor de } 16 \mathrm{~m} \text {. } \\
\text { - } \quad \text { Terrenos forestales de productividad baja, caracterizados por tener una } \\
\text { cobertura de copa inferior a } 20 \% \text {. } \\
\text { - Terrenos con vegetación forestal de zonas áridas. } \\
\text { - Terrenos adecuados para realizar forestaciones. } \\
\text { - Terrenos preferentemente forestales. }\end{array}$ \\
\hline Zonas de restauración & $\begin{array}{l}\text { - Terrenos forestales con degradación alta y que muestren evidencia de erosión } \\
\text { severa, con presencia de cárcavas. } \\
\text { - } \quad \text { Terrenos preferentemente forestales, caracterizados por carecer de vegetación } \\
\text { forestal y mostrar evidencia de erosión severa, con presencia de cárcavas. } \\
\text { - } \quad \text { Terrenos forestales o preferentemente forestales con degradación media, } \\
\text { caracterizados por tener una cobertura de copa menor a } 20 \% \text { y mostrar } \\
\text { evidencia de erosión severa, con presencia de canalillos. } \\
\text { - } \quad \text { Terrenos forestales o preferentemente forestales con degradación baja, } \\
\text { caracterizados por tener una cobertura de copa inferior a } 20 \% \text { y mostrar } \\
\text { evidencia de erosión laminar. } \\
\text { - Terrenos forestales o preferentemente forestales degradados que se } \\
\text { encuentren sometidos a tratamientos de recuperación, tales como forestación, } \\
\text { reforestación o regeneración natural. }\end{array}$ \\
\hline
\end{tabular}


Tabla 8. Atribuciones de SEMARNAT y CONAFOR

\begin{tabular}{|c|c|c|}
\hline $\begin{array}{c}\text { Atribución Federal } \\
\text { Art. } 12\end{array}$ & $\begin{array}{l}\text { SEMARNAT } \\
\text { Art. } 16\end{array}$ & $\begin{array}{l}\text { CONAFOR } \\
\text { Art. } 22\end{array}$ \\
\hline $\begin{array}{l}\text { I. Formular y conducir la política } \\
\text { nacional en materia de desarrollo } \\
\text { forestal sustentable; }\end{array}$ & $\begin{array}{l}\text { I. Formular y conducir la política } \\
\text { nacional de desarrollo forestal } \\
\text { sustentable y asegurar su } \\
\text { congruencia con la política } \\
\text { ambiental y de recursos } \\
\text { naturales nacional, así como las } \\
\text { relacionadas con el desarrollo } \\
\text { rural; }\end{array}$ & $\begin{array}{l}\text { I. Participar en la formulación y } \\
\text { aplicación de la política nacional de } \\
\text { desarrollo forestal sustentable; }\end{array}$ \\
\hline $\begin{array}{l}\text { II. Diseñar, organizar y aplicar } \\
\text { los instrumentos de política } \\
\text { forestal previstos en esta Ley, } \\
\text { garantizando una adecuada } \\
\text { coordinación entre la Federación, } \\
\text { las entidades federativas y los } \\
\text { municipios, en el marco del } \\
\text { Servicio Nacional Forestal; }\end{array}$ & $\begin{array}{l}\text { II. Diseñar los instrumentos de } \\
\text { política forestal previstos en esta } \\
\text { Ley y operar los que correspondan } \\
\text { a su competencia; } \\
\text { IV. Conducir el Servicio Nacional } \\
\text { Forestal, como instrumento de } \\
\text { integración de las dependencias y } \\
\text { entidades públicas vinculadas con } \\
\text { la atención del sector forestal }\end{array}$ & $\begin{array}{l}\text { II. Organizar y aplicar los } \\
\text { instrumentos de política forestal } \\
\text { previstos en la presente Ley; } \\
\text { V. Coadyuvar con la Secretaría en } \\
\text { la adopción y fortalecimiento del } \\
\text { Servicio Nacional Forestal; } \\
\text { VIII. Elaborar e integrar, bajo los } \\
\text { lineamientos que determine la } \\
\text { Secretaría, el Sistema Nacional } \\
\text { de Información Forestal para } \\
\text { incorporarlo en el Sistema Nacional } \\
\text { de Información Ambiental y de } \\
\text { los Recursos Naturales, y a los } \\
\text { sistemas de información estadísticos } \\
\text { y de información geográfica y } \\
\text { documental; }\end{array}$ \\
\hline $\begin{array}{l}\text { III. Elaborar, coordinar y aplicar } \\
\text { los programas a que se refiere } \\
\text { esta Ley en materia forestal, en } \\
\text { los ámbitos nacional y regional, } \\
\text { tanto de proyección sexenal, así } \\
\text { como de más largo plazo; }\end{array}$ & $\begin{array}{l}\text { III. Elaborar el Programa } \\
\text { Estratégico Forestal Nacional, con } \\
\text { la participación de la Comisión en } \\
\text { las materias de su competencia; }\end{array}$ & $\begin{array}{l}\text { III. Participar en la elaboración } \\
\text { del programa forestal de carácter } \\
\text { estratégico con visión de largo plazo; } \\
\text { XXX. Dirigir, promover y coordinar } \\
\text { los programas institucionales de } \\
\text { plantaciones forestales comerciales y } \\
\text { de desarrollo forestal; }\end{array}$ \\
\hline $\begin{array}{l}\text { IV. Aplicar y promover, en } \\
\text { coordinación con las entidades } \\
\text { federativas y los municipios, el } \\
\text { establecimiento de sistemas y } \\
\text { esquemas de ventanilla única } \\
\text { para la atención eficiente de los } \\
\text { diversos usuarios; }\end{array}$ & & $\begin{array}{l}\text { XXXVIII. Impulsar el uso de } \\
\text { tecnología de la información en los } \\
\text { trámites a su cargo, }\end{array}$ \\
\hline $\begin{array}{l}\text { V. Realizar el Inventario Nacional } \\
\text { Forestal y de Suelos y determinar } \\
\text { los criterios e indicadores } \\
\text { para el desarrollo, diseño y } \\
\text { actualización de los inventarios } \\
\text { correspondientes a las entidades; }\end{array}$ & $\begin{array}{l}\text { IX. Establecer los lineamientos } \\
\text { para elaborar e integrar el Sistema } \\
\text { Nacional de Información Forestal; } \\
\text { X. Regular la integración, } \\
\text { monitoreo y actualización del } \\
\text { Inventario Nacional Forestal y de } \\
\text { Suelos y coordinar el diseño del } \\
\text { mismo; }\end{array}$ & $\begin{array}{l}\text { VI. Integrar, monitorear y mantener } \\
\text { actualizado el Inventario Nacional } \\
\text { Forestal y de Suelos así como } \\
\text { participar en el diseño del mismo; }\end{array}$ \\
\hline
\end{tabular}




\begin{tabular}{|c|c|c|}
\hline $\begin{array}{l}\text { Atribución Federal } \\
\text { Art. } 12\end{array}$ & $\begin{array}{l}\text { SEMARNAT } \\
\text { Art. } 16\end{array}$ & $\begin{array}{l}\text { CONAFOR } \\
\text { Art. } 22\end{array}$ \\
\hline $\begin{array}{l}\text { VI. Llevar a cabo la zonificación } \\
\text { forestal del país; }\end{array}$ & $\begin{array}{l}\text { XI. Establecer los criterios, } \\
\text { metodología y procedimientos } \\
\text { para la integración, organización y } \\
\text { actualización de la zonificación; }\end{array}$ & $\begin{array}{l}\text { VII. Elaborar, integrar, organizar y } \\
\text { mantener actualizada la zonificación } \\
\text { de los terrenos forestales y } \\
\text { preferentemente forestales, con } \\
\text { base en el ordenamiento ecológico } \\
\text { del territorio y en los criterios, } \\
\text { metodología y procedimientos } \\
\text { que para tal efecto establezca la } \\
\text { Secretaría; }\end{array}$ \\
\hline $\begin{array}{l}\text { VII. Diseñar, organizar y } \\
\text { administrar el Registro Forestal } \\
\text { Nacional; }\end{array}$ & $\begin{array}{l}\text { VI. Regular, establecer, integrar, } \\
\text { operar y mantener actualizado } \\
\text { el Registro Forestal Nacional, así } \\
\text { como expedir los certificados } \\
\text { de inscripción previstos en las } \\
\text { disposiciones jurídicas aplicables; } \\
\text { VII. Llevar el registro y cuidar } \\
\text { la conservación de los árboles } \\
\text { históricos y notables del país; }\end{array}$ & \\
\hline $\begin{array}{l}\text { VIII. Emitir normas para la } \\
\text { reforestación en zonas de } \\
\text { conservación y restauración y } \\
\text { vigilar su cumplimiento; }\end{array}$ & & \\
\hline $\begin{array}{l}\text { IX. Elaborar y expedir normas } \\
\text { oficiales mexicanas en materia } \\
\text { forestal y vigilar su cumplimiento; }\end{array}$ & $\begin{array}{l}\text { VIII. Emitir normas oficiales } \\
\text { mexicanas en materia forestal y } \\
\text { vigilar su cumplimiento; }\end{array}$ & $\begin{array}{l}\text { IX. Participar en la elaboración de } \\
\text { normas oficiales mexicanas respecto } \\
\text { de las actividades del sector forestal } \\
\text { y en su vigilancia y cumplimiento; }\end{array}$ \\
\hline $\begin{array}{l}\text { X. Elaborar y adoptar } \\
\text { metodologías, tomando en } \\
\text { consideración, en su caso, } \\
\text { parámetros internacionales, para } \\
\text { la valoración de los bienes y } \\
\text { servicios ambientales; }\end{array}$ & $\begin{array}{l}\text { XII. Definir las metodologías para la } \\
\text { valoración de los bienes y servicios } \\
\text { ambientales de los ecosistemas } \\
\text { forestales; }\end{array}$ & $\begin{array}{l}\text { X. Proponer la valoración de los } \\
\text { bienes y servicios ambientales de los } \\
\text { ecosistemas forestales, conforme } \\
\text { a las metodologías definidas por la } \\
\text { Secretaría; } \\
\text { XV. Apoyar la ejecución de } \\
\text { programas de bienes y servicios } \\
\text { ambientales que generen los } \\
\text { recursos forestales; }\end{array}$ \\
\hline $\begin{array}{l}\text { XI. Establecer las bases e } \\
\text { instrumentos para promover un } \\
\text { mercado de bienes y servicios } \\
\text { ambientales, así como para } \\
\text { promover la compensación por } \\
\text { los bienes y servicios ambientales } \\
\text { que prestan los ecosistemas } \\
\text { forestales; }\end{array}$ & $\begin{array}{l}\text { XIII. Definir instrumentos para } \\
\text { promover un mercado de bienes y } \\
\text { servicios ambientales; } \\
\text { XIV. Definir mecanismos de } \\
\text { compensación por los bienes y } \\
\text { servicios ambientales que prestan } \\
\text { los ecosistemas forestales; }\end{array}$ & $\begin{array}{l}\text { XI. Coadyuvar en la definición y } \\
\text { promoción de mercados de bienes y } \\
\text { servicios ambientales; } \\
\text { XII. Participar en la definición de } \\
\text { mecanismos de compensación por } \\
\text { los bienes y servicios ambientales } \\
\text { que prestan los ecosistemas } \\
\text { forestales; }\end{array}$ \\
\hline
\end{tabular}




\begin{tabular}{|c|c|c|}
\hline $\begin{array}{l}\text { Atribución Federal } \\
\text { Art. } 12\end{array}$ & $\begin{array}{l}\text { SEMARNAT } \\
\text { Art. } 16\end{array}$ & $\begin{array}{l}\text { CONAFOR } \\
\text { Art. } 22\end{array}$ \\
\hline $\begin{array}{l}\text { XII. Generar mecanismos para } \\
\text { impulsar la participación directa } \\
\text { de los propietarios y poseedores } \\
\text { de los recursos forestales } \\
\text { en la protección, vigilancia, } \\
\text { ordenación, aprovechamiento, } \\
\text { cultivo, transformación y } \\
\text { comercialización de los mismos; }\end{array}$ & & $\begin{array}{l}\text { XVIII. Coordinar con las autoridades } \\
\text { estatales y municipales, los } \\
\text { programas y acciones que } \\
\text { coadyuven con los pueblos y } \\
\text { comunidades indígenas en la } \\
\text { conservación y mejoramiento } \\
\text { de su lugar de residencia y a } \\
\text { preservar la integridad de sus } \\
\text { tierras, promoviendo el desarrollo } \\
\text { sustentable de las mismas, con } \\
\text { base en programas educativos de } \\
\text { contenido forestal; } \\
\text { XIX. Impulsar la participación directa } \\
\text { de los propietarios y poseedores de } \\
\text { los recursos forestales } \\
\text { en la protección, vigilancia, } \\
\text { ordenación, aprovechamiento, } \\
\text { cultivo, transformación y } \\
\text { comercialización de } \\
\text { los mismos; }\end{array}$ \\
\hline $\begin{array}{l}\text { XIII. Celebrar acuerdos de } \\
\text { coordinación, cooperación y } \\
\text { concertación en materia forestal } \\
\text { nacional e internacional; }\end{array}$ & & $\begin{array}{l}\text { XIII. Coordinarse con las } \\
\text { dependencias o entidades de la } \\
\text { Federación, Estados, Distrito Federal } \\
\text { y Municipios, a fin de que el } \\
\text { desarrollo forestal sustentable } \\
\text { obedezca a políticas y criterios } \\
\text { integradores, para lo cual podrá } \\
\text { suscribir los acuerdos y convenios } \\
\text { que sean necesarios; } \\
\text { XXXVI. Impulsar y transferir funciones } \\
\text { y recursos hacia los gobiernos de } \\
\text { los estados y municipios en materia } \\
\text { forestal; }\end{array}$ \\
\hline $\begin{array}{l}\text { XIV. Diseñar, desarrollar, aplicar } \\
\text { y propiciar, en coordinación con } \\
\text { las dependencias y entidades } \\
\text { federales competentes, los } \\
\text { instrumentos económicos para } \\
\text { promover el desarrollo forestal; }\end{array}$ & $\begin{array}{l}\text { V. Diseñar y definir en el ámbito } \\
\text { de su competencia, estímulos e } \\
\text { incentivos económicos en materia } \\
\text { forestal y los lineamientos para su } \\
\text { aplicación y evaluación; }\end{array}$ & $\begin{array}{l}\text { IV. Diseñar, instrumentar y operar } \\
\text { en el ámbito de su competencia, } \\
\text { estímulos, incentivos e instrumentos } \\
\text { económicos en materia forestal; }\end{array}$ \\
\hline $\begin{array}{l}\text { XV. Promover el Fondo Forestal } \\
\text { Mexicano; }\end{array}$ & & $\begin{array}{l}\text { XVII. Fomentar y favorecer la } \\
\text { cadena productiva forestal y de sus } \\
\text { recursos asociados, impulsando } \\
\text { actividades forestales diversificadas } \\
\text { e integradas, así como la exportación } \\
\text { de productos forestales procesados } \\
\text { y semiprocesados; }\end{array}$ \\
\hline
\end{tabular}




\begin{tabular}{|c|c|c|}
\hline $\begin{array}{c}\text { Atribución Federal } \\
\text { Art. } 12\end{array}$ & $\begin{array}{l}\text { SEMARNAT } \\
\text { Art. } 16\end{array}$ & $\begin{array}{l}\text { CONAFOR } \\
\text { Art. } 22\end{array}$ \\
\hline $\begin{array}{l}\text { XVI. Coordinar las acciones } \\
\text { de prevención y combate de } \\
\text { incendios forestales, así como } \\
\text { elaborar y aplicar el Programa } \\
\text { Nacional de Prevención de } \\
\text { Incendios Forestales, con la } \\
\text { participación que corresponda } \\
\text { a los Estados, Distrito Federal, } \\
\text { Municipios y al Sistema Nacional } \\
\text { de Protección Civil; }\end{array}$ & & $\begin{array}{l}\text { XX. Constituirse en enlace con otras } \\
\text { dependencias y entidades de la } \\
\text { Administración Pública Federal } \\
\text { y con los gobiernos de las entidades } \\
\text { federativas y de los municipios, } \\
\text { para la ejecución de programas de } \\
\text { prevención y combate de incendios } \\
\text { forestales; }\end{array}$ \\
\hline $\begin{array}{l}\text { XVII. Deslindar, poseer y } \\
\text { administrar los terrenos } \\
\text { nacionales forestales; }\end{array}$ & $\begin{array}{l}\text { XV. Deslindar, poseer y administrar } \\
\text { los terrenos nacionales forestales; }\end{array}$ & \\
\hline $\begin{array}{l}\text { XVIII. Establecer medidas de } \\
\text { sanidad y ejecutar las acciones } \\
\text { de saneamiento forestales; }\end{array}$ & $\begin{array}{l}\text { XVI. Establecer las medidas de } \\
\text { sanidad forestal; }\end{array}$ & $\begin{array}{l}\text { XXXV. Formular, coordinar y evaluar } \\
\text { los programas y acciones de } \\
\text { saneamiento forestal, así como } \\
\text { diagnosticar, prevenir, combatir y } \\
\text { controlar las plagas y enfermedades } \\
\text { forestales; }\end{array}$ \\
\hline $\begin{array}{l}\text { XIX. Promover el uso de } \\
\text { prácticas, métodos y tecnologías } \\
\text { que conlleven a un manejo } \\
\text { forestal sustentable; }\end{array}$ & $\begin{array}{l}\text { XX. Expedir, por excepción las } \\
\text { autorizaciones de cambio de uso } \\
\text { de suelo de los terrenos forestales; }\end{array}$ & $\begin{array}{l}\text { XIV. Promover el desarrollo forestal } \\
\text { sustentable y de los recursos } \\
\text { asociados para que incidan en el } \\
\text { mejoramiento de la calidad de vida } \\
\text { de los propietarios o poseedores } \\
\text { de terrenos forestales o de } \\
\text { preferentemente forestales y de sus } \\
\text { comunidades; } \\
\text { XVI. Ejecutar y promover programas } \\
\text { productivos, de restauración, de } \\
\text { protección, de conservación y de } \\
\text { aprovechamiento sustentable de } \\
\text { los ecosistemas forestales y de } \\
\text { los suelos en terrenos forestales o } \\
\text { preferentemente forestales; } \\
\text { XXVIII. Efectuar campañas de } \\
\text { difusión sobre el desarrollo forestal } \\
\text { sustentable; }\end{array}$ \\
\hline \multicolumn{3}{|l|}{$\begin{array}{l}\text { XX. Promover el desarrollo } \\
\text { y fortalecimiento de las } \\
\text { organizaciones de productores } \\
\text { forestales; }\end{array}$} \\
\hline $\begin{array}{l}\text { XXI. Promover e invertir } \\
\text { en el mejoramiento de la } \\
\text { infraestructura en las regiones } \\
\text { forestales; }\end{array}$ & & \\
\hline
\end{tabular}




\begin{tabular}{|c|c|c|}
\hline $\begin{array}{c}\text { Atribución Federal } \\
\text { Art. } 12\end{array}$ & $\begin{array}{l}\text { SEMARNAT } \\
\text { Art. } 16\end{array}$ & $\begin{array}{l}\text { CONAFOR } \\
\text { Art. } 22\end{array}$ \\
\hline $\begin{array}{l}\text { XXII. Coadyuvar con los agentes } \\
\text { de las cadenas productivas } \\
\text { forestales en coordinación en la } \\
\text { defensa } \\
\text { del sector forestal en materia } \\
\text { de comercio internacional, la } \\
\text { promoción de las exportaciones } \\
\text { y el mejoramiento del mercado } \\
\text { interno; }\end{array}$ & & $\begin{array}{l}\text { XXVII. Coadyuvar con los agentes de } \\
\text { las cadenas productivas forestales } \\
\text { en la defensa del sector en materia } \\
\text { de comercio internacional, la } \\
\text { promoción de exportaciones y el } \\
\text { mejoramiento del mercado interno; } \\
\text { XXIX. Diseñar, proponer, desarrollar, } \\
\text { evaluar y dar seguimiento a } \\
\text { las políticas y estrategias de } \\
\text { cooperación y financiamiento; } \\
\text { XXXIII. Intervenir en foros y } \\
\text { mecanismos de cooperación y } \\
\text { financiamiento en los temas de su } \\
\text { competencia; }\end{array}$ \\
\hline $\begin{array}{l}\text { XXIII. Llevar a cabo las visitas de } \\
\text { inspección y labores de vigilancia } \\
\text { forestales; }\end{array}$ & $\begin{array}{l}\text { XVII. Llevar a cabo la inspección y } \\
\text { vigilancia forestales; }\end{array}$ & \\
\hline $\begin{array}{l}\text { XXIV. Desarrollar las auditorías } \\
\text { técnicas preventivas a las que se } \\
\text { refiere esta Ley; }\end{array}$ & & $\begin{array}{l}\text { XXVI. Desarrollar las auditorías } \\
\text { técnicas preventivas a que se refiere } \\
\text { la presente Ley; }\end{array}$ \\
\hline $\begin{array}{l}\text { XXV. Regular, expedir y validar } \\
\text { la acreditación de la legal } \\
\text { procedencia de las materias } \\
\text { primas forestales y productos } \\
\text { maderables, y vigilar y promover, } \\
\text { en el ámbito de su competencia, } \\
\text { el cumplimiento de esta Ley; }\end{array}$ & $\begin{array}{l}\text { XVIII. Promover la participación y } \\
\text { coordinación de las autoridades } \\
\text { competentes, propietarios, } \\
\text { poseedores y habitantes de } \\
\text { las zonas forestales, como los } \\
\text { transportistas, comerciantes e } \\
\text { industrializadores de materias } \\
\text { primas forestales, en materia de } \\
\text { vigilancia; }\end{array}$ & \\
\hline $\begin{array}{l}\mathrm{XXVI} \text { Imponer medidas de } \\
\text { seguridad y sanciones a las } \\
\text { infracciones que se cometan en } \\
\text { materia forestal; }\end{array}$ & $\begin{array}{l}\text { XXI. Imponer medidas de } \\
\text { seguridad y sancionar a las } \\
\text { infracciones que se cometan } \\
\text { en materia forestal, así como } \\
\text { hacer del conocimiento y en su } \\
\text { caso denunciar los delitos en } \\
\text { dicha materia a las autoridades } \\
\text { competentes }\end{array}$ & \\
\hline $\begin{array}{l}\text { XXVII. Participar en programas } \\
\text { integrales de prevención y } \\
\text { combate a la extracción y } \\
\text { tala clandestina junto con los } \\
\text { gobiernos de las entidades } \\
\text { federativas y de los municipios, } \\
\text { en el marco del Servicio Nacional } \\
\text { Forestal; } \\
\end{array}$ & & $\begin{array}{l}\text { XXV. Diseñar y ejecutar programas } \\
\text { de prevención, protección, } \\
\text { conservación, y restauración de los } \\
\text { recursos y suelos forestales; }\end{array}$ \\
\hline $\begin{array}{l}\text { XXVIII. Definir y aplicar las } \\
\text { regulaciones del uso del } \\
\text { suelo en terrenos forestales y } \\
\text { preferentemente forestales; }\end{array}$ & & \\
\hline
\end{tabular}




\begin{tabular}{|c|c|c|}
\hline $\begin{array}{c}\text { Atribución Federal } \\
\text { Art. } 12\end{array}$ & $\begin{array}{l}\text { SEMARNAT } \\
\text { Art. } 16\end{array}$ & $\begin{array}{l}\text { CONAFOR } \\
\text { Art. } 22\end{array}$ \\
\hline \multicolumn{3}{|l|}{$\begin{array}{l}\text { XXIX. Expedir, por excepción, } \\
\text { las autorizaciones de cambio } \\
\text { de uso del suelo de los terrenos } \\
\text { forestales, así como controlar y } \\
\text { vigilar el uso del suelo forestal; }\end{array}$} \\
\hline $\begin{array}{l}\text { XXX. Elaborar estudios para, en } \\
\text { su caso, recomendar al Ejecutivo } \\
\text { Federal el establecimiento, } \\
\text { modificación o levantamiento de } \\
\text { vedas forestales; }\end{array}$ & $\begin{array}{l}\text { XIX. Elaborar estudios para, en } \\
\text { su caso, recomendar al Ejecutivo } \\
\text { Federal el establecimiento, } \\
\text { modificación o levantamiento de } \\
\text { vedas forestales; }\end{array}$ & \\
\hline $\begin{array}{l}\text { XXXI. Expedir las autorizaciones } \\
\text { para el aprovechamiento de } \\
\text { los recursos forestales y de } \\
\text { las plantaciones forestales } \\
\text { comerciales, así como de los } \\
\text { métodos de marqueo; }\end{array}$ & $\begin{array}{l}\text { XXII. Otorgar, prorrogar, modificar, } \\
\text { revocar, suspender o anular todos } \\
\text { los permisos, autorizaciones, } \\
\text { certificados y licencias, así como } \\
\text { recibir los avisos de plantaciones } \\
\text { forestales comerciales y para el } \\
\text { aprovechamiento de recursos } \\
\text { forestales no maderables; } \\
\text { XXIII. Ejercer todos los actos de } \\
\text { autoridad relativos a la aplicación } \\
\text { de la política de aprovechamiento } \\
\text { sustentable, conservación, } \\
\text { protección restauración de los } \\
\text { recursos forestales y de los suelos, } \\
\text { que esta ley prevea; }\end{array}$ & $\begin{array}{l}\text { XXI. Brindar asesoría y capacitación } \\
\text { a los pueblos y comunidades } \\
\text { indígenas, para que éstos puedan } \\
\text { organizarse para la producción y } \\
\text { aprovechamientos forestales en los } \\
\text { términos previstos por esta ley y de } \\
\text { acuerdo con sus usos y costumbres } \\
\text { cuando así proceda; } \\
\text { XXII. Ejecutar y promover los } \\
\text { programas productivos, de } \\
\text { restauración, de conservación y de } \\
\text { aprovechamiento sustentable de } \\
\text { suelos y sus ecosistemas; }\end{array}$ \\
\hline \multicolumn{3}{|l|}{$\begin{array}{l}\text { XXXII. Recibir los avisos } \\
\text { de plantaciones forestales } \\
\text { comerciales y de } \\
\text { aprovechamiento de recursos } \\
\text { forestales no maderables; }\end{array}$} \\
\hline $\begin{array}{l}\text { XXXIII. Regular, controlar y } \\
\text { evaluar la prestación de los } \\
\text { servicios técnicos forestales; }\end{array}$ & & $\begin{array}{l}\text { XXIII. Promover, asesorar, capacitar y } \\
\text { evaluar la prestación de los servicios } \\
\text { técnicos forestales; } \\
\text { XXXII. Proponer y evaluar los } \\
\text { sistemas y procedimientos relativos } \\
\text { a la prestación de los servicios } \\
\text { técnicos forestales, así como } \\
\text { instrumentar, operar y llevar el } \\
\text { seguimiento de los mismos; }\end{array}$ \\
\hline $\begin{array}{l}\text { XXXIV. Regular el transporte } \\
\text { de materias primas forestales, } \\
\text { así como de productos y } \\
\text { subproductos forestales; }\end{array}$ & $\begin{array}{l}\text { XXIV. Regular, expedir y validar } \\
\text { la documentación con la que se } \\
\text { acredite la legal procedencia de } \\
\text { las materias primas y productos } \\
\text { forestales; } \\
\text { XXV. Regular el transporte de } \\
\text { materias primas productos y } \\
\text { subproductos forestales; }\end{array}$ & \\
\hline
\end{tabular}




\begin{tabular}{|c|c|c|}
\hline $\begin{array}{l}\text { Atribución Federal } \\
\text { Art. } 12\end{array}$ & $\begin{array}{l}\text { SEMARNAT } \\
\text { Art. } 16\end{array}$ & $\begin{array}{l}\text { CONAFOR } \\
\text { Art. } 22\end{array}$ \\
\hline $\begin{array}{l}\text { XXXV. Expedir los avisos y } \\
\text { permisos según corresponda } \\
\text { para el combate y control } \\
\text { de plagas y enfermedades } \\
\text { forestales, así como los } \\
\text { certificados y demás } \\
\text { documentación fitosanitaria para } \\
\text { la exportación e importación de } \\
\text { recursos forestales; }\end{array}$ & $\begin{array}{l}\text { XXVI. Expedir los certificados y } \\
\text { demás documentación fitosanitaria } \\
\text { para la exportación e importación } \\
\text { de materias primas y productos } \\
\text { forestales; }\end{array}$ & \\
\hline $\begin{array}{l}\text { XXXVI. Expedir los permisos } \\
\text { previos para el funcionamiento } \\
\text { de centros de almacenamiento } \\
\text { y transformación de materias } \\
\text { primas forestales, sin perjuicio } \\
\text { de las atribuciones que } \\
\text { correspondan a las autoridades } \\
\text { locales, y }\end{array}$ & & \\
\hline $\begin{array}{l}\text { XXXVII. Los demás que esta Ley } \\
\text { y otros ordenamientos aplicables } \\
\text { le confieren }\end{array}$ & $\begin{array}{l}\text { X. Regular la integración, } \\
\text { monitoreo y actualización del } \\
\text { Inventario Nacional Forestal y de } \\
\text { Suelos } \\
\text { y coordinar el diseño del mismo; } \\
\text { XXVII. Intervenir en foros } \\
\text { internacionales respecto de las } \\
\text { materias competencia de la } \\
\text { Secretaría con la participación que } \\
\text { corresponda a la Secretaría de } \\
\text { Relaciones Exteriores y proponer } \\
\text { a ésta la celebración de tratados y } \\
\text { acuerdos internacionales en tales } \\
\text { materias, y } \\
\text { XXVIII. Las demás que le confieran } \\
\text { la presente Ley, el Reglamento y } \\
\text { otras disposiciones legales. }\end{array}$ & $\begin{array}{l}\text { XXIV. Realizar actividades de } \\
\text { investigación y desarrollo tecnológico } \\
\text { y de cultura, capacitación y } \\
\text { educación en materia forestal así } \\
\text { como formular y coordinar la política } \\
\text { de investigación forestal y de } \\
\text { desarrollo tecnológico; } \\
\text { XXXI. Participar, en el ámbito de } \\
\text { su competencia, en la política } \\
\text { de manejo y aprovechamiento } \\
\text { sustentable de la fauna silvestre } \\
\text { que habita en zonas forestales o } \\
\text { preferentemente forestales, así como } \\
\text { del aprovechamiento sustentable de } \\
\text { los recursos forestales y sus recursos } \\
\text { asociados; } \\
\text { XXXIV. Proteger y conservar los } \\
\text { recursos genéticos forestales; } \\
\text { XXXVII. Promover el Servicio Civil de } \\
\text { Carrera; } \\
\text { XXXIX. Las demás que le señale la } \\
\text { presente Ley, el Reglamento y demás } \\
\text { disposiciones legales aplicables. }\end{array}$ \\
\hline
\end{tabular}

Nota: En negritas se resaltan las facultades, mientras que los temas son subrayados. 
Tabla 9. Trámites de aprovechamiento forestal

\begin{tabular}{|c|c|c|c|}
\hline $\begin{array}{c}\text { Tipo de } \\
\text { aprovechamiento }\end{array}$ & $\begin{array}{l}\text { Autoridad } \\
\text { competente }\end{array}$ & Plazo para resolver & Pago de derechos \\
\hline $\begin{array}{l}\text { Aprovechamiento de } \\
\text { recursos forestales } \\
\text { maderables en predios } \\
\text { particulares, ejidos y } \\
\text { comunidades agrarias. }\end{array}$ & $\begin{array}{l}\text { SEMARNAT a través de } \\
\text { la Dirección General de } \\
\text { Gestión Forestal y de } \\
\text { Suelos. }\end{array}$ & $\begin{array}{l}30 \text { días hábiles } \\
\text { Si hay irregularidades } \\
\text { la SEMARNAT requerirá } \\
\text { información adicional } \\
\text { dentro de los } 15 \text { días } \\
\text { hábiles siguientes a la } \\
\text { presentación. }\end{array}$ & $\begin{array}{l}\text { Especies maderables } \\
\text { clima templado y frío: } \\
\$ 4,193.18 \text { (500 a } 1.000 \\
\mathrm{~m}^{3} \text { ), } \\
\$ 5,730.68 \text { (más de } 1.000 \\
\text { a } 5.000 \mathrm{~m}^{3} \text { ), } \\
\$ 7,338.08 \text { (más de } 5.000 \\
\mathrm{~m}^{3} \text { ). } \\
\text { Especies maderables } \\
\text { clima árido y semiárido } \\
\$ 2,651.64 \text { (500 hasta } \\
1.500 \text { m³), } \\
\$ 3,579.71 \text { (más de } 1.500 \\
\text { hasta } 3.000 \text { m²), } \\
\$ 4,640.37 \text { (más de } 3.000 \\
\mathrm{~m}^{3} \text { ) } \\
\text { No se pagará cuando: } \\
\text { Se trate de una solicitud } \\
\text { de autorización } \\
\text { automática y venga } \\
\text { acompañada del } \\
\text { certificado de adecuado } \\
\text { cumplimiento del } \\
\text { programa de manejo o } \\
\text { del certificado del buen } \\
\text { manejo forestal. } \\
\text { La solicitud de } \\
\text { modificación sea } \\
\text { exclusivamente para } \\
\text { el aprovechamiento } \\
\text { de saldos de arbolado } \\
\text { derribado de anualidades } \\
\text { vencidas. }\end{array}$ \\
\hline $\begin{array}{l}\text { Aprovechamientos } \\
\text { forestales en selvas } \\
\text { tropicales mayores } \\
\text { a } 20 \text { hectáreas, } \\
\text { aprovechamientos de } \\
\text { especies forestales } \\
\text { de difícil regeneración } \\
\text { y en Áreas Naturales } \\
\text { Protegidas en predios } \\
\text { particulares, en ejidos y } \\
\text { comunidades agrarias. }\end{array}$ & $\begin{array}{l}\text { SEMARNAT a través de } \\
\text { la Dirección General de } \\
\text { Gestión Forestal y de } \\
\text { Suelos. }\end{array}$ & $\begin{array}{l}60 \text { días hábiles } \\
\text { Si hay irregularidades } \\
\text { la SEMARNAT requerirá } \\
\text { información adicional } \\
\text { dentro de los } 15 \text { días } \\
\text { hábiles siguientes a la } \\
\text { presentación. }\end{array}$ & $\begin{array}{l}\text { No tiene costo la } \\
\text { autorización de } \\
\text { aprovechamiento forestal. } \\
\text { Se pagan los derechos } \\
\text { por concepto del } \\
\text { procedimiento de } \\
\text { evaluación de impacto } \\
\text { ambiental. }\end{array}$ \\
\hline
\end{tabular}


Tabla 10. Criterios para el establecimiento de la legalidad de la madera (Ley Lacey-FLEGT)

\begin{tabular}{|c|c|c|c|}
\hline $\begin{array}{c}\text { Etapa } \\
\text { en la } \\
\text { cadena de } \\
\text { suministro }\end{array}$ & $\begin{array}{l}\text { Componente } \\
\text { Ley Lacey }\end{array}$ & Documentos a revisar & $\begin{array}{c}\text { Instrumentos en el marco } \\
\text { legal mexicano }\end{array}$ \\
\hline Bosque & $\begin{array}{l}\text { Derechos } \\
\text { legales de } \\
\text { aprovechamiento }\end{array}$ & $\begin{array}{l}\text { Evidencia de que la compañía } \\
\text { tiene un contrato o acuerdo } \\
\text { vigente que confiere el derecho a } \\
\text { manejar y aprovechar el bosque. } \\
\text { Puede incluir: } \\
\text { Certificado de la autoridad } \\
\text { forestal. } \\
\text { Licencia para el manejo del } \\
\text { bosque. } \\
\text { Licencia forestal para madera. } \\
\text { Permiso de manejo forestal. } \\
\text { Licencia para operar en el sector } \\
\text { forestal. } \\
\text { Planes aprobados de manejo } \\
\text { forestal. } \\
\text { Licencia de aprovechamiento. }\end{array}$ & $\begin{array}{l}\text { LGDFS } \\
\text { Autorizaciones para el } \\
\text { aprovechamiento de los recursos } \\
\text { forestales. } \\
\text { Programa de manejo que } \\
\text { acompañan la solicitud } \\
\text { de autorización para el } \\
\text { aprovechamiento. } \\
\text { Autorización para adelantar el } \\
\text { plan de corta, alterar el calendario } \\
\text { aprobado o modificar el programa } \\
\text { de manejo forestal. }\end{array}$ \\
\hline Bosque & $\begin{array}{l}\text { Derechos } \\
\text { legales de } \\
\text { aprovechamiento }\end{array}$ & $\begin{array}{l}\text { Evidencia de que la empresa } \\
\text { está registrada legalmente y tiene } \\
\text { los permisos necesarios para } \\
\text { operar el manejo forestal y el } \\
\text { aprovechamiento de madera. }\end{array}$ & $\begin{array}{l}\text { LGDFS, Ley Agraria } \\
\text { Para obtener autorización se } \\
\text { necesita copia certificada del } \\
\text { título que acredite el derecho de } \\
\text { propiedad o posesión respecto } \\
\text { del terreno o terrenos objeto de la } \\
\text { solicitud; tratándose de ejidos y } \\
\text { comunidades, deberán presentar } \\
\text { acta de asamblea. }\end{array}$ \\
\hline Bosque & $\begin{array}{l}\text { Derechos } \\
\text { legales de } \\
\text { aprovechamiento }\end{array}$ & $\begin{array}{l}\text { Evidencia de que la empresa } \\
\text { responsable del aprovechamiento } \\
\text { cuenta con el permiso para las } \\
\text { operaciones, incluyendo: } \\
\text { Permiso de aprovechamiento de } \\
\text { madera. } \\
\text { Licencia para el aprovechamiento. } \\
\text { Plan de aprovechamiento o } \\
\text { gestión. }\end{array}$ & $\begin{array}{l}\text { LGDFS } \\
\text { Autorizaciones para el } \\
\text { aprovechamiento de los recursos } \\
\text { forestales. } \\
\text { Programa de manejo que } \\
\text { acompañan la solicitud } \\
\text { de autorización para el } \\
\text { aprovechamiento. } \\
\text { Autorización para adelantar el } \\
\text { plan de corta, alterar el calendario } \\
\text { aprobado o modificar el programa } \\
\text { de manejo forestal. }\end{array}$ \\
\hline
\end{tabular}




\begin{tabular}{|c|c|c|c|}
\hline $\begin{array}{c}\text { Etapa } \\
\text { en la } \\
\text { cadena de } \\
\text { suministro }\end{array}$ & $\begin{array}{l}\text { Componente } \\
\text { Ley Lacey }\end{array}$ & Documentos a revisar & $\begin{array}{l}\text { Instrumentos en el marco } \\
\text { legal mexicano }\end{array}$ \\
\hline Bosque & $\begin{array}{l}\text { Pago de tasas, } \\
\text { impuestos y } \\
\text { cuotas tributarias }\end{array}$ & $\begin{array}{l}\text { Evidencia de que la empresa ha } \\
\text { pagado todos los impuestos o } \\
\text { tasas requeridas por la autoridad } \\
\text { nacional, regional o local para la } \\
\text { obtención del permiso de manejo } \\
\text { o el aprovechamiento; y los } \\
\text { impuestos dirigidos al derecho de } \\
\text { aprovechamiento forestal por el } \\
\text { volumen consignado. Incluye: } \\
\text { Tasa de reforestación. } \\
\text { Licencia de funcionamiento de la } \\
\text { empresa. } \\
\text { Título de registro tributario de la } \\
\text { empresa. } \\
\text { Pago de cuotas tributarias para el } \\
\text { aprovechamiento. } \\
\text { Impuestos a las ventas e } \\
\text { impuesto a las rentas. }\end{array}$ & $\begin{array}{l}\text { LGDFS y Ley Federal de } \\
\text { Derechos. } \\
\text { Para obtener las autorizaciones } \\
\text { de aprovechamiento se deben } \\
\text { pagar derechos conforme a la Ley } \\
\text { Federal de Derechos. }\end{array}$ \\
\hline Transporte & $\begin{array}{l}\text { Legalidad de } \\
\text { posesión y } \\
\text { transporte }\end{array}$ & $\begin{array}{l}\text { Evidencia de que la empresa } \\
\text { ha utilizado los documentos } \\
\text { necesarios en el transporte de } \\
\text { madera, incluyendo: } \\
\text { Certificado de transporte de } \\
\text { madera. } \\
\text { Guía de transporte forestal. } \\
\text { Licencia de carga de productos } \\
\text { forestales. } \\
\text { Guía de remisión. } \\
\text { Pase de movilización. } \\
\text { Permiso de movilización. }\end{array}$ & $\begin{array}{l}\text { LGDFS y su reglamento. } \\
\text { Debe acreditarse la legal } \\
\text { procedencia con } \\
\text { remisión forestal, reembarque } \\
\text { forestal, pedimento aduanal o } \\
\text { comprobantes fiscales. }\end{array}$ \\
\hline Transporte & $\begin{array}{l}\text { Legalidad de } \\
\text { posesión y } \\
\text { transporte }\end{array}$ & $\begin{array}{l}\text { Evidencia de que la empresa ha } \\
\text { empleado los sellos o marcas } \\
\text { exigidos para el transporte de } \\
\text { troncos o madera, incluyendo: } \\
\text { Etiquetas. } \\
\text { Marcas con códigos de barra. } \\
\text { Marcas a presión. } \\
\text { Marcas con pintura. }\end{array}$ & $\begin{array}{l}\text { LGDFS, su reglamento y } \\
\text { normas oficiales mexicanas que } \\
\text { establecen los procedimientos, } \\
\text { criterios y especificaciones para } \\
\text { realizar el aprovechamiento, } \\
\text { transporte y almacenamiento } \\
\text { de corteza, tallos y plantas } \\
\text { completas de vegetación forestal, } \\
\text { palma, látex y otros exudados } \\
\text { de vegetación forestal, resina de } \\
\text { pino. }\end{array}$ \\
\hline
\end{tabular}




\begin{tabular}{|c|c|c|c|}
\hline $\begin{array}{c}\text { Etapa } \\
\text { en la } \\
\text { cadena de } \\
\text { suministro }\end{array}$ & $\begin{array}{l}\text { Componente } \\
\text { Ley Lacey }\end{array}$ & Documentos a revisar & $\begin{array}{c}\text { Instrumentos en el marco } \\
\text { legal mexicano }\end{array}$ \\
\hline Transformación & $\begin{array}{l}\text { Legalidad en } \\
\text { los procesos de } \\
\text { transformación }\end{array}$ & $\begin{array}{l}\text { Evidencia de que la compañía ha } \\
\text { adquirido la licencia y permisos } \\
\text { necesarios para procesar madera, } \\
\text { incluyendo: } \\
\text { Licencia de funcionamiento. } \\
\text { Certificado de procesos para } \\
\text { madera. }\end{array}$ & $\begin{array}{l}\text { LGDFS y su reglamento. } \\
\text { Autorización para el } \\
\text { funcionamiento de centros de } \\
\text { almacenamiento y transformación } \\
\text { de materias primas forestales. } \\
\text { La autorización incluye aspectos } \\
\text { relacionados con contratos, } \\
\text { cartas de abastecimiento, } \\
\text { balances oferta-demanda, libros } \\
\text { de registro de entradas y salidas. }\end{array}$ \\
\hline Transformación & $\begin{array}{l}\text { Pago de tasas, } \\
\text { impuestos y } \\
\text { derechos }\end{array}$ & $\begin{array}{l}\text { Evidencia de que la empresa ha } \\
\text { pagado todos los impuestos o } \\
\text { tasas requeridas por la autoridad } \\
\text { nacional, regional o local para } \\
\text { la transformación de madera, } \\
\text { incluyendo: } \\
\text { - Licencia de funcionamiento de } \\
\text { negocio. } \\
\text { - Títulos de registro de la } \\
\text { empresa. } \\
\text { - Declaraciones de impuestos. }\end{array}$ & $\begin{array}{l}\text { LGDFS y Ley Federal de } \\
\text { Derechos } \\
\text { Para obtener las autorizaciones } \\
\text { de aprovechamiento se deben } \\
\text { pagar derechos conforme a la Ley } \\
\text { Federal de Derechos. }\end{array}$ \\
\hline Exportación & $\begin{array}{l}\text { Legalidad en el } \\
\text { comercio y la } \\
\text { exportación }\end{array}$ & $\begin{array}{l}\text { Evidencia de que la empresa } \\
\text { cuenta con los permisos } \\
\text { necesarios para comercializar } \\
\text { y que cumple con todos los } \\
\text { requisitos legales para la } \\
\text { exportación, incluyendo: } \\
\text { - Permiso de exportación. } \\
\text { - Lista de mercancía. } \\
\text { - Facturas. } \\
\text { - Boleta de embarque. } \\
\text { - Declaración de aduanas. } \\
\text { - Pago y recibos de la tarifa } \\
\text { - } \text { portuaria. } \\
\text { - Ontrato de compra-venta. } \\
\text { - Orden de embarque. } \\
\text { - Permiso CITES cuando } \\
\text { aplique. }\end{array}$ & $\begin{array}{l}\text { LGDFS, Ley Aduanera, LGVS. } \\
\text { Requisitos generales para la } \\
\text { exportación: } \\
\text { Contrato de compra venta. } \\
\text { Pedimento de exportación. } \\
\text { Factura comercial. } \\
\text { Documentos de transporte } \\
\text { (guía aérea, conocimiento de } \\
\text { embarque, carta de porte, talón } \\
\text { de embarque). } \\
\text { Certificado de origen. } \\
\text { Emisión del certificado CITES. } \\
\text { Certificado fitosanitario forestal. }\end{array}$ \\
\hline
\end{tabular}




\begin{tabular}{|c|l|l|l|}
\hline $\begin{array}{c}\text { Etapa } \\
\text { en la } \\
\text { cadena de } \\
\text { suministro }\end{array}$ & $\begin{array}{c}\text { Componente } \\
\text { Ley Lacey }\end{array}$ & \multicolumn{1}{|c|}{ Documentos a revisar } & $\begin{array}{c}\text { Instrumentos en el marco } \\
\text { legal mexicano }\end{array}$ \\
\hline Exportación & $\begin{array}{l}\text { Pago de tasas, } \\
\text { impuestos y } \\
\text { derechos }\end{array}$ & $\begin{array}{l}\text { Evidencia de que la empresa ha } \\
\text { pagado todos los impuestos o } \\
\text { tasas requeridas por la autoridad } \\
\text { nacional, regional o local para la } \\
\text { exportación, incluyendo: } \\
\text { - } \begin{array}{l}\text { Recibo de pago de tasas y } \\
\text { permisos. }\end{array}\end{array}$ & $\begin{array}{l}\text { Dependiendo de la fracción } \\
\text { arancelaria aplica la Tarifa de la } \\
\text { Ley de Impuestos Generales de } \\
\text { Importación y Exportación. }\end{array}$ \\
\hline $\begin{array}{l}\text { Recibo del pago de los } \\
\text { impuestos exigidos para las } \\
\text { exportaciones. } \\
\text { Recibo de pago a los servicios } \\
\text { de aduanas. } \\
\text { Recibo de pago por el } \\
\text { impuesto al valor añadido. }\end{array}$ & \\
\hline
\end{tabular}

Adaptado del documento "Exportando en un panorama legal cambiante", WWF-TRAFFIC 2013.

Tabla 11. Trámite certificado fitosanitario para comercio internacional

\begin{tabular}{|l|l|l|r|}
\hline \multicolumn{1}{|c|}{ Trámite } & \multicolumn{1}{|c|}{ Autoridad competente } & \multicolumn{1}{c|}{ Plazo de respuesta } & $\begin{array}{c}\text { Pago de } \\
\text { derechos }\end{array}$ \\
\hline $\begin{array}{l}\text { Exportación o } \\
\text { reexportación }\end{array}$ & $\begin{array}{l}\text { SEMARNAT a través de la } \\
\text { Dirección General de Gestión } \\
\text { Forestal y de Suelos. }\end{array}$ & $\begin{array}{l}\text { 9 días hábiles. } \\
\text { Si hay irregularidades, la SEMARNAT } \\
\text { requerirá información adicional dentro } \\
\text { de los 3 días hábiles siguientes a la } \\
\text { presentación. }\end{array}$ & $\$ 834.66$ \\
\hline Importación & $\begin{array}{l}\text { SEMARNAT a través de la } \\
\text { Dirección General de Gestión } \\
\text { Forestal y de Suelos. }\end{array}$ & $\begin{array}{l}\text { 3 días hábiles. } \\
\text { Si hay irregularidades, la SEMARNAT } \\
\text { requerirá información adicional dentro } \\
\text { de los 3 días hábiles siguientes a la } \\
\text { presentación. }\end{array}$ & $\$ 1,048.31$ \\
\hline
\end{tabular}




\section{Tabla 12. Normas oficiales mexicanas aplicables al aprovechamiento y} comercio forestal

\section{NORMAS OFICIALES MEXICANAS APLICABLES AL APROVECHAMIENTO FORESTAL}

NOM-016-SEMARNAT-2013: Regula fitosanitariamente la importación de madera aserrada nueva.

NOM-144-SEMARNAT-2012: Establece las medidas fitosanitarias reconocidas internacionalmente para el embalaje de madera que se utiliza en el comercio internacional de bienes y mercancías.

NOM-013-SEMARNAT-2010: Regula sanitariamente la importación de árboles de Navidad naturales de las especies de los géneros Pinus y Abies, y la especie Pseudotsuga menziesii.

NOM-059-SEMARNAT-2010: Protección ambiental. Especies nativas de México de flora y fauna silvestres. Categorías de riesgo y especificaciones para su inclusión, exclusión o cambio. Lista de especies en riesgo.

NOM-152-SEMARNAT-2006: Establece los lineamientos, criterios y especificaciones de los contenidos de los programas de manejo forestal para el aprovechamiento de recursos forestales maderables en bosques, selvas y vegetación de zonas áridas.

NOM-026-SEMARNAT-2005: Establece los criterios y especificaciones técnicas para realizar el aprovechamiento comercial de resina de pino.

NOM-142-SEMARNAT-2003: Establece los lineamientos técnicos para el combate y control del psílido del eucalipto Glycaspis brimblecombei Moore.

NOM-029-SEMARNAT-2003: Especificaciones sanitarias del bambú, mimbre, bejuco, ratán, caña, junco y rafia, utilizados principalmente en la cestería y espartería.

NOM-007-SEMARNAT-1997: Establece los procedimientos, criterios y especificaciones para realizar el aprovechamiento, transporte y almacenamiento de ramas, hojas o pencas, flores, frutos y semillas.

NOM-006-SEMARNAT-1997: Establece los procedimientos, criterios y especificaciones para realizar el aprovechamiento, transporte y almacenamiento de hojas de palma.

NOM-005-SEMARNAT-1997: Establece los procedimientos, criterios y especificaciones para realizar el aprovechamiento, transporte y almacenamiento de corteza, tallos y plantas completas de vegetación forestal.

NOM-012-SEMARNAT-1996: Establece los procedimientos, criterios y especificaciones para realizar el aprovechamiento de leña para uso doméstico.

NOM-025-SEMARNAT-1995: Establece las características que deben tener los medios de marqueo de la madera en rollo, así como los lineamientos para su uso y control.

NOM-062-SEMARNAT-1994: Establece las especificaciones para mitigar los efectos adversos sobre la biodiversidad que se ocasionen por el cambio de uso del suelo de terrenos forestales a agropecuarios.

NOM-061-SEMARNAT-1994: Establece las especificaciones para mitigar los efectos adversos ocasionados en la flora y fauna silvestres por el aprovechamiento forestal. 
Tabla 13. Competencias sector forestal

\begin{tabular}{|c|c|c|c|}
\hline Tema & Federación & Estados y D.F. & Municipios \\
\hline Política Forestal & $\begin{array}{l}\text { Formula y conduce la } \\
\text { política nacional. }\end{array}$ & $\begin{array}{l}\text { Diseña, formula y aplica } \\
\text { la política forestal en las } \\
\text { entidades federativas. }\end{array}$ & $\begin{array}{l}\text { Diseña, formula y aplica } \\
\text { la política forestal del } \\
\text { municipio. }\end{array}$ \\
\hline $\begin{array}{l}\text { Instrumentos de Política } \\
\text { Forestal }\end{array}$ & Diseña, organiza y aplica. & $\begin{array}{l}\text { Aplica criterios de política } \\
\text { forestal. }\end{array}$ & $\begin{array}{l}\text { Aplica los criterios } \\
\text { federales y estatales en } \\
\text { las materias que le estén } \\
\text { reservadas. }\end{array}$ \\
\hline Servicio Nacional Forestal & & $\begin{array}{l}\text { Coadyuva en la adopción } \\
\text { y consolidación. }\end{array}$ & $\begin{array}{l}\text { Apoya en su adopción y } \\
\text { consolidación. }\end{array}$ \\
\hline Programas Forestales & $\begin{array}{l}\text { Los elabora, coordina } \\
\text { y aplica en ámbitos } \\
\text { nacional y regional } \\
\text { (sexenalmente y a largo } \\
\text { plazo). }\end{array}$ & $\begin{array}{l}\text { Elabora, aplica y } \\
\text { coordina, vinculándolos } \\
\text { con los programas } \\
\text { nacionales y regionales, } \\
\text { así como con su Plan } \\
\text { Estatal de Desarrollo. } \\
\end{array}$ & \\
\hline $\begin{array}{l}\text { Programas Forestales } \\
\text { Regionales }\end{array}$ & & $\begin{array}{l}\text { Participa en la } \\
\text { elaboración de } \\
\text { programas de largo } \\
\text { plazo, de ámbito } \\
\text { interestatal o por cuencas } \\
\text { hidrológico-forestales. } \\
\end{array}$ & \\
\hline $\begin{array}{l}\text { Sistemas de Ventanilla } \\
\text { única }\end{array}$ & Aplica y promueve. & $\begin{array}{l}\text { Impulsa el } \\
\text { establecimiento de este } \\
\text { sistema. }\end{array}$ & $\begin{array}{l}\text { Participa en su } \\
\text { establecimiento. }\end{array}$ \\
\hline $\begin{array}{l}\text { Inventario Forestal y de } \\
\text { Suelos }\end{array}$ & $\begin{array}{l}\text { Realiza el inventario } \\
\text { nacional y determina los } \\
\text { criterios e indicadores } \\
\text { para los inventarios } \\
\text { estatales. }\end{array}$ & $\begin{array}{l}\text { Elabora, monitorea y } \\
\text { mantiene actualizado el } \\
\text { Inventario Estatal Forestal } \\
\text { y de Suelos e incorpora } \\
\text { su contenido al Sistema } \\
\text { Nacional de Información } \\
\text { Estatal. }\end{array}$ & $\begin{array}{l}\text { Coadyuva con el } \\
\text { gobierno de la entidad } \\
\text { en la realización y } \\
\text { actualización del } \\
\text { Inventario Estatal. }\end{array}$ \\
\hline $\begin{array}{l}\text { Uso Doméstico de los } \\
\text { Recursos Forestales }\end{array}$ & & $\begin{array}{l}\text { Compila y procesa la } \\
\text { información y la incorpora } \\
\text { al Sistema Estatal de } \\
\text { Información Forestal. }\end{array}$ & \\
\hline Zonificación Forestal & $\begin{array}{l}\text { La lleva a cabo en todo } \\
\text { el país. }\end{array}$ & & $\begin{array}{l}\text { Participa en coordinación } \\
\text { con la Federación. }\end{array}$ \\
\hline $\begin{array}{l}\text { Registro Forestal } \\
\text { Nacional }\end{array}$ & $\begin{array}{l}\text { Diseña, organiza y } \\
\text { administra. }\end{array}$ & & \\
\hline $\begin{array}{l}\text { Reforestación y } \\
\text { Forestación }\end{array}$ & $\begin{array}{l}\text { Emite normas y vigila } \\
\text { su cumplimiento en } \\
\text { zonas de conservación y } \\
\text { restauración. }\end{array}$ & $\begin{array}{l}\text { Elabora y aplica } \\
\text { programas en zonas } \\
\text { degradadas que no } \\
\text { sean competencia } \\
\text { de la Federación. } \\
\text { Elabora estudios de } \\
\text { recomendación a la } \\
\text { Federación. }\end{array}$ & $\begin{array}{l}\text { Participa en la planeación } \\
\text { y ejecución. }\end{array}$ \\
\hline
\end{tabular}




\begin{tabular}{|c|c|c|c|}
\hline Tema & Federación & Estados y D.F. & Municipios \\
\hline $\begin{array}{l}\text { Normas Oficiales } \\
\text { Mexicanas }\end{array}$ & $\begin{array}{l}\text { Elabora, expide y vigila } \\
\text { su cumplimiento. }\end{array}$ & & \\
\hline $\begin{array}{l}\text { Bienes y servicios } \\
\text { ambientales }\end{array}$ & $\begin{array}{l}\text { Elabora y adopta } \\
\text { metodologías para su } \\
\text { valoración. }\end{array}$ & $\begin{array}{l}\text { Promueve los bienes y } \\
\text { servicios ambientales } \\
\text { de los ecosistemas } \\
\text { forestales. }\end{array}$ & \\
\hline $\begin{array}{l}\text { Mercado de bienes y } \\
\text { servicios ambientales }\end{array}$ & $\begin{array}{l}\text { Establece las bases } \\
\text { e instrumentos para } \\
\text { promoverlo. }\end{array}$ & & \\
\hline $\begin{array}{l}\text { Participación de } \\
\text { propietarios y poseedores } \\
\text { de los recursos forestales }\end{array}$ & $\begin{array}{l}\text { Genera mecanismos } \\
\text { para su impulso, } \\
\text { en la protección, } \\
\text { vigilancia, ordenación, } \\
\text { aprovechamiento, } \\
\text { cultivo, transformación y } \\
\text { comercialización. }\end{array}$ & $\begin{array}{l}\text { Impulsa su participación } \\
\text { directa en la protección, } \\
\text { vigilancia, ordenación, } \\
\text { aprovechamiento, cultivo, } \\
\text { transformación y su } \\
\text { comercialización. }\end{array}$ & \\
\hline $\begin{array}{l}\text { Educación y Cultura } \\
\text { Forestal }\end{array}$ & & $\begin{array}{l}\text { Promueve programas } \\
\text { y proyectos de } \\
\text { capacitación e } \\
\text { investigación forestal. }\end{array}$ & $\begin{array}{l}\text { Promueve programas y } \\
\text { proyectos de educación, } \\
\text { capacitación e } \\
\text { investigación forestal. }\end{array}$ \\
\hline $\begin{array}{l}\text { Acuerdos de cooperación } \\
\text { forestal }\end{array}$ & $\begin{array}{l}\text { Los celebra en el ámbito } \\
\text { nacional e internacional. }\end{array}$ & $\begin{array}{l}\text { Celebra acuerdos } \\
\text { y convenios de } \\
\text { coordinación. }\end{array}$ & $\begin{array}{l}\text { Celebra acuerdos } \\
\text { de cooperación y } \\
\text { concertación. }\end{array}$ \\
\hline $\begin{array}{l}\text { Instrumentos económicos } \\
\text { para promover el } \\
\text { desarrollo forestal }\end{array}$ & $\begin{array}{l}\text { Diseña, desarrolla, aplica } \\
\text { y propicia. }\end{array}$ & $\begin{array}{l}\text { Diseña, desarrolla y } \\
\text { aplica instrumentos para } \\
\text { el desarrollo forestal de la } \\
\text { entidad. }\end{array}$ & \\
\hline Fondo Forestal Mexicano & Lo promueve. & & \\
\hline Uso de Fuego & & $\begin{array}{l}\text { Lo regula en las } \\
\text { actividades relacionadas } \\
\text { con las agropecuarias } \\
\text { que pudieran afectar los } \\
\text { ecosistemas forestales. }\end{array}$ & \\
\hline Incendios Forestales & $\begin{array}{l}\text { Previene y combate. } \\
\text { Aplica el programa } \\
\text { nacional de prevención } \\
\text { de incendios forestales. }\end{array}$ & $\begin{array}{l}\text { Realiza acciones de } \\
\text { prevención, capacitación } \\
\text { y combate. }\end{array}$ & $\begin{array}{l}\text { Participa y coadyuva } \\
\text { en las acciones de } \\
\text { prevención y combate. }\end{array}$ \\
\hline $\begin{array}{l}\text { Restauración de } \\
\text { ecosistemas forestales } \\
\text { afectados por incendios }\end{array}$ & & $\begin{array}{l}\text { Promueve programas y } \\
\text { participa en ellos. }\end{array}$ & \\
\hline Genético Forestal & & $\begin{array}{l}\text { Impulsa programas de } \\
\text { mejoramiento. }\end{array}$ & \\
\hline Terrenos Forestales & $\begin{array}{l}\text { Deslinda, posee y } \\
\text { administra los terrenos } \\
\text { nacionales. }\end{array}$ & $\begin{array}{l}\text { Realiza y supervisa las } \\
\text { labores de conservación, } \\
\text { protección y restauración } \\
\text { de los terrenos estatales. }\end{array}$ & \\
\hline
\end{tabular}




\begin{tabular}{|c|c|c|c|}
\hline Tema & Federación & Estados y D.F. & Municipios \\
\hline Medidas de Sanidad & $\begin{array}{l}\text { Las establece y } \\
\text { ejecuta las acciones de } \\
\text { saneamiento forestales. }\end{array}$ & $\begin{array}{l}\text { Lleva a cabo acciones de } \\
\text { saneamiento. }\end{array}$ & $\begin{array}{l}\text { Lleva a cabo acciones } \\
\text { de saneamiento en su } \\
\text { ámbito territorial. }\end{array}$ \\
\hline $\begin{array}{l}\text { Manejo Forestal } \\
\text { Sustentable }\end{array}$ & $\begin{array}{l}\text { Promueve el uso de } \\
\text { prácticas, métodos y } \\
\text { tecnologías. }\end{array}$ & $\begin{array}{l}\text { Presta asesoría y } \\
\text { capacitación. }\end{array}$ & $\begin{array}{l}\text { Diseña, desarrolla } \\
\text { y aplica incentivos } \\
\text { para promoverlo. } \\
\text { Promueve participación } \\
\text { de organismos } \\
\text { públicos, privados y no } \\
\text { gubernamentales en } \\
\text { proyectos. }\end{array}$ \\
\hline Productores Forestales & $\begin{array}{l}\text { Promueve el desarrollo } \\
\text { y fortalecimiento de las } \\
\text { organizaciones. }\end{array}$ & $\begin{array}{l}\text { Los asesora y capacita } \\
\text { en la elaboración y } \\
\text { ejecución de programas } \\
\text { de manejo forestal. }\end{array}$ & \\
\hline $\begin{array}{l}\text { Infraestructura en } \\
\text { regiones forestales }\end{array}$ & $\begin{array}{l}\text { Promueve e invierte en su } \\
\text { mejoramiento. }\end{array}$ & $\begin{array}{l}\text { Promueve e invierte en su } \\
\text { mejoramiento. }\end{array}$ & $\begin{array}{l}\text { Promueve su } \\
\text { construcción y } \\
\text { mantenimiento. }\end{array}$ \\
\hline $\begin{array}{l}\text { Cadenas Productivas } \\
\text { Forestales }\end{array}$ & $\begin{array}{l}\text { Coadyuva con } \\
\text { los agentes } \\
\text { correspondientes. }\end{array}$ & $\begin{array}{l}\text { Asesora y orienta a } \\
\text { ejidatarios, comuneros, } \\
\text { comunidades indígenas } \\
\text { y otros productores } \\
\text { forestales en el desarrollo } \\
\text { de su organización. }\end{array}$ & \\
\hline $\begin{array}{l}\text { Pueblos y Comunidades } \\
\text { Indígenas }\end{array}$ & & $\begin{array}{l}\text { Brinda atención en los } \\
\text { asuntos relacionados } \\
\text { con la conservación } \\
\text { y mejoramiento de su } \\
\text { hábitat natural. }\end{array}$ & \\
\hline Producción Forestal & & $\begin{array}{l}\text { Fortalece y amplia su } \\
\text { participación. }\end{array}$ & \\
\hline $\begin{array}{l}\text { Inspección y vigilancia } \\
\text { forestal }\end{array}$ & $\begin{array}{l}\text { Lleva a cabo las visitas y } \\
\text { labores de vigilancia. }\end{array}$ & $\begin{array}{l}\text { Lleva a cabo acciones de } \\
\text { acuerdo con convenios } \\
\text { con la federación. }\end{array}$ & $\begin{array}{l}\text { Participa en la vigilancia } \\
\text { forestal de acuerdo } \\
\text { con los convenios } \\
\text { establecidos. }\end{array}$ \\
\hline $\begin{array}{l}\text { Auditorías técnicas } \\
\text { preventivas }\end{array}$ & Las desarrolla. & & \\
\hline $\begin{array}{l}\text { Materias primas } \\
\text { forestales }\end{array}$ & $\begin{array}{l}\text { Regula, expide y valida la } \\
\text { acreditación de su legal } \\
\text { procedencia. }\end{array}$ & & \\
\hline $\begin{array}{l}\text { Infracciones en materia } \\
\text { forestal }\end{array}$ & $\begin{array}{l}\text { Impone medidas de } \\
\text { seguridad y sanciones. }\end{array}$ & $\begin{array}{l}\text { Las hace del } \\
\text { conocimiento de las } \\
\text { autoridades federales. }\end{array}$ & $\begin{array}{l}\text { Las hace del } \\
\text { conocimiento de las } \\
\text { autoridades competentes } \\
\text { de los delitos federales. }\end{array}$ \\
\hline $\begin{array}{l}\text { Combate a tala } \\
\text { clandestina }\end{array}$ & $\begin{array}{l}\text { Participa en programas } \\
\text { de prevención. }\end{array}$ & $\begin{array}{l}\text { Lleva a cabo acciones de } \\
\text { prevención y combate. }\end{array}$ & $\begin{array}{l}\text { Participa y coadyuva } \\
\text { en los programas de } \\
\text { prevención y combate. }\end{array}$ \\
\hline
\end{tabular}




\begin{tabular}{|c|c|c|c|}
\hline Tema & Federación & Estados y D.F. & Municipios \\
\hline $\begin{array}{l}\text { Uso de suelo en terrenos } \\
\text { forestales }\end{array}$ & $\begin{array}{l}\text { Define y aplica las } \\
\text { regulaciones. Expide } \\
\text { por excepción el cambio } \\
\text { de uso de suelo de los } \\
\text { terrenos forestales. }\end{array}$ & & \\
\hline Vedas Forestales & $\begin{array}{l}\text { Elabora estudios } \\
\text { de modificación o } \\
\text { levantamiento de vedas. }\end{array}$ & $\begin{array}{l}\text { Elabora estudios de } \\
\text { recomendación al } \\
\text { ejecutivo. }\end{array}$ & \\
\hline Producción de plantas & & & $\begin{array}{l}\text { Desarrolla y apoya } \\
\text { viveros y programas. }\end{array}$ \\
\hline $\begin{array}{l}\text { Recursos forestales y } \\
\text { métodos de marqueo }\end{array}$ & $\begin{array}{l}\text { Expide las autorizaciones } \\
\text { para su aprovechamiento. }\end{array}$ & & \\
\hline $\begin{array}{l}\text { Avisos de plantaciones } \\
\text { forestales }\end{array}$ & $\begin{array}{l}\text { Recibe los avisos de } \\
\text { plantaciones forestales } \\
\text { comerciales y de } \\
\text { recursos forestales no } \\
\text { maderables. }\end{array}$ & & \\
\hline $\begin{array}{l}\text { Servicios Técnicos } \\
\text { Forestales }\end{array}$ & $\begin{array}{l}\text { Regula, controla y evalúa } \\
\text { su prestación. }\end{array}$ & & \\
\hline $\begin{array}{l}\text { Transporte de materias } \\
\text { primas forestales }\end{array}$ & $\begin{array}{l}\text { Lo regula, así como } \\
\text { el de productos y } \\
\text { subproductos forestales. }\end{array}$ & & $\begin{array}{l}\text { Regula y vigila la } \\
\text { disposición final de } \\
\text { residuos provenientes de } \\
\text { la extracción de materias } \\
\text { primas forestales. }\end{array}$ \\
\hline $\begin{array}{l}\text { Avisos y permisos para } \\
\text { el combate y control de } \\
\text { plagas }\end{array}$ & $\begin{array}{l}\text { Los expide, así como } \\
\text { los certificados y } \\
\text { demás documentación } \\
\text { fitosanitaria. }\end{array}$ & & \\
\hline $\begin{array}{l}\text { Centros de } \\
\text { almacenamiento y } \\
\text { transformación de } \\
\text { materias primas } \\
\text { forestales }\end{array}$ & $\begin{array}{l}\text { Expide permisos para su } \\
\text { funcionamiento. }\end{array}$ & & $\begin{array}{l}\text { Expide licencias o } \\
\text { permisos (previo a } \\
\text { su instalación) para } \\
\text { el establecimiento } \\
\text { de centros de } \\
\text { almacenamiento o } \\
\text { transformación de } \\
\text { materias primas. }\end{array}$ \\
\hline
\end{tabular}

Fuente: Vargas, José Manuel, INE 
Tabla 14. Trámites para el aprovechamiento forestal contenidos en la LGDFS

\begin{tabular}{|c|c|c|c|}
\hline Trámite & $\begin{array}{l}\text { Autoridad } \\
\text { competente }\end{array}$ & Plazo de respuesta & Pago de derechos \\
\hline $\begin{array}{l}\text { Exportación o } \\
\text { reexportación }\end{array}$ & $\begin{array}{l}\text { SEMARNAT, a través de } \\
\text { la Dirección General de } \\
\text { Gestión Forestal y de } \\
\text { Suelos. }\end{array}$ & $\begin{array}{l}9 \text { días hábiles. } \\
\text { Si hay irregularidades, } \\
\text { la SEMARNAT requerirá } \\
\text { información adicional } \\
\text { dentro de los } 3 \text { días } \\
\text { hábiles siguientes a la } \\
\text { presentación. }\end{array}$ & $\$ 834.66$ \\
\hline Importación & $\begin{array}{l}\text { SEMARNAT, a través de } \\
\text { la Dirección General de } \\
\text { Gestión Forestal y de } \\
\text { Suelos. }\end{array}$ & $\begin{array}{l}3 \text { días hábiles. } \\
\text { Si hay irregularid ades, } \\
\text { la SEMARNAT requerirá } \\
\text { información adicional } \\
\text { dentro de los } 3 \text { días } \\
\text { hábiles siguientes a la } \\
\text { presentación. }\end{array}$ & $\$ 1,048.31$ \\
\hline $\begin{array}{l}\text { Aprovechamiento de } \\
\text { recursos forestales } \\
\text { maderables en predios } \\
\text { particulares }\end{array}$ & $\begin{array}{l}\text { SEMARNAT, a través de } \\
\text { la Dirección General de } \\
\text { Gestión Forestal y de } \\
\text { Suelos. }\end{array}$ & $\begin{array}{l}30 \text { días hábiles } \\
\text { Si hay irregularidades, } \\
\text { la SEMARNAT requerirá } \\
\text { información adicional } \\
\text { dentro de los } 15 \text { días } \\
\text { hábiles siguientes a la } \\
\text { presentación. }\end{array}$ & $\begin{array}{l}\text { Especies maderables de } \\
\text { clima templado y frío: } \\
\$ 4,193.18 \text { (más de } 500 \mathrm{~m}^{3} \\
\text { hasta } 1.000 \mathrm{~m}^{3} \text { ) } \\
\$ 5,730.68 \text { (más de } 1.000 \\
\mathrm{~m}^{3} \text { hasta } 5.000 \mathrm{~m}^{3} \text { ) } \\
\$ 7,338.02 \text { (más de } 5.000 \\
\mathrm{~m}^{3} \text { en adelante) } \\
\text { Especies maderables de } \\
\text { clima árido y semiárido: } \\
\$ 2,651.64 \text { (de más de } 500 \\
\mathrm{~m}^{3} \text { hasta } 1.500 \mathrm{~m}^{3} \text { ) } \\
\$ 3,579.71 \text { (más de } 1.500 \\
\mathrm{~m}^{3} \text { hasta } 3.000 \mathrm{~m}^{3} \text { ) } \\
\$ 4,640.37 \text { (más de } 3.000 \\
\mathrm{~m}^{3} \text { ) sin IVA }\end{array}$ \\
\hline $\begin{array}{l}\text { Aprovechamientos } \\
\text { forestales en selvas } \\
\text { tropicales mayores a } 20 \\
\text { hectáreas } \\
\text { Aprovechamientos de } \\
\text { especies forestales } \\
\text { de difícil regeneración } \\
\text { y en Áreas Naturales } \\
\text { Protegidas en predios } \\
\text { particulares }\end{array}$ & $\begin{array}{l}\text { SEMARNAT, a través de } \\
\text { la Dirección General de } \\
\text { Gestión Forestal y de } \\
\text { Suelos. }\end{array}$ & $\begin{array}{l}60 \text { días hábiles } \\
\text { Si hay irregularidades, } \\
\text { la SEMARNAT requerirá } \\
\text { información adicional } \\
\text { dentro de los } 15 \text { días } \\
\text { hábiles siguientes a la } \\
\text { presentación. }\end{array}$ & No \\
\hline
\end{tabular}




\begin{tabular}{|c|c|c|c|}
\hline Trámite & $\begin{array}{c}\text { Autoridad } \\
\text { competente }\end{array}$ & Plazo de respuesta & Pago de derechos \\
\hline $\begin{array}{l}\text { Aprovechamiento de } \\
\text { recursos forestales } \\
\text { maderables en predios } \\
\text { particulares, ejidos y } \\
\text { comunidades agrarias }\end{array}$ & $\begin{array}{l}\text { SEMARNAT, a través de } \\
\text { la Dirección General de } \\
\text { Gestión Forestal y de } \\
\text { Suelos. }\end{array}$ & $\begin{array}{l}30 \text { días hábiles } \\
\text { Si hay irregularidades, } \\
\text { la SEMARNAT requerirá } \\
\text { información adicional } \\
\text { dentro de los } 15 \text { días } \\
\text { hábiles siguientes a la } \\
\text { presentación. }\end{array}$ & $\begin{array}{l}\text { Especies maderables clima } \\
\text { templado y frío: } \\
\$ 4,193.18 \text { (500 a } 1.000 \mathrm{~m}^{3} \text { ) } \\
\$ 5,730.68 \text { (más de } 1.000 \text { a } \\
5.000 \mathrm{~m}^{3} \text { ) } \\
\$ 7,338.08 \text { (más de } 5.000 \\
\left.\mathrm{~m}^{3}\right) \text {. } \\
\text { Especies maderables clima } \\
\text { árido y semiárido: } \\
\$ 2,651.64 \text { (500 hasta } 1.500 \\
\mathrm{~m}^{3} \text { ) } \\
\$ 3,579.71 \text { (más de } 1.500 \\
\text { hasta } 3.000 \text { m³) } \\
\$ 4,640.37 \text { (más de } 3.000 \\
\mathrm{~m}^{3} \text { ) } \\
\text { No se pagará cuando: } \\
\text { Se trate de una solicitud } \\
\text { de autorización automática } \\
\text { y venga acompañada del } \\
\text { certificado de adecuado } \\
\text { cumplimiento del programa } \\
\text { de manejo o del certificado } \\
\text { del buen manejo forestal. } \\
\text { La solicitud de } \\
\text { modificación sea } \\
\text { exclusivamente para el } \\
\text { aprovechamiento de saldos } \\
\text { de arbolado derribado de } \\
\text { anualidades vencidas. }\end{array}$ \\
\hline $\begin{array}{l}\text { Aprovechamientos } \\
\text { forestales en selvas } \\
\text { tropicales mayores } \\
\text { a } 20 \text { hectáreas, } \\
\text { aprovechamientos de } \\
\text { especies forestales } \\
\text { de difícil regeneración } \\
\text { y en Áreas Naturales } \\
\text { Protegidas en predios } \\
\text { particulares, en ejidos y } \\
\text { comunidades agrarias }\end{array}$ & $\begin{array}{l}\text { SEMARNAT, a través de } \\
\text { la Dirección General de } \\
\text { Gestión Forestal y de } \\
\text { Suelos. }\end{array}$ & $\begin{array}{l}60 \text { días hábiles. } \\
\text { Si hay irregularidades } \\
\text { la SEMARNAT requerirá } \\
\text { información adicional } \\
\text { dentro de los } 15 \text { días } \\
\text { hábiles siguientes a la } \\
\text { presentación. }\end{array}$ & $\begin{array}{l}\text { No tiene costo la } \\
\text { autorización de } \\
\text { aprovechamiento forestal. } \\
\\
\text { Se pagan los derechos } \\
\text { por concepto del } \\
\text { procedimiento de } \\
\text { evaluación de impacto } \\
\text { ambiental. }\end{array}$ \\
\hline
\end{tabular}




\begin{tabular}{|c|c|c|c|}
\hline Trámite & $\begin{array}{l}\text { Autoridad } \\
\text { competente }\end{array}$ & Plazo de respuesta & Pago de derechos \\
\hline $\begin{array}{l}\text { Autorización de Colecta } \\
\text { de Recursos Biológicos } \\
\text { Forestales con fines } \\
\text { comerciales }\end{array}$ & $\begin{array}{l}\text { SEMARNAT, a través de } \\
\text { la Dirección General de } \\
\text { Gestión Forestal y de } \\
\text { Suelos. }\end{array}$ & $\begin{array}{l}30 \text { Hábiles. } \\
\text { Si hay irregularidades } \\
\text { la SEMARNAT requerirá } \\
\text { información adicional } \\
\text { dentro de los } 15 \text { días } \\
\text { hábiles siguientes a la } \\
\text { presentación. }\end{array}$ & $\$ 12,340.78$ sin IVA \\
\hline $\begin{array}{l}\text { Autorización para } \\
\text { adelantar el plan } \\
\text { de corta, alterar el } \\
\text { calendario aprobado o } \\
\text { modificar el programa de } \\
\text { manejo forestal }\end{array}$ & $\begin{array}{l}\text { SEMARNAT, a través de } \\
\text { la Dirección General de } \\
\text { Gestión Forestal y de } \\
\text { Suelos. }\end{array}$ & $\begin{array}{l}30 \text { días hábiles. } \\
\text { Si hay irregularidades } \\
\text { la SEMARNAT requerirá } \\
\text { información adicional } \\
\text { dentro de los } 15 \text { días } \\
\text { hábiles siguientes a la } \\
\text { presentación. }\end{array}$ & Sí \\
\hline $\begin{array}{l}\text { Autorización para el } \\
\text { aprovechamiento de } \\
\text { recursos forestales no } \\
\text { maderables }\end{array}$ & $\begin{array}{l}\text { SEMARNAT, a través de } \\
\text { la Dirección General de } \\
\text { Gestión Forestal y de } \\
\text { Suelos. }\end{array}$ & $\begin{array}{l}30 \text { Hábiles. } \\
\text { Si hay irregularidades } \\
\text { la SEMARNAT requerirá } \\
\text { información adicional } \\
\text { dentro de los } 15 \text { días } \\
\text { hábiles siguientes a la } \\
\text { presentación }\end{array}$ & No \\
\hline $\begin{array}{l}\text { Autorización para } \\
\text { el funcionamiento } \\
\text { de centros de } \\
\text { almacenamiento y } \\
\text { transformación de } \\
\text { materias primas } \\
\text { forestales }\end{array}$ & $\begin{array}{l}\text { SEMARNAT, a través de } \\
\text { la Dirección General de } \\
\text { Gestión Forestal y de } \\
\text { Suelos. }\end{array}$ & $\begin{array}{l}30 \text { días hábiles. } \\
\text { Si hay irregularidades } \\
\text { la SEMARNAT requerirá } \\
\text { información adicional } \\
\text { dentro de los } 20 \text { días } \\
\text { hábiles siguientes a la } \\
\text { presentación. }\end{array}$ & $\$ 1,537.50$ sin IVA \\
\hline $\begin{array}{l}\text { Autorización para } \\
\text { realizar plantaciones } \\
\text { forestales comerciales, } \\
\text { Modalidad } \mathrm{A} \text {, en terrenos } \\
\text { preferentemente } \\
\text { forestales en superficies } \\
\text { mayores a } 800 \text { hectáreas }\end{array}$ & $\begin{array}{l}\text { SEMARNAT, a través de } \\
\text { la Dirección General de } \\
\text { Gestión Forestal y de } \\
\text { Suelos. }\end{array}$ & $\begin{array}{l}30 \text { días hábiles. } \\
\text { Si hay irregularidades } \\
\text { la SEMARNAT requerirá } \\
\text { información adicional } \\
\text { dentro de los } 15 \text { días } \\
\text { hábiles siguientes a la } \\
\text { presentación. }\end{array}$ & $\$ 5,730.68$ sin IVA \\
\hline $\begin{array}{l}\text { Autorización para realizar } \\
\text { plantaciones forestales } \\
\text { comerciales, Modalidad } \\
\text { B, en sustitución de } \\
\text { vegetación nativa }\end{array}$ & $\begin{array}{l}\text { SEMARNAT, a través de } \\
\text { la Dirección General de } \\
\text { Gestión Forestal y de } \\
\text { Suelos. }\end{array}$ & $\begin{array}{l}30 \text { días hábiles. } \\
\text { Si hay irregularidades } \\
\text { la SEMARNAT requerirá } \\
\text { información adicional } \\
\text { dentro de los } 15 \text { días } \\
\text { hábiles siguientes a la } \\
\text { presentación. }\end{array}$ & $\$ 5,730.68$ sin IVA \\
\hline
\end{tabular}




\begin{tabular}{|c|c|c|c|}
\hline Trámite & $\begin{array}{l}\text { Autoridad } \\
\text { competente }\end{array}$ & Plazo de respuesta & Pago de derechos \\
\hline $\begin{array}{l}\text { Autorización para } \\
\text { utilizar o aplicar } \\
\text { materiales, equipos, } \\
\text { procesos, métodos de } \\
\text { prueba, mecanismos, } \\
\text { procedimientos o } \\
\text { tecnologías alternativas } \\
\text { a las establecidas en } \\
\text { las normas oficiales } \\
\text { mexicanas en materia } \\
\text { forestal de la Dirección } \\
\text { General de Gestión } \\
\text { Forestal y de Suelos } \\
\text { Modalidad: Métodos de } \\
\text { Prueba alternos que no } \\
\text { cuenten con autorización } \\
\text { anterior publicada en } \\
\text { el Diario Oficial de la } \\
\text { Federación }\end{array}$ & $\begin{array}{l}\text { SEMARNAT, a través de } \\
\text { la Dirección General de } \\
\text { Gestión Forestal y de } \\
\text { Suelos. }\end{array}$ & $\begin{array}{l}120 \text { días Días Naturales. } \\
\text { Si hay irregularidades } \\
\text { la SEMARNAT requerirá } \\
\text { información adicional } \\
\text { dentro de los } 20 \text { días } \\
\text { naturales siguientes a la } \\
\text { presentación. }\end{array}$ & No \\
\hline $\begin{array}{l}\text { Autorización para } \\
\text { utilizar o aplicar } \\
\text { materiales, equipos, } \\
\text { procesos, métodos de } \\
\text { prueba, mecanismos, } \\
\text { procedimientos o } \\
\text { tecnologías alternativas } \\
\text { a las establecidas en } \\
\text { las normas oficiales } \\
\text { mexicanas en materia } \\
\text { forestal de la Dirección } \\
\text { General de Gestión } \\
\text { Forestal y de Suelos } \\
\text { Modalidad: Métodos } \\
\text { de Prueba alternos que } \\
\text { cuenten con autorización } \\
\text { anterior publicada en } \\
\text { el Diario Oficial de la } \\
\text { Federación }\end{array}$ & $\begin{array}{l}\text { SEMARNAT, a través de } \\
\text { la Dirección General de } \\
\text { Gestión Forestal y de } \\
\text { Suelos. }\end{array}$ & $\begin{array}{l}15 \text { días días naturales. } \\
\text { Si hay irregularidades } \\
\text { la SEMARNAT requerirá } \\
\text { información adicional } \\
\text { dentro de los } 10 \text { días } \\
\text { naturales siguientes a la } \\
\text { presentación. }\end{array}$ & No \\
\hline $\begin{array}{l}\text { Certificado Fitosanitario } \\
\text { de Exportación o } \\
\text { Reexportación }\end{array}$ & $\begin{array}{l}\text { SEMARNAT, a través de } \\
\text { la Dirección General de } \\
\text { Gestión Forestal y de } \\
\text { Suelos. }\end{array}$ & $\begin{array}{l}9 \text { días hábiles. } \\
\text { Si hay irregularidades } \\
\text { la SEMARNAT requerirá } \\
\text { información adicional } \\
\text { dentro de los } 3 \text { días } \\
\text { hábiles siguientes a la } \\
\text { presentación. }\end{array}$ & $\$ 838.64$ sin IVA \\
\hline $\begin{array}{l}\text { Certificado Fitosanitario } \\
\text { de Importación }\end{array}$ & $\begin{array}{l}\text { SEMARNAT, a través de } \\
\text { la Dirección General de } \\
\text { Gestión Forestal y de } \\
\text { Suelos. }\end{array}$ & $\begin{array}{l}3 \text { días hábiles. } \\
\text { Si hay irregularidades } \\
\text { la SEMARNAT requerirá } \\
\text { información adicional } \\
\text { dentro de los } 3 \text { días } \\
\text { hábiles siguientes a la } \\
\text { presentación. }\end{array}$ & $\$ 1,048.31$ sin IVA \\
\hline
\end{tabular}




\begin{tabular}{|c|c|c|c|}
\hline Trámite & $\begin{array}{l}\text { Autoridad } \\
\text { competente }\end{array}$ & Plazo de respuesta & Pago de derechos \\
\hline $\begin{array}{l}\text { Dictamen técnico } \\
\text { de determinación } \\
\text { taxonómica }\end{array}$ & $\begin{array}{l}\text { SEMARNAT, a través de } \\
\text { la Dirección General de } \\
\text { Gestión Forestal y de } \\
\text { Suelos. }\end{array}$ & $\begin{array}{l}15 \text { días hábiles. } \\
\text { Si hay irregularidades } \\
\text { la SEMARNAT requerirá } \\
\text { información adicional } \\
\text { dentro de los } 5 \text { días } \\
\text { hábiles siguientes a la } \\
\text { presentación. }\end{array}$ & $\$ 1,188.07$ sin IVA \\
\hline $\begin{array}{l}\text { Inscripción en el Registro } \\
\text { Forestal Nacional como } \\
\text { Prestador de Servicios } \\
\text { Técnicos Forestales o } \\
\text { Auditor Técnico Forestal }\end{array}$ & $\begin{array}{l}\text { SEMARNAT, a través de } \\
\text { la Dirección General de } \\
\text { Gestión Forestal y de } \\
\text { Suelos. }\end{array}$ & $\begin{array}{l}15 \text { días hábiles. } \\
\text { Si hay irregularidades } \\
\text { la SEMARNAT requerirá } \\
\text { información adicional } \\
\text { dentro de los } 5 \text { días } \\
\text { hábiles siguientes a la } \\
\text { presentación. }\end{array}$ & $\$ 349.44$ sin IVA \\
\hline $\begin{array}{l}\text { Recolección de } \\
\text { germoplasma forestal } \\
\text { para reforestación y } \\
\text { forestación con fines } \\
\text { de conservación o } \\
\text { restauración }\end{array}$ & $\begin{array}{l}\text { SEMARNAT, a través de } \\
\text { la Dirección General de } \\
\text { Gestión Forestal y de } \\
\text { Suelos. }\end{array}$ & $\begin{array}{l}\text { Si hay irregularidades } \\
\text { la SEMARNAT requerirá } \\
\text { información adicional } \\
\text { dentro de los } 10 \text { días } \\
\text { hábiles siguientes a la } \\
\text { presentación. }\end{array}$ & No \\
\hline $\begin{array}{l}\text { Registro de personas } \\
\text { que certifican el manejo } \\
\text { sustentable de los } \\
\text { bosques, tratándose de } \\
\text { adquisiciones del sector } \\
\text { público }\end{array}$ & $\begin{array}{l}\text { SEMARNAT, a través de } \\
\text { la Dirección General de } \\
\text { Gestión Forestal y de } \\
\text { Suelos. }\end{array}$ & $\begin{array}{l}30 \text { días naturales. } \\
\text { Si hay irregularidades } \\
\text { la SEMARNAT requerirá } \\
\text { información adicional } \\
\text { dentro de los } 10 \text { días } \\
\text { naturales siguientes a la } \\
\text { presentación. } \\
\end{array}$ & No \\
\hline $\begin{array}{l}\text { Solicitud de autorización } \\
\text { de cambio de uso } \\
\text { de suelo en terrenos } \\
\text { forestales }\end{array}$ & $\begin{array}{l}\text { SEMARNAT, a través de } \\
\text { la Dirección General de } \\
\text { Gestión Forestal y de } \\
\text { Suelos. }\end{array}$ & $\begin{array}{l}60 \text { días hábiles. } \\
\text { Si hay irregularidades } \\
\text { la SEMARNAT requerirá } \\
\text { información adicional } \\
\text { dentro de los } 15 \text { días } \\
\text { hábiles siguientes a la } \\
\text { presentación. }\end{array}$ & $\begin{array}{l}\text { I) Hasta } 1 \text { hectárea: } \\
\$ 908.53 \\
\text { II) De } 1 \text { hasta } 10 \text { hectáreas: } \\
\$ 1,257.95 \\
\text { III) De } 10 \text { hasta } 50 \\
\text { hectáreas: } \$ 2,655.68 \\
\text { IV) De } 50 \text { hasta } 200 \\
\text { hectáreas: } \$ 5,311.37 \\
\text { V) De más de } 200 \\
\text { hectáreas: } \$ 8,106.82 \text { sin } \\
\text { IVA } \\
\text { Para el caso de terrenos } \\
\text { forestales incendiados se } \\
\text { pagará adicionalmente } \\
\text { 20\% de la cuota } \\
\text { establecida. }\end{array}$ \\
\hline
\end{tabular}




\begin{tabular}{|c|c|c|c|}
\hline Trámite & $\begin{array}{l}\text { Autoridad } \\
\text { competente }\end{array}$ & Plazo de respuesta & Pago de derechos \\
\hline $\begin{array}{l}\text { Solicitud de } \\
\text { autorización para el } \\
\text { uso de la marca que } \\
\text { atestigua la aplicación } \\
\text { de tratamientos } \\
\text { fitosanitarios en } \\
\text { embalaje de madera de } \\
\text { acuerdo con la NOM- } \\
\text { 144-SEMARNAT-2012 }\end{array}$ & $\begin{array}{l}\text { SEMARNAT, a través de } \\
\text { la Dirección General de } \\
\text { Gestión Forestal y de } \\
\text { Suelos. }\end{array}$ & $\begin{array}{l}20 \text { días hábiles. } \\
\text { Si hay irregularidades } \\
\text { la SEMARNAT requerirá } \\
\text { información adicional } \\
\text { dentro de los } 5 \text { días } \\
\text { hábiles siguientes a la } \\
\text { presentación. }\end{array}$ & No \\
\hline $\begin{array}{l}\text { Solicitud de constancia } \\
\text { de verificación para el } \\
\text { aprovechamiento de } \\
\text { recursos forestales que } \\
\text { provengan de terrenos } \\
\text { diversos a los forestales }\end{array}$ & $\begin{array}{l}\text { SEMARNAT, a través de } \\
\text { la Dirección General de } \\
\text { Gestión Forestal y de } \\
\text { Suelos. }\end{array}$ & 13 días hábiles. & No \\
\hline $\begin{array}{l}\text { SEMARNAT-03-047 } \\
\text { Solicitud de constancias } \\
\text { de inscripción en } \\
\text { el Registro Forestal } \\
\text { Nacional }\end{array}$ & $\begin{array}{l}\text { SEMARNAT, a través de } \\
\text { la Dirección General de } \\
\text { Gestión Forestal y de } \\
\text { Suelos. }\end{array}$ & $\begin{array}{l}15 \text { días hábiles. } \\
\text { Si hay irregularidades } \\
\text { la SEMARNAT requerirá } \\
\text { información adicional } \\
\text { dentro de los } 5 \text { días } \\
\text { hábiles siguientes a la } \\
\text { presentación. }\end{array}$ & $\$ 349.44$ sin IVA \\
\hline $\begin{array}{l}\text { Solicitud de } \\
\text { Reembarques Forestales } \\
\text { para acreditar la legal } \\
\text { procedencia de materias } \\
\text { primas forestales, por } \\
\text { primera vez }\end{array}$ & $\begin{array}{l}\text { SEMARNAT, a través de } \\
\text { la Dirección General de } \\
\text { Gestión Forestal y de } \\
\text { Suelos. }\end{array}$ & $\begin{array}{l}15 \text { días hábiles. } \\
\text { Si hay irregularidades } \\
\text { la SEMARNAT requerirá } \\
\text { información adicional } \\
\text { dentro de los } 10 \text { días } \\
\text { hábiles siguientes a la } \\
\text { presentación. }\end{array}$ & No \\
\hline $\begin{array}{l}\text { Solicitud de Refrendo } \\
\text { de la autorización de } \\
\text { aprovechamiento de } \\
\text { recursos forestales } \\
\text { maderables al término } \\
\text { de un ciclo de corta } \\
\text { Modalidad: Sin } \\
\text { autorización automática }\end{array}$ & $\begin{array}{l}\text { SEMARNAT, a través de } \\
\text { la Dirección General de } \\
\text { Gestión Forestal y de } \\
\text { Suelos. }\end{array}$ & $\begin{array}{l}30 \text { días hábiles. } \\
\text { Si hay irregularidades } \\
\text { la SEMARNAT requerirá } \\
\text { información adicional } \\
\text { dentro de los } 15 \text { días } \\
\text { hábiles siguientes a la } \\
\text { presentación. }\end{array}$ & $\$ 5,730.68$ sin IVA \\
\hline $\begin{array}{l}\text { Solicitud de Refrendo } \\
\text { de la autorización de } \\
\text { aprovechamiento de } \\
\text { recursos forestales } \\
\text { maderables al término } \\
\text { de un ciclo de corta } \\
\text { Modalidad: Con } \\
\text { autorización automática }\end{array}$ & $\begin{array}{l}\text { SEMARNAT, a través de } \\
\text { la Dirección General de } \\
\text { Gestión Forestal y de } \\
\text { Suelos. }\end{array}$ & $\begin{array}{l}5 \text { días hábiles. } \\
\text { Si hay irregularidades } \\
\text { la SEMARNAT requerirá } \\
\text { información adicional } \\
\text { dentro de los } 2 \text { días } \\
\text { hábiles siguientes a la } \\
\text { presentación. }\end{array}$ & No \\
\hline
\end{tabular}




\begin{tabular}{|c|c|c|c|}
\hline Trámite & $\begin{array}{l}\text { Autoridad } \\
\text { competente }\end{array}$ & Plazo de respuesta & Pago de derechos \\
\hline $\begin{array}{l}\text { Solicitud de Remisiones } \\
\text { Forestales para acreditar } \\
\text { la legal procedencia } \\
\text { de materias primas } \\
\text { forestales, por primera } \\
\text { vez }\end{array}$ & $\begin{array}{l}\text { SEMARNAT, a través de } \\
\text { la Dirección General de } \\
\text { Gestión Forestal y de } \\
\text { Suelos }\end{array}$ & $\begin{array}{l}15 \text { días hábiles. } \\
\text { Si hay irregularidades } \\
\text { la SEMARNAT requerirá } \\
\text { información adicional } \\
\text { dentro de los } 10 \text { días } \\
\text { hábiles siguientes a la } \\
\text { presentación. }\end{array}$ & No \\
\hline $\begin{array}{l}\text { Trámite unificado de } \\
\text { aprovechamiento forestal }\end{array}$ & $\begin{array}{l}\text { SEMARNAT, a través de } \\
\text { la Dirección General de } \\
\text { Gestión Forestal y de } \\
\text { Suelos }\end{array}$ & $\begin{array}{l}60 \text { días hábiles. } \\
\text { Si hay irregularidades } \\
\text { la SEMARNAT requerirá } \\
\text { información adicional } \\
\text { dentro de los } 10 \text { días } \\
\text { hábiles siguientes a la } \\
\text { presentación. }\end{array}$ & $\begin{array}{l}\$ 8,680 \text { y por la } \\
\text { modificación del } \\
\text { documento se pagará 35\% } \\
\text { del monto señalado en este } \\
\text { artículo, sin IVA }\end{array}$ \\
\hline $\begin{array}{l}\text { Trámite unificado de } \\
\text { cambio de uso de suelo } \\
\text { forestal, Modalidad A }\end{array}$ & $\begin{array}{l}\text { SEMARNAT, a través de } \\
\text { la Dirección General de } \\
\text { Gestión Forestal y de } \\
\text { Suelos }\end{array}$ & $\begin{array}{l}60 \text { días hábiles. } \\
\text { Si hay irregularidades } \\
\text { la SEMARNAT requerirá } \\
\text { información adicional } \\
\text { dentro de los } 10 \text { días } \\
\text { hábiles siguientes a la } \\
\text { presentación. }\end{array}$ & Sí \\
\hline
\end{tabular}

Tabla 15. Número de autorizaciones de aprovechamiento forestal 1997-2008

\begin{tabular}{|c|c|c|c|c|c|}
\hline \multirow{2}{*}{$\begin{array}{c}\text { Entidad } \\
\text { Federativa }\end{array}$} & \multirow[b]{2}{*}{ Año } & \multicolumn{2}{|c|}{ Número } & \multicolumn{2}{|c|}{$m^{3} r$} \\
\hline & & Valores & $\begin{array}{l}\text { Crecimiento } \\
\text { anual }\end{array}$ & Valores & $\begin{array}{l}\text { Crecimiento } \\
\text { anual }\end{array}$ \\
\hline \multirow[t]{12}{*}{ Aguascalientes } & 1997 & 20 & & 7,170 & \\
\hline & 1998 & 40 & $100 \%$ & 15,284 & $113,2 \%$ \\
\hline & 1999 & 18 & $-55 \%$ & 4,424 & $-71,1 \%$ \\
\hline & 2000 & 15 & $-16,7 \%$ & 12,256 & $177 \%$ \\
\hline & 2001 & 22 & $46,7 \%$ & 21,256 & $73,4 \%$ \\
\hline & 2002 & 87 & $295,5 \%$ & 24,702 & $16,2 \%$ \\
\hline & 2003 & 45 & $-48,3 \%$ & 32,522 & $31,7 \%$ \\
\hline & 2004 & 10 & $-77,8 \%$ & 13,471 & $-58,6 \%$ \\
\hline & 2005 & 12 & $20 \%$ & 9,553 & $-29,1 \%$ \\
\hline & 2006 & 16 & $33,3 \%$ & 31,440 & $229,1 \%$ \\
\hline & 2007 & 11 & $-31,3 \%$ & 12,969 & $-58,8 \%$ \\
\hline & 2008 & 5 & $-54,5 \%$ & 1,998 & $-84,6 \%$ \\
\hline \multirow[t]{6}{*}{ Baja California } & 1997 & 4 & & 2,184 & \\
\hline & 1998 & 4 & $0 \%$ & 2,246 & $2,8 \%$ \\
\hline & 1999 & 2 & $-50 \%$ & 185 & $-91,8 \%$ \\
\hline & 2000 & 2 & $0 \%$ & 546 & $195,1 \%$ \\
\hline & 2001 & 3 & $50 \%$ & 65,181 & $1.1837,9 \%$ \\
\hline & 2002 & 5 & $66,7 \%$ & 78,091 & $19,8 \%$ \\
\hline
\end{tabular}




\begin{tabular}{|c|c|c|c|c|c|}
\hline \multirow{2}{*}{$\begin{array}{l}\text { Entidad } \\
\text { Federativa }\end{array}$} & \multirow[b]{2}{*}{ Año } & \multicolumn{2}{|c|}{ Número } & \multicolumn{2}{|c|}{$\mathbf{m}^{3} r$} \\
\hline & & Valores & $\begin{array}{l}\text { Crecimiento } \\
\text { anual }\end{array}$ & Valores & $\begin{array}{c}\text { Crecimiento } \\
\text { anual }\end{array}$ \\
\hline & 2003 & 2 & $-60,0 \%$ & 21,392 & $-72,6 \%$ \\
\hline & 2004 & 0 & $-100 \%$ & - & $-100 \%$ \\
\hline & 2005 & 1 & NA & 464 & NA \\
\hline & 2006 & 4 & $300 \%$ & 20,815 & $4.386 \%$ \\
\hline & 2007 & 1 & $-75 \%$ & 644 & $-96,9 \%$ \\
\hline & 2008 & 2 & $100 \%$ & 1,996 & $209,9 \%$ \\
\hline \multirow[t]{12}{*}{ Baja California Sur } & 1997 & 32 & & 18,442 & \\
\hline & 1998 & 19 & $-40,6 \%$ & 7,246 & $-60,7 \%$ \\
\hline & 1999 & 26 & $36,8 \%$ & 19,843 & $173,8 \%$ \\
\hline & 2000 & 18 & $-30,8 \%$ & 21,359 & $7,6 \%$ \\
\hline & 2001 & 23 & $27,8 \%$ & 47,053 & $120,3 \%$ \\
\hline & 2002 & 16 & $-30,4 \%$ & 14,717 & $-68,7 \%$ \\
\hline & 2003 & 9 & $-43,8 \%$ & 11,187 & $-24 \%$ \\
\hline & 2004 & 8 & $-11,1 \%$ & 26,760 & $139,2 \%$ \\
\hline & 2005 & 17 & $112,5 \%$ & 19,948 & $-25,5 \%$ \\
\hline & 2006 & 7 & $-58,8 \%$ & 18,126 & $-9,1 \%$ \\
\hline & 2007 & 7 & $0 \%$ & 17,446 & $-3,8 \%$ \\
\hline & 2008 & 5 & $-28,6 \%$ & 8,354 & $-52,1 \%$ \\
\hline \multirow[t]{12}{*}{ Campeche } & 1997 & 23 & & 326,216 & \\
\hline & 1998 & 17 & $-26,1 \%$ & 168,410 & $-48,4 \%$ \\
\hline & 1999 & 15 & $-11,8 \%$ & 180,207 & $7 \%$ \\
\hline & 2000 & 21 & $40 \%$ & 138,144 & $-23,3 \%$ \\
\hline & 2001 & 11 & $-47,6 \%$ & 161,759 & $17,1 \%$ \\
\hline & 2002 & 29 & $163,6 \%$ & 135,972 & $-15,9 \%$ \\
\hline & 2003 & 52 & $79,3 \%$ & 96,912 & $-28,7 \%$ \\
\hline & 2004 & 25 & $-51,9 \%$ & 314,291 & $224,3 \%$ \\
\hline & 2005 & 24 & $-4 \%$ & 381,202 & $21,3 \%$ \\
\hline & 2006 & 11 & $-54,2 \%$ & 106,860 & $-72 \%$ \\
\hline & 2007 & 5 & $-54,5 \%$ & 69,159 & $-35,3 \%$ \\
\hline & 2008 & 12 & $140 \%$ & 151,557 & $119,1 \%$ \\
\hline \multirow[t]{10}{*}{ Coahuila } & 1997 & 12 & & 5,136 & \\
\hline & 1998 & 16 & $33,3 \%$ & 33,038 & $543,3 \%$ \\
\hline & 1999 & 21 & $31,3 \%$ & 21,442 & $-35,1 \%$ \\
\hline & 2000 & 35 & $66,7 \%$ & 38,593 & $80 \%$ \\
\hline & 2001 & 9 & $-74,3 \%$ & 38,384 & $-0,5 \%$ \\
\hline & 2002 & 23 & $155,6 \%$ & 2,706 & $-93 \%$ \\
\hline & 2003 & 17 & $-26,1 \%$ & 26,766 & $889,1 \%$ \\
\hline & 2004 & 18 & $5,9 \%$ & 27,877 & $4,2 \%$ \\
\hline & 2005 & 6 & $-66,7 \%$ & 7,697 & $-72,4 \%$ \\
\hline & 2006 & 4 & $-33,3 \%$ & 6,022 & $-21,8 \%$ \\
\hline
\end{tabular}




\begin{tabular}{|c|c|c|c|c|c|}
\hline \multirow{2}{*}{$\begin{array}{c}\text { Entidad } \\
\text { Federativa }\end{array}$} & \multirow[b]{2}{*}{ Año } & \multicolumn{2}{|c|}{ Número } & \multicolumn{2}{|c|}{$m^{3} r$} \\
\hline & & Valores & $\begin{array}{c}\text { Crecimiento } \\
\text { anual }\end{array}$ & Valores & $\begin{array}{l}\text { Crecimiento } \\
\text { anual }\end{array}$ \\
\hline & 2007 & 6 & $50 \%$ & 5,205 & $-13,6 \%$ \\
\hline & 2008 & 2 & $-66,7 \%$ & 700 & $-86,6 \%$ \\
\hline \multirow[t]{12}{*}{ Colima } & 1997 & 37 & & 3,848 & \\
\hline & 1998 & 51 & $37,8 \%$ & 2,309 & $-40 \%$ \\
\hline & 1999 & 68 & $33,3 \%$ & 25,503 & $1.004,5 \%$ \\
\hline & 2000 & 23 & $-66,2 \%$ & 46,206 & $81,2 \%$ \\
\hline & 2001 & 34 & $47,8 \%$ & 24,022 & $-48 \%$ \\
\hline & 2002 & 46 & $35,3 \%$ & 167,956 & $599,2 \%$ \\
\hline & 2003 & 37 & $-19,6 \%$ & 184,117 & $9,6 \%$ \\
\hline & 2004 & 15 & $-59,5 \%$ & 88,310 & $-52 \%$ \\
\hline & 2005 & 5 & $-66,7 \%$ & 25,434 & $-71,2 \%$ \\
\hline & 2006 & 9 & $80 \%$ & 17,309 & $-31,9 \%$ \\
\hline & 2007 & 9 & $0 \%$ & 17,309 & $0 \%$ \\
\hline & 2008 & 14 & $55,6 \%$ & 909 & $-94,7 \%$ \\
\hline \multirow[t]{12}{*}{ Chiapas } & 1997 & 113 & & $1,791,810$ & \\
\hline & 1998 & 87 & $-23 \%$ & 80,968 & $-95,5 \%$ \\
\hline & 1999 & 6 & $-93,1 \%$ & 12,062 & $-85,1 \%$ \\
\hline & 2000 & 111 & $1750 \%$ & 83,568 & $592,8 \%$ \\
\hline & 2001 & 69 & $-37,8 \%$ & 659,769 & $689,5 \%$ \\
\hline & 2002 & 86 & $24,6 \%$ & 401,169 & $-39,2 \%$ \\
\hline & 2003 & 150 & $74,4 \%$ & 164,942 & $-58,9 \%$ \\
\hline & 2004 & 27 & $-82 \%$ & 325,736 & $97,5 \%$ \\
\hline & 2005 & 53 & $96,3 \%$ & 522,176 & $60,3 \%$ \\
\hline & 2006 & 26 & $-50,9 \%$ & 201,883 & $-61,3 \%$ \\
\hline & 2007 & 18 & $-30,8 \%$ & 143,690 & $-28,8 \%$ \\
\hline & 2008 & 11 & $-38,9 \%$ & 60,125 & $-58,2 \%$ \\
\hline \multirow[t]{12}{*}{ Chihuahua } & 1997 & 417 & & $1,272,844$ & \\
\hline & 1998 & 344 & $-17,5 \%$ & $1,519,980$ & $19,4 \%$ \\
\hline & 1999 & 284 & $-17,4 \%$ & $1,493,324$ & $-1,8 \%$ \\
\hline & 2000 & 278 & $-2,1 \%$ & 857,277 & $-42,6 \%$ \\
\hline & 2001 & 813 & $192,4 \%$ & $2,558,734$ & $198,5 \%$ \\
\hline & 2002 & 239 & $-70,6 \%$ & 277,014 & $-89,2 \%$ \\
\hline & 2003 & 161 & $-32,6 \%$ & 303,869 & $9,7 \%$ \\
\hline & 2004 & 104 & $-35,4 \%$ & $2,337,234$ & $669,2 \%$ \\
\hline & 2005 & 97 & $-6,7 \%$ & 261,844 & $-88,8 \%$ \\
\hline & 2006 & 101 & $4,1 \%$ & 756,871 & $189,1 \%$ \\
\hline & 2007 & 73 & $-27,7 \%$ & 296,870 & $-60,8 \%$ \\
\hline & 2008 & 60 & $-17,8 \%$ & 449,035 & $51,3 \%$ \\
\hline \multirow[t]{3}{*}{ Distrito Federal } & 1997 & 2 & & 11,498 & \\
\hline & 1998 & 0 & $-100 \%$ & - & $-100 \%$ \\
\hline & 1999 & 1 & NA & 2,149 & NA \\
\hline
\end{tabular}




\begin{tabular}{|c|c|c|c|c|c|}
\hline \multirow{2}{*}{$\begin{array}{c}\text { Entidad } \\
\text { Federativa }\end{array}$} & \multirow[b]{2}{*}{ Año } & \multicolumn{2}{|c|}{ Número } & \multicolumn{2}{|c|}{$m^{3} r$} \\
\hline & & Valores & $\begin{array}{l}\text { Crecimiento } \\
\text { anual }\end{array}$ & Valores & $\begin{array}{l}\text { Crecimiento } \\
\text { anual }\end{array}$ \\
\hline & 2000 & 0 & $-100 \%$ & - & $-100 \%$ \\
\hline & 2001 & 4 & NA & 3,062 & NA \\
\hline & 2002 & 5 & $25 \%$ & 27,855 & $809,7 \%$ \\
\hline & 2003 & 1 & $-80 \%$ & 1,264 & $-95,5 \%$ \\
\hline & 2004 & 2 & $100 \%$ & 8,689 & $587,4 \%$ \\
\hline & 2005 & 1 & $-50 \%$ & 7,593 & $-12,6 \%$ \\
\hline & 2006 & 0 & $-100 \%$ & - & $-100 \%$ \\
\hline & 2007 & 2 & NA & 6,498 & NA \\
\hline & 2008 & 0 & $-100 \%$ & - & $-100 \%$ \\
\hline \multirow[t]{12}{*}{ Durango } & 1997 & 328 & & $1,615,392$ & \\
\hline & 1998 & 288 & $-12,2 \%$ & $1,625,784$ & $0,6 \%$ \\
\hline & 1999 & 294 & $2,1 \%$ & $1,101,922$ & $-32,2 \%$ \\
\hline & 2000 & 272 & $-7,5 \%$ & 711,223 & $-35,5 \%$ \\
\hline & 2001 & 894 & $228,7 \%$ & $3,640,246$ & $411,8 \%$ \\
\hline & 2002 & 258 & $-71,1 \%$ & $1,235,764$ & $-66,1 \%$ \\
\hline & 2003 & 115 & $-55,4 \%$ & 947,846 & $-23,3 \%$ \\
\hline & 2004 & 157 & $36,5 \%$ & 542,365 & $-42,8 \%$ \\
\hline & 2005 & 170 & $8,3 \%$ & 114,828 & $-78,8 \%$ \\
\hline & 2006 & 268 & $57,6 \%$ & $3,893,224$ & $3.290,5 \%$ \\
\hline & 2007 & 274 & $2,2 \%$ & $5,110,635$ & $31,3 \%$ \\
\hline & 2008 & 618 & $125,5 \%$ & $13,418,446$ & $162,6 \%$ \\
\hline \multirow[t]{12}{*}{ Guanajuato } & 1997 & 24 & & 60,175 & \\
\hline & 1998 & 11 & $-54,2 \%$ & 24,297 & $-59,6 \%$ \\
\hline & 1999 & 2 & $-81,8 \%$ & 11,166 & $-54 \%$ \\
\hline & 2000 & 37 & $1.750 \%$ & 79,786 & $614,5 \%$ \\
\hline & 2001 & 11 & $-70,3 \%$ & 63,257 & $-20,7 \%$ \\
\hline & 2002 & 11 & $0 \%$ & 26,264 & $-58,5 \%$ \\
\hline & 2003 & 15 & $36,4 \%$ & 17,223 & $-34,4 \%$ \\
\hline & 2004 & 2 & $-86,7 \%$ & 19,923 & $15,7 \%$ \\
\hline & 2005 & 12 & $500 \%$ & 18,762 & $-5,8 \%$ \\
\hline & 2006 & 14 & $16,7 \%$ & 181,112 & $865,3 \%$ \\
\hline & 2007 & 7 & $-50 \%$ & 106,111 & $-41,4 \%$ \\
\hline & 2008 & 2 & $-71,4 \%$ & 147,538 & $39 \%$ \\
\hline \multirow[t]{8}{*}{ Guerrero } & 1997 & 119 & & 697,807 & \\
\hline & 1998 & 53 & $-55,5 \%$ & 740,594 & $6,1 \%$ \\
\hline & 1999 & 38 & $-28,3 \%$ & 407,200 & $-45 \%$ \\
\hline & 2000 & 29 & $-23,7 \%$ & $1,038,291$ & $155 \%$ \\
\hline & 2001 & 24 & $-17,2 \%$ & 408,392 & $-60,7 \%$ \\
\hline & 2002 & 48 & $100 \%$ & 991,216 & $142,7 \%$ \\
\hline & 2003 & 37 & $-22,9 \%$ & 806,774 & $-18,6 \%$ \\
\hline & 2004 & 24 & $-35,1 \%$ & $1,279,266$ & $58,6 \%$ \\
\hline
\end{tabular}




\begin{tabular}{|c|c|c|c|c|c|}
\hline \multirow{2}{*}{$\begin{array}{c}\text { Entidad } \\
\text { Federativa }\end{array}$} & \multirow[b]{2}{*}{ Año } & \multicolumn{2}{|c|}{ Número } & \multicolumn{2}{|c|}{$m^{3} r$} \\
\hline & & Valores & $\begin{array}{l}\text { Crecimiento } \\
\text { anual }\end{array}$ & Valores & $\begin{array}{l}\text { Crecimiento } \\
\text { anual }\end{array}$ \\
\hline & 2005 & 22 & $-8,3 \%$ & 341,730 & $-73,3 \%$ \\
\hline & 2006 & 42 & $90,9 \%$ & $1,049,866$ & $207,2 \%$ \\
\hline & 2007 & 10 & $-76,2 \%$ & 242,934 & $-76,9 \%$ \\
\hline & 2008 & 13 & $30 \%$ & 361,235 & $48,7 \%$ \\
\hline \multirow[t]{12}{*}{ Hidalgo } & 1997 & 161 & & 123,688 & \\
\hline & 1998 & 141 & $-12,4 \%$ & 94,882 & $-23,3 \%$ \\
\hline & 1999 & 78 & $-44,7 \%$ & 31,559 & $-66,7 \%$ \\
\hline & 2000 & 53 & $-32,1 \%$ & 32,378 & $2,6 \%$ \\
\hline & 2001 & 326 & $515,1 \%$ & 109,267 & $237,5 \%$ \\
\hline & 2002 & 150 & $-54 \%$ & 103,707 & $-5,1 \%$ \\
\hline & 2003 & 211 & $40,7 \%$ & 136,094 & $31,2 \%$ \\
\hline & 2004 & 32 & $-84,8 \%$ & 20,039 & $-85,3 \%$ \\
\hline & 2005 & 50 & $56,3 \%$ & 24,648 & $23 \%$ \\
\hline & 2006 & 73 & $46 \%$ & 40,190 & $63,1 \%$ \\
\hline & 2007 & 82 & $12,3 \%$ & 67,456 & $67,8 \%$ \\
\hline & 2008 & 80 & $-2,4 \%$ & 168,737 & $150,1 \%$ \\
\hline \multirow[t]{12}{*}{ Jalisco } & 1997 & 430 & & 695,235 & \\
\hline & 1998 & 509 & $18,4 \%$ & 887,629 & $27,7 \%$ \\
\hline & 1999 & 365 & $-28,3 \%$ & 429,403 & $-51,6 \%$ \\
\hline & 2000 & 118 & $-67,7 \%$ & 126,541 & $-70,5 \%$ \\
\hline & 2001 & 233 & $97,5 \%$ & 205,248 & $62,2 \%$ \\
\hline & 2002 & 181 & $-22,3 \%$ & 159,826 & $-22,1 \%$ \\
\hline & 2003 & 79 & $-56,4 \%$ & 67,477 & $-57,8 \%$ \\
\hline & 2004 & 117 & $48,1 \%$ & 455,029 & $574,3 \%$ \\
\hline & 2005 & 120 & $2,6 \%$ & 909,084 & $99,8 \%$ \\
\hline & 2006 & 142 & $18,3 \%$ & $1,101,781$ & $21,2 \%$ \\
\hline & 2007 & 76 & $-46,5 \%$ & 471,225 & $-57,2 \%$ \\
\hline & 2008 & 93 & $22,4 \%$ & 479,807 & $1,8 \%$ \\
\hline \multirow[t]{12}{*}{ México } & 1997 & 226 & & 22,982 & \\
\hline & 1998 & 283 & $25,2 \%$ & 234,441 & $920,1 \%$ \\
\hline & 1999 & 183 & $-35,3 \%$ & 398,891 & $70,1 \%$ \\
\hline & 2000 & 118 & $-35,5 \%$ & 96,344 & $-75,8 \%$ \\
\hline & 2001 & 167 & $41,5 \%$ & 185,617 & $92,7 \%$ \\
\hline & 2002 & 68 & $-59,3 \%$ & 107,672 & $-42 \%$ \\
\hline & 2003 & 69 & $1,5 \%$ & 108,757 & $1 \%$ \\
\hline & 2004 & 0 & $-100 \%$ & - & $-100 \%$ \\
\hline & 2005 & 17 & NA & 87,811 & NA \\
\hline & 2006 & 14 & $-17,6 \%$ & 143,686 & $63,6 \%$ \\
\hline & 2007 & 36 & $157,1 \%$ & 405,185 & $182 \%$ \\
\hline & 2008 & 51 & $41,7 \%$ & 986,949 & $143,6 \%$ \\
\hline
\end{tabular}




\begin{tabular}{|c|c|c|c|c|c|}
\hline \multirow{2}{*}{$\begin{array}{c}\text { Entidad } \\
\text { Federativa }\end{array}$} & \multirow[b]{2}{*}{ Año } & \multicolumn{2}{|c|}{ Número } & \multicolumn{2}{|c|}{$m^{3} r$} \\
\hline & & Valores & $\begin{array}{c}\text { Crecimiento } \\
\text { anual }\end{array}$ & Valores & $\begin{array}{l}\text { Crecimiento } \\
\text { anual }\end{array}$ \\
\hline \multirow[t]{12}{*}{ Michoacán } & 1997 & 702 & & 999,870 & \\
\hline & 1998 & 723 & $3 \%$ & 978,149 & $-2,2 \%$ \\
\hline & 1999 & 208 & $-71,2 \%$ & 450,493 & $-53,9 \%$ \\
\hline & 2000 & 219 & $5,3 \%$ & 972,066 & $115,8 \%$ \\
\hline & 2001 & 239 & $9,1 \%$ & 666,803 & $-31,4 \%$ \\
\hline & 2002 & 600 & $151 \%$ & 598,581 & $-10,2 \%$ \\
\hline & 2003 & 398 & $-33,7 \%$ & 549,059 & $-8,3 \%$ \\
\hline & 2004 & 173 & $-56,5 \%$ & 496,116 & $-9,6 \%$ \\
\hline & 2005 & 145 & $-16,2 \%$ & 981,422 & $97,8 \%$ \\
\hline & 2006 & 123 & $-15,2 \%$ & 473,801 & $-51,7 \%$ \\
\hline & 2007 & 168 & $36,6 \%$ & $1,077,591$ & $127,4 \%$ \\
\hline & 2008 & 173 & $3 \%$ & $1,453,475$ & $34,9 \%$ \\
\hline \multirow[t]{12}{*}{ Morelos } & 1997 & 3 & & 5,390 & \\
\hline & 1998 & 1 & $-66,7 \%$ & 1,903 & $-64,7 \%$ \\
\hline & 1999 & 1 & $0 \%$ & 2,033 & $6,8 \%$ \\
\hline & 2000 & 2 & $100 \%$ & 8,471 & $316,7 \%$ \\
\hline & 2001 & 6 & $200 \%$ & 26,241 & $209,8 \%$ \\
\hline & 2002 & 4 & $-33,3 \%$ & 18,546 & $-29,3 \%$ \\
\hline & 2003 & 1 & $-75 \%$ & 45,281 & $144,2 \%$ \\
\hline & 2004 & 1 & $0 \%$ & 9,618 & $-78,8 \%$ \\
\hline & 2005 & 7 & $600 \%$ & 32,887 & $241,9 \%$ \\
\hline & 2006 & 2 & $-71,4 \%$ & 28,988 & $-11,9 \%$ \\
\hline & 2007 & 3 & $50 \%$ & 13,209 & $-54,4 \%$ \\
\hline & 2008 & 5 & $66,7 \%$ & 60,744 & $359,9 \%$ \\
\hline \multirow[t]{12}{*}{ Nayarit } & 1997 & 35 & & 115,235 & \\
\hline & 1998 & 39 & $11,4 \%$ & 294,307 & $155,4 \%$ \\
\hline & 1999 & 34 & $-12,8 \%$ & 570,625 & $93,9 \%$ \\
\hline & 2000 & 42 & $23,5 \%$ & 596,806 & $4,6 \%$ \\
\hline & 2001 & 17 & $-59,5 \%$ & 22,319 & $-96,3 \%$ \\
\hline & 2002 & 180 & $958,8 \%$ & 165,425 & $641,2 \%$ \\
\hline & 2003 & 77 & $-57,2 \%$ & 52,797 & $-68,1 \%$ \\
\hline & 2004 & 20 & $-74 \%$ & 26,883 & $-49,1 \%$ \\
\hline & 2005 & 29 & $45 \%$ & 176,213 & $555,5 \%$ \\
\hline & 2006 & 22 & $-24,1 \%$ & 91,067 & $-48,3 \%$ \\
\hline & 2007 & 15 & $-31,8 \%$ & 117,308 & $28,8 \%$ \\
\hline & 2008 & 2 & $-86,7 \%$ & 19,732 & $-83,2 \%$ \\
\hline \multirow[t]{5}{*}{ Nuevo León } & 1997 & 64 & & 160,277 & \\
\hline & 1998 & 54 & $-15,6 \%$ & 214,848 & $34 \%$ \\
\hline & 1999 & 48 & $-11,1 \%$ & 54,643 & $-74,6 \%$ \\
\hline & 2000 & 55 & $14,6 \%$ & 25,482 & $-53,4 \%$ \\
\hline & 2001 & 20 & $-63,6 \%$ & 28,135 & $10,4 \%$ \\
\hline
\end{tabular}




\begin{tabular}{|c|c|c|c|c|c|}
\hline \multirow{2}{*}{$\begin{array}{c}\text { Entidad } \\
\text { Federativa }\end{array}$} & \multirow[b]{2}{*}{ Año } & \multicolumn{2}{|c|}{ Número } & \multicolumn{2}{|c|}{$m^{3} r$} \\
\hline & & Valores & $\begin{array}{l}\text { Crecimiento } \\
\text { anual }\end{array}$ & Valores & $\begin{array}{l}\text { Crecimiento } \\
\text { anual }\end{array}$ \\
\hline & 2002 & 57 & $185 \%$ & 43,915 & $56,1 \%$ \\
\hline & 2003 & 38 & $-33,3 \%$ & 37,028 & $-15,7 \%$ \\
\hline & 2004 & 40 & $5,3 \%$ & 29,342 & $-20,8 \%$ \\
\hline & 2005 & 82 & $105 \%$ & 21,760 & $-25,8 \%$ \\
\hline & 2006 & 22 & $-73,2 \%$ & 153,225 & $604,2 \%$ \\
\hline & 2007 & 23 & $4,5 \%$ & 67,120 & $-56,2 \%$ \\
\hline & 2008 & 21 & $-8,7 \%$ & 113,788 & $69,5 \%$ \\
\hline \multirow[t]{12}{*}{ Oaxaca } & 1997 & 348 & & $1,452,922$ & \\
\hline & 1998 & 304 & $-12,6 \%$ & $1,202,003$ & $-17,3 \%$ \\
\hline & 1999 & 245 & $-19,4 \%$ & $1,427,842$ & $18,8 \%$ \\
\hline & 2000 & 220 & $-10,2 \%$ & $1,069,564$ & $-25,1 \%$ \\
\hline & 2001 & 214 & $-2,7 \%$ & 756,776 & $-29,2 \%$ \\
\hline & 2002 & 255 & $19,2 \%$ & 692,507 & $-8,5 \%$ \\
\hline & 2003 & 223 & $-12,5 \%$ & 723,922 & $4,5 \%$ \\
\hline & 2004 & 266 & $19,3 \%$ & 477,224 & $-34,1 \%$ \\
\hline & 2005 & 239 & $-10,2 \%$ & $1,001,942$ & $110 \%$ \\
\hline & 2006 & 210 & $-12,1 \%$ & $1,807,470$ & $80,4 \%$ \\
\hline & 2007 & 186 & $-11,4 \%$ & $1,233,784$ & $-31,7 \%$ \\
\hline & 2008 & 143 & $-23,1 \%$ & 630,233 & $-48,9 \%$ \\
\hline \multirow[t]{12}{*}{ Puebla } & 1997 & 320 & & 227,841 & \\
\hline & 1998 & 124 & $-61,3 \%$ & 80,197 & $-64,8 \%$ \\
\hline & 1999 & 203 & $63,7 \%$ & 304,398 & $279,6 \%$ \\
\hline & 2000 & 448 & $120,7 \%$ & 350,953 & $15,3 \%$ \\
\hline & 2001 & 195 & $-56,5 \%$ & 142,708 & $-59,3 \%$ \\
\hline & 2002 & 224 & $14,9 \%$ & 632,114 & $342,9 \%$ \\
\hline & 2003 & 213 & $-4,9 \%$ & 674,854 & $6,8 \%$ \\
\hline & 2004 & 162 & $-23,9 \%$ & 421,522 & $-37,5 \%$ \\
\hline & 2005 & 195 & $20,4 \%$ & 308,172 & $-26,9 \%$ \\
\hline & 2006 & 146 & $-25,1 \%$ & 193,881 & $-37,1 \%$ \\
\hline & 2007 & 124 & $-15,1 \%$ & 225,550 & $16,3 \%$ \\
\hline & 2008 & 102 & $-17,7 \%$ & 406,729 & $80,3 \%$ \\
\hline \multirow[t]{10}{*}{ Querétaro } & 1997 & 32 & & 11,675 & \\
\hline & 1998 & 86 & $168,8 \%$ & 10,728 & $-8,1 \%$ \\
\hline & 1999 & 143 & $66,3 \%$ & 25,727 & $139,8 \%$ \\
\hline & 2000 & 214 & $49,7 \%$ & 114,470 & $344,9 \%$ \\
\hline & 2001 & 153 & $-28,5 \%$ & 74,288 & $-35,1 \%$ \\
\hline & 2002 & 39 & $-74,5 \%$ & 5,163 & $-93,1 \%$ \\
\hline & 2003 & 99 & $153,8 \%$ & 10,224 & $98 \%$ \\
\hline & 2004 & 1 & $-99 \%$ & 253 & $-97,5 \%$ \\
\hline & 2005 & 3 & $200 \%$ & 66,709 & $26267,2 \%$ \\
\hline & 2006 & 2 & $-33,3 \%$ & 3,544 & $-94,7 \%$ \\
\hline
\end{tabular}




\begin{tabular}{|c|c|c|c|c|c|}
\hline \multirow{2}{*}{$\begin{array}{c}\text { Entidad } \\
\text { Federativa }\end{array}$} & \multirow[b]{2}{*}{ Año } & \multicolumn{2}{|c|}{ Número } & \multicolumn{2}{|c|}{$m^{3} r$} \\
\hline & & Valores & $\begin{array}{l}\text { Crecimiento } \\
\text { anual }\end{array}$ & Valores & $\begin{array}{c}\text { Crecimiento } \\
\text { anual }\end{array}$ \\
\hline & 2007 & 0 & $-100 \%$ & - & $-100 \%$ \\
\hline & 2008 & 0 & NA & - & NA \\
\hline \multirow[t]{12}{*}{ Quintana Roo } & 1997 & 53 & & 145,922 & \\
\hline & 1998 & 63 & $18,9 \%$ & 156,223 & $7,1 \%$ \\
\hline & 1999 & 62 & $-1,6 \%$ & 194,346 & $24,4 \%$ \\
\hline & 2000 & 29 & $-53,2 \%$ & 67,250 & $-65,4 \%$ \\
\hline & 2001 & 78 & $169 \%$ & 173,837 & $158,5 \%$ \\
\hline & 2002 & 73 & $-6,4 \%$ & 176,311 & $1,4 \%$ \\
\hline & 2003 & 65 & $-11 \%$ & 104,965 & $-40,5 \%$ \\
\hline & 2004 & 12 & $-81,5 \%$ & 19,576 & $-81,3 \%$ \\
\hline & 2005 & 9 & $-25 \%$ & 19,697 & $0,6 \%$ \\
\hline & 2006 & 5 & $-44,4 \%$ & 108,959 & $453,2 \%$ \\
\hline & 2007 & 1 & $-80 \%$ & 947 & $-99,1 \%$ \\
\hline & 2008 & 0 & $-100 \%$ & - & $-100 \%$ \\
\hline \multirow[t]{12}{*}{ San Luis Potosí } & 1997 & 18 & & 122,343 & \\
\hline & 1998 & 15 & $-16,7 \%$ & 69,608 & $-43,1 \%$ \\
\hline & 1999 & 18 & $20 \%$ & 151,457 & $117,6 \%$ \\
\hline & 2000 & 7 & $-61,1 \%$ & 79,671 & $-47,4 \%$ \\
\hline & 2001 & 11 & $57,1 \%$ & 13,853 & $-82,6 \%$ \\
\hline & 2002 & 74 & $572,7 \%$ & 619,706 & $4373,4 \%$ \\
\hline & 2003 & 84 & $13,5 \%$ & $1,515,950$ & $144,6 \%$ \\
\hline & 2004 & 3 & $-96,4 \%$ & 332,272 & $-78,1 \%$ \\
\hline & 2005 & 3 & $0 \%$ & 122,681 & $-63,1 \%$ \\
\hline & 2006 & 15 & $400 \%$ & 317,788 & $159 \%$ \\
\hline & 2007 & 11 & $-26,7 \%$ & 16,698 & $-94,7 \%$ \\
\hline & 2008 & 7 & $-36,4 \%$ & 59,048 & $253,6 \%$ \\
\hline \multirow[t]{12}{*}{ Sinaloa } & 1997 & 19 & & 527,232 & \\
\hline & 1998 & 19 & $0 \%$ & 193,879 & $-63,2 \%$ \\
\hline & 1999 & 9 & $-52,6 \%$ & 204,125 & $5,3 \%$ \\
\hline & 2000 & 8 & $-11,1 \%$ & 101,606 & $-50,2 \%$ \\
\hline & 2001 & 12 & $50 \%$ & 407,112 & $300,7 \%$ \\
\hline & 2002 & 68 & $466,7 \%$ & 842,271 & $106,9 \%$ \\
\hline & 2003 & 81 & $19,1 \%$ & 896,085 & $6,4 \%$ \\
\hline & 2004 & 26 & $-67,9 \%$ & 300,871 & $-66,4 \%$ \\
\hline & 2005 & 62 & $138,5 \%$ & $1,202,929$ & $299,8 \%$ \\
\hline & 2006 & 65 & $4,8 \%$ & $1,526,792$ & $26,9 \%$ \\
\hline & 2007 & 10 & $-84,6 \%$ & 290,615 & $-81 \%$ \\
\hline & 2008 & 10 & $0 \%$ & 145,452 & $-50 \%$ \\
\hline \multirow[t]{3}{*}{ Sonora } & 1997 & 75 & & 206,816 & \\
\hline & 1998 & 89 & $18,7 \%$ & 272,881 & $31,9 \%$ \\
\hline & 1999 & 83 & $-6,7 \%$ & 203,884 & $-25,3 \%$ \\
\hline
\end{tabular}




\begin{tabular}{|c|c|c|c|c|c|}
\hline \multirow{2}{*}{$\begin{array}{c}\text { Entidad } \\
\text { Federativa }\end{array}$} & \multirow[b]{2}{*}{ Año } & \multicolumn{2}{|c|}{ Número } & \multicolumn{2}{|c|}{$m^{3} r$} \\
\hline & & Valores & $\begin{array}{l}\text { Crecimiento } \\
\text { anual }\end{array}$ & Valores & $\begin{array}{l}\text { Crecimiento } \\
\text { anual }\end{array}$ \\
\hline & 2000 & 62 & $-25,3 \%$ & 388,016 & $90,3 \%$ \\
\hline & 2001 & 88 & $41,9 \%$ & 241,586 & $-37,7 \%$ \\
\hline & 2002 & 97 & $10,2 \%$ & 196,133 & $-18,8 \%$ \\
\hline & 2003 & 73 & $-24,7 \%$ & 277,410 & $41,4 \%$ \\
\hline & 2004 & 66 & $-9,6 \%$ & 284,028 & $2,4 \%$ \\
\hline & 2005 & 102 & $54,5 \%$ & 468,871 & $65,1 \%$ \\
\hline & 2006 & 83 & $-18,6 \%$ & 270,150 & $-42,4 \%$ \\
\hline & 2007 & 83 & $0 \%$ & 427,688 & $58,3 \%$ \\
\hline & 2008 & 79 & $-4,8 \%$ & 348,222 & $-18,6 \%$ \\
\hline \multirow[t]{12}{*}{ Tabasco } & 1997 & 13 & & 6,574 & \\
\hline & 1998 & 101 & $676,9 \%$ & 23,185 & $252,7 \%$ \\
\hline & 1999 & 0 & $-100 \%$ & - & $-100 \%$ \\
\hline & 2000 & 0 & NA & - & NA \\
\hline & 2001 & 72 & NA & 221,299 & NA \\
\hline & 2002 & 10 & $-86,1 \%$ & 72,107 & $-67,4 \%$ \\
\hline & 2003 & 99 & $890 \%$ & 40,316 & $-44,1 \%$ \\
\hline & 2004 & 0 & $-100 \%$ & - & $-100 \%$ \\
\hline & 2005 & 2 & NA & 36,054 & NA \\
\hline & 2006 & 0 & $-100 \%$ & - & $-100 \%$ \\
\hline & 2007 & 0 & NA & - & NA \\
\hline & 2008 & 0 & NA & - & NA \\
\hline \multirow[t]{12}{*}{ Tamaulipas } & 1997 & 70 & & 65,582 & \\
\hline & 1998 & 81 & $15,7 \%$ & 198,870 & $203,2 \%$ \\
\hline & 1999 & 27 & $-66,7 \%$ & 54,378 & $-72,7 \%$ \\
\hline & 2000 & 10 & $-63 \%$ & 16,041 & $-70,5 \%$ \\
\hline & 2001 & 39 & $290 \%$ & 165,613 & $932,4 \%$ \\
\hline & 2002 & 25 & $-35,9 \%$ & 154,626 & $-6,6 \%$ \\
\hline & 2003 & 37 & $48 \%$ & 528,565 & $241,8 \%$ \\
\hline & 2004 & 26 & $-29,7 \%$ & 411 & $-99,9 \%$ \\
\hline & 2005 & 15 & $-42,3 \%$ & 307 & $-25,3 \%$ \\
\hline & 2006 & 25 & $66,7 \%$ & 437,290 & $142.33 \%$ \\
\hline & 2007 & 32 & $28 \%$ & 610,864 & $39,7 \%$ \\
\hline & 2008 & 22 & $-31,3 \%$ & 47,344 & $-92,2 \%$ \\
\hline \multirow[t]{7}{*}{ Tlaxcala } & 1997 & 49 & & 121,137 & \\
\hline & 1998 & 50 & $2 \%$ & 108,932 & $-10,1 \%$ \\
\hline & 1999 & 67 & $34 \%$ & 56,984 & $-47,7 \%$ \\
\hline & 2000 & 24 & $-64,2 \%$ & 27,206 & $-52,3 \%$ \\
\hline & 2001 & 24 & $0 \%$ & 35,110 & $29,1 \%$ \\
\hline & 2002 & 37 & $54,2 \%$ & 39,679 & $13 \%$ \\
\hline & 2003 & 32 & $-13,5 \%$ & 25,684 & $-35,3 \%$ \\
\hline
\end{tabular}




\begin{tabular}{|c|c|c|c|c|c|}
\hline \multirow{2}{*}{$\begin{array}{c}\text { Entidad } \\
\text { Federativa }\end{array}$} & \multirow[b]{2}{*}{ Año } & \multicolumn{2}{|c|}{ Número } & \multicolumn{2}{|c|}{$m^{3} r$} \\
\hline & & Valores & $\begin{array}{l}\text { Crecimiento } \\
\text { anual }\end{array}$ & Valores & $\begin{array}{c}\text { Crecimiento } \\
\text { anual }\end{array}$ \\
\hline & 2004 & 10 & $-68,8 \%$ & 13,648 & $-46,9 \%$ \\
\hline & 2005 & 24 & $140 \%$ & 57,414 & $320,7 \%$ \\
\hline & 2006 & 16 & $-33,3 \%$ & 24,225 & $-57,8 \%$ \\
\hline & 2007 & 13 & $-18,8 \%$ & 30,002 & $23,8 \%$ \\
\hline & 2008 & 20 & $53,8 \%$ & 45,998 & $53,3 \%$ \\
\hline \multirow[t]{12}{*}{ Veracruz } & 1997 & 297 & & 138,716 & \\
\hline & 1998 & 760 & $155,9 \%$ & 352,230 & $153,9 \%$ \\
\hline & 1999 & 878 & $15,5 \%$ & 454,275 & $29 \%$ \\
\hline & 2000 & 183 & $-79,2 \%$ & 96,943 & $-78,7 \%$ \\
\hline & 2001 & 1,408 & $669,4 \%$ & 271,240 & $179,8 \%$ \\
\hline & 2002 & 348 & $-75,3 \%$ & 238,190 & $-12,2 \%$ \\
\hline & 2003 & 742 & $113,2 \%$ & 514,119 & $115,8 \%$ \\
\hline & 2004 & 258 & $-65,2 \%$ & 256,851 & $-50 \%$ \\
\hline & 2005 & 161 & $-37,6 \%$ & 72,068 & $-71,9 \%$ \\
\hline & 2006 & 157 & $-2,5 \%$ & 416,852 & $478,4 \%$ \\
\hline & 2007 & 237 & $51 \%$ & 231,758 & $-44,4 \%$ \\
\hline & 2008 & 262 & $10,5 \%$ & 270,280 & $16,6 \%$ \\
\hline \multirow[t]{12}{*}{ Yucatán } & 1997 & 1 & & 3,753 & \\
\hline & 1998 & 0 & $-100 \%$ & - & $-100 \%$ \\
\hline & 1999 & 0 & NA & - & NA \\
\hline & 2000 & 0 & NA & - & NA \\
\hline & 2001 & 296 & NA & 21,713 & NA \\
\hline & 2002 & 111 & $-62,5 \%$ & 25,941 & $19,5 \%$ \\
\hline & 2003 & 118 & $6,3 \%$ & 15,563 & $-40 \%$ \\
\hline & 2004 & 297 & $151,7 \%$ & 19,921 & $28 \%$ \\
\hline & 2005 & 8 & $-97,3 \%$ & 23,134 & $16,1 \%$ \\
\hline & 2006 & 8 & $0 \%$ & 42,024 & $81,7 \%$ \\
\hline & 2007 & 1 & $-87,5 \%$ & 70 & $-99,8 \%$ \\
\hline & 2008 & 4 & $300 \%$ & 29,079 & $41.44 \%$ \\
\hline \multirow[t]{12}{*}{ Zacatecas } & 1997 & 168 & & 126,333 & \\
\hline & 1998 & 64 & $-61,9 \%$ & 46,668 & $-63,1 \%$ \\
\hline & 1999 & 187 & $192,2 \%$ & 223,120 & $378,1 \%$ \\
\hline & 2000 & 50 & $-7,3 \%$ & 263,508 & $18,1 \%$ \\
\hline & 2001 & 52 & $4 \%$ & 358,597 & $36,1 \%$ \\
\hline & 2002 & 37 & $-28,8 \%$ & 104,357 & $-70,9 \%$ \\
\hline & 2003 & 85 & $129,7 \%$ & 235,865 & $126 \%$ \\
\hline & 2004 & 10 & $-88,2 \%$ & 12,035 & $-94,9 \%$ \\
\hline & 2005 & 18 & $80 \%$ & 44,944 & $273,4 \%$ \\
\hline & 2006 & 22 & $22,2 \%$ & 69,596 & $54,9 \%$ \\
\hline & 2007 & 33 & $50 \%$ & 62,206 & $-10,6 \%$ \\
\hline & 2008 & 25 & $-24,2 \%$ & 66,746 & $7,3 \%$ \\
\hline
\end{tabular}




\begin{tabular}{|l|l|r|r|r|r|}
\hline \multirow{2}{*}{$\begin{array}{c}\text { Entidad } \\
\text { Federativa }\end{array}$} & \multicolumn{2}{|c|}{ Año } & \multicolumn{2}{|c|}{ Número } & \multicolumn{2}{c|}{ m $^{3} r$} \\
\cline { 4 - 6 } & & Valores & $\begin{array}{c}\text { Crecimiento } \\
\text { anual }\end{array}$ & Valores & $\begin{array}{c}\text { Crecimiento } \\
\text { anual }\end{array}$ \\
\hline Nacional & 1997 & 4,215 & & $11,296,045$ & $-14,6 \%$ \\
\hline & 1998 & 4,436 & $5,2 \%$ & $9,641,719$ & $-11,7 \%$ \\
\hline & 1999 & 3,614 & $-18,5 \%$ & $8,517,610$ & $-12,4 \%$ \\
\hline & 2000 & 2,703 & $-25,2 \%$ & $7,460,565$ & $58,4 \%$ \\
\hline & 2001 & 5,567 & $106 \%$ & $11,818,968$ & $-29,1 \%$ \\
\hline & 2002 & 3,491 & $-37,3 \%$ & $8,380,203$ & $9,5 \%$ \\
\hline & 2003 & 3,465 & $-0,7 \%$ & $9,174,827$ & $-11 \%$ \\
\hline & 2004 & 1,912 & $-44,8 \%$ & $8,168,561$ & $-9,8 \%$ \\
\hline & 2005 & 1,711 & $-10,5 \%$ & $7,369,978$ & $83,6 \%$ \\
\hline & 2006 & 1,654 & $-3,3 \%$ & $13,534,837$ & $-15,9 \%$ \\
\hline & 2007 & 1,557 & $-5,9 \%$ & $11,378,746$ & $75,2 \%$ \\
\hline & 2008 & 1,843 & $18,4 \%$ & $19,934,256$ & \\
\hline
\end{tabular}

Fuente: SEMARNAT, Compendio de Estadísticas Ambientales 2012

Tabla 16. Importaciones especies CITES 2008-2013

\begin{tabular}{|c|c|c|c|c|c|}
\hline Año & País Origen & País reex. & Especie & $\mathbf{m}^{3}$ & Pieza \\
\hline \multirow[t]{6}{*}{2008} & \multirow[t]{3}{*}{ Perú } & Perú & Cedro & $11,507.84$ & 58.53 \\
\hline & & E.U.A. & Caoba & 290.00 & \\
\hline & & $\begin{array}{l}\text { Sin } \\
\text { información }\end{array}$ & Cedro & 44.41 & \\
\hline & \multirow[t]{2}{*}{ Bolivia } & Bolivia & Cedro & 148.45 & \\
\hline & & E.U.A. & Caoba & 77.46 & \\
\hline & Guatemala & Guatemala & Caoba & 40.11 & \\
\hline \multicolumn{4}{|l|}{\begin{tabular}{|l|} 
TOTAL 2008 \\
\end{tabular}} & $12,108.27$ & 58.53 \\
\hline \multirow[t]{6}{*}{2009} & \multirow[t]{3}{*}{ Perú } & \multirow[t]{2}{*}{ Perú } & Caoba & 36.57 & \\
\hline & & & Cedro & $4,444.17$ & \\
\hline & & E.U.A. & Caoba & 102.14 & \\
\hline & \multirow[t]{2}{*}{ Bolivia } & Bolivia & Cedro & 125.03 & \\
\hline & & E.U.A. & Caoba & 20.00 & \\
\hline & Guatemala & Guatemala & Cedro & 67.61 & \\
\hline \multicolumn{4}{|l|}{ TOTAL 2009} & $4,795.53$ & \\
\hline
\end{tabular}




\begin{tabular}{|c|c|c|c|c|c|}
\hline Año & País Origen & País reex. & Especie & $\mathbf{m}^{3}$ & Pieza \\
\hline \multirow[t]{8}{*}{2010} & \multirow[t]{2}{*}{ Perú } & \multirow[t]{2}{*}{ Perú } & Caoba & 29.83 & \\
\hline & & & Cedro & $3,933.84$ & \\
\hline & \multirow[t]{2}{*}{ Bolivia } & Bolivia & Cedro & 194.28 & \\
\hline & & E.U.A. & Caoba & 6.00 & \\
\hline & $\begin{array}{l}\text { Sin } \\
\text { información }\end{array}$ & E.U.A. & Caoba & 170.00 & \\
\hline & \multirow[t]{2}{*}{ Guatemala } & \multirow[t]{2}{*}{ Guatemala } & Caoba & 9.20 & \\
\hline & & & Cedro & 124.98 & \\
\hline & México & E.U.A. & Caoba & 6.32 & \\
\hline \multicolumn{4}{|l|}{ TOTAL 2010} & $3.933,84$ & \\
\hline \multirow[t]{5}{*}{2011} & Perú & Perú & Cedro & 832.44 & \\
\hline & Guatemala & Guatemala & Cedro & 202.83 & \\
\hline & Belice & E.U.A. & Caoba & 120 & \\
\hline & Bolivia & Bolivia & Cedro & 55.36 & \\
\hline & & E.U.A. & Caoba & 27.64 & \\
\hline \multicolumn{4}{|l|}{ TOTAL 2011} & $1,238.26$ & \\
\hline \multirow[t]{6}{*}{2012} & Costa de Marfil & Costa de Marfil & Cedro & 409.99 & \\
\hline & Belice & E.U.A. & Caoba & 120 & \\
\hline & Guatemala & Guatemala & Cedro & 77.72 & \\
\hline & Ghana & Ghana & Cedro & 74.07 & \\
\hline & Bolivia & Bolivia & Cedro & 58.47 & \\
\hline & Brasil & Brasil & Cedro & 42.24 & \\
\hline \multicolumn{4}{|l|}{ TOTAL 2012} & 782.49 & \\
\hline \multirow[t]{8}{*}{2013} & Costa de Marfil & Costa de Marfil & Cedro & $1,019.93$ & \\
\hline & Perú & Perú & Cedro & 554.73 & \\
\hline & \multirow[t]{2}{*}{ Ghana } & Perú & Cedro & 116.53 & \\
\hline & & Ghana & Cedro & 40.47 & \\
\hline & Bolivia & Bolivia & Cedro & 99.75 & \\
\hline & Belice & E.U.A. & Caoba & 96.44 & \\
\hline & Brasil & Brasil & Cedro & 71.2 & \\
\hline & Panamá & Panamá & Cedro & 58.09 & \\
\hline \multicolumn{4}{|l|}{ TOTAL 2013} & $2,057.13$ & \\
\hline
\end{tabular}


Tabla 17. Exportaciones de Madera de México: 2008-2013

\begin{tabular}{|c|c|c|c|c|c|c|}
\hline Año & Destino & Especie & kg & m3 & m2 & Pieza \\
\hline \multirow[t]{10}{*}{2008} & \multirow[t]{4}{*}{ E.U.A. } & Choya & 30,000 & & & \\
\hline & & Caoba & & $22,192.78$ & $2,029.83$ & \\
\hline & & Cactus & & & & 30 \\
\hline & & Caoba & & 1.42 & & \\
\hline & Alemania & Caoba & & 208.08 & & \\
\hline & Italia & Caoba & & 109.36 & & \\
\hline & Hong Kong & Guayacán & & 43 & & \\
\hline & Japón & Caoba & & 25.72 & & \\
\hline & & Guayacán & & 6.98 & & \\
\hline & México & Guayacán & & 9.09 & & \\
\hline TOTAL 2008 & & & 30,000 & $25,596.42$ & $2,029.83$ & 30 \\
\hline \multirow[t]{10}{*}{2009} & \multirow[t]{3}{*}{ E.U.A. } & Choya & 45,000 & 60 & & \\
\hline & & Caoba & & $2,246.43$ & & \\
\hline & & Guayacán & & 14 & & \\
\hline & Alemania & Guayacán & & 159.28 & & \\
\hline & Italia & Caoba & & 40.5 & & \\
\hline & Hong Kong & Guayacán & & 32.26 & & \\
\hline & Japón & Guayacán & & 25.12 & & \\
\hline & Filipinas & Guayacán & & 21.31 & & \\
\hline & Canadá & Caoba & & 19.08 & & \\
\hline & India & Guayacán & & 1.25 & & \\
\hline Total 2009 & & & 45,000 & $2,619.23$ & & \\
\hline \multirow[t]{10}{*}{2010} & \multirow[t]{3}{*}{ E.U.A. } & Caoba & & $1,634.84$ & & \\
\hline & & Choya & 1,100 & & & \\
\hline & & Guayacán & & 23.21 & & \\
\hline & \multirow[t]{2}{*}{ Alemania } & Guayacán & & 144.84 & & \\
\hline & & Caoba & & 8.42 & & \\
\hline & Canadá & Caoba & & 111.47 & & \\
\hline & Hong Kong & Guayacán & & 54.85 & & \\
\hline & Filipinas & Guayacán & & 31.16 & & \\
\hline & Japón & Guayacán & & 18.21 & & \\
\hline & Brasil & Guayacán & & 2.75 & & \\
\hline \multicolumn{3}{|l|}{ Total 2010} & 1,100 & $2,029.75$ & & \\
\hline
\end{tabular}




\begin{tabular}{|c|c|c|c|c|c|c|}
\hline Año & Destino & Especie & kg & m3 & $\mathrm{m} 2$ & Pieza \\
\hline \multirow[t]{13}{*}{2011} & \multirow[t]{2}{*}{ E.U.A. } & Choya & 10,678 & & & \\
\hline & & Caoba & & 882.48 & & \\
\hline & \multirow[t]{2}{*}{ Alemania } & Guayacán & & 55.54 & & \\
\hline & & Caoba & & 10.85 & & \\
\hline & Filipinas & Guayacán & & 56.4 & & \\
\hline & Francia & Cedro & & 40.49 & & \\
\hline & Canadá & Caoba & & 27.65 & & \\
\hline & China & Guayacán & & 25.04 & & \\
\hline & Italia & Caoba & & 22 & & \\
\hline & Suiza & Guayacán & & 20.97 & & \\
\hline & España & Caoba & & 17.24 & & \\
\hline & Japón & Guayacán & & 17.17 & & \\
\hline & $\begin{array}{l}\text { República } \\
\text { Dominicana }\end{array}$ & Cedro & & 5.98 & & \\
\hline \multicolumn{3}{|l|}{ Total 2011} & 10,678 & $1,181.8$ & & \\
\hline \multirow[t]{16}{*}{2012} & \multirow[t]{3}{*}{ E.U.A. } & Choya & $42,487.6$ & & & \\
\hline & & Caoba & & 1,565 & & \\
\hline & & Guayacán & & 31.93 & & \\
\hline & Cuba & Cedro & & 489.01 & 50.64 & \\
\hline & \multirow[t]{2}{*}{$\begin{array}{l}\text { República } \\
\text { Dominicana }\end{array}$} & Caoba & & 164.43 & & \\
\hline & & Cedro & & 59.66 & & \\
\hline & \multirow[t]{2}{*}{ Alemania } & Guayacán & & 84.35 & & \\
\hline & & Caoba & & 5.26 & & \\
\hline & \multirow[t]{2}{*}{$\begin{array}{l}\text { Antillas } \\
\text { Holandesas }\end{array}$} & Cedro & & 19.77 & & \\
\hline & & Caoba & & 19.77 & & \\
\hline & Canadá & Caoba & & 27.63 & & \\
\hline & Francia & Cedro & & 20.49 & & \\
\hline & China & Guayacán & & 17.58 & & \\
\hline & \multirow[t]{2}{*}{ Turquía } & Caoba & & 11.32 & & \\
\hline & & Guayacán & & 5.08 & & \\
\hline & Japón & Guayacán & & 2.03 & & \\
\hline \multicolumn{3}{|l|}{ Total 2012} & $42,487.6$ & 2,523.31 & 50.64 & \\
\hline
\end{tabular}




\begin{tabular}{|c|c|c|c|c|c|c|}
\hline Año & Destino & Especie & kg & m3 & $\mathrm{m} 2$ & Pieza \\
\hline \multirow[t]{15}{*}{2013} & Cuba & Cedro & & 431.1 & $66,000.00$ & \\
\hline & \multirow[t]{4}{*}{ E.U.A. } & Choya & 26,508 & & & \\
\hline & & Caoba & & $1,643.06$ & & \\
\hline & & Cedro & & 163.38 & & \\
\hline & & Guayacán & & 12.44 & & \\
\hline & Japón & Choya & 2,900 & & & \\
\hline & \multirow{2}{*}{$\begin{array}{l}\text { República } \\
\text { Dominicana }\end{array}$} & Cedro & & 284.74 & & \\
\hline & & Caoba & & 232.54 & & \\
\hline & \multirow[t]{2}{*}{ China } & Guayacán & & 57.78 & & \\
\hline & & Cedro & & 35.1 & & \\
\hline & \multirow[t]{3}{*}{ Alemania } & Guayacán & & 21.38 & & \\
\hline & & Caoba & & 9.5 & & \\
\hline & & Cedro & & 4.1 & & \\
\hline & Canadá & Caoba & & 27.93 & & \\
\hline & $\begin{array}{l}\text { Antillas } \\
\text { Holandesas }\end{array}$ & Cedro & & 19.59 & & \\
\hline Total 2013 & & & 29,408 & $2,942.64$ & $66,000.00$ & \\
\hline
\end{tabular}

Tabla 18. Acciones realizadas en materia de recursos forestales 2009-2012

\begin{tabular}{|l|l|l|l|l|l|}
\hline \multicolumn{7}{|c|}{ Acciones realizadas en materia de recursos forestales 2009-2012 (PROFEPA) } \\
\hline \multicolumn{1}{|c|}{ Acciones } & \multicolumn{1}{|c|}{$\mathbf{2 0 0 9}$} & \multicolumn{1}{|c|}{$\mathbf{2 0 1 0}$} & $\mathbf{2 0 1 1}$ & \multicolumn{1}{|c|}{$\mathbf{2 0 1 2}$} & \multicolumn{1}{c|}{$\%$} \\
\hline Acciones de inspección & 7.448 & 5.857 & 5.684 & 4.215 & $-56,59 \%$ \\
\hline Inspecciones a predios bajo aprovechamiento & 3.787 & 3.435 & 1.158 & 1.851 & $-48,85 \%$ \\
\hline Inspecciones a productos forestales en tránsito & 562 & 542 & 510 & 546 & $-97,15 \%$ \\
\hline Inspecciones en áreas críticas forestales & 2.478 & 2.375 & 770 & 1.836 & $-74,09 \%$ \\
\hline Acciones de vigilancia & 4.158 & 4.122 & 4.141 & 3.178 & $-61,61 \%$ \\
\hline Madera asegurada (incluye leña) $\left(m^{3}\right)$ & 15.828 & 15.547 & 9.081 & 1.530 & $-9,66 \%$ \\
\hline Carbón asegurado (Ton.) & 215 & 218 & 714 & 42 & $-19,53 \%$ \\
\hline Vehículos asegurados & 863 & 951 & 401 & 506 & $-58,63 \%$ \\
\hline Equipos y herramientas asegurados (unidades) & 411 & 372 & 350 & 387 & $-94,16 \%$ \\
\hline Personas puestas a disposición del Ministerio Público & 46 & 95 & 152 & 36 & $-78,26 \%$ \\
\hline Inspecciones a predios sin aprovechamiento & 440 & 391 & 661 & 590 & $134 \%$ \\
\hline
\end{tabular}

Fuente: Informe anual 2012, PROFEPA ${ }^{1}$

* Porcentaje (+/-) del último año respecto del año 2009

1. Procuraduría Federal de Protección al Ambiente. 'Informe Anual de PROFEPA 2012'. [pdf online]. <http:// www.profepa.gob.mx/innovaportal/file/5322/1/iap_2012_260813.pdf>. Accedido el 4 de abril de 2014. 
Tabla 19. Averiguaciones previas consignadas por delitos relacionados con actividades forestales*

\begin{tabular}{|c|c|c|c|c|c|c|}
\hline Delegación & 2008 & 2009 & 2010 & 2011 & 2012 & Ene-Ago 2013 \\
\hline Aguascalientes & 0 & 0 & 0 & 0 & 0 & 0 \\
\hline Baja California & 0 & 0 & 1 & 0 & 0 & 0 \\
\hline Baja California Sur & 0 & 0 & 0 & 1 & 0 & 0 \\
\hline Campeche & 0 & 0 & 0 & 3 & 5 & 5 \\
\hline Chiapas & 0 & 0 & 0 & 2 & 3 & 0 \\
\hline Chihuahua & 0 & 0 & 0 & 0 & 6 & 0 \\
\hline Coahuila & 0 & 0 & 1 & 0 & 0 & 0 \\
\hline Colima & 0 & 2 & 0 & 1 & 2 & 0 \\
\hline Distrito Federal & 0 & 0 & 0 & 0 & 0 & 0 \\
\hline Durango & 0 & 0 & 0 & 0 & 0 & 0 \\
\hline Guanajuato & 0 & 0 & 0 & 0 & 1 & 0 \\
\hline Guerrero & 0 & 0 & 2 & 0 & 0 & 1 \\
\hline Hidalgo & 0 & 1 & 1 & 1 & 3 & 4 \\
\hline Jalisco & 0 & 0 & 4 & 2 & 2 & 0 \\
\hline México & 0 & 0 & 2 & 2 & 14 & 4 \\
\hline Michoacán & 0 & 2 & 2 & 1 & 2 & 4 \\
\hline Morelos & 0 & 0 & 0 & 0 & 0 & 1 \\
\hline Nayarit & 0 & 2 & 2 & 2 & 1 & 1 \\
\hline Nuevo León & 0 & 0 & 0 & 0 & 0 & 1 \\
\hline Oaxaca & 0 & 2 & 2 & 5 & 12 & 9 \\
\hline Puebla & 0 & 3 & 3 & 0 & 2 & 0 \\
\hline Querétaro & 0 & 0 & 0 & 1 & 0 & 0 \\
\hline Quintana Roo & 0 & 1 & 2 & 2 & 0 & 1 \\
\hline San Luis Potosí & 0 & 1 & 1 & 2 & 1 & 0 \\
\hline Sinaloa & 0 & 0 & 1 & 7 & 2 & 3 \\
\hline Sonora & 0 & 1 & 2 & 5 & 4 & 2 \\
\hline Tabasco & 0 & 0 & 0 & 3 & 1 & 0 \\
\hline Tamaulipas & 0 & 0 & 0 & 0 & 0 & 0 \\
\hline Tlaxcala & 0 & 0 & 0 & 0 & 3 & 5 \\
\hline Veracruz & 0 & 0 & 4 & 11 & 4 & 7 \\
\hline Yucatán & 0 & 0 & 5 & 6 & 0 & 0 \\
\hline Zacatecas & 0 & 0 & 0 & 0 & 0 & 0 \\
\hline Subprocuradurías & 0 & 0 & 1 & 8 & 24 & 3 \\
\hline Total general & 0 & 15 & 36 & 67 & 93 & 52 \\
\hline
\end{tabular}

* Incluye consignaciones con detenido y sin detenido

Fuente: Sistema Institucional de Información Estadística 
Tabla 20. Tipos Penales Forestales

\begin{tabular}{|c|c|c|}
\hline \multicolumn{3}{|c|}{ TIPOS PENALES RELACIONADOS CON ACTIVIDADES FORESTALES } \\
\hline \multicolumn{3}{|c|}{ Daño en propiedad ajena } \\
\hline Artículo & Conducta & Pena \\
\hline 397 & $\begin{array}{l}\text { Causar incendio con daño o peligro en montes, } \\
\text { montes, bosques, selvas (...) o cultivos. }\end{array}$ & $\begin{array}{l}\text { De } 5 \text { a } 10 \text { años de prisión. } \\
\text { Multa de } 100 \text { a } 5 \text { mil pesos. } \\
\text { * Se perseguirá por querella. }\end{array}$ \\
\hline \multicolumn{3}{|c|}{ TÍTULO VIGÉSIMO QUINTO. Delitos contra el ambiente y la gestión ambiental } \\
\hline \multicolumn{3}{|c|}{ De la biodiversidad } \\
\hline 417 & $\begin{array}{l}\text { Introducir al territorio nacional o trafique con } \\
\text { recursos forestales, flora o fauna silvestre } \\
\text { viva o muerta, sus productos o derivados, } \\
\text { que porten, padezcan o hayan padecido, } \\
\text { según corresponda, alguna enfermedad } \\
\text { contagiosa, que ocasione o pueda ocasionar } \\
\text { su diseminación o propagación o el contagio } \\
\text { a la flora (...) a los recursos forestales o a los } \\
\text { ecosistemas. }\end{array}$ & $\begin{array}{l}1 \text { a } 9 \text { años de prisión. } \\
\text { Multa de } 300 \text { a } 3.000 \text { días multa (días de } \\
\text { salario). }\end{array}$ \\
\hline \multicolumn{3}{|c|}{ Comentario (vinculación con la ilegalidad en el comercio de madera) } \\
\hline 418 & $\begin{array}{l}\text { I. Desmonte o destruya la vegetación natural } \\
\text { [excepto cuando se realiza en zona urbana y } \\
\text { cuando el sujeto activo es campesino y realice } \\
\text { la actividad con fines de uso o consumo } \\
\text { doméstico dentro de su comunidad, artículo } \\
\text { 423]. } \\
\text { II. Corte, arranque, derribe o tale algún o } \\
\text { algunos árboles. } \\
\text { III. Cambie el uso del suelo forestal. }\end{array}$ & $\begin{array}{l}6 \text { meses a } 9 \text { años de prisión. } \\
\text { Multa de } 100 \text { a } 3.000 \text { días multa (días de } \\
\text { salario). } \\
\text { La pena de prisión aumentará } 3 \text { años y la } \\
\text { multa económica hasta en } 1.000 \text { días multa si } \\
\text { las conductas se realizan en un área natural } \\
\text { protegida. }\end{array}$ \\
\hline 419 & $\begin{array}{l}\text { (...) ilícitamente transporte, comercie, acopie, } \\
\text { almacene o transforme madera en rollo, } \\
\text { astillas, carbón vegetal, así como cualquier } \\
\text { otro recurso forestal maderable (...) [Delito: } \\
\text { transporte de recursos forestales] } \\
\text { [Excepto cuando el sujeto activo sea } \\
\text { campesino y realice la actividad con fines } \\
\text { de uso o consumo doméstico dentro de su } \\
\text { comunidad] }\end{array}$ & $\begin{array}{l}\text { De } 1 \text { a } 9 \text { años de prisión y de } 300 \text { a } 3.000 \text { días } \\
\text { multa. } \\
\text { La pena de prisión aumentará } 3 \text { años y la } \\
\text { multa económica hasta en } 1.000 \text { días multa si } \\
\text { las conductas se realizan en un área natural } \\
\text { protegida. } \\
\text { La misma pena se aplicará aun cuando la } \\
\text { cantidad sea inferior a cuatro metros cúbicos } \\
\text { si se trata de conductas reiteradas que } \\
\text { alcancen en su conjunto esta cantidad. }\end{array}$ \\
\hline 420 bis & $\begin{array}{l}\text { IV. Provoque un incendio en un bosque, selva, } \\
\text { vegetación natural o terrenos forestales, que } \\
\text { dañe elementos naturales, flora, fauna, los } \\
\text { ecosistemas o al ambiente. }\end{array}$ & $\begin{array}{l}\text { De } 2 \text { a } 10 \text { años de prisión y de } 300 \text { a } 1.000 \\
\text { días multa. } \\
\text { Pena adicional hasta de } 2 \text { años de prisión } \\
\text { hasta } 1.000 \text { días multa cuando las conductas } \\
\text { se realicen en un área natural protegida. }\end{array}$ \\
\hline
\end{tabular}




\section{Tabla 21. Jurisprudencia y tesis en materia ambiental}

\begin{tabular}{|c|c|}
\hline \multicolumn{2}{|r|}{ Jurisprudencia y tesis } \\
\hline 1 & 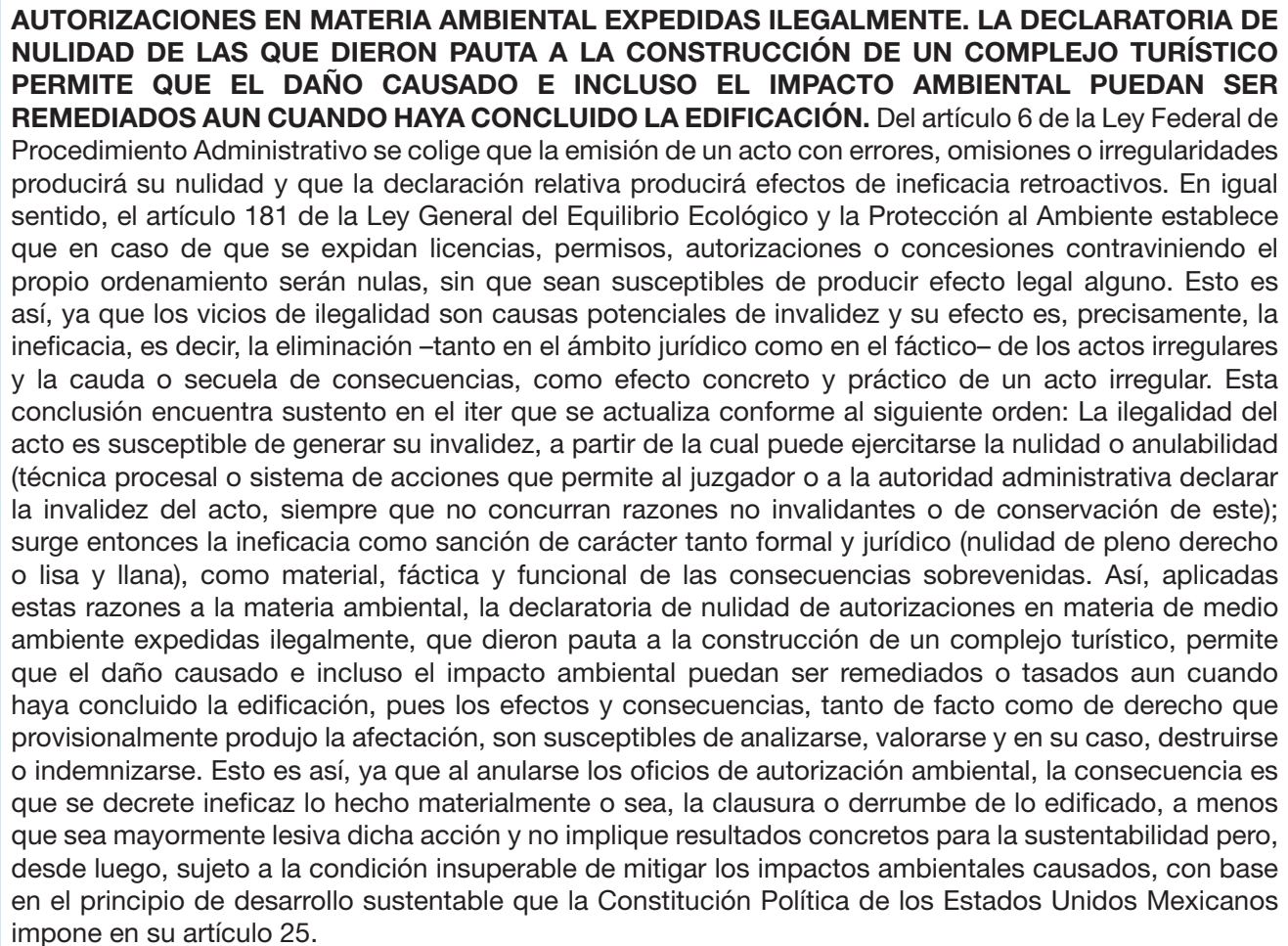 \\
\hline
\end{tabular}

\section{CUARTO TRIBUNAL COLEGIADO EN MATERIA ADMINISTRATIVA DEL PRIMER CIRCUITO}

Amparo directo 167/2011. Desarrollo Marina Vallarta, S.A. de C.V. 29 de septiembre de 2011. Unanimidad de votos. Ponente: Jean Claude Tron Petit. Secretaria: Alma Flores Rodríguez.

SíNTESIS 1: La tesis aislada I.4o.A.808 A (9a.) es un criterio del año 2012, el cual determina que, ante la emisión de un acto administrativo (permisos, autorizaciones, licencias, concesiones, etc.) con errores, omisiones e irregularidades es nulo y su declaración produce efectos retroactivos. Por lo tanto, en materia ambiental los daños causados deben ser tasados y compensados aun cuando el acto o proyecto esté realizado. Esto con el objeto de mitigar el daño causado con base en el principio de desarrollo sustentable.

MEDIO AMBIENTE. LA INDEMNIZACIÓN POR DAÑOS Y PERJUICIOS CAUSADOS DEBE INCLUIR SU REMEDIACIÓN, DE ACUERDO CON EXIGENCIAS DIVERSAS A LA MATERIA CIVIL. A diferencia de lo que sucede con los daños causados en materia de responsabilidad civil contractual y extracontractual, el daño ambiental no puede ser estudiado solo desde una perspectiva meramente económica e individualista; por consiguiente, en tanto implica un impacto sucesivo al equilibrio ambiental, atento a lo cual, la indemnización por daños y perjuicios debe incluir la remediación del medio ambiente afectado. Al respecto, el artículo $3^{\circ}$, fracción XXXIII, de la Ley General del Equilibrio Ecológico y la Protección al Ambiente, establece el concepto de reparación o remediación del medio ambiente afectado como: Por lo tanto, resulta que la reparación del impacto ambiental no solo incluye una dimensión económica, sino también se traduce en actividades de remediación, recuperación o mitigación de las consecuencias causadas por la actividad económica desplegada.

CUARTO TRIBUNAL COLEGIADO EN MATERIA ADMINISTRATIVA DEL PRIMER CIRCUITO

Amparo directo 167/2011. Desarrollo Marina Vallarta, S.A. de C.V. 29 de septiembre de 2011. Unanimidad de votos. Ponente: Jean Claude Tron Petit. Secretaria: Alma Flores Rodríguez. 


\begin{tabular}{|c|c|}
\hline & $\begin{array}{l}\text { SíNTESIS 2: La tesis I.4o.A.810 A (9a.) del } 2012 \text { establece que el daño o perjuicio en materia ambiental } \\
\text { se debe estudiar desde una perspectiva no solo económica y de manera individual, ya que los daños } \\
\text { en materia ambiental (incluido el daño a los recursos forestales) son daños sucesivos al ambiente y su } \\
\text { indemnización por el daño causado debe incluir la remediación y recuperación del medio ambiente. } \\
\text { Entendiendo remediación como "el conjunto de actividades tendentes a la recuperación y restablecimiento } \\
\text { de las condiciones que propician la evolución y continuidad de los procesos naturales". }\end{array}$ \\
\hline \multirow[t]{6}{*}{3} & $\begin{array}{l}\text { COMPENSACIÓN AMBIENTAL. EL DEPÓSITO QUE POR ESE CONCEPTO ESTABLECE EL } \\
\text { ARTíCULO } 118 \text { DE LA LEY GENERAL DE DESARROLLO FORESTAL SUSTENTABLE CONSTITUYE } \\
\text { UN APROVECHAMIENTO QUE NO SE RIGE POR LOS PRINCIPIOS DE JUSTICIA FISCAL. El indicado } \\
\text { precepto legal prevé que los interesados en el cambio de uso de terrenos forestales deberán acreditar } \\
\text { que otorgaron depósito ante el Fondo Nacional Forestal, por concepto de compensación ambiental para } \\
\text { actividades de reforestación o restauración y su mantenimiento, en los términos y condiciones establecidos } \\
\text { en el Reglamento de la Ley General de Desarrollo Forestal Sustentable. Ahora bien, el referido depósito } \\
\text { constituye una carga económica impuesta por el Estado por el daño ocasionado con motivo del cambio } \\
\text { de uso de suelo forestal, la que no puede estimarse como una sanción, en tanto se trata de un cambio } \\
\text { lícito, establecido y regulado en la Ley, que constituye un ingreso que percibe el Estado por funciones de } \\
\text { derecho público distinto de las contribuciones, por la realización de actividades en régimen de derecho } \\
\text { público, para la reforestación de los terrenos afectados por el cambio de uso de suelo, el que repercutirá } \\
\text { en beneficio no solo de quien haga la solicitud relativa, sino también de la colectividad, aunque de manera } \\
\text { indirecta. Por tanto, el depósito por concepto de compensación ambiental encuentra cabida en el término } \\
\text { de aprovechamiento a que se refiere el artículo } 3^{\circ} \text { del Código Fiscal de la Federación, lo que implica } \\
\text { que no está sujeto a los principios de justicia fiscal consagrados en la fracción IV del artículo } 31 \text { de la } \\
\text { Constitución Política de los Estados Unidos Mexicanos. }\end{array}$ \\
\hline & SEGUNDA SALA \\
\hline & $\begin{array}{l}\text { Amparo en revisión 956/2009. Granjas Marinas Río Yaqui, S.A. de C.V. } 2 \text { de junio de 2010. Cinco votos. } \\
\text { Ponente: Margarita Beatriz Luna Ramos. Secretaria: María Antonieta del Carmen Torpey Cervantes. }\end{array}$ \\
\hline & $\begin{array}{l}\text { Amparo en revisión 2220/2009. Acuacultura Delta, S.A. de C.V. } 2 \text { de junio de 2010. Cinco votos. Ponente: } \\
\text { Sergio A. Valls Hernández. Secretario: José Álvaro Vargas Ornelas. }\end{array}$ \\
\hline & $\begin{array}{l}\text { Amparo en revisión 2250/2009. José C. González González y otros. } 2 \text { de junio de 2010. Cinco votos. } \\
\text { Ponente: Sergio A. Valls Hernández. Secretario: José Álvaro Vargas Ornelas. }\end{array}$ \\
\hline & $\begin{array}{l}\text { SínTESIS 3: El criterio 2a. LXVII/2010 determina que ante el cambio de uso de suelo forestal debe } \\
\text { realizarse un depósito (garantía) que representa un ingreso para la federación y se realiza por concepto } \\
\text { de compensación ambiental, que se dispone para reforestación, restauración y mantenimiento de áreas } \\
\text { forestales. Este depósito significa una carga económica que impone el Estado por el daño que se genera } \\
\text { al cambiar el uso de un suelo forestal y una sanción, ya que se trata de un cambio de suelo permitido } \\
\text { por la ley. }\end{array}$ \\
\hline
\end{tabular}


4 REPARACIÓN DEL DAÑO. PARA SU CONDENA, TRATÁNDOSE DE DELITOS CONTRA EL MEDIO AMBIENTE, EL JUZGADOR DEBE SUJETARSE A LO QUE ESTABLECE EL ARTíCULO 421 DEL CÓDIGO PENAL FEDERAL. Tratándose de los delitos contra el medio ambiente que previene el título vigésimo quinto, capítulo único, del Código Penal Federal, cuando sea procedente la condena al pago de la reparación del daño que resulte con motivo de la responsabilidad penal del sentenciado en cualquiera de estos delitos, el juzgador no debe fundarse en los artículos del 30 al 38 del aludido ordenamiento legal, toda vez que esos delitos se encuentran contemplados en un apartado único del propio código dentro del cual se contienen diversas disposiciones especiales que regulan lo concerniente a las formas de reparación del daño para los indicados tipos penales, pues el artículo 421 del invocado código sustantivo, vigente en el momento de los hechos, dispone que: "Además de lo establecido en el presente título, el Juez podrá imponer alguna o algunas de las siguientes penas: I. La realización de las acciones necesarias para restablecer las condiciones de los elementos naturales que constituyen los ecosistemas afectados al estado en que se encontraban antes de realizarse el delito; II. La suspensión, modificación o demolición de las construcciones, obras o actividades, según corresponda, que hubieren dado lugar al delito ambiental respectivo; III. La reincorporación de los elementos naturales, ejemplares o especies de flora y fauna silvestre, a los hábitats de que fueron sustraídos; y, IV. El retorno de los materiales o residuos peligrosos o ejemplares de flora y fauna silvestres amenazados o en peligro de extinción al país de origen, considerando lo dispuesto en los tratados y convenciones internacionales de que México sea parte. -Para los efectos a que se refiere este artículo, el Juez deberá solicitar a la dependencia federal competente la expedición del dictamen técnico correspondiente"; por esa razón, ante la existencia de una disposición expresa que señala la forma en que debe repararse el daño en este tipo de delitos, no resulta aplicable la disposición general que regula la reparación del daño, prevista en los artículos del 30 al 38 del código sustantivo federal, máxime si se toma en cuenta que, en el caso, la parte denunciante es una autoridad a la cual no se le afectó su patrimonio y, por ello, no tiene el carácter de ofendida para la reparación del daño, pues en realidad quien sufrió el daño ocasionado con motivo del delito fue el ecosistema y no la denunciante, y si a tal consideración se suma el hecho de que el Ministerio Público al formular sus conclusiones acusatorias en el proceso, solicitó se condenara al inculpado al pago de la reparación del daño, en términos de lo dispuesto por los artículos 30 a 38 del aludido código sustantivo federal, es indudable que al no existir acusación especial en ese sentido, es decir, en términos del artículo 421 del multirreferido código punitivo, no procede la condena al pago de dicha reparación.

\section{SEGUNDO TRIBUNAL COLEGIADO EN MATERIA PENAL DEL TERCER CIRCUITO}

Amparo directo 61/2002. 3 de mayo de 2002. Unanimidad de votos. Ponente: Hugo Ricardo Ramos Carreón. Secretaria: María del Carmen Cabral Ibarra.

SÍNTESIS 4: la tesis III.2o.P.86 $\mathrm{P}$ es un criterio en materia penal que determina que ante la declaratoria de responsabilidad penal del sentenciado por un delito ambiental, la reparación del daño se determinará con base en las disposiciones de carácter especial contenidas en el mismo código penal, pero referente a la reparación en delitos ambientales, que contempla que además de las penas impuestas, el juez mediante un dictamen técnico, puede imponer algunas de las siguientes penas:

I La realización de las acciones necesarias para restablecer las condiciones de los elementos naturales que constituyen los ecosistemas afectados al estado en que se encontraban antes de realizarse el delito;

II La suspensión, modificación o demolición de las construcciones, obras o actividades, según corresponda, que hubieren dado lugar al delito ambiental respectivo;

III La reincorporación de los elementos naturales, ejemplares o especies de flora y fauna silvestre, a los hábitats de que fueron sustraídos; y

IV El retorno de los materiales o residuos peligrosos o ejemplares de flora y fauna silvestres amenazados o en peligro de extinción al país de origen, considerando lo dispuesto en los tratados y convenciones internacionales de que México sea parte. 
5 COMPENSACIÓN AMBIENTAL. EL ARTíCULO 118 DE LA LEY GENERAL DE DESARROLLO FORESTAL SUSTENTABLE QUE ESTABLECE UN DEPÓSITO POR ESE CONCEPTO NO VIOLA LA GARANTÍA DE IGUALDAD. Conforme al indicado precepto legal, los interesados en el cambio de uso de terrenos forestales deben otorgar depósito ante el Fondo Forestal Mexicano por concepto de compensación ambiental para actividades de reforestación o restauración y su mantenimiento, en términos del Reglamento de la Ley General de Desarrollo Forestal Sustentable. Por su parte, los artículos 123 y 124 de dicho Reglamento prevén que el monto de la compensación será determinado por la Secretaría de Medio Ambiente y Recursos Naturales, considerando los costos de referencia para reforestación o restauración y su mantenimiento, que establezca la Comisión Nacional Forestal, los cuales serán publicados en el Diario Oficial de la Federación; que el nivel de equivalencia para la compensación ambiental, por unidad de superficie, será acorde con los criterios técnicos establecidos por la Secretaría y que los recursos obtenidos serán destinados a actividades de reforestación o restauración y mantenimiento de los ecosistemas afectados. Luego, el artículo 118 de la Ley General de Desarrollo Forestal Sustentable, al fijar el monto del depósito por concepto de compensación ambiental en términos de su Reglamento, no viola la garantía de igualdad contenida en el artículo $1^{\circ}$ de la Constitución Política de los Estados Unidos Mexicanos, toda vez que establece una regulación abstracta y general sin determinar situaciones jurídicas referidas a una persona o grupo de personas, pues comprende a todos los que se encuentren en el supuesto de pretender el cambio de uso de suelo en terrenos forestales y no otorga un tratamiento privilegiado en relación con el resto de los gobernados que se ubiquen en una situación análoga, toda vez que no da un trato, jurisdicción o esfera competencial diferentes. Asimismo, el indicado artículo 118 en su aplicación trata de manera diferente a los interesados en el cambio de uso de suelo de terrenos forestales, pues conforme al Reglamento de la Ley, dependiendo de la superficie en cuestión, el monto del depósito por concepto de compensación ambiental varía. Empero, ese trato diferenciado se justifica y resulta razonable, en virtud de que la extensión de la superficie afectada revela en los interesados un diverso estatus que amerita un trato diferenciado, pues dependiendo de la extensión del terreno del cual se solicita el cambio de uso de suelo, se provoca una diversa afectación a la biodiversidad, lo cual exige un mayor aporte económico para restaurarla.

\section{SEGUNDA SALA}

Amparo en revisión 2250/2009. José C. González González y otros. 2 de junio de 2010. Cinco votos. Ponente: Sergio A. Valls Hernández. Secretario: José Álvaro Vargas Ornelas.

SÍNTESIS 5: El criterio 2a. LXVI/2010 del año 2010 referente a la materia forestal, determina que el depósito que debe realizar el promovente por cambio de uso forestal y que se destina para la compensación ambiental no es violatorio de la garantía de igualdad. Esto en base a que se determina por medio de criterios técnicos establecidos por la Secretaría de Medio Ambiente y Recursos Naturales, y tomando en cuenta la superficie afectada, ya que dependiendo de esta las afectaciones a la biodiversidad son diversas, lo cual exige un mayor aporte económico. 
Tabla 22. Cantidad de averiguaciones previas consignadas y sentencias condenatorias y absolutorias por delitos ambientales

\begin{tabular}{|l|l|l|l|l|l|l|}
\hline \multicolumn{1}{|c|}{ Concepto } & \multicolumn{1}{|c|}{2008} & \multicolumn{1}{|c|}{2009} & \multicolumn{1}{|c|}{2010} & \multicolumn{1}{|c|}{2011} & \multicolumn{1}{|c|}{2012} & Ene-Ago 2013 \\
\hline Consignados & 569 & 534 & 576 & 696 & 681 & 453 \\
\hline Sentencias condenatorias & 294 & 271 & 247 & 296 & 227 & $\mathrm{n} / \mathrm{d}$ \\
\hline Sentencias absolutorias & 15 & 16 & 34 & 33 & 40 & $\mathrm{n} / \mathrm{d}$ \\
\hline
\end{tabular}

Tabla 23. Presupuesto PROFEPA

\begin{tabular}{|c|c|c|c|c|c|c|c|}
\hline $\begin{array}{l}\text { Capítulo } \\
\text { de gasto }\end{array}$ & $\begin{array}{l}\text { Presu- } \\
\text { puesto }\end{array}$ & 2006 & 2007 & 2008 & 2009 & 2010 & 2011 \\
\hline \multirow[t]{2}{*}{1000} & Original & $558,930.60$ & $518,574.70$ & $547,616.30$ & 577,963 & $599,309.20$ & $596,157.20$ \\
\hline & Ejercido & $518,997.30$ & $517,558.60$ & $552,857.90$ & $584,476.50$ & $618,250.40$ & $612,990.80$ \\
\hline \multirow[t]{2}{*}{2000} & Original & 40,928 & 29,565 & $46,346.30$ & $48,261.20$ & $36,143.70$ & $114,254.50$ \\
\hline & Ejercido & $29,590.50$ & $34,304.50$ & $39,290.60$ & $38,404.50$ & $43,644.20$ & 37,231 \\
\hline \multirow[t]{2}{*}{3000} & Original & $134,002.30$ & $206,882.60$ & $176,221.50$ & $316,292.20$ & $258,517.50$ & $245,629.70$ \\
\hline & Ejercido & $148,317.20$ & $161,945.20$ & $203,664.90$ & $276,345.90$ & 252,491 & $230,158.10$ \\
\hline \multirow[t]{2}{*}{4000} & Original & 370 & 400 & 500 & 500 & 500 & 1,730 \\
\hline & Ejercido & 370 & 1,900 & $2,961.60$ & 500 & 500 & $2,637.90$ \\
\hline \multirow[t]{2}{*}{5000} & Original & $33,212.50$ & $70,457.50$ & $67,565.90$ & $89,565.90$ & $16,511.20$ & 15,000 \\
\hline & Ejercido & $25,098.70$ & $51,104.90$ & $57,037.40$ & $72,968.90$ & 0 & 0 \\
\hline \multirow[t]{2}{*}{6000} & Original & 0 & 0 & 2,000 & 10,000 & 10,248 & 10,000 \\
\hline & Ejercido & 0 & $10,031.30$ & $1,904.50$ & $1,436.40$ & 0 & 0 \\
\hline \multirow[t]{2}{*}{7000} & Original & 0 & 0 & 0 & 0 & $2,548.60$ & 0 \\
\hline & Ejercido & 370 & 1,071 & 1,071 & 1,071 & 959.3 & 0 \\
\hline \multirow[t]{2}{*}{ Total } & Original & $767,443.40$ & $825,879.80$ & $840,250.10$ & $1,042,592.40$ & $923,814.30$ & $1,012,771.30$ \\
\hline & Ejercido & $722,743.70$ & $778,025.60$ & 858,788 & $975,203.20$ & 915,845 & $883,017.90$ \\
\hline
\end{tabular}

Fuente: PROFEPA, 2012. Informe de Rendición de Cuentas 2006-2012 


\section{Anexos Guatemala}

\section{Detalle de Exportaciones e Importaciones 2003-2012}

Se presentan datos de comercio exterior (cuadros 10 y 11) de productos forestales de Guatemala en los últimos 10 años que aparecen en el Sistema de Información Forestal tomando como fuente el Sistema Arancelario Centroamericano, la Ventanilla Única Para las Exportaciones (VUPE) instalada en la Asociación de Guatemalteca de Exportadores (AGEXPORT), el Banco de Guatemala y la Superintendencia de Administración Tributaria (SAT).

Cuadro 1. Exportaciones 2003-2012 (en US\$)

\begin{tabular}{|c|c|c|c|c|c|c|c|c|}
\hline Año & 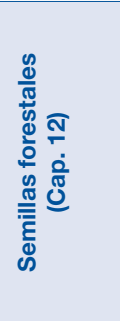 & 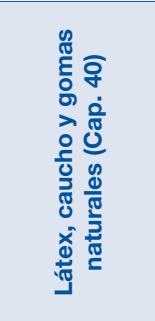 & 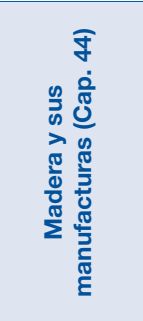 & 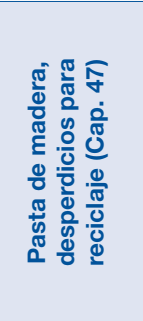 & 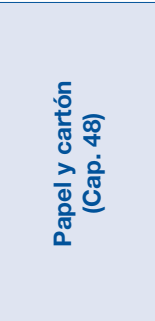 & 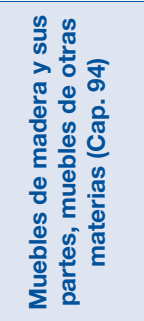 & 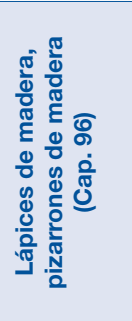 & Totales \\
\hline 2003 & 0 & $42,817,013$ & $34,431,383$ & $6,151,833$ & $70,711,795$ & $11,074,186$ & 504,809 & $165,691,020$ \\
\hline 2004 & 0 & $70,537,596$ & $37,164,007$ & $6,523,349$ & $84,287,345$ & $10,867,775$ & $4,455,165$ & $213,835,238$ \\
\hline 2005 & 800 & $81,368,936$ & $41,265,943$ & $7,637,401$ & $79,424,033$ & $10,357,423$ & $8,387,006$ & $228,441,542$ \\
\hline 2006 & 234 & $120,984,377$ & $39,160,726$ & $7,055,633$ & $104,014,713$ & $13,643,503$ & $5,148,600$ & $290,007,786$ \\
\hline 2007 & 0 & $144,944,618$ & $65,441,533$ & $8,158,853$ & $114,369,320$ & $15,410,789$ & $6,489,056$ & $354,814,168$ \\
\hline 2008 & 12,000 & $205,506,848$ & $67,444,593$ & $11,077,623$ & $126,717,820$ & $15,365,878$ & $4,003,282$ & $430,128,044$ \\
\hline 2009 & 27,629 & $132,304,319$ & $50,465,265$ & $8,471,919$ & $122,601,365$ & $8,698,037$ & $2,585,812$ & $325,154,345$ \\
\hline 2010 & 72,092 & $227,089,246$ & $49,208,482$ & $13,197,318$ & $165,894,617$ & $14,037,155$ & 225,021 & $469,723,932$ \\
\hline 2011 & 40,303 & $402,748,504$ & $57,636,784$ & $19,915,167$ & $193,598,958$ & $16,428,175$ & 163,232 & $690,531,122$ \\
\hline 2012 & 65,573 & $289,885,164$ & $59,793,158$ & $20,720,210$ & $194,980,286$ & $18,322,504$ & 302,952 & $584,069,847$ \\
\hline
\end{tabular}

Fuente: Sistema de Información Forestal de Guatemala [sitio web]. <http://www.sifgua.org.gt>. 
Cuadro 2. Importaciones de productos forestales 2003-2012

\begin{tabular}{|c|c|c|c|c|c|c|c|c|}
\hline Año & 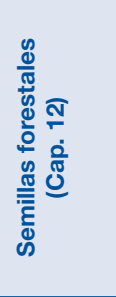 & 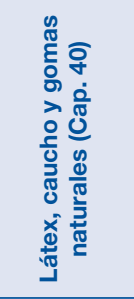 & 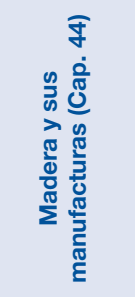 & 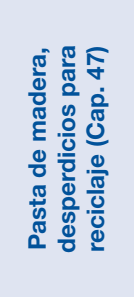 & 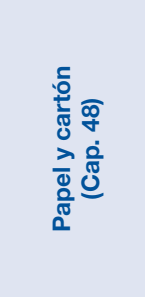 & 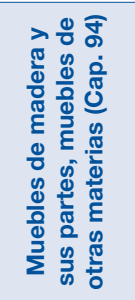 & 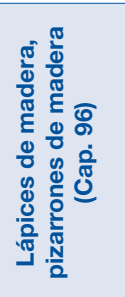 & Totales \\
\hline 2003 & 21,460 & 764,572 & $19,523,480$ & $7,312,363$ & $327,268,803$ & $20,070,631$ & $2,483,969$ & $377,445,279$ \\
\hline 2004 & 32,320 & $1,311,956$ & $19,183,925$ & $6,191,848$ & $366,759,300$ & $22,962,726$ & $3,209,584$ & $419,651,659$ \\
\hline 2005 & 28,500 & $1,104,993$ & $20,506,246$ & $7,842,526$ & $390,758,744$ & $27,413,588$ & $3,491,358$ & $451,145,954$ \\
\hline 2006 & 97,646 & $2,465,636$ & $27,456,512$ & $7,310,852$ & $444,575,490$ & $28,345,101$ & $2,610,711$ & $512,861,949$ \\
\hline 2007 & 69,399 & $5,605,149$ & $48,716,905$ & $9,622,770$ & $476,220,779$ & $36,442,313$ & $2,714,892$ & $579,392,207$ \\
\hline 2008 & 82,420 & $8,777,480$ & $49,210,774$ & $8,556,460$ & $517,440,802$ & $37,126,036$ & $2,834,378$ & $624,028,351$ \\
\hline 2009 & 96,129 & $2,256,502$ & $38,568,968$ & $8,710,668$ & $457,944,382$ & $25,421,883$ & $2,757,717$ & $535,756,248$ \\
\hline 2010 & 8,752 & $5,937,056$ & $43,229,644$ & $10,640,963$ & $529,850,425$ & $26,514,751$ & $2,654,378$ & $618,835,969$ \\
\hline 2011 & 6,983 & $12,328,209$ & $51,225,080$ & $12,812,961$ & $620,912,466$ & $30,877,733$ & $2,955,179$ & $731,118,611$ \\
\hline 2012 & 1,173 & $7,351,550$ & $56,542,994$ & $10,008,080$ & $531,612,672$ & $29,315,827$ & $3,343,622$ & $638,175,917$ \\
\hline
\end{tabular}

Fuente: Sistema de Información Forestal de Guatemala [sitio web]. <http://www.sifgua.org.gt>.

\section{Cuadro 3. Destino y origen de los productos forestales durante 2003-2012}

\begin{tabular}{|c|c|c|c|c|c|}
\hline \multicolumn{3}{|c|}{ Principales compradores para Guatemala } & \multicolumn{3}{|c|}{ Principales vendedores para Guatemala } \\
\hline \multicolumn{2}{|r|}{ País } & \multirow{2}{*}{$\begin{array}{c}\text { Total } \\
838,661,813.23\end{array}$} & \multicolumn{2}{|r|}{ País } & \multirow{2}{*}{$\begin{array}{c}\text { Total } \\
2,170,385,346.62\end{array}$} \\
\hline 1 & Estados Unidos & & 1 & Estados Unidos & \\
\hline 2 & México & $790,919,732.17$ & 2 & El Salvador & $679,097,229.54$ \\
\hline 3 & El Salvador & $430,713,987.88$ & 3 & México & $522,710,475.41$ \\
\hline 4 & Honduras & $367,779,908.65$ & 4 & Costa Rica & $324,674,233.01$ \\
\hline 5 & Costa Rica & $257,757,264.18$ & 5 & Canadá & $249,571,119.92$ \\
\hline 6 & Colombia & $220,028,451.41$ & 6 & Brasil & $190,496,234.15$ \\
\hline 7 & Perú & $176,270,882.94$ & 7 & Chile & $188,346,656.94$ \\
\hline 8 & Chile & $105,725,586.44$ & 8 & China & $180,042,841.66$ \\
\hline 9 & Panamá & $88,602,264.76$ & 9 & País no codificado & $120,508,732.17$ \\
\hline 10 & Nicaragua & $74,332,165.37$ & 10 & Panamá & $94,421,706.51$ \\
\hline 11 & Italia & $40,302,157.01$ & 11 & Honduras & $87,650,414.57$ \\
\hline 12 & Brasil & $36,182,086.72$ & 12 & Corea del Sur & $74,125,325.04$ \\
\hline 13 & Ecuador & $27,135,706.75$ & 13 & Colombia & $70,960,084.16$ \\
\hline 14 & Venezuela & $26,224,214.34$ & 14 & Alemania & $69,560,899.95$ \\
\hline 15 & Islas Vírgenes Británicas & $24,044,237.74$ & 15 & Suecia & $56,641,778.37$ \\
\hline 16 & República Dominicana & $23,571,976.18$ & 16 & Hong Kong & $13,274,994.41$ \\
\hline
\end{tabular}

Fuente: Sistema de Información Forestal de Guatemala [sitio web]. <http://www.sifgua.org.gt>. 


\section{Anexos El Salvador}

\section{ANEXO 1. Estructura organizativa del MAG}

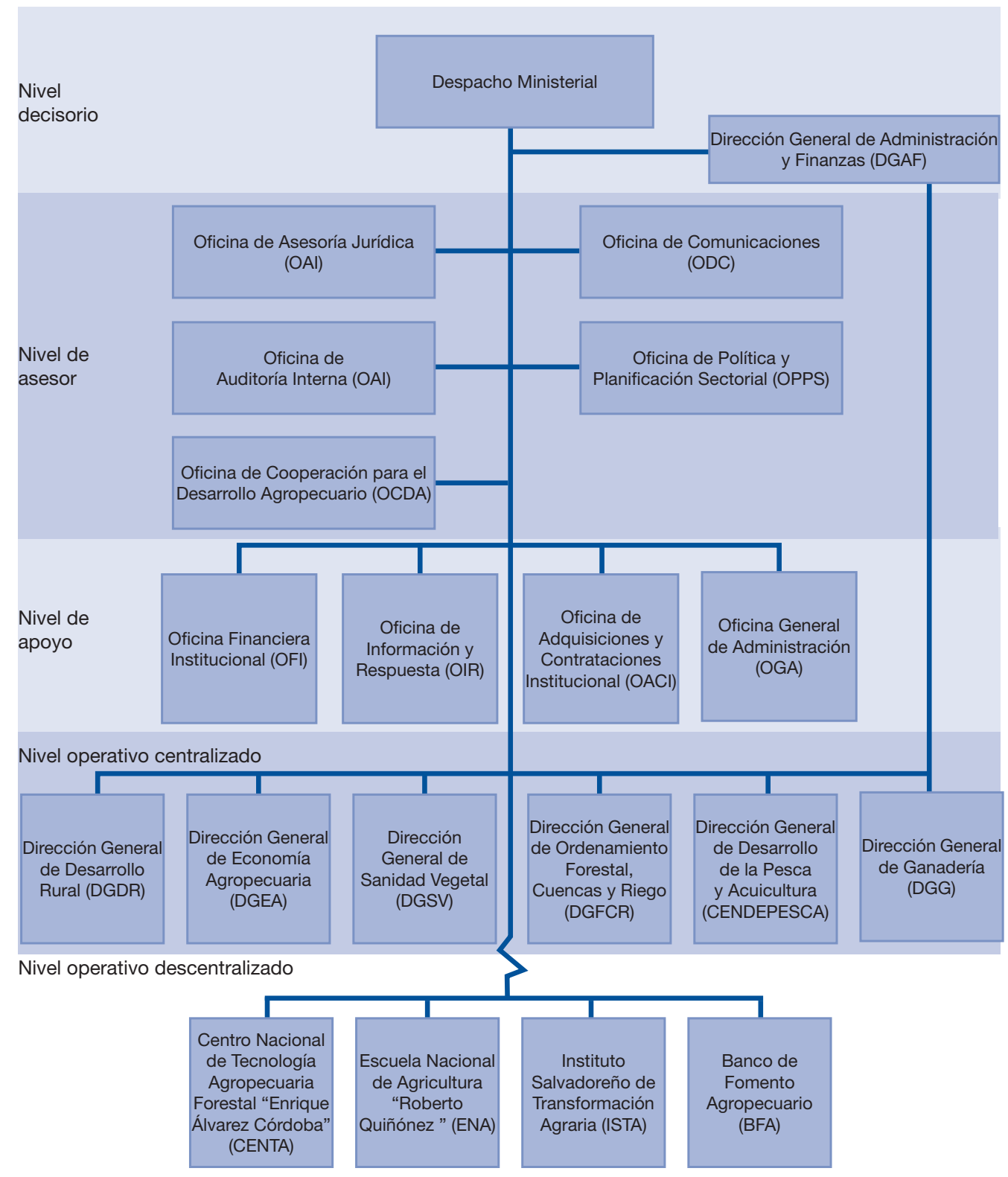

Fuente: Ministerio de Agricultura y Ganadería [stiio web]. http://<www.mag.gob.sv>. 


\section{Anexo 2. Estructura organizativa del Área de Recursos Forestales}

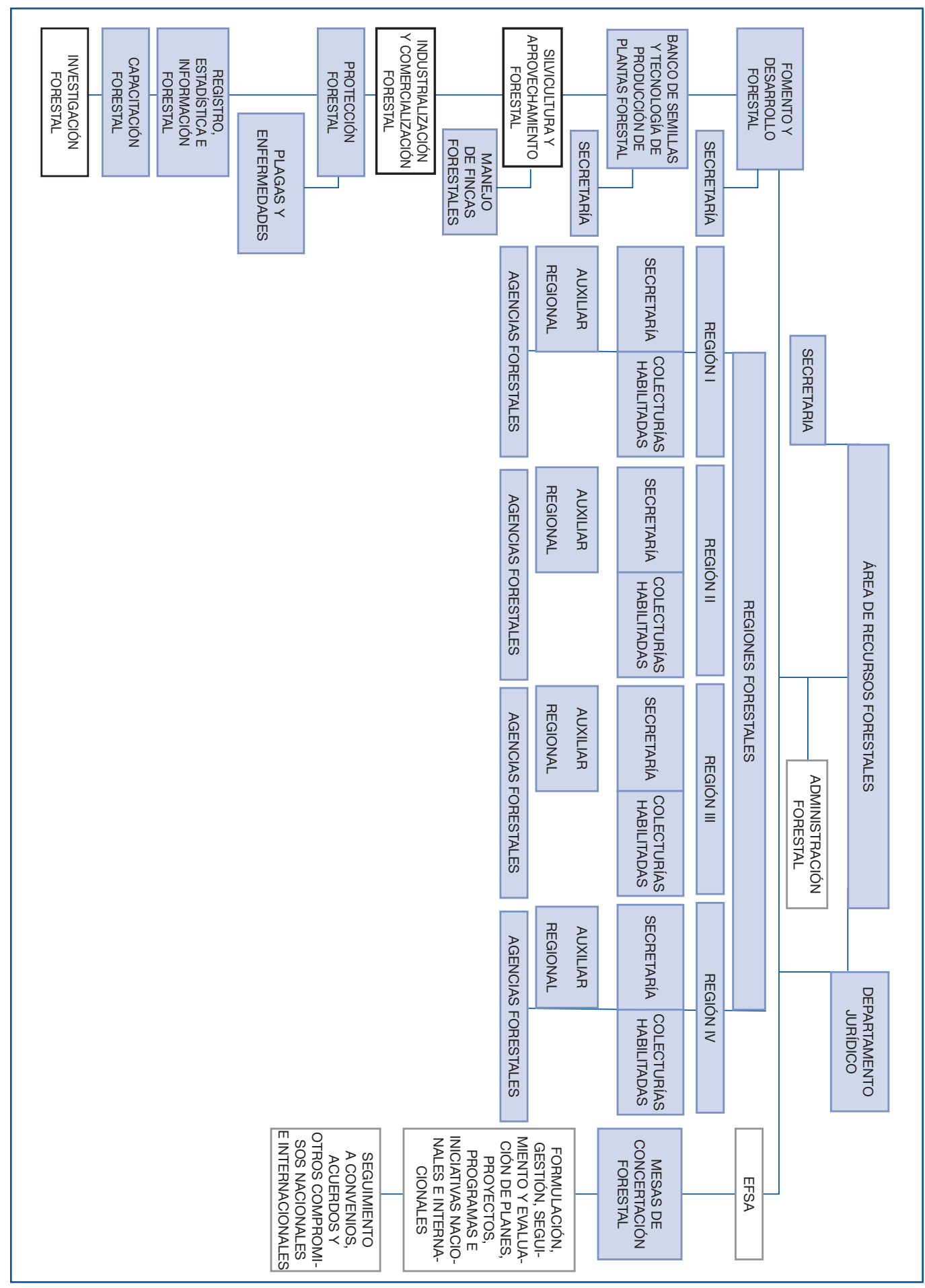




\section{Anexo 3. Mapa de la ubicación de Agencias Forestales por región}

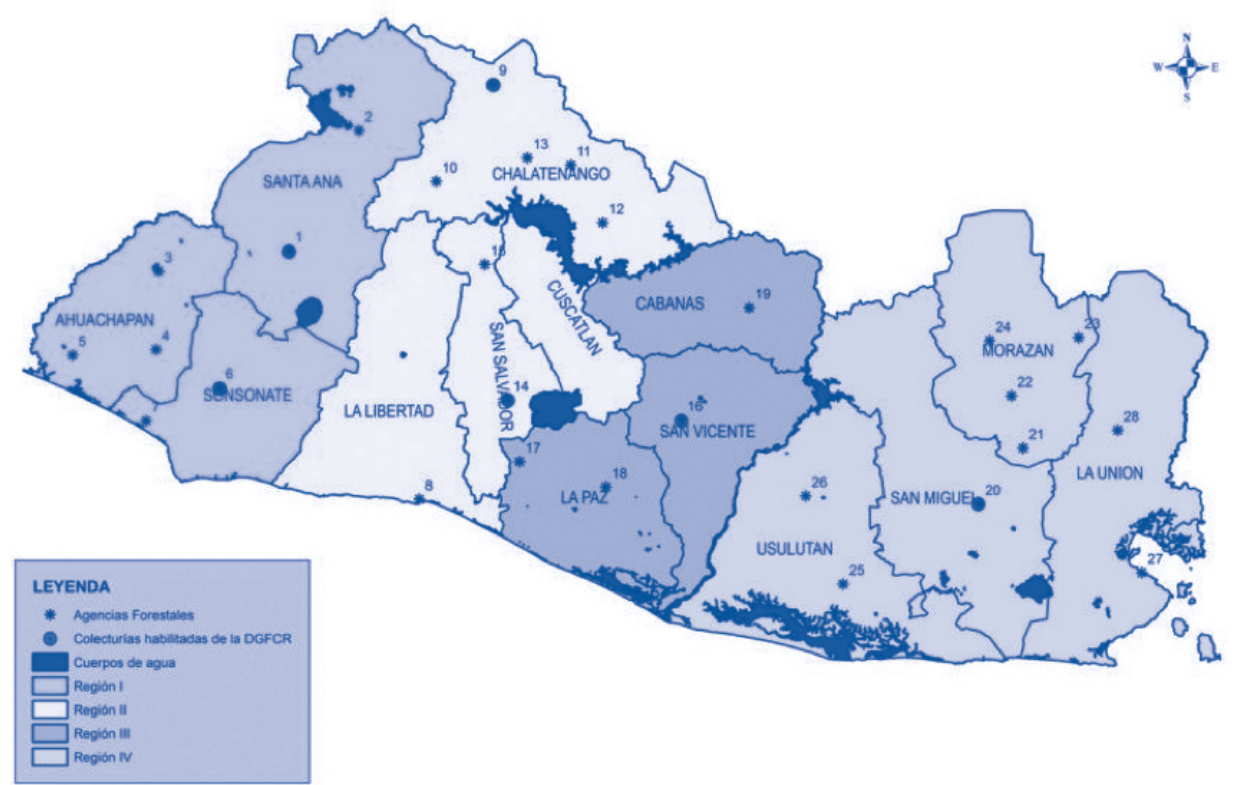

Fuente: Área de Recursos Forestales/DGFCR/MAG, 27 de enero de 2014

Escala 1:1,100,000

Fuente: Proporcionado por el personal del ARF 


\section{Anexo 4. Ubicación y personal técnico de las Agencias del ARF}

\begin{tabular}{|c|c|c|c|c|c|c|c|}
\hline \multirow{2}{*}{$\mathbf{N}^{\circ}$} & \multirow{2}{*}{ Oficina Forestal } & \multicolumn{4}{|c|}{ Ubicación de las Agencias Forestales } & \multicolumn{2}{|c|}{$\begin{array}{l}\text { Agentes y técnicos } \\
\text { forestales }\end{array}$} \\
\hline & & Departamento & Municipio & Dirección & Teléfono & Nombres & Cant. \\
\hline \multicolumn{7}{|c|}{ REGIÓN I } & 15 \\
\hline 1 & $\begin{array}{l}\text { Santa Ana } \\
\text { (Sede Regional) }\end{array}$ & Santa Ana & Santa Ana & $\begin{array}{l}\text { Local Ex IRA, } \\
\text { kilómetro } 70 \\
1 / 2, \text { Cantón El } \\
\text { Portezuelo, } \\
\text { Santa Ana } \\
\end{array}$ & $2432-0345$ & $\begin{array}{l}\text { Mario Alfredo } \\
\text { Barrientos } \\
\text { CalderónRI, } \\
\text { Roberto Alfonso } \\
\text { Castillo Ventura }\end{array}$ & \\
\hline 2 & Metapán & Santa Ana & Metapán & $\begin{array}{l}\text { MAG-ATRIDEST, } \\
\text { Metapán }\end{array}$ & $2442-0475$ & $\begin{array}{l}\text { Carlos Rigoberto } \\
\text { Peraza }\end{array}$ & 1 \\
\hline 3 & Ahuachapán & Ahuachapán & Ahuachapán & $\begin{array}{l}\text { Salida a las } \\
\text { Chinamas, Ctón. } \\
\text { Llano de Doña } \\
\text { María }\end{array}$ & $2373-0248$ & Ernesto Bonilla & 1 \\
\hline 4 & Jujutla & Ahuachapán & Jujutla & $\begin{array}{l}\text { Frente a la } \\
\text { Alcaldía Municipal } \\
\text { de Jujutla, Edif. } \\
\text { EX-ANTEL }\end{array}$ & & $\begin{array}{l}\text { Juan Bautista } \\
\text { Mejía Morales }\end{array}$ & 1 \\
\hline 5 & Cara Sucia & Ahuachapán & Cara Sucia & $\begin{array}{l}\text { Mercado } \\
\text { Municipal Cara } \\
\text { Sucia, edificio del } \\
\text { CAM }\end{array}$ & & $\begin{array}{l}\text { Ovidio Rivera } \\
\text { Dávila y Juan } \\
\text { Francisco Carballo }\end{array}$ & 2 \\
\hline 6 & Sonsonate & Sonsonate & Sonsonate & $\begin{array}{l}\text { Final 6a Av. Sur, } \\
\text { Calle Xaxual, Col. } \\
\text { Sensunapán, } \\
\text { contig. Ferretería } \\
\text { McComper, local } \\
\text { del CENTA }\end{array}$ & $2432-0339$ & $\begin{array}{l}\text { Lorenzo Cruz, } \\
\text { Aguilar, Adán } \\
\text { Arriaga Cortez } \\
\text { y Luis Alonso } \\
\text { Alvarado Baisdes }\end{array}$ & 3 \\
\hline 7 & Metalío & Sonsonate & Metalío & $\begin{array}{l}\text { Col. San José, } \\
\text { entrada al Ctón. } \\
\text { Metalío, local } \\
\text { de la Alcaldía } \\
\text { Municipal Metalío, } \\
\text { Acajutla }\end{array}$ & & $\begin{array}{l}\text { Juan Miguel } \\
\text { Iraheta y Roberto } \\
\text { Magno }\end{array}$ & 2 \\
\hline \multicolumn{7}{|c|}{ REGIÓN II } & 16 \\
\hline 8 & La Libertad & La Libertad & La Libertad & $\begin{array}{l}\text { Av. Simón Bolívar } \\
\text { y C. Gerardo } \\
\text { Barrios }\end{array}$ & $\begin{array}{l}2335-3050 \\
2346-0971\end{array}$ & $\begin{array}{l}\text { Jorge Humberto } \\
\text { López }\end{array}$ & 1 \\
\hline 9 & La Palma & Chalatenango & La Palma & $\begin{array}{l}\text { Barrio El Centro } \\
\text { Calle Gerardo } \\
\text { Barrios, La Palma }\end{array}$ & $2374-2048$ & $\begin{array}{l}\text { Héctor Salvador } \\
\text { Vásquez Ramírez, } \\
\text { Rafael Burgos } \\
\text { Cruz y José } \\
\text { Roberto Quezada } \\
\text { Gutiérrez }\end{array}$ & 3 \\
\hline 10 & $\begin{array}{l}\text { Nueva } \\
\text { Concepción }\end{array}$ & Chalatenango & $\begin{array}{l}\text { Nueva } \\
\text { Concepción }\end{array}$ & $\begin{array}{l}\text { Entrada a Nueva } \\
\text { Concepción } \\
\text { Barrio San José, } \\
\text { Oficina CENTA }\end{array}$ & $2335-7003$ & $\begin{array}{l}\text { Juan Antonio } \\
\text { Alvarado Ramírez }\end{array}$ & 1 \\
\hline 11 & $\begin{array}{l}\text { Dulce Nombre } \\
\text { de María }\end{array}$ & Chalatenango & $\begin{array}{l}\text { Dulce Nombre } \\
\text { de María }\end{array}$ & $\begin{array}{l}\text { Casa Comunal, } \\
\text { Calle Principal } \\
\text { Barrio El Centro, } \\
\text { contiguo a la } \\
\text { Alcaldía Municipal }\end{array}$ & $\begin{array}{l}2356-9265 \\
2304-0108 \\
\text { (CORREO) }\end{array}$ & $\begin{array}{l}\text { Jorge Alberto } \\
\text { Portillo y José } \\
\text { Alfredo Portillo }\end{array}$ & 2 \\
\hline
\end{tabular}




\begin{tabular}{|c|c|c|c|c|c|c|c|}
\hline \multirow{2}{*}{$\mathbf{N}^{\circ}$} & \multirow{2}{*}{ Oficina Forestal } & \multicolumn{4}{|c|}{ Ubicación de las Agencias Forestales } & \multicolumn{2}{|c|}{$\begin{array}{l}\text { Agentes y técnicos } \\
\text { forestales }\end{array}$} \\
\hline & & Departamento & Municipio & Dirección & Teléfono & Nombres & Cant. \\
\hline 12 & Chalatenango & Chalatenango & Chalatenango & $\begin{array}{l}\text { Entrada a } \\
\text { Chalatenango, } \\
\text { kilómetro } 78 \text { 1/2, } \\
\text { Colonia Veracruz, } \\
\text { Oficina CENTA }\end{array}$ & $2335-2082$ & $\begin{array}{l}\text { Félix Antonio } \\
\text { Menjívar }\end{array}$ & 1 \\
\hline 13 & Tejutla & Chalatenango & Tejutla & $\begin{array}{l}\text { Alcaldía } \\
\text { Municipal, Barrio } \\
\text { San Antonio, } \\
\text { frente al Parque } \\
\text { Central }\end{array}$ & $2353-6139$ & $\begin{array}{l}\text { Jorge Armando } \\
\text { Díaz Gutiérrez }\end{array}$ & 1 \\
\hline 14 & $\begin{array}{l}\text { Soyapango } \\
\text { (Sede Regional) }\end{array}$ & San Salvador & Soyapango & $\begin{array}{l}\text { Calle y Cantón } \\
\text { El Matazano, } \\
\text { Soyapango }\end{array}$ & $\begin{array}{l}\text { 2202-8254, } \\
2202-8224\end{array}$ & $\begin{array}{l}\text { Romeo Aníbal } \\
\text { HerreraRII, Julio } \\
\text { Alberto Bermúdez, } \\
\text { Moisés Rodas } \\
\text { Romero, Carlos } \\
\text { Alberto Alvarado } \\
\text { González, } \\
\text { Mardoqueo Juárez } \\
\text { Cáceres y Daniel } \\
\text { Zúñiga Alfaro }\end{array}$ & 6 \\
\hline 15 & Aguilares & San Salvador & Aguilares & $\begin{array}{l}\text { Alcaldía } \\
\text { Municipal, Barrio } \\
\text { El Centro entre } 1^{a} \\
\text { y } 3^{\mathrm{a}} \text { Ave. Norte, } \\
\text { frente al Parque } \\
\text { Central, Aguilares }\end{array}$ & $\begin{array}{l}2327-5106 \\
\text { fax } 2327- \\
5112\end{array}$ & $\begin{array}{l}\text { José Mario } \\
\text { Rodríguez }\end{array}$ & 1 \\
\hline \multicolumn{7}{|c|}{ REGIÓN III } & 6 \\
\hline 16 & $\begin{array}{l}\text { Santa Vicente } \\
\text { (Sede Regional) }\end{array}$ & San Vicente & San Vicente & \begin{tabular}{|l} 
Avenida José \\
María Cornejo y \\
$5^{\text {a }}$ Calle Poniente \\
NN$^{\circ}$, Barrio El \\
Calvario, San \\
Vicente (2393- \\
0299 CENTA)
\end{tabular} & $2314-9716$ & $\begin{array}{l}\text { Héctor Antonio } \\
\text { DíazRIII y Héctor } \\
\text { Antonio Martínez }\end{array}$ & 2 \\
\hline 17 & Olocuilta & La Paz & Olocuilta & $\begin{array}{l}\text { Casa particular, } \\
\text { Olocuilta, La Paz }\end{array}$ & 2374-2115 & $\begin{array}{l}\text { René Antonio } \\
\text { Delgado } \\
\text { Hernández }\end{array}$ & 1 \\
\hline 18 & $\begin{array}{l}\text { San Juan } \\
\text { Nonualco }\end{array}$ & La Paz & $\begin{array}{l}\text { San Juan } \\
\text { Nonualco }\end{array}$ & $\begin{array}{l}\text { Instalaciones } \\
\text { de la Alcaldía } \\
\text { Municipal }\end{array}$ & $2313-1354$ & \begin{tabular}{|l|} 
Candelario \\
Antonio Funes
\end{tabular} & 1 \\
\hline 19 & Guacotecti & Cabañas & Guacotecti & $\begin{array}{l}\text { Local del CENTA, } \\
\text { kilómetro } 82 \\
\text { carretera a } \\
\text { Sensuntepeque }\end{array}$ & $2374-2047$ & $\begin{array}{l}\text { Fernando Barrera } \\
\text { y David Benítez }\end{array}$ & 2 \\
\hline \multicolumn{7}{|c|}{ REGIÓN IV } & 14 \\
\hline 20 & $\begin{array}{l}\text { Santa } \\
\text { Miguel (Sede } \\
\text { Regional) }\end{array}$ & San Miguel & San Miguel & $\begin{array}{l}2^{a} \text { Avenida } \\
\text { Sur, No } 610 \\
\text { BIS, Barrio El } \\
\text { Calvario, San } \\
\text { Miguel }\end{array}$ & $2640-1798$ & $\begin{array}{l}\text { Mario Helmer } \\
\text { Rosas } \\
\text { CallejasRIV, } \\
\text { Jorge Alberto } \\
\text { Hernández, } \\
\text { José Luis } \\
\text { Iglesias Ochoa } \\
\text { y Miguel Ángel } \\
\text { Bautista }\end{array}$ & 4 \\
\hline
\end{tabular}




\begin{tabular}{|c|c|c|c|c|c|c|c|}
\hline \multirow{2}{*}{$\mathbf{N}^{\circ}$} & \multirow{2}{*}{ Oficina Forestal } & \multicolumn{4}{|c|}{ Ubicación de las Agencias Forestales } & \multicolumn{2}{|c|}{$\begin{array}{l}\text { Agentes y técnicos } \\
\text { forestales }\end{array}$} \\
\hline & & Departamento & Municipio & Dirección & Teléfono & Nombres & Cant. \\
\hline 21 & El Divisadero & Morazán & El Divisadero & $\begin{array}{l}\text { Cantón El } \\
\text { Rosario, Oficina } \\
\text { CD TG-MAG, El } \\
\text { Divisadero, San } \\
\text { Francisco Gotera, } \\
\text { Morazán }\end{array}$ & $\begin{array}{l}2637-0144 \\
7622-5749\end{array}$ & $\begin{array}{l}\text { José Hermenejildo } \\
\text { Martínez y José } \\
\text { Pablo Reyes } \\
\text { Benítez }\end{array}$ & 2 \\
\hline 22 & $\begin{array}{l}\text { San Francisco } \\
\text { Gotera }\end{array}$ & Morazán & $\begin{array}{l}\text { San Francisco } \\
\text { Gotera }\end{array}$ & $\begin{array}{l}\text { Calle El } \\
\text { Cementerio, } \\
\text { conocido como } \\
\text { CEDAF del MAG, } \\
\text { San Francisco } \\
\text { Gotera }\end{array}$ & $2637-0258$ & $\begin{array}{l}\text { José Salvador } \\
\text { Reyes }\end{array}$ & 1 \\
\hline 23 & Corinto & Morazán & Corinto & $\begin{array}{l}\text { Barrio El Centro } \\
\text { Corinto, Casa de } \\
\text { la Cultura }\end{array}$ & 7513-3132 & $\begin{array}{l}\text { Ernesto Villatoro } \\
\text { Oliva }\end{array}$ & 1 \\
\hline 24 & Osicala & Morazán & Osicala & $\begin{array}{l}\text { Casa de la } \\
\text { Cultura, Osicala }\end{array}$ & & $\begin{array}{l}\text { Leonicio Sorto } \\
\text { Romero y Ernesto } \\
\text { Ramos Rodríguez }\end{array}$ & 2 \\
\hline 25 & Usulután & Usulután & Usulután & $\begin{array}{l}\text { Final Col. El } \\
\text { Cocal, Calle a } \\
\text { San Dionisio }\end{array}$ & 2637-0096 & Wilfredo Flores & 1 \\
\hline 26 & Berlín & Usulután & Berlín & $\begin{array}{l}\text { Barrio El Centro, } \\
\text { Casa de la } \\
\text { Cultura }\end{array}$ & & $\begin{array}{l}\text { Miguel Ángel } \\
\text { López }\end{array}$ & 1 \\
\hline 27 & La Unión & La Unión & La Unión & $\begin{array}{l}\text { Centro de } \\
\text { Gobierno, } 2^{a} \\
\text { planta }\end{array}$ & $2614-7434$ & $\begin{array}{l}\text { Silvia Lorena } \\
\text { Álvarez }\end{array}$ & 1 \\
\hline 28 & $\begin{array}{l}\text { Santa Rosa de } \\
\text { Lima }\end{array}$ & La Unión & $\begin{array}{l}\text { Santa Rosa de } \\
\text { Lima }\end{array}$ & $\begin{array}{l}\text { Ruta Militar } \\
\text { Colonia EI MAG, } \\
\text { Oficina de } \\
\text { DGSVA/MAG de } \\
\text { Santa Rosa de } \\
\text { Lima }\end{array}$ & $2637-0163$ & $\begin{array}{l}\text { Juan Francisco } \\
\text { Alfaro }\end{array}$ & 1 \\
\hline
\end{tabular}

Fuente: Proporcionado por el personal del ARF 


\section{Anexo 5. Acuerdo de creación de la Comisión Forestal}

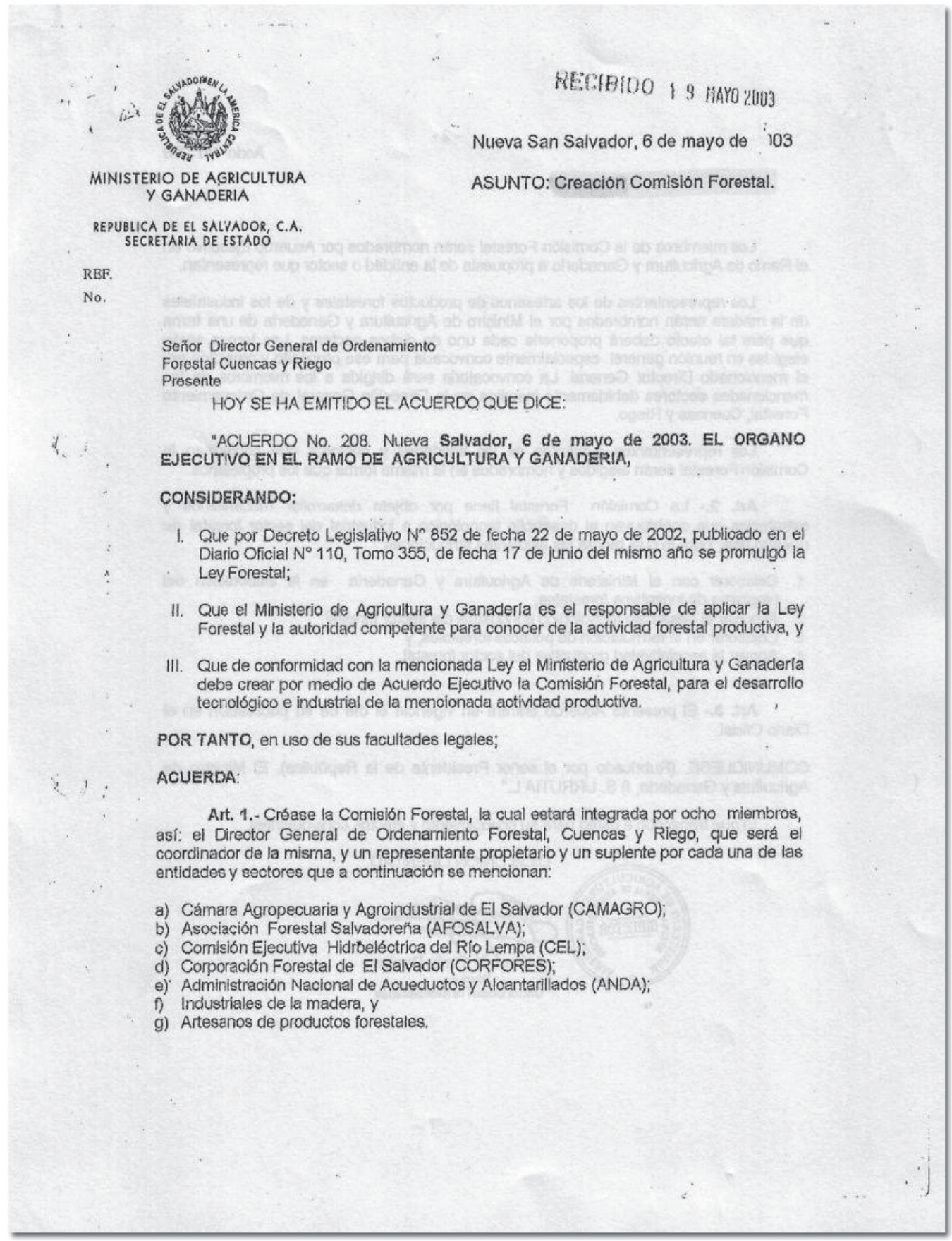


Los miembros de la Comisión Forestal serán nombrados por Acuerdo Ejecutivo en el Ramo de Agricultura y Ganaderla a propuesta de la entidad o sector que representan.

Los representantes de los artesanos de productos forestales y de los industriales de la madera serán nombrados por el Ministro de Agricullura y Ganaderla de una terna que para tal efecto deberá proponerle cada uno de dichos sectores. Las tornas serán elegidas en reunión general especiaimente convocada para ese propósito y presiclida por el mencionado Director General. La convocatoria será dirigida a los miembros de los mencionados sectores debidamente inscritos en la Dirección General de Ordenamiento Forestal, Cuencas y Riego.

Los representantes suplentes de las entidades y sectores que conforman la Comisión Forestal serán elegidos y nombrados en la misma forma que los propietarios.

Art. 2.- La Comisión Forestal fiene por objeto desarrollar mecanismos y estrategias que contribuyan al desarrollo tecnologico e inclustrial del sector forestal de nuestro pals, para lo cual tendrá las siguientes atribuciones:

1. Colaborar oon el Ministerio de Agrioultura y Canaderla en la olaboraoión dol programa de incentivos forestales;

2. Impulsar el desarrollo tecnologico e industriai del sector forestal;

3. Colaborar en la formulación do pollticas forestalos, y

4. Apoyar la asociatividad productiva del sector forestal.

Art. 3.- El presente Acuerdo entrará en vigencla el dla de su publicación en el Diario Oficial.

COMUNIQUESE. (Rubricado por el sefior Presidente de la República). El Ministro de Agricultura y Ganaderla, i) S. URRUTIA L."

El que transcribo a usted para su conocimiento y efectos consiguientes.

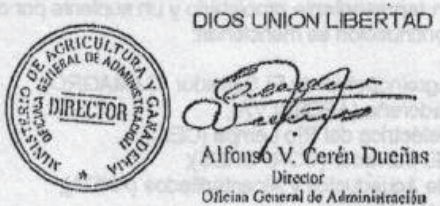




\section{Anexo 6. Marco Legal sobre Conservación y}

\section{Uso Sostenible de Recursos Forestales}

\begin{tabular}{|c|c|c|}
\hline Ley & Objetivo & $\begin{array}{l}\text { Autoridad } \\
\text { competente }\end{array}$ \\
\hline Ley Forestal & $\begin{array}{l}\text { Establecer disposiciones que permitan el incremento, } \\
\text { manejo y aprovechamiento en forma sostenible de } \\
\text { los recursos forestales y el desarrollo de la industria } \\
\text { maderera. }\end{array}$ & MAG \\
\hline Ley del Medio Ambiente & $\begin{array}{l}\text { Promover la protección, conservación y recuperación } \\
\text { del medio ambiente y el uso sostenible de los recursos } \\
\text { naturales. }\end{array}$ & MARN \\
\hline $\begin{array}{l}\text { Ley de Áreas Naturales } \\
\text { Protegidas }\end{array}$ & $\begin{array}{l}\text { Regular el establecimiento del régimen legal, } \\
\text { administración, manejo e incremento de las Áreas } \\
\text { Naturales Protegidas a través de un manejo sostenible } \\
\text { para beneficio de los habitantes del país. }\end{array}$ & MARN \\
\hline $\begin{array}{l}\text { Ley de Conservación de } \\
\text { Vida Silvestre }\end{array}$ & $\begin{array}{l}\text { Asegurar la protección, restauración, manejo, } \\
\text { aprovechamiento y conservación de la vida silvestre. } \\
\text { Esto incluye la regulación de actividades como cacería, } \\
\text { recolección y comercialización, y las demás formas de } \\
\text { uso y aprovechamiento de este recurso. }\end{array}$ & MARN \\
\hline $\begin{array}{l}\text { Reglamento Especial } \\
\text { para Regular el Comercio } \\
\text { Internacional de Especies } \\
\text { Amenazadas de Fauna } \\
\text { y Flora Silvestres, según } \\
\text { la Convención sobre el } \\
\text { Comercio Internacional de } \\
\text { Especies Amenazadas de } \\
\text { Fauna y Flora Silvestres. }\end{array}$ & $\begin{array}{l}\text { Desarrollar las disposiciones legales para regular el } \\
\text { comercio internacional de especies amenazadas de } \\
\text { fauna y flora silvestres, según la Convención CITES. }\end{array}$ & $\begin{array}{l}\text { MAG (autoridad } \\
\text { administrativa) } \\
\text { y MARN (autoridad } \\
\text { científica) }\end{array}$ \\
\hline
\end{tabular}

Fuente: Elaboración personal 


\section{Anexo 7. Organizaciones indígenas aglutinadas en el CCNIS}

\section{Organizaciones indígenas}

- Movimiento Autóctono Indígena Salvadoreño (MAIS)

- Asociación Democrática de Trabajadores Agropecuarios Indígenas Salvadoreños (ADTAIS)

- Asociación de Desarrollo Comunal Indígena Nahuat Pipil (ADCINP)

- Asociación Comunal Lenca de Guatajiagua (ACOLGUA)

- Artistas Para la Revivificación de la Cultura Original ARCO

- Asociación para la Recuperación de la Cultura Autóctona Salvadoreña (ARCAS)

- Alcaldía del Común de Izalco

- Asociación de Artesanos de El Salvador (ITZAMA)

- Asociación de Desarrollo Comunal de Santo Domingo de Guzmán (ADESCOIN)

- Asociación Cultural Ecológica de Panchimalco (ACEIS)

- Organización de Artesanos de los Planes de Renderos (OAP)

- Comunidad Indígena La COMARCA de Nuhulingo

- Asociación Indígena de Juayua

- Comisión de Derechos Humanos y Derechos de Pueblos Indígenas de El Salvador (CODEHUINESAL)

- Intercomunal Indígena de San Marcos

- Asociación de Desarrollo Comunal Cantón Sabana Grande (ADESCOG)

- Pasos del Jaguar de Nahuizalco

- Fundación Ama de Izalco

Fuente: Elaboración personal basada en el sitio web del Consejo Indígena de Centro América. $<h t t p: / / w w w$. cicaregional.org $>$.

\section{ANEXO 8 Contenido de las guías de transporte}

\section{Guías de transporte}

- Número de registro o autorización

- Nombre y generales del emisor

- Lugar de procedencia y nombre del inmueble de origen

- Descripción de los productos o subproductos forestales, incluyendo la cantidad o volumen de estos

- Nombre y generales del transportista y características esenciales del vehículo

- Fecha de vigencia

- Firma y sello del propietario o del funcionario autorizado por el MAG, en su caso

Fuente: Elaboración personal con base en el RLF 


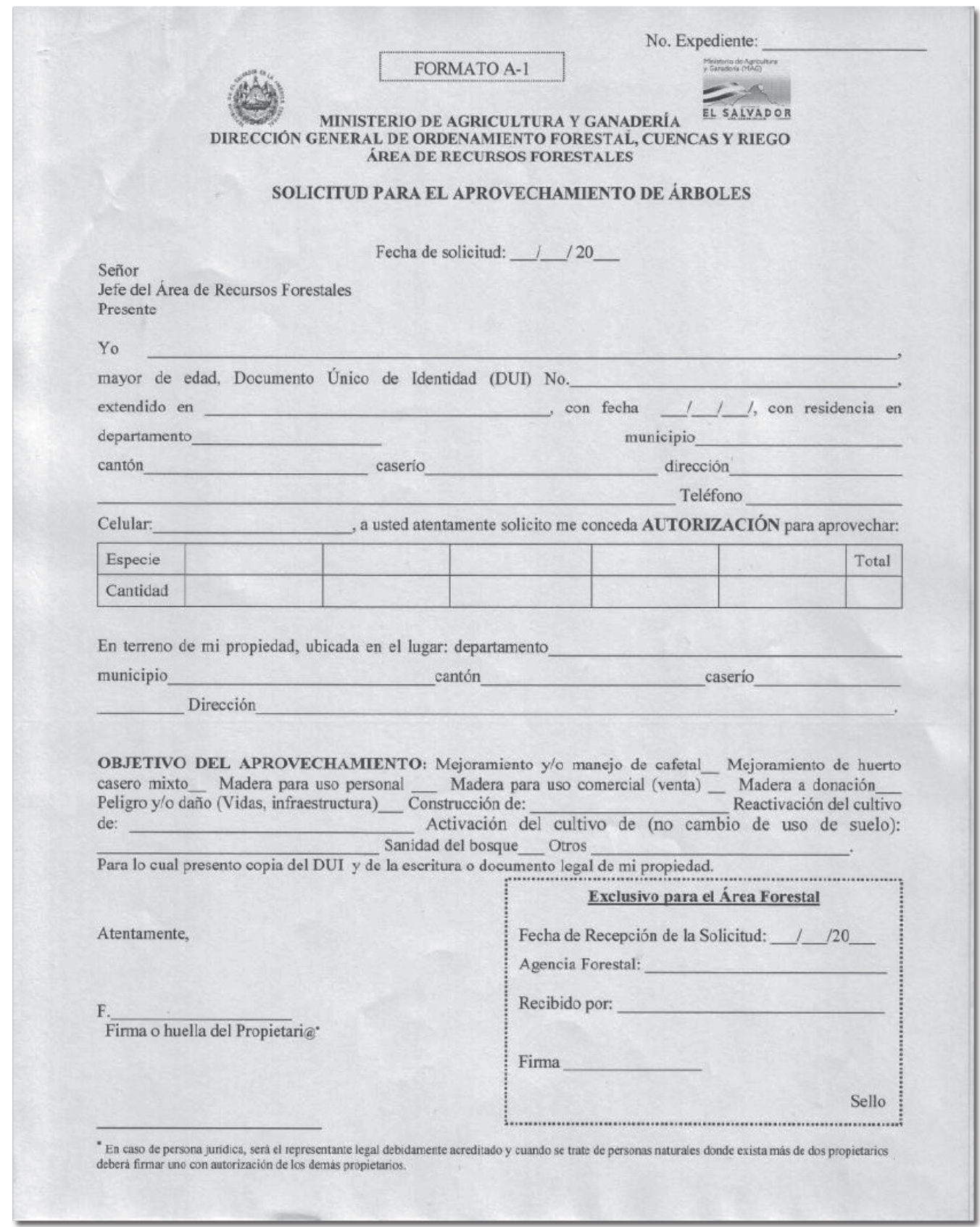


Anexo 9. Formulario A-2 del ARF

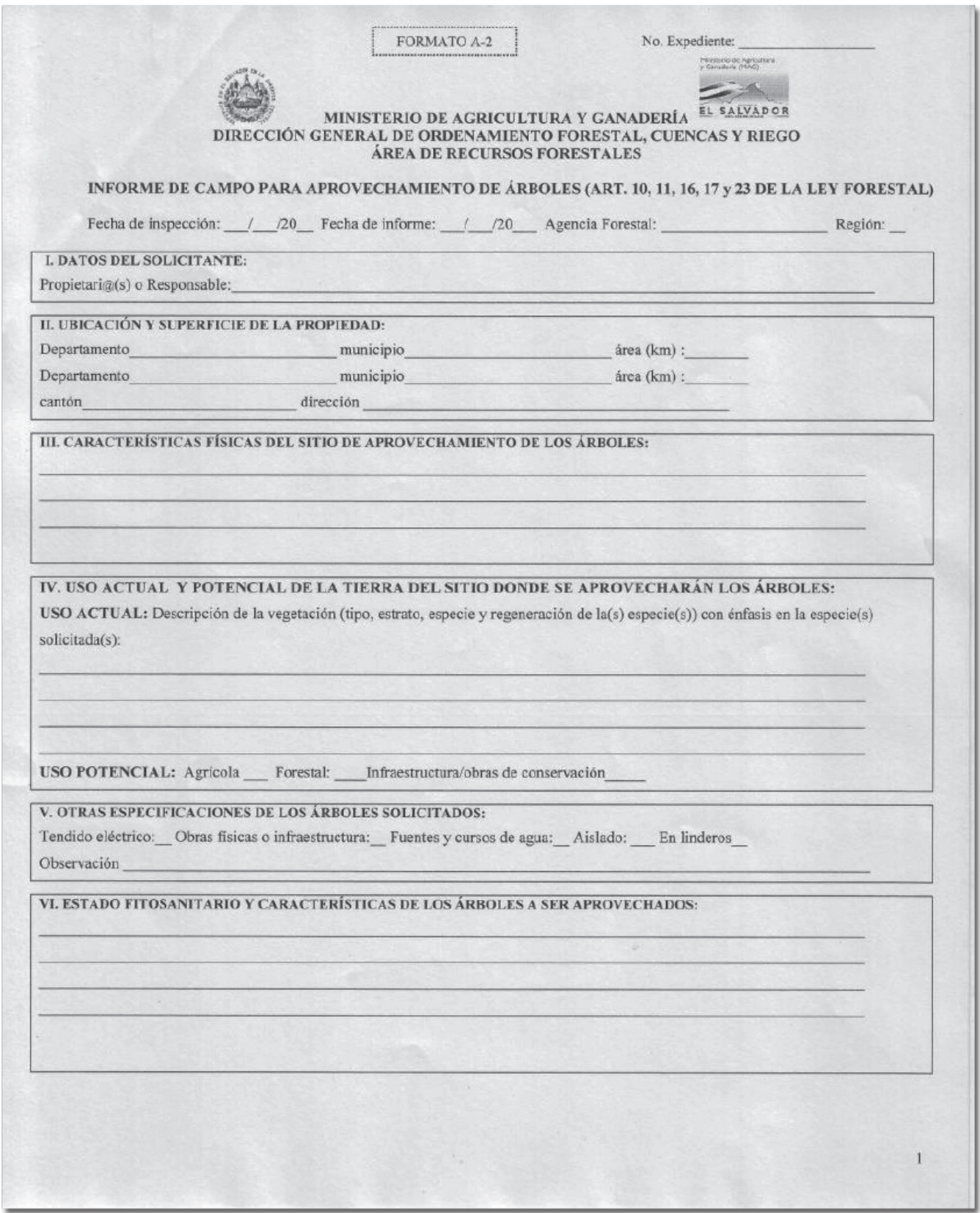

Fuente: Proporcionado por el personal del ARF 
Anexo 10. Formulario A-2a del ARF

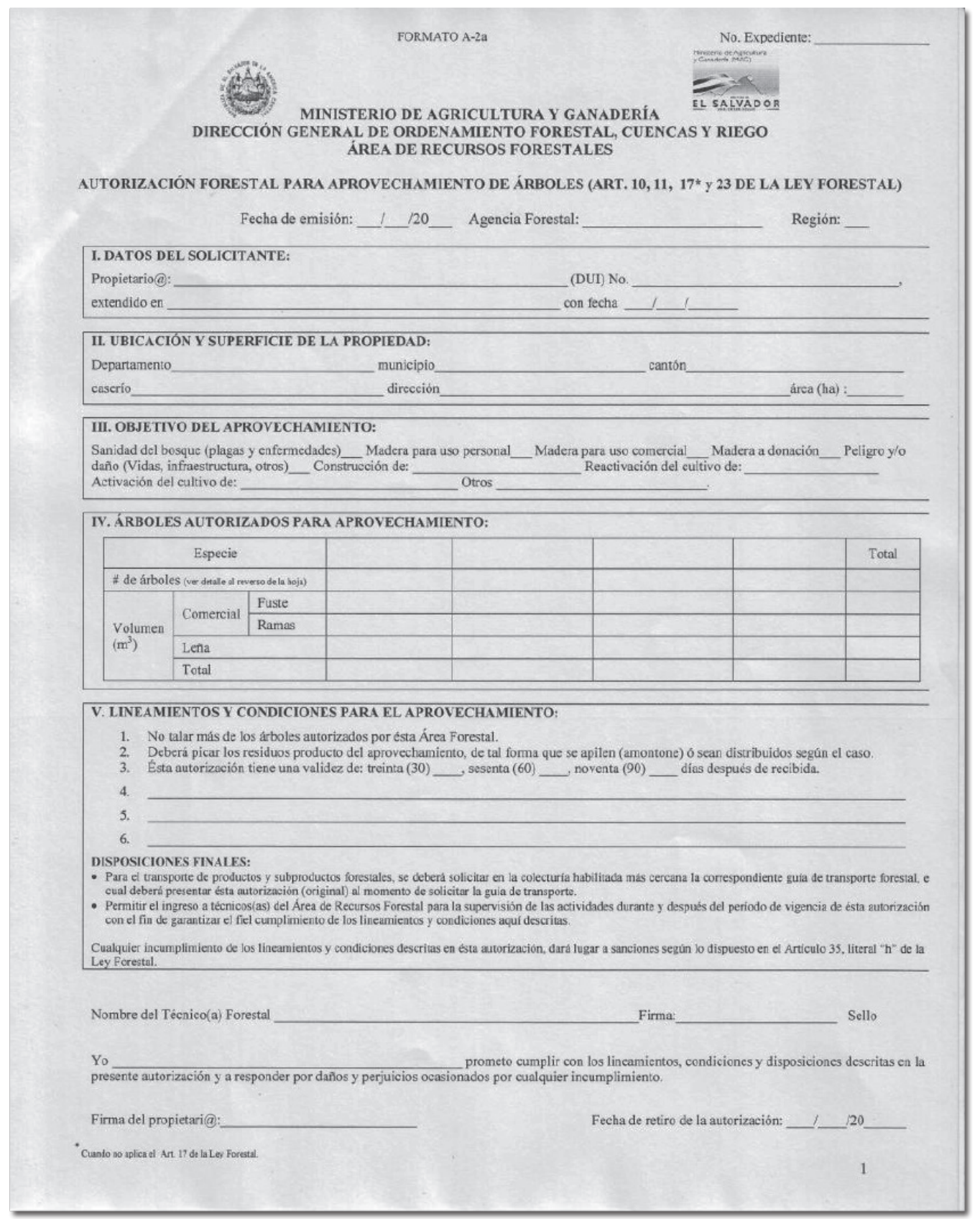

Fuente: Proporcionado por el personal del ARF 
Anexo 11. Formulario A-2b del ARF

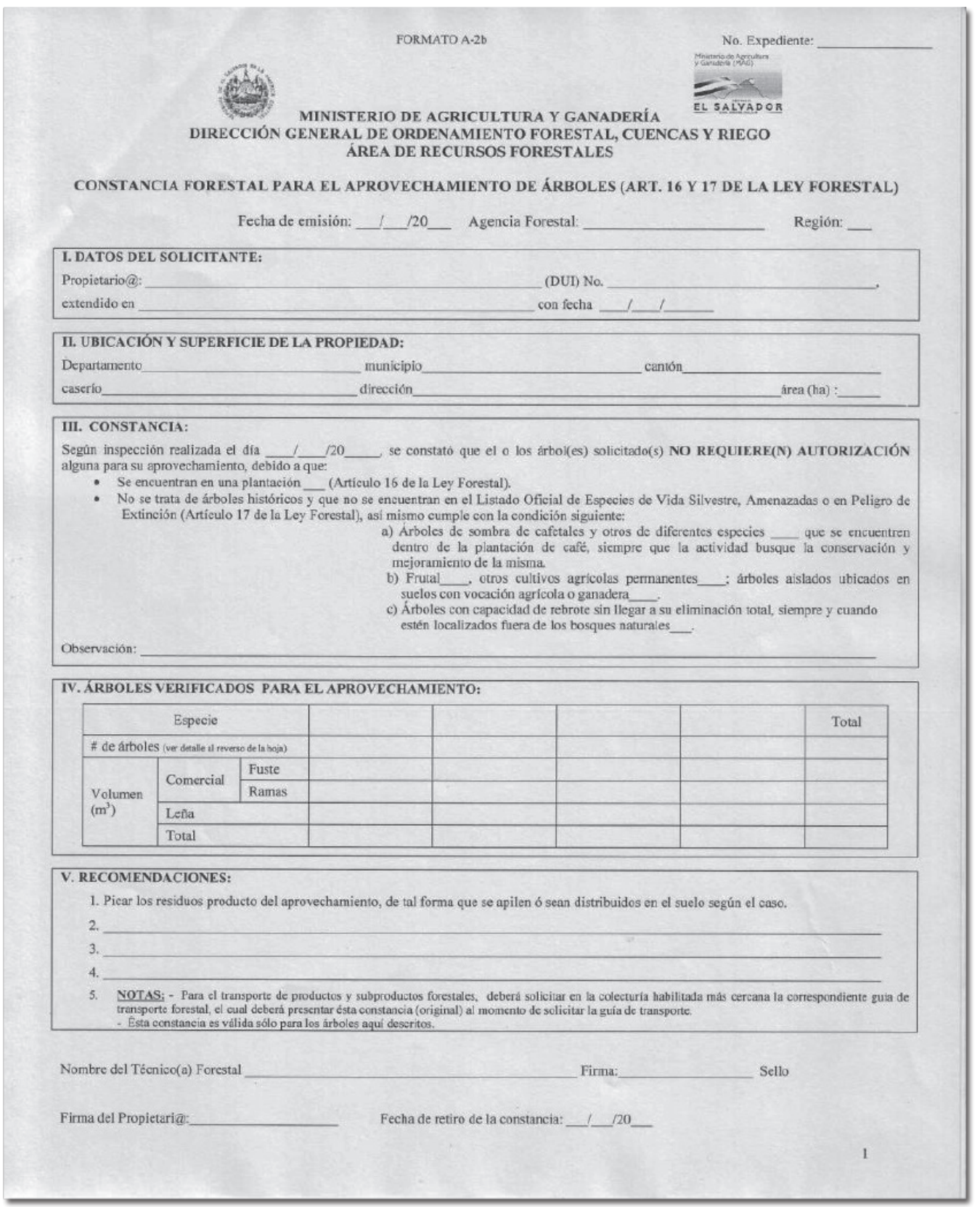


Anexo 12. Formulario A-2c del ARF

FORMATO A-2c

No. Expediente:

MINISTERIO DE AGRICULTURA Y GANADERIA EL SALYADOR DIRECCIÓN GENERAL DE ORDENAMIENTO FORESTAL, CUENCAS Y RIEGO ÁREA DE RECURSOS FORESTALES

DENEGACIÓN TOTAL PARA EL APROVECHAMIENTO DE ÁRBOLES (ART. 10, 11, 16, 17* y 23 DE LA LEY FORESTAL)

Fecha de emisión:

120

Agencia Forestal:

Región:

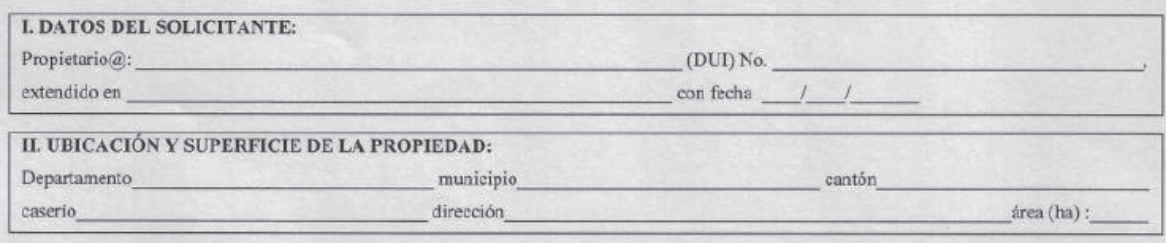

III. DENEGaCIÓN TOTAL:

Según inspección realizada el día se constató que el o los árbol(es) solicitado(s) NO SON APTOS PARA SU APROVECHAMIENTO, por la(s) razón(es) siguiente(s):

Nombre del Técnico(a) Forestal Firma: Sello

Firma del Propietaria:

Fecha de retiro de la constancia: 
Anexo 13. Formulario A-3 del ARF

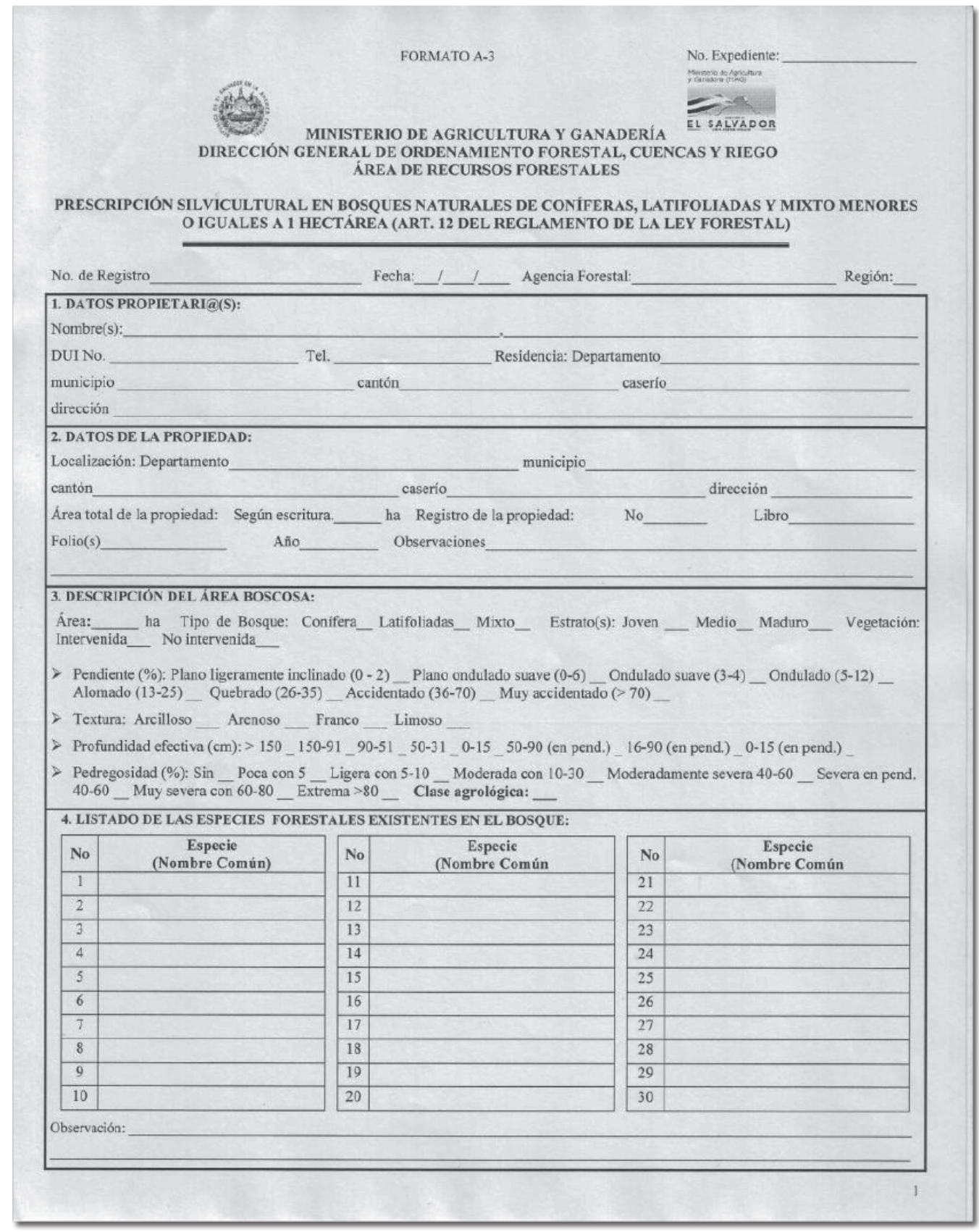




\section{JUSTIFICACIÓN DEL APROVECHAMIENTO:}

\section{6. ÁRBOL(ES) FORESTAL(ES) APROVECHAR:}

\begin{tabular}{|c|c|c|c|c|c|c|c|c|}
\hline \multirow{3}{*}{$\#$} & \multirow{3}{*}{ Especie } & \multirow{3}{*}{$\begin{array}{l}\text { DAP } \\
(\mathrm{cm})\end{array}$} & \multirow{2}{*}{\multicolumn{2}{|c|}{ Altura (m) }} & \multicolumn{4}{|c|}{ Volumen $\left(\mathrm{m}^{3}\right)$} \\
\hline & & & & & \multicolumn{2}{|c|}{ Comercial } & \multirow{2}{*}{ Lefia } & \multirow[b]{2}{*}{ Total } \\
\hline & & & Total & Comerc. & Fuste & Ramas & & \\
\hline \multicolumn{9}{|l|}{1} \\
\hline \multicolumn{9}{|l|}{2} \\
\hline \multicolumn{9}{|l|}{3} \\
\hline \multicolumn{9}{|l|}{4} \\
\hline \multicolumn{9}{|l|}{5} \\
\hline \multicolumn{9}{|l|}{6} \\
\hline \multicolumn{9}{|l|}{7} \\
\hline \multicolumn{9}{|l|}{8} \\
\hline \multicolumn{9}{|l|}{9} \\
\hline \multicolumn{9}{|l|}{10} \\
\hline \multicolumn{9}{|l|}{11} \\
\hline \multicolumn{9}{|l|}{12} \\
\hline \multicolumn{9}{|l|}{13} \\
\hline \multicolumn{9}{|l|}{14} \\
\hline \multicolumn{9}{|l|}{$15^{*}$} \\
\hline Total & & & & & & & & \\
\hline
\end{tabular}

- En caso de existir más árboles autorizados, deberá adjuntar cuadro(s) a esta nota.

7. RECOMENDACIONES SILVICULTURALES (PRESCRIPCIÓN):

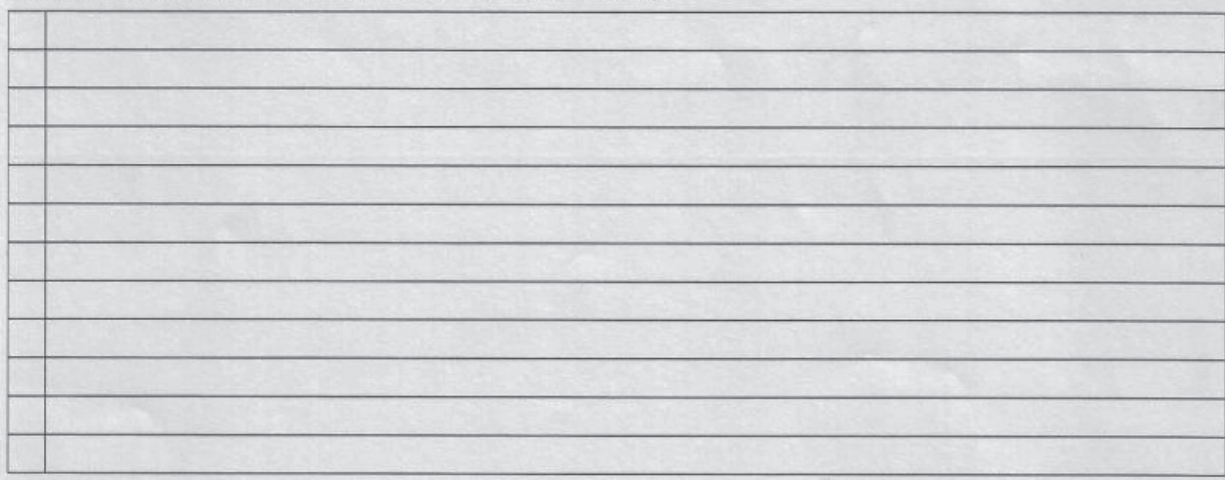

\section{AUTORIZACIÓN:}

Plazo de la Autorización:

A partir de

Meses:

Firma:

Nombre del Técnico(a) Forestal

Sello

Yo

autorización y a responder por dafíos y perjuicios ocasionados por cualquier incumplimiento.

Firma del propietari@:

Fecha de retiro de la autorización: 
Anexo 14. Listado oficial de especies de vida silvestre amenazadas o en peligro de extinción (plantas)

Ministerio de Medio Ambiente y recursos Naturales, Acuerdo $N^{\circ}$ 36, 2009

\begin{tabular}{|c|c|c|c|}
\hline Acanthaceae & Bravaisia intigerrima & Mangle Dulce & Amenazada \\
\hline \multirow[t]{2}{*}{ Actinidiaceae } & Saurauia waldheimii & Llorón & En peligro \\
\hline & Saurauia yasica & & Amenazada \\
\hline \multirow[t]{2}{*}{ Anemiaceae } & Anemia salvadorensis & & Amenazada \\
\hline & Asplenium seileri & & Amenazada \\
\hline \multirow[t]{3}{*}{ Annonaceae } & Annona glabra & Anona & Amenazada \\
\hline & Desmopsis bibracteata & & Amenazada \\
\hline & Xylopia frutescens & & Amenazada \\
\hline Apocynaceae & Vallesia aurantiaca & & Amenazada \\
\hline \multirow[t]{4}{*}{ Aquifoliaceae } & Ilex guianensis & & Amenazada \\
\hline & Ilex lamphophylla & & Amenazada \\
\hline & Ilex liebmannii & & Amenazada \\
\hline & Ilex pallida & & Amenazada \\
\hline Araliaceae & Oreopanax germinatus & Mano de León & Amenazada \\
\hline \multirow[t]{2}{*}{ Blechnaceae } & Blechnum wardiae & & Amenazada \\
\hline & Woodwaardia semicordata & & Amenazada \\
\hline \multirow[t]{5}{*}{ Bromeliaceae } & Tillandsia xerografica & Gallito & En peligro \\
\hline & Tillandsia pseudobaileyi & Gallito Frágil & Amenazada \\
\hline & Tillandsia imperialis & Gallito & Amenazada \\
\hline & Tillandsia concolor & Gallito & Amenazada \\
\hline & Pitcairnia calderonii & Gallito & En Peligro \\
\hline Caprifoliaceae & Viburnum mortanianum & & Amenazada \\
\hline Cibotiaceae & Cibotium regale & Helecho Arborescente & En Peligro \\
\hline \multirow[t]{7}{*}{ Cyatheaceae } & Alsophila salvinili & Helecho Azul & Amenazada \\
\hline & Cyathea divergens var. tuerckheimii & Helecho Arborescente & Amenazada \\
\hline & Alsophila tryoniana & Helecho Arborescente & Amenazada \\
\hline & Schaeropteris horrida & Helecho Arborescente & En Peligro \\
\hline & Cyathea bicrenata & Helecho Arborescente & En Peligro \\
\hline & Cyathea costaricensis & Helecho Arborescente & Amenazada \\
\hline & Cyathea schiedeana & Helecho Arborescente & Amenazada \\
\hline Culcitaceae & Culcita caniifolia & Helecho Arborescente & En Peligro \\
\hline \multirow[t]{2}{*}{ Dicksoniaceae } & Dicksonia sellowiana & Helecho Arborescente & En Peligro \\
\hline & Lophosoria quadripinnata & Helecho Arborescente & Amenazada \\
\hline \multirow[t]{2}{*}{ Dryopteridaceae } & Lastreopsis efussa var. divergens & & Amenazada \\
\hline & Olfersia cervina & & Amenazada \\
\hline Ebenaceae & Diospyros johnstoniana & Cacho de venado & Amenazada \\
\hline
\end{tabular}




\begin{tabular}{|c|c|c|c|}
\hline \multirow{12}{*}{$\begin{array}{l}\text { Leguminosae/ } \\
\text { Fabaceae }\end{array}$} & Dalbergia calderonil & & Amenazada \\
\hline & Dalbergia funera & & Amenazada \\
\hline & Eysenhardtia adenostylis & Taray & Amenazada \\
\hline & Leucaena Salvadorensis & & Amenazada \\
\hline & Leucaena shannonii & Guaje & Amenazada \\
\hline & Lonchocarpus michelianus & Sangre de Perro & Amenazada \\
\hline & Lonchocarpus molinae & & Amenazada \\
\hline & Lonchocarpus santarosanus & Chaperno & Amenazada \\
\hline & Lonchocarpus sanctarii & & Amenazada \\
\hline & Mimosa platycarpa & Zarza & En peligro \\
\hline & Platymiscium parviflorum & Hormiguillo & Amenazada \\
\hline & Ormosia macrocalyx & & Amenazada \\
\hline \multirow[t]{5}{*}{ Lilliaceae } & Huperzia cuernavacensis & & Amenazada \\
\hline & Huperzia linifolia & & Amenazada \\
\hline & Huperzia orizabae & & Amenazada \\
\hline & Lycopodiella alopecuroides & & Amenazada \\
\hline & Lycopodiella caroliniana & & Amenazada \\
\hline Lililaceae & Beaucarnea guatemalensis & & Amenazada \\
\hline Malvaceae & Hampea reynae & Majagua & Amenazada \\
\hline \multirow[t]{5}{*}{ Meliaceae } & Cedrela salvadorensis & Cedro blanco & Amenazada \\
\hline & Cedrela odorata & Cedro & Amenazada \\
\hline & Cedrela tonduzii & Cedro de Montaña & Amenazada \\
\hline & Swietenia humilis & Caoba & En peligro \\
\hline & Swietenia macrophyla & Caoba & En peligro \\
\hline \multirow[t]{3}{*}{ Myrtaceae } & Eugenia salamensis & Guacoco & Amenazada \\
\hline & Eugenia pachychlamys & & Amenazada \\
\hline & Eugenia juvtiapensis & & Amenazada \\
\hline Nyctaginaceae & Guapira witsbergeri & Siete Camisas Rojo & Amenazada \\
\hline \multirow[t]{2}{*}{ Ophioglosaceae } & Botrichium underwoodianum & & Amenazada \\
\hline & Ophioglossum reticulatum & & Amenazada \\
\hline \multirow[t]{3}{*}{ Orchidoceae } & Lycaste lasioglossa & Orquídea & Amenazada \\
\hline & Lycaste skinnerii & Orquídea & En peligro \\
\hline & Mormodes salvadorensis & Orquidea & Amenazada \\
\hline \multirow[t]{4}{*}{ Pinaceae } & Abies guatemalensis & Pinabete & En peligro \\
\hline & Pinus ayacahuite & Pino & Amenazada \\
\hline & Pinus maximinoi & Pino & Amenazada \\
\hline & Pinus tecunumanii & Pino & Amenazada \\
\hline Podocarpaceae & Podocarpus oleifolius & & En peligro \\
\hline \multirow[t]{2}{*}{ Polypodiaceae } & Ceradenia jungermannioides & & Amenazada \\
\hline & Micropolypodium basiattenuatum & & Amenazada \\
\hline \multirow[t]{2}{*}{ Psilotaceae } & Psilotum nudum & Helecho & Amenazada \\
\hline & Psilotum complanatum & Helecho & Amenazada \\
\hline
\end{tabular}




\begin{tabular}{|l|l|l|l|}
\hline \multirow{3}{*}{ Pteridaceae } & Cheiloplecton rigidum var. rigidum & Helecho & Amenazada \\
\cline { 2 - 4 } & Pellaea ternifolia var. ternifolia & Helecho & Amenazada \\
\cline { 2 - 4 } & Pityrogramma ochracea & Helecho & Amenazada \\
\hline Symplocaceae & Symplocos tacanensis & & Amenazada \\
\hline \multirow{2}{*}{ Thelypteridaceae } & Thelypteris obliterata & Helecho & Amenazada \\
\cline { 2 - 4 } & Thelypteris angustifolia & Helecho & Amenazada \\
\hline Thymeleaceae & Daphnopsis witsbergeri & & Amenazada \\
\hline Ulmaceae & Ulmus Mexicana & Mezcal & En peligro \\
\hline Zamiaceae & Zamia herrerae & Zamia & En peligro \\
\hline Zygophillaceae & Guaiacum sanctum & Guayacán & En peligro \\
\hline
\end{tabular}

FUENTE: Elaboración personal basada en el ACUERDO $N^{\circ} 36$, MARN. Diario Oficial $N^{\circ} 103$, Tomo $N^{\circ} 383$ de fecha 5 de junio de 2009 


\section{Anexos Honduras}

\section{Normas legales}

\section{Norma legal \\ Contexto Macro-Jurídico (Constitución y tratados internacionales)}

Constitución de la República

Convención Marco de las Naciones Unidas sobre el Cambio Climático

Convención de las Naciones Unidas de Lucha

Contra la Desertificación en Países Afectados por la

Sequía o Desertificación

Convenio 169 sobre Pueblos Indígenas y Tribales en Países Independientes

Convenio sobre la Diversidad Biológica

Convención para la Protección de la Capa de Ozono

\section{Leyes sectoriales}

\begin{tabular}{l}
\hline Ley Forestal, Áreas Protegidas y Vida Silvestre \\
\hline Ley General del Ambiente \\
\hline Ley para la Modernización y el Desarrollo del Sector \\
Agrícola
\end{tabular}

Ley para la Protección de la Actividad Caficultora

Ley para el Planeamiento de Zonas de Turismo

Ley Marco del Subsector Eléctrico

Ley que declara de Utilidad Pública el Desarrollo y

Generación de Energía por Fuentes Renovables

\section{Otras normas legales}

Ley Visión de País y un Plan de Nación para Honduras

Ley de Propiedad

Ley de Ordenamiento Territorial

Ley General de Aguas

Ley General de Minería

Ley de Municipalidades

Ley para la Adquisición de los Bienes Urbanos que Delimita el Artículo 107 de la Constitución de la República

Ley de Reforma Agraria

Ley de Expropiación Forzosa

Creación de la Unidad Especializada en Materia de Ecosistema y Ambiente

Reglamento General de la Ley Forestal, Áreas Protegidas y Vida Silvestre

Reglamento de Aplicación de CITES en Honduras

Autorización de permisos de importación de productos y subproductos de origen vegetal
Decreto 131, La Gaceta del 20 de enero de 1982

Decreto 26-95, La Gaceta del 29 de julio de 1995

Decreto 35-97, La Gaceta del 24 de junio de 1997

Decreto 26-94, La Gaceta del 30 de julio de 1994

Decreto 30-95, La Gaceta del 10 de junio de 1995

Decreto 73-93, La Gaceta del 21 de agosto de 1993

Decreto 98-2007, La Gaceta del 26 de febrero de 2008

Decreto 134-93, 30 de junio de 1993

Decreto 31-92, La Gaceta del 6 de abril de 1992

Decreto 81-92, La Gaceta del 18 de junio de 1992

Decreto 968-1980, La Gaceta del 22 de julio de 1980

Decreto 158-1994, La Gaceta del 26 de noviembre de 1994

Decreto 85-98, La Gaceta del $1^{\circ}$ de febrero de 1999

Decreto 134-90, La Gaceta del 29 de junio de 2004

Decreto 134-90, La Gaceta del 29 de junio de 2004

Decreto 180-2003, La Gaceta 30 de noviembre de 2003

Decreto 181-2009, La Gaceta del 24 de agosto de 2009

Decreto 292-1998, La Gaceta 6 de febrero de 1999

Decreto 134-90, La Gaceta 19 de noviembre de 1990

Decreto 90-90, La Gaceta del 29 de agosto de 1990

Decreto 170, La Gaceta del 30 de agosto de 1974

Decreto 113, La Gaceta del 9 de abril de 1914

Decreto 41-2011, La Gaceta del 27 de junio de 2011

Acuerdo Ejecutivo 031-2010, del 31 de agosto de 2010

Acuerdo 966-03, del 22 de diciembre de 2003

SAG. Resolución Nº10-2001 


\section{Anexo 1. Funciones de los Consejos Consultivos Forestales, Áreas Protegidas} y Vida Silvestre en sus diferentes niveles ${ }^{1}$

\section{Consejo Consultivo Nacional Forestal, Áreas Protegidas y Vida Silvestre (COCONAFOR)}

1. Asesorar al Instituto Nacional de Conservación y Desarrollo Forestal, Áreas Protegidas y Vida Silvestre (ICF) en la formulación, propuesta y evaluación de las estrategias generales y especiales en materia forestal, áreas protegidas y vida silvestre.

2. Proponer al Poder Ejecutivo por medio del ICF recomendaciones e iniciativas sobre políticas y acciones para alcanzar los objetivos de esta ley.

3. Proponer acciones de supervisión y control social sobre la gestión pública y privada, realizar acciones de supervisión sobre los Consejos Departamentales, Municipales, Comunitarios y otras instancias. Asimismo, este Consejo calificará o descalificará la labor que ejerzan los miembros que conforman los Consejos Departamentales, Municipales y Comunitarios.

4. Proponer observadores en aquellos asuntos e investigaciones de la gestión forestal que estime conveniente conocer y solicitar informes especiales.

5. Proponer al ICF la declaratoria de áreas protegidas, áreas de riesgo, áreas de conservación, restauración y protección, vedas temporales, emergencias y otras circunstancias que ameriten intervención particular de la autoridad en materia forestal.

6. Impulsar el desarrollo del sector mediante actividades de información y promoción.

7. Apoyar al ICF en acciones de concertación, solución de conflictos, mediación, canalización de denuncias y otras acciones de participación ciudadana vinculadas a la gestión forestal.

8. Conocer y recomendar sobre las Auditorías Técnicas Forestales.

9. Presentar una propuesta de un plan estratégico del Sistema Social Forestal.

10. Establecer la reglamentación interna para su funcionamiento.

11. Fortalecer la Estrategia Nacional de Protección Forestal, Áreas Protegidas y Vida Silvestre.

\section{Consejos Consultivos Departamentales Forestales, Áreas Protegidas y Vida Silvestre (COCODEFOR)}

1. Concertar y proponer las acciones de gestión forestal que se deban implementar en su Departamento.

2. Elaborar o apoyar propuestas de lineamientos y medidas para la definición e implementación del ordenamiento territorial en cumplimiento a lo establecido en la Ley de Ordenamiento Territorial.

3. Velar por el cumplimiento de las normas e instrumentos legales en la gestión forestal.

1. Este anexo es una copia textual de los Artículos 23, 25, 27 y 28 de la Ley Forestal, Áreas Protegidas y Vida Silvestre. Únicamente se utilizó las siglas del ICF y de los consejos consultivos después de nombrarlos la primera vez con el nombre completo. 
4. Ejercer contraloría social sobre el desarrollo de los planes, programas y proyectos forestales de su Departamento.

5. Mantenerse informados de los acuerdos y resoluciones adoptadas por el ICF y el COCONAFOR.

6. Establecer la regulación y normativa interna para su funcionamiento.

7. Apoyar al ICF y las municipalidades en la delimitación, protección y vigilancia de las cuencas y microcuencas abastecedoras de agua a las comunidades.

8. Seleccionar al representante de este Consejo ante el COCONAFOR.

9. Dar seguimiento y evaluar el avance del Sector Forestal, Áreas Protegidas y Vida Silvestre en su Departamento.

10. Otras de naturaleza afín a sus objetivos.

\section{Consejos Consultivos Municipales Forestales, Áreas Protegidas y Vida Silvestre}

1. Concertar y proponer a la Corporación Municipal las acciones de gestión forestal que se deban implementar en su Municipio.

2. Elaborar y apoyar propuestas de lineamientos y medidas para la definición e implementación del ordenamiento territorial en cumplimiento a lo establecido en la ley.

3. Velar por el cumplimiento de las normas e instrumentos legales en la gestión forestal.

4. Ejercer contraloría social sobre el desarrollo de los planes, programas y proyectos forestales de su Municipio.

5. Mantenerse informados de los acuerdos y resoluciones adoptadas por el ICF y el COCONAFOR.

6. Establecer la regulación y normativa interna para su funcionamiento.

7. Participar en la delimitación, protección y vigilancia de las cuencas y microcuencas abastecedoras de agua de las comunidades.

8. Colaborar con las Corporaciones Municipales en la organización de los cuadros de trabajo para actuar de inmediato en caso de incendio o plaga forestal.

9. Seleccionar el candidato que participará en la elección de los representantes de los Municipios ante el COCODEFOR, acreditándolo ante el Gobernador Departamental.

10. Velar por la transparencia y la plena aplicación de los Planes de Manejo Forestal y de Áreas Protegidas mediante la práctica de contralorías sociales.

11. Dar seguimiento y evaluar el avance del Sector Forestal, Áreas Protegidas y Vida Silvestre en su Municipio.

12. Informar semestralmente al COCODEFOR sobre el avance y obstáculos en el desarrollo de las Políticas Forestales, Áreas Protegidas y Vida Silvestre en el Municipio.

13. Otras de naturaleza afín a sus objetivos. 


\section{Consejos Consultivos Comunitarios Forestal, Áreas Protegidas y Vida Silvestre}

14. Vigilar por la Conservación, Protección y Manejo Sostenible de los bosques públicos, el agua y otros recursos naturales de la comunidad.

15. Asegurarse de que la ejecución de los planes de manejo no afecten el desarrollo de la comunidad.

16. Velar porque los proyectos y programas de reducción de la pobreza en materia forestal respondan a las necesidades y planes de desarrollo de la comunidad.

17. Participar en las actividades que se deriven del manejo racional e integral de los recursos naturales de la comunidad.

18. Concertar y proponer ante las autoridades e instituciones competentes los planteamientos orientados a responder a las necesidades de las comunidades.

19. Gestionar cooperación técnica y financiera ante las instituciones nacionales e internacionales para la ejecución de los programas y proyectos a ser ejecutados en sus comunidades a través de la municipalidad respectiva y en su defecto por el COCONAFOR.

20. Solicitar información a las dependencias correspondientes sobre sus recursos naturales a fin de que el diseño y formulación de sus proyectos sean elaborados de conformidad con la disponibilidad de los recursos.

21. Seleccionar el representante candidato que participará en la elección del representante de los Consejos Consultivos Comunitarios ante el respectivo Consejo Consultivo Forestal Municipal y Departamental, acreditándolo ante la autoridad que lo presida.

22. Participar en labores de prevención y combate de incendios y plagas forestales.

23. Practicar contralorías sociales sobre el desempeño de los entes ejecutores de planes de manejo, programas y proyectos en su comunidad.

24. Vigilar por el cumplimiento de lo preceptuado en la presente ley y su Reglamento. 


\section{Anexos Nicaragua}

\section{Anexo 1. Normas jurídicas vigentes que regulan el sector forestal}

\begin{tabular}{|c|c|}
\hline \multicolumn{2}{|l|}{ Norma Jurídica } \\
\hline Constitución & \\
\hline $\begin{array}{l}\text { Constitución Política de la República de Nicaragua, } \\
\text { publicada en La Gaceta, Diario Oficial No } 94 \text { del } 30 \text { de } \\
\text { abril de } 1987 \text { y en La Gaceta, Diario Oficial N } 176 \text { del } \\
16 \text { de septiembre de } 2010 \text {. }\end{array}$ & $\begin{array}{l}\text { Establece el derecho de los ciudadanos } \\
\text { nicaragüenses a gozar de un ambiente sano, así } \\
\text { como que los recursos naturales son patrimonio } \\
\text { nacional, la libertad de actividades económicas y } \\
\text { propiedad privada y los derechos de los pueblos } \\
\text { indígenas del país. }\end{array}$ \\
\hline \multicolumn{2}{|l|}{ Leyes } \\
\hline $\begin{array}{l}\text { Código Civil de la República de Nicaragua, } \\
\text { promulgado el } 1^{\circ} \text { de febrero de } 1904 \text {. }\end{array}$ & $\begin{array}{l}\text { El Código Civil, en su Artículo } 611 \text {, establece que } \\
\text { son públicas las cosas naturales o artificiales } \\
\text { apropiadas o producidas por el Estado y mantenidas } \\
\text { bajo su administración, de las cuales es lícito a } \\
\text { todos, individual o colectivamente, utilizarse con las } \\
\text { restricciones impuestas por la ley o por reglamentos } \\
\text { administrativos. }\end{array}$ \\
\hline $\begin{array}{l}\text { Ley } 462 \text {, Ley de Conservación, Fomento y Desarrollo } \\
\text { Sostenible del Sector Forestal, publicada en La } \\
\text { Gaceta, Diario Oficial N }{ }^{\circ} 168 \text { del } 4 \text { de septiembre de } \\
2003 .\end{array}$ & $\begin{array}{l}\text { Establece el régimen legal para la conservación, } \\
\text { fomento y desarrollo sostenible del sector forestal } \\
\text { tomando como base fundamental el manejo forestal } \\
\text { del bosque natural, el fomento de las plantaciones, la } \\
\text { protección, conservación y la restauración de áreas } \\
\text { forestales. }\end{array}$ \\
\hline $\begin{array}{l}\text { Ley } 487 \text {, Ley de reforma a la Ley } 462 \text {, Ley de } \\
\text { Conservación, Fomento y Desarrollo Sostenible } \\
\text { del Sector Forestal, publicada en La Gaceta, Diario } \\
\text { Oficial N }{ }^{\circ} 87 \text { del } 5 \text { de mayo de } 2004 \text {. }\end{array}$ & $\begin{array}{l}\text { Se reforma el Artículo } 67 \text { de la Ley N } 462 \text {, Ley de } \\
\text { Conservación, Fomento y Desarrollo Sostenible de } \\
\text { Sector Forestal, publicada en La Gaceta, Diario } \\
\text { Oficial N }{ }^{\circ} 168 \text { del } 4 \text { de septiembre de 2003, el que } \\
\text { se leerá así: "Arto. } 67 . \text { Se establece la vigencia de la } \\
\text { Ley N }{ }^{\circ} 402 \text {, Ley de Tasas por Aprovechamiento de } \\
\text { Servicios Forestales, publicada en La Gaceta, Diario } \\
\text { Oficial N }{ }^{\circ} 199 \text { del } 19 \text { de octubre de } 2001 \text {, la que } \\
\text { continuará aplicándose hasta el } 31 \text { de diciembre del } \\
\text { año } 2004 \text {. Vencido este plazo se tendrá por derogada } \\
\text { y se estará a lo dispuesto en el artículo } 48 \text { de la } \\
\text { presente Ley". }\end{array}$ \\
\hline $\begin{array}{l}\text { Ley 585, Ley de Veda para el Corte, Aprovechamiento } \\
\text { y Comercialización del Recurso Forestal, publicada } \\
\text { en La Gaceta, Diario Oficial N }{ }^{\circ} 120 \text { del } 21 \text { de junio de } \\
2006 .\end{array}$ & $\begin{array}{l}\text { Veda por un período de diez años para el corte, } \\
\text { aprovechamiento y comercialización de árboles de } \\
\text { caoba, cedro, pochote, pino, mangle y ceibo en todo } \\
\text { el territorio nacional, que podrá ser renovable por } \\
\text { períodos similares, menores o mayores. }\end{array}$ \\
\hline
\end{tabular}




\begin{tabular}{|c|c|}
\hline \multicolumn{2}{|l|}{ Norma Jurídica } \\
\hline Constitución & \\
\hline $\begin{array}{l}\text { Ley } 807 \text {, Ley de Conservación y Utilización } \\
\text { Sostenible de la Diversidad Biológica, publicada en } \\
\text { La Gaceta, Diario Oficial Nº } 200 \text { del } 19 \text { de octubre de } \\
2012 \text {. }\end{array}$ & $\begin{array}{l}\text { Regula la conservación y utilización sostenible } \\
\text { de la diversidad biológica existente en el país, } \\
\text { garantizando una participación equitativa y } \\
\text { distribución justa en los beneficios derivados } \\
\text { del uso de esta con especial atención a las } \\
\text { comunidades indígenas y afrodescendientes, así } \\
\text { como el respeto y reconocimiento de los derechos } \\
\text { de propiedad intelectual, formas de uso tradicional y } \\
\text { consuetudinarios de las comunidades locales. }\end{array}$ \\
\hline $\begin{array}{l}\text { Ley } 489 \text {, Ley de Pesca y Acuicultura, publicada en } \\
\text { La Gaceta, Diario Oficial N } 251 \text { del } 27 \text { de diciembre } \\
\text { de } 2004 \text {. }\end{array}$ & $\begin{array}{l}\text { Establece como infracción grave talar los bosques } \\
\text { de mangle que protegen el hábitat de los recursos } \\
\text { hidrobiológicos dentro del área de concesión. }\end{array}$ \\
\hline $\begin{array}{l}\text { Ley } 620 \text {, Ley General de Aguas Nacionales, } \\
\text { publicada en La Gaceta, Diario Oficial N }{ }^{\circ} 169 \text { del } 6 \text { de } \\
\text { septiembre de } 2007 \text {. }\end{array}$ & $\begin{array}{l}\text { Prohíbe la tala o corte de árboles o plantas de } \\
\text { cualquier especie que se encuentren dentro de un } \\
\text { área de doscientos metros a partir de las riberas de } \\
\text { los ríos y costas de lagos y lagunas, a fin de proteger } \\
\text { el recurso hídrico existente. }\end{array}$ \\
\hline $\begin{array}{l}\text { Ley 217, Ley General del Medio Ambiente y los } \\
\text { Recursos Naturales, publicada en La Gaceta, Diario } \\
\text { Oficial } N^{\circ} 105 \text { del } 6 \text { de junio de } 1996 .\end{array}$ & $\begin{array}{l}\text { Establece normas para la conservación, protección, } \\
\text { mejoramiento y restauración del medio ambiente y } \\
\text { los recursos naturales que lo integran, asegurando su } \\
\text { uso racional y sostenible. }\end{array}$ \\
\hline $\begin{array}{l}\text { Ley } 647 \text {, Ley de Reformas y Adiciones a la Ley } 217 \text {, } \\
\text { Ley General del Medio Ambiente y los Recursos } \\
\text { Naturales, publicada en La Gaceta, Diario Oficial N }{ }^{\circ} \\
62 \text { del } 3 \text { de abril de } 2008 \text {. }\end{array}$ & $\begin{array}{l}\text { Dispone que se establecerá una Zona de } \\
\text { Amortiguamiento colindante o circundante a cada } \\
\text { Área Protegida, para lo cual se deberá proceder de la } \\
\text { siguiente forma: ... En las zonas de amortiguamiento } \\
\text { de la Reserva de la Biosfera de Bosawás, las } \\
\text { Áreas Protegidas del Sureste y la Reserva Natural } \\
\text { Cerro Wawashang, así como en las futuras que se } \\
\text { acuerden, se establece un área perimetral externa de } \\
\text { diez kilómetros medidos a partir del límite del área } \\
\text { protegida que la constituye, en el que únicamente } \\
\text { se permitirá el aprovechamiento forestal con fines } \\
\text { domésticos no comerciales y para uso exclusivo en } \\
\text { el área. }\end{array}$ \\
\hline $\begin{array}{l}\text { Ley 290, Ley de Organización y Procedimientos del } \\
\text { Poder Ejecutivo, publicada en La Gaceta, Diario } \\
\text { Oficial № } 102 \text { del } 3 \text { de junio de } 1998 .\end{array}$ & $\begin{array}{l}\text { Tiene por objeto determinar la organización, } \\
\text { competencia y procedimientos del Poder Ejecutivo, el } \\
\text { cual está integrado por el Presidente de la República, } \\
\text { el Vicepresidente de la República, Ministerios } \\
\text { de Estados, entes gubernamentales, bancos y } \\
\text { empresas estatales, y para el mejor cumplimiento } \\
\text { de sus funciones puede organizarse de forma } \\
\text { descentralizada o desconcentrada. }\end{array}$ \\
\hline $\begin{array}{l}\text { Ley } 612 \text {, Ley de Reforma y Adición a la Ley } 290 \text {, } \\
\text { Ley de Organización, Competencia y Procedimiento } \\
\text { del Poder Ejecutivo, publicada en La Gaceta, Diario } \\
\text { Oficial } N^{\circ} 20 \text { del } 29 \text { de enero de } 2007 \text {. }\end{array}$ & $\begin{array}{l}\text { Se transfieren al Ministerio Agropecuario y Forestal } \\
\text { las facultades, competencias y recursos otorgados } \\
\text { a la Administración Forestal Estatal (AdForest) del } \\
\text { Ministerio de Fomento, Industria y Comercio. }\end{array}$ \\
\hline
\end{tabular}




\begin{tabular}{|c|c|}
\hline \\
\hline \multicolumn{2}{|l|}{\begin{tabular}{|c|} 
Norma Jurıdica \\
Constitución
\end{tabular}} \\
\hline $\begin{array}{l}\text { Ley } 804 \text {, Ley de Reforma y Adición a la Ley } 290 \text {, } \\
\text { Ley de Organización, Competencia y Procedimiento } \\
\text { del Poder Ejecutivo, publicada en La Gaceta, Diario } \\
\text { Oficial N }{ }^{\circ} 134 \text { del } 17 \text { de julio de } 2012 \text {. }\end{array}$ & $\begin{array}{l}\text { El Ministerio de Economía Familiar, Comunitaria, } \\
\text { Cooperativa y Asociativa estará regido por los } \\
\text { siguientes ejes transformadores: ... h) Conservación } \\
\text { y preservación del medio ambiente y los recursos } \\
\text { naturales: Impulsar compañas de reforestación y } \\
\text { saneamiento ambiental comunitarias, promover } \\
\text { la responsabilidad social empresarial cooperativa } \\
\text { en defensa de los recursos naturales y el medio } \\
\text { ambiente, promover una cultura conservacionista a } \\
\text { través del sistema de educación nacional. }\end{array}$ \\
\hline $\begin{array}{l}\text { Ley } 864 \text {, Ley de Reforma y Adición a la Ley } 290 \text {, } \\
\text { Ley de Organización, Competencia y Procedimiento } \\
\text { del Poder Ejecutivo, publicada en La Gaceta, Diario } \\
\text { Oficial N }{ }^{\circ} 91 \text { del } 20 \text { de mayo de } 2014 \text {. }\end{array}$ & $\begin{array}{l}\text { Le corresponde a la Presidencia de la República, } \\
\text { la administración Forestal en todo el territorio } \\
\text { nacional, la que ejecutará a través del Instituto } \\
\text { Nacional Forestal (INAFOR) en calidad de ente } \\
\text { de gobierno descentralizado, personalidad } \\
\text { jurídica propia, con autonomía funcional técnica y } \\
\text { administrativa, patrimonio propio y con capacidad } \\
\text { en materia de su competencia. El INAFOR estará } \\
\text { bajo la rectoría sectorial de la Presidencia de la } \\
\text { República, el Director, Directora, Subdirectora y } \\
\text { Subdirector del Instituto Nacional Forestal, serán } \\
\text { nombrados por el Presidente de la República. Se } \\
\text { transfiere al Instituto Nacional Forestal (INAFOR), } \\
\text { las facultades, competencias y recursos otorgados } \\
\text { de la administración forestal estatal (AdForest), del } \\
\text { Ministerio Agropecuario. }\end{array}$ \\
\hline $\begin{array}{l}\text { Ley } 862, \text { Ley Creadora del Instituto de Protección } \\
\text { y Sanidad Agropecuaria, publicada en La Gaceta, } \\
\text { Diario Oficial No } 91 \text { del } 20 \text { de mayo de } 2014 .\end{array}$ & $\begin{array}{l}\text { Crea el Instituto de Protección y Sanidad } \\
\text { Agropecuaria, adscrito a la Presidencia de la } \\
\text { República, como un ente descentralizado, con } \\
\text { personalidad jurídica propia, con una relación } \\
\text { de jerarquía desde el punto de vista orgánico } \\
\text { vinculado a ésta, con autonomía funcional, técnica y } \\
\text { administrativa, patrimonio propio, duración indefinida } \\
\text { y plena capacidad para adquirir derechos y contraer } \\
\text { obligaciones en materia de su competencia y que } \\
\text { será sucesor legal sin solución de continuidad } \\
\text { de la Dirección General de Protección y Sanidad } \\
\text { Agropecuaria (DGPSA), creada por la Ley No 291, } \\
\text { "Ley Básica de Salud Animal y Sanidad Vegetal”, } \\
\text { publicada en La Gaceta, Diario Oficial No } 136 \text { del } 22 \\
\text { julio de } 1998 \text {. }\end{array}$ \\
\hline $\begin{array}{l}\text { Ley } 40 \text { y } 261 \text {, Reformas e Incorporaciones a la Ley } N^{\circ} \\
40 \text {, Ley de los Municipios, publicada en La Gaceta, } \\
\text { Diario Oficial } N^{\circ} 155 \text { del } 17 \text { de agosto de } 1988 .\end{array}$ & $\begin{array}{l}\text { El Municipio es la unidad base de la división política } \\
\text { administrativa del país. Se organiza y funciona con la } \\
\text { participación ciudadana. }\end{array}$ \\
\hline $\begin{array}{l}\text { Ley } 786 \text {, Ley de Reforma y Adición a la Ley } 40 \text {, Ley } \\
\text { de Municipios, publicada en La Gaceta, Diario Oficial } \\
\text { N}^{\circ} 47 \text { del } 9 \text { de marzo de } 2012 \text {. }\end{array}$ & \\
\hline
\end{tabular}




\begin{tabular}{|c|c|}
\hline \multicolumn{2}{|l|}{ Norma Jurídica } \\
\hline Constitución & \\
\hline $\begin{array}{l}\text { Ley 28, Estatuto de Autonomía de las Regiones de } \\
\text { la Costa Atlántica de Nicaragua, publicada en La } \\
\text { Gaceta, Diario Oficial N } 238 \text { del } 30 \text { de octubre de } \\
1987 .\end{array}$ & $\begin{array}{l}\text { Establece los derechos, deberes y garantías de } \\
\text { los habitantes de las comunidades de las regiones } \\
\text { autónomas. Los habitantes de las Comunidades de la } \\
\text { Costa Atlántica tienen derecho a: ... } \\
\text { Usar, gozar y disfrutar de las aguas, bosques y } \\
\text { tierras comunales dentro de los planes de desarrollo } \\
\text { nacional. }\end{array}$ \\
\hline $\begin{array}{l}\text { Ley 445, Ley de Régimen de Propiedad Comunal de } \\
\text { los Pueblos Indígenas y Comunidades Étnicas de } \\
\text { las Regiones Autónomas de la Costa Atlántica de } \\
\text { Nicaragua y de los Ríos Bocay, Coco, Indio y Maíz. }\end{array}$ & $\begin{array}{l}\text { Garantiza a los pueblos indígenas y comunidades } \\
\text { étnicas el pleno reconocimiento de los derechos de } \\
\text { propiedad comunal, uso, administración, manejo } \\
\text { de las tierras tradicionales y sus recursos naturales } \\
\text { mediante la demarcación y titulación de estas. } \\
\text { Regula los derechos de propiedad comunal, uso y } \\
\text { administración de los recursos naturales en las tierras } \\
\text { comunales tradicionales de los pueblos indígenas y } \\
\text { comunidades étnicas. }\end{array}$ \\
\hline $\begin{array}{l}\text { Ley } N^{\circ} 765 \text {, Ley de Fomento a la Producción } \\
\text { Agroecológica u Orgánica. }\end{array}$ & $\begin{array}{l}\text { Este ley tiene como objetivo proteger y restaurar la } \\
\text { integridad de los ecosistemas, la diversidad biológica } \\
\text { y los procesos naturales que sustenten la vida y } \\
\text { lograr el Bien Común de la Madre Tierra y de la } \\
\text { Humanidad. }\end{array}$ \\
\hline $\begin{array}{l}\text { Ley 690, Ley para el Desarrollo de las Zonas } \\
\text { Costeras, publicada en La Gaceta, Diario Oficial № } \\
141 \text { del } 29 \text { de julio de } 2009 \text {. }\end{array}$ & $\begin{array}{l}\text { El objetivo que persigue el INTUR y AMUNIC es que } \\
\text { tanto los alcaldes y funcionarios públicos encargados } \\
\text { del Medio Ambiente u Ordenamiento Territorial de los } \\
\text { municipios puedan hacer uso facultativo de la Ley de } \\
\text { Zonas Costeras y de esta forma lograr potenciar al } \\
\text { máximo y en orden estos recursos naturales. }\end{array}$ \\
\hline $\begin{array}{l}\text { Ley } 641 \text {, Código Penal de la República de Nicaragua, } \\
\text { publicada en La Gaceta, Diario Oficial N }{ }^{\circ} 83,84,85 \text {, } \\
86 \text { y } 87 \text { del } 5,6,7,8 \text { y } 9 \text { de mayo de } 2008 .\end{array}$ & $\begin{array}{l}\text { Tipifica los delitos contra los recursos naturales y las } \\
\text { penas correspondientes. }\end{array}$ \\
\hline $\begin{array}{l}\text { Ley } 735 \text {, Ley de Prevención, Investigación } \\
\text { y Persecución del Crimen Organizado y de } \\
\text { la Administración de los Bienes Incautados, } \\
\text { Decomisados y Abandonados, publicada en Las } \\
\text { Gacetas } N^{\circ} 199 \text { y } 200 \text { del } 19 \text { y } 20 \text { de octubre de } \\
2010 .\end{array}$ & $\begin{array}{l}\text { Esta ley establece los delitos de crimen organizado. } \\
\text { Señala: “Independientemente de que en el futuro } \\
\text { cambie su denominación jurídica o la numeración } \\
\text { del artículo en que se tipifique en la Ley } N^{\circ} 641 \text {, } \\
\text { Código Penal a efectos de esta Ley se consideran } \\
\text { delitos de crimen organizado los delitos graves, que } \\
\text { revistan en su comisión las conductas típicas de esos } \\
\text { delitos, siendo estos los siguientes: ... 25) Corte, } \\
\text { aprovechamiento y veda forestal, tipificado en el } \\
\text { párrafo cuarto del artículo } 384 \text { del Código Penal. }\end{array}$ \\
\hline $\begin{array}{l}\text { Ley } 406 \text {, Código Procesal Penal, publicada en La } \\
\text { Gaceta, Diario Oficial N }{ }^{\circ} 243 \text { y } 244 \text { del } 21 \text { y } 24 \text { de } \\
\text { diciembre de } 2001 .\end{array}$ & $\begin{array}{l}\text { Regula lo relacionado con la jurisdicción penal que } \\
\text { se extiende a los delitos y faltas cometidos total o } \\
\text { parcialmente en el territorio nacional y a aquellos } \\
\text { cuyos efectos se producen en él. La Jurisdicción } \\
\text { penal se ejerce con exclusividad por los tribunales } \\
\text { previstos en la ley. }\end{array}$ \\
\hline
\end{tabular}




\begin{tabular}{|c|c|}
\hline \\
\hline \multicolumn{2}{|l|}{ Constitución } \\
\hline $\begin{array}{l}\text { Ley 346, Ley Orgánica del Ministerio Público, } \\
\text { publicada en La Gaceta, Diario Oficial N } 196 \text {, del } 17 \\
\text { de octubre de } 2000 .\end{array}$ & $\begin{array}{l}\text { "Créase el MP como una institución independiente, } \\
\text { con autonomía orgánica, funcional y administrativa, } \\
\text { que tiene a su cargo la función acusadora y la } \\
\text { representación de los intereses de la sociedad y de la } \\
\text { víctima del delito en el proceso penal. }\end{array}$ \\
\hline $\begin{array}{l}\text { Ley 411, Ley Orgánica de la Procuraduría General de } \\
\text { la República, publicada en La Gaceta, Diario Oficial } \\
\text { № } 244 \text { del } 24 \text { de diciembre de } 2001 .\end{array}$ & $\begin{array}{l}\text { La Procuraduría General de la República, adscrita } \\
\text { al Poder Ejecutivo con independencia funcional, } \\
\text { tiene a su cargo la presentación legal del Estado } \\
\text { de la República de Nicaragua en lo que concierne } \\
\text { a los intereses y las materias que la presente Ley } \\
\text { determine, con funciones específicas de asesoría y } \\
\text { consulta de los órganos y entidades dentro de los } \\
\text { órganos del Poder Ejecutivo. }\end{array}$ \\
\hline $\begin{array}{l}\text { Ley 339, Ley creadora de la Dirección General de } \\
\text { Servicios Aduaneros y de Reforma de la Ley creadora } \\
\text { de la Dirección General de Ingresos, publicada en La } \\
\text { Gaceta, Diario Oficial N } 69 \text { del } 6 \text { de abril de } 2000 \text {. }\end{array}$ & $\begin{array}{l}\text { La Dirección General de Servicios Aduaneros } \\
\text { (DGA) es un ente descentralizado con personalidad } \\
\text { jurídica propia, que goza de autonomía técnica, } \\
\text { administrativa y de gestión de sus recursos humanos. }\end{array}$ \\
\hline $\begin{array}{l}\text { Ley 228, Ley de la Policía Nacional, publicada en La } \\
\text { Gaceta, Diario Oficial N }{ }^{\circ} 162 \text { del } 28 \text { de agosto de } \\
1996 .\end{array}$ & $\begin{array}{l}\text { Son funciones de la policía, entre otras, las } \\
\text { siguientes: ... } \\
\text { 6) Coadyuvar en coordinación con el Ministerio } \\
\text { del Ambiente y Recursos Naturales, las Alcaldías y } \\
\text { Gobiernos Regionales en la vigilancia y protección } \\
\text { del ambiente y el aprovechamiento racional de los } \\
\text { recursos naturales. }\end{array}$ \\
\hline $\begin{array}{l}\text { Ley 181, Código de Organización, Jurisdicción y } \\
\text { Previsión Social Militar, publicada en La Gaceta, } \\
\text { Diario Oficial № } 165 \text { del } 2 \text { de septiembre de } 1994 .\end{array}$ & $\begin{array}{l}\text { El Ejército cumple las siguientes funciones: ... } \\
\text { 7) ... Coadyuvar en la conservación y renovación de } \\
\text { los recursos naturales, en mejorar el medio ambiente } \\
\text { y el equilibrio ecológico y demás planes estratégicos } \\
\text { que establezca el Presidente de la República. }\end{array}$ \\
\hline $\begin{array}{l}\text { Ley 749, Ley de Régimen Jurídico de Fronteras, } \\
\text { publicada en La Gaceta, Diario Oficial № } 244 \text { del } 22 \\
\text { de diciembre de } 2010 \text {. }\end{array}$ & $\begin{array}{l}\text { EI MARENA, en coordinación con las instituciones } \\
\text { públicas y privadas, autoridades regionales, locales } \\
\text { y territoriales, promoverá planes de desarrollo } \\
\text { que impulsen un modelo sostenible dirigido a la } \\
\text { salvaguarda del medio ambiente y los recursos } \\
\text { naturales ubicados en el territorio fronterizo. } \\
\\
\text { En el territorio fronterizo se prohíbe el } \\
\text { aprovechamiento forestal para todas las especies, } \\
\text { a excepción del aprovechamiento domiciliar y de } \\
\text { plantaciones, establecido en la normativa especial } \\
\text { de la materia, lo que está bajo vigilancia y control del } \\
\text { Ejército de Nicaragua, quien actúa en coordinación } \\
\text { con el Ministerio del Ambiente y de los Recursos } \\
\text { Naturales, el Instituto Nacional Forestal y demás } \\
\text { instituciones competentes. }\end{array}$ \\
\hline
\end{tabular}




\begin{tabular}{|c|c|}
\hline \multicolumn{2}{|l|}{ Norma Jurídica } \\
\hline Constitución & \\
\hline $\begin{array}{l}\text { Ley } 822 \text {, Ley de Concertación Tributaria, publicada en } \\
\text { La Gaceta, Diario Oficial } N^{\circ} 241 \text { del } 17 \text { de diciembre } \\
\text { de } 2012 \text {. }\end{array}$ & $\begin{array}{l}\text { Extiende hasta el } 31 \text { de diciembre del año } 2023 \\
\text { diversos beneficios fiscales para el sector forestal } \\
\text { y deroga los artículos } 38 \text { y } 48 \text { relacionados con los } \\
\text { incentivos de la Ley } 462 \text {, Ley de Conservación, } \\
\text { Fomento y Desarrollo Sostenible del Sector Forestal. }\end{array}$ \\
\hline $\begin{array}{l}\text { Ley N }{ }^{\circ} 445 \text { Ley del Régimen de Propiedad Comunal } \\
\text { de los Pueblos Indígenas y Comunidades Étnicas } \\
\text { de las Regiones Autónomas de la Costa Atlántica de } \\
\text { Nicaragua y de los Ríos Bocay, Coco, Indio y Maíz, } \\
\text { publicada en La Gaceta Diario Oficial, N } 16 \text { del } 23 \text { de } \\
\text { enero de } 2003 \text {. }\end{array}$ & $\begin{array}{l}\text { Entre otros aspectos, relacionados con el uso y } \\
\text { disfrute de los recursos naturales de estos pueblos, } \\
\text { para el caso de aprovechamiento de madera para } \\
\text { uso doméstico en las comunidades, no se requerirá } \\
\text { el aval de la municipalidad. El juez (Wihta) de la } \\
\text { comunidad vigilará porque no se abuse de dicho } \\
\text { aprovechamiento. En caso de abuso, la comunidad } \\
\text { impondrá la sanción correspondiente, sin detrimento } \\
\text { de las demás sanciones administrativas establecidas } \\
\text { en la ley. }\end{array}$ \\
\hline $\begin{array}{l}\text { Ley 431, Ley para el Régimen de Circulación } \\
\text { Vehicular e Infracciones de Tránsito. }\end{array}$ & $\begin{array}{l}\text { El Artículo } 115 \text { de la ley prohíbe la circulación de } \\
\text { vehículos que transportan madera en rollo y aserrada } \\
\text { entre las } 6 \text { de la tarde y las } 5 \text { de la mañana. }\end{array}$ \\
\hline \multicolumn{2}{|l|}{ Decreto } \\
\hline $\begin{array}{l}\text { Decreto 69-2008, Política Nacional de Desarrollo } \\
\text { Sostenible del Sector Forestal de Nicaragua, } \\
\text { publicado en La Gaceta, Diario Oficial N N } 3 \text { del } 7 \text { de } \\
\text { enero de } 2009 .\end{array}$ & $\begin{array}{l}\text { Propone mejorar la calidad de vida de las } \\
\text { generaciones actuales y futuras de la población } \\
\text { nicaragüense, priorizando las familias de pequeños } \\
\text { y medianos productores agropecuarios y forestales, } \\
\text { campesinos, trabajadores del campo, pueblos } \\
\text { indígenas, afrodescendientes y comunidades étnicas, } \\
\text { fomentando el desarrollo sostenible del sector } \\
\text { forestal orientado hacia la reposición del recurso } \\
\text { forestal, la deforestación evitada, el manejo forestal } \\
\text { racional y la forestaría comunitaria con una visión } \\
\text { empresarial. }\end{array}$ \\
\hline $\begin{array}{l}\text { Decreto 92-2007, Aprovechamiento Especial del } \\
\text { Recurso Forestal Derribado por Huracán Félix, } \\
\text { publicado en La Gaceta Diario Oficial N } 181 \text { del } 21 \\
\text { de septiembre de } 2007 .\end{array}$ & $\begin{array}{l}\text { Autoriza que el aprovechamiento de los árboles } \\
\text { forestales derribados por el huracán Félix será } \\
\text { manejado por las comunidades indígenas en } \\
\text { un enfoque de agroforestería comunitaria para } \\
\text { la rehabilitación socioeconómica de estas, } \\
\text { reconstrucción de viviendas e infraestructura de } \\
\text { las zonas afectadas. Incluye áreas protegidas en } \\
\text { coordinación con el MARENA. }\end{array}$ \\
\hline $\begin{array}{l}\text { Decreto 106-2005, Disposiciones que Regulan las } \\
\text { Concesiones Forestales, publicado en La Gaceta } \\
\text { Diario Oficial N }{ }^{\circ} 4 \text { del } 5 \text { de enero de } 2006 \text {. }\end{array}$ & $\begin{array}{l}\text { Establece las disposiciones administrativas y } \\
\text { técnicas para el otorgamiento de concesiones } \\
\text { forestales, así como los requisitos y procedimiento } \\
\text { para esta. }\end{array}$ \\
\hline $\begin{array}{l}\text { Decreto 104-2005, Reglamento de Procedimientos } \\
\text { para el Establecimiento, la Obtención y Aplicación de } \\
\text { los Incentivos para el Desarrollo Forestal de la Ley } \\
462 \text {, publicado en La Gaceta Diario Oficial N }{ }^{\circ} 250 \text { del } \\
27 \text { de diciembre de } 2005 \text {. }\end{array}$ & $\begin{array}{l}\text { Establece los procedimientos reglamentarios del } \\
\text { Capítulo VI "Fomento e Incentivos para el Desarrollo } \\
\text { Forestal" de la Ley } 462 .\end{array}$ \\
\hline
\end{tabular}




\begin{tabular}{|l|}
\hline \multicolumn{1}{|c|}{ Norma Jurídica } \\
\hline \multicolumn{1}{|c|}{ Constitución } \\
\hline $\begin{array}{l}\text { Decreto 9-96, Reglamento de la Ley General del } \\
\text { Medio Ambiente y los Recursos Naturales, publicado } \\
\text { en La Gaceta, Diario Oficial N }{ }^{\circ} 163 \text { del } 29 \text { de agosto } \\
\text { de 1996. }\end{array}$ \\
\hline
\end{tabular}

Decreto 02-2012, Reglamento General de la Ley 765, Ley de Fomento a la Producción Agroecológica u Orgánica, publicado en La Gaceta N ${ }^{\circ} 15$ del 25 de enero de 2012.

Decreto 71-98, Reglamento de la Ley 290, publicado en La Gaceta, Diario Oficial N²05 y 206 del 30 y 31 de octubre de 1998.

Decreto 76-2006, Sistema de Evaluación Ambiental, publicado en La Gaceta, Diario Oficial N 248 del 22 de diciembre de 2006.
Establece las normas reglamentarias de carácter general para la gestión ambiental y el uso sostenible de los recursos naturales en el marco de la Ley $\mathrm{N}^{\circ}$ 217.

Establece las disposiciones para la aplicación de la Ley N 765 "Ley de Fomento a la Producción Agroecológica u Orgánica”.

Establece las disposiciones para la aplicación de la Ley 290, Ley de Organización, Competencia y Procedimientos del Poder Ejecutivo.

Regula de forma completa el Sistema de Evaluación Ambiental en cuanto a lista de actividades, obras, proyectos e industrias y el procedimiento para el otorgamiento del permiso ambiental, incluyendo la Evaluación Ambiental Estratégica, los Formularios Ambientales Municipales y la Evaluación Ambiental en las Áreas Protegidas.

Previo a la autorización de manejo y aprovechamiento forestal en bosques naturales o en plantaciones forestales en superficies mayores a quinientas hectáreas (500 ha) deberá presentarse un Estudio de Impacto Ambiental.

Decreto 01-2007, Reglamento de Áreas Protegidas de Nicaragua, publicado en La Gaceta, Diario Oficial $N^{\circ} 8$ del 11 de enero de 2007.

Decreto 26-2007, Reforma al Decreto 01-2007, Reglamento de Áreas Protegidas de Nicaragua, publicado en La Gaceta N ${ }^{\circ} 63$ del 29 de marzo de 2007.

Decreto 24-2012, Reforma al Decreto 01-2007, Reglamento de Áreas Protegidas de Nicaragua.

Decreto $N^{\circ} 112-2007$, Creación de los Consejos y Gabinetes del Poder Ciudadano, publicado en La Gaceta N²30 del 29 de noviembre de 2007.
Establece las disposiciones necesarias relativas de las áreas protegidas.

Artículo 1. Se reforma el título de la sección III y los Artículos 67, 68 y 69 del Decreto N 01-2007.

Artículo 1. Se adicionan los numerales 8 y 9 al Artículo 22 del Decreto $N^{\circ}$ 01-2007.

Los Consejos y Gabinetes del Poder Ciudadano se crearon a fin de que el pueblo nicaragüense -en el ejercicio de la democracia participativa y directa de los diferentes sectores sociales del país- se organice y participe en el desarrollo integral de la nación de manera activa y directa, y apoye los planes y las políticas del Presidente de la República encaminadas a desarrollar estos objetivos. Los Consejos y Gabinetes del Poder Ciudadano tienen presencia en las comunidades, comarcas, barrios, distritos, municipios, departamentos, regiones autónomas y a nivel nacional, debiendo existir en cada una de ellos (a): ... Un coordinador para Medio Ambiente. 


\begin{tabular}{|c|c|}
\hline \multicolumn{2}{|l|}{ Norma Jurídica } \\
\hline Constitución & \\
\hline $\begin{array}{l}\text { Decreto 8-98, Normas y Procedimientos para la } \\
\text { Exportación e Importación de Especies de Flora y } \\
\text { Fauna Silvestre de Nicaragua. }\end{array}$ & $\begin{array}{l}\text { Reglamenta los Artículos } 62 \text { y } 68 \text { de la Ley } 217, \\
\text { Ley General del Medio Ambiente y los Recursos } \\
\text { Naturales, y regula la introducción y salida del país } \\
\text { de especies animales y vegetales o partes de estos } \\
\text { obtenidas de la naturaleza, criados en cautividad } \\
\text { o reproducidos artificialmente sean nativas o no y } \\
\text { establece atribuciones a las autoridad administrativa } \\
\text { y a la autoridad científica de CITES de acuerdo con } \\
\text { los principios y normas consignados a nivel nacional } \\
\text { y en los demás instrumentos internacionales. }\end{array}$ \\
\hline $\begin{array}{l}\text { Decreto Presidencial } 30-94 \text {, Creación de Ventanilla } \\
\text { Única de Exportaciones, Centro de Trámites de las } \\
\text { Exportaciones (CETREX). }\end{array}$ & $\begin{array}{l}\text { EI CETREX tiene como objetivo principal centralizar } \\
\text { la ejecución de las funciones específicas de las } \\
\text { entidades públicas que atienden los trámites } \\
\text { relacionados con las exportaciones. }\end{array}$ \\
\hline & $\begin{array}{l}\text { Cada entidad de las que se refiere el artículo anterior } \\
\text { conservará las atribuciones y responsabilidades } \\
\text { otorgadas por las leyes. CETREX informará a cada } \\
\text { institución sobre el cumplimiento de los trámites. } \\
\text { También cada institución enviará a la CNPE las } \\
\text { normas, reglamentos y disposiciones que CETREX en } \\
\text { delegación deberá hacer cumplir. }\end{array}$ \\
\hline \multicolumn{2}{|l|}{ Norma Técnica } \\
\hline $\begin{array}{l}\text { NTON 11-013-07, Norma Técnica Obligatoria } \\
\text { Nicaragüense para la Reglamentación de Medidas } \\
\text { Fitosanitarias para Embalaje de Madera Utilizado en } \\
\text { el Comercio Internacional. }\end{array}$ & $\begin{array}{l}\text { Reglamenta las medidas fitosanitarias para reducir } \\
\text { el riesgo de introducción y/o diseminación de plagas } \\
\text { cuarentenarias asociadas con el embalaje de madera } \\
\text { utilizado en el comercio internacional. Esta norma se } \\
\text { aplica a todos los embalajes de madera utilizados en } \\
\text { el comercio internacional. }\end{array}$ \\
\hline $\begin{array}{l}\text { NTN 25-001-06. De los Servicios de Asistencia } \\
\text { Técnica Agropecuaria y Forestal de Oferentes } \\
\text { Individuales, publicada en La Gaceta, Diario Oficial } \\
N^{\circ} 45 \text { del } 5 \text { de marzo de } 2007 \text {, publicada por el } \\
\text { Instituto Nicaragüense de Tecnología Agropecuaria } \\
\text { (INTA). }\end{array}$ & $\begin{array}{l}\text { Establece los requisitos para la certificación de } \\
\text { oferentes o proveedores individuales de Servicios de } \\
\text { Asistencia Técnica Agropecuaria y Forestal (SAT) para } \\
\text { garantizar su calidad. }\end{array}$ \\
\hline $\begin{array}{l}\text { NTON 18-001-04, Norma Técnica para el Manejo } \\
\text { Sostenible de los Bosques Naturales Latifoliados y de } \\
\text { Coníferas, publicada en La Gaceta, Diario Oficial N }{ }^{\circ} \\
250 \text { del } 24 \text { de diciembre de } 2012 \text {. }\end{array}$ & $\begin{array}{l}\text { Establece las directrices técnicas para el Manejo } \\
\text { Sostenible del Bosque Natural Latifoliado y del } \\
\text { Bosque de Coníferas. Esta norma aplica a toda } \\
\text { persona natural o jurídica que se dedique a la } \\
\text { actividad forestal en el territorio nicaragüense. }\end{array}$ \\
\hline
\end{tabular}




\begin{tabular}{|c|c|}
\hline \multicolumn{2}{|l|}{ Norma Jurídica } \\
\hline Constitución & \\
\hline $\begin{array}{l}\text { NTON 00-024-03, Uso Sostenible del Recurso } \\
\text { Forestal Maderable en el Bosque de Manglar en } \\
\text { el Pacífico de Nicaragua, publicado en La Gaceta, } \\
\text { Diario Oficial N }{ }^{\circ} 64 \text { del } 10 \text { de septiembre de } 2003 .\end{array}$ & $\begin{array}{l}\text { Establece las especificaciones técnicas que regirán } \\
\text { las actividades de utilización sostenible del recurso } \\
\text { forestal maderable en el bosque de manglar en } \\
\text { el Pacífico de Nicaragua. Es aplicable a todas } \\
\text { aquellas personas naturales o jurídicas dedicadas } \\
\text { a la utilización sostenible del recurso forestal } \\
\text { maderable en el bosque de manglar en el Pacífico de } \\
\text { Nicaragua. }\end{array}$ \\
\hline $\begin{array}{l}\text { NTON 05-003-99, Norma Técnica para el Manejo } \\
\text { Ambiental en Aserraderos, aprobado el } 12 \text { de octubre } \\
\text { de 1998, publicado en La Gaceta No } 153 \text { el } 15 \text { de } \\
\text { agosto de } 2000 .\end{array}$ & $\begin{array}{l}\text { Esta norma tiene por objeto establecer las } \\
\text { disposiciones para el manejo ambiental que deben } \\
\text { cumplir todos los propietarios de aserraderos en } \\
\text { Nicaragua. Regula la ubicación, instalación y manejo } \\
\text { de los aserraderos y las condiciones de seguridad } \\
\text { ambiental que deben ser reguladas a fin de garantizar } \\
\text { la protección de la población y el equilibrio ecológico. }\end{array}$ \\
\hline \multicolumn{2}{|l|}{ Resoluciones/Acuerdos } \\
\hline $\begin{array}{l}\text { Política Administrativa para el Uso y } \\
\text { Aprovechamiento de los Recursos Naturales y } \\
\text { Manejo Forestal, aprobado por la Contraloría General } \\
\text { de la República (CGR) el } 11 \text { de julio de } 2013 \text {. }\end{array}$ & $\begin{array}{l}\text { La CGR dio a conocer a los gobiernos municipales } \\
\text { de todo el país la normativa Política Administrativa } \\
\text { para el Uso y Aprovechamiento de los Recursos } \\
\text { Naturales y Manejo Forestal, que exige a las alcaldías } \\
\text { coordinarse con INAFOR Y MARENA para todo } \\
\text { lo concerniente a la extracción de la madera y la } \\
\text { protección del medio ambiente. } \\
\text { La normativa establece que INAFOR notifique a la } \\
\text { CGR sobre todos los permisos de extracción de } \\
\text { madera para verificar que se han cumplido con } \\
\text { todos lo que establece la ley. Asimismo, estipula } \\
\text { mecanismos de comunicación entre INAFOR y } \\
\text { MARENA con los alcaldes, PN, Ejército y CGR. }\end{array}$ \\
\hline $\begin{array}{l}\text { Resolución administrativa 33-2013, que "establece } \\
\text { el procedimiento para la implementación de la } \\
\text { trazabilidad forestal". }\end{array}$ & $\begin{array}{l}\text { Las disposiciones serán aplicadas en todo el territorio } \\
\text { nacional por INAFOR. } \\
\text { El Sistema de Registro y Control de Operaciones } \\
\text { Forestales (SIRCOF) es el único sistema para el } \\
\text { registro, emisión y seguimiento de la información } \\
\text { de las guías de transporte de producto forestal } \\
\text { provenientes de permisos de aprovechamiento, } \\
\text { plantaciones o subastas de productos forestales } \\
\text { autorizados por INAFOR. }\end{array}$ \\
\hline Resolución de MARENA № 02-01-2013 sobre Vedas. & $\begin{array}{l}\text { Establece la veda indefinida del almendro (Dipterix } \\
\text { panamensis). }\end{array}$ \\
\hline Resolución Administrativa 17-2013. & $\begin{array}{l}\text { Deroga los Artículos } 34,35 \text { y } 36 \text { de la Resolución } \\
\text { Administrativa } 69-2011 \text { y reforma su Artículo } 33 \\
\text { referido al registro de los propietarios de motosierra. }\end{array}$ \\
\hline
\end{tabular}




\section{\begin{tabular}{|c|}
\hline Norma Jurídica \\
\hline Constitución \\
\hline
\end{tabular}}

Resolución Administrativa N 69-2011, INAFOR, Normas Administrativas para el Funcionamiento de la Industria Forestal.

Se dicta con el fin de mejorar el control y seguimiento dentro de la cadena de custodia y reúne los criterios básicos para mejorar y maximizar sus técnicas de procesamientos y calidad de los productos, así como la protección del medio ambiente y recursos humanos que laboran en la empresa forestal. Deroga la Resolución Administrativa N 42-20011, INAFOR.

Reformada por la Resolución Administrativa 17-2013.

Resolución Administrativa $N^{\circ}$ 68-2011, INAFOR, Disposiciones Administrativas para el Manejo Sostenible de los Bosques Latifoliados, Coníferas, Plantaciones Forestales y Fincas, agosto de 2011.

Establece los procesos administrativos para tener acceso al recurso forestal de forma que se promuevan las actividades de Fomento y Protección Forestal, Investigación Científica Forestal y Mecanismos de Regulación y Control.

En cuanto al trasporte y seguimiento de los permisos, esta resolución fue modificada por la Resolución 33-2013.

Acuerdo Ministerial 31-2009, De los Precios de Referencia para la Aplicación del Pago Único por Derecho de Aprovechamiento del Recurso Forestal, publicado en La Gaceta, Diario Oficial N ${ }^{\circ} 227$ del 30 de noviembre de 2009.

Acuerdo Ministerial 013-2009, Funcionamiento del Comité de Incentivos del Sector Forestal, publicado en La Gaceta, Diario Oficial № 111 del 16 de junio de 2009.

Disposición Administrativa, Consejo Regional de la Región Autónoma del Atlántico Norte, № 20-0809-2008, Programa Ambiental de Aprovechamiento y Usufructo del Recurso Forestal Afectado por el Huracán Félix.

Resolución Administrativa 81-2007, que establece las Disposiciones Administrativas para el Manejo Sostenible de los Bosques Latifoliados, Coníferas, Plantaciones Forestales y Fincas, publicada en La Gaceta $N^{\circ} 10$ del 15 de enero de 2008. territorio de la Región.
Desarrolla lo establecido en los Artículos 48 y 49 de la Ley 462 y determina el precio de referencia por metro cúbico de madera en rollo de las especies forestales utilizando la metodología aprobada por CONAFOR y que fue concertada con más de 450 líderes y actores de las plataformas de Gobernanza Forestal territoriales de junio a septiembre de 2009.

Establece el funcionamiento del Comité de Incentivos del Sector Forestal.

Solicita al Presidente de la República, entre otras medidas, crear el Programa Ambiental de Aprovechamiento y Usufructo del Recurso Forestal afectado por el huracán Félix para la rehabilitación socio-económica, reconstrucción de vivienda e infraestructura y restauración del ecosistema marinocostero, bosque y cuencas hidrográficas en todo el

Las presentes disposiciones administrativas para el manejo sostenible de los bosques naturales latifoliados, coníferas, plantaciones forestales y fincas tienen por objeto desarrollar complementariamente las normas forestales vigentes.

Las presentes disposiciones administrativas obligan a toda persona natural o jurídica que aproveche recursos forestales en cualquiera de sus modalidades a reponer el recurso forestal.

Esta Resolución deroga la Resolución Administrativa 35-2004, publicada en La Gaceta Diario Oficial $N^{\circ} 158$ del 13 de agosto del año 2004 y cualquier disposición legal que se le oponga. 


\begin{tabular}{|c|c|}
\hline \\
\hline \multicolumn{2}{|l|}{\begin{tabular}{|c|} 
Norma Juridica \\
Constitución
\end{tabular}} \\
\hline $\begin{array}{l}\text { Resolución N 54-17-11-2005, Consejo Regional } \\
\text { de la Región Autónoma del Atlántico Norte, Sobre } \\
\text { el Ordenamiento del Sector Forestal en la Región } \\
\text { Autónoma del Atlántico Norte. }\end{array}$ & $\begin{array}{l}\text { Establece medidas para el ordenamiento, } \\
\text { administración y mecanismos de articulación entre la } \\
\text { Región Autónoma del Atlántico Norte con el sector } \\
\text { forestal como parte integrante del Sistema Nacional } \\
\text { de Administración Forestal (SNAF). }\end{array}$ \\
\hline $\begin{array}{l}\text { Reglamento de los Regentes Forestales, } 13 \text { de junio } \\
\text { de } 2005 .\end{array}$ & $\begin{array}{l}\text { Establece el procedimiento para la acreditación, } \\
\text { registro, desempeño y funciones de los Regentes } \\
\text { Forestales, así como sus obligaciones y derechos. }\end{array}$ \\
\hline $\begin{array}{l}\text { Resolución Administrativa N N } 73-2003 \text {, Normativa del } \\
\text { Registro Nacional Forestal. }\end{array}$ & $\begin{array}{l}\text { Establece los procedimientos para el registro de } \\
\text { los convenios y acuerdos que celebre INAFOR } \\
\text { en materia forestal, las plantaciones forestales, } \\
\text { las empresas e industrias forestales, los viveros o } \\
\text { centros de material genético forestal, los planes de } \\
\text { manejo aprobados, los permisos de aprovechamiento } \\
\text { forestal, los regentes, auditores forestales, técnicos } \\
\text { forestales municipales y regionales, el inventario } \\
\text { forestal nacional y las áreas forestales estatales y } \\
\text { nacionales. }\end{array}$ \\
\hline $\begin{array}{l}\text { Resolución Ministerial 13-04-13, que establece el } \\
\text { Procedimiento Administrativo para la Obtención } \\
\text { del Permiso para el Comercio Internacional de las } \\
\text { Especies Forestales Competencia de MARENA. } \\
\text { Publicada en La Gaceta, Diario Oficial No } 236 \text { del } 12 \\
\text { de diciembre de } 2013 \text {. }\end{array}$ & $\begin{array}{l}\text { Establece el procedimiento administrativo y requisitos } \\
\text { para la obtención del permiso para el comercio } \\
\text { internacional de las especies forestales competencia } \\
\text { de MARENA. Aunque esta resolución no lo señala } \\
\text { explícitamente, por su contenido entendemos que } \\
\text { deroga las Resoluciones Ministeriales 004-2007 y } \\
\text { 36-2003. }\end{array}$ \\
\hline $\begin{array}{l}\text { Resolución Ministerial, MARENA 004-2007, que } \\
\text { establece las Regulaciones para la Exportación de las } \\
\text { Especies: Caoba, Cedro Real, Pochote y Ceibo en su } \\
\text { Segunda Transformación. }\end{array}$ & $\begin{array}{l}\text { Establece las regulaciones para la exportación de las } \\
\text { especies: Caoba, Cedro Real, Pochote y Ceibo en su } \\
\text { segunda transformación. }\end{array}$ \\
\hline $\begin{array}{l}\text { Acuerdo Ministerial, MARENA No } 36-2003 \text {, } \\
\text { Procedimiento Administrativo para la Obtención del } \\
\text { Permiso de Exportación para la Especie Maderable } \\
\text { Swietenia macrophylla, especie incluida en el } \\
\text { Apéndice II del Convenio CITES. }\end{array}$ & $\begin{array}{l}\text { Establece el Procedimiento Administrativo para } \\
\text { la Obtención del Permiso de Exportación para la } \\
\text { Especie Maderable Swietenia macrophylla, especie } \\
\text { incluida en el Apéndice II del Convenio CITES. }\end{array}$ \\
\hline $\begin{array}{l}\text { Resolución Ministerial, MARENA N }{ }^{\circ} 26-2002 \text {, } \\
\text { Procedimiento Administrativo y Requisitos para } \\
\text { el Otorgamiento del Permiso Especial de Uso de } \\
\text { Manglares, Humedales y Recursos Asociados, } \\
\text { publicado en La Gaceta, Diario Oficial N }{ }^{\circ} 154 \text { del } 16 \\
\text { de agosto de } 2002 \text {. }\end{array}$ & $\begin{array}{l}\text { Establece el Procedimiento Administrativo y los } \\
\text { Requisitos para el Otorgamiento del Permiso Especial } \\
\text { de Uso de Manglares, Humedales y Recursos } \\
\text { Asociados, de conformidad con el Artículo } 91 \text { de } \\
\text { la Ley } 217 \text {, Ley General del Medio Ambiente y los } \\
\text { Recursos Naturales y los Artículos } 48 \text { y siguientes del } \\
\text { Decreto 9-96, Reglamento de la Ley } 217 \text { vigentes. Es } \\
\text { aplicable a todas las personas naturales y jurídicas, } \\
\text { nacionales y extranjeras que requieran ejercer } \\
\text { actividades de cualquier tipo en áreas cubiertas } \\
\text { de manglares, humedales y ambientes asociados } \\
\text { siempre y cuando no se encuentre en la lista taxativa } \\
\text { del Decreto } 76-2006 \text {. }\end{array}$ \\
\hline $\begin{array}{l}\text { Resolución Administrativa, INAFOR N }{ }^{\circ} 04-2001 \text {, } \\
\text { Procedimiento para la Venta al Martillo de Madera } \\
\text { Decomisada. }\end{array}$ & $\begin{array}{l}\text { Establece el procedimiento para la venta al martillo } \\
\text { de madera decomisada. }\end{array}$ \\
\hline
\end{tabular}




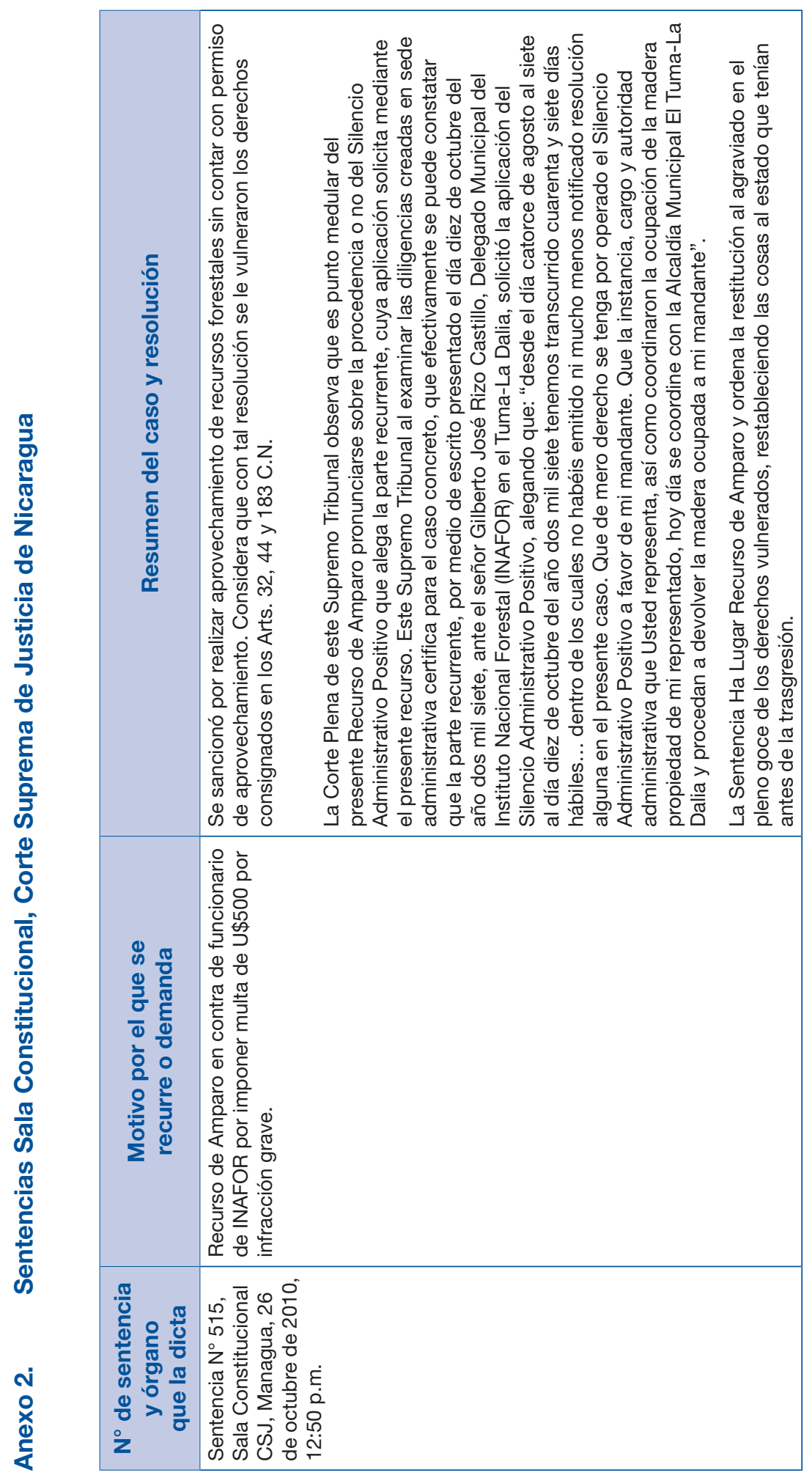




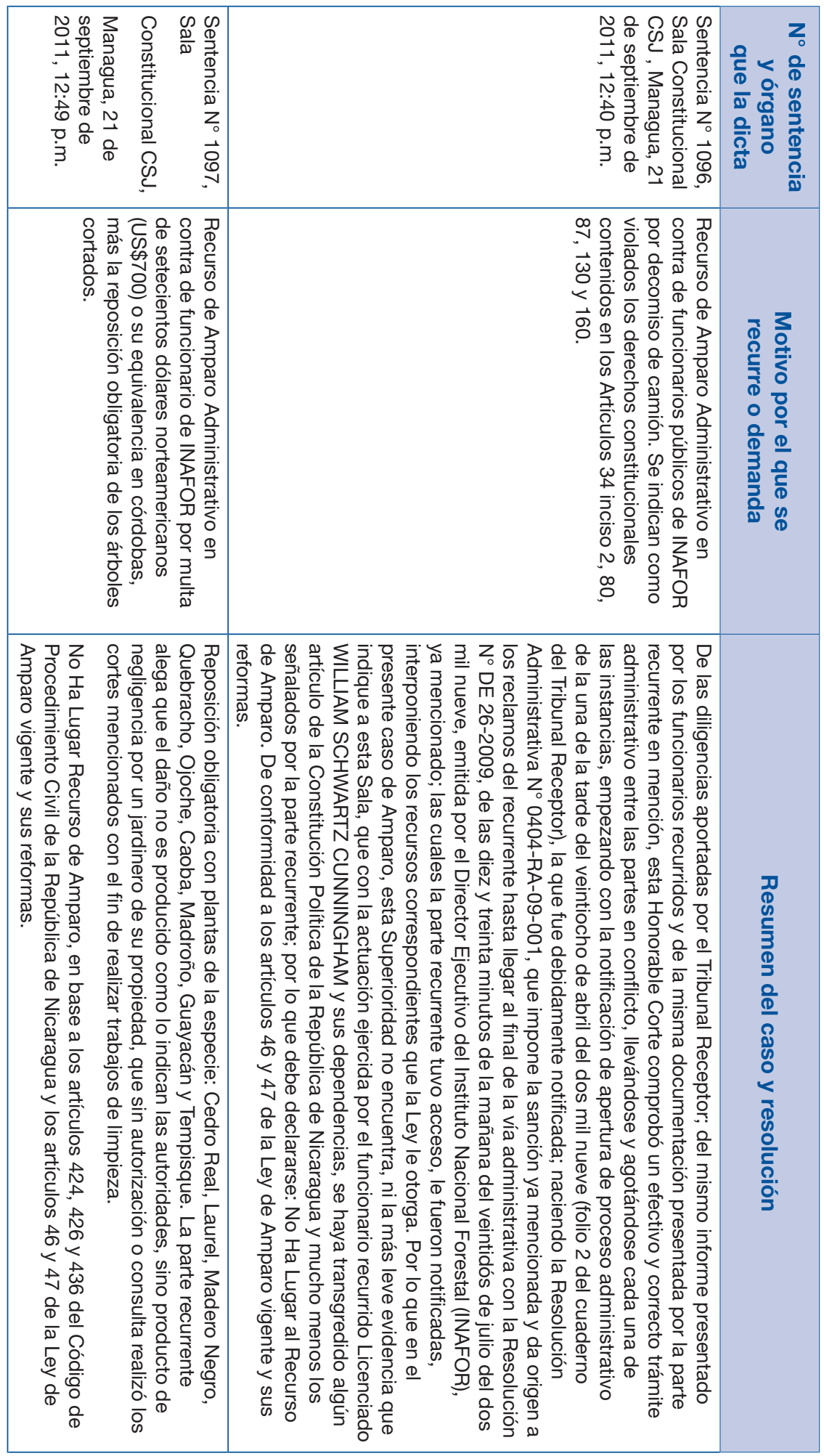




\begin{tabular}{|c|c|c|c|c|}
\hline 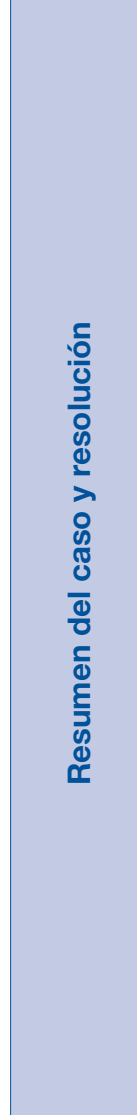 & 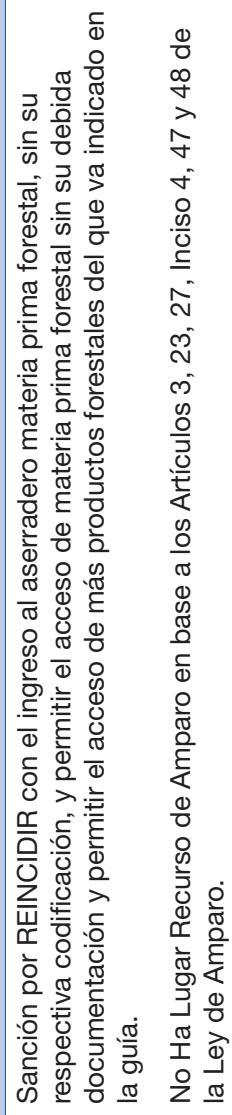 & 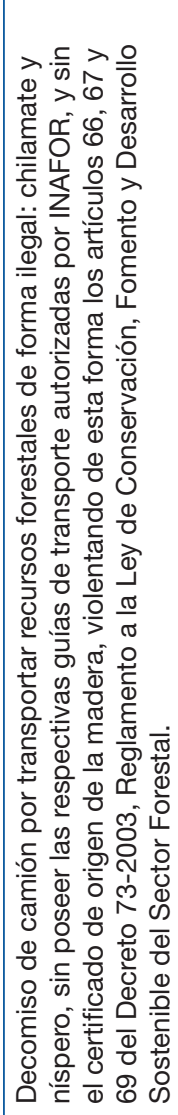 & 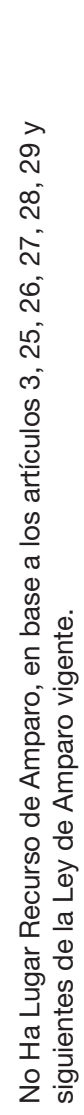 & 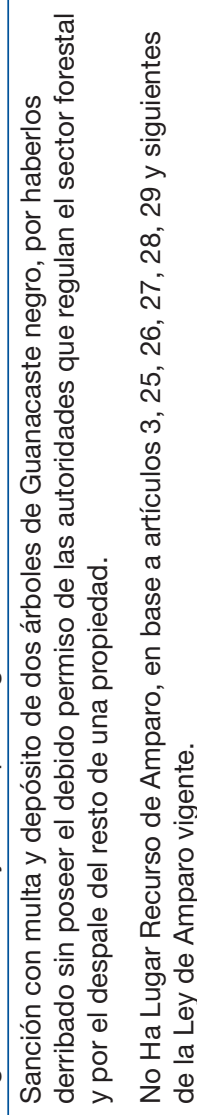 \\
\hline 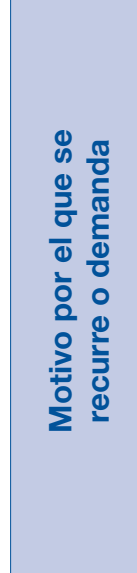 & 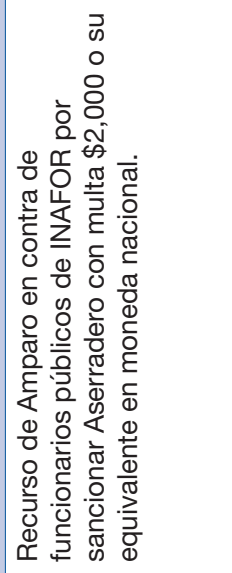 & 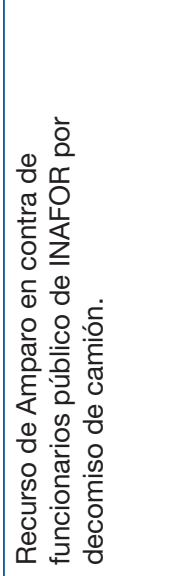 & & 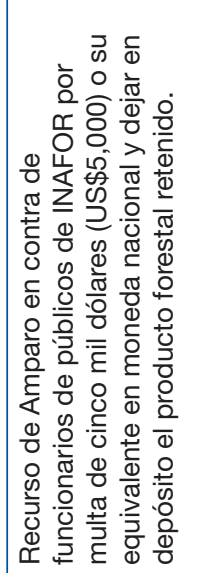 \\
\hline 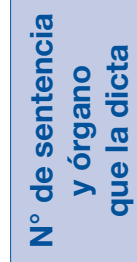 & 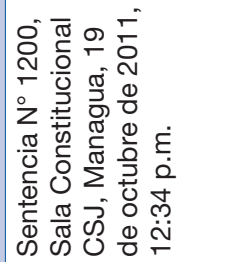 & 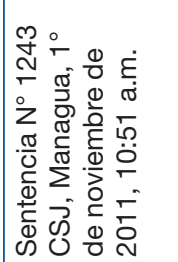 & & 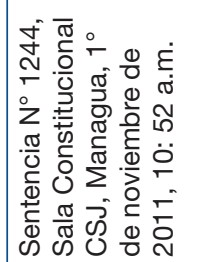 \\
\hline
\end{tabular}




\begin{tabular}{|c|c|}
\hline 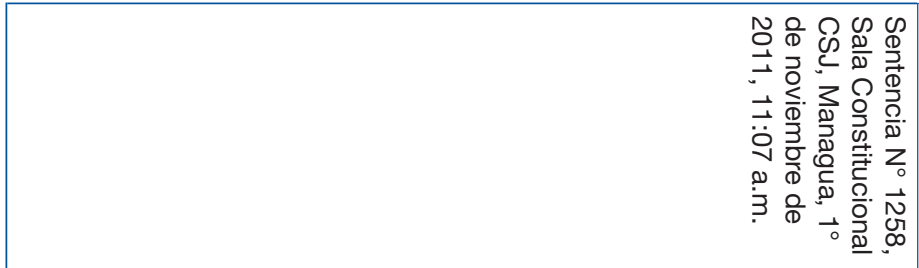 & 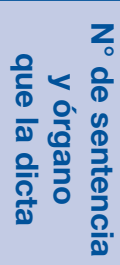 \\
\hline 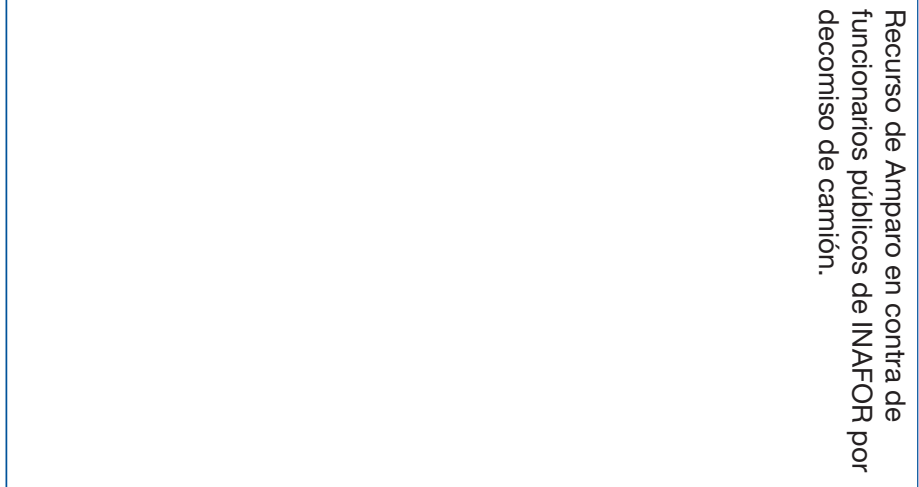 & 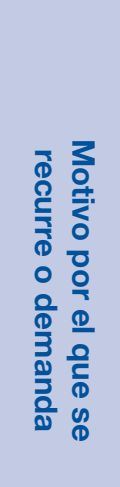 \\
\hline 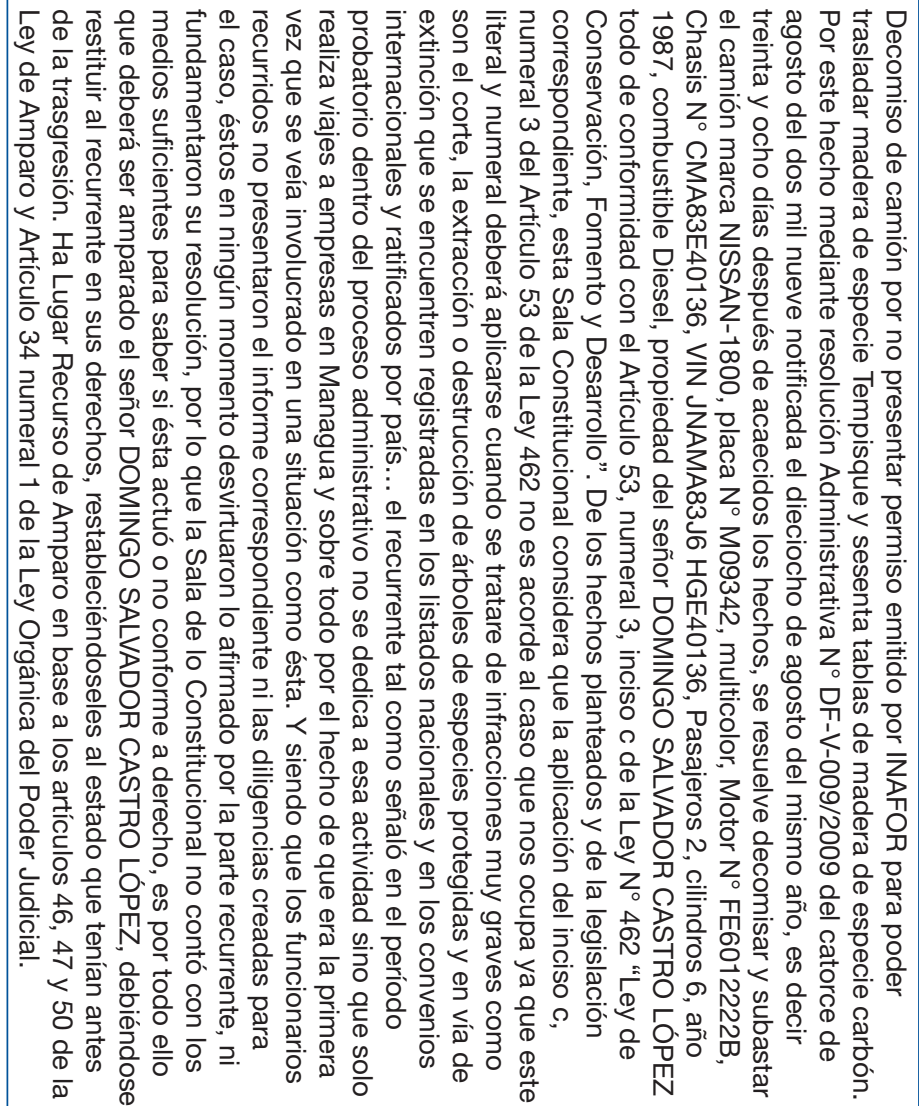 & 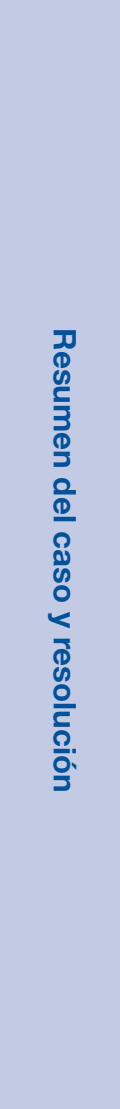 \\
\hline
\end{tabular}




\begin{tabular}{|c|c|c|}
\hline 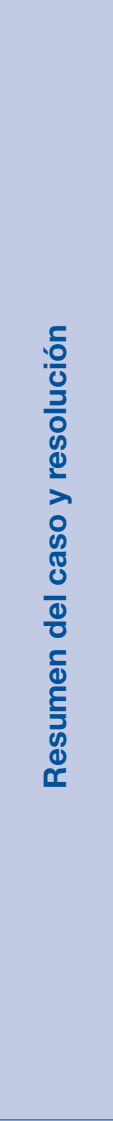 & 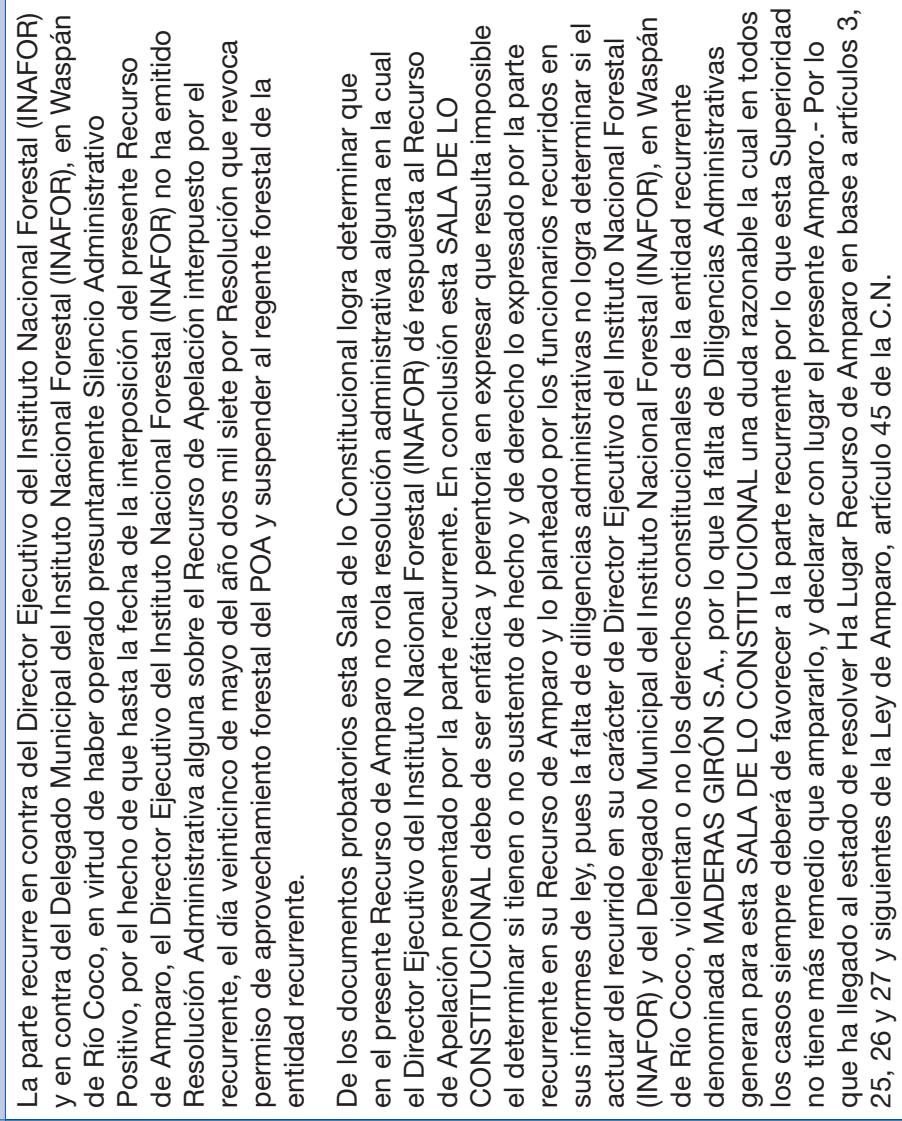 & 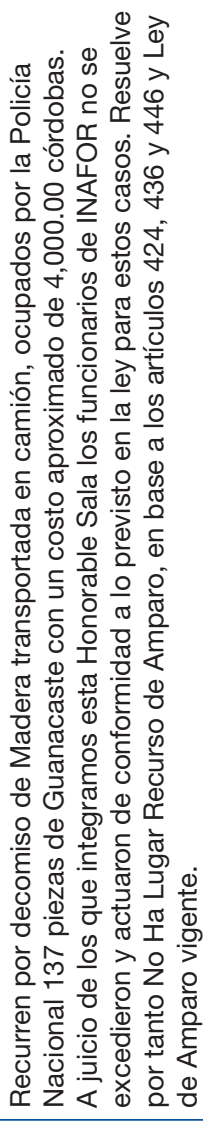 \\
\hline 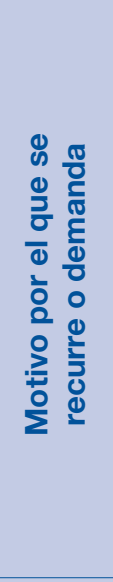 & 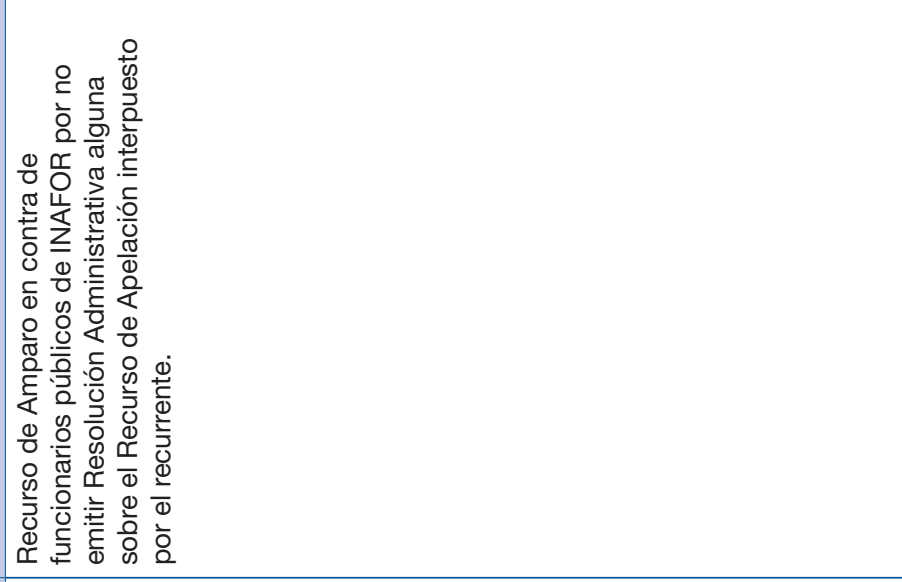 & 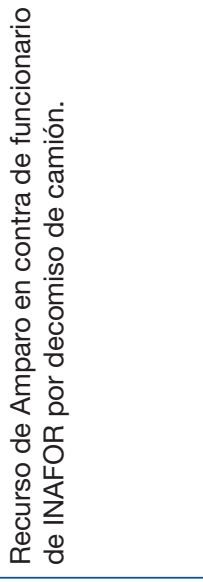 \\
\hline 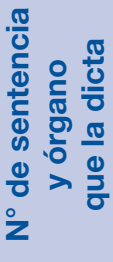 & 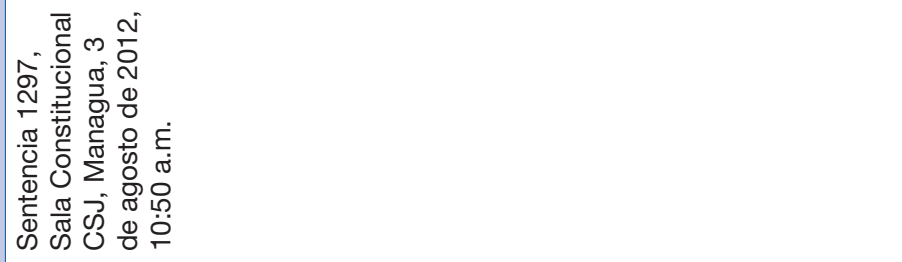 & 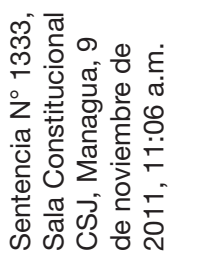 \\
\hline
\end{tabular}




\begin{tabular}{|c|c|}
\hline 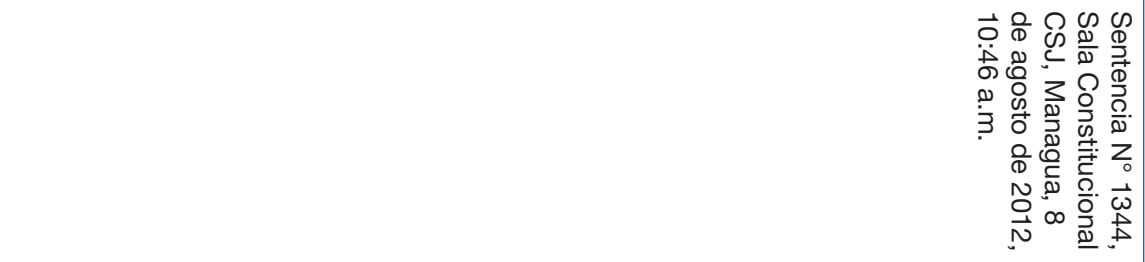 & 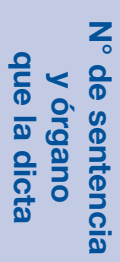 \\
\hline 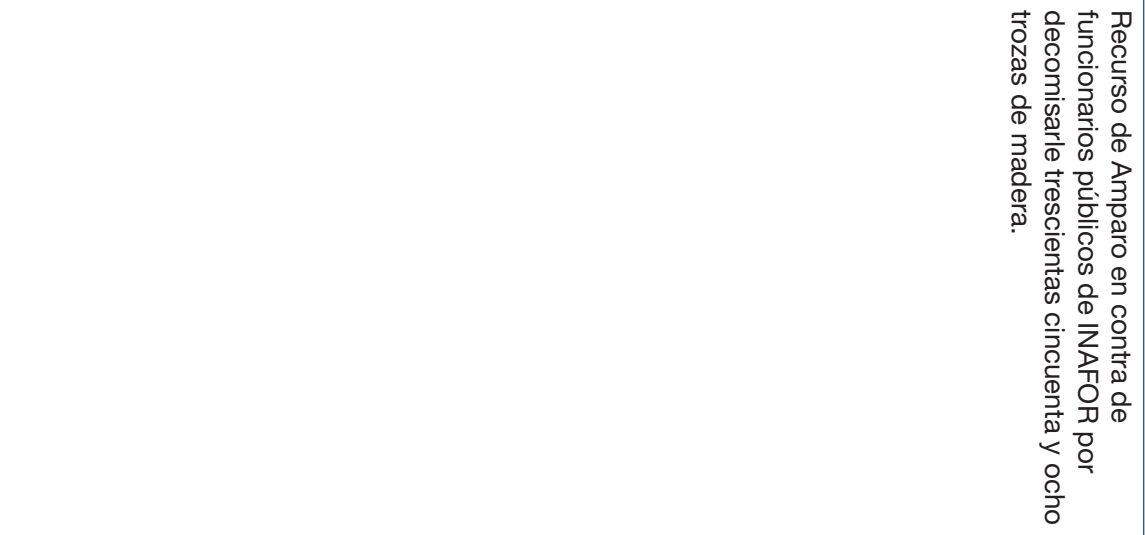 & 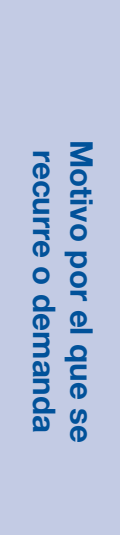 \\
\hline 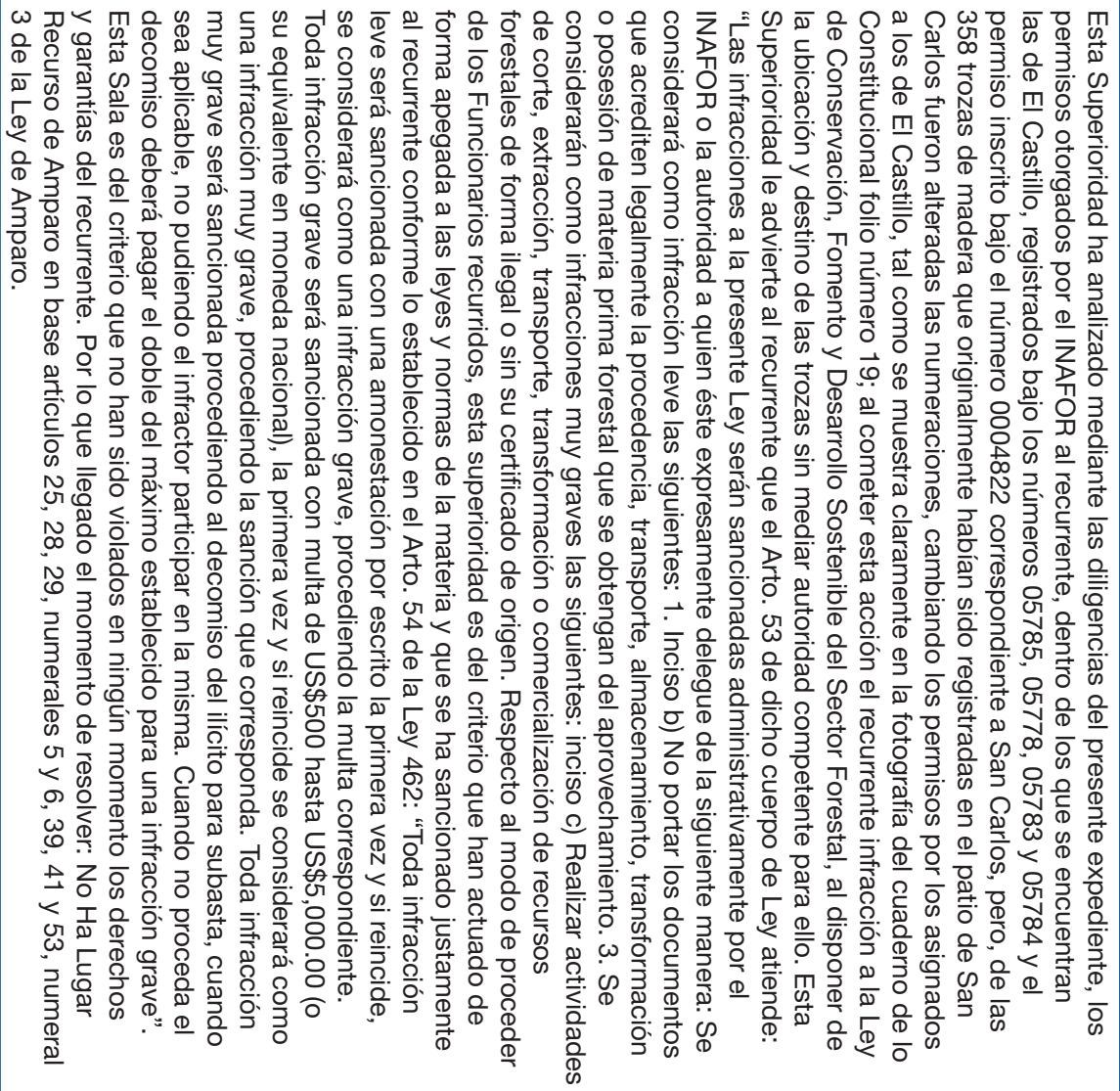 & 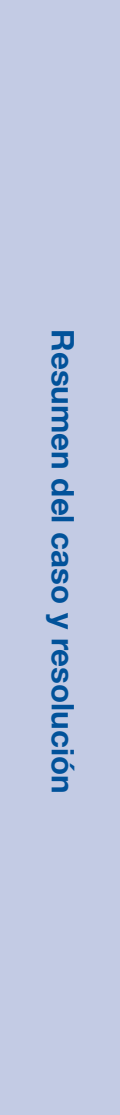 \\
\hline
\end{tabular}




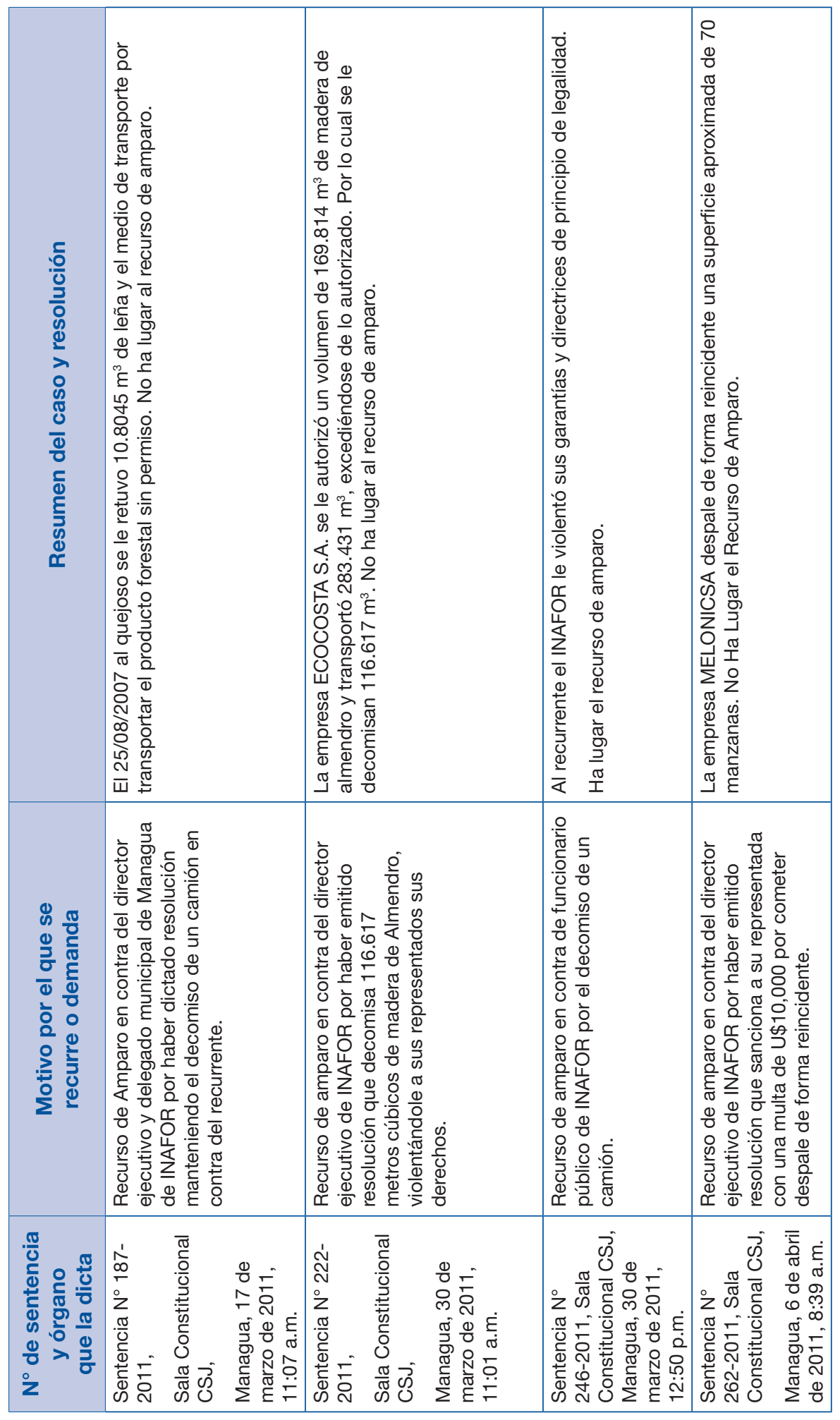




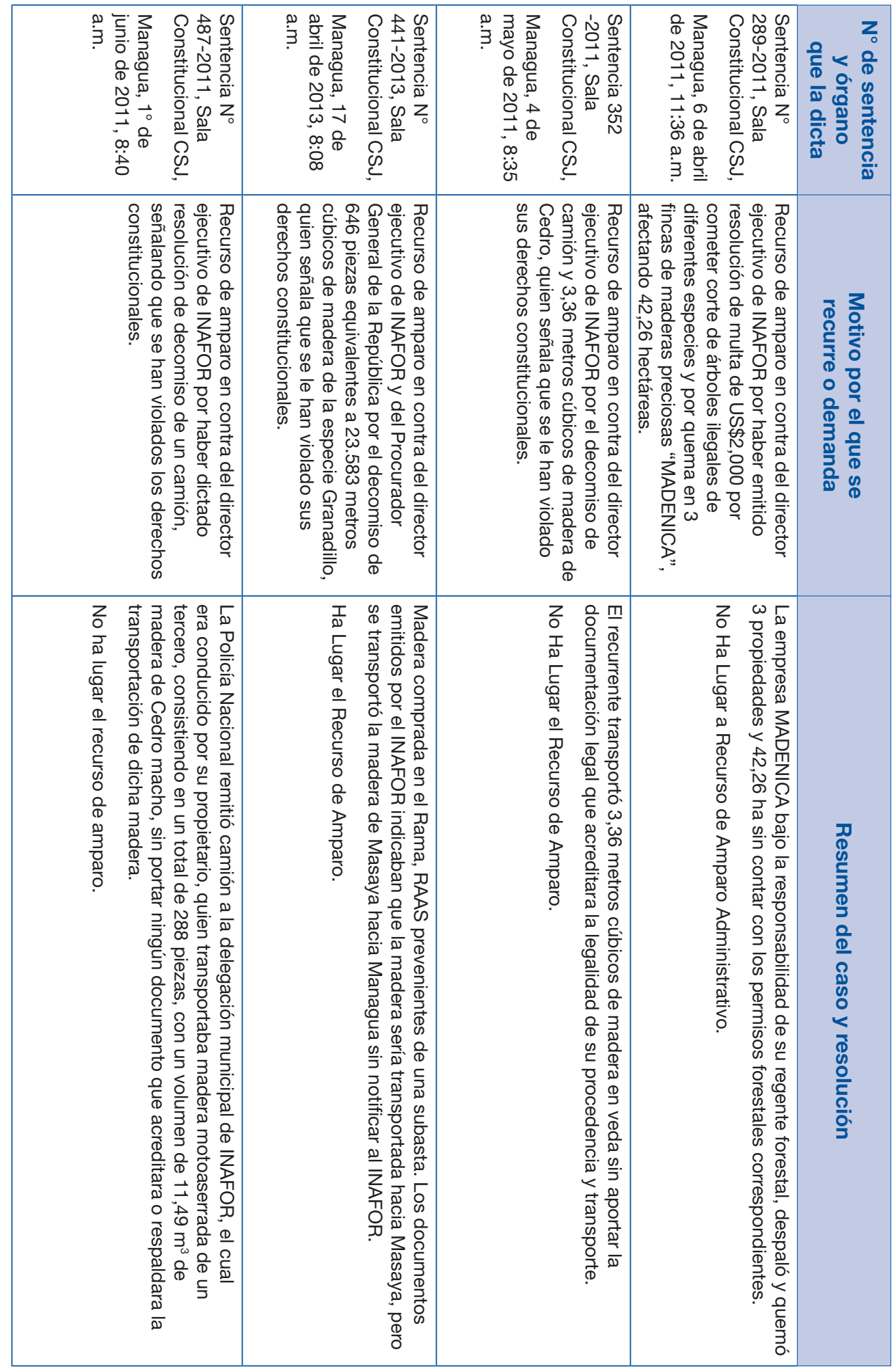




\begin{tabular}{|c|c|c|c|}
\hline 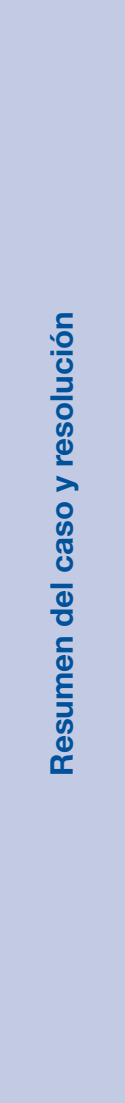 & 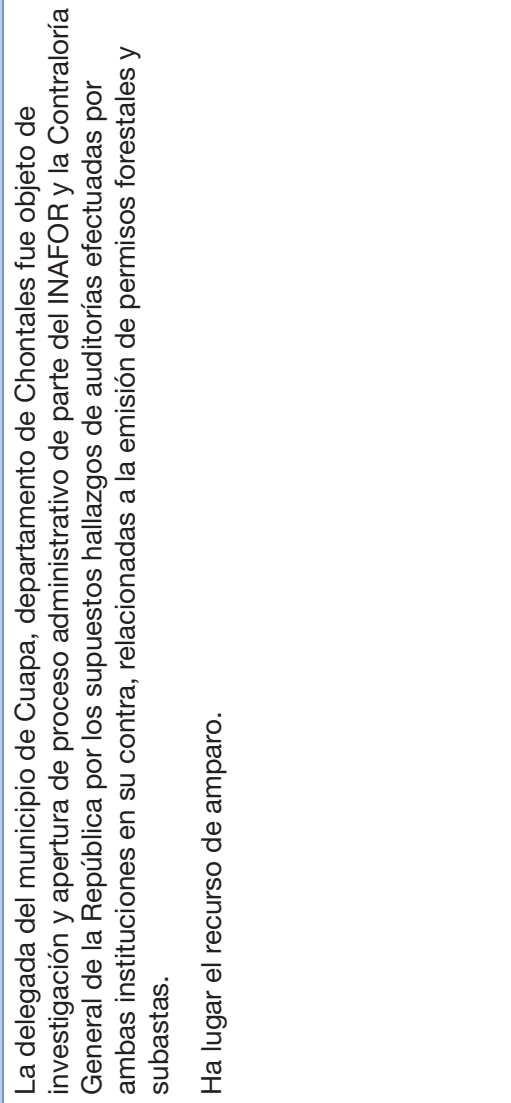 & 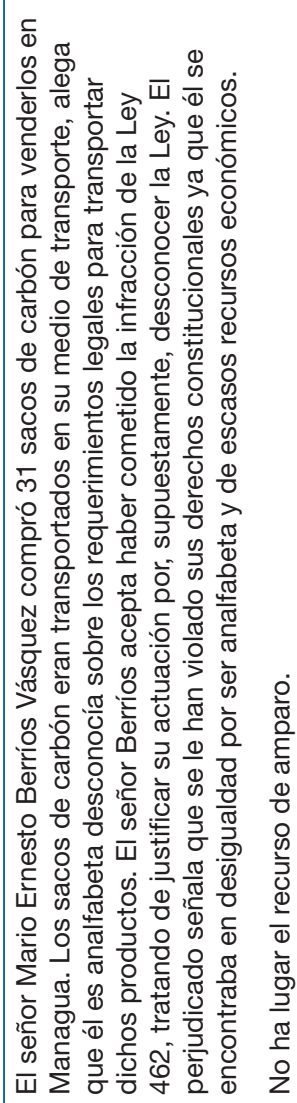 & 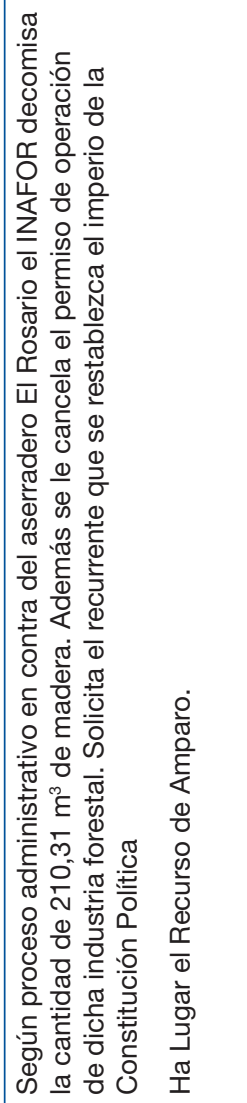 \\
\hline 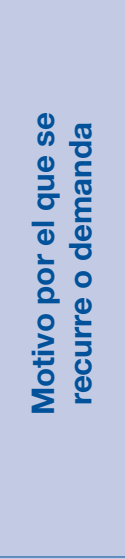 & 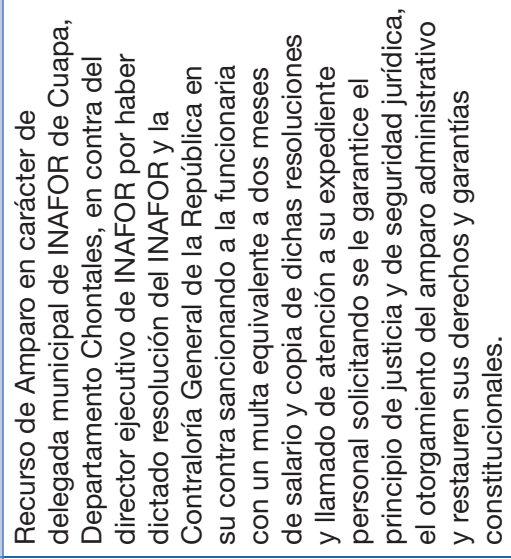 & 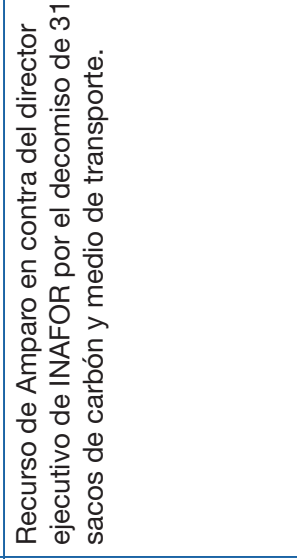 & 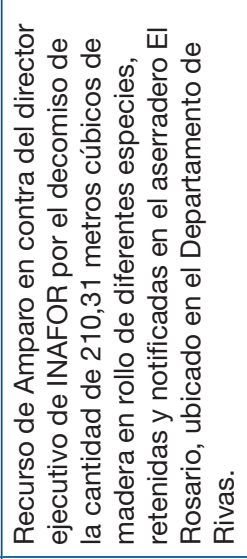 \\
\hline 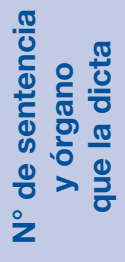 & 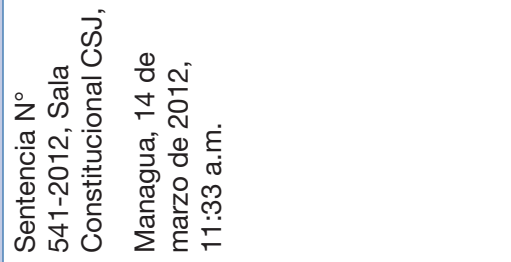 & 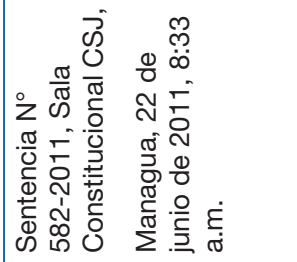 & 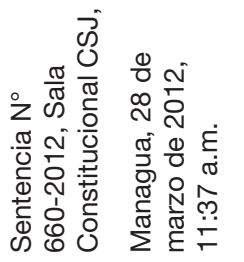 \\
\hline
\end{tabular}




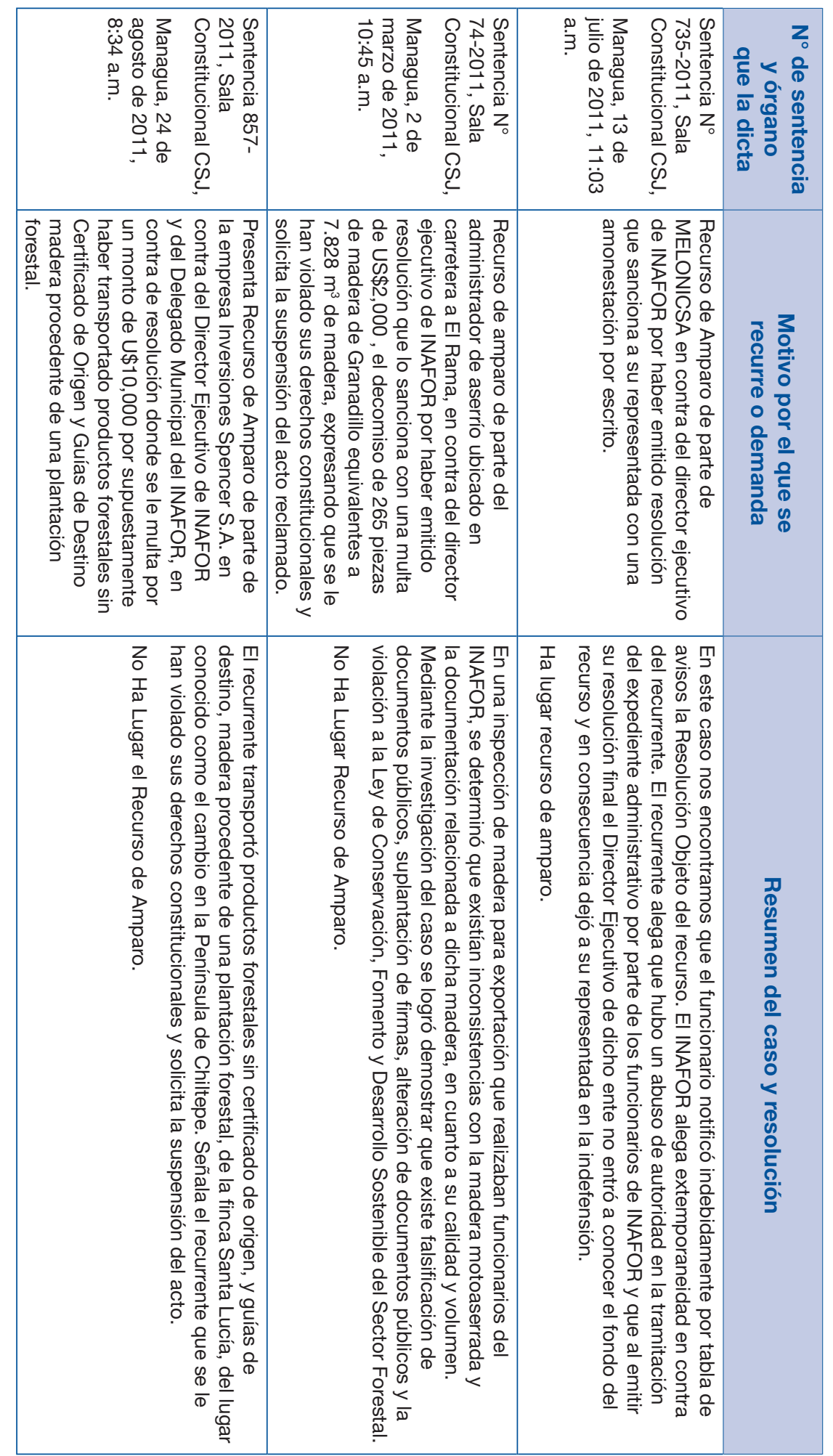




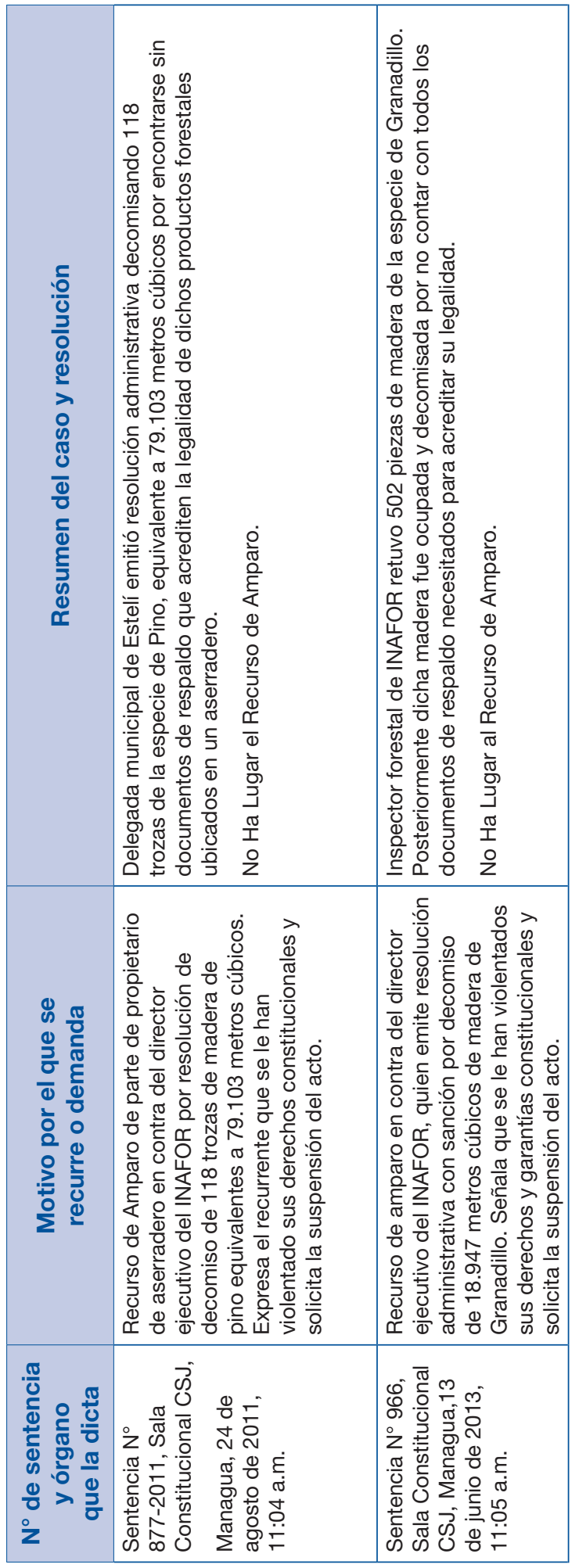




\section{Anexos Costa Rica}

\section{Requisitos legales para los permisos de aprovechamiento forestal y comercio internacional de productos forestales}

\begin{tabular}{|c|c|}
\hline Nombre del trámite: & $\begin{array}{l}\text { Permiso de aprovechamiento forestal en terrenos privados no } \\
\text { agropecuarios sin bosque }\end{array}$ \\
\hline Tipo institución: & Ministerios, Municipalidades, Consejos Regionales Ambientales \\
\hline Institución: & $\begin{array}{l}\text { Ministerio del Ambiente, Energía y Telecomunicaciones (MINAET), } \\
\text { Municipalidad, Consejo Regional Ambiental }\end{array}$ \\
\hline $\begin{array}{l}\text { Licencia, autorización o permiso } \\
\text { que se obtiene en el trámite: }\end{array}$ & $\begin{array}{l}\text { Permiso de aprovechamiento de árboles en terrenos de uso no } \\
\text { agropecuario y sin bosque }\end{array}$ \\
\hline
\end{tabular}

\section{Requisitos}

\section{Fundamento Legal}

1. Los requisitos generales: 1. Solicitud expresa por la persona (as) física (s) o jurídica, interesada legitimada, por lo que debe contener la siguiente información: Ley General de Administración Pública y Artículo 285 y Reglamento Ley Forestal Artículo 85

2. Fecha y lugar. Ley General de Administración Pública y Artículo 285 y Reglamento Ley Forestal Artículo 85

3. Nombre completo del propietario(a), copropietarios (as), calidades del petente (estado civil, ocupación, domicilio exacto) y número de cédula de identidad, pasaporte o carné de residencia, según sea el caso. Ley General de Administración Pública y Artículo 285 y Reglamento Ley Forestal Artículo 85

4. Ubicación administrativa del inmueble. Ley General de Administración Pública y Artículo 285 y Reglamento Ley Forestal Artículo 85

5. Descripción clara de lo que solicita en dicho acto. Ley General de Administración Pública y Artículo 285 y Reglamento Ley Forestal Artículo 85

6. Lugar dentro del perímetro judicial (1 km del perímetro de la Oficina Subregional) para recibir notificaciones; puede incluir número de fax. Ley General de Administración Pública y Artículo 285 y Reglamento Ley Forestal Artículo 85

7. Firma. Ley General de Administración Pública y Artículo 285 y Reglamento Ley Forestal Artículo 85

8. Fotocopia de la cédula de identidad. Ley General de Administración Pública y Artículo 285 y Reglamento Ley Forestal Artículo 85

9. Certificación de personería jurídica, cuando corresponda. Ley General de Administración Pública y Artículo 285 y Reglamento Ley Forestal Artículo 85

10. Si la solicitud la realiza una tercera persona, deberá presentar un Poder Especial en el que se especifique el acto o actos a los que ha sido facultada. Ley General de Administración Pública y Artículo 285 y Reglamento Ley Forestal Artículo 85

11. Certificación literal de la Propiedad reciente (máximo 3 meses de expedida), extendida por el Registro Nacional o por Notario Público donde se indique nombre y calidades del propietario, naturaleza, localización, medida y colindantes, folio real (o citas de inscripción), derechos y especificación de los gravámenes y anotaciones de la propiedad. Ley General de Administración Pública y Artículo 285 y Reglamento Ley Forestal Artículo 85

12. Estar al día con sus obligaciones obrero-patronales ante la CCSS; corresponderá a la AFE la constatación de este requisito. Ley General de Administración Pública y Artículo 285 y Reglamento Ley Forestal Artículo 85

13. En caso de propiedades no inscritas, para demostrar la titularidad de la posesión es necesario presentar Certificación Judicial de la sentencia en firme de la información posesoria concluida, salvo en los casos de excepción que establezca la Administración Forestal del Estado. Ley General de Administración Pública y Artículo 285 y Reglamento Ley Forestal Artículo 85 
14. En caso de ser ocupante reconocido de terrenos bajo la administración del IDA u otras dependencias del Estado, la solicitud debe incluir una autorización dada por Acuerdo en firme de la Junta Directiva, u órgano de máxima jerarquía de esa entidad, en la que autorice al petente para solicitar el aprovechamiento Ley General de Administración Pública y Artículo 285 y Reglamento Ley Forestal Artículo 85

15. Copia certificada del plano catastrado, con la respectiva ubicación cartográfica para facilitar su ubicación. De no poseer plano catastrado, deberá aportar hoja cartográfica o copia de la misma, con la ubicación de la finca, la cual deberá realizar y autenticar un profesional en topografía Ley General de Administración Pública y Artículo 285 y Reglamento Ley Forestal Artículo 85

16. Si el predio de la solicitud se encuentra ubicado en terrenos de propiedad privada dentro de Áreas Silvestres Protegidas, el SINAC ha definido dentro de su Guía Ambiental diseñada para tal efecto (anexo 5.) la presentación de una declaración jurada firmada por el interesado en materia de impacto ambiental (ANEXO 5. sección a.), así mismo de tramitarse solicitudes incluidas en el punto 1. (PUA-Pp) o en el punto 2. (PUA-IF) de este Capítulo I., en donde medie la figura de un Regente Forestal, se deberá presentar una nota de compromiso en materia de impacto ambiental por parte del mismo (ANEXO 5. sección b.). Ley General de Administración Pública y Artículo 285 y Reglamento Ley Forestal Artículo 85

Observaciones: Tratándose de aprovechamiento forestal o tala de árboles en terrenos sin bosque y que por sus características no son un sistema agroforestal, el Artículo 90 del Reglamento de la Ley Forestal dispone que las personas podrán decidir si solicitan la autorización ante el Consejo Regional Ambiental o en la Municipalidad donde se encuentre el inmueble, siempre y cuando no superen un total de veinte árboles por año.

Para aquellos casos donde el número de árboles a aprovechar sea superior a veinte árboles, en áreas arboladas excluidas de la definición de bosques, deberá ser tramitado en la Oficina Subregional del A.C. correspondiente, debiendo adicionar a los requisitos generales establecidos en este reglamento un inventario que deberá contener número de especies a cortar, número de individuos a cortar y volumen a extraer. Dicho inventario deberá ser elaborado y firmado por un profesional en ciencias forestales, además se debe elaborar un croquis de la finca indicando la ubicación aproximada de los árboles a cortar. La solicitud deberá contener una constancia del profesional en la cual establezca que el área no corresponde a un bosque o parte de un bosque según la definición de la Ley, y cumplir con los requisitos establecidos en el Artículo 85 del Reglamento Ley Forestal. Recibida la solicitud por la Oficina Subregional del A.C. correspondiente, esta verificará los requisitos y entregará el permiso correspondiente sin requerir de inspección previa. (Artículo 91 Reglamento Ley Forestal)

\begin{tabular}{l|l} 
Plazo de resolución: & En un plazo de 10 días los Consejos Regionales Ambientales deben
\end{tabular} resolver y extender los permisos de corta y transporte. Los Consejos Regionales Ambientales y las municipalidades están obligados a remitir copia de la documentación a la Administración Forestal del Estado (Artículo 90 Reglamento Ley Forestal).

Costo del trámite:

No tiene costo

\section{SOLICITUDES EN TERRENOS DE USO AGROPECUARIO Y SIN BOSQUE QUE NO EXCEDAN LOS TRES ÁRBOLES POR HECTÁREA, HASTA UN MÁXIMO DE 10 ÁRBOLES POR INMUEBLE POR AÑO (PUA-PP)}

\begin{tabular}{|l|l|}
\hline Nombre del trámite: & $\begin{array}{l}\text { Solicitudes en terrenos de uso agropecuario y sin bosque que no excedan } \\
\text { los tres árboles por hectárea, hasta un máximo de 10 árboles por inmueble } \\
\text { por año (PUA-Pp). }\end{array}$ \\
\hline Tipo institución: & Ministerios, Consejos Regionales Ambientales \\
\hline Institución: & Ministerio del Ambiente, Energía y Telecomunicaciones (MINAET) \\
\hline Dependencia: & $\begin{array}{l}\text { Consejo Regional Ambiental (CRA), Sistema Nacional de Áreas de } \\
\text { Conservación (SINAC) }\end{array}$ \\
\hline $\begin{array}{l}\text { Dirección de la dependencia, } \\
\text { sus sucursales y horarios: }\end{array}$ & $\begin{array}{l}\text { Áreas de Conservación, Oficinas Subregionales del SINAC en todo el país, } \\
\text { con horario de } 8 \text { a.m. a 4 p.m. }\end{array}$ \\
\hline $\begin{array}{l}\text { Licencia, autorización o } \\
\text { permiso que se obtiene en el } \\
\text { trámite: }\end{array}$ & $\begin{array}{l}\text { Permiso de aprovechamiento de árboles en terrenos de uso agropecuario } \\
\text { y sin bosque que no superen los 3 árboles maderables por hectárea, hasta } \\
\text { un máximo de 10 árboles por inmueble por año. }\end{array}$ \\
\hline
\end{tabular}




\section{Requisitos}

\section{Fundamento Legal}

1. 1. Solicitud expresa por la persona (as) física (s) o jurídica, interesada legitimada, por lo que debe contener la siguiente información: Ley General de Administración Pública y Artículo 285 y Reglamento Ley Forestal Artículo 85

2. a. Fecha y lugar. Ley General de Administración Pública y Artículo 285 y Reglamento Ley Forestal Artículo 85

3. b. Nombre completo del propietario(a), copropietarios (as), calidades del petente (estado civil, ocupación, domicilio exacto) y número de cédula de identidad, pasaporte o carné de residencia, según sea el caso. Ley General de Administración Pública y Artículo 285 y Reglamento Ley Forestal Artículo 85

4. c. Ubicación administrativa del inmueble. Ley General de Administración Pública y Artículo 285 y Reglamento Ley Forestal Artículo 85

5. d. Descripción clara de lo que solicita en dicho acto. Ley General de Administración Pública y Artículo 285 y Reglamento Ley Forestal Artículo 85

6. e. Lugar dentro del perímetro judicial ( $1 \mathrm{~km}$ del perímetro de la Oficina Subregional) para recibir notificaciones; puede incluir número de fax. Ley General de Administración Pública y Artículo 285 y Reglamento Ley Forestal Artículo 85

7. f. Firma. Ley General de Administración Pública y Artículo 285 y Reglamento Ley Forestal Artículo 85

8. 2. Fotocopia de la cédula de identidad. Ley General de Administración Pública y Artículo 285 y Reglamento Ley Forestal Artículo 85

9. 3. Certificación de personería jurídica, cuando corresponda. Ley General de Administración Pública y Artículo 285 y Reglamento Ley Forestal Artículo 85

10. 4. Si la solicitud la realiza una tercera persona, deberá presentar un Poder Especial en el que se especifique el acto o actos a los que ha sido facultada. Ley General de Administración Pública y Artículo 285 y Reglamento Ley Forestal Artículo 85

11. 5. Certificación literal de la Propiedad reciente (máximo 3 meses de expedida), extendida por el Registro Nacional o por Notario Público donde se indique nombre y calidades del propietario, naturaleza, localización, medida y colindantes, folio real (o citas de inscripción), derechos y especificación de los gravámenes y anotaciones de la propiedad. Ley General de Administración Pública y Artículo 285 y Reglamento Ley Forestal Artículo 85

12. 6. Estar al día con sus obligaciones obrero-patronales ante la CCSS; corresponderá a la AFE la constatación de este requisito. Ley General de Administración Pública y Artículo 285 y Reglamento Ley Forestal Artículo 85

13. 7. En caso de propiedades no inscritas, para demostrar la titularidad de la posesión es necesario presentar Certificación Judicial de la sentencia en firme de la información posesoria concluida, salvo en los casos de excepción que establezca la Administración Forestal del Estado. Ley General de Administración Pública y Artículo 285 y Reglamento Ley Forestal Artículo 85

14. 8. En caso de ser ocupante reconocido de terrenos bajo la administración del IDA u otras dependencias del Estado, la solicitud debe incluir una autorización dada por Acuerdo en firme de la Junta Directiva, u órgano de máxima jerarquía de esa entidad, en la que autorice al petente para solicitar el aprovechamiento. Ley General de Administración Pública y Artículo 285 y Reglamento Ley Forestal Artículo 85

15. 9. Copia certificada del plano catastrado, con la respectiva ubicación cartográfica para facilitar su ubicación. De no poseer plano catastrado, deberá aportar hoja cartográfica o copia de la misma, con la ubicación de la finca, la cual deberá realizar y autenticar un profesional en topografía. Para el caso de las solicitudes incluidas en el punto 1. del Capítulo I. (PUA-Pp), el administrado tendrá la posibilidad de presentar el plano catastrado original acompañado de una copia del mismo, con lo cual el funcionario que recibe los documentos, confrontará la copia del plano con el original y así lo hará constar en la misma. Ley General de Administración Pública y Artículo 285 y Reglamento Ley Forestal Artículo 85 
16. 10. Si el predio de la solicitud se encuentra ubicado en terrenos de propiedad privada dentro de Áreas Silvestres Protegidas, el SINAC ha definido dentro de su Guía Ambiental diseñada para tal efecto (ANEXO 5.) la presentación de una declaración jurada firmada por el interesado en materia de impacto ambiental (ANEXO 5. sección a.), así mismo de tramitarse solicitudes incluidas en el punto 1. (PUA-Pp) o en el punto 2. (PUA-IF) de este Capítulo I., en donde medie la figura de un Regente Forestal, se deberá presentar un nota de compromiso en materia de impacto ambiental por parte del mismo (ANEXO 5. sección b.). Ley General de Administración Pública y Artículo 285 y Reglamento Ley Forestal Artículo 85

Observaciones: Solo podrán cortarse hasta un máximo de tres árboles por hectárea anualmente en terrenos de uso agropecuario y sin bosque, después de obtener la autorización del Consejo Regional Ambiental. Si la corta sobrepasare los diez árboles por inmueble se requiere autorización de la Administración Forestal del Estado por medio del SINAC (Artículo 27 Ley Forestal)

\begin{tabular}{|l|l|}
\hline Plazo de resolución: & 30 días naturales (Artículo 86 Reglamento Ley Forestal) \\
\hline Costo del trámite: & No tiene costo \\
\hline
\end{tabular}

\section{CERTIFICADOS DE ORIGEN (CO) EN PLANTACIONES FORESTALES (CO-PF), SISTEMAS AGROFORESTALES (CO-SAF), ÁRBOLES PLANTADOS INDIVIDUALMENTE}

\begin{tabular}{|c|c|}
\hline Nombre del trámite: & $\begin{array}{l}\text { Certificados de Origen (CO) en plantaciones forestales (CO-PF), sistemas } \\
\text { agroforestales (CO-SAF), árboles plantados individualmente }\end{array}$ \\
\hline Tipo institución: & Ministerios \\
\hline Institución: & Ministerio del Ambiente, Energía y Telecomunicaciones (MINAET) \\
\hline Dependencia: & Sistema Nacional de Áreas de Conservación (SINAC) \\
\hline $\begin{array}{l}\text { Dirección de la dependencia, } \\
\text { sus sucursales y horarios: }\end{array}$ & $\begin{array}{l}\text { Oficinas Subregionales del SINAC en todo el país y CIAgro, con horario de } \\
8 \text { a.m. a } 4 \text { p.m. }\end{array}$ \\
\hline $\begin{array}{l}\text { Licencia, autorización o } \\
\text { permiso que se obtiene en el } \\
\text { trámite: }\end{array}$ & Certificado de Origen \\
\hline \multicolumn{2}{|r|}{ Requisitos } \\
\hline \multicolumn{2}{|r|}{ Fundamento Legal } \\
\hline \multicolumn{2}{|c|}{ 1. Formulario de Regencia Forestal $\mathrm{N}^{\circ}$ de Ley Forestal 7575 y Artículo 33} \\
\hline \multicolumn{2}{|c|}{ 2. Certificado de Origen correspondiente } \\
\hline Plazo de resolución: & 30 días naturales (Artículo 86 Reglamento Ley Forestal) \\
\hline Costo del trámite: & No tiene costo \\
\hline
\end{tabular}

\section{INTERVENCIÓN O APROVECHAMIENTO DE BOSQUE CONFORME AL ARTÍCULO 19 DE LEY FORESTAL}

\begin{tabular}{|l|l|}
\hline Nombre del trámite: & $\begin{array}{l}\text { Solicitud de intervención o aprovechamiento de bosque conforme al } \\
\text { Artículo 19 Ley Forestal }\end{array}$ \\
\hline Tipo institución: & Ministerios \\
\hline Institución: & Ministerio del Ambiente, Energía y Telecomunicaciones (MINAET) \\
\hline Dependencia: & Sistema Nacional de Áreas de Conservación (SINAC) \\
\hline $\begin{array}{l}\text { Dirección de la dependencia, } \\
\text { sus sucursales y horarios: }\end{array}$ & $\begin{array}{l}\text { Oficinas Subregionales del SINAC en todo el país y CIAgro, con horario de } \\
8 \text { a.m. a 4 p.m. }\end{array}$ \\
\hline $\begin{array}{l}\text { Licencia, autorización o } \\
\text { permiso que se obtiene en el } \\
\text { trámite: }\end{array}$ & $\begin{array}{l}\text { Permiso de intervención y/o aprovechamiento bosque conforme al Artículo } \\
19 \text { Ley Forestal }\end{array}$ \\
\hline
\end{tabular}




\section{Requisitos}

\section{Fundamento Legal}

1. Copia certificada del título de propiedad, personería jurídica o cédula de identidad en caso de que sea una persona física, y plano catastrado. La certificación de personería jurídica no tendrá un plazo superior a tres meses de expedida y la cédula de identidad deberá estar vigente y en buen estado.

Ley General de Administración Pública y Artículo 285 y Reglamento Ley Forestal Artículos 36 y 85

2. Mapa donde se delimite el área que se desea intervenir o aprovechar y el porcentaje que representa sobre la totalidad del inmueble. Ley General de Administración Pública y Artículo 285 y Reglamento Ley Forestal Artículos 36 y 85

3. Para efectos de determinar si es factible el otorgamiento del permiso de aprovechamiento los interesados deberán presentar la respectiva viabilidad ambiental debidamente aprobada por la SETENA. Ley General de Administración Pública y Artículo 285 y Reglamento Ley Forestal Artículos 36 y 85

4. Inventario forestal del área efectiva sujeta a la intervención o aprovechamiento, que incluya los árboles a intervenir o aprovechar, con diámetros iguales o superiores a los $15 \mathrm{~cm}$, medidos a $1,30 \mathrm{~m}$ del suelo (DAP), elaborado por un profesional en ciencias forestales debidamente incorporado al Colegio de Ingenieros Agrónomos.

Ley General de Administración Pública y Artículo 285 y Reglamento Ley Forestal Artículos 36 y 85

Observaciones: El permiso de intervención o aprovechamiento no podrá ser mayor del diez por ciento del área de bosque que posee el inmueble e incluye toda la infraestructura del proyecto, tales como caminos, senderos, miradores, edificaciones y similares. No se otorgarán permisos de intervención o aprovechamiento del bosque a los propietarios de las fincas que poseen bosque que hayan infringido el artículo 19 de la Ley Forestal; para tales casos la Administración Forestal del Estado (AFE) deberá constatar que exista sentencia judicial en firme, en la cual se determine la responsabilidad del solicitante o interesado. La simple interposición de la demanda o de la denuncia no será justa causa para suspender o paralizar el trámite de solicitud del permiso de intervención o aprovechamiento del bosque; sin embargo, si durante el trámite de la solicitud o aun después del otorgado el permiso, se demuestra que el solicitante fue declarado responsable de la infracción, tendrá la A.F.E. la facultad y obligación de rescindir de forma inmediata y con justa causa el permiso otorgado con todos sus alcances.

\begin{tabular}{|l|l|} 
Plazo de resolución: & $\begin{array}{l}\text { En un plazo no mayor de } 90 \text { días naturales, la Administración Forestal } \\
\text { del Estado (A.F.E.) deberá incluir en un Sistema de Registro de permisos } \\
\text { especiales la totalidad del área de bosque de la finca donde se desarrolla } \\
\text { el proyecto, a fin de llevar un estricto control y fiscalización de dichas } \\
\text { autorizaciones (Artículo 36 Reglamento Ley Forestal). }\end{array}$ \\
\hline Costo del trámite: & No tiene costo \\
\hline
\end{tabular}

\section{APROVECHAMIENTO FORESTAL EN BOSQUE PRIVADO}

\begin{tabular}{|l|l|}
\hline Nombre del trámite: & Solicitudes de aprovechamiento forestal en bosque privado \\
\hline Tipo institución: & Ministerios \\
\hline Institución: & Ministerio del Ambiente, Energía y Telecomunicaciones (MINAET) \\
\hline Dependencia: & Sistema Nacional de Áreas de Conservación (SINAC) \\
\hline $\begin{array}{l}\text { Dirección de la dependencia, } \\
\text { sus sucursales y horarios: }\end{array}$ & $\begin{array}{l}\text { Oficinas Subregionales del SINAC en todo el país y CIAgro, con horario de } \\
8 \text { a.m. a 4 p.m. }\end{array}$ \\
\hline $\begin{array}{l}\text { Licencia, autorización o } \\
\text { permiso que se obtiene en el } \\
\text { trámite: }\end{array}$ & Permiso de aprovechamiento de árboles en bosque privados \\
\hline
\end{tabular}




\section{Requisitos}

\section{Fundamento Legal}

1. Solicitud expresa por la persona (as) física (s) o jurídica, interesada legitimada, por lo que debe contener la siguiente información: Ley General de Administración Pública y Artículo 285 y Reglamento Ley Forestal Artículo 85

2. a. Fecha y lugar.

Ley General de Administración Pública y Artículo 285 y Reglamento Ley Forestal Artículo 85

3. Para efectos de determinar si es factible el otorgamiento del permiso de aprovechamiento los interesados deberán presentar la respectiva viabilidad ambiental debidamente aprobada por la SETENA. Ley General de Administración Pública y Artículo 285 y Reglamento Ley Forestal Artículos 36 y 85

3. Ib. Nombre completo del propietario(a), copropietarios (as), calidades del petente (estado civil, ocupación, domicilio exacto) y número de cédula de identidad, pasaporte o carné de residencia, según sea el caso. Ley General de Administración Pública y Artículo 285 y Reglamento Ley Forestal Artículo 85

3. Ib. Nombre completo del propietario(a), copropietarios (as), calidades del petente (estado civil, ocupación, domicilio exacto) y número de cédula de identidad, pasaporte o carné de residencia, según sea el caso. Ley General de Administración Pública y Artículo 285 y Reglamento Ley Forestal Artículo 85

4. c. Ubicación administrativa del inmueble. Ley General de Administración Pública y Artículo 285 y Reglamento Ley Forestal Artículo 85

5. d. Descripción clara de lo que solicita en dicho acto. Ley General de Administración Pública y Artículo 285 y Reglamento Ley Forestal Artículo 85

6. e. Lugar dentro del perímetro judicial ( $1 \mathrm{~km}$ del perímetro de la Oficina Subregional) para recibir notificaciones; puede incluir número de fax.

Ley General de Administración Pública y Artículo 285 y Reglamento Ley Forestal Artículo 85

7. f. Firma. Ley General de Administración Pública y Artículo 285 y Reglamento Ley Forestal Artículo 85

8. 2. Fotocopia de la cédula de identidad. Ley General de Administración Pública y Artículo 285 y Reglamento Ley Forestal Artículo 85

9. 3. Certificación de personería jurídica, cuando corresponda. Ley General de Administración Pública y Artículo 285 y Reglamento Ley Forestal Artículo 85

10. 4. Si la solicitud la realiza una tercera persona, deberá presentar un Poder Especial en el que se especifique el acto o actos a los que ha sido facultada. Contrato de regencia y Declaración Jurada del solicitante, del propietario y del regente forestal que garantice el cumplimiento de la legislación que regula la actividad forestal.

Ley General de Administración Pública y Artículo 285 y Reglamento Ley Forestal Artículo 85

11 5. Plan de manejo y regencia forestal. Ley Forestal Artículos 20 y 21

11. 6. Certificación literal de la Propiedad reciente (máximo 3 meses de expedida), extendida por el Registro Nacional o por Notario Público donde se indique nombre y calidades del propietario, naturaleza, localización, medida y colindantes, folio real (o citas de inscripción), derechos y especificación de los gravámenes y anotaciones de la propiedad. Ley General de Administración Pública y Artículo 285 y Reglamento Ley Forestal Artículo 85

12. 7. Estar al día con sus obligaciones obrero-patronales ante la CCSS; corresponderá a la AFE la constatación de este requisito. Ley General de Administración Pública y Artículo 285 y Reglamento Ley Forestal Artículo 85

13. 8. En caso de propiedades no inscritas, para demostrar la titularidad de la posesión es necesario presentar Certificación Judicial de la sentencia en firme de la información posesoria concluida, salvo en los casos de excepción que establezca la Administración Forestal del Estado. Ley General de Administración Pública y Artículo 285 y Reglamento Ley Forestal Artículo 85 
14. 9. En caso de ser ocupante reconocido de terrenos bajo la administración del IDA u otras dependencias del Estado, la solicitud debe incluir una autorización dada por Acuerdo en firme de la Junta Directiva, u órgano de máxima jerarquía de esa entidad, en la que autorice al petente para solicitar el aprovechamiento. Copia certificada del plano catastrado. Debe contener coordenadas para facilitar su ubicación. Copia certificada de hoja cartográfica con la ubicación de la finca. Plan de manejo original y una copia.

Ley General de Administración Pública y Artículo 285 y Reglamento Ley Forestal Artículo 85

\begin{tabular}{l|l|}
\hline Plazo de resolución: & 30 días naturales (Artículo 86 Reglamento Ley Forestal) \\
\hline Costo del trámite: & No tiene costo \\
\hline
\end{tabular}

\section{INSCRIPCIÓN ANTE AFE PARA INDUSTRIALIZACIÓN DE MATERIA PRIMA PROCEDENTE DE BOSQUE, DE ÁRBOLES PROCEDENTES DE TERRENOS DE USO AGROPECUARIO NO PLANTADOS O ÁRBOLES CAÍDOS, INDUSTRIAS ESTACIONARIAS O AMBULANTES}

\begin{tabular}{|l|l|}
\hline Nombre del trámite: & $\begin{array}{l}\text { Solicitud de inscripción para industrialización de materia prima procedente } \\
\text { de bosque }\end{array}$ \\
\hline Tipo institución: & Ministerios \\
\hline Institución: & Ministerio del Ambiente, Energía y Telecomunicaciones (MINAET) \\
\hline Dependencia: & Sistema Nacional de Áreas de Conservación (SINAC) \\
\hline $\begin{array}{l}\text { Dirección de la dependencia, } \\
\text { sus sucursales y horarios: }\end{array}$ & $\begin{array}{l}\text { Áreas de Conservación, Oficinas Subregionales del SINAC en todo el país, } \\
\text { con horario de 8 a.m. a 4 p.m. }\end{array}$ \\
\hline $\begin{array}{l}\text { Licencia, autorización o } \\
\text { permiso que se obtiene en el } \\
\text { trámite: }\end{array}$ & $\begin{array}{l}\text { Inscripción ante AFE para industrialización de materia prima procedente de } \\
\text { bosque, de árboles en terrenos de uso no agropecuario no plantados, de } \\
\text { árboles caídos, industrias estacionarias o ambulantes }\end{array}$ \\
\hline
\end{tabular}

\section{Requisitos}

\section{Fundamento Legal}

1. 11. Solicitud expresa por la persona (as) física (s) o jurídica, interesada legitimada, por lo que debe contener la siguiente información: Ley General de Administración Pública y Artículo 285 y Reglamento Ley Forestal Artículos 72 y 85

2. Calidades del Petente (persona física) Ley General de Administración Pública y Artículo 285 y Reglamento Ley Forestal Artículos 72 y 85

3. Ubicación exacta, caserío, distrito, cantón, provincia y otras señas de la industria. Ley General de Administración Pública y Artículo 285 y Reglamento Ley Forestal Artículos 72 y 85

4. Ubicación exacta, caserío, distrito, cantón, provincia y otras señas de la industria. Ley General de Administración Pública y Artículo 285 y Reglamento Ley Forestal Artículos 72 y 85

5. Descripción de la maquinaria principal utilizada y capacidad instalada. Ley General de Administración Pública y Artículo 285 y Reglamento Ley Forestal Artículos 72 y 85

6. Certificación de la Administración Tributaria de inscripción en el Registro de Contribuyentes. Ley General de Administración Pública y Artículo 285 y Reglamento Ley Forestal Artículos 72 y 85

\begin{tabular}{l|l|}
\hline Plazo de resolución: & $\begin{array}{l}\text { En un plazo no mayor de } 90 \text { días naturales, la Administración Forestal del } \\
\text { Estado (AFE) deberá incluir en un Sistema de Registro de permisos especiales } \\
\text { la totalidad del área de bosque de la finca donde se desarrolla el proyecto, } \\
\text { a fin de llevar un estricto control y fiscalización de dichas autorizaciones. }\end{array}$ \\
\hline Costo del trámite: & No tiene costo \\
\hline
\end{tabular}




\section{PERMISO MOVILIZACIÓN MADERA}

\begin{tabular}{|l|l|}
\hline Nombre del trámite: & Solicitud permiso de movilización madera \\
\hline Tipo institución: & Ministerios \\
\hline Institución: & $\begin{array}{l}\text { Ministerio del Ambiente, Energía y Telecomunicaciones (MINAET), Regente, } \\
\text { Municipalidad, Consejo Regional Ambiental }\end{array}$ \\
\hline Dependencia: & Sistema Nacional de Áreas de Conservación (SINAC) \\
\hline $\begin{array}{l}\text { Dirección de la dependencia, } \\
\text { sus sucursales y horarios: }\end{array}$ & $\begin{array}{l}\text { Áreas de Conservación, Oficinas Subregionales del SINAC en todo el país, } \\
\text { con horario de } 8 \text { a.m. a 4 p.m. }\end{array}$ \\
\hline $\begin{array}{l}\text { Licencia, autorización o } \\
\text { permiso que se obtiene en el } \\
\text { trámite: }\end{array}$ & Transporte y movilización madera \\
\hline
\end{tabular}

\section{Requisitos}

\section{Fundamento Legal}

1. Certificado de origen expedido por Regente Forestal o Consejo Regional Ambiental Decreto Ejecutivo 30494-MINAE-SP-MOPT

Resolución N R-SINAC-DG-010-2000 directrices para la entrega y empleo de guías y placas plásticas para el transporte de madera

2. Entregar copia a la AFE previo a la movilización madera Decreto Ejecutivo 30494-MINAE-SP-MOPT Resolución N R-SINAC-DG-010-2000 directrices para la entrega y empleo de guías y placas plásticas para el transporte de madera

Observaciones: Los requisitos para el transporte de madera se establecen en el Decreto Ejecutivo 30949-MINAE-SP-MOPT. El transporte de madera en troza y en block escuadrada y aserrada solo es posible de lunes a viernes de las 5 a.m. a las 9 p.m. y los sábados de 5 a.m. a 5 p.m. Se exceptúa a las plantaciones y depósitos de madera. Queda prohibido el transporte fuera del horario mencionado.

Transporte de productos forestales provenientes de plantaciones forestales o sistemas agroforestales (Entrega Guías y placas) requiere:

- Certificarse la existencia de la plantación forestal o sistema agroforestal en la finca determinada

El área plantada, número de árboles y las especies

Ubicación y el nombre del propietario

Las guías de transporte que emita la Administración Forestal del Estado para el transporte de madera en troza o aserrada no podrán tener una vigencia mayor de tres meses

Plazo de resolución:

\begin{tabular}{l|l} 
Costo del trámite: & No tiene costo
\end{tabular}

\section{TRÁFICO INTERNACIONAL DE MADERAS}

\begin{tabular}{|l|l|}
\hline Nombre del trámite: & $\begin{array}{l}\text { Solicitud de autorización para la importación y exportación de maderas y } \\
\text { productos forestales }\end{array}$ \\
\hline Tipo institución: & Ministerios \\
\hline Institución: & $\begin{array}{l}\text { Ministerio del Ambiente, Energía y Telecomunicaciones (MINAET) } \\
\text { Ministerio de Comercio Exterior } \\
\text { Ministerio de Hacienda }\end{array}$ \\
\hline Dependencia: & $\begin{array}{l}\text { Sistema Nacional de Áreas de Conservación (SINAC) } \\
\text { Dirección General de Aduanas }\end{array}$ \\
\hline $\begin{array}{l}\text { Dirección de la dependencia, } \\
\text { sus sucursales y horarios: }\end{array}$ & $\begin{array}{l}\text { Áreas de Conservación, Oficinas Subregionales del SINAC en todo el país, } \\
\text { con horario de } 8 \text { a.m. a 4 p.m. }\end{array}$ \\
\hline $\begin{array}{l}\text { Licencia, autorización o } \\
\text { permiso que se obtiene en el } \\
\text { trámite: }\end{array}$ & Exportación e importación de madera y productos forestales \\
\hline
\end{tabular}




\section{Requisitos}

\section{Fundamento Legal}

\section{Madera procedente de plantación}

Se encuentra exenta de los permisos de exportación del Ministerio de Ambiente y Energía (MINAE), pero debe presentar documentos que certifiquen que es proveniente de plantación, en el puerto de salida. Dicho documento debe ser emitido por el MINAE o por un Regente Forestal debidamente acreditado por el Colegio de Ingenieros Agrónomos.

Reglamento Ley Forestal 4669

2. Madera de especies no amenazadas de extinción procedente del Bosque

Solamente se autoriza su exportación siempre y cuando proceda de un Plan de Manejo de Bosque Natural previamente autorizado y certificado de origen, extendidos ambos por el MINAE; deben adjuntar copia de dichos documentos.

Reglamento Ley Forestal 4672

En el caso del Maderas en extinción, que estén incluidas en los apéndices CITES (Convención sobre el Comercio Internacional de Especies Amenazadas de Fauna y Flora Silvestre):

\section{Exportación}

Presentar original de permiso CITES en el Puerto de salida, el cual es emitido por la Autoridad Administrativa CITES o en la Ventanilla Única del Usuario en el MINAE. Cabe destacar que dicho permiso es emitido siempre y cuando sea de producto elaborado, y que la madera proceda de un plan de manejo, previamente aprobado por nuestro Ministerio.

\section{Importación}

Contar con permiso de exportación de la Autoridad Administrativa CITES del País de Origen y el permiso de Importación de la Autoridad Administrativa CITES de Costa Rica en el puerto de entrada.

Decreto Ejecutivo 27654 "Procedimiento para el trámite de permisos de importación y exportación de especies de flora y fauna silvestres"

Observaciones: La exportación de madera rolliza está prohibida en nuestro país, excepto la procedente de plantaciones, siempre y cuando no sean especies nacionales.

Las especies maderables en peligro de extinción, que se encuentran en CITES son: Caoba (Suletennia humilis), Caoba (Suletennia macrophylla), Cristóbal (Platymiscium pleiostackyum), Guayacán Real (Guaiacum sanctum), Ajo (Caryocar costarricenses). Todas estas especies requieren permiso CITES, tanto de entrada como de salida. Otras especies que requieren permiso de CITES, para el Tráfico Internacional, aunque algunas de estas no son nativas, también deben portar dichos permisos. Entre las cuales incluye a toda la familia de orquidacea y cactaceae (Cycas revoluta, Cycas circinales, todas las euforbias suculentas, Zamia Skinnerii y Zamia furfuracea).

En materia de control fitosanitario debe obtenerse la autorización NIMF-15 de conformidad con el Decreto Ejecutivo 32622 Regulación del Embalaje de Madera utilizado en el Comercio Internacional.

\begin{tabular}{|l|l|}
\hline Plazo de resolución: & 30 días naturales (Artículo 86 Reglamento Ley Forestal. \\
\hline Costo del trámite: & No tiene costo \\
\hline
\end{tabular}




\section{Anexos Panamá}

Cuadro 11. Estimación de la cobertura boscosa por tipo de bosque al año 20001

\begin{tabular}{|l|l|l|}
\hline \multicolumn{1}{|c|}{ Tipo de bosque } & \multicolumn{1}{|c|}{ Superficie (ha) } & \multicolumn{1}{c|}{ Porcentaje } \\
\hline Bosques de producción & 350.000 & 10,40 \\
Bosques de protección & 1.584 .682 & 47,10 \\
Bosques de mangle & 170.827 & 5,08 \\
Cobertura de bosque no clasificada & 1.259 .082 & 37,42 \\
\hline TOTAL & $\mathbf{3 . 3 6 4 . 5 9 1}$ & $\mathbf{1 0 0 , 0 0}$ \\
\hline
\end{tabular}

Fuente: Sistema de Información Forestal, ANAM, 2003 (tomado de la Exposición de Motivos del Proyecto de Ley Forestal versión 7.0 del 12 de mayo de 2012)

\section{Cuadro $2^{2}$. Estimaciones cronológicas del área boscosa} de Panamá (en hectáreas), 1947-1998²

\begin{tabular}{|l|l|l|l|}
\hline \multicolumn{1}{|c|}{ Año } & \multicolumn{1}{|c|}{ Superficie } & \multicolumn{1}{c|}{ Porcentaje } & \multicolumn{1}{c|}{ Fuente } \\
\hline 1947 & 5.245 .000 & 70,0 & GARVER \\
\hline 1970 & 4.081 .600 & 53,0 & FALLA 1978 \\
\hline 1974 & 3.900 .000 & 50,0 & FALLA 1978 \\
\hline 1986 & 3.664 .761 & 48,5 & SIG/ANAM 1994 \\
\hline 1992 & 3.358 .304 & 44,4 & SIG/ANAM 1995 \\
\hline $1998^{*}$ & 3.052 .304 & 40,4 & ENA/ANAM \\
\hline
\end{tabular}

Fuente: INRENARE, 1992 y 1995

* Análisis y estimaciones de ANAM, 1999, basados en la tasa de deforestación 1986-1992

1 El 40,2\% del bosque maduro (3.015.003 de hectáreas) está principalmente en las provincias de Darién y Panamá. Los manglares hacen el 5,18\% de la cobertura boscosa. Las tierras dedicadas a uso agropecuario y subsistencia comprenden una superficie de 1.874 .334 hectáreas, equivalente al $25 \%$ del territorio nacional.

2. $\quad$ ANAM (1999). Informe Ambiental de Panamá, Pág. 17. 
Cuadro 3. Evolución de la legislación forestal en la república de Panamá, participación pública

\begin{tabular}{|c|c|c|c|}
\hline & $\begin{array}{l}\text { Decreto Ley } 39 \text { de } \\
1966 \text { (derogado) }\end{array}$ & $\begin{array}{l}\text { Ley } 1 \text { de } 1994 \\
\text { (vigente) }\end{array}$ & $\begin{array}{l}\text { Proyecto de Ley } 2012 \\
\text { (consensuado actores clave } \\
\text { relevantes sector forestal) }\end{array}$ \\
\hline $\begin{array}{l}\text { Participación } \\
\text { pública }\end{array}$ & $\begin{array}{l}\text { Crea la Comisión } \\
\text { Nacional de Bosques, } \\
\text { multisectorial (a nivel de } \\
\text { gobierno) con funciones } \\
\text { meramente consultivas. } \\
\text { Integrada por entidades } \\
\text { de gobierno como } \\
\text { agricultura, comercio e } \\
\text { industrias, educación, } \\
\text { reforma agraria, } \\
\text { electricidad, agua } \\
\text { y un representante } \\
\text { de la asociación de } \\
\text { madereros (Art. 66). }\end{array}$ & $\begin{array}{l}\text { Establece la } \\
\text { obligatoriedad de } \\
\text { consultar con la } \\
\text { industria forestal } \\
\text { previo a la aprobación } \\
\text { de normas sobre } \\
\text { exportación e } \\
\text { importación de } \\
\text { productos y } \\
\text { subproductos forestales } \\
\text { (Arts. 56 y 67). } \\
\text { Establece la oposición } \\
\text { pública a las } \\
\text { concesiones forestales } \\
\text { (Arts. 29 y 30). } \\
\text { Comité Nacional } \\
\text { de Gestión Forestal } \\
\text { (Resolución 368 } \\
\text { del 2006). Foro } \\
\text { multisectorial de } \\
\text { coordinación y } \\
\text { consulta para fomentar } \\
\text { el crecimiento y la } \\
\text { inserción del sector } \\
\text { forestal en el mercado } \\
\text { internacional. } \\
\text { Conformado por } \\
\text { administrador general de } \\
\text { la ANAM, Viceministro } \\
\text { del MICl, Ministro del } \\
\text { MEF, un representante } \\
\text { de ANARAP, un } \\
\text { representante de la } \\
\text { Cámara Forestal, un } \\
\text { representante de la } \\
\text { Asociación Panameña } \\
\text { de Exportadores, un } \\
\text { representante de la } \\
\text { USAID, un representante } \\
\text { de las firmas consultoras } \\
\text { involucradas con el } \\
\text { sector forestal. } \\
\text { a }\end{array}$ & $\begin{array}{l}\text { Crea el Comité Nacional de } \\
\text { Gestión Forestal (CONAGEFOR) } \\
\text { como órgano de coordinación y } \\
\text { foro de concertación social del } \\
\text { sector forestal en los ámbitos de } \\
\text { la política y la estrategia forestal, } \\
\text { incluyendo los mecanismos de } \\
\text { incentivo y fomento (Art. 26). Estaría } \\
\text { conformado por las entidades } \\
\text { gubernamentales sectoriales } \\
\text { relacionadas con el sector forestal y } \\
\text { con un representante del Colegio de } \\
\text { Ingenieros Agrónomos, Asociación } \\
\text { de Técnicos Forestales, Asociación } \\
\text { Nacional de Reforestadores y Afines } \\
\text { de Panamá, Asociación Panameña } \\
\text { de Exportadores, Cámara Forestal } \\
\text { de Panamá, tres representantes } \\
\text { indígenas (uno por las comarcas, otro } \\
\text { por las tierras colectivas y uno por } \\
\text { las áreas indígenas), un representante } \\
\text { de las universidades estatales, un } \\
\text { representante de ONGs ambientales. } \\
\text { Propone que el Régimen Forestal } \\
\text { debe llevar a cabo la gestión y } \\
\text { administración del Patrimonio } \\
\text { Forestal Nacional con la participación } \\
\text { activa de la sociedad en todos los } \\
\text { niveles, ámbitos y procesos, con el } \\
\text { fin de equilibrar visiones, intereses y } \\
\text { expectativas diferentes en torno a los } \\
\text { bosques. La gestión de los bosques } \\
\text { naturales y sus recursos debe } \\
\text { contemplar la presencia e interacción } \\
\text { equitativa de diversas culturas, y la } \\
\text { posibilidad de generar expresiones } \\
\text { culturales compartidas, adquiridas por } \\
\text { medio del diálogo y de una actitud de } \\
\text { respeto mutuo. } \\
\text { Se garantiza la participación directa, } \\
\text { plena y efectiva de comarcas, tierras } \\
\text { colectivas y territorios indígenas en el } \\
\text { Régimen Forestal de la República, así } \\
\text { como su derecho a la consulta previa, } \\
\text { libre e informada sobre medidas que } \\
\text { afecten directamente sus derechos } \\
\text { colectivos (Art. 12). }\end{array}$ \\
\hline
\end{tabular}

Fuente: Decreto Ley 39 de 1966, Ley 1 de 1994 y propuesta nueva ley forestal versión 7.0 del 2012 


\section{Cuadro 4. Competencias en materia forestal}

\begin{tabular}{|c|c|c|c|c|c|c|c|c|}
\hline & $\sum_{\substack{\infty \\
<}}^{\pi}$ & 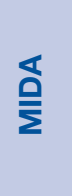 & $\overline{\bar{\Sigma}}$ & $\underset{<}{\longleftarrow}$ & $\frac{.0}{\frac{0}{0}} \frac{0}{\frac{0}{5}}$ & 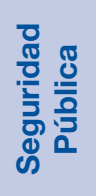 & 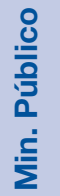 & 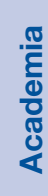 \\
\hline \multicolumn{9}{|l|}{ Competencias } \\
\hline \multicolumn{9}{|l|}{$\begin{array}{l}\text { Aprovechamiento forestal (concesiones, } \\
\text { permisos domésticos, subsistencia, } \\
\text { comunitarios, tala necesaria) }\end{array}$} \\
\hline Guía forestal transporte & 3 & & & & & & & \\
\hline $\begin{array}{l}\text { Guía forestal } \\
\text { exportación }\end{array}$ & 3 & & & & & & & \\
\hline Aprobación EsIA & 3 & & & & & & & \\
\hline Aprobación inventario forestal & 3 & & & & & & & \\
\hline Aprobación plan manejo forestal & 3 & & & & & & & \\
\hline Registro Forestal & 3 & & & & & & & \\
\hline CITES & 3 & & & & & & & \\
\hline REDD+ & 3 & & & & & & & \\
\hline Cubicación de madera & 3 & & & & & & & \\
\hline Inspección, control, fiscalización & 3 & & & & 3 & 3 & & \\
\hline $\begin{array}{l}\text { Proceso administrativo por } \\
\text { incumplimiento Ley Forestal }\end{array}$ & 3 & & & & & & & \\
\hline $\begin{array}{l}\text { Investigación delitos contra el ambiente } \\
\text { (i) }\end{array}$ & & & & & & & 3 & \\
\hline $\begin{array}{l}\text { Certificado fitosanitario para exportación } \\
\text { y NIMF-15 (ii) }\end{array}$ & & 3 & & & & & & \\
\hline Trámites exportación (ii) & & & & & 3 & & & \\
\hline $\begin{array}{l}\text { Cobro impuestos municipales por tala } \\
\text { forestal }\end{array}$ & & & 3 & 3 & & & & \\
\hline \multicolumn{9}{|c|}{$\begin{array}{l}\left({ }^{*}\right) \text { ANAM a través del Departamento de Servicio Forestal a nivel central y regional (las regionales coinciden } \\
\text { con el número de provincias y lugares que requieren la presencia de la autoridad por la complejidad en el } \\
\text { manejo de los recursos naturales que hay en el área, como Chepo y Panamá Oeste, entre otros). }\end{array}$} \\
\hline \multicolumn{9}{|c|}{$\begin{array}{l}\text { (i) El Código Penal panameño contiene normas penales parcialmente en blanco, por lo que las autoridades } \\
\text { designadas para perseguir los delitos contra el ambiente deben apoyarse en las normas que regulan la } \\
\text { materia y los criterios técnicos respaldados oficialmente por la ANAM. }\end{array}$} \\
\hline \multicolumn{9}{|c|}{$\begin{array}{l}\text { (ii) Requiere previa certificación por parte de la ANAM, licenciamiento previo como se le denomina. Incluye } \\
\text { que la ANAM certifique legalidad de la madera si la(s) especie(s) está(n) en anexos CITES para que la ANAM } \\
\text { certifique. }\end{array}$} \\
\hline
\end{tabular}

Fuente: Elaborado por Jessica Young, 2013 
Cuadro 5. Títulos de propiedad generados por provincia y período, 1999-2004 y 2004-2008

\begin{tabular}{|l|l|l|l|}
\hline \multicolumn{1}{|c|}{ Provincia } & \multicolumn{1}{c|}{$\begin{array}{c}\text { Septiembre } \\
\text { 1999-agosto 2004 }\end{array}$} & $\begin{array}{c}\text { Septiembre } \\
\text { 2004-agosto 2008 }\end{array}$ & \multicolumn{1}{c|}{ Total } \\
\hline Total & $\mathbf{3 0 . 7 3 3}$ & $\mathbf{7 1 . 6 1 6}$ & $\mathbf{1 0 2 . 3 4 9}$ \\
\hline Bocas del Toro & 225 & 176 & 401 \\
\hline Coclé & 3.040 & 9.279 & 12.319 \\
\hline Colón & 1.415 & 1.316 & 2.731 \\
\hline Chiriquí & 3.086 & 13.753 & 16.839 \\
\hline Darién & 620 & 3.208 & 3.828 \\
\hline Herrera & 3.303 & 7.222 & 10.525 \\
\hline Los Santos & 4.863 & 7.480 & 12.343 \\
\hline Panamá & 2.535 & 16.208 & 18.743 \\
\hline Veraguas & 11.46 & 12.974 & 24.620 \\
\hline
\end{tabular}

Nota: Incluye 25.039 títulos generados por DINRA desde 1999 hasta el 2008. Los Títulos del 2008 son datos preliminares. No se toman en cuenta las demarcaciones de las áreas protegidas ni los territorios indígenas.

Fuente: Programa Nacional de Administración de Tierras, 2008

Cuadro 6. Árboles con diámetros de gran magnitud, de alto valor ecológico, histórico, genético y escénico

\begin{tabular}{|l|l|l|}
\hline \multicolumn{1}{|c|}{ Nombre común } & \multicolumn{1}{c|}{ Nombre científico } & \multicolumn{1}{c|}{ Diámetro máximo de tala } \\
\hline Espavé & Anacardium excelsum & $250 \mathrm{~cm}$ \\
\hline Barrigón & Pseudobombax septunatum & $200 \mathrm{~cm}$ \\
\hline Cedro espino & Bombacopsis quinata & $200 \mathrm{~cm}$ \\
\hline Corotú & Enterolobium cyclocarpum & $200 \mathrm{~cm}$ \\
\hline Caoba & Swietenia macrophylla & $150 \mathrm{~cm}$ \\
\hline Cativo & Prioria copaifera & $150 \mathrm{~cm}$ \\
\hline Cedro amargo & Cedrela odorata & $150 \mathrm{~cm}$ \\
\hline Ceiba & Ceiba pentandra & $150 \mathrm{~cm}$ \\
\hline
\end{tabular}

Fuente: Resolución 438 del 2009 de la ANAM 
Cuadro 7. Normas y requisitos para los permisos forestales

\begin{tabular}{|c|c|c|c|c|c|}
\hline & 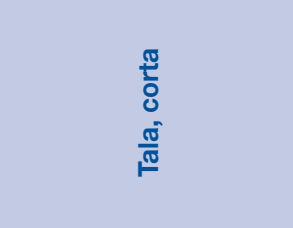 & 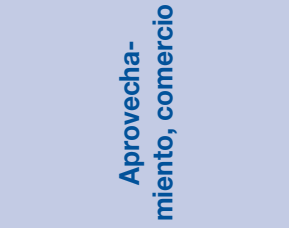 & 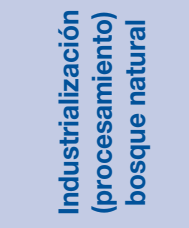 & 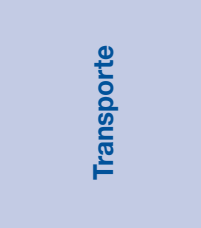 & 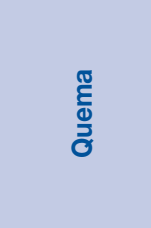 \\
\hline Normas & \multicolumn{5}{|c|}{ Requisitos } \\
\hline 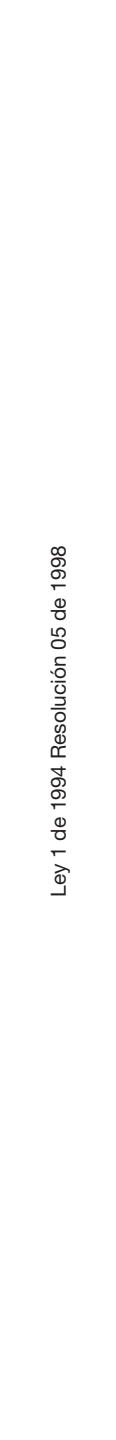 & 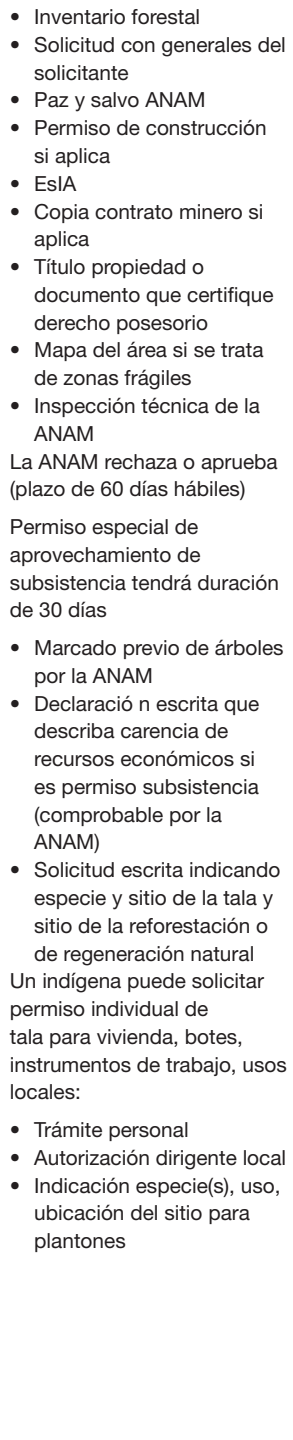 & 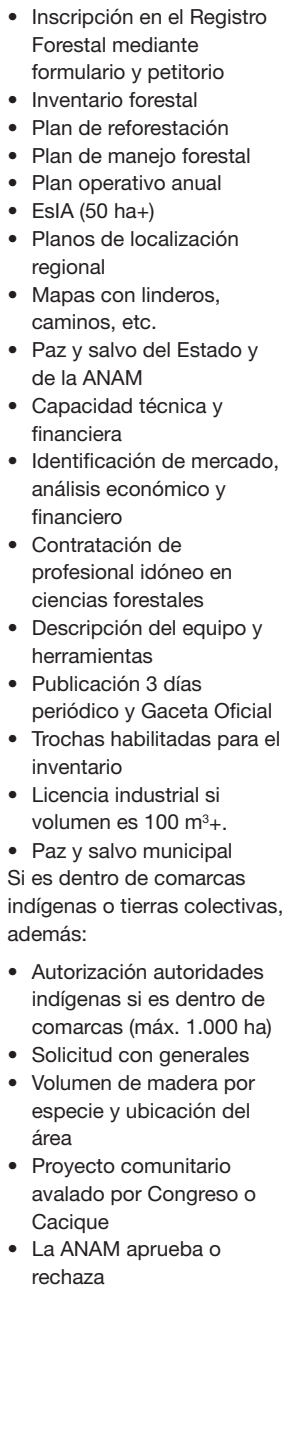 & $\begin{array}{l}\text { - Presentación } \\
\text { de declaración } \\
\text { jurada } \\
\text { - Pago de tarifa a } \\
\text { la ANAM } \\
\text { - Plantas deben } \\
\text { ser autorizadas } \\
\text { previo por la } \\
\text { ANAM, MICl y } \\
\text { municipio } \\
\text { - Suministran } \\
\text { información y } \\
\text { estadísticas } \\
\text { de forma } \\
\text { anual (sujeta a } \\
\text { verificación) } \\
\text { Deben llevar } \\
\text { un registro de } \\
\text { procedencia, } \\
\text { con detalle } \\
\text { de permisos, } \\
\text { contratos, guías } \\
\text { de transporte y } \\
\text { toda mentación } \\
\text { que ampare } \\
\text { los volúmenes } \\
\text { por especie } \\
\text { procesados y/o } \\
\text { empatiados. }\end{array}$ & 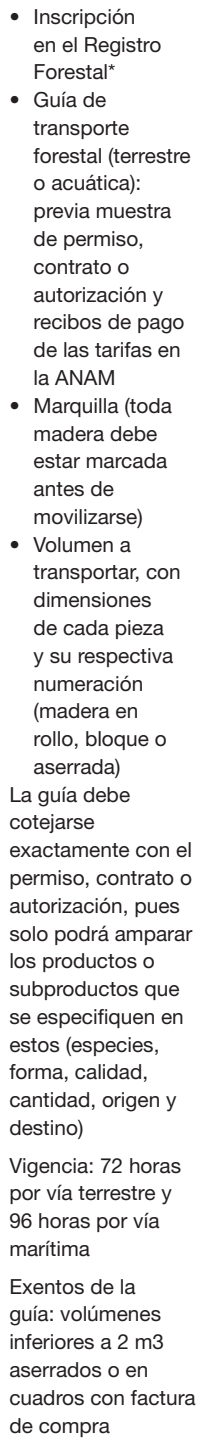 & $\begin{array}{l}\text { - Solicitar } \\
\text { permiso con } \\
15 \text { días de } \\
\text { antelación } \\
\text { - Presentar } \\
\text { título } \\
\text { propiedad o } \\
\text { documento } \\
\text { que acredita } \\
\text { posesión } \\
\text { - Avisar a } \\
\text { colindantes } \\
\text { fecha y hora } \\
\text { - Rondas } \\
\text { mínimo } 5 \text { m } \\
\text { ancho } \\
\text { - Personal } \\
\text { idóneo } \\
\text { - Prohibidas } \\
\text { las quemas } \\
\text { en bosques } \\
\text { primarios }\end{array}$ \\
\hline
\end{tabular}




\begin{tabular}{|c|c|c|c|c|c|}
\hline & 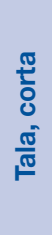 & 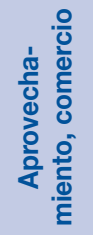 & 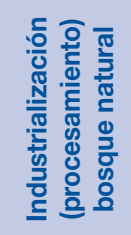 & 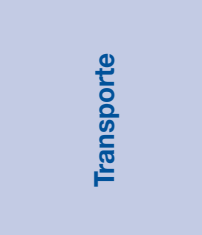 & 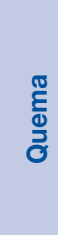 \\
\hline Normas & \multicolumn{5}{|c|}{ Requisitos } \\
\hline 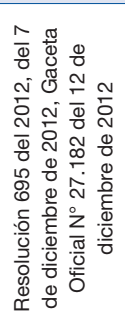 & & & & $\begin{array}{l}\text { En días y horarios } \\
\text { especificos. } \\
\text { Prohíbe los } \\
\text { domingos y } \\
\text { feriados, y en } \\
\text { horario de } 6 \text { p.m. a } \\
8 \text { a.m. }\end{array}$ & \\
\hline
\end{tabular}

Fuente: Elaborado por Jessica Young, 2013

Cuadro 8. Denuncias Ambientales de la República de Panamá recibidas en el Sistema 3-1-1

\begin{tabular}{|c|c|c|c|c|c|}
\hline Mes & $\begin{array}{l}\text { Contra los } \\
\text { recursos } \\
\text { naturales }\end{array}$ & $\begin{array}{l}\text { Contra los } \\
\text { animales } \\
\text { domésticos }\end{array}$ & $\begin{array}{l}\text { Contra la vida } \\
\text { silvestre }\end{array}$ & $\begin{array}{l}\text { Delitos de } \\
\text { tramitación y } \\
\text { cumplimiento } \\
\text { urbanístico }\end{array}$ & Total \\
\hline $\begin{array}{l}\text { Enero } \\
\text { Tala }\end{array}$ & $\begin{array}{l}2 \\
0\end{array}$ & 5 & ---- & ---- & 7 \\
\hline $\begin{array}{l}\text { Febrero } \\
\text { Tala }\end{array}$ & $\begin{array}{l}3 \\
2\end{array}$ & 2 & 3 & ----- & 8 \\
\hline $\begin{array}{l}\text { Marzo } \\
\text { Tala }\end{array}$ & $\begin{array}{l}5 \\
3\end{array}$ & 1 & 1 & 1 & 8 \\
\hline $\begin{array}{l}\text { Abril } \\
\text { Tala }\end{array}$ & $\begin{array}{l}5 \\
2\end{array}$ & 3 & 1 & 1 & 10 \\
\hline $\begin{array}{l}\text { Mayo } \\
\text { Tala }\end{array}$ & $\begin{array}{l}6 \\
2\end{array}$ & 3 & ---- & ---- & 9 \\
\hline $\begin{array}{l}\text { Junio } \\
\text { Tala }\end{array}$ & $\begin{array}{l}3 \\
0\end{array}$ & 1 & ---- & ---- & 4 \\
\hline $\begin{array}{l}\text { Julio } \\
\text { Tala }\end{array}$ & $\begin{array}{l}5 \\
4\end{array}$ & 1 & ---- & 17 & 23 \\
\hline $\begin{array}{l}\text { Agosto } \\
\text { Tala }\end{array}$ & $\begin{array}{l}7 \\
2\end{array}$ & 5 & 0 & 0 & 12 \\
\hline
\end{tabular}




\begin{tabular}{|l|l|l|l|l|l|}
\hline \multicolumn{1}{|c|}{ Mes } & \multicolumn{1}{|c|}{$\begin{array}{c}\text { Contra los } \\
\text { recursos } \\
\text { naturales }\end{array}$} & $\begin{array}{c}\text { Contra los } \\
\text { animales } \\
\text { domésticos }\end{array}$ & $\begin{array}{c}\text { Delitos de } \\
\text { Contra la vida } \\
\text { silvestre } \\
\text { tramitación y } \\
\text { cumplimiento } \\
\text { urbanístico }\end{array}$ & \multicolumn{1}{c|}{ Total } \\
\hline $\begin{array}{l}\text { Septiembre } \\
\text { Tala }\end{array}$ & 2 & 3 & 0 & 0 & 5 \\
\hline Total & 38 & 24 & 5 & 19 & 86 \\
Tala Total & 15 & & & & \\
\hline
\end{tabular}

Fuente: Ministerio Público, Fiscalía Quinta de Circuito de Primer Circuito Judicial de Panamá, a septiembre 2013

\section{Cuadro 9. Estadísticas de ambiente de enero al 6 de agosto de 2013}

\begin{tabular}{|l|l|l|l|l|}
\hline \multicolumn{1}{|c|}{ Denuncia } & \multicolumn{1}{|c|}{2010} & \multicolumn{1}{c|}{2011} & & \multicolumn{1}{c|}{2012} \\
\hline $\begin{array}{l}\text { Destrucción de } \\
\text { mangle }\end{array}$ & 1 & 5 & 5 & 2 \\
\hline $\begin{array}{l}\text { Roza, quema, } \\
\text { secuela }\end{array}$ & 54 & 19 & 7 & 3 \\
\hline Tala & 249 & 146 & 100 & 40 \\
\hline Tráfico ilegal & 5 & 7 & - & - \\
\hline
\end{tabular}

Fuente: ANAM, Asesoría Legal, 2013. 


\section{Cuadro 10. Costos de trámites en la ANAM por servicios para aprovechamiento forestal}

Los costos en la ANAM se clasifican según el trámite o servicio que presta la institución.

- US $\$ 2 / h a$ (dos dólares) por hectárea concesionada al año (excepto fincas privadas)

- US\$30 (treinta dólares) por inspección técnica

- US\$10 (diez dólares) por registro (recepción, evaluación y emisión)

- US\$0.30/ha (treinta centavos de dólar) por hectárea hasta 5.000 hectáreas para inventario forestal y plan de manejo forestal

- US $\$ 0.15 /$ ha (quince centavos de dólar) de 5.000 hectáreas en adelante

- US\$30 (treinta dólares) para inspeccionar planes de manejo forestales en ejecución

- US $\$ 15 / \mathrm{m}^{3}$ (quince dólares) en pie o en tuca de maderas duras y finas por servicios técnicos

- US $\$ 20 / \mathrm{m}^{3}$ (veinte dólares) en bloque o cuadrado de maderas duras

- US $\$ 10 / \mathrm{m}^{3}$ (diez dólares) en pie o en tuca de madera blanda.

- US $\$ 15 / \mathrm{m}^{3}$ (quince dólares) en bloque o cuadro

- US\$5 (cinco dólares) por árbol que se aprovechará para personas de escasos recursos

- US $\$ 1 / \mathrm{m}^{3}$ (un dólar) o fracción de $\mathrm{m}^{3}$ para guía forestal de transporte marítimo o terrestre

- $1 \%$ del CIF para guía de importación productos forestales importados

- $1 \%$ del FOB para guía de exportación productos forestales

- US $\$ 2 / \mathrm{m}^{3}$ (dos dólares) de madera procesada proveniente de bosque natural

- US\$10 (diez dólares) por permiso inscripción de motosierra

- US\$5 (cinco dólares) por renovación permiso inscripción motosierra

- US\$10 por inspección para permisos de rozas y quemas

Fuente: Elaboración propia basado en las normas 
Gráfica 1. Superficie boscosa en la República de Panamá, años 1947-2000

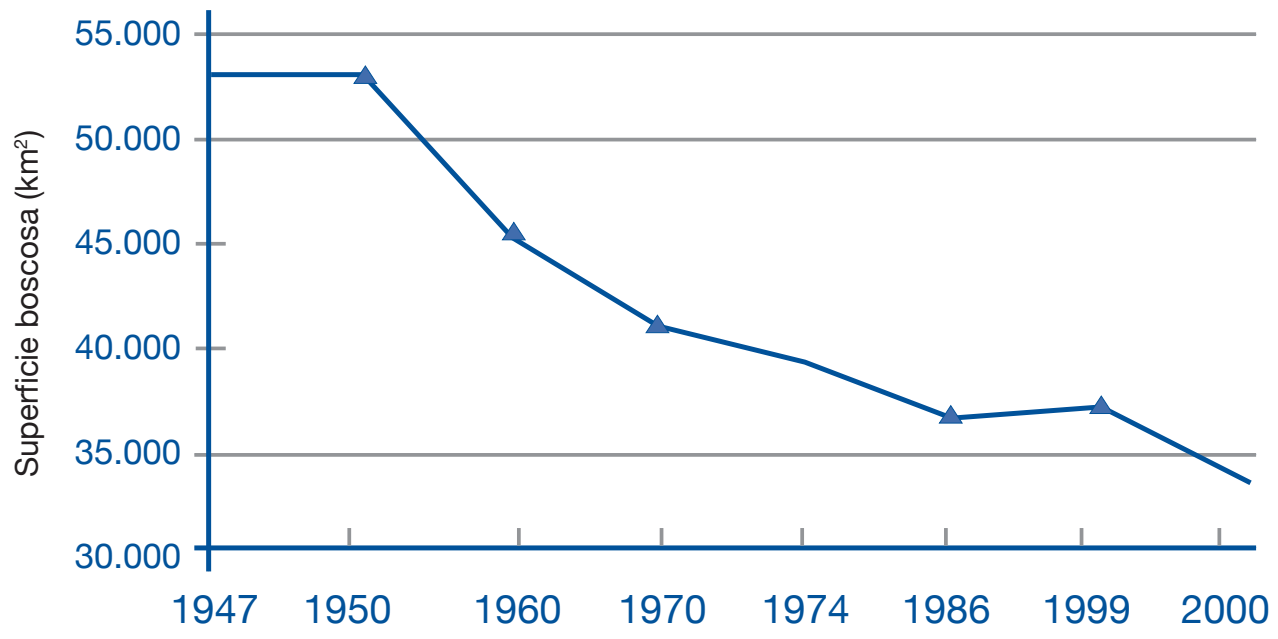

Fuente: ANAM, 2003 


\section{Gráfica 2. Sistema integrado de gestión aduanera}

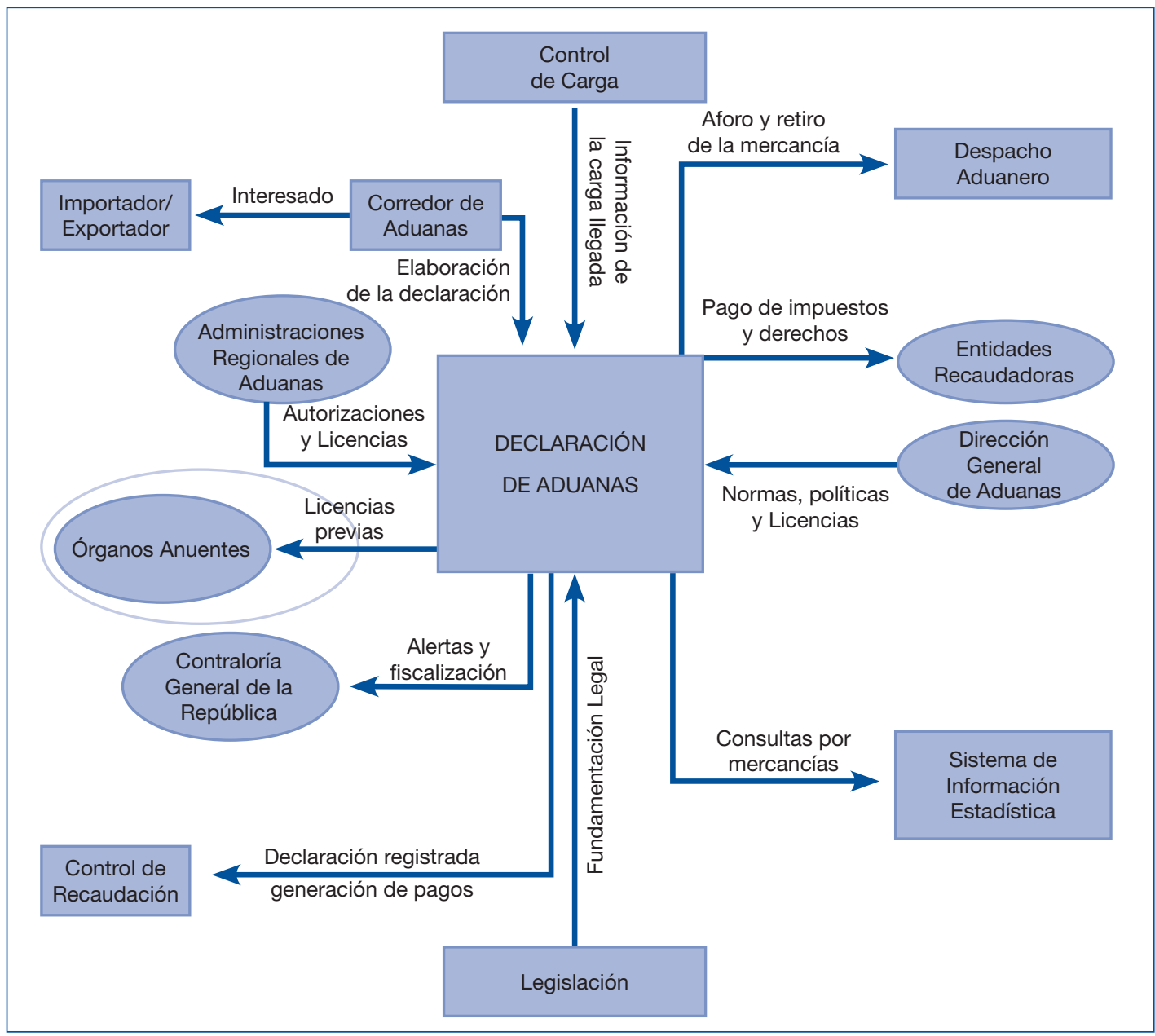

Fuente: Autoridad Nacional de Aduanas, SIGA-ANA, 2013 


\section{Gráfica 3. Diagrama de flujo del proceso de exportación de madera}

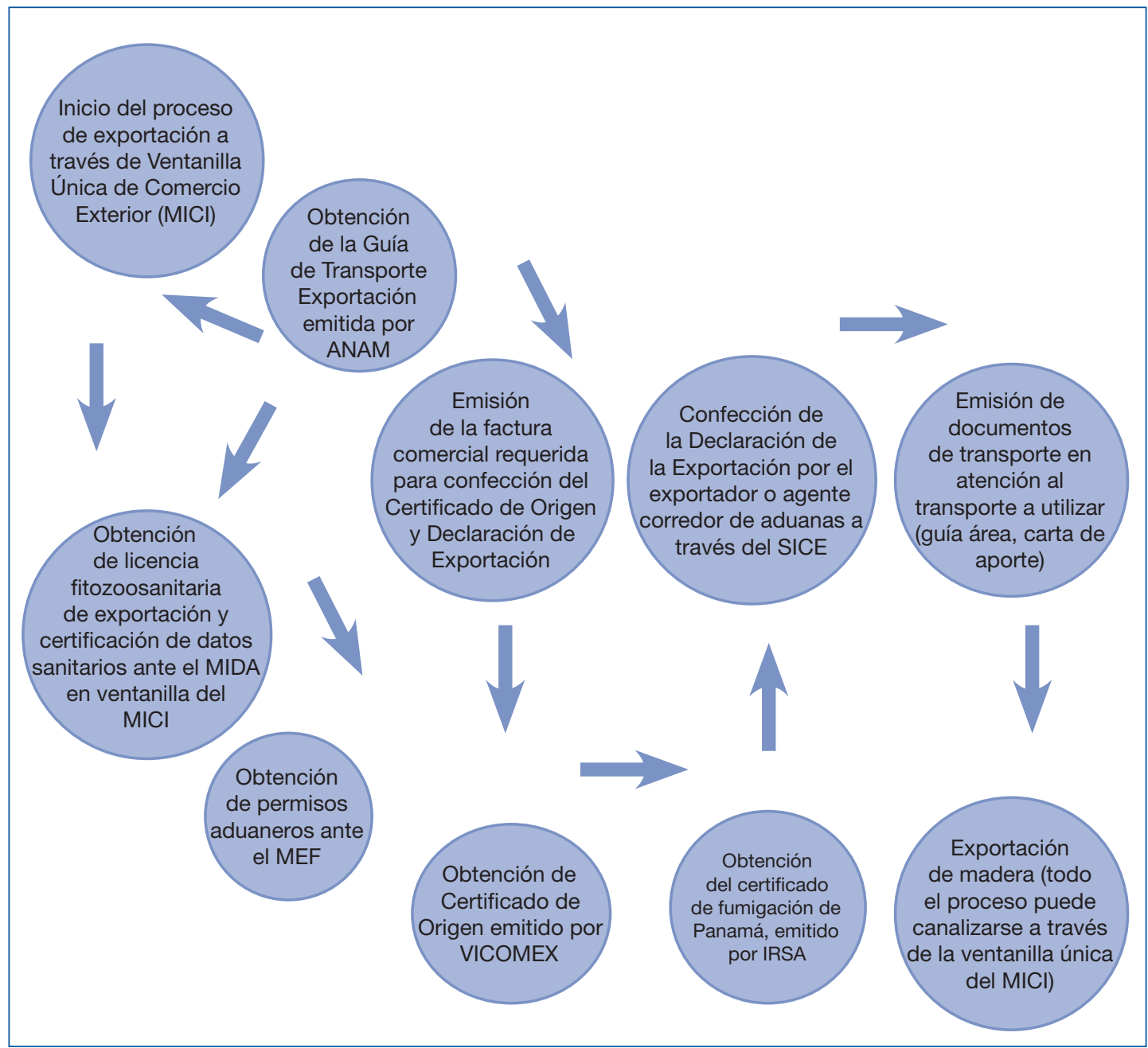

Fuente: Marco normativo vigente aplicable 


\section{Gráfica 4. Diagrama de flujo para que productos de madera accedan a mercados de exportación}

\begin{tabular}{|c|c|c|c|}
\hline & ACTIVIDAD & RESPONSABLES & OBSERVACIONES \\
\hline 1 & $\begin{array}{l}\text { Solicita, electrónicamente, } \\
\text { la Licencia Previa para que } \\
\text { el Órgano Anuente proceda } \\
\text { con la concesión respectiva. }\end{array}$ & SICE & $\begin{array}{l}\text { La solicitud de Licencia Previa contendrá } \\
\text { como mínimo la siguiente información: } \\
\text { Número de la Predeclaración (número y } \\
\text { dígito verificador) } \\
\text { Fecha de la solicitud } \\
\text { Número de la solicitud } \\
\text { Partida Arancelaria del artículo de la } \\
\text { Declaración } \\
\text { Cédula o RUC del Importador/Exportador } \\
\text { Motivo (justificación de la solicitud de } \\
\text { Licencia) } \\
\text { Identificación y número de la Licencia del } \\
\text { Corredor } \\
\text { Firma digital del Corredor o del Exportador } \\
\text { En caso de que necesite más información } \\
\text { con respecto a la importación de las } \\
\text { mercancías, el Órgano Anuente podrá } \\
\text { consultar la Predeclaración en forma } \\
\text { electrónica. }\end{array}$ \\
\hline 2 & $\begin{array}{l}\text { Actúa de conformidad con } \\
\text { respecto al estudio y análisis } \\
\text { de la solicitud de Licencia. }\end{array}$ & Órgano Anuente & $\begin{array}{l}\text { Los Órganos Anuentes legalmente } \\
\text { constituidos tramitarán las solicitudes } \\
\text { conforme a lo establecido en sus } \\
\text { respectivas reglamentaciones que regulan } \\
\text { la materia. }\end{array}$ \\
\hline 3 & $\begin{array}{l}\text { Decide en relación con la } \\
\text { solicitud de Licencia Previa } \\
\text { aprobándola o negándola. }\end{array}$ & Órgano Anuente & $\begin{array}{l}\text { En caso necesario, el Órgano Anuente } \\
\text { podrá contactar al Corredor para } \\
\text { que suministre elementos de juicio } \\
\text { indispensables para tomar la decisión } \\
\text { conforme las reglamentaciones vigentes. }\end{array}$ \\
\hline 4 & $\begin{array}{l}\text { Registra en SICE la decisión } \\
\text { tomada. }\end{array}$ & Órgano Anuente & $\begin{array}{l}\text { La decisión será refrendada con la firma } \\
\text { digital e identificación del funcionario } \\
\text { autorizado del Órgano Anuente para } \\
\text { formalizar el acto administrativo de la } \\
\text { concesión o negación de la Licencia Previa. }\end{array}$ \\
\hline
\end{tabular}




\begin{tabular}{|l|l|l|l|}
\hline $\begin{array}{l}\text { Incorpora a la Predeclaración } \\
\text { la información relativa a } \\
\text { la decisión tomada por el } \\
\text { Órgano Anuente. }\end{array}$ & SICE & $\begin{array}{l}\text { Para cada Licencia Previa el sistema } \\
\text { incorporará los siguientes datos a la } \\
\text { Predeclaración: }\end{array}$ \\
& $\begin{array}{l}\text { Número de cédula del funcionario del } \\
\text { Órgano Anuente que expide la Licencia } \\
\text { Previa } \\
\text { Número de la Licencia concedida } \\
\text { Fecha de concesión } \\
\text { Vigencia de la Licencia concedida } \\
\text { Si la Licencia Previa no es concedida, } \\
\text { se registrarán en el Sistema las razones } \\
\text { correspondientes. }\end{array}$ \\
\hline
\end{tabular}

\section{PARA ÓRGANOS NO INCORPORADOS. Cuando las entidades o autoridades competentes para expedir la Licencia Previa no se encuentren integrados al SICE, el trámite se hará de acuerdo con el siguiente procedimiento:}

\begin{tabular}{|c|l|l|l|}
\hline \multicolumn{1}{|c|}{ Actividad } & \multicolumn{1}{|c|}{ Responsables } & \multicolumn{1}{c|}{ Observaciones } \\
\hline 1 & $\begin{array}{l}\text { Activa la función } \\
\text { análisis en el } \\
\text { módulo Declaración } \\
\text { para conocer el } \\
\text { diagnóstico del } \\
\text { Sistema con respecto } \\
\text { a las mercancías que } \\
\text { requieren Licencias } \\
\text { Previas. }\end{array}$ & Corredor de Aduanas & $\begin{array}{l}\text { Este comando solo será aceptado si la } \\
\text { Predeclaración está libre de errores e } \\
\text { inconsistencias. }\end{array}$ \\
\hline 2 & $\begin{array}{l}\text { Indica y despliega el } \\
\text { tipo de Licencias que se } \\
\text { requieren. }\end{array}$ & SICE & $\begin{array}{l}\text { La necesidad de Licencias puede ser por: } \\
\text { Tipo de mercancía u operación (acuerdos, } \\
\text { exención, legislación, etc.) }\end{array}$ \\
\hline 3 & $\begin{array}{l}\text { Todas las Declaraciones que requieran Licencias } \\
\text { Previas deberán pasar por la verificación } \\
\text { documental y física, y recibirán indicación de luz } \\
\text { roja al momento del Despacho. }\end{array}$ \\
\hline 4 & $\begin{array}{l}\text { Activa la función } \\
\text { Le "Solicitud de } \\
\text { Licencia" e informa al } \\
\text { Sredeclaración que } \\
\text { necesita Licencias. }\end{array}$ & $\begin{array}{l}\text { Solicita, } \\
\text { electrónicamente las } \\
\text { licencias requeridas para } \\
\text { posteriormente proceder } \\
\text { con la concesión } \\
\text { respectiva, previa } \\
\text { autorización del Órgano } \\
\text { Anuente. }\end{array}$ & Corredor de Aduanas \\
\hline
\end{tabular}




\begin{tabular}{|c|c|c|c|}
\hline & Actividad & Responsables & Observaciones \\
\hline 5 & $\begin{array}{l}\text { Imprime el extracto de la } \\
\text { Predeclaración. }\end{array}$ & Corredor de Aduanas & $\begin{array}{l}\text { Imprime el encabezado de la Predeclaración } \\
\text { y las hojas de las mercancías que requieren } \\
\text { Licencias. }\end{array}$ \\
\hline 6 & $\begin{array}{l}\text { Elabora la solicitud de } \\
\text { Licencia Previa y realiza } \\
\text { los trámites que exija el } \\
\text { Órgano Anuente para } \\
\text { las mercancías que la } \\
\text { requieran. }\end{array}$ & Corredor de Aduanas & $\begin{array}{l}\text { La solicitud contendrá como mínimo la siguiente } \\
\text { información: } \\
\text { - Número de la Predeclaración } \\
\text { - Fecha de la solicitud } \\
\text { - Número de la solicitud } \\
\text { - Partida Arancelaria de la mercancía } \\
\text { - RUC del Importador/Exportador } \\
\text { - Motivo (justificación de la solicitud de } \\
\text { - licencia) } \\
\text { - } \text { Identificación y número de la licencia del } \\
\text { - Firma del Corredor o del Exportador } \\
\end{array}$ \\
\hline 7 & $\begin{array}{l}\text { Presenta la solicitud } \\
\text { junto con la } \\
\text { Predeclaración impresa } \\
\text { al Órgano Anuente para } \\
\text { su revisión y expedición. }\end{array}$ & Corredor de Aduanas & \\
\hline 8 & $\begin{array}{l}\text { Actúa de conformidad } \\
\text { con respecto al estudio } \\
\text { y análisis de la solicitud } \\
\text { de Licencia Previa. }\end{array}$ & Órgano Anuente & $\begin{array}{l}\text { Los Órganos Anuentes legalmente constituidos } \\
\text { tramitarán las solicitudes conforme a lo } \\
\text { establecido en sus respectivas reglamentaciones } \\
\text { que regulan la materia. }\end{array}$ \\
\hline 9 & $\begin{array}{l}\text { Decide en relación con } \\
\text { la solicitud de Licencia } \\
\text { Previa aprobándola o } \\
\text { negándola. }\end{array}$ & Órgano Anuente & $\begin{array}{l}\text { En caso necesario, el Órgano Anuente podrá } \\
\text { contactar al Corredor para que suministre } \\
\text { elementos de juicio indispensables para tomar } \\
\text { la decisión conforme las reglamentaciones } \\
\text { vigentes. }\end{array}$ \\
\hline 10 & $\begin{array}{l}\text { Retira de las oficinas } \\
\text { del Órgano Anuente } \\
\text { la Licencia Previa } \\
\text { expedida. }\end{array}$ & Corredor de Aduanas & $\begin{array}{l}\text { La Licencia Previa podrá ser expedida } \\
\text { mediante nota o formulario según lo indique la } \\
\text { reglamentación de la autoridad competente. }\end{array}$ \\
\hline 11 & $\begin{array}{l}\text { Entra a la función } \\
\text { de "Registro de la } \\
\text { Declaración" y ejecuta la } \\
\text { función de análisis. }\end{array}$ & Corredor de Aduanas & $\begin{array}{l}\text { El análisis indicará si existe la necesidad de } \\
\text { Licencias. }\end{array}$ \\
\hline 12 & $\begin{array}{l}\text { Activa la función } \\
\text { "Registrar Concesión" } \\
\text { para informar los } \\
\text { datos de las Licencias } \\
\text { otorgadas. }\end{array}$ & Corredor de Aduanas & $\begin{array}{l}\text { Si el análisis de la Predeclaración indica la } \\
\text { necesidad de más de una Licencia, el Corredor } \\
\text { deberá informar y registrar solo las Licencias } \\
\text { otorgadas por los Órganos Anuentes que no } \\
\text { estén conectados al SICE. De esta forma, } \\
\text { pueden existir para una Declaración Licencias } \\
\text { registradas directamente por los Órganos } \\
\text { Anuentes conectados al SICE y otras registradas } \\
\text { por el Corredor. }\end{array}$ \\
\hline
\end{tabular}




\begin{tabular}{|c|l|l|l|}
\hline 13 & \multicolumn{1}{|c|}{ Actividad } & \multicolumn{1}{|c|}{ Responsables } & Observaciones \\
\hline 13 & $\begin{array}{l}\text { Finalmente, activa la } \\
\text { función "Registro de la } \\
\text { Declaración" para que } \\
\text { el sistema le asigne } \\
\text { número y la formalice. }\end{array}$ & SICE & \\
\hline
\end{tabular}

Fuente: Sistema Integrado de Comercio Exterior, flujograma para la obtención de permisos de exportación. Tomado de su página web: <http://www.aduanas.gob.pa/Manual\%20de\%20declaraci\%C3\%B3n\%20aduanera\%20-\%20 explorer\%20\%2809-04-01\%29.html>.

\section{Gráfica 5. Tipo de información que maneja el Sistema de Información de}

\section{Estadísticas Forestales}

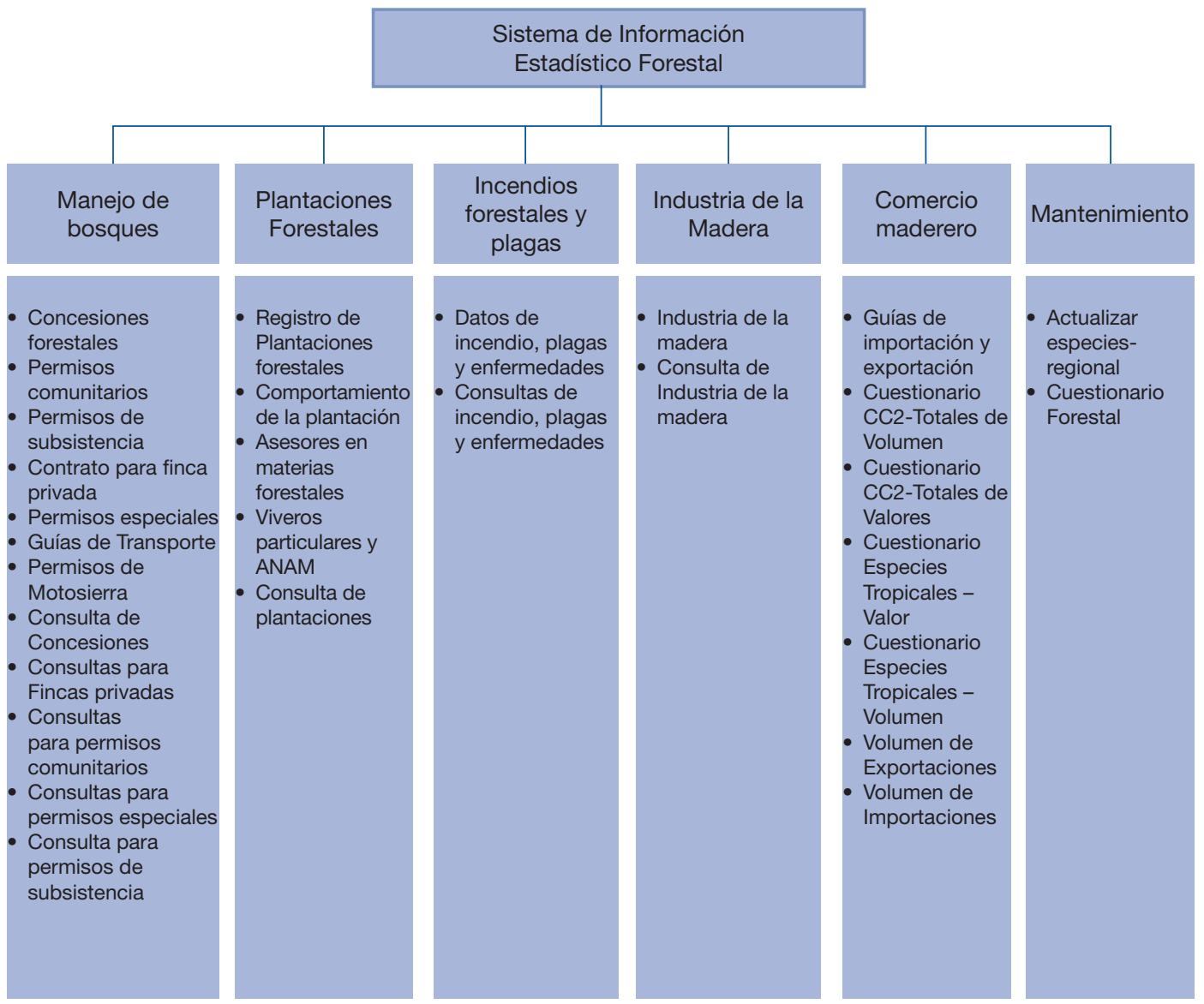

Fuente: ANAM, 2005 
Gráfica 6. Denuncias ambientales registradas en la República de Panamá, según tipo de infracción (a junio de 2013)

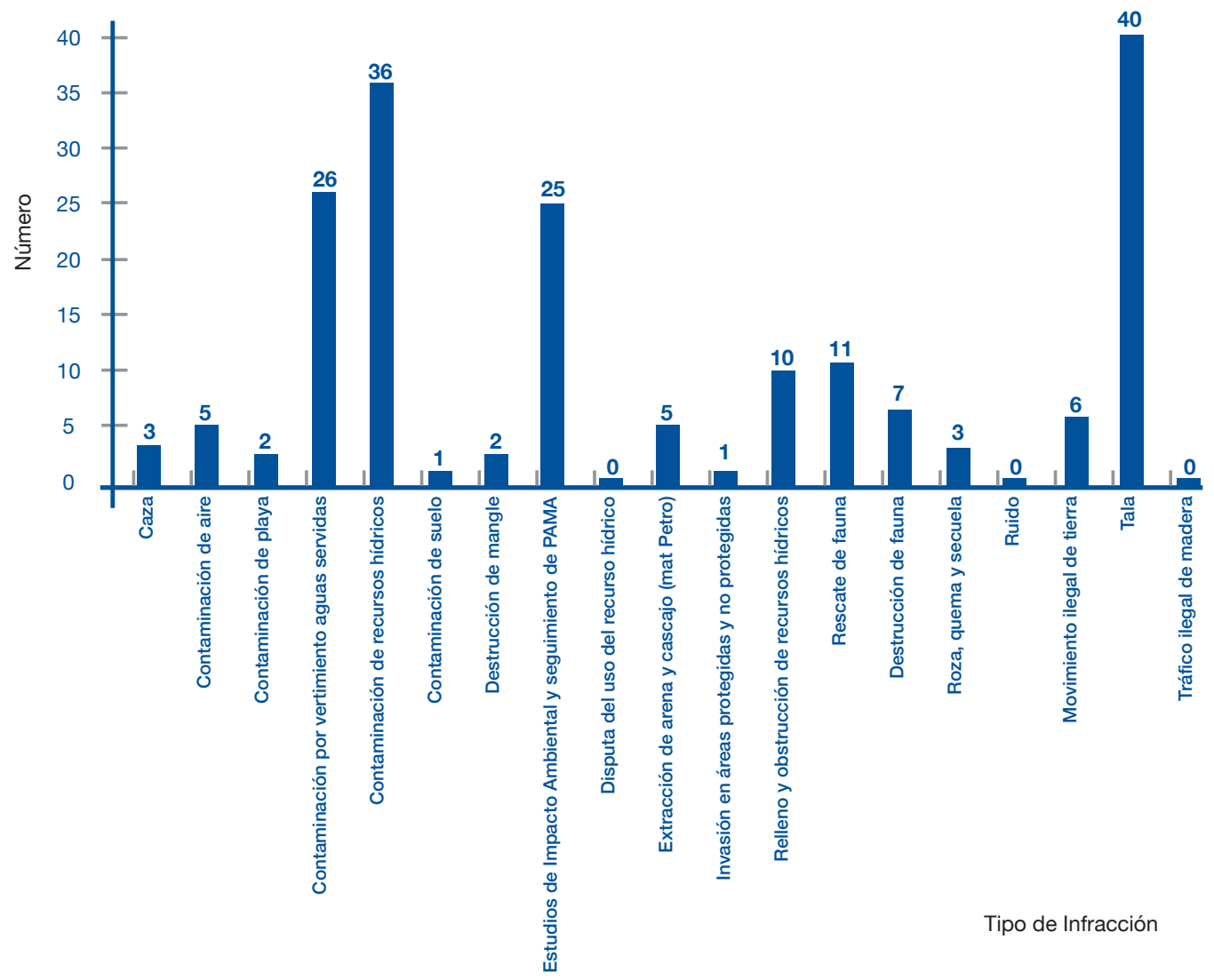

Fuente: ANAM, 2013, Línea 311, Centro de Atención Ciudadana 


\section{Gráfica 7. Expedientes por cobro coactivo ANAM, por tipo de deuda (año 2012)}

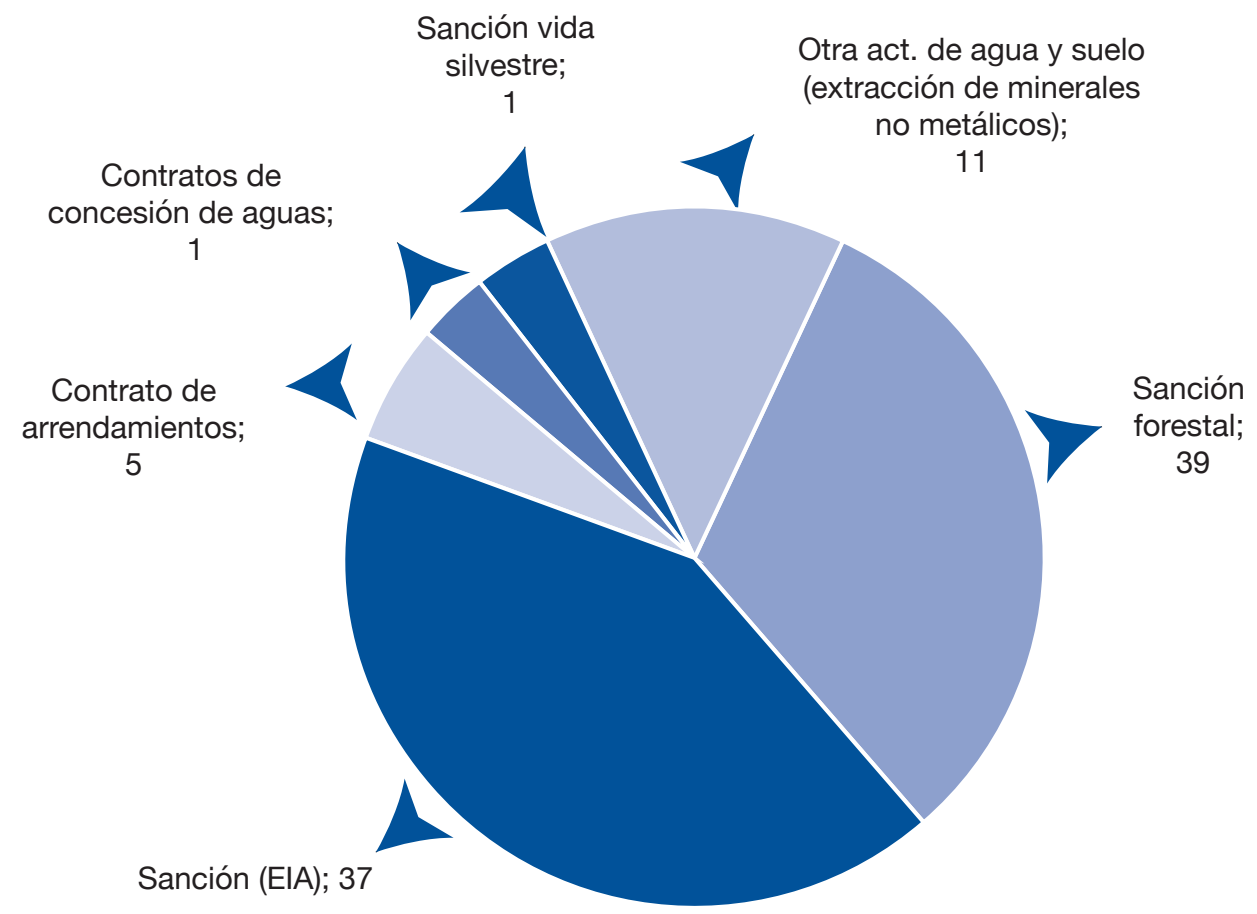

NOTA. E.I.A. (Estudio de Impacto Ambiental)

Fuente: Autoridad Nacional del Ambiente. Juzgado Ejecutor, 2011-2012. 


\section{Gráfica 8. Esquema de tala y comercio ilegal de madera en Darién}

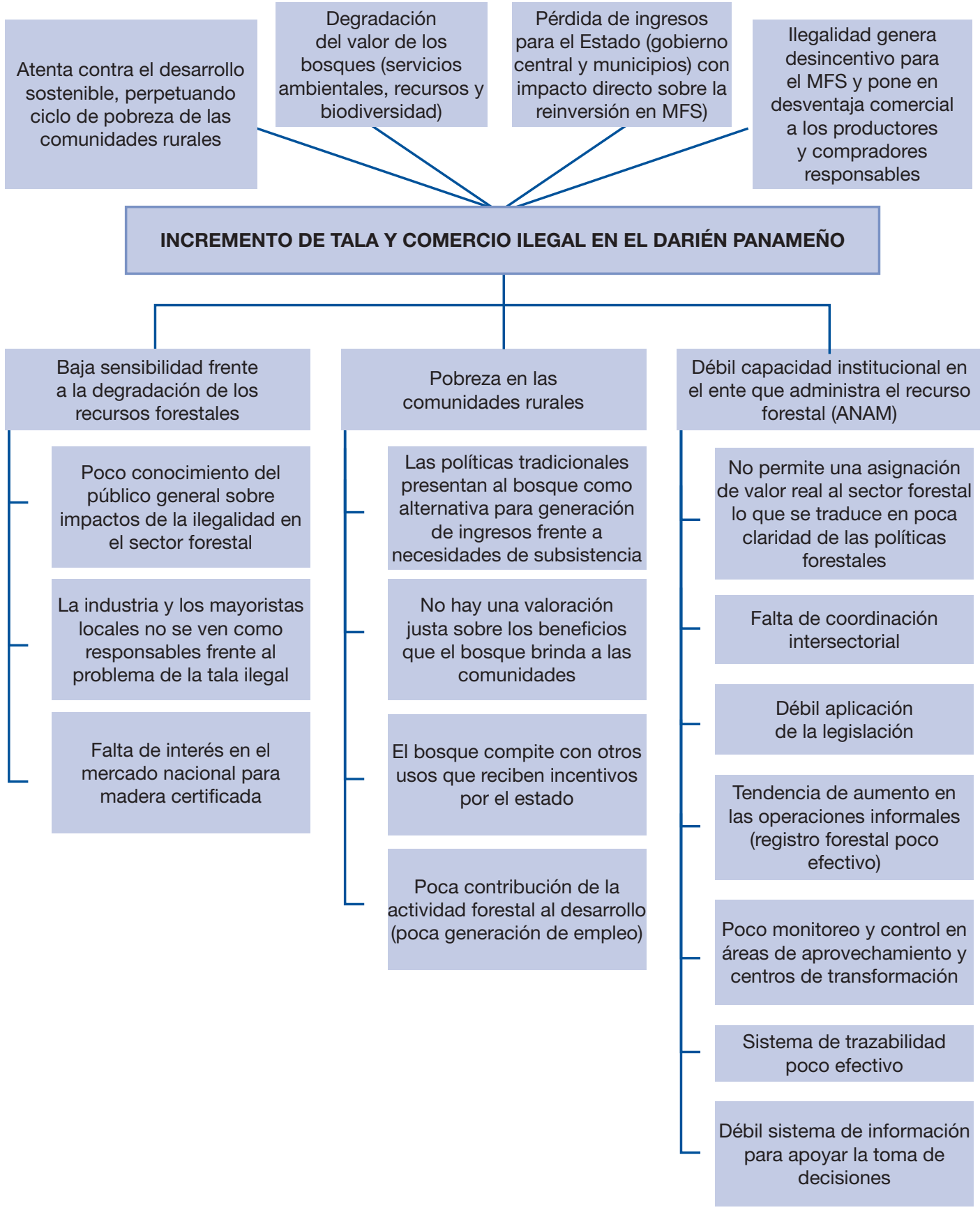

Fuente: WWF, 2013 


\section{Gráfica 9. Diagrama flujo procedimiento administrativo por denuncia ante la ANAM}

\begin{tabular}{|c|c|c|c|}
\hline Infracción Ambiental & \multicolumn{2}{|c|}{ + Denuncia } & $\begin{array}{c}\text { ANAM } \\
\text { Dirección de Asesoría Legal }\end{array}$ \\
\hline \multicolumn{4}{|c|}{ Expediente prenumerado y consecutivo } \\
\hline $\begin{array}{l}\text { Si la denuncia tiene méritos } \\
\text { para una investigación, } \\
\text { I. notifica al denunciado } \\
\text { En un plazo de cinco (5) días } \\
\text { hábiles tras la recepción del } \\
\text { formulario }\end{array}$ & \multicolumn{2}{|c|}{$\begin{array}{l}\text { Si la denuncia No tiene méritos } \\
\text { para hacer una investigación, } \\
\text { II. notifica al denunciante } \\
\text { En un plazo no mayor de } \\
\text { cinco (5) días hábiles tras la } \\
\text { recepción del formulario }\end{array}$} & $\begin{array}{l}\text { Si NO demuestra la existencia } \\
\text { de infracción administrativa, } \\
\text { III. notifica al denunciante y } \\
\text { al denunciado } \\
\text { Si NO demuestra la existencia } \\
\text { de infracción administrativa }\end{array}$ \\
\hline & \multicolumn{3}{|c|}{ La denuncia sigue adelante } \\
\hline $\begin{array}{l}\text { El presunto infractor tendrá } \\
\text { diez (10) días hábiles para } \\
\text { presentar sus alegatos y } \\
\text { pruebas de descargo }\end{array}$ & $\begin{array}{l}\text { Plazo para la } \\
\text { ANAM }\end{array}$ & $\begin{array}{l}\text { La Administración } \\
\text { Regional de la } \\
\text { ANAM adoptará } \\
\text { su decisión }\end{array}$ & $\begin{array}{c}\text { El presunto infractor } \\
\text { puede presentar Recursos } \\
\text { de Reconsideración } \\
\text { (Administración Regional de } \\
\text { la ANAM) }\end{array}$ \\
\hline
\end{tabular}

Fuente: Decreto Ejecutivo No 57 de 2000

Producto elaborado con insumos legales y supervisión técnico-legal del Programa de Incidencia Política de Fundación MarViva

Tomado del Manual de Acceso a la Información y Participación Ciudadana en Temas Ambientales de MarViva, 2012. 


\section{Anexo 1. Glosario de siglas}

\begin{tabular}{|l|l|}
\hline ANA & Autoridad Nacional de Aduanas \\
\hline ANAM & Autoridad Nacional del Ambiente \\
\hline ANATI & Autoridad Nacional de Tierras \\
\hline CATIE & Centro agronómico tropical de investigación y enseñanza \\
\hline EsIA & Estudio de impacto ambiental \\
\hline FAO & Programa de las Naciones Unidas para la agricultura, la pesca y la alimentación \\
\hline MEF & Ministerio de Economía y Finanzas \\
\hline MIDA & Ministerio de Desarrollo Agropecuario \\
\hline OIMT & Organización Internacional de Maderas Tropicales \\
\hline PNUD & Programa de las Naciones Unidas para el Desarrollo \\
\hline TIR & Tasa Interna de Retorno \\
\hline USAID & Agencia de los Estados Unidos para la Cooperación Internacional \\
\hline WWF & Fondo Mundial para la Naturaleza \\
\hline
\end{tabular}

\section{Anexo 2. Superficie de cobertura boscosa, 1947-2000}

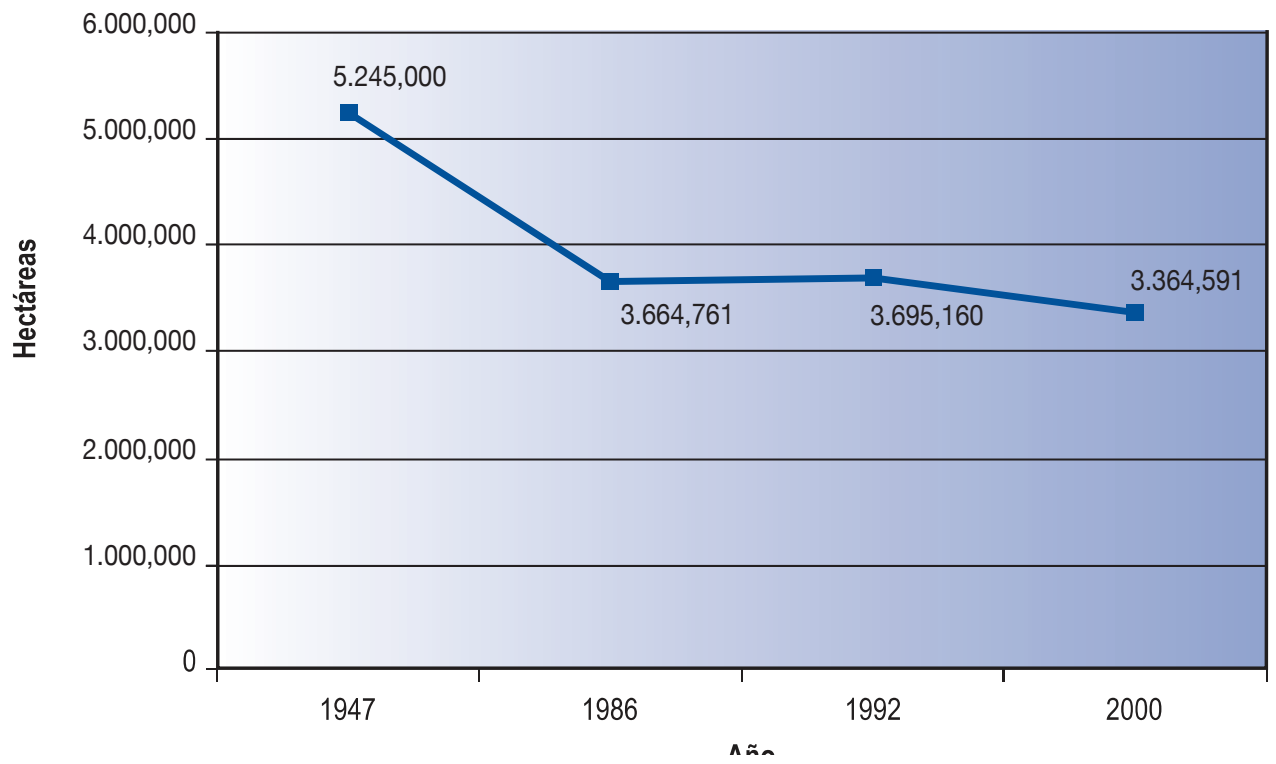

Fuente: ANAM, 2008. Plan Nacional de Desarrollo Forestal: Modelo Forestal Sostenible 
Anexo 3. Volumen de madera otorgada para el aprovechamiento forestal, por tipo de permiso, según Regional, enero-junio 2013

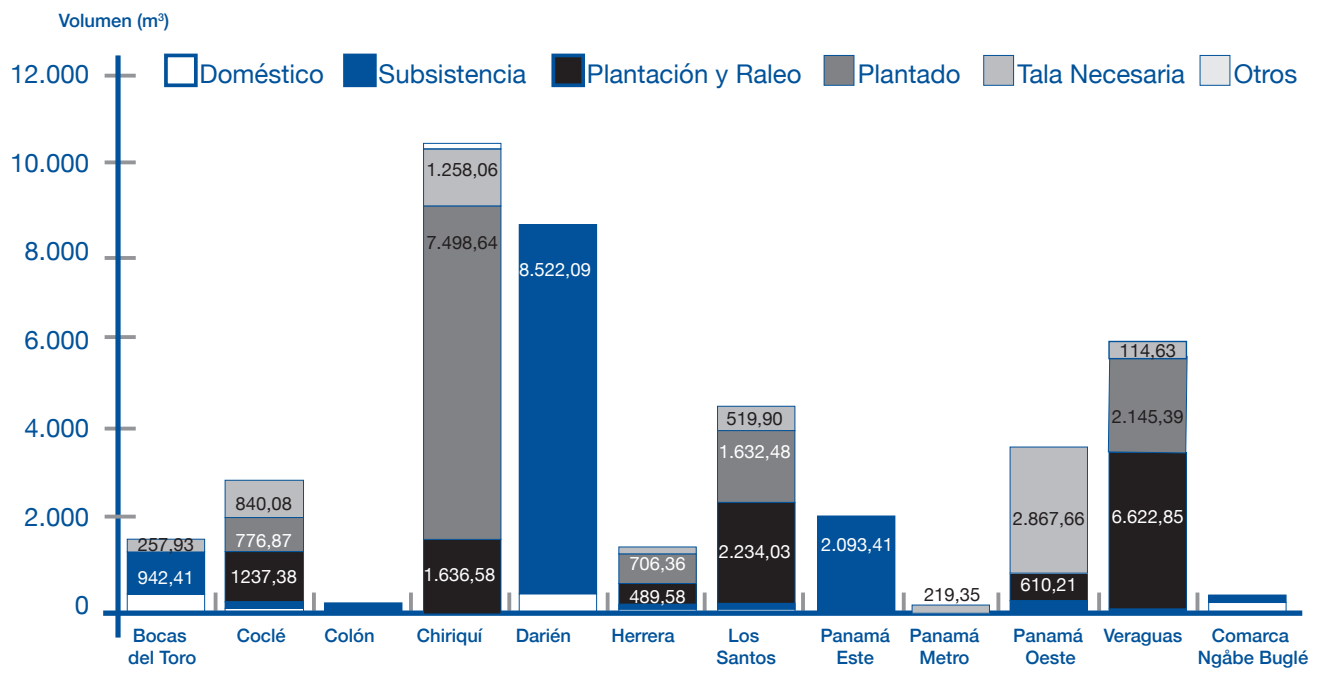

Fuente: ANAM, 2013. Compendio Estadístico Ambiental 2013 (primer semestre) 
Anexo 4. Comisiones Consultivas Ambientales

\section{Comisiones Consultivas Ambientales \\ Espacios de participación pública en la República de Panamá}

\begin{tabular}{|c|c|c|c|}
\hline $\begin{array}{l}\text { Nacional: } \\
\text { Órgano de consulta } \\
\text { de la ANAM en la } \\
\text { toma de decisiones } \\
\text { sobre cuestiones } \\
\text { ambientales. Puede } \\
\text { hacer recomendaciones } \\
\text { al Consejo Nacional del } \\
\text { Ambiente. }\end{array}$ & $\begin{array}{l}\text { Provincial: } \\
\text { Analizan los temas } \\
\text { ambientales que } \\
\text { afectan a la provincia } \\
\text { y formulan propuestas } \\
\text { y recomendaciones al } \\
\text { Administrador Regional } \\
\text { de la ANAM }\end{array}$ & $\begin{array}{l}\text { Distrital: } \\
\text { Analizan los temas } \\
\text { ambientales que } \\
\text { afectan un Distrito y } \\
\text { formulan propuestas } \\
\text { y recomendaciones al } \\
\text { Administrador Regional } \\
\text { de la ANAM }\end{array}$ & $\begin{array}{l}\text { Comarcal: } \\
\text { Analizan los temas } \\
\text { ambientales que } \\
\text { afectan una Comarca } \\
\text { y formulan propuestas } \\
\text { y recomendaciones al } \\
\text { Administrador Regional } \\
\text { de la ANAM que } \\
\text { corresponda }\end{array}$ \\
\hline $\begin{array}{l}\text { Integrantes: } \\
\text { - } \quad \text { Administrador } \\
\text { General ANAM } \\
\text { - } \quad \text { Un representante } \\
\text { de cada Ministro del } \\
\text { Consejo Nacional del } \\
\text { Ambiente } \\
\text { - Dos representantes } \\
\text { empresa privada } \\
\text { - Un representante } \\
\text { trabajadores } \\
\text { - Dos representantes } \\
\text { ONG ambiente y } \\
\text { derechos humanos } \\
\text { Un representante } \\
\text { sector académico } \\
\text { Un representante } \\
\text { productores } \\
\text { agropecuarios } \\
\text { Un representante } \\
\text { gobiernos locales } \\
\text { Un representante gremios } \\
\text { profesionales } \\
\text { Dos representantes de } \\
\text { las comarcas indígenas }\end{array}$ & $\begin{array}{l}\text { Integrantes: } \\
\text { - } \text { Administrador } \\
\text { Regional del } \\
\text { Ambiente } \\
\text { - Gobernador de la } \\
\text { Provincia } \\
\text { - Un representante } \\
\text { de la Junta Técnica } \\
\text { (gobierno central) } \\
\text { - Dos representantes } \\
\text { del Consejo Provincial } \\
\text { de Coordinación } \\
\text { Un representante } \\
\text { de organizaciones } \\
\text { empresariales } \\
\text { Un representante de } \\
\text { organizaciones de } \\
\text { trabajadores } \\
\text { Un representante de } \\
\text { ONGs ambientalistas } \\
\text { y de derechos } \\
\text { humanos } \\
\text { Un representante } \\
\text { sector académico } \\
\text { Un representante } \\
\text { de productores } \\
\text { agropecuarios } \\
\text { Un representante de } \\
\text { gremios profesionales }\end{array}$ & $\begin{array}{l}\text { Integrantes: } \\
\text { - } \quad \text { El alcalde, quien la } \\
\text { presidirá } \\
\text { - Representantes del } \\
\text { Consejo Municipal } \\
\text { - } \quad \text { Representantes de la } \\
\text { sociedad civil del área }\end{array}$ & $\begin{array}{l}\text { Integrantes: } \\
\text { - } \quad \text { Representante del } \\
\text { Congreso General } \\
\text { Indígena, quien la } \\
\text { presidirá } \\
\text { - Representantes del } \\
\text { Congreso General } \\
\text { Indígena } \\
\text { - Representantes } \\
\text { del Consejo de } \\
\text { Coordinación } \\
\text { Comarcal } \\
\text { Junta Técnica de } \\
\text { la(s) Provincia(s) que } \\
\text { corresponda(n)- } \\
\text { Representantes de la } \\
\text { sociedad civil del área }\end{array}$ \\
\hline
\end{tabular}

Fuente: Decreto Ejecutivo 57 del 2000 
Anexo 5. Formularios para permisos especiales de aprovechamiento forestal de carácter doméstico o de subsistencia y para la emisión de guías de movilización de madera, aprobados por Resolución 466 del 2003, del 20 de octubre de 2003, Gaceta Oficial N 24.995 publicada el 20 de febrero de 2004

AUTORIDAD NACIONAL DEL AMBIENTE

ADMINISTRACIÓN REGIONAL DE

GUÍA DE TRANSPORTE DE PRODUCTOS FORESTALES

Marquilla No.:

GUÍA No:

RECIBO DE CAJA No.:

La Autoridad Nacional del Ambiente, en cumplimiento con la Ley no. 31 de 3 de febrero de 1994 y la Resolución de Junta Directiva 05-98 de 22 de enero de 1998, expide el presente documento que autoriza la movilización de los siguientes productos:

\begin{tabular}{|l|l|l|l|}
\hline Especies & Forma de producto & Cantidad & Volumen $\left(\mathbf{m}^{3}\right)$ \\
\hline & & & \\
\hline & & & \\
\hline & & & \\
\hline & & & \\
\hline & & & \\
\hline & & & \\
\hline & & & \\
\hline TOTAL & & & \\
\hline
\end{tabular}

Descripción del Transporte:

$\square$ Terrestre

$\square$ Acuático

Placa o matrícula: Domicilio del Transportista/Teléfono

Propietario:

No. de Resolución o Permiso:

(Especificar nombre del concesionario)

Domicilio del Concesionario:

Lugar de procedencia:

Lugar

Corregimiento

Provincia

Destino:

Aserradero: Propiedad de:

Otro: Propiedad de: 
El presente documento sólo ampara el producto descrito, todo producto transportado no descrito será retenido en cumplimiento a la Ley No. 1 de 3 de febrero de 1994 y se aplicaran las sanciones correspondientes.

Expedido en el

día $\frac{1}{\text { mes }} \frac{}{\text { año }}$

OBSERVACIÓN: La guía de transporte tendrá validez de 72 horas para transporte terrestre y 96 horas para y transporte fluvial o marítimo. No se permitirá transporte terrestre después de las 6:00 p.m.

Nota: El presente formu

lario debe ser completado con letra imprenta o molde y no debe dejarse ningún campo o espacio en blanco 
No.

FECHA:

AUTORIDAD NACIONAL DEL AMBIENTE

ADMINISTRACIÓN REGIONAL DE

SOLICITUD DE PERMISO ESPECIAL DE APROVECHAMIENTO FORESTAL

Para árboles de bosques naturales

Yo , con cédula de identidad

personal con domicilio en

Solicito permiso especial de aprovechamiento forestal en:

Terreno de mi propied ad:

Terreno con derecho posesorio:

Terrenos nacionales:

Otros:

Ubicado en la comunidad de

Corregimiento

de

Distrito de

Provincia de

Permiso para usos:

Doméstico:

Subsistencia: 
Especie (s) solicitada (s):

\begin{tabular}{|l|l|l|}
\hline Especies & Número de árboles & Volumen $\left(\mathrm{m}^{3}\right)$ \\
\hline & & \\
\hline & & \\
\hline & & \\
\hline & & \\
\hline & & \\
\hline & & \\
\hline & & \\
\hline & & \\
\hline
\end{tabular}

Se deberá adjuntar a la presente solicitud:

1. Fotocopia de la cédula de identidad personal.

2. Declaración escrita del solicitante, indicando su carencia de recursos económicos.

3. Paz y Salvo de la ANAM.

4. Acreditar la propiedad del terreno, cuando corresponda.

\section{Se hace de conocimiento del solicitante que:}

1. La solicitud del permiso debe ser tramitado por el interesado o autorización escrita a otra persona para que realice el trámite.

2. La obligación del beneficiario de los permisos especiales de aprovechamiento forestal de plantar diez (10 ( plantones, con un mínimo de $70 \%$ de prendimiento, al finalizar el primer año de plantados, por cada árbol talado.

\section{Firma y cédula del (la) solicitante}


AUTORIDAD NACIONAL DEL AMBIENTE

ADMINISTRACIÓN REGIONAL DE

PERMISO ESPECIAL DE APROVECHAMIENTO FORESTAL No.

Marquilla No.

Recibo de Caja No.

\section{CONSIDERANDO}

Que la administración regional de de la ANAM está facultada para expedir el permiso de aprovechamiento y determinar el monto a cancelar en concepto de servicios técnicos correspondientes.

Que el señor (a) con cédula de identidad personal

nacionalidad con domicilio en

Que los árboles a aprovechar están ubicados en

provincia: distrito: , Corregimiento:

\section{RESUELVE}

1. Conceder a , el permiso solicitado, previo el pago de los servicios técnicos según legislación vigente, el cual corresponde a: (B/. ), sobre la siguiente madera:

\begin{tabular}{|l|l|l|}
\hline NOMBRE COMÚN & NÚMERO DE ÁRBOLES & VOLUMEN $\left(\mathrm{m}^{3}\right)$ \\
\hline & & \\
\hline & & \\
\hline & & \\
\hline & & \\
\hline & & \\
\hline
\end{tabular}


2. El ben eficiario de este permiso deberá respetar los Derechos de Propiedad.

3. Este permiso estará vigente por treinta (30) días, a partir de la fecha de su publicación.

4. El Señor o la Señora quedará sujeto a lo establecido en la Ley No. 41 de 1998, Ley No. 1 d 3 de febrero de 1994, su reglamentación y otras normas complementarias y concordantes.

5. En los casos de los permisos con carácter doméstico se prohíbe la venta o comercialización de la madera talada.

Nombre del Inspector Forestal:

Firma del Administrador regional: Fecha de expedición:

Notificada al solicitante a las del de de 200

Nombre y firma del beneficiario

\section{SOLO PARA USO DE LA ANAM EN EL PUESTO DE CONTROL}

\begin{tabular}{|l|c|c|c|c|c|c|}
\hline ESPECIES & $\begin{array}{c}\text { FORMA DE } \\
\text { PRODUCTO }\end{array}$ & $\begin{array}{c}\text { VOLUMEN } \\
\text { APROBADO }\end{array}$ & $\begin{array}{c}\text { VOLUMEN } \\
\text { TRANSPORTADO }\end{array}$ & $\begin{array}{c}\text { FECHA DE } \\
\text { TRANSPORTE }\end{array}$ & $\begin{array}{c}\text { SALDO } \\
\text { PENDIENTE }\end{array}$ & OBSERVACIÓN \\
\hline & & & & & & \\
\hline & & & & & & \\
\hline & & & & & & \\
\hline
\end{tabular}

Todo producto extraído sin el amparo del presente Permiso será motivo de multa y decomiso de acuerdo a la Ley No. 1 de 3 de febrero de 1994 (Ley Forestal de la república de panamá).

Nota: El presente formulario debe ser completado con letra imprenta o molde y no debe dejarse ningún campo o espacio en blanco.

Firma Inspector puesto de control

Firma Inspector puesto de control

Firma Inspector puesto de control

$$
\text { Fecha }
$$

Fecha

Fecha
Puesto de Control

Puesto de Control

Puesto de Control 
Anexo 6. Modificaciones y derogación de disposiciones de la Ley 24 de 1992, de incentivos a la actividad de reforestación, por la Ley 6 del 2005 (ver texto explicativo)

\section{Ley 24 de 1992 Incentivos a la Reforestación (versión original)}

Art. 3. Se consideran las plantaciones

forestales como un cultivo con libertad para el aprovechamiento, transformación comercialización a nivel nacional e internacional; sin embargo, los propietarios deben informar a la autoridad forestal para obtener la guía gratuita de transporte y para consignar la información en los registros estadísticos.

Art. 4. Las utilidades de personas naturales o jurídicas derivadas de la comercialización de productos extraídos de plantaciones forestales, hasta el corte final de la plantación forestal, y cuyo cumplimiento se realice dentro de los veinticinco (25) años, contados a partir de la vigencia de esta Ley, estarán exentas del pago de impuesto sobre la renta, siempre que los propietarios estén inscritos en el registro Forestal de la ANAM.

Art. 5 Se consideran gastos deducibles del impuesto sobre la renta el $100 \%$ de la inversiones forestales o de las inversiones forestales indirectas, efectuadas por personas naturales o jurídicas, si las sumas invertidas provienen de una fuente distinta a la actividad de reforestación. Las inversiones indirectas deben mantenerse por un periodo mínimo de cinco años.

Art. 6. Quedan exentos del pago de impuestos de importación y demás aranceles, la introducción de maquinaria y equipo agrícola, forestal, industrial, rodante, herramientas, agro-químicos, semillas, estacas, plantas y equipo de investigación utilizado en el manejo y aprovechamiento de la reforestación.

Art. 7. Se declaran exentas del pago de impuestos de inmuebles y del impuesto de transferencia de bienes inmuebles, las fincas dedicadas a la reforestación en más de $50 \%$ de su terreno y que tengan un mínimo de 200 ha reforestadas.

Art. 8. Las utilidades de bonos, acciones y valores de sociedades dedicadas a la reforestación y sus actividades derivadas y afines, y las ganancias que se obtengan en la enajenación de estos bonos, acciones y valores estarán exentas del pago de impuestos sobre la renta. Los tenedores de estos bonos, acciones y valores podrán utilizar estos documentos como garantías de transacciones bancarias.

\section{Modificación en la Ley 2 de Equidad Fiscal, de febrero de 2005}

Art. 3 Queda igual.

Art. 4. Las utilidades, de personas naturales o jurídicas derivadas de la comercialización de productos extraídos de plantaciones forestales, hasta el corte final de la plantación forestal, y cuyo cumplimiento se realice dentro de los trece (13) años, contados a partir de la vigencia de esta Ley, estarán exentas del pago de impuesto sobre la renta, siempre que los propietarios estén inscritos en el registro Forestal de la ANAM.

Art. 5. Derogado.

Art. 6 Queda igual.

Art. 7. Se declaran exentas del pago de impuestos de inmuebles y del impuesto de transferencia de bienes inmuebles, las fincas dedicadas exclusivamente a la reforestación en más de $75 \%$ de su terreno, siempre que se encuentre inscrita en el registro forestal de ANAM.

Art. 8 Derogado. 
Ley 24 de 1992 Incentivos a la Reforestación (versión original)

Art. 9. El Órgano Ejecutivo fomentará la creación de líneas de crédito con intereses preferenciales y de préstamos forestales preferenciales para reforestación a través de instituciones de crédito oficiales y banca privada, asociaciones de ahorro y préstamo, financieras. (...) Los préstamos forestales preferenciales tendrán un tramo preferencial de hasta cuatro puntos porcentuales inferior a la tasa de interés de mercado local

Art. 11. Todo inversionista extranjero que realice una inversión forestal o inversión forestal indirecta por la suma de US $\$ 40,000$ o más, dentro de la República de Panamá, podrá optar por la visa de inmigrante inversionista, a través de compra de acciones, bonos, valores o inversionista a cuenta propia.

\section{Modificación en la Ley 2 de} Equidad Fiscal, de febrero de 2005

Art. 9 Derogado.
Art. 11. Derogado por Ley 2 de 2005. Transferido a la Ley de Migración.

Fuente: ANAM, 2008b 


\section{Anexo 7. Proceso forestal de la tala ilegal en el Darién}

Flujograma de Procesos Forestales Darién

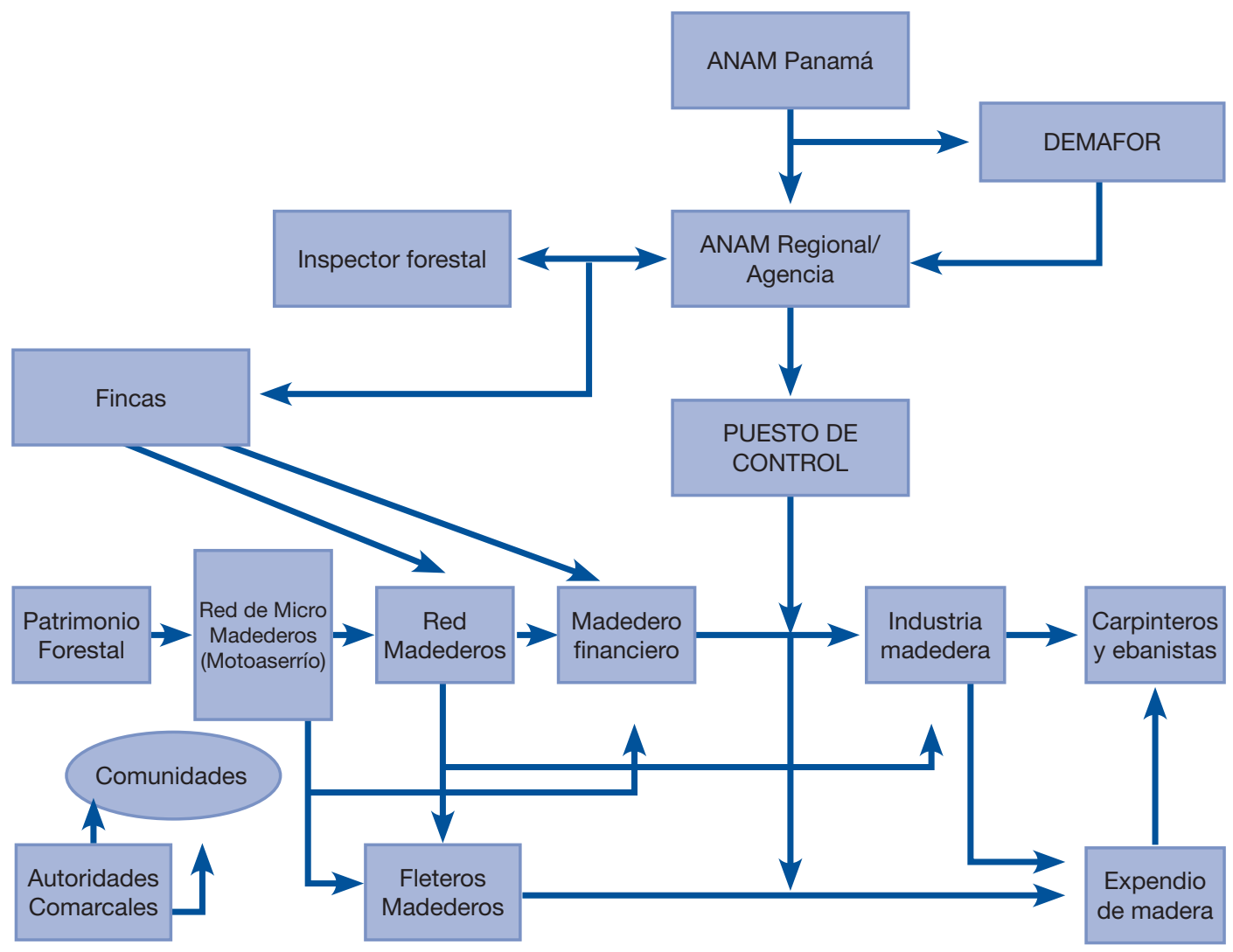

Fuente: Argüelles, 2010 
Anexo 8. Maderas comerciables de alto valor comercial en Panamá

\begin{tabular}{|l|l|}
\hline \multicolumn{1}{|c|}{ Nombre común } & \multicolumn{1}{c|}{ Nombre científico } \\
\hline Amargo amargo & Vatairea sp \\
\hline Caoba & Swietenia macrophylla \\
\hline Cedro amargo & Cedrela odorata \\
\hline Cedro cebolla & Cederla tonduzii \\
\hline Cedro espino & Bombacopsis quinata \\
\hline Cocobolo & Dalbergia retusa \\
\hline Guayacán & Tabebuia guayacan \\
\hline Laurel & Cordia alliodora \\
\hline María & Calophyllum brasilensis \\
\hline Nazareno & Peltogyne purpurea \\
\hline Pino amarillo & Pithecelobium manguense \\
\hline Quira & Platymiscium pinnatum \\
\hline Roble, roble de sabana & Tabebuia pen \\
\hline Tangaré, cedro bateo, cedro macho & Carapa sp \\
\hline Las especies maderables comerciables de alto valor comercial generan un pago por servicios a la ANAM de \\
$15 \$ \mathrm{~m}^{3}$ de madera en rollo (tuca) y de $20 \$ \mathrm{x} \mathrm{m}^{3}$ de madera aserrada. \\
\hline
\end{tabular}

\section{Anexo 9. Maderas comerciables de menor valor comercial en Panamá}

\begin{tabular}{|l|l|}
\hline \multicolumn{1}{|c|}{ Nombre común } & \multicolumn{1}{c|}{ Nombre científico } \\
\hline Amarillo & Terminalia amazónica \\
\hline Amarillo Guayaquil & Centrolobium yavizanum \\
\hline Amarillo pepita & Lafoensia punicifolia \\
\hline Ajo & Cassipourea sp \\
\hline Alcarreto & Aspicosperma megalocarpon \\
\hline Alcornoque & Nora oleifera \\
\hline Algarrobo & Hymenaea courbaril \\
\hline Almendro & $\begin{array}{l}\text { Coumarouna oleifera } \\
\text { Sin. Dipteryx panamensis Olelcorpon panamensis } \\
\text { Sin. Platymiscium polystachyum Dalbergia custatlanica }\end{array}$ \\
\hline Baco & Magnolia sororum \\
\hline Balsa & Ochroma lagopus \\
\hline Bálsamo & Miroxylon balsamun \\
\hline Bambito amarillo & Ocotea sp \\
\hline Bambito rosado & Ocotea austinli \\
\hline Berbá & Brosimum utile \\
\hline Bongo & Ceiba pentandra \\
\hline Cabimo & Copaifera aromatica \\
\hline Cañafístula & Cassia fistula \\
\hline Cativo & Prioria copaifera \\
\hline Cerillo, Cero & Symphonia globulifera \\
\hline Coco & Lecythis tuyrana \\
\hline Corotú & Enterolobium cyclocarpum \\
\hline & \\
\hline
\end{tabular}




\begin{tabular}{|c|c|}
\hline Nombre común & Nombre científico \\
\hline Cortezo & Apeaba aspera \\
\hline Cuajao & Vitex cooperi \\
\hline Cutarro & Swartzia panamensis \\
\hline Espavé & Anacardium excelsum \\
\hline Frijolillo & Poeppigia procera \\
\hline Guayabillo & Terminalia lucia \\
\hline Guayabo de montaña & Eugenia sp \\
\hline Jobo & Spondia mombís \\
\hline Madroño & Calycophyllum candissium \\
\hline Mamecillo colorado & Sloanea $s p$ \\
\hline Mango & Manguifera indica \\
\hline Mata hombro & Cornus disciflora \\
\hline Mayo blanco, Corozo & Vochysia hondurensis \\
\hline Mayo negro & Vochysia ferruginea \\
\hline Membrillo & Gustabia sp \\
\hline Miguelario & Virola $s p$ \\
\hline Nance & Byrsoniama crassifolia \\
\hline Níspero & Manilkara achras \\
\hline Nuno, Ceibo & Hura crepitans \\
\hline Olivo, Ñipa & Sapium sp \\
\hline Orey & Camprosperma panamensis \\
\hline Panamá & Sterculia apetala \\
\hline Pava, Mangabé, Gargorán, Pavo & Didymopanax morototoni \\
\hline Punula & Quararibea sp \\
\hline Sandé & Brosimum $s p$ \\
\hline Sangre & Ptercarpus officinalis \\
\hline Sangrillo negro & Panamachaerium gruberi \\
\hline Sigua & Nectandra sp \\
\hline Tachuelo, Alcabú & Zanthoxylum sp \\
\hline Yaya & $\begin{array}{l}\text { Oxandra sp } \\
\text { Sin Unonopsis sp }\end{array}$ \\
\hline Zapatero, Plátano, Pilón & Hyeronyma alchorneoides \\
\hline Zorro & Astronium graveolens \\
\hline \multicolumn{2}{|c|}{$\begin{array}{l}\text { Las especies maderables comerciables y potencialmente comerciales clasificadas de menor valor comercia } \\
\text { (y de menor diámetro) generan un pago por servicios a la ANAM de } 10 \$ \mathrm{x} \mathrm{m}^{3} \text { de madera en rollo (tuca) y } 15 \\
\mathrm{x} \mathrm{m}^{3} \text { de madera aserrada. }\end{array}$} \\
\hline
\end{tabular}




\section{Anexo 10. Tipos penales relacionados con actividades forestales en la República de Panamá}

\begin{tabular}{|c|c|c|}
\hline \multicolumn{3}{|c|}{$\begin{array}{c}\text { Título XIII } \\
\text { Delitos contra el Ambiente y el Ordenamiento Territorial } \\
\text { Capítulo I: Delitos contra los recursos naturales }\end{array}$} \\
\hline Artículo & Conducta & Pena \\
\hline 399 & $\begin{array}{l}\text { Destruir, extraer, contaminar o degradar recursos naturales } \\
\text { infringiendo las normas de protección al ambiente. } \\
\text { Agravantes: En áreas protegidas, ecosistemas } \\
\text { costeros marinos o humedales, daño directo a cuencas } \\
\text { hidrográficas, daño a áreas de especial valor biológico, } \\
\text { histórico, arqueológico o científico. Cuando se afecten } \\
\text { ostensiblemente recursos hídricos que incida negativamente } \\
\text { en el ecosistema; si pone en peligro la salud o la vida } \\
\text { de las personas; si la conducta la realiza una industria o } \\
\text { actividad sin que haya obtenido la respectiva autorización } \\
\text { o aprobación; cuando haya mediado falsedad, ocultado } \\
\text { información, obstaculizado inspección. Cuando el daño sea } \\
\text { irreversible. }\end{array}$ & $\begin{array}{l}\text { De } 3 \text { a } 6 \text { años de prisión } \\
\text { Se aumenta la pena de } 1 / 3 \text { a la } \\
1 / 2 \text {. }\end{array}$ \\
\hline 403 & $\begin{array}{l}\text { Quien venda o traspase a cualquier título permiso de } \\
\text { subsistencia doméstica sin autorización legal. } \\
\text { Si se trata de permiso de explotación comunitaria, es } \\
\text { agravante. }\end{array}$ & $\begin{array}{l}50 \text { a } 100 \text { días multa } \\
1 \text { a } 3 \text { años de prisión }\end{array}$ \\
\hline 404 & $\begin{array}{l}\text { Quien compre o adquiera del beneficiario un permiso } \\
\text { doméstico o de subsistencia para la tala de árboles que no le } \\
\text { corresponda. } \\
\text { Si se trata de permiso de explotación comunitaria, es } \\
\text { agravante. }\end{array}$ & $\begin{array}{l}1 \text { a } 3 \text { años de prisión } \\
3 \text { a } 5 \text { años de prisión }\end{array}$ \\
\hline 405 & $\begin{array}{l}\text { Talar árboles con autorización excediendo la cantidad, } \\
\text { especie o el área concedida. }\end{array}$ & $\begin{array}{l}2 \text { a } 5 \text { años de prisión } \\
\text { Se reduce a la mitad si hay culpa. }\end{array}$ \\
\hline 406 & $\begin{array}{l}\text { Talar, destruir o degradar formaciones vegetales arbóreas o } \\
\text { arbustivas constitutivas de bosque o sujetas a protección } \\
\text { especial, en áreas protegidas, cuencas hidrográficas, en } \\
\text { zonas prohibidas o restringidas, o cuando estas protejan } \\
\text { vertientes que provean de agua potable a la población, sin } \\
\text { autorización o incumpliendo la normativa existente. }\end{array}$ & 3 a 7 años de prisión \\
\hline 407 & $\begin{array}{l}\text { Incendiar masas vegetales sin autorización de autoridad } \\
\text { competente. } \\
\text { Se agrava la pena si se produce pérdida de fertilidad del } \\
\text { suelo o desecación; si se afecta superficie de más de } 5 \text { ha; } \\
\text { si se producen daños significativos a la calidad de la vida } \\
\text { vegetal; si se realiza para obtener un beneficio económico; si } \\
\text { se realiza en áreas protegidas o cuencas hidrográficas. }\end{array}$ & $\begin{array}{l}1 \text { a } 3 \text { años de prisión o } \\
\text { equivalente días multa o arresto } \\
\text { fin de semana } \\
\text { Se aumenta de } 1 / 4 \text { a } 1 / 2 \text {. } \\
\text { Se reduce a la mitad si hay culpa. } \\
\text { Se exime de la pena si es por } \\
\text { subsistencia familiar. }\end{array}$ \\
\hline
\end{tabular}




\begin{tabular}{|c|c|c|}
\hline \multicolumn{3}{|c|}{$\begin{array}{c}\text { Título XIII } \\
\text { Delitos contra el Ambiente y el Ordenamiento Territorial } \\
\text { Capítulo I: Delitos contra los recursos naturales }\end{array}$} \\
\hline Artículo & Conducta & Pena \\
\hline \multicolumn{3}{|c|}{$\begin{array}{l}\text { Capítulo III } \\
\text { Delitos de tramitación, aprobación } \\
\text { y cumplimiento urbanístico territorial }\end{array}$} \\
\hline 412 & $\begin{array}{l}\text { Incorporar o suministrar información falsa o inexacta, u } \\
\text { omita información fundamental, a sabiendas, si con ello } \\
\text { pone en peligro la salud humana o el ambiente, la persona } \\
\text { debidamente autorizada para realizar estudios de impacto } \\
\text { ambiental, planes de manejo forestal, inventarios forestales u } \\
\text { otros estudios de naturaleza similar. } \\
\text { La pena se agrava si se genera daño a la salud, al ambiente } \\
\text { o a alguno de sus componentes. }\end{array}$ & Aumenta de $1 / 3$ a $1 \frac{2}{2}$ \\
\hline 413 & $\begin{array}{l}\text { El servidor público que, inobservando la normativa ambiental } \\
\text { correspondiente al ejercicio de sus funciones, promueva la } \\
\text { aprobación o apruebe un estudio de impacto ambiental (...) u } \\
\text { otro documento aprobado por la ANAM. }\end{array}$ & 2 a 4 años de prisión \\
\hline 414 & $\begin{array}{l}\text { El promotor o el concesionario que incumpla los estudios } \\
\text { de impacto ambiental, planes de manejo forestal, inventario } \\
\text { forestal u otros documentos de naturaleza similar aprobados } \\
\text { por la ANAM, o la resolución que los aprueba. } \\
\text { Si se producen daños graves a la salud humana o al } \\
\text { ambiente o a algunos de sus componentes, o a las } \\
\text { actividades económicas se agrava. }\end{array}$ & $\begin{array}{l}2 \text { a } 5 \text { años de prisión } \\
\text { Aumenta de } 1 / 3 \text { a la } 1 / 2 \text {. } \\
\text { Se reduce a la mitad si hay culpa. }\end{array}$ \\
\hline 415 & $\begin{array}{l}\text { Quien conociendo la irregularidad cometida haga uso o } \\
\text { derive provecho de cualquier modo, de los tipos penales } \\
413 \text { y } 414 \text {, aunque no haya participado en su ejecución, será } \\
\text { sancionado como autor. }\end{array}$ & 2 a 5 años de prisión \\
\hline 417 & $\begin{array}{l}\text { Los promotores, constructores o técnicos directores } \\
\text { que realicen una construcción no autorizada en suelos } \\
\text { destinados a servidumbres de ríos o cauces naturales, en } \\
\text { áreas verdes, en bienes de dominio público, o en lugares } \\
\text { que tengan legal o administrativamente reconocido su valor } \\
\text { paisajístico, ecológico, artístico, histórico o cultural, o que } \\
\text { por los mismos motivos hayan sido considerados de especial } \\
\text { protección. }\end{array}$ & 3 a 6 años de prisión \\
\hline 418 & $\begin{array}{l}\text { El promotor o el concesionario que inicie la ejecución de } \\
\text { una obra o de actividades sujetas a la aprobación previa } \\
\text { del estudio de impacto ambiental, plan de manejo forestal } \\
\text { u otros documentos similares, que de acuerdo con la ley, } \\
\text { sean requisitos previos o condicionales para iniciar, sin } \\
\text { haber obtenido la aprobación de la autoridad competente } \\
\text { correspondiente. } \\
\text { Si causa daño al ambiente, o alguno de sus componentes, a } \\
\text { la salud humana o a la economía nacional. }\end{array}$ & $\begin{array}{l}\text { Se aumenta la pena de } 1 / 3 \text { a la } \\
1 / 2 \text {. }\end{array}$ \\
\hline
\end{tabular}




\section{Título XIII}

Delitos contra el Ambiente y el Ordenamiento Territorial Capítulo I: Delitos contra los recursos naturales

\begin{tabular}{|c|c|c|}
\hline Artículo & Conducta & Pena \\
\hline \multicolumn{3}{|c|}{$\begin{array}{c}\text { Capítulo V } \\
\text { Disposiciones Comunes }\end{array}$} \\
\hline 423 & $\begin{array}{l}\text { Cuando una persona jurídica sea utilizada para promover, } \\
\text { ocasionar, subsidiar o dirigir algunos de los hechos } \\
\text { punibles lesivos al ambiente, descritos en el presente Título, } \\
\text { dependiendo de la gravedad del daño ambiental causado. }\end{array}$ & $\begin{array}{l}\text { Multa de US5,000\$ máximo } 100 \\
\text { millones de dólares }\end{array}$ \\
\hline \multicolumn{3}{|c|}{ Fuente: Elaborado por Jessica Young, 2013} \\
\hline
\end{tabular}




\section{Anexo 11. Jurisprudencia y criterios Procuraduría de la Administración}

Respuesta a Nota AG-1147-2001 de 18 de junio de 2001, en la que el Administrador General Encargado de la Autoridad Nacional del Ambiente (ANAM) eleva consulta sobre la vigencia de las Resoluciones Administrativas que autorizan Permisos Anuales de Corta, otorgados con fundamento en las Concesiones de Aprovechamiento Forestal o los Permisos Comunitarios de Aprovechamiento Forestal.

C-214 de 6 de septiembre de 2001 consulta del Ing. Gonzalo Menéndez, Administrador General Encargado de la ANAM

La ANAM otorgó permisos comunitarios de aprovechamiento forestal en determinados polígonos de áreas indígenas, con vigencia de dos (2) años. Dentro del mismo radio de acción y con ocasión de dichos permisos, se concedieron a su vez Permisos Anuales de Corta, mediante Resoluciones Administrativas [distintas], pero por un período de un (1) año. Sin embargo, el meollo del asunto estriba en que aun cuando las Resoluciones Administrativas que conceden los permisos anuales de corta a la comunidad indígena sólo tienen una duración de un (1) año, lo cierto es que éstos comienzan a surtir sus efectos a partir de su notificación, de allí que sobrepasen el período de dos (2) años en que han sido otorgados los permisos comunitarios de aprovechamiento forestal.

La Constitución Política en su artículo 116, al referirse a los recursos naturales, sujeta la utilización y aprovechamiento racional de los recursos naturales a la fiscalización y reglamentación del Estado. La Ley 1 de 1994, que regula la materia forestal en la República de Panamá, reglamentada a través de la Resolución de Junta Directiva $N^{\circ}$ 05-98 de 1998, establece las formalidades y requisitos que deben reunirse para el adecuado aprovechamiento forestal mediante los permisos, autorizaciones y concesiones que tengan a bien otorgarse para beneficiar a la comunidad que así lo requiera. En su artículo 28 se establece que: "Los volúmenes y especies totales y anuales a otorgar, el tamaño de las unidades de manejo forestal, así como los períodos de vigencia de los permisos, contratos y autorizaciones de aprovechamiento forestal, se basarán en los siguientes criterios técnicos: posibilidad anual del bosque, diámetros mínimos de corta permisibles, masa forestal remanente, ciclo de corta y condiciones ecológicas del área". También debe tomarse en cuenta las especificaciones contempladas en el Plan de Manejo Forestal como instrumento elaborado por profesionales idóneos en ciencias forestales y contentivo de los inventarios y planes de reforestación de los bosques naturales o artificiales. En este sentido la Ley Forestal es clara al expresar que el incumplimiento del Plan de Manejo Forestal impide el otorgamiento de la siguiente autorización anual de aprovechamiento (corta) hasta que se subsane la situación (Cfr. Artículo 25, numeral 6) de la Resolución $N^{\circ}$ 05-98 de 1998).

El artículo 37 establece que: "Los permisos, contratos o autorizaciones de aprovechamiento forestal, previa justificación, podrán prorrogarse por un período de hasta cinco (5) años, siempre que hayan cumplido de manera satisfactoria con los términos del permiso, contrato o autorización con el plan de manejo forestal aprobado por INRENARE -hoy la ANAM- y con las medidas de mitigación ambiental. El cumplimiento del plan de manejo a satisfacción de la autoridad competente otorgará a los interesados el derecho de renovación de los respectivos permisos, concesiones o autorizaciones forestales, por un período igual al ciclo de corta. Dicha renovación será únicamente para el aprovechamiento del bosque y no otorga derechos sobre la tierra. Como puede observarse, la norma copiada resalta el hecho de que las autorizaciones, permisos y concesiones pueden prorrogarse (...), siempre que se haya cumplido a satisfacción con los términos del permiso, contrato o autorización, así como con el plan de manejo y con las medidas de mitigación ambiental. Por su parte, la Ley General de Ambiente señala la respuesta, se encarga de establecer principios y normas básicas para la protección, conservación y recuperación del ambiente, promoviendo el uso sostenible de los recursos naturales. Dentro de este contexto, el artículo 62 de la Ley General de Ambiente, Ley 41 de 1998, sostiene que la presente ley tiene entre sus objetivos incorporar el concepto de sostenibilidad y el de racionalidad en el aprovechamiento de los recursos naturales.

La vigencia de los permisos anuales de corta no puede exceder el período de tiempo concedido en los permisos comunitarios de aprovechamiento forestal. 
SÍNTESIS 1: El acto administrativo principal lo constituye la resolución administrativa que aprueba los permisos comunitarios, mientras que la resolución administrativa que aprueba y otorga los permisos anuales de corta deriva del mismo o está sujeta al primero, si ello es así, entonces eso significa que al extinguirse los efectos del acto primero o principal igual suerte corre el acto segundo o permisos anuales de corta, siguiendo un principio o aforismo latino que dice: accessorium cedit principali, que quiere decir que lo accesorio accede a lo principal. Y, es que lógicamente al quedar sin efecto el acto principal quedan sin efecto igualmente las condiciones y controles que deben ejercerse en función de él y consiguientemente se pierden los objetivos perseguidos.

En tal virtud, nos permitimos sugerir que para evitarse conflictos al respecto, al expedirse los permisos anuales de corta, deben ajustarse a las fechas de vigencia y expiración de los actos principales.

DEMANDA CONTENCIOSO ADMINISTRATIVA DE PLENA JURISDICCIÓN INTERPUESTA POR EL LICENCIADO CID AGUILERA, EN REPRESENTACIÓN DE ALBERTO MEDINA, PARA QUE SE DECLARE NULA, POR ILEGAL, LA RESOLUCIÓN ADMINISTRATIVA No ARAPE 012-2002 DE 9 DE ABRIL DE 2002, DICTADA POR EL ADMINISTRADOR REGIONAL DEL AMBIENTE DE PANAMÁ ESTE, EL ACTO CONFIRMATORIO, Y PARA QUE SE HAGAN OTRAS DECLARACIONES. PONENTE: ARTURO HOYOS. PANAMÁ, VEINTIOCHO (28) DE JUNIO DE DOS MIL CUATRO (2004).

Tribunal: Corte Suprema de Justicia, Panamá. Sala: Tercera de lo Contencioso Administrativo Ponente: Arturo Hoyos. Fecha: 28 de junio de 2004. Materia: Acción contenciosa administrativa. Plena Jurisdicción. Expediente: 362-02.

El licenciado Cid Aguilera, actuando en nombre y representación de ALBERTO MEDINA, presentó ante la Sala Tercera de la Corte Suprema demanda contencioso administrativa de plena jurisdicción para que se declare nula, por ilegal, la Resolución Administrativa No ARAPE 012-2002 de 9 de abril de 2002, emitida por el Administrador Regional de la Autoridad Nacional del Ambiente de Panamá Este, el acto confirmatorio, y para que se hagan otras declaraciones. El apoderado judicial del demandante solicita a esta Sala declare que es nula, por ilegal, la Resolución Administrativa N ARAPE 012-2002 de 9 de abril de 2002, dictada por la Autoridad Nacional del Ambiente de Panamá Este, mediante la cual se sanciona al señor ALBERTO MEDINA con multa de setecientos ochenta balboas $(B / .780 .00)$ por infringir la Ley $\mathrm{N}^{\circ} 1$ de 3 de febrero de 1994, y se ordena decomisar las cuarenta y dos (42) tucas de caoba de propiedad del demandante. Asimismo, solicita se declare la nulidad del acto confirmatorio contenido en la Resolución Administrativa ARAPE № 016-002 de 6 de mayo de 2002, expedida por el Administrador Regional de la Autoridad Nacional del Ambiente de Panamá Este. Además, y como consecuencia de las declaraciones anteriores, el demandante solicita se levante la sanción impuesta y se le entregue la madera que le fue decomisada.

Por su parte, la Procuradora de la Administración, licenciada Alma Montenegro de Fletcher, por medio de Vista $N^{\circ} 586$ de 29 de octubre de 2002, solicita sean denegadas las pretensiones del demandante. Ello puesto que, a juicio de la representante del Ministerio Público, no han sido infringidas ninguna de las normas alegadas pues ellas hacen alusión al procedimiento por denuncia y en el caso que nos ocupa, señala la señora Procuradora, ha quedado acreditado que las 42 tucas de caoba fueron encontradas por los inspectores de la ANAM.

Según se desprende del expediente administrativo, el 26 de marzo de 2002, funcionarios del Departamento de Administración Forestal de la ANAM detectaron en el área de Cañazas, Corregimiento de Tortí, un patio con cuarenta y dos (42) tucas de caoba, pertenecientes al señor ALBERTO MEDINA, las cuales fueron extraídas de la comunidad indígena de Wala en la Provincia de Darién, previo a la expedición del permiso de aprovechamiento forestal y sin que las mismas contaran con guía de movilización emitida por la ANAM.

(...) que las citadas tucas de caoba fueran ubicadas durante una gira de fiscalización e inspección para titulación de tierras, efectuada por inspectores del Departamento de Administración Forestal de Panamá Este.

ARTURO HOYOS, WINSTON SPADAFORA FRANCO y ADÁN ARNULFO ARJONA L.

JANINA SMALL (Secretaria) 
SÍNTESIS 2: La Corte Suprema, Sala Contencioso Administrativa, administrando justicia en nombre de la República y por autoridad de la Ley, DECLARA QUE NO ES ILEGAL la Resolución Nº ARAPE 012-2002 de 9 de abril de 2002, proferida por el Administrador de la Autoridad Nacional del Ambiente de Panamá Este y se NIEGAN las demás pretensiones. Se mantiene la multa por tala ilegal, posesión ilegal, transporte ilegal de madera.

DEMANDA CONTENCIOSO-ADMINISTRATIVA DE PLENA JURISDICCIÓN, INTERPUESTA POR LA LICENCIADA MARÍA TORRES MARTÍNEZ EN REPRESENTACIÓN DE CAYETANO TORRES HENRÍQUEZ, PARA QUE SE DECLARE NULA, POR ILEGAL, LA RESOLUCIÓN ADMR-PM-017-02-02 DE 20 DE JUNIO DE 2002, DICTADA POR LA ADMINISTRADORA REGIONAL DEL AMBIENTE DE PANAMÁ METROPOLITANA, EL ACTO CONFIRMATORIO Y PARA QUE SE HAGAN OTRAS DECLARACIONES. PONENTE: ADÁN ARNULFO ARJONA L. PANAMÁ, NUEVE (9) DE JULIO DE DOS MIL CUATRO (2004).

Tribunal: Corte Suprema de Justicia, Panamá. Sala: Tercera de lo Contencioso Administrativo. Ponente: Adán Arnulfo Arjona L. Fecha: 9 de julio de 2004. Materia: Acción contenciosa administrativa. Plena Jurisdicción. Expediente: 49-2002.

La Licenciada María Torres Martínez, actuando en representación de CAYETANO TORRES HENRÍQUEZ, ha interpuesto Demanda Contencioso-Administrativa de Plena Jurisdicción a fin de que se declare nula, por ilegal, la Resolución ADMR-PM-017-02-02 de 20 de junio de 2002, dictada por la Administradora Regional del Ambiente de Panamá Metropolitana, así como el acto confirmatorio y para que se hagan otras declaraciones. El señor Cayetano Torres fue sancionado por la Administradora Regional de la Autoridad Nacional del Ambiente, por considerar ésta que el señor Torres había incurrido en la infracción que consiste en "socuela de rastrojo a orillas del río Chagres sin la debida autorización". Desde hace muchos años, los agricultores de la región se dedican a sus labores sin autorización escrita porque los guardaparques dan la autorización verbal para proceder con la tala y siembra, y en la mayoría de los casos no se llegan a concretizar los respectivos permisos por escrito. El guardabosques Rolando Guerrero otorgó permiso verbal al señor Cayetano Torres, a través de su padre, para iniciar la tala, informando que la autorización escrita la traería después y que la inspección no era necesaria. Este hecho, presenciado por dos testigos más, es negado posteriormente por el señor Guerrero. La tala data de hace 5 años y nunca se sancionó a ninguno de los moradores del área que se dedican a estas labores, a pesar de que los guardabosques eran conocedores de la actividad, toda vez que los mismos otorgaban los permisos irregularmente. Que la sanción fue impuesta sobre la base de un informe de técnico, sin que se haya efectuado una inspección a fin de determinar el daño causado al medio ambiente ni la existencia de sembradíos existentes, a pesar de que la misma ha sido solicitada por el señor Torres.

Artículos 23 y 24 de la Ley $\mathrm{N}^{\circ} 1$ de 3 de febrero de 1994

"Artículo 23: Queda prohibido el aprovechamiento forestal; el dañar o destruir árboles o arbustos en las zonas circundantes al nacimiento de cualquier cauce natural de agua, así como en las áreas adyacentes a lagos, lagunas, ríos y quebradas. Esta prohibición afectará una franja de bosques de la siguiente manera. 1. Las áreas que bordean los ojos de agua que nacen en los cerros en un radio de 200 metros y de cien metros si nacen en terrenos planos; 2. En los ríos y quebradas, se tomará en consideración el ancho del cauce y se dejará a ambos lados una franja de bosque igual o mayor al ancho del cauce que en ningún caso será menor de 10 metros; 3. Una zona de hasta 100 metros desde la ribera de los lagos y embalses naturales; 4. Las áreas de recarga acuífera de los ojos de agua en que las aguas sean para consumo social. Estos bosques a orillas de los cuerpos de agua no pueden ser talados bajo ningún argumento y serán considerados bosques de preservación permanente". "Artículo 24: En las cabeceras de los ríos, a lo largo de las corrientes de agua y en los embalses naturales o artificiales, cuando se trate de bosques artificiales, queda prohibido el aprovechamiento forestal, así como daños o destrucción de árboles o arbustos dentro de las siguientes distancias: 1. Las áreas que bordean los ojos de agua que nacen en los cerros en un radio de 100 metros y de 50 metros, si nacen en terrenos planos; 2. En los ríos y quebradas, se tomará en consideración el ancho del cauce y se dejará el ancho del mismo a ambos lados, pero en ningún caso será menor de 10 metros. También podrá dejarse una franja de bosque, como distancia, no menor de 10 metros. 3. Las áreas de recarga acuífera en un radio de 50 metros de los ojos de agua en que las aguas sean para consumo social. En los embalses naturales o artificiales hasta de diez (10) metros desde su nivel de aguas máximo. Y cuando sean explotables, podrán talarse árboles que estén previamente marcados por el INRENARE -hoy la ANAM- siempre y cuando el propietario o inversionista se obligue a la reforestación, a más tardar en la época lluviosa inmediata". 
En primer lugar, debemos iniciar señalando que el Artículo 27 de la Ley 1 de 3 de febrero de 1994 señala que "Los bosques pertenecientes al Patrimonio Forestal del Estado podrán ser aprovechados por una de las siguientes modalidades:

1. Mediante permisos especiales de aprovechamiento forestal que otorgará el INRENARE, con carácter doméstico o de subsistencia al solicitante, previa comprobación de carencia de recursos económicos. Estos permisos serán reglamentados por la Junta Directiva del INRENARE, a más tardar un (1) año después de promulgada esta Ley...".

Además, el Artículo 80 de la misma excerta legal establece claramente que "Para limpiar, socolar, rozar o talar un bosque natural primario o secundario en ternos bajo derecho de posesión o propiedad privada, se requiere necesariamente permiso de la autoridad competente, que podrá ser extendido previa inspección obligatoria".

Queda entonces comprobado que la autorización para socolar debe ser, en efecto, emitida por el INRENARE (hoy Autoridad Nacional del Ambiente) y que, tal como lo afirma el demandante, las autorizaciones verbales de los guardabosques no tienen ningún fundamento legal válido. El hecho de que este sistema haya estado o esté siendo utilizado por los guardaparques del área no exime de culpa al demandante, puesto que el mismo es conocedor del procedimiento establecido por ley, como lo señala su apoderada judicial en los hechos quinto y noveno de la demanda. Esta afirmación se puede comprobar también a foja 64 del expediente, donde la apoderada judicial del demandante, en su escrito de alegatos, señala: "De no haberse otorgado autorización para el socuelo, jamás se hubiese dado tanta revuelta con respecto a la misma, ya que el señor Cayetano Torres hubiese aceptado la culpa. Los hechos son muy diferentes, él siempre ha tenido conocimiento que hay que tener permiso para cualquier actividad relacionada con la agricultura...".

Es necesario dejar en claro, en conclusión, que el permiso no es válido sino hasta que la autoridad competente lo emite por escrito y talar o realizar cualquier otra actividad de ese tipo sin contar con la documentación correspondiente no puede ser permitido bajo el argumento de que es la práctica usual del área. Además, no consta en el expediente razón alguna por la cual el señor Torres no pudiera conseguir estos permisos adecuadamente. Esta falta está tipificada en la Ley 1 de 3 de febrero de 1994, en su Artículo 94, que señala: Artículo 94. Se consideran infracciones a esta ley: 1. El aprovechamiento de los bosques naturales sin autorización del INRENARE; 2 . El incumplimiento de las obligaciones que imponen los permisos, concesiones de aprovechamiento forestal y planes de manejo; (...). La tala a orillas de los ojos de agua, lagos, lagunas, ríos y quebradas; y todo incumplimiento de la presente Ley".

Artículo 95 de la Ley Forestal, 1 de 1994. Las infracciones señaladas en el artículo anterior serán sancionadas con multa de hasta cincuenta mil balboas $(\mathrm{B} / .50,000.00)$ según la gravedad, la condición socioeconómica, cultural o la reincidencia del infractor, sin perjuicio de lo que dispongan las leyes penales y civiles. La imposición de las sanciones por las infracciones descritas será competencia del INRENARE, quien las reglamentará en función a través de la Junta Directiva".

ADÁN ARNULFO ARJONA L., ARTURO HOYOS y WINSTON SPADAFORA FRANCO

JANINA SMALL (Secretaria)

SÍNTESIS 3: DECLARAN QUE NO ES ILEGAL la Resolución ADMR-PM-017-02-02 de 20 de junio de 2002 dictada por la Administradora Regional del Ambiente de Panamá y NIEGA las demás pretensiones contenidas en el libelo de la Demanda Contencioso-Administrativa de Plena Jurisdicción interpuesta en representación de CAYETANO TORRES HENRÍQUEZ. Para socolar la legislación exige que medie previo permiso otorgado por la ANAM. Para limpiar, socolar, rozar o talar un bosque natural primario o secundario en ternos bajo derecho de posesión o propiedad privada, se requiere necesariamente permiso de la autoridad competente, que podrá ser extendido previa inspección obligatoria.

DEMANDA CONTENCIOSO ADMINISTRATIVA DE PLENA JURISDICCIÓN INTERPUESTA POR WATSON \& ASSOCIATES, EN REPRESENTACIÓN DE MENCUTO INTERNACIONAL, S.A., PARA QUE SE DECLARE NULA, POR ILEGAL, LA RESOLUCIÓN NN 179-2001 DE 8 DE JUNIO DE 2001, DICTADA POR LA DIRECCIÓN DE ORNATO Y MEDIO AMBIENTE DE LA ALCALDÍA DE PANAMÁ, EL ACTO CONFIRMATORIO, Y PARA QUE SE HAGAN OTRAS DECLARACIONES. PONENTE: ARTURO HOYOS. PANAMÁ, SIETE (7) DE OCTUBRE DE DOS MIL CUATRO (2004). Tribunal: Corte Suprema de Justicia, Panamá Sala: Tercera de lo Contencioso Administrativo Ponente: Arturo Hoyos. Fecha: 7 de Octubre de 2004. Materia: Acción contenciosa administrativa. Plena Jurisdicción. Expediente: 77-02 
Ley 55 de 1973, art. 41: Los derechos sobre extracción de madera, explotación y tala de árboles y bosques naturales con fines comerciales e industriales, tanto en tierras estatales como privadas, serán fuente de ingresos municipales. Se entiende por bosques naturales aquéllos formados sin la intervención del hombre. Artículo 44: Los servidores públicos municipales están obligados a velar por el cumplimiento de las disposiciones legales y reglamentarias relativas a la conservación, protección y desarrollo de los recursos naturales renovables en tierras públicas o privadas. Para tales fines, actuarán en forma coordinada con la Dirección General de Recursos Naturales Renovables del Ministerio de Desarrollo Agropecuario.

Ley 55 de 1973 "Por la cual se regula la administración, fiscalización y cobro de varios tributos municipales", modificada por la Ley 32 de 1996, las autoridades locales tienen competencia legal y especial en materia de tala de árboles. En este sentido, expresa la señora Procuradora, el artículo 41 de la citada Ley establece el derecho del Municipio de cobrar por la extracción de madera, explotación y tala de árboles de bosques naturales, entendiendo como tal, los formados sin la intervención del hombre.

A juicio de la representante del Ministerio Público, la Ley 1 de 1994 y 41 de 1998 son complementarias de la Ley 55 de 1973, y en ningún caso aquéllas excluyen la competencia del Municipio de Panamá para participar en las actividades que comprometan los recursos naturales de su circunscripción. Ello se corrobora, manifiesta la señora Procuradora, con el texto del artículo 7 de la Ley 41 de 1998, el cual en su numeral 12 indica que es atribución de la Autoridad Nacional del Ambiente "promover la transferencia a las autoridades locales de las funciones relativas a los recursos naturales y el ambiente dentro de sus territorios y apoyar técnicamente a las municipalidades en la gestión ambiental local".

Para finalizar, la señora Procuradora manifiesta que en el presente caso no existe doble tributación. Ello porque a la Alcaldía le compete el cobro de derechos por la tala de árboles y a la Autoridad Nacional del Ambiente le corresponde el cobro de una tasa por la inspección forestal previa a la tala y por la evaluación del estudio de impacto ambiental, a tenor de lo dispuesto por los artículos 94, numeral 3 y 42 de la Ley 1 de 1994.

ARTURO HOYOS, WINSTON SPADAFORA FRANCO y ADÁN ARNULFO ARJONA L.

JANINA SMALL (Secretaria)

SÍNTESIS 4: La empresa MENCUTO INTERNACIONAL, S.A., propietaria del proyecto "Lotificación Valle de San Francisco", no tramitó los permisos correspondientes para la tala de doscientos treinta y cuatro (234) árboles de varias especies, se le sancionó por el daño ecológico causado, mediante la resolución impugnada en esta demanda.

DEMANDA CONTENCIOSO ADMINISTRATIVA DE PLENA JURISDICCIÓN, INTERPUESTA POR EL LCDO. ROLANDO E. MEJÍA EN REPRESENTACIÓN DE FARALLÓN DEVELOPMENT RESORTS INC., PARA QUE LA SALA DECLARE QUE ES NULA POR ILEGAL, LA RESOLUCIÓN N AG-0011-2001, DICTADA POR EL ADMINISTRADOR GENERAL DE LA AUTORIDAD NACIONAL DEL AMBIENTE, ACTO CONFIRMATORIO Y PARA QUE SE HAGAN OTRAS DECLARACIONES. PONENTE: JORGE FÁBREGA PONCE. PANAMÁ, NUEVE (9) DE MARZO DE DOS MIL CINCO (2005). Tribunal: Corte Suprema de Justicia, Panamá. Sala: Tercera de lo Contencioso Administrativo. Ponente: Jorge Fábrega Ponce. Fecha: 09 de marzo de 2005. Materia: Acción contenciosa administrativa. Plena Jurisdicción. Expediente: 660-01.

El Lcdo. Rolando E. Mejía, actuando en representación de FARALLÓN DEVELOPMENT RESORTS INC., ha presentado demanda contencioso administrativa de plena jurisdicción, con el fin de que la Sala declare que es nula, por ilegal, la Resolución N AG-0011-2001 de 16 de enero de 2001, dictada por el Administrador Nacional del Ambiente, acto confirmatorio y para que se hagan otras declaraciones. 


\section{ACTO IMPUGNADO}

Mediante la Resolución Nº AG-0011-2001 de 16 de enero de 2001, el Administrador Nacional del Ambiente resuelve lo siguiente: "PRIMERO: SANCIONAR a la empresa FARALLÓN DEVELOPMENT RESORT INC. con multa de VEINTE MIL CUATROCIENTOS BALBOAS (B/20.400). SEGUNDO: ORDENAR a la empresa FARALLÓN DEVELOPMENT RESORT INC., que en compensación por la tala de 1.2 hectáreas de mangle y 6 hectáreas de restrojos, reforeste (10) hectáreas con mangle ubicadas en el área del Agallito, Boca Vieja y estereo (sic) La Pipota, corregimiento de Llano Bonito, distrito de Chitré, provincia de Herrera; para lo cual debe presentar un Plan de Reforestación en un mes contados a partir de la notificación de la presente Resolución. Inspección realizada el día 13 de enero de 2000, por la Autoridad Nacional del Ambiente, Agencia de Antón, se detectó el desmonte total de 1.2 hectáreas de ecosistema de manglar conformado por diversas especies de mangle, además del desmonte de 6 hectáreas de bosque secundario, sin los permisos respectivos. Constituyen una infracción administrativa que puede ser sancionada con multa hasta cincuenta mil balboas $(B / 50,000.00)$, teniendo en cuenta que la empresa había sido previamente sancionada según Resolución № ARAC-003-99 de 16 de abril de 1999, por haber desmontado mangle en el mismo sector.

SÍNTESIS 5: Multan con VEINTE MIL CUATROCIENTOS BALBOAS $(\mathrm{B} / 20,400.00)$ y se le ordena que en compensación por la tala 1.2 hectáreas de mangle y 6 hectáreas de rastrojos, reforeste diez (10) hectáreas con mangle.

DEMANDA CONTENCIOSO ADMINISTRATIVA DE PLENA JURISDICCIÓN, INTERPUESTA POR LA FIRMA AROSEMENA Y AROSEMENA, EN REPRESENTACIÓN DE J.D. HARDWOOD INDUSTRIES INC., PARA QUE SE DECLARE NULA, POR ILEGAL, LA NOTA No AG-1099-2002 DE 11 DE JUNIO DE 2002, DICTADA POR LA AUTORIDAD NACIONAL DEL AMBIENTE (ANAM), EL ACTO CONFIRMATORIO Y SE HAGAN OTRAS DECLARACIONES. PONENTE: WINSTON SPADAFORA F. PANAMÁ, DIECINUEVE (19) DE SEPTIEMBRE DE DOS MIL CINCO (2005). Tribunal: Corte Suprema de Justicia, Panamá Sala: Tercera de lo Contencioso Administrativo

Ponente: Winston Spadafora Franco. Fecha: 19 de septiembre de 2005. Materia: Acción contenciosa administrativa. Plena Jurisdicción. Expediente: 438-02.

La firma forense Arosemena y Arosemena, en representación de la sociedad J. D. HARWOOD INDUSTRIES INC., ha promovido demanda contencioso administrativa de plena jurisdicción, para que se declare nula, por ilegal, la Nota № AG-1099-2002, de 14 de junio de 2002, dictada por la Autoridad Nacional del Ambiente. A través de la nota impugnada, la referida entidad le indicó al representante legal de la sociedad demandante que no podía darle trámite a las solicitudes de exportación de madera debido a que el Decreto Ejecutivo de 5 de junio de 2002, prohibió la exportación de madera en trozas, tucas, rollos, bloques, aserradas o simplemente cepilladas de cualquier especie, procedente de los bosques naturales o de maderas sumergidas en cualquier cuerpo de agua artificial. corresponde a madera tratada o impregnada con parafina, mediante spray.

El 24 de septiembre de 2002, la empresa J.D.S. Hardwood Industries, Inc. solicitó al ANAM permiso para obtener permiso de exportación del producto de madera procesada en su planta, identificada con el código arancelario de Aduanas $\mathrm{N}^{\circ}$ 4413.00.90. A dicha solicitud, el ANAM, respondió mediante Nota AG -1821-2002, de 24 de octubre de 2002, que no era su competencia autorizar exportaciones de productos forestales. Posterior a esto, el 24 de octubre de 2002, la empresa solicitó la suspensión de la Nota AG-1099-2002, a lo que el ANAM, reiteró el contenido de la nota AG -1821-2002 y señalando que todo producto forestal que se movilice dentro del territorio nacional hacia los puntos de salida debe contar con una guía y transporte.

A través de la Vista № 296 de 25 de abril de 2003, tal y como se deja ver de fojas 245 a 256, la Procuradora de la Administración solicitó a la Sala que no se accediera a las pretensiones de la parte actora, toda vez que no le asiste la razón en su pretensión, pues la nota impugnada no hace otra cosa que informar al ingeniero Hamed Díaz, que no se podía dar trámite a las solicitudes de madera de caoba para los Estados Unidos y República Dominicana, por la Prohibición del Decreto № 57 de 5 de junio de 2002.

Igualmente indica, que la medida adoptada a través del Decreto Ejecutivo № 57 de 5 de junio de 2002, fue a consecuencia de la deforestación y el mal uso de los recursos naturales, por lo que había que implementar medidas para la protección de los bosques naturales y mantener así un equilibrio ecológico. 
En cuanto a las disposiciones alegadas de infringidas, expresa la funcionaria en mención, que no hay violación alguna, pues, no se ha demostrado que el trámite de exportación de la madera hubiere iniciado antes que se promulgara el Decreto $\mathrm{N}^{\circ} 57$ de 5 de junio de 2002.

Es importante indicar que tal medida se hizo ineludible y forzosa, debido a la grave crisis acontecida en nuestro país, producto de la deforestación y mal uso de los recursos naturales. Razón por el que las autoridades correspondientes, la ANAM y el Ministerio de Comercio de Industrias, previa consulta con los industriales de la madera, en conformidad con la política forestal, y los estudios correspondientes en la materia, implementaron estas normas para la protección de nuestros bosques naturales. En este sentido, no puede perderse de vista que la protección de nuestros bosques, es de interés público o colectivo y que frente a los grandes perjuicios que pueda sufrir la empresa demandante, deberá prevalecer, pues los mismos actúan en beneficio de la colectividad, de conformidad con el artículo 50 (anteriormente 46) de la Constitución Política.

El interés público al que se ha hecho referencia, debía prevalecer sobre el interés particular de esta empresa, en atención al principio constitucional de "primacía o preeminencia del interés público o social sobre el interés particular", consagrado en el artículo 46 de la Carta Fundamental.

WINSTON SPADAFORA FRANCO, HIPÓLITO GILL S., ARTURO HOYOS

JANINA SMALL (Secretaria)

Síntesis 6: DECLARA QUE NO ES ILEGAL la Nota AG-1099-2002, de 14 de junio de 2002, expedida por la Autoridad Nacional del Ambiente y niega las demás pretensiones. Existía una prohibición general para exportar madera no procesada, de ninguna especie, es decir, no se puede exportar madera en tuca o en bloque.

Fuente: Elaborado por Jessica Young, para la presente consultoría 


\section{UICN}

Oficina Regional para México,

América Central y el Caribe (ORMACC)

Los Yoses, San Pedro de Montes de Oca

Tel: $\quad++50622838449$

Fax: ++50622838472

ormacc@iucn.org

www.iucn.org/law

Programa de Derecho Ambiental de la UICN

Centro de Derecho Ambiental

Godesberger Allee 108-112

53175 Bonn

Alemania

Tel.: $++49228 / 269223$

Fax: ++49 228/ 2692250

elcsecretariat@iucn.org

www.iucn.org/law 